\title{
Stratigraphy and Origin of the Chinle Formation and Related Upper Triassic Strata in the Colorado Plateau Region
}

By J. H. STEWART, F. G. POOLE, and R. F. WILSON

With a section on SEDIMENTARY PETROLOGY

By R. A. CADIGAN

and a section on CONGLOMERATE STUDIES

By WILLIAM THORDARSON, H. F. ALBEE, and J. H. STEWART

GEOLOGICAL SURVEY PROFESSIONAL PAPER 690

Prepared on behalf of the

U.S. Atomic Energy Commission

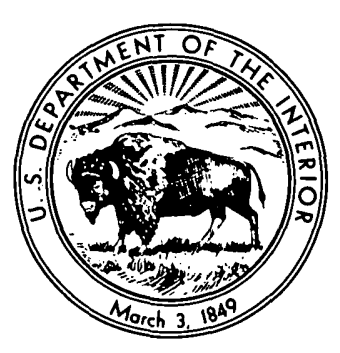

UNITED STATES GOVERNMENT PRINTING OFFICE, WASHINGTON : 1972 
UNITED STATES DEPARTMENT OF THE INTERIOR

ROGERS C. B. MORTON, Secretary

\section{GEOLOGICAL SURVEY}

V. E. McKelvey, Director

Library of Congress catalog-card No. 74-178212

For sale by the Superintendent of Documents, U.S. Government Printing Office, Washington, D.C.

Stock Number 2401-2186 


\section{CONTENTS}

Abstract

Introduction.

Methods of study and scope of report.

Field and office work.

Key to numbered localities

The Colorado Plateau region.

Previous work and history of nomenclature

Stratigraphy.

Lower (bentonitic) part of Chinle Formation

Mottled strata.

Shinarump and related members.

Shinarump Member...

Agua Zarca Sandstone Member

Sandstone member.

Gartra Member.

Monitor Butte and related members

Monitor Butte Member.

Lower red member.

Mesa Redondo Member.

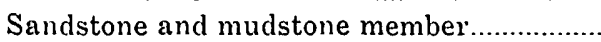

Salitral Shale Tongue.

Moss Back and related members.

Moss Back Member..

Lower member of Dolores Formation.

Poleo Sandstone Lentil.

Petrified Forest Member and ocher siltstone member..

Petrified Forest Member

Ocher siltstone member.

Upper (red-beds) part of Chinle Formation..

Owl Rock Member.

Church Rock Member and related units

Church Rock Member.

Rock Point Member of Wingate

Sandstone.

Unit in Bluewater Creek area, west-central New Mexico...

Siltstone member in north-central

New Mexico.

Middle and upper members of Dolores Formation in southern part of San Juan Mountains region. Middle nember.

Upper member

Dolores Formation in northern part of San Juan Mountains region.

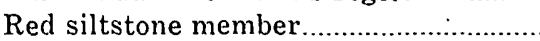

Sandstone and conglomerate member...

Upper member.

Sedimentary facies

Lower (bentonitic) part of Chinle Formation

Lithologic types.
Sedimentary facies - Continued

Lower (bentonitic) part of Chinle

Formation - Continued

Method of facies analysis...................................... 52

Results of facies analysis...................................... 53

Upper (red-beds) part of Chinle Formation.............. 53

Lithologic types.................................................. 53

Structureless and horizontally bedded

siltstone

Wavy-stratified siltstone and sandstone....

Trough-cross-stratified sandstone, siltstone, and conglomerate....................... 54

Planar-cross-stratified sandstone.................. $\quad 55$

Method of facies analysis.................................... $\quad 55$

Results of facies analysis..................................... $\quad 56$

Sedimentary petrology, by R. A. Cadigan.......................... 56

Sandstone and conglomerate..................................... 56

Quartz and other siliceous components............... 57

Feldspar......................................................... 58

Volcanic detritus................................................... 58

Heavy minerals................................................ 58

Clay minerals................................................. $\quad 59$

Cementing minerals.............................................. 60

Fine-textured and carbonate rocks.............................. 61

Texture and composition of various

stratigraphic units..

Conglomerate studies, by William Thordarson,

H. F. Albee, and J. H. Stewart

Methods of pebble analysis........................................... 62

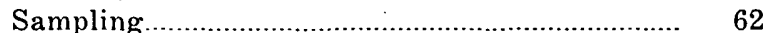

Composition ........................................................... 62

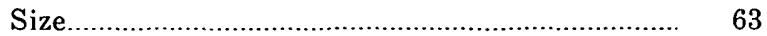

Roundness and sphericity .................................. 63

Results of pebble studies............................................ 64

Shinarump Member of Chinle Formation........... 64

Sandstone member and Agua Zarca

Sandstone Member of Chinle Formation.......... 68

Basal sandstone unit of Chinle Formation

near Moab, Utah............................................ 68

Gartra Member of Chinle Formation.................. 68

Mesa Redondo Member of Chinle Formation..... $\quad 69$

Moss Back Member of Chinle Formation............ 69

Poleo Sandstone Lentil of Chinle Formation......... 74

Sonsela Sandstone Bed of Petrified Forest

Member of Chinle Formation.

Petrified Forest Member of Chinle Formation

exclusive of Sonsela Sandstone Bed.

Basal unit and lower member of Dolores

Formation.

Sedimentary-structure studies..................................... $\quad 75$

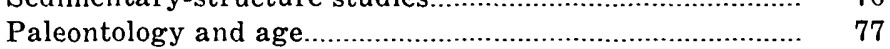

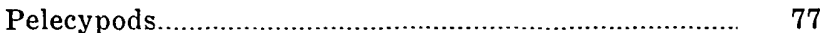

III 
Paleontology and age - Continued

Gastropods

Arthropods

Fish

Amphibians

Reptiles......

Order Thecodontia

Suborder Pseudosuchia

Suborder Phytosauria

Order Saurischia

Order Therapsida.

Plants.

Sphenopsids

Cycadophytes

Conifers.

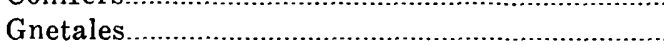

Monocotyledons.

Age of the Chinle Formation

Interpretations.

Lower (bentonitic) part of Chinle Formation

Environment of deposition as indicated by

fossils.

Mottled strata

Cross-stratified sandstone and conglomerate......

Cross-stratified clayey sandstone.

Ripple-laminated sandstone.

Structureless or horizontally stratified claystone and clayey siltstone...

Location and terrane of source areas................... Mogollon highland

Uncompahgre highland.

Front Range highland

Upper (red-beds) part of Chinle Formation

Environment of deposition as indicated by fossils.

Structureless and horizontally bedded

siltstone

Limestone.

Wavy-stratified siltstone and sandstone...............

Trough-cross-stratified sandstone, siltstone, and conglomerate.

Planar-cross-stratified sandstone.

Location and terrane of source areas.

References cited

Stratigraphic sections

Arizona.

A-2, Black Mountain Wash

A-3, Chee Dodge.

A-4, Horse Mesa Creek.

A-6b, Lukachukai Trading Post

A-7, Lupton.

A-8a, Nazlini Trading Post section A

A-8b, Nazlini Trading Post section B.

A-9b, St. Johns section B

A-9c, St. Johns section C

A-9d, St. Johns section D

A-10, Black Point.

A-13, Owl Rock

Colorado.

C-1, Piedra River

C-2, East Brush Creek.

C-4, South Canyon Creek

C-5, Durango.
Page
Stratigraphic sections - Continued

Colorado - Continued

C-6, Bridgeport.

C-7, Carson Hole.

$\mathrm{C}-8$, The Palisade..

C-9, The Serpents Trail

C-11. Miller Countain......................................... 149

C-13, Vermilion Creek.............................................. 153

C-14a, Stoner section A ....................................... 155

C-14b, Stoner section B..................................... 156

C-15, Paradox Valley ......................................... 158

C-16, Ouray ...................................................... 160

C-17, A spen........................................................... 162

C-18, Meeker (Oak Ridge) ................................... 164

Nevada

C-19, Sawpit

N-1, Horse Spring Valley

N-2, Spring Mountains........................................ 172

$\mathrm{N}-3$, Valley of Fire ....................................... 175

New Mexico.......................................................... 179

NM-1a, Chavez-Prewitt section A.................... 179

NM-1b, Chavez-Prewitt section B........................ 182

NM-2, Fort Defiance section............................... 185

NM-3a, Fort Wingate section A ....................... 186

NM-3b, Fort Wingate section B ........................ 189

NM-4, Todilto Park................................................ 191

NM-5a, Zuni section A.......................................... 193

NM-5b, Zuni section B......................................... 194

NM-6, Abiquiu................................................ 195

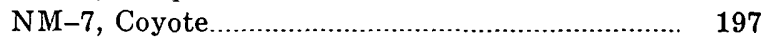

NM-8, Gallina .................................................. 199

NM-9, Ghost Ranch............................................. 200

NM-11, Toadlena ............................................... 201

NM-12, Arroyo de los Pinos.................................. 203

NM-13, San Ysidro............................................... 206

NM-14, Senorito Canyon....................................... 207

NM-15, White Mesa............................................ 209

NM-18, Bluewater Creek................................... 210

NM-19, Correo ................................................. 211

NM-21, Petoch Butte.......................................... 213

Utah.

U-1, Lake Fork River............................................. 214

U-3, Buckhorn Wash......................................... 216

U-4, Cane Wash................................................... 219

U-5, Lucky Strike Mine...................................... 221

U-6, Muddy River.............................................. 223

U-7, Straight Wash............................................. 225

U-8, Temple Mountain......................................... 229

U-9, Buckacre Point............................................ 231

U-10, Horse Canyon............................................ 235

U-11, Muley Twist............................................... 236

U-13, Range Canyon............................................ 238

U-14, Silver Falls Creek..................................... 241

U-15, South Block ............................................... 243

U-16, South Draw............................................. 245

U-18, Richardson Amphitheater.......................... 248

U-19, Spring Canyon.......................................... 250

U-20, Moab Canyon............................................ 252

U-21, Westwater Canyon .................................... 254

U-22, Kanarraville............................................. 255

U-23, Fossil Wood Wash..................................... 258

U-24, Paria ........................................................ 261 
Stratigraphic sections - Continued

Utah - Continued

$\mathrm{U}-25$, Bears Ears.

U-26, Bridger Jack Mesa

U-27, Comb Wash................................................ 271

U-28, Cottonwood Creek...................................... 274

U-29, Hite....................................................... 277

U-30, Jacobs Chair.............................................. 281

U-31, Johnson Creek............................................ 286

U-32, Lockhart Canyon......................................... 288

U-33, Milk Ranch Point...................................... 291

U-34, Monitor Butte............................................... 294

U-35, North Sixshooter Peak..
Stratigraphic sections - Continued

Utah - Continued

U-36, Poncho House...

U-37a, Rincon section A

U-37b, Rincon section B..................................... 305

U-39, Taylor Canyon......................................... 306

U-40, Cliff Creek ............................................... $\quad 310$

U-41, Vernal (Brush Creek) .............................. 312

U-43, Chimney Rock............................................ 315

U-44, Millard Canyon.......................................... 317

U-45, Leeds........... 320

U-46, Rockville .................................................. 326

Index.

\section{ILLUSTRATIONS}

[Plates are in pocket]

Plate 1. Maps of the Colorado Plateau region, showing outcrops of Triassic strata and localities in the Chinle Formation and related strata.

2. Fence diagram of Chinle Formation and related strata in the Colorado Plateau region.

3. Paleogeologic map of the surface below Chinle Formation and isopach map of Chinle Formation and related strata in the Colorado Plateau region.

4. Maps showing distribution, thickness, and inferred depositional pattern of the lower (bentonitic) part of the Chinle Formation and related strata in the Colorado Plateau region.

5. Isopach maps and sedimentary facies map of the upper (red-beds) part of the Chinle Formation in the Colorado Plateau region.

FIGURE 1. Correlation chart showing nomenclature of the Chinle Formation and related strata in the Colorado Plateau region.

2. Diagrammatic section showing correlation of Chinle Formation from Circle Cliffs to San Rafael Swell, Utah.

3. Diagrammatic section showing correlation of Chinle Formation in northeastern Utah and northwestern Colorado.

4. Photograph of mottled strata in basal part of Chinle Formation.

5. Diagrammatic section showing correlation of Triassic and some Jurassic rocks in west-central and central New Mexico

6. Sketch of plan view of a group of trough cross-strata in Shinarump Member of Chinle Formation at Canyon De Chelly, Ariz.

7. Photograph of Shinarump and Monitor Butte Members of Chinle Formation on Monitor Butte, Utah..........

8. Diagrammatic section showing correlation of Triassic and some Jurassic rocks in north-central New Mexico.

9. Map and diagrammatic section showing inferred depositional limits and stratigraphic relations of Moss Back, Gartra, and Shinarump Members of Chinle Formation

10. Diagrammatic section showing correlation of the Chinle Formation northeastward across southeastern Utah.

11. Photograph of contorted strata in Monitor Butte Member of Chinle Formation in Capitol Reef area, Utah

12. Diagrammatic section showing correlation of Chinle Formation in north-central Arizona and south-central Utah

13. Map showing areal distribution and direction of sediment transport of the Moss Back Member and the Poleo Sandstone Lentil of the Chinle Formation and of the lower member of Dolores Formation.

14. Photograph of Moss Back Member of Chinle Formation at Buckacre Point along Dirty Devil River, Utah......

15. Diagrammatic section showing correlation of some Triassic and Jurassic rocks in southeastern Utah and southwestern Colorado.

16. Histogram showing percentage of main color groups in Petrified Forest Member of Chinle Formation at the Rockville stratigraphic section (loc. U-46), Utah

17. Photograph showing horizontally stratified claystone in Petrified Forest Member of Chinle Formation near abandoned town of Paria, Utah.

18. Photograph showing frothy weathering surface developed on claystone in Petrified Forest Member of Chinle Formation near Joseph City, Ariz.

Page 
FigURE 19. Photograph showing shallow trough sets of low-angle cross-strata in Petrified Forest Member of Chinle Formation near Cameron, Ariz..

20. Map showing areal distribution and direction of sediment transport of Sonsela Sandstone Bed of Chinle Formation.

21. Photograph of Owl Rock Member of Chinle Formation in southern part of Red Rock Valley in northeastern Arizona.

22. Map showing distribution of Hite Bed and so-called Black Ledge of the Church Rock Member..

23. Photograph of Owl Rock Member of Chinle Formation and Rock Point and Lukachukai Members of Wingate Sandstone in the southern part of Red Rock Valley in northeastern Arizona

24. Fence diagram of Church Rock Member of Chinle Formation and Rock Point and Lukachukai Members of Wingate Sandstone in southeastern Utah, northeastern Arizona, and northwestern New Mexico.

25. Map showing location of samples from the Gartra Member, basal sandstone unit, Agua Zarca Sandstone Member, sandstone member, and Shinarump (or Shinarump(?)) Member of the Chinle Formation.

26. Map showing location of samples from Mesa Redondo Member, Moss Back Member, Poleo Sandstone Lentil, Sonsela Sandstone Bed, and Petrified Forest Member of the Chinle Formation and from basal unit and lower member of the Dolores Formation.

27. Maps showing regional differences in the proportions of quartz, quartzite, and chert pebbles in the Shinarump Member of the Chinle Formation.

28. Isopleth map of maximum sizes of pebbles to boulders (quartz, quartzite, and chert) in the Shinarump, Agua Zarca Sandstone, and Gartra Members and the sandstone member of the Chinle Formation.

29. Isopleth map of maximum sizes of pebbles and cobbles (quartz, quartzite, and chert) and percentage of quartzite pebbles and cobbles in the Moss Back Member of the Chinle Formation

30. Isopleth map of maximum sizes of pebbles to cobbles (quartz, quartzite, and chert) from the Sonsela Sandstone Bed.

31. Isopach map showing current directions in sandstone and conglomerate units and source areas of the lower (bentonitic) part of Chinle Formation and related strata.

32. Idealized map and section showing deposits of a meandering river

33. Isopach map showing current directions in sandstone units and source areas of upper (red-beds) part of Chinle Formation and related strata

34. Diagrams showing development of cyclic deposits in Rock Point Member of Wingate Sandstone.

\section{TABLES}

TABLE 1. Index to location of control points shown on plate 1 and referred to in text, and source of data for each.........

2. Members and units assigned to lower and upper parts of the Chinle Formation and related strata.

3. Data sheet for sedimentary-facies study of the lower part of the Chinle Formation.

4. Data sheet for sedimentary-facies study of upper part of Chinle Formation.

5. Approximations of grain-size distribution properties and proportions of certain mineral components of the sandstone in groups of similar stratigraphic units of the Chinle Formation and related strata.....

6. Composition, size, roundness, and sphericity of pebbles from the Chinle and Dolores Formations...

7. Fossils from chert pebbles in Shinarump Member of Chinle Formation.

8. Fossils from chert pebbles in Moss Back Member of Chinle Formation

9. Fossils from chert pebbles in Petrified Forest Member of Chinle Formation, exclusive of the Sonsela Sandstone Bed. 


\title{
STRATIGRAPHY AND ORIGIN OF THE CHINLE FORMATION AND RELATED UPPER TRIASSIC STRATA IN THE COLORADO PLATEAU REGION
}

\author{
By J. H. Stewart, F. G. Poole, and R. F. Wilson
}

\section{ABSTRACT}

The Chinle Formation of Late Triassic age is composed of various rocks of continental origin, including claystone, sandstone, limestone, siltstone, and conglomerate. It extends over most of the Colorado Plateaus province, and related strata are recognized in adjoining regions. In the southern part of the Colorado Plateau it ranges in thickness from a wedge edge to slightly more than 1,700 feet but is generally more than 1,000 feet thick. The formation thins irregularly northward and is only 200 to 500 feet thick in much of northeastern Utah and northwestern Colorado.

The Chinle Formation rests unconformably on the underlying strata. In most of the Colorado Plateau it overlies the Moenkopi Formation, of Early and Middle(?) Triassic age. Along the eastern margin of the Colorado Plateaus province, it rests on strata of Permian age and locally on rocks of older Paleozoic age. On the flanks of the Uncompahgre and Front Range highlands, it overlies Precambrian igneous and metamorphic rocks. The Chinle Formation is conformably, but locally unconformably, overlain for the most part by the Glen Canyon roup of Triassic and Jurassic age, but in some places it is unconformably overlain by younger Jurassic or Cretaceous strata.

The Chinle Formation and related strata are divided into a lower (bentonitic) part and an upper (red-beds) part. The lower part consists principally of variegated bentonitic claystone, clayey siltstone, clayey sandstone, and thin widespread layers of sandstone and conglomerate. It contains an abundant fossil fauna and flora, including pelecypods, gastropods, arthropods, fish, amphibians, reptiles, and plants. The upper part consists principally of reddish horizontally bedded or structureless siltstone and generally minor amounts of limestone, ripple-laminated siltstone and sandstone, limestone pebble conglomerate, and cross-stratified sandstone. Fossils are much scarcer in the upper part than in the lower and are mostly pelecypods and gastropods. The contact between these two parts of the formation is gradational and intertonguing and is difficult to locate in some areas. The lithologic differences between the two parts indicate differences in environment of deposition and in source of sediments.

The lower part of the Chinle Formation extends over most of the Colorado Plateau region. It is over 1,000 feet thick near its southern margin in Arizona and New Mexico, and at some places in this area it is over 1,500 feet thick. It thins to the northeast and is generally no more than a few hundred feet thick in most of northwestern Colorado. It may conveniently be divided into five general stratigraphic units. These are, in ascending order: (1) Mottled strata, (2) Shinarump and related members, (3) Monitor Butte and related members, (4) Moss Back and related members, and (5) Petrified Forest Member and the ocher siltstone member.

The mottled strata are rocks with a peculiar mottling in reddish purple, pale reddish brown, and light greenish gray. The mottling is thought to have been caused by alteration, perhaps associated with the formation of a soil. The alteration commonly crosses stratigraphic boundaries and locally extends downward into the top few feet of the rocks directly underlying the Chinle Formation. These mottled strata consist mainly of siltstone but locally include sandstone, conglomerate, and other rocks. They are generally a few feet to 25 feet thick and have a widespread, though spotty, distribution.

The Shinarump Member, a thin ledge-forming layer of cross-stratified sandstone and conglomerate, extends over much of the southern part of the Colorado Plateau. The sandstone is fine to coarse grained and consists mostly of quartz mixed with small amounts of sodic and potassic feldspar and of altered volcanic debris. The gravel-sized fragments in the conglomerate consist of either quartz, quartzite, chert, or volcanic rock. Some of the chert pebbles contain identifiable fossils - mostly fusulinids, brachiopods, and bryozoa - that indicate source rocks of Permian age. The maximum size of gravel fragments in the Shinarump Member decreases toward the north. Three other members of the Chinle Formation are lithologically similar to, although not identical with, the Shinarump Member and are also basal or nearly basal units of the Chinle Formation. These three members are (1) the Agua Zarca Sandstone Member, in north-central New Mexico, (2) an unnamed sandstone member, in north-central New Mexico, and (3) the Gartra Member, in northeastern Utah and northwestern Colorado.

Slope-forming claystone and clayey sandstone and interstratified thin lenses of ledge-forming ripple-laminated sandstone overlie the Shinarump and related members. These strata are generally 50 to 200 feet thick and are designated by different names in different areas. Difference in names reflects to some extent lithologic differences in the members. The Monitor Butte Member is recognized in southeastern Utah and in the Monument Valley area in northeastern Arizona; the lower red member, in the Defiance uplift area in northeastern Arizona and in the Zuni uplift in west-central New Mexico; the Mesa Redondo Member, in the St. JohnsHunt area in east-central Arizona; a sandstone and mudstone member, in the Cameron, Echo Cliffs, and Lees Ferry areas in north-central Arizona; and the Salitral Shale Tongue, in north-central New Mexico.

The Moss Back Member is a thin ledge-forming unit composed of cross-stratified fine- to medium-grained sandstone 
and conglomerate. It extends throughout much of southeastern Utah and possibly into parts of westernmost Colorado. The sandstone is composed of quartz and small amounts of feldspar and altered detrital volcanic debris. The gravel-sized fragments in the conglomerate consist mostly of quartz, quartzite, and chert. The lower member of the Dolores Formation in southwestern Colorado and the Poleo Sandstone Lentil of the Chinle Formation in north-central New Mexico are lithologically similar to the Moss Back Member and may be laterally continuous with that member, although exact correlations are uncertain.

The Petrified Forest Member is the thickest and most widespread member in the lower part of the Chinle Formation. It is present throughout the southern part of the Colorado Plateau. It is over 1,000 feet thick in most of east-central Arizona and west-central New Mexico, thins and grades out into other members of the Chinle Formation toward the northeast, and reaches a poorly defined northeast limit in southeastern Utah, southwesternmost Colorado, and northernmost New Mexico. The member is composed predominantly of brightly colored and variegated horizontally stratified claystone and clayey siltstone and cross-stratified clayey sandstone. These rocks contain montmorillonitic clay probably derived from the alteration of volcanic glass, and sand-sized material composed of volcanic debris. In some areas the member contains units of cross-stratified ledge-forming sandstone and conglomerate, the most conspicuous of which is the Sonsela Sandstone Bed, which covers a large part of northeastern Arizona and northwestern New Mexico.

A unit of ocher and red siltstone and claystone locally containing spherulites and nodules of analcite occurs in the Uinta Mountains of northeastern Utah and northwestern Colorado and is referred to informally as the ocher siltstone member. Much of the clay in this member is montmorillonite, which indicates a similarity to the Petrified Forest Member to the south, although the two members appear to have been deposited in separate basins.

The upper part of the Chinle Formation covers northeastern Arizona, eastern Utah, western Colorado, and parts of northwestern New Mexico. It is more than 1,000 feet thick in parts of west-central and southwesternmost Colorado but thins fairly rapidly in all directions away from those areas. The upper part of the Chinle Formation is divided into two members: (1) the Owl Rock Member and, at the top, (2) the Church Rock Member and related units.

The Owl Rock Member occurs in an elliptical area embracing most of northeastern Arizona and southeastern Utah and small parts of northwestern New Mexico and southwestern Colorado. It is typically composed of reddish-brown horizontally stratified or structureless coarse siltstone interstratified with thin pale-red and light-greenish-gray limestone beds that generally form about 5 to 10 percent of the member. The detrital grains in the siltstone consist mostly of quartz, although small amounts of sodic and potassic feldspar and of volcanic debris occur. Much of the limestone has apparently formed by replacement of volcanic ash or altered ash. The member is as much as 400 feet thick and grades eastward into the Church Rock Member and related units.

At the top of the upper part of the Chinle Formation are red-bed units that have been given different names in different areas, although they are considered to be physically continuous, at least in part, with one another. These units are (1) the Church Rock Member of the Chinle Formation in southeastern Utah and the Monument Valley area, Arizona,
(2) the Rock Point Member of the Wingate Sandstone in northeastern Arizona and westernmost New Mexico, (3) a siltstone member of the Chinle Formation in the Bluewater Creek area in west-central New Mexico, (4) a siltstone member of the Chinle Formation in the Rio Chama area of northcentral New Mexico, (5) the middle and upper members of the Dolores Formation in the southern part of the San Juan Mountains area and all of the Dolores Formation in the northern part of that area, and (6) the sandstone and conglomerate, red siltstone, and upper members of the Chinle Formation in northeastern Utah and western Colorado.

The Church Rock Member and related units are composed of reddish-brown and light-brown horizontally stratified or structureless coarse siltstone and sandy (very fine grained) siltstone, and in many areas minor amounts of horizontally laminated, ripple-laminated, and wavy-stratified siltstone and sandstone, cross-stratified sandstone, and limestone pebble conglomerate. Most of these strata are arkosic. Cross-stratified sandstone and associated ripple-marked siltstone are abundant in the member and in correlative strata in a narrow northwest-trending belt extending from southwestern Colorado to central Utah. The Church Rock Member and correlative strata are as much as 1,000 feet thick.

The lower part of the Chinle Formation is considered to be a continental deposit laid down in streams and lakes and on flood plains; this interpretation is based largely on the types of sedimentary structures and fossils. Thin widespread sandstone and conglomerate units, such as the Shinarump and Moss Back Members, are probably point-bar deposits produced by the lateral migration of meandering streams. Stream directions, as indicated by the orientation of crossstrata, were mostly north to northwest, indicating a source area to the south of the Colorado Plateau region. This source, the Mogollon highland, was predominantly a volcanic terrane, as indicated by the abundance of volcanic debris in the lower Chinle. Fossil-bearing chert pebbles in conglomerate layers in the lower Chinle, on the other hand, indicate that some sedimentary rocks were exposed in the source area. The Uncompahgre and Front Range highlands of Colorado and adjacent areas-the ancestral Rocky Mountains-also contributed some detrital material to the lower part of the Chinle Formation.

The upper part of the Chinle Formation may be predominantly a lake deposit, as indicated by the fine texture and even bedding of the strata and by the type of fossils. Cross-stratified sandstone layers, interpreted to be stream deposits, are abundant locally and are most abundant in a narrow belt extending from southwestern Colorado to central Utah. This belt of sandstone is considered to mark the location of a major river system. The Uncompahgre and Front Range highlands of western Colorado and adjacent areas and the Mogollon highland in southern Arizona and adjacent States are considered to have been the main source areas during deposition of the upper part of the Chinle Formation. Granitic and metamorphic rocks and some sedimentary rocks were exposed in the Uncompahgre and Front Range highlands. Rocks exposed in the Mogollon highland were mainly volcanic.

\section{INTRODUCTION}

The Chinle Formation in the Colorado Plateau region (pl. 1) has long attracted the attention of geologists, both for its scenic qualities and for its scientific interest. The brightly colored painted des- 
erts and petrified forests of Arizona, typified by the Petrified Forest National Park, are carved in the Chinle Formation. The strata of the Chinle Formation are widely exposed in canyons and cliffs throughout the Colorado Plateau, and contribute to the beauty of Capitol Reef National Monument and Dinosaur National Monument in Utah and of Colorado National Monument in Colorado. The formation became the object of scientific interest with the first geologic work on the plateau, and it was described in the classic studies of the Colorado Plateau by Maj. John W. Powell, G. K. Gilbert, and C. E. Dutton in the 1870 's and 1880 's. Since that time, the formation has been extensively studied. The Chinle Formation is particularly well known for vertebrate fossils and for plant fossils such as the silicified tree logs in the Petrified Forest National Park in Arizona. In the 1950's, development of uranium, vanadium, and copper deposits in the formation and search for new deposits led to an increased interest in the stratigraphy and origin of the formation.

The present investigation of the Triassic strata of the Colorado Plateau region was designed to obtain information regarding areal distribution, local and regional differences in rock types, conditions of deposition, and sources and character of constituents. This study, undertaken by the U.S. Geological Survey on behalf of the U.S. Atomic Energy Commission, Division of Raw Materials, as a part of the investigations of the uranium deposits of the Colorado Plateau, has led to a better understanding of the habits and stratigraphic settings of the ore deposits.

Study of the Moenkopi Formation of Early and Middle(?) Triassic age, which underlies the Chinle Formation in much of the Colorado Plateau, was undertaken at the same time as study of the Chinle Formation. The results of the study of the Moenkopi Formation are given in a separate report (Stewart and others, 1972).

\section{METHODS OF STUDY AND SCOPE OF REPORT}

The study of the Chinle Formation comprised six principal subjects of investigation: (1) regional stratigraphy, (2) lithofacies, (3) orientation of sedimentary structures, (4) clay mineralogy, (5) sedimentary petrology, and (6) characteristics of conglomerate layers.

Regional stratigraphic study consisted of detailed correlation of lithologic units throughout the Colorado Plateau region to establish a firm background on the distribution, lithology, facies, and thickness of units. About 100 stratigraphic sections were measured and described in outcrops, and many sections measured by other geologists were studied in the field. Stratigraphic units were correlated between sections on the basis of lithologic characteristics and also by tracing of units along outcrops. The study consisted mostly of examining outcrops, which are plentiful. Some study of drill-hole logs was undertaken to correlate units in the subsurface and determine thicknesses, but this part of the investigation was minor in comparison with the surface study.

The lithofacies study consisted of determining the regional variation in rock types within different parts of the Chinle Formation. Examination of over 100 stratigraphic sections has led to an understanding of the overall change in sedimentary facies and has helped delimit possible source areas and dominant sedimentary environments.

Study of sedimentary structures consisted of determining the orientation of cross-strata and, to a lesser extent, of ripple marks and fossil logs in the Chinle Formation. It led to interpretation of regional drainage patterns and source areas and assisted in determination of sedimentary environments.

Determination of clay minerals by X-ray diffraction methods indicated differences in clay mineralogy between stratigraphic units that led to interpretations of the origin and source areas of the Chinle Formation.

Study of sedimentary petrology determined regional differences in composition and texture of the strata, particularly sandstone and coarse siltstone units, by means of statistical analyses of grain-size distribution and of composition of detrital and allogenic constituents. It also led to interpretations of the origin and source areas of the formation.

The conglomerate characteristics determined were the composition, average and maximum size, color, roundness, and sphericity of gravel-sized material at more than 100 localities. Fossils in pebbles and cobbles were identified by paleontologists of the U.S. Geological Survey to determine the age of the strata from which the clasts were derived. Results of this study of the conglomerate layers contributed largely to the delineation of possible source areas.

This report describes in full the results of the regional stratigraphic and lithofacies studies and summarizes the results of studies of sedimentary structures, sedimentary petrology, and conglomerates. The results of the clay-mineralogy study have already been published (Schultz, 1963). The report also summarizes the paleontology of the formation and interprets the depositional history.

\section{FIELD AND OFFICE WORK}

Fieldwork on the project started in the summer of 1951 and continued, during the field season, through 
1956. Some field checking was done during 1957. Laboratory research and compilation of material was done as the project continued.

The following geologists worked on the project: Laurence C. Craig (1951-52), Thomas E. Mullen (1951-52), Phillip Katich (1951), George A. Williams (1951-55), Howard F. Albee (1952-55), John H. Stewart (1952-58), Omer B. Raup (1953-55), Forest G. Poole (1954-58), William Thordarson (1955-56), and Richard F. Wilson (1955-58). The project was originally headed by L. C. Craig, who continued as advisor to the project throughout the study. G. A. Williams was in charge from 1953 to 1955 , and J. H. Stewart, from 1955 until completion. Physical stratigraphy was investigated mainly by J. H. Stewart, F. G. Poole, and R. F. Wilson; lithofacies, by R. F. Wilson; sedimentary structures, by F. G. Poole, O. B. Raup, and G. A. Williams; and conglomerates, by William Thordarson and H. F. Albee. Two related studies were carried on in coordination with the main work; sedimentary petrology was studied by R. A. Cadigan from 1951 to 1961 , and clay mineralogy was studied by L. G. Schultz from 1954 to 1957.

The project benefited from consultations of project personnel with other geologists of the Geological Survey and the Atomic Energy Commission and with geologists associated with universities and the mining and oil companies. The help of these other geologists is gratefully acknowledged. Of particular help were discussions with J. W. Harshbarger, M. E. Cooley, and C. A. Repenning, who mapped and studied the stratigraphy of the Navajo Indian Reservation in Arizona. We also thank the many field assistants who helped with the project.

\section{KEY TO NUMBERED LOCALITIES}

Plate 1 shows the location of numbered localities referred to in this report, and table 1 shows, by State, the number, name, and location of the locality and the source of information. The numbering system is separate for each State and consists of a letter prefix and a number; locality $\mathrm{C}-1$, for example, refers to the first numbered locality in Colorado, and $\mathrm{U}-1$, to the first numbered locality in Utah. Numbers for localities are the same as those used in a report on the Moenkopi Formation (Stewart and others, 1972) ; gaps in numbers represent localities not pertinent to this report.

Where data presented in the figures and text differ from those given in the basic source material, differences indicate a reinterpretation of the data.

THE COLORADO PLATEAU REGION

The Colorado Plateau (pl. 1) is a relatively elevated structural platform of flat-lying sedimentary strata comprising an area of 150,000 square miles in Utah, Colorado, Arizona, and New Mexico. It is bounded on the south and west by the Basin and Range faultblock mountains of New Mexico, Arizona, and Nevada; on the northwest and north by the Wasatch Mountains and the Uinta Mountains, respectively, both in the central Rocky Mountain system; and on the east by the southern Rocky Mountain system (pl. 1). The structure within the Colorado Plateau is relatively simple: the mantle of sedimentary rocks is flat-lying or gently dipping in most areas. Monoclines, faulted monoclines, and normal faults fold and break the strata along generally north- or northwest-trending belts. Broad uplifts, including the Zuni, Defiance, Monument, Circle Cliffs, and Uncompahgre uplifts and the San Rafael Swell, elevate the strata; even larger basins, including the San Juan, Black Mesa, Uinta, and Piceance basins, depress the strata. Belts of northwest-trending salt structures, characterized by thickened masses of salt that have intruded and disrupted the overlying rocks, occur in east-central Utah and west-central Colorado. Laccolithic mountains of Cretaceous(?) and Tertiary age puncture the sedimentary layers in isolated areas and include the Carrizo, Ute, La Plata, Rico, Abajo, Henry, and La Sal Mountain groups. Volcanic rocks of Tertiary and Quaternary age occur within the Colorado Plateau but are most abundant along the margins.

For the most part, the sedimentary strata that mantle the Colorado Plateau are relatively thin formations of wide extent. The plateau throughout much of Paleozoic and Early Mesozoic time was a broad shelf area (craton) lying to the east of the great Cordilleran geosyncline of western Utah and of Nevada and California. Many of the formations thicken in the western part of the plateau into or toward this geosyncline. Although locally thickened masses of strata were deposited in deep basins, no persistent geosynclines existed on the plateau.

The Colorado Plateau is generally an arid desert region characterized by sparse vegetation and few perennial streams. Some of the higher country, such as the Uncompahgre Plateau and the laccolithic mountains, however, is thickly vegetated and maintains large stands of pine trees. A few perennial streams, such as the Colorado and Green Rivers, are exceptions to the general desert character of the region.

In the desert region of the plateau, rocks are ideally exposed for the study of stratigraphy.

\section{PREVIOUS WORK AND HISTORY OF} NOMENCLATURE

Geologic work on the Colorado Plateau began in 1853 and continued at an expanding rate. The earliest 
TABLE 1. - Index to location of control points shown on plate 1 and referred to in text, and source of data for each

[Locality No.: A, A rizona: C, Colorado; N, Nevada: NM, New Mexico; U, Utah. Locality: where locality number represents a drill hole, owner and name of drill hole are given. Location in county, reference meridian or base line: GSRM, Gila and Salt River Meridian; MDM, Mount Diablo Meridian; NBL, Navajo Base Line; NMPM. New Mexico Principal Meridian; Stratigaphic section, this report; Sed. facies, sedimentary facies study, this report: AEC. A tomic Energy Commission: Am Strat log. American Stratigraphic Co. drill-hole log; *, unpub. datal

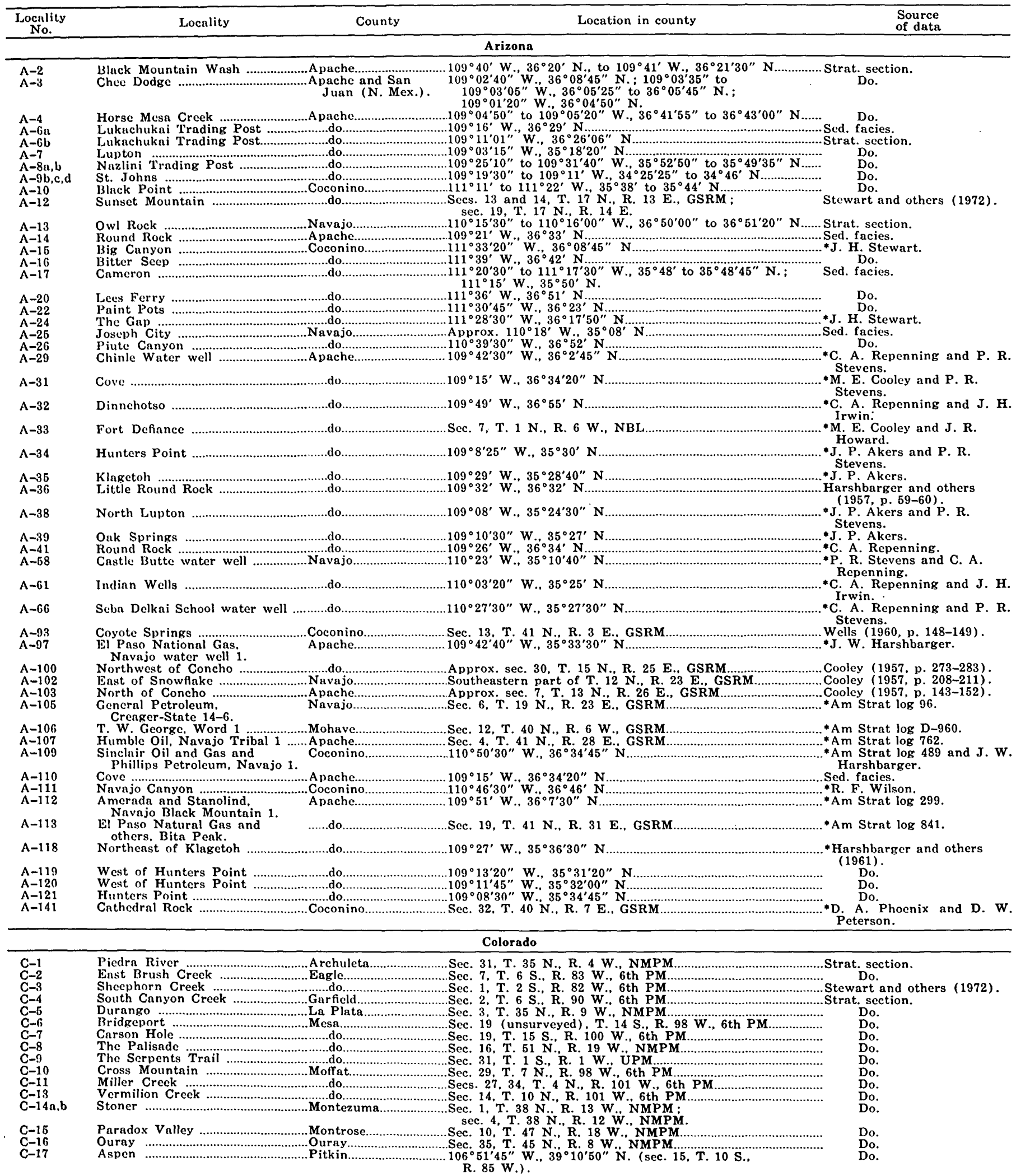


TABLE 1. - Index to location of control points shown on plate 1 and referred to in text, and source of data for each.-Continued

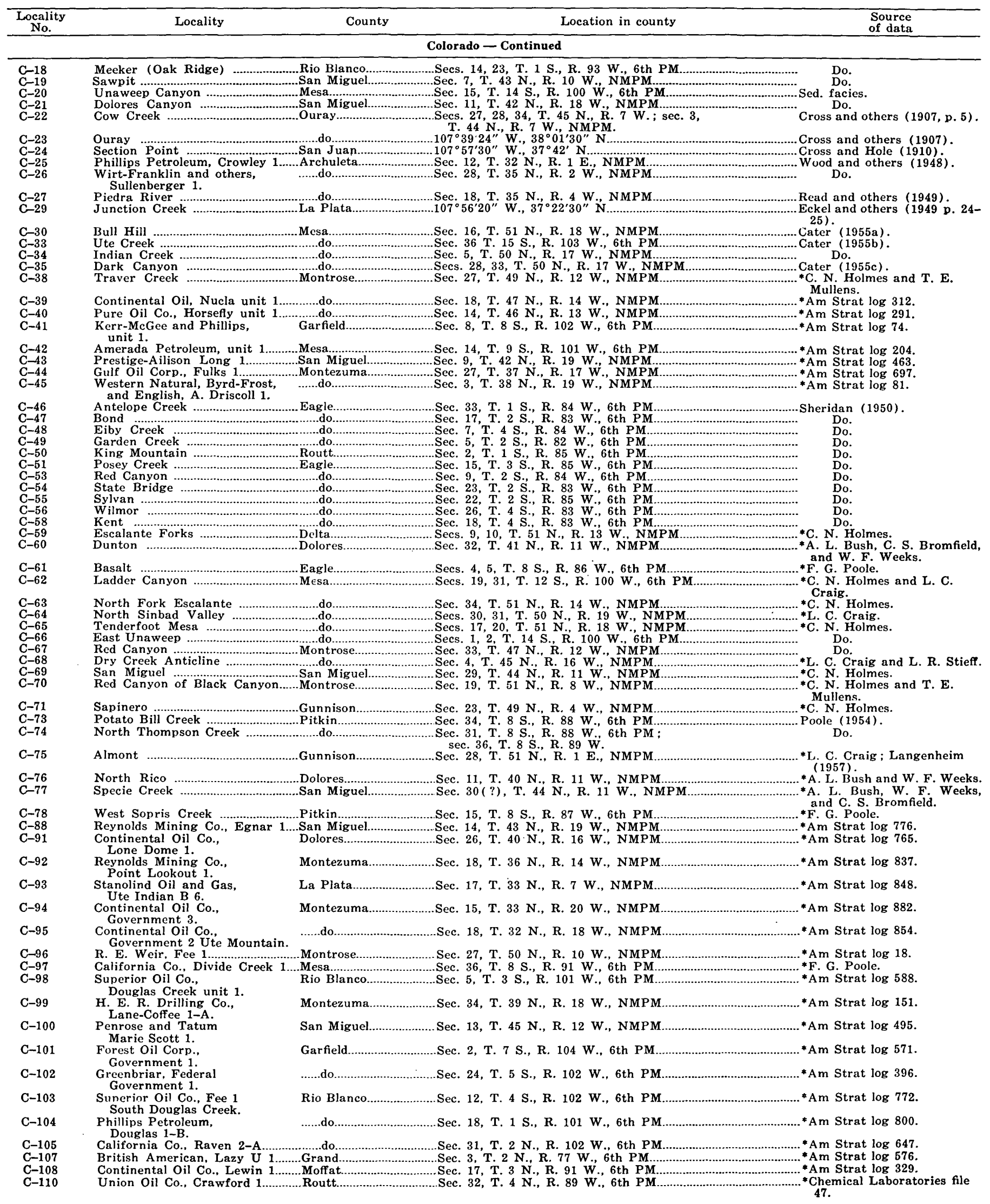


TABLE 1. - Index to location of control points shown on plate 1 and referred to in text, and source of data for each-Continued




TABLE 1. - Index to location of control points shown on plate 1 and referred to in text, and source of data for each-Continued

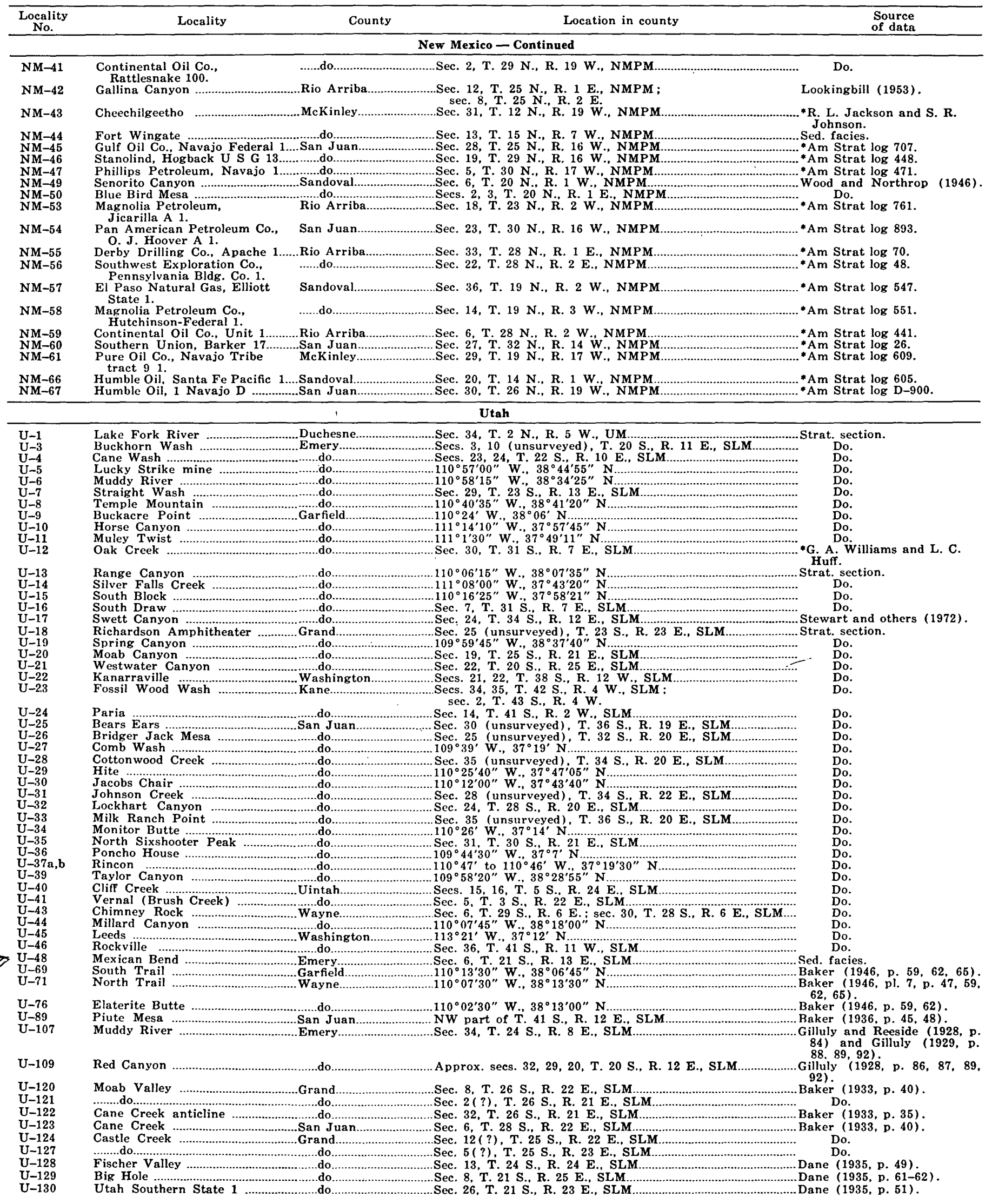


TABLE 1. - Index to location of control points shown on plate 1 and referred to in text, and source of data for each-Continued

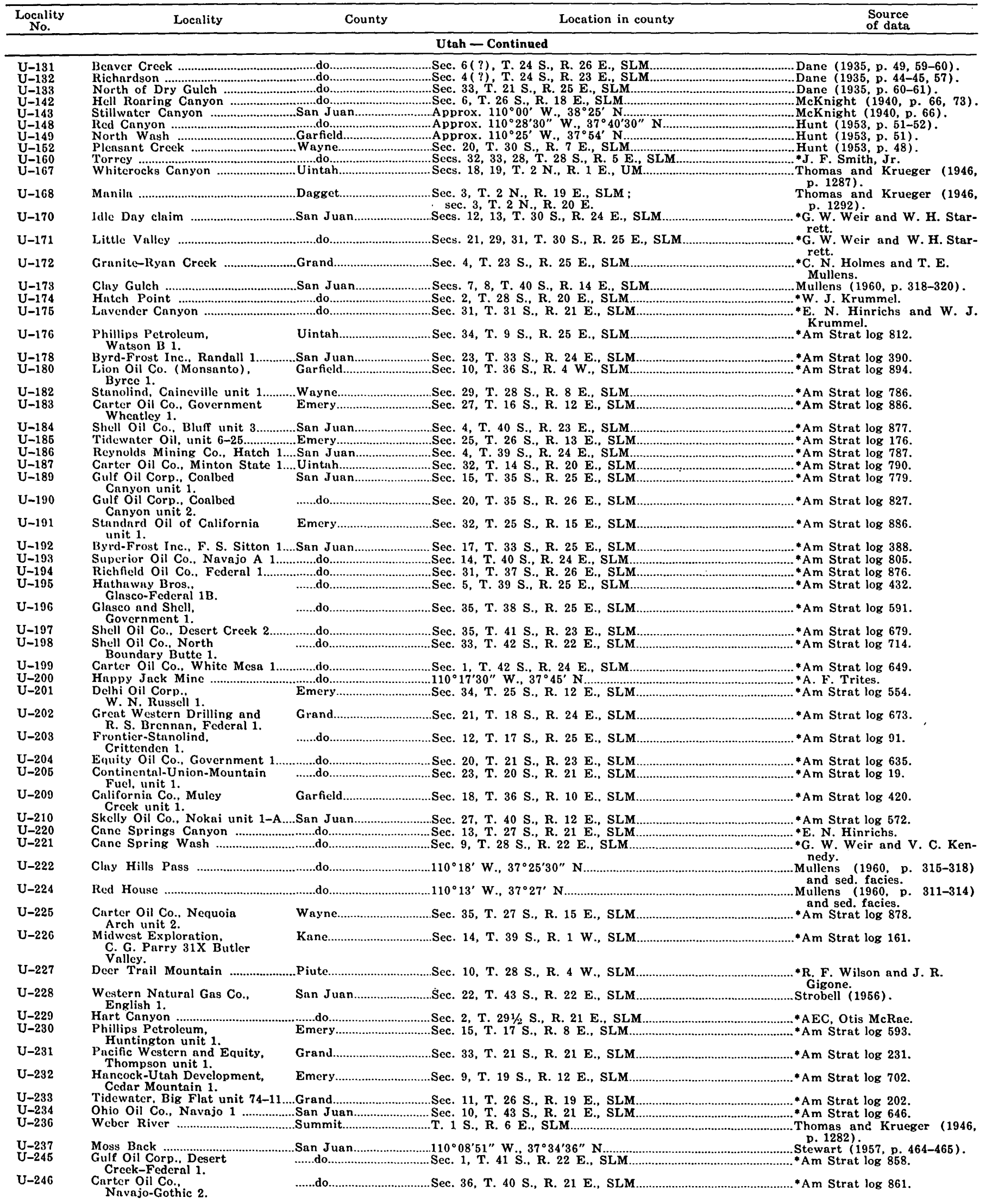


TABLE 1. - Index to location of control points shown on plate 1 and referred to in text, and source of data for each-Continued

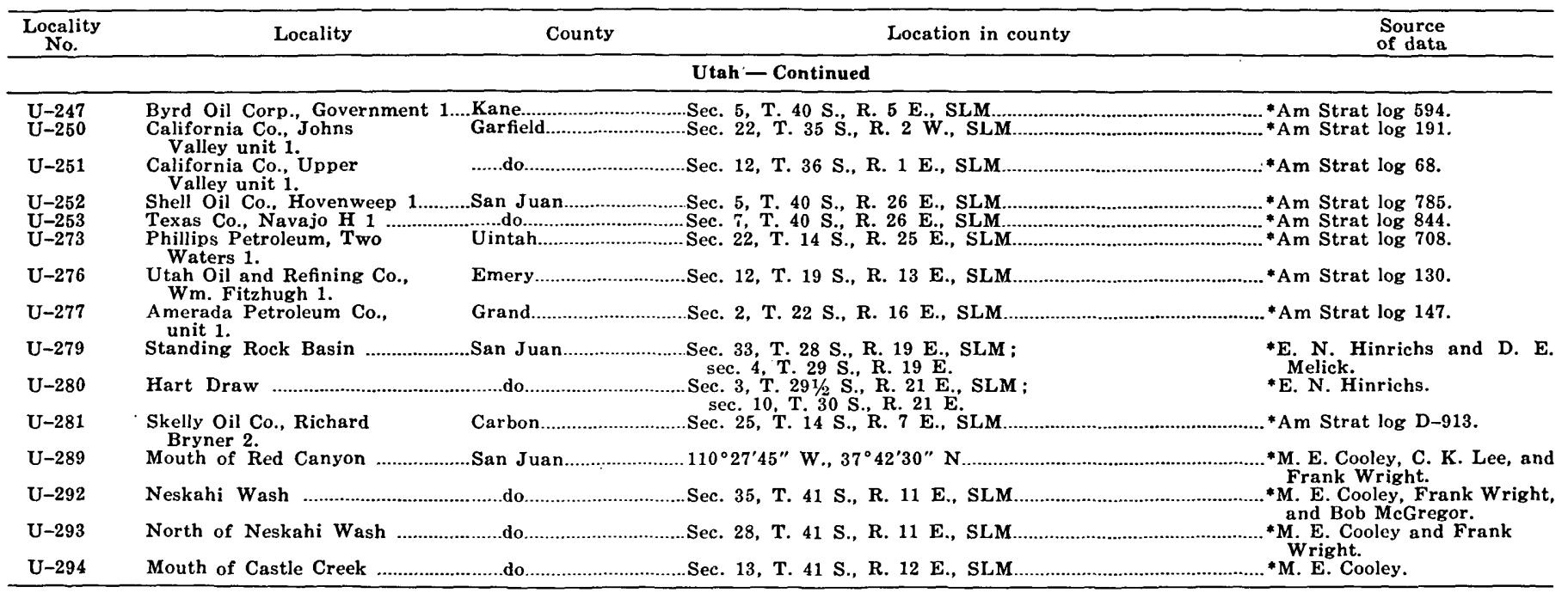

work, in 1853, was by Jules Marcou $(1855,1858)$, who traversed central New Mexico and Arizona and recognized various stratigraphic units, including his New Red Sandstone, which corresponds to the present-day Triassic rocks. J. S. Newberry $(1861,1876)$, first as a member of the Ives expedition in 1857 and 1858 and later with the Macomb expedition in 1859, briefly described the geology, including the Triassic strata, in northern Arizona, northwestern New Mexico, southwestern Colorado, and southwestern Utah.

During the 1860's, 1870's, and 1880's, the Colorado Plateau was the site of four great surveys that were sponsored largely by the U.S. Government: the famous Wheeler, Hayden, King, and Powell Surveys. The Wheeler Survey (U.S. Geographical Surveys West of the One-Hundredth Meridian), under the direction of the U.S. Army, undertook the geologic study of the Colorado Plateau, particularly the western border in southwestern Utah and northwestern Arizona. The Hayden Survey (Geological and Geographical Survey of the Territories), under the direction of the Department of the Interior, covered most of Colorado and small adjacent parts of Utah, Arizona, and New Mexico. The King Survey party (U.S. Geological Exploration of the Fortieth Parallel), under the direction of the U.S. Army, investigated and described the geology of parts of northern Utah and Colorado. The work done under direction of Maj. John W. Powell, often referred to as the Powell Survey, included studies carried out with private funds as well as those made under the Department of the Interior. The Powell Survey included parts of northern Arizona, eastern Utah, and northwestern Colorado. These early surveys recognized and named many stratigraphic units, some of which were correlated throughout a large part of the Colorado Plateau. Perhaps the most impressive attempt at regional correlation was that of Powell (1876), who recognized four major groups of strata of Trias and Jura age, as he called them. The divisions are, in ascending order, the Shinarump Group, the Vermilion Cliff Group, the White Cliff Group, and the Flaming Gorge Group. Powell correlated these groups between the Uinta Mountains on the north and northwestern Arizona on the south. The Shinarump Group included the Moenkopi and Chinle Formations as recognized today.

Of the names proposed by Powell, only Shinarump is used today. Powell used the term Shinarump in a dual sense: to describe a group, and to describe a thin sandstone and conglomerate unit (his Shinarump Conglomerate) within that group. This latter usage is the one that has been retained as the Shinarump Member of the Chinle Formation.

From 1899 to 1914, Whitman Cross and his associates examined and described the geology of the San Juan Mountains region (pl. 1) in southwestern Colorado. In this work, Cross and his associates defined the Dolores Formation (Cross, 1899); they later modified this definition (Cross and Howe, 1905a). The term Dolores Formation as used in Cross's modified definition is applied to rocks equivalent to the Chinle Formation, but the term is retained because of long-standing usage.

The next major work in the Colorado Plateau region was that by Gregory $(1914,1916$, and 1917), who described many of the salient features of the Triassic stratigraphy in north-central and east-central Arizona. Gregory's paper (1917) on the Navajo country (largely what is now included in the Navajo Indian Reservation) is an outstanding contribution to the stratigraphy of the Colorado Plateau. Although 
much of Gregory's work has been revised, many of his names and stratigraphic divisions are still used today. Gregory $(1915,1917)$ recognized the Shinarump Conglomerate and named the overlying Chinle Formation. His Shinarump Conglomerate is largely the same as the unit now called the Shinarump Member of the Chinle Formation. Gregory named the Chinle Formation for exposures in Chinle Valley in northeastern Arizona and recognized four divisions of the formation; these are, in descending order, his A, B, C, and $\mathrm{D}$ divisions. These divisions correspond to units now recognized as formally named members. The A division is the Rock Point Member of the Wingate Sandstone (and the laterally equivalent Church Rock Member of the Chinle Formation); the $\mathrm{B}$ division, the Owl Rock Member; the $\mathrm{C}$ division, the Petrified Forest Member; and the $\mathrm{D}$ division, the Monitor Butte and lower red members. These members are the basis of much of the detailed stratigraphic work recently done on the Colorado Plateau.

In the 1920's, 1930's, and 1940's, many detailed geologic mapping projects and stratigraphic studies were carried out on the Colorado Plateau, mostly under the direction of the U.S. Geological Survey. The most important stratigraphic paper resulting from these studies is one by Baker, Dane, and Reeside (1936) on the correlation of Jurassic formations in parts of Utah, Arizona, New Mexico, and Colorado. This paper, though mainly concerned with Jurassic formations, also contains considerable information on Triassic rocks. Other papers of this period that contain important stratigraphic information include those by Baker $(1933,1936,1946)$, Baker, Dane, and Reeside (1947), Dane (1935), McKnight (1940), Longwell, Miser, Moore, Bryan and Paige (1923), Gilluly and Reeside (1928), Gregory and Moore (1931), and Gregory (1938).

During the 1950's and 1960's, a large number of publications described the Chinle Formation and related strata, and members of the Chinle Formation were named and defined. These publications, though not discussed in chronological order, are referred to in the following discussion of the nomenclature used in different areas of the Colorado Plateau.

The nomenclature used in northern Arizona and adjacent parts of Nevada, Utah, and New Mexico (fig. 1, col. A) had its roots in the work of Gregory (in Gregory and Williams, 1947; Gregory, 1950) in Zion National Park and vicinity in southwestern Utah, but Gregory's nomenclature has been extensively modified. In the Zion area, Gregory recognized the Shinarump Conglomerate and the overlying Chinle Formation. The Shinarump Conglomerate has since been everywhere regarded as a member of the
Chinle Formation (Longwell, 1952; Stewart, 1957), a practice followed here. Also in the Zion area, Gregory divided the Chinle Formation into four members, which are, in ascending order : Lower sandstones; Petrified Forest Member; Springdale Sandstone Member; and upper sandstones. The thin "lower sandstones" unit is difficult to recognize as a distinct member and is included here in the Petrified Forest Member. The name Petrified Forest Member was first used in print by Maxey (1946, p. 337) and was defined by Gregory (in Gregory and Williams, 1947, p. 223 ; in Gregory, 1950, p. 67), but, as has been described by Averitt, Detterman, Harshbarger, Repenning, and Wilson (1955) and Harshbarger, Repenning, and Irwin (1957), the upper part of Gregory's original Petrified Forest Member, as well as his Springdale Sandstone Member and upper sandstones, is part of the Glen Canyon Group, which overlies the Chinle Formation elsewhere on the Colorado Plateau. The Chinle Formation as now recognized in the Zion area and adjacent areas in southwestern Utah and northwestern Arizona, therefore, is only the lower part of what was originally considered to be the Chinle Formation by Gregory. Similarly, the Chinle Formation as presently recognized in southern Nevada (Wilson and Stewart, 1967) is only the lower part of what was originally considered to be Chinle Formation by Longwell $(1928,1949)$ and Hewett (1956).

In northeastern Arizona, exclusive of the Monument Valley area, and in northwestern New Mexico (eastern part of area $A$, fig. 1), the nomenclature used here is largely the same as that used by Akers, Cooley, and Repenning (1958), Cooley (1959), and Repenning, Cooley, and Akers (1969). Here, the following members are recognized, in ascending order: (1) Shinarump Member, (2) the lower red member and the related, but geographically separate, Mesa Redondo Member and sandstone and mudstone member, (3) the Petrified Forest Member, and (4) the Owl Rock Member. The name "lower red member" was first used by Akers, Cooley, and Repenning (1958), and the Mesa Redondo Member was named by Cooley (1958). The sandstone and mudstone member is described in this report. The Petrified Forest Member, as already mentioned, was named by Maxey (1946) and Gregory (in Gregory and Williams, 1947) in the Zion National Park area in southwestern Utah. A prominent sandstone unit in the Petrified Forest Member in northeastern Utah and adjacent parts of New Mexico, termed the "Sonsela" by Kiersch (1955, p. 5), has been called the Sonsela Sandstone Bed by Akers, Cooley, and Repenning (1958). The name Owl Rock Member was first used by Kiersch $(1956$, p. 5), Witkind (1956, pl. 6), and Stewart (1957); the type 
$A$

SOUTHERN NEVADA, SOUTHWESTERN UTAH, NORTHWESTERN AND WESTCENTRAL NEW MEXICO, AND NORTHERN ARIZONA EXCLUSIVE OF MONUMENT VALLEY AREA

Harshbarger, Repenning, and Irwin (1957) Repenning, Cooley, and Akers (1969) Averitt, Detterman, Harshbarger, Repenning, and Wilson (1955) Wilson and Stewart (1967)

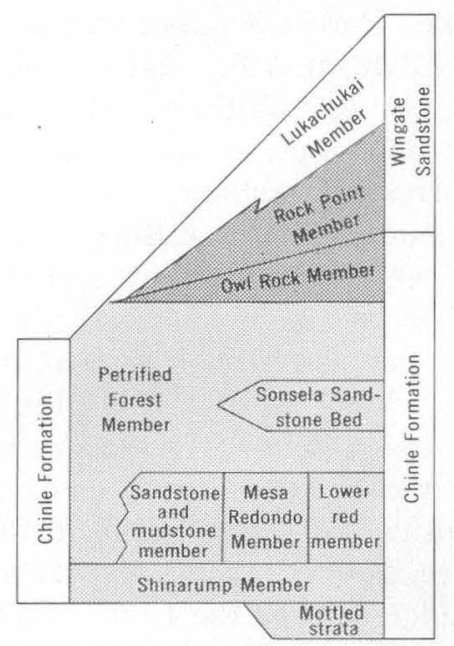

$D$

SOUTHWESTERN COLORADO

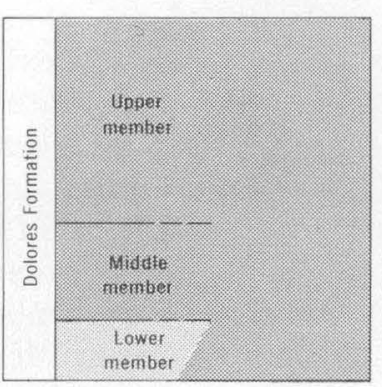

EXPLANATION

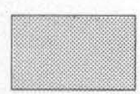

Upper (red-bed) part of Chinle Formation and related strata

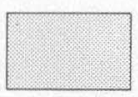

Lower (bentonitic) part of Chinle Formation and related strata

\section{$B$}
SOUTHEASTERN AND EAST-CENTRAL
UTAH AND MONUMENT VALLEY AREA, NORTHERN ARIZONA Stewart (1957)
Stewart, Williams, Albee, and Raup (1959) Witkind and Thaden (1963)

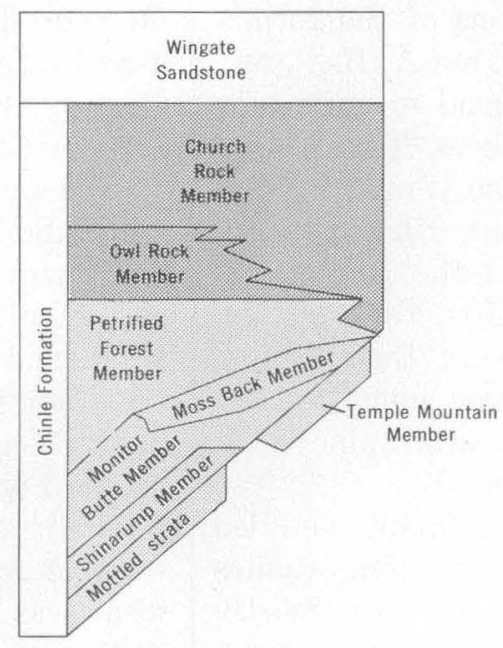

$E$

WEST-CENTRAL AND CENTRAL COLORADO Poole and Stewart (1964)

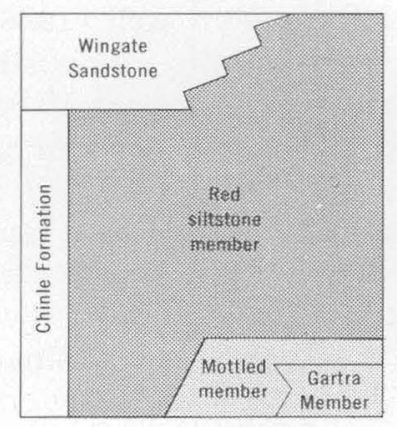

C

NORTH-CENTRAL NEW MEXICO

Modified from Wood and Northrop (1946)

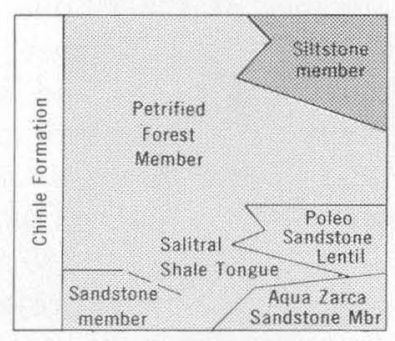

F

NORTHEASTERN UTAH AND NORTHWESTERN COLORADO

Poole and Stewart (1964)

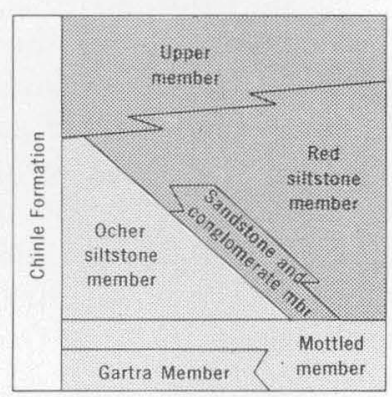

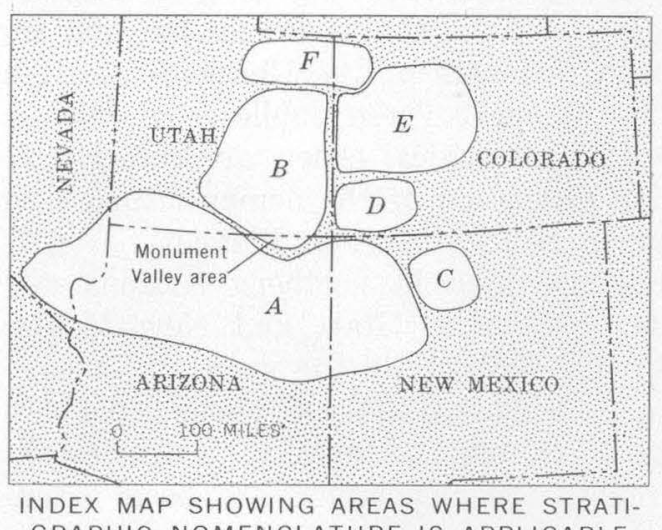

GRAPHIC NOMENCLATURE IS APPLICABLE

FigURE 1. - Nomenclature of the Chinle Formation and related strata in the Colorado Plateau region. 
section was described by Witkind and Thaden (1963, p. 30-32).

As originally defined by Gregory (1917) in northeastern Arizona, the uppermost part of the Chinle Formation included red siltstone, called Division A, and the top of the Chinle Formation was placed at the contact between siltstone below and the massive sandstone of the Wingate Sandstone above. Harshbarger, Repenning, and Irwin (1957), however, removed the red siltstone (Gregory's Division A) from the Chinle Formation and assigned it to the overlying Wingate Sandstone. Their Wingate Sandstone thus consists of a lower member of red siltstone, which they called the Rock Point Member, and an upper member of massive sandstone, the original Wingate Sandstone, which they called the Lukachukai Member. This nomenclature is used in this report, although, as will be described later, the writers feel that the red siltstone termed the Rock Point Member is lithologically more related to the Chinle than to the Wingate.

For southeastern and east-central Utah and the Monument Valley area, northeastern Arizona (fig. 1 , col. $B$ ), the nomenclature used here is largely the same as that used by Stewart (1957) and by Stewart, Williams, Albee and Raup (1959). Here, in ascending order, the following members are recognized: Shinarump, Monitor Butte, Moss Back, Petrified Forest, Owl Rock, and Church Rock. The names Monitor Butte and Owl Rock Members were first used by Kiersch (1956, p. 4), Witkind (1956, pl.6) and Stewart (1957) ; the type sections were described by Witkind and Thaden (1963, p. 26-28, 30-32). The Moss Back Member was first described as the "Moss Back" sandstone unit by Stewart and Smith (1954, p. 31 ), and later it was defined as a member by Stewart (1957). The name Church Rock Member was first used by Stewart (1957); the section that is considered to be the type section was described by Witkind and Thaden (1963, p. 32-34) in Monument Valley, northeastern Arizona. The Church Rock Member in the type area consists mostly of red siltstone at the top of the Chinle Formation and is considered to be the same unit as the Rock Point Member of the Wingate Sandstone as defined by Harshbarger, Repenning, and $\operatorname{Irwin}^{\circ}(1957)$ to the south in adjacent areas in Arizona. Here, and also in Harshbarger, Repenning and Irwin (1957) and in Witkind and Thaden (1963), the name Rock Point Member of the Wingate Sandstone is used for the unit of red siltstone south of Laguna Creek in Arizona, and the name Church Rock Member of the Chinle Formation is used for the same unit north of Laguna Creek. The details of this nomenclatural problem are described in the section on the upper part of the Chinle Formation.

In southeastern Utah and locally elsewhere in the Colorado Plateau, thin units composed principally of mottled siltstone occur locally at the base of the Chinle Formation. In the San Rafael Swell, these mottled strata form a well-defined unit that has been named the Temple Mountain Member of the Chinle Formation by Robeck (1956) .

In north-central New Mexico (fig. 1, col. $C$ ), the names Agua Zarca Sandstone Member and the Salitral Shale Tongue of the Chinle Formation were proposed and defined by Wood and Northrop (1946). The Poleo Sandstone Lentil was originally called the "Poleo Top Sandstone" by Huene (1911) and later was defined as a lentil by Wood and Northrop (1946). The informal name "sandstone member" is here used for strata that were originally included in the Agua Zarca, but, as described later, appear to form a lithologically distinct unit separate from the Agua Zarca. Use of the name Petrified Forest Member in north-central New Mexico is based on information presented in this report. The informal name "siltstone member" is used in north-central New Mexico to describe a local unit of red beds.

In southwestern Colorado (fig. 1, col. $D$ ), the longstanding name Dolores Formation is used, although it is correlative with the Chinle Formation recognized elsewhere in the Colorado Plateau region. In the southern part of southwestern Colorado, three members are recognized in the Dolores Formation. In the northern part of the area, a thin basal sandstone is the most conspicuous unit in the formation; there the three members cannot be recognized.

In most of west-central and central Colorado (fig. 1, col. E), the Gartra, mottled, and red siltstone members are recognized in the Chinle Formation (Poole and Stewart, 1964); but in the southwestern part of this area, the Gartra and mottled members are not recognized, and the Chinle consists of a basal sandstone unit and an overlying red siltstone member.

In northeastern Utah and northwestern Colorado (fig. 1, col. F), the Shinarump and the overlying part of the Chinle Formation have been recognized by most geologists (Thomas and others, 1945; Huddle and McCann, 1947; Kinney, 1951, 1955; Brill, 1944; Donner, 1949; Sheridan, 1950). The name Gartra was originally proposed by Thomas and Krueger (1946), who used the term Gartra Grit Member of the Stanaker Formation. Because of regional work on the Colorado Plateau, the Shinarump in this area can be shown to be a separate unit and has been redefined as the Gartra Member of the Chinle Forma- 
tion (Poole and Stewart, 1964). Overlying the Gartra Member, a mottled member, an ocher siltstone member, and an upper member have been recognized by Poole and Stewart (1964). The nomenclature of Poole and Stewart is used here.

\section{STRATIGRAPHY}

The Chinle Formation and the laterally continuous Dolores Formation extend over most of the Colorado Plateau and adjacent areas. The distribution of these formations and the lateral relations of the various units within them is shown on the fence diagram (pl. 2 ). The name Chinle Formation is generally used in Colorado and Utah, but to the north, in Wyoming, rocks of similar age and lithologic type are largely included in the Popo Agie Formation. To the east, in north-central and central Colorado, the Chinle Formation pinches out on the flanks of the ancestral Uncompahgre and Front Range highlands. To the southeast, rocks of Late Triassic age extend into southeastern Colorado, eastern New Mexico, the panhandle of Oklahoma, southwestern Kansas, and western Texas (McKee and others, 1959). In these areas, the term Dockum Group, consisting of the Santa Rosa Sandstone and the Chinle Formation, is mostly used. To the south, the Chinle Formation probably did not extend beyond the north flank of the Mogollon highland, an ancient highland which occupied southern Arizona and adjacent parts of California and New Mexico. The Chinle Formation is well defined in the southern part of the Spring Mountains near Las Vegas, Nev., but correlation of the formation west of this area is uncertain. Upper Triassic rocks, however, occur extensively in western Nevada and at several localities in southeastern California (Reeside and others, 1957). The Chinle Formation represents only a part of the extensive Upper Triassic deposits of the western United States (McKee and others, 1959).

On most of the Colorado Plateau, the Chinle Formation unconformably overlies the Moenkopi Formation of Early and Middle (?) Triassic age or laterally continuous strata (pl. 3). In the eastern part of the plateau, the Moenkopi Formation is absent, and the Chinle Formation rests unconformably on rocks of Permian age. On the flanks of the ancestral Uncompahgre and Front Range highlands in Colorado and New Mexico, the Chinle Formation locally rests uncomformably on pre-Permian rocks, and nearer the crest it rests on igneous and metamorphic rocks of Precambrian age.

The lower boundary of the formation is everywhere an unconformity. The unconformity is a remarkably flat surface in some areas but in other areas consists of swales or of channels scoured into the underlying rocks and filled with the strata of the Chinle Formation. In only a few areas, mostly along the flanks of the Uncompahgre and Front Range highlands, can angularity be noted between the Chinle Formation and the underlying sedimentary rocks. Such angularity occurs in the Ouray area in southwestern Colorado, where the Dolores Formation (a lateral equivalent of the Chinle Formation) rests with a discordance of $6^{\circ}$ or $7^{\circ}$ on formations of Paleozoic age (Cross and Howe, 1905b).

In most of the Colorado Plateau region, the Chinle Formation is overlain by formations of the Glen Canyon Group. In the central part of the plateau, the basal formation of this group, the Wingate Sandstone (Upper Triassic), overlies the Chinle Formation. The contact of the Chinle Formation and Wingate Sandstone is a flat plane and is considered to be a disconformity in the central part of southeast Utah, although it appears conformable in easternmost Utah, western Colorado, and parts of northeastern Arizona. In north-central Arizona, southwestern Utah, and southern Nevada, the Moenave Formation (Triassic?) or the Moenave and Kayenta Formations undifferentiated (also Triassic?) of the Glen Canyon Group disconformably overlie the Chinle Formation. In southwestern and northeastern Utah and northwesternmost Colorado, the Glen Canyon Sandstone (Triassic and Jurassic) conformably overlies the Chinle Formation. Along the eastern margin of the Colorado Plateau, the Entrada Sandstone (Upper Jurassic) of the San Rafael Group truncates older formations eastward and unconformably rests on the Chinle Formation in north-central New Mexico and south-central, central, and parts of north-central Colorado. Along the southern margin of the Colorado Plateau, the Dakota Sandstone (Early and Late Cretaceous in age) truncates older formations southward and on outcrops in east-central Arizona and west-central New Mexico unconformably overlies the Chinle Formation. In east-central Arizona, the Dakota Sandstone truncates the entire Chinle Formation and rests directly on the Moenkopi Formation. Such southward beveling and total truncation of the Chinle Formation by erosion prior to the deposition of the Dakota Sandstone can be demonstrated only in eastcentral Arizona but probably occurred elsewhere or everywhere along the southern margin of the Colorado Plateau. Locally, in the eastern part of the Defiance uplift in northeast Arizona, the Chinle is overlain disconformably by the Bidahochi Formation of Tertiary age.

The Chinle Formation and related strata range in thickness from a wedge edge to slightly more than 
1,700 feet (pl. 3). Thickness is greatest, generally more than 1,000 feet, in east-central Arizona and west-central New Mexico and decreases to the north and northeast; it is also slightly more than 1,000 feet in a local basin in northwestern Colorado.

The Chinle Formation is divided into two major parts (fig. 1) on the basis of distinct lithologic characteristics that closely reflect differences in the environment of deposition and in the source of constituting material. The lower (bentonitic) part consists of variegated bentonitic claystone and clayey sandstone of the Monitor Butte, Petrified Forest, and related members and of thin widespread ledge-forming sandstone and conglomerate units such as the Shinarump and Moss Back Members. These strata contain abundant volcanic debris largely derived from a southern source, the Mogollon highland in southern Arizona. A minor contribution of sediment was from the Uncompahgre and Front Range highlands of Colorado and northern New Mexico.

The upper (red-beds) part of the Chinle Formation is composed of reddish-brown horizontally bedded or structureless siltstone and sandstone, limestone pebble conglomerate, and cross-stratified sandstone. It consists of the Owl Rock Member overlain by the Church Rock Member and related units. These strata are commonly arkosic and were largely derived from the igneous and metamorphic terrane of the Uncompahgre and Front Range highlands of Colorado and northern New Mexico, although some sediment was from the Mogollon highland in southern Arizona.

The contact between the upper and lower parts of the Chinle Formation is gradational and intertonguing, and although the lithologic differences between the two parts are marked, the exact boundary is difficult to locate precisely in many areas. In some areas, the contact is gradational across at least 200 feet.

The units and members in the Chinle Formation are of two general types: (1) thin lithologically homogeneous sandstone and conglomerate units, such as the Shinarump Member, Moss Back Member, and the Sonsela Sandstone Bed, and (2) thick lithologically heterogeneous units such as the Monitor Butte, Petrified Forest, Owl Rock, and Church Rock Members. Units of the first type are fairly easy to study, and few problems arise about correlation. Units of the second type, however, present many problems of definition and correlation, and study of them has led to conflicting concepts of what strata are included in a unit and of how far a unit extends. These different concepts are related to the complexity of the stratigraphy of the rocks being studied. The formation is composed of complexly intertonguing and intergrad- ing units rather than of a simple stack of widespread and lithologically distinct units.

The members described here are recognized on the basis of lithologic characteristics that distinguish them from overlying and underlying units, but considerable freedom is retained in the usage so that laterally continuous strata of somewhat different facies and unusual local rock types can be included. Lateral gradation of part or all of one member into another is common, and upward or downward transgression of a unit within the Chinle also occurs. In addition, no age correlation is intended in the use of a member name; possibly a unit may be entirely younger in one area than the same lithic and probably physically continuous unit in another area. Probably most of these members are complex internally, and some are difficult to distinguish from overlying and underlying rocks. Some uncertainty will therefore probably always remain as to the most logical way of dividing the Chinle.

\section{LOWER (BENTONITIC) PART OF CHINLE FORMATION}

The lower part of the Chinle Formation, which is composed mainly of variegated bentonitic claystone, clayey sandstone, and thin widespread units of sandstone and conglomerate, extends throughout much of the Colorado Plateau (pl. 4). It is thickest, generally over 1,000 feet, in east-central Arizona and westcentral New Mexico, and it thins to the north.

The lower (bentonitic) part of the Chinle Formation contains 11 members or units with formal names and nearly that many with informal names (fig. 1). In addition, some of the members contain regionally persistent units, some of which have been given informal names. Many of these members and units are distinguished only in a part of the Colorado Plateau region and grade laterally into other recognized units. Description of these complexly interrelated units requires some sort of grouping to give a coherent picture. To do this, the lower part of the formation is divided into five units or groups of related units, which are, in ascending order: (1) Mottled strata, (2) Shinarump Member and related units, (3) Monitor Butte and related members, (4) Moss Back and related members, and (5) Petrified Forest and ocher siltstone members. This grouping is somewhat arbitrary and perhaps presents an oversimplification of the stratigraphic relationships, but it emphasizes gross lithologic similarities of units.

\section{MOTTLED STRATA}

The term "mottled strata" describes rocks with a peculiar mottling of reddish purple, pale reddish brown, and light greenish gray that occur pre- 
dominantly in the basal part of the Chinle Formation. The mottled coloration is believed to have formed by some process of alteration, probably during the formation of a soil. The alteration commonly crosses strattigraphic boundaries and has been imposed on different kinds of rocks in different places. Locally, the alteration extends downward into the top few feet of the sedimentary or metamorphic rocks directly below the Chinle Formation.

With few exceptions, the mottled strata occur at the base, or in the basal part, of the Chinle Formation or in the top few feet of the rocks directly below the Chinle Formation. The rocks directly below the Chinle on which the mottled coloration is developed include the Moenkopi Formation in much of the Colorado Plateau, the Cutler Formation (Permian) in southwestern Colorado and northcentral New Mexico, the DeChelly Sandstone (Permian) in northeastern Arizona, and meta- morphic rocks of Precambrian age in southwestern Colorado. Locally the mottled strata occur both in the basal few feet of the Chinle Formation and in the top few feet of the underlying formation, and the basal contact of the Chinle Formation lies within the mottled strata.

The mottled strata in the basal part of the Chinle Formation occur in several stratigraphic units, including the Shinarump Member, Agua Zarca Sandstone Member, and sandstone and mudstone member. In addition, the Temple Mountain Member (Robeck, 1956) (fig. 2) in the San Rafael Swell and the mottled member (Poole and Stewart, 1964) (fig. 3) in northeastern Utah and northwestern Colorado are composed predominantly of mottled rocks. In some areas, the mottled rocks form fairly distinct units at the base of the Chinle Formation and are not assignable to any established stratigraphic unit. In
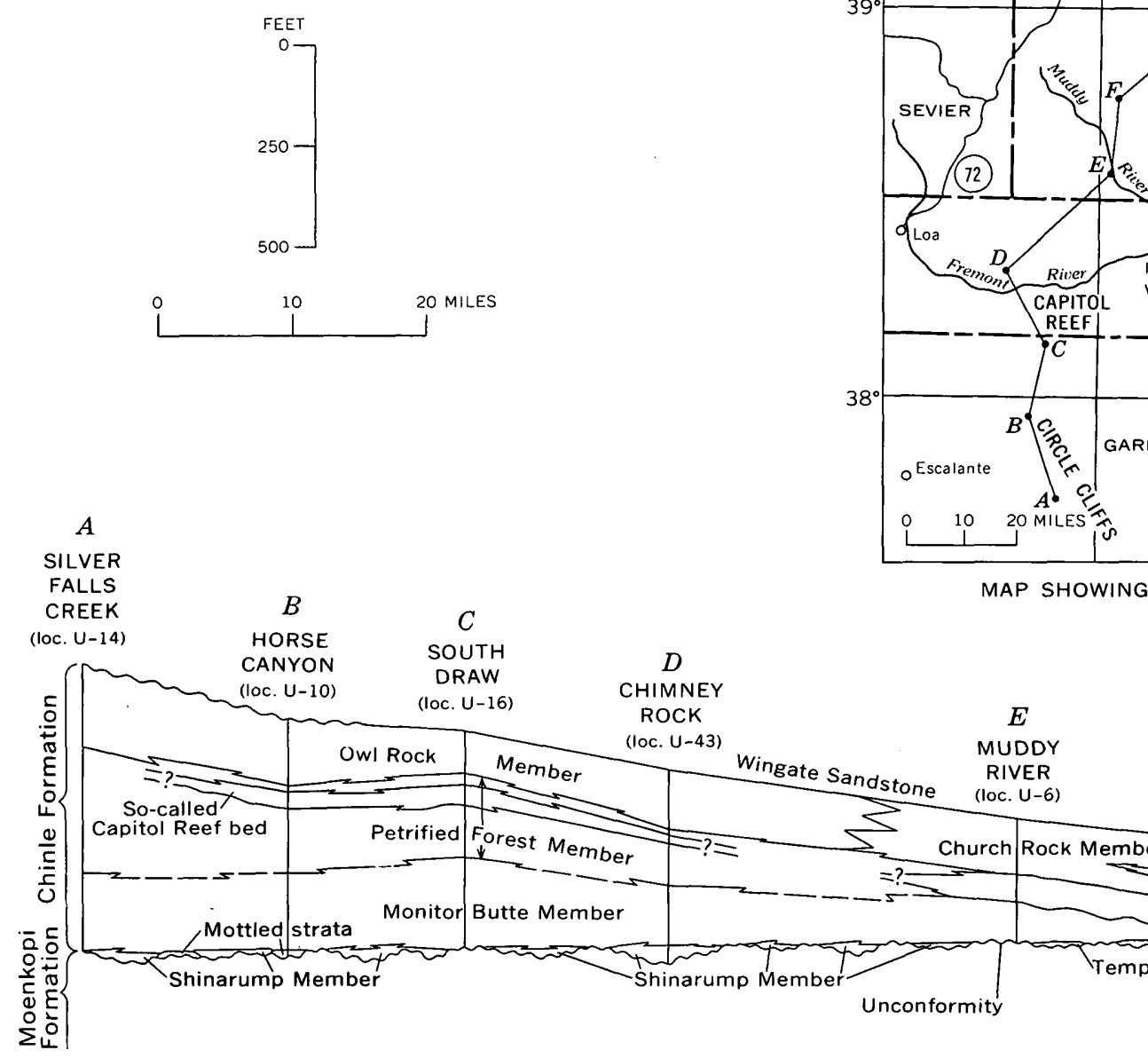

FIgURE 2. - Correlation of Chinle Formation from Circle Cliffs to San Rafael Swell, Utah.

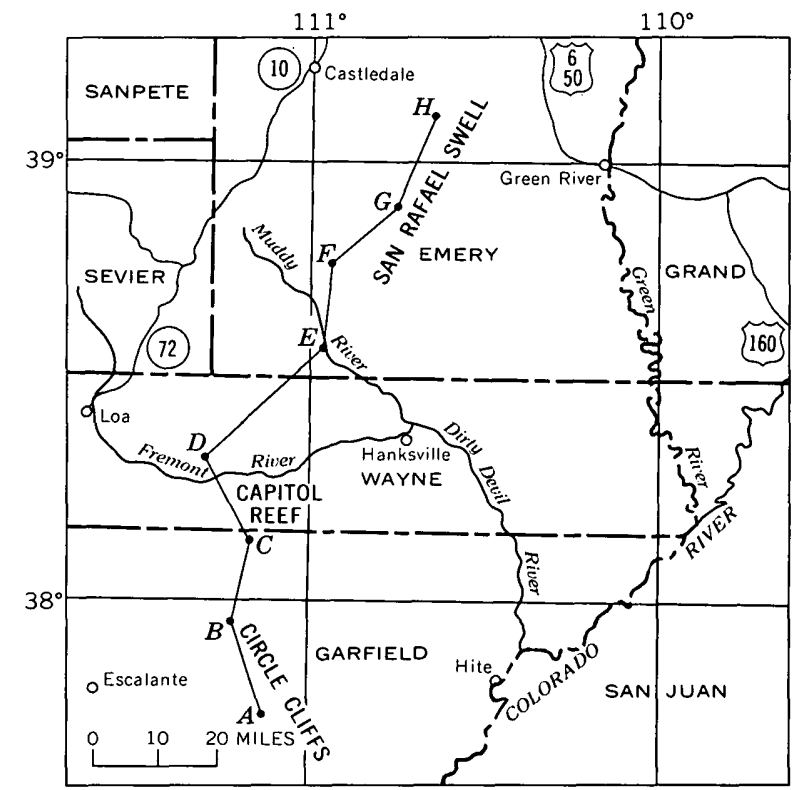

LOCATION OF SECTION 
these areas, the rocks are referred to informally as mottled strata.

The mottled member in northeastern Utah and northwestern Colorado differs from other occurrences of such rock in that it overlies the basal sandstone and conglomerate unit, the Gartra Member of the Chinle Formation, whereas elsewhere these mottled strata generally underlie such units. Another unusual occurrence of the mottled strata is along Echo Cliffs in northeastern Arizona, where thin intervals of mottled siltstone, sandstone, and con- glomeratic sandstone occur as much as 240 feet above the base of the Chinle Formation.

The mottled rocks have a widespread but spotty distribution on the Colorado Plateau. They probably occur on less than 10 percent of the outcrops of the Chinle Formation but have been found in almost every area of the plateau and adjacent regions. The most characteristic occurrence is in poorly defined lenses 5 to 10 feet thick that extend along the outcrop for 100 feet to several thousand feet. In some areas, the mottled strata are continuous for several

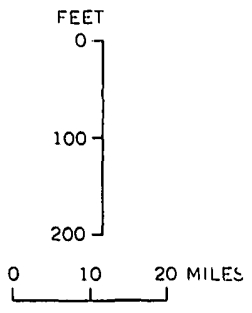

\section{$A$}

LAKE FORK

RIVER

(loc. U-1)

है

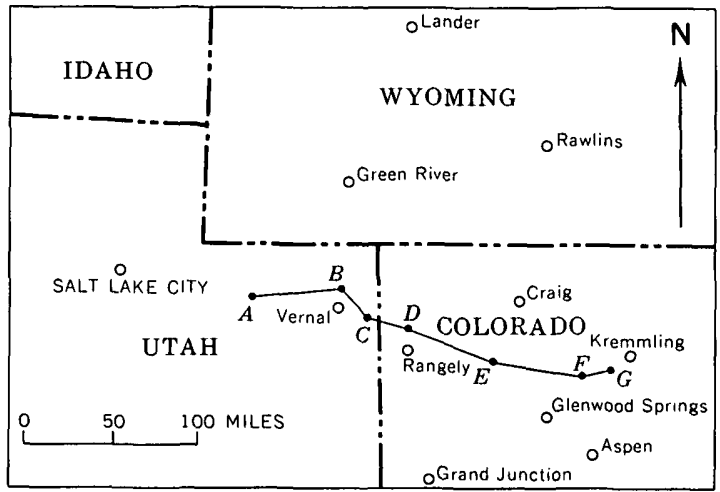

MAP SHOWING LOCATION OF SECTION

$E$

MILLER

CREEK

CRE-

1

RED SHEEPHORN (loc. $\mathrm{C}-3)$

\section{MEEKER}

(OAK RIDGE)

(loc. C-18)

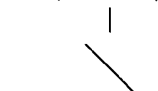

Morrison Formation and Curtis

Formation undivided

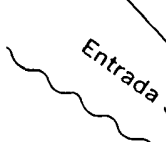

CANYON CRE

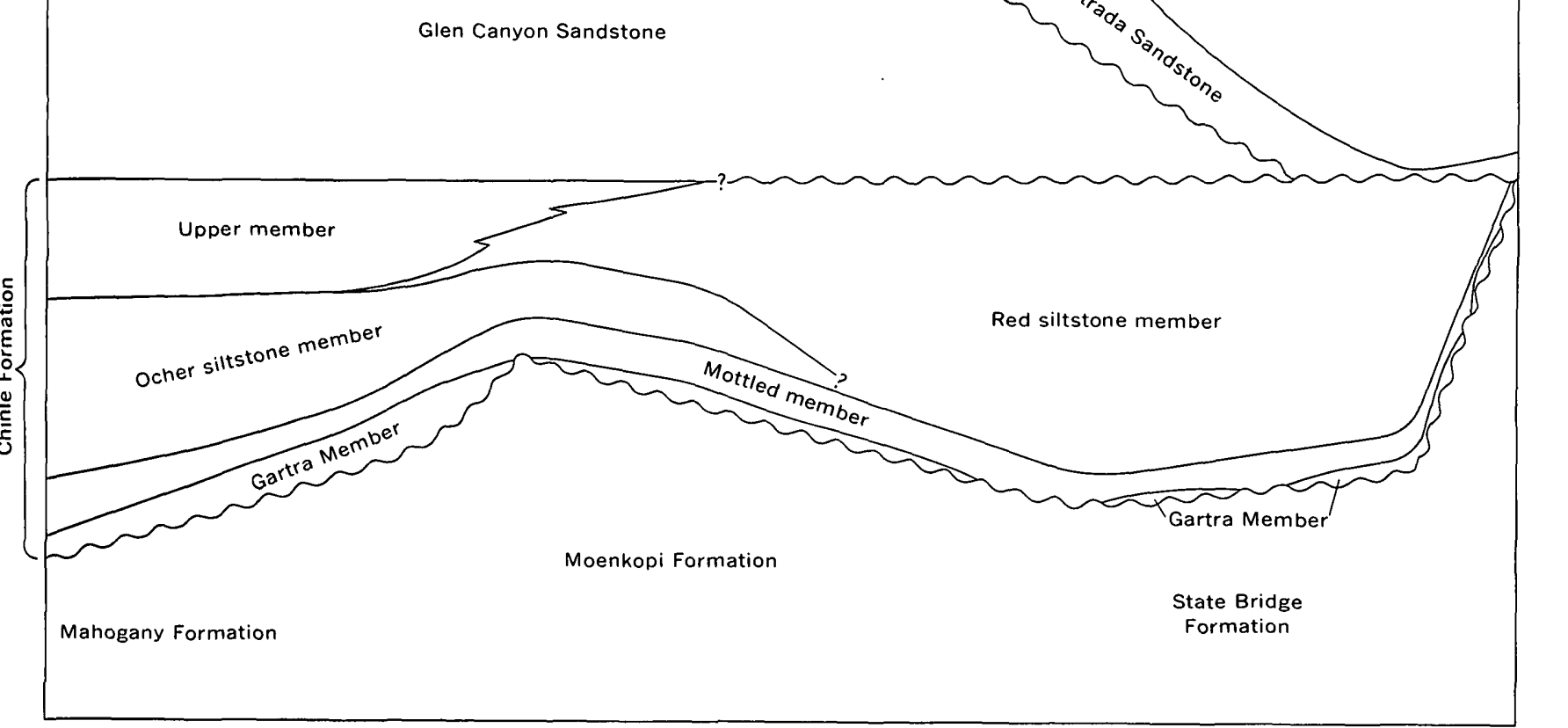

Figure 3. - Correlation of Chinle Formation in northeastern Utah and northwestern Colorado. 
miles. The Temple Mountain Member, which is composed predominantly of mottled rock, extends for many miles without interruption and occurs on 85 percent of the outcrops of the Chinle Formation in the San Rafael Swell (Robeck, 1956). The mottled member (Poole and Stewart, 1964) in northeastern Utah and northwestern Colorado is also a persistent unit.

Rocks characterized by a distinctive mottled coloration, striking and unmistakable in its typical form, include siltstone, sandy siltstone, sandstone, and conglomerate, and even granitic or metamorphic rock (fig. 4). In these rocks, reddish purple, pale reddish brown, and light greenish gray are intricately mottled; irregular blotches generally 1 or 2 inches across of one color are intricately interwoven with blotches of the other colors. In a few areas, irregular vertical gray bands a few inches across produce conspicuous stripes.

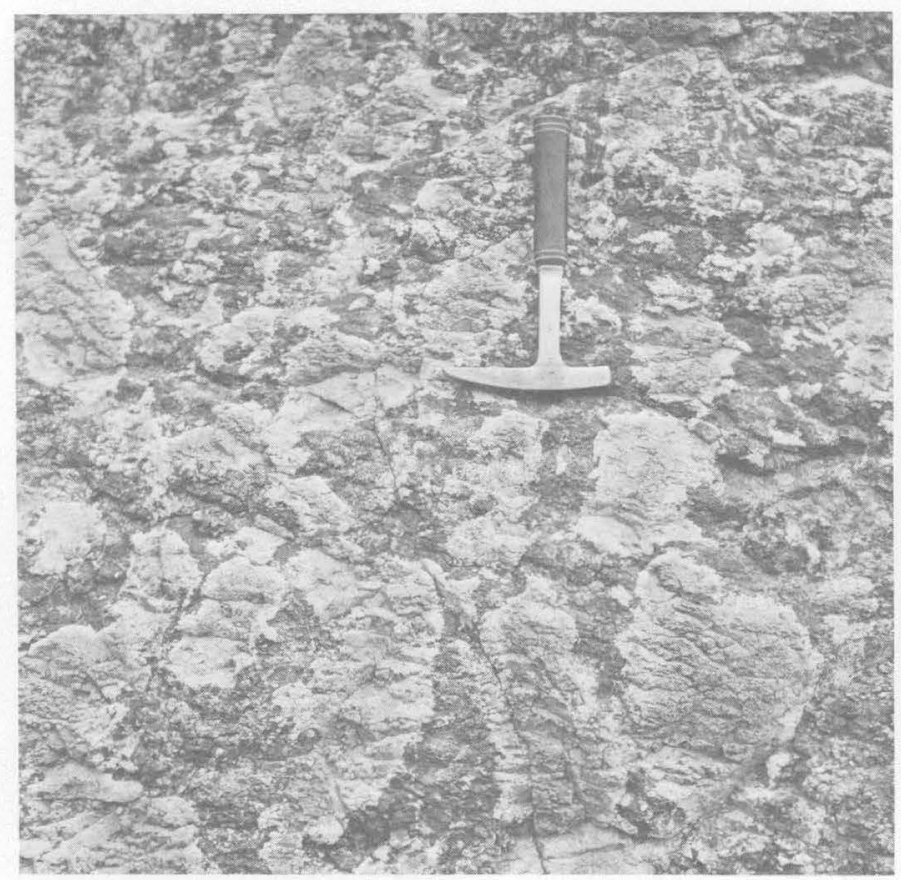

Figure 4. - Mottled strata in basal part of Chinle Formation about 7 miles up the Colorado River from Moab, Utah.

The most common mottled rock is siltstone that contains scattered fine to very coarse rounded grains of quartz. Such grains of quartz have not been noted in the mottled strata of the Moenkopi Formation, and the presence or absence of these grains, therefore, is one basis for distinguishing the mottled strata of the Chinle Formation from strata that may occur directly below at the top of the Moenkopi Formation.

The mottled strata are most commonly 5 to 25 feet thick. The Temple Mountain Member, which is composed mainly of mottled rock, is generally about 20 to 30 feet thick in the San Rafael Swell (fig. 2) and attains a maximum thickness of 101 feet in a channel fill (Robeck, 1956). The mottled member (Poole and Stewart, 1964) in northeastern Utah and northwestern Colorado is generally 20 to 50 feet thick. The mottled strata are unusually thick - at least 200 feet - at the locality about 7 miles up the Colorado River from Moab, Utah, where the photograph (fig. 4) was taken.

The contact of the mottled strata with underlying rocks is, in most places, poorly defined and transitional. The upper contact is commonly sharp but may be gradational.

\section{SHINARUMP AND RELATED MEMBERS}

Thin, relatively widespread cross-stratified sandstone and conglomerate units, all considered to be stream deposits, occur at the base of the Chinle Formation or are separated from the base by a few feet of mottled strata. These units include (1) the Shinarump Member, throughout a large part of the Colorado Plateau, (2) the Agua Zarca Sandstone Member, in the Rio Chama, San Pedro Mountain, and Nacimiento Mountains areas in north-central New Mexico, (3) an unnamed sandstone member, in the San Ysidro area of north-central New Mexico, and (4) the Gartra Member, in northeastern Utah and northwestern Colorado. Although these units resemble each other in gross lithologic characteristics, they are geographically separate stratigraphic units.

\section{SHINARUMP MEMBER}

The Shinarump Conglomerate, as it was originally called, was named for the Shinarump Cliffs (pl. 1) in southwestern Utah. The unit was first recognized by Powell (1873), who used the name Shinarump Cliffs for the topographic feature developed on the unit, although he did not specifically use the name Shinarump Conglomerate. The term was first used in print by Gilbert (1875) and Howell (1875), and these geologists are often given credit for the name. References to Powell in the works of Gilbert and Howell, however, leave little doubt that they considered Powell the originator of the term, even though he did not publish the name until 1876. The Shinarump Conglomerate was considered a separate formation until recently, when it was recognized as a member of the Chinle Formation (Longwell, 1952; Stewart, 1957).

The Shinarump Member is a sandstone and conglomerate unit believed to have been deposited by a complex stream system in which the time of deposition and the provenance of the deposits varied 
somewhat from place to place. Such a complex of stream deposits creates nomenclatural difficulties because one cannot be sure how widely to apply a particular stratigraphic name. Many geologists have used the term Shinarump throughout much of the Colorado Plateau and beyond, but such a policy seems unfortunate if the term ilas been extended so far that it has lost specific meaning other than to indicate any sandstone or conglomerate in a particular stratigraphic position. On the other hand, to apply individual names to each isolated lens or to a small natural grouping of lenses seems to be equally inappropriate if it leads to a proliferation of formal terms. The policy used here is a compromise between the two views and attempts to lump together similar units but does not extend the term over too wide an area. Nonetheless, it is difficult to be completely consistent in applying the name Shinarump, and geologists differ in their concept of how the term should be used.

The Shinarump Member occurs in about 140,000 square miles of the southwestern two-thirds of the Colorado Plateau region, although it is absent in several large areas and many small areas within this region (pl. 4). The distribution of the member is difficult to depict on a small-scale map because details of the occurrence of the member are highly complex. In some areas, the member occurs along much of the outcrop and is absent only locally; in other areas, it occurs only along a small part of the outcrop. An attempt has been made on the map to show areas where the member is present along about 90 percent of the outcrop and also areas where it is absent along about 90 percent of the outcrop. This arbitrary arrangement gives some idea of the distribution, though one far from satisfactory or complete. Outside of areas of outcrop, the distribution pattern is highly interpretive and presents a conceptual picture rather than a factual one.

The Shinarump Member also occurs as isolated lenses in outcrops in west-central and central New Mexico (fig. 5), although this is not shown on plate 4. Such lenses occur at Fort Wingate (fig. 5, loc. A) and on the west side of the Lucero uplift (pl. 1), in sec. 4 , T. 6 N., R. 4 W.

In southeastern Utah, Young (1964, p. 856-860) has recognized the Shinarump Member over a larger area than we do in this report. He considers that the Shinarump Member extends as isolated lenses far north of the northern limit recognized in this report, and he recognizes an unconformity between his Shinarump and the overlying part of the Chinle Formation. We feel that the units that he calls Shinarump near the Colorado River north of Elk
Ridge are probably coarse basal deposits of the Moss Back Member, which in this area lies at the base of the Chinle Formation.

The Shinarump Member is typically yellowishgray and pale-yellowish-orange fine- to coarsegrained friable sandstone. Lenses of conglomeratic sandstone and conglomerate containing granules and pebbles predominantly of quartz, quartzite, and chert are common. Some conglomerate layers, mostly near the base of the member, are composed largely or entirely of siltstone fragments derived locally from erosion of underlying rocks. Fragments and $\operatorname{logs}$ of silicified and carbonized wood are locally abundant. Most of the unit is cross stratified, although horizontally stratified and structureless layers occur also. The cross-strata (fig. 6) are in tabularplanar and trough sets, generally 0.5 foot to 2 feet thick. Rib-and-furrow structures (also called microcross-strata or small-scale cross-strata) are common near the top of the member. The member is a resistant unit that forms vertical cliffs (fig. 7) and in some areas underlies broad benches.

The thickness of the Shinarump Member is variable but may average about 30 feet; in some areas, it is 60 feet along many miles of outcrop. The member is commonly 100 or more feet thick where it fills channels and is 250 feet thick in a channel fill reported by Young (1964, p. 860).

The lower contact of the Shinarump Member is an erosion surface. In some areas, the contact is marked by conspicuous channels cut into the Moenkopi Formation and filled with the sedimentary rocks of the Shinarump. These channels commonly are a few hundred feet wide and cut 25 to 75 feet into the Moenkopi Formation (Witkind, 1956). Some, however, are much wider, up to 2,300 feet wide; and others are much deeper, as much as 150 feet deep, especially where local deeper scours occur within a channel (Black and others, 1962, fig. 65B). Channels have been traced for distances as great as 4 miles (Witkind and Thaden, 1963, p. 104). They are most conspicuous in the Shinarump in Circle Cliffs, Utah; in Monument Valley, Utah and Arizona; and near Lees Ferry, Ariz.

The lower contact of the Shinarump Member is also marked by broad swales or valleys which range in width from 1 to 3 miles and have a relief of about 40 feet in the Monument Valley area, Arizona (Witkind, 1956). A swale at Lees Ferry (pl. 1) in north-central Arizona is at least 10 miles wide and extends 175 feet into the Moenkopi Formation (Phoenix, 1963, fig. 6).

In areas where channels and swales are not present, the lower contact of the Shinarump Member is 


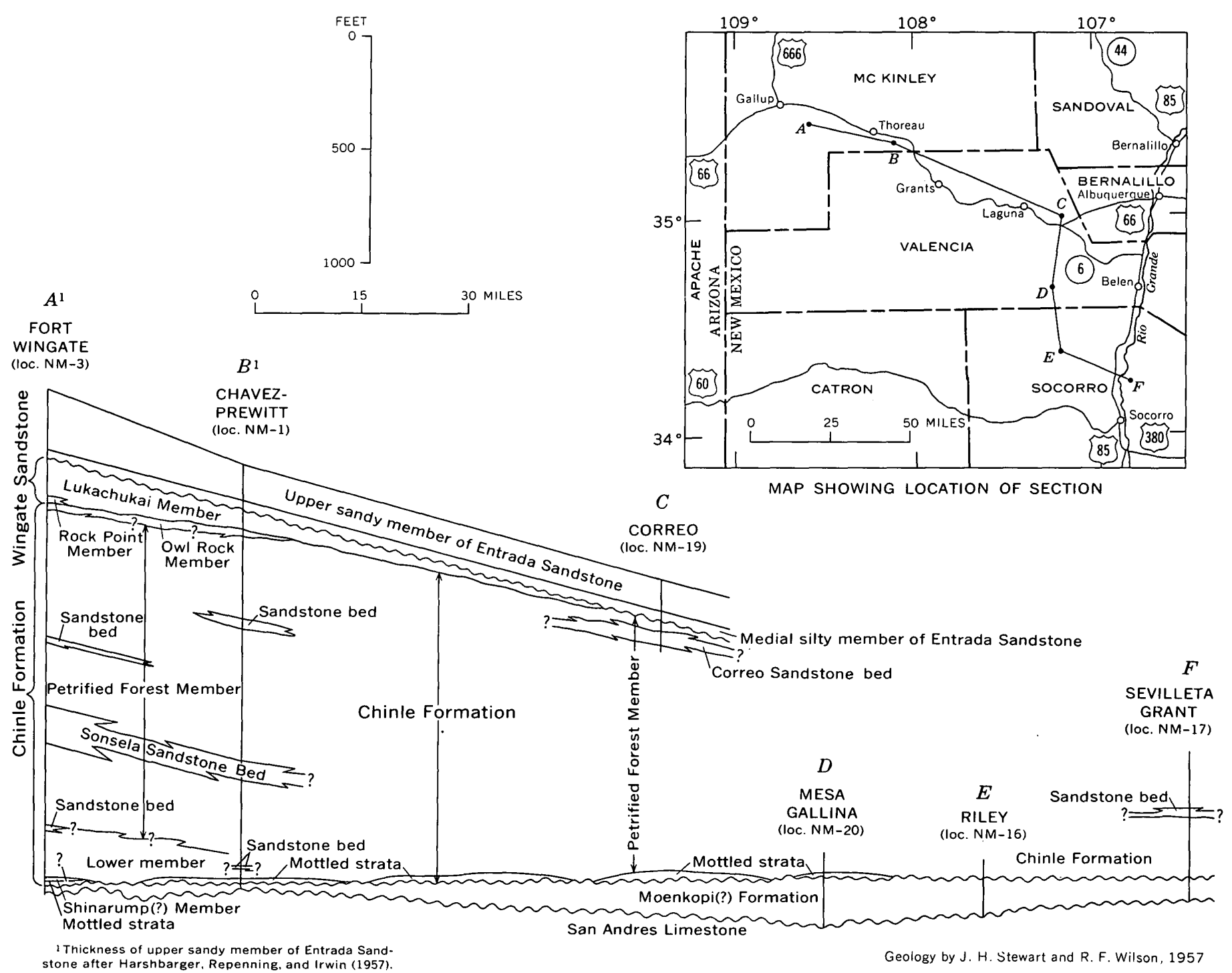

Figure 5. - Correlation of Triassic and some Jurassic rocks in west-central and central New Mexico.

virtually flat and is marked only by a few scours a foot or two deep.

The Shinarump Member in most areas grades upward into and intertongues with claystone, siltstone, or clayey sandstone. The upper contact is generally placed at the top of the highest crossstratified sandstone.

A sandstone and conglomerate unit in southern Nevada that differs slightly in lithology from the Shinarump Member elsewhere is referred to as the Shinarump (?) Member (Wilson and Stewart, 1967). The lithologic difference may reflect a difference in the source of the sediments. The unit in southern Nevada differs from typical Shinarump to the east in that it locally contains a conspicuous clay matrix in the sandstone and contains abundant chert pebbles. At the Spring Mountains section (loc.
$\mathrm{N}-2$ ), the lower 12 feet of the Shinarump (?) Member is composed entirely of chert pebble conglomerate. The Shinarump(?) of Nevada is otherwise similar to that elsewhere.

The Shinarump Member in the Elk Ridge-White Canyon area in southeastern Utah (pl. 4) also differs lithologically, although very slightly, from the member elsewhere. Pebbles in the Shinarump Member in the Elk Ridge-White Canyon area are predominantly quartz, and the proportion of quartz, quartzite, and chert pebbles in that area is statistically different from that in most areas to the south and west (Thordarson, Albee, and Stewart, "Conglomerate Studies," this report). Stream directions in the member in the Elk Ridge-White Canyon area, as determined from studies of the direction of dip of cross-strata, are dominantly west, whereas else- 
where in the Colorado Plateau region they are generally north to northwest. These relationships suggest that the Shinarump of the Elk Ridge-White Canyon area may have been derived from a different source than the member elsewhere, as has been suggested by Johnson and Thordarson (1959).

\section{AGUA ZARCA SANDSTONE MEMBER}

The Agua Zarca Sandstone Member was named by Wood and Northrop (1946) for exposures on Agua Zarca Creek 75 miles north of Albuquerque in northcentral New Mexico. The member is recognized on outcrops in the Rio Chama area (pl. 1), although it is absent at some localities there, and in the San Pedro Mountain area and the northern part of the Nacimiento Mountains (pl. 4; fig. 8). The term Agua Zarca Sandstone Member is not as widely applied here as it was by Wood and Northrop (1946). These geologists recognized the Agua Zarca Sandstone Member in the San Ysidro area and in the southern part of the Nacimiento Mountains; but, as will be discussed later, recognition of the Agua Zarca Sandstone Member as far south as San Ysidro is uncertain. In this report, the informal term "sand-

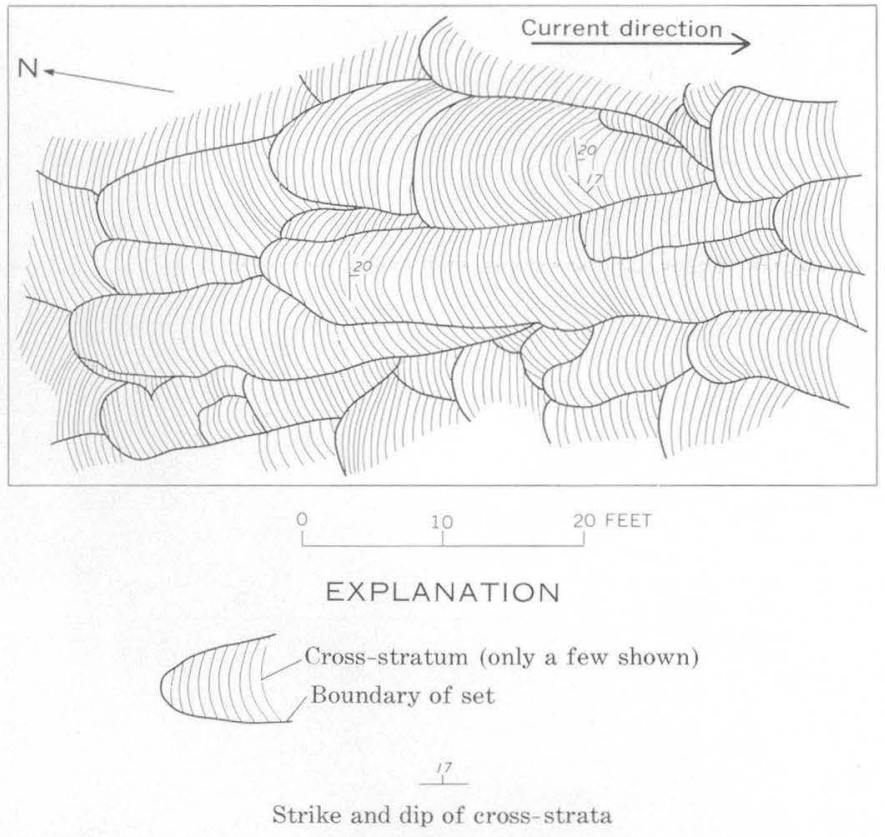

Figure 6. - Sketch of plan view of a group of trough crossstrata in Shinarump Member of Chinle Formation at Canyon De Chelly, Ariz.

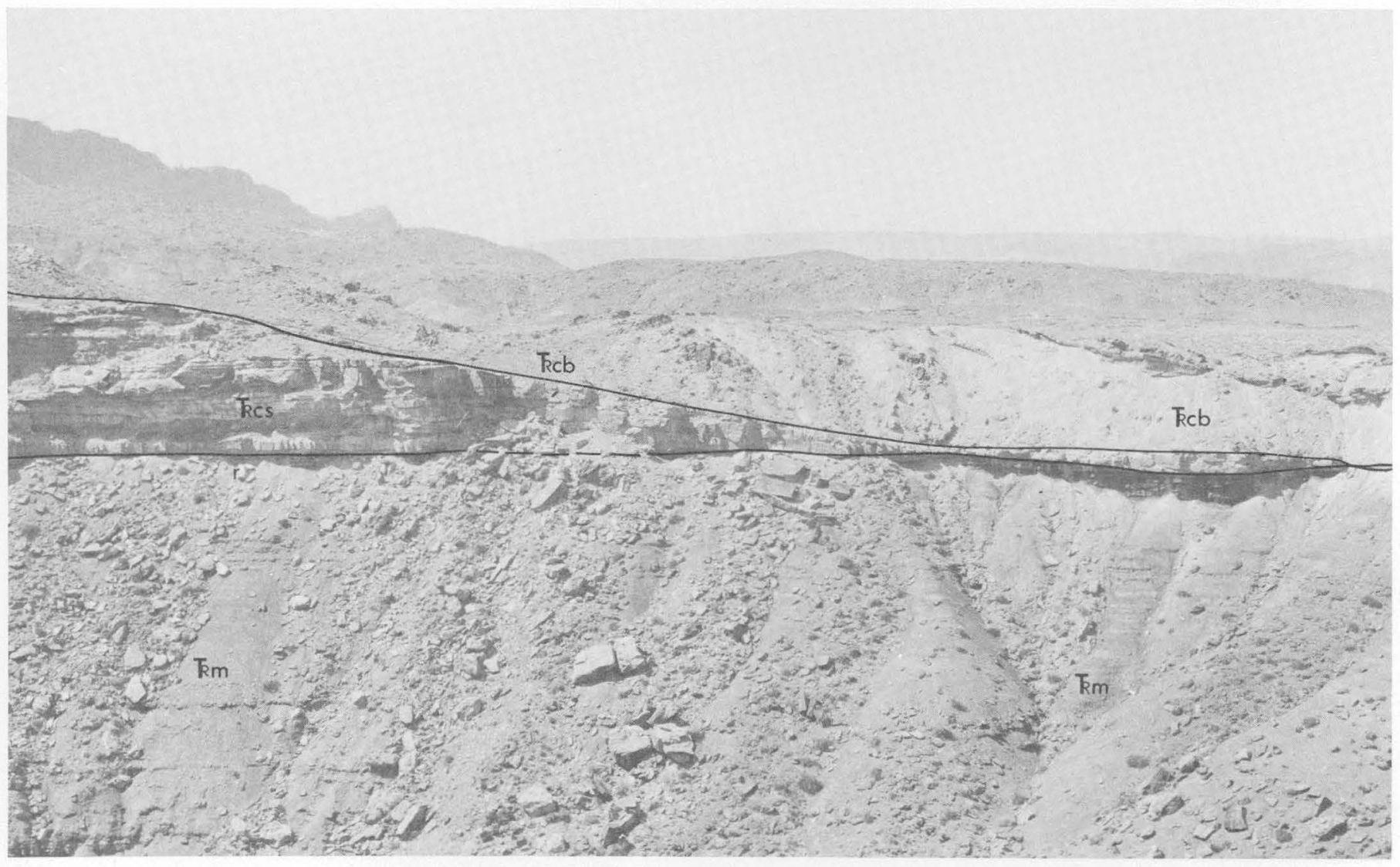

Figure 7. - Shinarump and Monitor Butte Members of Chinle Formation on Monitor Butte, Utah. A channel is cut into the Shinarump Member and filled with strata of the Monitor Butte Member. Km, Moenkopi Formation; kcs, Shinarump Member of Chinle Formation; Kcb, Monitor Butte Member of Chinle Formation. Thickness of Shinarump Member at left edge of photograph is about 40 feet. 

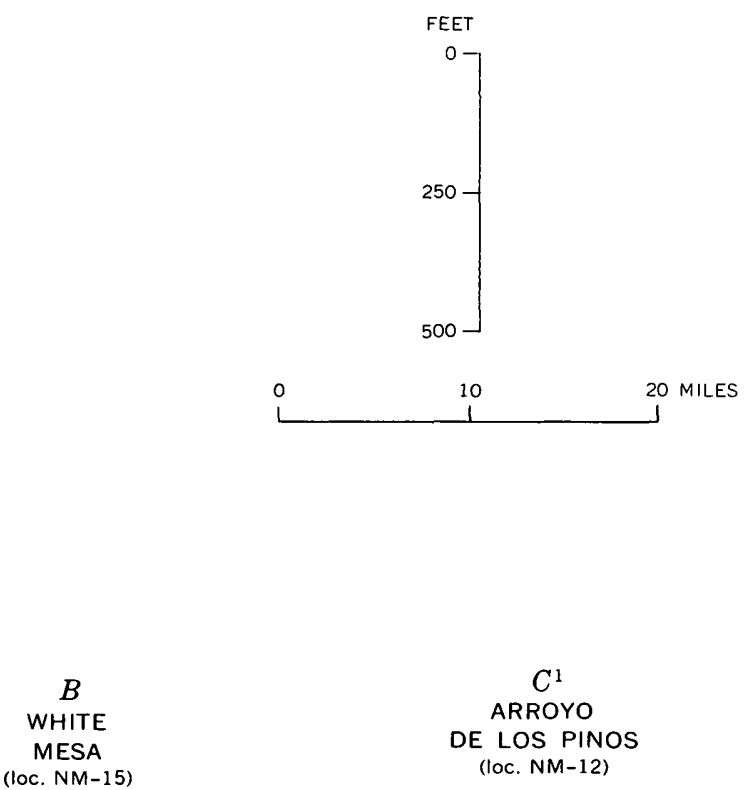

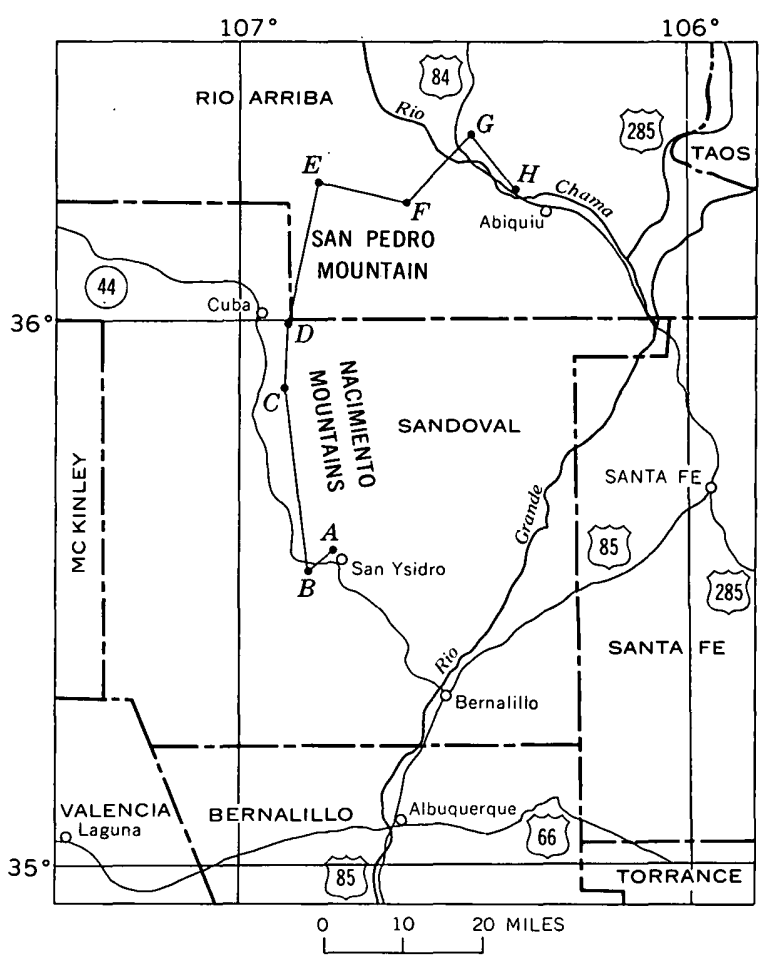

MAP SHOWING LOCATION OF SECTION

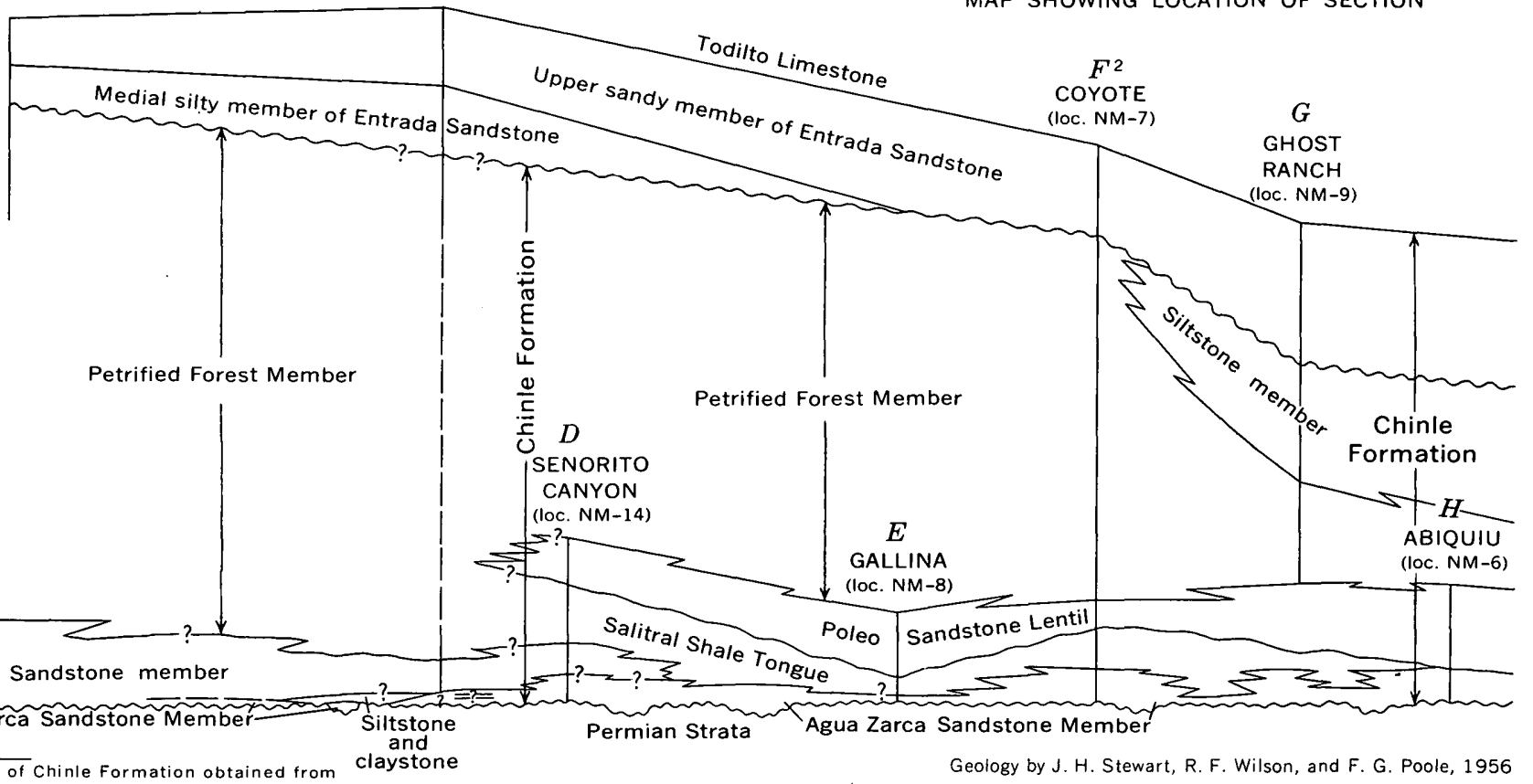

earby drill holes.

2 Thickness of Entrada Sandstone from nearby section measured by G. H. Wood and S. A. Northrop (oral commun., 1956).

Figure 8. - Correlation of Triassic and some Jurassic rocks in north-central New Mexico.

stone member" is used in the San Ysidro area and in the southern part of the Nacimiento Mountains instead of the name Agua Zarca Sandstone Member. In the northern part of the Nacimiento Mountains, the sandstone member and Agua Zarca Sandstone Member are both present, and the sandstone member overlies the Agua Zarca.
The Agua Zarca Sandstone Member is composed of sandstone and minor amounts of conglomerate and siltstone. The sandstone is generally grayish red, grayish purple, yellowish gray, grayish yellow, very light gray, and bluish white; in many places the colors are intricately intermixed. The sandstone is characteristically coarse to very coarse grained, but 
very fine to medium-grained layers are common. It is composed of thin- to thick-trough sets of smallto medium-scale low-angle cross-strata; in some places the stratification is difficult to see and the sandstone appears structureless; in other places, the sandstone is horizontally laminated. Lenses of conglomerate occur locally, and all gradations from conglomerate to pebbly sandstone are present. The conglomerate is composed of granules, pebbles, and cobbles of quartz, quartzite, and chert.

In many localities, sandstone and conglomerate constitute the entire Agua Zarca Sandstone Member, but at some localities silty claystone and siltstone are abundant in the member. Near Coyote (loc. NM-7), mottled red, purple, gray, and orange silty claystone and siltstone containing swelling clays occur in two units 10 to 12 feet thick interstratified with the sandstone and conglomerate.

The thickness of the Agua Zarca Sandstone Member varies considerably. It is $\mathbf{1 1 4}$ feet thick in Senorito Canyon and 67 feet thick at Coyote and Abiquiu (fig. 15). A 15-foot-thick unit near Gallina is tentatively assigned to the member.

The member rests unconformably on the Cutler Formation (called Abo Formation south of lat $36^{\circ}$ N.). Small scours cut into the Cutler Formation and filled with sandstone and conglomerate of the Agua Zarca Sandstone Member occur along the contact, which is placed at the change from red and brown siltstone and sandstone below to purple, red, orange, brown, and gray sandstone and conglomerate above.

The member is conformably overlain by the Salitral Shale Tongue of the Chinle Formation in most areas. The contact is at the change from sandstone and conglomerate below to variegated bentonitic claystone and siltstone above.

The Agua Zarca Sandstone Member and Salitral Shale Tongue intertongue extensively, which accounts in part for the large local variation in the thickness of these members. Near Abiquiu (fig. 8, loc. $H$ ), the Salitral Shale Tongue is absent, and the Agua Zarca Sandstone Member is directly overlain by the Poleo Sandstone Lentil. Here the contact is marked by a change from red, purple, yellow, and gray medium- to coarse-grained sandstone and conglomeratic sandstone below to yellowish-gray fine- to medium-grained sandstone and dark yellowish-orange conglomerate above.

The Agua Zarca Sandstone Member and the Shinarump Member are similar in that they both consist of cross-stratified sandstone and conglomerate and lie at the base of the Chinle Formation. The two units, however, do not appear to be physically continuous; the Shinarump Member is absent from almost all of west-central New Mexico, the area where the two units would join if they were the same. They are also somewhat different lithologically: the Agua Zarca Sandstone Member is commonly red and purple, whereas the Shinarump Member is commonly yellowish gray; and the Agua Zarca Sandstone Member is in many places coarser than the Shinarump Member and contains more interstitial clay and silt. Finally, stream directions as determined from the orientation of cross-strata are south to southwest in the Agua Zarca Sandstone Member but generally north to northwest in the Shinarump Member (pl. 4). As is shown later, the Agua Zarca Sandstone Member was probably derived from a source in the southern part of the Uncompahgre highland in northern New Mexico and southernmost Colorado, whereas most of the Shinarump Member was derived from a source in southern Arizona and adjacent regions.

\section{SANDSTONE MEMBER}

A unit of sandstone, and locally conglomerate, at the base of the Chinle Formation in the San Ysidro area 30 miles north of Albuquerque in north-central New Mexico (fig. 8, loc. $A$ ) and in the southern part of the Nacimiento Mountains is designated informally in this report as a sandstone member. In the northern part of the Nacimiento Mountains, it overlies the Agua Zarca Sandstone Member.

The sandstone member includes the same rocks that Wood and Northrop (1946) mapped in the San Ysidro area as the Agua Zarca Sandstone Member. The name Agua Zarca is not used here for these rocks because the Agua Zarca in its type area seems distinctly different lithologically from the sandstone member. The Agua Zarca Sandstone Member as typically developed on Agua Zarca Creek is composed predominantly of red, purple, gray, yellow, and white coarse to very coarse grained sandstone containing conglomerate lenses with pebbles and cobbles commonly as much as 3 inches in diameter. The sandstone member, on the other hand, is predominantly very pale orange and yellowish-gray fine- to medium-grained sandstone containing conglomerate lenses with pebbles rarely exceeding 1 inch in maximum diameter.

Study of the orientation of cross-strata also indicates a further difference between the Agua Zarca Sandstone Member and the sandstone member. The cross-strata in the Agua Zarca Sandstone Member in the Rio Chama and Senorito Canyon areas dip dominantly south to southwest, indicating south- to southwest-flowing streams (pl. 4). The cross-strata in the sandstone member dip dominantly north to 
northeast, indicating north- to northeast-flowing streams. The Agua Zarca Sandstone Member and the sandstone member, therefore, were probably deposited by streams with different drainage patterns and different source areas.

The sandstone member is 165 feet thick in a section measured 1 mile northwest of San Ysidro (fig. 8, loc. $A$ ) and is there composed of sandstone and minor amounts of conglomerate (13 percent) and siltstone (13 percent). The sandstone is very pale orange and yellowish gray and fine to medium grained and rarely contains very fine grained or coarse-grained parts. It is cross stratified or horizontally laminated to very thin bedded. The conglomerate contains granules and pebbles of quartz, quartzite, and chert generally less than 1 inch in diameter. The siltstone is light gray and light greenish gray and occurs as thin to very thick lenses or beds interstratified with the sandstone and conglomerate.

The sandstone member extends northward over the Agua Zarca Sandstone Member and probably grades out laterally into the upper part of the Agua Zarca and the lower part of the Salitral Shale Tongue (fig. 8). Although the sandstone member occupies the same stratigraphic position as the Shinarump Member, the two are not considered to be the same, largely because the Shinarump Member is absent from almost all of west-central New Mexico, the area where the two units would join if they were the same. The sandstone member may correlate, at least in part, with the Santa Rosa Sandstone of eastern and northeastern New Mexico; the two units are lithologically similar. The exact correlations, however, have not been determined.

\section{GARTRA MEMBER}

The Gartra Grit Member of the Stanaker Formation was named and described by H. D. Thomas and Krueger (1946) for a thin unit within the Upper Triassic sequence in the Vernal area of northeastern Utah. The names were not generally accepted because the well-established Colorado Plateau names Shinarump Conglomerate and Chinle Formation were already in use for these strata in northeastern Utah and northwestern Colorado (Powell, 1876; C. R. Thomas and others, 1945). Subsequent to Thomas and Krueger's work in the Uinta Mountains, geologists working there continued to use the names Shinarump Conglomerate and Chinle Formation (Huddle and McCann, 1947; Kinney and Rominger, 1947 ; Kinney, 1951, 1955; and Hansen, 1955).

Regional stratigraphic work, however, has shown that the Shinarump is a member of the Chinle Formation that does not extend north of central
Utah (Stewart, 1957) and that the Gartra occurs only in the northern and northeastern parts of the Colorado Plateau (Poole and Stewart, 1964) (fig. 9). As the Gartra and Shinarump probably are not correlative and their relative age is uncertain, the name Gartra is preferred for the basal sandstone and conglomerate unit of the Chinle Formation in northeastern Utah and northwestern Colorado. Such a usage has been proposed by Poole and Stewart (1964, p. D32) and is used in this report.

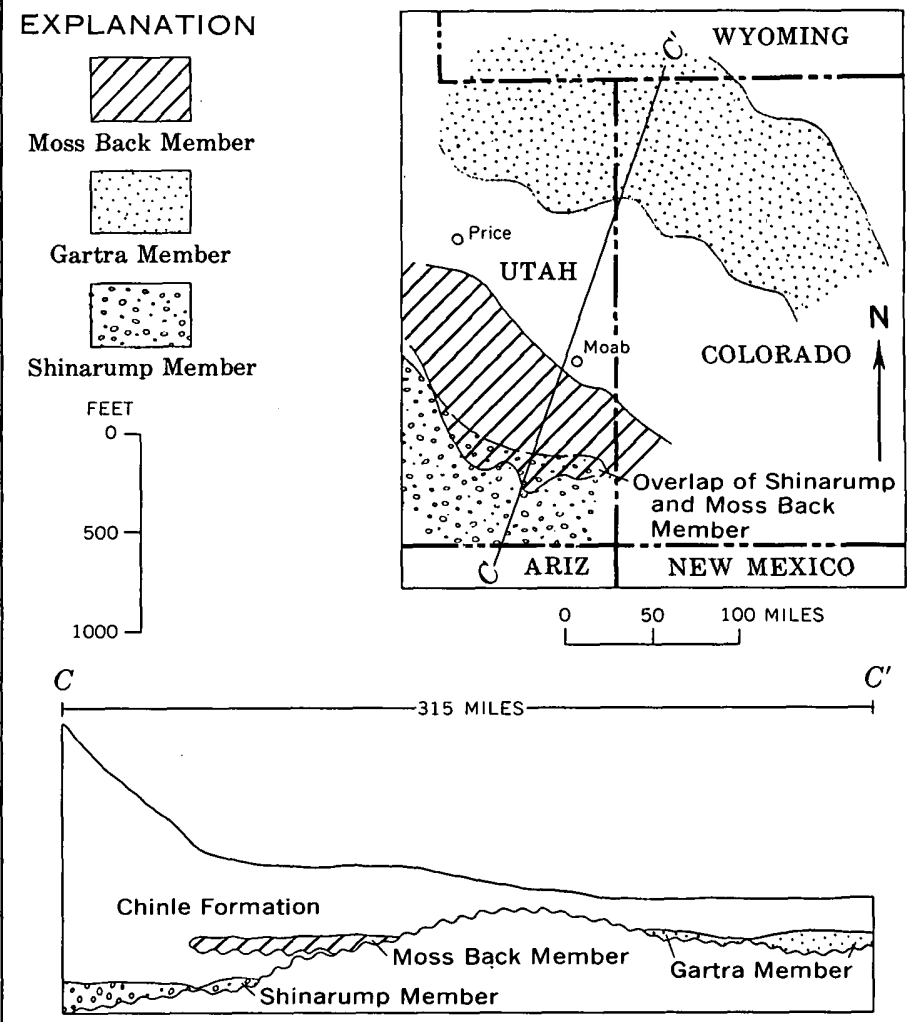

Figure 9. - Inferred depositional limits and stratigraphic relations of Moss Back, Gartra, and Shinarump Members of Chinle Formation.

The Gartra Member extends throughout much of northeastern Utah and northwestern Colorado ( $p l$. 4). It is discontinuous, particularly in parts of Colorado, where it occurs only as isolated lenses.

The Gartra Member consists mainly of lightcolored sandstone, conglomeratic sandstone, and some conglomerate. Locally the member is stained purple and red. The conglomerate layers contain pebbles and scattered cobbles of quartz, some chert and quartzite, and sparse feldspar, quartzose sandstone, and limestone. The member is cross stratified in most areas and locally contains silicified log fragments. 
The Gartra Member varies greatly in thickness. In northeastern Utah it is generally 20 to 50 feet thick, but in northwestern Colorado it is generally only 5 to 30 feet thick. The member is thickest where it fills channels cut into the underlying rocks.

In the exposures examined, a sharp erosional contact was noted between the light-colored Gartra Member and the underlying red beds. The contact is undulating and marked by small channels and scours. Beds above and below the contact appear concordant at all outcrops, and the contact is an apparent erosional disconformity; however, eastward the Gartra rests on progressively older beds, and the contact is clearly a regional angular unconformity.

The Gartra Member is overlain by the mottled member, a member intimately related to the Gartra. The contact between these members is placed at the top of rather continuous light-colored sandstone and conglomerate that extends to the base of the Chinle Formation. The contact is gradational and intertonguing. Gartra-like sandstone and conglomerate occur as lenses within the mottled member, especially in northwestern Colorado, and tongues of mottled rock extend into the Gartra.

\section{MONITOR BUTTE AND RELATED MEMBERS}

Slope-forming claystone and clayey sandstone and interstratified thin lenses of ledge-forming sandstone overlie the sandstone and conglomerate of the Shinarump and related members. These strata are generally 50 to 200 feet thick and are designated by different names in different areas. In some areas, they are a transitional sequence between coarse clastic units at the base of the Chinle Formation and overlying clay-rich units. In other areas, sandstone units like the Moss Back Member intervene between the transitional strata and clay-rich units.

The geographically separate units above the Shinarump and related members are (1) the Monitor Butte Member in southeastern Utah and the adjacent Arizona part of the Monument Valley area, (2) a lower red member in northwestern Arizona and the central part of western New Mexico, (3) the Mesa Redondo Member in east-central Arizona, (4) a sandstone and mudstone member in north-central Arizona, and (5) the Salitral Shale Tongue in northcentral New Mexico. The different names reflect to some extent lithologic differences between the members.

\section{MONITOR BUTTE MEMBER}

The name Monitor Butte Member was first used by Kiersch (1956), Witkind (1956, pl. 6), and Stewart (1957). The type section is on Monitor Butte just south of the San Juan River in south- eastern Utah and has been described by Witkind and Thaden (1963, p. 26-28). These strata were part of Division D of Gregory (1917).

The Monitor Butte Member occurs throughout most of southeastern Utah and in the adjacent Arizona part of the Monument Valley area (pl. 4; fig. 10). It reaches a northeastern limit along a northwest line passing directly north of the Elk Ridge area and through the southern part of the San Rafael Swell. The northeastern limit is irregular; locally outlying lenses of the member occur a short distance north of the main margin of the member. In the Clay Hills and Comb Ridge areas, the member cannot be separated, or can be separated only with uncertainty, from the overlying Petrified Forest Member. In other places also the member is difficult to separate from overlying strata, and recognition of the member throughout much of southeastern Utah is tentative.

The member consists predominantly of greenishgray bentonitic claystone and clayey fine-grained sandstone that weathers to form a "frothy" or "puffy" surfaced slope. The stratification in the claystone and clayey sandstone is obscure, but probably both cross-stratified and structureless parts occur. Flakes of carbonaceous material and wellpreserved plant remains are common in the claystone and clayey sandstone. (See section "Paleontology and Age.")

Interstratified with the claystone and clayey sandstone are resistant ledge-forming sandstone lenses that are commonly 1 to 10 feet thick. The lenses constitute from 5 to 20 percent of the member in most places, but locally they are absent. The sandstone is characteristically very fine grained, micaceous, well cemented, ripple laminated, and platy splitting. Cross-stratified parts occur locally. A few of the sandstone lenses are conglomeratic and contain pebbles of limestone and siltstone and a very few pebbles of weathered chert.

The sandstone lenses commonly are broken into large blocks that are orientated at various angles to the regional dip of the formation. The blocks range in size from a few tens of square feet to several thousands of square feet. They strike in various directions and may be shallow dipping, steeply dipping, or vertical. The attitude of the blocks has no apparent pattern; blocks side by side may dip in opposite directions or strike at right angles to one another. Commonly the blocks are warped and intricately folded (fig. 11), rarely into overturned folds. The tilted and folded blocks have been interpreted either as recent landslide blocks or as slump features developed during the deposition 


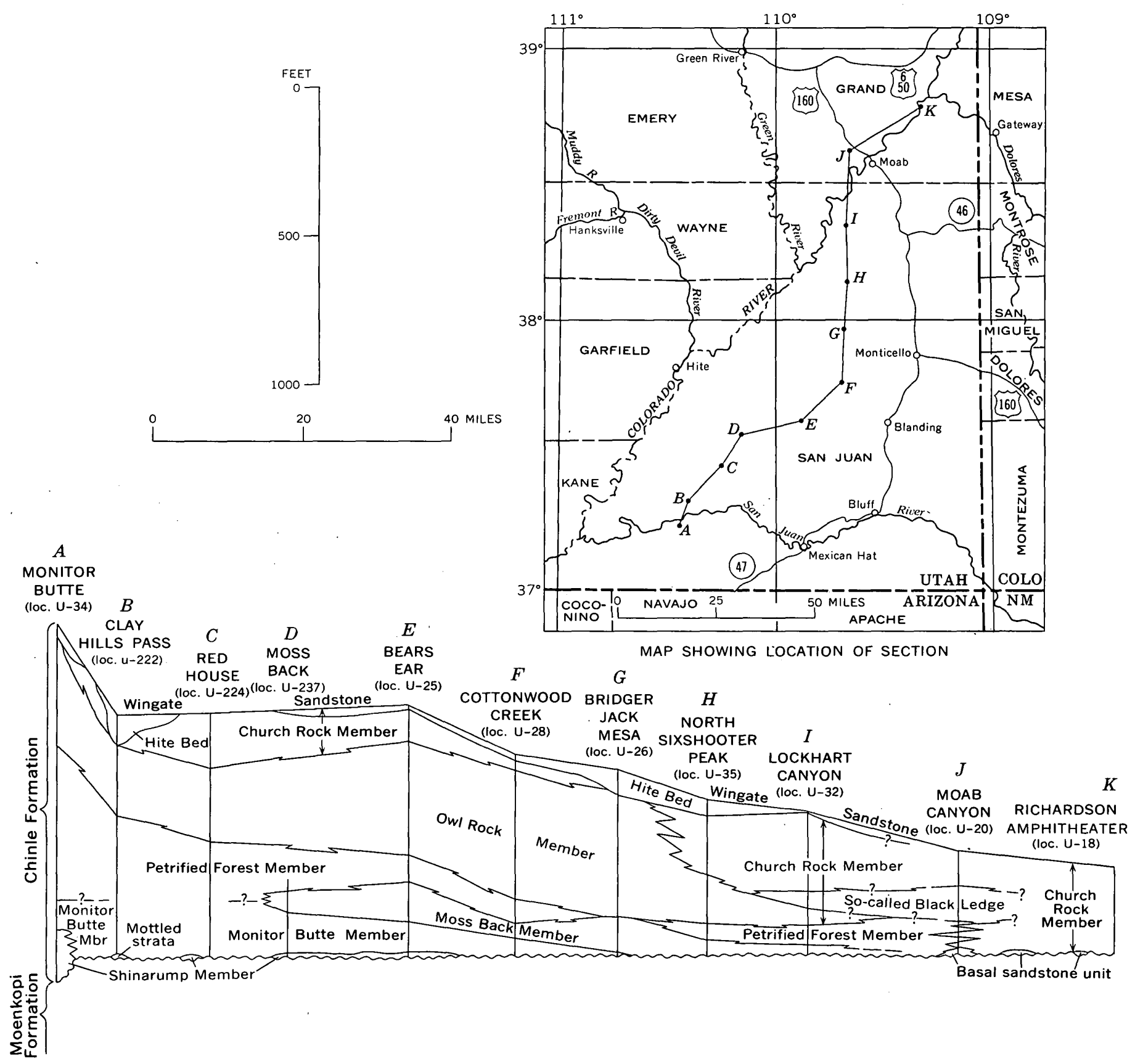

Figure 10. - Correlation of the Chinle Formation northeastward across southeastern Utah.

of the member. The latter interpretation is supported by the occurrence of flat-lying sandstone beds that were deposited across the truncated edges of underlying steeply dipping blocks. In addition, much of the observed slumping occurs where recent landslides cannot be definitely identified.

The Monitor Butte Member in southeastern Utah and in the Monument Valley area, Arizona, ranges in thickness from 0 to about 255 feet (pl. 4). It thins from 200 feet in White Canyon to zero along a northwest line passing about 35 miles north of
White Canyon. In the San Rafael Swell, it ranges in thickness from 0 to 100 feet.

The contact between the Monitor Butte and Shinarump Members is conformable and is placed at the change from the generally medium- to coarse-grained cross-stratified sandstone beds of the Shinarump to the ripple-laminated sandstone or structureless claystone of the Monitor Butte Member. The contact is well defined in some localities and transitional in others. Intertonguing between the Shinarump and Monitor Butte Members has been observed at many 
places in southeastern Utah. Where the Monitor Butte Member directly overlies the Moenkopi Formation, the contact is sharp and unconformable and is placed at the change from the reddish-brown micaceous, ripple-laminated siltstone beds of the Moenkopi to the greenish-gray bentonitic claystone or clayey sandstone and ripple-laminated sandstone beds of the Monitor Butte. Locally the Monitor Butte Member overlies mottled strata at the base of the Chinle.

In the northern part of the Monument Valley area and in the Circle. Cliffs area, the contact of the Monitor Butte and Shinarump Members is locally an erosion surface (fig. 7). Greenish-gray silty claystone, siltstone, and clayey sandstone of the Monitor Butte Member fill channels cut into the underlying Shinarump Member. These channels are commonly several hundred feet across and 30 to 40 feet deep.

The lower red member of the Chinle Formation in the Defiance uplift and adjacent areas in Arizona and New Mexico is considered to be the lateral continuation of the Monitor Butte Member. Both units occur above the Shinarump Member and below the Petrified Forest Member and are of similar thickness. In addition, both are composed of alternating layers of ledge-forming sandstone and slope-forming siltstone and claystone. The sandstone in both members is commonly ripple laminated and contorted. The lower red member, however, is predominantly reddish brown, whereas the Monitor Butte Member is predominantly greenish gray.

\section{LOWER RED MEMBER}

The lower red member in northeastern Arizona and western New Mexico was first described by Gregory (1917), who referred to it as Division D of the Chinle Formation. Akers, Cooley, and Repenning (1958) have used the term "lower red member" for this unit, and their nomenclature is adopted here. Gregory's terminology is unacceptable now because his A, B, and C divisions, of which Division D was a continuation, have since been given formal member names.

The lower red member is essentially a sandy unit lying between the Shinarump Member below and the Petrified Forest Member above. In places, it is a transitional sequence between the Shinarump and Petrified Forest Members.

The lower red member extends throughout the Defiance uplift and, according to Cooley (1957), as a thin unit westward as far as Holbrook (pl. 4). To the east, the unit extends into the Zuni uplift, but there the unit is difficult to distinguish from the overlying Petrified Forest Member.

The lower red member consists of ledge-forming sandstone units ranging in thickness between 10

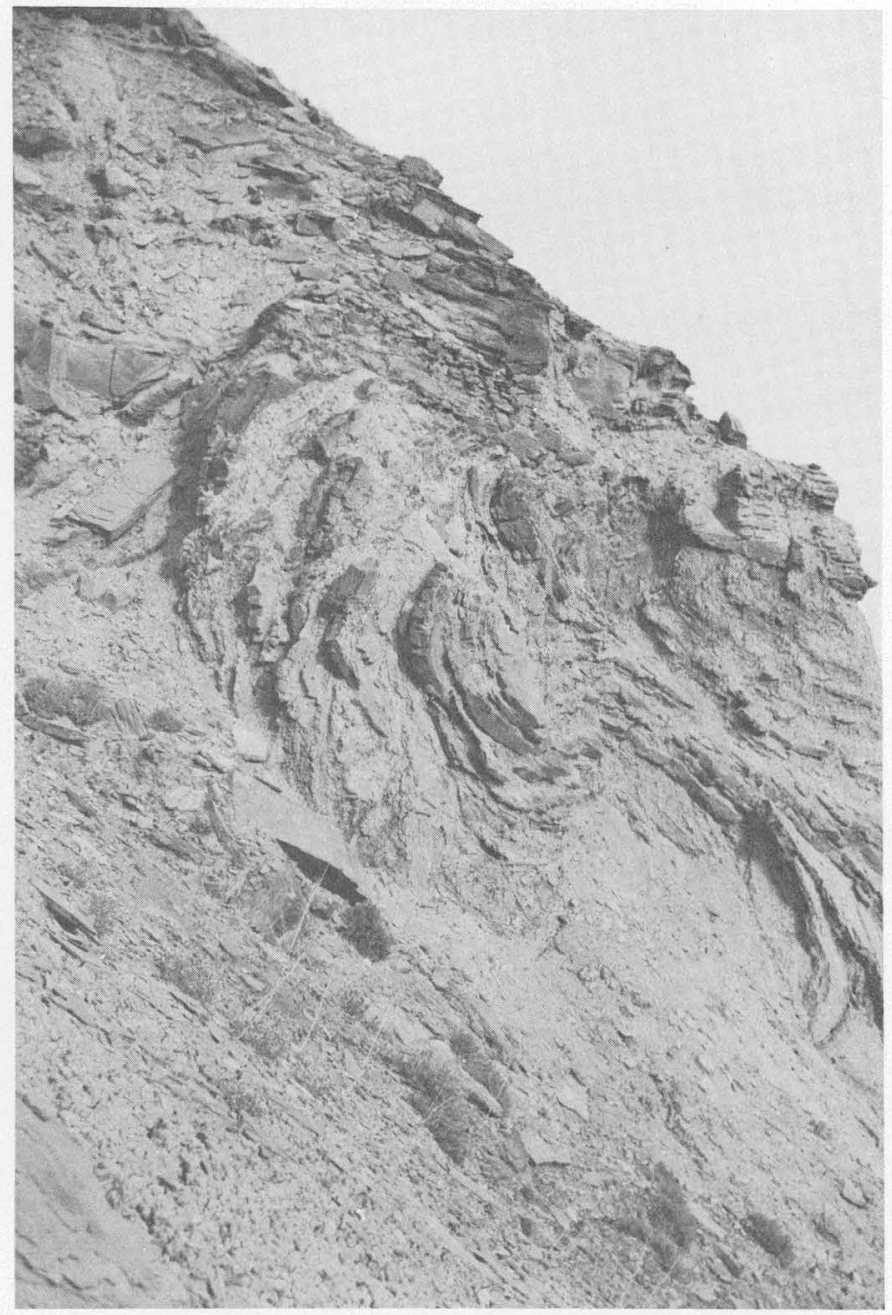

Figure 11. - Contorted strata in Monitor Butte Member of Chinle Formation in Capitol Reef area, Utah. About 20 feet of vertical outcrop shown.

and 40 feet, slope-forming mudstone and siltstone units ranging in thickness between 20 and 75 feet (Cooley, 1959; Repenning and others, 1969), and minor amounts of limestone pebble conglomerate. The sandstone, according to Cooley (1959), ranges from pale red purple to brownish gray or light olive gray and is very fine to fine grained. It is either horizontally laminated, ripple laminated, or cross stratified. Quartz and jasper pebbles are present in sandstone in the lower part of the member (Cooley, 1957). The sandstone occurs as discontinuous lenticular beds complexly intertonguing with the mudstone and siltstone units.

The mudstone and siltstone units are color banded in various shades and hues of red, purple, green, and gray; grayish red is predominant. The units contain swelling bentonitic clay that weathers to a frothysurfaced slope. The mudstone and siltstone units are composed of lenses or horizontal beds ranging in 
thickness from one-half foot to 30 feet (Cooley, 1957).

Large primary slump features are characteristic of the member, as they are also of the laterally continuous Monitor Butte Member. In places, these features can be confused with tectonic structures, but in detail the structures can be shown to be truncated and overlain by higher units in the Chinle Formation (Cooley, 1957; Repenning and others, 1969). Anticlinal and synclinal structures caused by slumpage can be seen in places, and locally the strata are highly contorted into overturned, chaotic structures. Slumpage features range in size from small contortions a few feet across to broad folds about a fourth of a mile long.

The lower red member generally ranges in thickness from about 100 feet to about 300 feet (pl. 4) . The variation in thickness is mainly related to intertonguing between the lower red member and the overlying Petrified Forest Member.

The lower red member rests on the Shinarump Member or, where that member is absent, on the Moenkopi Formation. The contact is placed at the change from cross-stratified sandstone of the Shinarump Member below to mudstone and siltstone of the lower red member above. The two members intertongue and intergrade, and locally the contact is transitional over several tens of feet. Where the Shinarump Member is absent, the contact of the lower red member and the Moenkopi Formation marks an abrupt change from red siltstone and sandstone of the Moenkopi to brightly colored mudstone and sandstone of the lower red member.

The contact between the lower red member and the overlying Petrified Forest Member is placed at the top of the highest ledge-forming sandstone unit. Because the sandstone units in the lower red member are lenticular, the position of the contact differs from place to place, depending on the position of the highest sandstone.

The lower red member, as mentioned in the foregoing section, is considered to be the lateral continuation of the Monitor Butte Member of southeastern Utah and the Arizona part of the Monument Valley area.

To the west, near Holbrook, the lower red member grades into the Petrified Forest Member. South of Holbrook and near Lupton, Ariz., and Zuni, N. Mex., the lower red member grades laterally southward into the Mesa Redondo Member.

MESA REDONDO MEMBER

The Mesa Redondo Member was named by Cooley (1958) for exposures at the base of Mesa Redondo, 40 miles southeast of Holbrook in east-central
Arizona (pl. 1). The type section was measured near Hunt, 15 miles northeast of the mesa.

The Mesa Redondo Member is present in a relatively small part of east-central Arizona and western New Mexico (pl. 4). It is composed of siltstone and silty claystone and interstratified lenses of sandstone. The siltstone and silty claystone is grayish red and grayish red purple and differs from most finetextured rocks in the lower part of the Chinle in that, except for a few thin layers, it does not contain claystone that swells noticeably on contact with water. The sandstone in the Mesa Redondo Member is grayish red, medium to coarse grained, and silty and clayey. It is composed of thin trough sets of medium-scale cross-laminae and contains conglomerate layers composed of granules to cobbles of limestone, chert, jasper, and quartz (Cooley, 1958). Silicified logs as large as 3 feet in diameter and 40 feet long occur locally in the basal part of the member (Cooley, 1958).

The Mesa Redondo Member is 84 feet thick in a section measured by the writers near St. Johns (loc. A-9) ; Cooley (1958) reported a thickness of 159 feet near this locality. The member generally is about 100 feet thick (pl. 4).

The Mesa Redondo Member overlies the Shinarump Member, or the Moenkopi Formation where the Shinarump is absent. The contact between the Shinarump and Mesa Redondo Members is placed at the change from sandstone and conglomerate below to siltstone or silty claystone above. Where the Mesa Redondo Member rests directly on the Moenkopi Formation, however, the contact is difficult to locate; both units are composed dominantly of reddish siltstone. The Mesa Redondo Member, however, locally contains silicified logs and thin light-colored layers that contain swelling clays, whereas the Moenkopi Formation does not.

The contact between the Mesa Redondo Member and the overlying Petrified Forest Member is placed at the change from red siltstone and clayey siltstone of the Mesa Redondo Member to the variegated bentonitic claystone, siltstone, and clayey sandstone of the Petrified Forest Member. The contact can be seen at a distance as a distinct color change from red below to green, red, and purple above. In some places the contact between the two members is sharp, but in other places it is gradational through about 50 feet of beds (Cooley, 1958).

To the west, the Mesa Redondo Member grades laterally into the Petrified Forest Member. To the north, it grades laterally into the lower part of the lower red member (Repenning and others, 1969; fig. $5)$. 
SANDSTONE AND MUDSTONE MEMBER

A unit of sandstone and mudstone is recognized in north-central Arizona (pl. 4). It overlies the Shinarump Member or, where the Shinarump is absent, the Moenkopi Formation and underlies the Petrified Forest Member. These strata were referred to as a sandstone and mudstone unit of the Chinle Formation by Phoenix (1963, p. 20-21) at Lees Ferry, and his informal term is used here with the modification that the unit is considered a member. A member status is appropriate because the unit is fairly widespread and is lithologically distinct from other members in the formation. The strata that comprise the sandstone and mudstone member had been included by Wanek and Stephens (1953) and Akers, Cooley, and Repenning (1958) in the Shinarump Member, although Phoenix (1963) mapped them as as overlying the Shinarump and underlying the Petrified Forest Member.

The sandstone and mudstone member, where it is well defined, is restricted to outcrops extending from House Rock Valley, about 25 miles west of Lees Ferry, to about 15 miles south-southeast of Cameron (pl. 4 ; fig. 12). Strata questionably correlative with the member occur 1 mile north of Joseph City (75 miles southeast of Cameron) and near Owl Rock (loc. A-13) in Monument Valley (90 miles northeast of Cameron). At the locality near Joseph City, the

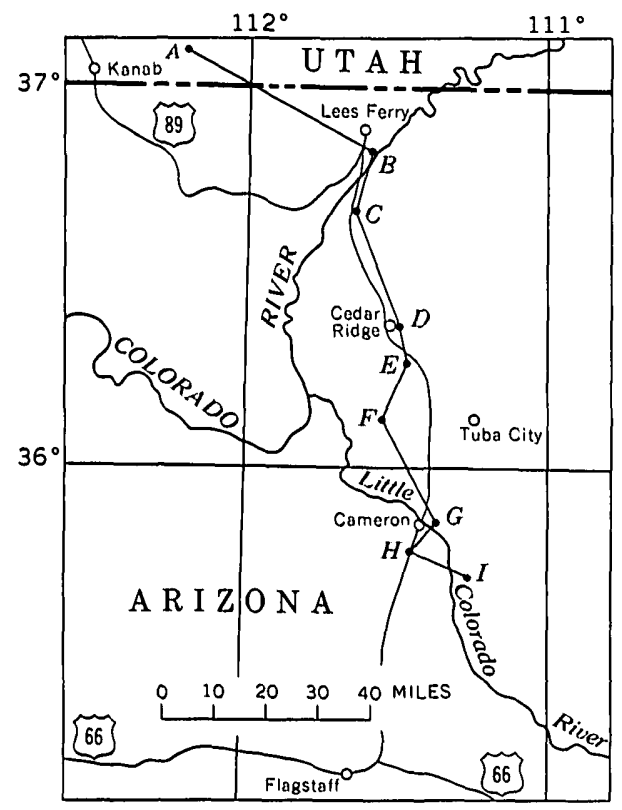

MAP SHOWING LOCATION OF SECTION
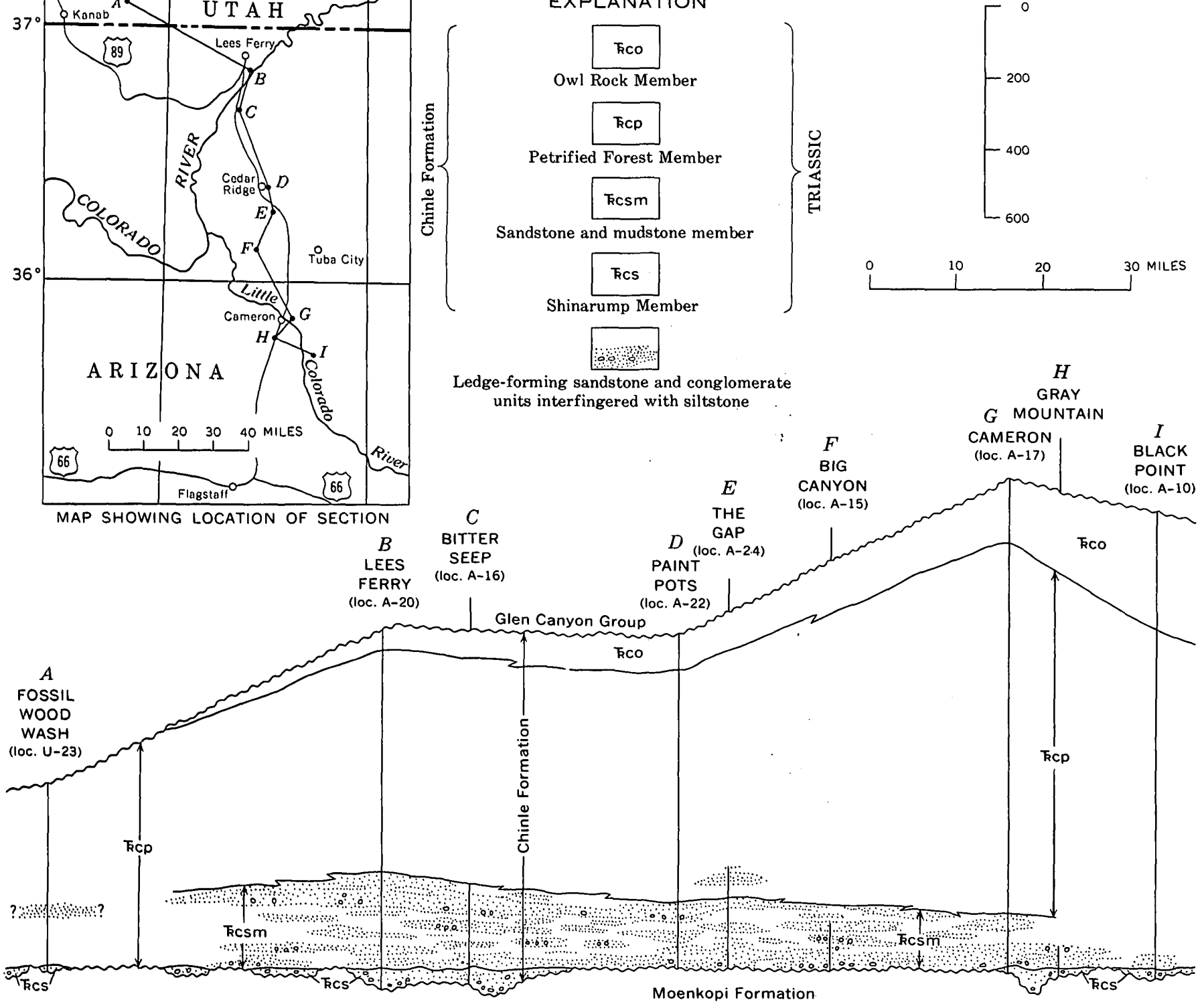

Distribution of rock types is generalized
EXPLANATION

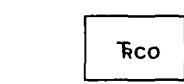

Owl Rock Member

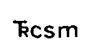

Sandstone and mudstone member

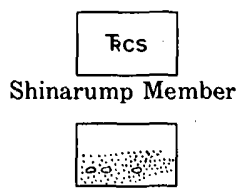

Ledge-forming sandstone and conglomerate units interfingered with siltstone
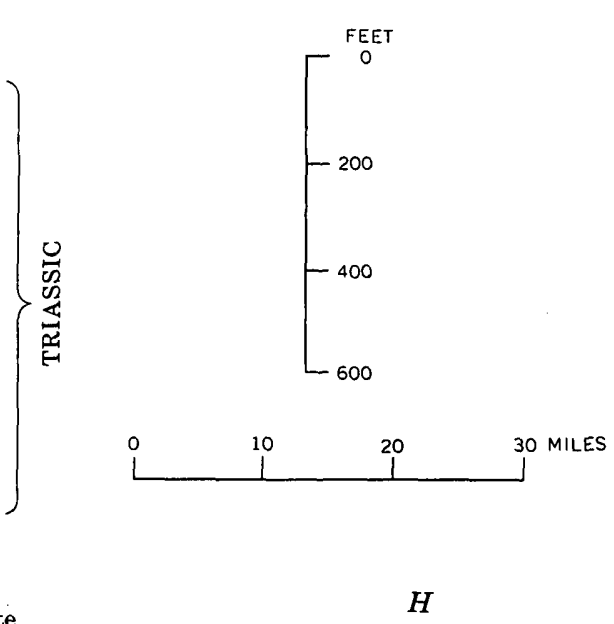

GRAY $G$ MOUNTAIN $F \quad \begin{gathered}\text { CAMERON } \\ \text { (loc. A-17) }\end{gathered}$ BIG
CANYON

C BITTER SEEP
oc. A-16)

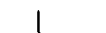

Glen Canyon Group
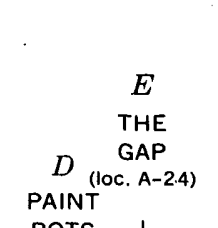

POTS

Moenkopi Formation

Geology by J. H. Stewart and R. F. Wilson, 1957

Figure 12. - Correlation of Chinle Formation in north-central Arizona and south-central Utah. 
unit is 25 feet thick and consists of sandstone and conglomerate lying at the base of the Chinle Formation and overlain by the Petrified Forest Member. Near Owl Rock, the strata consist of 41 feet of sandstone and siltstone overlying the Shinarump Member, and at this locality the strata have been included in the Monitor Butte Member as it is defined by mapping there (Witkind and Thaden, 1963).

The sandstone and mudstone member is composed of complexly interfingering units of sandstone and mudstone. The sandstone, which is yellowish gray, grayish red, pale red purple, and locally light greenish gray, contains abundant interstitial white silt and clay (commonly 20 percent) and is fine to coarse grained. It is composed of milky and clear quartz and probably some feldspar. Green, yellow, and gray chert(?) grains are characteristic of the sandstone and locally make up as much as about 30 percent of the rock. Thin to thick planar-and-trough sets of low-angle small- to medium-scale cross-strata are the dominant type of stratification. Horizontally laminated parts are locally common.

The sandstone in most places contains either disseminated granules, pebbles, and cobbles or lenses of conglomeratic sandstone or conglomerate. The granules, pebbles, and cobbles are predominantly of quartzite, but some are of quartz or chert. A few pebbles of volcanic rock are present in most areas; this type of pebble is much more common than in most members of the Chinle Formation.

The mudstone, including some siltstone, is grayish red, grayish purple, and light greenish gray and is structureless. The mudstone units weather to form slopes; the sandstone units form ledges and, in some areas, broad benches.

The sandstone and mudstone member gradually increases in thickness northward (fig. 12). About 15 miles southeast of Cameron (fig. 12, loc. I), the member consists of a single sandstone unit 41 feet thick.. Farther north, it is commonly over 200 feet thick.

The sandstone and mudstone member overlies the Shinarump Member in the Lees Ferry and Cameron areas; elsewhere, the Shinarump Member is absent, and the sandstone and mudstone member overlies the Moenkopi Formation. The contact between the Moenkopi Formation and the sandstone and mudstone member is sharp and easily recognized at the change from red siltstone below to the light-colored sandstone above. The contact between the Shinarump Member and the sandstone and mudstone member is sharp in detail but difficult to locate. Perhaps the most distinctive difference between the two members is the abundance of mudstone lenses in the sandstone and mudstone member and the rarity or absence of these lenses in the Shinarump. In addition, the sandstone in the sandstone and mudstone member is yellowish gray, grayish red, and pale red purple and contains abundant interstitial silt or clay and common amounts of green, yellow, and gray chert (?) grains. The sandstone in the Shinarump Member, on the other hand, is predominantly yellowish gray and contains little interstitial silt or clay and few, if any, grains of green, yellow, and gray chert(?). Conglomerate lenses in the sandstone and mudstone member contain abundant quartzite and rare quartz pebbles; conversely, in the Shinarump Member, quartzite pebbles are relatively rare and quartz common. Granules and pebbles of volcanic rocks are common in the sandstone and mudstone member, and rare or absent in the Shinarump Member.

\section{SALITRAL SHALE TONGUE}

The Salitral Shale Tongue was named by Wood and Northrop (1946) for exposures 3 miles west of Coyote and 75 miles north of Albuquerque in northcentral New Mexico. The tongue separates the Agua Zarca Sandstone Member and the Poleo Sandstone Lentil and cannot be differentiated from the overlying part of the Chinle Formation where the Poleo Sandstone Lentil is absent.

The Salitral Shale Tongue is present in the San Pedro Mountain area and in part of the Rio Chama area (pl. 4). It is absent near Abiquiu, where the Poleo Sandstone Lentil rests directly on the Agua Zarca Sandstone Member (fig. 8). The member is apparently absent 13 miles north of Gallina (Lookingbill, 1953), where the basal unit of the Chinle Formation is an 82-foot-thick sandstone and conglomerate layer probably correlative mostly or entirely with Poleo Sandstone Lentil. It is recognized as far south as Senorito Canyon.

The Salitral Shale Tongue is composed predominantly of grayish-red, pale-reddish-brown, pale-purple, and light-greenish-gray bentonitic structureless silty claystone and siltstone. Locally the tongue contains lenses of very fine to coarse-grained sandstone. In general, the tongue is lithologically similar to the Petrified Forest Member. It weathers to form a slope, or, in areas where the strata dip steeply, a valley.

The Salitral Shale Tongue ranges in thickness from 0 to at least 100 feet (pl. 4). Its lower contact is placed at the change from sandstone and conglomerate of the Agua Zarca Sandstone Member below to silty claystone and siltstone of the Salitral above. The upper contact is placed at the change from the fine-textured strata of the Salitral Shale 
Tongue to the coarse-textured strata of the Poleo Sandstone Lentil.

Correlation of the Salitral Shale Tongue with any other unit on the Colorado Plateau is uncertain. The Salitral occupies roughly the same stratigraphic position as the lower red member, but the lower red is characterized by the presence of ledge-forming sandstone layers, which are rare in the Salitral.

\section{MOSS BACK AND RELATED MEMBERS}

The Moss Back Member in southeastern Utah and adjacent Colorado, the lower member of the Dolores Formation in southwestern Colorado, and the Poleo Sandstone Lentil in north-central New Mexico are all thin widespread ledge-forming sandstone and conglomerate units that may be, at least in part, correlative. These units represent a significantly younger depositional event than the lithologically similar Shinarump and related members. Along its southern margin, the Moss Back Member lies more than 200 feet above the Shinarump Member. The Poleo along its southernmost outcrops lies at a comparable distance above an unnamed sandstone member that occupies the same stratigraphic position as the Shinarump. The Moss Back Member overlaps the underlying part of the Chinle to the north and in parts of southeastern Utah is at the base of the formation. The lower member of the Dolores Formation, a member possibly correlative with the Moss Back, also lies at the base of the Upper Triassic sequence.

\section{MOSS BACK MEMBER}

The Moss Back Member was first described as the Moss Back sandstone unit by Stewart and Smith (1954, p. 29-32) and was later formally named for exposures in the White Canyon area in southeastern Utah by Stewart $(1957$, p. 453$)$. It forms a northwest-trending lens extending from the White Canyon, Elk Ridge, and Abajo Mountains areas on the southeast to beyond the San Rafael Swell on the northwest (fig. 13). It is locally absent within the main depositional area.

The Moss Back Member is typically a yellowishgray and very pale orange fine- to medium-grained well-sorted sandstone that weathers to form a cliff (fig. 14). The sandstone is composed of subrounded clear quartz and rare black accessory grains. The stratification is predominantly thin to thick trough and planar sets of medium-scale cross-strata, but horizontally stratified sets are common. Carbonaceous material and silicified wood are abundant.

Conglomerate and conglomeratic sandstone lenses are common in the Moss Back Member. The conglomerate lenses are of two types: those that contain pebbles of light-brown and gray siltstone and limestone, and those that contain pebbles of quartz, quartzite, and chert. Generally both types of conglomerate lenses are found in the same outcrop. In places the two pebble assemblages are mixed in the same lens, and in such places the limestone and siltstone pebbles are generally 15 to 20 times more abundant than the quartzose pebbles.

A different facies of the Moss Back Member occurs in an area near the junction of the Green and Colorado Rivers. This facies is in a belt about 10 miles wide along the northern limit of the member and is characterized by sandstone containing abundant interstitial green silt and clay and a few quartzose pebbles. Interstratified lenses of greenishgray siltstone and claystone are common.

Sandstone units lithologically similar to, though not identical with, the Moss Back Member occur in the Lisbon Valley area (fig. 15, locs. $D$ and $E$ ) in easternmost Utah and near Egnar (fig. 15, loc. $F$ ) in westernmost Colorado. These units consist of greenish-gray to light-greenish-gray fine-grained ledge-forming sandstone that contains both horizontally laminated and cross-stratified layers. Lenses of limestone or siltstone pebble conglomerate and of greenish-gray siltstone are irregularly interstratified with the sandstone. The sandstone units in the Lisbon Valley and Egnar areas were originally considered a finer grained facies of the Moss Back Member (Stewart, 1957), but further work indicates that the stratigraphic relationships may not be that simple. Strata lithologically similar to the Moss Back are now known to occur above that member in the area near the junction of the Green and Colorado Rivers; and in places, such as at Cane Spring Wash (fig. 15, loc. $C$ ), these higher sandstone layers are virtually inseparable from the Moss Back. The sandstone units in the Lisbon Valley area and near Egnar could therefore be partly or entirely equivalent to these higher lenses instead of entirely to the Moss Back.

In some areas, the Moss Back Member can be distinguished on the basis of grain size and pebble types from the Shinarump Member and other sandstone units in the Chinle. The Moss Back is generally fine to medium grained, whereas the Shinarump is medium to coarse grained; the other sandstone units in the Chinle are generally very fine to fine grained. In addition, the Moss Back contains a different pebble assemblage than the Shinarump Member. In the Elk Ridge-White Canyon area, where both the Moss Back and Shinarump Members are present, the average ratios between pebbles of quartz, quartzite, and chert are 12:37:51 in the Moss Back and 


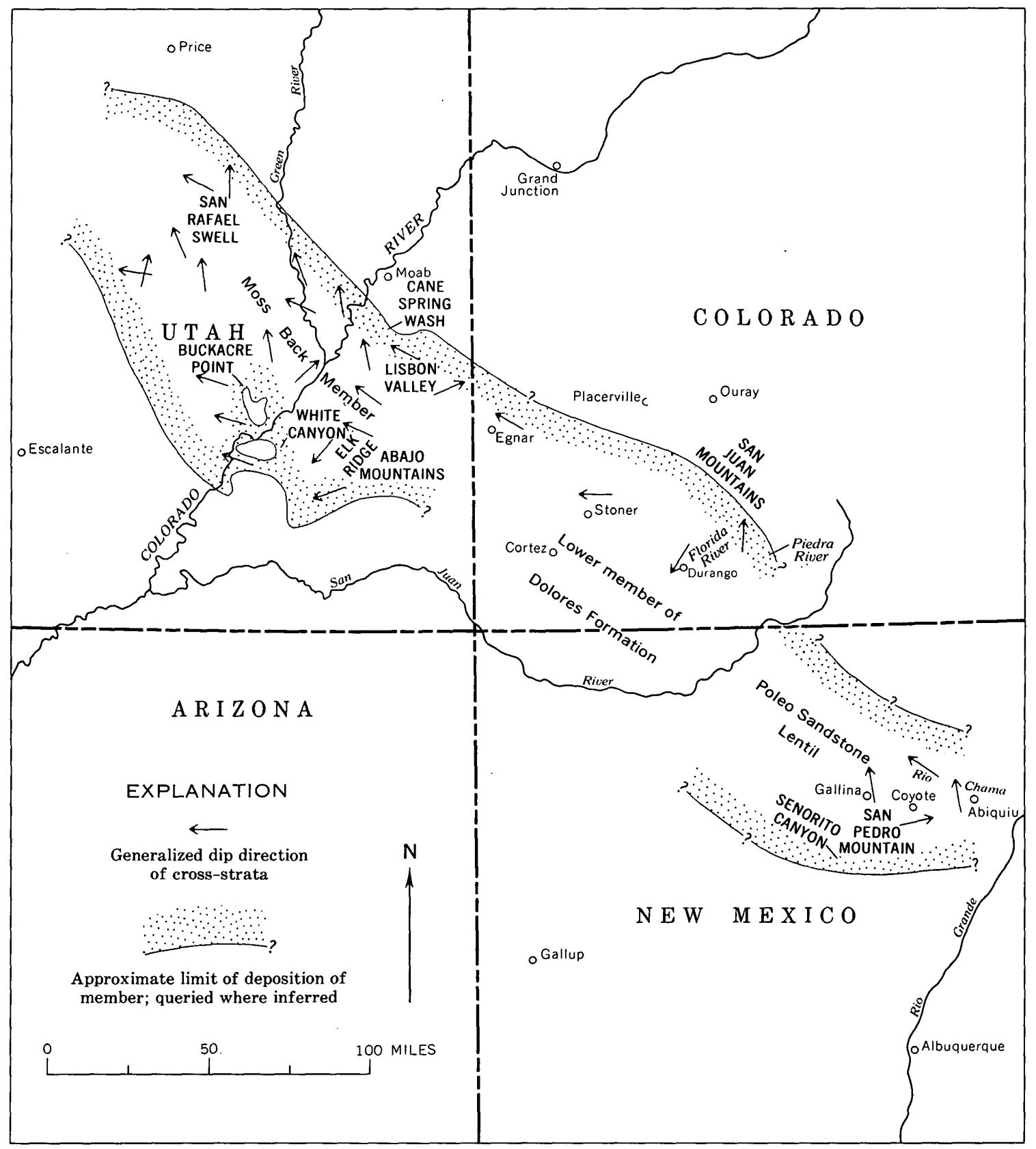

Figure 13. - Areal distribution and direction of sediment transport of the Moss Back Member and the Poleo Sandstone Lentil of the Chinle Formation and of the lower member of Dolores Formation.

$82: 16: 2$ in the Shinarump (Albee, 1957). In addition, the Moss Back Member commonly contains conglomeratic sandstone lenses containing pebbles of only siltstone and limestone; the Shinarump Member rarely contains this type of rock. Conglomerate beds in other parts of the Chinle Formation generally contain few, if any, quartzose pebbles.

The Moss Back Member averages about 60 feet in thickness but is as much as 150 feet thick where it fills channels. It is absent locally within its main 


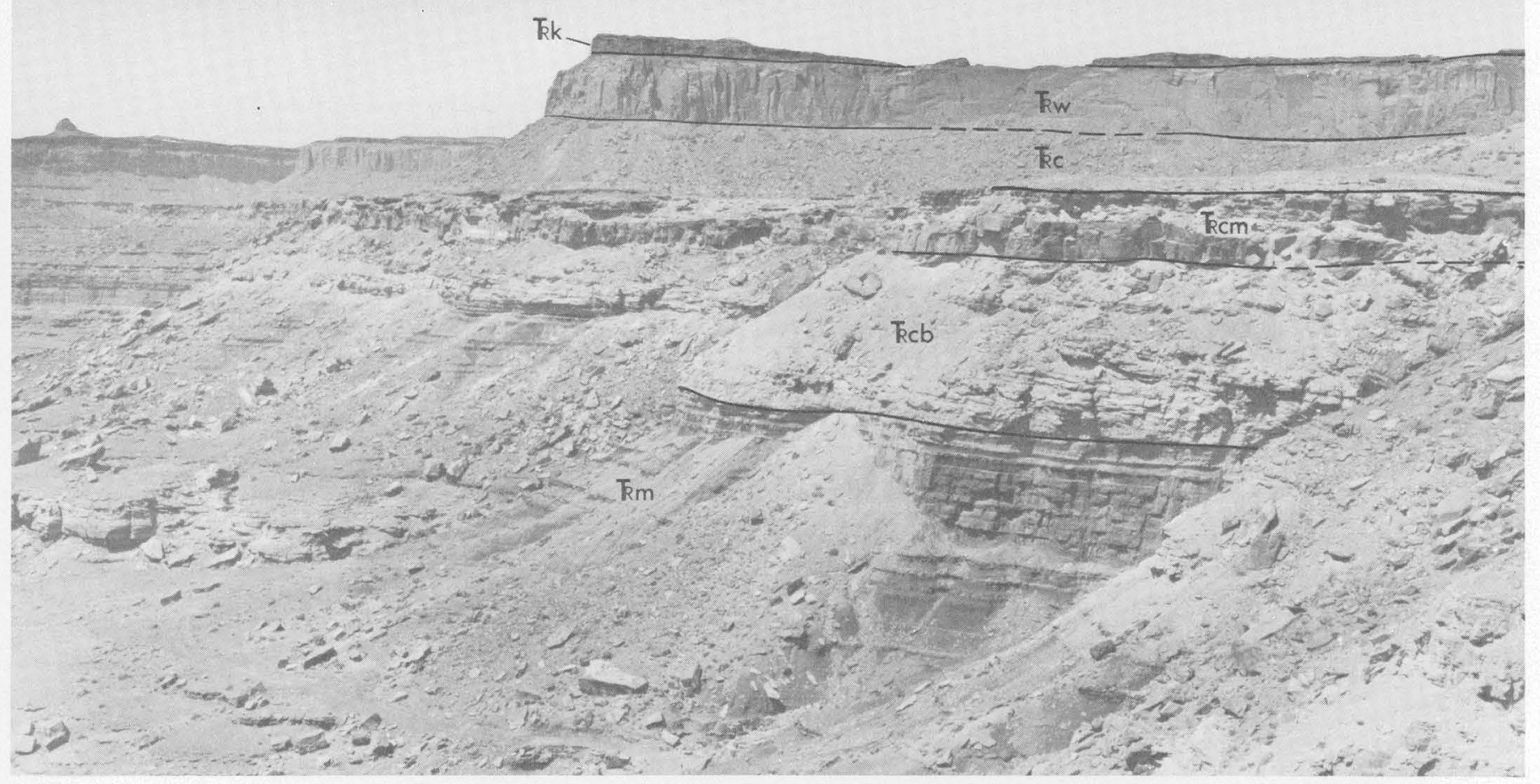

Figure 14. - Moss Back Member of Chinle Formation at Buckacre Point along Dirty Devil River, Utah. ₹m, Moenkopi Formation; kcb, Monitor Butte Member of Chinle Formation; $\mathrm{kcm}$, Moss Back Member of Chinle Formation; $\mathrm{kc}$, remainder of Chinle Formation; Kw, Wingate Sandstone; Kk, Kayenta Formation. Monitor Butte Member about 30 feet thick.

area of deposition and is discontinuous near its northeastern limit.

The lower contact of the Moss Back Member is placed at the break between the channel-filling crossstratified cliff-forming sandstone of the Moss Back Member and either the underlying siltstone and claystone of the Chinle Formation or, where the Moss Back is at the base of the Chinle, the siltstone of the underlying Moenkopi Formation. Locally, sandstone of the underlying Monitor Butte Member merges with that of the Moss Back Member, and the two members become virtually inseparable (Lewis and Campbell, 1965, p. B18-B19).

The Moss Back Member becomes progressively closer to the base of the Chinle Formation northeastward across southeastern Utah (fig. 10). Near the junction of the Green and Colorado Rivers, the member lies at the base of the Chinle Formation or is separated from the base by thin discontinuous mottled strata.

LOWER MEMBER OF DOLORES FORMATION

The Dolores Forma tion in the southern part of the San Juan Mountains :egion is divided into three members, referred to informally as lower, middle, and upper. The lower member is a light-colored ledge-forming sandstone, whereas the upper two are slope-forming red-bed units. The middle and upper members are considered to correlate with the upper part of the Chinle Formation and are discussed under that section.

The lower member has been recognized near Stoner, Durango, and Piedra River (figs. 13 and 15) and in some intervening areas. It also appears to be present in drill holes southwest of the area of outcrop. It is not present in outcrops near Placerville and Ouray and apparently grades out or pinches out northeastward in the San Juan Mountains region. 


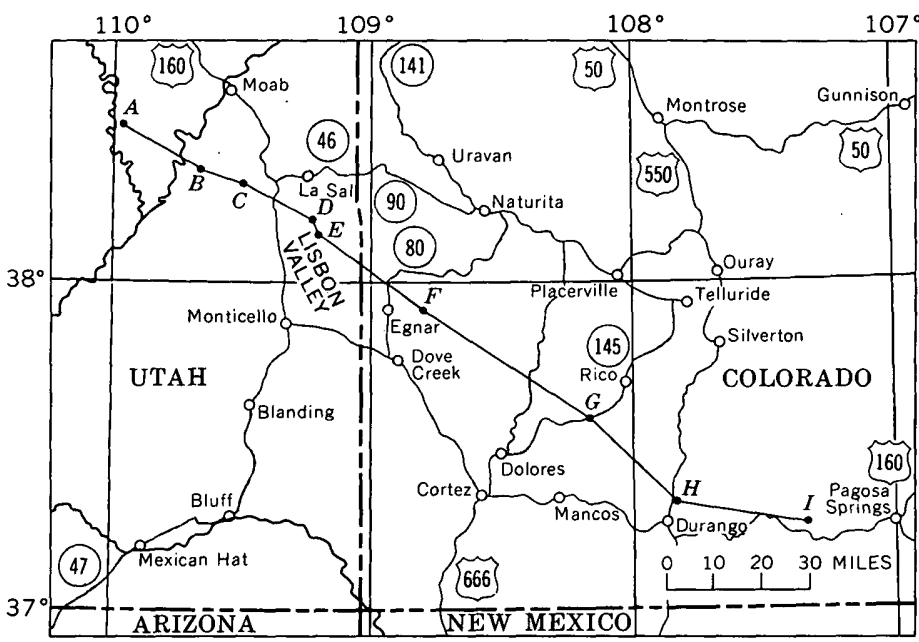

MAP SHOWING LOCATION OF SECTION

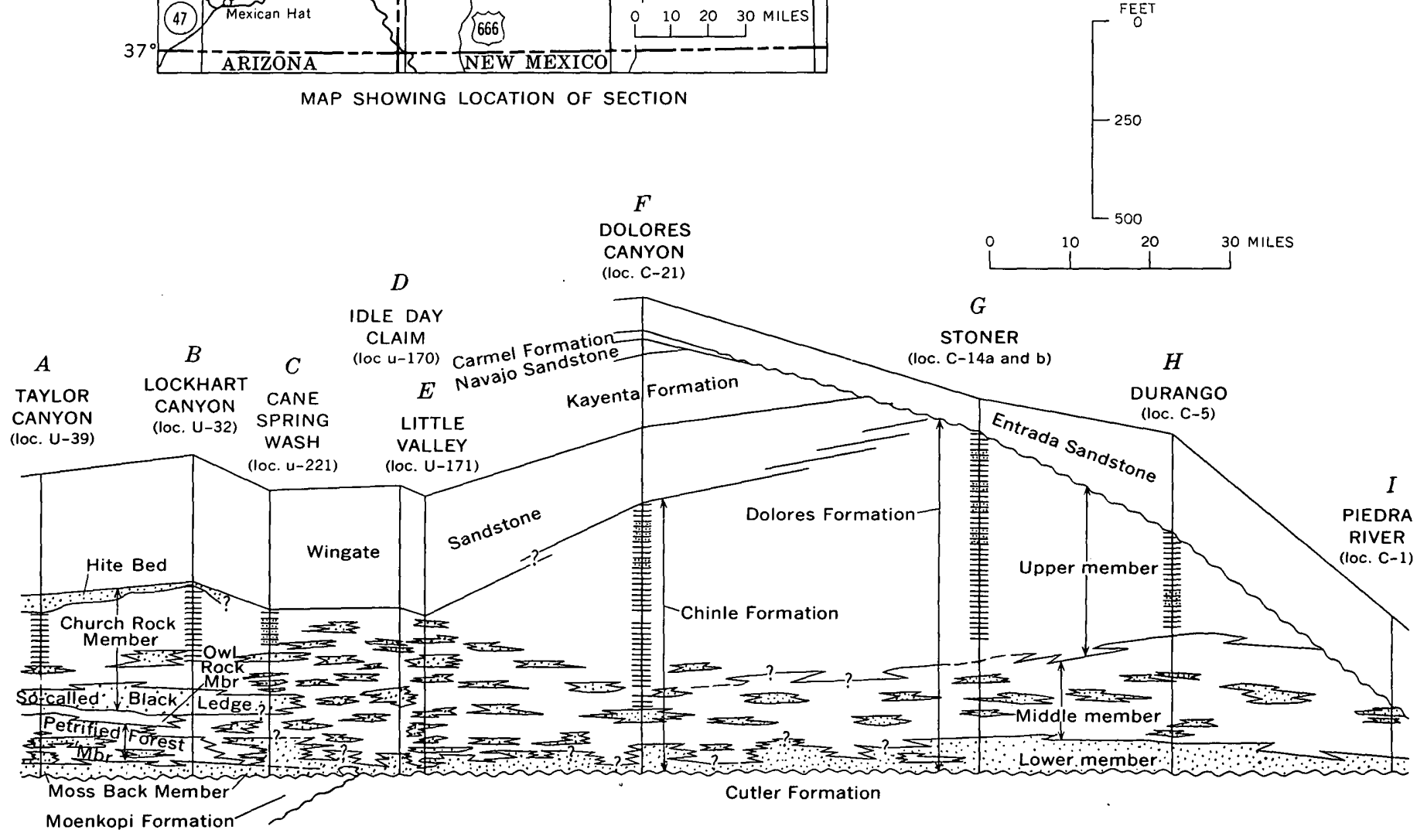

FIgURE 15. - Correlation of some Triassic and Jurassic rocks in southeastern Utah and southwestern Colorado.

The lower member is composed of light-greenishgray or greenish-gray very fine to fine-grained sandstone and subordinate amounts of limestone conglomerate. The sandstone contains much white and dark-green mica and flakes of carbonaceous material. Characteristically, it is horizontally laminated to very thin bedded and contains thin to thick trough and planar sets of small- to medium-scale, predominantly low-angle, cross-laminae. The limestone conglomerate is composed of rounded very coarse grains to small pebbles of limestone or limy siltstone in a limy sand matrix. The limestone conglomerate locally contains chert pebbles as much as 2 inches in

EXPLANATION

奎

Reddish-brown structureless or horizontally laminated siltstone

掣

Reddish-brown structureless or horizontally laminated sandstone

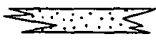

Greenish-gray or reddish-brown sandstone containing trough sets of small- to medium-scale cross-strata; probably fluvial FEET

$G$ c. C-14a and b) $\quad H$ 
stone of the lower member above. Mottled strata locally occur at the top of the Cutler Formation directly below the lower member.

Correlation of the lower member outside of the San Juan Mountains region is not certain. The basal sandstone units of the Chinle Formation in the Lisbon Valley and Egnar areas are lithologically similar to the lower member and are probably in part equivalent to it (fig. 15).

POLEO SANDSTONE LENTIL

The Poleo Sandstone Lentil of the Chinle Formation in north-central New Mexico was originally named the "Poleo top sandstone" by Huene (1911). Darton $(1922,1928)$ called it the Poleo Sandstone and considered it a separate formation underlying his Chinle(?) Formation. In some places his Poleo Sandstone probably included strata now called the Agua Zarca Sandstone Member and the Salitral Shale Tongue. Wood and Northrop redefined the Poleo Sandstone in 1946 as a lentil in the Chinle Formation.

The Poleo Sandstone Lentil is exposed in outcrops throughout the Rio Chama, Gallina, and San Pedro Mountain areas of north-central New Mexico (figs. 8 and 13). It probably includes most of the 82-foot-thick unit of sandstone and conglomerate at the base of the Chinle Formation, described by Lookingbill (1953), at a locality 13 miles north of Gallina. The Poleo Sandstone Lentil is well defined at Senorito Canyon (fig. 8, loc. $D$ ) and wedges out south of there in the Petrified Forest Member.

This lentil is a cliff-forming unit of sandstone and associated conglomerate, silty claystone, siltstone, and sandy siltstone. The sandstone is yellowish gray and fine to medium grained. It is horizontally laminated or composed of thin to thick trough and possibly planar sets of small- to medium-scale lowand high-angle cross-strata. In many places the sandstone appears structureless, but in these places stratification may be obscured. It is locally marked by cuspate ripple marks. The conglomerate, which is dark yellowish orange to very pale orange, forms lenses from a few feet to at least 13 feet thick interstratified with the sandstone. The conglomerate consists mainly of granules and pebbles of quartz, quartzite, and chert but contains a few of limestone or siltstone. At some localities, conglomerate occurs only as a few thin lenses; at other localities, it constitutes from 15 to 20 percent of the lentil.

The Agua Zarca Sandstone Member and Poleo Sandstone Lentil are lithologically similar but not identical. Both are cliff-forming units consisting of cross-stratified sandstone and conglomerate, and rock types present in one unit are usually duplicated in the other, but each has some distinguishing lithologic characteristics. In most areas the Agua Zarca is a mixture of red, purple, gray, yellow, and white rocks, whereas the Poleo is mostly yellowish gray. At Senorito Canyon, however, both units are yellowish gray. The Agua Zarca is mostly coarse to very coarse grained, though in part very fine to medium grained, whereas the Poleo is all fine to medium grained. The conglomerates in the two units also differ. Those of the Agua Zarca contain abundant pebbles and cobbles of very coarse grained quartzite and some of quartzitic conglomerate. No pebbles of these kinds were observed in the Poleo conglomerates, which are characterized by granules and pebbles of red and orange chert. These chert pebbles are also present in the Agua Zarca locally, but not abundantly.

The thickness of the Poleo Sandstone Lentil is 86 feet at Senorito Canyon (loc. NM-14), 125 feet at Gallina (loc. NM-8), 51 feet at Coyote (loc. NM-7), and 162 feet near Abiquiu (loc. NM-6). The thickness varies markedly in some places, partly because the Poleo fills channels cut into the underlying unit and partly because it intertongues extensively with the overlying unit.

The lower and upper contacts of the Poleo Sandstone Lentil are generally so placed as to separate the sandstone and conglomerate of the lentil from the claystone and siltstone of the underlying and overlying units. The bottom contact is a surface of erosion, along which small scours can be noted in places. Sandstone in the upper part of the Poleo Sandstone Lentil intertongues irregularly with the overlying Petrified Forest Member.

The Poleo Sandstone Lentil is not known to be physically continuous with any other sandstone unit in the Chinle Formation. The Poleo Sandstone Member may correlate with the lower member of the Dolores Formation in the southern part of the San Juan Mountains, which in turn may be continuous, at least in part, with the Moss Back Member in southeastern Utah, but these correlations are uncertain because of gaps in outcrops and limited drill-hole information.

\section{PETRIFIED FOREST MEMBER AND OCHER SILTSTONE MEMBER}

The Petrified Forest Member is a thick widespread unit composed predominantly of variegated claystone and clayey sandstone. It extends throughout most of the southern part of the Colorado Plateau and typifies the lower part of the Chinle Formation. Much of the claystone in the unit is believed to have been formed by alteration of volcanic debris. The 
ocher siltstone member, which occurs only in the northernmost part of the plateau region where the Petrified Forest Member is absent, probably also contains some volcanic debris.

\section{P'ETRIFIED FOREST MEMBER}

The Petrified Forest Member was named by Gregory (1950, p. 67) after Petrified Forest National Park in eastern Arizona, though he regarded it as being most typically exposed in the Zion Park region in southwestern Utah. The name was first used by Maxey (1946, p. 337) and was defined by Gregory (in Gregory and Williams, 1947, p. 233; Gregory, 1950, p. 67). The name has been widely applied in southern Nevada (Wilson and Stewart, 1967), northern Arizona (Repenning and others, 1969), northwestern New Mexico (Repenning and others, 1969; Colbert and Gregory, in Reeside and others, 1957, table 2), and southern Utah (Gregory, 1950; Stewart, 1957). The wide use of the name seems justified, for the unit is one of the most distinctive in the entire Triassic sequence on the Colorado Plateau.

The Petrified Forest Member is present throughout the southern part of the Colorado Plateau (pls. 2 and 4) and extends westward into southern Nevada. It is present in the most southerly outcrops of the

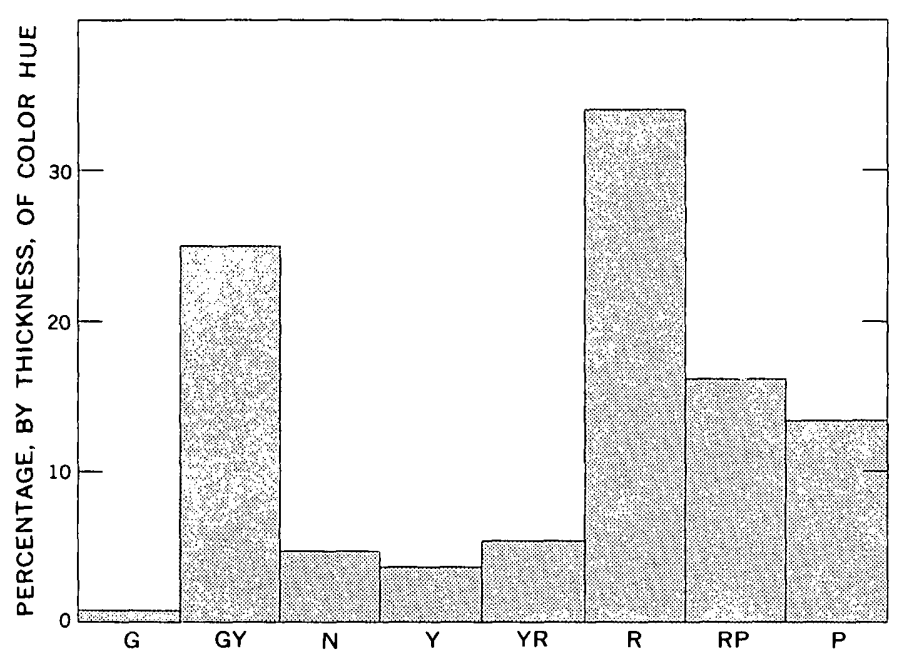

Figure 16. - Histogram showing percentage of main color groups in Petrified Forest Member of Chinle Formation at the Rockville stratigraphic section (loc. U-46), Utah.

Actual colors occurring in measured section (colors in parentheses occur in minor amounts) :

G Light greenish gray.

GY Light greenish gray, greenish gray).

N Medium gray to white.

Y Yedium gray to white.

YR Pale brown, pinkish gray (dark yellowish orange, light brownish gray).

R Grayish red, pale red (grayish pink)

RP Grayish red purple, pale red purple (very dusky red purple).

$P$ Grayish purple, pale purple. "Rock-Color Chart" Goddard and others
Color names and hues as listed in "Ror (1948).
Chinle Formation and is probably equivalent to part of the Dockum Group in eastern New Mexico. It is more than 1,000 feet thick in much of east-central Arizona and most of west-central New Mexico (pl. 4). Toward the north it thins and grades out into other members of the Chinle Formation, reaching a poorly defined northeastern limit in southeastern Utah, southwesternmost Colorado, and northernmost New Mexico.

One of the most characteristic features of the Petrified Forest Member is its bright, varied coloring. Its rocks are mostly red or green, but some are tinted in shades of purple, blue, orange, yellow, or gray. The variety of color is shown in figure 16, which is a histogram of the percentages of various hues (based on "Rock Color Chart," Goddard and others, 1948) occurring in a measured section of the Petrified Forest Member near Rockville (loc. U-46), near Zion National Park, in southwestern Utah.

The Petrified Forest Member is composed of three interfingering lithologic types: (1) structureless nonresistant claystone or clayey siltstone, (2) crossstratified nonresistant clayey sandstone, and (3) cross-stratified ledge-forming sandstone that is locally conglomeratic. The first two types are about equally abundant, and together they constitute the greater part of the member. Rocks of the third type nowhere constitute more than 20 percent of the member, and they are absent in large parts of the Colorado Plateau.

The claystone and clayey siltstone (type 1) are structureless or indistinctly bedded in layers from less than a foot to over 10 feet in thickness (fig. 17). They commonly enclose irregular nodules of limestone, generally 1 to 2 inches in diameter, which may either be concentrated in sheets or be scattered irregularly throughout horizontal layers from less than a foot to several feet in thickness. The clay is rich in montmorillonite (Schultz, 1963, p. C37), and it expands readily on contact with water, so that the clayey strata weather with a frothy or "popcorn" surface (fig. 18). These montmorillonite-rich rocks are considered to have been derived from the alteration of volcanic material (Schultz, 1963, p. C37).

The clayey sandstone (type 2 ) is characteristically cross stratified (fig. 19); the cross-strata occur in shallow trough sets and generally dip about $5^{\circ}$ to $10^{\circ}$ - at a lower angle than most of those in the Shinarump Member and similar units. The clayey sandstone is generally fine to medium grained and composed of grains of quartz, volcanic rock, and a minor proportion of potassium feldspar and plagioclase, in a matrix of montmorillonitic clay (Cadigan, 1957b, 1959a, 1959b; Schultz, 1963, p. C37). Layers 


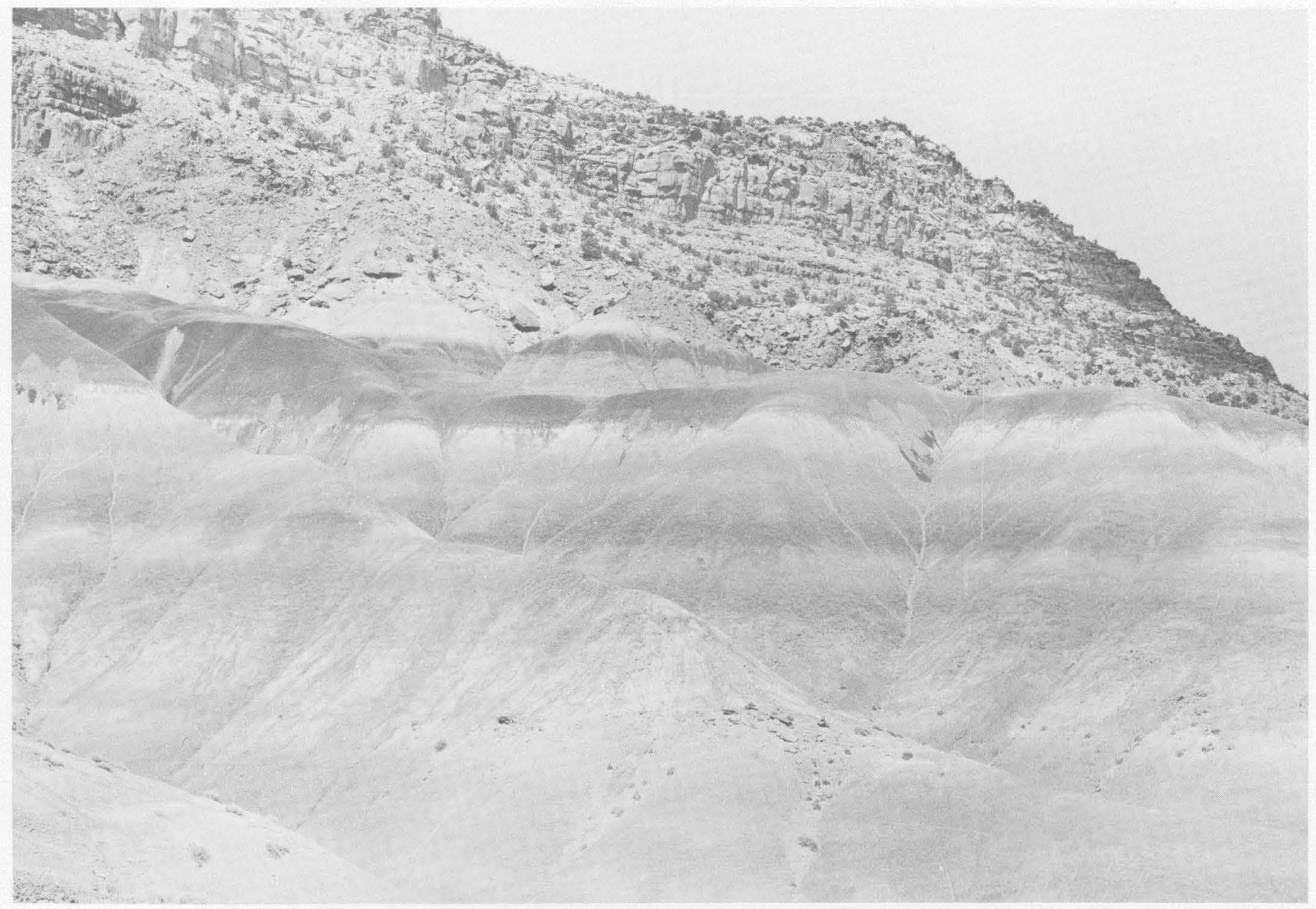

Figure 17. - Horizontally stratified claystone in Petrified Forest Member of Chinle Formation near abandoned town of Paria, Utah. Cliffs in background are in units of the Glen Canyon Group.

of clayey sandstone from less than a foot to several hundred feet in thickness are interstratified with layers of claystone or clayey siltstone that have a comparable range in thickness.

The third lithologic type in the Petrified Forest Member, the cross-stratified ledge-forming sandstone and conglomerate, is most conspicuously exposed in the Sonsela Sandstone Bed (Akers and others, 1958, p. 93).

The Sonsela Sandstone Bed extends throughout an area of 24,000 square miles in northeastern Arizona and northwestern New Mexico (fig. 20). It is generally 30 to 40 feet thick but is locally over 100 feet thick. In most places it lies about 300 feet above the base of the Petrified Forest Member and 800 feet below the top. It is composed of white, very pale orange, or yellowish-gray fine- to coarse-grained cross-stratified sandstone and conglomerate with planar and trough crossbedding. Conglomerate layers occur throughout the unit but are most abundant near the base. They consist mainly of granules, pebbles, and cobbles of chert but contain some pebbles of quartz, quartzite, limestone, and siltstone. Pebbles of volcanic rock, probably mostly vitric and crystal tuffs and vitrophyres, are locally present, but they generally constitute less than 4 percent of the gravel fragments. The Sonsela commonly contains a few bentonitic siltstone and claystone layers from less than a foot to over 20 feet thick interstratified with the sandstone and conglomerate.

Other ledge-forming sandstone units, similar to the Sonsela Sandstone Bed, occur in the Petrified Forest Member both above and below the Sonsela (Cooley, 1959, p. 71). These are most numerous in the Petrified Forest National Park, in east-central Arizona. In one of the sandstone units near the boundary of the park, 66 percent of the gravel fragments are of volcanic rocks. (See section on "Conglomerate Studies.") In southeastern Utah, a prominent sandstone bed, referred to informally as the Capitol Reef bed (Stewart and others, 1959, p. 516 ), occurs in the member in the Capitol Reef area 


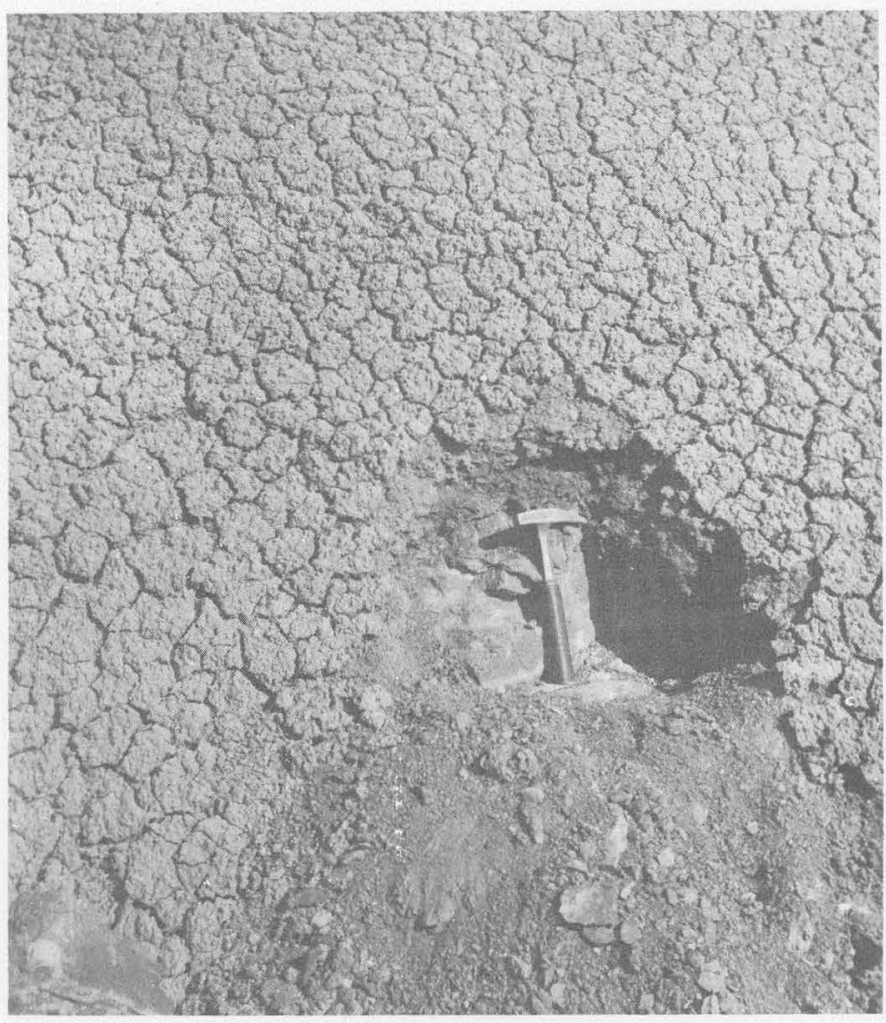

Figure 18. - Frothy weathering surface developed on claystone in Petrified Forest Member of Chinle Formation near Joseph City, Ariz.

and the northern part of the Circle Cliffs area (fig. 2, locs. $B, C$, and $D$ ). In west-central New Mexico, at the Correo section (NM-19), a prominent ledgeforming layer of sandstone and conglomerate occurs near the top of the Chinle Formation on the south side of Mesa Gigante (fig. 5, loc. C). This layer was named the Correo Sandstone Member of the Chinle Formation by Kelley and Wood (1946), but it is both overlain and underlain by strata lithologically similar to those common in the Petrified Forest Member. For this reason, the Correo is hereby redefined as a bed within the Petrified Forest Member. The only known outcrop of the Correo Sandstone Bed is along the south side of Mesa Gigante.

OCHER SILTSTONE MEMBER

The informal name "ocher siltstone member" has been assigned (Poole and Stewart, 1964, p. D36) to a unit present throughout the Uinta Mountains of northeastern Utah and northwestern Colorado (fig. 3 ). This unit is included under the same heading as the Petrified Forest Member largely because both members contain fine-textured rocks rich in montmorillonitic clay that is interpreted as having been derived from volcanic debris (Schultz, 1963, p. C37). The ocher siltstone member, however, appears to have been deposited in a separate basin from the main part of the Chinle Formation to the south in the Colorado Plateau.

The member consists of structureless ocher-colored and reddish siltstone and clayey siltstone and minor amounts of silty claystone. The siltstone and claystone commonly contain spherulites, carbonate nodules, and secondary gypsum veinlets. Many spherulites and nodules contain analcite (Keller, 1953 ), and much of the clay in the unit is montmorillonitic (Schultz, 1963, p. C37-C38). The ocher color probably is due to goethite (L. G. Schultz, written commun., 1958).

The thickness of the member increases from east to west in the Uinta Mountains and is about 200 feet in the western part of these mountains.

The ocher siltstone member is lithologically identical with part of the Popo Agie Member of the Chugwater Formation in the Lander area, Wyoming, as was indicated originally by Keller (1953). South and east from the Uinta Mountains the ocher siltstone member apparently wedges out.

\section{UPPER (RED-BEDS) PART OF CHINLE FORMATION}

The upper part of the Chinle Formation and related strata consist of reddish-brown coarse siltstone and minor amounts of limestone, sandstone, and limestone pebble conglomerate. These strata extend throughout northeastern Arizona, southeastern Utah, western Colorado, and parts of northwestern New Mexico (pl. 5). They are more than 1,000 feet thick in a part of west-central Colorado and in southwesternmost Colorado and thin fairly rapidly away from these areas. The upper part of the Chinle Formation is divided into two members; these are, in ascending order, (1) the Owl Rock Member, and (2) the Church Rock Member and related units.

OWL ROCK MEMBER

The name Owl Rock Member was first used by Kiersch (1956, p. 4), Witkind (1956, pl. 6), and Stewart (1957) ; the type section in the Monument Valley area of Arizona was described by Witkind and Thaden (1963, p. 30-32). The Owl Rock occurs in an elliptical area (pl. 5) embracing most of northeastern Arizona and southeastern Utah and small adjacent parts of New Mexico and Colorado. It intertongues and intergrades extensively with overlying and underlying members of the Chinle Formation, and in many areas its margin is marked by lateral gradation of the member into other units of the Chinle Formation (pl. 2).

The Owl Rock Member typically is composed of pale-red and pale-reddish-brown coarse siltstone interstratified with pale-red and light-greenish-gray 


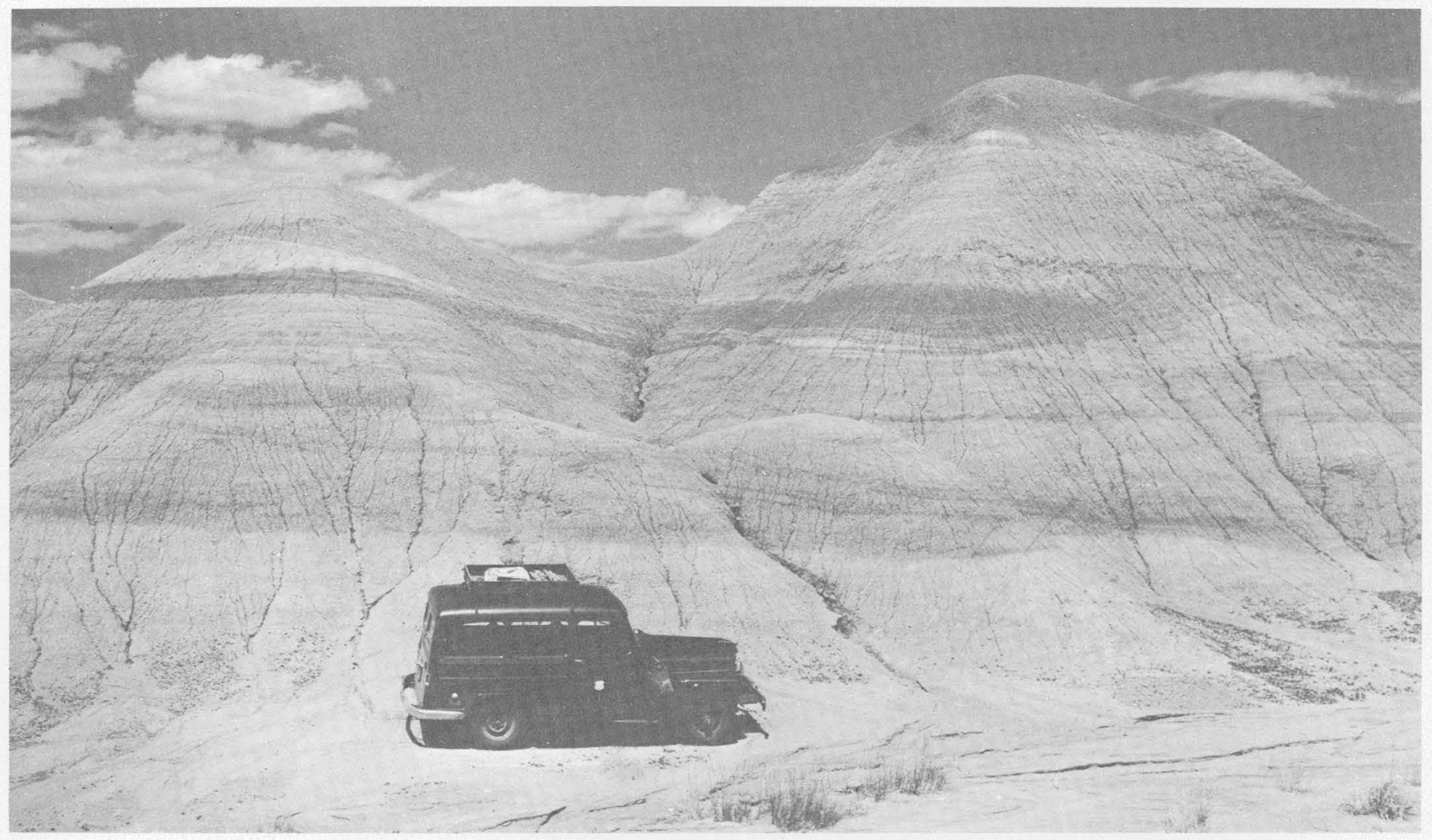

Figure 19.- Shallow trough sets of low-angle cross-strata in Petrified Forest Member of Chinle Formation near Cameron, Ariz.

limestone beds that form about 5 to 10 percent of the member (fig. 21). The siltstone is indistinctly bedded in layers from less than a foot to over 10 feet thick. The lithologic character of the siltstone in the member changes regionally from purplish palered fine-grained siltstone in the southern part of the Colorado Plateau region to largely reddish-brown coarse-grained siltstone in the northern part. This change is most noticeable northward along Comb Ridge between the San Juan River and Elk Ridge in southeastern Utah.

The limestone in the Owl Rock Member occurs as horizontal beds that average 1 foot in thickness. In some places, the limestone beds appear to have formed by the growth and coalescence of limestone nodules; all gradations can be seen from layers containing a few scattered limestone nodules to layers containing a tight coalescing mass of nodules. Some of the limestone beds, particularly those in the lower part of the member, contain reddish-orange or gray chert in highly irregular masses which are generally less than 2 inches across. Some of the chert occurs as irregular stringers in the rock.

The Owl Rock Member also locally contains beds of horizontally laminated and ripple-laminated siltstone and sandstone, cross-stratified sandstone, and limestone and siltstone pebble conglomerate. The mem- ber is a moderately resistant unit that weathers to form escarpments. The limestone beds weather to form ledges.

In the Horse Mesa Creek area (loc. A-4), about 15 miles northeast of the Lukachukai Mountains in northeastern Arizona, the Owl Rock Member contains layers of sandstone, sandy siltstone, and conglomerate. Pale-reddish-brown, pale-purple, and yellowish-gray very fine grained cross-stratified or horizontally laminated sandstone grades to sandy siltstone. The conglomerate occurs as irregular lenses in the sandstone and contains granules, pebbles, and cobbles of siltstone and minor amounts of limestone. The sandstone, sandy siltstone, and conglomerate are similar to rock types that occur in the lower and middle members of the Dolores Formation in the San Juan Mountains area in southwestern Colorado and could be partly correlative with these strata ( $\mathrm{pl}$. 2, locs. 16, 34).

The Owl Rock Member ranges in thickness from 0 to perhaps as much as 500 feet (pl. 5).

The contacts of the Owl Rock Member are poorly defined in most areas. The authors have placed the lower contact at the change from bentonitic claystone and clayey sandstone of the Petrified Forest Member below to the mainly nonbentonitic, or at least less bentonitic, reddish-brown siltstone of the 


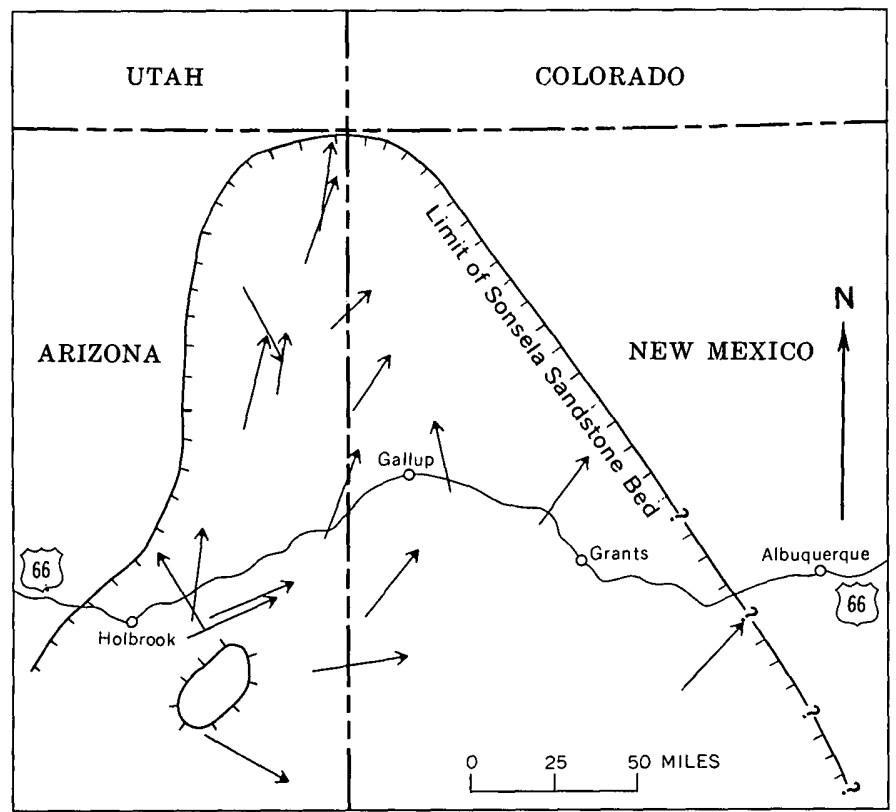

EXPLANATION

Resultant dip direction of cross-strata

Length of arrow is proportional to consist-

ency factor. Base of arrow is location of study

Figure 20. - Areal distribution and direction of sediment transport of Sonsela Sandstone Bed of Chinle Formation.

Owl Rock Member above. In places, this contact is at the base of the lowest limestone in the Owl Rock Member, but in other places it is several tens of feet or even as much as 200 feet below the lowest limestone. It is placed at the change from strata below that weather to badlands with frothy or puffy surfaces to strata above that weather to generally smooth slopes covered by a thin loose veneer of small angular fragments. In the field, the contact is located in detail by testing rock samples with water (or saliva) to determine their swelling properties. A drop of water on rocks containing swelling clays (and thus probably montmorillonitic and bentonitic clays) produces a raised chalky lightcolored spot. The contact is placed at the change from rocks that swell in such a manner to rocks that do not. In some areas, however, some bentonitic layers also occur within the Owl Rock Member, particularly in the southern part of the Colorado Plateau, and in these areas the contact is transitional over 100 feet or more.

Detailed study of clays in the Chinle Formation does not entirely substantiate our basis for locating the contact. The clays in the Chinle Formation do not show an abrupt change in clay types; instead, they show a gradual one from montmorillonitic types in the lower part to less montmorillonitic types in the upper part (Schultz, 1963, pl. 3). Locally, in both the upper and lower parts of the formation, rocks rich in montmorillonite are interstratified with rocks less rich in that component. Nonetheless, strata that contain montmorillonite, rather than mixed layer montmorillonite, are almost entirely in the lower part of the Chinle Formation. In part at least, the swelling properties of the rocks, which are the basis on which we locate the contact, may be related to factors other than the type of clay; the amount and type of cementation, for example, may partly influence the swelling properties of the rocks.

Our definition of the lower contact of the Owl Rock Member is somewhat different from that of other geologists, who generally place the contact at the base of the lowest limestone. We found that the change from bentonitic to less bentonitic strata in the Chinle Formation appeared to be at a more consistent stratigraphic position from section to section than the base of the lowest limestone. In addition, the change in bentonitic character of the strata, although gradual, appeared to be a more fundamental lithologic change in the formation than the position of the lowest limestone. Because we place the contact lower, our thicknesses of the Owl Rock Member are commonly larger than those of other geologists.

The upper contact of the Owl Rock Member is in most areas placed at the top of the highest limestone bed. Locally, the contact is placed a few feet or a few tens of feet above the highest limestone, where a more significant change in lithology appears to mark a higher contact. In northernmost Arizona and in some parts of southeastern Utah, the contact chosen is at a slight color change from purplish-palered strata below to reddish-brown siltstone above; the highest limestone is commonly at the color change, but in places some purplish siltstone occurs above the limestone, and here the contact is placed at the color change rather than at the limestone.

\section{CHURCH ROCK MEMBER AND RELATED UNITS}

The Church Rock Member and related units, which are widely distributed on the Colorado Plateau (pl. 5 ), consist mainly of thick-bedded red siltstone, but in some areas they include ripple-laminated and cross-stratified coarse siltstone and sandstone and locally some conglomeratic strata. These units contain a wide variety of lithologic types, and facies changes appear to be more pronounced in them than in other parts of the Triassic stratigraphic sequence. 




Figure 21. - Owl Rock Member of Chinle Formation in southern part of Red Rock Valley in northeastern Arizona. Ledgeforming units are limestone; slope-forming are siltstone.

The strata that are described here have been given different names in different areas and include the following units: (1) The Church Rock Member of the Chinle Formation in southeastern Utah and the Monument Valley area, Arizona, (2) the Rock Point Member of the Wingate Sandstone in northeastern Arizona and westernmost New Mexico, (3) a siltstone unit of the Chinle Formation in the Bluewater Creek area of west-central New Mexico, (4) a siltstone member of the Chinle Formation in the Rio Chama area of north-central New Mexico, (5) the middle and upper members of the Dolores Formation in the southern part of the San Juan Mountains region of southwestern Colorado and undifferentiated Dolores in the northern part of that region, and (6) the red siltstone member of the Chinle Formation in northeastern Utah and western Colorado, including an underlying sandstone and conglomerate member and an overlying upper member in the Uinta Mountains of northwestern Colorado and northeastern Utah.

These strata are over 1,000 feet thick in a part of west-central Colorado and in southwestern Colorado, where they constitute the entire upper (red-beds) part of the Chinle Formation or related strata, but in most areas they are only a few hundred feet thick.

\section{CHURCH ROCK MEMBER}

The name Church Rock Member was first used by Stewart (1957); the type section has not been specifically designated but is here considered to be the section described by Witkind and Thaden (1963, p. 33) in the Monument Valley area about 4 miles north of Church Rock. The member is recognized in much of southeastern Utah (Stewart, 1957, p. 459460 ) as well as in the Monument Valley area, Arizona.

Stewart, Williams, Albee, and Raup (1959, p. 518) informally referred to a widespread sandstone and conglomerate at the top of the Church Rock Member as the Hite bed. This unit is of particular importance in regional correlations and is hereby formally named the Hite Bed. The type section (see stratigraphic section U-29) is in San Juan County, Utah, 
on a southeast-trending promontory about $13 / 4$ miles south-southeast of the now-abandoned town of Hite, from which it is named, and one-half mile north of the Colorado River at the Horn. At the type section, the Hite Bed is 34 feet thick.

Detailed study by O'Sullivan (1970) of the upper part of the Chinle Formation along Comb Ridge near the Arizona-Utah State line, subsequent to the author's fieldwork, has led to uncertainty about the validity of the name Church Rock Member in southeastern Utah. O'Sullivan has found that most of the Church Rock Member at the type section in the southern part of Comb Ridge in Arizona thins to the north and wedges out into a layer of sandstone and conglomerate (the Hite Bed). This sandstone and conglomerate unit forms only the topmost part of the Church Rock Member in southeastern Utah; most of the Church Rock Member in Utah is thus older than most of the type Church Rock in Arizona. O'Sullivan has also suggested that a widespread unconformity occurs at the base of the Hite Bed, separating strata above that are correlative with the type Church Rock in Arizona from strata below that are the lower part of what is here assigned to the Church Rock in southeastern Utah. Although we did not recognize such an unconformity during our. fieldwork, we realize that its existence would affect particularly our isopach maps of the upper part of the Chinle Formation.

Some geologists have suggested that the name Church Rock Member should not be applied to rocks in southeastern Utah because, as has been suggested by O'Sullivan (1970), most of the strata included in the member there by Stewart (1957) and Stewart, Williams, Albee, and Raup (1959) are not laterally equivalent, physically or temporally, to the type Church Rock in Arizona. In this report, the name Church Rock Member is retained in southeastern Utah, although we recognize the questionable affinity there. We apply the name to a red-bed sequence in the uppermost part of the Chinle Formation in southeastern Utah that has the same general, although not identical, lithologic characteristics as the type Church Rock in Arizona and that lies between the Owl Rock Member of the Chinle and the Wingate Sandstone, as does also the Church Rock Member in Arizona. We realize, however, that the internal stratigraphy of this member is complex and that additional work on a regional scale may lead to a more precise nomenclature.

The Church Rock Member is composed chiefly of pale-reddish-brown, reddish-orange, and light-brown fine to coarse siltstone that is structureless or in thin to thick horizontal beds. The lithologic character of the siltstone varies somewhat from place to place and locally includes some pale-red fine-textured clayrich siltstone that weathers with a slight purplish tint. Typically, the siltstone in the member breaks into small angular fragments that thinly cover the weathered slopes. It is locally interstratified with thin beds of horizontally laminated or ripple-laminated siltstone.

Irregular lenses or persistent beds of sandstone and sandy siltstone occur widely in the Church Rock Member, and in places they constitute more than half of it. These rocks are pale red or light greenish gray, fine to very fine grained, and horizontally laminated, ripple laminated, or cross stratified on a small to medium scale. They locally contain pebbles, cobbles, or boulders of siltstone.

Two persistent units of sandstone occur in the Church Rock Member (figs. 2 and 10). One of them,

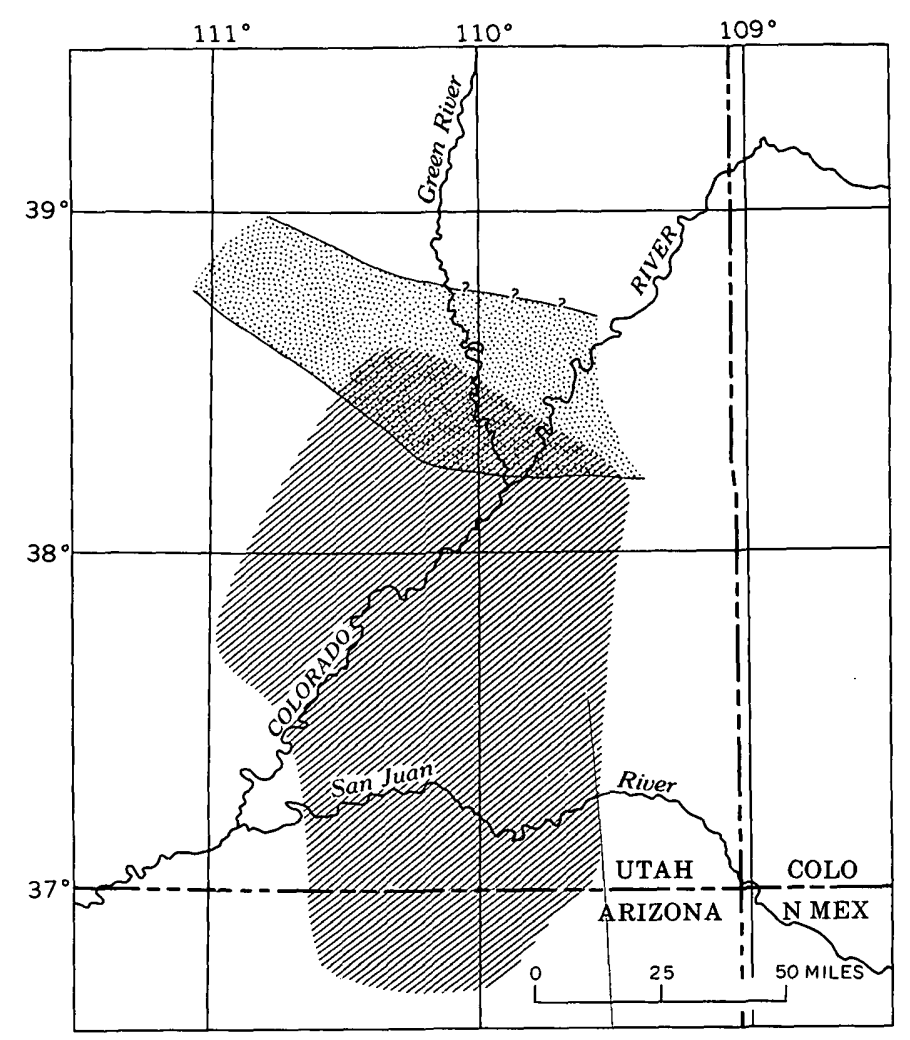

EXPLANATION

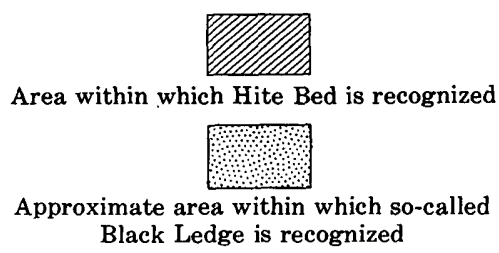

Figure 22. - Distribution of Hite Bed and so-called Black Ledge of the Church Rock Member. 
at or near the base of the member, is informally referred to as the Black Ledge (Stewart and others, 1959 , p. 518); the other, at the top of the member, is now formally named the Hite Bed. The approximate distribution of the two units is shown in figure 22. The so-called Black Ledge consists mainly of cross-stratified sandstone that grades upward through horizontally and ripple-laminated siltstone into structureless or thin- to thick-bedded siltstone typical of the Church Rock Member. It is generally 30 to 40 feet thick and lies at the base of the Church Rock Member along the Colorado and Green Rivers and from about 45 to 95 feet above the base of the member in the San Rafael Swell.

The Hite Bed consists of cross-stratified sandstone and interstratified lenses of reddish-brown siltstone and claystone. It is 20 to 60 feet thick in most areas but is locally as much as 85 feet thick and is absent at some places within its main area of deposition.

The areal extent of the Hite Bed is not well known. To the north and east, it may extend into a more sandy facies of the Church Rock Member and be indistinguishable from other sandstone units in the member; to the south and west it may wedge out in areas where Triassic strata are covered by younger formations.

In addition to the so-called Black Ledge and the Hite Bed, the Church Rock Member contains many sandstone lenses, concentrated in a fairly well defined northwest-trending belt extending from southwestern Colorado on the southeast to the northern part of the San Rafael Swell on the northwest. In the area near the junction of the Green and Colorado Rivers and in the San Rafael Swell, sandstone locally constitutes ffrom 60 to 70 percent of the member. (See description under "Sedimentary Facies.")

The contact of the Church Rock Member with the underlying Owl Rock Member is placed, in most areas, at or near the top of the highest limestone in the Owl Rock Member. In the Monument Valley, Clay Hills, and White Canyon areas, and in the southern part of the Orange Cliffs area, however, it is generally placed at the change from pale-purplishred fine siltstone below to pale-reddish-brown or light-brown coarse siltstone above. Locally, as at Jacobs Chair (loc. U-30) in the White Canyon area, a few limy siltstone beds occur in the Church Rock Member. In the northern part of the Orange Cliffs area and near the junction of the Green and Colorado Rivers, the contact is generally put at the base of the Black Ledge, but this again is near the top of the highest limestone.

Much of the Church Rock Member near the junction of the Green and Colorado Rivers appears to grade laterally into the Owl Rock Member farther south. This relationship is shown between Bridger Jack Mesa (fig. 10, loc. $G$ ) and Lockhart Canyon (fig. 10, loc. $I$ ).

The Church Rock Member is generally from 0 to about 300 feet thick but is locally thicker (pl. 5). It is thickest in the northeastern and eastern parts of southeastern Utah and thinnest in the western part of southeastern Utah. Correlative rocks in Colorado (red siltstone member) are over 1,000 feet thick locally (pl. 5).

ROCK POINT MEMBER OF WINGATE SANDSTONE

Considerable disagreement has arisen about the stratigraphic assignment of the strata here described. They were originally recognized as a unit by Gregory (1917, p. 42), who referred to them as "Division A" of the Chinle Formation, but later they were assigned to the basal part of the Wingate Sandstone and named the Rock Point Member by Harshbarger, Repenning, and Irwin (1957, p. 5-8). Correlative rocks in the Monument Valley area were called the Church Rock Member of the Chinle Formation by Stewart (1957) and by Witkind and Thaden (1963). In present-day usage, the name Rock Point Member of the Wingate Sandstone is used south of Laguna Creek (which runs along the south side of the Monument Valley area), and the name Church Rock Member of the Chinle Formation is used for the same unit north of Laguna Creek. This separation in nomenclature has been indicated by Harshbarger, Repenning, and Irwin (1957, pl. 2), Stewart (1957, p. 460), and Witkind and Thaden $(1963$, p. 34) and is followed in this report.

The assignment of these strata to the Wingate Sandstone by Harshbarger, Repenning, and Irwin (1957, p. 5-8) was based on similarities between the Rock Point and the Wingate in respect to (1) grain size and composition, (2) areal distribution, and (3) physical relationships; but the evidence on which they chiefly relied was apparently the intertonguing of the Rock Point with the overlying part of the Wingate Sandstone. Although this intertonguing is impressive and in places makes separation of the Rock Point from overlying strata difficult, our observations suggest that only a few of the so-called tongues actually merge with the overlying part of the Wingate, and that many may be isolated lenses in the Rock Point Member. We feel that the main lithologic type of the Rock Point Member, horizontally stratified red siltstone, is more characteristic of the Chinle Formation, which includes many such red-bed units elsewhere on the Colorado Plateau, than of the overlying Wingate, which is a distinctive 
cross-stratified massive sandstone. As has been pointed out elsewhere (Stewart, 1969), the Upper Triassic strata on the Colorado Plateau are divisible into three major lithogenetic sequences: a bentonitic sequence composed mostly of the lower part of the Chinle Formation, a red-bed sequence composed of the upper part of the Chinle Formation and laterally equivalent strata in the Dolores Formation, and a sandstone sequence constituting the entire Wingate Sandstone in places or the upper member (Lukachukai Member) of the Wingate in other places. Lithologically, therefore, the red beds of the Rock Point Member seem to be more closely related to the upper part of the Chinle Formation and laterally equivalent strata in the Dolores than to the Wingate, and they are here included with the Chinle Formation on the isopach and lithofacies maps.

The Rock Point Member occurs in northeastern Arizona, exclusive of the Monument Valley area, and in westernmost New Mexico. Its western boundary is a north-south line passing about 20 miles east of Cameron.
The main mass of the Rock Point Member is composed of pale-reddish-brown and light-brown horizontally bedded sandy siltstone and silty sandstone. Its bedding planes are indistinct, but individual beds are mostly from 1 foot to 10 feet thick. In many places the strata are composed of a mixture of coarse silt and very fine sand in about equal proportions, so that it is difficult to classify the rock in the field as either sandstone or siltstone. Both rocks weather as slopes mantled with angular fragments.

Along the east side of the Defiance uplift from Lukachukai to Fort Defiance, and in outcrops extending northward from the Lukachukai Mountains for 20 miles, the Rock Point Member contains units 10 to 40 feet thick of ledge-forming sandstone (fig. 23) of probable eolian origin. This sandstone is light brown, or locally pale reddish brown, very fine grained, and well sorted and is composed of subrounded grains of reddish-stained quartz. It is generally cross stratified; the cross-strata occur in thin to very thick planar sets of small to medium scale. Parts of some units are horizontally laminated.

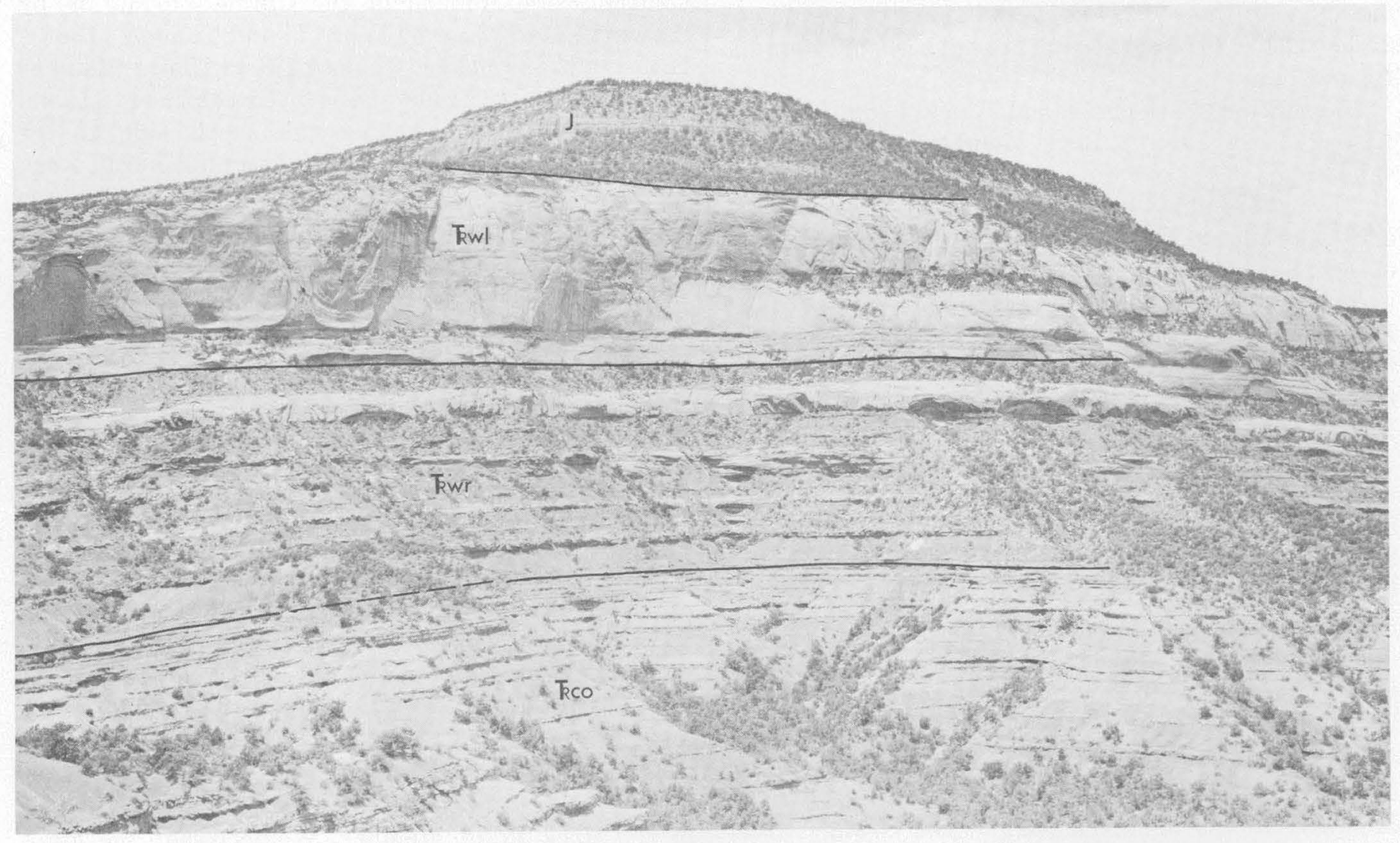

FIgURe 23. - Owl Rock Member of Chinle Formation and Rock Point and Lukachukai Members of Wingate Sandstone in the southern part of Red Rock Valley in northeastern Arizona. Resistant beds in Owl Rock Member ( $k c 0$ ) are limestone or limy siltstone. Resistant beds in Rock Point Member ( $\mathrm{k} w r$ ) are sandy siltstone and very fine grained sandstone. Slopeforming units in both the Owl Rock and Rock Point Members are siltstone and sandy siltstone. Kwl, Lukachukai Member of Wingate Sandstone; J, formations of Jurassic age. 
The units of supposed eolian origin occur in a cyclic repetition of strata. The cycle is, from bottom to top: (1) Thin to very thick horizontally bedded sandy siltstone or silty sandstone, a few feet to several hundred feet thick; (2) horizontally to wavylaminated sandy siltstone or silty sandstone (locally containing a few ripple-marked layers), 5 to 40 feet thick; and (3) cross-stratified sandstone, 10 to 40 feet thick, of supposed eolian origin. At some localities, the cycle is repeated three or four times within the Rock Point Member.

Some of the sandstone units of probable eolian origin can be demonstrated to be southward-extending tongues of the Lukachukai Member of the Wingate Sandstone; others could be either tongues that connect with the Lukachukai Member in areas away from outcrops or, more likely, isolated lenses within the Rock Point Member. Along the southwest face of the Lukachukai Mountains, two cross-stratified sandstone units can be shown to separate from the main part of the Lukachukai Member and extend into the horizontally bedded strata of the Rock Point Member. These relationships are shown between sections $B$ and $C$ in figure 24 . Along that same slope, also, other sandstone units are observed to come in below the tongues described above, without grading into the main part of the Lukachukai Member.

Correlation of the cross-stratified sandstone units in the Rock Point Member southward along the east side of the Defiance uplift cannot be made with assurance because the outcrops there are discontinuous. The correlations shown in figure 24, however, are considered reasonable, and if they are correct the Entrada Sandstone progressively truncates the Wingate Sandstone southward. The rocks representing the Lukachukai Member at Fort Wingate (fig. 24, loc. $J$ ) probably grade into sandstone units in the Rock Point Member and may all be older than those representing the Lukachukai Member in the northern part of the Defiance uplift.

The rocks assigned to the Rock Point Member at Lupton (fig. 24, loc. $H$ ) and at Zuni (fig. 24, loc. I) include light-brown, grayish-red, very pale orange, and light-greenish-gray sandstone and sandy siltstone in trough sets of small- to medium-scale crossstrata. Some of the sandstone and sandy siltstone is in part horizontally laminated but commonly contains cuspate and parallel ripple marks and mud-crack fillings. These rocks constitute almost all of the Rock Point Member at Zuni. To the northwest and north from Zuni, they grade into the pale-reddish-brown sandy siltstone and silty sandstone that constitute the main part of the Rock Point Member in the Defiance uplift (fig. 24, loc. $B-G$ ). Northeast of Zuni they grade into the light-brown sandstone that constitutes the Lukachukai Member of the Wingate Sandstone at Fort Wingate (fig. 24, loc. $J$ ).

The Rock Point Member is thickest (over $500 \mathrm{ft}$ thick) in a northeast-trending area extending from outcrops north of Winslow (near loc. 66, pl. 5) to the northern part of the Defiance uplift (near loc. $6 \mathrm{~b}, \mathrm{pl} .5)$, and it thins in all directions from this area.

The Rock Point Member of the Wingate Sandstone overlies the Owl Rock Member of the Chinle Formation in the Defiance uplift. The contact between them is conformable and is generally placed at the top of the highest continuous limestone of the Owl Rock Member. In the Zuni area, the Rock Point Member overlies the Petrified Forest Member. Here, the contact marks an abrupt change in lithology from the variegated bentonitic claystone of the Petrified Forest Member to the brown or red fine-grained sandstone of the Rock Point Member. A few granules and pebbles of chert, and still fewer of quartzite, are scattered in the sandstone or siltstone in the basal few inches of the Rock Point Member. These are faceted and pitted and may be ventifacts. The sharpness of the contact between these members in the Zuni area, together with the occurrence of granules and pebbles just above it, suggests an unconformity.

In much of northeastern Arizona the Rock Point Member is overlain by the Lukachukai Member of the Wingate Sandstone. The contact is placed at the change from horizontally stratified siltstone and silty sandstone below to cross-stratified sandstone above. In areas where the Rock Point and Lukachukai Members intertongue, the contact is placed at the top of the highest thick unit of horizontally stratified siltstone and silty sandstone (fig. 24).

Along the east side of the Defiance uplift in northeastern Arizona and westernmost New Mexico and in the Zuni area of New Mexico, the Rock Point Member is unconformably overlain by the medial silty member of the Entrada Sandstone of Late Jurassic age. Although this contact marks a significant break in deposition, it is difficult to locate in many areas. Both members consist mainly of sandy siltstone and silty sandstone. The Rock Point Member, however, is predominantly thin to very thick bedded, whereas most of the overlying strata are horizontally laminated or composed of wavy disrupted laminae and in many areas contain a few disseminated well-rounded medium- to coarse-sized grains of quartz and chert, not ordinarily found in the Rock Point Member except in the eolian sandstone units. At Chee Dodge, Todilto Park, and Fort Defiance (fig. 24, locs. $E, F$, and $G$ ), the contact is 


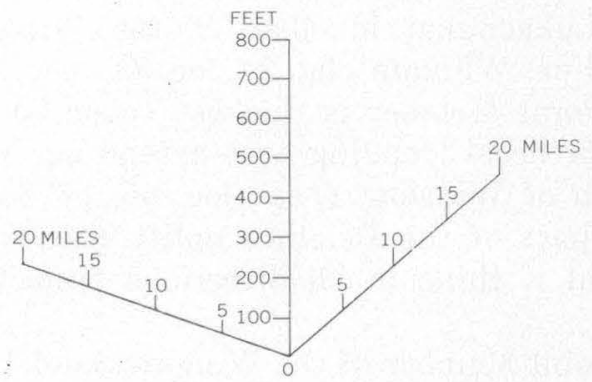

DATUM IS BASE OF FENCE

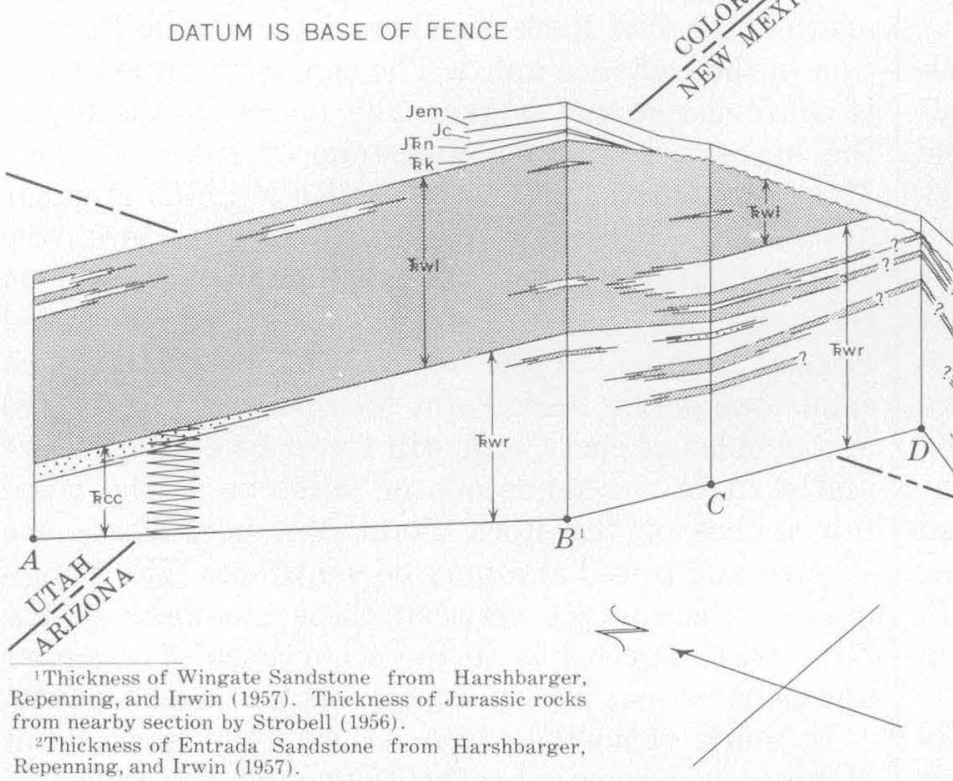

EXPLANATION

\section{LOCALITIES}

A. PONCHO HOUSE (IOC. U-36)

B. ROUND ROCK (loc. A-14)

C. LUKACHUKAI TRADING POST (loc. A-6b)

D. TOADLENA (loc. NM-11)

E. CHEE DODGE (loc. A-3)

F. TODILTO PARK (loc. NM-4)

G. FORT DEFIANCE (Ioc. NM-2)

H. LUPTON (loc. A-7)

I. ZUNI (IOC. NM-5)

J. FORT WINGATE (loc. NM-44)
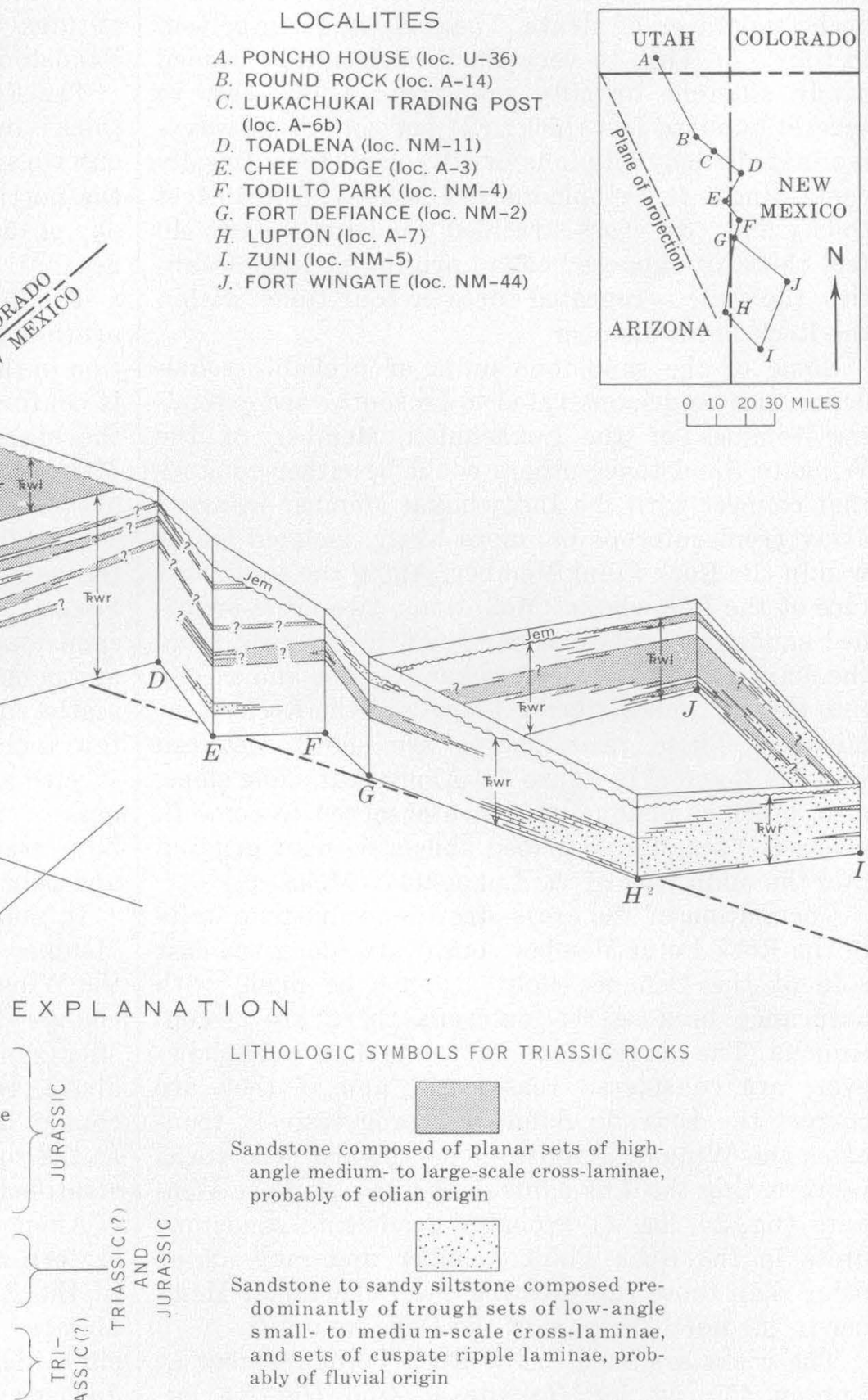

Medial silty member of Entrada Sandston
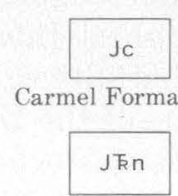

Navajo Sandstone

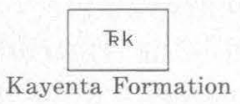

$\int \leqslant$

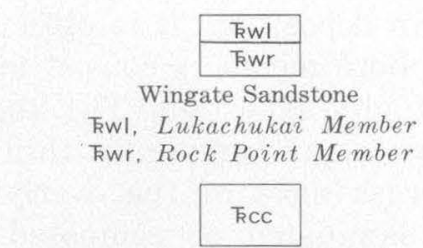

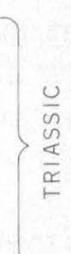

Church Rock Member of Chinle Formation

ably of fluvial origin

Predominantly siltstone to silty sandstone composed of horizontal sets of very thick beds (at Fort Wingate includes horizontally stratified sandstone similar to horizontally stratified sandstone in the Wingate Sandstone elsewhere)

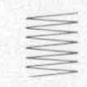

Arbitrary nomenclature boundary

FIGURE 24. - Fence diagram of Church Rock Member of Chinle Formation and Rock Point and Lukachukai Members of Wingate Sandstone in southeastern Utah, northeastern Arizona, and northwestern New Mexico. 
placed at the base of a thin discontinuous layer of light-colored sandstone or sandy siltstone containing many disseminated grains of quartz and chert. At Chee Dodge small scours occur at the base of this layer, which may have been formed by reworking of the underlying sediments before the deposition of the main part of the Entrada Sandstone.

UNIT IN BLUEWATER CREEK AREA, WEST-CENTRAL NEW MEXICO

A unit referred to by Silver $(1948$, p. 73 ) as the Red Sandstone Member is exposed in the Bluewater Creek area, west of the Lucero uplift and about 50 miles southwest of Albuquerque, N. Mex. This unit, which is in the uppermost part of the Chinle Formation, overlies the Petrified Forest Member and it unconformably underlies the Wingate Sandstone or, in some areas, younger formations. Silver showed the outcrops of this unit as extending from a point 8 miles south of Bluewater Creek to one about 5 miles north of that stream. We, however, have observed the unit on the south side of Petoch Butte, 11 miles north of Bluewater Creek, and have noted that its outcrops reach a northern limit on the east side of that butte. We have not examined the outcrops between Petoch Butte and Bluewater Creek and do not know if the member is continuous between the two areas.

At Bluewater Creek (loc. NM-18), where the unit is 217 feet thick, it consists mostly of light-brown, pale-reddish-brown, and grayish-red medium- to coarse-grained siltstone. Except for a few layers of horizontally laminated siltstone, the rock appears strutureless on close examination, but when viewed from a distance the rock is seen to contain horizontal stratification planes. The upper 60 feet of the unit at Bluewater Creek consists predominantly of horizontally to wavy-laminated siltstone and sandy siltstone that form several ledges. The main part of the member weathers to a steep slope covered with a thin loose veneer of small angular fragments of the siltstone.

On Petoch Butte, the unit contains the same lithologic types except that horizontally laminated layers are not present. It is only about 40 feet thick on the south side of Petoch Butte and thins northward within about 2,000 feet to a thin edge on the east side of the butte.

The lower contact of the unit is conformable and is placed at the color change from slightly purple, though dominantly red, siltstone of the underlying part of the Chinle Formation to light-brown siltstone above. The contact is also marked by a subtle textural change; the rock below is composed of fine silt that is slightly bentonitic in some places, whereas that above is predominantly light brown and nowhere bentonitic.

The upper contact of the so-called red sandstone member of Silver (1948) is an unconformity. On Petoch Butte the member is overlain unconformably by the Wingate Sandstone, but to the south the Wingate is overlapped by the Entrada Sandstone, which in much of the area between Petoch Butte and Bluewater Creek overlies the red sandstone member. The Entrada Sandstone is in turn overlapped by a sandstone probably equivalent to the Summerville Formation, of Late Jurassic age. This sandstone overlies the red sandstone member in the northern part of the Bluewater Creek area. Southward, in the Bluewater Creek area, the Dakota Sandstone, of Cretaceous age, truncates the probable equivalent of the Summerville Formation, and in the southern part of the Bluewater Creek area it overlies the unit that is being considered here (Silver, 1948).

At Bluewater Creek this unit is lithologically similar to the strata of the Rock Point Member of the Wingate Sandstone at the type area of that member, and it is also similar to red-bed units in the uper part of the Chinle Formation elsewhere on the Colorado Plateau. Exact correlation is uncertain, however, because the unit occurs in an isolated area.

SILTSTONE MEMBER IN NORTH-CENTRAL NEW MEXICO

The informal name "siltstone member of the Chinle Formation" is used here for a local unit at the top of the Chinle Formation in the Ghost Ranch area (fig. 8, loc. $G$ ) in north-central New Mexico. It conformably overlies the Petrified Forest Member of the Chinle Formation and is unconformably overlain by the Entrada Sandstone. It grades into the upper part of the Petrified Forest Member in outcrops to the southwest, but at Ghost Ranch it seems sufficiently well defined to be considered a separate member.

At Ghost Ranch (loc. NM-9), this unit is 230 feet thick and consists of light-brown, pale-reddish-brown, and grayish-red apparently structureless siltstone and clayey siltstone; from a distance, however, a few horizontal stratification planes can be seen. In the top 114 feet the siltstone contains large grains and some nodules of limestone. Some thin beds in the middle of the member contain low-angle mediumscale cross-strata.

This member, except in the basal 35 feet, does not contain clay that swells noticeably on contact with water; thus, it does not on field examination appear bentonitic. Schultz (1963, pl. 3), however, has shown that much of the clay in this member is montmorillonite and not much different from that in the underlying strata of the Petrified Forest Member. 
The lower contact of the member is conformable and is placed at the change from dominantly reddish clayey rocks below to brownish silty rocks above. The upper contact is an unconformity and is marked by a change from slope-forming siltstone below to massive cliff-forming sandstone of the Entrada Sandstone above.

The siltstone member grades laterally to the southwest into the upper part of the Petrified Forest Member; the limit of the member to the southwest is therefore arbitrary.

The red shale and clay of the Chinle Formation exposed at Canones Creek 10 miles northeast of Tierra Amarilla in northern New Mexico, described by Dane (1948) and Muehlberger (1957), may be the siltstone member, but we have not examined them. In that area the Chinle Formation rests on Precambrian rocks.

The siltstone member of the Ghost Ranch area is similar to other red-bed units in the upper part of the Chinle Formation, but exact correlations are uncertain because of the large distances between the Ghost Ranch area and outcrops of red-bed units elsewhere.

MIDDLE AND UPPER MEMBERS OF DOLORES FORMATION IN SOUTHERN PART OF SAN JUAN MOUNTAINS REGION

The Dolores Formation in the southern part of the San Juan Mountains area of southwestern Colorado (fig. 15 , locs. $G, H, I$ ) is divided into three members, referred to informally as the lower, middle, and upper members. The lower member, a ledgeforming sandstone regarded as probably correlative, at least in part, with the Moss Back Member of the Chinle Formation in southeastern Utah, has been described in the section "Moss Back and Related Members." The middle and upper members consist predominantly of reddish-brown siltstone considered to be laterally equivalent to strata elsewhere included in the upper part of the Chinle Formation (fig. 15).

\section{Middle Member}

The middle member is composed of grayish-red, grayish-red-purple, light-brownish-gray, and lightgreenish-gray micaceous siltstone, sandy siltstone, and very fine grained sandstone. The strata are ripple laminated in some parts of the member and horizontally laminated and bedded in other parts. Both cuspate and parallel ripples are present rarely. The member varies greatly from place to place in lithologic character because of lensing and grading out of individual units. It commonly contains carbonaceous material and fragments of bone. It includes thin lenses of limestone pebble conglomerate in which pebbles and very coarse grains of limestone or limy siltstone are embedded in a matrix of limy silt. The member weathers to form a slope from which lenses of resistant sandy siltstone and sandstone, commonly containing cross-strata, project as ledges.

The middle member is at least 170 feet thick at Stoner (loc. C-14a), where the top of the member is covered; 270 feet at Durango (loc. C-5) ; and 129 feet along the Piedra River (loc. C-1), where it is truncated by pre-Entrada erosion.

The lower contact of the member is gradational and intertonguing. The lower member of the Dolores Formation is predominantly sandstone, whereas the middle member is at least half siltstone; the contact is generally placed at the base of the lowest thick siltstone unit in the middle member. Sandstones in the lower and middle members are, however, lithologically similar, and the distinction between the two members is not pronounced.

Some of the sandstone, sandy siltstone, and conglomerate in the lower and middle members of the Dolores Formation are lithologically similar to strata in the Owl Rock Member in the Horse Mesa Creek area (loc. A-4) in northeastern Arizona. (See p. 39.) These rock types in the Owl Rock Member are unusual, as most of that member is siltstone, and they could be the marginal deposits of strata correlative with at least part of the lower and middle members of the Dolores Formation (pl. 2).

\section{UPPER MEMBER}

The upper member consists mainly of horizontally stratified light-brown and reddish-brown siltstone and sandy siltstone. When viewed from a distance, it appears to be made up of beds from a few feet to about 20 feet thick; but on close examination these beds are difficult to separate, and the strata locally appear structureless. A few layers are horizontally laminated. The member weathers to form steep slopes below the cliff-forming Upper Jurassic Entrada Sandstone. The siltstone and sandy siltstone, where well exposed, weather to small angular fragments that form a loose veneer on the slope. Locally some of the beds contain rounded nodules of limy siltstone up to 1 inch in diameter.

Units of silty sandstone and sandstone, ranging in thickness from about 10 to 50 feet and weathering as smooth massive ledges, occur in the upper member in the Stoner and Durango areas (fig. 15, locs. $G$ and $H$ ). The silty sandstone and sandstone are light brown, very fine grained, and well sorted, and they consist predominantly of subrounded red-stained quartz grains. The upper and lower boundaries of the units are flat bedding planes. Within the units, the strata are horizontally laminated; the laminae 
are characterized by an indistinct waviness that suggests some type of low-amplitude ripples or irregularities. In the Durango stratigraphic section (loc. C-5) there is only one of these units, which is from 75 to 109 feet above the base of the member; in the Stoner stratigraphic section (loc. C-14) there are at least four, all in the upper 300 feet of the member. In the Stoner area, the top 70 feet of the upper member is composed of siltstone, sandy siltstone, and sandstone that intergrade and are difficult to separate into distinct units. The coarser layers are similar to the ledge-forming silty sandstone and sandstone units in the underlying part of the member, except that some of them contain scattered fine to coarse, rounded, red-strained, frosted quartz grains, which constitute as much as 10 percent of some units. One of the coarser grained units near the top of the formation at Stoner contains thin trough sets of small- to medium-scale low-angle cross-strata.

The upper member is about 540 feet thick at Stoner and 259 feet thick at Durango and is absent along the Piedra River (fig. 15). Wells to the southwest of outcrops of the Dolores Formation contain 600 to 700 feet of strata assignable to the upper member. The abrupt thinning of the unit eastward and its absence along the Piedra River are thought to be due to pre-Entrada erosion.

The contact between the upper and middle members is placed at the change from purplish ripple-marked siltstone and sandstone below to reddish-brown and light-brown horizontally stratified homogeneous sandy siltstone and silty sandstone above. This contact is difficult to place, for it is probably gradational over several tens of feet.

The contact of the upper member with the overlying Entrada Sandstone is a regional unconformity along which the Entrada truncates much of the Dolores Formation eastward (fig. 15). In many places the contact is difficult to locate because much of the sandstone in the upper part of the Dolores is lithologically similar to that in the lower part of the Entrada Sandstone. In most places, however, the Entrada Sandstone forms a smooth-weathering rounded cliff ("slick rim"), which contrasts sharply with the moderate slopes formed on the upper member of the Dolores Formation. The contact is also marked by subtle lithologic differences. The topmost unit of the upper member of the Dolores Formation is generally a sandy siltstone, whereas the overlying Entrada Sandstone is a very fine grained sandstone containing scattered fine to medium grains; the upper member is generally horizontally stratified, whereas the Entrada Sandstone is cross stratified; the upper member is reddish brown or light brown, whereas the Entrada Sandstone is characteristically very pale orange. Wherever observed, the contact is sharp and flat; no scour surfaces were noted.

The upper member of the Dolores Formation is considered to be a lateral continuation of the Rock Point Member of the Wingate Sandstone in the Defiance uplift. Both units are composed largely of reddish-brown siltstone, and both locally contain ledge-forming sandstone units. The sandstone units in the upper member are finer grained than those in the Rock Point Member and do not contain the highangle cross-strata characteristic of those in the Rock Point Member, but these differences could be facies changes within laterally equivalent strata. Some of the sandstone units in the Rock Point Member are tongues of the Lukachukai Member of the Wingate Sandstone, which consist mainly of cross-stratified sandstone, whereas others are probably discrete units entirely within the Rock Point Member. Similarly, some of the sandstone units in the upper member of the Dolores Formation could be tongues of the Wingate, whereas others could be within the upper member. The exact correlations are uncertain, largely because of the lack of outcrops and information in the area between the San Juan Mountains and the Defiance uplift.

\section{DOLORES FORMATION IN NORTHERN PART OF SAN JUAN MOUNTAINS REGION}

The Dolores Formation in the northern part of the San Juan Mountains region comprises a lightcolored locally conglomeratic basal sandstone unit and an overlying sequence of red beds consisting largely of reddish-brown and pale-red siltstone and sandstone.

The basal unit, which is a few tens of feet thick at most, consists of coarse to very coarse grained sandstone locally containing lenses of conglomerate. At Ouray (loc. C-16), the conglomerate contains granules, pebbles, and cobbles of limestone, chert, quartz, feldspar, granite, gneiss, schist, slate, greenstone, and possible metavolcanic basic rock; elsewhere the conglomerate fragments are mostly quartz and quartzite. The basal sandstone unit is considered to be correlative with a lithologically similar unit at the base of the Chinle Formation in the salt-anticline area northwest of the San Juan Mountains. It is probably not correlative, however, with other basal sandstone units of the Upper Triassic series, such as the Moss Back Member of the Chinle Formation or the lower member of the Dolores Formation, as these units are much finer grained. It is believed to have been formed by local reworking of strata along the pre-Dolores unconformity and is considered to be a 
basal coarse deposit of the upper (red-beds) part of the Chinle Formation.

The main body of the Dolores Formation in the northern part of the San Juan Mountains region is composed of a lithologically variable sequence of reddish-brown and pale-red siltstone and sandstone considered to be largely correlative with the middle and upper members of the Dolores Formation in the southern part of the San Juan Mountains region. At Sawpit (loc. C-19), this part of the Dolores Formation is about 455 feet thick and consists of structureless, horizontally laminated, thick-bedded, or ripple-laminated reddish-brown siltstone, pale-red very fine grained horizontally laminated or crossstratified sandstone, and subordinate limestone and siltstone pebble conglomerate. It contains abundant cuspate and parallel ripple marks.

In the Ouray area (loc. C-16), that part of the Dolores Formation above the basal sandstone unit is only about 100 feet thick and consists of grayishred horizontally laminated to very thick bedded siltstone. In this area the formation does not contain the ripple-laminated siltstone and cross-stratified sandstone that was noted at Sawpit.

The top 30 feet or more of the Dolores Formation in the Placerville area, including the Sawpit stratigraphic section (loc. C-19), consists of very pale orange or reddish-brown very fine grained wellsorted horizontally thin bedded sandstone. This sandstone has been regarded by some geologists (Bush and others, 1959; McKee and others, 1959) as a lateral continuation of the Wingate Sandstone, but such a correlation seems to us uncertain. The strata at the top of the Dolores do not contain crossstrata, a typical feature of the Wingate Saridstone. In fact, some lithologically similar strata in the saltanticline region to the northwest are placed in the uppermost part of the Chinle Formation and lie below strata typical of the Wingate Sandstone. (See Paradox Valley stratigraphic section, loc. C-15.) For these reasons, we believe that these sandstone units are equivalent to the upper part of the Chinle Formation, as mapped in the salt-anticline area, rather than to the Wingate Sandstone.

\section{Red Siltstone Member}

The informal name "red siltstone member" has been applied by Poole and Stewart (1964, p. D36D37) to a unit of red siltstone, containing minor amounts of sandstone and conglomerate, in the easttern Uinta Mountains and in northwestern and westcentral Colorado (fig. 3). It is probably laterally equivalent to the Church Rock Member of the Chinle Formation in southeastern Utah and to most of the
Dolores Formation in the San Juan Mountains region in southwestern Colorado (pl. 2). The name is extended here to include correlative strata in the Uncompahgre Plateau and salt-anticline area in the central part of western Colorado.

This member consists mainly of pale-reddishbrown and grayish-red siltstone which is limy in places. From a distance this rock appears to be thin to thick bedded; on close inspection, however, it appears either structureless or only crudely stratified. Thin lenses of conglomerate with pebbles of limestone or siltstone characteristically occur interstratified with the siltstone and locally constitute 5 percent of the member.

In a fairly well defined northwest-trending belt extending northwestward from Placerville, in the San Juan Mountains region, across the salt-anticline region, into the northern part of the San Rafael Swell, the red siltstone member and also the Church Rock Member and correlative strata in the Dolores Formation contain a large proportion of sandstone. The sandstone forms irregular lenses or layers, as much as 100 feet thick, that interfinger with the siltstone. The sandstone is dominantly pale red or grayish red and very fine to fine grained. Most of the sandstone is horizontally laminated, but, locally, small to medium-scale low-angle cross-strata and ripplemarked layers are common. The sandstone locally grades to coarse siltstone.

Locally in the salt-anticline region in the central part of western Colorado and adjacent part of Utah, the top part of the Chinle Formation contains lightbrown very fine grained horizontally laminated to thick-beded sandstone units ranging in thickness from 1 to 20 feet (Paradox Valley stratigraphic section, loc. C-15). The sandstone in these units is similar in color and texture to that of the overlying Wingate Sandstone, but it does not contain the cross-strata characteristic of the Wingate Sandstone. The proportion of sandstone increases upward in the red siltstone member - so much so in some places as to suggest an intergradation between the Chinle Formation and the Wingate Sandstone. In most places, however, the contact between the Chinle and the Wingate is sharp, and the sandstone below the contact is clearly a part of the Chinle Formation.

The red siltstone member is over 1,000 feet thick in central Colorado (fig. 15) and thins to the northwest and west. It appears to grade laterally into the upper member of the Chinle Formation in the eastern part of the Uinta Mountains. In many parts of northwestern and west-central Colorado, it is very uneven in thickness because of pre-Jurassic erosion.

In west-central Colorado and in the central part 
of western Colorado, the red siltstone member constitutes most of the Chinle Formation. It overlies the mottled member in most of this area, but in the Uncompahgre Plateau and salt-anticline area, it lies either on thin basal sandstone units of the Chinle Formation or on pre-Chinle rocks. The basal sandstone unit has been described by Dane (1935, p. 55$56)$, Shoemaker $(1955,1956 \mathrm{~b})$, and Cater (1955a, $b, c)$. In the eastern part of the Uinta Mountains it is underlain, perhaps disconformably, by the ocher siltstone member, which is itself underlain by the mottled member.

Between Cliff Creek (fig. 3, loc. $C$ ) and Vernal (fig. 3 , loc. $B$ ) in the Uinta Mountains, the red siltstone member is believed to interfinger with the sandier, upper member, and there the contact is generally placed between the highest structureless red siltstone and the lowest brown sandstone of the upper member. Where the upper member is absent, the red siltstone member is immediately overlain by the Glen Canyon Sandstone, of Triassic and Jurassic age. In the central part of western Colorado, the Wingate Sandstone of the Glen Canyon Group overlies the red siltstone member.

In northwestern Colorado, beyond the eastern limit of the Glen Canyon Sandstone, the Chinle Formation is overlain by the Entrada Sandstone of Late Jurassic age, or equivalent strata. Beds above and below the contact appear to be parallel in nearly all outcrops; regional study has shown, however, that from west to east the Chinle is overlain by younger and younger beds, which indicates that the contact is a regional unconformity.

\section{Sandstone and Conglomerate Member}

The sandstone and conglomerate member (Poole and Stewart, 1964, p. D36) is composed of gray, pink, and brown siltstone, sandstone, and conglomerate. This member is restricted to outcrops in the easternmost Uinta Mountains at Cross Mountain (pl. 1, loc. C-10), Vale of Tears (pl. 1, loc. C-155), and Disappointment Creek (pl. 1) ; it is thickest, 115 feet thick, at Cross Mountain. It is regarded as a coarse basal facies of the red siltstone member, and its basal contact may be a disconformity.

The lower part of the member consists mainly of sandstone but includes some siltstone and conglomerate. The conglomerate contains many granules and pebbles of limy siltstone and a few of siliceous rocks. The remainder of the member consists of siltstone, of sandstone, and of mudstone pebble conglomerate. The member is characterized by horizontal lamination, thin beds with ripple laminae, current lineation, and crossbedding.

\section{UPPER MEMBER}

The informal name "upper member" was applied by Kinney (1955) to a sequence of orange, brown, and gray sandstone; red, gray, and brown siltstone; and red, brown, gray, and green claystone at the top of the Chinle Formation. This member is best developed in the western and central Uinta Mountains, where it reaches a maximum thickness of 137 feet (loc. U-1, Lake Fork River). It contains many beds of massive-weathering sandstone resembling the dominant rock of the overlying Glen Canyon Sandstone, and these may in fact be lenses or tongues of the Glen Canyon. The upper member may thus be transitional into the Glen Canyon Sandstone.

The sandstone layers are very fine to medium grained and are horizontally laminated to thick. bedded. Ripple laminae and thin to thick planar and trough sets of small- and medium-scale crosslaminae are present in the upper parts of a few sandstone beds. Cuspate ripples, current lineation, and mud cracks were noted on the surfaces of a few beds.

The siltstone is thinly laminated to thick bedded; some parts are structureless. A few units contain ripple laminae, mud cracks, and pellets of clayey siltstone. The claystone is generally silty and laminated. A pale-red to grayish-red silty claystone unit 15-25 feet thick is at the top of the upper member throughout the central and most of the eastern Uinta Mountains.

The upper member is about 135 feet thick and consists of sandstone, siltstone, and claystone in widely varying proportions. At Vernal (fig. 3, loc. $B$ ) it is about 72 percent sandstone, 20 percent siltstone, and 8 percent claystone; the proportion of sandstone decreases both eastward and westward. At Lake Fork River (fig. 3, loc. $A$ ), west of Vernal, the member is 19 percent sandstone, 51 percent siltstone, and 30 percent claystone. At Cliff Creek (fig. 3, loc. $C$ ), east of Vernal, where this member appears to intertongue with the red siltstone member and is thin, it is 4 percent sandstone, 70 percent siltstone (which may be chiefly tongues of the red siltstone member), and 26 percent claystone.

The upper member overlies the ocher siltstone member west of the Green River. East of the Green River, the upper member overlies the red siltstone member (fig. 3). The contact between the upper member and red siltstone member is characterized by intertonguing, and the upper member is not recognized eastward near Miller Creek (fig. 3, loc. D) above or at the top of the red siltstone member.

The upper member is overlain by the Glen Canyon Sandstone with apparent conformity. The contact 
between them in the central and eastern Uinta Mountains is at the top of a persistent grayish-red silty claystone which underlies a massive cliff-forming sandstone of the Glen Canyon Sandstone.

\section{SEDIMENTARY FACIES}

The sedimentary facies study of the Chinle Formation was initiated to determine regional variations in the lithologic character of laterally equivalent strata. The facies of the lower (bentonitic) part and upper (red-beds) part of the Chinle Formation are described separately, because these two parts differ from one another in lithology, sedimentary history, and principal sources of sediment.

\section{LOWER (BENTONITIC) PART OF CHINLE FORMATION}

The lower part of the Chinle Formation consists of variegated bentonitic claystone, clayey siltstone, clayey sandstone, and thin widespread layers of sandstone and conglomerate. (See p. 15.) It includes members of the Chinle Formation and a laterally equivalent lower member of the Dolores Formation (table 2).

\section{LITHOLOGIC TYPES}

Study of the facies of the lower part of the Chinle Formation is based upon determination of the regional distribution of three main lithologic types. These types are: (1) Ledge-forming cross-stratified fairly to very well sorted sandstone and conglomerate, (2) slope-forming cross-stratified poorly sorted clayey sandstone, commonly bentonitic, (3) slope- forming largely bentonitic, silty claystone and siltstone. The ledge-forming rocks form thin, persistent units such as the Shinarump and Moss Back Members; the other two types form the bulk of the lower part of the Chinle Formation.

\section{METHODS OF FACIES ANALYSIS}

The relative amounts of the three main lithologic types in the lower part of the Chinle Formation were roughly estimated at 53 measured sections scattered over the Colorado Plateau and adjacent areas. All the data were from surface outcrops; well $\operatorname{logs}$ were not considered suitable for use in this type of study. Data obtained at each measured section are listed in table 3 , and the location of these sections can be obtained from plate 1 and table 1.

In the field, the proportion of ledge-forming sandstone and conglomerate was easily determined by measuring the thickness of individual ledges and comparing their total thickness with the total thickness of the lower part of the Chinle. The amount of clayey sandstone and of silty claystone and siltstone could not be determined so easily, because these rocks commonly weather to form slopes that are largely covered with soil and waste. Exact determinations of their relative abundance could have been made only by trenching, but this was not practical. Rough estimates were made, however, by digging holes at 10 -foot stratigraphic intervals

TABLE 2. - Members and units assigned to lower and upper parts of the Chinle Formation and related strata [Members and units are part of Chinle Formation unless otherwise indicated]

\begin{tabular}{|c|c|c|c|c|c|}
\hline $\begin{array}{l}\text { Southern Nevada, } \\
\text { southwestern Utah, } \\
\text { northwestern } \\
\text { and west-central } \\
\text { New Mexico, and } \\
\text { northern Arizona } \\
\text { exclusive of Monu- } \\
\text { ment Valley area }\end{array}$ & $\begin{array}{l}\text { Southeastern and } \\
\text { east-central Utah } \\
\text { and Monument } \\
\text { Valley area, } \\
\text { northern Arizona }\end{array}$ & $\begin{array}{l}\text { North-central New } \\
\text { Mexico }\end{array}$ & $\begin{array}{l}\text { Southwestern } \\
\text { Colorado }\end{array}$ & $\begin{array}{l}\text { West-central and } \\
\text { central Colorado }\end{array}$ & $\begin{array}{l}\text { Northeastern Utah } \\
\text { and northwestern } \\
\text { Colorado }\end{array}$ \\
\hline \multicolumn{6}{|c|}{ UPPER PART } \\
\hline $\begin{array}{l}\text { Rock Point Member of } \\
\text { Wingate Sandstone }\end{array}$ & Church Rock Member & Siltstone member & $\begin{array}{l}\text { Middle and upper } \\
\text { members of the } \\
\text { Dolores Formation } \\
\text { and laterally } \\
\text { equivalent strata }\end{array}$ & Red siltstone member & $\begin{array}{l}\text { Upper member } \\
\text { Red siltstone member }\end{array}$ \\
\hline Owl Rock Member & Owl Rock Member & & & & $\begin{array}{l}\text { Sandstone and } \\
\text { conglomerate } \\
\text { member }\end{array}$ \\
\hline \multicolumn{6}{|c|}{ LOWER PART } \\
\hline $\begin{array}{l}\text { Petrified Forest } \\
\text { Member }\end{array}$ & $\begin{array}{l}\text { Petrified Forest } \\
\text { Member } \\
\text { Moss Back Member }\end{array}$ & $\begin{array}{l}\text { Petrified Forest } \\
\text { Member } \\
\text { Poleo Sandstone } \\
\text { Lentil }\end{array}$ & $\begin{array}{l}\text { Lower member of the } \\
\text { Dolores Formation }\end{array}$ & & $\begin{array}{l}\text { Ocher siltstone } \\
\text { member }\end{array}$ \\
\hline $\begin{array}{l}\text { Sandstone and mud- } \\
\text { stone member } \\
\text { Mesa Redondo Member } \\
\text { Lower red member }\end{array}$ & $\begin{array}{l}\text { Monitor Butte } \\
\text { member }\end{array}$ & Salitral Shale Tongue & & & \\
\hline Shinarump Member & Shinarump Member & $\begin{array}{l}\text { Agua Zarca } \\
\text { Sandstone Member } \\
\text { Sandstone Member }\end{array}$ & & $\begin{array}{l}\text { Mottled member }{ }^{2} \\
\text { Gartra Member }\end{array}$ & $\begin{array}{l}\text { Mottled member }{ }^{2} \\
\text { Gartra Member }\end{array}$ \\
\hline Mottled strata & $\begin{array}{l}\text { Mottled strata } \\
\text { Temple Mountain } \\
\text { Member }\end{array}$ & & & & \\
\hline
\end{tabular}

${ }^{1}$ At Bluewater Creek in western New Mexico, a "reddish sandstone member" of Silver (1948) (see stratigraphic section NM-18) is also included in the upper part of the Chinle Formation. Also, in the Zuni uplift in western New Mexico, the Lukachukai Member of the Wingate Sandstone is included with the upper part of the Chinle Formation in the facies study because it is believed to tongue laterally into the Rock Point Member of the Wingate, which

'Omitted from consideration because it was not studied in detail as part of facies study. 
TABLE 3. - Data sheet for sedimentary-facies study of the lover part of the Chinle Formation

[A, Arizona; C. Colorado; N, Nevada ; NM, New Mexico: U, Utah]

\begin{tabular}{|c|c|c|c|}
\hline $\begin{array}{c}\text { Locnlity } \\
\text { No. } \\
\text { (pl. 1; } \\
\text { table 1) }\end{array}$ & $\begin{array}{c}\text { Ledge- } \\
\text { forming } \\
\text { sandstone } \\
\text { and } \\
\text { conglomernte } \\
\text { (percent) } \\
\end{array}$ & $\begin{array}{c}\text { Slope- } \\
\text { forming } \\
\text { clayey } \\
\text { sandstone } \\
\text { (percent) }\end{array}$ & $\begin{array}{c}\text { Silty } \\
\text { claystone } \\
\text { and } \\
\text { siltstone } \\
\text { (percent) }\end{array}$ \\
\hline A-6 & Lukachukai Trading Post 31 & 4 & 65 \\
\hline A-8 & Nazlini Trading Post ...... 13 & 5 & 82 \\
\hline A-9 & St. Johns ........................... 17 & 22 & 61 \\
\hline A-13 & Owl Rock ....................... 27 & 39 & 34 \\
\hline A-17 & Cameron ……......................... 11 & 35 & 54 \\
\hline A-20 & Lees Ferry …….................. 30 & 15 & 55 \\
\hline $\mathrm{A}-22$ & Paint Pots ......................... 19 & 27 & 54 \\
\hline$A-25$ & Joseph City ...................... 8 & 22 & 70 \\
\hline C-1 & Piedra River ....................100 & 0 & 0 \\
\hline $\mathrm{C}-5$ & Durango ............................... & 0 & 0 \\
\hline C-14 & 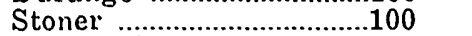 & 0 & 0 \\
\hline $\mathrm{C}-21$ & Dolores Canyon ............ & 0 & 0 \\
\hline $\mathrm{N}-1$ & Horse Spring Valley & 32 & 62 \\
\hline $\mathrm{N}-2$ & Spring Mountains ........ & 18 & 52 \\
\hline $\mathrm{N}-\overline{3}$ & Valley of Fire $\ldots \ldots \ldots \ldots \ldots \ldots . . . . . .36$ & 16 & 48 \\
\hline NM-1 & Chavez-Prewitt ……........... 21 & 11 & 68 \\
\hline NM-3 & Fort Wingate ...................... 17 & 10 & 73 \\
\hline $\mathrm{NM}-7$ & Coyote & 6 & 82 \\
\hline NM-9 & Ghost Ranch-Abiquiu & 0 & 50 \\
\hline $\mathrm{NM}-12$ & Arroyo de los Pinos ........ 22 & 3 & 75 \\
\hline $\mathrm{U}-3$ & Buckhorn Wash ............. 81 & 0 & 19 \\
\hline $\mathrm{U}-4$ & Cane Wash ......................... 79 & 0 & 21 \\
\hline$\tilde{U}-\overline{5}$ & Lucky Strike mine ............ 74 & 0 & 26 \\
\hline $\mathrm{U}-6$ & Muddy River ..................... 45 & 7 & 48 \\
\hline U-7 & Straight Wash ............... 79 & 0 & 21 \\
\hline $\mathrm{U}-8$ & Temple Mountain .......... & 0 & 21 \\
\hline $\bar{U}-9$ & Buckacre Point .................. 70 & 5 & 25 \\
\hline $\mathrm{U}-10$ & Horse Canyon .................... 22 & 13 & 65 \\
\hline U-11 & Muley Twist ......................... & 3 & 89 \\
\hline $\mathrm{U}-13$ & Range Canyon ................... 77 & 11 & 12 \\
\hline $\mathrm{U}-14$ & Silver Falls Creek .......... 13 & 15 & 72 \\
\hline $\mathrm{U}-16$ & South Draw ......................... 27 & 13 & 60 \\
\hline U-19 & Spring Canyon ................ 42 & 0 & 58 \\
\hline $\mathrm{U}-22$ & Kanarraville .................... 26 & 7 & 67 \\
\hline$U-24$ & Paria .................................. 10 & 28 & 62 \\
\hline $\mathrm{U}-26$ & Bridger Jack Mesa ........... 83 & 1 & 16 \\
\hline $\mathrm{U}-27$ & Comb Wash .................. 11 & $1 \overline{8}$ & 71 \\
\hline U-29 & Hite ................................ 28 & 8 & 64 \\
\hline $\mathrm{U}-30$ & Jacobs Chair ................... 38 & 22 & 40 \\
\hline $\mathrm{U}-32$ & Lockhart Canyon ............... 74 & 0 & 16 \\
\hline $\mathrm{U}-33$ & Milk Ranch Point .............. 39 & 38 & 23 \\
\hline & Monitor Butte …................. 18 & 22 & 60 \\
\hline $\mathrm{U}-$ & North Sixshooter Peak .. 43 & 47 & 10 \\
\hline $\mathrm{U}-39$ & Taylor Canyon .................. 58 & 13 & 29 \\
\hline $\mathrm{U}-43$ & Chimney Rock ............... 30 & 25 & 45 \\
\hline $\mathrm{U}-44$ & Millard Canyon ................. 58 & 17 & 25 \\
\hline & Leeds .......................................... 37 & 0 & 63 \\
\hline & Rockville ............................ 18 & 13 & 69 \\
\hline & Mexican Bend ............. 90 & 0 & 10 \\
\hline & Idle Day claim ................... 95 & 0 & 5 \\
\hline & Little Valley ..................... 63 & 0 & 37 \\
\hline $\bar{U}-222$ & Clay Hills Pass ................. 27 & 14 & 59 \\
\hline & Red House ....................... 19 & 7 & \\
\hline
\end{tabular}

along every line of section. Each hole was made deep enough to expose unweathered rock, and the general character of that rock was recorded. The number of spot determinations in clayey sandstone in relation to those in silty claystone and siltstone gives a crude estimate of the relative abundance of these two constituents.

\section{RESULTS OF FACIES ANALYSIS}

The lithologic character of the lower part of the Chinle Formation varies greatly from area to area, and the facies study did not reveal regional variations useful in interpreting depositional history. The amount of slope-forming clayey sandstone, for example, in Arizona ranges from 4 to 39 percent but does not show a consistent change in any direction across the State. The only significant regional trend indicated by the facies study is an increase in the amount of ledge-forming sandstone and conglomerate near the northeastern limit of the lower part of the Chinle in southeastern Utah, southwestern Colorado, and northwestern New Mexico. In most of these areas the lower part of the Chinle is thin and comprises only a single member that consists wholly of sandstone. The abundance of sandstone and conglomerate near the northeastern limit of the lower part of the Chinle is not regarded as evidence that the sediments came from the northeast, but rather that fine-textured units have thinned and wedged out to the north and northeast.

\section{UPPER (RED-BEDS) PART OF CHINLE FORMATION}

The upper part of the Chinle Formation consists principally of reddish-brown horizontally bedded or structureless siltstone and generally minor amounts of limestone, ripple-laminated siltstone and sandstone, limestone pebble conglomerate, and crossstratified sandstone. (See p. 38.) It includes members of the Chinle Formation, laterally equivalent members of the Dolores Formation, and a related lower member (Rock Point Member) of the Wingate Sandstone (table 2).

\section{LITHOLOGIC TYPES}

Study of the facies of the upper part of the Chinle Formation is based upon determination of the regional distribution of five main lithologic types: (1) structureless and horizontally bedded siltstone, (2) limestone, (3) wavy-stratified siltstone and sandstone, (4) trough-cross-stratified sandstone, siltstone, and conglomerate, and (5) planar-cross-stratified sandstone.

STRUCTURELESS AND HORIZONTALLY BEDDED SILTSTONE

Rocks grouped as structureless and horizontally bedded siltstone include silty claystone, siltstone, and sandy siltstone units that are characterized by an apparent lack, in most localities, of sedimentary structures except for rather vaguely defined widely spaced bedding planes. In some areas, particularly in the Rock Point Member of the Wingate Sandstone in the Defiance uplift, vaguely defined features resembling large-scale low-angle cross-stratification planes were noted in the structureless siltstone and suggest the possibility that some of the siltstone may be crudely cross stratified. Structureless siltstone is the finest grained clastic rock in the upper part of the Chinle Formation. It is interstratified in thin to very thick layers with all other lithologic types and weathers to form slopes and recesses. 
Structureless siltstone is in general the most abundant rock in the upper part of the Chinle Formation. It is subordinate in only a few areas, notably in western New Mexico, parts of the San Rafael Swell in Utah, and parts of the Uncompahgre Plateau in Colorado.

The fine-grained nature and lack of current-formed sedimentary structures indicate that the structureless siltstone was deposited largely in quiet water, probably in lakes and on flood plains.

\section{LIMESTONE}

The limestone in the upper part of the Chinle Formation occurs in light-colored very thin to thick layers interstratified, in most areas, with structureless siltstone. Most of these layers are horizontally very thin to thick bedded, although some are horizontally laminated. Many of the layers are remarkably persistent, and some have been traced for as much as 20 miles (C. A. Repenning, written commun., 1956). Other layers are lenticular and grade into structureless siltstone. In the facies study, limy siltstone similar in color and appearance to limestone with which it is associated has been grouped together under the same lithologic heading as limestone. The limestone and limy siltstone layers typically weather to form cliffs and ledges.

In most places, limestone occurs in only small amounts in the upper part of the Chinle Formation, and practically all of it is in the Owl Rock Member, the basal member of the upper part of the Chinle.

The limestone in the upper part of the Chinle Formation was probably formed by the mechanical and chemical deposition of carbonate in fresh-water lakes and also by carbonate replacement of glassy volcanic material on lake bottoms.

\section{WAVY-STRATIFIED SILTSTONE AND SANDSTONE}

The most abundant type of rock included under wavy-stratified siltstone and sandstone is laminated to thin-bedded siltstone and sandstone with stratification planes characterized by a vaguely defined low-amplitude waviness. In some places these strata grade into distinctly ripple-laminated rocks. In other places the waviness of the stratification is so poorly defined that separation from interstratified sets of structureless siltstone is difficult, and the two types can only be roughly separated on the basis of the slightly coarser grain of the wavy-stratified siltstone and the tendency of the wavy-stratified strata to weather out as cliffs and ledges. The wavy-stratified siltstone to sandstone is intermediate in grain size between structureless siltstone and trough-crossstratified sandstone.

Also included under wavy-stratified siltstone and sandstone are (1) strata composed of well-defined sets of parallel or cuspate ripple laminae and (2) well-sorted sandstone or silty sandstone composed of fairly well defined horizontal beds or laminae and containing some wavy planes. Except for stratification and a somewhat finer grain size, this well-sorted sandstone, which is scarce in the upper Chinle, resembles the planar-cross-stratified sandstone described below.

In places where horizontally laminated siltstone similar in grain size and lithologic aspect to the wavy-stratified siltstone is interstratified with, or grades into, wavy-stratified rock, it has been included with wavy-stratified siltstone and sandstone in the facies study.

Wavy-stratified siltstone and sandstone make up, on the average, about 12 percent of each of the sections of the upper part of the Chinle that were examined, but the percentage ranges from 0 to 38 .

For reasons that will be further discussed (see $p$. 97), the wavy-stratified rocks are believed to have been deposited by the sheet-flow action of unconfined currents, or by waves, in shallow water.

TROUGH-CROSS-STRATIFIED SANDSTONE, SILTSTONE, AND CONGLOMERATE

Grouped as a lithologic type are those deposits of sandstone and, to a lesser extent, of siltstone and conglomerate in the upper part of the Chinle Formation that are chiefly characterized by trough sets of small- to medium-scale low- and high-angle crossstrata. Limestone pebble conglomerate and calcarenite, both in part cross bedded, are in some places a relatively abundant part of this category. The trough-cross-stratified rocks, particularly those in the sandier parts of the Church Rock Member, are commonly associated with cuspate-ripple-laminated strata. Some of these ripple-laminated strata grade laterally into trough-cross-stratified strata, and where this gradation can be shown to occur, the cuspate-ripple-laminated strata are included with the trough-cross-stratified rocks. The trough-crossstratified rocks are the coarsest grained rocks in the upper part of the Chinle Formation and form cliffs and ledges on weathered slopes. They are generally interstratified with structureless or horizontally laminated siltstone.

Trough-cross-stratified sandstone averages about 20 percent of the upper part of the Chinle Formation in the sections examined but was found to range from 0 to 70 percent from section to section.

For reasons to be discussed later, the trough-crossstratified sandstone is believed to have been deposited by rather strong, but fluctuating, confined water currents, probably in or near stream channels. 
PLANAR-CROSS-STRATIFIED SANDSTONE

The term "planar-cross-stratified sandstone" is applied to light-brown very fine grained well-sorted sandstone characterized by wedge- and tabularplanar sets of cross-strata that are predominantly medium scale, high angle, and tangentially inclined. Rock of this character generally weathers to form vertical or rounded cliffs or ledges and is commonly associated with wavy-stratified sandy siltstone and structureless siltstone.

Planar-cross-stratified sandstone is absent in the upper part of the Chinle Formation over most of the Colorado Plateau region. It occurs mostly in the Rock Point Member of the Wingate Sandstone, which is considered the lateral equivalent of the Church Rock Member of the Chinle Formation. Layers of this sandstone, which generally constitute less than 10 percent of the Rock Point Member, occur along the east side of the Defiance uplift in northeastern Arizona and adjoining parts of New Mexico. In the Zuni uplift, the Lukachukai Member of the Wingate Sandstone, which, as has already been said, is considered equivalent to the Rock Point Member and thus to the upper Chinle, consists chiefly of planar-cross-stratified sandstone - a fact that helps to account for the high proportion (41 to 55 percent) of such rock in parts of New Mexico (table 4).

Planar-cross-stratified sandstone is also present at Vernal, Utah (loc. U-41). There the upper part of the Chinle Formation contains two units that have horizontal laminae and thin to thick wedge-planar sets of small- to medium-scale cross-laminae.

The planar cross-stratification in this rock is similar to that in modern sand dunes (McKee, 1957, p. 1718-1726), from which it is inferred that the planar-cross-stratified sandstone was probably formed by the accumulation of windblown sand into dunes.

\section{METHODS OF FACIES ANALYSIS}

The relative amounts of the five main lithologic types in the upper part of the Chinle Formation were measured at 87 localities scattered over the Colorado Plateau and adjacent regions. Most of the data at the control points are based upon sections measured by the authors, but a few stratigraphic sections, both published and unpublished, measured by other workers, were found suitable for use in the facies study. Only data from surface outcrops were used. Data obtained at each measured section are listed in table 4 and the location of these sections can be obtained from plate 1 and table 1 .

The general sedimentary trends of the upper part of the Chinle Formation are shown on a facies map (pl. 5), developed as follows.
Strata in the upper part of the Chinle at each control point were grouped into three categories on the basis of process of deposition. These categories are $(A)$ structureless siltstone and limestone believed to have formed by mechanical and chemical sedimentation in relatively quiet water; $(B)$ troughcross-stratified sandstone, siltstone, and conglomerate believed to have been deposited by fluctuating confined currents, such as those in stream channels; and $(C)$ wavy-laminated siltstone to sandstone believed to have been deposited or reworked by sheetflow currents, bottom currents, and wave action. (See pl. 5.) Planar-cross-stratified sandstone cannot be fitted easily into this classification and is omitted from consideration. Such an omission, however, has little effect on the facies patterns, since rock of this type is relatively scarce in the Chinle Formation and related strata in the Colorado Plateau.

The three categories of lithologic types listed above are treated as end members of a triangular diagram that is divided into fields based upon the ratios between the end members or a grouping of end members (pl. 5). These ratios are:

Channel-deposit ratio: $B / C$

and

Current-deposit ratio: $(B+C) / A$.

The method is analogous to facies differentiation based upon sand-shale and clastic ratios as used by Sloss, Krumbein, and Dapples (1949) except that differentiation of rock types is based upon inferred depositional process. As stated by Sloss, Krumbein, and Dapples (1949, p. 100), the ratios represent "indices of the relative amounts of material in the numerator of the ratio deposited per unit thickness of material in the denominator." A channel-deposit ratio of 1.2 indicates that 1.2 feet of channel or confined-current deposits (trough-cross-stratified sandstone, siltstone, and conglomerate) accumulated for every foot of sheet-flow or unconfined-current deposits (wavy-stratified siltstone to sandstone). A currentdeposit ratio of 1.2 indicates that 1.2 feet of current deposits (trough-cross-stratified sandstone, siltstone, and conglomerate plus wavy-stratified siltstone to sandstone) accumulated for every 1 foot of quietwater deposits (structureless siltstone and limestone).

The triangular diagram (pl. 5) has been divided into eight fields. The horizontal lines dividing the diagram are based upon current-deposit ratios of $0.125,0.25,0.50$, and 1.0 . The vertical line dividing the diagram is based upon a channel-deposit ratio of 1.0. The eight fields thus delimited have been assigned patterns and are used in the construction of the sedimentary-facies map of the upper part of the Chinle Formation (pl. 5). 


\section{RESULTS OF FACIES ANALYSIS}

The distribution of facies in the upper part of the Chinle Formation (pl. 5) is rather irregular; but, in general, trough-cross-stratified and wavy-stratified rocks are abundant in the eastern part of the region and structureless siltstone and limestone are abundant in the western part. The general distribution of facies shows little correlation with the thickness trends in the upper part of the Chinle Formation as shown on the isopach map (pl. 5).

One of the most evident features shown on the facies map is a rather narrow, slightly sinuous, northwest-trending belt of abundant cross-stratified sandstone, siltstone, and conglomerate extending from southwest Colorado into east-central Utah. Although the highest percentages of trough-crossstratified rocks in this belt are in Utah, the highest proportion of total current deposits is at Sawpit, Colo. (loc. C-19), where they constitute about 84 percent of the upper part of the Chinle Formation.

\section{SEDIMENTARY PETROLOGY}

By R. A. CADIGAN

The sedimentary petrology was studied chiefly to aid in determining the provenance and location of the source areas of the variety of clastic rocks that make up the Chinle Formation. This section of the report contains descriptions of the general texture and composition of these rocks and notes conspicuous regional differences in the composition of the rocks.
Classified according to texture alone, these rocks are claystone, mudstone, siltstone, sandstone, and pebble conglomerate; classified according to composition they are calcareous siltstone, calcarenite, limestone, sedimentary tuff, orthoquartzite, and arkose. The minerals that make up the sandstone and conglomerate are described first; then the minerals in the fine-textured clastic rocks and carbonate rocks. The petrography of the major stratigraphic units in the formation is summarized.

The textural and compositional classifications used in this report are the same as described previously by the writer (Cadigan, 1967).

\section{SANDSTONE AND CONGLOMERATE}

The most common types of sandstone and conglomerate in the Chinle Formation are, in order of abundance, feldspathic orthoquartzite (more than 9 percent but less than 25 percent feldspathic components), orthoquartzite, tuff, feldspathic tuff, tuffaceous orthoquartzite, and their calcareous varieties. The sandstone strata consist approximately of 45 percent orthoquartzites, 35 percent tuffs, 15 percent arkoses, and 5 percent miscellaneous sedimentary rocks, mostly calcareous ones. "Orthoquartzite," a petrologic term, is used in preference to "quartzite," a field term, because the former can be more precisely defined than the latter. Descriptions of the components of the sandstones and conglomerates are given below.

TABLE 4. - Data sheet for sedimentary facies study of upper part of Chinle Formation [A, Arizona; C, Colorado; NM, New Mexico; U, Utah]

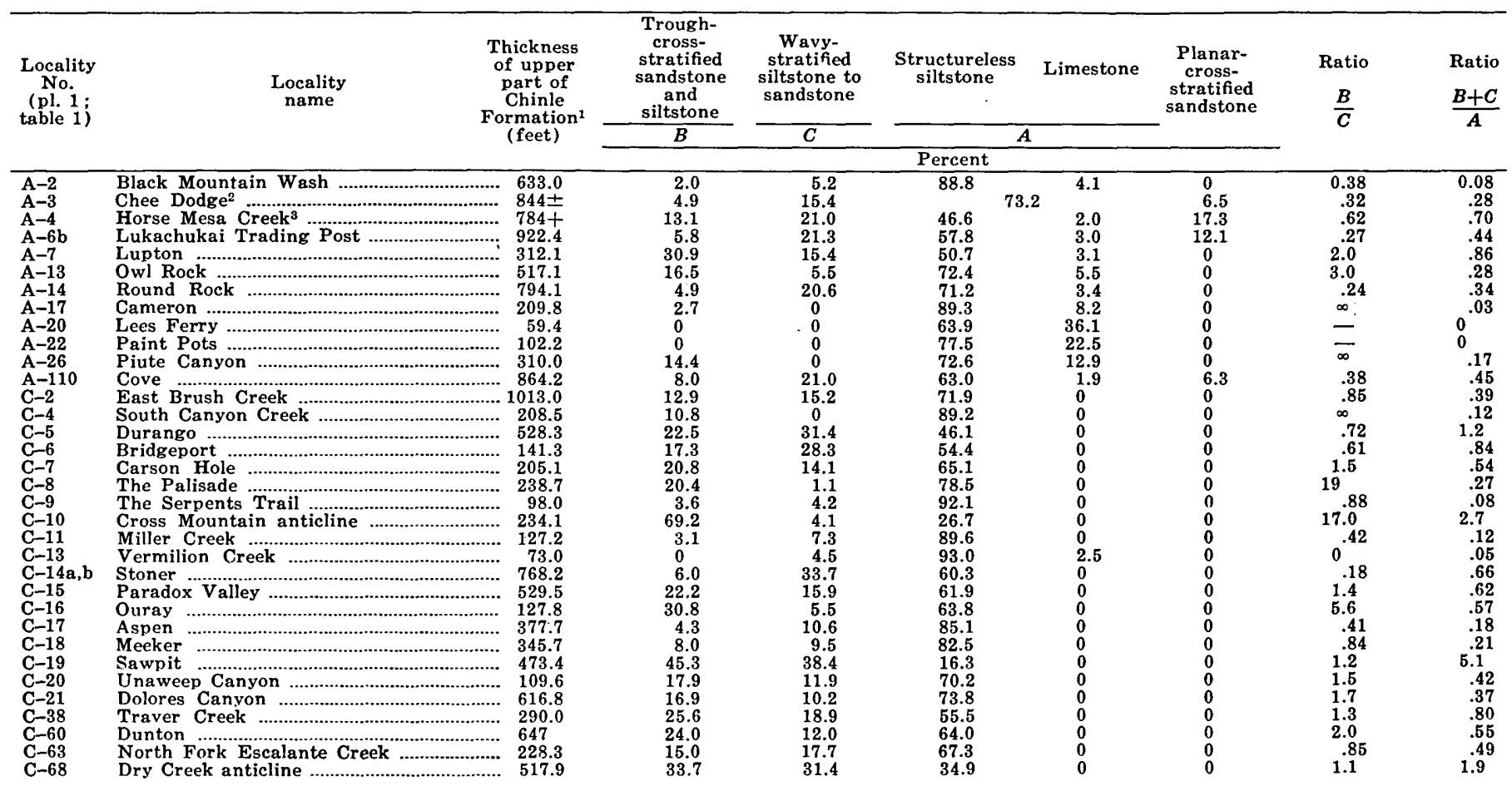


TABLE 4. - Data sheet for sedimentary facies study of upper part of Chinle Formation - Continued

\begin{tabular}{|c|c|c|c|c|c|c|c|c|c|}
\hline \multirow[t]{2}{*}{$\begin{array}{l}\text { Locality } \\
\text { No. } \\
\text { (pl. } 1 \\
\text { table 1) }\end{array}$} & \multirow[t]{2}{*}{$\begin{array}{c}\text { Locality } \\
\text { name }\end{array}$} & \multirow[t]{2}{*}{$\begin{array}{l}\text { Thickness } \\
\text { of upper } \\
\text { part of } \\
\text { Chinle } \\
\text { Formation } \\
\text { (feet) }\end{array}$} & $\begin{array}{c}\begin{array}{c}\text { Trough- } \\
\text { cross- } \\
\text { stratified } \\
\text { sandstone } \\
\text { and } \\
\text { siltstone }\end{array} \\
B\end{array}$ & $\begin{array}{c}\text { Wavy- } \\
\text { stratified } \\
\text { siltstone to } \\
\text { sandstone }\end{array}$ & $\begin{array}{l}\text { Structureles } \\
\text { siltstone }\end{array}$ & Limestone & $\begin{array}{l}\text { Planar- } \\
\text { cross- } \\
\text { stratified } \\
\text { sandstone }\end{array}$ & \multirow[t]{2}{*}{$\begin{array}{l}\text { Ratio } \\
\frac{B}{C}\end{array}$} & \multirow[t]{2}{*}{$\begin{array}{l}\text { Ratio } \\
\frac{B+C}{A}\end{array}$} \\
\hline & & & \multicolumn{5}{|c|}{ Percent } & & \\
\hline $\mathrm{C}-76$ & 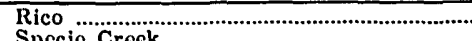 & .... 571 & 21.2 & 19.4 & 59.4 & 0 & 0 & 1.1 & .69 \\
\hline N-77 & 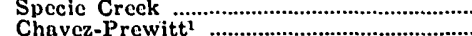 & $\begin{array}{ll}\ldots . . & 575 \\
\cdots . . & 110.7\end{array}$ & $\begin{array}{c}47.8 \\
0\end{array}$ & $\begin{array}{r}24.9 \\
31.6\end{array}$ & $\begin{array}{l}27.3 \\
23.2\end{array}$ & $\stackrel{0}{4.5}$ & 00 & 1.9 & 2.7 \\
\hline $\begin{array}{ll}N M-10 \\
N M-2\end{array}$ & 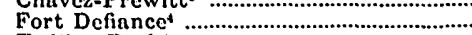 & … $656 \pm$ & 5.5 & $\begin{array}{r}1.0 \\
5.2\end{array}$ & & 82.8 & $\begin{array}{r}40.7 \\
6.4\end{array}$ & 1.0 & 0.13 \\
\hline NM-4 & 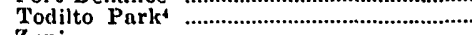 & ..... $670 \pm$ & 8.4 & 10.3 & & 72.9 & 8.5 & 0.81 & .26 \\
\hline $\mathrm{NM}-5 \mathrm{~b}$ & Zuni & …. $\quad 199.3$ & 69.9 & 14.8 & 9.3 & $0_{0}$ & 6.0 & 4.7. & 9.2 \\
\hline NM-11 & Tondlenn & … $\quad 796.7$ & 3.6 & 18.7 & 71.2 & 4.3 & 1.6 & .21 & .30 \\
\hline NM-18 & 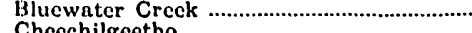 & … 216.9 & 00 & 21.4 & 78.6 & 0 & 0 & 0 & .27 \\
\hline $\begin{array}{l}N M-43 \\
N M-44\end{array}$ & $\begin{array}{l}\text { Choechilgetho } \\
\text { Fort Wingate' }\end{array}$ & $\begin{array}{l}281.4 \\
\cdots . . \\
\cdots\end{array}$ & $\begin{array}{r}60.9 \\
6.4\end{array}$ & 27.2 & 11.9 & 0 & 00 & 2.2 & 7.4 \\
\hline $\mathrm{U}_{\mathrm{U}-1}^{\mathrm{N}-44}$ & 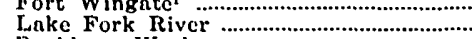 & $\ldots . .136 .8$ & $\begin{array}{l}6.4 .0 \\
21.0\end{array}$ & 37.0 & 42.0 & 0 & ${ }_{0}^{56.6}$ & .26 & $\begin{array}{l}2.3 \\
1.4\end{array}$ \\
\hline $\mathrm{U}-3$ & Buckhorn Wash ............................................ & ..... 194.7 & 45.3 & 3.1 & 51.6 & 0 & 0 & 14.6 & .94 \\
\hline $\mathbf{U}-4$ & Cane Wash & .... $\quad 178.0$ & 42.0 & 10.7 & 47.3 & 0 & 0 & 3.9 & 1.1 \\
\hline $\mathbf{U}-5$ & Lucky Strike mine & .... $\quad 167.4$ & 41.4 & 2.4 & 56.1 & 0 & 0 & 17. & .78 \\
\hline $\begin{array}{l}U-6 \\
U-7\end{array}$ & 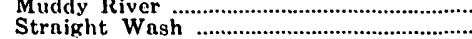 & $\begin{array}{ll}\cdots . . & 138.5 \\
\ldots . . & 251.9\end{array}$ & $\begin{aligned} 7.4 \\
55.9\end{aligned}$ & 0.7 & $\begin{array}{l}85.9 \\
36.5\end{array}$ & $\begin{array}{l}5.9 \\
1.0\end{array}$ & ${ }_{0}^{0}$ & 9.6 & .09 \\
\hline $\mathrm{U}-8$ & 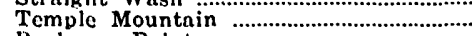 & … 256.3 & 53.7 & 1.6 & 40.4 & $\begin{aligned}-4.0 \\
4.2\end{aligned}$ & 0 & 34.0 & 1.2 \\
\hline $\mathrm{U}-9$ & 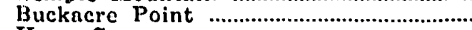 & .... 333.5 & 17.5 & 0 & 80.1 & 2.4 & 0 & $\infty$ & .21 \\
\hline $\mathrm{U}-10$ & 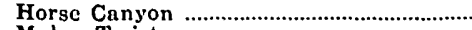 & ..... 163.8 & 6.3 & 0 & 89.4 & 4.3 & 0 & $\infty$ & .07 \\
\hline $\mathrm{U}-11$ & Muley Twist & $\ldots . \quad 327.2$ & 6.8 & 0 & 88.2 & 5.0 & 0 & $\infty$ & .07 \\
\hline 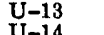 & 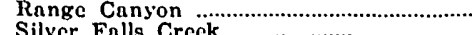 & … $\quad 359.2$ & 9.0 & 3.2 & 86.9 & 0.9 & 0 & 2.8 & .14 \\
\hline $\begin{array}{l}U-14 \\
U-15\end{array}$ & & $\begin{array}{r}205.7 \\
380.0\end{array}$ & $\begin{array}{r}8.9 \\
12.1\end{array}$ & 0 & 80.8 & 10.3 & 0 & $\infty$ & .10 \\
\hline$U-16$ & 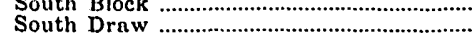 & $\begin{array}{ll}3 . . & 380.0 \\
\cdots . . . & 118.3\end{array}$ & $\begin{array}{l}12.1 \\
9.6\end{array}$ & 2.9 & 74.6 & 12.8 & 0 & 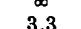 & .14 \\
\hline $\mathrm{U}-18$ & Richardson Amphitheater ......................... & … 295.5 & 29.4 & 6.6 & 64.0 & 0 & 0 & & .146 \\
\hline $\mathrm{U}-19$ & 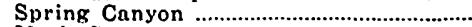 & ..... 319.0 & 58.2 & 19.6 & 21.0 & 1.2 & 0 & $\begin{array}{l}4.4 \\
3.0\end{array}$ & 3.50 \\
\hline $\mathrm{U}-20$ & 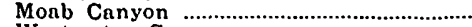 & .... $238.2 ?$ & 53.2 & 7.0 & 39.8 & 0 & 0 & 7.6 & $\begin{array}{l}3.0 \\
1.8\end{array}$ \\
\hline $\mathrm{U}-21$ & Westwater Canyon & …. $\quad 78.2$ & 0 & 9.0 & 91.0 & 0 & 0 & 0 & .10 \\
\hline $\mathrm{U}-25$ & Bears Ears & .... $\quad 512.3$ & 5.2 & 7.5 & 86.4 & 1.0 & 0 & .69 & .15 \\
\hline $\mathrm{U}-26$ & Bridger Jnck Mesa ………………………... & 495.3 & 6.4 & 8.4 & 81.1 & 4.1 & 0 & .76 & .17 \\
\hline $\mathrm{U}-27$ & Comb Wash & .... $\quad 627.1$ & 15.8 & 15.8 & 66.7 & 1.6 & 0 & 1.0 & .46 \\
\hline $\mathrm{U}-28$ & Cottonwood Creek ………………………… & … 485.7 & 12.5 & 2.1 & 82.3 & 3.0 & 0 & 6.0 & .17 \\
\hline $\mathrm{U}-29$ & 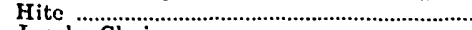 & ..... 258.0 & 20.6 & 20.4 & 52.8 & 6.2 & 0 & 1.0 & .69 \\
\hline$\underset{U}{U}-30$ & & .... $\quad 373.4$ & 9.8 & 13.9 & 72.5 & 3.8 & 0 & .71 & .31 \\
\hline 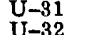 & 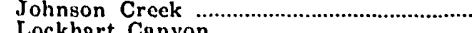 & … $\quad 567.6$ & 6.7 & 14.8 & 74.5 & 4.0 & 0 & .45 & .27 \\
\hline $\begin{array}{l}U-32 \\
U-33\end{array}$ & $\begin{array}{l}\text { Lockhart Canyon } \\
\text { Milk Ranch Point }\end{array}$ & $\begin{array}{r}383.2 \\
541 .\end{array}$ & 14.4 & 9.5 & $\begin{array}{l}76.1 \\
87.8\end{array}$ & 0 & 0 & 1.5 & .31 \\
\hline $\mathrm{U}-34$ & 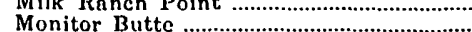 & $\begin{array}{lll}\ldots . . & 641.1 \\
\ldots . . & 403.1\end{array}$ & $\begin{array}{l}6.1 \\
23.2\end{array}$ & 2.1 & $\begin{array}{l}87.8 \\
67.9\end{array}$ & 6.9 & 0 & 11.5 & .34 \\
\hline $\mathrm{U}-35$ & North Sixshooter Peak ............................. & … 420.0 & 6.8 & 5.1 & 83 & $\begin{array}{l}0.9 \\
4.8\end{array}$ & 0 & 1.3 & .13 \\
\hline $\mathrm{U}-36$ & 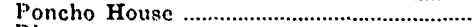 & … 572.9 & 19.8 & $\begin{array}{l}0.1 \\
9.7\end{array}$ & 68.3 & 2.1 & 0 & 2.0 & .42 \\
\hline$U-37 a, b$ & Rincon & .... 366.5 & 13.2 & 6.2 & 76.9 & 3.8 & 0 & 2.1 & .24 \\
\hline $\mathrm{U}-39$ & & 295.5 & 28.9 & 15.6 & 54.0 & 1.6 & 0 & 1.8 & .80 \\
\hline $\mathrm{U}-40$ & Cliff Croek & ...... 94.3 & 19.3 & 4.2 & 76.5 & 0 & 0 & 4.6 & .31 \\
\hline & 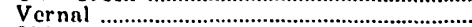 & ...... 134.6 & 6.2 & 37.5 & 31.0 & 0 & 25.3 & .16 & 1.4 \\
\hline $\mathrm{U}-43$ & 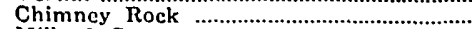 & ..... 147.9 & 0 & 0 & 87.1 & 12.9 & 0 & & \\
\hline$U-44$ & 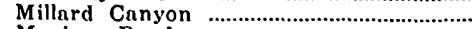 & ..... 378.3 & 13.1 & 4.5 & 74.2 & 8.2 & 0 & 2.9 & .21 \\
\hline U-48 & 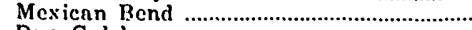 & ..... 181.8 & 35.5 & 7.7 & 56.9 & 0 & 0 & 4.6 & .76 \\
\hline U-133 & Dry Gulch & ..... $\quad 109.2$ & 9.8 & 18.8 & 71.4 & 0 & 0 & .52 & .41 \\
\hline 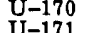 & 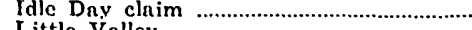 & .... $\quad 365.5$ & 26.3 & 17.5 & 56.2 & 0 & 0 & 1.5 & .78 \\
\hline & Little Valley & … $\quad 356.3$ & $\begin{array}{l}31.4 \\
36.7\end{array}$ & 25.7 & $\begin{array}{l}42.9 \\
379\end{array}$ & $0_{0}^{0}$ & 0 & 1.2 & 1.3 \\
\hline & $\begin{array}{l}\text { Cane Spring Wash .................................... } \\
\text { Clay Hills Pass . }\end{array}$ & 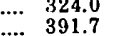 & $\begin{array}{l}36.7 \\
20.9\end{array}$ & $\begin{aligned} 25.4 \\
5.0\end{aligned}$ & $\begin{array}{l}37.9 \\
72.0\end{array}$ & 2.1 & $\begin{array}{l}0 \\
0\end{array}$ & 1.4 & 1.6 \\
\hline $\mathrm{U}-224$ & 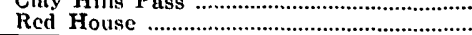 & … 427.0 & 17.1 & 0.8 & 78.8 & 3.2 & 0 & 21.2 & .22 \\
\hline
\end{tabular}

'Wingate Sandstone (Lukachukai Member) in Zuni uplift included in the calculations of thickness and lithology of upper part of Chinle Formation. ${ }^{2}$ Thickness of $\mathrm{Owl}$ Rock member, based on nearby thicknesses is assumed to be 331 feet. Owl Rock is assumed to consist of 2 percent trough-crossstratificd sandstone and 98 percent structureless siltstone and limestone.

${ }^{3}$ Thickness of Owl Rock member, based on ncarby thicknesses, is assumed to be 350 feet. This thickness is about 74 feet greater than that given in stratigraphic section A-4 and is estimated to consist of 72 feet of structureless siltstone and 2 feet of limestone.

Thickness of Owl Rock member, based on nearby thicknesses, is assumed to be 350 feet. Owl Rock is assumed to consist of 100 percent structureless siltstone and limestone.

\section{QUARTZ AND OTHER SILICEOUS COMPONENTS}

The dominant mineral in the sandstone and conglomerate of the Chinle Formation is crystalline quartz in detrital monomineralic grains. Most singlecrystal grains show unstrained extinction; quartzcrystal aggregates and some single-crystal grains show undulating extinction. Grains range in shape from angular to rounded. Some single-crystal grains show embayments suggestive of quartz of extrusive igneous origin. Inclusions are commonly crystals of potassic feldspar, tourmaline, needle-shaped rutile, and biotite; some crystals with particularly distorted extinction contain wavy, closely spaced bands of dustlike inclusions which in multicrystal grains cross crystal boundaries. Detrital quartz also occurs in several microcrystalline forms: as homogeneous grains of chert; as heterogeneous-appearing silicified-rock fragments containing microlites of mica, calcite, and clay minerals enclosed in a matrix of partially isotropic interstitial silica; as structureless particles composed of poorly crystallized microcrystalline quartz aggregates in a nearly isotropic silica-silicate or silica matrix, and which may be fragments of either devitrified glass or silicified limestone; and as fragments of silicified limestone containing filamentous algae or other microfossil structures.

Quartz commonly forms authigenic optically oriented overgrowths on detrital quartz grains. Overgrowths may form thin peripheral layers containing 
saw-tooth projections or may form thick euhedral to subhedral shells which replace interstitial clay matrix and form the primary interstitial component or principal cementing component in a mosaic of quartz grains and interstitial crystalline quartz.

Coarse-grained sandstone as in the Shinarump Member of the Chinle is most commonly cemented by mutually adhering quartz overgrowths which fill many of the interstices between grains but rarely produce a completely silicified rock. Some angular sand- to silt-size particles with low sphericity, observed in thin section, were formed by the exfoliation and fracturing of grains in place, probably due to intrastratal compression. These particles are slightly displaced relative to one another and are separately enclosed in the interstitial clay matrix. Some of these brecciated grains had developed overgrowths before being fractured, but there is no evidence of overgrowths formed afterward.

\section{FELDSPAR}

Detrital grains of feldspar constitute from 0 to 60 percent of the volume of the sandstone strata; approximately three-fourths of the samples taken range from 5 to 20 percent feldspar.

The Church Rock and red siltstone members of the Chinle Formation and the partly equivalent Dolores Formation contain the highest overall proportion of detrital feldspar, although higher extreme percentages were observed in some strata of the Petrified Forest Member of the Chinle. The detrital feldspar includes the potassic varieties orthoclase, microcline, and sanidine, and the sodic varieties albite, oligoclase, and anorthoclase. Potassic-sodic sanidine and sodic-potassic anorthoclase are most common in the Petrified Forest Member. Microcline typically exhibits polysynthetic twinning. Albite and oligoclase, when twinned, exhibit albite and carlsbad twinning. Anorthoclase exhibits pseudopolysynthetic twinning. Most albite and othoclase grains do not exhibit twinning; rarely, orthoclase appears in carlsbad twins. Grain shapes range from rounded to angular and include euhedral cleavage fragments and phenocrysts. The albite-oligoclase grains appear more altered than orthoclase or microcline where all varieties are present. Albite tends to be replaced by calcite or to alter conspicuously to chlorite (chinochlore?).

\section{VOLCANIC DETRITUS}

Volcanic detritus in the sandstone and conglomerate of the Chinle Formation is most abundant along the southern margin of the region and decreases in abundance northward. It is present in nearly all sandstone strata in the south, but in the sandstone in the central part of the region it tends to be concentrated in particular beds and lenses. It is most abundant in the Petrified Forest Member of the Chinle, constituting from a trace to approximately 100 percent by volume of various sandstone strata of that member throughout the region; approximately three-fourths of the strata contain from 5 to 20 percent. Other members commonly containing volcanic detritus include the Monitor Butte, Moss Back, Owl Rock, and Church Rock and equivalent strata. The red siltstone member of the Chinle and the equivalent parts of the Dolores Formation contain the smallest amounts. Three-fourths of all Chinle and equivalent sandstone strata, excluding the Petrified Forest Member, consist of approximately 3 to 10 percent volcanic detritus.

The rock components termed "volcanic detritus" consist of devitrified and altered fragments of tuff and felsite and fine ash of potassic and sodic rhyolitic composition. Fragments of vitric, crystal, and lithic tuff are present. The vitric tuff, though devitrified and silicified, consists of feldspar inclusions in a nearly isotropic siliceous matrix which in some grains shows relict vitrophyric structure. The crystal tuff is characterized by feldspar and biotite phenocrysts with a minimum of matrix. The lithic tuff consists of microcrystalline quartz with inclusions of mica, calcite, and feldspar. Some sodic vitric tuff fragments show incipient albitization with the formation of poorly crystallized anhedral albite within the siliceous matrix. Ash has been altered to interstitial cryptocrystalline, partly isotropic silica, clay minerals, and silicified relicts of pumice fragments and shards. Sodic and potassic tuffaceous detritus tend to alter to chloritic clay minerals and to montmorillonitic or kaolinitic clay minerals, respectively. Orthoclase and quartz, as determined by staining and X-ray techniques, compose the nearly isotropic altered glass matrix observed in altered vitrophyric tuff fragments in some tuffaceous sandstone beds of the Petrified Forest Member in southwestern Utah.

\section{HEAVY MINERALS}

Detrital heavy-mineral grains in sandstone and conglomerate range in abundance from about 0.01 to 1.00 percent by weight, with a median (middle value) of approximately 0.40 percent. Precise quantitative determinations of their total percentages are difficult because of the presence in some samples of relatively large amounts (forming from 2 to 65 percent of the rock) of authigenic heavy minerals, particularly hematite and barite. The detrital mineral species vary in kind and proportions in the different stratigraphic members, and to an even greater degree in different parts of the region. 
Some notable occurrences of certain detrital heavy minerals include monazite in the Petrified Forest Member along the south-central border of the region; staurolite in the Agua Zarca Sandstone Member; pale-green crystalline detrital penninite in the Poleo Sandstone Lentil; and fracture fragments of subhedral columnar crystals of green epidote and euhedral crystals of biotite in samples of the Owl Rock Member in southeastern Utah.

The minerals in the heavy-mineral concentrates are not limited to those described in the paragraphs to follow, but the listed minerals probably compose at least 98 percent of the detrital and authigenic heavy-mineral fraction in the Chinle Formation.

The most plentiful detrital heavy-mineral grains are those of the iron oxide-titanium oxide group. Magnetite, magnetite-ilmenite, and ilmenite occur as metallic black euhedral to rounded vitreousappearing grains and as earthy brown rounded to angular opaque grains. Leucoxene occurs as white opaque well-rounded spherical grains or as rims, halos, or seams on ilmenite and ilmenite-magnetite. Various combinations of magnetite, ilmenite, and their alteration products (hematite, anatase and leucoxene) occur also, as black, red, yellow, and white-mottled subrounded opaque to semiopaque grains.

Zircon is the most plentiful of the nonopaque detrital heavy minerals and occurs in several varieties, including clear colorless or pale-pink rounded grains, colorless or pink metamict zircon in rounded grains or in euhedral crystals with pyramidal terminations, and colorless or pink clear euhedral crystals, some of which are elongate to lathlike and some of which have highly developed zoning structures. All these varieties contain miscellaneous inclusions.

Tourmaline is present as rounded to angular fracture fragments and as euhedral prismatic columnar crystal fragments with hexagonal cross section; it exhibits many pleochroic color combinations, including blue and pink, but yellow, green, and brown shades predominate. Garnet is present as colorless, pale-yellow, or pink isotropic angular, subangular, or subrounded adamantine grains; surface structures include concave fractures and etched surfaces resembling an aggregation of paralleloriented cubes.

A few samples contain staurolite as pale-golden, slightly pleochroic, angular or splintery-looking fracture fragments or subrounded grains. Epidote occurs as fresh-looking subrounded characteristically pleochroic lemon-yellow to greenish-yellow grains and as subangular to rounded slightly weathered pale-green to colorless grains with cleavage traces. Rutile occurs as reddish-brown to golden-brown, or rarely bloodred, rounded grains, and as subangular goldenbrown crystal fragments that show cruciform twinning.

A little apatite occurs as rounded, colorless, oval grains. Biotite occurs as dark-green and dark-brown subangular or subrounded pleochroic flakes and as subhedral hexagonal crystals or books, some of which have been partly or completely replaced by opaque microcrystalline hematite; some flakes are partly altered to chlorite or to a colorless mica. Muscovite occurs as angular to rounded low birefringent colorless to pale-green cleavage flakes.

Brookite is present as brownish-orange, reddishbrown, and yellowish-brown slightly pleochroic subangular fracture fragments and as euhedral striated prisms. Collophane occurs in some samples as brown aggregates of microcrystalline isotropic grains which, though rounded, may be authigenic. Monazite is present in a few samples as rounded golden yellow grains that contain irregularly shaped brown inclusions.

Penninite (?) occurs as pale-green subangular crystal fragments that show the typical "ultra-blue" interference color under crossed nicols.

The authigenic heavy minerals found in these rocks include hematite, barite, leucoxene, and perhaps anatase. Hematite occurs as red irregularly shaped interstitial mineral particles with translucent borders; as translucent fine-silt-size blood-red euhedral crystals; and as opaque rounded detritalgrain-shaped subhedral particles which may be relicts of altered mafic minerals. Barite occurs as colorless irregular particles, some of them of ragged, and as rounded to euhedral crystals. Anatase occurs as pale-yellow cloudy amorphous irregular crystal aggregates and clear pale-yellow euhedral tabular crystals. Dull brassy pyrite occurs as subrounded particles, as cubes, or as aggregates of cubes, some of them partly oxidized.

Authigenic leucoxene forms white semiopaque rims, halos, or bands on ilmenite and ilmenite-magnetite grains. The anatase was probably derived directly from ilmenite or from the recrystallization of leucoxene; anatase never has the appearance of a detrital mineral when observed in thin section.

\section{CLAY MINERALS}

Most of the clay in the Chinle Formation, including that in sandstone and conglomerate as well as that in the fine-textured rocks, was produced by diagenesis and is thus authigenic rather than allogenic. Most of the clay minerals in these sediments are probably 
alteration products of sediments derived from extrusive and intrusive igneous rocks including volcanic ejectamenta. A short discussion of clay minerals is given here. A more comprehensive study of the clays has been made by Schultz (1963).

The dominant clay minerals in the sandstone and conglomerate strata of the Chinle are mica-montmorillonite clays. These clays are colorless, pale greenish gray, or reddish, and they appear under the microscope as moderately well to poorly crystallized interstitial aggregates of microcrystalline platelets with low birefringence in an isotropic groundmass. Montmorillonite-mica mixed clays have a similar appearance but have a higher degree of preferred orientation of the platelets and significantly greater swelling properties. Mica clay occurs principally as colorless or red-hematite-strained highly birefringent well-crystallized rims on sand grains, particularly in red sandstones.

Pale-green or colorless chlorite clays, in most instances mixed with montmorillonite, are abundant in sandstones containing relatively high proportions of sodic feldspar and sodic tuffaceous detritus. They commonly form the matrix of such a rock and also permeate fragments of feldspar and tuff as alteration products. The chlorite minerals in the clay have been tentatively identified as pennine and clinochlore. These are intermixed in various proportions with mica, mica-montmorillonite, montmorillonite, or, rarely, kaolinite clay minerals.

Montmorillonite clay under the microscope appears as a brownish poorly crystallized interstitial crystalline mineral; it shows a swirling pattern of oriented microcrystalline platelets against an isotropic groundmass. Kaolinite occurs in poorly to wellcrystallized colorless worm-shaped aggregates of parallel platelets with high relief and low birefringence; kaolinite may be present in isolated wads in a matrix composed dominantly of other clays or may constitute the principal interstitial clay mineral in the rock.

Mixed clays include both physical and mineralogical mixtures, either of which forms a relatively homogeneous clay. The clay matrix of a sandstone may be either homogeneous or heterogeneous; that is, it may consist of either a single end member (for example, chlorite) or mixed clay (for example, mica-montmorillonite) or be composed of two or more end members or mixed clays.

The several clay minerals tend to be associated with sand-size detritus of related composition. Montmorillonite and montmorillonite-mica clays are commonly found with fragments of potassic or potassic-sodic tuff ; kaolinite is abundant in strata contain- ing much potassic feldspar; and chloritic clays are abundant in strata containing much sodic or sodicpotassic feldspar and tuffaceous detritus, as mentioned on p. 58. Some rounded aggregates of montmorillonite clay in tuffaceous sandstone strata are apparently relicts of glassy tuff (pumice) fragments that have been completely replaced by clay.

Kaolinite is significantly more abundant, on the average, in basal Chinle sandstone near uranium deposits than in similar sandstones in unmineralized areas.

\section{CEMENTING MINERALS}

Calcite is one of the two principal interstitial cementing minerals in the sandstone strata of the Chinle; it occurs either as isolated anhedral octopuslike crystals or as a continuous coarsely crystalline cement which appears, in thin section, to replace some or most of the clay matrix as well as all or parts of some detrital grains, particularly feldspars. Calcite also occurs as microlites and euhedral rhombs suspended in the clay matrix and in altered mineral grains or rock fragments.

Quartz, in the form of optically oriented overgrowths or as aggregates of randomly polarized microcrystals, is the other principal cementing mineral in the sandstones. The overgrowths form either small euhedral prismatic projections on detrital quartz grains, or, when further developed, externally euhedral shells around the grains. In many instances the expanding overgrowths appear to have replaced the matrix between grains to form a mosaic of quartz crystals separated by euhedral crystal boundaries. Where interstitial calcite cement is in contact with quartz overgrowths, the overgrowths tend to be replaced, which suggests that the calcite cement formed later than the overgrowths. A matrix of microcrystalline quartz cement is composed of nearly isotropic silica; the cement is completely anhedral in form and precipitates along the edges of interstices and builds out toward the center, apparently replacing any clay matrix present. In sedimentary tuffs, the microcrystalline quartz and silica form isolated blobs suspended in the altered ashy matrix which fills the interstices.

Red and brownish-red iron oxide composed mostly of hematite, and probably derived from altered mafic minerals including biotite, is present interstitially in some sandstone strata but is of much less importance as a cement than calcite and quartz. It is conspicuous locally in some parts at least of almost every member of the Chinle and is the pigment of the red rocks. In some sandstone strata, hematite forms a massive dark-red opaque interstitial cement that is localized 
in laminae, seams, and concretionary zones. It appears to entirely replace the clay matrix, previous cements, and part of the detrital grains. In a few places it forms as much as 65 percent of the rock.

In most occurrences, particularly in red rocks, the hematite forms red dustlike microcrystals which impregnate the clay matrix or calcite cement in sandstone, siltstone or calcareous rocks. The degree of impregnation is roughly indicated by the degree of opacity of the interstitial material. The interstices of some such red sandstones are filled with what appears in thin section as a translucent homogeneous mixture of mica clay, microcrystalline calcite, and microcrystalline hematite.

Gypsum is rare as a cement in the sandstone of the Chinle Formation, and where present it forms bladed, fibrous, coarsely crystalline interstitial aggregates. It probably constitutes a late-forming cement. Gypsum is associated with calcite cement but tends to replace it as well as interstitial clay.

Barite is common but sparse as a cement in sandstone of the Chinle Formation and forms microscopic aggregates of radiating lathlike crystals which are associated with and partly replace calcite cement. It forms as much as 1 percent of the rock by volume.

In areas of economically important mineralization, ore minerals of uranium and copper in sandstone act as interstitial cements and appear to have replaced other cements as well as the clay matrices and parts of sand-size detrital grains.

\section{FINE-TEXTURED AND CARBONATE ROCKS}

The fine-textured rocks of the Chinle Formation contain essentially the same rock-forming components as the sandstone strata, but in different proportions and textures. The mudstone, siltstone, and claystone strata are approximately 10 percent orthoquartzitic, 10 percent arkosic, 15 percent tuffaceous, and 25 percent graywacke; the remaining 40 percent consists of miscellaneous calcareous ( 25 to 75 percent carbonates) rocks. The graywackes are so classified because of their content of mica-montmorillonite, chlorite, and mica clays. In some rocks, clays were probably diagenetically derived from ashy tuffaceous detritus.

The fine-textured rocks contain, on the average, more calcite and more clay composed of mica-montmorillonite and montmorillonite-mica mixed clays than the sandstones, and less kaolinite, quartz, and feldspar. They range widely in composition so that averages of mineral composition are not very meaningful. The red strata tend to be moderately to well consolidated and have quartz, calcite, clay, feldspar, and iron oxide as the chief constituents. The matrices of these rocks consist of mica-montmorillonite or mica clay impregnated with various proportions of microcrystalline calcite and red iron oxide. The gray and variegated strata, which are commonly bentonitic, include much poorly consolidated sediment in which montmorillonite, chlorite, mica-clay mineral mixtures, quartz, feldspar, and fine fragments of altered tuff are the important constituents. These rocks grade into the limestones or dolomites (75 percent or more carbonate minerals) that are characteristic of the Owl Rock Member of the Chinle Formation. The calcite in the calcareous rocks appears to replace both fine and coarse tuffaceous detritus, and this fact, together with the presence of euhedral crystals of biotite and other minerals in some samples, suggests that the calcareous rocks in the variegated strata of the Chinle may have been formed in large part by the calcification of tuffaceous sediments.

The carbonate rocks, which are pale grayish green, pale purple, and mottled with pale red, are mainly calcitic but include a little interbedded dolomite. Many massive limestone strata contain large proportions of rounded sand- to pebble-size calcite concretions which show radiating crystal structures and tend to weather out to form what have locally been called "ball-bearing" slopes because of the hazards involved in traversing them on foot. Such concretionary beds resemble calcarenites but are not composed of detrital carbonate fragments.

\section{TEXTURE AND COMPOSITION OF VARIOUS STRATIGRAPHIC UNITS}

The texture and composition of strata in the Chinle Formation vary from one member to another. To show this in a general way, the textural and compositional characteristics of the sandstone in various stratigraphic units in the Chinle Formation and related strata are summarized in table 5 . The stratigraphic units shown are mottled strata, Shinarump and related members, Monitor Butte and related members, Moss Back and related members, Petrified Forest Member, Owl Rock Member, and Church Rock Member and related units. The general divisions are the same as used elsewhere in this report. (See "Stratigraphy" part of report.)

The sorting, skewness, and kurtosis classification systems used have been published previously (Cadigan, 1961, p. 130-131). The average values reported are based on the median rather than the mean. Although the ranges of values are large, differences between averages are significant. For example, certain sandstone of the Petrified Forest Member may resemble certain sandstone of the Shinarump 
TABLE 5. - Approximations of grain-size distribution properties and proportions of certain mineral components of the sandstone in groups of similar stratigraphic units of the Chinle Formation and related strata

\begin{tabular}{|c|c|c|c|c|c|c|c|c|c|c|}
\hline \multirow{2}{*}{$\begin{array}{l}\text { Stratigraphic } \\
\text { units }\end{array}$} & \multicolumn{4}{|c|}{$\begin{array}{c}\text { Grain-size distribution properties } \\
\text { (range) }\end{array}$} & \multicolumn{5}{|c|}{$\begin{array}{c}\text { Average percent (and range) of some mineral } \\
\text { components present }\end{array}$} & \multirow{2}{*}{$\begin{array}{l}\text { Principal } \\
\text { rock types }\end{array}$} \\
\hline & Grain size & Sorting & Skewness & Kurtosis & Quartz & $\begin{array}{c}\text { Sodic } \\
\text { feldspar }\end{array}$ & $\begin{array}{l}\text { Potassic } \\
\text { feldspar }\end{array}$ & $\begin{array}{l}\text { Volcanic } \\
\text { detritus }\end{array}$ & Calcite & \\
\hline $\begin{array}{l}\text { Church Rock } \\
\text { Member and } \\
\text { related units. }\end{array}$ & $\begin{array}{l}\text { Fine (very } \\
\text { fine } \\
\text { to coarse). }\end{array}$ & $\begin{array}{l}\text { Moderate } \\
\text { (poor to } \\
\text { well). }\end{array}$ & $\begin{array}{l}\text { Moderate } \\
\text { (slight to } \\
\text { high). }\end{array}$ & $\begin{array}{l}\text { Moderate } \\
\text { (normal } \\
\text { to very } \\
\text { high). }\end{array}$ & $\begin{array}{c}47 \\
(20-86)\end{array}$ & $(0-30)$ & $(0-24)$ & $(0-32)$ & $\begin{array}{l}15 \\
(0-70)\end{array}$ & $\begin{array}{l}\text { Arkose, ortho- } \\
\text { quartzite, and } \\
\text { tuff. }\end{array}$ \\
\hline Owl Rock Member.. & $\begin{array}{l}\text {... Very fine } \\
\text { (very fine to } \\
\text { granules). }\end{array}$ & $\begin{array}{l}\text { Poor (poor } \\
\text { to well). }\end{array}$ & $\begin{array}{l}\text { Slight } \\
\text { (normal } \\
\text { to high). }\end{array}$ & $\begin{array}{l}\text { Moderate } \\
\text { (negative } \\
\text { to mod- } \\
\text { erate) }\end{array}$ & $\stackrel{5}{(0-35)}$ & $\stackrel{2}{2}(0-17)$ & $(0-4)$ & $(2-55)$ & $(0-74)$ & $\begin{array}{l}\text { Tuff, ortho- } \\
\text { quartzite, and } \\
\text { limestone. }\end{array}$ \\
\hline $\begin{array}{l}\text { Petrified Forest } \\
\text { Member }\end{array}$ & $\begin{array}{l}\text { Fine (very } \\
\text { fine } \\
\text { to coarse). }\end{array}$ & $\begin{array}{l}\text { Poor (poor } \\
\text { to well.) }\end{array}$ & $\begin{array}{l}\text { Slight } \\
\text { (slight to } \\
\text { high). }\end{array}$ & $\begin{array}{l}\text { Moderate } \\
\text { (negative } \\
\text { to very } \\
\text { high) }\end{array}$ & $\begin{array}{c}35 \\
(1-80)\end{array}$ & $(0-36)$ & $\begin{array}{c}6 \\
(0-25)\end{array}$ & $\begin{array}{c}25 \\
(0-95)\end{array}$ & $\stackrel{2}{2}(0-68)$ & Tuff and arkose. \\
\hline $\begin{array}{l}\text { Moss Back and } \\
\text { related members. }\end{array}$ & $\begin{array}{l}\text { Fine (very } \\
\text { fine } \\
\text { to granules). }\end{array}$ & $\begin{array}{l}\text { Moderate } \\
\text { (poor } \\
\text { to mod- }\end{array}$ & $\begin{array}{c}\text { Moderate } \\
\text { (low to } \\
\text { high). }\end{array}$ & $\begin{array}{l}\text { Moderate } \\
\text { (negative } \\
\text { to high). }\end{array}$ & $\begin{array}{c}70 \\
(30-85)\end{array}$ & $\begin{array}{c}5 \\
(1-23)\end{array}$ & $(0-7)$ & $\stackrel{3}{3}(1-19)$ & $\begin{array}{c}7 \\
(0-40)\end{array}$ & $\begin{array}{l}\text { Orthoquartzite, } \\
\text { arkose, and tuff. }\end{array}$ \\
\hline $\begin{array}{l}\text { Monitor Butte and } \\
\text { related members. }\end{array}$ & $\begin{array}{l}\text { Very fine } \\
\text { (very fine to } \\
\text { granules). }\end{array}$ & $\begin{array}{l}\text { Moderate } \\
\text { (poor to } \\
\text { well). }\end{array}$ & $\begin{array}{l}\text { Slight } \\
\text { (normal } \\
\text { to high). }\end{array}$ & $\begin{array}{l}\text { Moderate } \\
\text { (negative } \\
\text { to very }\end{array}$ & $\begin{array}{c}57 \\
(5-85)\end{array}$ & $\begin{array}{c}2.5 \\
(0-22)\end{array}$ & $\begin{array}{c}6 \\
(0-15)\end{array}$ & $\begin{array}{c}3 \\
(0-84)\end{array}$ & $\begin{array}{c}5 \\
(0-70)\end{array}$ & $\begin{array}{l}\text { Orthoquartzite } \\
\text { and tuff. }\end{array}$ \\
\hline $\begin{array}{l}\text { Shinarump and } \\
\text { related members. }\end{array}$ & $\begin{array}{l}\text { Medium (very } \\
\text { fine to } \\
\text { granules). }\end{array}$ & $\begin{array}{l}\text { Moderate } \\
\text { (poor to } \\
\text { well). }\end{array}$ & $\begin{array}{l}\text { Moderate } \\
\text { (negative } \\
\text { to very } \\
\text { hich) }\end{array}$ & $\begin{array}{l}\text { Moderate } \\
\text { (flattened } \\
\text { to very }\end{array}$ & $\begin{array}{c}68 \\
(11-90)\end{array}$ & $\left(\begin{array}{c}1 \\
(0-9)\end{array}\right.$ & $\stackrel{2}{2}$ & $\begin{array}{c}4 \\
(0-63)\end{array}$ & $\begin{array}{c}<1 \\
(0-40)\end{array}$ & $\begin{array}{l}\text { Orthoquartzite } \\
\text { and tuff. }\end{array}$ \\
\hline Mottled strata & Fine & & nugni. & Moderate ...... & $\begin{array}{c}6.5 \\
(55-75)\end{array}$ & $<1$ & $<1$ & $\begin{array}{l}<1 \\
(0-31)\end{array}$ & $(0-11)$ & $\begin{array}{l}\text { Orthoquartzite } \\
\text { and tuff. }\end{array}$ \\
\hline
\end{tabular}

Member, but most of the sandstone in the two members falls into two distinct populations.

\section{CONGLOMERATE STUDIES}

By William Thordarson, H. F. Albee, and J. H. Stewart

Studies were made of the composition, mean and maximum size, roundness, and sphericity of pebbles in most of the conglomeratic units of the Chinle and Dolores Formations. These studies were designed to determine whether regional differences exist in the types of pebbles in the conglomeratic units, and to aid in determining the source rocks and source directions of the sediments composing these formations.

The term "pebble" as used in this section of the report denotes any rounded fragment of granule, pebble, cobble, or boulder size contained in a conglomeratic unit.

Special collections were made of pebbles containing fossils. These fossils were identified by Richard Rezak, L. G. Henbest, Helen Duncan, G. A. Cooper, Mackenzie Gordon, Jr., and Ellis Yochelson, all of the U.S. Geological Survey.

\section{METHODS OF PEBBLE ANALYSIS SAMPLING}

Pebbles were collected from most of the conglomeratic units of the Chinle and Dolores Formations at 113 sites throughout the Colorado Plateaus province and adjoining regions (figs. 25 and 26 ). The sample site numbers used in the pebble studies (figs. 25 and 26 , and table 6 ) are not the same as locality numbers used in the description of the stratigraphy and sedimentary facies of the Chinle Formation (pl. 1 and table 1). The number of pebbles collected at any one site ranged from 47 to 150 (table 6). Fifty pebbles were collected at most sites, and this number seems to be adequate to show major regional variations within a member and to show major differences between members.

The conglomerate layers in the Chinle and Dolores Formations commonly contain two kinds of pebbles: those that are resistant to erosion (quartz, quartzite, chert, and igneous and metamorphic rocks) and were probably derived from distant source areas, and those that are relatively nonresistant (limestone and siltstone) and probably came from nearby sources. In this study only the pebbles of resistant rocks have been considered.

Collections were made in most sites from pebbles lying loose on outcrops of conglomerate. Care was taken to select sample sites where contamination by younger, particularly Tertiary and Quaternary, conglomerate or gravel layers was unlikely. In some areas the pebbles were chopped from the surface of an outcrop, which insured against any possibility of contamination. At most sites, the pebbles were collected in a surface area of no more than a few square feet - sometimes less than 1 square foot. All sizes and types of clasts within a specific surface area were collected, so that there would be no temptation to select the larger or more distinctive pebbles in preference to the smaller ones and those of the more common rocks. The maximum size of the pebbles found in the vicinity of each sample site was also measured, the pebble with the largest maximum diameter being considered the largest. In some places, special collections were made of pebbles containing fossils or composed of volcanic material.

\section{COMPOSITION}

The pebbles consist mainly of quartz, quartzite, and chert, although pebbles of igneous rocks occur 


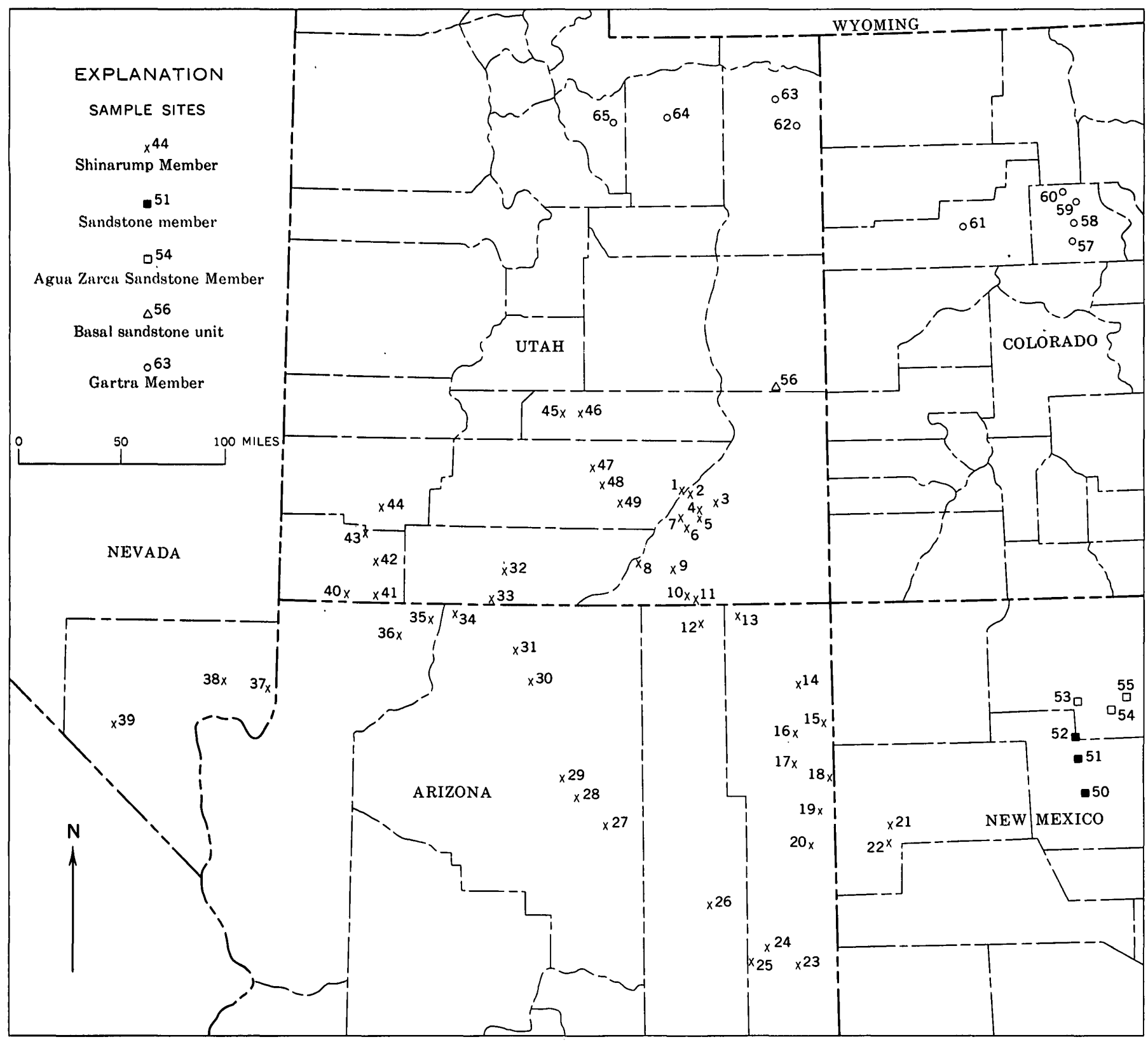

Figure 25. - Location of samples from the Gartra Member, basal sandstone unit, Agua Zarca Sandstone Member, sandstone member, and Shinarump (or Shinarump(?)) Member of the Chinle Formation.

at some sites. The term "chert" as applied in this report includes sedimentary chert and also other kinds of cryptocrystalline quartz such as jasper, chalcedony, and agate. After measurements of size, roundness, and sphericity, each pebble was broken to determine its lithology.

SIZE

The long, intermediate, and short diameters of each pebble were measured. The mean of the intermediate diameters, referred to as the mean size, was computed for each sample (table 6). The mean size of the pebbles of each lithologic type was also deter- mined for many samples (table 6). Generally 5 to 20 percent of the pebbles in a sample were broken, either by weathering or in the process of detaching them from consolidated rock, and their size was not included in calculating the mean.

\section{ROUNDNESS AND SPHERICITY}

Roundness and sphericity of pebbles were determined by methods proposed by Krumbein (1941) . Roundness was determined by comparison with images of pebbles that grade in roundness by tenths from 0.1 (least round) to 0.9 (most round). Individual pebbles generally ranged in roundness from 


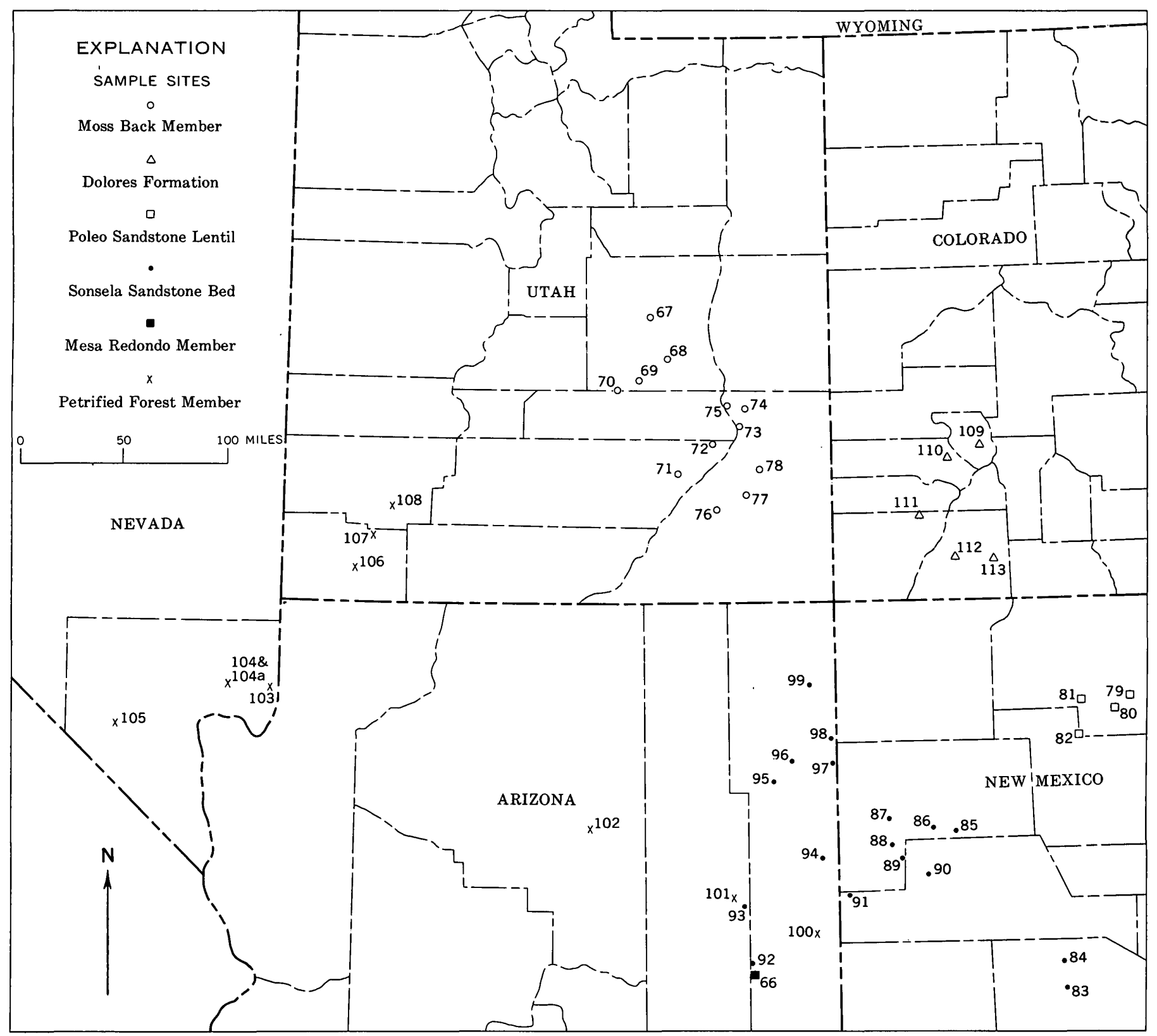

Figure 26. - Location of samples from Mesa Redondo Member, Moss Back Member, Poleo Sandstone Lentil, Sonsela Sandstone Bed, and Petrified Forest Member of the Chinle Formation and from basal unit and lower member of the Dolores Formation.

0.4 to 0.7 . Sphericity was determined from ratios of the lengths of the long, intermediate, and short diameters of the pebbles. The determinations of roundness and many of the measurements of sphericity are accurate to only one significant figure, as given in table 6 .

The average roundness and sphericity varied only slightly, if at all, from site to site and from unit to unit. The average roundness is generally 0.5 to 0.6 , and the average sphericity, 0.7 to 0.8 (table 6).

\section{RESULTS OF PEBBLE STUDIES}

\section{SHINARUMP MEMBER OF CHINLE FORMATION}

The Shinarump Member, including probable correlatives in southern Nevada and west-central New Mexico, is widely distributed on the Colorado Plateau. Forty-nine samples have been collected from this member (table 6).

Quartz, quartzite, and chert are the dominant types of pebbles in the Shinarump Member. The percentages of these types vary greatly from area 
TABLE 6. - Composition, size, voundness, and sphericity of pebbles from the Chinle and Dolores Formations Avg, average : Qtz, quartz : Qtzt, quartzite; Cht, chert. Dashed line indicates no information available]

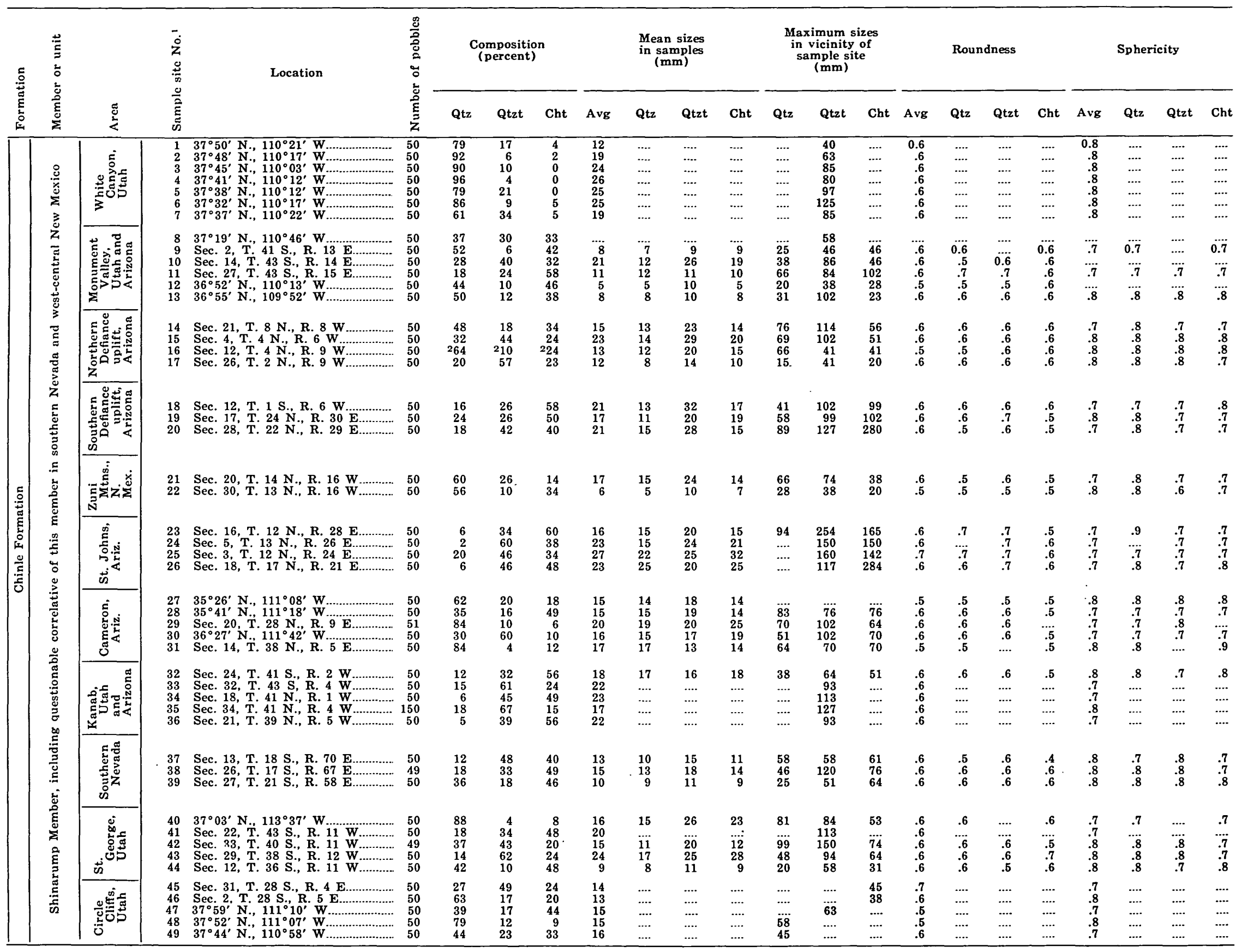


TABLE 6. - Composition, size, roundness, and sphericity of pebbles from the Chinle and Dolores Formations - Continued

\begin{tabular}{|c|c|c|c|c|c|c|c|c|c|c|c|c|c|c|c|c|c|c|c|c|c|c|c|}
\hline \multirow{2}{*}{ 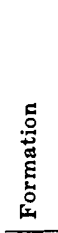 } & \multirow{2}{*}{ 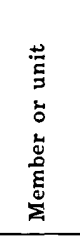 } & \multirow[b]{2}{*}{ 芯 } & \multirow{2}{*}{ 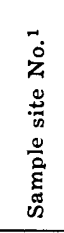 } & \multirow[t]{2}{*}{ Location } & \multirow{2}{*}{ 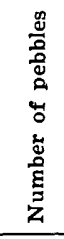 } & \multicolumn{3}{|c|}{$\begin{array}{c}\text { Composition } \\
\text { (percent) }\end{array}$} & \multicolumn{4}{|c|}{$\begin{array}{l}\text { Mean sizes } \\
\text { in samples } \\
(\mathrm{mm})\end{array}$} & \multicolumn{3}{|c|}{$\begin{array}{l}\text { Maximum sizes } \\
\text { in vicinity of } \\
\text { sample site } \\
(\mathrm{mm})\end{array}$} & \multicolumn{4}{|c|}{ Roundness } & \multicolumn{4}{|c|}{ Sphericity } \\
\hline & & & & & & Qtz & Qtzt & Cht & Avg. & Qtz & Qtzt & Cht & Qtz & Qtzt & Cht & Avg & Qtz & Qtzt & Cht & Avg & Qtz & Qtzt & Cht \\
\hline & 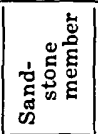 & 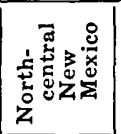 & $\begin{array}{l}50 \\
51\end{array}$ & 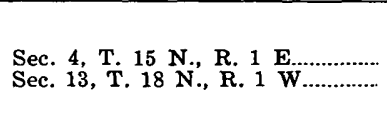 & $\begin{array}{l}50 \\
50\end{array}$ & $\begin{array}{l}18 \\
66\end{array}$ & $\begin{array}{l}10 \\
26\end{array}$ & $\begin{array}{r}72 \\
8\end{array}$ & $\begin{array}{l}10 \\
13\end{array}$ & $\begin{array}{l}12 \\
10\end{array}$ & $\begin{array}{r}9 \\
24\end{array}$ & $\begin{array}{l}10 \\
13\end{array}$ & $\begin{array}{l}58 \\
51\end{array}$ & $\begin{array}{l}127 \\
152\end{array}$ & $\begin{array}{l}69 \\
23\end{array}$ & $\begin{array}{l}.6 \\
.5\end{array}$ & $\begin{array}{l}.6 \\
.5\end{array}$ & $\begin{array}{l}.6 \\
.5\end{array}$ & $\begin{array}{l}.6 \\
. . .\end{array}$ & $\begin{array}{l}.8 \\
.8\end{array}$ & $\begin{array}{l}.8 \\
.8\end{array}$ & $\begin{array}{l}.8 \\
.8\end{array}$ & $\begin{array}{l}.7 \\
. . .\end{array}$ \\
\hline & 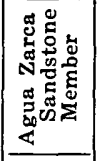 & 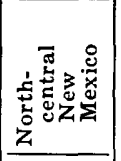 & $\begin{array}{l}52 \\
53 \\
54 \\
55\end{array}$ & 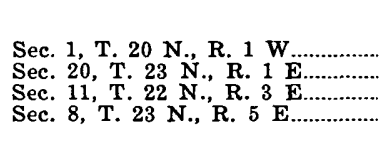 & $\begin{array}{l}50 \\
50 \\
50 \\
50\end{array}$ & $\begin{array}{l}28 \\
12 \\
52 \\
44\end{array}$ & $\begin{array}{l}16 \\
6 \\
48 \\
54\end{array}$ & $\begin{array}{r}56 \\
82 \\
0 \\
2\end{array}$ & $\begin{array}{l}11 \\
12 \\
16 \\
20\end{array}$ & $\begin{array}{l}12 \\
12 \\
12 \\
10\end{array}$ & $\begin{array}{l}18 \\
10 \\
23 \\
20\end{array}$ & $\begin{array}{r}8 \\
12 \\
\cdots \\
\cdots\end{array}$ & $\begin{array}{l}38 \\
36 \\
66 \\
51\end{array}$ & $\begin{array}{r}91 \\
36 \\
132 \\
137\end{array}$ & $\begin{array}{l}41 \\
56 \\
63 \\
-\ldots\end{array}$ & $\begin{array}{l}.6 \\
.5 \\
.5 \\
.5\end{array}$ & $\begin{array}{l}.6 \\
.6 \\
.5 \\
.5\end{array}$ & $\begin{array}{l}.6 \\
.6 \\
.5 \\
.5\end{array}$ & $\begin{array}{l}.5 \\
.5 \\
\ldots . . \\
. \ldots .\end{array}$ & $\begin{array}{l}.8 \\
.7 \\
.8 \\
.8\end{array}$ & $\begin{array}{l}.8 \\
.7 \\
.8 \\
.8\end{array}$ & $\begin{array}{l}.7 \\
.8 \\
.7 \\
.7\end{array}$ & $\begin{array}{l}.7 \\
.7 \\
\ldots . . \\
. . .\end{array}$ \\
\hline & 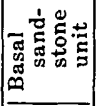 & 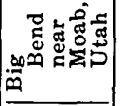 & 56 & Sec. 4, T. 25 S., R. 22 E................. & 50 & 84 & 16 & 0 & $\ldots$ & $\ldots$. & .... & $\ldots$ & 86 & $\ldots$. & $\ldots$. & .4 & $\ldots$. & $\cdots$. & $\ldots$. & .... & $\cdots$. & $\ldots$. & .... \\
\hline & 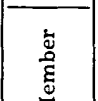 & & $\begin{array}{l}57 \\
58 \\
59 \\
60\end{array}$ & 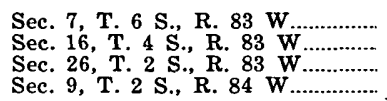 & $\begin{array}{r}100 \\
50 \\
50 \\
50\end{array}$ & $\begin{array}{l}86 \\
94 \\
82 \\
98\end{array}$ & $\begin{array}{l}4 \\
2 \\
6 \\
2\end{array}$ & $\begin{array}{r}10 \\
4 \\
12 \\
0\end{array}$ & $\begin{array}{l}\dddot{15} \\
17 \\
16\end{array}$ & $\begin{array}{l}\cdots . . \\
\cdots . \\
\cdots .\end{array}$ & $\begin{array}{l}\cdots . . \\
\cdots . \\
\cdots .\end{array}$ & $\begin{array}{c}\cdots . . \\
\cdots . . \\
\cdots\end{array}$ & $\begin{array}{l}81 \\
31 \\
76 \\
76\end{array}$ & $\begin{array}{l}86 \\
56 \\
\cdots \\
\cdots .\end{array}$ & $\begin{array}{l}86 \\
33 \\
\cdots \ldots . \\
\ldots . .\end{array}$ & $\begin{array}{l}.5 \\
.5 \\
.5\end{array}$ & $\begin{array}{l}.5 \\
.5 \\
.5\end{array}$ & $\begin{array}{l}.5 \\
.5 \\
.5\end{array}$ & $\begin{array}{l}.5 \\
.5 \\
. \ldots\end{array}$ & $\begin{array}{l}.8 \\
.8 \\
.7\end{array}$ & $\begin{array}{l}.7 \\
.8 \\
.7\end{array}$ & $\begin{array}{l}.8 \\
.7 \\
.9\end{array}$ & $\begin{array}{c}.8 \\
.7 \\
.7 .\end{array}$ \\
\hline & $\sum$ & 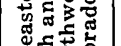 & 61 & Sec. 27 , T. 4 S., R. 92 W............. & $\begin{array}{l}\text { Field } \\
\text { est. }\end{array}$ & 95 & & & $\ldots$. & $\ldots$. & $\ldots$. & $\ldots$. & 56 & $\ldots$ & 64 & $\ldots$ & $\ldots$. & $\ldots$. & $\ldots$. & $\ldots$ & $\ldots$ & $\ldots$. & $\ldots$. \\
\hline & 矛 & 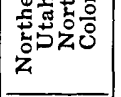 & $\begin{array}{l}62 \\
63 \\
64 \\
65\end{array}$ & 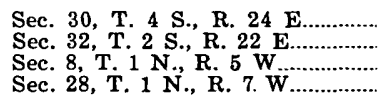 & $\begin{array}{l}50 \\
50 \\
50 \\
50\end{array}$ & $\begin{array}{r}98 \\
398 \\
96 \\
96\end{array}$ & $\begin{array}{r}0 \\
30 \\
4 \\
0\end{array}$ & $\begin{array}{r}2 \\
30 \\
0 \\
4\end{array}$ & $\begin{array}{r}16 \\
15 \\
9 \\
6\end{array}$ & $\begin{array}{l}\cdots . \\
\cdots . \\
\cdots .\end{array}$ & $\begin{array}{l}\cdots . \\
\cdots . \\
\cdots .\end{array}$ & $\begin{array}{l}\cdots . \\
\cdots . \\
\cdots .\end{array}$ & $\begin{array}{l}64 \\
51 \\
36 \\
23\end{array}$ & $\begin{array}{l}\ldots 1 \\
7 \ldots . \\
\ldots .\end{array}$ & $\begin{array}{l}99 \\
\ldots 25 \\
15\end{array}$ & $\begin{array}{l}.5 \\
.5 \\
.5 \\
.4\end{array}$ & $\begin{array}{l}.5 \\
.5 \\
.5 \\
.4\end{array}$ & $\begin{array}{l}\cdots . \\
.6 . \\
. .6\end{array}$ & $\begin{array}{l}\cdots . . \\
. . . \\
.3\end{array}$ & $\begin{array}{l}.8 \\
.7 \\
.7 \\
.8\end{array}$ & $\begin{array}{l}.8 \\
.7 \\
.7 \\
.8\end{array}$ & $\begin{array}{l}\cdots . . \\
. .8 \\
. \ldots .\end{array}$ & $\begin{array}{l}\cdots . . \\
. \cdots . \\
. .8\end{array}$ \\
\hline | & 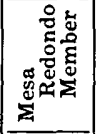 & 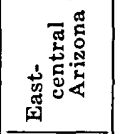 & 66 & Sec. 23, T. 12 N., R. 24 E........... & 50 & 2 & 20 & 78 & 18 & $\ldots$. & $\ldots$. & $\cdots$. & $\ldots$. & 58 & 99 & .6 & $\ldots$ & .7 & .5 & .7 & $\ldots$. & .7 & .7 \\
\hline 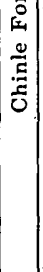 & 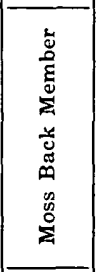 & 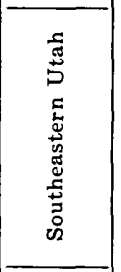 & $\begin{array}{l}67 \\
68 \\
69 \\
70 \\
71 \\
72 \\
73 \\
74 \\
75 \\
76 \\
77 \\
78\end{array}$ & 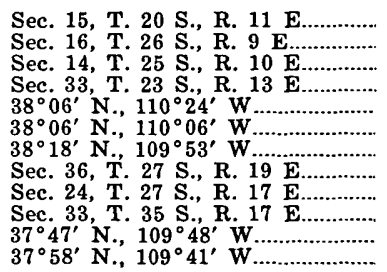 & $\begin{array}{l}150 \\
150 \\
150 \\
150 \\
150 \\
150 \\
150 \\
150 \\
150 \\
150 \\
150 \\
150\end{array}$ & $\begin{array}{r}16 \\
21 \\
9 \\
13 \\
9 \\
13 \\
12 \\
8 \\
9 \\
9 \\
20 \\
6\end{array}$ & $\begin{array}{l}65 \\
61 \\
31 \\
26 \\
28 \\
48 \\
28 \\
33 \\
49 \\
48 \\
46 \\
18\end{array}$ & $\begin{array}{l}19 \\
18 \\
60 \\
61 \\
63 \\
39 \\
60 \\
59 \\
42 \\
43 \\
34 \\
76\end{array}$ & $\begin{array}{l}23 \\
16 \\
18 \\
17 \\
20 \\
20 \\
22 \\
21 \\
23 \\
17 \\
22 \\
19\end{array}$ & $\begin{array}{l}\cdots . \\
\cdots . \\
\cdots . . \\
\cdots . . \\
\cdots . . \\
\cdots \cdots \\
\cdots \\
\cdots \\
\cdots \\
\cdots\end{array}$ & $\begin{array}{l}\cdots . . \\
\cdots . \\
\cdots . \\
\cdots . \\
\cdots . \\
\cdots . \\
\cdots . \\
\cdots . \\
\cdots \\
\cdots\end{array}$ & $\begin{array}{l}\cdots . . \\
\cdots . . \\
\cdots . . \\
\cdots . . \\
\cdots . . \\
\cdots . . \\
\cdots \cdots \\
\cdots . . \\
\cdots\end{array}$ & $\begin{array}{r}102 \\
85 \\
58 \\
60 \\
70 \\
75 \\
75 \\
95 \\
89 \\
70 \\
83 \\
84\end{array}$ & $\begin{array}{l}\cdots . \\
\cdots . . \\
\cdots . . \\
\cdots . . \\
\cdots . . \\
\cdots . . \\
\cdots . . \\
\cdots \\
\cdots\end{array}$ & $\begin{array}{c}\ldots . . \\
\ldots \ldots . \\
\ldots \ldots . \\
\ldots \ldots . \\
\ldots \ldots . \\
\ldots \ldots . \\
\ldots \ldots . \\
\ldots \ldots \\
\ldots .\end{array}$ & $\begin{array}{l}.6 \\
.6 \\
.6 \\
.6 \\
.6 \\
.6 \\
.6 \\
.6 \\
.6 \\
.6 \\
.6\end{array}$ & 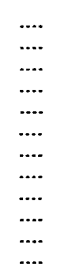 & 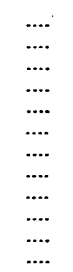 & 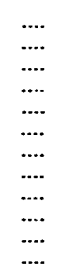 & $\begin{array}{l}.7 \\
.7 \\
.8 \\
.8 \\
.7 \\
.8 \\
.7 \\
.7 \\
.7 \\
.8\end{array}$ & $\begin{array}{c}\cdots \\
\cdots \\
\cdots \\
\cdots \\
\cdots \\
\cdots \\
\cdots \\
\cdots \\
\cdots \\
\cdots \\
\cdots \\
\cdots \\
\cdots\end{array}$ & 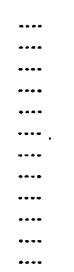 & $\begin{array}{c}\cdots \\
\cdots \\
\cdots \\
\cdots \\
\cdots \\
\cdots \\
\cdots \\
\cdots \\
\cdots \\
\cdots \\
\cdots \\
\cdots\end{array}$ \\
\hline & 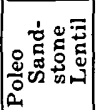 & 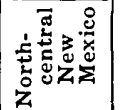 & $\begin{array}{l}79 \\
80 \\
81 \\
82\end{array}$ & 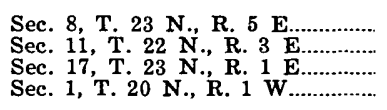 & $\begin{array}{l}50 \\
50 \\
50 \\
48\end{array}$ & $\begin{array}{l}30 \\
44 \\
62 \\
92\end{array}$ & $\begin{array}{l}2 \\
4 \\
2 \\
4\end{array}$ & $\begin{array}{r}68 \\
52 \\
36 \\
4\end{array}$ & $\begin{array}{r}10 \\
5 \\
7 \\
.6\end{array}$ & $\begin{array}{l}5 \\
5 \\
7 \\
5\end{array}$ & $\begin{array}{l}4 \\
5 \\
9 \\
7\end{array}$ & $\begin{array}{r}12 \\
6 \\
8 \\
16\end{array}$ & $\begin{array}{l}63 \\
33 \\
36 \\
15\end{array}$ & $\begin{array}{r}168 \\
31 \\
211\end{array}$ & $\begin{array}{l}58 \\
33 \\
38 \\
17\end{array}$ & $\begin{array}{l}.5 \\
.5 \\
.5 \\
.5\end{array}$ & $\begin{array}{l}.5 \\
.5 \\
.5 \\
.5\end{array}$ & $\begin{array}{c}\ldots . \\
\ldots . \\
\ldots . \\
\ldots .\end{array}$ & $\begin{array}{l}.5 \\
.5 \\
.5 \\
\ldots . .\end{array}$ & $\begin{array}{l}.7 \\
.7 \\
.8 \\
.8\end{array}$ & $\begin{array}{l}.7 \\
.7 \\
.8 \\
.8\end{array}$ & $\begin{array}{c}\ldots . \\
\cdots \cdots \\
\cdots \\
\cdots\end{array}$ & $\begin{array}{l}.7 \\
.7 \\
.7 \\
. . .\end{array}$ \\
\hline & 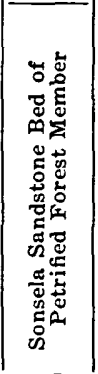 & 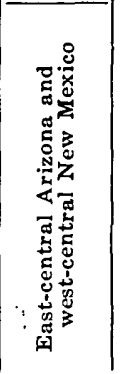 & $\begin{array}{r}483 \\
484 \\
85 \\
86 \\
87 \\
88 \\
89 \\
90 \\
91 \\
92 \\
93 \\
94 \\
95 \\
96 \\
97 \\
98 \\
99\end{array}$ & 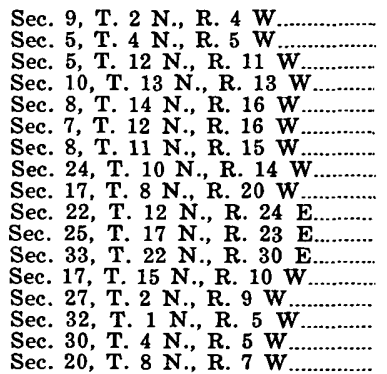 & $\begin{array}{l}50 \\
50 \\
50 \\
50 \\
47 \\
50 \\
49 \\
50 \\
50 \\
50 \\
50 \\
49 \\
49 \\
49 \\
49 \\
49 \\
50\end{array}$ & $\begin{array}{r}18 \\
10 \\
20 \\
4 \\
4 \\
2 \\
8 \\
2 \\
2 \\
0 \\
50 \\
2 \\
0 \\
50 \\
4 \\
6 \\
2\end{array}$ & $\begin{array}{r}30 \\
14 \\
40 \\
20 \\
11 \\
18 \\
14 \\
0 \\
4 \\
8 \\
52 \\
16 \\
0 \\
54 \\
18 \\
2 \\
8\end{array}$ & $\begin{array}{r}52 \\
76 \\
40 \\
76 \\
85 \\
80 \\
78 \\
98 \\
94 \\
92 \\
594 \\
82 \\
100 \\
592 \\
78 \\
92 \\
90\end{array}$ & $\begin{array}{r}11 \\
6 \\
8 \\
13 \\
6 \\
7 \\
15 \\
14 \\
15 \\
11 \\
99 \\
13 \\
10 \\
11 \\
11 \\
10 \\
13\end{array}$ & $\begin{array}{r}\ldots . \\
\ldots 6 \\
61 \\
11 \\
5 \\
8 \\
8 \\
5 \\
8 \\
\cdots . \\
\cdots \\
\cdots \\
9 \\
9 \\
9 \\
8\end{array}$ & $\begin{array}{l}\ldots . \\
\cdots 8 \\
14 \\
10 \\
6 \\
24 \\
15 \\
10 \\
10 \\
12 \\
\ldots 1 \\
11 \\
10 \\
21 \\
12\end{array}$ & $\begin{array}{r}\ldots . \\
\ldots 9 \\
13 \\
13 \\
6 \\
8 \\
14 \\
15 \\
16 \\
11 \\
9 \\
13 \\
10 \\
12 \\
11 \\
10 \\
13\end{array}$ & $\begin{array}{l}53 \\
13 \\
18 \\
71 \\
13 \\
51 \\
25 \\
25 \\
74 \\
\ldots . \\
\ldots . \\
13 \\
\ldots . \\
\ldots . \\
10 \\
15 \\
28\end{array}$ & $\begin{array}{r}74 \\
21 \\
30 \\
76 \\
25 \\
114 \\
89 \\
91 \\
152 \\
61 \\
\ldots 3 \\
33 \\
76 \\
33 \\
41 \\
38\end{array}$ & $\begin{array}{r}58 \\
10 \\
64 \\
147 \\
46 \\
109 \\
97 \\
107 \\
147 \\
97 \\
76 \\
76 \\
51 \\
65 \\
33 \\
36 \\
48\end{array}$ & $\begin{array}{l}.5 \\
.5 \\
.5 \\
.5 \\
.5 \\
.5 \\
.5 \\
.5 \\
.5 \\
.5 \\
.5 \\
.5 \\
.5 \\
.5 \\
.5\end{array}$ & 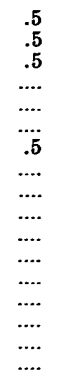 & $\begin{array}{c}.5 \\
.5 \\
.5 \\
.6 \\
.5 \\
.5 \\
.6 \\
\ldots . . \\
.6 \\
.6 \\
.5 \\
\ldots . . \\
. .6 \\
. .7\end{array}$ & $\begin{array}{l}.5 \\
.5 \\
.5 \\
.5 \\
.5 \\
.5 \\
.5 \\
.5 \\
.5 \\
.5 \\
.5 \\
.5 \\
.5 \\
.6 \\
.5 \\
.5\end{array}$ & $\begin{array}{l}.9 \\
.8 \\
.7 \\
.8 \\
.8 \\
.7 \\
.7 \\
.8 \\
.8 \\
.8 \\
.8 \\
.8 \\
.8 \\
.8 \\
.8\end{array}$ & 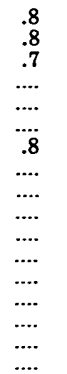 & $\begin{array}{l}.7 \\
.7 \\
.7 \\
.8 \\
.7 \\
.7 \\
.7 \\
\ldots . . \\
\ldots .8 \\
. .8 \\
.8 \\
. .7 \\
.7 \\
. .7\end{array}$ & $\begin{array}{l}.7 \\
.7 \\
.7 \\
.8 \\
.8 \\
.8 \\
.7 \\
.8 \\
.8 \\
.8 \\
.8 \\
.8 \\
.8 \\
.8 \\
.8\end{array}$ \\
\hline
\end{tabular}




\begin{tabular}{|c|c|c|c|c|c|c|c|c|c|c|c|c|c|c|c|c|c|c|c|c|c|c|c|}
\hline | & 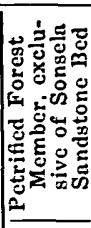 & 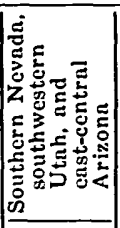 & \begin{tabular}{|l}
$\quad 6100$ \\
7101 \\
9102 \\
1102 \\
11103 \\
11104 \\
$12104 \mathrm{~A}$ \\
13105 \\
11406 \\
1107 \\
15108
\end{tabular} & 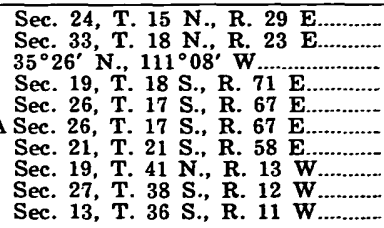 & $\begin{array}{l}50 \\
50 \\
50 \\
50 \\
50 \\
50 \\
50 \\
50 \\
50 \\
50\end{array}$ & $\begin{array}{r}22 \\
50 \\
50 \\
2 \\
13 \\
56 \\
4 \\
4 \\
50 \\
0\end{array}$ & $\begin{array}{r}22 \\
54 \\
550 \\
54 \\
33 \\
52 \\
44 \\
28 \\
522 \\
0\end{array}$ & $\begin{array}{r}76 \\
574 \\
544 \\
44 \\
54 \\
526 \\
52 \\
68 \\
576 \\
100\end{array}$ & $\begin{aligned} 8 \\
18 \\
26 \\
18 \\
15 \\
9 \\
19 \\
16 \\
13 \\
8\end{aligned}$ & $\begin{array}{l}\cdots . . \\
\cdots . . \\
\cdots . . \\
\cdots . \\
\cdots . . \\
\cdots . . \\
\cdots .\end{array}$ & $\begin{array}{l}\cdots . . \\
\cdots . \\
\cdots . . \\
\cdots . . \\
\cdots . . \\
\cdots . . \\
\cdots\end{array}$ & $\begin{array}{l}\cdots . . \\
\cdots . . \\
\cdots . . \\
\ldots . . \\
\cdots . . \\
\cdots . . \\
\cdots .\end{array}$ & $\begin{array}{l}58 \\
\ldots \ldots \\
\ldots 1 \\
21 \\
28 \\
66 \\
61 \\
51 \\
\ldots . .\end{array}$ & $\begin{array}{r}58 \\
891 \\
152 \\
84 \\
43 \\
19 \\
74 \\
48 \\
38 \\
28\end{array}$ & $\begin{array}{c}74 \\
899 \\
104 \\
108 \\
68 \\
45 \\
84 \\
76 \\
89 \\
38\end{array}$ & $\begin{array}{l}.5 \\
.6 \\
.7 \\
.6 \\
.6 \\
.6 \\
.6 \\
.6 \\
.5\end{array}$ & $\begin{array}{c}.5 \\
\cdots \\
\cdots \\
\cdots \\
.5 \\
.5 \\
\ldots . . \\
\cdots \cdots \\
\ldots . .\end{array}$ & $\begin{array}{c}\ldots . \\
.8 \\
.7 \\
.6 \\
.6 \\
.7 \\
.7 \\
.6\end{array}$ & $\begin{array}{l}.5 \\
.5 \\
.6 \\
.5 \\
.6 \\
.5 \\
.6 \\
.5\end{array}$ & $\begin{array}{l}.7 \\
. .8 \\
.7 \\
.8 \\
.8 \\
.8 \\
.7 \\
.8\end{array}$ & 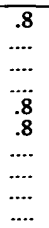 & $\begin{array}{c}\ldots . \\
\ldots .7 \\
.8 \\
.7 \\
\ldots .8 \\
.8 \\
.7 \\
\ldots .\end{array}$ & \begin{tabular}{l}
.7 \\
\hdashline .8 \\
.7 \\
.8 \\
.8 \\
.8 \\
.7 \\
.7
\end{tabular} \\
\hline \multirow{3}{*}{ 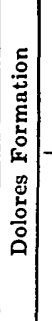 } & 莺 & 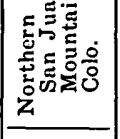 & $\begin{array}{l}109 \\
110\end{array}$ & 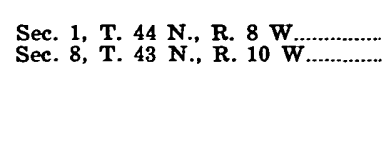 & $\begin{array}{l}50 \\
50\end{array}$ & $\begin{array}{r}1628 \\
68\end{array}$ & $\begin{array}{r}1656 \\
24\end{array}$ & $\begin{array}{r}162 \\
8\end{array}$ & $\begin{array}{l}20 \\
12\end{array}$ & $\cdots$ & $\cdots$. & $\ldots .$. & $\begin{array}{r}1781 \\
56\end{array}$ & $\begin{array}{r}17119 \\
127\end{array}$ & $\begin{array}{r}1779 \\
51\end{array}$ & .5 & $\cdots$. & $\cdots$. & $\cdots .$. & .8 & $\cdots$. & $\cdots$ & $\cdots$ \\
\hline & \multirow{2}{*}{ 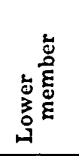 } & \multirow{2}{*}{ 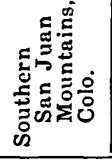 } & $\begin{array}{l}111 \\
112\end{array}$ & Sec. 35 , T. $39 \mathrm{~N} .$, R. $13 \mathrm{~W} . . . . . .$. & \multirow{2}{*}{$\begin{array}{l}100 \\
\text { Field } \\
\text { est. } \\
\text { Field } \\
\text { est. }\end{array}$} & $\begin{array}{l}1851 \\
2090\end{array}$ & $\begin{array}{r}1811 \\
0\end{array}$ & $\begin{array}{r}189 \\
0\end{array}$ & 12 & $\cdots$ & $\cdots$ & $\cdots$ & $\begin{array}{r}1932 \\
5\end{array}$ & 1922 & $\cdots$ & .5 & $\cdots$ & $\cdots$ & $\cdots$ & .7 & $\cdots$ & $\cdots$ & $\cdots$ \\
\hline & & & 113 & Sec. 23, T. 36 N., R. 7 W...... & & 95 & \multicolumn{2}{|c|}{$\mathbf{5}$} & $\cdots$. & $\ldots$. & $\cdots$ & .... & 4 & $\cdots$ & $\ldots$ & .... & $\cdots$ & $\cdots$ & .... & $\cdots$ & $\cdots$ & $\cdots$ & $\cdots$ \\
\hline
\end{tabular}

${ }^{1}$ Numbers are not the same as locality numbers used in stratigraphic and sedimentary facies studies. 2 percent hematite.

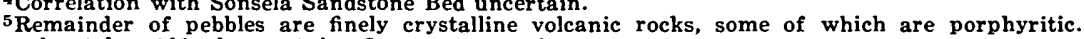

Sample at loc.

7 About $42 \mathrm{ft}$ above top of Sonsela Sandstone Bed.

Also $132 \mathrm{~mm}$ (finely crystalline igneous rock).

10 About 240 ft above be of mer.
11 About $120 \mathrm{ft}$ above base of member.

13 About $205 \mathrm{ft}$ above base of member.

14 A bout $210 \mathrm{ft}$ above base of member.

15 Middle of member.
16 Also 6 percent granitic rock, 4 percent orthoclase, and 4 percent felsite (?).

cent mafic igneous rock (ic)

19. Also $25 \mathrm{~mm}$ (granitic rock) 
to area (table 6 ; fig. 27). In figure 27 , data from individual sites within an area have been grouped together, and the mean of the individual studies (mean of the mean) and the expected range of this mean, within 95-percent confidence limits, have been calculated for the three lithologic types. Lines between areas indicate where the expected ranges of the mean in the two areas, for one of the lithologic types, do not overlap.

Perhaps the most significant difference in the relative amounts of quartz, quartzite, and chert between areas (fig. 27) is the high proportion of quartz in the White Canyon area and the low proportion of quartz in the Kanab and St. Johns areas.

The mean sizes of the pebbles of the three types at individual sites range from 5 to $27 \mathrm{~mm}$ (table 6), but this wide variation in mean appears to have little, if any, regional significance.

The maximum sizes of pebbles of quartz, quartzite, and chert do, however, show significant regional variation (fig. 28). Sizes exceed $200 \mathrm{~mm}$ (the largest was $284 \mathrm{~mm}$ ) in the southernmost part of the area of distribution of the Shinarump Member and are less than $50 \mathrm{~mm}$ in the eastern (northeastern Arizona) and in the northernmost parts of that area. The maximum sizes also appear to be unusually high in southeastern Utah (White Canyon, sites 1-7, table 6), as compared with those in areas to the south in northeastern Arizona (fig. 28). Some of the data in figure 28 are from individual observations not listed in table 6 .

Fossiliferous chert pebbles in the Shinarump Member contain fusulinids, brachiopods, bryozoans, and, to a lesser extent, pelecypods, gastropods, crinoidal material, and corals (table 7 ). The fusulinids include Schwagerina sp. (middle Wolfcamp to Leonard age, Permian) and Parafusulina sp. (Leonard and Guadalupe age, Permian). The brachiopods include Dictyoclostus sp. and Enteletes sp., most likely of Pennsylvanian and Permian age. The bryozoans include Fenestella and suggest a possible Permian age. Most of the fossils in the pebbles of the Shinarump Member probably came from Permian rocks. Many of them are similar to those occurring in the Kaibab Limestone, or equivalent formations, of Permian age. Some of them may be from rocks of Pennsylvanian or even Mississippian age, but these designations are uncertain.

A few pebbles of volcanic material occur in the Shinarump Member in the Cameron area and in a possible correlative of the Shinarump Member in an area about 25 miles north of Flagstaff, Ariz. The largest volcanic cobble noted $(205 \mathrm{~mm})$ was in this area north of Flagstaff. Most of the volcanic pebbles, however, are between 25 and $50 \mathrm{~mm}$ in maximum diameter. The abundance of potassium feldspar and quartz phenocrysts indicates that these pebbles are of rhyolitic composition. The groundmass contains common relicts of glass shards and tuff particles, indicating that many of the pebbles were probably originally vitric and crystal tuffs.

SANDSTONE MEMBER AND AGUA ZARCA SANDSTONE MEMBER OF CHINLE FORMATION

The sandstone member and the Agua Zarca Sandstone Member occur at the base of the Chinle Formation in north-central New Mexico (fig. 28). The two members may be laterally continuous, at least in part, with one another.

Only two samples were collected in the sandstone member. One contained abundant chert (site 50, table 6 ) ; the other, abundant quartz (site 51, table 6) . The maximum size of pebbles noted in this member was $152 \mathrm{~mm}$ (fig. 28 ; table 6 ).

Four samples were collected from the Agua Zarca Sandstone Member. These samples show considerable variation in the relative amounts of quartz, quartzite, and chert (table 6). The member characteristically contains pebbles of very coarse grained quartzite or quartzite conglomerate that are commonly 50 to $75 \mathrm{~mm}$ in diameter and rarely as much as $250 \mathrm{~mm}$ in diameter. Granite pebbles and cobbles as much as $100 \mathrm{~mm}$ in diameter also occur in the member but are rare.

The maximum sizes of pebbles in the Agua Zarca Sandstone Member range from 56 to $330 \mathrm{~mm}$ (fig. 28). The largest clast in the Agua Zarca, a quartzite boulder, was the largest clast noted in any unit in the Chinle Formation.

\section{BASAL SANDSTONE UNIT OF CHINLE FORMATION NEAR MOAB, UTAH}

One sample (site 56, table 6) was collected from the basal sandstone unit of the Chinle Formation at the Big Bend of the Colorado River near Moab, Utah. This unit has been described by Baker (1933, p. 37-38), by Dane (1935, p. 56), and by Shoemaker and Newman $(1959$, p. 1847-1848). The pebbles in it are 84 percent quartz and 16 percent quartzite, and the largest one noted was $86 \mathrm{~mm}$ in maximum diameter.

\section{GARTRA MEMBER OF CHINLE FORMATION}

Nine samples were collected from the Gartra Member of the Chinle Formation in northeastern Utah and northwestern Colorado. Most of the pebbles are quartz ( 82 to 98 percent) (table 6 ); the others are quartzite and chert. The maximum pebble sizes in the member generally decrease irregularly from $86 \mathrm{~mm}$ in northwestern Colorado to $23 \mathrm{~mm}$ in north- 


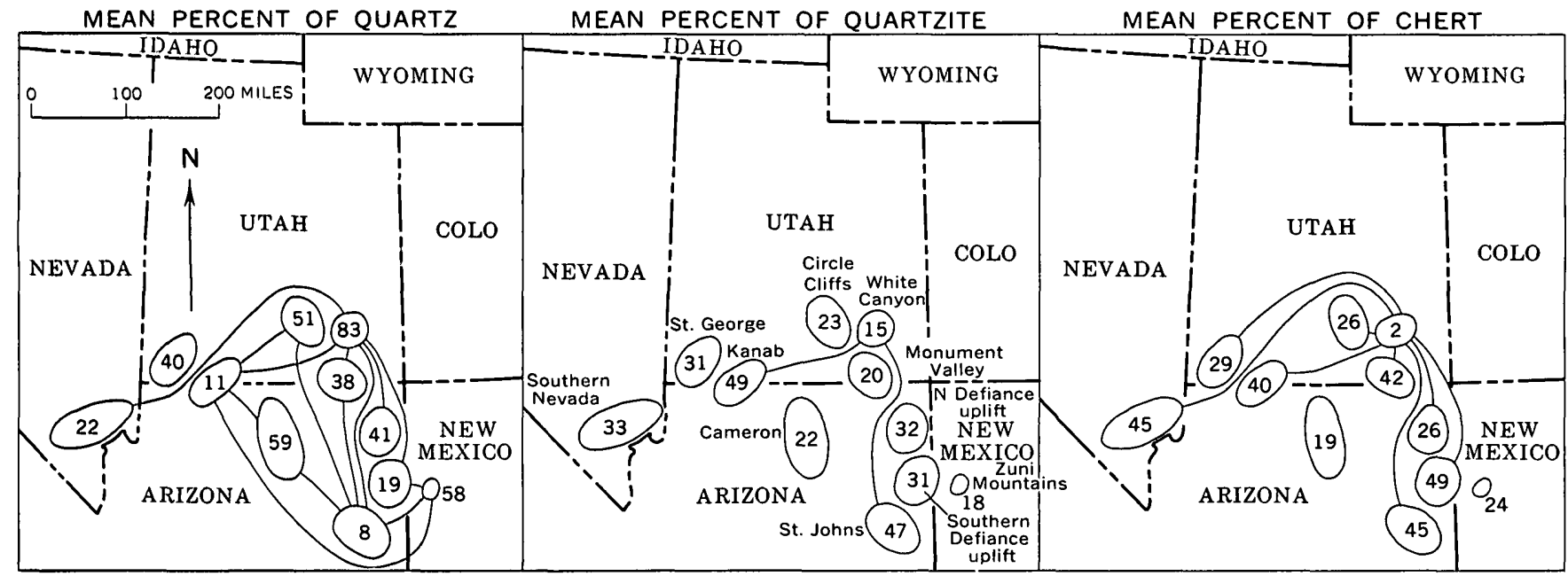

\begin{tabular}{|c|c|c|c|c|c|c|c|}
\hline \multirow{2}{*}{ AREA } & \multirow{2}{*}{$\begin{array}{l}\text { NUMBER } \\
\text { OF } \\
\text { SAMPLES }\end{array}$} & \multicolumn{2}{|c|}{ PERCENT OF QUARTZ } & \multicolumn{2}{|c|}{ PERCENT OF QUARTZITE } & \multicolumn{2}{|c|}{ PERCENT OF CHERT } \\
\hline & & Mean & $\begin{array}{c}\text { Expected } \\
\text { range of mean } 1\end{array}$ & Mean & $\begin{array}{l}\text { Expected } \\
\text { range of mean } 1\end{array}$ & Mean & $\begin{array}{c}\text { Expected } \\
\text { range of mean } 1\end{array}$ \\
\hline Southern Nevada & 3 & 22 & $0-53$ & 33 & $0-70$ & 45 & $34-56$ \\
\hline St. George. Utah & 5 & 40 & $3-76$ & 31 & $1-60$ & 29 & $7-52$ \\
\hline Kanab, Utah and Arizona & 5 & 11 & $4-18$ & 49 & $30-68$ & 40 & $16-64$ \\
\hline Circle Cliffs. Utah & 5 & 51 & $21-76$ & 23 & $4-43$ & 26 & $10-43$ \\
\hline White Canyon. Utah & 7 & 83 & $72-94$ & 15 & $5-25$ & 2 & $0-6$ \\
\hline Monument Valley, Arizona and Utah & 6 & 38 & $24-52$ & 20 & $6-34$ & 42 & $31-52$ \\
\hline Cameron, Arizona & 5 & 59 & $27-91$ & 22 & $0-59$ & 19 & $0-41$ \\
\hline Northern Defiance uplift. Arizona & 4 & 41 & $10-72$ & 32 & $0-66$ & 26 & $18-35$ \\
\hline Southern Defiance uplift, Arizona & 3 & 19 & $9-30$ & 31 & $9-54$ & 49 & $27-72$ \\
\hline St. Johns, Arizona & 4 & 8 & $0-21$ & 47 & $31-65$ & 45 & $27-63$ \\
\hline Zuni Mountains, New Mexico & 2 & 58 & $33-83$ & 18 & $0-100$ & 24 & $0-100$ \\
\hline \multicolumn{8}{|c|}{$\begin{array}{l}\text { Numbers indicate the mean percent of the lithologic } \\
\text { type in the circled areas. } \\
\text { Lines connect areas where expected ranges of the } \\
\text { mean, within 95-percent confidence limits, do not overlap. }\end{array}$} \\
\hline
\end{tabular}

iWithin 95-percent confidence limits.

Figure 27. - Regional differences in the proportions of quartz, quartzite, and chert pebbles in the Shinarump Member of the Chinle Formation.

eastern Utah (fig. 28). A 99-mm clast was noted at one site in northeastern Utah.

\section{MESA REDONDO MEMBER OF CHINLE FORMATION}

One sample (site 66, table 6) was collected from the Mesa Redondo Member of the Chinle Formation in east-central Arizona. Most pebbles in this collection are chert (78 percent) ; the rest are quartzite (20 percent) and quartz ( 2 percent) (table 6$)$. The maximum pebble size noted was $99 \mathrm{~mm}$.

\section{MOSS BACK MEMBER OF CHINLE FORMATION}

Twelve samples were collected from the Moss Back Member in southeastern Utah. The average ratio of quartz, quartzite, and chert pebbles in this member, as indicated by a study of 3,000 pebbles, is 12:40:48 (table 6; Albee, 1957, p. 140). The relative amount of quartz is low in all the samples, but the ratio between quartzite and chert varies considerably, quartzite being dominant in some samples and chert in others. In the samples studied, the proportion of quartzite appears to decrease southwestward and southeastward (fig. 29), but the sample sites were too widely scattered to afford clear evidence on this point.

The maximum sizes of pebbles in the Moss Back Member apparently decrease from about $100 \mathrm{~mm}$ in the northeast to about $60 \mathrm{~mm}$ in the southwest (fig. 29). This appearance, however, is also based on relatively few observations, and the decrease may be only apparent. If the sizes do in fact decrease southwestward, the direction is anomalous for the Chinle Formation, because as will be shown later, the direction of dip of cross-strata indicates that the streams which deposited the Moss Back Member flowed northwestward and that, consequently, the sediment must have been derived from the southeast of southeastern Utah.

Fossiliferous chert pebbles from the Moss Back Member contain fusulinids, brachiopods, bryozoans, algae, and, to a lesser extent, gastropods, sponge 


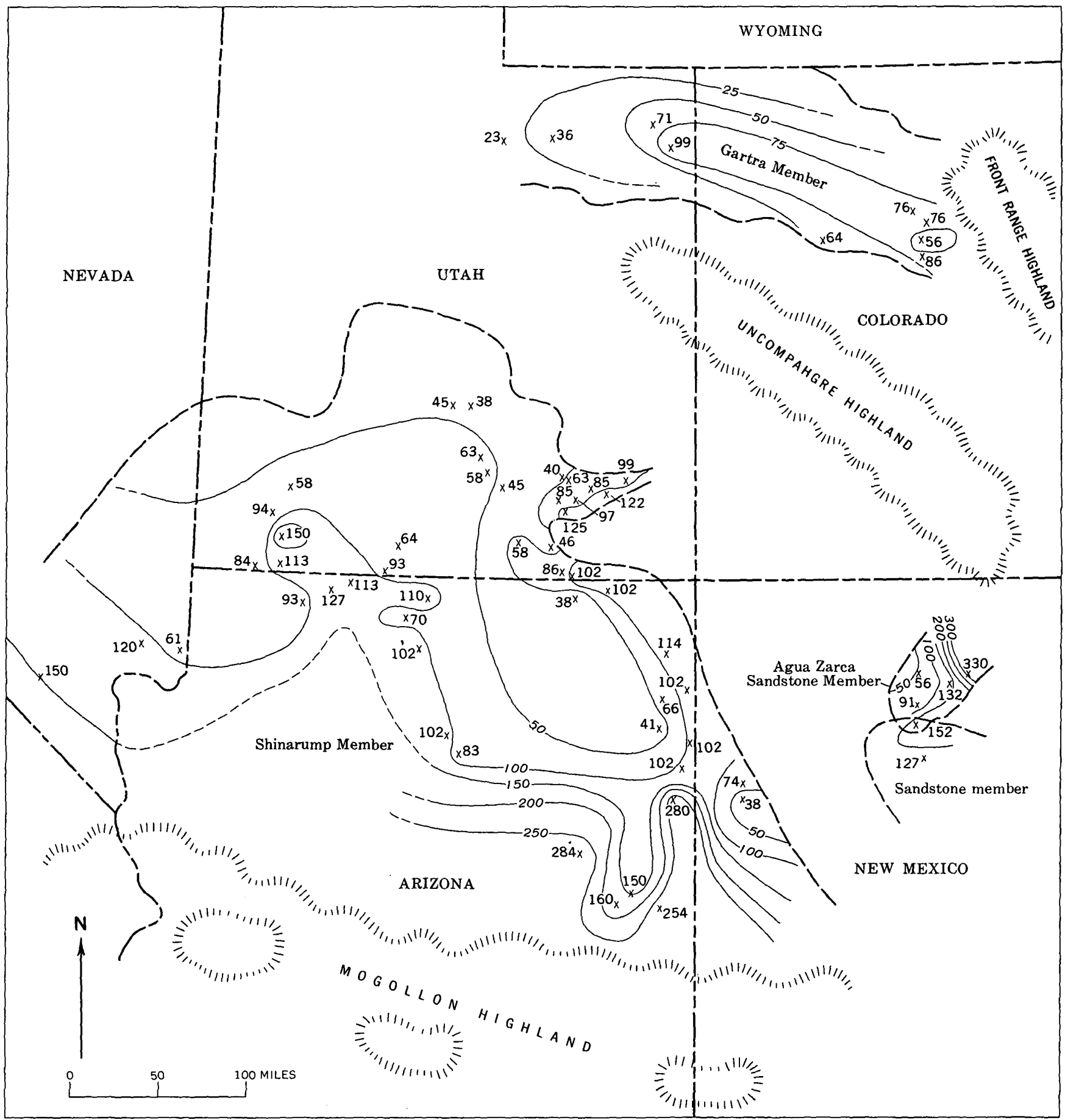

EXPLANATION

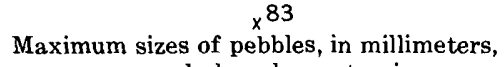
measured along longest axis

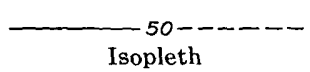

Isopleth

Dashed where inferred. Interval $50 \mathrm{~mm}$. Isopleth interval is $25 \mathrm{~mm}$ in Gartra Member
Approximate limit of member

Figure 28. - Isopleth map of maximum sizes of pebbles to boulders (quartz, quartzite, and chert) in the Shinarump, Agua Zarca Sandstone, and Gartra Members and the sandstone member of the Chinle Formation. 
TABLE 7. - Fossils from chert pebbles in Shinarump Member of Chinle Formation

\begin{tabular}{|c|c|c|c|}
\hline Locality & $\begin{array}{l}\text { Sample site No. } \\
\text { (fig. 25) }\end{array}$ & $\begin{array}{l}\text { Fossils in chert pebbles } \\
\text { (some localities include } \\
\text { identifications from } \\
\text { more than one pebble) } \\
\end{array}$ & $\begin{array}{l}\text { Age of chert } \\
\text { (based on fossils) }\end{array}$ \\
\hline \multicolumn{4}{|c|}{ White Canyon, Utah } \\
\hline $\begin{array}{l}\text { Lat } 37^{\circ} 32^{\prime} \text { N., long } \\
110^{\circ} 17^{\prime} \text { W. }\end{array}$ & 6 & $\begin{array}{l}\text { Fenestella sp. } \\
\text { Fragment suggestive of Derbyia sp. or } \\
\text { Orthotetes sp. } \\
\text { Fragment doubtfully suggestive of Schizo- } \\
\text { dus sp. } \\
\text { Indeterminate horn coral. } \\
\text { Possible stenoporoid bryozoa. }\end{array}$ & \\
\hline \multicolumn{4}{|c|}{ Circle Cliffs, Utah } \\
\hline $\begin{array}{l}\text { Sec. } 31, \text { T. } 28 \text { S., R. } \\
5 \text { W. }\end{array}$ & 45 & $\begin{array}{l}\text { Indeterminate bryozoan. } \\
\text { Possible Septopora } \text { sp. }\end{array}$ & $\begin{array}{l}\text { Bryozoans suggest derivation from Kai- } \\
\text { bab Limestone of Permian (Leonard) } \\
\text { age (Helen Duncan, written commun., } \\
\text { 1953). }\end{array}$ \\
\hline \multicolumn{4}{|c|}{ Monument Valley, Utah and Arizona } \\
\hline $\begin{array}{l}\text { Lat } 36^{\circ} 51^{\prime} \text { N., long } \\
109^{\circ} 53^{\prime} 10^{\prime \prime} \text { W. }\end{array}$ & $\begin{array}{l}\text { Near } \\
13\end{array}$ & $\begin{array}{l}\text { Rhomboporid and stenoporid bryozoans. } \\
\text { Indeterminable fragment of brachiopod. }\end{array}$ & $\begin{array}{l}\text { Late Pennsylvanian or Early Permian } \\
\text { (Helen Duncan, written commun., } \\
\text { 1954). }\end{array}$ \\
\hline $\begin{array}{l}\text { Lat } 36^{\circ} 50^{\prime} \mathrm{N} . \text {, long } \\
110^{\circ} 14^{\prime} \mathrm{W} \text {. }\end{array}$ & $\begin{array}{l}\text { Near } \\
12\end{array}$ & $\begin{array}{l}\text { Cobble crowded with fusulinids but not } \\
\text { preserved enough to tel if they are } \\
\text { species of Schwagerina, "Dunbarinella," } \\
\text { and Pseudoschwagerina(?) or species } \\
\text { of Parafusulina and advanced forms of } \\
\text { Schwagerina. }\end{array}$ & $\begin{array}{l}\text { Most likely Permian (late Wolfcamp or } \\
\text { Leonard) (L. G. Henbest, written com- } \\
\text { mun., 1952). }\end{array}$ \\
\hline $\begin{array}{l}\text { Sec. } 26 \text { or } 27, \text { T. } 43 \\
\text { S., R. } 15 \text { E. }\end{array}$ & 11 & $\begin{array}{l}\text { Poorly preserved brachiopods. } \\
\text { Poorly preserved gastropod. } \\
\text { Poorly preserved stenoporoid, ramose, and } \\
\text { fenestrate - (Polypora? }- \text { bryozoans. }\end{array}$ & $\begin{array}{l}\text { Bryozoans are believed to indicate Car- } \\
\text { boniferous or Permian age (Helen Dun- } \\
\text { can, written commun., 1953). }\end{array}$ \\
\hline \multicolumn{4}{|c|}{ Kanab, Utah and Arizona } \\
\hline $\begin{array}{l}\text { Sec. } 32(?), \text { T. } 43 \text { S., } \\
\text { R. } 4 \text { W. }\end{array}$ & 33 & $\begin{array}{l}\text { Enteletes sp. } \\
\text { Schwagerina sp., advanced form. } \\
\text { Parafusulina sp., primitive form. }\end{array}$ & $\begin{array}{l}\text { Fusulinids indicate Permian (latest Wolf- } \\
\text { camp or Leonard) age (R. C. Douglass, } \\
\text { written commun., 1953). }\end{array}$ \\
\hline $\begin{array}{l}\text { Sec. } 18, T .41 \text { N., R. } \\
1 \text { W. }\end{array}$ & 34 & $\begin{array}{l}\text { Fenestella sp. } \\
\text { Meekopora? sp. } \\
\text { Parafusulina sp. } \\
\text { Dictyoclostus sp. } \\
\text { Crinoidal material. }\end{array}$ & $\begin{array}{l}\text { Crinoidal material and bryozoan frag- } \\
\text { ments in some pebbles look like forms } \\
\text { in Kaibab Limestone of Permian (Leo- } \\
\text { nard) age (Helen Duncan, written } \\
\text { commun., 1953). } \\
\text { Parafusulina sp. indicates probable Per- } \\
\text { mian (Leonard) age (R. C. Douglass, } \\
\text { written commun., 1953). }\end{array}$ \\
\hline $\begin{array}{l}\text { Sec. } 3(?), \text { T. } 39 \text { N., } \\
\text { R. } 5 \text { W. }\end{array}$ & 36 & $\begin{array}{l}\text { ?Hustedia sp. } \\
\text { ?Phricodothyris sp. } \\
\text { Parafusulina sp., advanced form. }\end{array}$ & $\begin{array}{l}\text { Parafusulina sp. indicates a Permian } \\
\text { (Leonard or possibly as high as Gua- } \\
\text { dalupe) age (R. C. Douglass, written } \\
\text { commun., 1953). }\end{array}$ \\
\hline $\begin{array}{l}\text { Sec. } 20, \text { T. } 37 \text { S., R. } \\
11 \text { W. }\end{array}$ & $\underset{44}{\text { Near }}$ & $\begin{array}{l}\text { Poorly preserved fragments of pelecy- } \\
\text { pods, including indeterminate species } \\
\text { of either Schizodus or Myophoria. }\end{array}$ & \\
\hline \multicolumn{4}{|c|}{$\begin{array}{l}\text { Sunset Mountain, Ariz. } \\
\end{array}$} \\
\hline $\begin{array}{l}\text { Sec. } 24, \text { T. } 17 \text { N., R. } \\
13 \text { E. }\end{array}$ & & $\begin{array}{l}\text { Spandelina sp. } \\
\text { Geinitzina sp. } \\
\text { Parafusulina sp. aff. } P \text {. bakeri and } P . \\
\text { sellardsi Dunbar and Skinner. } \\
\text { Endothyra sp. } \\
\text { Globivalvulina or Endothyra sp. } \\
\end{array}$ & $\begin{array}{l}\text { Permian (Leonard or Guadalupe) age. } \\
\text { Kaibab Limestone or younger rocks } \\
\text { would appear to be source (L. G. Hen- } \\
\text { best, written commun., 1955). }\end{array}$ \\
\hline \multicolumn{4}{|c|}{ Cameron, Ariz. } \\
\hline $\begin{array}{l}\text { Near Cameron (data } \\
\text { from McKee, 1936, } \\
\text { p. 261). }\end{array}$ & $\begin{array}{l}\text { Near } \\
29\end{array}$ & $\begin{array}{l}\text { Productus (Dictyoclostus) occidentalis } \\
\text { Newberry. } \\
\text { Crinoids, sections and stems. }\end{array}$ & $\begin{array}{l}\text { McKee (1938, p. 262) stated that these } \\
\text { fossils are typical of marine facies of } \\
\text { upper limestone member of Kaibab } \\
\text { Limestone (Permian). This facies is } \\
\text { restricted to an area west of a north- } \\
\text { south line passing near Flagstaff, Ariz. }\end{array}$ \\
\hline
\end{tabular}

spicules, ostracodes, echinoid spines, corals, and crinoidal material (table 8). The fusulinids include Parafusulina sp., of Permian (Leonard or Guadalupe) age. The brachiopods include Dictyoclostus, most likely of Pennsylvanian or Permian age. The bryozoans include Hemitrya, probably of Late Mississippian age, and Rhabdomeson, of Carboniferous or Permian age. The algae include Mizzia sp., which is restricted to the Permian, and Gymnocodium sp. Most of the fossils indicate rocks of Permian age, 


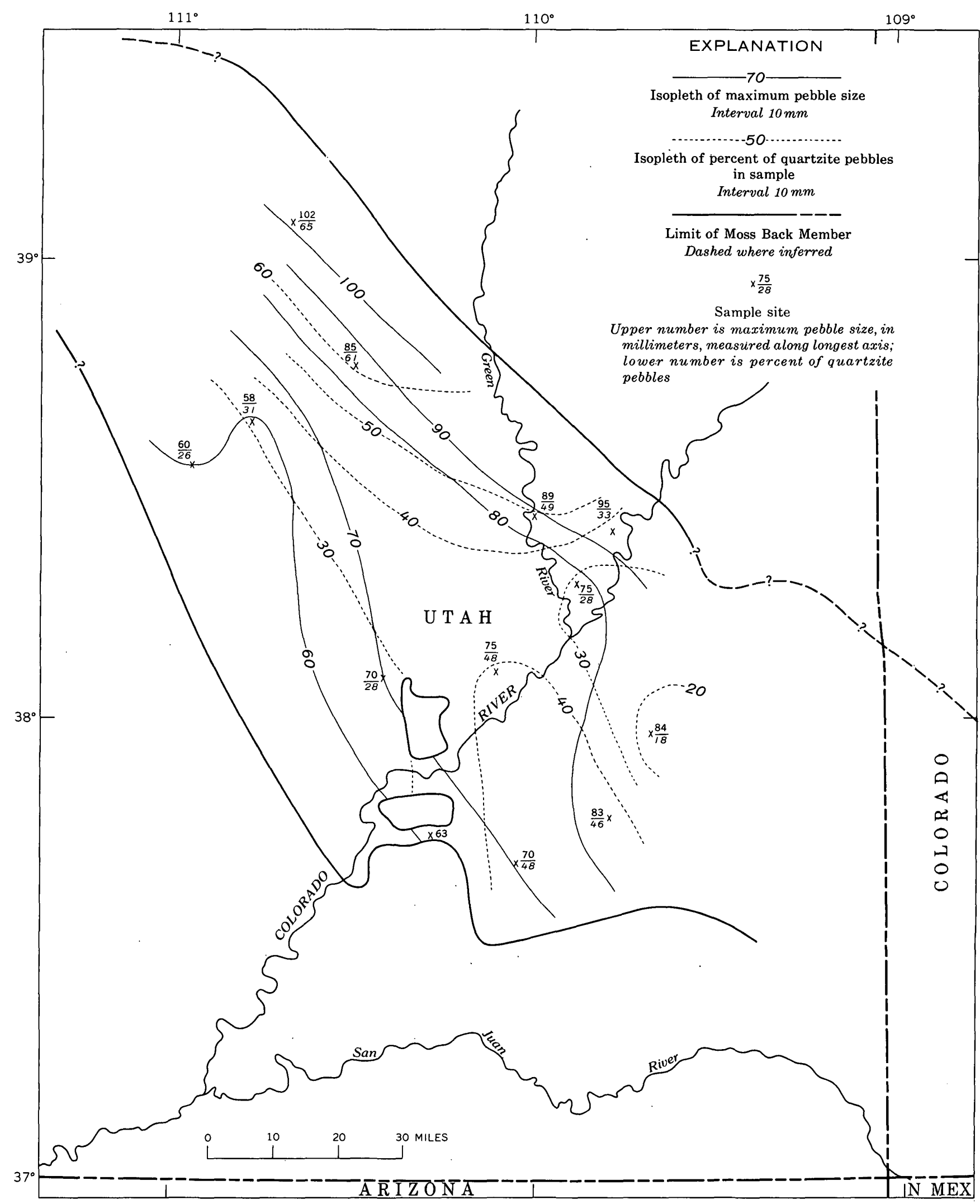

Figure 29. - Isopleth map of maximum sizes of pebbles and cobbles (quartz, quartzite, and chert) and percentage of quartzite pebbles and cobbles in the Moss Back Member of the Chinle Formation. 
TABLE 8. - Fossils from chert pebbles in Moss Back Member of Chinle Formation

\begin{tabular}{|c|c|c|c|}
\hline $\begin{array}{c}\text { Sample } \\
\text { site } \\
\text { location }\end{array}$ & $\begin{array}{l}\text { Sample site No. } \\
\text { (fig. 26) }\end{array}$ & $\begin{array}{l}\text { Fossils in chert pebbles } \\
\text { (Some localities include identifications } \\
\text { from more than one pebble) }\end{array}$ & $\begin{array}{c}\text { Age of chert } \\
\text { (based on fossils) }\end{array}$ \\
\hline \multicolumn{4}{|c|}{ San Rafael Swell, Utah } \\
\hline $\begin{array}{l}\text { Sec. 10, T. } 20 \text { S., R. } \\
11 \text { E. }\end{array}$ & 66 & $\begin{array}{l}\text { Mizzia sp. } \\
\text { Gymnocodium sp. }\end{array}$ & $\begin{array}{l}\text { Mizzia is known only from Permian Pe- } \\
\text { riod (Richard Rezak, written commun., } \\
\text { 1954). }\end{array}$ \\
\hline $\begin{array}{l}\text { NE1/4 sec. } 6, \text { T. } 21 \\
\text { S., R. } 11 \text { E. }\end{array}$ & Near 66 & $\begin{array}{l}\text { Productus (Dictyoclostus) sp. (group of } \\
\text { P. ivesi Newberry). }\end{array}$ & $\begin{array}{l}\text { Fossil is characteristic of Kaibab Lime- } \\
\text { stone of Permian age (Mackenzie Gor- } \\
\text { don, Jr., written commun., 1952). }\end{array}$ \\
\hline $\begin{array}{l}\text { Sec. } 18 \text { (unsurveyed) } \\
\text { T. } 25 \text { S., R. } 11 \mathrm{E} .\end{array}$ & Near 68 & $\begin{array}{l}\text { Hemitrypa sp. } \\
\text { Tabulipora? sp. } \\
\text { Penniretepora? sp. } \\
\text { Reteporida? sp. } \\
\text { Rhomboporid bryozoans. }\end{array}$ & $\begin{array}{l}\text { This assemblage suggests Upper Missis- } \\
\text { sippian rocks (Helen Duncan, written } \\
\text { commun., 1953). }\end{array}$ \\
\hline
\end{tabular}

Sec. $19(?)$, T. 23 S., R. $10 \mathrm{E}$.

Sec. 23, T. 24 S., R. $8 \mathrm{E}$.
Bastromellid bryozoan.

Parafusulina sp.

Fusulinid is believed to be Permian (late Leonard or Guadalupe) in age (L. G. Henbest, written commun., 1954).

Near junction of Green and Colorado Rivers, Utah

\begin{tabular}{|c|c|c|c|}
\hline $\begin{array}{l}\text { Lat } 38^{\circ} 26^{\prime} 20^{\prime \prime} \mathrm{N} . \\
\text { long } 109^{\circ} 50^{\prime} 00^{\prime \prime} \mathrm{W} \text {. }\end{array}$ & 74 & $\begin{array}{l}\text { Endothyra. } \\
\text { Spandelina (?). } \\
\text { Brachiopod fragments. } \\
\text { Ostracode fragments. }\end{array}$ & $\begin{array}{l}\text { Probably Permian (L. G. Henbest, writ- } \\
\text { ten commun., 1955). }\end{array}$ \\
\hline
\end{tabular}
ments. Elk Ridge-White Canyon, Utah

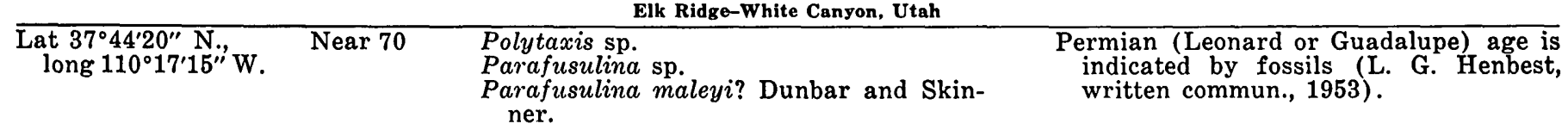

Lat $38^{\circ} 08^{\prime} 00^{\prime \prime} \mathrm{N} .$,
long $110^{\circ} 11^{\prime} 30^{\prime \prime} \mathrm{W} . \quad$ Near $71 \quad$ Pugnoides pingus (Girty) ?

Lat $38^{\circ} 17^{\prime} 30^{\prime \prime} \mathrm{N} ., \quad 72 \quad$ Polypora sp.

long $109^{\circ} 52^{\prime} 30^{\prime \prime} \mathrm{W}$. Stenoporid bryozoan.

Several indeterminate brachiopods.

Algae:

Gymnocodium sp.

Mizzia sp.

Solenopora? sp.

Sec. 16, T. 28 S., R. Near 73 $20 \mathrm{E}$.

Parafusulina sp. aff. $P$. bakeri and $P$. sellardsi Dunbar and Skinner.

Marginiferoid brachiopod.

Crinoid columnals and possible ostracode.

Sec. 21, T. 36 S., R. $75 \quad$ Rhabdomeson sp.

$17 \mathrm{E}$.

Sec. 1 (unsurveyed),

76 Coral.

T. 35 S., R. 19 E. $\quad$ Bryozoan.

?Sponge spicules.

Echinoid spines.

Sec. 36 (unsurveyed)

$77 \quad$ Bradyina sp.

?Monaxon sponge spicules.
This species is fairly common in Kaibab Limestone of Permian age (Mackenzie Gordon, Jr., written commun., 1955).

Bryozoans are very much like types found in Kaibab Limestone of Permian age (Helen Duncan, written commun., 1954).

Mizzia is known only from Permian Period (Richard Rezak, written commun., 1954).

Fusulinid is Permian (Leonard or Guadalupe) in age (L. G. Henbest, written commun., 1955).

Brachiopod is a new genus restricted to Permian (G. A. Cooper, written commun., 1955).

This bryozoan is common in Pennsylvanian and Permian rocks of western United States (Helen Duncan, written commun., 1954).

Coral and bryozoan are Carboniferous to Permian in age (Helen Duncan, written commun., 1955).

Bradyina sp. is Late Mississippian to Permian in age (L. G. Henbest, written commun., 1955). 
probably the Kaibab Limestone or equivalent strata. Some may indicate rocks of Mississippian or Pennsylvanian age.

POLEO SANDSTONE LENTIL OF CHINLE FORMATION

Four samples (table 6) were collected from the Poleo Sandstone Lentil in north-central New Mexico. The pebbles in some samples are predominantly quartz, whereas in others they are predominantly chert. Quartzite pebbles constitute a small part of all the samples. The proportion of quartz pebbles decreases gradually from 92 percent in the southwestern part of the area of distribution of the lentil to 30 percent in the northeastern part. The percentage of chert, on the other hand, gradually increases in the same direction from 4 to 68 percent.

Maximum pebble sizes increase from $21 \mathrm{~mm}$ in the southwestern part of the area of distribution to 168 $\mathrm{mm}$ in the northeastern part.

\section{SONSELA SANDSTONE BED OF PETRIFIED FOREST} MEMBER OF CHINLE FORMATION

Fifteen samples (table 6) were collected from the Sonsela Sandstone Bed of the Petrified Forest Member of the Chinle Formation in east-central Arizona and west-central New Mexico, and two samples (sites 83 and 84) were collected from a unit in the Puertocito-Riley area of New Mexico that is tentatively correlated with the Sonsela Sandstone Bed.

The pebbles in the Sonsela Sandstone Bed, including tentatively correlative strata, are predominantly chert (table 6). The ratio of quartz, quartzite, and chert pebbles is 1:8:91 in the St. Johns-Petrified Forest National Park-Ojo Caliente area (samples at sites 92-94), 2:6:92 in the southern Defiance uplift (samples at sites 95-99), and 7:17:76 in the Zuni uplift area (samples at sites 85-90).

The maximum pebble sizes in the Sonsela Sandstone Bed range from $152 \mathrm{~mm}$ to $33 \mathrm{~mm}$ (fig. 30). They generally decrease to the north within the depositional area of the member.

Some of the chert pebbles in the Sonsela Sandstone Bed contain fossils, including fusulinids, brachiopods, bryozoans, and pelecypods. These fossils have not been identified but are probably similar to those occurring in the Shinarump Member of the Chinle Formation.

Volcanic pebbles occur in the Sonsela Sandstone Bed in east-central Arizona, but they generally constitute less than 4 percent of the total number of pebbles. The largest pebbles of volcanic material noted were about $50 \mathrm{~mm}$ in maximum diameter. The pebbles contain phenocrysts of plagioclase, quartz, and rarely biotite (Schultz, 1963, p. C37, and written commun., 1958). Many of the feldspars are altered to kaolinite. The plagioclase was not fresh enough to be optically identified except in a few pebbles, where it was found to be oligoclase (L. G. Schultz, written commun., 1958). The aphanitic groundmass generally consists mainly of quartz and kaolinite; in a few pebbles it contains illite, chlorite, plagioclase, and possibly montmorillonite. It commonly contains relicts of glass shards and tuff particles. Many of the pebbles may originally have been vitric and crystal tuffs; some were probably vitrophyres. The phenocrysts of oligoclase and quartz and the lack or rarity of orthoclase or sanidine suggest that the pebbles in the Sonsela Sandstone Bed are of an intermediate composition, perhaps quartz latite or dacite (Schultz, 1963, p. C37).

PETRIFIED FOREST MEMBER OF CHINLE FORMATION EXCLUSIVE OF SONSELA SANDSTONE BED

Ten samples (table 6) were collected from various conglomeratic sandstone units in the Petrified Forest Member, exclusive of the Sonsela Sandstone Bed, in east-central Arizona, southwestern Utah, and southern Nevada. The samples are from unnamed units mostly within the lower and middle parts of the member.

The pebbles in these samples are mostly chert and quartzite; relatively few are of quartz. Finely crystalline volcanic rocks constitute 20 percent of sample 101 (east-central Arizona), 6 percent of sample 102 (east-central Arizona), 66 percent of sample 104A (southern Nevada), and 2 percent of sample 107 (southwestern Utah). A few volcanic pebbles were also seen near sample sites 105,106 , and 108, although there are none in the collections made at those sites.

The maximum size of pebbles in these units ranges from $38 \mathrm{~mm}$ for a chert pebble at sample site 108 to $152 \mathrm{~mm}$ for a quartzite cobble at site 102 .

Fossils found in chert pebbles from these units consist of fusulinids, brachiopods, bryozons, pelecypods, corals, crinoidal material, and a sponge (table 9 ). These fossils indicate that the chert was derived from Permian rocks, possibly from the Kaibab Limestone or equivalent strata (McKee, 1936; table $9)$. 


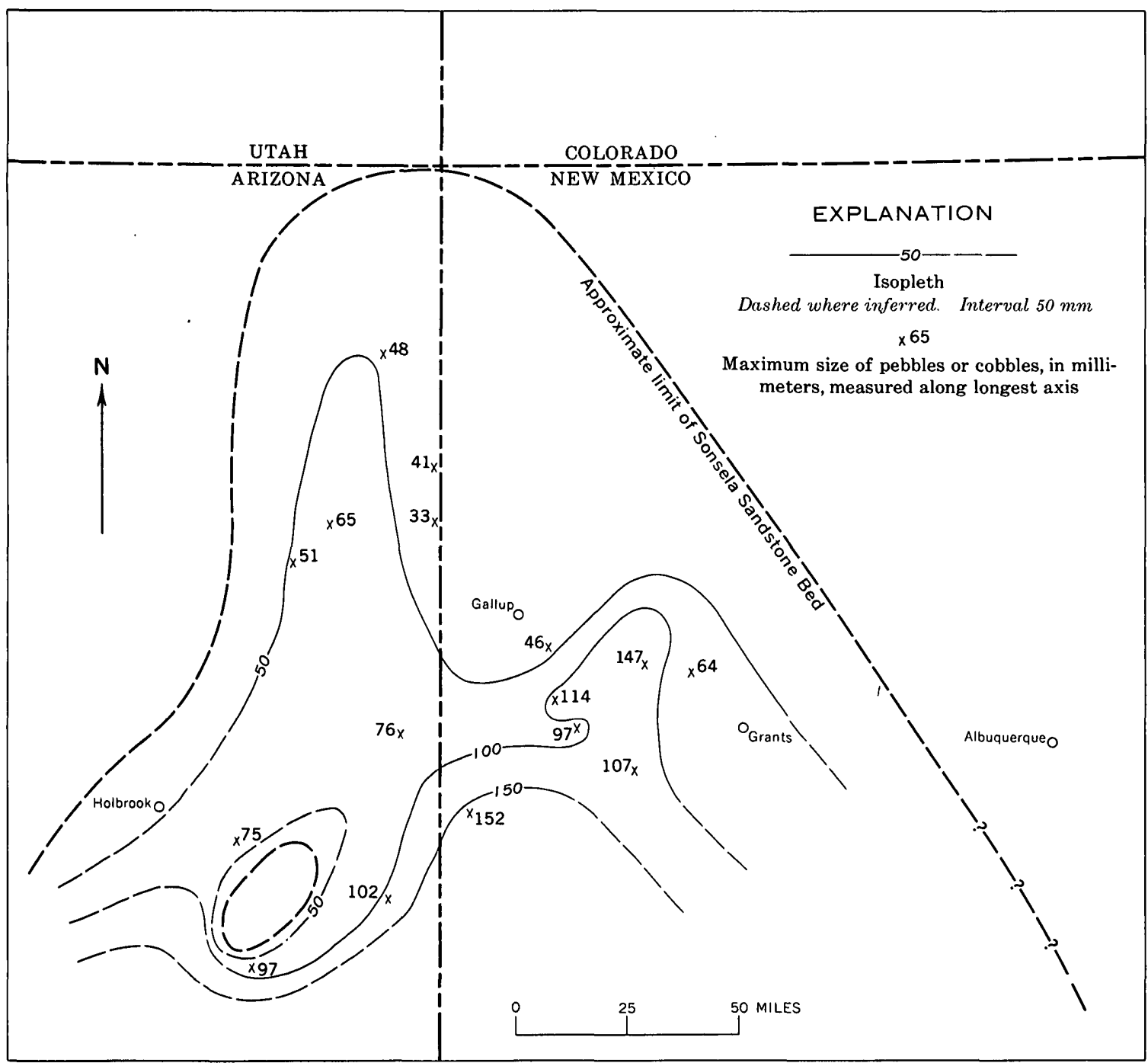

Figure 30. - Isopleth map of maximum sizes of pebbles to cobbles (quartz, quartzite, and chert) from the Sonsela Sandstone Bed in the Petrified Forest Member of the Chinle Formation.

The volcanic pebbles in the Petrified Forest Member have not been studied in as much detail as those in the Shinarump Member and the Sonsela Sandstone Bed, but they probably include tuffs, vitrophyres, and felsites. Thin-section study indicates that pebbles collected at site 101 are composed of phenocrysts of quartz and altered feldspar set in a fine groundmass. Spectrographic analyses indicate that these same pebbles are high in sodium and low in potassium, calcium, iron, and magnesium (E. M. Shoemaker, written commun., 1956). The spectro- graphic analyses further indicate that the volcanic rocks are chemically similar to quartz keratophyres.

\section{BASAL UNIT AND LOWER MEMBER OF DOLORES} FORMATION

Two samples (table 6) were collected from the basal unit of the Dolores Formation in the northern part of the San Juan Mountains area, and three were collected from the lower member of the Dolores Formation in the southern part of that area.

One of the samples from the basal unit (site 109, in the Ouray area) is composed predominantly of quartzite and quartz but contains a variety of other 
TABLE 9.-Fossils from chert pebbles in Petrified Forest Member of Chinle Formation, exclusive of the Sonsela Sandstone Bed

\begin{tabular}{|c|c|c|}
\hline Locality & $\begin{array}{c}\text { Fossils in chert pebbles } \\
\text { (some localities include } \\
\text { identifications from more } \\
\text { than one pebble) }\end{array}$ & $\begin{array}{c}\text { Age of chert } \\
\text { (based on fossils) }\end{array}$ \\
\hline $\begin{array}{l}\text { Petrified Forest National Park, } \\
\text { Ariz.; lat } 34^{\circ} 50^{\prime} \text { N., long } 109^{\circ} \\
50^{\prime} \text { W. }\end{array}$ & $\begin{array}{l}\text { Schwagerina sp. } \\
\text { Protoretepora sp. } \\
\text { Rhabdomeson sp. } \\
\text { Possible Clausotrypa sp. } \\
\text { Fenestella sp. or Cervella sp. }\end{array}$ & $\begin{array}{l}\text { Schwagerina sp. is a form that has a } \\
\text { maximum range of middle:Wolfcamp } \\
\text { through Leonard (Permian) (R. C. } \\
\text { Douglass, written commun., 1954). } \\
\text { As the bryozoans Protoretepora, } \\
\text { Rhabdomeson, and Clausotrypa are } \\
\text { fairly common in the Kaibab Lime- } \\
\text { stone, these were very likely derived } \\
\text { from the Kaibab Limestone (Per- } \\
\text { mian) (Helen Duncan, written com- } \\
\text { mun., 1954). }\end{array}$ \\
\hline $\begin{array}{l}\text { Petrified Forest National Park, } \\
\text { Ariz.; data from McKee (1936, } \\
\text { p. 261). }\end{array}$ & $\begin{array}{l}\text { Lophophyllum sp. } \\
\text { Productus (Dictyoclostus) occidentalis } \\
\text { Newberry, } \\
\text { Productus (Dictyoclostus) ivesi New- } \\
\text { berry. } \\
\text { Crinoid columnals. } \\
\text { Aviculopecten occidentalis Newberry. } \\
\text { Spiriferina hilli Girty. } \\
\text { Sponge. } \\
\text { Bryozoans, mostly of Fenestella group. }\end{array}$ & $\begin{array}{l}\text { McKee (1936) stated that these fos- } \\
\text { sils are typical of the marine facies } \\
\text { of the upper limestone of the Kai- } \\
\text { bab Limestone of Permian age. This } \\
\text { facies is restricted to an area west } \\
\text { of a north-south line passing near } \\
\text { Flagstaff, Ariz. }\end{array}$ \\
\hline $\begin{array}{l}\text { Near Paria, Utah; sec. } 13 \text {, T. } 41 \\
\text { S., R. } 2 \text { W. }\end{array}$ & $\begin{array}{l}\text { Parafusulina sp. aff. } P \text {. bakeri and } P \text {. } \\
\text { sellardsi Dunbar and Skinner. } \\
\text { Indeterminate Pleurophorus-like pelec- } \\
\text { ypod. }\end{array}$ & $\begin{array}{l}\text { Fusulinid is Permian (Leonard or } \\
\text { Guadalupe) (L. G. Henbest, written } \\
\text { commun., 1955). }\end{array}$ \\
\hline
\end{tabular}

lithologic types, including chert ( 2 percent), granitic rock (6 percent), orthoclase $(4$ percent), and felsite (?) (4 percent). The other sample from the basal unit (site 110, near Placerville) consists mostly of quartz and quartzite; chert constitutes a small part of the sample, but other lithologic types are absent.

The maximum pebble size in the Ouray area is $178 \mathrm{~mm}$, for both a granitic rock and a felsite(?). In the Placerville area, the maximum pebble size noted was $127 \mathrm{~mm}$, for a quartzite.

The lower member of the Dolores Formation, which may be correlative in part with the Moss Back Member, consists predominantly of quartz pebbles, but in some areas it contains pebbles of quartzite, chert, granitic rock, granitoid gneiss, orthoclase, and mafic igneous (?) rock. The maximum sizes of pebbles in this member are small, ranging from 4 to $32 \mathrm{~mm}$.

\section{SEDIMENTARY-STRUCTURE STUDIES}

Studies of sedimentary structures in the Chinle Formation consisted of determinations of resultant dip directions of cross-strata at about 200 localities, and determinations of the orientation of fossil logs at a few localities. The information thus obtained is useful in outlining the general directions of stream flow and in indicating possible source areas. The results of these studies have been given in reports by Poole and Williams (1956), by Stewart, Williams, Albee, and Raup (1959), and by Poole $(1961,1962)$, and only a brief summary of part of the data is presented here.
In the field, the amount and direction of dip of cross-strata are measured in a number of individual sets in the unit being studied. The number of measurements that are necessary for adequate sampling at a given locality depends on the diversity in dip directions of the cross-strata, but in general 50 to 150 individual measurements are sufficient. If each dip direction reading is considered a vector, a resultant of the readings can be obtained by mathematical or graphical methods. This resultant is the average down-current direction, from which a transportation direction and a source direction can be inferred. The spread of the readings in a study is measured in terms of a consistency ratio (Reiche, 1938 ), expressed numerically from 0.00 to 1.00 . In a study in which all the readings are in the same direction, the consistency ratio would be 1.00 , whereas in a study in which the readings are equally distributed through $360^{\circ}$, the consistency ratio would be zero.

The resultant dip directions of cross-strata at the localities studied in the Shinarump Member, the Agua Zarca Sandstone Member, the sandstone member in north-central New Mexico, and the Gartra Member are shown on plate 4 . The resultant dip directions in the Shinarump Member are predominantly northwest, and to a lesser extent north and northeast; a few are east (St. Johns area) and a few are west (White Canyon and Spring Mountains areas). In the Agua Zarca Sandstone Member they are south to southwest, and in the sandstone member at two localities in north-central New Mexico they 
are northerly. At a locality in the area of possible intertonguing of the sandstone member and the Agua Zarca Sandstone Member, the resultant dip direction is westerly. In the Gartra Member, the resultants are predominantly west to northwest, although at one locality the resultant is southwest and in another south.

The resultant dip directions of cross-strata in the Shinarump Member are similar to the trends of channels at the base of that member, which are predominantly to the northwest, except in the White Canyon and Elk Ridge areas, where they are west or west-southwest (as determined by the work of Witkind (1956), Phoenix (1957), Davidson, Carswell, and Miller (1957), Finch (1959), Johnson (1959), Lewis and Trimble (1959), and Witkind, Hemphill, Fillmore, and Morris (1960).

The resultant dip directions in the Moss Back Member of the Chinle Formation, and in its possible equivalents, the Poleo Sandstone Lentil of the Chinle Formation and the lower member of the Dolores Formation, are shown in figure 13. In the Moss Back Member they vary, but are dominantly northwestward (Poole and Williams, 1956). In the Poleo Sandstone Lentil they are mostly north to northwest. In the lower member of the Dolores Formation they are variably to the west, southwest, and north.

The resultant dip directions in the Sonsela Sandstone Bed of the Petrified Forest Member are shown in figure 20 and are mostly north to northeast.

\section{PALEONTOLOGY AND AGE}

The Chinle Formation contains a varied continental flora and fauna including pelecypods, gastropods, arthropods, fish, amphibians, reptiles, and plants. A summary is presented here of the fossils and their age; also included is detailed information on fossils collected by the authors and identified largely by paleontologists of the U.S. Geological Survey.

\section{PELECYPODS}

Fresh-water pelecypods are relatively abundant in the Chinle Formation, particularly in the Petrified Forest Member, which locally contains beds that consist almost entirely of pelecypod shells or shell fragments. Pelecypods have been reported in the Chinle over a large part of its area of distribution. The pelecypods thus far identified in the Chinle all belong to the family Unionidae, and most of them appear to represent various species of the genus Unio; but many of the pelecypods found in the Chinle are too fragmentary or poorly preserved to be identified with certainty.

The occurrence of pelecypods in the Chinle Formation was first reported by Cope $(1875$, p. 81$)$, who found Unio shells associated with reptile bones and teeth in what is probably the Petrified Forest Member north of Gallina, N. Mex. These forms were described and identified by F. B. Meek (in Cope, 1875 , p. 83-84), who recognized three new species of Unio. One species, the dominant one in the assemblage, was fully described and was named Unio cristonensis Meek. The other two species, based on fragmentary remains and described in very little detail, were named $U$. gallinensis and $U$. terraerubrae. Neither of these has since been reported in the Chinle, but both were described so incompletely that they could hardly be recognized with certainty if they were found. Unio cristonensis, on the other hand, has been reported from the Zion National Park region (Gregory, 1950, p. 72), from near the top of the Chinle at the northeastern end of Monument Valley, Utah (Woodruff, 1912, p. 89), from the Petrified Forest and Owl Rock Members of northeastern Arizona (Gregory, 1917, p. 47), and from near Fort Defiance, Ariz. (Allen and Balk, 1954, p. 70). Forms nearly or possibly identical with $U$. cristonensis Meek have also been reported from what is probably the Owl Rock Member 6 miles west of Moenkopi Village in Arizona (Gregory, 1917, p. 68 ), and in the Chinle near Moab, Utah (Cross, 1907, p. 654).

At the Moab locality, according to Cross, the Chinle contains forms comparable to, and possibly identical with, $U$. dockumensis Simpson and $U$. dumblei Simpson, both of which had previously been reported from the Dockum Group of Texas.

Two new species of Unio were described by Henderson (1934, p. 259-260) from the Chinle of Apache County, Ariz. These species were named $U$. thomasi, a form closely related to $U$. cristonensis Meek, and $U$. arizonensis. According to Henderson, $U$. arizonensis may also be present in a collection from the Chinle near Fort Wingate, N. Mex.

Specifically indeterminate Unios also have been reported from the Dolores Formation near Telluride, Colo. (Cross, 1899), from the Chinle in the Salt Valley area, Utah (Dane, 1935, p. 63), and from the Chinle in the Moab area, Utah (Baker, 1933, p. 40).

A new form of unionid pelecypod, named Diplodon gregoryi by Reeside (1927, p. 477), has been found in the basal part of the Chinle Formation in the Navajo Indian Reservation in Arizona.

During the course of the present investigation, several new Unio localities were found by the authors and other workers on the Colorado Plateau. J. B. Reeside, Jr., examined some of the fossils collected at these localities, and his comments on them are quoted on the following page. 
Lot 23584. Collection obtained by I. J. Witkind from a limestone bed in Owl Rock Member of Chinle Formation on the east side of Tyende Mesa about 5 miles north of Kayenta, Ariz., lat $36^{\circ} 48^{\prime} 38^{\prime \prime}$ N., long $110^{\circ} 15^{\prime} 45^{\prime \prime} \mathrm{W}$.

Unio n. sp.

"Only one species appears to be present, and it does not match any of the dozen or so of described Upper Triassic species."

Lot 24345. Collection obtained by the authors in the Owl Rock Member of the Chinle Formation 10 feet below the base of the Wingate Sandstone in Burr Canyon, on the east side of Circle Cliffs, Garfield County, Utah (sec. 16 (unsurveyed), T. 34 S., R. 8 E.).

Unio sp.

"I cannot get enough of these specimens uncovered to show more than that they belong to the fresh-water group commonly called Unio. It is believed that the Triassic forms are more closely related to South American genera than to the North American Jurassic and later genera, which are thought to be immigrants from Asia."

Unio dumblei Simpson

Lot 24780. Collection obtained from the Chinle Formation in White Canyon, San Juan County, Utah, by J. D. Lowell. Lot 25589. Collection obtained by the writers 344 feet above the base of the Petrified Forest Member northeast of Joseph City, Ariz. (loc. A-25).

"These fossils include 16 right valves and one left valve of a species of Unio close to Unio dockumensis Simpson of the Dockum Group of Texas."

Lot 26314. Collection obtained by J. D. Wells in a reddish sandstone about 50 feet below the top of the Chinle Formation at the southern end of House Rock Valley, Coconino County, Ariz. (sec. 30 ?, T. 39 N., R. 4 E.).

Single valve of "Unio" graciliratus Simpson

"The shell has not been found above the Triassic and can be taken to indicate Upper Triassic, but its range is not well known."

Lot 26347. Collection obtained by D. A. Phoenix in a limy sandstone in the Petrified Forest Member 150 feet below the top of the Chinle Formation near Lees Ferry, Ariz. (sec. 25, T. 40 N., R. 7 E.).

Unio graciliratus Simpson

Unio aff. U. dumblei Simpson, probably unnamed "These species were named from the Dockum of Texas, but not enough occurrences have been reported to define ranges within the Upper Triassic. Fresh-water faunas are usually characterized by abundance of individual specimens but paucity of species, and this collection is of that sort. The unios in the Holocene fauna are said to prefer a river environment."

Lot 26617. Collection obtained by R. W. Kopf from the Monitor Butte Member of the Chinle Formation, 110 feet above the Shinarump Member and 50 feet below the Moss Back Member, at the northwestern corner of the abandoned dam at the head of Fry Canyon, lat $37^{\circ} 33^{\prime} 42^{\prime \prime}$ N., long $110^{\circ} 8^{\prime} 24^{\prime \prime}$ W., San Juan County, Utah.

"These specimens represent one species of unionid pelecypod, preserved as internal molds. The form is like that of Unio graciliratus Simpson, which has been reported from the Chinle of the region, or like Unio dockumensis Simpson. These species are determined by external characters of the shell, not shown by the internal mold."

Another collection of pelecypods, obtained by the authors 407 feet above the base of the Petrified Forest Member (36.6 ft. above base of unit 3, Nazlini Trading Post section B, loc. A-8b) near Nazlini, Apache County, Ariz., has been identified by N. J. Silberling as Unio (Antediplodon) cf. U. (A.) dockumensis.

\section{GASTROPODS}

Fresh-water gastropods have been reported from a few localities in the Chinle Formation and equivalent strata, but they are relatively scarce. They were first reported by Cross (1899), who noted the occurrence of a small gastropod belonging to the genus Viviparus or a closely allied genus in a conglomerate at what is probably the base of the Dolores Formation near Telluride, Colo. Viviparus? was also reported by Woodruff $(1912$, p. 89$)$ from beds near the top of the Chinle, probably the Owl Rock Member, in the northeastern part of Monument Valley.

The occurrence of gastropods in the Chinle was next reported by Baker (1946, p. 63), who collected specimens in what is probably the Owl Rock Member at The Cove, in southeastern Utah. Baker's specimens were described by Yen and Reeside (1946), who assigned them to two species of a new genus of the family Amnicolidae and named them Triasamnicola pilsbryi and T. latispira.

Yen (1951) reported two occurrences of gastropods in the Chinle Formation of northern Arizona. One collection, from the Owl Rock Member along the Echo Cliffs, consisted of Triasamnicola cf. T. pilsbryi Yen and Reeside, Triasamnicola assiminoides n. sp., Triasamnicola sp. indet., and Lioplacodes canaliculatus $\mathrm{n}$. sp. The other collection, from what is probably the Owl Rock Member near Black Falls, consisted of a form identified by Yen as "Valvata" gregorii Robinson. $V$. gregorii had previously been reported by Robinson (1915) from beds now referred to the lower part of the Glen Canyon Group near Cameron, Ariz. Valvata gregorii has also been reported by Harshbarger, Repenning, and Irwin (1957, p. 28) from the Owl Rock Member near Cedar Ridge, Ariz. Apparently the generic assignment of "Valvata" gregorii is questionable. (See Harshbarger and others, 1957, footnote on page 28.)

The presence of gastropods in the Owl Rock Member of the Chinle Formation at two additional localities, near Kayenta and near Round Rock in Arizona, has been noted by R. A. Repenning, M. E. Cooley, and J. P. Akers (written commun., 1956).

Three new gastropod localities in the Chinle Formation, as yet unreported in the literature, have been discovered in recent years. At the first of these, molluscs were collected by Otis McRae of the Atomic Energy Commission about 10.5 airline miles N. 52 
W. of Moab, Utah, from two sandstone and conglomerate horizons 118 feet and 97 feet above the base of the Chinle Formation, probably near the contact between the Church Rock Member and the underlying siltstone unit of the Chinle. Concerning these collections (lot 24954), J. B. Reeside, Jr., stated in an unpublished report: "The only shell in this sample that can actually be identified is a specimen of 'Valvata' gregorii Robinson."

Another gastropod collection (lot 24347), obtained by $\mathrm{T}$. E. Mullens from a bed of clayey limestone in the Owl Rock Member 442 feet above the base of the Chinle at Red House (loc. U-224) in the Clay Hills area of southeastern Utah, and identified by J. B. Reeside, Jr., consists of Triasamnicola assiminoides Yen.

The third gastropod locality was discovered by G. W. Weir in the lower part of the Chinle Formation, possibly the Moss Back Member, on a bench near the top of the lower Chinle unit that forms a cliff and bench above Big Indian Wash (NW1/4.SW1/4 sec. 35, T. 291/2 S., R. 24 E.), San Juan County, Utah. Concerning this collection (lot 26857), J. B. Reeside, Jr., stated, in an unpublished report:

This lot contains an abundance of small gastropods that seem to me to be the form called Triasamnicola latispira by Yen and Reeside. There are also fragments of a large pelecypod that I would call Unio sp., though diagnostic characters are not preserved, and coprolites of fish and reptile.

\section{ARTHROPODS}

Remains of arthropods, both crustaceans and insects, have been found at a few localities in the Chinle Formation.

Crustaceans are represented in the Chinle Formation by fresh-water branchiopods and ostracodes. Ostracodes were noted in a collection made by the writers 7.5 feet above the base of the Chinle Formation one-fourth mile east of the Happy Jack mine in White Canyon, San Juan County, Utah, and identified by R. E. Peck. Fresh-water branchiopods, identified by J. B. Reeside, Jr., have been found in two drill cores obtained by Neil Young, of the Atomic Energy Commission. One of these was 145 feet above the base of the Chinle Formation, in drill hole R-3 in the Lisbon Valley area, San Juan County, Utah (lot 25242 ) ; the other was 50 feet above the base of the Chinle Formation, in drill hole 41-B, Amuranium Co., in Big Indian Wash, Utah (sec. 20, R. 24 E., T. 29 S.) (lot 25590). Branchiopods were also collected by the authors in a lenticular limestone near the top of the Petrified Forest Member in sec. 16, T. 10 N., R. 18 W., Black Rock area, McKinley County, N. Mex. (lot 26199). These collections all contain branchipods of similar types. Concerning the Black
Rock collection (lot 26199), Reeside stated in an unpublished report:

The most abundant fossils in this lot are the valves of a bivalved crustacean commonly called Estheria ovata Lea. The species was described originally from the Newark Group, and there may be some doubt as to the name of the western form. Also, the generic name is not available. Probably the best name for it at present is Cyzicus cf. C. ovatus (Lea).

These forms are now known as Lioestheria aff. $L$. ovata (Lea) (Lewis and others, 1961, p. 1439).

Insects are represented in the Chinle Formation by trails and burrows in petrified wood in the Petrified Forest National Park in Arizona. These are believed by Walker $(1938, p .138)$ to have been formed by larvae of wood borers or bark beetles. Walker named three new genera and five new species on the basis of these trails and burrows and noted (p. 140) that they were confined to a single species of wood, Araucarioxylon arizonicum. An object that appears to be a beetle has also been noted by Roland Brown in a plant collection obtained by him and the authors in the Shinarump Member of the Chinle on Elk Ridge in southeastern Utah (NW1/4 sec. 7, T. 25 S., R. 20 E.).

\section{FISH}

Chondrostean, holostean, crossopterygian, and dipnoan fishes from various parts of the Chinle Formation have been reported in the literature. A discussion of most of these fishes and descriptions of several new genera and species were given by Schaeffer (1967).

Five species of chondrostean fishes are known from the Chinle Formation. These occur in the uppermost part of the formation at two localities in the Lisbon Valley area in the easternmost part of southeastern Utah and also in the uppermost part of the formation at two localities near Paradox Valley in the westernmost part of southwestern Colorado (Schaeffer, 1967). The fishes from these localities are Turseodus dolorensis, Cionichthys dunklei, Lasalichthys hillsi, Synorichthys stewarti, and Tanaocrossus kalliokoskii. Cionichthys also has been tentatively identified (Schaeffer, 1967, p. 302) at a locality in the Dolores Formation 11/2 miles northwest of Telluride in the San Juan Mountains region in southwestern Colorado (Schaeffer, 1967). In addition, an indeterminate chondrostean fish occurs in the Petrified Forest Member of the Chinle Formation at Ghost Ranch in north-central New Mexico (Schaeffer, 1967, p. 327).

Two genera of holostean fishes, Semionotus and Hemicalypterus, are known in the Chinle Formation (Schaeffer, 1967). Semionotus sp. occurs at the two localities in the Lisbon Valley area and the two near Paradox Valley. In addition, scales of Semionotus or 
Lepidotus occur associated with the pseudosuchian reptile Hersperosuchus in the Petrified Forest Member near Cameron, Ariz. (Colbert, 1952, p. 591). It should be mentioned here that the occurrences of Semionotus and Lepidotus reported in the literature (Eastman, 1917, p. 283; Hesse, 1935; Schaeffer and Dunkle, 1950; Gregory and Moore, 1931, p. 58; and Gregory, 1950, p. 72) as having been found in the Chinle Formation at Kanab and at Zion National Park, Utah, are in strata now assigned to the overlying Moenave Formation.

A species of crossopterygian fish (Chinlea sorenseni) occurs in the uppermost part of the Chinle Formation at one of the localities in the Lisbon Valley area and at both of the localities near Paradox Valley (Schaeffer, 1967). In addition, this same species is questionably identified from the Petrified Forest Member at Ghost Ranch in northcentral New Mexico (Schaeffer, 1967).

The dipnoan lungfish Ceratodus occurs in the Chinle Formation in Arizona and New Mexico (Colbert, 1948, p. 232 ; Colbert, 1950, p. 64; Camp and Welles, 1956, p. 259; Colbert and Gregory, in Reeside and others, 1957, p. 1463).

Occurrences of fish not identified as to genus include fish scales associated with the remains of Typothorax north of Gallina, N. Mex. (Cope, 1875, p. 84) and ganoid fish scales and bones a few feet below the top of the Chinle Formation 2 miles south of Moab, Utah (Camp, 1930, p. 12-13; Baker, 1933, p. $40-41)$.

\section{AMPHIBIANS}

All amphibian remains thus far described from the Chinle Formation represent stereospondylid labyrinthodonts belonging to the family Metoposauridae. The metoposaurs from the Chinle Formation have been assigned in the literature to several different genera, but Colbert and Imbrie (1956), in their review of Triassic metoposaurs, assigned all the metoposaurs found in the Chinle Formation and the Dockum Group to a single species, Eupelor fraasi, but placed those of the Chinle Formation in a separate subspecies, Eupelor fraasi fraasi (Lucas). According to Colbert and Gregory (in Reeside and others, 1957, p. 1462 and 1464), Eupelor is among the most abundant fossils in the Petrified Forest Member of the Chinle in northern Arizona and is common in the Chinle of northern New Mexico. It has not been reported to occur above the Petrified Forest Member of the Chinle Formation.

Metoposaurs from the Chinle Formation that have been placed in synonomy with Eupelor fraasi fraasi by Colbert and Imbrie (1956, p. 418) include Metoposaurus fraasi, described by Lucas (1904, p. 193-
194) from the lower part of the Petrified Forest Member of the Chinle near Tanners Crossing near Cameron, Ariz.; Kalamoiketor pinkleyi, described by Branson and Mehl (1929, p. 225-227) from the Chinle about 8 miles west of Adamana, Ariz.; and Buettneria(?) major, described by Branson and Mehl $(1929$, p. 227) from the lower part of the Chinle about 2 miles north of Joseph City, Ariz. Another form probably in synonomy with Eupelor fraasi fraasi is one noted by $\mathrm{H}$. E. Gregory $(1917$, p. 35 and 97) as "closely allied to Metoposaurus fraasi" that occurs in beds probably near the base of the Chinle Formation about 5 miles north-northwest of Winslow, Ariz.

Generically indeterminate amphibian remains occur locally in the Chinle Formation. These include stegocephalian fragments at Mesa Poleo and Laguna, N. Mex. (Huene, 1926, p. 4), a large stegocephalian at Coyote, N. Mex. (Camp and others, 1947, p. 8), and amphibian remains in the Placerias quarry near St. Johns, Ariz. (Camp and Welles, 1956, p. 259).

During the course of the present investigation, unidentifiable amphibian remains were noted by $D$. H. Dunkle in material taken from the Chinle Formation at two localities in Utah. A specimen sent by J. D. Lowell from Fry Canyon, southeastern Utah, contains what "would appear to be the impression of bone located in the temporal region of the skull of a stereospondylous amphibian," according to Dunkle. Material obtained by H. F. Albee in the basal part of the Chinle Formation in the western part of sec. 13, T. 41 S., R. 2 W., at Paria, Utah, contains part of the skull roof of a stereospondylous amphibian.

The reptiles constitute the most abundant and widespread element of the vertebrate fauna in the Chinle Formation and equivalent strata. Reptiles that have been identified as to genera include thecodonts, saurischians, and theraspids. Thecodonts, represented chiefly by the phytosaurs, are those most abundant in the Chinle.

\section{ORDER THECODONTIA}

The thecodonts are represented in the Chinle by members of the suborders Pseudosuchia and Phytosauria.

\section{SUBORDER PSEUDOSUCHIA}

A bipedal ornithosuchid pseudosuchian has been found in the Chinle Formation at one locality. This is the new genus and species Hesperosuchus agilis. It was taken from the Petrified Forest Member, 160 feet above the base of the Chinle Formation, at the "Ward bone bed" locality, on the north side of the Little Colorado River about 6 miles southeast of 
Cameron, Ariz. According to Colbert (1952, p. 591), Hesperosuchus is the smallest of the known Chinle reptiles and is an upland form.

Pseudosuchian thecodonts belonging to the family Stagonolepidae have been found at various horizons in the Chinle Formation in New Mexico, Arizona, and Utah.

The first stagonolepid-in fact, the first vertebrate - known to have been found in the Chinle Formation was Typothorax coccinarum, described by Cope $(1875$, p. 84). It came from beds now referred to the Petrified Forest Member of the Chinle Formation, exposed in the Gallina area, N. Mex. Typothorax has since been found near Cameron, Ariz., in what is probably the "Ward bone bed" (Huene, 1926, p. 5), in the Chinle Formation at a horizon 113 feet below the base of the Wingate Sandstone 11/2 miles due south of Moab, Utah (Camp, 1930, p. 12), at Ghost Ranch in what is probably the Petrified Forest Member (Colbert, 1950, p. 59 and 62; J. T. Gregory, 1953a, p. 12), and from the Petrified Forest Member at the Placerias quarry near St. Johns, Ariz. (Camp and Welles, 1956, p. 259).

In 1887, Cope (1887b, p. 213) described a new genus and species, Episcoposaurus horridus, from the same locality as the type Typothorax. Subsequently, Episcoposaurus was found in what is probably the "Ward bone bed" near Cameron, Ariz., in the Petrified Forest Member (Lucas, 1901; Lucas, 1904, p. 193; Huene, 1926, p. 5 and 9), and Episcoposaurus (=Desmatosuchus) was found in the Petrified Forest Member at the Placerias quarry near St. Johns, Ariz. (Camp and Welles, 1956, p. 259). According to J. T. Gregory (1953a), the type of Episcoposaurus horridus Cope is probably synonymous with Typothorax coccinarum Cope and should therefore be referred to Typothorax. The same is probably true for Episcoposaurus reported at other places in the Chinle, except perhaps at St. Johns.

Another form that may be synonymous with Typothorax is Acompsosaurus wingatensis Mehl, described by Mehl (1915) and by Mehl, Toepelmann, and Schwartz $(1916$, p. 33) as occurring in red shales and clays that constitute either the lowest part of the Petrified Forest Member or the upper part of the lower red member of the Chinle near Fort Wingate, N. Mex. (See J. T. Gregory, 1953a.)

Another stagonolepid, the genus Desmatosuchus Case, originally described by Case (1920) and first found in the Dockum of Texas, has recently been found in the lower part of the Chinle of northern Arizona. The reported occurrences consist of a right "horn" of Desmatosuchus, collected about 8 miles west of Lupton, Ariz. (Brady, 1954, p. 19); bone fragments referred to Desmatosuchus, collected near St. Michaels, Ariz. (Brady, 1958, p. 61-62); and Episcoposaurus (=Desmatosuchus), found in the Placerias quarry near St. Johns, Ariz. (Camp and Welles, 1956, p. 259).

\section{SUBORDER PHYTOSAURIA}

The crocodilelike phytosaurs are the most abundant element of the vertebrate fauna of the Chinle Formation and have been found at many localities and horizons in the Chinle and Dolores Formations. Most of the reported occurrences of phytosaurs are in the Petrified Forest Member, and most of the described specimens are from northern Arizona. The phytosaurs of the Chinle have been studied extensively by Camp (1930) and by Colbert (1947b) .

At present, all the phytosaur remains described from the Chinle and Dolores Formations can be referred to the genus Phytosaurus (Colbert, 1960, p. $60)$. All these forms had previously been referred to the genus Machaeroprosopus Mehl, orginally described by Mehl, Toepelmann, and Schwartz (1916, p. 5) and based on material from the Petrified Forest Member near Cameron, Ariz. Phytosaurs from the Chinle Formation have been assigned to many different genera and species, but many of them may in fact belong to a single genus or even a single species (Colbert, 1947b, p. 77-78; Colbert and Gregory, in Reeside and others 1957, p. 1458).

The phytosaurs from the Chinle and Dolores Formations that are now considered in synonomy with Phytosaurus are (1) Machaeroprosopus validus, described by Mehl, Toepelmann, and Schwartz (1916, p. 5) from the Petrified Forest Member near Cameron, Ariz.; (2) five new species of Machaeroprosopus-M. zunii, M. adamanensis, M. gregorii, $M$. lithodendrorum, and $M$. tenuis-described by Camp (1930) from the lower part of the Chinle Formation in Arizona; (3) a form similar to Belodon priscus, noted by Hills (1880) and Cross (1899) in the basal part of the Dolores Formation near Telluride, Colo.; (4) Belodon buceros Cope (1881), from the Chinle of New Mexico, considered by Mehl, Toepelmann, and Schwartz (1916, p. 23), Camp (1930, p. 143), and Colbert (1947b, p. 68) to be a species of "Machaeroprosopus"; (5) Belodon scolopax Cope (1881), also from the Chinle of New Mexico, regarded by Camp (1930, p. 144) as possibly representing the young of "M." buceros; (6) Heterodontosuchus ganei Lucas, originally described by Lucas (1898), from beds probably near the top of the Chinle Formation in the Clay Hills area of southeastern Utah, and subsequently found in the Petrified Forest Member near Cameron, Ariz. 
(Ward, 1900, p. 322; Lucas, 1901; Lucas, 1904, p. 193), and possibly from the Dolores Formation of Colorado (Cross and Howe, 1905b, p. 468), regarded by Colbert (1947b, p. 68) as an indeterminate type probably identical with "Machaeroprosopus"; (7) Angistorhinus? sp., described by Mehl, Toepelmann, and Schwartz (1916, p. 26) from the Petrified Forest Member near Cameron, Ariz., regarded by Camp $(1930$, p. 144) as probably being a young specimen of "M." validus Mehl; (8) Paleorhinus? sp., described by Mehl, Toepelmann, and Schwartz (1916, p. 40) from the Acompsosaurus horizon in the lowest part of the Petrified Forest Member or the upper part of the lower red member of the Chinle near Fort Wingate, N. Mex., regarded by Camp (1930, p. 144) as possibly an unnamed species of "Machaeroprosopus"; and (9) Pseudopalatus pristinus, described by Mehl (1928) from the Chinle near Adamana, Ariz., regarded by Camp (1930, p. 144) and Colbert $(1947 \mathrm{~b}$, p. 68) as a new species of "Machaeroprosopus."

Forms from the Chinle and Dolores Formations that probably are also synonymous with Phytosaurus are those referred, sometimes questionably, to the genus Palaeoctonus Cope. This was done by Cross (1899) and by Cross and Howe (1905b, p. 468) in writing about the Dolores Formation of southwestern Colorado, by Lucas $(1901 ; 1904$, p. 195) in relation to the Chinle Formation near Cameron, Ariz., and by Huene $(1926$, p. 4) in relation to the Chinle Formation near Adamana, Ariz. Branson and Mehl (1929, p. 163) referred the Dolores Palaeoctonus to the phytosaurs; and Camp (1930, p. 11) referred the Adamana forms to "Machaeroprosopus."

The known phytosaurs appear to be very useful for age zonation in the Chinle Formation. Camp (1930) recognized several species of Machaeroprosopus (=Phytosaurus) that he felt were useful for that purpose, and Colbert and Gregory (in Reeside and others, 1957, p. 1457-1458, 1462) and Colbert $(1960$, p. 61$)$ indicated that a progressive development of phytosaur evolution may be useful in determining the relative ages of the Chinle Formation, Dockum Group, and Popo Agie Formation.

Many occurrences of phytosaur remains in the Chinle Formation are recorded in the literature, particularly by Camp (1930), and several others were discovered during the course of the present investigation. These are a probable phytosaur jaw, collected by J. D. Lowell and identified by D. H. Dunkle, from the Chinle Formation in White Canyon, Utah (long $110^{\circ} 15^{\prime} \mathrm{W}$., lat $37^{\circ} 45^{\prime} \mathrm{N}$.) ; a phytosaur tooth, tentatively assigned to "Machaeroprosopus," collected by H. F. Albee and identified by D. H. Dunkle, from the Moss Back Member of the Chinle on the southwest side of Deer Flat in San Juan County, Utah (long $110^{\circ} 00^{\prime}$ W., lat $37^{\circ} 40^{\prime}$ N.) ; a probable phytosaur vertebral centrum, collected by R. Q. Lewis and D. E. Trimble and identified by D. H. Dunkle, from the lower 15 feet of the Shinarump Member of the Chinle in Monument Valley, Utah (SW1/4 NW1/4 sec. 35, T. 43 S., R. 15 E.) ; a probable phytosaurian tooth, collected by D. P. Elston and identified by P. P. Vaughn, from the Monitor Butte Member in a conglomerate 8 feet below the base of the Moss Back Member of the Chinle and about 10 feet above the base of the Chinle Formation in the San Rafael Swell, Utah (long $110^{\circ} 57^{\prime}$ W., lat $38^{\circ} 45^{\prime}$ N.) ; two phytosaurian teeth, collected by the authors and identified by P. P. Vaughn, from the upper part of the upper member of the Chinle Formation in Dinosaur National Monument, Utah (S1/2, sec. 22, T. 45., R. 23 E.) ; and phytosaur remains, collected by the authors and identified by G. E. Lewis as ?Phytosaurus sp., from the sandstone and conglomerate member of the Chinle Formation, about 120 feet below the top of the Chinle, at Cross Mountain anticline, Moffat County, Colo. (SW1/4, sec. 29, T. 7 N., R. 98 W.). With regard to the Cross Mountain collection, P. P. Vaughn stated, in an unpublished report:

F-FP-63 includes a number of fragments of the lower jaw of a phytosaur, several of which I was able to fit together to reconstruct a portion, about $90 \mathrm{~mm}$ long, of the posterior part of the symphyseal region of the mandible. Other phytosaur fragments in F-FP-63 are: Another, smaller (about $30 \mathrm{~mm}$ long) jaw fragment, a tooth, the centrum of a middorsal vertebra, fragments of several other vertebrae, a part of a rib, a fragment of a dermal scute, and other fragments.

\section{ORDER SAURISCHIA}

The saurischian dinosaurs are represented in the Chinle Formation by the carnivorous coelurosaurian theropod genus Coelophysis. All specific references to Coelophysis localities in the Chinle Formation are in northern New Mexico, but Colbert and Gregory (in Reeside and others, 1957, p. 1464) noted that the genus "occurs sparsely in the Chinle of Arizona."

Coelophysis was first described, from material found in the Chinle of New Mexico, by E. D. Cope (1887a) under the generic name Coelurus, including two species. Later in the same year, Cope $(1887 \mathrm{~b}$, p. 221-227) referred these species and an additional new one to the genus Tanystrophaeus, but still later (Cope, 1889) he referred them to a new genus, Coelophysis. Cope did not give any location for the Coelophysis horizon other than New Mexico, but Williston and Case (1912, p. 11) found bones provisionally referred to Coelophysis at what they thought was probably the type locality, "hardly less 
than 100 feet" above the basal Upper Triassic sandstone (probably the Poleo Sandstone Lentil) in the Gallina area, New Mexico. According to Huene (1915, p. 503-504), most of the bones of Coelophysis came from the Gallina area, but some came from a nearby area.

A general description of much more complete skeletons of Coelophysis discovered in the Chinle Formation at Ghost Ranch, N. Mex. (loc. NM-9) by the American Museum of Natural History has been given by Colbert (1947a, 1950). At this locality, completely articulated skeletons of Coelophysis were found about 100 feet above the base of the cliffs (Colbert, 1950, p. 62). This horizon is probably in the lower part of a siltstone member of the Chinle, a unit believed equivalent to the Dolores Formation of southwestern Colorado. Colbert more recently has given further information about this genus and its occurrence $(1960$, p. 60$)$.

\section{ORDER THERAPSIDA}

Therapsid reptiles (subclass Synapsida) are represented in the Chinle Formation by the dicynodont genus Placerias. All the reported occurrences of Placerias are in the lower part of the Petrified Forest Member in northern Arizona.

Placerias was first reported from the Chinle by Lucas $(1904$, p. 194), who based the genus upon a humerus collected by Barnum Brown 3 miles north of Tanners Crossing. Lucas proposed the name Placerias hesternus for this form. According to Camp and Welles (1956, p. .256-258), the P. hesternus locality is about 225 feet above the base of the Chinle Formation.

Camp and Welles (1956) have described abundant material referred to Placerias from a quarry in the Petrified Forest Member near St. Johns, Ariz. The exact horizon of the find is not known, but the quarry also contains Machaeroprosopus (=Phytosaurus) zunii, which in the St. Johns region is found from 15 to 100 feet above the base of the Chinle (Camp and Welles, 1956, p. 258-259). Camp and Welles (p. 262) refered all of their Placerias material to a single species which they regarded as distinct from $P$. hesternus and for which they proposed the name Placerias gigas.

Camp and Welles (1956, p. 256) listed several other localities where Placerias had been found: east and southeast of Cameron near the type locality and horizon of $P$. hesternus, in the Petrified Forest National Park about 237 feet above the base of the Chinle Formation, and near the horizon and type locality of Machaeroprosopus (=Phytosaurus) lithodendrorum in Carrizo Wash near Adamana, Ariz.
According to Camp (1930, p. 44), the horizon of the type locality of " $M$." lithodendrorum is 346 feet above the base of the Chinle Formation.

Some reptilian remains from the Chinle Formation have been reported in the literature but not identified as to genus. These include a vertebra probably belonging to a Triassic form of carnivorous dinosaur, or possibly a phytosaur, from a conglomerate 100 feet below the base of the Wingate Sandstone near Moab, Utah, and "a portion of a fibula (lacking the distal end) of a carnivorous Dinosaur" in the Chinle at West Side Creek (Cross, 1907, p. $652-653)$; reptilian bones near the top of the Chinle in the northeastern part of Monument Valley, Utah (Woodruff, 1912, p. 89) ; assorted parasuchian bones at various localities in New Mexico and saurischian vertebrae near Tanners Crossing, Ariz. (Huene, 1926, p. 4-5) ; and a possible small dinosaur and a large undetermined carnivorous reptile at the Placerias quarry near St. Johns, Ariz. (Camp and Welles, 1956, p. 259).

\section{PLANTS}

Plant remains, particularly petrified conifer wood, are fairly common in the lower part of the Chinle Formation and are especially abundant in some areas. Plant remains have also been found in the upper part of the Chinle Formation and in the Dolores Formation. Most of the described genera and species of fossil plants in the Chinle Formation are from exposures of the Petrified Forest Member in the vicinity of Petrified Forest National Park in Arizona; these exposures contain the most spectacular display of fossil plants in the Chinle. The most complete description of the Chinle flora is that presented by L. H. Daugherty (1941), who described 38 forms of plant life in the Chinle, mostly collected from the Petrified Forest National Park area. The flora described by Daugherty consists of fungi, ferns, sphenopsids, lycopods, cordaitales, cycadophytes, a ginkgo, conifers, and a possible gnetalean. Its most abundant elements are cycadophytes and conifers, which comprise almost all the plant forms reported from the Chinle by Daugherty's predecessors. Daugherty (1941) was the first to describe the fungi, ferns, lycopods, cordaitales, and ginkgos of the Chinle. Descriptions and identifications of these forms and their occurrence can be found in Daugherty's report (1941) and in more recent studies by Ash $(1967,1969)$; they are therefore not discussed here. The more abundant and widespread elements of the flora-the sphenopsids, cycadophytes, and conifers - as well as occurrences of gnetales and monocotyledons, are discussed on the following pages. 


\section{SPHENOPSIDS}

Prior to the work of Daugherty (1941), the only sphenopsids reported from the Chinle were those found by Fontaine and Knowlton $(1890$, p. 283) near the copper mines, near Abiquiu, N. Mex., probably in strata now included in the Agua Zarca Sandstone Member of the Chinle. These fossils were assigned in part to Equisetum abiquiense, which is now regarded as equivalent to Neocalamites virginiensis (Daugherty, 1941, p. 59). Neocalamites has since been reported by Daugherty $(1941$, p. 20-23) from various localities in the Petrified Forest Member in the Petrified Forest National Park area in Arizona and from the Poleo Sandstone Lentil near Coyote, $\mathrm{N}$. Mex. It also occurs in the lower red member of the Chinle in the Zuni uplift, western New Mexico (Ash, 1967).

Two other sphenopsid genera, all belonging to the Equisetales, from the Chinle in Arizona have also been described by Daugherty (1941).

\section{CYCADOPHYTES}

Cycadophytes, considered the dominant element of the Chinle flora (Daugherty, 1941, p. 24), have been found in the Chinle Formation at many localities. The most abundant and widespread cycad in the flora is Otozamites powelli (see Daugherty, 1941, p. 24 ; and Ash, 1967, p. 128), originally described by Fontaine and Knowlton (1890, p. 284) from the copper mines near Abiquiu, N. Mex., under the name Zamites powelli and later described and renamed by Berry (1927) from specimens collected from the top of the Shinarump Member east of Wagon Box Mesa in the Circle Cliffs area in Utah. (See also Gregory and Moore, 1931, p. 53.) Daugherty (1941, p. 20-23) listed several localities of Otozamites powelli in the Chinle in Arizona and one locality in the Dockum of Texas.

The first cycads from the Chinle to be described were Otozamites macombii and Zamites occidentalis, named by Newberry (1876) and collected at the copper mines near Abiquiu, N. Mex., from what is probably the Agua Zarca Sandstone Member. $Z$. occidentalis was also questionably listed by Fontaine and Knowlton $(1890$, p. 284) as coming from the same locality. Two other cycads from this locality, Cycadites? and Ctenophyllum? were also listed, but not described, by Fontaine and Knowlton (1890, p. 284).

Another cycad named by Berry (1930, p. 459), Pterophyllum bakeri, was found in the Shinarump Member on the east side of Nokai Creek, in the Monument Valley area, Utah. Hills (1880) had previously noted the presence of Pterophyllum in what is probably the Dolores Formation near San Miguel, Colo.

Besides Otozamites powelli, Daugherty (1941, p. 26) listed five other cycadophyte genera that he found in the Chinle of Arizona. Of these, the most significant are Macrotaeniopteris magnifolia and Lepacyclotes circularis, because both species are also present in the Upper Triassic Newark Group of Virginia.

\section{CONIFERS}

The principal representative of the conifers in the Chinle Formation is the araucarian wood Araucarioxylon arizonicum, originally described by Knowlton $(1888$, p. 3$)$ from specimens from the Petrified Forest Member in the Petrified Forest National Park area in Arizona and from near Fort Wingate in New Mexico, but since identified at many localities and horizons in the Chinle and related formations. Araucarioxylon is abundant in the Petrified Forest National Park area (Knowlton, 1913, p. 210) and has been reported to occur at the copper mines near Abiquiu, N. Mex. (Fontaine and Knowlton, 1890, p. 285) ; in the Shinarump Member near Cedar City, Utah (Lee, 1907, p. 367) and in the Zion National Park region (Gregory, 1950, p. 72) ; in the Chinle at many localities in Nevada, Utah, Arizona, and New Mexico; and in the Dockum Group of New Mexico and Texas (Daugherty, 1941, p. 88-89).

The only other conifer wood reported from the Chinle is Woodworthia arizonica, originally described from the Petrified Forest National Park area in Arizona by Jeffrey (1910). Woodworthia is common in the Petrified Forest National Park area (Daugherty, 1941, p. 24) but is known to occur in only two other areas - the Chinle of the Zion National Park area (Gregory, 1950a, p. 72) and the Dockum of Texas (Daugherty, 1941, p. 23). Conifer wood from the Petrified Forest Member of the Chinle near Cameron, Ariz., described by Ward (1905, pt. 1, p. 35) as Araucarites monilifer, was shown by Daugherty (1941, p. 5 and 44 ) to be Araucarioxylon arizonicum attacked by heart rot.

Conifers, twigs, leaves, cones, and spores also have been described from the Chinle. These include Pagiophyllum newberryi, originally figured as Pachyphyllum? from the copper mines near Abiquiu, N. Mex., by Newberry $(1876, \mathrm{pl}$. V and VI) but renamed by Ward $(1900$, p. 318) and since reported by Daugherty (1941) from the Petrified Forest National Park area in Arizona; two forms of Palissya originally noted by Fontaine and Knowlton (1890, p. 284) as Cheirolepis münsteri and Palissya braunii? from the copper mines near Abiquiu and later considered by Knowlton $(1919$, p. 428 and 429$)$ to 
represent, respectively, Palissya diffusa (Emmons), named by Ward $(1900$, p. 322), and $P$. sphenolepis (Braun); a petrified cone, Araucarites chiquito, from the Petrified Forest Member near Cameron, Ariz.; coniferous stems and twigs, named by Ward (1905, pt. 1, p. 30) Araucarites shinarumpensis from the Chinle near Cameron; two new species, Podozamites arizonicus and Pityosporites chinleana, described by Daugherty (1941) from the Petrified Forest Member in the Petrified Forest National Park; and Brachyphyllum münsteri Schenk, described by R. W. Brown (1956, p. 206) from the Dolores Formation near Placerville, Colo.; this is probably the same as Pachyphyllum münsteri, noted by Cross (1899) as being present in the basal part. of the Dolores Formation in the valley of the Dolores River (Brown, 1956, p. 205-206).

\section{GNETALES}

The fossil wood Schilderia adamanica Daugherty (1934) may be the sole representative of this order in the Chinle Formation. It occurs in the Petrified Forest Member at two localities within the Petrified Forest National Park, Ariz. (Daugherty, 1941, p. 97).

\section{MONOCOTYLEDONS}

An important discovery of plant remains in the Dolores Formation near Placerville, Colo., has been described by R. W. Brown (1956). Among the plants found is a new form which Brown (1956, p. 207) named Sanmiguelia lewisi and regarded "tentatively but credibly as a primitive palm." If Sanmiguelia is a palm, it is geologically the oldest one known to have been identified as such.

During the course of the present investigation, several collections of fossil plants from the Chinle Formation were obtained by the authors and others. These collections were studied by R. W. Brown, whose identifications are given in the following notes.

1. Ferns, sphenopsides, cordaitales, and cycadophytes obtained by $R$. W. Brown and the authors from the Shinarump Member about 5 miles southeast of St. Johns, Ariz. (sec. 20 or 29, T. 12 N., R. 29 E.) :

Cladophlebis sp.

Equisetites sp.

Yuccites sp.

Macrotaeniopteris magnifolia (Rogers) Schimper

Ctenophyllum braunianum Goeppert

Otozamites powelli (Fontaine) Berry

Sphenozamites rogersianus Fontaine

2. A collection of ferns and cycadophytes obtained by the authors in greenish-gray claystone and siltstone of the sandstone and mudstone member 15 feet above the top of the Moenkopi Formation on north side of the Little Colorado River, 2,000 feet north of Cameron, Ariz., and 1,000 feet $\mathrm{N}$. $62^{\circ} \mathrm{W}$. of north tower of old Cameron bridge (long $111^{\circ} 25^{\prime} 15^{\prime \prime}$ W., lat $35^{\circ} 52^{\prime} 45^{\prime \prime}$ N.) : Cladophlebis sp.

Phlebopteris smithi (Daugherty) Arnold

Lonchopteris virginiensis Fontaine

Sphenozamites rogersianus Fontaine

3. A collection of cycadophytes and conifers obtained by R. W. Brown and the authors from the Temple Mountain Member at a mine prospect in the northwestern part of San Rafael Swell, Utah (NW1/4, sec. 29, T. 20 S., R. 12 E.) :

Otozamites powelli (Fontaine) Berry

Podozamites lanceolatus (L. and H.) Braun

Coniferous twigs, cones and seeds

4. A collection of conifers obtained by R. W. Brown and the authors from the Temple Mountain Member at mine prospect in the northwestern part of the San Rafael Swell, Utah (SE1/4 sec. 10, T. 20 S., R. 11 E.) :

Podozamites lanceolatus (L. and H.) Braun

Coniferous twigs, cones, seeds

5. A collection of conifers obtained by H. S. Johnson frem the Temple Mountain Member in the San Rafael Swell, Utah (SW $1 / 4$ sec. 30 , T. 22 S., R. 11 E.) :

?Brachyphyllum sp.

6. A cycadophyte collection obtained by R. W. Brown from the Monitor Butte Member in the southeast corner of the San Rafael Swell, Utah:

Otozamites powelli (Fontaine) Berry

7. A collection of cycadophytes and conifers obtained by R. C. Robeck from the Monitor Butte Member about 20 feet above the base of the Chinle Formation and 80 feet below the base of the Moss Back Member at the southeast corner of the San Rafael Swell, Utah:

Otozamites powelli (Fontaine) Berry

Fragment of a coniferous twig

8. A collection of cycadophytes and conifers obtained by R. W. Brown and the authors from the Shinarump Member on the north side of The Notch, Elk Ridge, Utah (NE1/4 sec. 7, T. 25 S., R. 20 E.) :

Macrotaeniopteris magnifolia (Rogers) Schimper

Otozamites powelli (Fontaine) Berry

Podozamites lanceolatus (L. and H.) Braun

Object that appears to be a beetle

9. A cycadophyte collection obtained by F. J. Kleinhampl from the base of the Shinarump Member in the southeastern part of Deer Flat, San Juan County, Utah (sec. 27 ?, T. 36 S., R. 17 E.) :

Ctenophyllum braunianum Goeppert

10. A cycadophyte collection obtained by F. J. Kleinhampl from the base of the Shinarump Member in the Circle Cliffs, Utah (sec. 32 , T. 32 S., R. 7 E.) :

?small leaf of Sphenozamites rogersianus Fontaine

11. A cycadophyte collection obtained by W. I. Finch from the Moss Back Member in Poison Spring Box Canyon, Utah (sec. 14, unsurveyed, T. 31 S., R. 13 E.) :

Pterophyllum bakeri Berry

12. A collection of ferns and cycadophytes obtained by the authors from the Monitor Butte Member in the White Canyon area, Utah (long $110^{\circ} 07^{\prime} 06^{\prime \prime}$ W., lat $37^{\circ} 38^{\prime} 19^{\prime \prime}$ N.) :

Cladophlebis subfalcata Fontaine

Otozamites powelli (Fontaine) Berry

13. A collection of cycadophytes and conifers obtained by the authors from the Monitor Butte Member, 55 feet above the base of the Chinle Formation on the northeast side 
of Monitor Butte, Utah:

Otozamites powelli (Fontaine) Berry

Podozamites emmonsi Newberry

14. A conifer collection obtained by J. Fred Smith, Jr., in a gray shale of the Monitor Butte Member immediately overlying the Shinarump Member about 3 miles northnortheast of Torrey, Wayne County, Utah: Palissya sp.

15. A conifer collection obtained by J. B. Reeside, Jr., from the Chinle Formation in Red Rock Valley, Ariz.: Cephalotaxopsis sp.

Of the forms listed above, Ctenophyllum braunianum, Sphenozamites rogersianus, Podozamites lanceolatus, P. emmonsi, Cladophlebis subfalcata, and Cephalotaxopsis have not previously been reported from the Chinle Formation. All of them except Podozamites lanceolatus are listed by Knowlton (1919) as present in the Newark Group of eastern North America.

\section{AGE OF THE CHINLE FORMATION}

The Chinle Formation is now generally believed to be of Late Triassic age and equivalent to the Keuper as recognized in Germany (Colbert and Gregory, in Reeside and others, 1957, p. 1458). Evidence for this age designation has been supplied through comparisons of vertebrate and plant remains; the vertebrate remains chiefly by Lucas (1904), Camp (1930), Colbert (1950, p. 63), and, most recently, Colbert and Gregory (in Reeside and others, 1957), and the plant remains chiefly by Daugherty. (1941).

The evidence afforded by vertebrates, as summarized by Colbert and Gregory (in Reeside and others, 1957, p. 1458), includes the close relationship of Eupelor in the Chinle with Metoposaurus in the Keuper; of Hesperosuchus in the Chinle with Ornithosuchus in the New Red Sandstone of Scotland; and of "Machaeroprosopus" (=Phytosaurus) in the Chinle with Phytosaurus in the Keuper. In addition, J. T. Gregory (1953b) noted the presence of pseudosuchian scutes in the German Keuper that resemble those of Typothorax in the Chinle, further strengthening the faunal similarity.

Daugherty (1941, p. 38) listed 11 species in the Chinle flora that are closely related to species in the Keuper of Germany and stated that "the Chinle flora of Arizona is more closely related to that of the Keuper of Germany than to any other except the Newark flora of eastern United States," and that "a larger percentage of identical or closely related Arizona species is found in the eastern Triassic and Keuper than in any younger or older formations."

Three Upper Triassic units in North America contain continental faunas comparable to the fauna of the Chinle. These units are the Newark Group of eastern North America, the Dockum Group of eastern New Mexico and western Texas, and the Popo Agie Formation in Wyoming. The age relations of these units, as inferred from their vertebrate faunas, have been discussed by Colbert and Gregory (in Reeside and others, 1957).

The fauna and flora of the Newark Group appear closely comparable to that of the Chinle. Of the vertebrates, both units contain the amphibian genus Eupelor and the holostean fish Semionotus, and the phytosaur Clepsysaurus of the Newark may represent the same genus as Machaeroprosopus (=Phytosaurus) of the Chinle (Colbert, 1947b, p. 67). Daugherty $(1941$, p. $37-38)$ has shown the floras to be closely comparable; he has listed six species of plants that are common to the Chinle and the Newark and eight Chinle species that are closely related to species in the Newark. To the former group should be added Palissya diffusa and $P$. sphenolepis, listed by Knowlton (1919, p. 428 and 429) as present both in the Newark Group and in the Chinle Formation at the copper mines near Abiquiu, N. Mex., and the new forms identified by $\mathrm{R}$. W. Brown during the course of the present investigation, Ctenophyllum braunianum, Sphenozamites rogersianus, Podozamites emmonsi, and Cladophlebis subfalcata, all listed by Knowlton (1919) as occurring in the Newark Group. Ash (1969), however, in recent work has questioned the idea that the Chinle Formation and Newark Group have similar faunas and indicates that some of the supposed similarities are based on misidentifications.

Colbert (1957) and Colbert and Gregory (in Reeside and others, 1957) have summarized the fauna and general age relations of the Popo Agie Formation. They concluded that while the Popo Agie fauna is probably of Late Triassic age, it may be slightly older than comparable faunas in the Chinle. The Popo Agie contains the typical Late Triassic metoposaur Eupelor, and it also contains phytosaurs. But the phytosaur genera Paleorhinus and Angistorhinus, which are present in the Popo Agie but not in the Chinle, appear to be more primitive than the typical Chinle phytosaurs and thus may indicate that the Popo Agie is older. Furthermore, as noted by Colbert (1957, p. 91-92), while the Popo Agie contains a mammallike dicynodont that is comparable to Placerias of the Chinle, this animal was regarded by Camp $(1956$, p. 329$)$ as having traits characteristic of Middle Triassic dicynodonts, another fact suggesting that the Popo Agie is older than the Chinle. Colbert and Gregory (in Reeside and others, 1957, p. 1462) wrote that "there may be some justification for supposing that the Popo Agie is of early Keuper age, comparable in this respect to the lower 
portion of the Dockum and definitely earlier than the typical Chinle of Arizona and New Mexico." Some evidence on the other side is afforded, however, by the presence in the Popo Agie of the ornithischian dinosaur Poposaurus. According to Colbert and Gregory (in Reeside and others, 1957, p. 1462), "Poposaurus shows some advanced ornithischian characters," and thus might constitute evidence for placing the Popo Agie in a higher, rather than a lower, part of the Upper Triassic sequence.

Colbert and Gregory (in Reeside and others, 1957, p. 1464-1466) have summarized the vertebrate occurrences and probable age relations of the Dockum Group of eastern New Mexico and Texas. In eastern New Mexico the amphibian Eupelor has been found in the Dockum, and other vertebrate fossils have been found high in the Dockum near Tucumcari, N. Mex. Concerning the Tucumcari locality, Colbert and Gregory (in Reeside and others, 1957, p. 1464) stated that

an advanced species of phytosaur from this level is comparable with those from the Ghost Ranch locality in northwestern New Mexico and from the uppermost fossiliferous levels of the Petrified Forest Member of the Chinle at Adamana, Arizona.

In Texas, two faunas have been reported from the Dockum Group. The first of these, consisting of Eupelor, Typothorax, phytosaurs indistinguishable from those of the Chinle, and other forms, is "comparable to that of lower levels of the Petrified Forest member of the Chinle formation in the Petrified Forest region" (Colbert and Gregory, in Reeside and others, 1957, p. 1465-1466). The second fauna, which occurs in the lower part of the Dockum near the base of the group, contains, among other forms, Paleorhinus and Angistorhinus and is considered similar to that of the Popo Agie Formation (Colbert and Gregory, in Reeside and others, 1957, p. 1466). The lower part of the Dockum Group thus appears to be equivalent to the Popo Agie Formation, whereas higher strata in the group are probably equivalent to the Petrified Forest Member of the Chinle Formation.

In summary, the Chinle Formation appears to be of Keuper age and roughly equivalent to the Newark Group in eastern North America and to at least most of the Dockum Group. On the basis of vertebrate fossils, the lowest part of the Dockum Group and the Popo Agie Formation may be slightly older than the Petrified Forest Member, the main vertebrate-bearing part of the Chinle Formation in the central part of the Colorado Plateau. According to Colbert and Gregory (in Reeside and others, 1957, p. 1464), the Petrified Forest Member "may be thought of as representing approximately a middle segment of Upper Triassic or Keuper sedimentation."

\section{INTERPRETATIONS}

The Chinle Formation and related strata consist of a wide variety of strata deposited under different environmental conditions and derived from several source areas. The environments under which the various rock types were deposited and the sources of the sediment are described here. As the lower and upper parts of the Chinle Formation differ significantly in their depositional history, the origin of each part is discussed separately.

\section{LOWER (BENTONITIC) PART OF CHINLE FORMATION}

The lower (bentonitic) part of the Chinle Formation consists of variegated claystone, clayey siltstone, and clayey sandstone and thin widespread units of ledge-forming sandstone and conglomerate such as the Shinarump and Moss Back Members and the Sonsela Sandstone Bed. It is believed to consist of continental deposits laid down in streams and lakes and on flood plains. The primary source of the detrital material was probably the Mogollon highland, in southern Arizona, and adjacent areas (fig. 31 ). This highland supplied mainly volcanic debris but also supplied some material derived from limestone, sandstone, metasedimentary rocks, and probably granitic rocks. The Uncompahgre and Front Range highlands of Colorado and adjacent areas also supplied some material, derived from Precambrian granitic and metamorphic rocks and probably Paleozoic sedimentary rocks, to this part of the Chinle Formation.

ENVIRONMENT OF DEPOSITION AS INDICATED BY FOSSILS

The lower part of the Chinle Formation contains an abundant fossil fauna and flora, including pelecypods, gastropods, arthropods, fish, amphibians, reptiles, and plants. All these fossils indicate a continental environment of deposition.

Invertebrate remains occurring in the lower part of the Chinle Formation are mainly from freshwater forms that lived in lakes and streams. Unio, a common pelecypod in the formation, is a freshwater form today and probably has been throughout its geologic history. The gastropod Triasamnicola, a genus named for specimens found in the Chinle Formation, has been regarded as a fresh-water form because of its association with other fresh-water invertebrates (Yen and Reeside, 1946). Arthropods, including ostracodes, branchiopods, and insects, have been found in the lower part of the Chinle Formation. Since ostracodes occur in both fresh-water and marine environments (Moore and others, 1952), they do not give definite evidence for either. Branchiopods are represented by bivalve crustaceans referred to the genus "Lioesteria," a form similar to Estheria, which is a brackish- or fresh-water form that has 


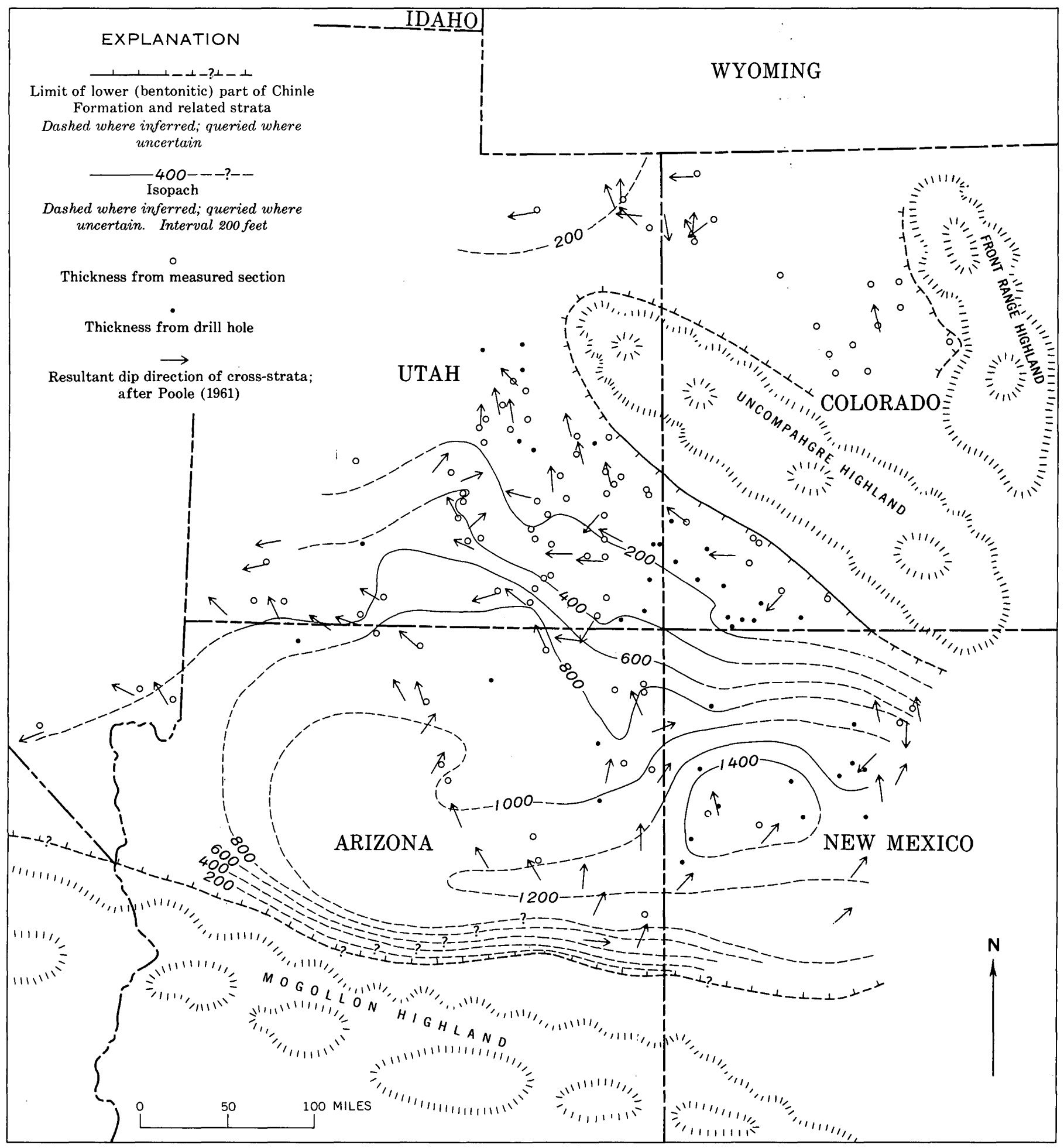

Figure 31. - Isopach map, current directions in sandstone and conglomerate units, and source areas of the lower (bentonitic) part of Chinle Formation and related strata.

been reported from Pleistocene fresh-water clays in Canada (Moore and others, 1952). Insects are represented mainly by trails and burrows in petrified wood (Walker, 1938). An "object that appears to be a beetle" has been identified by Roland Brown (written commun., 1955) in southeastern Utah.

Vertebrate remains occurring in the lower part of the Chinle Formation are from aquatic and dry-land 
upland forms. The fish Semionotus is considered by Colbert (1952) to have lived in shallow streams and lakes. The lung fish Ceratodus is likewise a freshwater form. The only living species of Ceratodus (or Neoceratodus) is found only in Australian rivers, where it lives in stagnant pools and water holes ( $\mathrm{J}$. W. Bridge, quoted in Lull, 1947). The amphibian Eupelor was generally about 4 to 6 feet long and characterized by an enormous flat skull and small feeble limbs (Colbert and Imbrie, 1956). It was aquatic and may never have left the water (Colbert and Imbrie, 1956; Branson and Mehl, 1929). The reptiles include Hesperosuchus, Typothorax, Phytosaurus (Machaeroprosopus), Coelophysis, and Placerias. Hesperosuchus (Colbert, 1952) was a lightly constructed bipedal carnivorous animal about 4 or 5 feet long, the smallest reptile known to have occurred in the Chinle Formation. It was adapted to move rapidly and was probably an upland form living on firm dry ground. Typothorax was an armored herbivorous quadrupedal flat reptile about 10 feet long whose limbs were large and well developed but short. It was probably an upland form that lived mostly on land (Colbert, 1950, p. 63; 1960, p. 60), where its armor made it practically impregnable to attack. Phytosaurus was a four-footed carnivorous animal closely resembling, but not related to, the present-day crocodile (Camp, 1930; Colbert, $1947 \mathrm{~b})$. The largest individuals were probably as much as 20 feet long. This animal probably lived along the banks of streams much like the presentday crocodile. Coelophysis, one of the first dinosaurs, was carnivorous and bipedal. It was 6 to 8 feet long but so lightly built that it probably weighed only 40 or 50 pounds (Colbert, $1955 ; 1960$, p. 60 ). Its hind legs were very strong and well adapted for walking; its front legs were short and bore mobile hands adapted for grasping. Coelophysis must have inhabited fairly dry land over which it could move with agility (Colbert, $1950 ; 1960$, p. 60). Placerias (Camp and Welles, 1956) was a herbivorous quadrupedal mammallike reptile about 7 feet long and 3 feet high. It had "tusks" extending out from the upper jaw, and jaws capable of mashing and grinding food. Placerias was the chief herbivorous reptile of its time and was probably an upland form.

Plants, both land and swamp forms, are the most abundant fossils in the lower part of the Chinle Formation. They grew on the depositional plain of the Chinle Formation (Daugherty, 1941, p. 29 and 35). Upright stumps with roots traceable for more than 10 feet, and pith casts of Neocalamites with rhizomes traceable for several feet (Daugherty, 1941, p. 29), indicate that some of the plants are preserved in their original position. Petrified logs of the conifer Araucarioxylon arizonicum are commonly 3 or 4 feet in diameter and from 60 to 100 feet in length. Judging from the habitat of living araucarians, this conifer lived along the borders of streams or on moist slopes (Daugherty, 1941, p. 30). Remains of Macrotaeniopteris and Neocalamites are abundant, and these plants probably required a swamp environment (Daugherty, 1941, p. 31, 33). The swollen and fluted bases of Schilderia adamanica are similar to the trunks of the bald cypress that grows in today's swamps (Daugherty, 1941, p. 31). The remaining plant fossils include fungi, ferns, lycopods, cordaites, cycadophytes, a ginkgo, and other conifers and sphenopsids, most of which required moist land areas.

\section{MOTTLED STRATA}

The mottled strata are rocks with a peculiar mottling of reddish purple, pale reddish brown, and light greenish gray that occur mainly in the basal part of the Chinle Formation and in the top few feet of the strata - of the Moenkopi Formation, for example - that immediately underlie the Chinle Formation. Several ideas have been proposed to explain the origin of the mottled strata. Most geologists (W. L. Stokes, quoted in Johnson, 1957; Johnson, 1957, 1964; G. M. Richmond, quoted in Finch, 1959, p. 151; and Schultz, 1963) believe these strata to represent fossil soils. Robeck (1956) believes that the mottled colors were produced by circulating solutions shortly afterr deposition of the strata, whereas Kerr and Abdel-Gawad (1964) believe them to be due to the action of hydrothermal solutions.

Available evidence seems to support the idea that the mottled strata are fossil soil zones, although, as indicated by the above-cited discussions, their origin is still in controversy. The mottling occurs mostly along the pre-Chinle unconformity, where a soil would be likely to form, although very rarely similar mottling occurs as much as 250 feet above the base of the Chinle. The wide distribution of the mottled strata and their development in different types and ages of rocks, but generally in the basal few feet of the Chinle Formation or the top few feet of directly underlying rocks, suggests widespread soil zones developed on rocks of different characters. In most places, moreover, the mottling decreases downward and gradually gives way to the normal colors of the underlying unaltered rock, in a way that is characteristic of the lower part of a soil profile.

The mineralogic differences between the mottled strata and unaltered rock are also indicative of a soil zone. The mottled strata at the top of the Moenkopi Formation, where they underlie the Chinle Forma- 
tion, commonly contain more kaolinite, more mixedlayer illite-montmorillonite, and less illite than the unaltered rocks of the Moenkopi Formation (Schultz, 1963 , p. C47-C48). These mottled strata in the Moenkopi Formation contain little chlorite and no feldspar, although both these minerals are common in the unaltered Moenkopi rocks. Such development of kaolinite and destruction of feldspar and chlorite commonly occur in soils, particularly in those of tropical and subtropical regions.

Finally, as has been indicated by Schultz (1963, p. C53) and Johnson (1964), this type of mottled coloration is common in paleosoils and modern soils elsewhere.

\section{CROSS-STRATIFIED SANDSTONE AND CONGLOMERATE}

Cross-stratified sandstone and conglomerate such as occur in the Shinarump and Moss Back Members and the Sonsela Sandstone Bed are believed to be stream deposits. Such an origin is indicated by the presence of cross-strata, channel and scour surfaces, and conglomerate layers. A fluvial environment is also suggested by the common occurrence of plant debris and the local occurrence of continental vertebrate remains.

The sandstone and conglomerate layers in these stratigraphic units are lithologically similar to the modern point-bar deposits described by Frazier and Osanik (1961), by Harms, MacKenzie, and McCubbin (1963), and by Harms and Fahnestock (1965), and are regarded as áncient examples of such deposits. The point-bar deposits in modern streams are formed by lateral accretion on the convex sides of meander bends as the stream migrates laterally (fig. 32). They are characteristically made up of trough sets of cross-strata, although planar sets occur locally. The uppermost layers in these modern deposits are generally ripple laminated (small-scale trough cross-strata), and the ripple laminae are commonly of a type called rib-andfurrow structures (Stokes, 1953). The size and shape of the cross-strata in the Chinle are commonly very similar to those in modern point-bar deposits; ripplelaminated layers (rib-and-furrow structures) occur at the top of the sandstone units in the Chinle, as they do in modern deposits. In addition, conglomerate layers characteristically occur at the bases of these layers in the Chinle Formation, and according to Allen (1964) these "channel-lag deposits" are common at the bases of modern point-bar deposits. According to Visher (1965, fig. 13), point-bar deposits are commonly 5 to 50 feet thick, and some are as much as 100 feet thick (Frazier and Osanik, 1961) ; the sandstone and conglomerate units in the Chinle Formation show a similar range of thickness.

In a few areas, the Shinarump Member contains features that may be "clay plugs" (fig. 32). Clay plugs on the Mississippi River (Fisk, 1944, 1947) and Sacramento River (Lorens and Thronson, 1955) consist of clay and fine silt deposited in abandoned channels or sloughs. At the top of the Shinarump Member, or rarely within it, are elongate masses of greenish-gray silty claystone, siltstone, and clayey sandstone that fill channels cut into sandstone; it seems almost certain that these are fossil clay plugs.

Many, and perhaps most, of the channels at the base of the Shinarump Member and of other members of the Chinle are considered to be valleys filled in by stream deposits. Some of the channels at the base of the Shinarump Member in the Monument Valley area (Witkind, 1956) are 50 feet or more -deep and only 150 to 400 feet wide-much too deep relative to their width to be the cross section of a river. The deeper channels, therefore, were probably valleys in an old land surface in which the streams may have flowed 40 or more feet below the surrounding land area even during flood stage.

The fluvial Shinarump and Moss Back Members and Sonsela Sandstone Bed of the Chinle Formation have been considered remarkable by many geologists because their distribution is so widespread in comparison with their thickness. The Shinarump Member occurs in an area of about 140,000 square miles, although it is locally absent within this area. It may average about 30 feet in thickness, though it is locally as much as 200 feet thick. The Moss Back Member is more continuous and covers at least 10,000 square miles. It averages about 60 feet in thickness. The Sonsela Sandstone Bed covers about 24,000 square miles and averages about 30 to 40 feet in thickness.

Such thin widespread fluvial units are fairly common in other parts of the geologic section. Stokes (1950) discussed several conglomerate units of this type on the Colorado Plateau and adjacent regions, including "the Shinarump and equivalents of Triassic age, the Buckhorn and equivalents of probably early Cretaceous age, and the Dakota of probable late Cretaceous age." In addition, several thin widespread fluvial units occur in the Tertiary and Quaternary strata of the United States. These include the Flaxville Formation (Miocene or Pliocene) of the northern Great Plains (Alden, 1932; Collier and Thom, 1918), the Bishop Conglomerate (Oligocene or Miocene) of the north flank of the Uinta Mountains in Utah and Wyoming (Bradley, 1936), and the "graveliferous" deposits (Holocene) of the Missis- 

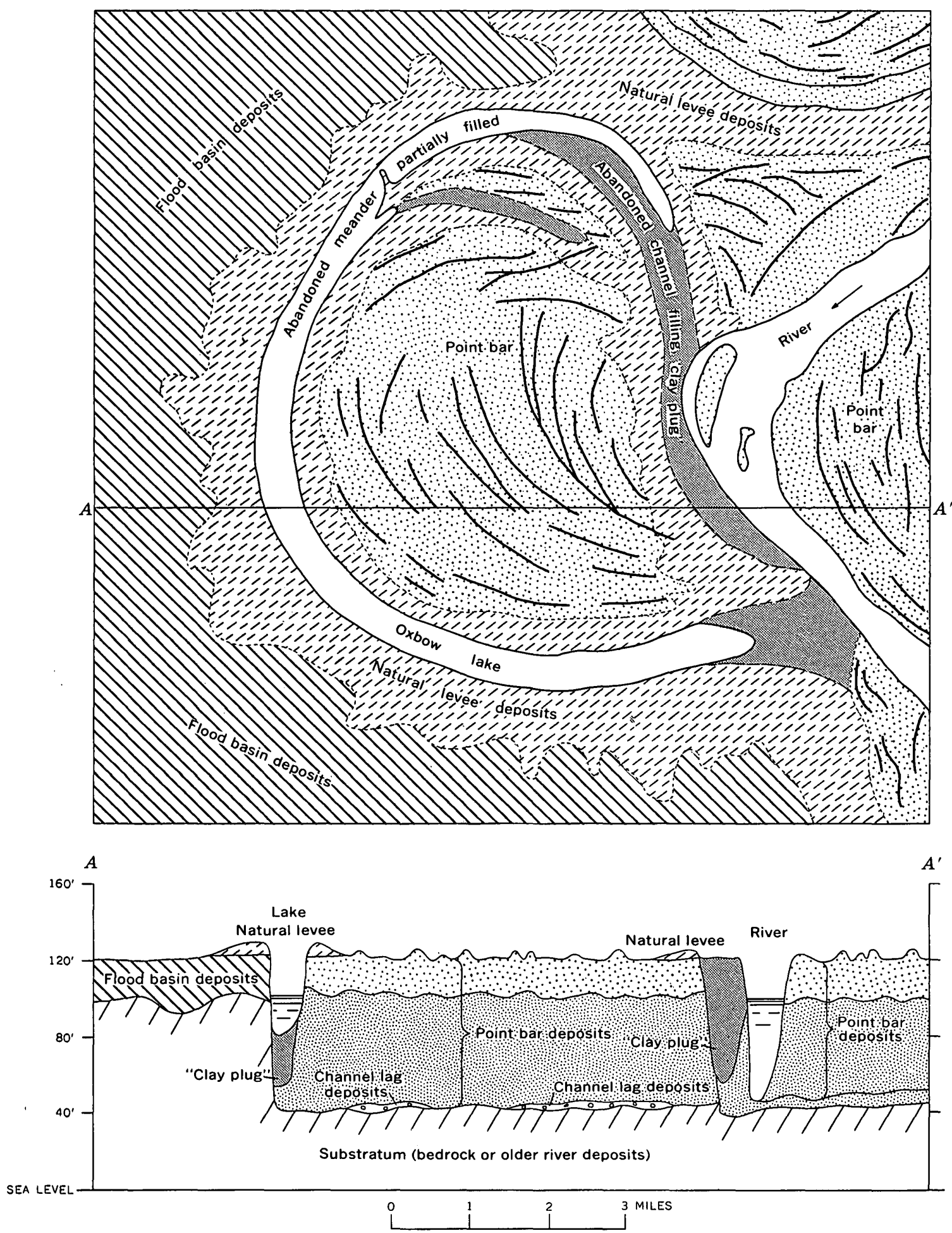

Figure 32. - Idealized map and section showing deposits of a meandering river.

sippi River (Fisk, 1944, 1947). The upland gravels (Pliocene?) of Maryland (Schlee, 1957; Hack, 1955) are also thin fluvial deposits, but they cover only a relatively small area.

The wide distribution of these units has generally been attributed to one of two causes: (1) lateral accretion as a stream migrates across a plain, or (2) aggradation due to a change in regimen of a stream flowing across a plain.

The lateral accretion hypothesis is based on the 
often observed relation that a stream leaves behind a thin alluvial deposit (point-bar deposit) as it migrates laterally (fig. 32). The underlying erosion surface is produced by the stream as it migrates. Drilling has shown that a Holocene deposit of this type extending along the Mississippi River is nearly 2 miles wide (Frazier and Osanik, 1961, fig. 2), and presumably others are even wider.

According to the second hypothesis, the formation of such a deposit is due to a change in regimen of a stream flowing across a plain. A study by Happ (1948) showed that the middle Rio Grande, in New Mexico, is aggrading its channel at the rate of about 1 foot in 12 years throughout this 133-mile-long part of its course. It is now depositing a long narrow ribbon of sediment, but if in the future it is allowed to continually shift its course across the plain, it could, according to this hypothesis, cover a belt several miles wide.

The first of these hypotheses is the one that seems most applicable to the Chinle Formation. The sandstone and conglomerate units in the Chinle Formation closely resemble those of modern point-bar deposits, and their wide distribution may also be due to this type of deposition.

\section{CROSS-STRATIFIED CLAYEY SANDSTONE}

Clayey sandstone is common in the Monitor Butte and related members and in the Petrified Forest Member and is lithologically distinct from the crossstratified sandstone and conglomerate that occur in the Shinarump and similar members. The clayey sandstone commonly contains at least 20 percent silt or clay, occurs in nonresistant slope-forming layers, and is composed of very low angle crossstrata in very shallow trough sets. The sandstone and conglomerate of the Shinarump and related members, on the other hand, commonly contain no more than 10 percent clay, occur in ledge-forming layers, and are largely composed of medium- to high-angle cross-strata in trough- and tabular-planar sets.

The clayey sandstone units are believed to be stream deposits, and the reasons for their lithologic differences from the Shinarump and similar members are not understood. Their high clay content may reflect a difference in the type of material supplied to them, or it may indicate that the sediments in these units were less reworked than those in the relatively clean sandstone of the Shinarump. It is possible, on the other hand, that at least part of the clay in these units was formed, after their deposition, by alteration of volcanic debris (Schultz, 1963, p. C30-C39). The hydraulic conditions under which the clayey sandstone and shallow trough sets of lowangle cross-strata formed are not known, but they appear to have been different from those attending the deposition of the sandstone and conglomerate of the Shinarump and similar members.

\section{RIPPLE-LAMINATED SANDSTONE}

Very fine grained ripple-laminated sandstone units are common at the top of the Shinarump Member, in the Monitor Butte and lower red members, and locally elsewhere in the lower part of the Chinle Formation. The prominent ledge-forming sandstone units, from a few feet to 20 feet thick, in the Monitor Butte and lower red members are commonly composed entirely of ripple-laminated beds.

The ripple-laminated sandstone in the lower part of the Chinle Formation locally contains parallel ripples, both symmetrical and asymmetrical, but most of the ripple-laminated strata have what is called a rib-and-furrow structure (Stokes, 1953) believed by Allen (1963) to have been formed by downstream migration of lunate or linguoid ripples.

The ripple-laminated strata (mostly rib-andfurrow structures) at the top of the Shinarump Member are considered to be the uppermost part of point-bar deposits. Almost identical structures have been described in the topmost layers of modern point-bar deposits by Harms, MacKenzie, and McCubbin (1963, pl. 4B) and by Harms and Fahnestock (1965, pl: 4, fig. 3 ).

The similar ripple-laminated strata in the Monitor Butte and lower red members, however, may not be related to point-bar deposition. They occur in sandstone layers interstratified with slope-forming clayey sandstone, siltstone, and claystone. These slopeforming clay- and silt-rich strata, to judge from their fine texture and even stratification, may represent, in part at least, flood-plain or lake deposits. Ripple-laminated strata are characteristic of flood plains where abundant sand is introduced and quickly deposited (McKee, 1965), and those in the Monitor Butte and lower red members may have that origin.

The ripple-laminated strata in the Monitor Butte and lower red members occur commonly in contorted layers (fig. 11) or in irregular blocks lying at almost any attitude. Some of the disruption of strata may be due to recent landslides, but in places some of the strata are truncated at the top and overlain, with a sedimentary contact, by undeformed horizontal beds.

The most likely explanation of the contorted strata is that they were involved in landslides that occurred during Chinle time. The possible clay plugs (fillings 
of abandoned channels) commonly contain contorted strata, as they likely would if the contortion is due to slumping.

\section{STRUCTURELESS OR HORIZONTALLY STRATIFIED CLAYSTONE AND CLAYEY SILTSTONE}

Structureless or horizontally stratified claystone and clayey siltstone consitute a large part of the Petrified Forest Member and a lesser part of the Monitor Butte and related members. As has already been said, they consist largely of montmorillonitic clay and contain rounded fragments of altered pumice, many as much as $3 \mathrm{~mm}$ in diameter, and some silty material composed of quartz and feldspar. The clay in the rock was formed by alteration of pumice and volcanic ash. The claystone and clayey siltstone commonly contain limestone nodules.

The claystone and clayey siltstone could have formed either from ash-fall deposits or from ash and pumice carried in streams and deposited in lakes or river basins. The ash-fall hypothesis is apparently ruled out for at least two reasons. First, the rock itself contains rounded fragments of pumice, at least $0.2 \mathrm{~mm}$ in diameter, that seem too large to have been transported in the air for the necessary distances. Second, the wind directions indicated by structures in the Permian, Triassic, and Jurassic rocks of the Colorado Plateau are consistently southerly (Poole and Williams, 1956; Poole, 1962), whereas only northerly winds could have transported debris from the presumed source of the pumice in southern Arizona and adjacent States.

As ash falls seem unlikely, transport of the glassy volcanic material in streams and deposition of it in river basins or lakes are indicated. Quiet-water deposition is suggested by the even, horizontal bedding of the claystone and clayey siltstone. The presence of limestone nodules is also consistent with the idea of subaqueous deposition.

\section{LOCATION AND TERRANE OF SOURCE AREAS}

The main source for sediment in the lower part of the Chinle Formation is considered to be a broad area in southern Arizona and adjacent parts of New Mexico and California for which Harshbarger, Repenning, and Irwin (1957, p. 44) proposed the name "Mogollon highland." The Uncompahgre and Front Range highlands of Colorado and adjacent States also contributed some material. These source areas are indicated by the direction of streamflow, distribution of types of constituent material, and stratigraphic hiatuses in the supposed source areas.

MOGOLLON HIGHLAND

A southern source in the Mogollon highland for rocks in the lower part of the Chinle Formation is strongly indicated by several lines of evidence. The streams that deposited the rocks are shown by the orientation of cross-strata to have flowed northwest to north-northeast (fig. 31) across most of the Colorado Plateau. This source is also indicated by regional differences in maximum sizes of pebbles, cobbles, and boulders in the lower part of the Chinle Formation. The maximum size of detrital material in the Shinarump Member in east-central Arizona is $284 \mathrm{~mm}$, whereas it is generally 40 to $50 \mathrm{~mm}$ in parts of southeastern Utah, about 200 miles to the north (fig. 28) ; and the Sonsela Sandstone Bed shows a decrease in maximum gravel size from more than $150 \mathrm{~mm}$ in the southern part of its area of distribution to less than $50 \mathrm{~mm}$ in the northern part (fig. $30)$.

The distribution of certain types of constituent material also supports the conclusion that a source area lay south of the Colorado Plateau. Volcanic pebbles occur almost exclusively in the southern part of the plateau (Thordarsen and others, "Conglomerate Studies," this report), and tuffaceous detritus and detrital feldspar are most abundant in the sandstone of the Shinarump and Petrified Forest Members in this same general area (R. A. Cadigan, "Sedimentary Petrology," this report, and written commun., 1965).

Additional evidence of a southern source is that erosion is known to have taken place during early or middle Mesozoic time in the appropriate area in southern Arizona and adjacent regions. In southern Arizona and southwestern New Mexico, and in Sonora, Mexico, Cretaceous rocks rest unconformably on Paleozoic or Precambrian rocks (Darton, 1925, p. 135; Butler and Wilson, 1938, p. 13; Ross, 1925; Gilluly, 1956; Paige, 1922 ; Lasky, 1936; Taliaferro, 1933). In Cochise County, Ariz., the Cretaceous strata overlie rocks ranging in age from Precambrian to Permian on a surface having considerable relief (Gilluly, 1956, p. 123). Clearly, then, southern Arizona and adjacent regions were land areas during at least part of early Mesozoic time.

The Mogollon highland is considered to have been mainly a volcanic terrane. The volcanic debris in the lower part of the Chinle Formation, as said above, consists of volcanic pebbles, pumice fragments, and montmorillonite probably derived from the alteration of volcanic debris. The volcanic pebbles in this part of the Chinle are vitric and crystal tuffs and vitrophyres of rhyolitic composition in the Shinarump Member; they are of intermediate composition, perhaps quartz latite or dacite, in the Petrified Forest Member (Schultz, 1963).

Volcanic rocks of definite or possible early Mesozoic age that could be a source for the volcanic 
debris in the Chinle Formation occur in southeastern Arizona and in southeastern California. Hayes, Simons, and Raup (1965) described rhyolitic lavas, rhyolitic welded tuffs, and subordinate sedimentary rocks in southeastern Arizona that are younger than Early Permian and older than Early Cretaceous. In the same region, Gilluly (1956) recognized granite, granite porphyry, quartz monzonite, monzonite porphyry, and associated alaskite that intrude Paleozoic formations as young as Permian and are unconformably overlain by sedimentary rocks of Early Cretaceous age. In southeastern California, Triassic and (or) Jurassic andesite flows, pyroclastic rocks, welded tuff, and volcanic sandstone have been described by Grose (1959, p. 1526-1528); possible Triassic andesite flows have been described by $\mathrm{B}$. K. Johnson (1957, p. 385-388), and possible Triassic andesitic flows, tuffs, and breccias have been described by Merriam (1963, p. 31).

The presence of fossiliferous chert pebbles in the lower part of the Chinle Formation indicates that marine cherty limestone or dolomite was exposed in the southern source area. The fossils include fusulinids, brachiopods, bryozoa, and, to a lesser extent, gastropods, pelecypods, corals, algae, crinoidal material, sponges, ostracodes, and echinoid spines (Thordarson and others, "Conglomerate Studies," this report; McKee, 1936). The great majority of the fossils in the pebbles are of Permian age ; a few may be of Pennsylvanian or Mississippian age. Most of the brachiopods and bryozoa are of types that occur in the Kaibab Limestone (Thordarson and others, "Conglomerate Study," this report; McKee, 1936). Fusulinids, on the other hand, are not known to occur in the Kaibab Limestone (L. G. Henbest, written commun., 1954), and the source of the fusulinid-bearing pebbles must therefore be fusulinid-bearing strata laterally equivalent to the Kaibab.

Pebbles of quartz and quartzite in the lower Chinle in the southern part of the Colorado Plateau region may have been derived directly from quartz veins and quartzite formation in the Mogollon highlana or, indirectly, from conglomerate layers in sedimentary rocks there. The Precambrian rocks of southern Arizona, composed of gneiss, schist, granite, and various types of metasedimentary rocks, including quartzite (Darton, 1925), are a likely source. Some of the quartz and quartzite pebbles could have been derived from conglomerate layers which occur in the Precambrian and Cambrian rocks (Darton, 1925) and, to a lesser extent, in higher Paleozoic formations in Arizona. Stoyanow (1942) mentioned conglomerate layers of Pennsylvanian age containing boulders of Precambrian quartzite in Gila County, Ariz.

The lower part of the Chinle Formation in the southern plateau region contains some grains of microcline, and some quartz grains enclosed in quartz overgrowths that have been rounded by attrition. The feldspar grains could well have come, directly or indirectly, from a granitic rock in the Mogollon highland, and the quartz grains, from quartzite or some quartz-bearing sandstone exposed on that highland.

\section{UNCOMPAHGRE HIGHLAND}

A small amount of sediment is believed to have been contributed to the lower part of the Chinle from the Uncompahgre highland, which lies northeast of the main depositional area of the Chinle. The Shinarump Member in the White Canyon-Elk Ridge area, the Agua Zarca Sandstone Member in northcentral New Mexico, and possibly some other material in the lower part of the Chinle Formation had this source. The stream directions in the Shinarump Member (pl. 4) in the White Canyon-Elk Ridge area are mostly to the west, indicating a highland somewhere to the east. Stream directions in the Agua Zarca Sandstone Member (pl. 4) in northcentral New Mexico are to the south and southwest, indicating a highland to the north or northeast. Pebble sizes decrease generally to the northwest and west in the Shinarump Member in the White Canyon-Elk Ridge area and generally to the southwest in the Agua Zarca Sandstone Member (Thordarson and others, "Conglomerate Studies," this report; fig. 28). In addition, the pebbles in the Shinarump Member in the White Canyon-Elk Ridge area are, on the average, over 80 percent quartz, whereas in other areas they are generally not more than 50 percent quartz (Thordarson and others, "Conglomerate Studies," this report; fig. 27; table 6). The Agua Zarca Sandstone Member contains large pebbles and cobbles of quartzite and quartzite conglomerate that may have been derived from metamorphic rocks to the north (Gabelman and Brown, 1955).

The rocks exposed in the Uncompahgre highland during Late Triassic time consisted dominantly of Precambrian igneous and metamorphic rocks. The rocks now exposed in the rejuvenated parts of this highland include granite, gneiss, schist, and quartzite (Shoemaker, 1956a ; Larsen and Cross, 1956 ; Montgomery, 1956). The Chinle Formation is underlain on the flanks of the Uncompahgre highland by Paleozoic rocks, mostly red arkosic sandstone, conglomerate, and siltstone of Pennsylvanian and Permian age (pl. 3). These rocks also must have 
contributed sediment to the lower part of the Chinle Formation.

\section{FRONT RANGE HIGHLAND}

In the northern part of the Colorado Plateau and adjacent areas, a major source area for strata in the lower part of the Chinle Formation was the Front Range highland. In the Gartra Member of the Chinle Formation, which constitutes much of the thin lower part of the Chinle Formation in that area, the stream directions (pl. 4) indicated by the orientation of cross-strata are to the west and northwest, indicating a source to the east and southeast. This evidence is confirmed by a westward decrease in gravel sizes, from over $75 \mathrm{~mm}$ in central Colorado to less than $25 \mathrm{~mm}$ in northeastern Utah (fig. 28).

In the Uinta Mountains the ocher siltstone member of the Chinle Formation, which is there at the top of the lower Chinle, contains abundant montmorillonitic clay believed to have been formed by alteration of volcanic debris (Schultz, 1963, p. C37C38). In this respect, the ocher siltstone member resembles the Petrified Forest Member, but, as has already been said in the sections on these members, the ocher siltstone member appears to have been deposited in a separate basin extending northward into Wyoming, where the correlative Popo Agie Formation occurs. These relationships suggest that some volcanic source existed far to the north of the one in the Mogollon highland.

In the Front Range highland, as in the Uncompahgre highland, the rocks exposed during Late Triassic time were dominantly Precambrian igneous and metamorphic rocks and Paleozoic sedimentary rocks, mostly red arkosic sandstone, conglomerate, and siltstone (pl. 3).

UPPER (RED-BEDS) PART OF CHINLE FORMATION

The upper (red-beds) part of the Chinle Formation consists mainly of reddish-brown horizontally bedded siltstone but includes some limestone, horizontally laminated, ripple-laminated, or wavy-stratified siltstone or sandstone, cross-stratified fluvial sandstone, irregularly bedded limestone pebble conglomerate, and cross-stratified eolian sandstone. Most of it, except for the fluvial and eolian units, was probably deposited in a large shallow lake. Its main source areas (fig. 33) were the Uncompahgre and Front Range highlands, but it received some debris from the Mogollon highland.

ENVIRONMENT OF DEPOSITION AS INDICATED BY FOSSILS

The fauna and flora of the upper part of the Chinle Formation are scanty compared with those in the lower part, but the fossils in the two parts are mostly of the same type. The apparent decrease in fauna and flora has been interpreted as an indication of increased aridity (Daugherty, 1941, p. 28) during late Chinle time, but a relative scarcity of fossils could also be explained by poor conditions for preservation.

The most abundant types of fossils in the upper part of the formation are fresh-water pelecypods and gastropods. The pelecypod Unio, which occurs in limestone of the Owl Rock Member and in siltstone, sandstone, and limestone pebble conglomerate elsewhere in the upper part of the formation, lives today in lakes and rivers and has probably been a fresh-water form through its geologic history. The gastropod Triasamnicola, which occurs in the limestone of the Owl Rock Member, was called a freshwater form by Yen and Reeside (1946).

Vertebrate remains in the Chinle, including fishes and reptiles, indicate aquatic and, to a lesser extent, dry-land conditions. Fish remains, which occur in the narrow belt of fluvial sandstone in the upper part of the formation that extends from southwestern Colorado to central Utah, appear from their association with other fresh-water fossils to be fresh-water forms. The reptile remains include Phytosaurus, which is fairly common, and Typothorax and Coelophysis, which are known from only one locality each. Phytosaurus was a crocodilelike animal that lived in streams and along their banks (Camp, 1930; Colbert, 1947b). Typothorax probably was an upland form (Colbert, 1950, p. 63; 1960, p. $60)$. Coelophysis, which occurs in beds transitional between the lower and upper parts of the formation in north-central New Mexico, was probably an agile dry-land animal (Colbert, $1950 ; 1960$, p. 60). Many of the reptile remains occur in fluvial sandstone and conglomerate units, commonly in limestone pebble conglomerate.

The only plant fossils in the upper part of the Chinle Formation are a few remains of cycads (Hills, $1880)$, conifers, and what may have been a palm tree (Brown, 1956).

Most of the fossil animals and plants in the upper part of the Chinle Formation, then, are aquatic fresh-water forms, and only a few are dry-land or upland forms. Perhaps most of the sedimentary basin was under water at this time and land areas were small. The lower part of the Chinle Formation, on the other hand, contains many upland vertebrate remains and was probably deposited in an area that included much dry land.

\section{STRUCTURELESS AND HORIZONTALLY BEDDED SILTSTONE}

The dominant lithologic type in the upper part of the Chinle Formation is pale-reddish-brown hori- 


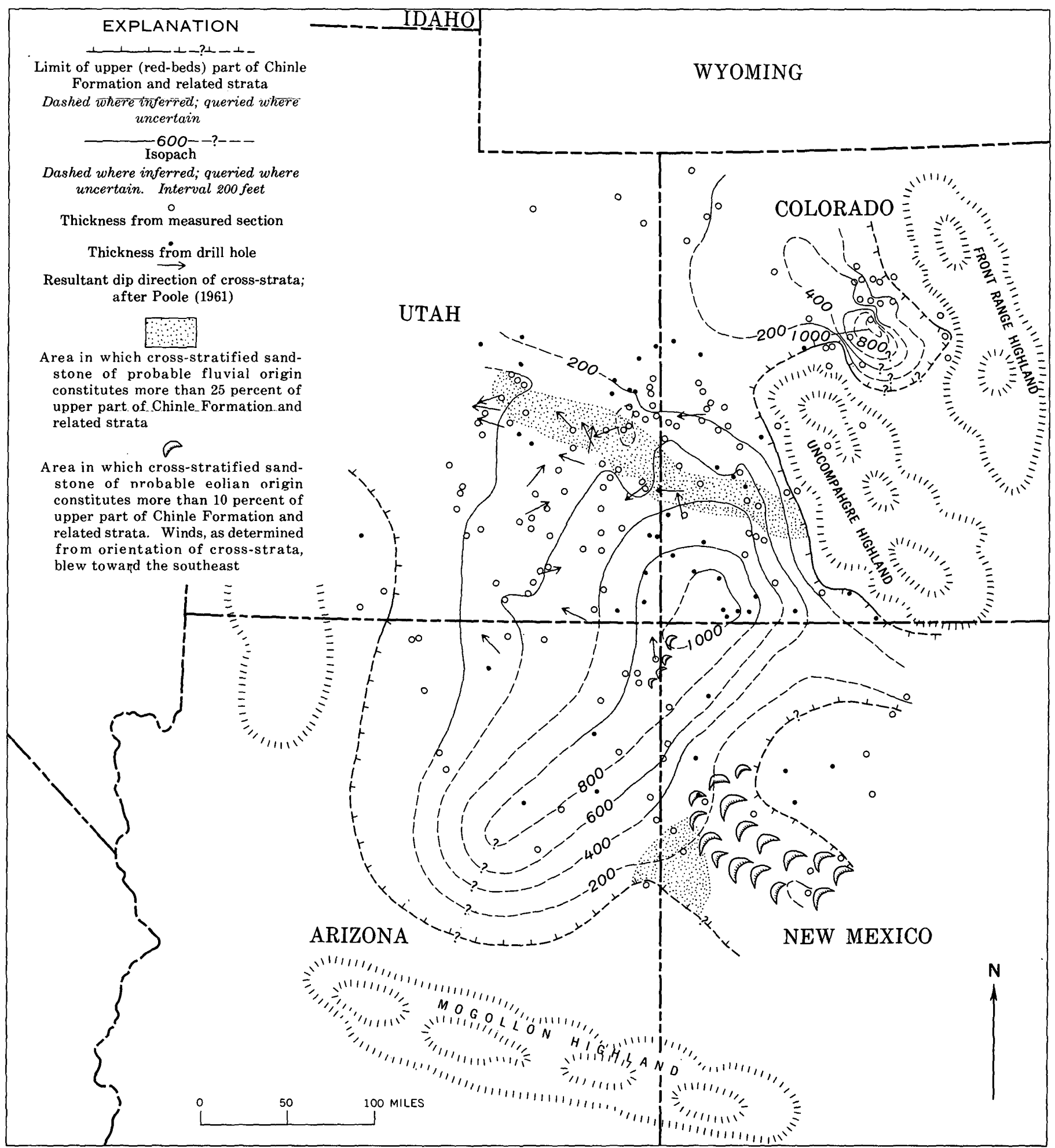

FIGURE 33. - Isopach map, current directions in sandstone units, and source areas of upper (red-beds) part of Chinle Formation and related strata. Isopach map includes part of Dolores Formation in southwestern Colorado and all of Rock Point Member of Wingate Sandstone in northeastern Arizona and northwestern New Mexico.

zontally stratified coarse siltstone and very fine $\mid$ siltstone occur in poorly defined horizonal beds less grained sandy siltstone, locally grading into silty claystone and fine siltstone. The siltstone and sandy than a foot to more than 4 feet thick. No fossils are known to have been found in these rocks. 
The origin of these strata is uncertain. Because of their relatively fine texture and the rarity in them of sedimentary structures that indicate current action, it is safe to say that they were deposited in quiet water. The siltstone and sandy siltstone are, in fact, interstratified, in the Owl Rock Member, with limestone that contains fresh-water fossils such as Unio and that may have been deposited in a lake. The horizontal bedding in these strata is also indicative of a lake environment. Some modern lake sediments contain delicately layered sediments (Bradley, 1929; Hough, 1958), whereas others contain indistinctly bedded or unlaminated sediments (Hunt and others, 1953; Hough, 1958) similar to those in the upper part of the Chinle Formation.

The siltstone and sandy siltstone are not, however, by any means typical lake deposits. Most lake deposits are much finer grained. In present-day or Quaternary lake deposits, the grain size is generally from 1 to 5 microns (Emery, 1954; Hunt and others, 1953; Hamilton, 1951; Rolfe, 1957; Hough, 1958), whereas in the siltstone and sandy siltstone of the upper part of the Chinle Formation it ranges from about 40 to 80 microns (Harshbarger and others, 1957; Cadigan, 1957a), which is approximately the grain size of material carried in suspension in streams (Sykes, 1937; Colby and others, 1953; Fisk and others, 1954; Johnston, 1921). Most lake sediments are gray, greenish gray, or black (Hough, 1958; Hunt and others, 1953; Bradley, 1929), owing in part to the presence of ferrous-iron compounds formed under the reducing conditions brought about by abundant decaying vegetation on the lake bottoms. But the siltstone and sandstone in the upper part of the Chinle Formation are red because of the presence of ferric iron in their hematitic pigment, and they contain no preserved organic material.

In places, the horizontally stratified siltstone and sandy siltstone is interstratified with ripple-laminated and cross-stratified sandstone and siltstone that were probably deposited in streams. This association of quiet water and fluvial deposits suggests that some of the siltstone and sandy siltstone may have been deposited on flood plains. The proportion of lake and flood-plain deposits in the upper part of the Chinle is not known, but as fluvial deposits are relatively scarce in the upper Chinle, flood-plain deposits may be also.

\section{LIMESTONE}

Limestone occurs in thin to thick horizontal beds interstratified with reddish-brown horizontally stratified siltstone and sandy siltstone in the Owl Rock Member. Some of it has been formed where calcite and dolomite have partially replaced water- laid volcanic sandstone, composed originally of subrounded to rounded grains of glassy porphyritic volcanic rock and pumice set in a finer grained matrix. Other limy rock includes calcareous arkosic or feldspathic siltstone in which a carbonate cement, which fills interstitial spaces, constitutes a large part of the rock. Some of the limestone beds may have formed by the growth and coalescence of limestone nodules; all gradations occur from layers containing a few scattered limestone nodules to layers containing a tight coalesced mass of nodules.

The limestone is believed to have been formed in lakes, because it contains a fresh-water fauna, including the pelecypod Unio. Some of the limestone beds appear to have formed by diagenetic replacement of tuffaceous layers on a lake floor. Other beds, some of which might more accurately be called calcareous siltstone, were formed by carbonate cementation of detrital siltstone. In some places carbonate minerals may have been chemically precipitated on a lake floor and mixed with detrital minerals coming from outside the basin of deposition.

WAVY-STRATIFIED SILTSTONE AND SANDSTONE

The rocks considered here include sandy siltstone and silty sandstone that exhibit a vaguely defined low-amplitude waviness on their stratification planes, ripple-laminated siltstone and sandstone, and wellsorted horizontally laminated to bedded sandstone and silty sandstone in which the bedding surfaces are slightly wavy. These rocks from thin to very thick beds interstratified with the structureless to horizontally bedded siltstone, and less commonly with other lithologic types, in the upper part of the Chinle Formation.

The dominant types of wavy-stratified siltstone and sandstone in the upper part of the Chinle Formation exhibit a vaguely defined low-amplitude waviness on their bedding planes. In some places the bedding planes are marked by films of darker colored finer grained siltstone or claystone or by swarms of claystone pellets. Mud-cracked surfaces, worm borings, and raindrop impressions occur locally. In some places the wavy-stratified siltstone and sandstone grade into rocks that exhibit well-defined ripple laminae, while in other places they grade into, and are difficult to separate from, the structureless to horizontally bedded siltstone. The Wavy-stratified siltstone and sandstone may have been deposited by the sheet-flow action of unconfined currents, or by waves, in shallow water. Most likely they were deposited along lake shores or in or near streams. The presence of mud-cracked surfaces and raindrop impressions indicates that they were sometimes exposed to the air. 
Strata composed of well-defined sets of parallel or cuspate ripple laminae or of horizontal laminae and thin horizontal beds also occur in the upper part of the Chinle Formation but are not as common as the low-amplitude wavy-stratified siltstone and sandstone. The ripple-laminated strata are commonest in areas containing a large amount of troughcross-stratified sandstone and siltstone; one of these areas is a belt extending from west-central Colorado to central Utah. As the ripples in these strata are mostly asymmetrical, indicating deposition by current action, they were probably deposited in stream channels or on river flood plains.

Some well-sorted horizontally laminated to bedded sandstone and silty sandstone, in which the bedding surfaces are slightly wavy, occur in the Chinle Formation and related strata. These rocks are most abundant in the upper part of the Dolores Formation in southwestern Colorado and in the Rock Point Member of the Wingate Sandstone in parts of the Defiance uplift. Their texture closely resembles that of planar-cross-stratified sandstone in the Rock Point Member of the Wingate Sandstone in the Defiance uplift that is believed to be eolian, and possibly these horizontally stratified rocks were formed by fluvial reworking of eolian deposits.

TROUGH-CROSS-STRATIFIED SANDSTONE, SILTSTONE, AND CONGLOMERATE

Trough-cross-stratified sandstone, siltstone, and conglomerate are fairly common in the upper part of the Chinle Formation but have a spotty distribution. They form the main part of the so-called Black Ledge and the Hite Bed, both of which are thin units widespread in southeastern Utah, and are also abundant in the upper Chinle in an elongate belt extending from southwestern Colorado to central Utah (pl. 5 and fig. 33). Trough-cross-stratified sandstone is also common in some other areas on the Colorado Plateau. The scale of the cross-stratification and the presence of local channels indicate that this rock was stream deposited. The so-called Black Ledge and the Hite Bed may be point-bar deposits similar to the Shinarump and Moss Back Members, although they are finer grained and contain more siltstone layers.

The narrow elongate belt of sandstone extending from southwestern Colorado to central Utah (pl. 5 and fig. 33) contains irregular lenses or tabular sheets of sandstone. The sandstone commonly fills channels and is associated with ripple-laminated or horizontally stratified siltstone and sandstone. This belt may mark the position of a large river system in the upper part of the Chinle Formation.

Limestone and siltstone pebble conglomerate and calcarenite are common at some places in the upper part of the Chinle Formation. They are commonly associated with trough-cross-stratified sandstone but also occur as isolated layers. They make up irregular lenses, generally from 0.5 to 3 feet thick, composed of pebbles, granules, or coarse to very coarse grains of limestone, silty limestone, and siltstone in a calcareous and silty matrix. They contain many reptile remains. These conglomerate and calcarenite units were probably formed by reworking of underlying layers by stream action or by bottom currents.

\section{PLANAR-CROSS-STRATIFIED SANDSTONE}

Units of planar-cross-stratified very fine to finegrained sandstone occur in the Rock Point Member of the Wingate Sandstone, a member laterally equivalent to strata in the upper Chinle near the boundary between northeastern Arizona and northwestern New Mexico. The sandstone occurs in units 10 to 50 feet thick containing cross-strata of the tabular-planar, wedge-planar, and trough types. The sandstone in these units is similar to, or identical with, that in the Wingate Sandstone, of which some of the units are tongues.

These cross-stratified sandstone units are believed to be eolian sand-dune deposits. This interpretation is based largely on the type of cross-strata, which is similar to that of modern dunes as illustrated by McKee (1957, figs. 20-22 and pl. 3), Bagnold (1941, pl. 14b), Jones (1953, fig. 3), Thompson (1937), Huntington (1907, pl. 36, fig. 2 and pl. 38), and Beadnell (1910, fig. 11). In addition, high-index ripple marks interpreted as of eolian origin occur locally in the Wingate Sandstone. Ripple marks in the Wingate near Fort Wingate, N. Mex., have a ripple index of $1: 45$, which is characteristic of eolian ripple marks; aqueous ripple marks have indices generally between $1: 4$ and 1:10 (Kindle and Bucher, 1926). Some of the fossils in the upper part of the Chinle Formation indicate dry-land conditions, showing that an environment suitable for the development of sand dunes existed, at least at times.

The eolian units show a cyclic pattern of deposition (fig. 34). The cycle began with deposition of a siltstone and sandy siltstone unit, commonly 50 to 100 feet thick or more, made up of thin to very thick horizontal beds. Next followed deposition of a unit of horizontally laminated and wavy-laminated sandy siltstone and sandstone, generally from 5 to 40 feet thick, that locally contains a few ripple-marked strata, followed in turn by deposition of an eolian unit 10 to 50 feet thick, which completed the cycle. At Chee Dodge, in the Defiance uplift, this cycle is repeated four times in the Rock Point Member. Each 


\begin{tabular}{|c|c|}
\hline $\begin{array}{c}\text { Horizontally stratified siltstone } \\
\text { and sandy siltstone }\end{array}$ & $\begin{array}{l}\text { Beginning of cycle. } \\
\text { Deposition of horizontally strati- } \\
\text { fied siltstone and sandy silt- } \\
\text { stone in a lake. }\end{array}$ \\
\hline 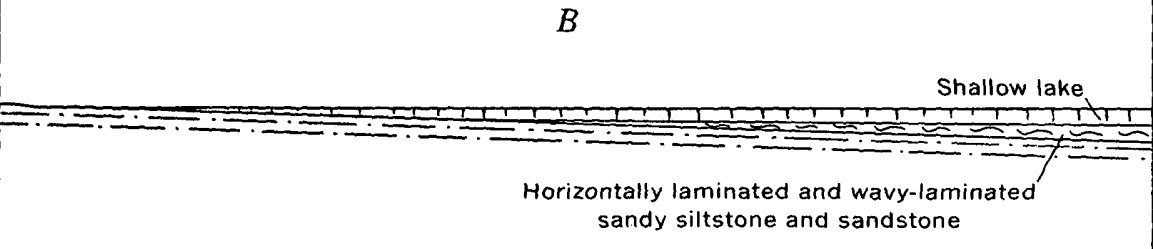 & $\begin{array}{l}\text { Deposition of horizontally lamin- } \\
\text { ated and wavy-laminated sandy } \\
\text { siltstone and sandstone in shallow } \\
\text { lake water. }\end{array}$ \\
\hline Wind direction & $\begin{array}{l}\text { Drying up of lake and formation } \\
\text { of eolian dunes. }\end{array}$ \\
\hline 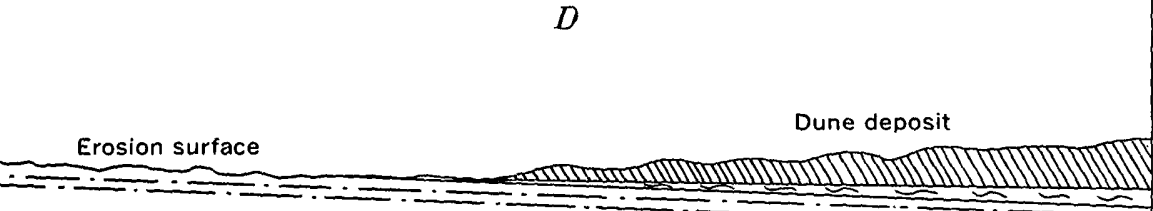 & End of dune deposition. \\
\hline E & $\begin{array}{l}\text { Submergence and deposition of } \\
\text { horizontally stratified siltstone } \\
\text { and sandy siltstone in a lake. } \\
\text { End of cycle. }\end{array}$ \\
\hline
\end{tabular}

Figure 34. - Development of cyclic deposits in Rock Point Member of Wingate Sandstone.

cycle is believed to record the following sequence of events: Gradual drying up of a body of water, formation of dunes, and, finally, return of the lake waters (fig. 34). The horizontally laminated and wavy-stratified layers below the eolian units are probably shallow-water nearshore deposits formed in the receding waters of the lake.

LOCATION AND TERRANE OF SOURCE AREAS

The main source areas for the upper part of the Chinle Formation were the Uncompahgre and Front
Range highlands of Colorado and the Mogollon highland of southeastern Arizona and southwestern New Mexico. The Uncompahgre and Front Range highlands are composed of Precambrian igneous and metasedimentary rocks and are flanked by Paleozoic and lower Mesozoic sedimentary rocks. The Mogollon highland was probably composed mostly of volcanic rocks. Perhaps a land area rose in northwestern Arizona and southwestern Utah at or near the close of Chinle deposition. 
The location of the source areas of the upper part of the Chinle Formation is indicated by the direction of streamflow, facies trends, the distribution of clay types, and stratigraphic breaks in the supposed source areas.

A source of sediment in the Uncompahgre highland of western Colorado and north-central New Mexico is indicated by the general northwest direction of stream flow (fig. 33) in upper Chinle strata in southwestern Colorado to southeastern Utah. Chlorite (Schultz, 1963, fig. 8) occurs in this part of the Chinle near the Uncompahgre highland but not to the west, and a likely source for this mineral is Precambrian igneous and metamorphic rock exposed in the highland. Feldspar is most abundant in the Church Rock and related units near the Uncompahgre highland in southwestern Colorado and adjacent areas (Cadigan, 1957a; "Sedimentary Petrology," this report), and the Uncompahgre highland is a likely source for this mineral also. Finally, the Uncompahgre highland is known to have been a land mass during much of late Paleozoic and early Mesozoic time (Heaton, 1933, 1950) and thus was likely to have been a highland during deposition of the upper part of the Chinle Formation.

The Front Range highland of central Colorado also contributed sediment to the upper part of the Chinle Formation. The general facies pattern for the upper part of the Chinle Formation in northwestern Colorado indicates an increase in coarser current deposits to the east and northeast (pl. 5). Chlorite occurs along the eastern margin of deposition of the upper part of the formation near the Front Range but decreases in quantity to the west, indicating that it probably was derived from the igneous and metamorphic rocks and younger arkosic strata of the highland. Finally, the Front Range highland was a persistent landmass during much of Paleozoic and Mesozoic time (Lovering and Johnson, 1933, p. 372) and thus is likely to have been a highland during deposition of the upper part of the Chinle Formation.

Material was also derived from the Mogollon highland. This source is indicated by an increasing amount of montmorillonitic clay in the upper part of the Chinle Formation, and the related Rock Point Member of the Wingate Sandstone, toward the south (Schultz, 1963, fig. 8 and pl. 4). As outlined before, the montmorillonitic clay in the lower part of the Chinle Formation was mostly derived from the alteration of glassy volcanic detritus derived from the Mogollon highland. In addition, fluvial sandstone units occur in the Rock Point Member of the Wingate Sandstone near its southern limit along the
Arizona-New Mexico State line (pl. 5) but are absent farther north. The upper part of the Chinle Formation near its southern margin contains less montmorillonitic clay and a smaller amount of coarse detritus in comparison with the lower part of the Chinle, suggesting that the Mogollon highland was less prominent topographically and had less volcanic activity during deposition of the upper part of the formation.

A land area may have existed in northwestern Arizona and southwestern Utah during the closing stages of deposition of the Chinle Formation. The possibility of such a land area is suggested by northeast stream directions (Stewart and others, 1959, fig. 79) in a unit (the Hite Bed) at the top of the Chinle Formation in southeastern Utah and by the westward truncation in northwest Arizona and southwest Utah of the Owl Rock Member of the Chinle Formation by overlying units of the Glen Canyon Group toward the supposed land area.

\section{REFERENCES CITED}

Akers, J. P., Cooley, M. E., and Repenning, C. A., 1958, Moenkopi and Chinle formations of Black Mesa [Arizona] and adjacent areas, in New Mexico Geol. Soc. Guidebook 9th Field Conf., Black Mesa Basin, northeastern Arizona, 1958 ; p. 88-94.

Albee, H. F., 1957, Comparison of the pebbles of the Shinarump and Moss Back Members of the Chinle formation [Colorado Plateau]: Jour. Sed. Petrology, v. 27, no. 2, p. 135-142.

Alden, W. C., 1932, Physiography and glacial geology of eastern Montana and adjacent areas: U.S. Geol. Survey Prof. Paper 174, 133 p.

Allen, J. E., and Balk, Robert, 1954, Mineral resources of Fort Defiance and Tohatchi quadrangles, Arizona and New Mexico: New Mexico Bur. Mines and Mineral Resources Bull. 36, 192 p.

Allen, J. R. L., 1963, Asymmetrical ripple marks and the origin of water-laid cosets of cross-strata: Liverpool and Manchester Geol. Jour., v. 3, pt. 2, p. 187-236.

1964 , Studies in fluviatile sedimentation-six cyclothems from the Lower Red Sandstone, Anglo-Welsh basin: Sedimentology, v. 3, no. 3, p. 163-198.

Ash, S. R., 1967, The Chinle (Upper Triassic) megafiora of the Zuni Mountains, New Mexico, in New Mexico Geol. Soc. Guidebook 18th Field Conf., Defiance-Zuni-Mt. Taylor region, Arizona and New Mexico, 1967: p. 125-131.

1969, Ferns from the Chinle Formation (Upper Triassic) in the Fort Wingate area, New Mexico: U.S. Geol. Survey Prof. Paper 613-D, 50 p.

Averitt, Paul, Detterman, J. S., Harshbarger, J. W., Repenning, C. A., and Wilson, R. F., 1955, Revisions in correlation and nomenclature of Triassic and Jurassic formations in southwestern Utah and northern Arizona: Am. Assoc. Petroleum Geologists Bull., v. 39, no. 12, p. 2515-2524.

Bagnold, R. A., 1941, The Physics of blown sand and desert dunes: London, Methuen \& Co., Ltd., 265 p.

Baker, A. A., 1933, Geology and oil possibilities of the Moab district, Grand and San Juan Counties, Utah: U.S. Geol. Survey Bull. 841, 95 p. 
1936, Geology of the Monument Valley-Navajo Mountain region, San Juan County, Utah: U.S. Geol. Survey Bull. 865, 106 p.

1946, Geology of the Green River Desert-Cataract Canyon region, Emery, Wayne, and Garfield Counties, Utah: U.S. Geol. Survey Bull. 951, 122 p.

Baker, A. A., Dane, C. H., and Reeside, J. B., Jr., 1936, Correlation of the Jurassic formations of parts of Utah, Arizona, New Mexico, and Colorado: U.S. Geol. Survey Prof. Paper 183, 66 p.

1947, Revised correlation of Jurassic formations of parts of Utah, Arizona, New Mexico, and Colorado: Am. Assoc. Petroleum Geologists Bull., v. 31, no. 9, p. 1664-1668.

Beadnell, H. J. L., 1910, The sand-dunes of the Libyan Desert: Geol. Jour., v. 35, p. 379-395.

Berry, E. W., 1927, Cycads in the Shinarump conglomerate of southern Utah: Washington Acad. Sci. Jour., v. 17, no. 11, p. 303-307.

1930, A new Pterophyllum from the Shinarump conglomerate in Utah: Washington Acad. Sci. Jour., v. 20, no. 18, p. 458-563.

Black, R. A., Frischknecht, F. C., Hazlewood, R. M., and Jackson, W. H., 1962, Geophysical methods of exploring for buried channels in the Monument Valley area, Arizona and Utah: U.S. Geol. Survey Bull. 1083-F, p. 161-288.

Bradley, W. H., 1929, The varves and climate of the Green River epoch: U.S. Geol. Survey Prof. Paper 158-E, p. 87-110.

1936, Geomorphology of the north flank of the Uinta Mountains [Utah] : U.S. Geol. Survey Prof. Paper 185-I, p. 163-199.

Brady, L. F., 1954, Desmatosuchus in northern Arizona: Plateau, v. 27 , no. 1, p. 19-21.

1958, New occurrence of Desmatosuchus in northern Arizona: Plateau, v. 30 , no. 3 , p. 61-63.

Branson, E. B., and Mehl, M. G., 1929, Triassic amphibians from the Rocky Mountain region: Missouri Univ. Studies, v. 4 , no. 2 , p. $155-255$.

Brill, K. G., Jr., 1944, Late Paleozoic stratigraphy, westcentral and northwestern Colorado: Geol. Soc. America Bull., v. 55, no. 5, p. 621-655.

Brown, R. W., 1956, Palmlike plants from the Dolores formation (Triassic) southwestern Colorado: U.S. Geol. Survey Prof. Paper 274-H, p. 205-209.

Bush, A. L., Bromfield, C. S., and Pierson, C. T., 1959, Areal geology of the Placerville quadrange, San Miguel County, Colorado: U.S. Geol. Survey Bull. 1072-E, p. 299-384.

Butler, B. S., and Wilson, E. D., 1938, General features, Pt. 1 of Some Arizona ore deposits: Arizona Bur. Mines Bull. 145, Geol. Ser. 12, p. 9-25.

Cadigan, R. A., 1957a, Lithologic studies, in Geologic investigations of radioactive deposits - Semiannual progress report, Dec. 1, 1956 to May 31, 1957: U.S. Geol. Survey TEI-690, p. 354-365, issued by U.S. Atomic Energy Comm. Tech. Inf. Service Ext., Oak Ridge, Tenn.

1957b, Lithologic studies, in Geologic investigations of radioactive deposits - Semiannual progress report, June 1 to Nov. 30, 1957: U.S. Geol. Survey TEI-700, p. 124-139, issued by U.S. A tomic Energy Comm. Tech. Inf. Service Ext., Oak Ridge, Tenn.

1959a, Lithologic studies, in Geologic investigations of radioactive deposits - Semiannual progress report, Dec. 1, 1958 to May 31, 1959 : U.S. Geol. Survey TEI-751, p. 47-60, issued by U.S. Atomic Energy Comm. Tech. Inf. Service Ext., Oak Ridge, Tenn.
$1959 \mathrm{~b}$, Characteristics of the host rock, Pt. 2 of Garrels and Larsen, compilers, Geochemistry and mineralogy of the Colorado Plateau uranium ores: U.S. Geol. Survey Prof. Paper 320, p. 13-24.

1961, Geologic interpretation of grain-size distribution measurements of Colorado Plateau sedimentary rocks: Jour. Geology, v. 69, no. 2, p. 121-144.

1967, Petrology of the Morrison Formation in the Colorado Plateau region: U.S. Geol. Survey Prof. Paper $556,113 \mathrm{p}$.

Camp, C. L., 1930, A study of the phytosaurs with description of new material from western North America: California Univ. Mem., v. 10, 174 p.

1956, Triassic Dicynodonts compared, Pt. 2 of Triassic dicynodont reptiles: California Univ. Mem., v. 13, no. 4, p. 305-341.

Camp, C. L., Colbert, E. H., McKee, E. D., and Welles, S. P., 1947, A guide to the continental Triassic of northern Arizona: Plateau, v. 20, no. 1, p. 1-9.

Camp, C. L., and Welles, S. P., 1956, The North American genus Placerias [Arizona], Pt. 1 of Triassic dicynodont reptiles: California Univ. Mem., v. 13, no. 4, p. 255-304.

Case, E. C., 1920, Preliminary description of a new suborder of phytosaurian reptiles, with a description of a new species of Phytosaurus: Jour. Geology, v. 28, no. 16, p. 524-535.

Cater, F. W., Jr., 1955a, Geology of the Gateway quadrangle, Colorado: U.S. Geol. Survey Geol. Quad. Map GQ-55, scale $1: 24,000$.

$1955 \mathrm{~b}$, Geology of the Pine Mountain quadrangle, Colorado: U.S. Geol. Survey Geol. Quad. Map GQ-60, scale $1: 24,000$.

$1955 \mathrm{c}$, Geology of the Calamity Mesa quadrangle, Colorado: U.S. Geol. Survey Geol. Quad. Map GQ-61, scale $1: 24,000$.

Colbert, E. H., 1947a, Little dinosaurs of Ghost Ranch [New Mexico] : Nat. History, v. 56, no. 9, p. 392-399, 427-428.

$1947 \mathrm{~b}$, Studies of the phytosaurs Machaeroprosopus and Rutiodon [Arizona, North Carolina]: Am. Museum Nat. History Bull., v. 88, art. 2, p. 53-96.

1948, Triassic life in the southwestern United States: New York Acad. Sci. Trans., ser. 2, v. 10, no. 7, p. 229235.

1950, Mesozoic vertebrate faunas and formations of northern New Mexico, in Soc. Vertebrate Paleontology Guidebook 4th Field Conf., Northwestern New Mexico, 1950: p. 57-73.

1952, A pseudosuchian reptile from Arizona: Am. Mus. Nat. History Bull., v. 99, art. 10, p. 561-592.

1955, Evolution of the vertebrates - A history of the backboned animals through time: New York, John Wiley \& Sons, 479 p.

1957, Triassic vertebrates of the Wind River Basin, in Wyoming Geol. Assoc. Guidebook 12th Ann. Field Conf., southwest Wind River Basin, 1957: p. 89-93.

1960, Triassic rocks and fossils, in New Mexico Geol. Soc. Guidebook 11th Field Conf., Rio Chama country, 1960 : p. 55-62.

Colbert, E. H., and Imbrie, John, 1956, Triassic metoposaurid amphibians: Am. Mus. Nat. History Bull., v. 110, art 6, p. 399-452.

Colby, B. R., Matejka, D. Q., and Hubbell, D. W., 1953, Investigations of fluvial sediments of the Niobrara River near Valentine, Nebraska: U.S. Geol. Survey Circ. 205, 57 p. 
Collier, A. J., and Thom, W. T., Jr., 1918, The Flaxville gravel and its relation to other terrace gravels of the northern Great Plains: U.S. Geol. Survey Prof. Paper 108, p. 179-184.

Cooley, M. E., 1957, Geology of the Chinle Formation in the upper Little Colorado drainage area, Arizona and New Mexico: Tucson, Arizona Univ. M.S. thesis, 320 p.

1958, The Mesa Redondo member of the Chinle formation, Apache and Navajo Counties, Arizona: Plateau, v. 31 , no. 1 , p. 7-15.

1959, Triassic stratigraphy in the state line region of west-central New Mexico and east-central Arizona, in New Mexico Geol. Soc. Guidebook 10th Field Conf., westcentral New Mexico, 1959: p. 66-73.

Cope, E. D., 1875, Report on the geology of that part of northwestern New Mexico, examined during the field season of 1874: U.S. Geog. Surveys West of 100 th Meridian (Wheeler) Ann. Rept., App. GI, p. 61-97.

1881, Belodon in New Mexico: Am. Naturalist, v. 15, p. 922-923.

1887a, The dinosaurian genus Coelurus: Am. Naturalist, v. 21, p. 367-369.

$1887 \mathrm{~b}, \mathrm{~A}$ contribution to the history of the vertebrata of the Trias of North America: Am. Philos. Soc. Proc., v. 24, p. $209-228$.

1889, On a new genus of Triassic Dinosauria [Coelophysis] : Am. Naturalist, v. 23, p. 626.

Cross, Whitman, 1899, Description of the Telluride quadrangle [Colorado]: U.S. Geol. Survey Geol. Atlas, Folio 57.

1907, Stratigraphic results of a reconnaissance in western Colorado and eastern Utah: Jour. Geology, v. 15, p. 634-679.

Cross, Whitman, and Hole, A. D., 1910, Description of the Engineer Mountain quadrangle, Colorado: U.S. Geol. Survey Geol. Atlas, Folio 171.

Cross, Whitman, and Howe, Ernest, 1905a, Description of the Silverton quadrangle [Colorado]: U.S. Geol. Survey Geol. Atlas, Folio 120.

$1905 \mathrm{~b}$, Red Beds of southwestern Colorado and their correlation: Geol. Soc. America Bull., v. 16, p. 447-498.

Cross, Whitman, Howe, Ernest, and Irving, J. D., 1907, Description of the Ouray quadrangle [Colorado]: U.S. Geol. Survey Geol. Atlas, Folio 153.

Dane, C. H., 1935, Geology of the Salt Valley anticline and adjacent areas, Grand County, Utah: U.S. Geol. Survey Bull. 863, 184 p.

1948, Geologic map of part of eastern San Juan Basin, Rio Arriba County, New Mexico: U.S. Geol. Survey Oil and Gas Inv. (Prelim.) Map 78, scale approx. 1 in. to 1 mile.

Darton, N. H., 1922, Geologic structure of parts of New Mexico: U.S. Geol. Survey Bull. 726, p. 173-275.

1925, A résumé of Arizona geology: Arizona Bur. Mines Bull. 119, 298 p.

1928, "Red beds" and associated formations in New Mexico, with an outline of the geology of the State: U.S. Geol. Survey Bull. 794, 356 p.

Daugherty, L. H., 1934, Shilderia admanica, a new fossil wood from the petrified forests of Arizona: Bot. Gazette, v. 7, no. 2 , p. 363-366.

1941, The Upper Triassic flora of Arizona, with a discussion of its geologic occurrence by H. R. Stagner: Carnegie Inst. Washington Pub. 526, Contr. Paleontology, $108 \mathrm{p}$.
Davidson, E. S., Carswell, L. D., and Miller, G. A., 1957, Circle Cliffs, Utah, in Geologic investigations of radioactive deposits - Semiannual progress report, Dec. 1, 1956 to May 31, 1957: U.S. Geol. Survey TEI-690, p. 124-129, issued by U.S. Atomic Energy Comm. Tech. Inf. Service Ext., Oak Ridge, Tenn.

Dings, M. G., and Robinson, C. S., 1957, Geology and ore deposits of the Garfield quadrangle, Colorado: U.S. Geol. Survey Prof. Paper 289, 110 p.

Donner, H. F., 1949, Geology of the McCoy area, Eagle and Routt Counties, Colorado: Geol. Soc. America Bull., v. 60 , no. 8, p. 1215-1247.

Eastman, C. R., 1917, Fossil fishes in the collection of the United States National Museum: U.S. Natl. Mus. Proc., v. 52, pub. 2177, p. 235-304.

Eckel, E. B., and others, 1949, Geology and ore deposits of the La Plata district, Colorado: U.S. Geol. Survey Prof. Paper 219, $179 \mathrm{p}$.

Emery, K. O., 1954, Some characteristics of southern California sediments: Jour. Sed. Petrology, v. 24, p. 50-59.

Finch, W. I., 1959, Geology of uranium deposits in Triassic rocks of the Colorado Plateau region: U.S. Geol. Survey Bull. 1074-D, p. 125-164.

Fisk, H. N., 1944, Geological investigation of the alluvial valley of the lower Mississippi River: U.S. Mississippi River Comm. Rept., 78 p.

1947, Fine-grained alluvial deposits and their effects on Mississippi River activity: U.S. Mississippi River Comm., v. 1, $82 \mathrm{p}$.

Fisk, H. N., McFarlan, E., Jr., Kolb, C. R., and Wilbert, L. J., Jr., 1954, Sedimentary framework of the modern Mississippi delta [Louisiana]: Jour. Sed. Petrology, v. 24, no. 2, p. 76-99.

Fontaine, W. M., and Knowlton, F. H., 1890, Notes on Triassic plants from New Mexico: U.S. Natl. Museum Proc., v. 13, pub. 821 , p. 281-285.

Frazier, D. E., and Osanik, A., 1961, Point-bar deposits, Old River Locksite, Louisiana: Gulf Coast Assoc. Geol. Soc. Trans., v. 11, p. 127-137.

Gabelman, J. W., and Brown, H. G., 3d, 1955, Possible Triassic chalcocite placer, Rio Arriba County, New Mexico [abs.]: Geol. Soc. America Bull., v. 66, p. 1674.

Gilbert, G. K., 1875, Report on the geology of portions of Nevada, Utah, California, and Arizona, examined in the years 1871 and 1872 : U.S. Geog. and Geol. Surveys West of 100th Meridian (Wheeler), v. 3, p. 17-187.

Gilluly, James, 1929, Geology and oil and gas prospects of part of the San Rafael Swell, Utah: U.S. Geol. Survey Bull. 806, p. 69-130.

1956, General geology of central Cochise County, Arizona: U.S. Geol. Survey Prof. Paper 281, 169 p.

Gilluly, James, and Reeside, J. B., Jr., 1928, Sedimentary rocks of the San Rafael Swell and some adjacent areas in eastern Utah: U.S. Geol. Survey Prof. Paper 150, p. 61-110.

Goddard, E. N. (chm.) and others, 1948, Rock-color chart: Washington, D. C., Natl. Research Council; reprinted by Geol. Soc. America, 1951.

Gregory, H. E., 1914, A reconnaissance of a portion of the Little Colorado Valley, Arizona: Am. Jour. Sci., 4th ser., v. 38, p. $491-501$.

1915, The igneous origin of the "glacial deposits" on the Navajo Reservation, Arizona and Utah: Am. Jour. Sci., 4th ser., v. 40, p. 97-115. 
1916, The Navajo country, a geographic and hydrographic reconnaissance of parts of Arizona, New Mexico, and Utah: U.S. Geol. Survey Water-Supply Paper 380, 219 p.

1917, Geology of the Navajo country - A reconnaissance of parts of Arizona, New Mexico, and Utah: U.S. Geol. Survey Prof. Paper 93, 161 p.

1938, The San Juan country, a geographic and geologic reconnaissance of southeastern Utah, with contributions by M. R. Thorpe and H. D. Miser: U.S. Geol. Survey Prof. Paper 188, 123 p.

1948, Geology and geography of central Kane County, Utah: Geol. Soc. America Bull., v. 59, no. 8, p. 211-247.

1950, Geology and geography of the Zion Park region, Utah and Arizona: U.S. Geol. Survey Prof. Paper 220, $200 \mathrm{p}$.

Gregory, H. E., and Moore, R. C., 1931, The Kaiparowits region, a geographic and geologic reconnaissance of parts of Utah and Arizona: U.S. Geol. Survey Prof. Paper 164, $161 \mathrm{p}$.

Gregory, H. E., and Williams, N. C., 1947, Zion National Monument, Utah: Geol. Soc. America Bull., v. 58, no. 3, p. 211-244.

Gregory, J. T., 1953a, Typothorax and Desmatosuchus: Yale Univ. Peabody Mus. Nat. History, Postilla 16, 27 p.

1953b, Typothorax scutes from Germany: Yale Univ. Peabody Museum Nat. History, Postilla 15, 6 p.

Grose, L. T., 1959, Structure and petrology of the northeast part of the Soda Mountains, San Bernardino County, California: Geol. Soc. America Bull., v. 70, no. 12, pt. 1, p. 1509-1548.

Hack, J. T., 1955, Geology of the Brandywine area and origin of the upland of southern Maryland: U.S. Geol. Survey Prof. Paper 267-A, p. 1-43.

Hamilton, W. B., 1951, Playa sediments of Rosamond Dry Lake, California: Jour. Sed. Petrology, v. 21, p. 147-150.

Hansen, W. R., 1955, Geology of the Flaming Gorge quadrangle, Utah-Wyoming: U.S. Geol. Survey Geol. Quad. Map GQ-75, scale $1: 24,000$.

Happ, S. C., 1948, Sedimentation in the middle Rio Grande Valley, New Mexico: Geol. Soc. America Bull., v. 59, no. 12, pt. 1, p. 1191-1215.

Harms, J. C., and Fahnestock, R. K., 1965, Stratification, bed forms, and flow phenomena (with an example from the Rio Grande), in Primary sedimentary structures and their hydrodynamic interpretation: Soc. Econ. Paleontologists and Mineralogists Special Pub. 12, p. 84-115.

Harms, J. C., MacKenzie, D. B., and McCubbin, D. G., 1963, Stratification in modern sands of the Red River, Louisiana: Jour. Geology, v. 71, no. 5, p. 566-580.

Harshbarger, J. W., Repenning, C. A., and Irwin, J. H., 1957, Stratigraphy of the uppermost Triassic and Jurassic rocks of the Navajo country [Colorado Plateau]: U.S. Geol. Survey Prof. Paper 291, 74 p.

Harshbarger, J. W., and others, 1961, Maps of Navajo Indian Reservation and vicinity, Arizona: U.S. Geol. Survey open-file maps, 9 figs.

Hayes, P. T., Simons, F. S., and Raup, R. B., 1965, Lower Mesozoic extrusive rocks in southeastern Arizona - $\mathrm{Ca}$ nele Hills Volcanics: U.S. Geol. Survey Bull. 1194-M, 9 p.

Heaton, R. L., 1933, Ancestral Rockies and Mesozoic and late Paleozoic stratigraphy of Rocky Mountain region: Am. Assoc. Petroleum Geologists Bull., v. 17, no. 2, p. 109-168. 1950, Late Paleozoic and Mesozoic history of Colo- rado and adjacent areas: Am. Assoc. Petroleum Geologists Bull., v. 34, no. 8, p. 1659-1698.

Henderson, Junius, 1934, Some new Mesozoic mollusca from the Rocky Mountain region and Arizona: Jour. Paleontology, v. 8, no. 3, p. 259-263.

Hesse, C. J., 1935, Semionotus cf. gigas, from the Triassic of Zion Park, Utah: Am. Jour. Sci., 5th ser., v. 29, p. 526531.

Hewett, D. F., 1956, Geology and mineral resources of the Ivanpah quadrangle, California and Nevada: U.S. Geol. Survey Prof. Paper 275, 172 p.

Hills, R. C., 1880, Note on the occurrence of fossils in the Triassic and Jurassic beds near San Miguel in Colorado: Am. Jour. Sci., 3d ser., v. 19, p. 490.

Hough, J. L., 1958, Geology of the Great Lakes: Urbana, Illinois Univ. Press, 313 p.

Howell, E. E., 1875, Report on the geology of portions of Utah, Nevada, Arizona, and New Mexico, examined in 1872 and 1873: U.S. Geog. and Geol. Surveys West of 100th Meridian (Wheeler), v. 3, p. 227-301.

Hubert, J. F., 1954, Structure and stratigraphy of an area east of Brush Creek, Eagle County, Colorado: Colorado Univ., M.S. thesis.

Huddle, J. W., and McCann, F. T., 1947, Late Paleozoic rocks exposed in the Duchesne River area, Duchesne County, Utah: U.S. Geol. Survey Circ. 16, 21 p.

Huene, Friedrich von, 1911, Kurze Mitteilung über Perm, Trias and Jura in New Mexico: Neues Jahrb. Mineralogie, Geologie, u. Paläontologie Beil.-Band 32, p. 730-739. 1915, On reptiles of the New Mexican Trias in the Cope collection: Am. Museum Nat. History Bull. 34, p. 485-507.

1926, Notes on the age of the continental Triassic beds in North America, with remarks on some fossil vertebrates: U.S. Natl. Museum Proc., v. 69, 10 p.

Hunt, C. B., 1953, Geology and geography of the Henry Mountains region, Utah: U.S. Geol. Survey Prof. Paper 228, 234 p. [1954].

Hunt, C. B., Varnes, H. D., and Thomas, H. E., 1953, Lake Bonneville - Geology of northern Utah Valley, Utah: U.S. Geol. Survey Prof. Paper 257-A, p. 1-99.

Huntington, Ellsworth, 1907, Some characteristics of the glacial period in nonglaciated regions: Geol. Soc. America Bull., v. 18, p. 351-388.

Intermountain Association of Petroleum Geologists, 1955, Guidebook to the geology of northwest Colorado, 6th Ann. Field Conf., 1955, held with Rocky Mtn. Assoc. Geologists, Ann. Field Conf.: 185 p.

Jeffrey, E. C., 1910, A new araucarian genus from the Triassic: Boston Soc. Nat. History Proc., v. 34, p. 325-332.

Johnson, B. K., 1957, Geology of a part of the Manly Peak quadrangle, southern Panamint Range, California: California Univ. Pubs., Dept. Geol. Sci. Bull., v. 30, no. 5, p. 353-424.

Johnson, H. S., Jr., 1959, Uranium resources of the Green River and Henry Mountains districts, Utah - A regional synthesis: U.S. Geol. Survey Bull. 1087-C, p. 59-104.

1964, Alteration of Chinle siltstone and uranium emplacement, Arizona and Utah - Discussion: Geol. Soc. America Bull., v. 75, no. 8, p. 775-776.

Johnson, H. S., Jr., and Thordarson, William, 1959, The Elk Ridge-White Canyon channel system, San Juan County, Utah - Its effect on uranium distribution: Econ. Geology, v. 54, no. 1, p. 119-129. 
Johnston, W. A., 1921, Sedimentation of the Fraser River delta: Canada Geol. Survey Mem. 125, 46 p.

Jones, D. J., 19.53, Gypsum-oolite dunes, Great Salt Lake Desert, Utah: Am. Assoc. Petroleum Geologists Bull., v. 37 , p. 2530-2538.

Keller, W. D., 1953, Analcime in the Chinle formation of Utah, correlative with the Popo Agie of Wyoming: Jour. Sed. Petrology, v. 23, no. 1, p. 10-12.

Kelley, V. C., and Wood, G. H., Jr., 1946, Lucero uplift, Valencia, Socorro, and Bernalillo Counties, New Mexico: U.S. Geol. Survey Oil and Gas Inv. (Prelim.) Map 47, scale approx. $1 \mathrm{in}$. to 1 mile.

Kerr, P. F., and Abdel-Gawad, A. M., 1964, Alteration of Chinle siltstone and uranium emplacement, Arizona and Utah-Reply: Geol. Soc. America Bull., v. 75, no. 8, p. 777-780.

Kiersch, G. A., 1955, Nonmetallic minerals - Geology, evaluation, and uses, v. 2 of Mineral resources Navajo-Hopi Indian Reservations, Arizona-Utah: Tucson, Univ. Arizona Press, 105 p.

1956, Metalliferous minerals and mineral fuels, Geology, evaluation, and uses, with a section on general geology, v. 1 of Mineral resources Navajo-Hopi Indian Reservations, Arizona-Utah: Tucson, Univ. Arizona Press, $75 \mathrm{p}$.

Kindle, E. M., and Bucher, W. H., 1926, Ripple mark and its interpretation, in Twenhofel, W. H., Treatise on sedimentation: Baltimore, Md., Williams \& Wilkins Co., p. 451-483.

Kinney, D. M., 1951, Geology of the Uinta River and Brush Creek-Diamond Mountain areas, Duchesne and Uintah Counties, Utah: U.S. Geol. Survey Oil and Gas Inv. Map OM-123, scale $1: 63,360$.

1955, Geology of the Uinta River-Brush Creek area, Duchesne and Uintah Counties, Utah: U.S. Geol. Survey Bull. 1007, $185 \mathrm{p}$.

Kinney, D. M., and Rominger, J. F., 1947, Geology of the Whiterocks River-Ashley Creek area, Uintah County, Utah: U.S. Geol. Survey Oil and Gas Inv. Prelim. Map 82 , scale approx. 1 in. to 1 mile.

Knowlton, F. H., 1888, New species of fossil wood (Araucarioxylon arizonicum) from Arizona and New Mexico: U.S. Natl. Museum Proc., v. 11, p. 1-4.

1913, The fossil forests of Arizona: Am. Forestry, v. 19 , p. $207-218$.

1919, A catalogue of the Mesozoic and Cenozoic plants of North America: U.S. Geol. Survey Bull. 696, 815 p.

Krumbein, W. C., 1941, Measurement and geologic significance of shape and roundness of sedimentary particles: Jour. Sed. Petrology, v. 11, no. 2, p. 64-72.

Langenheim, R. L., Jr., 1957, Jurassic stratigraphy in Elk Mountains, west-central Colorado: Am. Assoc. Petroleum Geologists Bull., v. 41, no. 11, p. 2576-2581.

Larsen, E. S., Jr., and Cross, Whitman, 1956, Geology and petrology of the San Juan region, southwestern Colorado: U.S. Geol. Survey Prof. Paper 258, 303 p.

Lasky, S. G., 1936, Geology and ore deposits of the Bayard area, Central mining district, New Mexico: U.S. Geol. Survey Bull. 870, 144 p.

Lee, W. T., 1907, The Iron County coal field, Utah: U.S. Geol. Survey Bull. 316, p. 359-375.

Lewis, G. E., Irwin, J. H., and Wilson, R. F., 1961, Age of Glen Canyon Group (Triassic and Jurassic) on the Colorado Plateau: Geol. Soc. America Bull., v. 72, no. 9, p. 1437-1440.
Lewis, R. Q., Sr., and Campbell, R. H., 1965, Geology and uranium deposits of Elk Ridge and vicinity, San Juan County, Utah: U.S. Geol. Survey Prof. Paper 474-B, 69 p.

Lewis, R. Q., Sr., and Trimble, D. E., 1959, Geology and uranium deposits of Monument Valley, San Juan County, Utah: U.S. Geol. Survey Bull. 1087-D, p. 105-131.

Longwell, C. R., 1928, Geology of the Muddy Mountains, Nevada, with a section through the Virgin Range to the Grand Wash Cliffs, Arizona: U.S. Geol. Survey Bull. 798, $152 \mathrm{p}$.

1949, Structure of the northern Muddy Mountains area, Nevada: Geol. Soc. America Bull., v. 60, no. 5, p. 923-967.

1952, Basin and Range geology west of the St. George basin, Utah, in Thune, H. W., ed., Cedar City, Utah, to Las Vegas, Nevada, Utah Geol. Soc. Guidebook 7: p. 2442; also Intermountain Assoc. Petroleum Geologists $3 \mathrm{~d}$ Ann. Field Conf.

Longwell, C. R., Miser, H. D., Moore, R. C., Bryan, Kirk, and Paige, Sidney, 1923, Rock formations in the Colorado Plateau of southeastern Utah and northern Arizona: U.S. Geol. Survey Prof. Paper 132-A, p. 1-23.

Lookingbill, J. L., 1953, Stratigraphy and structure of the Gallina uplift, Rio Arriba County, New Mexico: Albuquerque, New Mexico Univ. M.S. thesis.

Lorens, P. J., and Thronson, R. E., 1955, Geology of the finegrained alluvial deposits in Sacramento Valley and their relationship to seepage, in Seepage conditions in Sacramento Valley: California Div. Water Rept. to Water Project Authority, p. A1-A26.

Lovering, T. S., and Goddard, E. N., 1950, Geology and ore deposits of the Front Range, Colorado: U.S. Geol. Survey Prof. Paper 223, 319 p.

Lovering, T. S., and Johnson, J. H., 1933, Meaning of unconformities in stratigraphy of central Colorado: Am. Assoc. Petroleum Geologists Bull., v. 17, no. 4, p. 353-374.

Lucas, F. A., 1898, A new crocodile from the Trias of southern Utah, in Contributions to paleontology: Am. Jour. Sci., 4th ser., v. 6, p. 399.

1901, Vertebrates from the Trias of Arizona: Science, new ser., v. 14, p. 376 .

1904, A new batrachian and a new reptile from the Trias of Arizona: U.S. Natl. Mus. Proc., v. 27, pub. 1353, p. 193-195.

Lull, R. S., 1947, Organic evolution [rev. ed.]: New York, Macmillan Co., 744 p.

McKee, E. D., 1936, Triassic pebbles in northern Arizona containing invertebrate fossils: Am. Jour. Sci., 5th ser., v. 33 , p. $260-263$.

1957, Primary structures in some Recent sediments [U.S. and Mexico]: Am. Assoc. Petroleum Geologists Bull., v. 41, no. 8, p. 1704-1747.

1965, Experiments on ripple lamination, in Primary sedimentary structures and their hydrodynamic interpretation: Soc. Econ. Paleontologists and Mineralogists Spec. Pub. 12, p. 66-83.

McKee, E. D., Oriel, S. S., Ketner, K. B., MacLachlan, M. E., Goldsmith, J. W., MacLachlan, J. C., and Mudge, M. R., 1959, Paleotectonic maps of the Triassic system: U.S. Geol. Survey Misc. Geol. Inv. Map I-300, 33 p.

McKee, E. D., and Weir, G. W., 1953, Terminology for stratification and cross-stratification in sedimentary rocks: Geol. Soc. America Bull., v. 64, p. 381-390.

McKnight, E. T., 1940, Geology of area between Green and 
Colorado Rivers, Grand and San Juan Counties, Utah: U.S. Geol. Survey Bull. 908, 147 p.

Marcou, Jules, 1855, Résumé of a geological reconnaissance extending from Napoleon, at the junction of the Arkansas with the Mississippi, to the Pueblo de los Angeles in California, in Whipple, A. W., Report of explorations for a railway route near the thirty-fifth parallel of latitude from the Mississippi River to the Pacific Ocean: U.S. Pacific RR. Explor. Railway Route Mississippi to Pacific, v. 3, pt. 4, p. 165-171; also U.S. Cong., 33d., 1st sess., House Ex. Doc. 129, v. 18, pt. 2.

1858, Geology of North America: Zurich, Zürcher and Furrer, and New York, Wiley and Holstead, 144 p.; revised by J. D. Dana, Am. Jour. Sci., 2d ser., v. 26, p. 323-333.

Maxey, G. B., 1946, Geology of part of the Parant Range, Millard County, Utah: Am. Jour. Sci., v. 244, no. 5, p. 324-356.

Mehl, M. G., 1915, New reptiles from the Trias of Arizona and New Mexico: Science, new ser., v. 41, p. 735.

1928, Pseudopalatus pristinus, a new genus and species of phytosaurs from Arizona: Missouri Univ. Studies, v. 3 , no. 1 , p. 3-22.

Mehl, M. G., Toepelmann, W. C., and Schwartz, G. M., 1916, New or little known reptiles from the Trias of Arizona and New Mexico, with notes on the fossil bearing horizons near Wingate, New Mexico: Oklahoma Univ. Bull., new ser., no. 103, $44 \mathrm{p}$.

Merriam, C. W., 1963, Geology of the Cerro Gordo mining district, Inyo County, California: U.S. Geol. Survey Prof. Paper 408, 83 p.

Montgomery, Arthur, 1956, Precambrian geology of the Picuris Range, north-central New Mexico, in New Mexico Geol. Soc. Guidebook 7th Field Conf., southeastern Sangre de Christo Mountains, New Mexico, 1956: p. 143-146.

Moore, R. C., Lalicker, C. G., and Fischer, A. G., 1952, Invertebrate fossils [1st ed.] : New York, McGraw-Hill Book Co., $766 \mathrm{p}$.

Muehlberger, W. R., 1957, Pennsylvanian outcrops along Brazos uplift, Rio Arriba County, New Mexico: Am. Assoc. Petroleum Geologists Bull., v. 41, no. 1, p. 140-145.

Mullens, T. E., 1960, Geology of the Clay Hills area, San Juan County, Utah: U.S. Geol. Survey Bull. 1087-H, p. 259-336.

Newberry, J. S., 1861, Geological report, in Ives, J. C., Report upon the Colorado River of the West, explored in 1857 and 1858 by Lt. Joseph C. Ives: U.S. Engineer Dept. Geol. Rept., pt. 3, 154 p.

1876, Descriptions of the Carboniferous and Triassic fossils collected, in Macomb, J. N., Report of the exploring expedition from Santa Fe, New Mexico, to the junction of the Grand and Green Rivers of the Great Colorado of the West in 1859: U.S. Army Eng. Dept., p. 135-148.

O'Sullivan, R. B., 1970, The upper part of the Upper Triassic Chinle Formation and related rocks, southeastern Utah and adjacent areas: U.S. Geol. Survey Prof. Paper 644-E, $22 \mathrm{p}$.

Paige, Sidney, 1922, Copper deposits of the Tyrone district, New Mexico: U.S. Geol. Survey Prof. Paper 122, 53 p.

Phoenix, D. A., 1957, The Lees Ferry area, in Geologic investigations of radioactive deposits - Semiannual progress report, Dec. 1, 1956 to May 31, 1957: U.S. Geol. Survey TEI-690, p. 154-159, issued by U.S. Atomic Energy Comm. Tech. Inf. Service Ext., Oak Ridge, Tenn. 1963, Geology of the Lees Ferry area, Coconino County, Arizona: U.S. Geol. Survey Bull. 1137, 86 p.
Poole, F. G., 1954, Geology of the southern Grand Hogback area, Garfield and Pitkin Counties, Colorado: Boulder, Colorado Univ. M.S. thesis.

1961, Stream directions in Triassic rocks of the Colorado Plateau, in Short papers in the geologic and hydrologic sciences: U.S. Geol. Survey Prof. Paper 424-C, p. C139-C141.

1962, Wind directions in late Paleozoic to middle Mesozoic time on the Colorado Plateau, in Geological Survey research 1962: U.S. Geol. Survey Prof. Paper 450-D, p. D147-D151.

Poole, F. G., and Stewart, J. H., 1964, Chinle Formation and Glen Canyon Sandstone in northeastern Utah and northwestern Colorado, in Geological Survey research 1964: U.S. Geol. Survey Prof. Paper 501-D, p. D30-D39.

Poole, F. G., and Williams, G. A., 1956, Direction of sediment transport in the Triassic and associated formations of the Colorado Plateau, in Page, L. R., Stocking, H. E., and Smith, H. B., compilers, Contributions to the geology of uranium and thorium by the United States Geological Survey and Atomic Energy Commission for the United Nations International Conference on Peaceful Uses of Atomic Energy, Geneva, Switzerland, 1955: U.S. Geol. Survey Prof. Paper 300, p. 227-231.

Powell, J. W., 1873, Some remarks on the geological structure of a district of country lying to the north of the Grand Canyon of the Colorado: Am. Jour. Sci., 3d ser., v. 5, p. 456-465.

1876, Report on the geology of the eastern portion of the Uinta Mountains and a region of country adjacent thereto: U.S. Geol. and Geog. Survey Terr. (Powell), 2d div., $218 \mathrm{p}$.

Read, C. B., Wood, G. H., Wanek, A. A., and Mackee, P. V., 1949, Stratigraphy and geologic structure in the Piedra River Canyon, Archuleta County, Colorado: U.S. Geol. Survey Oil and Gas Inv. (Prelim.) Map 96, scale approx. 1 in. to 1 mile.

Reeside, J. B., Jr., 1927, Two new unionid pelecypods from the upper Triassic: Washington Acad. Sci. Jour., v. 17, no. 19 , p. 476-478.

Reeside, J. B., Jr. (chm.), and others, 1957, Correlation of the Triassic formations of North America exclusive of Canada, with a section on Correlation of continental Triassic sediments by vertebrate fossils, by E. H. Colbert and J. T. Gregory: Geol. Soc. America Bull., v. 68, no. 11, p. 1451-1513.

Reiche, Parry, 1938, An analysis of cross-lamination; the Coconino sandstone: Jour. Geology, v. 46, no. 7, p. 905-932.

Repenning, C. A., Cooley, M. E., and Akers, J. P., 1969, Stratigraphy of the Chinle and Moenkopi Formations, Navajo and Hopi Indian Reservations, Arizona, New Mexico, and Utah: U.S. Geol. Survey Prof. Paper 521-B, $34 \mathrm{p}$.

Robeck, R. C., 1956, Temple Mountain member - New member of Chinle formation in San Rafael Swell, Utah: Am. Assoc. Petroleum Geologists Bull., v. 40, no. 10, p. 24992506.

Robinson, W. I., 1915, Two new fresh-water gastropods from the Mesozoic of Arizona: Am. Jour. Sci., 4th ser., v. 40, p. 649-651.

Rocky Mountain Association of Geologists, 1957, Guidebook to the geology of North and Middle Parks basin, Colorado, 9th Ann. Field Conf., Denver, Colo., 1957: 152 p.

Rolfe, B. N., 1957, Surficial sediments in Lake Mead [ArizonaNevada]: Jour. Sed. Petrology, v. 27, no. 7, p. 378-386. 
Ross, C. P., 1925, Geology and ore deposits of the Aravaipa and Stanley mining district, Graham County, Arizona: U.S. Geol. Survey Bull. 763, 120 p.

Schaeffer, Bobb, 1967, Late Triassic fishes from the Western United States: Am. Museum Nat. History Bull., v. 135, art. 6, p. 287-342.

Schaeffer, Bobb, and Dunkle, D. H., 1950, A semionotid fish from the Chinle formation, with consideration of its relationships: Am. Museum Novitates, No. 1457, 29 p.

Schlee, John, 1957, Upland gravels of southern Maryland: Geol. Soc. America Bull., v. 68, no. 10, p. 1371-1409.

Schultz, L. G., 1963, Clay minerals in Triassic rocks of the Colorado Plateau: U.S. Geol. Survey Bull. 1147-C, p. C1-C71.

Sheridan, D. S., 1950, Permian(?), Triassic, and Jurassic stratigraphy of the McCoy area of west-central Colorado: Compass, v. 27, p. 126-147; abs. in Geol. Soc. America Bull., v. 61, p. 1559.

Shoemaker, E. M., 1955, Geology of the Juanita Arch quadrangle, Colorado: U.S. Geol. Survey Geol. Quad. Map GQ-81, scale $1: 24,000$.

$1956 a$, Precambrian rocks of the north-central Colorado Plateau, in Intermountain Assoc. Petroleum Geologists Guidebook 7th Ann. Field Conf., Geology and economic deposits of east-central Utah, 1956: p. 54-57.

$1956 \mathrm{~b}$, Geology of the Roc Creek quadrangle, Colorado: U.S. Geol. Survey Geol. Quad. Map GQ-83, scale $1: 24,000$.

Shoemaker, E. M., and Newman, W. L., 1959, Moenkopi formation (Triassic? and Triassic) in salt anticline region, Colorado and Utah: Am. Assoc. Petroleum Geologists Bull., v. 43, no. 8, p. 1835-1851.

Silver, Caswell, 1948, Jurassic overlap in western New Mexico: Am. Assoc. Petroleum Geologists Bull., v. 32, no. 1, p. 68-81.

Sloss, L. L., Krumbein, W. C., and Dapples, E. C., 1949, Integrated facies analysis, in Longwell, C. R., chm., Sedimentary facies in geologic history: Geol. Soc. America Mem. 39, p. 91-124.

Stark, J. T., and others, 1949, Geology and origin of South Park, Colorado: Geol. Soc. America Mem. 33, 188 p.

Stewart, J. H., 1957, Proposed nomenclature of part of Upper Triassic strata in southeastern Utah: Am. Assoc. Petroleum Geologists Bull., v. 41, no. 3, p. 441-465.

1969, Major Upper Triassic lithogenetic sequences in Colorado Plateau region: Am. Assoc. Petroleum Geologists Bull., v. 53, no. 9, p. 1866-1879.

Stewart, J. H., Poole, F. G., and Wilson, R. F., 1972, Stratigraphy and origin of the Triassic Moenkopi Formation and related strata in the Colorado Plateau region, with a section on Sedimentary petrology, by R. A. Cadigan: U.S. Geol. Survey Prof. Paper 691 (in press).

Stewart, J. H., and Smith, J. F., Jr., 1954, Triassic rocks in the San Rafael Swell, Capital Reef, and adjoining parts of southeastern Utah, in Geology of portions of the High Plateaus and adjacent canyon lands, central and southcentral Utah: Intermountain Assoc. Petroleum Geologists Guidebook 5th Ann. Field Conf., 1954, p. 25-33.

Stewart, J. H., Williams, G. A., Albee, H. F., and Raup, O. B., 1959, Stratigraphy of Triassic and associated formations in part of the Colorado Plateau region, with a section on Sedimentary petrology, by R. A. Cadigan: U.S. Geol. Survey Bull. 1046-Q, p. 487-576.

Stokes, W. L., 1950, Pediment concept applied to Shinarump and similar conglomerates: Geol. Soc. America Bull., v. 61, no. 2, p. 91-98.

1953, Primary sedimentary trend indicators as applied to ore finding in the Carrizo Mountains, Arizona and New Mexico: U.S. Atomic Energy Comm. RME-3043, pt. 1, 48 p., issued by Tech. Inf. Service Ext., Oak Ridge, Tenn.

Stoyanow, Alexander, 1942, Paleozoic paleogeography of Arizona: Geol. Soc. America Bull., v. 53, no. 9, p. 1255-1282.

Strobell, J. D., Jr., 1956, Geology of the Carrizo Mountains areas in northeastern Arizona and northwestern New Mexico: U.S. Geol. Survey Oil and Gas Inv. Map OM-160, scale $1: 48,000$.

Sykes, G. G., 1937, The Colorado Delta: Carnegie Inst. Washington Pub. 460, $193 \mathrm{p}$.

Taliaferro, N. L., 1933, An occurrence of Upper Cretaceous sediments in northern Sonora, Mexico: Jour. Geology, v. 41 , no. 1 , p. 12-37.

Thomas, C. R., McCann, F. T., and Raman, N. D., 1945, Mesozoic and Paleozoic stratigraphy in northwestern Colorado and northeastern Utah: U.S. Geol. Survey Oil and Gas Inv. (Prelim.) Chart 16, scale 1 in. to 12 miles.

Thomas, H. D., and Krueger, M. L., 1946, Late Paleozoic and early Mesozoic stratigraphy of Uinta Mountains, Utah: Am. Assoc. Petroleum Geologists Bull., v. 30, no. 8, p. 1255-1293.

Thompson, W. O., 1937, Original structures of beaches, bars, and dunes: Geol. Soc. America Bull., v. 48, no. 6, p. 723751.

Visher, G. S., 1965, Fluvial processes as interpreted from ancient and recent fluvial deposits, in Primary sedimentary structures and their hydrodynamic interpretations: Soc. Econ. Paleontologists and Mineralogists Spec. Pub. 12, p. 116-132.

Walker, M. V., 1938, Evidence of Triassic insects in the Petrified Forest National Monument, Arizona: U.S. Natl. Museum Proc., v. 85, pub. 3033, p. 137-141.

Wanek, A. A., and Stephens, J. G., 1953, Reconnaissance geologic map of the Kaibito and Moenkopi Plateaus and parts of the Painted Desert, Coconino County, Arizona: U.S. Geol. Survey Oil and Gas Inv. Map OM-145, scale $1: 150,000$.

Ward, L. F., 1900, Status of the Mesozoic floras of the United States - The older Mesozoic: U.S. Geol. Survey 20th Ann. Rept., pt. 2, p. 211-748.

Ward, L. F., with the collaboration of Fontaine, Wm., Bibbens, Arthur, and Wieland, G. R., 1905, Status of the Mesozoic floras of the United States: U.S. Geol. Survey Mon. 48, 616 p.

Wells, J. D., 1960, Stratigraphy and structure of the House Rock Valley area, Coconino County, Arizona: U.S. Geol. Survey Bull. 1081-D, p. 117-158.

Williston, S. W., and Case, E. C., 1912, The Permo-Carboniferous of northern New Mexico: Jour. Geology, v. 20, p. 1-12.

Wilson, R. F., and Stewart, J. H., 1967, Correlation of Upper Triassic and Triassic(?) formations between southwestern Utah and southern Nevada: U.S. Geol. Survey Bull. 1244-D, $20 \mathrm{p}$.

Witkind, I. J., 1956, Channels and related swales at the base of the Shinarump conglomerate, Monument Valley, Arizona, in Page, L. R., Stocking, H. E., and Smith, H. B., compilers, Contributions to the geology of uranium and thorium by the United States Geological Survey and 
Atomic Energy Commission for the United Nations International Conference on Peaceful Uses of Atomic Energy, Geneva, Switzerland, 1955: U.S. Geol. Survey Prof. Paper 300, p. 233-237; enlarged as Uranium deposits at base of the Shinarump conglomerate, Monument Valley, Arizona: U.S. Geol. Survey Bull, 1030-C, p. 99-130.

Witkind, I. J., Hemphill, W. R., Fillmore, C. L., and Morris, R. H., 1960, Isopach mapping by photogeologic methods as an aid in the location of swales and channels in the Monument Valley area, Arizona: U.S. Geol. Survey Bull. 1043-D, p. 57-85.

Witkind, I. J., and Thaden, R. E., 1963, Geology and uraniumvanadium deposits of the Monument Valley area, Apache and Navajo Counties, Arizona: U.S. Geol. Survey Bull. 1103, $171 \mathrm{p}$.

Wood, G. H., Jr., Kelley, V. C., and MacAlpin, A. J., 1948, Geology of southern part of Archuleta County, Colorado:
U.S. Geol. Survey Oil and Gas Inv. (Prelim.) Map 81, scale 1 in. to 1 mile.

Wood, G. H., Jr., and Northrop, S. A., 1946, Geology of Nacimiento Mountains, San Pedro Mountain, and adjacent plateaus in parts of Sandoval and Rio Arriba Counties, New Mexico: U.S. Geol. Survey Oil and Gas Inv. (Prelim.) Map 57, scale 1 in. to $1 \frac{1}{2}$ miles.

Woodruff, E. G., 1912, Geology of the San Juan oil field, Utah : U.S. Geol. Survey Bull. 471, p. 76-104.

Yen, Teng-Chien, 1951, Some Triassic fresh-water gastropods from northern Arizona: Am. Jour. Sci., v. 249, p. 671-675.

Yen, Teng-Chien, and Reeside, J. B., Jr., 1946, Triassic freshwater gastropods from southern Utah: Am. Jour. Sci., v. 244, p. 49-51.

Young, R. G., 1964, Distribution of uranium deposits in the White Canyon-Monument Valley district, Utah-Arizona: Econ. Geology, v. 59, no. 5, p. 850-873.

\section{STRATIGRAPHIC SECTIONS}

The stratigraphic sections are listed by State and by locality numbers within the State. The localities are shown on plate 1. A complete list of localities used in this report, including sections measured by other geologists and not published here, is given in table 1.

The stratigraphic sections were mostly measured with an Abney hand level. A few were measured with a planetable and alidade. The color descriptions follow the "Rock Color Chart" of the National Research Council (Goddard and others, 1948). The description of stratification largely follows that recommended by McKee and Weir (1953).

\section{ARIZONA}

\section{A-2. BLACK MOUNTAIN WASH}

Measured on north side of Black Mountain Wash west of Many Farms-Rough Rock Road. Units 1-5 measured at long $109^{\circ} 40^{\prime} \mathrm{W}$., lat $30^{\circ} 20^{\prime} \mathrm{N}$., and units 6 and 7 measured at long $109^{\circ} 41^{\prime} W$., lat $36^{\circ} 21^{\prime} 30^{\prime \prime}$ N., A pache County [Measured by R. F. Wilson, May 1956]

Top of section; top of good exposure. Top of section is S. $40^{\circ} \mathrm{W}$. of Round Rock.

Kayenta Formation (unmeasured) :

7. Sandstone pale red $(5 R 6 / 2)$ to pale reddish brown $(10 R 5 / 4)$, weathering same colors, fine to medium grained, fair sorted; composed of clear, milky, and reddish-stained quartz and white mineral (chert?, feldspar?) and common dark accessory mineral ; firmly cemented, calcareous; composed of trough sets of low-angle mediumscale cross-laminae; weathers to form ledgy slope. Unit appears to channel slightly into underlying unit. Only basal few feet of unit examined....Unmeasured

Wingate Sandstone: Lukachukai Member:

6. Sandstone, light brown $(5 Y R 6 / 4)$ and minor pale reddish brown $(10 R 5 / 4)$, weathering same colors, very fine grained with scattered fine to medium
Wingate Sandstone-Continued

Lukachukai Member-Continued

grains, well sorted; composed of subrounded to rounded clear, frosted, and reddish-stained quartz and common dark accessory mineral; fairly to poorly cemented, calcareous in parts; composed predominantly of wedgeplanar sets of medium to very large scale high-angle cross-laminae, but from 0 to $12 \mathrm{ft}$ is structureless, and from 252 to $285 \mathrm{ft}$ and from 336 to $410 \mathrm{ft}$ contains common interbeds of horizontal laminae to high- and lowangle medium- to small-scale troughtype cross-laminae; weathers to form vertical cliff with slope at top. Ripple marks with a high index and tubular structures resembling worm borings are common along some lamination planes

Total Lukachukai Member

Offset at base of unit 6 , so that units 6 and 7 were measured 1.9 miles north of underlying units.

Rock Point Member:

5. Siltstone to sandy siltstone, light brown $(5 Y R 6 / 4)$, weathering same color, coarse silt to very fine sand; composed of clear and reddish-stained quartz and common dark accessory mineral; firmly cemented, calcareous; basal $22 \mathrm{ft}$ horizontally laminated to very thin bedded with some ripple laminae, upper $15 \mathrm{ft}$ predominantly thick to very thick bedded; weathers to form irregular cliff. Unit may contain a few sets of very low angle medium-scale cross-laminae in basal $22 \mathrm{ft}$
Feet \begin{tabular}{l}
492.8 \\
\hline 492.8 \\
\hline \hline
\end{tabular}

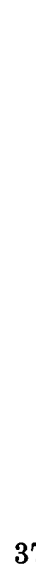

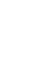

4. Siltstone, grayish red $(10 R 4 / 2)$ and light brown (5YR 6/4), weathering light brown (5YR 6/4) and moderate reddish orange $(10 R 6 / 6)$, medium to coarse silt, sandy in places; firmly 
Wingate Sandstone-Continued

Rock Point Member-Continued

to well cemented, calcareous; horizontally very thick to thin bedded; weathers to form long irregular slope with poorly developed "hoodoo" weathering. From 176 to $187 \mathrm{ft}$ unit contains a set of sandy siltstone with poorly developed ripple laminae and possibly some cross-laminae

Total Rock Point Member

Total of Wingate Sandstone

Chinle Formation (incomplete) :

Owl Rock Member (incomplete):

3. Limy siltstone to silty limestone, pale red $(10 R 6 / 2)$ with light-greenishgray $(5 G Y \quad 8 / 1)$ mottling; well cemented; horizontally thin bedded; weathers to form weak ledge on dip slope

2. Siltstone, light brown (5YR 6/4), weathering same color, medium to coarse silt; firmly cemented, calcareous; structureless; weathers to form slope

1. Limestone to limestone pebble conglomerate, pale red $(10 R 6 / 2)$ to light greenish gray ( $5 G Y 8 / 1)$, weathering same colors, dense, in part composed of granules to pebbles of limestone in a limy matrix; well cemented; horizontally to gnarly bedded; weathers to form ledge and conspicuous light-colored band on dip slope of cuesta

Total incomplete Owl Rock Member

Total incomplete Chinle Formation

Base of section; not base of exposure. Base of section is 1.3 miles north of Black Mountain Wash on west side of road to Rough Rock.

\section{A-3. CHEE DODGE}

Units 1-9 measured on north side of canyon of Whisky Creek about $1 / 2$ mile north of where Fort Defiance-Lukachukai road crosses the creek, long $109^{\circ} 02^{\prime} 40^{\prime \prime} W$., lat $36^{\circ} 08^{\prime} 45^{\prime \prime} N$.; units 10-17 measured on outcrops on southeast side of Sonsela Buttes from $1 / 2$ mile southwest of Chee Dodge to $1 / 2$ mile northeast of Chee Dodge, long $109^{\circ} 03^{\prime 35^{\prime \prime}}$ to $109^{\circ} 03^{\prime} 05^{\prime \prime} W$., lat $36^{\circ} 05^{\prime} 25^{\prime \prime}$ to $36^{\circ} 05^{\prime} 45^{\prime \prime} N$.; units $18-22$ measured $13 / 4$ miles S. 67 E. of Chee Dodge, long $109^{\circ} 01^{\prime 2} 20^{\prime \prime}$ W., lat $36^{\circ} 04^{\prime} 50^{\prime \prime}$ N., A pache County, Ariz., and San Juan County, N. Mex.

[Measured by J. H. Stewart and R. F. Wilson, April 1956]

Top of section; not top of exposure.

Entrada Sandstone (incomplete) :

Upper sandy member (unmeasured) :

22. Sandstone, light brown $(5 Y R \quad 5 / 6$ and $5 Y R 6 / 4)$, weathering same color, very fine to fine grained, rare medium to coarse grains, fair to well sorted; composed of subrounded reddishstained quartz and abundant black accessory minerals, medium to coarse

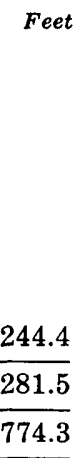

Entrada Sandstone (incomplete)-Continued

Upper sandy member-Continued

grains are well rounded and composed of clear quartz and minor white chert(?); poorly cemented, slightly calcareous; horizontally laminated and thin, poorly defined sets of lowangle, possibly some high-angle small- to medium-scale cross-laminae; weathers to form most prominent cliff in Chee Dodge area. Only basal $20 \mathrm{ft}$ of unit examined. Unit about $200 \mathrm{ft}$ thick. Basal 1 foot of unit is yellowish gray $(5 Y 8 / 1)$. In detail, unit appears to grade downward into underlying unit, but, from a distance, base of unit appears sharp and persistent. Downward gradation takes place in $1 / 2-f t$ interval Unmeasured

Medial silty member

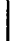

Wingate Sandstone:

Rock Point Member:

19. Siltstone and sandstone. Siltstone, grayish red $(10 R 4 / 2)$, pale reddish brown $(10 R 5 / 4)$, and light brown $(5 Y R$ $6 / 4)$, weathering same colors, medium to coarse silt; firmly cemented, calcareous; structureless, horizontally laminated, some wavy laminae. Sandstone, light brown (5YR 5/6), weathering same color, very fine grained, well sorted, composed of subrounded reddish-stained quartz and rare black accessory mineral; firmly cemented, calcareous; stratification obscure, possibly horizontally lami-
Feet 
Wingate Sandstone-Continued

Rock Point Member-Continued

nated. Sandstone is present from 0.0 to $3.0 \mathrm{ft}$ and from 4.6 to $9.0 \mathrm{ft}$ above base of unit. Unit weathers to form slopes on siltstone and ledges on sandstone. Unit forms fourth, or highest, of the ledges in the member..

18. Siltstone, light brown $(5 Y R 6 / 4)$ and pale reddish brown $(10 R 5 / 4)$, weathering same colors, coarse silt; firmly cemented, calcareous; structureless, some horizontal bedding planes; weathers to form slope

Long offset in section. Units 18-22 measured $11 / 2$ miles southeast of where unit 17 measured.

17. Sandstone, same as unit 9 , composed of thin to thick wedge-planar(?) sets of high- and low-angle cross-strata......

16. Siltstone, same as unit 8. Mostly horizontally laminated in basal $10 \mathrm{ft}$. Weathers to form vertical cliff

15. Siltstone, light brown $(5 Y R 6 / 4)$ and grayish red $(10 R 4 / 2)$ to pale reddish brown $(10 R 5 / 4)$, weathering same colors, medium to coarse silt; firmly cemented, calcareous; horizontally very thin bedded to very thick bedded; weathers to form steep ledgy slope. Coarse siltstone layers are mostly light brown and form thin to thick ledges, whereas medium siltstone layers are red and form slopes. Two thin horizontal beds of structureless sandstone, similar to that in unit 9 , are present in basal $15 \mathrm{ft}$. Possibly a few shallow scour surfaces in middle of unit

14. Sandstone, same as unit 9. Most of unit appears structureless, some medium-scale high-angle cross-laminae are present, and also some horizontal laminae. Weathers to form cap of ledge formed by units 13 and 14. This ledge is the second of the four prominent ledges in the Rock Point Member

13. Siltstone, same as unit 8. Weathers to form cliff. Horizontally laminated in places

12. Siltstone to silty sandstone, pale reddish brown $(10 R 5 / 4)$ and light brown (5YR 6/4), weathering same colors, medium siltstone to silty very fine grained sandstone composed of subrounded reddish-stained quartz and abundant black accessory mineral; firmly cemented, calcareous; composed of very thick horizontal beds, some beds have shallow scours at base, these scours are mostly less than 6 in. deep; weathers to form ledgy slope. Sandier parts of unit are mostly light brown and form lighter color
Feet Wingate Sandstone-Continued Feet Rock Point Member-Continued

ledges. In most places the ledges are separated by pale-reddish-brown siltstone that forms slopes. The unit, however, has a complete intergradation in rock types from siltstone to silty sandstone

11. Sandstone, same as unit 9 except some parts appear structureless and crossstrata are on medium scale

10. Siltstone, pale reddish brown $(10 R 5 / 4)$, weathering same color, medium silt; firmly cemented, calcareous; structureless; weathers to form reentrant

Long offset so that units 10-17 measured $31 / 4$ miles south of units 1-9. Units 10-17 measured within 1 mile west of Chee Dodge along south side of East Sonsela Butte. Offset in top of lowest cliff-forming unit in Rock Point Member.

9. Sandstone, light brown (5YR 6/4), weathering same color, very fine grained, well sorted; composed of subrounded reddish-stained quartz and abundant black accessory mineral; firmly cemented, calcareous; composed of thin to very thick planar(?) sets of low and high-angle small- to medium-scale cross-laminae; weathers to form vertical cliff continuous with that of underlying units. Units 8 and 9 form lowest of four prominent ledges in the Rock Point Member

8. Siltstone, light brown (5YR 6/4), weathering same color; coarse silt, sandy (very fine grained) in part; firmly to well cemented, calcareous; horizontally very thin to thick bedded; weathers to form vertical cliff.

7. Siltstone, light brown $(5 Y R \quad 6 / 4)$ and minor pale reddish brown $(10 R 5 / 4)$, grades from fine siltstone to very fine grained sandy siltstone and, rarely, silty very fine grained sandstone; firmly to well cemented, calcareous; structureless, from a distance appears to be horizontally bedded; weathers to form steep slope

6. Silty sandstone, pale red $(10 R 6 / 2)$ and pale reddish brown $(10 R 5 / 4)$, weathering same colors, very fine grained, well sorted; firmly cemented, calcareous; horizontally laminated, minor ripple laminae, a few poorly defined low-angle small-scale crossstrata; weathers to form irregular ledge. Unit appears to be transitional from underlying unit to overlying unit

5. Sandy siltstone to silty sandstone, pale red $(10 R 6 / 2)$, weathering same color, grades from sandy siltstone to very fine grained well-sorted silty sandstone; firmly cemented, calcareous; 
Wingate Sandstone-Continued

Rock Point Member-Continued

cuspate ripple laminated in basal 1.7 $\mathrm{ft}$, horizontally laminated in rest of unit, some poorly defined low-angle cross-laminae and a few scour surfaces; weathers to form irregular ledge. Stratification of unit appears lenticular from a distance. Thin lenses of intraformational conglomerate at $1.5 \mathrm{ft}$ above base of unit. These lenses contain granules and pebbles of purplish siltstone and silty sandstone

4. Siltstone, light brown (5YR 6/4), weathering same color, fine siltstone in basal $8 \mathrm{ft}$ and coarse siltstone in rest of unit; firmly to well cemented, calcareous; structureless, appears horizontally bedded on distant exposures; weathers to form steep slope

3. Limestone, pale red $(10 R 6 / 2)$, weathering same color; dense; well cemented; unit is a thin horizontal bed; weathers to form ledge. This unit is not placed in Owl Rock Member because it is present for only a short distance on either side of the line of section. The top of unit 1 marks the most conspicuous lithologic break in the sequence of strata and the top of the highest persistent limestone ...............

2. Siltstone, moderate reddish brown $(10 R$ $4 / 6)$, pale red $(10 R 6 / 2)$ in top foot, weathering same colors, medium to coarse silt; poorly cemented, calcareous; structureless; weathers to form slope

Total of Rock Point Member ........

Total of Wingate Sandstone

Chinle Formation (unmeasured):

Owl Rock Member (unmeasured) :

1. Limestone (20 percent) and siltstone (80 percent). Limestone, pale red $(5 R 6 / 2)$ and light greenish gray ( $5 G Y 8 / 1$ ), weathering same colors; dense; well cemented; present as horizontally thin to thick bedded sets interstratified with siltstone. Siltstone, grayish red $(10 R \quad 4 / 2)$ and pale reddish brown $(10 R 5 / 4)$, weathering same colors, fine silt; firmly indurated, clay binding, noncalcareous; structureless. Unit as whole weathers to form steep slope with ledges on limestone sets. About 80 $\mathrm{ft}$ of unit exposed. Top of unit at top of a limestone Unmeasured

Base of section; base of exposure. Base of section about 1/2 miles northeast of northeast side of East Sonsela Butte.

\section{A-4. HORSE MESA CREEK}

Measured starting at Horse Mesa Creek, 2 miles northwest of Horse Mesa, and extending southward for about 1 mile,

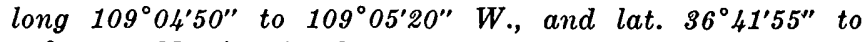
$36^{\circ} 43^{\prime} 00^{\prime \prime}$ N., A pache County

[Measured by J. H. Stewart and R. F. Wilson, April 1956]

Top of section; top of exposure.

Wingate Sandstone (incomplete) :

Rock Point Member (incomplete) :

26. Sandstone, same as unit 16 .

25. Sandstone to siltstone, same as unit 15 ..

24. Sandstone, same as unit 16 , a few scattered medium amber-stained quartz grains; horizontally thin bedded in basal $15 \mathrm{ft}$; appears structureless in top $13 \mathrm{ft}$ iltstone, pale reddish-brown $(10 R$ $5 / 4)$ and minor light brown (5YR $6 / 4)$, weathering same colors, medium to coarse silt; firmly to well cemented, noncalcareous, horizontally very thin to thin bedded and structureless; weathers to form steep slope with vertical cliff at top

22. Sandstone, same as unit 16 except is fine grained and contains a few scattered medium well-rounded quartz grains. Good exposure of top surface of unit about $1,000 \mathrm{ft}$ long shows cross-laminae to be linear in plan view

21. Sandstone to siltstone, same as unit 15

20. Sandstone, same as unit 16

19. Sandstone to siltstone, same as unit $\mathbf{1 5}$ except is horizontally laminated in top $3 \mathrm{ft}$

18. Sandstone, same as unit 16 except composed of thin wedge-planar sets of small- to medium-scale high- and lowangle cross-laminae

17. Sandstone to sandy siltstone, same as unit 15. Horizontally laminated and rare poorly defined very low angle cross-laminae in top $4 \mathrm{ft}$.....................

16. Sandstone, light brown (5YR 6/4), weathering same color, very fine grained, well sorted; composed of subrounded reddish-stained quartz and abundant black accessory mineral; poorly cemented, calcareous, composed of thin to very thick wedge-planar sets of low- and high-angle small- to large-scale cross-laminae.

15. Sandstone and minor siltstone, light brown $(5 Y R \quad 6 / 4)$ and pale reddish brown $(10 R 5 / 4)$, weathering same colors; very fine grained sand to medium silt, well sorted; sand composed of subrounded reddish-stained quartz and abundant black accessory mineral; poorly to firmly cemented, slightly calcareous; structureless; weathers to form gentle slope along line of section. This unit contains less siltstone than overlying units designated as being the same as this unit 
Wingate Sandstone (incomplete)-Continued Rock Point Member (incomplete)-Continued

14. Sandy siltstone, pale red $(10 R 6 / 2)$ and pale reddish brown $(10 R 5 / 4)$, weathering light brown (5YR 6/4), very fine grained sandy, coarse siltstone; firmly to well cemented, calcareous; horizontally laminated in basal half, structureless in upper half; weathers to form vertical cliff in lower half and gentle slope in upper half. Separated from overlying unit on basis of color and grain size..

13. Siltstone, pale reddish brown $(10 R 5 / 4)$ and minor pale red $(10 R \quad 6 / 2$ and $5 R 6 / 2$ ), weathering same colors, fine to medium silt; poorly to well cemented, noncalcareous in places, calcareous in other places; stratification mostly concealed, structureless in places; weathers to form gentle slope in lower $20 \mathrm{ft}$ and steep slope in rest of unit. Basal $17 \mathrm{ft}$ of unit contains three thin to thick sets of pale-red $(5 R 6 / 2)$ very fine grained well-sorted sandstone composed of horizontal laminae and possibly a few low-angle cross-strata. These sets are interstratified with the siltstone.

12. Sandstone, pale red $(5 R 6 / 2)$, slightly coarser than unit 11 , otherwise same as unit 11. Locally basal $5 \mathrm{ft}$ of unit is composed almost entirely of conglomerate. This conglomerate is composed of coarse grains to cobbles of reddish siltstone and gray limestone in a limy silt matrix. Largest cobbles are 8 in. across, and fragments as large as 2 to 4 in. are locally common. Unit weathers to form ledge in lower part and bench in upper part. Top $5 \mathrm{ft}$ of unit is poorly exposed and may contain some reddish siltstone lenses

11. Siltstone, grayish red $(10 R \quad 4 / 2$ and $5 R 4 / 2)$, weathering pale reddish brown $(10 R 5 / 4)$, medium to coarse silt; poorly cemented, calcareous; stratification concealed; weathers to form slope. A thin bed of conglomerate is present about $2 \mathrm{ft}$ above base of unit. This conglomerate is composed of coarse grains to granules of limestone and siltstone in a limy silt matrix. Some parts of unit are poorly exposed

10. Sandstone, pale reddish brown $(10 R$ $5 / 4$ ) and pale red (10R 6/2), weathering same colors, fine grained, some silt in places, well sorted; composed of angular to subrounded clear and milky quartz and rare black accessory minerals; poorly to firmly cemented, calcareous; composed of thin to thick trough(?) sets of mediumscale very low angle cross-laminae;
Feet $\begin{array}{r}\text { Wingate Sandstone (incomplete)-Continued } \\ \text { Rock Point Member (incomplete)-Continued } \\ \text { weathers to form ledge. Thickness } \\ \text { highly variable. Channels cut } 20 \mathrm{ft} \\ \text { into underlying unit are present to } \\ \text { west of line of section. Away from } \\ \text { line of section unit locally contains } \\ \text { thin to thick conglomerate lenses com- } \\ \text { posed of granules to pebbles of red- } \\ \text { dish siltstone and grayish limestone } \\ \text { in a silt matrix. Unit may contain a } \\ \text { few thin lenses of reddish siltstone in } \\ \text { top } 3 \mathrm{ft} \text {. Units } 9 \text { and } 10 \text { form higher } \\ \text { of two prominent ledges in local ex- } \\ \text { posure .............................................. }\end{array}$

9. Sandy siltstone, light brown (5YR $6 / 4)$ and pale reddish brown $(10 R$ $5 / 4)$, weathering same colors; sandy (very fine grained) coarse siltstone; firmly cemented, calcareous; horizontally laminated in basal $8 \mathrm{ft}$, structureless in rest of unit; weathers to form ledge in lower $8 \mathrm{ft}$ and steep slope in rest of unit. Upper 10 ft poorly exposed. On nearby outcrops unit appears to contain many shallow scour surfaces. Upper $20 \mathrm{ft}$ of unit cut out at top by overlying unit to west of line of section. On exposures to west of line of section, unit marks horizon of lowest prominent lightbrown ledge in stratigraphic sequence, but locally forms part of higher of two prominent ledges

Total of incomplete Rock Point Member

Total of incomplete Wingate Sandstone

Chinle Formation:

Owl Rock Member (incomplete) :

8. Limestone and siltstone. Limestone, pale red $(10 R 6 / 2)$ and light greenish gray (5GY 8/1), weathering same colors; dense; well cemented; horizontally very thin to thin-bedded. Siltstone, pale reddish brown $(10 R 5 / 4)$, weathering same color, medium to fine silt; firmly cemented, calcareous; structureless. Unit as whole weathers to form steep slopes with limestone ledges. On distant exposures, unit forms pale-red outcrop lying between reddish siltstone below and lightbrown siltstone above. Limestone is present from 0.0 to $1.5,6.0$ to 11.6 $\mathrm{ft}$, and 14.1 to $17.8 \mathrm{ft}$ above base of unit. Top of Owl Rock member placed at top of highest limestone..

7. Siltstone and minor sandy siltstone, pale reddish brown $(10 R 5 / 4)$ and grayish red $(10 R 4 / 4)$, weathering same colors, medium to coarse silt, minor very fine grained sandy siltstone; common fine-grained accessory white mica; structureless, minor horizon- 
Chinle Formation-Continued

Owl Rock Member (incomplete)—Continued tally laminated parts, some concealed stratification; weathers to form steep slope

6. Sandy siltstone to sandstone, pale reddish brown (10R 5/4), dominantly pale red $(10 R 6 / 2)$ and grayish yellow $(5 Y 8 / 4)$ in top $8 \mathrm{ft}$, weathering same colors, grades from sandy (very fine grained) coarse siltstone to well-sorted very fine grained sandstone; composition masked; well cemented, slightly calcareous; dominantly ripple laminated, some stratification concealed; weathers to form ledge. Units 5 and 6 form irregular ledge that is lower of two prominent ledges in local exposure. Lithologic character of this ledge is variable. Locally units 5 and 6 are either absent or form a slope. To west of line of section, top of unit is composed of an 8-ft-thick layer of yellowish-gray $(5 Y 8 / 4)$ very fine to fine-grained well-sorted sandstone. This sandstone is composed of subangular to angular clear and milky quartz and abundant black accessory minerals. The sandstone is composed of very thick trough (?) sets of largescale low-angle cross-laminae ..............

5. Sandstone to conglomeratic sandstone, pale purple (5P 6/2), light gray $(N$ $7)$, yellowish gray (5Y 7/2), and light greenish gray ( $5 G Y 8 / 1)$, weathering brownish gray $(5 Y R 4 / 1)$, very fine grained, well sorted; common medium-grained accessory white mica; well cemented, calcareous; poorly defined low-angle medium-scale cross-laminae, some horizontal laminae; some structureless parts; weathers to form ledge. Forms basal part of prominent ledge formed by units 5 and 6 . Unit contains minor amount of conglomeratic sandstone containing granules to cobbles as large as $3 \mathrm{in}$. of siltstone and minor limestone. Conglomeratic sandstone is mostly in basal $2 \mathrm{ft}$. Base of unit is scour surface with scours as deep as 6 in. Two quartz pebbles and one chert pebble were noted in unit.

4. Siltstone, pale red $(10 R 6 / 2)$ and pale reddish brown $(10 R 5 / 4)$, weathering same colors, fine to coarse silt; firmly to well cemented, calcareous; structureless; weathers to form steep slope. Unit contains thin beds of limestone from 85.0 to $86.0 \mathrm{ft}$ and from 99.2 to $99.7 \mathrm{ft}$. Limestone is pale red $(5 R 6 / 2)$ and light greenish gray ( $5 G Y 8 / 1)$, dense, and well cemented. A few thin layers in unit contain abundant limestone nodules
Feet

Chinle Formation-Continued

Owl Rock Member (incomplete)-Continued

3. Conglomeratic sandstone to conglomerate $(80$ percent) and siltstone (20 percent). Conglomeratic sandstone to conglomerate, grayish red (10R 4/2) and light greenish gray ( $5 G Y 8 / 1)$, weathering same colors, composed of coarse grains to cobbles of reddish siltstone and grayish limestone in a limy silt matrix. Largest cobbles are 3 in. across. In places rock is composed of coarse grains and minor granules and pebbles in a limy silt matrix; in other places it is composed entirely of granules, pebbles, and cobbles in a limy silt matrix; well cemented, calcareous; stratification variable, either structureless, horizontally laminated, or composed of thin lenticular beds or poorly defined trough sets of low-angle mediumscale cross-laminae. Siltstone, same as that in underlying unit; present as thin to thick sets interstratified with rest of unit

2. Siltstone, pale reddish brown $(10 R 5 / 4)$ and moderate reddish brown $(10 R$ $4 / 6$ ), weathering same colors, medium silt; firmly indurated, slightly calcareous, clay binding; stratification concealed; weathers to form gentle slope

1. Siltstone and silty limestone. Siltstone, pale reddish brown $(10 R 5 / 4)$ and minor pale red $(5 R 6 / 2)$, weathering same colors; firmly cemented, calcareous; structureléss. Silty limestone is present as two sets from 5.6 to $6.4 \mathrm{ft}$ and from 9.4 to $11.5 \mathrm{ft}$. Lower silty limestone is pale red $(10 R 6 / 2)$, and upper silty limestone is light greenish gray $(5 G Y 8 / 1)$; dense; well cemented, very thin to thin bedded. Unit as whole weathers to form steep slope with small ledges developed on silty limestone. Top silty limestone forms small bench.

Total of incomplete Owl Rock Member

Total of incomplete Chinle Formation

Base of section; base of exposure. Base of section at Horse Mesa Creek.

A-6b. LUKACHUKAI TRADING POST

Measured 3.4 miles N. $65^{\circ}$ E. of Lukachukai Trading Post, lat $36^{\circ} 26^{\prime} 6^{\prime \prime}$ N., long $109^{\circ} 11^{\prime} 1^{\prime \prime} W$., A pache County

[Measured by R. F. Wilson, September 1955]

Top of section; top of good exposure. Top of section is 4.1 miles $\mathrm{N}$. $60^{\circ} \mathrm{E}$. of Lukachukai Trading Post.

Todilto Limestone (incomplete) :

18. Limestone, pale red $(10 R 6 / 2)$, weathering light brownish gray (5YR
Feet 
Todilto Limestone (incomplete)-Continued $6 / 1$ ), sandy (very fine grained), well indurated; horizontally laminated; weathers to form ledge

Total incomplete Todilto Limestone

Entrada Sandstone:

17. Sandstone (90 percent) and siltstone (10 percent). Sandstone, moderate reddish orange $(10 R 6 / 6)$ and pale reddish brown $(10 R 5 / 4)$, weathering same colors, very fine grained, silty, fair to well sorted; composed of subangular to rounded reddishstained quartz and common to sparse dark and light accessory minerals; poorly cemented, calcareous; apparently horizontally stratified. Sandstone contains sparse scattered reddish medium-sized quartz grains. Siltstone, grayish red $(5 R 4 / 2)$ and light greenish gray $(5 G 8 / 1)$, weathering same colors, firmly cemented, calcareous; horizontally laminated. Unit as a whole weathers to form partially covered slope

Total Entrada Sandstone

Wingate Sandstone:

16. Sandstone, moderate reddish orange $(10 R \quad 6 / 6)$ to light brown (5YR $6 / 4)$, weathering same colors; very fine grained with 5 percent medium to fine grains, well sorted; composed of clear, frosted, and reddish-stained quartz with common black and white accessory minerals; poorly cemented, calcareous in part; basal $39.2 \mathrm{ft}$ of unit is horizontally thin bedded to laminated with some low-angle trough sets of medium-scale cross-strata, rest of unit is composed of thick to very thick planar sets of high-angle medium- to large-scale cross-laminae; massive splitting; weathers to form vertical cliff with extensive bench at top. The fine to medium sand is concentrated along lamination planes and is particularly abundant at or near the base of individual sets of cross-strata

15. Sandstone ( 80 percent) and limestone (20 percent). Sandstone, pale reddish brown $(10 R 5 / 4)$, white $(N 9)$, grayish pink (5R 8/2), and pale red $(10 R 6 / 2)$, weathering same colors, very fine grained, silty in places, well sorted; composed of subangular to subrounded clear and reddishstained quartz with common black and reddish accessory minerals; firmly to well cemented, calcareous, limy in places; mostly horizontally very thin bedded to laminated, but some sandstone in basal $2 \mathrm{ft}$ of unit may

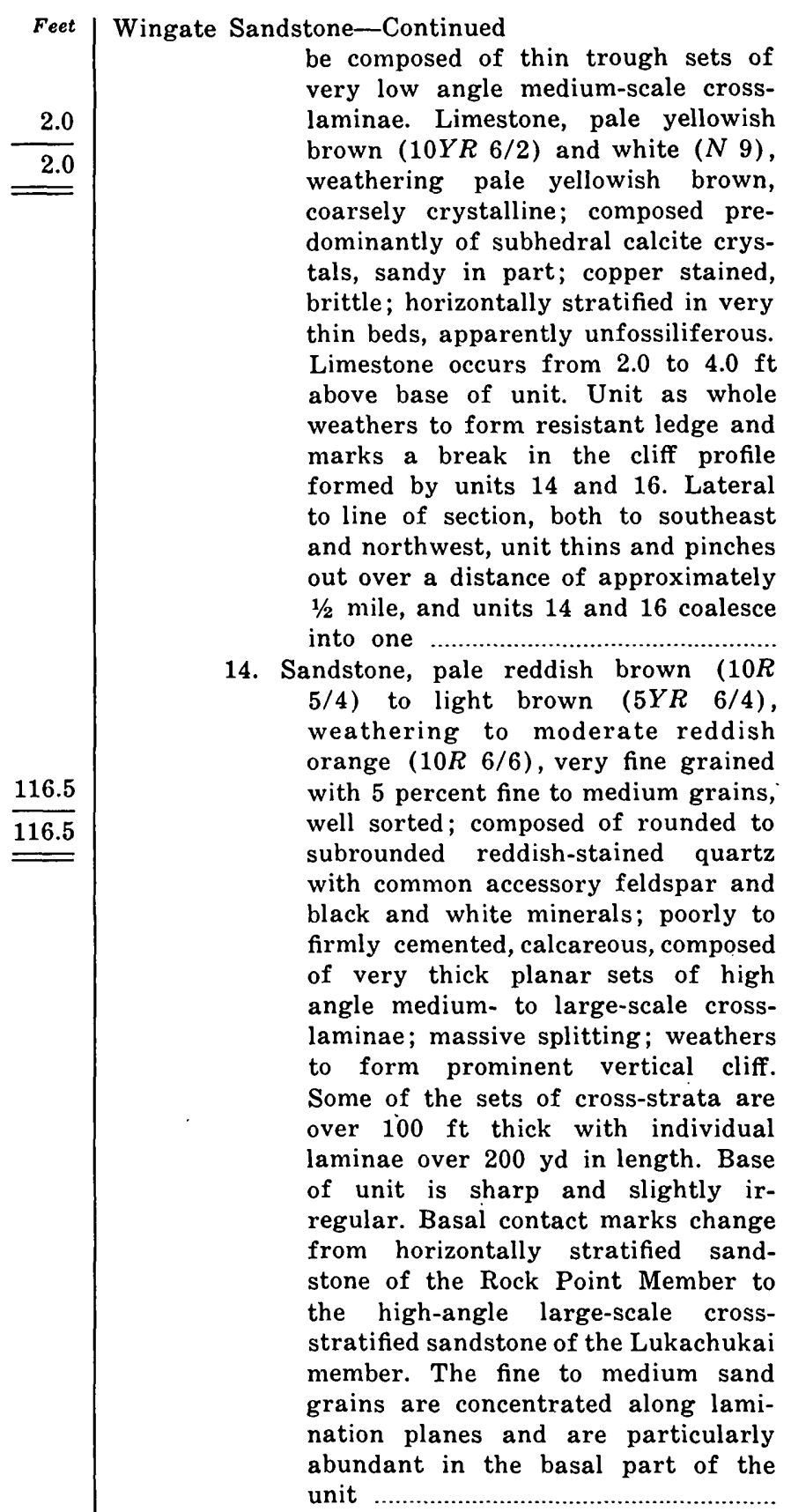

Rock Point Member:

13. Sandstone, pale reddish brown $(10 R$ $5 / 4)$ and light brown $(5 Y R 6 / 4)$, weathering same colors, very fine grained with thin lenses in basal 6 ft containing common to abundant fine to medium grains; fair to well sorted; composed of subangular to subrounded clear and reddish-stained quartz and abundant dark accessory mineral; firmly cemented, calcareous; stratification obscure but appears to be horizontal thick to very thick beds; weathers to form cliff. This
Feet 
Wingate Sandstone-Continued

Rock Point Member-Continued

unit is similar to unit 12 except for the presence of zones of abundant fine to medium quartz and feldspar (?) grains. The basal contact of the unit, locally, is sharp and very slightly irregular

12. Sandstone ( 80 percent) and siltstone (20 percent). Sandstone, pale reddish brown $(10 R 5 / 4)$ and light brown (5YR 6/4), with minor mottling to white, weathering same colors, very fine grained, silty in part, well sorted; composed of subangular to subrounded clear and reddish-stained quartz and common dark accessory mineral, poorly to well cemented, slightly calcareous to calcareous; stratification obscured but some of sandstone is horizontally laminated and other parts are very thickly bedded; massive splitting. Siltstone, pale reddish brown $(10 R 5 / 4)$, weathering same color; well cemented, calcareous; horizontally laminated to very thin bedded. Unit as whole weathers to ledgy slope with a fairly prominent ledge of sandstone from 28 to $34 \mathrm{ft}$. Upper $2 \mathrm{ft}$ of unit contains a few scattered fine to medium quartz grains

11. Sandstone, between light brown (5YR $6 / 4)$ and moderate reddish orange (10R 6/6), weathering same colors, very fine grained, well sorted; composed of rounded to subangular clear and reddish-stained quartz and minor to very minor dark accessory mineral; poorly to firmly cemented, calcareous; composed of very thick sets of medium- to large-scale high-angle planar cross-laminae; massive splitting; weathers to form vertical cliff..

10. Sandstone, pale reddish brown (10R 5/4) with minor mottling to white (N 9), weathering same colors, very fine grained, silty, well sorted; composed of subrounded to subangular clear and reddish-stained quartz and common dark accessory mineral; firmly cemented, calcareous; bedding obscured but appears to be horizontally laminated; weathers to form recess in cliff profile.

9. Sandstone, light brown (5YR 6/4), weathering same/ color, very fine grained, well sorted; composed of subangular to subrounded reddishstained quartz and minor light and dark accessory minerals; poorly to firmly cemented, calcareous; composed of very thick planar sets of medium- to large-scale high-angle cross-laminae, very thickly bedded
Feet | Wingate Sandstone-Continued Feet Rock Point Member-Continued in upper $10 \mathrm{ft}$; massive splitting; weathers to form vertical cliff. Unit is quite similar to units 5 and $7 \ldots \ldots .$.

8. Siltstone (85 percent) and sandstone (15 percent). Siltstone, light brown (5YR 6/4), very minor mottling to white $(N 9)$, weathering same colors, fairly coarse siltstone, sandy in part, fair sorted; firmly to well cemented, calcareous; bedding obscured in most places, but some horizontal laminations; shaly to massive splitting; weathers to slopes and ledges. Sandstone, light brown (5YR 6/4), weathering same color, very fine grained, silty; well sorted; composed of subangular to subrounded clear and reddish-stained quartz with minor light and dark accessory minerals, poorly to firmly cemented, calcareous; horizontally laminated with some medium-scale low-angle trough sets of cross-laminations; forms ledge from 50.4 to $62.6 \mathrm{ft}$ above base of unit. Unit as whole weathers to ledgy covered slope with ledges from 28.0 to $42.2 \mathrm{ft}$ and from 50.4 to 62.6 $\mathrm{ft}$.....

Offset of 0.35 mile to east on top of bed 7 , so that above units are measured beginning at point 3.9 miles $N .66^{\circ}$ E. of Lukachukai Trading Post and continuing along $a N$. $5^{\circ} \mathrm{W}$. line to point 4.1 miles $N .60^{\circ} \mathrm{E}$. of Lukachukai Trading Post. Probably no more than $10 \mathrm{ft}$ of stratigraphic section gained or lost in transfer.

7. Sandstone, pale reddish brown $(10 R$ $5 / 4)$, weathering same color, very fine grained, well sorted; composed predominantly of reddish-stained quartz with minor feldspar and accessory white mica and dark minerals; firmly to well cemented, calcareous; composed of very thick planar sets of medium- to large-scale high-angle cross-laminae, massive splitting; weathers to form cliff..

6. Sandstone (75 percent) and siltstone (25 percent). Sandstone, light brown (5YR 6/4 and $5 Y R 5 / 6$ ), weathering same colors, very fine grained, silty, well sorted; composed of reddishstained quartz with a few percent white feldspar and common dark accessory mineral and white mica; firmly cemented, calcareous; horizontally laminated to thick bedded; weathers to form ledges. Siltstone, light brown (5YR 6/4), weathering same color, very fine grained, sandy in part; well cemented, calcareous; horizontally laminated; weathers to form slopes. Unit as a whole weathers
28.0 
Wingate Sandstone-Continued

Rock Point Member-Continued

to form an irregular slope with protruding ledges of sandstone. Basal 10 $\mathrm{ft}$ of unit is composed of very fine grained sandstone that forms a continuous cliff face with unit 5. The basal contact is placed at the horizon marking the change from the crossstratification of unit 5 to the horizontal stratification of unit 6 . Half a mile to the north, unit 6 thins and disappears and units 5 and 7 appear to coalesce into one. To the south the same situation may occur, for unit 6 is considerably thinner. Thus, unit 6 may be a lens

5. Sandstone, pale reddish brown $(10 R$ $5 / 4)$ to moderate reddish orange $(10 R 6 / 6)$, weathering pale reddish brown $(10 R 5 / 4)$, very fine grained, well sorted; composed of subrounded to subangular reddish-stained quartz and minor dark accessory mineral; poorly to firmly cemented, calcareous; composed of thick to very thick planar sets of medium- to largescale high-angle planar crosslaminae; massive splitting; weathers to form vertical cliff. The base of this unit forms a continuous cliff face with the upper $8 \mathrm{ft}$ of unit 4 ; the contact is placed at the horizon marking the change from horizontal stratification below to cross-stratification above

4. Siltstone, light brown (5YR 6/4), weathers same colors, coarse, sandy (very fine grained) in part, well sorted; composed of subangular clear and reddish-stained quartz and common accessory white mica and black mineral; firmly to well cemented, calcareous; composed of thin to very thin sets of horizontal laminations and very thin beds, weathers to form irregular cliff. The upper $8 \mathrm{ft}$ composed of light-brown very fine grained massive, horizontally stratified sandstone

3. Siltstone, predominantly light brown (5YR 6/4) with minor pale reddish brown $(10 R 5 / 4)$, weathers light brown; fine to coarse silt; well cemented, calcareous, with some clay binding in finer siltstone; stratification largely obscured, but some of coarser siltstone is very thinly bedded to laminated, and some of the finer siltstone is very thickly bedded; unit as whole weathers to form slope with a few protruding irregular ledges. Ledges occur from 0 to $12 \mathrm{ft}$, 61.0 to $68.2 \mathrm{ft}, 84.0$ to $89.6 \mathrm{ft}$, and 112.0 to $135.4 \mathrm{ft}$; ledge from 112.0 to
Feet
Rock Point Member-Continued
$135.4 \mathrm{ft}$ possibly contains a few sets
of medium-scale low-angle trough
cross-lamination. Coarser siltstone
comprises the ledges and part of the
slopes, while fine siltstone is confined
to the slopes

Total of Rock Point Member.

Total of Wingate Sandstone...

Owl Rock Member (incomplete):

2. Siltstone, pale reddish brown $(10 R$ $5 / 4)$, weathers pale red $(10 R 6 / 2)$, well cemented, calcareous; horizontally stratified; bedding largely obscured, but some of unit is very thinly bedded; weathers to form slope. Siltstone contains minor (5 percent) nodules of calcite from $1 / 4$ to $1 \mathrm{~mm}$. in diameter. Top of unit is 6-in. layer of pale-red $(10 R 6 / 2)$ silty limestone. No limestone occurs above this horizon, and the siltstone of the Rock Point Member has a distinctly more brownish hue.

1. Limestone, light greenish gray (5G $8 / 1)$ and pale red $(10 R 6 / 2)$, weathering to pale reddish brown $(10 R$ $5 / 4$ ) and greenish gray (5G 6/1), microcrystalline, well cemented; horizontally thinly bedded to laminated; weathers to form ledge. Upper 6 in. to $1 \mathrm{ft}$ of unit is composed of limestone nodules and pebbles from $1 / 4$ to 1 in. in diameter

Total of incomplete Owl Rock Member

Total of incomplete Chinle Forma-

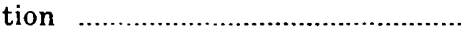

Base of section; not base of exposure. Section begins at a point 3.4 miles N. $65^{\circ}$ E. of Lukachukai Trading Post.

\section{A-7. LUPTON}

Measured on the Defiance monocline at place 3 miles southsoutheast of Lupton, long $109^{\circ} 03^{\prime} 15^{\prime \prime} W$., lat $35^{\circ} 18^{\prime} 20^{\prime \prime} N$., A pache County

[Measured by J. H. Stewart and R. F. Wilson, April 1956]

Top of section; top of accessible exposure.

Entrada Sandstone (unmeasured) :

13. Sandstone, pale reddish brown (10R $5 / 4)$ and minor light greenish gray $(5 G Y 8 / 1)$, weathering same colors, very fine grained, fair sorted; composed of subrounded clear and amberstained quartz and rare black accessory mineral; firmly cemented, calcareous; horizontally laminated to thin bedded, minor ripple laminae; weathers to form vertical cliff. Grades to siltstone in places. Sandstone contains about 2 percent disseminated fine to medium well-rounded quartz grains. Only basal $10 \mathrm{ft}$ of unit ex- 
Entrada Sandstone-Continued amined. Basal contact of unit appears conformable and marks change from slope-forming siltstone below to cliffforming sandstone above Unmeasured

Wingate Sandstone:

Rock Point Member:

12. Sandy siltstone to siltstone, light brown $(10 Y R 6 / 4)$ and pale reddish brown $(10 R 5 / 4)$, weathering same colors; grades from fine siltstone to very fine grained sandy siltstone, rarely grades to very fine grained sandstone composed of subrounded clear quartz and rare black accessory minerals; poorly to firmly cemented, calcareous; horizontally and ripple laminated, cuspate-type ripples, possibly as much as 20 percent structureless siltstone, rarely contains thin trough sets of low-angle small-scale cross-laminae; weathers to form slope containing some thin ledges which probably are on more sandy parts of unit..

11. Sandstone, light brown $(10 Y R 6 / 4)$ and pale reddish brown $(10 R 5 / 4)$, weathering same colors, very fine grained, fair sorted; composed of subrounded amber-stained quartz and common black accessory mineral; poorly cemented, calcareous; horizontally laminated in places and thin to thick very shallow trough sets of very low angle cross-laminae in other places; weathers to form vertical cliff in lower half and dip slope in upper half. Unit forms prominent hogback in Rock Point Member. Sandstone contains disseminated fine to medium sand grains in some parts. Also contains clay and silt pellets in some of the trough sets. Contains several thick lenses of grayish red $(10 R 4 / 2)$ siltstone interstratified with the sandstone. Top $20 \mathrm{ft}$ of unit composed of light-brown (5YR 6/4) sandy siltstone $(80$ percent $)$ interstratified with thin beds of grayish-red $(10 R$ $4 / 2$ ) siltstone (20 percent). Sandy siltstone is ripple laminated with cuspate-type ripples

10. Siltstone, pale reddish brown $(10 R$ $5 / 4)$, weathering same color; firmly cemented, calcareous; structureless, weathers to form slope

Total of Rock Point Member........

Total of Wingate Sandstone..........

Chinle Formation (incomplete) :

Owl Rock Member:

9. Siltstone and limestone. Siltstone, grayish red $(5 R 4 / 2)$, and minor pale reddish brown $(10 R 5 / 4)$, weathering grayish red purple ( $5 R P 4 / 2)$; firmly cemented, calcareous; structureless.
Feet

Chinle Formation (incomplete)-Continued Owl Rock Member-Continued

Limestone, pale red purple (5RP $6 / 2$ ) and light greenish gray (5GY $8 / 1$ ), colors mottled, weathering same colors, dense; well cemented; present as thin horizontal beds from 12.0 to $13.0 \mathrm{ft}$ and 25.5 to $26.0 \mathrm{ft}$. Unit as whole weathers to form steep slope with ledges of limestone. Locally away from line of section lenticular limestone beds occur at different horizons in unit..

Offset at base of unit 9 so that units 1-8 measured about 1,500 ft south of where units 9-13 measured.

8. Limestone, pale red purple (5RP 6/2), weathering same color, dense; well cemented; horizontally thin bedded; weathers to form ledge which is most prominent and continuous ledge in Owl Rock Member. Unit contains a few gray chert nodules and seams.... Clayey siltstone and silty claystone,
grayish red $(5 R 4 \% 2)$, pale reddish brown $(10 R 5 / 4)$, and sparse light brown $(10 Y R 6 / 4)$, weathering pale red purple (5RP 6/2); firmly cemented, calcareous and clay binding; structureless; weathers to form steep slope. Probably does not contain swelling clays

6. Limestone, pale red purple (5RP 6/2) and light greenish gray $(5 G Y 8 / 1)$, colors mottled, weathering same colors; dense; horizontally thin to very thin bedded; weathers to form ledge. Unit contains two thin sets of silty limestone containing films and laminae of siltstone. Top foot of unit contains gray seams of chert that constitute 5 percent of top foot of unit

5. Silty claystone, pale red purple (5RP $6 / 2)$ and grayish red purple (5RP $4 / 2$ ), weathering same colors; swelling clays; structureless; weathers to form steep forthy-surfaced slope..

4. Silty claystone to clayey siltstone, pale reddish brown $(10 R 5 / 4)$, weathering same color; firmly cemented, calcareous and clay binding; structureless; weathers to form earthy-surfaced slope. Probably does not contain swelling clays

3. Limestone, pale red $(5 R 6 / 2)$ and light greenish gray $(5 G Y 8 / 1)$, colors mottled, weathering light brown ( $5 Y R$ $6 / 4)$, dense, well cemented; horizontally very thin to thin bedded; weathers to form small ledge.

Total of Owl Rock Member

Petrified Forest Member (incomplete) :

2. Clayey siltstone, pale reddish brown 
Chinle Formation (incomplete)-Continued Petrified Forest Member (incomplete)-Con. $(10 R 5 / 4)$, weathering same color; firmly cemented, slightly calcareous in parts, clay binding; structureless, some horizontal stratification planes; weathers to form steep slope. Swelling clays noted in a few parts of unit. Top $8 \mathrm{ft}$ of unit contains some grayish-red (5R 4/2) mottling and weathers to pale red purple (5RP $6 / 2)$. This top $8 \mathrm{ft}$ also contains common limestone nodules. The unit is differentiated from that below mainly by weathering characteristics. Unit 1 weathers with a frothy surface whereas this unit weathers with an earthy surface. Perhaps base of this unit represents change from bentonitic rocks below to nonbentonitic, or largely nonbentonitic, rocks above

1. Silty claystone, dark reddish brown $(10 R 3 / 4)$ to pale reddish brown (10R 5/4), weathering same colors; swelling clays; firmly cemented, clay and calcareous cement; structureless; weathers to form frothy-surfaced slope. About $100 \mathrm{ft}$ exposed above alluvium Unmeasured

Total of incomplete Petrified Forest Member

Total of incomplete Chinle Formation

Base of section; base of exposure.

\section{A-8a. NAZLINI TRADING POST SECTION A}

Mcasured starting $13 / 4$ miles southeast of Nazlini Trading Post and continuing up cliffs along a southeast line, long $109^{\circ} 25^{\prime} 10^{\prime \prime} W$., lat $35^{\circ} 52^{\prime} 50^{\prime \prime}$ N., A pache County

[Measured by J. H. Stewart and R. F. Wilson, September 1955]

Top of section; top of exposure. Top of section is about $2 \frac{1 / 4}{4}$ miles S. $54^{\circ}$ E. of Nazlini Trading Post. Chinle Formation (incomplete) :

Petrified Forest Member (incomplete) :

Sonsela Sandstone Bed:

15. Sandstone (85 percent) and limestonegrain sandstone to conglomeratic sandstone (15 percent). Sandstone, white $(N 9)$ to yellowish gray ( $5 Y$ $8 / 1)$, weathering yellowish gray ( $5 Y$ $8 / 1$ ), fine to medium grained, well sorted, composed of subrounded to subangular clear quartz and 5 percent black grains; firmly to well cemented, calcareous, composed of thin trough and minor planar sets of small-scale low-angle cross-laminae. Limestone-grain sandstone to conglomeratic sandstone, greenish gray (5GY 6/1), weathering olive gray (5Y 4/1), composed of medium grains to pebbles of greenish-gray rounded limestone or siltstone in a matrix of limy silt or sand. The medium grains to pebbles of lime-
Feet

Chinle Formation (incomplete)-Continued

Petrified Forest Member (incomplete)-Con.

Sonsela Sandstone Bed-Continued

stone or siltstone may comprise from as much as 60 percent to only a few percent of the rock. Limestone-grain sandstone to conglomeratic sandstone is poorly sorted, well cemented, and calcareous and is present as thin to thick structureless lenses interstratified with the sandstone in the basal half of the unit. Unit weathers to form ledge and underlies extensive bench in the Nazlini area.

14. Silty claystone, grayish red purple (5RP 4/2) with abundant light-greenishgray $(5 G Y 8 / 1)$ mottling, weathering pinkish gray ( $5 Y R 8 / 1)$; poorly cemented, calcareous, clay binding, stratification concealed; weathers to form slope

13. Sandstone; light greenish gray ( $5 G Y$ $8 / 1$ ) in lower $5 \mathrm{ft}$ and light brownish gray $(5 Y R 6 / 1)$ in rest of unit, weathering same colors, very fine to fine-grained; fair sorted, composed of subangular clear quartz, and 10 percent orange, green, and gray minerals, abundant coarse to very coarse accessory dark-green mica; firmly to well cemented, noncalcareous; horizontally laminated, rare thin trough sets of small- to medium-scale lowangle cross-laminae; weathers to form ledgy slope

12. Covered; weathers to form rubble-covered slope

11. Silty claystone, grayish purple $(5 P$ $4 / 2)$, minor grayish red $(10 R 4 / 2)$, and abundant light-greenish-gray (5GY 8/1) mottling, weathering same colors; poorly cemented, calcareous cement in places and clay binding in other places; stratification concealed; weathers to form rubblecovered slope

10. Sandstone, yellowish gray $(5 Y \quad 8 / 1)$ to white $(N 9)$, and minor pinkish gray (5YR 8/1), weathering yellowish gray (5Y 8/1), fine to medium grained, fair sorted; composed of subangular milky quartz, and common black grains; firmly cemented, calcareous; composed of thin planar sets of small- to medium-scale crosslaminae. Basal $2 \mathrm{ft}$ of the unit is conglomeratic sandstone composed of white to gray granules to pebbles (as large as $3 / 4$ in.) of chert and rare quartzite in a medium- to coarsegrained matrix. Away from line of section, unit contains a few claystone or siltstone beds. Unit exposed in a series of slump blocks probably only slightly dislocated from original
Feet 
Chinle Formation (incomplete)-Continued

Petrified Forest Member (incomplete)-Con.

Sonsela Sandstone Bed-Continued position. Unit forms the lower of the two prominent ledges in the Sonsela in the local area

Total of Sonsela Sandstone Bed.....

Lower part:

9. Claystone to clayey siltstone, grayish red purple (5RP 4/2), grayish red $(5 R 4 / 2)$ and medium-gray $(N 5)$, abundant light-greenish-gray (5GY $8 / 1$ ) mottling throughout unit, weathering same colors; poorly cemented, noncalcareous, clay binding; horizontally stratified in beds from 5 to 20 ft thick; weathers to form steep frothy-surfaced badland slope. Some of clay swells on contact with water. From a distance, unit appears as purplish and whitish unit covered with talus debris of sandstone. Unit contains 2 sandstone layers; one from 0.0 to $1.0 \mathrm{ft}$ and the other from 36.7 to $42.3 \mathrm{ft}$. The lower sandstone is light greenish gray ( $5 G Y 8 / 1)$, coarse grained, fair sorted, composed of angular to subangular milky quartz and 10 percent orange, green, and black minerals, and horizontally thinly bedded. The upper sandstone is light brownish gray $(5 Y R 6 / 1)$, fine grained, fair sorted, and horizontally laminated and is composed of subangular milky quartz, 10 percent black mineral, and 5 percent orange mineral. The upper sandstone has a few layers of siltstone. Both sandstone layers occur only along line of section

Total of lower part of Petrified Forest Member

Total of Petrified Forest Member (composite of Nazlini Trading Post sections $A$ and $B$, using thickness of Sonsela Sandstone Bed from section B).

Lower red member:

8. Clayey siltstone, grayish red $(10 R$ $4 / 2$ and $5 R 4 / 2$ ), weathering same colors; firmly cemented, noncalcareous, clay binding; horizontally stratified in beds from 5 to $10 \mathrm{ft}$ thick, possibly some lenticular units; weathers to form slope. Unit contains a few limestone nodules. Top of lower red member of the Chinle Formation placed at the top of this unit because color break at this horizon appears to be prominent locally

7. Siltstone, pale red $(10 R$ " $5 " / 2)$ and light greenish gray (5GY 8/1), mottled in part, weathering pale red
Feet | Chinle Formation (incomplete)-Continued Lower red member-Continued

$(10 R 6 / 2)$; abundant medium-grained accessory dark and white mica; well cemented, calcareous; cuspate-type ripple lamination; weathers to form ledge. About 10 percent of unit is pale-reddish-brown $(10 R$ 5/4) claystone that is the same as that in underlying units. This claystone is present as thin to very thin beds interstratified with the siltstone

6. Claystone and minor siltstone; pale-reddish-brown $(10 R \quad 5 / 4)$, grayish-red $(5 R 4 / 2)$, minor grayish-blue $(5 P B$ $5 / 2$ ) color bands in lower half of unit, and a few thin light-greenishgray ( $5 G Y 8 / 1)$ color bands throughout unit; weathering same colors; firmly cemented, slightly calcareous in parts; composed of horizontal beds from 5 to $20 \mathrm{ft}$ thick; weathers to form steep slope. Clays do not swell on contact with water. A few thin sets of ripple laminated siltstone are present about $20 \mathrm{ft}$ below top of unit.

5. Claystone (60 percent) and siltstone (40 percent). Claystone, same as that in upper half of unit below. Siltstone, light greenish gray ( $5 G Y$ $8 / 1)$ and grayish red $(5 R \quad 4 / 2)$, colors mottled in part, weathering same colors; abundant mediumgrained white mica; well cemented, calcareous; horizontally laminated, possibly some cuspate-type ripple lamination. Siltstone is present as very thin to thin sets interstratified with the claystone. Unit weathers to form small ledge

4. Claystone; grayish red $(5 R 4 / 2)$ in lower half, grading up to pale reddish brown $(10 R 5 / 4)$ in upper half, weathering same colors; firmly cemented; stratification concealed although some horizontal beds can be seen from a distance; weathers to form steep frothy-surfaced slope. Some limestone nodules noted

3. Claystone to siltstone, medium light gray $(N 6)$, light greenish gray (5GY 8/1), several grayish red $(5 R 4 / 2)$ thick color bands in top $20 \mathrm{ft}$, weathering same colors; firmly cemented, noncalcareous, clay binding; stratification concealed; weathers to form frothy-surfaced badlands. Unit contains several thin sets of sandstone in basal $10 \mathrm{ft}$ of unit. This sandstone is yellowish gray ( $5 Y$ $8 / 1$ ) and medium grained and contains abundant interstitial clay and common clay pellets. Sandstone is present as horizontal very thin beds. Unit forms greenish-colored interval
Feet

76.4 
Chinle Formation (incomplete)-Continued Lower red member-Continued

at base of Chinle. The basal half of unit contains abundant carbonaceous material. Clays do not swell on contact with water, although claystone weathers like bentonite. Some limestone nodules present in parts of unit

Total of lower red member

Shinarump Member:

2. Sandstone, mottled yellowish gray ( $5 Y$ $8 / 1$ ) and grayish purple (5P 4/2), yellowish gray $(5 Y 8 / 1)$ in top few feet, weathering same colors, fine to medium grained, fair sorted; composed of subangular clear quartz; well cemented, slightly calcareous, but probably mostly siliceous cement; stratification mostly concealed but is horizontally bedded in some parts, one thin set of low-angle large-scale cross-stratification noted; weathers to form ledge and underlies bench. Mottling of colors very intricate; in many places the two colors form alternating bands a few millimeters thick, giving impression of crosslaminae. Unit contains a few disseminated pebbles of quartzite and yellow chert as large as $1 \frac{1 / 8}{\mathrm{in} \text {. in }}$ maximum dimension. Base of unit is not easily located but is placed at texture and stratification change. On line of section, purplish colors are confined to the Shinarump, but at a locality about $1 / 2$ mile north of Nazlini Trading Post the purple colors occur in the topmost part of the underlying De Chelly...

De Chelly Sandstone (unmeasured) :

Total of Chinle Formation (composite of Nazlini Trading Post sections $A$ and $B$ )

$\underline{\underline{1,091} .2}$

1. Sandstone, pinkish gray (5YR 8/1), weathering very pale orange $(10 Y R$ $8 / 2$ ), very fine to fine grained, well sorted; composed of subangular to subrounded clear quartz and rare black and orange accessory minerals; firmly cemented, slightly calcareous; very thick to thick sets of large-scale cross-strata; weathers to form cliff. Unit examined in small canyon; only top $10 \mathrm{ft}$ examined... Unmeasured

Base of section; base of local exposure.

A-8b. NAZLINI TRADING POST SECTION B

Mcasured starting $61 / 2$ miles southwest of Nazlini Trading Post and continuing west for $11 / 4$ miles to westernmost of two promontories of the northern end of Ganado Mesa, long $109^{\circ} 31^{\prime} 40^{\prime \prime} W$., lat $35^{\circ} 49^{\prime} 35^{\prime \prime}$ N., Apache County

[Mcnsured by J. H. Stewart and R. F. Wilson, September 1955]
Feet Top of section; top of exposure. Top of section is at southeasterly of two promontories and about 500 $\mathrm{ft}$ northwest of slight monoclinal fold. Top of section is $\mathrm{S} .46^{\circ} \mathrm{W}$. of Nazlini Trading Post.

Bidahochi Formation:

10. Sandstone, very pale orange (10YR $8 / 2$ ), weathering same color, fine to medium grained, poorly to fair sorted; composed of rounded to subangular clear and amber-stained quartz and about 5 percent orange and black minerals; poorly cemented, calcareous; horizontally thinly to very thinly bedded, rare mediumscale low-angle cross-strata; weathers to form cliff or very steep slope. Base of unit is an unconformity that cuts out about $50 \mathrm{ft}$ of the Rock Point in about $1,000 \mathrm{ft}$ along the outcrop. Basal $0.4 \mathrm{ft}$ of unit contains granules of reddish siltstone, gray limestone, and white chert. Only basal $20 \mathrm{ft}$ of unit examined; thickness estimated.

Wingate Sandstone:

Rock Point Member:

9. Siltstone, grayish red $(10 R \quad 4 / 2)$ and light brown (5YR 6/4), weathering same colors, very fine grained sandy in places; firmly to well cemented, calcareous; horizontally stratified in beds from 5 to $10 \mathrm{ft}$ thick; weathers to form slope. Unit from 10.2 to 18.7 $\mathrm{ft}$ is sandy siltstone and weathers to form a ledge. Base of unit is conformable

Total of Rock Point Member.

Total of Wingate Sandstone..

Chinle Formation (incomplete) :

Owl Rock Member:

8. Siltstone and limestone. Siltstone, pale reddish brown $(10 R 5 / 4)$, grayish red $(10 R 4 / 2)$, light brown $(5 Y R 6 / 4)$, and rare color bands of grayish red $(5 R 4 / 2)$ to pale red purple (5RP $6 / 2$ ), weathering same colors; limestone nodules that range in size from a few millimeters to over 1 centimeter constitute a few percent to 10 percent of the siltstone in most places; firmly cemented, calcareous; horizontally stratified in beds from a few feet to $20 \mathrm{ft}$ thick. Limestone, light greenish gray $(5 G Y 8 / 1)$, minor pale red (5R 6/2), weathering light greenish gray $(5 G Y 8 / 1)$, dense; second highest limestone bed is oolitic; well cemented. Limestone is present as thin to thick horizontal beds interstratified with the siltstone. Limestone beds have following positions: 135.1 to $136.5 \mathrm{ft}, 173.1$ to $174.1 \mathrm{ft}$, 208.2 to $209.9 \mathrm{ft}, 212.0$ to $214.0 \mathrm{ft}$, 226.1 to $228.8 \mathrm{ft}, 236.0$ to $238.5 \mathrm{ft}$, and 250.1 to $250.9 \mathrm{ft}$ above base of 
Chinle Formation (incomplete) -Continued

Owl Rock Member-Continued

unit. Limestone contains rare gray or white chert nodules mostly less than $1 / 4$ in. in maximưm dimension. Thickness and position of limestone beds varies considerably along exposure. Limestone weathers to form ledges whereas siltstone weathers to form slopes. Second highest limestone bed forms cap to prominent line of cliffs to the north of section.

7. Limestone and siltstone. Limestone, pale red purple (5RP 6/2) and light greenish gray $(5 G Y 8 / 1)$, weathering same colors, dense; well cemented, horizontally thinly bedded; weathers to form ledges. Limestone contains gray chert nodules as large as 2 in. in maximum dimension. Siltstone, pale red purple (5RP 6/2) and grayish red $(5 R 4 / 2)$, weathering same colors; firmly cemented, calcareous. Siltstone is present as thin to very thick structureless beds interstratified with thin to thick beds of limestone. Siltstone weathers to form slopes and contains aburiant limestone nodules. Unit as whole weathers to form prominent dark-colored ledge. This unit contains a total of $5.0 \mathrm{ft}$ of limestone. In places the siltstone grades laterally to limestone....

Total of Owl Rock Member

Petrified Forest Member (incomplete) : Upper part:

6. Siltstone, light brown (5YR 6/4) to grayish red $(10 R \quad 4 / 2)$, one $10-\mathrm{ft}$ pale-red $(10 R 6 / 2)$ interval in middle of unit, weathering same colors; firmly cemented, calcareous; horizontally stratified in beds from a few feet to $20 \mathrm{ft}$ thick; weathers to form steep slope. The base of unit appears to mark the top of bentonitic claystone in the stratigraphic section and the base of siltstone similar to that in the Owl Rock Member. From a disstance, the base of unit is easy to pick; the underlying unit weathers to frothy-surfaced badlands that have smooth rounded forms, whereas unit described here weathers as a steep slope with relatively intricate gullies and a relatively thin veneer of weathered rock. In detail, the contact is difficult to locate. Siltstone contains common limestone nodules the size of coarse grains to pebbles. At 78.4 to $81.6 \mathrm{ft}$, unit contains abundant palered $(10 R 6 / 2)$ limestone nodules that in places join to form a thin irregular mass of limestone
Feet

Chinle Formation (incomplete)-Continued

Petrified Forest Member (incomplete)-Con. Upper part-continued

5. Silty claystone, pale reddish brown ( $10 R$ $5 / 4)$, grayish red $(10 R 4 / 2)$ and moderate red $(5 R 5 / 4)$, common light-greenish-gray (5GY 8/1) mottling, weathering same colors; probably grades from claystone to siltstone; bentonitic clays; firmly cemented, calcareous in parts; structureless, some suggestion of horizontal stratification planes at places; weathers to form badlands. Surface is frothy and has weathered zone from $1 / 2$ to $1 \mathrm{ft}$ thick. Unit contains many horizons of limestone nodules. Basal $6 \mathrm{ft}$ of unit is clayey sandstone which is pale red $(10 R 6 / 2)$ with abundant light-greenish-gray mottling and is very fine grained and fair sorted. The clayey sandstone is composed of subangular to angular milky quartz and about 2 percent coarsegrained dark-green mica, has concealed stratification and weathers to form a slope

Note. - Units 3 and 4 are laterally equivalent to units included in Sonsela Sandstone Bed in Nazlini Trading Post section A.

4. Siltstone and limestone nodules. Siltstone, grayish red $(5 R 4 / 2$ and $10 R$ $4 / 2)$, weathering medium gray $(N$ $5)$; firmly cemented, calcareous; some horizontal stratification planes. Limestone nodules, pale red $(10 R 6 / 2)$ and medium light gray $(N 6)$, dense, as large as $1 \frac{1 / 2}{\mathrm{in}}$. in largest dimension, comprise about 20 percent of unit. Unit forms conspicuous grayish color band in the otherwise reddish sequence of strata. Locally unit contains very thin to thin lenses of limy siltstone. At a few places the unit grades laterally into cliff-forming sandstone. Directly to the east of base of this section, unit appears to grade laterally into a sandstone bed that forms part of the Sonsela Sandstone Bed. Unit is either at the same position or close to the same position ( $\pm 25 \mathrm{ft}$ ) as unit 15 in Nazlini Trading Post section A.......

Offset at the base of this unit 4 so that overlying units measured $1,500 \mathrm{ft}$ west of underlying units.

3. Silty claystone to siltstone (60 percent) and sandstone (40 percent). Silty claystone to siltstone, pale reddish brown $(10 R 5 / 4)$ and grayish red (5R 4/2), weathering same colors; poorly to well cemented, slightly calcareous; stratification concealed;
Feet 
Chinle Formation (incomplete)-Continued

Petrified Forest Member (incomplete)-Con.

Upper part-Continued

papery splitting in lower half. Sandstone, pale pink $(5 R P 8 / 2)$, bluish white $(5 B 9 / 1)$, and light greenish gray $(5 G Y 8 / 1)$, weathering same colors, fine to medium grained, clayey in parts, fair-sorted; composed of subangular milky quartz and 1 to 5 percent black mineral; firmly cemented, clay binding, slightly calcareous in parts; stratification concealed; viewed from a distance, sandstone is lenticular and contains low-angle cross-strata. Unit as a whole weathers to form badlands. Clays swell on contact with water. A thin lens of sandstone at $36.6 \mathrm{ft}$ that contains abundant pelecypods. The pelecypods are poorly preserved, are conposed of calcite, and are as long as about $11 / 2$ in. This sandstone also contains a few bone fragments

Total of upper part of Petrified Forest Member

Sonsela Sandstone Bed:

2. Sandstone, pale pink ( $5 R P 8 / 2)$ to pale red purple (5RP 6/2) and light greenish gray ( $5 G Y 8 / 1)$, weathering light olive gray $(5 Y 6 / 1)$, fine grained, fair sorted; composed of subangular milky quartz and about 5 percent orange and green minerals, rare coarse-grained accessory white mica; firmly cemented, slightly calcareous; composed of thin wedgeplanar and trough sets of small- to medium-scale cross-laminae; weathers to form most prominent local ledge and underlies a bench in places. Basal 3 in. contains about 40 percent gray rounded granules and pebbles of siltstone and limestone. Unit intertongues extensively with overlying unit. This unit may be the same as unit 10 of Nazlini Trading Post section A

Total of Sonsela Sandstone Bed...

Lower part (incomplete):

1. Claystone to siltstone (70 percent) and clayey sandstone ( 30 percent). Claystone to siltstone, grayish purple (5P $4 / 2)$ and grayish red ( $5 R 4 / 2)$, and abundant light greenish gray ( $5 G Y$ $8 / 1$ ) mottling, weathering same colors; firmly cemented, noncalcareous; probably horizontally stratified in beds from 5 to $10 \mathrm{ft}$ thick. Clayey sandstone, pale red purple (5RP $6 / 2$ with abundant light-greenish-gray (5GY 8/1) mottling, some yellowish gray $(5 Y 8 / 1)$, fine to medium
Feet

Chinle Formation (incomplete)-Continued

Petrified Forest Member (incomplete)-Con.

Lower part (incomplete)-Continued

grained; fair sorted; composed of angular to subangular clear and milky quartz and about 10 percent orange mineral, 5 percent green mineral, and 3 percent dark-green mica; poorly cemented, slightly calcareous, mostly clay binding; stratification concealed, but from a distance sandstone appears to form lenses and fill channels several feet deep cut into underlying beds. Unit as whole weathers to form steep frothy-surfaced slope. Position and amount of sandstone greatly variable. Thickness of unit estimated. This unit is the same, at least for the most part, as unit 9 of Nazlini Trading Post section A

$125.0 \pm$

Total of incomplete lower part of Petrified Forest Member

$125.0 \pm$

Total of incompleted Petrified Forest Member

481.2

Total of incomplete Chinle Formation

Base of section; base of exposure. Base of section about $1 \frac{1}{2}$ miles east of prominent line of cliffs formed by the Owl Rock Member. Section starts in large north-south canyon and at point about 2,000 $\mathrm{ft}$ south of monocline.

\section{A-9b. ST. JOHNS SECTION B}

Measured 6 miles S. $20^{\circ} \mathrm{E}$. of St. Johns and 1 mile N. $20^{\circ} \mathrm{E}$. of northeasternmost part of basalt-capped mesa, long $109^{\circ} 19^{\prime} 30^{\prime \prime} W$., lat $34^{\circ} 25^{\prime} 25^{\prime \prime}$ N., A pache County

[Measured by J. H. Stewart and R. F. Wilson, August 1955]

Top of section; top of exposure. Top of section at point several hundred feet west of a uranium prospect.

Chinle Formation (incomplete) :

Petrified Forest Member (incomplete):

9. Sandstone, grayish orange $(10 Y R 7 / 4)$, weathers to dark yellowish orange $(10 Y R 6 / 6)$; fine grained, base of unit contains abundant thin lenses of yellowish-gray $(5 Y 8 / 1)$ to dark-gray ( $N$ 3 $)$ medium- to coarse-grained friable sandstone as well as conglomerate lenses composed of clay galls and of granules to pebbles of chert and quartzite. Sandstone is well sorted and is composed of subangular to subrounded clear to yellowishstained quartz with rare black accessory mineral and mica; well cemented, calcareous. Unit is composed of very thin to thick trough sets of medium-scale cross-strata and weathers to form prominent vertical cliff that forms cap of escarpment extending for several miles

8. Clayey pebbly sandstone, yellowish-gray (5Y 7/2), mottled with moderate
Feet 
Chinle Formation (incomplete)-Continued

Petrified Forest Member (incomplete)-Con. yellow $(5 Y 7 / 6)$, weathering same colors, medium to coarse grained, poorly sorted; sand grains are composed of subangular to subrounded clear quartz with uncommon black accessory mineral and white mica; clay comprises 20 percent of the unit; pebbles of chert and quartzite as large as $3 / 4 \mathrm{in}$. in maximum diameter constitute 10 percent of unit and occur disseminated throughout the sandstone. Clayey pebbly sandstone is poorly cemented and has a slightly calcareous clay binding; it probably is thin bedded but stratification is largely concealed. Unit weathers to form slope. Unit contains abundant carbonaceous and siliceous plant remains

7. Claystone, light-olive-gray (5Y 6/1) mottled with moderate yellow (5Y $7 / 6$ ), weathering same colors, contains minor very fine sand and silt grains; fair sorted; contains swelling clays; sand and silt grains are composed dominantly of subangular to subrounded milky quartz; noncalcareous; structureless; weathers to form slope

Total of incomplete Petrified Forest Member

Mesa Redondo Member:

6. Siltstone to claystone, grayish red ( $10 R$ $4 / 2)$, minor grayish-purple (5P 4/2) mottling in upper $2 \mathrm{ft}$, weathering same colors; firmly cemented, noncalcareous; stratification concealed; weathers to form slope

5. Clayey sandstone, grayish red purple (5RP 4/2) and light greenish gray (5GY 8/1), mottled; weathering pinkish gray $(5 Y R \quad 8 / 1)$; medium to coarse grained, poorly sorted; contains 15 to 20 percent clay; composed of subangular grains, dominantly clear quartz, about 20 percent black grains, and 10 percent orange and green grains; poorly cemented, slightly calcareous; stratification concealed; weathers to form steep slope. A few granules and pebbles of chert noted

4. Siltstone to sandstone (80 percent) and sandstone (20 percent), grayish red $(10 R 4 / 2)$, rare grayish red purple (5RP 4/2), and light-greenish-gray (5GY 8/1) mottling; weathering moderate red $(5 R 5 / 4)$, sandy (very fine grained) in parts; common medium-grained accessory mica; firmly to well cemented, slightly calcareous; structureless. Sandstone, grayish red $(5 R 4 / 2)$, weathering same color,
Feet Chinle Formation (incomplete)-Continued Mesa Redondo Member-Continued medium to coarse grained, silty; composed of angular reddish-stained quartz, firmly cemented; calcareous; composed of thin trough sets of medium-scale cross-laminae. Sandstone is present as thin to very thick lenses interstratified with rest of unit. Unit as whole weathers to form bench in lower part and gentle slope in upper part

Total of Mesa Redondo Member.....

Long offset in section. Section transferred so that overlying units measured starting 2,000 ft S. $26^{\circ}$ E. of unit 3. Possibly 10 $f t$ of strata gained or lost in transfer.

3. Sandstone to conglomeratic sandstone, brownish gray $(5 Y R 4 / 1)$ and pale reddish brown $(10 R 5 / 4)$, weathering grayish red $(10 R \quad 4 / 2)$ and light brown $(5 Y R 6 / 4)$, coarse grained, fair sorted; composed of subrounded to subangular reddish-stained quartz; poorly cemented, calcareous in parts; composed of thin trough sets of small- to medium-scale cross-laminae; weathers to form extensive bench. Granules to cobbles comprise about 5 percent of unit and occur disseminated in the sandstone or concentrated in poorly defined thin beds. The granules to cobbles are composed of quartzite, chert, and rare quartz, average about $1 \mathrm{in}$. in diameter, and are as large as $3 \mathrm{in.}$ in diameter

Total of Shinarump Member. Mottled strata

2. Sandstone, light greenish gray ( $5 G Y$ $8 / 1$ ) with irregular mottled areas of grayish red $(5 R 4 / 2)$, grayish purple $(5 P 4 / 2)$ and dark yellowish orange $(10 Y R 6 / 6)$, mottling occurs mostly along vertical zones from a few inches to $1 \mathrm{ft}$ wide; weathers same colors, fine grained, poorly sorted; composed of angular milky quartz and about 5 percent black minerals; well cemented, noncalcareous; stratification largely concealed by mottling, but unit contains some small- to medium-scale cross-strata; unit weathers to form a vertical cliff, and forms conspicuous purplish mottled interval

Total of mottled strata

Total of Chinle Formation (composite of St. Johns sections B, C, and D)

Moenkopi Formation (incomplete) :

1. Siltstone to claystone, grayish red ( $5 R$ $4 / 2$ and $10 R 4 / 2$ ) and grayish purple (5P 4/2); firmly cemented, noncal-
33.6

eet

$\begin{array}{r} \\ \hline 9.2 \\ \hline 84.6 \\ \hline\end{array}$

\begin{tabular}{l}
6.8 \\
\hline 6.8 \\
\hline 5.8 \\
\hline
\end{tabular}

$1,035.8$ 
Moenkopi Formation (incomplete) - Continued careous; structureless; weathers to form steep slope along side of creek; base of unit not exposed

Total of incomplete Moenkopi Formation

Base of section; base of exposure. Base of section about $3,000 \mathrm{ft} \mathrm{N} .55^{\circ} \mathrm{W}$. of prospect.

\section{A-9c. ST. JOHNS SECTION C}

Measured on exposure 3-4 miles east to northeast of St. Jolus. Units $1-3$ at long $109^{\circ} 17^{\prime} 50^{\prime \prime} W$., lat $34^{\circ} 30^{\prime} 10^{\prime \prime} N$.; unit 4 at long $109^{\circ} 18^{\prime} 50^{\prime \prime} W$., lat $34^{\circ} 31^{\prime} 40^{\prime \prime} N$., and units 5-8 at long $109^{\circ} 18^{\prime} 30^{\prime \prime} W$., lat $34^{\circ} 32^{\prime} 15^{\prime \prime}$ N., A pache County

[Measured by J. H. Stewart and F. G. Poole, June 1955]

Top of section; top of exposure. Top of section at highest exposure on cliffs 4.0 miles northeast of St. Johns and 3.5 miles N. $41^{\circ} \mathrm{E}$. of bridge across Little Colorado River on east side of St. Johns.

Chinle Formation (incomplete):

Upper part of Petrified Forest Member (incomplete) :

8. Claystone to siltstone, grayish purple (5P 4/2) and greenish gray (5GY $6 / 1)$, weathering same colors; swelling clay; well cemented, noncalareous; structureless, color bands suggest a few horizontal bedding planes; weathers to form badlands. Unit contains several horizons of limestone nodules. Unit measured to highest exposure

Total of incomplete upper part of Petrified Forest Member

Sonsela Sandstone Bed:

7. Sandstone, very pale orange (10YR $8 / 2)$ and yellowish gray $(5 Y 8 / 1)$, weathering grayish orange (10YR $7 / 4$ ) in lower half and very pale orange $(10 Y R 8 / 2)$ in upper half; fine to medium grained, fair sorted; composed of subangular to subrounded clear quartz and common orange accessory minerals in upper half; poorly cemented in lower half and firmly to well cemented in upper half, clay binding, noncalcareous; stratification largely concealed, but unit contains very thin to thin horizontal beds in top half; weathers to form steep slope. Unit forms conspicuous $\tan$ band on outcrop. About 2,000 ft southwest of line of section unit forms a cliff and caps small mesa; unit contains carbonaceous material in lower half, silicified wood common lateral to line of section; also lateral to line of section unit contains conglomeratic beds near base with granules and pebbles of chert and quartzite

Total of Sonsela Sandstone Bed......

\author{
Feet
$\frac{10+}{10+}$
St.
N.;
nits
Feet
}

(2)

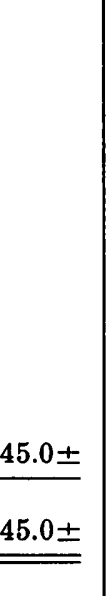

$\mid$
Chinle Formation (incomplete)-Continued

Lower part of Petrified Forest Member:

6. Claystone to clayey sandstone, grayish purple $(5 P 4 / 2)$, grayish red $(5 R$ $4 / 2)$, and greenish gray ( $5 G Y 6 / 1)$, weathering same colors. Clay sandstone, very fine grained, poorly sorted; composition largely masked but contains 5 to 10 percent orange and green minerals, and 1 percent dark-green mica. Claystone to clayey sandstone, firmly cemented, clay binding, noncalcareous; structureless; weathers to form badlands. To north of line of section this unit is mostly greenish and forms a conspicuous greenish band. Thickness of unit may be in error by as much as $10 \mathrm{ft}$.

5. Clayey sandstone, white $(N 9)$, pinkish gray $(5 Y R 8 / 1)$, pale olive $(10 Y$ $6 / 2)$ and grayish red $(5 R 4 / 2)$ in top $2 \mathrm{ft}$, fine grained, poorly sorted; composed of angular milky quartz and 10 percent orange and green minerals, abundant dark-green mica; poorly cemented, clay binding, noncalcareous; stratification concealed; weathers to form badlands

Offset on top of unit 4 so that units 5-8 measured starting at point 2,500 ft northeast of top of unit 4. Units 5-8 measured starting at point $N .45^{\circ} \mathrm{E}$. of bridge.

4. Claystone, variegated in horizontal bands, grayish purple (5P 4/2), grayish red purple $(5 R P 4 / 2)$, medium gray $(N 5)$, and light greenish gray $(5 G Y 8 / 1)$ in thin bands and as mottling throughout, weathering same colors; swelling clays; firmly to well cemented, noncalcareous; structureless, horizontal color bands suggest horizontal stratification planes; weathers to form frothysurfaced badlands. Several limestonenodule horizons. Many fossil vertebrate fragments. Thickness of unit probably accurate within $10 \mathrm{ft}$..

Long offset in section at color change at top of unit 3 , so that unit 4 measured starting at point about 1.9 miles $N$. $30^{\circ} \mathrm{W}$. of place where unit 3 measured. Color change appears to be consistent stratigraphically, so that probably not more than $15 \mathrm{ft}$ was lost or gained in offset. Unit 4 measured at place 3.0 miles $N .60^{\circ} \mathrm{E}$. of bridge across Little Colorado River at east side of St. Johns and 1.4 miles N. $44^{\circ} E$. of cemetery.

3. Claystone (80 percent) and sandstone (20 percent). Claystone, grayish red $(10 R 4 / 2)$ to grayish yellow green $(5 G Y 7 / 2)$, very dusky red $(10 R 2 / 2)$ at top, weathering same colors; swelling clays, common finegrained white mica; well cemented,
Feet 
Chinle Formation (incomplete)-Continued

Lower part of Petrified Forest Member-Con. clay binding calcareous cement; horizontally bedded and structureless. Sandstone, grayish red $(10 R 4 / 2)$, grayish yellow green $(5 G Y 7 / 2)$, and dusky yellow (5Y 6/4), weathering same colors, very fine grained, well sorted; composed of clear quartz, abundant white mica; well cemented, calcareous cement and clay binding; very thin to thin sets of ripple laminae. Unit as whole weathers to form steep slope. Unit from distance appears as conspicuous brownish band over greenish rocks of underlying unit

Lcwer sandy unit:

2. Claystone to siltstone and sandstone. Claystone to siltstone, greenish gray $(5 G Y 6 / 1)$, a $15 \mathrm{ft}$ interval of grayish red $(10 R 4 / 2)$ in middle of unit and abundant grayish red purple $(5 R P 4 / 2)$ in top $10 \mathrm{ft}$, weathering same colors; firmly to well indurated; structureless; weathers to form frothy-surfaced slope. Sandstone, greenish gray $(5 G Y 6 / 1)$ and light brownish-gray (5YR 6/1), weathering grayish brown $(5 Y R 3 / 2)$, very fine grained, well sorted; composition unknown, abundant medium-grained accessory white mica; well cemented, calcareous; ripple laminated, cuspatetype ripples; weathers to form ledges. Sandstone is present as thin to very thick sets interstratified with claystone and siltstone; along line of section only a few thin sets of sandstone are present, but away from line of section as much as 10 percent of unit is composed of these sets of sandstone; in places the sets of sandstone are contorted by many small-scale folds and faults; from a distance the unit gives a hummocky appearance. Claystone to siltstone contains rare flakes of carbonaceous material; basal $2.5 \mathrm{ft}$ of unit is grayish-blue (5PB $5 / 2$ ) claystone containing swelling clays

Total of lower sandy unit.

Total of lower part of Petrified Forest Member

Total of Petrified Forest Member (composite of St. Johns sections $C$ and $D$ using thickness of Sonsela Sandstone Bed from section D)

Mesa Redondo Member (unmeasured) :

1. Claystone and sandstone. Claystone, grayish red (10R $4 / 2$ and $5 R \quad 4 / 2$ ), pale red purple ( $5 R P 6 / 2)$, weathering same colors, abundant white
Feet

\section{Chinle Formation (incomplete)-Continued}

Mesa Redondo Member-Continued

mica; firmly cemented; structureless; shaly splitting in part. Sandstone, light greenish gray $(5 G 8 / 1)$, to brownish gray $(5 Y R 4 / 1)$, weathers yellowish gray $(5 Y \quad 7 / 2)$ and pale brown $(5 Y R 5 / 2)$, medium to coarse grained, fair sorted; composed of subangular to subrounded quartz and rare chert, 1 to 2 percent white and green mica; poorly cemented, calcareous and clay cement; composed of 1to 2-ft-thick lenticular beds, minor trough sets of small-scale crossstratification. Unit as a whole weathers to form slope. Only top $10 \pm \mathrm{ft}$ of unit exposed Unmeasured

Total of incomplete Chinle Formation

Base of section; base of exposure. Base of section is 3.3 miles east of the bridge across the Little Colorado River on the east side of St. Johns. Base of section near head of 1,000 -ft-wide reentrant in Chinle outliers; base of section 1.8 miles S. $68^{\circ}$ E. of cemetery.

\section{A-9d. ST. JOHNS SECTION D}

Measured across an anticline about 16 miles north of St. Johns and 1 mile east of highway U.S. 666-Arizona 61. Section starts at Argo Co. drill hole at long $109^{\circ} 15^{\prime} \mathrm{W}$., lat $34^{\circ} 42^{\prime} N$., and continues to northeast with several offsets to promontory at long $109^{\circ} 11^{\prime} W$., lat $34^{\circ} 46^{\prime} N$., A pache County

[Measured by J. H. Stewart and F. G. Poole, June 1955]

Top of section; top of exposure. Top of section at point 6 miles N. $37^{\circ} \mathrm{E}$. of Argo Co. drill hole. Top of section is 1 mile east of a northern limit of a lava flow.

Dakota Sandstone (incomplete):

12. Sandstone, grayish orange $(10 Y R 7 / 4)$, weathering same color, fine grained, well sorted; composed of subrounded clear quartz and rare black accessory mineral; firmly cemented, noncalcareous; composed of thin planar sets of small-scale cross-laminae, minor horizontal very thin beds; massive splitting; weathers to form ledge and underlies bench at top of cliff.

11. Siltstone (80 percent) and sandstone (20 percent). Siltstone, dark gray $(N 3)$ to light gray $(N 7)$ and minor yellowish gray $(5 Y 8 / 1)$, weathering light gray $(N)$; poorly to well cemented, clay binding; stratification concealed. Sandstone, dusky yellow $(5 Y 6 / 4)$ and very pale orange $(10 Y R \quad 8 / 2)$, weathering very pale orange $(10 Y R \quad 8 / 2)$, very fine grained, fair sorted; composed of subangular quartz and common black accessory mineral; well cemented, calcareous; horizontally laminated and minor thin planar sets of small-
Feet 
Dakota Sandstone (incomplete)-Continued scale cross-laminae. Unit as whole weathers to form slope with ledges on the sandstone; the sandstone is present as thick to very thick layers interstratified with the siltstone; dark-gray siltstone is probably carbonaceous

10. Sandstone, grayish orange $(10 Y R 7 / 4)$ and rare moderate orange pink $(10 R$ $7 / 4)$, weathering grayish orange (10YR 7/4); fine grained, fair sorted; composed of subangular clear quartz and rare black accessory minerals; firmly cemented, slightly calcareous; composed of thin to thick trough sets of medium-scale cross-laminae. Lower half of unit contains much contorted stratification with gnarly appearance; weathers to form ledge. Basal third of unit contains several lenses containing angular granules and pebbles of siltstone; basal contact sharp; basal strata contain casts of worm borings (?)

Total of incomplete Dakota Sandstone

Chinle Formation (incomplete):

Petrified Forest Member (incomplete) :

Upper part:

9. Siltstone, pale olive $(10 Y 6 / 2)$ and light greenish gray ( $5 G Y 8 / 1$ ), weathering same colors; firmly to well cemented, calcareous; structureless; weathers to form steep slope that forms greenish band below overlying sandstone unit. Basal contact of unit is gradational, across $10 \mathrm{ft}$ of beds, with reddish siltstone of underlying unit. Top $2 \mathrm{ft}$ of unit is dominantly dark yellowish orange. This unit may be entirely or partly the basal bed of the Dakota Sandstone, but is tentatively considered a bleached bed at the top of the Chinle Formation. It is considered Chinle because it does not contain carbonaceous beds typical of the Dakota and because it appears to grade downward into typical Chinle..

8. Sandstone ( 60 percent) and siltstone (40 percent). Sandstone, moderate red $(5 R 4 / 6)$ and pale red $(5 R 6 / 2)$ with common light-greenish-gray (5GY 8/1) mottling, weathering same colors, very fine to fine grained, fair sorted; composed of subangular clear quartz and 5 to 10 percent orange and black minerals, common white mica; firmly to well indurated, slightly calcareous cemented, some clay binding; horizontally laminated to very thin bedded, rare ripple laminae and rare trough sets of medium-scale cross-laminae. Siltstone,
Chinle Formation (incomplete)-Continued

Feet

Petrified Forest Member (incomplete)-Con.

Upper part-Continued

grayish red $(10 R 4 / 2)$ and pale reddish brown $(10 R 5 / 4)$, weathering same colors, clayey in parts; firmly to well cemented, calcareous; structureless. Unit as whole weathers to form steep slope; siltstone forms top $135 \mathrm{ft}$ of unit, and sandstone predominates in rest of unit. Unit contains several lenses with abundant limestone nodules and several lenses of very coarse grained sandstone composed of rounded limestone grains in a silt matrix

7. Covered. Forms about 2.6 miles of wide flat. Dip estimated to average $0^{\circ}$ because exposures at both ends of covered interval have about this dip. Possibly some error in thickness due to inaccuracy in estimating dip .........

Long offset in section, so that base of unit 7 is measured about 2.8 miles $N .14^{\circ}$ $W$. of unit 6 . Unit 7 measured starting at point about 3.4 miles $N .30^{\circ}$ E. of Argo Co. drill hole and continuing along line $N$. $47^{\circ} E$. to point on cliffs about 2.7 miles distant. Offset on exposed top surface of sandstone.

6. Sandstone (80 percent) and conglomerate $(20$ percent). Sandstone, pale red (10R 6/2), weathering same color, fine to medium grained, fair sorted, composed of subangular to subrounded milky quartz and abundant black and rare orange accessory minerals, poorly cemented, calcareous, composed of thin to thick planar and trough sets of medium-scale cross-laminae. Conglomerate, pale red $(10 R 6 / 2)$ and minor yellowish gray (5Y 8/1), weathering pale yellowish brown $(10 Y R 6 / 2)$. Clasts in conglomerate average $1 / 4$ to $1 / 2$ in. in diameter and are composed of light-gray, yellow, and red chert, white quartz, and darkgray quartzite. Matrix of conglomerate in places is fine to medium sand and in other places is sandy silt. Conglomerate is firmly to well cemented, calcareous, structureless, and in places cross stratified; all gradations occur from conglomerate to sandstone. Unit as whole weathers to form prominent ledge that caps cliffs about 2.5 miles east of Argo Co. drill hole. One silicified $\log$ about 9 in. in diameter was noted. Top of unit 6 at point approximately N. $80^{\circ} \mathrm{E}$. of Argo Co. drill hole.

5. Clayey sandstone (50 percent) and claystone to siltstone (50 percent). Clayey sandstone, pale red $(10 R 6 / 2)$, rare light-greenish-gray (5GY 8/1) 
Chinle Formation (incomplete)-Continued

Petrified Forest Member (incomplete)-Con.

Upper part-Continued

mottling and thin bands, weathering same colors; very fine to fine grained, rare'medium to coarse grained parts, abundant clay, fair sorted; composed of subangular milky quartz, and common green accessory mineral, abundant dark-green mica; firmly to well cemented, slightly calcareous; horizontally laminated to thin bedded and minor thin trough sets of mediumscale cross-laminae. Claystone to siltstone, grayish red $(10 R \quad 4 / 2)$ and minor pale red $(10 R 6 / 2)$, weathering same colors; swelling clays in places; firmly cemented, slightly calcareous; structureless. Unit weathers to form steep reddish slope. All gradations from clayey sandstone and siltstone to claystone occur; individual beds within unit are discontinuous............

4. Covered. Unit forms a 0.8-mile-wide flat. Dip estimated to average about $0^{\circ}$. Possibly some error in thickness due to inaccuracy in estimating dip....

Total of upper part of Petrified Forest Member

Long offset in section, so that overlying unit is measured starting 1 mile N. $80^{\circ} \mathrm{E}$. of underlying unit. Units 4,5 , and 6 measured along line $N .85^{\circ} E$. across a flat and up cliffs 0.8 mile distant. Offset on exposed top surface of sandstone.

Sonsela Sandstone Bed:

3. Sandstone to conglomeratic sandstone, white $(N 9)$ to very light gray $(N$ $8)$, weathering pale red $(10 R 6 / 2)$ to grayish orange pink (10YR 7/2), fine to coarse grained, well to fair sorted; composed of subangular to subrounded clear quartz and rare pink quartz, common black accessory minerals, and uncommon white mica; well to poorly cemented, noncalcareous; medium-scale trough sets; weathers to form ledge and forms prominent bench. Pebbles occur chiefly as lenses in lower $2 / 3$ of unit. They are composed chiefly of rounded white chert. Many chert pebbles are badly weathered. Other pebbles are quartzitic, and a few are igneous material, quartz, or siltstone. Minor siltstone partings are present

Total of Sonsela Sandstone Bed

Lower part (incomplete) :

2. Claystone and clayey sandstone. Claystone, grayish red purple (5RP 4/2) and minor light greenish gray ( $5 G Y$ $8 / 1)$ and dark reddish brown (10R $3 / 4)$, weathering pale red purple ( $5 R P$

Feet

Chinle Formation (incomplete)-Continued

Petrified Forest Member (incomplete)-Con.

Lower part (incomplete)-Continued

$6 / 2)$ and light greenish gray (5GY $8 / 1$ ) ; swelling clays; firmly indurated, noncalcareous; structureless. Clayey sandstone, light greenish gray $(5 G Y \quad 8 / 1)$ and grayish red $(10 R$ $4 / 2$ ), weathering same colors; fine to coarse grained, clayey, poorly sorted; composed of angular milky quartz, 5 to 10 percent orange and green minerals, and 1 to 2 percent dark-green mica; poorly indurated, clay binding; structureless. Unit weathers to form steep badland slopes. Claystone contains many limestone nodules. Clayey sandstone is confined to top $50 \mathrm{ft}$ of unit and forms about 90 percent of top $50 \mathrm{ft}$...

176.4

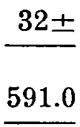

591.0

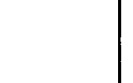

Base of section at Argo Co. drill hole.............. measured along line N. $7^{\circ} \mathrm{E}$. to top of promontory about 0.6 miles from drill hole.

\section{A-10. BLACK POINT}

Measured on the south side of a mesa (remnant of pediment surface on top) directly east of Black Point, starting about $11 / 2$ miles east of the Little Colorado River, continuing up the Chinle cliffs to the east of Black Point, and finishing near the head of a wash about 9 miles east of Black Point, long $111^{\circ} 11^{\prime}$ to $111^{\circ} 22^{\prime} W$., lat $35^{\circ} 38^{\prime}$ to $35^{\circ} 44^{\prime} \mathrm{N}$, Coconino County

[Measured by J. H. Stewart, H. F. Albee, O. B. Raup, and F. G. Poole, November 1954]

Top of section; not top of exposure. Top of section is N. $82^{\circ} \mathrm{E}$. of about middle of Black Point.

Wingate Sandstone (unmeasured):

14. Sandstone, light brown $(5 Y R \quad 5 / 6)$, weathering same color, very fine to fine grained, about 15 percent medium to very coarse grains, fair sorted; composed of subrounded clear quartz. Medium to very coarse grains are rounded and composed of milky quartz and rare orange and gray minerals. Unit is poorly cemented, calcareous; composed of horizontal laminae and thin trough and planar sets of small- to medium-scale crosslaminae; massive splitting; weathers to form bare rounded knolls. Basal $1.5 \mathrm{ft}$ is light greenish gray (5GY $8 / 1$ ). Basal contact sharp and hori-
Feet 
Wingate Sandstone-Continued zontal. Only basal $15 \mathrm{ft}$ of unit examined.

Chinle Formation:

Owl Rock Member:

13. Siltstone and limy siltstone. Siltstone same as in unit 11. Limy siltstone, light greenish gray $(5 G Y 8 / 1)$ and pale red $(10 R 6 / 2)$, weathering same colors, firmly cemented; composed of thin to very thin horizontal beds and lenses interstratified with siltstone. Unit as whole weathers to form steep slope containing conspicuous light color bands developed on the limy siltstone. A thick interval containing common limestone nodules occurs 4.0 $\mathrm{ft}$ below the top. Totally, about $1.5 \mathrm{ft}$ of unit is limy siltstone.

12. Siltstone to silty claystone, pale reddish brown $(10 R 5 / 4)$, weathering same color, probably composed in part of bentonitic clay; firmly cemented, calcareous; structureless, rare horizontal stratification planes; fractures into angular fragments; weathers to form $1 / 2$-mile-wide flat. Parts of unit poorly exposed. Thick interval contains abundant limestone nodules at $118.8 \mathrm{ft}$

11. Siltstone and limestone. Siltstone, light brown $(5 Y R 6 / 4)$, pale reddish brown $(10 R 5 / 4)$, and uncommon grayish red $(5 R \quad 4 / 2)$, weathering light brown (5YR 6/4); nonbentonitic; firmly cemented, noncalcareous; structureless; fractures into small angular fragments. Limestone, pale red $(10 R 6 / 2$ and $5 R 6 / 2)$ and light greenish gray ( $5 G Y 8 / 1)$, weathering same colors, dense and aphanitic; common seams and granule-sized masses of coarsely crystalline calcite; well cemented; very thin to thick horizontally bedded. Limestone is present as about six thin to thick beds interstratified with the siltstone and as nodules in common thick to very thick intervals. Totally the limestone beds comprise about $6 \mathrm{ft}$ of the unit. Unit as whole weathers to form bench and badlands topography, with minor ledges and conspicuous benches on the top of limestone beds. Unit spread over about $3 / 4$ mile along line of section. Base of unit 11 in north branch of a prominent wash entering the Little Colorado River about at the northern limit of the Black Point basalt flow. Section continues directly east to a conspicuous promontory capped by the basal part of the Wingate Sandstone

Section transferred on top of unit 10 so that overlying units were measured 6 miles N. $45^{\circ} \mathrm{E}$. of unit 10.
Feet

Chinle Formation-Continued

Owl Rock Member-Continued

10. Limestone, pale red $(10 R 6 / 2)$ and light greenish gray ( $5 G Y 8 / 1)$, weathering same colors, dense and aphanitic; well cemented; composed of thin horizontal beds; weathers to form vertical cliff and underlies extensive bench that extends for several miles down dip. Unit, along with top part of underlying unit, forms most conspicuous cliff in prominent escarpment developed on the Chinle Formation. Unit contains about 25 percent palereddish-brown siltstone which is present as thin beds interstratified with the limestone. Unit rarely contains stringers of orange and white chert. The limestone beds in this unit appear to be more continuous than the limestone beds in the top part of the underlying unit, and form a light-colored cap to the vertical cliff. Line of section at this unit is S. $85^{\circ}$ E. of central part of Black Point......

Total of Owl Rock Member

Petrified Forest Member:

9. Claystone to siltstone and silty limestone. Claystone to siltstone, pale red $(5 R 6 / 2)$ and common greenish-gray (5GY 6/1) mottling, weathering same colors, bentonitic; firmly cemented, calcareous in parts; structureless. Silty limestone, pale red $(10 R 6 / 2)$ and common greenishgray $(5 G Y 6 / 1)$ mottling, aphanitic; well cemented. Limestone is present as nodules generally about 1 in. in diameter and as a few irregular lenses in top $15 \mathrm{ft}$. Limestone nodules in basal $17 \mathrm{ft}$ form about 70 percent of unit and in part form a network. Unit from 17 to $45.2 \mathrm{ft}$ above base contains about 30 percent limestone nodules, from 45.2 to $86.4 \mathrm{ft}$ about 5 percent, and from 86.4 to $108.5 \mathrm{ft}$ about 50 percent. To north of line of section the unit from 45.2 to 86.4 $\mathrm{ft}$ appears to contain sandstone similar to that of underlying unit. Unit as whole tabular and weathers to form steep slope with a ledge in basal $17 \mathrm{ft}$ and a vertical cliff, continuous with that of the overlying unit, from 86.4 to $108.5 \mathrm{ft}$.

8. Claystone and sandstone. Claystone, grayish red purple $(5 R P 4 / 3)$ and minor pale reddish brown (10R $5 / 4)$, weathering pale red $(5 R 6 / 2)$; bentonitic; firmly cemented; structureless. Sandstone, light greenish gray $(5 G Y 8 / 1)$, yellowish gray ( $5 Y$ $8 / 1)$, with common grayish-red $(10 R$ $4 / 2$ ) mottling, weathering yellowish gray $(5 Y 8 / 1)$, very fine to coarse 
Chinle Formation-Continued

Petrified Forest Member-Continued grained; poorly sorted; composed of subangular milky and clear minerals and common orange accessory minerals, 2 to 3 percent coarse-grained dark-green mica; firmly cemented, noncalcareous; composed of thin trough sets of low-angle small-scale cross-laminae. Along line of section standstone forms middle $1 / 3$ of unit but away from line of section the standstone channels into and in places entirely cuts out the underlying claystone unit. Unit as whole weathers to form steep slope and badland topography. Thin resistant bed of sandstone from 36.1 to $36.9 \mathrm{ft}$ forms small ledge

7. Silty claystone and silty limestone. Silty claystone, grayish red purple (5RP 4/2), weathering pale red purple $(5 R P 6 / 2)$; bentonitic; firmly cemented, noncalcareous; structureless. Silty limestone, light greenish gray $(5 G Y 8 / 1)$ and pale red $(5 R$ $6 / 2$ ), weathering same colors; aphanitic; contains rare rounded granule-sized masses of limestone; well cemented. Silty limestone is present as irregular nodules as large as 9 in. in diameter and as thin lenses extending for at least $50 \mathrm{ft}$ along. the outcrop. Silty limestone constitutes about 50 percent of the unit. Unit is tabular and weathers to form second most prominent ledge in the Chinle

6. Clayey sandstone and siltstone to claystone. Clayey sandstone, light greenish gray $(5 G Y 8 / 1)$ with lightbrownish-gray (5YR 6/1) mottling, minor pale reddish brown $(10 R 5 / 4)$, weathers pale red $(10 R 6 / 2)$ and light greenish gray ( $5 G Y 8 / 1)$; same type of clayey sandstone as in unit 4 . Clayey sandstone has some horizontally laminated sets and some thin trough sets of low-angle small-scale cross-laminae. Siltstone to claystone, pale reddish brown $(10 R 5 / 4)$, pale red $(10 R 6 / 2)$ and pale red purple $(5 R P 6 / 2)$, weathers dominantly pale reddish brown; bentonitic; firmly cemented; structureless. Unit as whole weathers to form steep slopes and badland. Base of unit is near or at base of cliffs. Unit differentiated from units below by presence of conspicuous pale-reddish-brown color bands. Base of unit arbitrarily placed at base of lowest pale-reddish-brown color band. Unit contains common limestone nodules. A crude estimate
Feet Chinle Formation-Continued Fe

Petrified Forest Member-Continued suggests that totally about $60 \mathrm{ft}$ of unit is claystone

183.1

5. Clayey sandstone, siltstone, and claystone, same as underlying unit except is about 50 percent red and, to a lesser extent, purple and 50 percent gray. In addition, the unit contains many thin to very thick intervals containing common to abundant limestone nodules. These nodules are pale red $(10 R 6 / 2)$ and light greenish gray $(5 G Y 8 / 1)$ and average from $1 / 2$ to 1 in. in diameter. A very crude estimate suggests that about $100 \mathrm{ft}$ of unit is claystone and siltstone. Units 4 and 5 are completely exposed and form a broad flat about $31 / 2$ miles across. The thickness of units 4 and 5 was calculated from a planetable traverse. The thickness, however, of these units could be in error possibly as much as $100 \mathrm{ft}$

4. Clayey sandstone, siltstone, and claystone, greenish gray ( $5 G Y 6 / 1)$, light greenish gray (5GY 8/1), light gray $(N 7)$ to medium light gray $(N 6)$, common grayish red $(10 R 4 / 2$ and $5 R$ $4 / 2)$, rare grayish red purple (5RP $4 / 2)$ and pale red $(5 R 6 / 2)$, weathering dominantly yellowish gray (5Y $8 / 1)$ and light greenish gray (5GY $8 / 1$ ) with minor purples and red, colors banded. Clayey sandstone, very fine to medium grained, poorly sorted; composed of subangular milky grains and about 10 percent orange and green grains, about 5 percent darkgreen medium- to coarse-grained mica; poorly cemented, clay binding. Stratification appears to be expressed in color bands; color bands are dominantly horizontal, with changes in color a few inches to as much as $20 \mathrm{ft}$ apart. Probably 10 to 20 percent of the clayey sandstone has inclined color bands, suggesting trough sets of low-angle large-scale cross-beds. These sets are generally 5 to $10 \mathrm{ft}$ thick. Siltstone and claystone, all gradations from claystone to sandy siltstone; firmly cemented, structureless or in horizontal beds from 5 to $20 \mathrm{ft}$ thick. Clays in unit are bentonitic. Unit as whole weathers to form light colored badlands. Many silicified tree logs from 92 to $102 \mathrm{ft}$ below top of unit. Logs are as large as $4.2 \mathrm{ft}$ in diameter and $85 \mathrm{ft}$ long. A crude estimate suggests that a total of 70 $\mathrm{ft}$ of the unit is claystone and siltstone. Commonly the clayey sandstone contains clay galls 
Chinle Formation-Continued

Petrified Forest Member-Continued

Total of Petrified Forest Member..

Sandstone and mudstone member:

3. Sandstone, grayish red $(10 R 4 / 2)$ and yellowish gray $(5 Y 8 / 1)$, colors streaked and mottled, weathering same colors, fine grained, rare medium to coarse grains, abundant interstitial white materiál, fair sorted; composed of subangular milky grains, rare orange and gray accessory minerals, rare medium-grained accessory dark mica; firmly cemented, slightly calcareous; composed of thin planar sets of small- to medium-scale cross-laminae; weathers to form ledge and underlies bench. Top 5 to $10 \mathrm{ft}$ of unit is well cemented with a calcareous cement and appears to form an irregular contact with overlying unit. Lateral relations of unit are complex and poorly exposed. Along line of section, a 10 -ft-thick set of grayish-red ( $5 R 4 / 2)$ siltstone is present in basal half of unit. To the south, the sandstone above the siltstone appears to pinch out in a few hundred feet, and the siltstone merges with the overlying unit. To the north the siltstone pinches out and the unit is entirely a massive sandstone. To the north the unit appears to fill a broad channel that cuts out the underlying unit. Probably the measured thickness of the unit is excessive for the local area

Total of Sandstone and mudstone..

Shinarump Member:

2. Conglomerate to pebbly sandstone $(80$ percent), sandstone (10 percent), and siltstone (10 percent). Conglomerate, grayish red $(5 R 4 / 2)$, pale red $(10 R 6 / 2)$, very pale orange $(10 Y R$ $8 / 2)$, and pale yellowish orange (10YR 8/6), weathering very pale orange $(10 Y R 8 / 6)$ and pale yellowish orange $(10 Y R 8 / 6)$; matrix, fine to very coarse grained, poorly sorted, composed of subangular clear quartz; granules to pebbles of rounded quartz, quartzite, and minor chert averaging from $1 / 2$ to $1 \mathrm{in}$. in diameter but as large as 2 in. in diameter; poorly cemented, noncalcareous; composed of thin to thick trough sets of mediumscale cross-laminae; sets commonly poorly defined, some structureless parts. Sandstone same as matrix of conglomerate to pebbly sandstone, except that some parts are fair sorted and fine grained. Siltstone, pale red $(5 R 6 / 2)$ and light gray $(N$
Feet

$\underline{918.1}$

Chinle Formation-Continued

Shinarump Member-Continued

7 ), weathering same colors; well cemented, noncalcareous; forms irregular lenses. Unit as whole is lenticular, weathers to form a ledge, and underlies prominent bench..........

Total of Shinraump Member ........

Total of Chinle Formation...

$\begin{array}{r}30.3 \\ \hline 30.3 \\ \hline 1,317.2\end{array}$

Contact of Chinle and Moenkopi Formations sharp and has minor irregularities as much as $1 \mathrm{ft}$ in depth. To the north of the section the contact appears to form a channel cutting at least $3 \mathrm{ft}$ into the Moenkopi.

Moenkopi Formation (unmeasured) :

1. Siltstone, pale reddish brown $(10 R$ $5 / 4)$ and grayish red $(10 R \quad 4 / 2)$, weathering same colors; common very fine grained accessory white mica; well cemented, noncalcareous; composed of very thin to thick horizontal beds and of horizontal and minor ripple laminae; weathers to form steep rubble-covered slope. About $30 \mathrm{ft}$ of the unit is exposed along the line of section. Unit contains some grayish and purplish color bands. Top $5 \mathrm{ft}$ is massive.

Base of section; base of exposure. Base of section is $\mathrm{N} .77^{\circ} \mathrm{E}$. of house at base of monocline on the west side of the Little Colorado River. Base of section at head of amphitheater formed by Shinarump Member of Chinle Formation. Section starts about $3 \frac{1 / 2}{2}$ miles N. $45^{\circ} \mathrm{E}$. of central part of Black Point and about $1 \frac{1 / 2}{2}$ miles east of the Little Colorado River.

$\frac{40.6}{40.6}$

\section{A-13. OWL ROCK SECTION}

Units 1-6 measured in and near wash about 2.5 miles $N$. $20^{\circ} \mathrm{W}$. of Owl Rock and about 1,200 ft east of Mexican Hat-Kayenta road, long $110^{\circ} 16^{\prime}$ W., lat $36^{\circ} 51^{\prime} 20^{\prime \prime}$ N.; units 7-33 measured starting at Mexican Hat-Kayenta road at place about $11 / 4$ miles $N .4^{\circ} \mathrm{W}$. of Owl Rock and continuing southwestward, with minor offsets, to cliffs developed on Wingate sandstone about 1 mile N. $53^{\circ} \mathrm{W}$. of Owl Rock, long $110^{\circ} 15^{\prime} 30^{\prime \prime} W$., lat $36^{\circ} 50^{\prime}$ N., Navajo County

[Measured by L. C. Craig, T. E. Mullens, and W. E. Benson in May 1951, and J. $H$. Stewart in May 1957]

Top of section; top of accessible exposure. Top of section is N. $83^{\circ}$ W. of Agathla Peak and N. $53^{\circ}$ W. of Owl Rock. Top of section is $200 \mathrm{ft}$ north of prominent arch in Wingate Sandstone.

Wingate Sandstone (unmeasured) :

33. Sandstone, light brown $(5 Y R 6 / 4)$ and very pale orange $(10 Y R 8 / 2)$, weathering same colors, very fine grained, well sorted; composed of subround red-stained quartz and 1 percent black grains; 1 to 5 percent of rock is disseminated medium to coarse grains of clear quartz and minor white chert(?); poorly cemented, calcareous; basal, $10 \mathrm{ft}$ is tabular-planar set of very low angle 
Wingate Sandstone-Continued

cross-laminae; wedge-planar sets common above the basal planar set; weathers to form vertical cliff. Only basal $5 \mathrm{ft}$ examined. Basal contact flat and sharp

Unmeasured

Chinle Formation:

Church Rock Member:

Hite (?) Bed:

32. Sandstone, pale red $(5 R 6 / 2)$ in lower third and pale reddish brown $(10 R$ $5 / 4)$ in upper two-thirds, weathering same colors, very fine to fine grained, fair sorted; composed of subangular clear and milky quartz and 5 percent dark-gray and orange minerals; poorly to firmly cemented, calcareous; horizontally thinly laminated to laminated, minor thin trough sets of small- to medium-scale low-angle to very low angle cross-strata; weathers to form vertical cliff. Basal 10 to 20 $\mathrm{ft}$ of unit contains abundant flakes of red siltstone

Total of Hite (?) bed

31. Siltstone, same as unit 29 , except contains a thick coarse siltstone set with some horizontal laminae in middle of unit and about $12 \mathrm{ft}$ of this type siltstone at top of unit. This coarse siltstone may grade to very fine grained sandstone. Unit weathers to form slope with ledge in coarse siltstone in middle and top of unit ........

30. Siltstone, pale reddish brown (10R 5/4), weathering same color, coarse silt, may grade locally to very fine grained sandstone; firmly to well cemented, slightly calcareous; horizontally laminated, faint suggestion of very low angle cross-laminae in places; weathers to form most prominent ledge in Church Rock Member

29. Siltstone, grayish red $(10 R 4 / 2)$ to pale reddish brown $(10 R 5 / 4)$, weathering pale reddish brown $(10 R 5 / 4)$, fine silt, some coarse silt; firmly cemented, calcareous; structureless, faint horizontal stratification planes can be seen from distance; weathers to form slope

Total of Church Rock Member..

Owl Rock Member:

28. Siltstone, grayish red $(10 R 4 / 2)$ and pale reddish brown $(10 R 5 / 4)$, weathering pale red $(5 R 6 / 2)$, firmly to well cemented, calcareous; structureless; weathers to form slope. Unit forms light-color interval at base of slope developed on Church Rock Member. A pale-red (5R 6/2) limestone lens is locally present at top of unit. Unit appears transitional between Owl Rock.and Church Rock
Feet | Chinle Formation-Continued

Owl Rock Member-Continued

Members. Placed in Owl Rock Member because of light weathering color and because of limestone lens at top

Offset on top of limestone bed, $8.0 \mathrm{ft}$ below top of unit 27 , so that overlying units measured 1,000 ft west of underlying units. Unit 28 measured at head of most prominent reentrant in cliff formed by Owl Rock Member. Units 28 to 39 measured westward from reentrant.

27. Siltstone and limestone. Siltstone, same as unit 21 except contains rare grayish-red $(5 R 4 / 2)$ parts. Siltstone from 72.4 to $76.9 \mathrm{ft}$ and from 104.3 to 105.9 $\mathrm{ft}$ above base of unit is horizontally laminated to thin bedded and weathers to form a ledge. Rest of siltstone is structureless and weathers to form slopes. Limestone, greenish gray ( $5 G Y$ $6 / 1)$, light greenish gray (5GY 8/1), and pale red $(10 R 6 / 2)$, weathering same colors; grades to limy siltstone, dense; well cemented; horizontally thin to thick bedded; weathers to form ledge. Extensive bench is developed in top $8 \mathrm{ft}$ of unit. Some beds contain white or orange chert nodules as large as $1 \mathrm{in}$. in diameter. From its base upward, the unit comprises: Siltstone, 0.0 to $10.1 \mathrm{ft}$; silty limestone, 10.1 to $11.8 \mathrm{ft}$; siltstone, 11.8 to $26.3 \mathrm{ft}$; silty limestone, 26.3 to $29.6 \mathrm{ft}$; siltstone, 29.6 to $32.7 \mathrm{ft}$; limestone with some chert, 32.7 to $37.6 \mathrm{ft}$; siltstone, 37.6 to $84.3 \mathrm{ft}$; limestone with some chert, 84.3 to $86.7 \mathrm{ft}$; siltstone, 86.7 to 95.0 $\mathrm{ft}$; silty limestone, 95.0 to $97.6 \mathrm{ft}$; limestone with some chert, 97.6 to $102.1 \mathrm{ft}$; siltstone, 102.1 to $108.5 \mathrm{ft}$; and limestone from 108.5 to $110.1 \mathrm{ft}$..

26. Sandstone to sandy siltstone, pale-red $(10 R 6 / 2)$, light-greenish-gray ( $5 G Y$ $8 / 1$ ) mottling, weathering same colors; sand fraction is very fine grained, fair to well sorted; firmly to well cemented, calcareous; horizontally laminated; laminae are slightly wavy and probably lenticular, suggesting current action; some thin to very thin trough sets of low-angle small-scale cross-laminae; weathers to form ledge. Thickness highly variable along exposure. Contains rare (5 percent disseminated medium to coarse rounded limestone grains........

Offset at top of unit 25, so that overlying units measured about 500 ft northwest of undertying units.

25. Siltstone, same as unit 21; weathers to form slope

24. Limestone and siltstone. Limestone,
Feet

19.8

110.1 
Chinle Formation-Continued

Owl Rock Member-Continued

light greenish gray $(5 G Y 8 / 1)$, rare pale red $(10 R 6 / 2)$, weathering same colors, dense, well indurated; horizontally thin bedded to laminated. Contain rare chert nodules. Rare limestone grains and pebbles suggesting some reworking of deposit by currents. Siltstone, same as in unit 21. All gradations from limestone to siltstone. From its base upward, the unit comprises: limy siltstone, 0.0 to $1.0 \mathrm{ft}$; siltstone, 1.0 to $2.2 \mathrm{ft}$; limestone, 2.2 to $8.5 \mathrm{ft}$; siltstone, 8.5 to $9.7 \mathrm{ft}$; and limestone, 9.7 to $12.7 \mathrm{ft}$. Unit weathers to form ledge............

23. Siltstone, same as unit 21 ; weathers to form slope

22. Siltstone $(60$ percent $)$ and siltstone pebble conglomerate (40 percent). Siltstone, pale red $(10 R 6 / 2)$, weathering same color; firmly to well cemented, highly calcareous; horizontally laminated to thin bedded, and thin trough sets of very low angle medium- to small-scale cross-laminae. Siltstone pebble conglomerate, pale red $(10 R 6 / 2)$ and pale reddish brown $(10 R 5 / 4)$, weathering same colors; composed of rounded coarse grains to cobbles of reddish-brown and minor greenish-gray siltstone in a silt matrix; well cemented, highly calcareous; present as thin structureless lenses and as thin trough sets of low-angle small-scale cross-laminae. All gradations from siltstone to siltstone pebble conglomerate. Conglomerate mostly in lower half of unit. Unit weathers to form ledge.

21. Siltstone, grayish red $(10 R 4 / 2)$ to pale reddish brown $(10 R 5 / 4)$, weathering same colors, does not contain swelling clays; firmly cemented, noncalcareous; structureless; weathers to form steep slope

Total of Owl Rock Member

Petrified Forest Member:

20. Siltstone to sandy siltstone, grayish red $(10 R 4 / 2)$ to pale reddish brown (10R $5 / 4)$, weathering pale reddish brown $(10 R 5 / 4)$, sandy (very fine grained) in places; contains swelling clays in places; firmly cemented, slightly calcareous; weathers to form frothysurfaced slope. Highest unit in Chinle containing definite swelling clays. Unit appears to grade upward into overlying unit

19. Sandstone, pale red $(10 R 6 / 2)$ and light greenish gray (5GY 8/1), weathing same colors, fine to medium grained, fair sorted; composed of
Feet | Chinle Formation-Continued Petrified Forest Member-Continued subangular to angular clear and milky quartz, rare orange and gray accessory grains, rare accessory darkgreen mica; poorly indurated, slightly calcareous; stratification poorly exposed, suggestion of low-angle crossstrata, some sandstone cosets of thin trough sets of low-angle small-scale cross-strata; weathers to form steep slope. About 5 percent of unit is limestone pebble conglomerate the same as that in underlying unit. Limestone pebble conglomerate is present as thin lenses throughout unit......
12.7

52.8

7.6

$\frac{59.7}{296.6}$

$\underline{2}$
18. Sandstone to limestone pebble conglomerate, pale red $(5 R 6 / 2)$, and lightgreenish-gray (5GY 8/1) mottling. Sandstone, fine grained, fair sorted; composed of subangular to angular clear and milky quartz and 5 percent gray and minor orange grains. Limestone pebble conglomerate, composed of rounded medium grains to small pebbles of limestone in a sand matrix the same as the sand in the sandstone. All gradations from sandstone to limestone pebble conglomerate. Sandstone to limestone pebble conglomerate is firmly cemented, calcareous; composed of very low angle medium-scale cross-strata, some trough sets of small-scale low-angle cross-strata, some horizontally laminated to very thin bedded parts; weathers to form small ledge

17. Silty claystone to very fine grained sandstone, pale red $(10 R 6 / 2)$ to grayish red $(10 R 4 / 2)$, weathering same colors; swelling clays; firmly cemented, clay binding; structureless; weathers to form frothy-surfaced slope

16. Sandstone, pale red $(5 R 6 / 2)$, weathering same color, medium grained, fair sorted; composed of subangular to angular clear and milky quartz, and rare $(<5$ percent) orange, green, and gray minerals; poorly cemented, slightly calcareous; horizontally laminated, rare thin trough sets of small-scale very low angle cross-laminae; weathers to form a steep slope or a ledge

15. Claystone to siltstone, grayish red $(10 R$ $4 / 2)$ to pale reddish brown (10R $5 / 4)$, weathering same colors, sandy (very fine grained) in places, swelling clays; firmly to well cemented, structureless; weathers to form frothy-surfaced slope ...........................

14. Siltstone, pale red $(5 R 6 / 2)$ to pale red purple $(5 R P 6 / 2)$, weathering same colors; siltstone contains rare (2 percent) rounded limestone grains from
36.4 
Chinle Formation-Continued

Petrified Forest Member-Continued

1 to $2 \mathrm{~mm}$ in diameter; firmly to well cemented, calcareous; structureless, a few horizontal stratification planes; weathers to form steep slope and vertical cliff in top $30 \mathrm{ft}$. Contains very limy intervals from 66 to $69 \mathrm{ft}$ and 86 to $91 \mathrm{ft}$ above base of unit. These limy intervals contain irregular nodules as large as 6 in. in diameter of limy siltstone to limestone. The limy nodules have the same color as the surrounding siltstone and are more limy parts of that siltstone. The limy intervals form ledges along the outcrop that can be traced throughout the mile-wide area of good outcrops near Owl Rock. Unit forms distinctive purplish unit

13. Silty claystone and clayey siltstone (70 percent), and sandstone (30 percent). Silty claystone and clayey siltstone, pale red $(5 R 6 / 2)$ and grayish red $(5 R 4 / 2)$, weathering same colors, swelling clays, contain disseminated very fine to medium grains in places; structureless, possibly some low-angle cross-strata. Sandstone, pale red $(5 R 6 / 2)$ and light greenish gray (5GY 8/1), weathering same colors, very fine to medium grained, clayey in parts, fair to poorly sorted; composed of a subangular to angular milky grains and 20 to 30 percent orange, green, and gray grains; lowangle medium- to small-scale crossstrata, some horizontally laminated parts, stratification concealed in some places. Unit weathers to form steep slope. Sandstone present in basal 20 $\mathrm{ft}$, as thick set in middle of unit, and as thin sets in some other parts of unit. Basal $20 \mathrm{ft}$ of unit contains thin to thick lenses of limestone pebble conglomerate. Some cross-strata in this conglomerate

12. Clayey siltstone to silty claystone, pale reddish brown $(10 R 5 / 4)$, weathering same color, swelling clays; firmly to well indurated; weathers to form slope. Unit forms prominent pink band along outcrop

11. Sandstone in basal $10 \mathrm{ft}$ grading through siltstone to silty claystone in top $5 \mathrm{ft}$, grayish red $(5 R \quad 4 / 2)$, weathering same color; sandstone is fine to very fine grained, fair sorted; composed of subangular to angular grains, composition masked; clay in unit is swelling type; unit is firmly indurated, clay binding; stratification concealed; weathers to form slope....

10. Sandstone, clayey in parts, light greenish gray $(5 G Y 8 / 1)$, rare pale-red
Chinle Formation-Continued

Petrified Forest Member-Continued

$(10 R 6 / 2)$ mottling, weathering same color, fine to coarse grained, poorly sorted; composed of angular to subangular milky grains and 20 percent orange grains, 20 percent dark-gray grains, and 5 percent green grains, rare accessory dark mica; poorly indurated, clay binding; stratification not distinct, probably low-angle crossstrata in places; weathers to form steep slope. Locally contains lenses of greenish-gray or grayish-red clayey siltstone. Some carbonaceous material is present as flakes in siltstone and as poorly developed logs in sandstone

9. Silty claystone, grayish red purple (5RP 4/2) grading upward to grayish red $(5 R 4 / 2)$ in top $8 \mathrm{ft}$, weathering same color, swelling clays; firmly cemented, slightly calcareous; stratification concealed, probably structureless; weathers to form frothy-surfaced slope. Forms purplish color band .......

8. Sandstone to clayey sandstone, pale olive $(10 Y 6 / 2)$ and light olive gray $(5 Y 5 / 2)$, and minor light-gray $(N$ 7 ), common pale-red $(5 R 6 / 2)$ mottling in top $10 \mathrm{ft}$, weathering same colors, very fine to fine grained, clayey, fair to poorly sorted; composed of subangular to subround milky quartz and 5 percent orange and green accessory minerals; poorly cemented, slightly calcareous clay binding; stratification concealed; weathers to form wide flat and basal part of slope developed on Chinle Formation. This unit is lithologically similar to units included in the Monitor Butte Member in other areas. It is typical of Monitor Butte except that it does not include ledge-forming sandstone sets like those in the underlying unit. Unit measured across wide flat in area where dips could not be accurately determined. Thickness of unit may be in error by as much as 10 to 20 percent

Total of Petrified Forest Member.

Monitor Butte Member:

7. Silty claystone to clayey siltstone (90 percent) and sandstone (10 percent). Silty claystone to clayey siltstone, light greenish gray $(5 G Y 8 / 1)$ to greenish gray ( $5 G Y 6 / 1)$, weathering same colors and pale olive $(10 Y 6 / 2)$; swelling clays; firmly cemented, noncalcareous to slightly calcareous; stratification concealed, probably structureless. Sandstone, grayish orange $(10 Y R 7 / 4)$ to dark yellowish
Feet 
Chinle Formation-Continued

Monitor Butte Member-Continued brown (10YR 4/2), brownish gray (5YR 4/1), and minor pale olive (10Y 6/2), weathering brownish gray $(5 Y R 4 / 1)$ and dark yellowish brown $(10 Y R 4 / 2)$, very fine to fine grained, fair to well sorted; composed of subround to round clear quartz, common interstitial limonite; well cemented, probably siliceous cement, rock is mostly quartzitic; horizontally laminated and ripple laminated, cuspate ripples. Sandstone is present as very thin to thick sets interstratified with the rest of the unit. Sets of sandstone are highly contorted. Individual sets have fairly constant strike, but different sets vary greatly in strike, and dips vary from $0^{\circ}$ to as much as $60^{\circ}$. Unit as whole weathers to form wide flat. Sandstone sets weather to form rocky knolls. Unit measured in area where dips cannot be accurately determined. Thickness of unit may be in error as much as 10 to 20 percent..

Long offset in section, so that overlying units measured about 1.5 miles $S .45^{\circ} \mathrm{E}$. of underlying units.

6. Sandstone, clayey in parts, grayish red $(5 R 4 / 2)$ and minor yellowish gray (5Y 8/1), weathering same colors, fine to coarse grained, fair to poorly sorted; composed of subangular clear and milky quartz, 5 percent orange and green accessory minerals, and abundant dark-green accessory mica; firmly cemented, calcareous; horizontally laminated to very thin bedded, minor thin trough sets of small-scale cross-laminae; weathers to form ledge. Top of unit underlies extensive benches to northwest of Mexican Hat-Kayenta road. Top $10 \mathrm{ft}$ of unit is altered in color to yellowish gray (5Y 8/1), pale purple (5P 6/2), and grayish yellow $(5 Y 8 / 4)$. These colors are mottled; mottling decreases in amount downward. The altered colors in places extend down into the grayish-red part of the unit as irregular vertical stringers. This alteration is similar to the "purplewhite" alteration (mottled strata) in southeastern Utah. The unit as a whole resembles the sandstone and mudstone member of the Chinle Formation along Echo Cliffs in Arizona

5. Claystone, greenish gray (5GY 6/1) and medium gray ( $N 5$ ), weathering same colors, silty in parts, swelling clays in parts; poorly to firmly cemented, noncalcareous; stratification concealed; papery splitting in
Feet Chinle Formation-Continued Feet Monitor Butte Member-Continued places; weathers to form gentle rubble-covered slope. Basal half poorly exposed or covered

$\frac{15.0}{110.9}$

Total of Monitor Butte Member....

Shinarump Member:

4. Sandstone, partly conglomeratic, very pale orange $(10 Y R 8 / 2)$, pale-yellowish-orange $(10 Y R 8 / 6)$, and grayishyellow (5Y 8/4); medium grained and coarser; composed of clear subangular quartz with common black accessory minerals, lenticular bedded stratum with asymmetrical concave large- to medium-scale cross-laminae. Conglomeratic parts consist of pebbles of gray and tan chert, gray and pink quartzite, and clear to white quartz concentrated in lenses in lower $15 \pm \mathrm{ft}$ of unit; unit shows prominent medium-scale festoon laminations in upper part. Many scour surfaces in unit; scours are as deep as 10 to $20 \mathrm{ft}$ in lower part of unit, and are less than $5 \mathrm{ft}$ in upper part of unit. Numerous irregular greenish clay pebbles common at base of unit. Top of Shinarump intertongues with Monitor Butte Member. Top of Shinarump drops lower and lower in section to the north (probably $50 \mathrm{ft}$ drop). Cement moderately calcareous

$\begin{array}{r}106.3 \\ \hline 106.3 \\ \hline 1,396.7 \\ \hline\end{array}$

Total of Shinarump Member..

Total of Chinle Formation

Moenkopi Formation (incomplete) :

3. Claystone, silty, micaceous, grayish-red $(10 R 4 / 2)$; shaly to earthy weathering; 6 in. of light-greenish-gray $(5 G 6 / 1)$ claystone at top

2. Sandstone with minor claystone and siltstone partings. Sandstone, pale red $(10 R 6 / 2)$, weathering grayish red $(5 R 4 / 2)$, interbedded with very pale orange $(10 Y R 8 / 2)$, weathering grayish orange $(10 Y R \quad 7 / 4)$; red is very fine to fine grained, orange fine to medium grained; composed of clear subangular quartz with rare gray and pink accessory minerals; red part of sandstone is micaceous. Siltstone and claystone, grayish red ( $5 R \quad 4 / 2$ ), highly calcareous; form thin parallel laminae and beds up to 6 in. thick. Red sandstone shows parallel bedding and parallel laminae to ripple laminae; orange sandstone shows wedging medium-scale crosslaminae; scour surface at base of light-colored sandstone cut as much as $1 \mathrm{ft}$ in underlying beds. Basal contact sharp, slightly irregular; 
Moenkopi Formation (incomplete)-Continued parallel bedding truncating crosslaminations of underlying unit............

1. Sandstone, grayish-orange $(10 Y R 7 / 4)$ to dark-yellowish-orange (10YR 6/6) and moderate-yellowish-brown $(10 Y R$ $5 / 2)$; composed of clear subangular to rounded quartz, common white and rare gray, black, light-green, and pink accessory minerals; large-scale cross-laminations. Forms massive outcrop in bottom of wash. Thickness estimated

Total of incomplete Moenkopi Formation

Base of section; base of exposure.

\section{COLORADO}

\section{C-l. PIEDRA RIVER}

Measured on west side of Piedra River Canyon directly west of Tres Piedra Ranch, east edge of sec. $31, T .35$ N., R. 4 W., NMPM, Archuleta County

[Measured by J. H. Stewart, W. Thordarson, and R. F. Wilson, August 26, 1955]

Top of section; not top of exposure. Top of section Feet S. $89^{\circ} \mathrm{W}$. of lodge of Tres Piedra Ranch.

Entrada Sandstone:

14. Sandstone, very pale orange $(10 Y R$ $8 / 2)$, weathers grayish orange $(10 Y R$ $7 / 4$ ), fine grained with 10 to 15 percent medium to coarse grains, fair sorted; composed of clear, milky and yellowish-stained quartz and minor dark accessory minerals, medium to coarse grains are composed of subrounded to rounded frosted quartz; well cemented, calcareous; horizontally laminated in some places near base, in part composed of thin to thick trough and planar sets of highand low-angle cross-laminae; weathers to form prominent white vertical cliff which is in places at least 200 $\mathrm{ft}$ thick. Only basal $20 \mathrm{ft}$ of unit examined. Contact with underlying Dolores Formation is sharp and marked by scours cut into top of underlying unit as much as $2.5 \mathrm{ft}$ in a horizontal distance of $30 \mathrm{ft}$. Contact marks change from reddish to grayish siltstone and silty sandstone of the underlying Dolores Formation to the very pale orange fine-grained sandstone with coarser grains of the Entrada Formation ...................... Unmeasured

Dolores Formation (upper member and perhaps part of middle member missing owing to pre-Entrada erosion) :

Middle member:

13. Siltstone ( 70 percent) and silty sandstone (30 percent). Siltstone, grayish red $(10 R 4 / 2)$, weathers same color; firmly cemented, slightly calcareous, clay binding; common accessory white mica; very thinly horizontally laminated to very thin bedded. Silty sand-

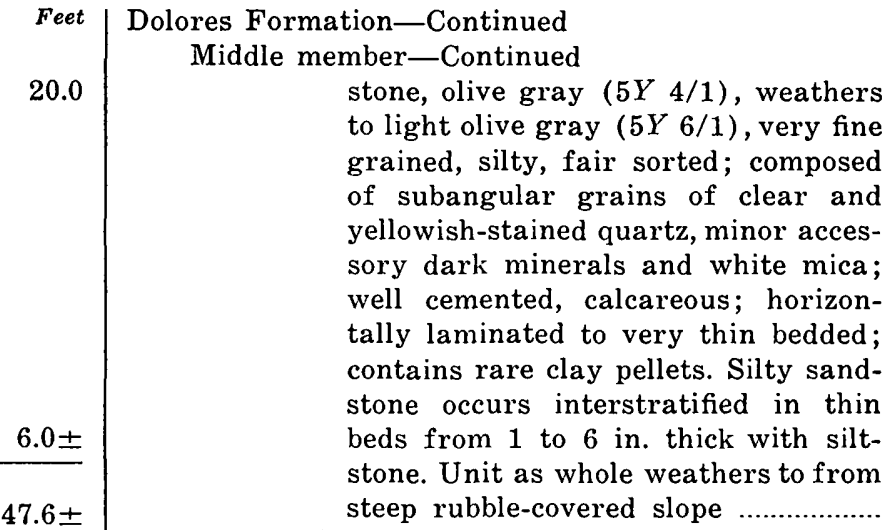

Feet

12. Sandstone (80 percent), limestone-grain sandstone (10 percent), siltstone (10 percent). Sandstone, light brownish gray $(5 Y R 6 / 1)$ and yellowish gray (5Y 8/1), weathering light brownish gray $(5 Y R 6 / 1)$, very fine grained, fair sorted; composed of subangular clear and milky quartz and abundant black accessory mineral, common to abundant coarse light and dark mica; firmly to well cemented, slightly calcareous in parts; composed of thin trough and minor planar sets of small-scale low-angle cross-laminae, rare horizontally laminated to thinly bedded parts and rare ripple-laminated parts. Limestone-grain sandstone, greenish gray (5GY 6/1), weathering same color; composed of rounded coarse grains to granules of gray limestone and minor rounded granules to cobbles as large as 6 in. in diameter of yellowish-gray siltstone in a greenish limy silt matrix; well cemented; present as thin to thick structureless lenses interstratified with sandstone in lower $6 \mathrm{ft}$ of unit. Siltstone, greenish gray ( $5 G Y$ 6/1) and brownish gray $(5 Y R \quad 4 / 1)$, weathering same colors; rare finegrained accessory white mica; poorly cemented, clay binding; structureless. Siltstone is present as 10-ft-thick bed in middle of unit along line of section, but away from line of section interfingers irregularly with sandstone. Unit as whole weathers to form vertical cliff which is most prominent one in Dolores Formation. The sandstone contains rare clay pebbles and carbonaceous material....

11. Siltstone and limestone pebble conglomerate. Siltstone, grayish red $(10 R$ $4 / 2$ ), thin layers at top of unit and above higher limestone pebble conglomerate contain light-greenish-gray (5GY 8/1) mottling, fine silt, rare accessory white mica; firmly cemented, calcareous; thin sets of horizontal laminae commonly present in
7.3 
Dolores Formation-Continued

Middle member-Continued

unit, rest of unit is structureless; weathers to a steep slope covered with a veneer of angular siltstone fragments. Limestone pebble conglomerate, greenish gray ( $5 G Y 6 / 1)$, weathering same color and moderate brown (5YR 4/4); composed of rounded coarse sand grains to pebbles of gray limestone and rare orange-brown siltstone in a green limy silt matrix; largest pebble is $11 \%$ in.; poorly sorted; well cemented. Limestone pebble conglomerate is present as thin bed at base of unit and at $16 \mathrm{ft}$ above the base of unit. Limestone pebble conglomerate weathers to form small ledges

10. Siltstone, dark reddish brown $(10 R$ $3 / 4)$ to pale reddish brown $(10 R 5 / 4)$, rare light-greenish-gray mottling, weathers same colors, very fine to fine silt; abundant white and dark mica ; firmly cemented, calcareous and some clay binding in upper half; lower half predominantly horizontally thinly laminated, upper half structureless; fractures into angular fragments; weathers to a steep slope. Top foot of unit contains grayish red $(5 R 4 / 2)$ limestone nodules. Lateral to line of section a southward dipping slump structure occurs. Strata in basal foot of slump structure contain parallel laminated siltstone with abundant ripple(?) marks. Ripple(?) marks have a wavelength of $1 / 8$ to $1 / 1 ;$ in. and an amplitude of less than $1 \mathrm{~mm}$. Strata in basal foot of the slump structure are overlain by reddish-brown siltstone near line of section, but laterally this reddishbrown siltstone grades into a grayishred siltstone

9. Sandy siltstone and minor silty sandstone, grayish red $(10 R 4 / 2)$, light greenish gray $(5 G Y$ 8/1) in top foot, weathers same colors, mostly very fine grained sandy siltstone, minor amounts of silty very fine grained sandstone; abundant white and dark accessory mica; firmly to well cemented, calcareous; mostly horizontally laminated with traces of ripple laminations, minor trough sets of medium-scale low-angle cross-laminae to very thin crossbeds scattered through unit; shaly to flaggy splitting; weathers to form ledge and a small cliff. Top foot may be gradational with overlying unit. Unit forms lowest prominent exposure in Dolores Formation
Feet Dolores Formation-Continued Middle member-Continued

Total of middle member

Feet

129.4

Lower member:

8. Covered. Lateral to line of section poor exposures indicate that the unit is the same as underlying unit

7. Sandstone, light greenish gray ( $5 G Y$ $8 / 1$ ), weathers same color, fine grained, well sorted; composed of subangular clear quartz and common accessory white mica; well cemented, calcareous; horizontally laminated to very thin bedded, minor thin trough sets of small-scale low-angle crosslaminae; weathers to form minor ledge. This unit is probably the same as the lower member of the Dolores Formation at Durango and Stoner. Locally within the Piedra River Canyon this unit forms a prominent 20 - to 30 -ft-thick ledge

6. Covered. Weathers to form gentle slope. Probably most of this covered unit belongs in the Dolores Formation. In most places where the basal ledge of the Dolores Formation is exposed locally, it is from 20 to $30 \mathrm{ft}$ thick. Along line at section only the top $5.3 \mathrm{ft}$ (unit 7) is exposed

Cutler Formation (incomplete):

5. Quartzitic sandy siltstone to quartzitic silty sandstone, grayish red $(10 R$ $4 / 2)$, grayish purple $(5 P 4 / 2)$, and yellowish gray $(5 Y 8 / 1)$, colors mottled, weathering same colors, grades from siltstone containing 20 percent fine to coarse sand grains to a coarse-grained sandstone containing about 20 percent silt, fair to poorly sorted; sand grains are angular to subangular and composed of clear quartz, 10 percent orange chert, and rare black mineral; well cemented, probably siliceous; mostly structureless but contains some thin horizontal beds; weathers to form steep slope. Unit contains a few granules and pebbles of quartz and orange chert. Top $3 \mathrm{ft}$ of unit is grayish red purple (5RP 4/2), poorly cemented, clayey siltstone. Unit contains many irregular nodules and stringers of moderatereddish-orange $(10 R 6 / 6)$ chert. Lateral to line of section one thin bed of this chert was noted. This unit is similar to mottled strata occurring near the base of Upper Triassic strata in the Colorado Plateaus province. The unit is different from both typical Cutler and typical Dolores. It is 
Cutler Formation (incomplete)-Continued assigned to the Cutler as it lies below what is believed to be the lower member of the Dolores and because it contains coarse-grained parts that appear to more related to Cutler than Dolores. Purplish mottled units similar to this one were noted at the top of the Cutler Formation in the Stoner section and in the Florida River canyon. The mottled strata in the Florida River canyon contain orange chert identical with that in this section

4. Covered. Weathers to form steep slope..

3. Siltstone, pale reddish brown $(10 R$ $5 / 4)$, weathering same color; abundant fine-grained accessory white mica; poorly cemented, clay binding; stratification concealed; weathers to form steep slope

2. Sandstone, pale red $(5 R 6 / 2)$ and minor light greenish gray ( $5 G Y 8 / 1)$, weathering same colors, coarse to very coarse grained, fair sorted; composed of subangular clear quartz and milky and pink feldspar, rare coarse-grained accessory white and dark mica; firmly cemented, calcareous; composed of horizontal laminae to thin beds and minor thin planar sets of small- to medium-scale lowangle cross-laminae; weathers to form ledge. Unit contains disseminated granules to pebbles as large as $\mathbf{1 . 1}$ in. in diameter. Granules and pebbles are quartz, orthoclase, chert, and possibly granite

1. Siltstone to silty sandstone (60 percent) and sandstone (40 percent). Siltstone to silty sandstone, pale reddish brown $(10 R 5 / 4)$, minor grayish-red $(10 R \quad 4 / 2)$ and rare lightgreenish-gray (5GY 8/1) mottling, weathering same colors, grades from siltstone to silty fine-grained sandstone, fair to poorly sorted; composition masked, 1 to 2 percent dark and white mica; poorly cemented, clay binding; horizontally laminated to thin bedded. Sandstone, moderate red ( $5 R 5 / 4)$, pale red $(5 R 6 / 2)$, and minor pale reddish brown $(10 R$ $5 / 4)$, weathering same colors, fine to medium grained, silty in parts, fair to poorly sorted; composed of angular milky quartz and feldspar, 1 to 2 percent dark and white mica; poorly cemented, calcareous and clay binding; horizontally laminated to very thin bedded, rare thin trough sets of medium-scale low-angle crosslaminae. The two lithologic types intergrade. Sandstone is present as thin to very thick sets or cosets inter-
Cutler Formation (incomplete)-Continued stratified with the rest of the unit. Unit as whole weathers to form steep slope. Only top $50 \mathrm{ft}$ of unit examined in detail Unmeasured

Total of incomplete Cutler Formation

Base of section; not base of exposure. Base of section is about 2,000 ft west of lodge of Tres Piedra Ranch. Section starts about $300 \mathrm{ft}$ up west side of Piedra River Canyon.
21.0

15.9

11.9

\section{C-2. EAST BRUSH CREEK}

Measured on north side of canyon near middle of sec. $7, T$. 6 S., R. 83 W., 6th PM, about one-half mile east of EagleThomasville road, Eagle County

[Measured by F. G. Poole and C. H. Roach, July 1956]

Top of section; top of good exposure. Contact with overlying Morrison Formation is covered.

6.7 Glen Canyon(?) Sandstone and Entrada Sandstone:

18. Sandstone, grayish orange pink $(5 Y R$ $7 / 2)$, moderate orange pink (5YR $8 / 4)$, and light brown (5YR 6/4), weathering same colors; very fine to medium grained, silty, fair to well sorted; composed of well-rounded clear, milky, and amber-stained quartz grains and common black accessory minerals. Common wellrounded coarse to very coarse clear, milky, smoky, and amber-stained quartz grains scattered as berries throughout unit, mainly concentrated along cross-stratum planes; firmly to well cemented, calcareous and siliceous cement; medium- and large-scale planar and subordinate trough sets of high-angle cross-strata; cross-laminated to thinly crossbedded. A few asymmetrical parallel ripples of high index were noted. Platy to slabby splitting. Weathers to form vertical cliff. The lower part of this unit may be, in part, equivalent to the Glen Canyon Sandstone of the Uinta Mountains

Unconformity.

Chinle Formation:

Red siltstone member:

17. Same as unit 15 . Unit 17 weathers to a vertical cliff and therefore could not be examined closely. Upper contact of unit is sharp and unconformable with overlying unit

16. Sandstone to coarse siltstone, moderate reddish orange $(10 R 6 / 6)$ to light brown $(5 Y R 6 / 4)$, weathers same colors and lighter shades, very fine grained, silty, well sorted; composed of rounded to well-rounded amberstained quartz and rare white mica; firmly cemented, calcareous; very thick bedded; forms massive cliff; no sedimentary structures were noted.
184.0

Feet 
Chinle Formation-Continued

Red siltstone member-Continued

Unit is the most conspicuous bed near top of Chinle Formation. This unit, in addition to the other very fine grained sandstones in the upper part of this member, may be equivalent to the lower part of the Glen Canyon Sandstone of the Unita Mountains

15. Very fine grained sandstone to siltstone $(25$ percent) and structureless siltstone $(75$ percent $)$. Very fine grained sandstone, moderate reddish orange $(10 R 6 / 6)$, pale reddish brown $(10 R 5 / 4)$, and light brown (5YR $6 / 4)$, weathering same colors and moderate orange pink (10R 7/4), silty, well sorted, composed of rounded to well-rounded amber-stained quartz and rare black accessory minerals; firmly to well cemented, calcareous; thin to thick bedded; slabby to blocky spitting. Weathers to form prominent ledges on steep slope. Lower one-half of unit contains common claystonesiltstone chips. The very fine grained part of this unit may be equivalent to the lower part of the Glen Canyon Sandstone of the Uinta Mountains. Structureless siltstone, pale reddish brown $(10 R 5 / 4)$, weathering same colors and lighter shades, firmly cemented, calcareous; irregular fracturing, breaks into angular fragments. Weathers to form steep rubble-covered slope ..............................

14. Coarse siltstone (50 percent) and structureless siltstone (50 percent). Coarse siltstone, pale reddish brown $(10 R$ $5 / 4)$ to light brown (5YR 6/4), weathering same colors and moderate reddish orange $(10 R 6 / 6)$; well sorted; amber-stained quartz grains, firmly to well cemented, calcareous, thin to very thick bedded, slabby to massive splitting. Coarse siltstone weathers to five well-defined ledges in lower three-fourths of unit. A few mud cracks were noted. Common clay coatings on bedding planes. Structureless siltstone, grayish red (10R $4 / 2)$ to pale reddish brown (10R $5 / 4$ ), weathering same colors, firmly cemented, calcareous to very slightly calcareous, irregular fracturing, breaks into angular fragments. Weathers to form steep rubble-covered slope

13. Structureless siltstone (75 percent) and bedded siltstone (25 percent). Structureless siltstone, pale reddish brown $(10 R 5 / 4)$, grayish red $(10 R$ $4 / 2)$ to moderate brown $(5 Y R 4 / 4)$,
Feet $\begin{aligned} & \text { Chinle Formation-Continued } \\ & \text { Red siltstone member-Continued }\end{aligned}$ with pale-red $(5 R 6 / 2)$, grayish-red (5R 4/2), pale-red-purple (5RP 6/2), grayish-red-purple $(5 R P \quad 4 / 2)$, and minor yellowish-gray (5Y 7/2) mottling, weathering same colors and lighter shades; firmly to well cemented, calcareous; common vertical fracturing, breaks into angular fragments. Common white streaks, and limy pockets, and limy pebbles scattered throughout the structureless siltstone. Pale-red-purple mottling more abundant near top of unit. Weathers to form steep rubble-covered slope between the better cemented bedded siltstone. Bedded siltstone, moderate reddish brown $(10 R 4 / 6)$ to pale reddish brown (10R 5/4), weathering same colors and light brown (5YR 6/4); firmly to well cemented, calcareous; horizontally laminated, shaly splitting; laminated siltstone grades vertically and laterally into thin to very thick beds. These beds weather to form rough ledges

12. Structureless siltstone $(80$ percent $)$, laminated siltstone (10 percent), and bedded siltstone (10 percent). Structureless siltstone, pale reddish brown $(10 R 5 / 4)$, moderate reddish brown $(10 R 4 / 6)$, grayish red $(10 R 4 / 2$ and $5 R 4 / 2)$, pale red $(5 R 6 / 2)$, and pale red purple $(5 R P 6 / 2)$, weathering same colors and lighter shades; firmly to well cemented, calcareous; vertical fracturing, contains limy nodules and scattered pebbles. Structureless siltstone breaks into angular fragments. Weathers to form steep rubble-covered slope. Laminated siltstone, grayish red $(10 R 4 / 2)$, pale reddish brown $(10 R 5 / 4)$, and pale red $(10 R 6 / 2)$, weathering same colors and lighter shades; well cemented, calcareous; minor small-scale trough sets of lowangle cross-laminae; common horizontal laminae and ripple laminae, shaly splitting, weathers to form minor ribs on steep slopes. Limestone and siltstone pebble conglomerate 1-ftthick grading laterally into ripplelaminated siltstone. Laminated siltstone in lower part of unit. Bedded siltstone, pale reddish brown (10R $5 / 4)$ to moderate reddish brown ( $10 R$ $4 / 6)$, weathering light brown (5YR $5 / 6)$ to moderate reddish orange $(10 R 6 / 6)$; well cemented, calcareous; rare small-scale trough sets of low-angle cross-laminae; thin to thick bedded; slabby to blocky splitting; weathers to form resistant ledges....
Feet 
Chinle Formation-Continued

Red siltstone member-Continued

11. Limestone and siltstone pebble conglomerate, pale red $(10 R 6 / 2$ and $5 R 6 / 2)$ and grayish red $(10 R \quad 4 / 2$ and $5 R$ $4 / 2$ ), with limestone pebbles medium gray $(N 5)$ and medium light gray $(N 6)$, and siltstone pebbles dark reddish brown (10R 3/4) and grayish red $(10 R 4 / 2)$. Unit weathers same colors and lighter shades. Limy siltstone matrix, pebbles as much as $2 \frac{1}{2}$ in. in maximum diameter, granules and pebbles are subrounded to rounded; firmly cemented, calcareous, unit channels as much as $3 \mathrm{ft}$ into underlying unit, top of unit interfingers with overlying unit. Thick bedded to very thick bedded; blocky to massive splitting. Weathers to form rough ledge

10. Limy siltstone (95 percent) and limestone and siltstone pebble conglomerate $(5$ percent). Limy siltstone, grayish red $(10 R 4 / 2$ and $5 R 4 / 2)$, pale red $(5 R 6 / 2$ and $10 R 6 / 2)$, and pale reddish brown $(10 R 5 / 4)$, minor greenish-gray $(5 G Y \quad 6 / 1)$ mottling, weathering same colors, firmly cemented, calcareous, structureless siltstone constitutes about 40 percent of entire unit, stratified siltstone is thinly laminated to thin bedded; abundant small-scale trough sets of low-angle cross-laminae and abundant ripple laminae; papery to slabby splitting. Limestone and siltstone pebble conglomerate, grayish red (10R $4 / 2$ and $5 R \quad 4 / 2)$ and light brownish gray $(5 Y R 6 / 1)$, with minor greenish-gray (5GY 6/1) mottling, weathers same colors and lighter shades. Matrix is limy siltstone; clasts are composed of subangular to rounded pebbles as much as $15 \mathrm{~mm}$ in maximum diameter. Lenticular unit of laminated to thin beds, unit as whole weathers to form steep slope. Platy to slabby splitting. Some interbedded siltstone

9. Limy siltstone (90 percent) and limestone and siltstone pebble conglomerate (10 percent). Limy siltstone, pale reddish brown (10R 5/4), moderate red $(5 R 5 / 4)$, and pale red purple (5RP 6/2), weathering same colors and pale red $(10 R 6 / 2)$, contains many limy pockets; well cemented; minor small-scale trough sets of low-angle cross-laminae and minor ripple laminae. Limy siltstone in top $30 \mathrm{ft}$ of unit lacks bedding and contains abundant peculiar vertical cylindrical structures as much as $4 \mathrm{ft}$ in length and as much as 3 in. in
Feet

Chinle Formation-Continued

Red siltstone member-Continued

diameter (average of $1 \frac{1 / 2}{\text { in. in }}$ diameter). Some of the cylinders taper downward. Limy siltstone contains scattered limestone and siltstone pebbles. Limestone and siltstone pebble conglomerate, pale red $(10 R$ $6 / 2$ and $5 R 6 / 2$ ), brownish gray $(5 Y R 4 / 1)$, and medium gray $(N 5)$, weathers same colors and lighter shades. Matrix is chiefly limy siltstone, coarse fraction ranges from sandstone to pebble conglomerate. Clasts are subrounded to well-rounded limestone and siltstone pebbles as much as $2 \frac{1}{2}$ in. in maximum diameter. Conglomerate is firmly to well cemented, and occurs as lenticular very thin bedded to thick bedded layers in limy siltstone in lower $30 \mathrm{ft}$ of unit. Conglomerates weather to form inconspicuous ledges in lower part of unit. Upper part of unit weathers to form cliffs

8. Silty claystone, pale reddish brown $(10 R 5 / 4)$, upper few feet of unit pale red $(5 R 6 / 2)$ and grayish red $(5 R 4 / 2)$, weathering same colors, rare well-rounded limestone and siltstone pebbles as much as $6 \mathrm{~mm}$ in maximum diameter; firmly cemented, calcareous; thinly laminated to laminated, papery and shaly splitting. Weathers to form smooth slope.

7. Siltstone (80 percent) and sandstone to pebble conglomerate (20 percent). Siltstone, grayish red (10R 4/2), moderate red $(5 R 4 / 6)$, and light red $(5 R \quad 6 / 6)$ with light-greenish-gray coloring in upper few feet, weathering same colors, common medium to coarse subangular to rounded clear and milky quartz grains and rare pink feldspar grains near base; firmly cemented, calcareous. Upper foot of unit grades laterally from limy siltstone through very limy siltstone to limestone conglomerate, thinly laminated to thin-bedded small-scale trough sets of low-angle crosslaminae which grade into ripple laminae, papery to slabby splitting. Weathers to form cliff. Sandstone to pebble conglomerate, light greenish gray $(5 G Y 8 / 1)$, pale red $(10 R 6 / 2$ and $5 R 6 / 2)$, and grayish red (5R $4 / 2$ and $10 R 4 / 2$ ), weathering same colors and lighter shades. Fine-grained sandstone to pebble conglomerate, fair to poorly sorted; composed of subangular to rounded clear, smoky, and milky quartz grains and chert grains. Granules and pebbles composed of clear and milky quartz,
Feet 
Chinle Formation-Continued

Red siltstone member-Continued

chert, limestone, and siltstone. Firmly to well cemented, calcareous; laminated to thick bedded, minor crosslaminae of small-scale sets of lowangle cross-strata and minor ripple laminae; platy to slabby splitting. Weathers to form cliffs. Note. Gravel is as much as 2 in. in diameter and rarely as much as 3 in.

6. Sandstone, fine to conglomeratic, mottled and banded white ( $N 9)$, grayish pink ( $5 R 8 / 2)$, pale reddish brown $(10 R 5 / 4)$, pale red $(5 R 6 / 2)$, grayish red ( $5 R \quad 4 / 2$ and $10 R 4 / 2)$, pale red purple $(5 R P 6 / 2)$, and grayish red purple $(5 R P 4 / 2)$, weathers same colors, fine-grained sandstone to pebble conglomerate, minor percentage of cobble gravels as much as 4 in. in maximum diameter in basal few feet, fair to poorly sorted; composed of subangular to rounded clear and milky quartz grains and common chert grains. Granule sand, pebble and cobble gravels are composed of vein quartz with subordinate chert and metaquartzite. Well cemented to poorly cemented, calcareous, siliceous, siliceous and clay binding; sandstone and conglomerate within unit are lenticular, very thin bedded to very thick bedded, thin units of medium- to small-scale planar and subordinate trough sets of high- and low-angle cross-laminae and crossbeds; flaggy to massive splitting. Basal $15 \mathrm{ft}$ is silica cemented and weathers to form vertical cliff. The upper part has calcareous and clay cement and weathers to form steep slopes. The upper 10 to $20 \mathrm{ft}$ is partly covered but appears to be friable coarse sandstone. Basal 15 $\mathrm{ft}$ contains thin conglomerate lenses and isolated gravels in a fine- to medium-grained sandstone matrix, whereas the upper part is chiefly medium to granule sand. Silicified logs were noted at base of unit..........

Total Gartra Member

Total Chinle Formation

Unconformity.

State Bridge Formation (incomplete):

Upper nember (incomplete) :

5. Sandstone, moderate-red $(5 R \quad 5 / 4)$, pale-red $(5 R 6 / 2)$, dark-reddishbrown $(10 R 3 / 4)$, and grayish-red (5R 4/2 and $10 R \quad 4 / 2$ ); weathers same colors; very fine grained, well

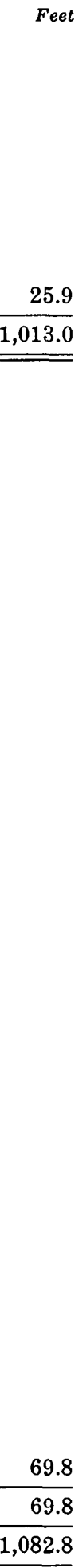

State Bridge Formation (incomplete)-Continued

Feet

Upper member (incomplete)-Continued

sorted; composed of rounded to wellrounded clear and amber-stained quartz grains and common white and black accessory minerals, abundant white and green coarse to very fine grained mica, firmly to well cemented, calcareous to noncalcareous; medium-scale trough and planar sets of low-angle thinly cross-laminated to very thinly crossbedded strata; unit is laminated to very thick bedded, platy to massive splitting. Weathers to form cliff. Upper contact is an erosional unconformity. This sandstone unit is probably correlative with the sandstone directly below the Chinle Formation near Wolcott, Basalt, and Aspen, Colo.

4. Coarse siltstone to very fine grained sandstone and claystone to silty claystone. Coarse siltstone to very fine grained sandstone, grayish red $(10 R$ $4 / 2)$ and pale reddish brown (10R $5 / 4)$, with minor greenish-gray ( $5 G Y$ $6 / 1$ and $5 G 6 / 1$ ) mottling, weathering same colors and minor red-purple (5RP 6/2) mottling, well sorted; very fine sandstone is composed of rounded to well-rounded clear and amberstained quartz grains and common white and black accessory minerals, abundant white mica; firmly to well cemented, calcareous; persistent, parallel thinly laminated to thin-bedded ribs; many of the more resistant ribs contain cross laminae of small-scale trough sets of low-angle cross-strata. Many of these ribs contain ripple laminae; part of unit appears to be structureless, weathers to form alternating resistant ribs and less resistant slopes. Claystone to silty claystone, dark reddish brown (10R 3/4), grayish red $(10 R \quad 4 / 2$ and $5 R \quad 4 / 2)$, pale red purple $(5 R P 6 / 2)$, grayish red purple $(5 R P 4 / 2)$, and greenish gray $(5 G 6 / 1)$, weathers same colors; common very fine grained mica; firmly to well cemented, calcareous to noncalcareous; thinly laminated to laminated, papery to shaly splitting. Claystone to silty claystone constitutes top 10 to $15 \mathrm{ft}$ of unit. Upper contact appears to be an erosional disconformity

3. Sandstone, pale reddish brown (10R $5 / 4)$, weathering same colors and moderate reddish orange $(10 R 6 / 6)$, very fine grained, well sorted; composed of rounded to well-rounded clear and amber-stained quartz grains and common black accessory mineral; firmly cemented, calcareous; very 
State Bridge Formation (incomplete)-Continued Upper member (incomplete) - Continued thin bedded to thin bedded; ripple laminated; flaggy to slabby splitting. Few bedding planes contain siltstone and claystone coating. Weathers to form conspicuous ledge.

2. Sandstone and silty claystone. Sandstone, pale reddish brown $(10 R 5 / 4)$, grayish red $(10 R \quad 4 / 2)$, and light brown $(5 Y R 6 / 4)$, with minor paleolive $(10 Y 6 / 2)$ and grayish-green (10GY 5/2) mottling, weathering same colors, very fine grained, silty, fair to well sorted; composed of rounded to well-rounded clear, milky, and amber-stained quartz grains with common rounded to well-rounded coarse clear, smoky, and milky quartz grains, and common white and black accessory minerals, common finegrained mica; firmly cemented, calcareous; thinly laminated to thin bedded; abundant ripple laminae of low ripple index (7-8); platy to slabby splitting. Weathers to form resistant ribs on steep slope. Numerous siltstone and silty claystone pockets within the sandstone. Silty claystone, dark reddish brown (10R $3 / 4)$, weathering pale reddish brown $(10 R 5 / 4)$ and light brown $(5 Y R$ $6 / 4)$; common very fine grained mica; firmly cemented, noncalcareous; thinly ripple laminated to ripple laminated; papery to shaly splitting. Weathers to form thin less resistant ribs on steep slope

1. Sandstone, pale reddish brown $(10 R$ $5 / 4)$ and light brown (5YR 6/4), weathering same colors, very fine grained, well sorted; composed of rounded to well-rounded clear, milky, and amber-stained quartz grains with common rounded to well-rounded coarse clear, smoky, and milky quartz grains and common white and black accessory minerals; common finegrained mica; firmly cemented, calcareous; very thin bedded to thick bedded; medium- to small-scale trough and planar sets of low-angle crosslaminations to very thin crossbeds; flaggy to blocky splitting. Weathers to form smooth ledge

$\frac{5.3}{264.7-}$

Total of incomplete upper member..

$$
\text { Formation }
$$

Base of section; base of good exposure.

\section{C-4. SOUTH CANYON CREEK}

Section on west side of canyon $S .70^{\circ} \mathrm{W}$. from bridge crossing Colorado River at mouth of South Canyon Creek, about
Feet $4 \frac{1}{2}$ miles west of Glenwood Springs, NW1/4 of sec. 2, T. 6 S., R. 90 W., 6th PM, Garfield County

[Measured by F. G. Poole and L. G. Schultz, April and May 1956]

Top of section; not top of exposure. Section ends at base of Morrison Formation.

Entrada Sandstone:

16. Sandstone, light greenish gray (5GY $8 / 1)$, yellowish gray $(5 Y 7 / 2)$, and grayish yellow $(5 Y 7 / 2)$, weathers same colors and moderate yellow ( $5 Y$ $7 / 6$ ), fine to medium grained, fair to well sorted, composed of well-rounded clear, milky, smoky, and amberstained quartz and red and black chert grains, colorful coarse-grained berries in lower few feet of unit with same composition as the finer fraction, firmly cemented, calcareous; mediumand large-scale thin to very thick trough and planar sets of high-angle thin cross-laminae to thin crossbeds, upper part is largely horizontally laminated to thinly laminated. Unit weathers to form rounded massive cliff or steep slope. Upper contact is not well exposed along line of section

Total of Entrada Sandstone.

Unconformity.

Chinle Formation:

Red siltstone member:

15. Structureless siltstone $(60$ percent $)$, lenticular well-cemented coarse siltstone (30 percent), limestone and siltstone pebble conglomerate ( 8 percent), and limestone pebble conglomerate ( 2 percent). Pale reddish brown $(10 R 5 / 4)$ and moderate reddish brown $(10 R \quad 4 / 6)$ with dark-gray (N 3) limestone pebbles. Unit weathers same colors, with the limestone pebbles weathering purplish. Upper $40 \mathrm{ft}$ of unit is chiefly well-cemented coarse siltstone with conspicuous vertical fracturing. Unit as whole weathers to form steep rubble-covered slope, with the well-cemented coarse siltstones forming thin- to thick-bedded resistant ribs while the structureless siltstones form most of the intervening slope. Upper contact is unconformable with overlying Entrada Sandstone. Contact is sharp and undulating, with clastic dikes of Entrada Sandstone filling fractures and penetrating the upper Chinle surface a foot or more

14. Siltstone (70 percent) and limy siltstone (30 percent). Siltstone, dark reddish brown $(10 R 3 / 4)$, weathering grayish red $(10 R 4 / 2)$, same as unit 12 . Limy siltstone, grayish red $(10 R 4 / 2)$ with minor light-greenish-gray (5GY 8/1) 
Chinle Formation-Continued

Red siltstone member-Continued

mottling and abundant pale-red (5R $6 / 2$ ) limestone and siltstone pebbles as much as 0.5 in. in maximum diameter, firmly to well cemented, very calcareous; structureless. Weathers to form steep rubble-covered slope

13. Limy to sandy siltstone, pinkish gray (5YR 8/1), light greenish gray $(5 G Y 8 / 1)$, and greenish gray ( $5 G Y$ $6 / 1)$ to medium light gray ( $N 6)$. Sandy siltstone contains abundant to rare rounded to well-rounded clear, milky, and smoky medium to very coarse quartz grains and common fine to very fine white mica; firmly to well cemented, calcareous. Limy siltstone forms irregular lenses in upper part of unit. In places, unit is minutely cross-laminated (small-scale planar sets); in other places, unit is thinly laminated to very thin bedded. Weathers to form small inconspicuous rib on steep slope

12. Siltstone, dark reddish brown $(10 R$ $3 / 4)$, weathering grayish red $(10 R$ $4 / 2$ ), common to rare very fine to coarse rounded to well-rounded clear and amber-stained quartz grains, fair to well sorted, firmly cemented, calcareous, rare very coarse wellrounded silt grains; structureless, irregular fracturing. Weathers to form steep slope

Total red siltstone member.

Offset in section. Transferred so that overlying units measured approximately 50 yd to west and up slope.

Mottled member :

11. Silty claystone, dark reddish brown $(10 R 3 / 4)$ and grayish red $(10 R$ $4 / 2)$, weathers grayish red $(10 R$ $4 / 2$ ), uncommon to rare rounded clear and amber-stained fine to medium quartz grains, firmly cemented, calcareous, irregular bedding, irregular fracturing. Weathers to form steep slope

10. Sandy siltstone to clayey siltstone $(90$ percent) and silty claystone (10 percent). Sandy siltstone to clayey siltstone, grayish red purple (5RP 4/2), yellowish gray $(5 Y 8 / 1)$, dusky blue (5PB 3/2), grayish red $(10 R 4 / 2)$, dark reddish brown $(10 R 3 / 4)$, and grayish purple (5P 4/2), weathers same colors, and pale purple $(5 P$ $6 / 2$ ), and pale red purple (5RP 6/2) common to sparse subrounded to wellrounded medium to very coarse clear and amber-stained quartz grains, and abundant to uncommon white mica; poorly to well cemented, fair
$14.2 \quad \begin{aligned} & \text { Chinle Formation-Continued } \\ & \text { Mottled member-Continued } \\ & \text { to poorly sorted, calcareous to non- } \\ & \text { calcareous; zone approximately two- } \\ & \text { thirds above base contains abundant } \\ & \text { red iridescent iron oxide blebs with } \\ & \text { streaks of soft white clay; irregular } \\ & \text { bedding and fracturing to thinly } \\ & \text { laminated to very thin bedded with } \\ & \text { shaly splitting. Weathers to form } \\ & \text { steep slope: Unit is a pale to pale-red- } \\ & \text { purple and pinkish to yellowish-gray } \\ & \text { zone at base of Chinle Formation.... } \\ & \text { Total of mottled member.............. } \\ & \text { Total of Chinle Formation............. }\end{aligned}$

Unconformity.

State Bridge Formation (incomplete):

Upper member:

9. Silty claystone (75 percent), siltstone (20 percent), and sandstone ( 5 percent). Silty claystone, pale red (10R $6 / 2$ and $5 R 6 / 2$ ), weathers same color, micaeous; firmly cemented, slightly calcareous to noncalcareous; shaly splitting to irregular fracturing. Siltstone, grayish red $(10 R \quad 4 / 2$ and $5 R 4 / 2$ ), weathers same color, abundant white and dark-green (chloritic?) mica; firmly cemented, noncalcareous; irregular fracturing. Sandstone, grayish red (10R 4/2), greenish gray $(5 G 6 / 1)$, dark greenish gray (5GY 4/1), and light greenish gray $(5 G 8 / 1)$, weathers same colors, very fine to very coarse grained, fair to poorly sorted; composed of rounded to well-rounded clear and milky quartz and abundant white and dark-green (chloritic?) mica; the coarse to very coarse grains are wellrounded milky quartz; well cemented, calcareous to noncalcareous; very thin bedded, fine to very fine grained sandstone is ripple laminated; lenticular sandstones are present at base and near top of unit. Weathers to form small resistant ribs on steep slope. Unit as whole weathers to form steep dark-red slope

8. Siltstone to clayey siltstone (55 percent) and coarse siltstone to very fine grained sandstone ( 45 percent), pale reddish brown $(10 R 5 / 4)$, dark reddish brown $(10 R 3 / 4)$, and grayish red $(10 R 4 / 2)$ with minor lightgreenish-gray (5G 8/1) mottling, weathers same colors; clayey siltstone to very fine grained sandstone with sparse well-rounded medium milky- and amber-stained quartz grains and common white and darkgreen (chloritic?) mica; firmly to well cemented, calcareous to slightly cal- 
State Bridge Formation (incomplete)-Continued Upper member-Continued careous; ripple laminated (10 percent, estimated) and horizontal thin to thick bedded ( 90 percent, estimated) ; irregular fracturing. Weathers to form steep ribbed orange-red slope with coarse fraction (45 percent) forming three ribs and fine fraction ( 55 percent) forming rubble-covered intervening slope

Total of upper member

Total of incomplete State Bridge Formation

Base of section; not base of exposure.

Note. - Units 1-7 described in Stewart, Poole, and Wilson (1972).

\section{C-5. DURANGO}

Measured on east side of Animas River valley at point 5 miles north of Durango, sec. 3, T. 35 N., R. $g$ W., NMPM, La Plata County

[Measured by J. H. Stewart and R. F. Wilson, August 1955]

Top of section; top of accessible exposure. Top of section is N. $35^{\circ} \mathrm{E}$. of main part of Durango, S. $84^{\circ} \mathrm{E}$. of prominent side canyon on west side of Animas River valley, and N. $85^{\circ} \mathrm{E}$. of most southerly exposure of basal unit of Dolores Formation on west side of Animas River valley.

Entrada Sandstone (unmeasured) :

14. Sandstone, grayish orange pink (5YR $7 / 2)$, weathering very pale orange $(10 Y R 8 / 2)$, very fine to fine grained, in most places contains 5 to 10 percent medium to coarse grains, fair sorted; composed of subangular clear quartz and rare orange and black minerals; medium to coarse grains are rounded clear quartz; firmly cemented, slightly calcareous; thick bedded in lower $4 \mathrm{ft}$, thin to thick trough and planar sets of mediumscale low-angle cross-laminae in overlying $26 \mathrm{ft}$; massive splitting; weathers to form vertical cliff. Only basal $30 \mathrm{ft}$ of unit examined. Base of Entrada is sharp. Contact marks change from reddish colors of Dolores to pale orange of Entrada, from the sandy siltstone of the Dolores to the very fine grained sandstone containing disseminated coarser grains of the Entrada, and from the horizontally laminated rocks of the Dolores to the cross-stratified rocks of the Entrada Unmeasured

Dolores Formation:

Upper member :

13. Sandy siltstone, pale reddish brown $(10 R 5 / 4)$, weathering same color, firmly cemented, slightly calcareous; horizontally laminated, appears structureless in some parts, but stratification may be concealed; weathers to \begin{tabular}{l} 
Feet \\
$\frac{36.1}{55.6}$ \\
\hline 55.6 \\
\\
5 \\
\hline int
\end{tabular}

Feet

Dolores Formation-Continued Upper member-Continued

form vertical cliff continuous with that of Entrada Sandstone; unit contains common yellowish-gray (5Y 8/1) mottling

12. Siltstone, grayish red $(10 R \quad 4 / 2$ and $5 R 4 / 2$ ) and uncommon pale reddish brown $(10 R 5 / 4)$, weathering pale reddish brown $(10 R 5 / 4)$; firmly cemented, calcareous; composed of horizontal beds ranging in thickness from a few feet to possibly as much as $20 \mathrm{ft}$; horizontally laminated in a few parts; weathers to form steep ledgy slope; ledges form about 10 percent of the unit and are horizontal beds from 1 to $4 \mathrm{ft}$ thick. The ledges are sandier than the rest of the unit and grade in a few places to very fine grained silty sandstone. The siltstone commonly contains limy nodules that are mostly very coarse sand or granule size but may be as large as $1 \mathrm{in}$. in diameter. The siltstone from 66.0 to $70.5 \mathrm{ft}$ is horizontally laminated and contains mud-crack fillings on almost every lamination plane ......

11. Silty sandstone, light brown (5YR 6/4), weathering same color, very fine grained, silty, well sorted; composed of subrounded reddish-stained quartz and rare black accessory mineral; firmly to well cemented, slightly calcareous; horizontally laminated, some parts of unit appear structureless, in some places laminae have undulations that suggest ripples with an amplitude of 0.1 in. and a wavelength of 2 in. Unit forms conspicuous vertical cliff in local area.

10. Siltstone, pale reddish brown $(10 R 5 / 4)$ and minor light brown (5YR 6/4), weathers pale reddish brown $(10 R$ 5/4), fair sorted, contains common fine-grained accessory white mica; well cemented, calcareous; composed of horizontal laminae to very thick beds; massive splitting in part; along line of section forms a vertical cliff but elsewhere forms a ledgy slope....

9. Siltstone, pale reddish brown $(10 R 5 / 4)$ and common grayish red $(10 R 4 / 2)$, and rare light greenish gray (5GY 8/1); well cemented, calcareous; lower half of unit is ripple laminated with minor horizontal laminations, upper half of unit is structureless; weathers to form a loose slope. Base of unit along line of section is marked by a very thin set of lightgreenish-gray $(5 G Y$ 8/1) sandstone composed of medium to very coarse
Feet

119.2 
Dolores Formation-Continued

Upper member-Continued grains of rounded gray limestone in a silt matrix

Total of upper member

Middle member:

8. Siltstone, grayish red $(10 R 4 / 2)$ and pale reddish brown $(10 R 5 / 4)$, weathers same colors, firmly cemented, slightly calcareous cement with clay binding; stratification obscured but probably structureless; weathers to form a debris-covered slope. Unit contains a 5-ft set of sandy siltstone 5 ft above base. This sandy siltstone set is similar to that in underlying unit. Unit also contains one very thin set of light-greenish-gray ( $5 G Y$ $8 / 1$ ) sandstone composed of rounded medium to very coarse grains and sparse granules of siltstone and limestone. Top of this unit marks a color change from purplish colors below to reddish colors above. This color break is conspicuous on the cliffs on the west side of the Animas River Canyon

7. Clayey siltstone to sandy siltstone, grayish red (5R 4/2) and rare greenish gray ( $5 G Y 6 / 1)$, weathering same colors; well cemented, calcareous. Unit is composed of thin to thick sets of sandy siltstone (40 percent) interstratified with thin to very thick sets of siltstone and clayey siltstone (60 percent). The sandy siltstone contains very fine grained sand and probably grades to very fine grained sandstone. The sandy siltstone sets are composed of slightly inclined laminae that appear to be foreset layers. Unit as whole weathers to form ledgy slope....

6. Sandstone ( 75 percent), limestone-grain sandstone and conglomerate (15 percent), and siltstone (10 percent). Sandstone, light brownish gray (5YR $6 / 1$ ) and minor pale red purple (5RP $6 / 2)$, weathering grayish red $(5 R$ $4 / 2$ ), very fine grained, well sorted, composition masked, abundant coarsegrained accessory white mica, well cemented, calcareous; horizontally laminated, and thin to thick trough sets of medium-scale low-angle crossstrata. Limestone-grain sandstone and conglomerate, grayish red $(5 R$ $4 / 2$ ) and light greenish gray ( $5 G Y$ $8 / 1$ ), weathering same colors; composed of rounded coarse to very coarse grains of gray limestone in a silt matrix, well cemented; composed of trough sets of medium-scale lowangle crossbedding. Siltstone, grayish red $(5 R 4 / 2)$ and light greenish gray

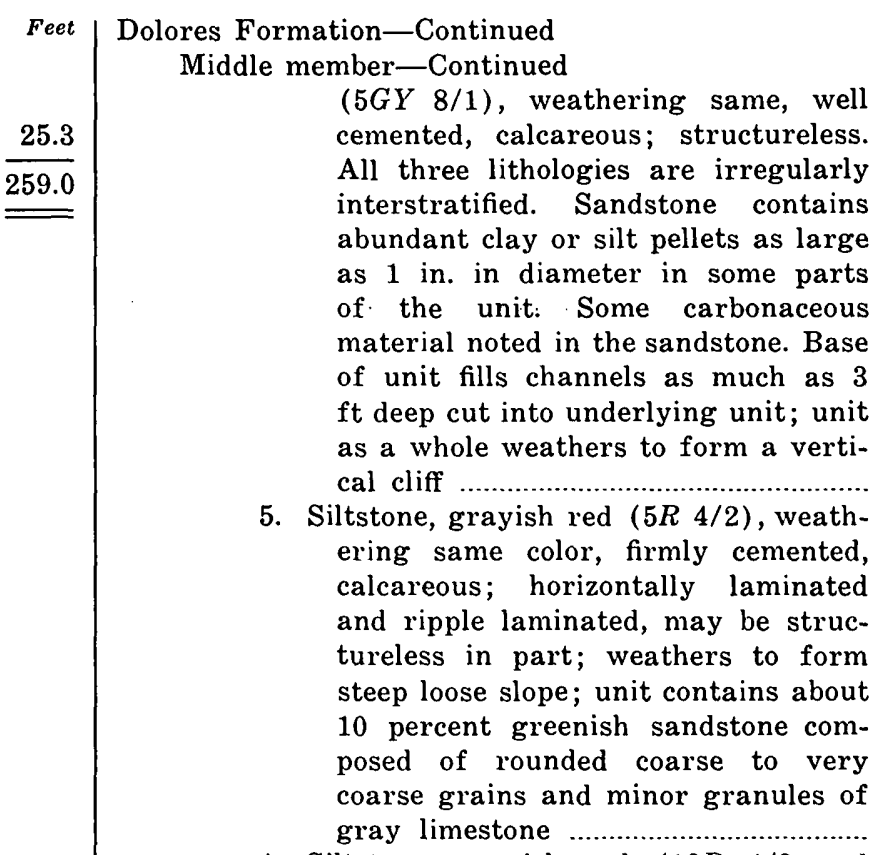

Feet (5GY 8/1), weathering same, well cemented, calcareous; structureless. All three lithologies are irregularly as 1 in in diameter in some parts of the unit: Some carbonaceous material noted in the sandstone. Base of unit fills channels as much as 3 t deep cut into underlying unit; unit as a whole weathers to form a vertial cliff

4. Siltstone, grayish red $(10 R \quad 4 / 2$ and $5 R 4 / 2$ ), weathering same color, common fine-grained accessory white mica; well cemented, calcareous; ripple laminated, cuspate-type ripples; one thick set of medium-scale crosslaminae noted; weathers to form vertical cliff; locally basal 1 to 2 $\mathrm{ft}$ is sandstone composed of coarse to very coarse grains of reddish siltstone and gray limestone set in a silt matrix. This sandstone in places is cross stratified and locally contains granules and pebbles as large as 1 in. of siltstone and limestone................

Offset in section on top of unit 3 so that units 4-14 measured starting at point about 1,000 ft south of place where unit 3 measured. Units $4-14$ measured on east side of Animas River Canyon, starting at point N. $84^{\circ}$ E. of most southerly exposure of basal unit of Dolores on west side of Animas River Canyon and $S .85^{\circ} E$. of prominent side canyon on west side of Animas River Canyon.

3. Siltstone to sandstone, grayish red $(5 R$ $4 / 2$ ), with light greenish gray ( $5 G Y$ $8 / 1$ ) in basal $3 \mathrm{ft}$ and rarely in rest of unit, weathering same colors, grades from coarse siltstone to very fine grained sandstone (sandstone confined to basal $1 / 3$ of unit) fair sorted; well cemented, slightly calcareous; 60 percent of unit is ripple laminated, predominantly cuspate-type ripples. Stratification is largely concealed in rest of unit, but is probably both horizontally and ripple laminated; platy splitting, weathers to form steep purplish-appearing slope. A few linear ripple marks noted in upper few feet of unit; one thin set of contorted ripple laminae 
Dolores Formation-Continued

Middle member-Continued

noted $2 \mathrm{ft}$ below top of unit. Unit from 44.0 to $67.0 \mathrm{ft}$ contains about 20 percent thin sandy siltstone lenses interstratified with siltstone. This sandy siltstone contains about 40 percent rounded coarse to very coarse grains of gray limestone set in a silt matrix

Total of middle member

Lower member:

2. Sandstone, light greenish gray ( $5 G Y$ $8 / 1)$, and minor yellowish gray (5Y $8 / 1)$, top $10 \mathrm{ft}$ is dominantly light brownish gray $(5 \mathrm{Y} R$ 6/1), weathering light olive gray ( $5 Y 6 / 1)$, very fine grained and minor fine grained; fair sorted, composed of subangular to subrounded clear quartz and abundant white and dark-green mica; well cemented, calcareous; horizontally laminated to very thin bedded. About 10 percent of unit is thin to thick trough and minor planar sets of small- to medium-scale dominantly low-angle cross-laminae; abundant ripple laminae in top $3 \mathrm{ft}$; some of the horizontal laminae actually may be extremely low-angle cross-laminae; weathers to form ledge that is prominent throughout this part of the Animas River Canyon. In places the sandstone grades to conglomeratic sandstone or conglomerate with clasts as large as $2 \mathrm{in}$. in diameter of rounded limestone and rounded to angular siltstone. Along line of section about 5 percent of unit is conglomeratic sandstone to conglomerate. Elsewhere the conglomerate forms a greater part of the section; a few quartz pebbles were noted in the conglomerate away from the line of section. The conglomerate mostly occurs in the lower $10 \mathrm{ft}$ of the unit. The basal contact of the unit is not well exposed along line of section, but an exposure to one side indicates the contact is sharp and erosional; scours as much as 2 in. deep are cut into the underlying unit. To one side of the line of section, a few chert nodules as large as 2 in. in diameter are present in the basal foot of the unit. The unit contains a few thin lenses of greenish siltstone. Carbonaceous material occurs along lamination planes in the sandstone and a fragment of a possible fossil tooth was noted in a conglomeratic layer..

Total of lower member

Total of Dolores Formation
Feet
$\frac{99.0}{269.3}$

Cutler Formation (unmeasured) :

1. Siltstone, grayish red $(10 R 4 / 2)$ and pale reddish brown $(10 R 5 / 4)$, weathering same colors, contains some very fine grained sand, poorly sorted, contains from 1 to 5 percent white and dark-green mica; firmly to well cemented, calcareous and probably clay binding, stratification largely concealed, but is partly horizontally laminated to thin bedded, weathers to form steep rubble-covered slope, only top $40 \mathrm{ft}$ of unit examined..Unmeasured

Base of section; base of good local exposure. Section starts on east side of Animas River Canyon at point $\mathrm{N} .88^{\circ} \mathrm{E}$. of prominent canyon in west wall of Animas River Canyon and N. $74^{\circ}$ E. of most southerly exposure of basal sandstone ledge of Dolores Formation on west side of Animas River Canyon.

\section{C-6. BRIDGEPORT}

Measured 1 mile south of Bridgeport; about $1 / 2$ mile up canyon to the southwest of the Gunnison River. Northeastern part of sec. 19 (unsurveyed), T. 14 S., R. $98 \mathrm{~W}$. 6th PM, Mesa County

[Measured by J. H. Stewart and F. J. Kleinhampl, June 1955]

Top of section. Top of good local exposure.

Feet

Entrada Sandstone (incomplete) :

8. Sandstone, light brown (5YR 6/4), and minor yellowish gray $(5 Y 8 / 1)$, weathering same colors, very fine to fine grained, some coarse-grained parts, fair sorted; composed of subrounded clear quartz and rare black accessory minerals; poorly cemented, calcareous; thin to thick horizontally bedded, some wavy bedding; weathers to form gentle slope with several small ledges. Unit forms slope above typical "Slick Rim" Entrada. A few beds are silty. About $30 \mathrm{ft}$ exposed along line of section .......................................... Unme

7. Sandstone, light brown (5YR 6/4), weathering same color, very fine grained, well sorted; composed of subrounded clear quartz and rare black accessory minerals; poorly cemented, calcareous; horizontally thinly to thickly bedded, several 5 - to $10-\mathrm{ft}$ layers are composed of thin to thick trough sets of small- to medium-scale high-angle cross-stratification; massive splitting; weathers to form bare rock slope ("Slick Rim" weathering). Many parts of unit contain from 5 to 20 percent amber-stained round very coarse quartz grains (Entrada "berries"). Basal contact is sharp, and scours as much as 4 in. deep are present along contact

Total of incomplete Entrada Sandstone 
Wingate Sandstone:

6. Sandstone, light brown (5YR 6/4), and minor very pale orange $(10 Y R 8 / 2)$, weathering light brown (5YR 6/4), very fine to fine grained, well sorted; composed of subrounded clear quartz and rare black accessory minerals; poorly cemented, calcareous, a few parts are well-cemented and highly calcareous; composed of thin to very thick trough sets of small- to large-scale cross-strata, a few 5 to 10 ft layers of very thin to thin-bedded sandstone; massive splitting; weathers to form a vertical cliff with a rounded slope in the top $20 \mathrm{ft}$. Basal contact sharp; no evidence of intertonguing or intergrading with underlying unit

Total of Wingate Sandstone.

Chinle Formation:

Red siltstone member:

5. Conglomerate (50 percent) and siltstone $(50$ percent). Conglomerate, pale reddish brown $(10 R 5 / 4)$ and grayish red (10R 4/2), weathering same colors. Clasts are limy siltstone to limestone granules and small pebbles. Matrix is silt. Conglomerate is well cemented (calcareous) and present as thin to thick lenses interstratified with siltstone. Siltstone, same as that in unit 4. Unit weathers to form vertical cliff. Basal part of unit fills channels cut as deep as $1 \mathrm{ft}$ into the underlying unit.

4. Siltstone to sandy siltstone, grayish red $(10 R 4 / 2)$ and pale reddish brown $(10 R 5 / 4)$, weathering pale reddish brown $(10 R 5 / 4)$, very fine grained, sandy; well cemented, slightly calcareous; composed of 10 - to $20-\mathrm{ft}$ thick layers of structureless rock interstratified with 1- to 20-ft layers of horizontally laminated rock. Horizontally laminated rock is mostly sandy siltstone. Unit fractures into angular fragments. Unit weathers to form a steep slope; ledges form on the sandy siltstone layers. Unit contains about three thin lenses of limestone pebble conglomerate (or siltstone with minor limestone grains). These rocks contain from 10 to 60 percent very coarse grains to small pebbles of reddish and grayish limestone or limy siltstone

3. Siltstone, grayish red $(5 R 4 / 2)$, weathering grayish red purple (5RP 4/2); firmly cemented, slightly calcareous; structureless; weathers to form slope

2. Clayey sandstone ( 60 percent) and conglomerate (40 percent), light greenish gray $(5 G Y 8 / 1)$, and minor olive \begin{tabular}{c} 
Feet \\
$\underline{176.2}$ \\
\hline 176.2 \\
\hline
\end{tabular}

Chinle Formation-Continued

Red siltstone member-Continued

gray $(5 Y 4 / 1)$ and pale reddish brown $(10 R 5 / 4)$, weathering same colors. Clayey sandstone, coarse grained, poorly sorted; composed of angular quartz grains (clay may be decomposed feldspar); stratification concealed. Conglomerate in some parts is composed of pebbles of palereddish-brown siltstone in a silt matrix; in other parts it is composed of pebbles and cobbles of quartz and gneiss in a coarse sand matrix. Unit is heterogeneous and is reworked material from the underlying gneiss. The siltstone pebbles were probably derived from local reworking of the Chinle

Total of red siltstone member

$\frac{3.0}{141.3}$

Precambrian:

Feet

. Gneiss, grayish red $(10 R 4 / 2)$, minor very light gray $(N 8)$, weathering same colors, coarsely crystalline, composed of feldspar, quartz, and about 3 percent light and dark mica; contains thin pegmatite veins with crystals as large as $1 / 4 \mathrm{in}$. and rare very thin veins of bull quartz. Foliation is close to vertical. Top $3 \mathrm{ft}$ are poorly indurated, are greenish gray $(5 G Y$ $6 / 1)$, and possibly represent a weathered interval on top of the gneiss Unmeasured

Base of section; base of exposure.

\section{C-7. CARSON HOLE}

Measured on northeast side of Carson Hole on west side of Big Dominguez Creek, west central part of sec. 19, T. 15 S., R. 100 W., 6th PM, Mesa County.

[Measured by R. F. Wilson, June 1956]

Top of section; not top of exposure.

Feet

Wingate Sandstone

8. Sandstone, light brown (5YR 6/4), weathering same color, very fine grained with scattered fine to medium grains in places, well sorted; composed of subrounded, clear and reddish-stained quartz and common dark accessory mineral; well cemented, calcareous; composed predominantly of wedge planar sets of medium- to large-scale high- and low-angle crosslaminae, but horizontal laminae and parting planes are common; weathers to form high vertical cliff......Unmeasured

Chinle Formation:

Red siltstone member:

12.8

7. Siltstone to sandy siltstone, light brown $(5 Y R 6 / 4)$ and minor pale reddish brown $(10 R 5 / 4)$, weathering light brown, medium to coarse silt, sandy 
Chinle Formation-Continued

Red siltstone member-Continued

(very fine grained) in part; firmly to well cemented, calcareous; stratification arranged as follows : $0-6 \mathrm{ft}$ composed of trough sets of small- to medium-scale low-angle cross-laminae, 6-15 ft structureless, $15-28 \mathrm{ft}$ composed of horizontal and ripple laminae (both parallel and cuspate types) and a few thin sets of small-scale low-angle cross-laminae, 28-50.4 ft structureless, 50.4-59 ft composed of 60 percent horizontal and ripple laminae and 40 percent small- to mediumscale low-angle cross-laminae, 59-72.8 $\mathrm{ft}$ structureless; weathers to form ledgy slope with ledges formed in laminated or cross-laminated parts of unit

6. Conglomerate to conglomeratic sandstone (50 percent) and siltstone to sandy siltstone (50 percent). Conglomerate to conglomeratic sandstone same as in unit 4 . Siltstone to sandy siltstone, light brown (5YR 6/4), weathering same color, coarse silt, sandy (very fine grained) in places; contains common accessory white mica, firmly to well cemented, calcareous; horizontally laminated to ripple laminated, and thin trough sets of small-scale low-angle cross-laminae. Siltstone to sandy siltstone is present as thin to thick sets interstratified with conglomerate to conglomeratic sandstone. Unit weathers to form prominent ledge ...................

5. Siltstone, light brown $(5 Y R 6 / 4)$ and pale reddish brown $(10 R 5 / 4)$, weathering same colors, medium to coarse silt; firmly to well cemented, calcareous; structureless in lower $40 \mathrm{ft}$ except for $2 \mathrm{ft}$ of horizontally laminated siltstone in basal $8 \mathrm{ft}$, upper $9.3 \mathrm{ft}$ is horizontally laminated to very thin bedded with a suggestion of ripple laminae in places; weathers to form ledgy slope, with ledge at top continuous with overlying unit

4. Conglomerate to conglomeratic sandstone, light brown $(5 Y R 6 / 4)$ and pale reddish brown $(10 R 5 / 4)$, weathering pale reddish brown (10R 5/4); fair to poorly sorted; composed of coarse grains to pebbles as large as 2 in. in diameter of siltstone and some limy siltstone in a limy matrix; firmly to well cemented, calcareous; composed of trough sets of mediumscale low-angle cross-laminae to thin beds; weathers to form ledge

3. Siltstone, pale reddish brown (10R $5 / 4)$, weathering same color, medium to coarse silt; firmly cemented, cal-
Feet

Chinle Formation-Continued

Red siltstone member-Continued

careous; structureless; weathers to form partially covered earthy slope....

2. Conglomerate to conglomeratic sardstone, grayish orange pink $(5 Y R$ $7 / 2$ ), weathering same color, fair sorted, composed of medium sand grains to pebbles as large as $11 / 4$ in. in diameter of angular to subrounded clear and white quartz, feldspar, granite, and siltstone; firmly to well cemented, calcareous; composed of trough sets of medium-scale low-angle cross-laminae; weathers to form ledge in gully; unit fills scours cut into underlying unit

Total of red siltstone member........

Total Chinle Formation

Precambrian granite:

1. Decomposed granite, pale reddish brown $(10 R 5 / 4)$, grayish orange $(10 Y R$ $7 / 4)$ and grayish orange pink (5YR $7 / 2$ ), weathering light brownish gray $(5 Y R$ 6/1), coarsely crystalline; composed of quartz and weathered feldspar and biotite; crumbly; weathers to form partly covered slope; only $10 \mathrm{ft}$ of unit exposed. Upper $4 \mathrm{ft}$ of unit is very decomposed and forms a pale purple $(5 P 6 / 2)$ to very light gray $(N 8)$ soil... Unmeasured

Base of section; base of exposure. Base of section is on Carson Hole trail on west side of Big Dominguez Creek.

Measured about $200 \mathrm{ft}$ west of the southernmost part of The Palisade, northeastern part of sec. 16, T. 51 N., R. 19 W., NMPM, Mesa County

[Measured by J. H. Stewart, E. M. Shoemaker, H. F. Albee, and D. A. McManus, August 1954]

Top of section; top of accessible exposure. Top of section is on the west side of The Palisade and about $40 \mathrm{ft}$ north of the most southerly tip of The Palisade.

Wingate Sandstone:

49.3 14. Sandstone, grayish orange pink (5YR $7 / 2)$ to light brown $(5 Y R 6 / 4)$, weathering light brown (5YR 6/4), very fine grained, well sorted; composed of subrounded clear quartz and rare black accessory minerals; firmly to well cemented, slightly calcareous; composed of thin trough sets of smallto medium-scale cross-laminae and horizontal laminae to thin beds; weathers to form vertical cliff. Only 25 $\mathrm{ft}$ of unit examined. Basal $15 \mathrm{ft}$ of unit is dominantly horizontally laminated to thinly bedded. Basal contact of Wingate Sandstone is irregular with relief of about $0.5 \mathrm{ft}$. Basal 0.5
Feet

50.4

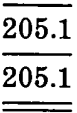


Wingate Sandstone-Continued $\mathrm{ft}$ of unit is light greenish gray (5G $8 / 1)$ ...Unmeasured

Chinle Formation:

Red siltstone member:

13. Silty claystone to siltstone, grayish red (10R $4 / 2$ to $5 R 4 / 2$ ), weathering same color; rare very fine grained accessory white mica; firmly cemented, noncalcareous; horizontally thinly laminated to laminated in lower half of unit and structureless in upper half; papery splitting in part; weathers to form rubble-covered slope........

12. Sandstone, grayish orange pink (5YR $7 / 2)$ to light brown (5YR 6/4), weathering same colors, very fine grained, well sorted; composed of subrounded clear quartz and common black accessory minerals; firmly cemented, slightly calcareous; composed of horizontal laminae, minor very thin beds, and common thin planar and trough sets of small- and medium-scale cross-laminae; massive splitting; weathers to form vertical cliff. Unit contains very thin set of pale-red $(5 R 6 / 2)$ horizontally laminated very fine grained sandstone at $2.6 \mathrm{ft}$ below top of unit. Unit appears to be similar to the lower part of the Wingate in color, texture, and stratification

11. Siltstone, pale reddish brown $(10 R$ $5 / 4)$ and grayish red $(10 R 4 / 2)$, weathering pale reddish brown $(10 R$ $5 / 4)$; well cemented, slightly calcareous; structureless with rare horizontal stratification planes and thin to very thick horizontal beds; fractures into angular fragments; weathers to form steep loose slope with many small ledges. Unit contains rare thin to thick layers containing about 10 percent coarse grains to granules of reddish and grayish limestone to limy siltstone.

10. Siltstone (70 percent) and siltstone (containing limestone and limy siltstone clasts) to limestone granule conglomerate (30 percent). Siltstone, pale reddish brown $(10 R 5 / 4)$ and minor grayish red $(10 R 4 / 2)$, weathering same colors; well cemented, calcareous; horizontally very thin to thick bedded. Siltstone (containing limestone and limy siltstone clasts) to limestone granule conglomerate, same colors as siltstone except for sparse light greenish gray (5GY 8/1) and pale red purple (5RP 6/2), weathering same colors, grades from siltstone containing about 10 percent very coarse grains, granules, and pebbles of red and gray limestone and
Feet Chinle Formation-Continued

Feet

Red siltstone member-Continued

limy siltstone to limestone granule conglomerate composed of rounded gray limestone granules in a lime and silt matrix; poorly to well cemented, calcareous; present as thin to very thick horizontal beds and lenses. Unit as whole weathers to form steep slope containing many ledges. The siltstone containing limestone and limy siltstone clasts and the limestone granule conglomerate are not everywhere easily separable from the remainder of the unit and vary considerably laterally; some limestone grains appear to be detrital in origin whereas others may be limy nodules. All gradations from siltstone to limestone granule conglomerate occur

9. Claystone to clayey siltstone, grayish red ( $5 R \quad 4 / 2$ and $10 R 4 / 2$ ), weathering pale red $(5 R \quad 6 / 2)$; contains rare ( 5 percent) fine to coarse grains of clear quartz; poorly cemented, noncalcareous; structureless; weathers to form steep slope. Upper half of unit contains abundant (30 percent) limestone nodules averaging about 1.5 in. in diameter..

Basal sandstone unit:

8. Sandstone, grayish red purple (5RP $4 / 2$ ), light greenish gray (5GY $8 / 1)$, and minor grayish red $(5 R \quad 4 / 2)$, weathers pale pink $(5 R P 8 / 2)$, fine to coarse grained, abundant interstitial silt, poorly sorted; composed of angular to subangular clear quartz; poorly cemented, noncalcareous; structureless and sparse thin horizontal lenses; weathers to form conspicuous white or pinkish-gray ledge. Unit contains 2 percent very coarse grains to pebbles of clear and milky quartz. Unit commonly grades to sandy siltstone

Contact of Chinle and Moenkopi Formations placed at color change from browns of Moenkopi to purples of Chinle. This contact marks a change from the sandstone of the Moenkopi containing dominantly granite, quartz, and feldspar granules and pebbles to the sandstone in the Chinle Formation containing quartz granules and pebbles.

Moenkopi Formation (incomplete) :

Ali Baba Member:

7. Conglomerate and minor conglomeratic sandstone, pale red $(5 R 6 / 2)$, weathering same color, composed of granules to cobbles of granite, feld- 
Moenkopi Formation (incomplete)-Continued Ali Baba Member-Continued spar, schist, and quartz in a medium to very coarse grained matrix of quartz and feldspar, minor silt, poorly sorted; a few percent of mediumto coarse-grained biotite; poorly cemented, calcareous in parts; stratification indistinct but appears to be mostly horizontally thin bedded, sparse small-scale cross-strata in basal $10 \mathrm{ft}$. Unit weathers to form steep loose slope. Sparse grayish red $(5 R 4 / 2)$ very thin to thin siltstone sets

6. Siltstone and sandstone (80 percent) and conglomerate sandstone (20 percent). Siltstone and sandstone, grayish red (5R $4 / 2$ and $10 R \quad 4 / 2)$ and minor pale reddish brown $(10 R 5 / 4)$, weathers same colors, grades from siltstone to fine-grained sandstone, fair sorted; composition concealed, a few percent of coarse-grained biotite; firmly to well cemented, calcareous; horizontally laminated to very thinly bedded, minor ripple laminae. Conglomeratic sandstone to conglomerate, pale red $(5 R 6 / 2)$, mottled with light greenish gray (5GY 8/1), weathers same colors, granules and minor pebbles of feldspar, granite, and quartz in a fine to very coarse grained matrix, poorly sorted; a few percent of coarse-grained biotite and white mica; poorly to firmly cemented, calcareous; composed of thin to very thin horizontal beds and minor sets of small-scale cross-laminae. Unit as a whole is tabular and weathers to form ledgy slope

Total of Ali Baba Member

Total of incomplete Moenkopi

Formation

Base of section; not base of exposure.

Note. - Units 1-5 described in Stewart, Poole, and Wilson (1972).

\section{C-9. THE SERPENTS TRAIL}

Measured in Colorado National Monument; begins in a west tributary wash of No Thoroughfare Canyon and ends just below the old road (The Serpents Trail). Wash runs eastward from highway tunnel into No Thoroughfare Canyon. Line of section trends $N$. $75^{\circ}$ E., beginning in Precambrian and ending in lower part of Wingate Sandstone. NW1/4 sec. $31, T .1$ S., R. 1 W., UPM, Mesa County

[Measured by F. G. Poole and P. A. Clark, August 1956]

Top of section; not top of exposure. Section ends near base of precipitous Wingate cliff. Top of section S. $65^{\circ}$ E. from highway tunnel.

Wingate Sandstone:

4. Sandstone, grayish orange $(10 Y R 7 / 4)$, pale yellowish orange $(10 Y R 8 / 6)$, moderate yellowish brown (10YR
Feet \begin{tabular}{|l} 
Wingate Sandstone-Continued \\
$5 / 4)$, and light brown $(5 Y R \quad 6 / 4)$, \\
weathering same colors and moderate \\
brown (5YR $4 / 4$ and $5 Y R 3 / 4)$, very \\
fine to fine grained, silty, fair to \\
well sorted; composed of rounded to \\
well-rounded clear and amber-stained \\
quartz grains with common black and \\
white (clay?) accessory minerals; \\
firmly to well cemented, calcareous \\
to noncalcareous; very thin bedded to \\
very thick bedded in places; in other \\
places composed of very thin to thick \\
small- and medium-scale planar sets \\
of cross-laminae and very thin cross- \\
beds, abundant contorted bedding. \\
Unit weathers to massive vertical \\
cliff. Basal 5 ft of unit contains \\
abundant angular to well-rounded \\
fine sand grains to granules composed \\
of reworked Chinle (?) rock types \\
and of weathered chert (?). Many of \\
the coarse sand and granules are disk \\
shaped. Only basal 10 ft of unit ex- \\
amined. Examined part of Wingate \\
appears to be fluvial ................. Unmeasured
\end{tabular} Chinle Formation:

Red siltstone member:

3. Limy siltstone (90 percent) and limy siltstone pebble conglomerate (10 percent). Limy siltstone, pale reddish brown $(10 R 5 / 4)$ to moderate brown (5YR 4/4), weathering dark reddish brown $(10 R 3 / 4)$, moderate brown $(5 Y R 4 / 4)$, and grayish red $(5 R 4 / 2$ and $10 R 4 / 2$ ) with minor pale-yellowish-brown $(10 Y R \quad 6 / 2)$, yellowishgray $(5 Y 8 / 1)$ and light-greenish-gray (5GY 8/1) mottling, fine to coarse silt, well sorted, abundant to rare limy siltstone and silty limestone pebbles and nodules; firmly to well cemented, very calcareous; laminated to thick bedded but mostly (about 70 percent) structureless. Unit weathers irregularly to sharp angular fragments. Limy siltstone pebble conglomerate; color same as limy siltstone except many of the pebbles are light gray $(N 7)$ to yellowish gray (5Y $8 / 1$ ) ; fair to well sorted; composed of subangular to rounded very coarse grains, granules, and pebbles (as large as $2.5 \mathrm{in}$.) of limy siltstone and silty limestone set in a fine to coarse silt matrix; firmly to well cemented, very calcareous; conglomerate occurs as lenticular laminae to thick beds which channel into underlying beds and is best developed in middle part of unit. Unit as whole weathers to form steep rubble-covered slope and appears brick red from a distance. Note. - Top few feet of unit contains many clayey 
Chinle Formation-Continued

Red siltstone member-Continued siltstone laminae. Upper contact is gently undulatory, irregular, and sharp in most places; however, in one place Chinle-like siltstone occurs above but near the base of the Wingate Sandstone ..............................

Total red siltstone member.

Total of Chinle Formation

Precambrian igneous and metamorphic rocks:

2. Regolith (bleached zone), dark greenish gray (5GY $4 / 1$ and $5 G 4 / 1)$, light greenish gray $(5 G Y \quad 8 / 1$ and $5 G 8 / 1$ ), pale red purple (5RP 6/2), pale red (5R 6/2 and $10 R 6 / 2$ ), grayish red $(5 R \quad 4 / 2$ and $10 R 4 / 2)$, and minor very dusky red $(10 R 10 / 2)$ and dark reddish brown $(10 R 3 / 4)$, weathering same colors. This bleached zone is deeply weathered and altered rock of underlying unit; composed of smoky and milky quartz, iron oxide, badly weathered feldspar and biotite. Weathers to form smooth steep slope. Unit is a prominent bleached zone at the top of the Precambrian rocks ...............................

1. Quartz-biotite gneiss and schist with minor felsic pegmatite dikes. Gneiss and schist, greenish black ( $5 G Y 2 / 1$ and $5 G 2 / 1)$ to olive black $(5 Y 2 / 1)$, weathering same colors; dark color due to large amount of biotite mica and chlorite present, medium to coarse texture; composed of quartz, biotite, feldspar, and chlorite. Pegmatite dikes are composed of pink and gray feldspar, smoky and milky quartz, and subordinate muscovite and biotite. Top $25 \mathrm{ft}$ of unit is deeply weathered and forms a smooth steep slope. Top few feet of unit is lighter colored due to large clay content. The lower $58 \mathrm{ft}$ of unit is fresh rock and exhibits spheroidal weathering

Total of incomplete Precambrian igneous and metamorphic rocks..

Base of section; base of exposure. Base of section is in bottom of tributary wash to No Thoroughfare Canyon.

\section{C-10. CROSS MOUNTAIN}

Measured on north side of canyon of Little Snake River in SW1/4 sec. 29, T. 7 N., R. 98 W., 6th PM, Moffat County

[Mensured by F. G. Poole and J. H. Stewart, September 1956]

Top of section; not top of exposure. Section ends at base of precipitous cliff of Glen Canyon Sandstone.

Glen Canyon Sandstone:

9. Sandstone, same as that in unit 8 , grades upward into very thick bedded \begin{tabular}{l|l} 
Feet & Glen Canyon Sandstone-Continued \\
sandstone, basal $2 \mathrm{ft}$ contains numer- \\
ous ripple laminae of parallel and \\
cuspate type and mudcrack fillings. \\
Only lower $10 \mathrm{ft}$ of unit examined. \\
Lower part of Glen Canyon Sandstone \\
is almost entirely horizontally bedded \\
(fluvial) whereas the upper part is \\
cross stratified (eolian)
\end{tabular}

Chinle Formation (incomplete):

Upper member :

8. Clayey siltstone to sandy siltstone (60 percent) and sandstone (40 percent). Clayey siltstone to sandy siltstone, pale reddish brown $(10 R 5 / 4)$ with minor yellowish-gray $(5 Y 8 / 1)$ to light-greenish-gray $(5 G Y 8 / 1)$ mottling, weathering same color, coarse silt to fine sand; fine sand grains are composed of subrounded to wellrounded clear and amber-stained quartz and common to rare white mica; firmly to poorly cemented, calcareous; horizontally laminated to very thin bedded, structureless, or ripple laminated; shaly, platy, and slabby splitting. Sandstone, light greenish gray $(5 G Y 8 / 1)$, very pale green $(10 G 8 / 2)$, pale green $(5 G$ $7 / 2)$, pale yellowish green (10GY $7 / 2)$, grayish yellow $(5 Y 8 / 4)$, and light brown (5YR 6/4), weathering same colors, but dominantly light brown $(5 Y R$ 6/4), very fine to coarse grained, fair to well sorted; composed of subrounded to wellrounded clear, milky, smoky, and amber-stained quartz grains with minor varicolored chert grains and sparse to common feldspar and black accessory mineral; slightly to highly calcareous; horizontally laminated to thin bedded and ripple laminated, (a 1.5-ft-thick bed $4 \mathrm{ft}$ from top of unit contains numerous contorted laminae) sparse very thin to thin trough sets of small-scale crosslaminae; platy to slabby splitting. Rare small rounded siliceous pebbles as much as $1 / 2$ in. in diameter are present. The well-rounded medium and coarse grains commonly occur as berries in the finer matrix. Unit as whole weathers to form steep ribbed slope with sandstone beds forming ledges and siltstone intervening slopes. Top of unit is gradational with overlying unit 
Chinle Formation (incomplete)-Continued

Upper member-Continued

smoky, and amber-stained quartz grains and sparse to common feldspar and black accessory mineral and varicolored chert; firmly cemented, very calcareous; very thin to thick bedded, common ripple laminae and rare thin trough sets of low-angle cross-laminae; platy to blocky splitting. Weathers to form prominent ledge. Upper contact is gradational with overlying unit. Lower part of unit contains very coarse sand to small disk-shaped pebbles as much as $1 \mathrm{in}$. in diameter of limy sandstone

Total of upper member

Red siltstone member:

6. Siltstone, pale reddish brown $(10 R$ $5 / 4)$, dark reddish brown $(10 R 3 / 4)$ with minor grayish red (10R 4/2), pale red (10R $6 / 2$ and $5 R 6 / 2)$, and light greenish gray (5GY 8/1), weathering same colors; fine- to coarse-grained silt; coarse silt is composed of rounded to well-rounded amber-stained quartz and rare white mica; firmly cemented, very calcareous; structureless with rare poorly defined thin to thick beds; breaks into sharp angular fragments. Weathers to form steep rubble-covered slope. Upper contact is well defined and sharp

5. Siltstone to very fine grained sandstone, pale red $(10 R 6 / 2$ and $5 R \quad 6 / 2)$, minor pale red purple $(5 R P 6 / 2)$ and light greenish gray $(5 G Y \quad 8 / 1)$, weathering same colors, very fine sand; composed of rounded to wellrounded clear, milky, and amberstained quartz with common iron oxide and sparse green copper staining; firmly to well cemented, very calcareous; horizontally laminated to thin bedded, some ripple laminae of cuspate type, sparse structureless parts, very thin to thin trough sets of small-scale low-angle cross-laminae; platy and shaly to slabby splitting. Lower three-fourths of unit weathers to form steep ledgy slope, and upper one-fourth weathers to form steep rubble-covered slope. Minor amount of limy siltstone to silty limestone pebble conglomerate present. Lower part of unit contains rare plant-stem imprints. Upper contact is poorly exposed.

Total red siltstone member

Sandstone and conglomerate member:

4. Siltstone to very fine grained sandstone and conglomerate, same colors as
Feet Chinle Formation (incomplete)-Continued Feet Sandstone and conglomerate member-Con. underlying unit, weathering same colors and pinkish gray $(5 Y R 8 / 1)$ to grayish pink $(5 R 8 / 2)$, lithology same as underlying unit. One limy siltstone bed contains slightly calcareous and ferruginous vertical cylindrical structures as much as 2 ft long and $1 \frac{1}{2}$ in. in diameter. Most pebble conglomerate beds contain phytosaur bone fragments. Trough cross-stratification and sedimentary structures similar to that in underlying unit. Unit weathers to form rough ledges and long dip slope in top. $5 \mathrm{ft}$. Unit is highest prominent ledgy unit in Chinle Formation

3. Siltstone to very fine grained sandstone and conglomerate, very light gray $(N 8)$ to medium gray ( $N 5)$, light brownish gray $(5 Y R 6 / 1)$, pale red $(10 R 6 / 2)$, and pale pink (5RP 8/2), to grayish pink $(5 R 8 / 2)$, with minor grayish orange $(10 Y R 7 / 4)$, and pale yellowish brown (10YR 6/2), weathering same colors with dominant reddish-pink tint, siltstone grades into clayey siltstone and very fine grained sandstone; sandstone is composed of very fine to fine rounded to wellrounded clear, milky, smoky, and amber-stained quartz grains and sparse to common feldspar and black accessory mineral; conglomerate is composed predominantly of rounded to well-rounded granules and small pebbles of limy siltstone to silty limestone and, to a lesser extent, of siliceous granules and pebbles, matrix ranges from limy silt to very coarse sand. Entire unit very calcareous to slightly calcareous; horizontally laminated to thin bedded, some ripple laminae (cuspate and subordinate parallel ripples), common thin trough sets of small- and medium-scale lowangle cross-laminae, common current lineation. Unit as whole weathers to form rough ledges and steep dip slopes. Unit 2 and basal $15 \mathrm{ft}$ of unit 3 form prominent ledgy interval at base of Chinle Formation. Conspicuous structures on bedding planes appear to be worm trails

2. Siltstone to fine-grained sandstone, very light gray $(N 8)$, light gray $(N 7)$, yellowish gray (5Y 7/2 and $5 Y 8 / 1)$, and grayish yellow $(5 Y 8 / 4)$, weathering same colors and grayish orange (10YR 7/4), well sorted; sandstone composed of subrounded to wellrounded clear, milky, and amberstained quartz and sparse to common mica and black accessory mineral; 
Chinle Formation (incomplete)-Continued

Sandstone and conglomerate member-Con. horizontally laminated to thin bedded, some ripple laminae of parallel and cuspate type, common thin trough sets of medium- and small-scale cross-laminae, common current lineation; platy, shaly, to slabby splitting. A lenticular bed composed of very fine to very coarse sandstone and as much as 4 in. thick is present about $12 \mathrm{ft}$ above base of unit. The coarse to very coarse grains in this sandstone are composed of rounded to well-rounded clear, milky, and pink quartz, and sparse to uncommon gray chert. This sandstone is very limy with numerous limy siltstone pebbles and granules. Lower half of unit weathers to form rough ledge, and upper half to smooth steep slope......

Total sandstone and conglomerate member

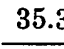

114.5

Ocher siltstone member (incomplete) :

1. Silty claystone to clayey siltstone, dark yellowish orange $(10 Y R 6 / 6)$, moderate reddish orange $(10 R 6 / 6)$ to pale red $(10 R 6 / 2)$, weathering same colors, contains scattered rounded to well-rounded very fine to medium clear and amber-stained quartz grains and sparse mica, some yellow iron oxides; firmly cemented, noncalcareous; structureless. Weathers to form smooth steep slope. Member is poorly exposed

Total of incomplete ocher siltstone member

Total of incomplete Chinle Formation

Base of section; lowest part of Chinle Formation not exposed, although Gartra Member and mottled member of Chinle Formation and Moenkopi Formation exposed elsewhere in local area.

\section{C-11. MILLER CREEK}

Measured east of Miller Creek water gap on south flank of Skull Creek anticline in secs. 27, 34,T. 4 N., R. $101 \mathrm{~W}$., 6th PM, Moffat County

[Measured by F. G. Poole and J. H. Stewart, September 1956]

Top of section; not top of exposure. Top of section is approximately N. $60^{\circ} \mathrm{E}$. from Miller Creek water gap through lower Glen Canyon Sandstone.

\section{Glen Canyon Sandstone:}

16. Sandstone, grayish yellow green ( $5 G Y$ $7 / 2)$, pale yellowish green $(10 G Y$ $7 / 2)$, white $(N 9)$, pale greenish yellow $(10 Y 8 / 2)$, moderate orange pink $(10 R 7 / 4)$, and light brown (5YR 6/4), weathering same colors, very fine to fine grained, well sorted; composed of rounded to well-rounded clear, milky, and amber-stained quartz grains and sparse to common

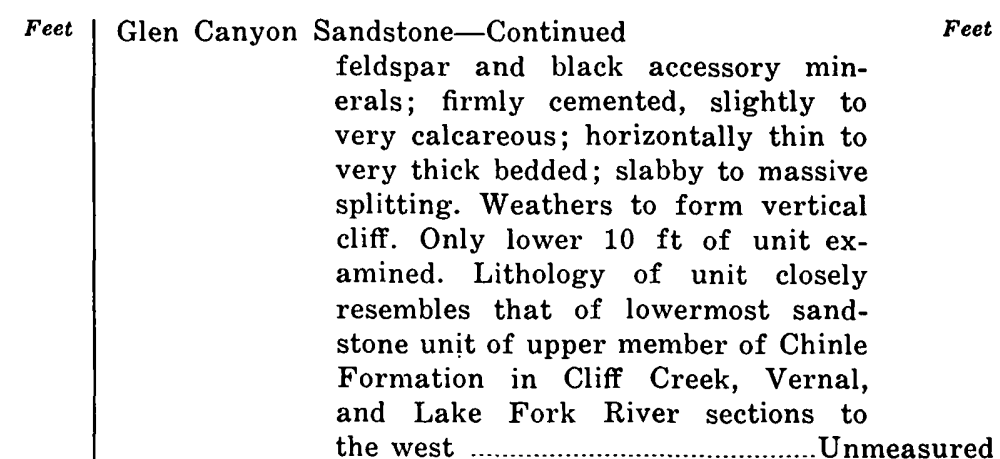

Chinle Formation:

Red siltstone member:

15. Siltstone, moderate brown (5YR 4/4), pale reddish brown $(10 R 5 / 4)$, dark reddish brown $(10 R 3 / 4)$, grayish red $(10 R 4 / 2)$, and minor yellowish gray $(5 Y 8 / 1)$, and greenish-gray (5G 6/1) mottling, weathers same colors; fine to coarse silt; firmly to well cemented, very calcareous to slightly calcareous; structureless with subordinate horizontally laminated to very thick bedded layers and ripplelaminated layers; breaks into sharp angular fragments. Weathers to form steep rubble-covered slope containing several prominent ledges of wellcemented siltstone. Upper contact appears gradational with overlying sandstone unit. Basal $5.3 \mathrm{ft}$ of unit is ripple laminated and contains minor amounts of small-scale trough sets of low-angle cross-laminae. Unit contains a total of about $4 \mathrm{ft}$ of pebble conglomerate with clasts of limy siltstone in a siltstone matrix. Clasts are subrounded to well rounded and as much as $2 \mathrm{in}$. in maximum diameter. Prominent ledge from 5.3 to 15.4 ft above base of unit contains numerous pale-red $(10 R 6 / 2)$ to pale-redpurple $(5 R P 6 / 2)$ vertical cylindrical structures several feet long and as much as $1 \mathrm{in}$. in diameter which appear to be higher in lime content than adjacent red siltstone. Abundant limy masses and pebbles scattered throughout unit. Top few inches of unit altered to pale yellowish green $(10 G Y 7 / 2)$ and grayish yellow green (5GY 7/2)

14. Siltstone, pale reddish brown $(10 R 5 / 4)$ and minor light-greenish-gray (5GY 8/1) mottling, weathering same colors, contains common amounts of well-rounded medium to very coarse grains which are composed of limy material and siltstone similar to that in underlying unit; firmly cemented, very calcareous, argillaceous; structureless; breaks into small angular fragments. Weathers to form steep 
Chinle Formation-Continued

Red siltstone member-Continued rubble-covered slope. Grades into overlying unit

Total red siltstone member

Ocher siltstone member:

13. Siltstone to clayey siltstone (70 percent) and silty claystone (30 percent). Siltstone to clayey siltstone, light brown $(5 Y R 6 / 4)$ to moderate brown ( $5 Y R 4 / 4$ and $5 Y R 3 / 4)$, with minor light-greenish-gray ( $5 G Y \quad 8 / 1$ and $5 G 8 / 1$ ) mottling, weathering same colors; contains common wellrounded coarse and very coarse limy grains, contains goethite staining and oolitic, pisolitic (?), and nodular structures with probably the same composition; firmly to well cemented, very calcareous; structureless; breaks into sharp angular fragments. Silty claystone, moderate yellowish brown $(10 Y R 5 / 4)$ with minor light-greenish-gray ( $5 G Y 8 / 1)$ mottling, weathering same colors and pale yellowish orange $(10 Y R \quad 8 / 6)$; same as remainder of unit except that it contains swelling clays in basal $10 \mathrm{ft}$ of unit. Unit weathers to form steep rubble-covered slope; frothy-surfaced slope in lower third of unit. Silty claystone is confined to lower third of unit and appears as conspicuous ocherous zone in the lower part of the Chinle Formation

Total ocher siltstone member

Mottled member:

12. Silty claystone, grayish red $(10 R 4 / 2)$ to dark reddish brown (10R 3/4), weathering same colors and grayish red $(5 R 4 / 2)$ to pale red $(5 R 6 / 2)$, contains sparse rounded to wellrounded medium to very coarse amber-stained quartz grains; firmly cemented, noncalcareous; ferruginous, clay binding, minor amounts of secondary gypsum; structureless to very poorly laminated; slickensided. Weathers to steep frothy slope. Contains swelling clays

11. Sandy siltstone (70 percent) and silty sandstone (30 percent). Sandy siltstone, mottled grayish red purple (5RP 4/2), grayish purple (5P 4/2), pale red purple $(5 R P 6 / 2)$, light greenish gray ( $5 G Y 8 / 1$ and $5 G 8 / 1$ ), white $(N 9)$, grayish red $(10 R \quad 4 / 2$ and $5 R 4 / 2)$ and dusky yellow ( $5 Y$ $6 / 4$ ), weathering same colors, contains abundant subrounded to wellrounded clear, smoky, and amberstained quartz grains and granules and abundant clay and iron oxide;

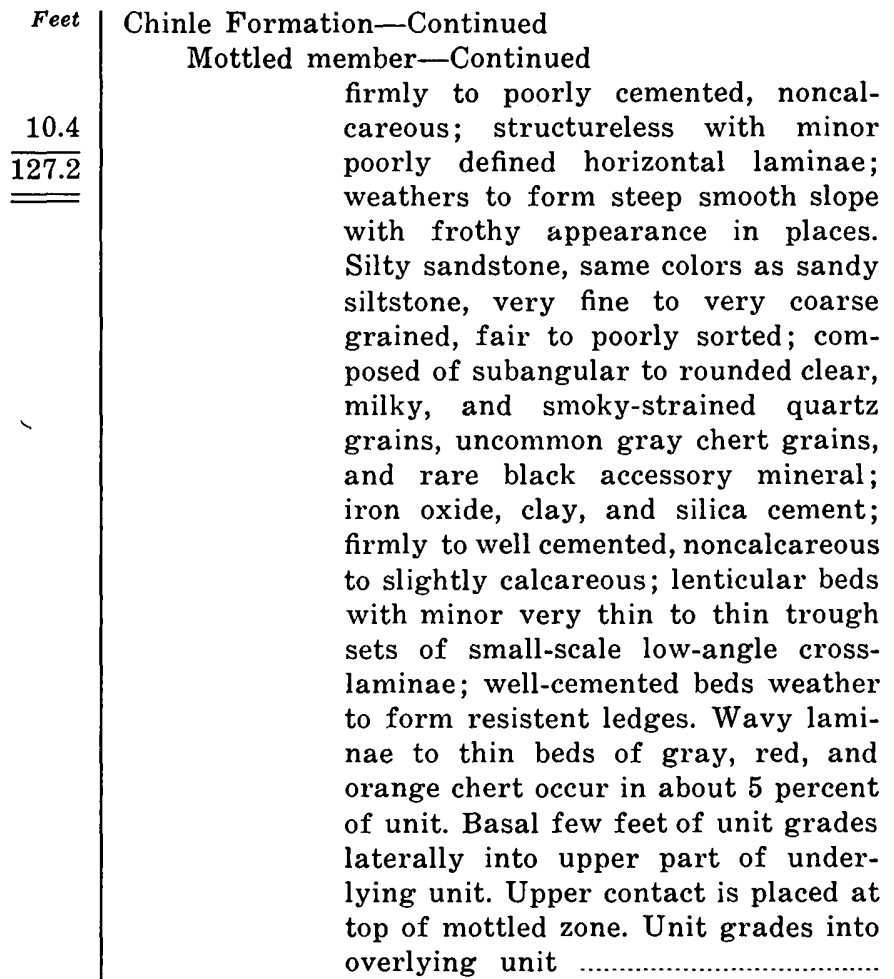

Total of mottled member

Gartra Member :

10. Sandstone to conglomeratic sandstone, white $(N 9)$, pale red $(10 R 6 / 2)$, grayish pink $(5 R 8 / 2)$, pale reddish brown $(10 R 5 / 4)$ and minor grayish red purple $(5 R P 4 / 2)$ and grayish orange $(10 Y R 7 / 4)$, weathers same colors, coarse sand to granules and minor amounts of very fine to medium sand and small pebbles, fair to poorly sorted; composed of subangular to rounded clear, milky, smoky, and amber-stained quartz, minor feldspar and gray chert grains, and sparse mica; firmly to poorly cemented, noncalcareous to slightly calcareous; clay binding; lenticular layers of very thin to thick trough and planar sets of small- and medium-scale low-angle cross-laminae to very thin crossbeds, unit contains many horizontal laminae to very thick beds. Weathers to form conspicuous white ledge. Sparse sandy siltstone partings in unit. Granules and pebbles are composed of subrounded to well-rounded quartz and subordinate chert as much as 1.2 in. in diameter. Pebbles occur in thin lenses and as isolated clasts. Many of the pebbles are disk shaped and imbricated. Top of unit gradational with overlying unit 
Chinle Formation-Continued

Mottled strata :

9. Clayey siltstone to sandy siltstone, mottled dark reddish brown (10R $3 / 4)$, grayish red purple (5RP $4 / 2)$, pale red purple (5RP 6/2) and minor grayish yellow $(5 R 8 / 4)$ and light greenish gray (5GY 8/1), weathering same colors and lighter shades, contains abundant subrounded to well-rounded medium-size grains to granules of clear, milky, and amberstained quartz and sparse common white mica; poorly cemented, slightly calcareous; horizontally laminated to structureless. Weathers to form smooth steep slope continuous with that developed on underlying unit. Unit appears to represent a reworking of material from the Moenkopi Formation

Total mottled strata

Total of Chinle Formation.

Section offset so that unit 9 and overlying units measured about $11 / 2$ miles east of underlying units. Section offset across water gap where Miller Creek turns south and crosses Chinle Formation.

Unconformity.

Moenkopi Formation (incomplete) :

8. Fine to coarse siltstone (45 percent), and clayey siltstone to silty claystone (55 percent). Fine to coarse siltstone, light brown $(5 Y R 6 / 4)$ to grayish red $(10 R 4 / 2)$, minor light greenish gray ( $5 G Y 8 / 1$ and $5 G 8 / 1$ ), weathers same colors; coarse fraction composed of rounded to well-rounded clear and amber-stained quartz grains and abundant to sparse white and darkgreen mica; firmly to well cemented, calcareous; horizontally laminated and sparse ripple laminae of cuspate and parallel type and sparse small scours; shaly to massive splitting. Clayey siltstone to silty claystone, colors same as in fine to coarse siltstone, contains common dark-green mica; firmly to well cemented, calcareous; horizontally thinly laminated to structureless; shaly and flaggy splitting. Unit as whole weathers to form steep ledgy slope. Ledges form on fine to coarse siltstone, and slopes form on clayey siltstone to silty claystone. Most prominent ledges are coarse siltstone. Unit contains two prominent ledges; one from 0.0 to $27.2 \mathrm{ft}$ and one from 67.2 to $87.6 \mathrm{ft}$ above base of unit. Top half of unit is largely clayey siltstone to silty claystone

Total of incomplete Moenkopi Formation
Feet Base of section; not base of exposure.

Note. - Units 1-7 described in Stewart, Poole, and Wilson (1972).

\section{C-13. VERMILION CREEK}

Measured between Irish Lake and Vermilion Creek in $S 1 / 2$ of sec. 14, T. 10 N., R. 101 W., 6th PM, Moffat County

[Measured by F. G. Poole and J. H. Stewart, September 1956]

Top of section; not top of exposure.

Glen Canyon Sandstone:

10. Sandstone, white $(N 9)$ to grayish yellow $(5 Y 8 / 4)$, weathering same colors and grayish orange $(10 Y R 7 / 4)$ to light brown $(5 Y R 6 / 4)$, very fine to fine grained with abundant mediumand coarse-grained sand berries; composed of rounded to well-rounded clear, milky, and amber-stained quartz grains, and common feldspar and sparse black accessory mineral; firmly cemented, calcareous; horizontally thin to very thick bedded, common ripple laminae of parallel and cuspate type, and minor amounts of very thin to thin trough and planar sets of smallto medium-scale cross-laminae; flaggy to massive splitting. Weathers to form precipitous cliff. Basal $100 \mathrm{ft}$ appears to be almost entirely fluvial. Rest of Glen Canyon Sandstone has typical large- and medium-scale crossstrata and appears to be almost entirely eolian ...............................Unmeasured

Chinle Formation:

Upper member:

9. Sandstone, pale greenish yellow $(10 Y$ $8 / 2)$ to grayish yellow $(5 Y 8 / 4)$, with subordinate pale yellowish green (10GY 7/2), weathering same colors and light brown (5YR 6/4), contains minor amounts of pale-green ( $5 G$ $7 / 2$ ) silty claystone partings; firmly to well cemented, calcareous; horizontally and wavy laminated to thin bedded, minor amounts of ripple laminae of parallel type, sparse very thin trough sets of low-angle small-scale cross-laminae; shaly, platy, to slabby splitting. Unit weathers to form recess below cliff developed in overlying unit. Unit is very similar to unit 7. Upper contact is transitional with overlying unit

8. Silty claystone to clayey siltstone, grayish red $(10 R 4 / 2)$, to pale red ( $5 R$ $6 / 2$ ), with minor light-olive-gray (5Y 6/1) mottling; firmly cemented, slightly calcareous; horizontally laminated; shaly splitting; weathers to form steep smooth slope.

Feet andstone, light greenish gray (5GY $8 / 1$ ), yellowish gray ( $5 Y 8 / 1)$, grayish orange $(10 Y R 7 / 4)$, weathering same colors and light brown (5YR $6 / 4)$, very fine grained, well sorted; 
Chinle Formation-Continued

Upper member-Continued

composed of rounded to well-rounded clear and amber-stained quartz grains, uncommon to sparse fine to coarse grains of rounded to well-rounded feldspar and clear and amber-stained quartz, and sparse black accessory mineral (iron oxide?); firmly to well cemented, very calcareous; horizontal and wavy laminae to thin beds, minor amounts of ripple laminae of parallel type; platy to slabby splitting. Weathers to form steep ribbed slope. Upper contact is transitional with overlying unit

Total upper member

Red siltstone member:

6. Silty claystone to clayey siltstone (50 percent) and siltstone (50 percent). Silty claystone to clayey siltstone, grayish orange $(10 Y R \quad 7 / 4)$ with minor light-greenish-gray $(5 G Y 8 / 1)$ mottling; firmly cemented, very calcareous; structureless. This lithology constitutes lower half of unit. Siltstone, moderate brown $(5 Y R 4 / 4)$ to light brown (5YR 6/4), weathering same colors, same as upper part of underlying unit. This lithology constitutes upper half of unit. Unit as whole weathers to form steep smooth slope. Upper contact is well defined and sharp

5. Silty claystone (50 percent) and clayey siltstone to siltstone (50 percent). Silty claystone, grayish red $(10 R$ $4 / 2)$, pale red $(10 R 6 / 2)$, minor light-greenish-gray (5GY 8/1) mottling; firmly cemented, calcareous; structureless; breaks into sharp angular fragments. This lithology constitutes lower half of unit. Clayey siltstone to siltstone, pale reddish brown $(10 R 5 / 4)$ to light brown (5YR 6/4), weathering same colors, contains common coarse silt grains of clear and amber-stained quartz and calcite crystals; firmly cemented, calcareous; structureless. This lithology constitutes upper half of unit. Unit as whole weathers to form steep smooth slope

4. Limy siltstone, pale reddish brown $(10 R 5 / 4)$ and minor light greenish gray $(5 G Y 8 / 1)$, weathering same colors and light brown (5YR 6/4) and yellowish gray ( $5 Y 8 / 1)$; firmly to well cemented; structureless and thin bedded; slabby splitting; weathers to form prominent ledge. This unit forms the only prominent ledge in the Chinle Formation

Total red siltstone member
Feet Chinle Formation-Continued Ocher siltstone member:

3. Silty claystone (50 percent) and clayey siltstone to siltstone (50 percent). Silty claystone, moderate yellowish brown $(10 Y R 5 / 4)$, grayish orange $(10 Y R 7 / 4)$, pale yellowish orange $(10 Y R 8 / 6)$ to dark yellowish orange $(10 Y R$ 6/6), minor light-greenishgray $(5 G Y 8 / 1)$ and yellowish-gray $(5 Y 8 / 1)$ mottling; weathering same colors; composed of gray oolitic structures; firmly cemented, calcareous; structureless. Numerous silty lime nodules as much as $3 \mathrm{in}$. in diameter occur in upper part. The silty claystone forms a conspicuous ocherous band near base of Chinle Formation. Clayey siltstone to siltstone, pale reddish brown $(10 R 5 / 4)$ to light brown $(5 Y R 6 / 4)$, weathering same colors; siltstone contains common coarse silt grains of amber-stained quartz; firmly cemented, very calcareous; structureless. Unit as a whole weathers to form smooth gentle slope

Total ocher siltstone member

Gartra Member:

2. Sandstone to pebble conglomerate, white $(N 9)$, very light gray $(N 8)$, yellowish gray (5Y 8/1), light greenish gray $(5 G Y 8 / 1)$, light brown $(5 Y R$ $6 / 4)$, and various shades of gray depending on hydrocarbon content and various shades of yellow and brown because of iron-oxide staining, weathering same colors, very fine grained sandstone to pebble conglomerate, dominant coarse sand to granules; well to poorly sorted with better sorting in very fine to medium-grained sand; composed of subangular to well-rounded clear, milky, and amber-stained quartz, common to sparse feldspar, gray chert and black accessory mineral, and uncommon to sparse white mica; well to poorly cemented, noncalcareous to very calcareous; calcite and clay binding; very thin to very thick trough and planar sets of mediumand small-scale cross-laminae to thin crossbeds, common ripple laminae (parallel and cuspate types) in upper fourth of unit; platy to massive splitting; weathers to form cliff. Lower $28.5 \mathrm{ft}$ of unit is very limy very fine to medium-grained sandstone. Upper few feet of unit is similar to basal $28.5 \mathrm{ft}$ and contains abundant solid hydrocarbon. Pebbles are composed of subrounded and rounded varicolored quartz and chert with subordinate limestone and feldspar; the
Feet 
Chinle Formation-Continued

Gartra Member-Continued

limestone and chert pebbles are as much as $2 \frac{1}{2} \mathrm{in}$. in diameter, whereas maximum diameter for the quartz and feldspar is about half as much. The granule and pebble conglomerate is best developed in middle part of unit. Coarser grains are localized along bedding planes and commonly are imbricated. Many pebbles are disk shaped. Three silicified logs were noted in basal part of unit near line of section. Upper contact not well exposed

Unconformity.

Moenkopi Formation:

1. Siltstone, greenish gray, weathers to form crusty-surfaced slope. About 50 ft exposed ..Unmeasured

Base of section; base of good exposure.

\section{C-14a. STONER SECTION A}

Measured on northwest side of Dolores River canyon, starting at point about 8.0 miles by road up canyon from Stoner, Colo. Line of section mostly northwest. Sec. 4, T. 38 N., R. 12 W., NMPM, Montezuma County

[Measured by J. H. Stewart and R. F. Wilson, August 1955]

Top of section; not top of exposure. Top of section is about $3 / 4$ mile N. $20^{\circ} \mathrm{W}$. of ranch on south side of Dolores River.

Entrada Sandstone:

12. Sandstone, pale reddish brown $(10 R$ $5 / 4)$ and light brown (5YR 6/4), weathering grayish orange $(10 Y R$ $7 / 4)$, very fine grained, from 1 to 5 percent fine to coarse rounded reddish-stained quartz grains, fair sorted; composed of subrounded reddish-stained quartz and sparse black accessory mineral; firmly to well cemented, calcareous; stratification obscure in places, but appears to be thin to thick trough sets of smallto medium-scale cross-laminae; massive splitting; weathers to form vertical cliff. Only basal $20 \mathrm{ft}$ of unit examined

Unmeasured

Dolores Formation:

Upper member :

11. Sandy siltstone to silty sandstone, pale reddish brown $(10 R 5 / 4)$ and minor light brown (10YR 6/4), weathering same colors, grades from very fine grained sandy siltstone to silty very fine grained sandstone, well sorted; firmly to well cemented, calcareous; composed of horizontal laminae to very thick beds, rare horizontal beds have waviness with amplitude of 3 in., possibly basal $10 \mathrm{ft}$ of unit contains minor cross-strata; top $23 \mathrm{ft}$ of
Feet Dolores Formation-Continued

Upper member-Continued

unit contains rare to abundant fine to coarse rounded reddish-stained quartz grains. A few of these grains were found below top $23 \mathrm{ft}$ of unit; thus these grains do not appear to be a valid basis for differentiating Dolores from Entrada Formation in this area. Top of the Dolores Formation placed at the top of the highest siltstone. The Entrada contains more fine to coarse grains than the top part of the Dolores. In addition, the Entrada appears to be entirely cross stratified, although mostly of small-scale types near the base, whereas the Dolores is dominantly horizontally stratified..

10. Silty sandstone to siltstone, grades upward from silty sandstone similar to that in the underlying unit, to siltstone. Siltstone, pale reddish brown (10R 5/4), weathering same color; sparse fine-grained accessory white mica; firmly cemented, calcareous; stratification concealed. Unit as whole weathers to form steep rubble-covered slope. Parts of unit poorly exposed....

9. Silty sandstone, same as unit 7 . Weathers to form ledge along line of section, but is covered away from section

8. Covered, weathers to form steep slope..

7. Sandstone, light brown (5YR 6/4), weathering same color, very fine grained, silty, well sorted; composed of subrounded reddish-stained quartz and common black accessory mineral; firmly to well cemented, calcareous; composed of well-developed laminae that in places are horizontal, but in other places are inclined; laminae have a slight waviness that in places suggests ripple lamination; massive splitting. This splitting makes stratification difficult to see. Unit weathers to form ledge

Total of upper member exposed ....

6. Covered. Unit measured along an approximate $\mathrm{N}$. $40^{\circ} \mathrm{W}$. line for about $2,000 \mathrm{ft}$. Unit measured across a prominent gully from 100 to $200 \mathrm{ft}$ deep. Thickness of unit could be in error if section crossed concealed fault; however, no evidence of faulting was seen

Middle member:

5. Very poorly exposed claystone to siltstone, grayish red $(5 R 4 / 2$ and $10 R$ $4 / 2)$, weathering grayish red $(5 R$ $4 / 2)$, siltstone contains sparse to common accessory white mica; stratification concealed; weathers to form steep slope; lithologic types in unit determined from poor exposures and from surface rubble
Feet 
Dolores Formation-Continued

Middle member-Continued

4. Sandy siltstone to sandstone, pale red $(5 R 6 / 2)$ and minor greenish gray ( $5 G Y 6 / 1)$, weathering pale red $(5 R 6 / 2)$, grades from very fine grained sandy siltstone to very fine grained sandstone; fair sorted, composed of subangular quartz grains and about 2 percent dark and green mica; firmly to well cemented, calcareous; horizontally laminated to very thin bedded, and minor thin trough sets of medium-scale crossstrata, top $2 \mathrm{ft}$ composed of cuspatetype ripple laminae; weathers to form ledge along line of section, but covered in most places in local area. Unit contains thin bed of limestone granule conglomerate $4 \mathrm{ft}$ above base of unit. Limestone granule conglomerate, greenish gray (5GY 6/1), composed of rounded very coarse grains to pebbles of gray limestone in a limy silt matrix; well cemented, calcareous; structureless

3. Mostly covered. Some poor exposures indicate that unit is composed of siltstone and sparse sandstone. Siltstone and sandstone, light greenish gray $(5 G Y 8 / 1)$ and greenish gray (5GY $6 / 1)$, and minor grayish red $(5 R$ $4 / 2$ ), siltstone grading to very fine grained sandstone similar to that in underlying unit; firmly to well cemented, calcareous; horizontally laminated, cuspate-type ripple lamination and probably rare structureless parts; weathers to form steep soil and rubble-covered slope. A few beds of limestone granule conglomerate the same as that in underlying unit are present in lower half of unit; one bone fragment noted in a conglomerate bed

Total of middle member exposed....

Lower member:

2. Sandstone and limestone granule conglomerate. Sandstone, light greenish gray $(5 G Y 8 / 1)$ to greenish gray $(5 G Y 6 / 1)$, grayish red $(5 R 4 / 2)$ in top $5 \mathrm{ft}$, weathering light olive gray $(5 Y 6 / 1)$, very fine grained, fair sorted; composed of subangular clear quartz and about 2 percent white and light-green mica; poorly to firmly cemented, calcareous; horizontally laminated to thin bedded, sparse thin sets of ripple laminae, cuspate type. Thin to thick trough sets of dominantly low-angle medium- to large-scale cross-strata form basal 23 $\mathrm{ft}$ and are common in top $16 \mathrm{ft}$ of unit. Sandstone is platy splitting in
Feet

Dolores Formation-Continued

Lower member-Continued

many parts of unit. Limestone granule conglomerate, same fresh and weathering colors as sandstone; granules to very coarse grains of gray limestone; matrix of limy sand which is same as that in sandstone part of unit. Conglomerate is well cemented, calcareous; and is present as thin to very thick structureless lenses interstratified with rest of unit. Limestone conglomerate forms about 40 percent of basal $23 \mathrm{ft}$ of unit and is present rarely in rest of unit. Limestone conglomerate in basal 23 $\mathrm{ft}$ contains rare granules and pebbles as large as 2 in. in diameter of tan siltstone. Unit as whole weathers to form a vertical cliff. This unit occurs extensively in the Stoner area; elsewhere in the Stoner area contains pebbles to granules of feldspar, quartz, and possibly some granite. Unit along line of section and elsewhere in area contains sparse to abundant carbonaceous material as flakes and as carbonized stems in the sandstone

Total of lower member

Total of Dolores Formation

Cutler Formation:

1. Silty sandstone, grayish red $(5 R 4 / 2)$ grayish blue $(5 P B 5 / 2)$, and yellowish gray $(5 Y 8 / 1)$, colors mottled, weathering same colors, fine to medium grained, poorly sorted; composed of subangular milky quartz and pink feldspar; poorly cemented, clay and silt binding; structureless, large-scale low-angle cross-strata noted in places; weathers to form steep slope extending from road to ledge-forming unit at the base of the Dolores Formation, about $30 \mathrm{ft}$ of the unit is exposed Unmeasured

Base of section; base of exposure. Base of section at point about 8.0 miles by road east of Stoner. Section starts at point where basal ledge of Dolores is well exposed along river and at road level. Section starts at point $50 \mathrm{ft}$ west of prominent fault.

\section{C-14b. STONER SECTION B}

-Measured on northwest side of Dolores River canyon at point about 5.3 miles by road up canyon from Stoner, Colo. Line of section is about N. $5^{\circ}$ W. Sec. $1, T .38$ N., R. 13 W., NMPM, Montezuma County

[Measured by J. H. Stewart and R. F. Wilson, August 1955]

Top of section; top of exposure.

Entrada Sandstone (incomplete) :

10. Sandstone, very pale orange $(10 Y R$ $8 / 2)$, light brown $(5 Y R 6 / 4)$ and pale reddish brown $(10 R 5 / 4)$, weath-
Feet

89.6

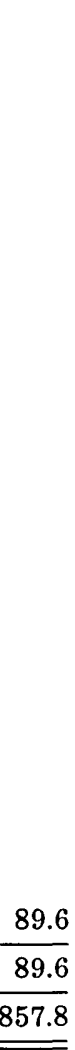


Entrada Sandstone (incomplete)-Continued ering same colors, very fine to fine grained, fair to well sorted; composed of subangular to subrounded clear quartz and abundant black accessory mineral; poorly to firmly cemented, calcareous; horizontally laminated to very thin bedded, medium-scale crossstratification is commonly present above basal $34 \mathrm{ft}$; massive splitting, weathers to form vertical cliff. Parts of unit contain from 1 to 5 percent medium to coarse rounded frosted reddish-stained quartz. These medium to coarse grains occur disseminated in the sandstone and concentrated along stratification planes. Above basal $34 \mathrm{ft}$ unit is entirely very pale orange $(10 Y R 8 / 2)$. Top $20 \mathrm{ft}$ of unit is poorly exposed and slabby splitting

Total of incomplete Entrada Sandstone

Dolores Formation (incomplete):

Upper member (incomplete):

9. Siltstone, pale reddish brown $(10 R$ $5 / 4)$ and minor light brown (5YR $6 / 4$ ), weathering same colors; firmly to well cemented, calcareous; structureless and common horizontally laminated parts; weathers to form steep ledgy slope. From a distance unit has distinct horizontally stratified appearance. Unit from 31.6 to $36.5 \mathrm{ft}$ is a silty very fine grained sandstone similar to that in underlying unit. This silty sandstone appears to be structureless and contains 1 to 5 percent fine to coarse sand grains similar to those in underlying unit. Silty sandstone has common light-greenish-gray (5GY 8/1) mottling along top and bottom. Top $10 \mathrm{ft}$ of unit have about 5 percent rounded frosted or etched milky and reddish-stained fine to very coarse quartz grains. The very coarse grains are angular

8. Silty sandstone, light brown $(5 Y R 6 / 4)$, weathering same color, very fine grained, basal half of unit contains from 1 to 10 percent rounded fine to coarse grains of clear reddish-stained and gray quartz, fair to well sorted; composed of subangular to subrounded clear and reddish-stained quartz and common black accessory mineral; firmly cemented, calcareous; horizontally laminated to very thin bedded, in places laminae and beds have waviness with amplitude of 3 in., laterally to line of section basal 2 $\mathrm{ft}$ of unit exhibits thin trough sets of small- to medium-scale low-angle \begin{tabular}{l} 
Feet \\
$93+$ \\
$93+$ \\
\hline
\end{tabular}

Dolores Formation (incomplete)-Continued Upper member (incomplete)-Continued cross-stratification; massive splitting; weathers to form vertical cliff. The fine to coarse grains and type of cross-stratification suggest that this unit may be closely related to the Wingate Sandstone. Possibly it is a tongue of the Wingate in the Dolores Formation

7. Sandy siltstone, same as unit 5, except it is horizontally laminated in basal $5 \mathrm{ft}$ and does not contain limestone nodules. Unit from 12.6 to $33.6 \mathrm{ft}$ is silty sandstone or sandy siltstone similar to unit 4 and weathers to form ledge. Rest of unit weathers to form steep slope

6. Silty sandstone, same as unit 4 except horizontally laminated and platy splitting in lower half. Upper half of unit appears structureless in places, but probably has concealed horizontal laminations. Unit as a whole weathers to form steep ledgy slope and lateral to line of section weathers to form a vertical cliff in places.

27.0

5. Siltstone to sandy siltstone, grayish red $(10 R \quad 4 / 2)$ and light brown $(5 Y R$ $6 / 4)$, weathering same colors, sandy (very fine grained) in parts; firmly to well cemented, calcareous; structureless; weathers to form steep slope. Unit contains a few gray limestone nodules as large as $3 \frac{1}{8}$ in. in diameter

4. Silty sandstone, light brown (5YR 6/4), weathering same color, silty, very fine grained, well sorted; composed of subrounded reddish-stained quartz and common black accessory mineral; firmly cemented, calcareous, structureless; weathers to form ledge........

3. Sandy siltstone, pale reddish brown (10R 5/4), weathering same color, sandy (very fine grained) in most parts but coarse siltstone in some parts; firmly cemented, calcareous; structureless, with common (15 percent) horizontally laminated parts; weathers to form steep slope. Unit contains a few layers that contain grayish limy nodules the size of granules

2. Silty sandstone, light brown (5YR 6/4), weathering same color, silty very fine grained, well sorted; composed of subrounded reddish-stained quartz and common black accessory mineral; well cemented, calcareous; horizontally laminated; laminae have indistinct waviness that may represent low-amplitude ripples, faint suggestion of low-angle large-scale cross-stratification; massive splitting; weathers 
Dolores Formation (incomplete)-Continued

Upper member (incomplete)-Continued to form most conspicuous ledge in Dolores Formation. This unit is the same as unit 7 in Stoner section A

1. Siltstone to sandy siltstone, grayish red $(10 R 4 / 2)$, pale reddish brown $(10 R$ $5 / 4)$ and light brown $(5 Y R \quad 6 / 4)$, weathering same colors; firmly cemented, calcareous; structureless, minor sets of horizontally laminated siltstone and possibly a few sets of cross-stratified rock; weathers to form a steep slope containing some thick to very thick ledges. The coarser siltstone contains a minor amount of very fine grained sand and in places may grade to silty very fine grained sandstone. This coarse siltstone comprises about 20 percent of the unit, and is light brown and horizontally laminated; it weathers to form the ledges in the unit. Siltstone contains a few limestone pebbles and limestone concretions with brecciated interiors. The angular fragments within the concretions are bordered with crystalline calcite. The limestone pebble conglomerate is not common

Total of incomplete upper member

Total of incomplete Dolores Formation

Base of section; base of exposure. Base of section at point about 5.3 miles up road from Stoner, about 2.8 miles down road from Stoner section A.

\section{C-15. PARADOX VALLEY}

Measured on a point to the south of the Dolores River on the northeast side of Paradox Valley. Section at junction of the south face of the Dolores River canyon with the northeast face of Paradox Valley, north-central part sec. 10, T. 47 N., R. 18 W., NMPM, Montrose County

[Measured by J. H. Stewart, E. M. Shoemaker, H. F. Albee, D. A. McManus, August 1954]

Top of section; top of accessible exposure.

Wingate Sandstone:

24. Sandstone, light brown $(5 Y R 6 / 4)$ to pale reddish brown $(10 R 5 / 4)$, weathering same colors, very fine grained, well sorted; composed of subrounded clear quartz and sparse black accessory mineral; firmly cemented, calcareous in parts; horizontally laminated and minor very thin to thin trough sets of small-scale cross-laminae; massive splitting; weathers to form vertical cliff. Only basal $10 \mathrm{ft}$ of unit examined. Contact between Chinle Formation and Wingate Sandstone appears to be gradational, but the Wingate appears to be somewhat coarser grained and to contain minor amounts of cross-stratification. Contact is marked by a grayish-yellow

42.2
Feet Wingate Sandstone-Continued

Chinle Formation:

(5Y 8/1) color in the basal few feet of the Wingate. The Wingate forms a continuous massive cliff whereas the underlying Chinle forms a fractured and less massive cliff. Commonly the base of the Wingate overhangs the Chinle Unmeasured

Red siltstone member:

23. Sandy siltstone to sandstone (50 percent) and siltstone (50 percent). Sandy siltstone to sandstone, light brown $(5 Y R 6 / 4)$, weathering same color, very fine grained, well sorted; firmly cemented, noncalcareous; horizontally laminated to thick bedded, massive splitting. Sandy siltstone to sandstone is present as thin to 20 ft-thick sets interstratified with siltstone. Siltstone, pale reddish brown $(10 R 5 / 4)$, weathering same color; rare very fine grained accessory white mica; well cemented, noncalcareous; structureless. Unit as whole weathers to form ledge and slope topography with ledges on sandy siltstone to sandstone sets and slopes on siltstone sets. On the cliffs to the northwest of the Dolores River, this unit in most places weathers to form a vertical cliff continuous with that of the Wingate Sandstone. Units 21, 22, and 23 contain lithologic rock types similar to those in the overlying Wingate Sandstone

22. Siltstone, pale reddish brown $(10 R 5 / 4)$ and sparse pale red $(10 R 6 / 2)$ and light greenish gray $(5 G Y \quad 8 / 1)$, light greenish gray occurs as mottles, sandy (very fine grained) in parts; sparse very fine grained accessory white mica; poorly cemented, calcareous; stratification concealed; weathers to form a steep loose slope.

21. Sandy siltstone, pale reddish brown $(10 R 5 / 4)$, and minor light brown (5YR 6/4), weathering light brown (5YR 6/4), very fine grained sandy; sparse fine-grained accessory white mica; well cemented, calcareous; horizontally very thin to thin bedded; bedding planes very even; weathers to form minor ledge

20. Siltstone (70 percent) and sandy siltstone (30 percent). Siltstone, grayish red $(10 R 4 / 2)$ and pale reddish brown $(10 R 5 / 4)$, weathering same colors; firmly cemented, calcareous; structureless; weathers to form slope. Sandy siltstone, pale red $(10 R 6 / 2)$, pale reddish brown $(10 R 5 / 4)$ and light greenish gray ( $5 G Y 8 / 1)$, weathering same colors, sandy (very fine grained); well cemented, calcareous. 
Chinle Formation-Continued

Red siltstone member-Continued

Sandy siltstone in basal $2 \mathrm{ft}$ contains very low angle cross-strata. Rest of the sandy siltstone is thinly horizontally bedded. Sandy siltstone in basal $2 \mathrm{ft}$ contains abundant silt flakes and galls. Unit is highly variable along outcrop. To west of line of section, sandy siltstone becomes dominant lithologic type

19. Sandy siltstone (50 percent) and siltstone (50 percent). Sandy siltstone, pale reddish brown $(10 R 5 / 4)$, weathering same color, sandy (very fine grained); common fine- to mediumgrained accessory white and dark mica; firmly cemented, calcareous; composed of horizontal laminae to very thin beds and thin planar sets of small-scale cross-laminae; commonly platy to flaggy splitting. Sandy siltstone occurs as thin to thick sets interstratified with the siltstone. The sandy siltstone is found in the lower two-thirds of the unit only. Siltstone, grayish red (10R $4 / 2$ and subordinate $5 R 4 / 2$ ), weathering same colors, sparse very fine to fine-grained accessory white mica; firmly cemented, slightly calcareous; structureless. Unit as whole weathers to form steep slope with many small ledges

18. Sandstone (80 percent) and siltstone (20 percent). Sandstone, pale red ( $5 R$ $6 / 2)$ and sparse light greenish gray $(5 G Y 8 / 1)$ and yellowish gray (5Y $8 / 1)$, weathering pale red $(10 R 6 / 2)$, very fine grained, well sorted; contains common coarse-grained white and dark mica; firmly cemented, calcareous; composed of ripple laminae (cuspate type); one example of parallel type noted, and subordinate thin trough sets of low-angle mediumscale cross-laminae. Sandstone contains common intervals containing abundant grayish-red $(10 R 4 / 2)$ siltstone pellets. Siltstone, grayish red $(5 R \quad 4 / 2)$ and pale reddish brown $(10 R 5 / 4)$, weathering same colors; common fine-grained accessory white and dark mica; firmly cemented, noncalcareous; structureless. Siltstone is present as very thin to very thick lenses interstratified with the sandstone. The content of siltstone is highly variable along the exposure. Unit as whole weathers to form most conspicuous ledge in Chinle Formation. Top of unit placed at topographic break between ledgy layers below and slope-forming layers above,
Feet Chinle Formation-Continued Feet Red siltstone member-Continued which also marks horizon where siltstone becomes dominant upward ......

17. Siltstone, same as unit 15 except for one thick interval of grayish red $(5 R 4 / 2)$ siltstone and for several thick intervals of moderate yellowish brown $(10 Y R$ 5/4) siltstone. Unit contains one horizontally very thinly bedded and ripple-laminated siltstone set about $10 \mathrm{ft}$ above base. Unit contains sparse ( 2 percent) very thin to thin beds of siltstone containing about 10 to 40 percent rounded medium to very coarse grains and granules of siltstone

16. Siltstone, pale reddish brown $(10 R 5 / 4)$ to light brown (5YR 6/4), weathering same colors, very fine grained sandy in parts; well cemented, calcareous; composed of thin to thick trough sets of low-angle medium-scale crossstrata, sparse horizontal very thin beds; weathers to form fairly conspicuous ledge. Unit contains one thin lens of siltstone-grain sandstone composed of coarse to very coarse grains and minor granules of a reddish siltstone in a silt matrix

15. Siltstone, same as unit 13 except contains common thin beds and mottled areas of light greenish gray ( $5 G Y$ $8 / 1)$ and grayish orange $(10 Y R 7 / 4)$. Unit contains common thin to thick horizontal beds. One thin bed about $15 \mathrm{ft}$ above base of unit contains abundant worm borings (?)

14. Limestone to limestone-grain sandstone (calcarenite), pale red $(10 R 6 / 2)$ and minor light gray $(N \quad 7)$ and light greenish gray $(5 G Y 8 / 1)$, weathers light brown $(5 Y R 6 / 4)$. Unit ranges in composition from dense limestone containing abundant remnants of pale-reddish-brown $(10 R 5 / 4)$ siltstone to sandstone composed of coarse grains to pebbles of limestone and siltstone in a lime matrix; well cemented; structureless in lower $\mathbf{5}$ ft and crudely horizontally thinly bedded in top $1.2 \mathrm{ft}$; weathers to form nodular-weathering ledge. This unit contains textures difficult to interpret. Basal half of unit gives impression of having once been siltstone and then of being saturated with lime so that only angular granule- and pebble-sized remnants of the siltstone remain. The top half of the unit, however, is composed of grains that appear to be detrital in origin, although probably locally derived. No definite contact can be
10.2

70.8 
Chinle Formation-Continued

Red siltstone member-Continued

located between these two textures, as one appears to grade upward into the other

13. Siltstone, pale reddish brown $(10 R$ $5 / 4)$ and grayish red $(10 R \quad 4 / 2)$, weathers same colors; firmly cemented, slightly calcareous; stratification mostly concealed, sparse exposures indicate horizontal stratification planes and minor horizontal and ripple laminae; weathers to form steep loose slope. One thin bed of grayish-orange $(10 Y R \quad 7 / 4)$ siltstone seen near top of unit

Basal sandstone unit:

12. Sandstone and siltstone. Sandstone, pale red $(10 R 6 / 2)$, grayish red $(10 R 4 / 2)$ and minor light greenish gray $(5 G Y 8 / 1)$, weathers light brown (5YR 6/4); consists of all gradations from sandstone composed of fine to medium grains of quartz and feldspar to sandstone composed dominantly of reddish very coarse grains and granules of siltstone and very fine grained sandstone, fair to poorly sorted; well cemented, interstitial spaces appear to be filled with calcite although rock effervesces only very slightly in acid; composed of very thin to thin irregular wavy horizontal beds and minor very thin to thin planar sets of small-scale cross-laminae. Bedding planes are bounded by silt film. Top $1.0 \mathrm{ft}$ of unit locally is sandstone composed of medium to very coarse grains and minor granules of limestone and siltstone in a lime matrix. Siltstone, grayish red $(5 R 4 / 2)$, weathers same; very fine grained sand in parts; well cemented, noncalcareous; structureless. Siltstone is present from 1.3 to $3.1 \mathrm{ft}$ above base of unit. Unit as whole weathers to form ledge

11. Sandstone, pale red purple $(5 R P 6 / 2)$, light greenish gray $(5 G Y 8 / 1)$ and uncommon grayish red purple (5RP $4 / 2)$ and white $(N 9)$, weathers same colors, medium to very coarse grained, common. interstitial silt, fair sorted; composed of angular to subangular milky grains; poorly cemented, slightly calcareous, generally has no cohesion; stratification only rarely exposed but where seen is composed of horizontal laminae to thin beds and minor thin planar sets of small-scale cross-laminae; weathers to form steep rubble-covered slope. Top $1.4 \mathrm{ft}$ of unit is a grayish-redpurple $(5 R P 4 / 2)$ siltstone containing minor medium to very coarse grains.
Feet

Chinle Formation-Continued

Red siltstone member-Continued

Basal sandstone unit-Continued

All except top $1.4 \mathrm{ft}$ of unit contains a few percent of quartz granules and pebbles

Total of basal sandstone unit ........

Total of red siltstone member

Total of Chinle Formation

Moenkopi Formation (incomplete) :

Sewemup Member:

10. Siltstone, grayish red $(10 R \quad 4 / 2)$ and minor pale reddish brown $(10 R 5 / 4)$, weathers same colors, common finegrained accessory light and dark mica; firmly cemented, noncalcareous; structureless to horizontally and ripple laminated; weathers to form steep rubble-covered slope. About 10 percent of unit is thin sets of siltstone that in places grade to very fine grained sandy siltstone. These sets are mostly pale reddish brown and ripple laminated. Unit from 88.6 to $93.0 \mathrm{ft}$ is sandstone. Sandstone, pale red $(5 R 6 / 2)$ and pale reddish brown $(10 R 5 / 4)$, weathers pale reddish brown $(10 R 5 / 4)$, very fine to fine grained; firmly cemented, slightly calcareous, horizontally laminated, minor thin planar sets of small-scale cross-laminae. This sandstone weathers to form minor ledge in middle of unit. Unit contains a similar sandstone from 12 to $9 \mathrm{ft}$ below top. Some of the finer grained grayishred siltstone beds are very thinly laminated and are markedly more fissile than siltstone in lower members. Uppermost 2 to $3 \mathrm{ft}$ of siltstone, mottled green gray, grayish red, and purple, is evidently an alteration zone immediately beneath the basal sandstone of the Chinle Formation ...........

Total of Sewemup Member

Total of incomplete Moenkopi Formation

Base of section; not base of exposure.

Units 1-9 described in Stewart, Poole, and Wilson (1972).

\section{C-16. OURAY}

Measured on east side of canyon of the Uncompahgre River about 6 miles north of Ouray, sec. $35, T .45 N ., R .8 W$., NMPM, Ouray County

[Measured by J. H. Stewart and R. F. Wilson, August 1955]

Top of section; top of exposure. Top of section is $\mathrm{N}$. $10^{\circ} \mathrm{E}$. of cemetery and N. $85^{\circ}$ E. of road with switchbacks on west side of canyon.

Wanakah Formation (incomplete) :

Pony Express Limestone Member (incomplete) :

5. Limestone, medium dark gray $(N 4)$, weathering same color, dense; well 
Wanakah Formation (incomplete)-Continued Pony Express Limestone Member-Continued cemented; horizontally laminated to very thinly bedded; weathers to form small ledge. Limestone gives fetid odor

Total of incomplete Pony Express

Limestone Member

Total of incomplete Wanakah

Formation

Entrada Sandstone:

4. Sandstone, grayish orange $(10 Y R 7 / 4)$ and very light gray $(N 8)$, weathering very pale orange $(10 Y R 8 / 2)$, fine grained, fair sorted; composed of subangular clear and milky quartz; poorly cemented, calcareous; stratification concealed in lower $20 \mathrm{ft}$, horizontally laminated in about next 40 ft (laminations in places have waviness with amplitude of as much as 3 in.), rest of unit is composed of very thin to very thick wedge-planar sets of high- and low-angle smallto medium-scale cross-laminae; massive splitting; weathers to form steep bare rock slope; sandstone contains a few percent of coarse to medium rounded quartz grains in some parts of unit. Top and bottom contacts sharp. Top $20 \mathrm{ft}$ of unit poorly exposed

Total of Entrada Sandstone

Dolores Formation:

3. Siltstone, grayish red $(10 R 4 / 2)$, rare light-greenish-gray (5GY 8/1) mottling; weathering pale reddish brown $(10 R 5 / 4)$, fine to coarse silt, basal 7 $\mathrm{ft}$ of unit is sandy (very fine grained) sparse very fine grained accessory white mica; firmly to well cemented, calcareous; horizontally thinly laminated to very thick bedded; weathers to form steep ledgy slope; ledge from 60.5 to $64.8 \mathrm{ft}$ contains minor thin trough sets of small- to medium-scale low-angle cross-laminae, and a few casts of mud cracks; at many places in unit, the siltstone contains reddish limy nodules that range from a few millimeters to 1 centimeter in diameter; basal $7 \mathrm{ft}$ of unit contains rare ripple laminations of the cuspate type

Basal sandstone unit:

2. Sandstone, conglomeratic sandstone to conglomerate, and siltstone. Sandstone, bluish white $(5 B 9 / 1)$, minor light greenish gray (5GY 8/1), sparse grayish red $(5 R 4 / 2)$, weathering yellowish gray (5Y 8/1), medium to coarse grained, poorly to fair sorted; composed of subangular
Feet Dolores Formation-Continued Feet Basal sandstone unit-Continued milky quartz and minor pink feldspar, rare dark-green and white accessory mica; well cemented, calcareous, possibly some siliceous cement; stratification mostly concealed or structureless, common thin to very thin planar sets of small-scale low-angle cross-laminae. Conglomeratic sandstone to conglomerate, same as sandstone except is structureless and contains granules to cobbles of angular to rounded limestone, chert, quartz, feldspar, granite, gneiss, schist, slate, and greenstone. Conglomeratic sandstone grades into sandstone. Siltstone, grayish red $(5 R$ $4 / 2$ ), weathering same color, firmly cemented, calcareous; structureless and horizontally laminated. The sandstone and conglomerate parts of unit weather to form ledges and the siltstone parts weather to form slopes. Detailed lithologic character of unit is as follows: 0.0 to $6.5 \mathrm{ft}$, conglomerate to conglomeratic sandstone; 6.5 to $11.5 \mathrm{ft}$, siltstone; 11.5 to $14.0 \mathrm{ft}$, conglomeratic sandstone; 14.0 to 19.5 $\mathrm{ft}$, sandstone; 19.5 to $23.5 \mathrm{ft}$, siltstone; 23.5 to $27.0 \mathrm{ft}$, conglomeratic sandstone to sandstone; 27.0 to 29.0 $\mathrm{ft}$, sandstone; 29.0 to $32.5 \mathrm{ft}$, siltstone and minor sandstone; 32.5 to $36.5 \mathrm{ft}$, sandstone. Maximum cobble size is 11 in. Granules and pebbles in upper half of unit are dominantly quartz. About 20 percent of top $4 \mathrm{ft}$ of unit is composed of very coarse grains to granules of reddish siltstone. Lateral to line of section amount and position of siltstone, sandstone, and conglomerate vary considerably. This unit is placed in the Dolores Formation, as it is similar in many respects to the basal unit of the Dolores at Placerville and because it lies immediately below undoubtable Dolores. This unit marks an abrupt change in lithology vertically. The base of the unit is sharp, and the basal strata fills scours cut as deep as 3 in. into the underlying unit. The unit lies directly on rocks of undoubtable Cutler Formation. The granules and cobbles in this unit are unique for the Dolores and are probably related to the truncation of the Paleozoic rock by the Dolores in the Ouray area as has been described by Cross and Howe (1905a)

Total of basal sandstone unit 
Cutler Formation:

1. Siltstone (90 percent) and sandstone (10 percent). Siltstone, pale reddish brown $(10 R 5 / 4)$ and grayish red $(5 R 4 / 2)$, weathering pale reddish brown $(10 R 5 / 4)$, sandy (very fine grained) in parts; abundant white and dark mica along laminae; well cemented, calcareous; horizontally laminated to very thinly bedded, sparse thin trough sets of smallscale cross-laminae. Sandstone, grayish red $(5 R 4 / 2)$, weathering same color, fine to coarse grained, poorly to fair sorted; composed of subangular reddish-stained quartz and feldspar, 1 to 2 percent of darkgreen mica; firmly cemented, calcareous, some clay binding; horizontally laminated and thin trough sets of small- to medium-scale lowangle cross-laminae. Sandstone is present as very thin to very thick sets interstratified with the siltstone. Unit as whole weathers to form steep ledgy slope Unmeasured

Base of section; not base of exposure. Base of section N. $5^{\circ} \mathrm{W}$. of cemetery and N. $85^{\circ}$ E. of switchback road up west side of canyon.

\section{C-17. ASPEN}

Begins $N .40^{\circ} W$. from first road bridge across Maroon Creek and about N. $33^{\circ}$ E. from Pyramid Peak. Line of section trends $N .22^{\circ} E$. Measured about 2 miles southwest of Aspen, Colo., lat $39^{\circ} 10^{\prime} 15^{\prime \prime}$ N., long $106^{\circ} 51^{\prime} 45^{\prime \prime} W$., east-central part of sec. $15, T .10$ S., R. $85 \mathrm{~W}$. , Pitkin County

[Measured by F. G. Poole and F. H. Spence, September 1956]

Top of section; not top of exposure.

Entrada Sandstone:

7. Sandstone, grayish pink (5R 8/2), grayish orange pink $(10 R 8 / 2)$, pale red $(10 R 6 / 2)$, pale pink $(5 R P 8 / 2)$, and grayish orange pink $(5 Y R 7 / 2)$, weathering same colors and pale brown $(5 Y R 5 / 2)$ to pale yellowish brown $(10 Y R 6 / 2)$, very fine to coarse grained, fair to well sorted; composed of rounded to well-rounded clear, milky, and smoky quartz and abundant white (clay or badly weathered chert) and uncommon black accessory minerals; firmly to well cemented, calcareous, siliceous, and ferruginous cement; thin to thick planar and trough sets of small- and medium-scale (sparse large-scale) sets of cross-laminae to thin crossbeds; unit contains common horizontal beds; slabby to massive splitting; weathers to form vertical cliff. Upper contact appears gradational with overlying Curtis Formation or Morrison Formation. Most coarse grains occur as "berries" localized along
Entrada Sandstone-Continued

cross-stratum planes and scattered randomly in a finer matrix. The Entrada Sandstone appears to be dipping about $5^{\circ}$ less than the underlying Chinle Formation, which suggests an angular unconformity ...........

Total of Entrada Sandstone

Chinle Formation:

Red siltstone member:

6. Siltstone to very fine grained sandstone, dark reddish brown $(10 R 3 / 4)$, grayish red $(10 R 4 / 2)$, pale reddish brown $(10 R 5 / 4)$, and pale red $(10 R$ $6 / 2$ ), minor amounts of light-greenish-gray $(5 G Y \quad 8 / 1$ and $5 G \quad 8 / 1)$, pale-red $(5 R 6 / 2)$, and pale-redpurple (5RP 6/2) mottling, minor amounts of yellowish-gray ( $5 Y 7 / 2)$, pale-yellowish-brown $(10 Y R \quad 6 / 2)$, grayish-orange $(10 Y R \quad 7 / 4)$, and grayish-orange-pink $(5 Y R \quad 7 / 2)$ discoloration in upper part of unit, weathering same colors, fine to coarse silt and very fine sand, well sorted; coarse silt and very fine sand is composed of rounded to well-rounded clear and amber-stained quartz and minor white mica; firmly to well cemented, very calcareous; structureless with minor amounts of horizontal laminae to thick beds and ripple laminae; structureless part breaks into sharp angular fragments, the layered part has platy, shaly, or blocky splitting. Unit weathers to form steep rubble-covered slope with more resistant beds weathering to rough ledges and vertical cliffs. Silty limestone masses and pebbles are scattered throughout unit. Upper part of unit contains numerous vertical and horizontal slightly sinuous cylindrical structures similar to those described in unit 5. Upper contact is well defined, sharp, and gently undulatory and appears unconformable

5. Pebble conglomerate (60 percent) and limy siltstone to very fine grained sandstone (40 percent). Pebble conglomerate, very light gray $(N 8)$ to medium dark gray $(N 4)$, grayish red $(10 R 4 / 2)$, and pale red $(5 R 6 / 2)$, weathering same colors with dominant pale red $(10 R 6 / 2)$, composed of rounded to well-rounded coarse sand to pebbles of silty limestone and limy siltstone set in a fine to coarse silt matrix; pebbles as much as 1 in. in maximum diameter; very calcareous; lenticular thin to thick beds; slabby to blocky splitting. Pebble conglomerate constitutes lower part of unit and appears to channel into under- 
Chinle Formation-Continued

Red siltstone member-Continued

lying unit. Limy siltstone to very fine grained sandstone, light brown $(5 Y R 6 / 4)$, grayish red $(5 R 4 / 2$ and $10 R 4 / 2)$, pale red $(5 R 6 / 2)$, and minor light gray $(N 7)$, weathering same colors and pale reddish brown $(10 R 5 / 4)$; very fine sand is composed of rounded to well-rounded clear and amber-stained quartz; firmly to well cemented, very calcareous; horizontally laminated to thin bedded with common ripple laminae and very thin to thin trough and planar sets of small-scale cross-laminae; platy shaly, to slabby splitting. Limy siltstone to very fine grained sandstone constitutes upper part of unit and is present as minor very thin to thin beds in lower part of unit. Numerous clayey siltstone films on bedding planes and in mud crack fillings. Unit as whole weathers to form prominent rough ledge. Upper contact is gradational with overlying unit. The conglomerate part of this unit is the only well-developed pebble conglomerate composed of silty limestone and limy siltstone clasts in this section

4. Limy siltstone, grayish red $(10 R 4 / 2)$, pale red $(5 R 6 / 2)$, pale reddish brown $(10 R 5 / 4)$, minor mottling of lightgreenish-gray $(5 G Y 8 / 1)$, pale-redpurple $(5 R P 6 / 2)$, and pale-red (5R 6/2 and $10 R 6 / 2$ ), uncommon pale brown $(5 Y R 5 / 2)$, olive gray (5Y 4/1), and light olive gray $(5 Y 6 / 1)$, silty limestone masses and pebbles, weathering same colors with dominant pale reddish brown $(10 R$ $5 / 4)$ to dark reddish brown (10R $3 / 4)$, fine to coarse silt; composed of rounded to well-rounded amberstained quartz; firmly to well cemented, very calcareous; structureless, about 1 percent of unit is either horizontally laminated to thin bedded, composed of very thin trough and planar sets of small-scale crosslaminae, or composed of ripple laminae. Unit as whole weathers to form steep rubble-covered slope with the better cemented siltstones forming ledges. Basal few feet of unit is not well exposed. Upper contact is conformable with overlying unit. Abundant silty limestone masses and pebbles scattered throughout unit. Locally these pebbly layers form conglomeratic beds. These conglomeratic beds constitute about 5 percent of unit and grade laterally and vertically into limy siltstones. Numerous verti-
Feet | Chinle Formation-Continued

Feet

Red siltstone member-Continued

cal cylindrical structures as much as 2 in. in diameter and a few feet long were noted in a few of the more limy beds

137.4

Total red siltstone member

$\overline{377.7}$

Mottled member:

3. Clayey and sandy siltstone, grayish red (5R $4 / 2$ and $10 R 4 / 2$ ), minor lightgreenish-gray $(5 G Y$ 8/1) mottling, weathering same colors and pale red $(5 R 6 / 2)$; sand grains composed of very fine to fine rounded clear and amber-stained quartz; some swelling(?) clays; firmly to poorly cemented, noncalcareous to slightly calcareous; appears structureless. Weathers to form smooth steep slope. Unit as whole is poorly exposed. Upper contact is not exposed..

Total mottled member

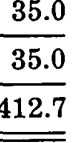

Unconformity.

State Bridge Formation:

2. Sandstone, light brown (5YR 6/4), weathering same color and darker shades, very fine to fine grained, well sorted; composed of subrounded to well-rounded clear and amberstained quartz, common white and dark-green mica and black accessory minerals; firmly to well cemented, slightly calcareous to very calcareous; horizontally laminated to very thick bedded, some very thin to thin trough and planar sets of small- and mediumscale cross-laminae to very thin crossbeds; platy to massive splitting. Unit weathers to form steep ledgy slope and vertical cliff. Upper contact is not exposed. Base is gradational with underlying conglomerate bed.

1. Sandstone, conglomerate, and siltstone interbedded, dark reddish brown $(10 R 3 / 4)$, grayish red $(10 R 4 / 2)$, pale reddish brown $(10 R 5 / 4)$, and moderate reddish brown $(10 R 4 / 6)$, weathering same colors with dominant pale reddish brown $(10 R 5 / 4)$. Sandstone composed of subangular to wellrounded clear, milky, smoky, and amber-stained quartz and abundant very fine to coarse-grained white mica; poorly to firmly cemented, calcareous. Unit composed of lenticular layers with very thin to thick trough and planar sets of small- and medium-scale cross-strata, with horizontal laminae, and with beds containing ripple laminae of parallel and cuspate types; some mud-crack fillings. Unit weathers to form steep 
State Bridge Formation-Continued

rubble-covered slope, ledgy slope, or vertical cliff. Cobbles are as much as 6 in. in maximum diameter and are composed mainly of subrounded to well-rounded igneous and metamorphic rocks indicative of Precambrian source rock Unmeasured

Total of incomplete State Bridge Formation

Base of section; not base of exposure.

\section{C-18. MEEKER (OAK RIDGE)}

Measured on north side of White River valley and north of Colorado State Highway 132 on $K / K$ Ranch. Line of section is approximately due north in secs. 14 and 23, T. 1 S., R. 93 W., 6th PM, Rio Blanco County

[Measured by F. G. Poole, L. G. Schultz, and C. Koteff, April, May, and August 1956

Top of section; not top of exposure. Section ends at base of Curtis Formation or Morrison Formation. Entrada Sandstone:

23. Sandstone, light brown $(5 Y R 6 / 4)$ to moderate orange pink $(5 Y R \quad 8 / 4)$, weathering same colors; very fine to fine grained, well sorted; composed of rounded to well-rounded clear and amber-stained quartz grains and common black accessory mineral; poorly to firmly cemented, calcareous; very thinly crossbedded, small- to largescale trough and planar sets, numerous horizontal very thin to thick beds near top of unit. Unit weathers to form steep slope with rounded ledges. Upper contact apears to be conformable with the overlying Curtis Formation or Morrison Formation...

Total of Entrada Sandstone

Glen Canyon Sandstone:

22. Sandstone, moderate orange pink $(10 R$ $7 / 4$ and $5 Y R 8 / 4)$, weathers same color, fine grained, well sorted; composed of subrounded to rounded clear and amber-stained quartz grains, common black accessory mineral; firmly cemented, calcareous; mediumto large-scale trough and planar sets of high-angle very thin to thick crossbeds; basal few feet contain some horizontally thinly laminated to laminated layers; several parallel asymmetrical ripple marks with very high ripple index (45-50) were noted on cross-strata planes. Unit weathers to form vertical cliff. Upper contact not exposed but placed at change in slope, in type of cross-stratification, and in nature of weathering. Separation of Glen Canyon Sandstone and Entrada Sandstone in section is, however, uncertain

$\frac{160.0}{160.0}$
Feet Unconformity.

Chinle Formation:

Red siltstone member:

21. Coarse siltstone to very fine sandstone, pale reddish brown $(10 R 5 / 4)$, weathering same colors; rare scattered fine and medium amber-stained quartz grains. Very fine grained sandstone, well sorted; composed of rounded to well-rounded amberstained quartz, firmly to well cemented, slightly calcareous; horizontally thin to thick bedded with minor small-scale planar sets of low-angle cross-laminae. Unit weathers to form prominent vertical cliff below Glen Canyon Sandstone. Upper contact is sharp, appears slightly undulatory, and is an unconformity....

20. Fine to coarse siltstone, dark reddish brown $(10 R 3 / 4)$, pale reddish brown $(10 R 5 / 4)$, and grayish red $(10 R$ $4 / 2)$, minor pale-red $(10 R 6 / 2)$. and light-greenish-gray $(5 G Y \quad 8 / 1$ and $5 G 8 / 1$ ) mottling, similar to fine and coarse siltstone in unit 18. Unit is virtually structureless except for minor small-scale trough sets of lowangle cross-laminae in a few of the more resistant beds. Unit weathers to form steep rubble-covered slope..........

19. Pebble conglomerate, moderate brown $(5 Y R 4 / 4)$, pale reddish brown $(10 R$ $5 / 4)$, light brown (5YR 5/6), grayish red $(10 R 4 / 2)$, and dusky yellowish brown $(10 Y R 2 / 2)$, weathering dark yellowish brown (10YR 4/2), pale yellowish brown (10YR 6/2), light olive gray (5Y 6/1), and grayish red $(10 R 4 / 2)$, rounded to well-rounded limestone and siltstone granules and pebbles as much as $2.0 \mathrm{in}$. in the maximum diameter set in limy siltstone matrix; fair sorted; well cemented, very calcareous; secondary calcite occurs as crust and as crystals on surface and along fractures. Only well-developed pebble conglomerate with clasts of limestone and siltstone noted in this section of the Chinle Formation. Unit weathers to form a ledge

18. Coarse siltstone (90 percent) and fine to clayey siltstone ( 10 percent $)$, moderate reddish brown $(10 R 4 / 6)$ to dark reddish brown $(10 R 3 / 4)$, weathering pale reddish brown (10R 5/4) and light greenish gray ( $5 G Y 8 / 1)$, well sorted; composed of subrounded amber-stained quartz grains, micaceous, firmly to well cemented, calcareous; structureless; scattered limestone and siltstone pebbles noted near top of unit. Coarse siltstone beds weather to form prominent
Feet 
Chinle Formation-Continued

Red siltstone member-Continued

ledges and the fine argillaceous siltstone beds weather to form intervening slopes

17. Clayey siltstone, dark reddish brown $(10 R 3 / 4)$ to grayish red $(10 R 4 / 2)$, weathers pale reddish brown $(10 R$ $5 / 4)$, common rounded coarse quartz grains, micaceous; firmly cemented, calcareous; abundant lime masses in resistant unit near middle of unit, weathers to form smooth steep slope..

16. Covered. Probably mostly dark-reddishbrown siltstone

Total red siltstone member

Mottled member:

15. Claystone, dark reddish brown $(10 R$ $3 / 4)$ to pale reddish brown $(10 R 5 / 4)$ with minor light greenish gray $(5 G$ $8 / 1)$, weathers grayish red $(10 R$ $4 / 2$ and $5 R \quad 4 / 2$ ) and grayish red purple (5RP 4/2), silty, calcareous to slightly calcareous. Unit as whole weathers to form smooth deeply weathered slope

14. Sandstone to siltstone, mottled pale red purple (5RP 6/2), grayish red purple $(5 R P 4 / 2)$, grayish purple $(5 P 4 / 2)$, pale blue $(5 P B 7 / 2)$, white $(N 9)$, and grayish yellow (5Y 8/4), weathers same colors. Sandstone is very fine to medium grained, silty, fair to poorly sorted; composed of subrounded clear and amber-stained quartz grains, common coarse to very coarse clear and amber-stained subrounded quartz grains, a few red and black mineral grains, most larger quartz grains seen were $2-3 \mathrm{~mm}$ in maximum diameter, sparse red chert grains as much as $6 \mathrm{~mm}$ in maximum diameter noted at top of unit; well cemented, calcareous, siliceous, especially near top; bedding poorly defined. Gray, yellow, brown, and red secondary (?) chert beds in upper 2-3 ft of unit, some of the chert has wavy laminae; chert beds average 3-5 in. in thickness but may be as much as $1 \mathrm{ft}$ thick. Unit weathers to form resistant ledge

13. Sandstone, mottled grayish red purple $(5 R P 4 / 2)$, grayish red $(5 R 4 / 2)$, grayish purple $(5 P 4 / 2)$, and very light gray $(N 8)$, weathers to lighter shades, very fine to very coarse grained, lower $2 \mathrm{ft}$ very silty, poorly sorted; composed of subangular to subrounded clear and amber-stained quartz grains, common subangular quartz grains as much as $3 \mathrm{~mm}$ in maximum diameter, micaceous; friable, noncalcareous to very slightly
Feet

Chinle Formation-Continued

Mottled member-Continued

calcareous; structureless, weathers to form smooth slope

Total of mottled member.

Total of Chinle Formation

Feet

30.0

Unconformity.

State Bridge Formation (incomplete) :

Upper member (incomplete) :

12. Siltstone (90 percent). and sandstone (10 percent). Siltstone, dark reddish brown $(10 R 3 / 4)$ and grayish red $(10 R 4 / 2)$, weathers pale red $(10 R$ $6 / 2$ ) and moderate reddish brown $(10 R 4 / 6)$, argillaceous, micaceous; firmly cemented; horizontally thinly laminated to very thin bedded. Sandstone, light greenish gray (5G $8 / 1$ and $5 G Y 8 / 1$ ), weathers to lighter shades, very fine to medium grained, fair sorted, composed of subrounded to rounded clear quartz with orange and black accessory minerals, abundant green and black mica; poorly cemented, calcareous, very thin bedded; unit as a whole weathers to form a smooth slope

Total of incomplete State Bridge

Formation

31.0

Base of section; not base of exposure.

Units 1-11 described in Stewart, Poole, and Wilson (1972).

\section{C-19. SAWPIT}

Measured on north side of San Miguel Canyon directly north of Sawpit, sec. 7, T. 43 N., R. 10 W., NMPM, San Miguel County

[Measured by J. H. Stewart, J. C. Wright, and J. S. Pomeroy, July 1955]

Top of section; top of well-exposed section. Top of Feet section N. $5^{\circ}$ E. of store at Sawpit.

Wanakah Formation (incomplete):

Pony Express Limestone Member:

23. Limestone, dark gray $(N 3)$, weathering same color or medium gray $(N$ $5)$, dense, wavy bedded in very lenticular units 1 to 6 in. thick, a minor part of the unit has thin laminae........

22. Transition interval, sandstone same as underlying unit interstratified with very limy siltstone. Sandstone strata are $3 / 4$ in. thick to rarely as much as 3 in. thick. Limy siltstone is dark gray $(N 3)$ to medium gray $(N 5)$, weathering same colors, thinly laminated in places, other parts structureless. Laminae are formed by alternating fine dark and coarse light material, all within siltstone range. Limy siltstone strata are irregular and range from 0 to $1 \mathrm{in}$. in thickness. These siltstone strata show partial 
Wanakah Formation (incomplete)-Continued

Pony Express Limestone Member-Continued disruption by later reworking. The unit caps cliff developed on the Entrada

Total of Pony Express Limestone Member

Total of incomplete Wanakah Formation

Entrada Sandstone:

21. Sandstone, same as unit 20 except that it contains horizontal laminae and weathers to form vertical cliff.

20. Sandstone, very pale orange (10YR $8 / 2$ ), weathering same color, very fine grained, well sorted; composed of subangular to subrounded quartz grains, and about 2 percent unidentifiable fine-grained black mineral, lower 3 to $4 \mathrm{ft}$ of unit contains scattered medium well-rounded quartz grains (Entrada "berries"). This 3 - to 4-ft ledge is nearly structureless and massive splitting. Remaining $25 \mathrm{ft}$ is composed of thin trough sets of medium-scale low-angle crosslaminae. Most cross-stratified sets are 6 to 18 in. thick. Exposures are only partial along strike, but there do not seem to be any persistent horizontal planes bounding these sets. Crossstratification is less abundant and lower angle in upper $15 \mathrm{ft}$ of unit. Unit is poorly cemented, calcareous, and weathers to form smooth slightly rounded slope. One and one-half feet below top of unit is the top of a nonpersistent chromite-bearing layer as thick as 6 in. A vanadium-bearing layer directly overlies the chromitebearing layer and ranges in thickness from 0 to $3 \mathrm{in.}$. It is less persistent than the chromite-bearing layer. These layers cross details of bedding. Galena layer could not be observed between the two. There is a brilliant yellow mineral encrusting parts of vanadium-bearing layer

\section{Total of Entrada Sandstone}

Contact between Dolores Formation and Entrada Sandstone placed at base of lowest occurrence of Entrada "berries." This contact appears to be at bedding plane, but color across boundary is identical. Entrada appears very slightly coarser than top unit of Dolores.

Dolores Formation:

19. Sandstone, very pale orange $(10 Y R$ $8 / 2$ ) and rare pale reddish brown (10R 5/4), weathering same colors, very fine grained, well sorted; composed of subrounded clear quartz, no accessory minerals noted; firmly to well cemented, slightly calcareous;

\section{Feet Dolores Formation-Continued} structureless in parts and horizontally to thinly bedded in other parts, may be entirely horizontally laminated to thinly bedded; massive splitting in most places; weathers to form lightcolored vertical cliff. This unit and unit 17 may be equivalent to Wingate Sandstone to the west. The sandstone and sandy siltstone of these units have a similar texture to some Wingate but do not have any Wingatetype cross-stratification

18. Siltstone, moderate red $(5 R 4 / 6)$, weathering same color; noncalcareous at base and slightly calcareous in upper part; horizontally thinly laminated in lower $7 \mathrm{ft}$ and structureless in upper $4 \mathrm{ft}$; weathers to rubble-covexed slope. Many prominent vertical irregular light-greenish-gray $(5 G Y$ $8 / 1$ ) calcareous stringers about 1 in. wide

17. Sandy siltstone, pale reddish brown $(10 R 5 / 4)$, weathering same color, ranges from very fine sandstone to siltstone, well sorted; well cemented, calcareous; horizontally laminated to thinly bedded; weathers to form vertical cliff. One thin trough set of medium-scale low-angle cross-laminae noted at base of unit

16. Interbedded sets of sandstone and siltstone. Sandstone, grayish red $(10 R$ $4 / 2$ and $5 R 4 / 2$ ), weathers same color or moderate red $(5 R 5 / 4)$, very fine grained sandstone grading to siltstone; fair sorted; firmly cemented, calcareous; dominantly horizontally laminated, minor thin trough sets of small-scale low-angle crosslaminae; cross-stratified sets are generally 6 in. to $3 \mathrm{ft}$ thick, some as large as $8 \mathrm{ft}$; these sets weather to form ledges. Siltstone, moderate red $(5 R 5 / 4)$, to pale reddish brown $(10 R 5 / 4)$, weathers same colors, minor amounts of very fine sand mixed with the silt; well cemented, calcareous; sets in lower part of unit are dominantly horizontally laminated, sets in upper part are dominantly ripple laminated, both types are present throughout unit; weathers to form rubble-strewn slope covered by platy or angular fragments. Much of the pinkish color in the ripplelaminated siltstone is concentrated in a thin film at top of each laminae. Thicker coarser fraction at base is commonly pale red (5R 6/2). Unit as whole weathers to form very steep ledgy slope. From 36 to $43 \mathrm{ft}$ above base of unit are thin lenses of sandstone composed of coarse limy silt-
Feet 
Dolores Formation-Continued

stone grains ( 50 percent) in a matrix (50 percent) of limy red silt. At 7.2 $\mathrm{ft}$ below top of unit is thin bed of locally prominent light-greenish-gray (5GY 8/1) slightly silty limestone that weathers to yellowish gray (5Y 8/1). Upper $1 / 3$ of unit contains a considerable number of mud-crack impressions. Mud chips common in lower $10 \mathrm{ft}$ of sandstone

15. Sandstone, pale red $(5 R 6 / 2)$, weathering moderate orange pink (10R $7 / 4)$, very fine grained, well sorted; composed of subangular amber-stained quartz, sparse medium-grained white mica; horizontally laminated, sparse medium-scale low-angle cross-stratification; weathers to form most prominent vertical cliff along line of section. Forms extensive cliff throughout San Miguel Canyon. Unit contains sparse thin discontinuous sets of palereddish-brown (10R 5/4) horizontally laminated siltstone which weathers to form small reentrants. Unit is lithologically very similar to units such as the so-called Black Ledge in Utah..

14. Siltstone, grayish red $(10 R \quad 4 / 2$ and $5 R 4 / 2$ ), weathering same color and pale reddish brown $(10 R 5 / 4)$; sparse fine-grained white mica; well cemented, calcareous; structureless, horizontally laminated and ripple laminated, sparse small-scale trough cross-stratification; platy splitting in part and massive in other parts; weathers to form steep slope; unit contains about 5 percent limestone pebble conglomerate and limestonegrain sandstone; this conglomerate and sandstone is similar to that in unit 11 and is present as very thin to thin horizontal beds or lenses interstratified with the siltstone. To west of section unit contains sets of largescale cross-stratification. Basal strata of these sets fill channels cut about $4 \mathrm{ft}$ into underlying strata

13. Siltstone to sandstone, pale reddish brown $(10 R 5 / 4)$ and grayish red $(5 R 4 / 2)$, weathering pale red $(5 R$ $6 / 2)$, siltstone to very fine grained sandstone; common medium-grained white mica; well cemented, calcareous; horizontally laminated to thin bedded; weathers to form vertical cliff

12. Siltstone, same as unit 10 except contains some suggestion of horizontal bedding, contains a light-greenishgray $(5 G Y 8 / 1)$ siltstone with about 40 percent coarse rounded grains of limestone. This siltstone bed containing coarse grains is about 3 in. thick
Feet $\begin{array}{r}\text { Dolores Formation-Continued } \\ \text { and lenticular and lies about in the }\end{array}$ middle of the unit ...............................

11. Conglomerate and siltstone. Conglomerate, pale reddish brown $(10 R 5 / 4)$ and yellowish gray $(5 Y 8 / 1)$ weathering pale reddish brown $(10 R 5 / 4)$; subrounded granules to cobbles of reddish siltstone and grayish limestone. Largest cobble is 5 in. long and is reddish siltstone. Matrix is limy silt. Conglomerate is well cemented (calcareous) and composed of thin to thick horizontal beds. Siltstone, pale reddish brown $(10 R 5 / 4)$, weathering same color; well cemented, calcareous; horizontally laminated. Unit as a whole weathers to form a ledge. Siltstone is present as thin sets interstratified with conglomerate......

10. Siltstone, pale reddish brown $(10 R$ $5 / 4)$ and grayish red $(10 R \quad 4 / 2)$, weathering to same colors; well cemented, slightly calcareous; structureless; fractures into angular fragments, weathers to form slope............
57.0
9. Siltstone, pale reddish brown $(10 R 5 / 4)$, weathering same color, grades to very fine grained sandstone; firmly to well cemented, calcareous; poorly developed stratification, dominantly horizontally laminated to thin bedded, minor small-scale cross-stratification and large shallow channel surfaces; weathers to form ledge. Basal $3 \mathrm{ft}$ of unit is light-brownish-gray (5YR 6/1) cross-stratified coarse-grained sandstone

8. Unit poorly exposed but appears to be mostly siltstone. Siltstone, pale reddish brown (10R 5/4) and grayish red $(10 R 4 / 2)$, weathering same colors; grades to very fine grained sandstone, common coarse white and dark mica; poorly cemented, slightly calcareous; horizontally laminated, minor ripple laminae and cross-stratification; weathers to form slope........

Basal sandstone unit:

7. Sandstone, very light gray $(N 8)$ and yellowish gray $(5 Y 8 / 1)$, weathering yellowish gray $(5 Y 8 / 1)$, coarse to very coarse grained, fair sorted; composed of subangular milky and clear quartz, common interstitial white clay; poorly cemented, slightly calcareous, siliceous in parts; stratification poorly developed but appears to be structureless in parts, horizontally laminated, and sparse low-angle cross-strata; weathers to form ledge. Unit forms conspicuous widely distributed light-colored ledge throughout San Miguel Canyon. Unit contains sparse granules and pebbles as
Feet

55.8 
Dolores Formation-Continued

Basal sandstone unit-Continued

large as $1 \mathrm{in.}$ in diameter of quartz and quartzite. Unit has abundant limonite stain

Total of basal sandstone unit ........

Total of Dolores Formation.

Cutler Formation:

6. Poorly exposed, outcrops of about half the unit along the line of section and more complete outcrops $500 \mathrm{ft}$ west of line of section indicate unit is mostly siltstone. Siltstone, pale reddish brown $(10 R 5 / 4)$ and grayish red (10R $4 / 2$ and $5 R 4 / 2$ ), weathering same colors; well cemented, calcareous; structureless, minor poorly developed horizontal bedding; weathers to form steep rubble-covered slope. Unit contains a thick unit of massive medium-grained sandstone near base

5. Siltstone (30 percent) and sandstone (70 percent). Siltstone, grayish red $(10 R 4 / 2)$, weathering same color; well cemented, calcareous; structureless and horizontally laminated in parts. Sandstone, grayish red $(5 R$ $4 / 2)$, sparse grayish red purple ( $5 R P$ $4 / 2$ ), weathering same color, very fine grained; composition masked, common medium-grained white mica; well cemented, calcareous; horizontally laminated to very thin bedded and minor poorly developed thin trough sets of small- and mediumscale low-angle cross-laminae, sparse ripple laminae; weathers to form vertical cliff near base and ledgy slope near top. Away from line of section unit is in places entirely ledgy slope..

4. Sandstone, greenish gray $(5 G Y 6 / 1)$, weathering same color and pale reddish brown $(10 R 5 / 4)$, very fine to medium-grained, sparse coarsegrained parts near base, fair sorted; composed of subangular clear and milky quartz and minor pink and white feldspar; well cemented, calcareous; composed of very thin horizontal beds and minor thin trough sets of medium-scale low-angle crosslaminae; weathers to form vertical cliff which is in most places continuous with that of the overlying unit; 3 -in.-thick reddish siltstone in middle of unit

3. Siltstone to very fine grained sandstone, grayish red $(10 R 4 / 2)$, weathering same color; sand is composed of subangular milky quartz(?), abundant dark and white mica; firmly cemented, slightly calcareous; structureless, some horizontally laminated
Cutler Formation-Continued

parts; weathers to form steep rubblecovered slope

2. Sandstone to conglomeratic sandstone, pale red $(5 R 6 / 2)$ and very pale orange $(10 Y R 8 / 2)$, weathering same colors; medium to very coarse grained, fair sorted; composed of subangular to angular clear quartz and pink and white feldspar; granules to pebbles as large as $2 \mathrm{in}$. in diameter of gneiss, quartzite, quartz, and schist; firmly to well cemented, calcareous; composed of very thin horizontal beds and minor thin trough sets of medium-scale low-angle cross-laminae; weathers to form conspicuous ledge. Unit is highest typical conglomeratic bed of the Cutler Formation. Basal strata fill scours cut as much as $1 / 2 \mathrm{ft}$ into underlying unit ....

1. Siltstone, grayish red $(10 R 4 / 2)$, weathering same color, contains about 5 percent medium to coarse quartz grains; firmly cemented, calcareous; stratification concealed; weathers to form slope. Only top $2 \mathrm{ft}$ examined ........................................Unm

Total of incomplete Cutler Formation

Base of section; not base of exposure. Section starts

N. $15^{\circ} \mathrm{E}$. of store at Sawpit.

\section{NEVADA \\ N-l. HORSE SPRING VALLEY}

Measured in Horse Spring Valley east of Tramp Range about 2 miles north of Horse Spring and 3 miles south of Mud Well; line of section averages about $N$. $60^{\circ} \mathrm{E}$. (including offsets), in or near sec. 12 (unsurveyed), T. $18 \mathrm{~S} ., R .70$ E., MDM, Clark County

[Measured by J. H. Stewart, R. F. Wilson, and W. Thordarson, November

NoTE. - This section was measured in an area containing many small faults, and some of the unit thicknesses may be in error because of concealed faults.

Top of section; top of exposure. Top of section is Feet N. $61^{\circ} \mathrm{E}$. of base of section.

Aztec Sandstone:

36. Sandstone, light brown $(5 Y R 6 / 4)$ to pale reddish brown $(10 R 5 / 4)$, weathering same colors, very fine grained, sparse fine to coarse grains, well sorted; composed of subrounded to rounded clear and reddish-stained quartz and common black accessory mineral; poorly cemented, slightly calcareous; composed of thick to very thick planar sets of medium-scale high-angle cross-laminae; weathers to form low rolling hills. Only basal 50 $\mathrm{ft}$ of unit examined. A mile to the north, this unit is about $1,000 \mathrm{ft}$ thick

Unmeasured

12.5

eet et 
Probable equivalents of Moenave and Kayenta Formations:

35. Siltstone to sandstone, pale reddish brown $(10 R 5 / 4)$ and minor light brown (5YR 6/4), grades from coarse silt in basal half to very fine grained sand in upper half, fair sorted; sand is composed of subrounded to rounded reddish-stained quartz and common black accessory mineral; poorly to well cemented, noncalcareous; stratification appears to be composed of irregular wavy horizontal laminae; weathers to form ledge........

34. Sandstone (65 percent) and siltstone (35 percent). Sandstone, pale red $(5 R 6 / 2)$ to grayish red $(5 R 4 / 2)$, weathering same colors, very fine to coarse grained, silty, poorly to fair sorted; composed of subangular reddish-stained and milky quartz; firmly to poorly cemented, noncalcareous; horizontally laminated to thick bedded and common thin to thick trough sets of medium-scale low-angle cross-laminae. Siltstone, pale reddish brown (10R 5/4), weathering same color, fine to coarse silt, minor very fine grained sand in parts; common coarse-grained accessory dark-green mica; firmly cemented, noncalcareous; horizontally laminated to thick bedded. Siltstone is present as thin to very thick sets interstratified with sandstone. Unit as whole weathers to form low rolling hills. Middle part of unit covered by wash

33. Siltstone (95 percent) and gypsum (5 percent). Siltstone, same as siltstone in underlying unit. Gypsum, white $(N 9)$, weathering same color, mostly fibrous. Gypsum present as laminae to very thin beds and as seams in siltstone. Unit as whole weathers to form rolling hills. Unit probably contains a few sandstone beds in top $100 \mathrm{ft}$ similar to those in overlying unit, but due to poor exposures their position cannot be located. Unit contains in basal 100 ft a few limestone beds similar to those in underlying unit

32. Siltstone (75 percent) and siltstone to sandstone (25 percent). Siltstone, grayish red $(5 R 4 / 2)$, weathering pale reddish brown $(10 R 5 / 4)$, grades from fine to coarse silt, very fine grained sandy in part; firmly cemented, noncalcareous, clay binding; horizontally thick to very thick bedded. Siltstone to sandstone, grayish red $(5 R 4 / 2)$, weathering same color, grades from coarse silt in part to medium-grained sandstone in part;
Feet

Probable equivalents of Moenave and Kayenta Formations-Continued

fair sorted. Sandstone is composed of subangular to angular clear and milky quartz and 1 or 2 percent dark-green mica. Siltstone to sandstone is poorly to well cemented, calcareous; horizontally laminated ( 30 percent) to ripple laminated (20 percent) and 50 percent thin trough sets of medium-scale low-angle cross-laminae. Unit as whole weathers to form low hills with small ledges on siltstone and sandstone parts. Siltstone to sandstone present as thin to very thick sets interstratified with siltstone. Unit contains sparse very thin gypsum beds ( 2 percent) and seams. Unit contains a few thin beds of paleyellowish-brown (5YR 6/2) limestone (1 percent)

31. Silty sandstone to conglomeratic sandstone, grayish red $(5 R 4 / 2)$ and abundant light-greenish-gray (5GY 8/1) mottling, weathering same colors, fine to coarse grains in a silt matrix, poorly sorted; composed of reddish-stained clear and milky quartz; poorly to firmly cemented, calcareous; stratification concealed; weathers to form small ledges. Unit contains disseminated granules to cobbles of quartzite, chert, and quartz. The cobbles reach a maximum long diameter of 5 in. Many of the pebbles and cobbles have pitted surfaces, and some have several flat and pitted surfaces and may be ventifacts. This unit is considered part of the probable equivalents of the Moenave and Kayenta Formations because of its stratigraphic position and the similarity of the conglomerate to basal conglomerates of the Moenave Formation elsewhere

Total of probable equivalents of Moenave and Kayenta Formations

Chinle Formation

Petrified Forest Member:

30. Mostly covered. Basal $72 \mathrm{ft}$ is about 50 percent exposed and is composed of grayish-red-purple (5RP 4/2) sandstone and siltstone. Sandstone, fine grained, clayey, poorly sorted, and firmly cemented, noncalcareous. The composition is masked and the stratification concealed. The unit from 72 to $288 \mathrm{ft}$ contains a few exposures of pale-red-purple (5RP 6/2) claystone to siltstone. The unit from 288 to 324 $\mathrm{ft}$ is entirely exposed and composed of silty claystone. Silty claystone, grayish red purple $(5 R P 4 / 2)$ and 
Chinle Formation-Continued

Petrified Forest Member-Continued minor moderate red $(5 R 5 / 4)$, weathering pale red purple $(5 R P 6 / 2)$; bentonitic; poorly cemented, noncalcareous; and stratification concealed. Silty claystone contains about 5 percent white ( $N$ 9) gypsum. Gypsum is present as regular nodules. Unit as whole weathers to form low rounded hills. Unit contains some limestone nodules at the base of about the

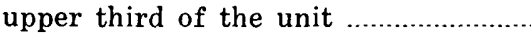

29. Sandstone, yellowish gray $(5 Y 8 / 1)$, pinkish gray (5YR 8/1), and minor grayish purple $(5 R 4 / 2)$, weathering same colors, medium to coarse grained, minor fine-grained parts, some interstitial clay, poorly sorted; composed of subangular clear and milky quartz and 10 percent orange mineral, common coarse-grained accessory dark-green mica; poorly cemented, noncalcareous; horizontally laminated, possibly some very lowangle cross-laminae; weathers to form low ridge. Unit is only exposed along line of section

28. Silty claystone to siltstone, grayish red $(10 R \quad 4 / 2$ and $5 R \quad 4 / 2)$, greenish gray $(5 G Y 6 / 1)$ and medium gray $(N 5)$, color variegated, weathering light greenish gray $(5 G Y 8 / 1)$ and pale red purple $(5 R P 6 / 2)$; bentonitic; poorly to firmly cemented, noncalcareous; stratification concealed; weathers to form low rounded hills. Unit contains minor amounts of finegrained clayey sandstone

27. Sandstone, grayish red purple (5RP $4 / 2$, grayish-red $(5 R 4 / 2)$ and abundant light-greenish-gray (5GY 8/1) mottling, weathering same colors, medium to coarse grained, poorly sorted; composed of angular to subangular clear and milky quartz, composition partly masked; poorly cemented, calcareous in parts, clay binding; stratification concealed, possibly horizontally laminated in part; weathers to form low partly covered hill. Sandstone contains some clay and minor amounts of very coarse sand. A few scattered granules to pebbles as large as 2 in. in diameter of quartz, quartzite, and chert are present ..................

26. Silty claystone to siltstone $(80$ percent) and clayey to silty sandstone (20 percent). Silty claystone to siltstone, grayish red $(5 R 4 / 2)$, grayish purple $(5 P 4 / 2)$, light greenish gray $(5 G Y 8 / 1)$, and greenish gray ( $5 G Y$ $6 / 1$ ), weathering same colors, clay to coarse silt; bentonitic clays, common accessory light and dark mica;
Feet $\mid$ Chinle Formation-Continued Feet

324.0

17.0

151.0

\section{Shinarump(?) Member:}

24. Sandstone ( 80 percent $)$ and conglomeratic sandstone to conglomerate (20 percent). Sandstone, white $(N 9)$ and grayish orange (10YR $7 / 4)$, weathering same colors and pale yellowish orange (10YR $8 / 6$, medium to coarse grained, fair to well sorted with some clay matrix; composed of subangular to subrounded clear and yellowish-stained quartz with common to abundant accessory dark mica and dark and orange mineral; firmly cemented, calcareous in part, clay binding; stratification largely obscured, but some thin to thick trough sets of low-angle medi- 
Chinle Formation-Continued

Shinarump (?) Member-Continued um-scale cross-laminae and some horizontal laminae. Conglomeratic sandstone to conglomerate, similar to sandstone except it contains granules to pebbles of black, orange, and gray chert, quartzite, and white quartz. The conglomeratic sandstone to conglomerate is present as thin sets interstratified with the sandstone. As a whole, the unit weathers to form part of valley floor with several protruding sandstone ledges. Unit contains common fragments of silicified wood

Total of Shinarump(?) Member....

Total of Chinle Formation.

Moenkopi Formation (incomplete) :

Upper red member (incomplete) :

23. Silty to sandy claystone to clayey sandstone. Silty to sandy claystone, greenish gray ( $5 G Y 6 / 1)$, light greenish gray $(5 G Y 8 / 1)$, and minor pale purple $(5 P 6 / 2)$, weathers light greenish gray, contains varying amounts of very fine sand and silt grains, grades to siltstone and sandstone; clays are apparently bentonitic and swell when wet; well cemented, noncalcareous; stratification concealed. Clayey sandstone, light greenish gray $(5 G Y$ 8/1) with minor pale-red-purple $(5 R P$ 6/2) mottling, weathers same colors, very fine grained, fair to poor sorting with clay matrix approximately 25 percent; composition mostly concealed but where seen it consists of subrounded quartz and possibly some limestone grains; firmly to poorly cemented, noncalcareous; stratification concealed. Unit as whole weathers to form covered slope with poor exposures below ledge of Shinarump(?) Member. The lithology of this unit is much more similar to that of the overlying units of the Chinle Formation than to that of underlying units of the Moenkopi Formation, and, therefore, the unit could be part of the Chinle Formation.

Note. - Units 23-25 measured at northernmost good exposures of the Moenkopi and Chinle Formations.

22. Siltstone, grayish red $(10 R \quad 4 / 2)$, weathers same color, medium size silt grains; common accessory white mica; firmly cemented, calcareous in part, clay binding; stratification concealed; weathers to form part of slope between unit 21 and the Shinarump(?) Member of the Chinle Formation \begin{tabular}{l} 
Feet \\
$\qquad \frac{28.7}{28.7}$ \\
\hline 781.2 \\
\hline
\end{tabular}

Moenkopi Formation (incomplete) - Continued Upper red member (incomplete)-Continued

21. Calcarenite, similar to unit 19 except is coarser grained with sparse quartz and granules to pebbles of limestone; weathers to form small ledge...

20. Siltstone, light brown $(5 Y R 6 / 4)$ and grayish red $(10 R 4 / 2)$, weathers same colors, medium to coarse silt, sandy (very fine grained) in part, abundant very fine grained accessory white mica; poorly to firmly cemented, calcareous; stratification concealed; weathers to form slope between ledges of underlying and overlying unit

Note. - Offset at top of unit 19 so that overlying units were measured $2,000 \mathrm{ft}$ northeast of unit 19.

19. Calcarenite, grayish yellow green ( $5 G Y$ $7 / 2)$, weathers olive gray $(5 Y 4 / 1)$, fine to medium grained with scattered coarse grains and granules of limestone, fair sorted; composed of rounded to subrounded grains of limestone and lesser amounts of quartz with common accessory white mica; well cemented, calcareous; horizontally very thin bedded; weathers to form small ledge in valley floor. Unit contains about 3 in. of limestone and siltstone pebble conglomerate at base

18. Siltstone, type 1 ( 85 percent) and type 2 (10 percent), and gypsum (5 percent). Siltstone, type 1 , pale reddish brown $(10 R 5 / 4)$, moderate brown $(10 Y R 4 / 4)$, and grayish red (10R $4 / 2$ ), weathers pale reddish brown $(10 R 5 / 4)$, fine silt; sparse very fine grained accessory white mica; poorly to firmly cemented, calcareous in parts; horizontally thinly laminate to very thick bedded. Siltstone, type 2, pale reddish brown (10R 5/4), grayish red $(10 R 4 / 2)$, minor grayish orange $(10 Y R 7 / 4)$, and sparse light greenish gray ( $5 G Y 8 / 1)$; weathers same colors; medium to coarse silt, sandy (very fine grained) in a few layers; common very fine grained accessory white mica; well cemented, calcareous; ripple laminated, minor horizontal laminae. Gypsum, white (N 9), weathers same color; fibrous; firmly cemented; present as horizontal laminae to very thin beds interstratified with siltstone. Siltstone type 2 is present as thin to thick sets interstratified with siltstone (type 1 ), and is found predominantly in basal $240 \mathrm{ft}$ of unit. Unit as a whole weathers to form low hills.

Total of incomplete upper red member 
Moenkopi Formation (incomplete)-Continued Upper red member (incomplete) - Continued

Total of incomplete Moenkopi Formation

Base of section; not base of exposure.

Units 1-17 described in Stewart, Poole, and Wilson (1972).

\section{N-2. SPRING MOUNTAINS}

Measured 20 miles west-southwest of Las Vegas, Nev., on east side of Spring Mountains 9 miles north of Potosi Mountain, secs. 27 and 28, T. 21 S., R. 58 E., MDM, Clark County

[Measured by J. H. Stewart and R. F. Wilson, November 1955]

Top of section; top of accessible exposure. Top of section is N. $53^{\circ} \mathrm{W}$. of buildings of Blue Diamond Co. and N. $85^{\circ} \mathrm{W}$. of northernmost road on prospects of the Blue Diamond Co.

Aztec Sandstone:

24. Sandstone, white (N 9) and yellowish gray $(5 Y 8 / 1)$, weathering same colors, fine grained with 5 percent medium to coarse grains, well sorted; composed of rounded to subrounded clear and frosted quartz and minor dark accessory minerals; poorly to firmly cemented; slightly calcareous; composed of thin to thick tabular and wedge-planar sets of medium- to large-scale high- and low-angle crosslaminae; weathers to form vertical cliff. Only basal $20 \mathrm{ft}$ of unit examined Unmeasured

Probable equivalents of Moenave and Kayenta Formations:

23. Sandstone and silty sandstone, white $(N 9)$, pinkish gray $(5 Y R 8 / 1)$, mottled to pale reddish brown $(10 R 5 / 4)$, grayish red $(5 R 4 / 2)$, and pale red (5R 6/2), weathering same colors, fine to very fine grained, minor silt in parts, well sorted; composed of rounded to subangular clear, frosted, and pinkish-stained quartz with uncommon dark and orange accessory minerals; horizontally laminated to very thin bedded, but from 0.0 to 6.1 $\mathrm{ft}$ and 24.6 to $33.3 \mathrm{ft}$ above base contains common thin to thick planar sets of high- and low-angle small- to medium-scale cross-laminae; weathers to form irregular ledgy cliff. This unit marks the highest horizontally laminated strata in section and marks the top of the probable equivalent of Kayenta Formation

22. Sandy siltstone to silty sandstone, pale reddish brown $(10 R 5 / 4)$ with minor parts of pale red $(5 R 6 / 2)$, light greenish gray ( $5 G Y 8 / 1)$, white $(N$ $9)$, and grayish red ( $5 R 4 / 2)$, weathering same colors, grades from coarse silt to very fine grained sand,
Feet Probable equivalents of Moenave and Kayenta Formations-Continued mostly sandy siltstone in lower $80 \mathrm{ft}$, well sorted; composed of subangular to subrounded clear and reddish-stained quartz; firmly cemented, slightly calcareous; horizontally wavy laminated, and minor very thin to thin-bedded parts; weathers to form irregular ledgy cliff. Base of unit is transitional with top of underlying unit

21. Sandy siltstone to silty sandstone, like unit 19 except contains more wavy laminated parts and has no pale-red $(10 R 6 / 2)$ parts; weathers to form slope. From 2.3 to $4.9 \mathrm{ft}$ above base, unit contains a thick set of siliceous silty sandstone that contains numerous veinlets of chert crosscutting bedding planes

20. Sandstone, white ( $N 9)$, pinkish gray $(5 Y R 8 / 1)$, minor moderate orange pink $(10 R 7 / 4)$, minor pale-purple (5P 6/2) mottling, weathering very light gray $(N 8)$, fine grained with lesser very fine grained parts, well sorted; composed of rounded to subrounded clear, frosted, and subordinate reddish-stained quartz and uncommon dark accessory mineral; firmly cemented, slightly calcareous; composed of thin to very thick tabular- and minor wedge-planar sets of small- to medium-scale high- and lowangle cross-laminae; weathers to form vertical cliff. This unit is similar in lithology to the Aztec Sandstone and may represent a tongue of the Aztec..

19. Sandy siltstone to silty sandstone, pale reddish brown $(5 R 5 / 4)$ with minor mottling of light greenish gray ( $5 G Y$ $8 / 1)$, minor pale red $(10 R 6 / 2)$ in upper $30 \mathrm{ft}$, weathering same colors, grades from coarse silt to finegrained sand, most of unit is probably sandy siltstone, well sorted; composed of subangular to rounded clear and reddish-stained quartz and minor dark accessory mineral; firmly cemented, slightly calcareous; in part horizontally very thin bedded to laminated, in part wavy bedded, some bedding planes have slight irregular waviness suggestive of poorly developed ripple marks; weathers to form steep ledgy slope. Upper $30 \mathrm{ft}$ of unit weathers to form an irregular ledge..

18. Sandstone, moderate orange pink (10R $7 / 4$ ) and minor pale reddish brown $(10 R 5 / 4)$, weathering same colors, very fine grained, silty in part, well sorted; composed of rounded to subrounded clear, frosted (?) and red-
Feet

116.7

69.6

50.0 
Probable equivalents of Moenave and Kayenta Formations-Continued

dish-stained quartz and minor dark accessory minerals; firmly to well cemented, slightly calcareous; horizontally laminated in part, in part composed of thin to thick planar sets of small- to medium-scale low-angle cross-laminae; weathers to form orange-colored ledge

17. Siltstone to sandy siltstone, pale reddish brown (10R 5/4) and grayish red (5R 4/2 and $10 R 4 / 2)$ and minor grayish brown ( $5 Y R 3 / 2)$ near base of unit, very minor mottling to light greenish gray $(5 G Y 8 / 1)$ in places, weathering same colors, medium to coarse silt, contains as much as 20 percent very fine to fine sand grains in places; firmly to well cemented, calcareous; horizontally laminated to very thick bedded with majority of stratification apparently thick bedded; weathers to form steep rubblecovered slope. Unit contains about 1 to 2 percent thin to thick sets of silty very fine grained sandstone interstratified with siltstone to sandy siltstone. Unit contains two sets of calcarenite from 37.1 to $41.5 \mathrm{ft}$ and 63.7 to $65.3 \mathrm{ft}$ above base of unit. Calcarenite is light brownish gray $(5 Y R 6 / 1)$ and is apparently composed of rounded greenish-gray ( $5 G Y$ $6 / 1)$ medium to very coarse grains and granules of limestone and minor siltstone; well cemented; horizontally thin to thick bedded; weathers to form ledges. Upper $30 \mathrm{ft}$ of unit is composed of pale-reddish-brown $(10 R$ $5 / 4)$ to moderate-reddish-orange $(10 R$ $6 / 6)$ sandy siltstone to very fine grained sandstone that is horizontally laminated to wavy bedded and weathers to form a ledgy slope

16. Sandstone, same as that in unit $14 \mathrm{ex}$ cept is fine to very fine grained, is entirely thin to thick bedded, and does not contain granules to pebbles. Contains some claystone pellets. Weathers to form uppermost of two black ledges at base of probable equivalents of Moenave and Kayenta Formations

15. Siltstone, brownish gray (5YR 4/1), weathering same color, medium to coarse silt, contains scattered fine to very fine sand grains; firmly cemented, calcareous in part; stratification concealed; weathers to form slope

14. Sandstone to conglomeratic sandstone, medium dark gray (N 4), weathering same color, fine to me-

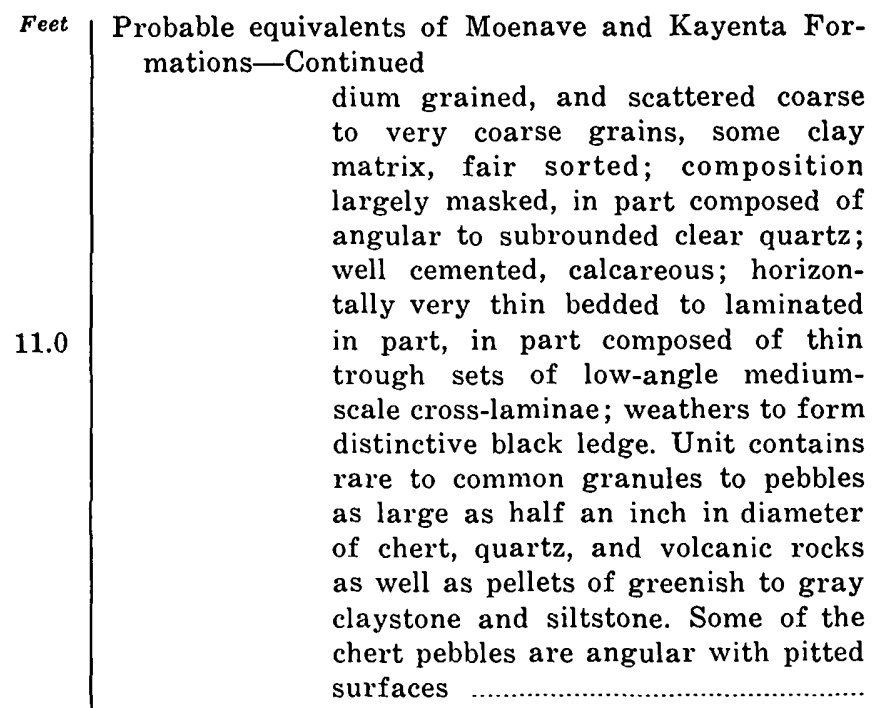

Total of probable equivalents of Moenave and Kayenta Formations ...............................................

Feet

Chinle Formation:

Petrified Forest Member:

13. Covered, weathers to form slope. Unit probably is part of Chinle Formation

12. Siltstone to silty claystone, grayish red $(5 R 4 / 2)$ and dusky red $(5 R 3 / 4)$ in basal $17 \mathrm{ft}$ and pale red (10R 6/2), grayish red purple $(5 R P 4 / 2)$, and light greenish gray $(5 G Y 8 / 1)$ in top $10 \mathrm{ft}$; weathering same colors; bentonitic clays in top $10 \mathrm{ft}$ firmly cemented, noncalcareous; stratification concealed; weathers to form slope......

11. Sandstone to conglomeratic sandstone, pale red $(5 R 6 / 2)$, weathering same color, fine to medium grained, common coarse to very coarse grains, fair sorted; composed of subangular to angular clear quartz and 10 percent orange grains and 5 to 10 percent black grains; firmly cemented, slightly calcareous; composed of thin to thick trough and planar sets of medium- to possibly large-scale lowangle cross-laminae, possibly some horizontally laminated to thin bedded parts; weathers to form prominent pinkish ledge near top of Chinle Formation. Unit contains a $3-\mathrm{ft}$ bed of grayish-red $(5 R 4 / 2)$ silty claystone in top one-fourth of unit. Unit contains scattered granules to cobbles and local concentrations in which the granules to pebbles comprise 20 percent of rock. Granules to cobbles are composed of quartz, quartzite, and chert and reach maximum diameters of about 5 in

27.5

6.0

10. Silty claystone to clayey siltstone $(65$ percent) and clayey sandstone to sandstone ( 35 percent). Silty clay- 
Chinle Formation-Continued

Petrified Forest Member-Continued

stone to clayey siltstone, greenish gray $(5 G Y 6 / 1)$, dark greenish gray $(5 G Y 4 / 1)$, grayish red $(5 R 4 / 2)$, medium gray $(N 5)$, and grayish purple $(5 P 4 / 2)$, weathering mostly pale red $(5 R 6 / 2)$; bentonitic; firmly cemented, noncalcareous; stratification concealed. Clayey sandstone to sandstone, grayish red $(5 R 4 / 2)$, greenish gray $(5 G Y 6 / 1)$ and light brownish gray $(5 Y R 6 / 1)$, weathering same colors, very fine to medium grained, fair to poorly sorted; composition mostly concealed, probably composed of quartz and 10 percent orange grains, grains are subangular to angular; poorly cemented, slightly calcareous; stratification concealed. Unit as whole weathers to form steep rubble-covered slope. Parts of unit covered along line of section, but all parts of unit can be seen at some place along the local outcrop. Along one small gully near line of section unit contains a ledge-forming sandstone from 34 to $57 \mathrm{ft}$ above base of unit. This sandstone is very pale orange $(10 Y R 8 / 2)$ with subordinate greenish gray ( $5 G Y 6 / 1)$, medium grained, fair to well sorted; composed of subangular clear and milky quartz, 10 percent orange grains and 5 to 10 percent green and gray grains; firmly cemented, calcareous; composed of medium-scale low-angle cross-laminae

9. Sandstone, grayish orange $(10 Y R 7 / 4)$, weathering same color, medium grained, fair sorted; composed of subangular to subrounded clear and milky quartz, 10 percent orange mineral and 5 percent grayish mineral, firmly to well cemented, noncalcareous; stratification mostly concealed, some horizontal very thin to thin beds; weathers to form ledgy slope. Unit forms yellowish band that can locally be seen on both sides of canyon

8. Silty claystone (65 percent) to clayey siltstone (10 percent) and clayey sandstone (25 percent). Silty claystone to clayey siltstone, dark greenish gray ( $5 G Y 4 / 1)$, greenish gray $(5 G Y 6 / 1)$, medium dark gray $\left(N_{4}\right)$, and minor grayish purple (5P 4/2), weathering light greenish gray ( $5 G Y$ 8/1) ; bentonitic; firmly cemented, noncalcareous; stratification concealed. Clayey sandstone, pale red $(5 R 6 / 2)$ and greenish gray (5GY $6 / 1$ ), weathering same colors, fine
Feet Chinle Formation-Continued

Petrified Forest Member-Continued grained, minor medium- and coarsegrained parts, clayey, poorly to fair sorted; composed of subangular to subrounded clear and milky quartz, 5 percent orange grains, 2 to 3 percent green grains, and abundant coarse-grained accessory dark-green mica; poorly cemented, calcareous in parts; stratification concealed. Clayey sandstone is confined to basal $50 \mathrm{ft}$ of unit and contains a few interstratified lenses of silty claystone. Unit as whole weathers to form steep rubblecovered slope and is only exposed in 100 -ft-wide belt along line of section. Top $10 \mathrm{ft}$ covered along line of section, but lateral exposures indicate this interval is the same as the rest of the unit

Total of Petrified Forest Member.

Shinarump (?) Member:

Offset in section so that overlying unit measured $1,500 \mathrm{ft}$ south of underlying units. Units 8 to 24 measured on south side of minor canyon.

7. Sandstone (95 percent) to conglomeratic sandstone ( 5 percent), yellowish gray $(5 Y 7 / 2)$ and $(5 Y 8 / 1)$, grayish yellow $(5 Y 8 / 4)$, weathering same colors, coarse grained, minor medium to very coarse grained parts, fair sorted; composed of subangular to subrounded clear and milky quartz, feldspar, 1 percent orange grains, and abundant accessory black grains; poorly to firmly cemented, calcareous; stratification difficult to determine, some parts structureless, some parts composed of thin to thick planar sets of small-scale low-angle cross-laminae, other parts composed of mediumscale very low angle cross-laminae; weathers to form ledgy slope. Conglomeratic sandstone is present as thin to thick lenses interstratified with sandstone and is composed of chert, quartz, and quartzite pebbles and granules as large as 1 in. in diameter in a sandstone matrix

6. Chert pebble conglomerate, pale yellowish orange $(10 Y R 8 / 6)$ and moderate yellowish brown $(10 Y R 5 / 4)$, weathering same colors; composed of angular to rounded dark-reddish-brown $(10 R 3 / 4)$ and dark-yellowish-orange $(10 Y R$ 6/1) granules and pebbles of chert in a matrix composed of silt to very coarse sand; sand part of matrix is composed of angular to subrounded clear and milky quartz and red and orange chert. Rock as whole is poorly sorted, well cemented, calcareous;
Feet

155.0

90.0 
Chinle Formation-Continued

Shinarump (?) Member-Continued

horizontally very thin to thick bedded; weathers to form ledge that is the most prominent ledge near base of slopes developed on Chinle Formation and is present at many places along several miles of outcrop

Total of Shinarump(?) Member...

Total of Chinle Formation.

Moenkopi Formation (incomplete) :

Upper red member (incomplete) :

5. Mostly covered, rare outcrops along and lateral to line of section suggest this unit is dominantly grayish red $(5 R$ $4 / 2$ ), bentonitic, silty claystone. Because the color and bentonitic character of this unit are typical of the Chinle Formation, the unit could be assigned to the Chinle Formation rather than to the Moenkopi Formation. Unit weathers to form rubble. covered slope

4. Mostly covered, a few exposures of pale-olive $(10 Y 6 / 2)$ siltstone to very fine grained ripple-laminated sandstone. Top foot of unit is probably calcarenite. Calcarenite, medium gray (N 5) ; composed of rounded medium to coarse grains of limestone in a lime matrix, contains a few medium to coarse quartz and chert grains and greenish-gray siltstone pellets. Calcarenite forms irregular ledge and abundant float in top foot of unit. Unit as whole weathers to form rubble-covered slope ............................

3. Siltstone and calcarenite to conglomerate, light olive gray $(5 Y 6 / 1)$ and medium gray $(N 5)$, weathering light olive gray ( $5 Y$ 6/1); composed of angular to rounded coarse grains to pebbles of gray and greenish-gray limestone and siltstone in a limy silt and very fine sand matrix. Sand matrix is composed of subangular clear quartz. Rock as whole poorly sorted; well cemented, calcareous; horizontally very thin to thin bedded; weathers to form ledge. Most of siltstone and limestone grains are very coarse grains or granules. The pebbles reach a maximum diameter of half an inch. Limestone and siltstone grains comprise about 60 to 80 percent of the rock

2. Siltstone, greenish gray $(5 G Y \quad 6 / 1)$ and minor pale greenish yellow ( $10 Y$ $8 / 2$ ), weathering same colors, medium to coarse silt; firmly cemented, calcareous; stratification concealed; weathers to form rubble-covered slope. Unit contains two thin beds of

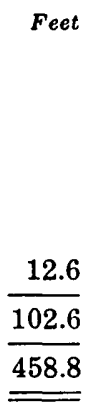

Moenkopi Formation (incomplete)-Continued

Upper red member (incomplete)-Continued very fine grained sandstone, one $3 \mathrm{ft}$ above base and one $3 \mathrm{ft}$ below top of unit

Feet

1. Siltstone, grayish red $(10 R 4 / 2)$, weathering same color, fine silt; poorly to firmly cemented, calcareous; stratification concealed; weathers to form gentle slope Unmeasured

Total of incomplete upper red member

Total of incomplete Moenkopi Formation

124.0

Base of section; base of exposure. Base of section directly east of prominent outlying knoll about $1,000 \mathrm{ft}$ from main line of cliffs.

\section{N-3. VALLEY OF FIRE}

Measured $91 / 2$ miles south-southwest of Overton, Nev., at southeast end of Valley of Fire, western half sec. 26, T. 17 S., R. 67 E., MDM, Clark County

[Measured by J. H. Stewart and R. F. Wilson, November 1955]

NOTE. - This section is measured in a faulted area, and some of the units may be thin because of this faulting. Units 2 to 24 were measured with several small offsets to avoid faults, and the thicknesses of these units are believed to be fairly accurate. Faulting could be seen where units 25 to 29 were measured, but the amount of offset on the faults could not be seen. The thicknesses of units 25 to 29 , therefore, may be greatly in error.

Top of section; top of accessible exposure.

Feet Aztec Sandstone:

30. Sandstone, moderate orange pink $(10 R$ $7 / 4)$, weathering moderate orange pink $(5 Y R 8 / 4)$, very fine grained with scattered fine to medium grains, well sorted; composed of clear and pinkish-stained quartz with some wellrounded quartz grains; firmly cemented, calcareous; stratification obscure but appears to be horizontally laminated; weathers to form vertical cliff. This unit is placed in the Aztec Sandstone because it appears to be related to the cross-stratified eolian sandstone that overlies this unit. Thickness estimated at $30 \mathrm{ft}$. Above this $30 \mathrm{ft}$ is medium- to large-scale cross-stratification ..........................Unmeasured

Probable equivalents of Moenave and Kayenta Formations:

29. Sandstone (25 percent) and siltstone to sandy siltstone ( 75 percent). Sandstone, pale reddish brown $(10 R 5 / 4)$, weathering same color, fine to very fine grained, well sorted; composed of subangular to subrounded clear and reddish-stained quartz and common accessory dark mineral; firmly cemented, calcareous; composed of thin to thick trough sets of low-angle small- to medium-scale cross-laminae. Siltstone to sandy siltstone, same as 
Probable equivalents of Moenave and Kayenta Formations-Continued

that in unit 26 except siltstone in this unit is predominantly horizontally to ripple laminated. Unit as whole weathers to form ledgy slope. Sandstone occurs as thick sets interstratified with siltstone to sandy siltstone..

28. Siltstone to sandy siltstone, pale reddish brown $(10 R 5 / 4)$ to light brown ( $5 Y R$ $5 / 6)$, weathering pale reddish brown $(10 R 5 / 4)$, dominantly coarse silt with minor medium silt, sandy (very fine grained) in part, well sorted; composed of reddish-stained quartz and common accessory very fine grained dark and white mica, gypsiferous in part; firmly to well cemented, calcareous; stratification mostly obscured, coarse siltstone is horizontally laminated to ripple laminated, some structureless parts; weathers to form rolling hills and slopes. Minor seams and veins of gypsum occur in unit

27. Sandstone to silty sandstone (70 percent) and siltstone (30 percent). Sandstone to silty sandstone, pale reddish brown $(10 R 5 / 4)$, weathering same color, fine to very fine grained, silty in part, well sorted; composed of subangular to subrounded reddishstained quartz, common accessory dark and white mica and dark mineral; firmly cemented, slightly calcareous; composed of thin to thick trough and planar sets of low-angle to very low angle small- to mediumscale cross-laminae. Siltstone, same as that in underlying unit, sparse ripple laminations. Unit as whole weathers to form low rolling hills. Sandstone to silty sandstone forms three very thick sets interstratified with siltstone. Top and bottom of unit are marked by sandstone sets....

26. Siltstone to sandy siltstone (95 percent) and silty sandstone ( 5 percent). Siltstone to sandy siltstone, pale reddish brown $(10 R 5 / 4)$ and minor grayish red $(10 R 4 / 2)$, very minor mottling of light greenish gray (5GY 8/1) in spots, weathering pale reddish brown $(10 R 5 / 4)$, predominantly coarse silt with minor medium to fine silt, sandy (very fine grained) in places, common accessory very fine grained dark and white mica, firmly cemented, calcareous; stratification concealed, but at least part is very thick bedded or structureless. Silty sandstone, pale reddish brown $(10 R 5 / 4)$, weathering same color, very fine grained, silty, well sorted;
Feet Probable equivalents of Moenave and Kayenta Formations-Continued composed of subangular to subrounded reddish-stained quartz and common accessory dark and white mica and dark mineral; poorly to firmly cemented, calcareous; stratification concealed in part, in part horizontally laminated or ripple laminated. Unit as whole weathers to form low rolling hills. Silty sandstone is concentrated in lower $70 \mathrm{ft}$ of unit and forms thick to very thick sets interstratified with siltstone. Much of siltstone is gypsiferous........

25. Covered, forms wash directly north of hogback mentioned in unit 24

252.0

24. Sandstone, pale red $(10 R 6 / 2)$, weathering same color and pale red $(5 R$ $6 / 2)$, very fine grained, composed of subrounded clear and reddish quartz, 10 percent white mineral (feldspar?) and common dark accessory mineral; poorly to firmly cemented, calcareous in part; horizontally thin bedded to laminated in part, in part composed of thin to thick trough sets of mediumto large-scale low-angle to very low angle cross-laminae and lesser amounts of planar-cross-laminated sets; weathers to form top $40 \mathrm{ft}$ and back slope of hogback to north of road. Unit contains scattered clay pellets in places and minor ripplelaminated sets

23. Sandy siltstone, pale reddish brown $(10 R 5 / 4)$ with very minor mottling to white $(N 9)$ in places, weathering same colors, coarse silt, sandy (very fine grained) in part, well sorted; composed predominantly of subrounded to subangular reddish-stained quartz; poorly to firmly cemented, slightly calcareous; horizontally laminated in part, in part ripple laminated with ripples of the cuspate type; weathers to form ledgy slope....

22. Conglomeratic sandstone, grayish red $(10 R 4 / 2)$, weathering brownish gray ( $5 Y R$ 4/1), medium to very coarse grained, poorly sorted; composed of rounded to subangular clear, milky, and reddish-stained quartz and limestone grains; well cemented, calcareous; stratification obscure in places but some thin to very thin trough sets of low-angle cross-laminae; weathers to form ledge. Unit contains about 20 percent granules to pebbles as large as 3 in. in diameter of quartz, chert, quartzite, and limestone. Some of the siliceous pebbles have pitted surfaces, are faceted, and may be ventifacts.
Feet 
Probable equivalents of Moenave and Kayenta Formations-Continued

Total of probable equivalents of Moenave and Kayenta Formations

Chinle Formation:

Petrified Forest Member:

21. Silty claystone to claystone, grayish red purple (5RP 4/2) and minor grayish red $(10 R 4 / 2)$ and pale reddish brown $(10 R 5 / 4)$, weathering pale red purple (5RP 6/2) ; bentonitic; firmly cemented, noncalcareous; stratification concealed; weathers to form steep slope. Unit contains several thin beds of grayish red-purple (5RP 4/2) silty very fine to fine-grained sandstone in basal $5 \mathrm{ft}$. A thin bed of grayish and reddish silica (probably chalcedony) is present $10 \mathrm{ft}$ above base of unit. Upper half of unit contains common limestone nodules, some as large as 5 in. in diameter. A poorly exposed thick bed of white ( $N$ 9) coarsely crystalline gypsum is present about 5 $\mathrm{ft}$ below top of unit.

20. Sandstone, pale red $(5 R 6 / 2)$, and sparse very pale orange $(10 Y R 8 / 2)$ parts, weathering same colors, fine to medium grained, some coarse grains; composed of subangular to angular clear and milky quartz, 10 percent orange grains and 5 percent gray grains; firmly to well cemented, calcareous; stratification concealed; weathers to form ledge.

19. Siltstone to silty sandstone, pale reddish brown $(10 R \quad 5 / 4)$ and grayish red $(10 R 4 / 2)$, weathering same colors, grades from siltstone to silty, fine-grained sandstone; composition concealed; firmly to well cemented, noncalcareous; stratification mostly concealed, some thin horizontal beds at base; weathers to form steep slope

18. Sandstone, pale red $(5 R 6 / 2)$ and very pale orange $(10 Y R 8 / 2)$, weathering moderate brown $(5 Y R 4 / 4)$, fine to coarse grained, some very coarse grains, fair to poorly sorted; composed of subangular to angular clear and milky quartz and 10 percent orange grains, rare coarse-grained accessory dark-green mica; firmly cemented, slightly calcareous; composed of thin to thick trough and planar sets of low-angle and possibly high-angle small- to mediumscale cross-laminae; weathers to form prominent brownish ledge in upper part of Chinle. Unit contains a few scattered granules and small pebbles of quartz, quartzite, and chert. $\begin{array}{r}\text { Feet } \\ 630.0 \\ \hline\end{array}$

Chinle Formation-Continued Petrified Forest Member-Continued

17. Silty claystone (70 percent) and clayey sandstone to sandstone (30 percent). Silty claystone, medium gray (N 5$)$, greenish gray $(5 G Y 6 / 1)$, and minor grayish red ( $5 R 4 / 2)$, weathering same colors; bentonitic clays; firmly cemented, noncalcareous; stratification concealed. Sandstone to clayey sandstone, greenish gray (5GY 6/1), light gray $(N 7)$, and minor grayish red purple ( $5 R P 4 / 2)$, weathering same colors, medium to very fine grained. Coarser sands are composed of subangular clear and milky quartz and 10 percent orange grains. Sandstone to clayey sandstone is poorly to well cemented, noncalcareous; stratification mostly concealed, some ripplelaminated sets in basal $10 \mathrm{ft}$. Unit as whole weathers to form steep slope. Sandstone to clayey sandstone is confined to basal $20 \mathrm{ft}$ of unit and is interstratified with silty claystone..... andstone, greenish gray ( $5 G Y 6 / 1)$, very pale orange $(10 Y R 8 / 2)$ and grayish orange $(10 Y R 7 / 4)$, weathering same colors, medium to coarse grained, common interstitial clay, fair sorted; composed of subangular clear and milky quartz, 10 percent orange grains, and 10 to 20 percent gray grains; firmly cemented, calcareous; stratification poorly exposed, some small-scale low-angle cross-stratification; weathers to form ledge. Unit together with underlying unit form conspicuous greenish ledge and slope along exposure. Unit contains a few scattered very coarse grains to pebbles as large as half an inch in diameter of quartz, quartzite, and chert

15. Clayey sandstone to silty claystone, light brownish gray $(5 Y R 6 / 1)$ and light greenish gray ( $5 G Y 8 / 1)$, weathering same colors, grades from clayey very fine grained sandstone to silty claystone, some fine to coarse grains; composition masked, bentonitic clay, some subrounded quartz grains; poorly cemented, noncalcareous; stratification concealed; weathers to form slope

14. Sandstone (90 percent) to conglomeratic sandstone (10 percent), medium dark gray $(N 4)$, weathering brownish black (5YR 2/1), medium to coarse grained, 10 to 20 percent dense to crystalline calcite matrix, poorly sorted; composed of subangular clear and milky quartz (30 percent), orange grains, possibly feldspar (10 percent) and greenish and gray grains $(60$
Feet 
Chinle Formation-Continued

Petrified Forest Member-Continued percent), possibly much of green and gray grains are lithic fragments of volcanic rocks; well cemented; stratification obscure, but some low-angle cross-strata; weathers to form ledge continuous with underlying unit, forms conspicuous black ledge along exposure. Conglomeratic parts of unit contain very coarse grains to pebbles as large as half an inch in diameter of volcanic rocks and subordinate quartz and chert

13. Sandstone, light brownish gray (5YR $6 / 1)$ to pale red purple $(5 R P 6 / 2)$, medium to coarse grained, common very coarse grains and silt, fair to poorly sorted; composed of subangular to angular clear and milky quartz, 10 percent gray grains and 5 percent orange grains (possibly feldspar); poorly cemented, slightly calcareous; composed of thin to thick trough and planar sets of small- to medium-scale low-angle cross-laminae; weathers with overlying unit to form ledge. Unit contains a few granules to pebbles as large as half an inch in diameter of quartz and chert.

12. Clayey siltstone to siltstone, pale reddish brown $(10 R 5 / 4)$ to grayish red $(10 R 4 / 2)$, greenish gray $(5 G Y 6 / 1)$ in upper $8 \mathrm{ft}$, weathering same colors, fine to coarse silt; bentonitic clay matrix ; firmly cemented, noncalcareous; stratification concealed; weathers to form rubble-covered slope. Unit poorly exposed and covered by dark-colored talus of overlying unit..

11. Sandstone, pale red $(5 R 6 / 2)$, weathering pale reddish brown $(10 R 5 / 4)$, fine grained, well sorted; composition masked; well cemented, slightly calcareous; composed of thin trough and planar sets of low-angle small- to medium-scale cross-laminae; weathers to form ledge

10. Sandstone (70 percent) and siltstone (30 percent). Sandstone, grayish red $(5 R 4 / 2)$, grayish purple (5P 4/2), and yellowish gray $(5 Y 8 / 1)$, colors mottled in top $15 \mathrm{ft}$, weathering same colors, fine to coarse grained, common interstitial silt and clay, fair to poorly sorted; composed of subangular to angular clear and milky quartz and 30 percent orange grains (possibly feldspar) and 5 percent black grains; firmly to well cemented, calcareous; stratification mostly concealed, but some low-angle medium-scale cross-lamination and some structureless parts. Siltstone, grayish red
Feet Chinle Formation-Continued

\section{Petrified Forest Member-Continued}

$(10 R 4 / 2)$, weathering same color; firmly cemented, noncalcareous; stratification concealed. Unit as whole weathers to form steep rubble-covered slope. Unit covered or poorly exposed in places. Siltstone is present as thick to very thick sets interstratified with sandstone.

9. Sandstone, light olive gray $(5 Y 6 / 1)$ sparse dark greenish gray ( $5 G Y 4 / 1)$ and pinkish gray $(5 Y R 8 / 1)$, weathering light olive gray, medium to coarse grained, fair sorted; composed of subangular to angular clear and milky quartz and 30 to 40 percent orange mineral (orthoclase?) ; firmly cemented, calcareous, some clay binding; composed of thin planar and minor trough sets of small- to medium-scale cross-laminae; weathers to form ledge and fairly extensive dip slope. Unit contains a few very coarse grains to pebbles as large as 1 in. in diameter of quartz and chert.

8. Silty claystone to siltstone, greenish gray $(5 G Y 6 / 1)$, sparse grayish red (5R 4/2), weathering light greenish gray ( $5 G Y 8 / 1)$; probably bentonitic; poorly cemented, noncalcareous; stratification concealed, weathers to form slope. Unit contains sparse fineto medium-grained poorly cemented clayey sandstone

7. Sandstone, yellowish gray (5Y 7/2) and subordinate dusky yellow (5Y $6 / 4)$, weathering yellowish gray ( $5 Y$ $7 / 2$ ), fine to coarse grained, common interstitial clay, fair to poorly sorted; composed of subangular to angular clear and milky quartz and about 10 percent orange grains (probably orthoclase); firmly cemented, slightly calcareous in parts; composed of planar and minor trough sets of small- to medium-scale low-angle cross-laminae; weathers to form ledge. Abundant "limonite" spots and stains. Unit contains some casts of fossil tree stems and $\operatorname{logs}$

6. Silty claystone to siltstone, grayish red $(10 R 4 / 2)$ and light greenish gray (5GY 8/1), weathering same colors; clays possibly bentonitic; firmly cemented, noncalcareous; stratification concealed; weathers to form steep rubble-covered slope. Unit contains 5 - $\mathrm{ft}$ set of grayish-red $(5 R 4 / 2)$ siltstone in top one-third of unit. Siltstone is composed of coarse silt, contains abundant accessory fine-grained dark-green mica, and is ripple laminated, probably cuspate type. This
Feet 
Chinle Formation-Continued

Petrified Forest Member-Continued siltstone supplies float to much of the unit, and gives unit purplish color. Parts of unit poorly exposed......

Total of Petrified Forest Member..

Shinarump (?) Member:

5. Sandstone (80 percent) and conglomeratic sandstone to conglomerate (20 percent). Sandstone, very pale orange (10YR 8/2), yellowish gray (5Y $8 / 1$ ), and minor greenish gray ( $5 G Y$ $6 / 1)$, weathering same colors, fine to medium grained, some parts contain minor very coarse grains, fair sorted; composed of subangular to angular milky quartz and 1 to 3 percent black grains; poorly to firmly cemented, calcareous; stratification obscure, but unit contains some thin to thick trough and planar sets of medium-scale cross-laminae, parts of unit appear structureless. Conglomeratic sandstone to conglomerate, same as sandstone except contains as much as 60 percent granules to cobbles of black, reddish, and gray quartzite, chert, and rare quartz. Conglomeratic sandstone to conglomerate is found mostly in basal 10 to $20 \mathrm{ft}$. Unit as whole weathers to form vertical cliff. Common silicified wood in basal $20 \mathrm{ft}$. Pebbles have maximum long diameter of $4.9 \mathrm{in}$.

Total of Shinarump(?) Member....

Total of Chinle Formation

Moenkopi Formation (incomplete) :

Upper red member (incomplete) :

4. Mostly covered; a few outcrops near base of unit are grayish-red-purple (5RP 4/2) siltstone. Unit weathers to form rubble-covered slope. This unit could be considered as part of the Chinle Formation, because of its color, but exposures do not permit detailed study, and it is included here with the Moenkopi (compare with unit 5, Spring Mountains section)......

3. Limestone and siltstone pebble conglomerate, greenish gray $(5 G Y 6 / 1)$, weathering moderate yellowish brown (10YR 5/4); composed of coarse grains to pebbles of reddish siltstone and grayish limestone in a dense to finely crystalline lime matrix. Matrix forms 20 to 30 percent of the rock; poorly sorted; well cemented, calcareous; horizontally very thin to thin bedded; weathers to form small ledge. Unit similar to calcarenite and conglomerate in top $30 \mathrm{ft}$ of Moenkopi in Horse Spring Valley section and Spring Mountains section.
Moenkopi Formation (incomplete)-Continued Upper red member (incomplete)-Continued

2. Siltstone, grayish red $(10 R 4 / 2)$, weathering same color, fine to coarse silt; firmly cemented, calcareous; stratification concealed except for minor interstratified thin sets of ripplelaminated siltstone; weathers to form steep rubble-covered slope. Ripplelaminated sets are coarse silt part of unit, and one set $10 \mathrm{ft}$ below top of unit grades to very fine grained sandstone. One thin set about $5 \mathrm{ft}$ above base of unit contains about 20 percent fine to coarse sand grains of quartz and red and green chert(?)....

1. Siltstone, grayish red $(10 R 4 / 2)$ and moderate brown $(5 Y R 4 / 4)$, weathering pale reddish brown $(10 R 5 / 4)$, medium to coarse silt; common very fine grained accessory white mica; firmly cemented, calcareous; stratification concealed, probably in part horizontally thin to very thick bedded; weathers to form badlands topography. Unit contains sparse very thin beds of fibrous white ( $N 9)$ gypsum. About $200 \mathrm{ft}$ of this unit is exposed before being repeated by faulting .........................................Unmeasured

Total of incomplete upper red member ....

Total of incomplete Moenkopi Formation

Base of section; base of exposure.

\section{NEW MEXICO}

NM-la. CHAVEZ-PREWITT SECTION A

Measured about 3 miles east of Bluewater Reservoir; units 1 and 2 measured on north side of a small canyon in the east-central part of sec. 36, T. 13 N., R. 12 W., NMPM; units 3-16 measured along a north line starting in wash and ending on a prominent point along cliffs north of Bluewater Canyon, central and north-central parts of sec. 36, T. 13 N., R. 12 W., McKinley County

[Measured by J. H. Stewart and R. F. Wilson, April 1956]

Top of section; top of exposure. Top of section $\mathrm{S}$. $25^{\circ} \mathrm{W}$. of oil refinery, N. $53^{\circ} \mathrm{W}$. of Anaconda uranium mill, and N. $72^{\circ}$ E. of Syman.

Chinle Formation (incomplete) :

Petrified Forest Member (incomplete) :

Sonsela Sandstone Bed (incomplete) :

16. Sandstone to conglomerate, same as unit 14, weathers to form small knoll. Most, if not all, of the Sonsela Sandstone Bed is probably exposed in this section

15. Silty claystone, same as unit 11 , weathers to form gentle slope

14. Sandstone to conglomerate, very pale orange $(10 Y R \quad 8 / 2)$ and yellowish gray (5Y 8/1), weathering same color, fine to medium grained, sparse coarse-grained parts, fair sorted;
Feet 
Chinle Formation (incomplete)-Continued

Petrified Forest Member (incomplete)-Con.

Sonsela Sandstone Bed (incomplete)-Con. composed of subangular clear quartz and sparse black accessory minerals; poorly to firmly cemented, slightly calcareous in parts; composed of thin to thick trough sets of low-angle smallto medium-scale cross-laminae; weathers to form vertical cliff and underlies part of dip slope developed on Sonsela Sandstone Bed. About 45 percent of unit contains granules to pebbles. In places the rock contains only a few scattered granules and pebbles whereas in other places the rock is a conglomerate. Granules to pebbles are composed of chert, quartzite, and minor quartz. They are mostly $1 / 4$ to $1 / 2$ in. in maximum diameter but are as large as $2 \frac{1}{2}$ in. in maximum diameter

Total of Sonsela Sandstone Bed

Lower part:

13. Covered, weathers to form rubblecovered slope

12. Very poorly exposed. Some exposures indicate unit grades from claystone to siltstone, light greenish gray ( $5 G Y$ $8 / 1)$, greenish gray $(5 G Y 6 / 1)$, and minor grayish red $(10 R 4 / 2)$, swelling clays in places; stratification concealed; weathers to form rubble-covered slope. Top of unit placed at highest exposure

11. Silty claystone, grayish purple $(5 P$ $4 / 2$ ) and abundant light-greenishgray (5GY 8/1) mottling, 5-ft interval of grayish red $(5 R 4 / 2)$ about $10 \mathrm{ft}$ below top, weathering same colors, swelling clays; firmly indurated, noncalcareous; structureless; weathers to form steep frothy-surfaced slope

10. Siltstone, grayish red $(10 R 4 / 2)$, some grayish-red $(5 R 4 / 2)$ and light greenish-gray ( $5 G Y 8 / 1)$ mottling in top $10 \mathrm{ft}$, weathering same colors and pale reddish brown $(10 R 5 / 4)$, fine silt, minor medium to coarse silt, very fine grained accessory white mica common in parts; firmly to well cemented, calcareous; horizontally thinly laminated to laminated, uncommon (10 percent) thin sets of ripple laminae, top $15 \mathrm{ft}$ is structureless; weathers to form steep slope. Basal $6 \pm \mathrm{ft}$ of unit on either side of section is a prominent ledge-forming siltstone. This siltstone is mottled light greenish gray $(5 G Y 8 / 1)$ and grayish red $(5 R 4 / 2)$, weathers grayish red $(10 R 4 / 2)$, is composed of coarse silt, contains common very fine
Chinle Formation (incomplete)-Continued

Petrified Forest Member (incomplete)-Con. Lower part-Continued

to fine-grained accessory white mica, is well cemented with a calcareous cement, and is ripple laminated.

9. Silty claystone and minor clayey siltstone, grayish red ( $5 R \quad 4 / 2$ and rare $10 R 4 / 2$ ), weathering same color; swelling clays; firmly indurated, noncalcareous, clay binding; papery and platy splitting, splitting suggests that unit is horizontal laminated and thinly laminated; weathers to form steep frothy-surfaced slope.

8. Clayey siltstone, light greenish gray (5GY 8/1) and sparse light brownish gray $(5 Y R 6 / 1)$, weathering light greenish gray $(5 G Y 8 / 1)$, rare very fine to fine-grained accessory white mica; firmly cemented, calcareous; papery to platy splitting, splitting suggests that unit is horizontally laminated to thinly laminated; weathers to form steep slope. Unit forms conspicuous greenish unit on exposure

- Clayey siltstone to silty claystone, color bands from 10 to $40 \mathrm{ft}$ thick of pale reddish brown $(10 R 5 / 4)$ alternate with color bands from 10 to $40 \mathrm{ft}$ thick of grayish red purple (5RP $4 / 2)$ and grayish red (5R 4/2), weathering same colors, swelling clays; firmly cemented, calcareous clay binding; horizontally bedded in beds from 1 to $10 \mathrm{ft}$ thick, one bed about $5 \mathrm{ft}$ thick contains light color bands crossing at low angles to overall bedding of unit suggesting medium-scale low-angle cross-strata; weathers to form steep frothy-surfaced slope. Unit contains several thin color bands of light greenish gray ( $5 G Y 8 / 1)$, and some of these color bands are horizontally and ripple-laminated siltstone. From a distance unit forms well-exposed color-banded unit

6. Clayey siltstone to silty claystone, grayish purple $(5 P 4 / 2)$, weathers same color, swelling clays; firmly indurated, noncalcareous clay binding; structureless; weathers to form frothysurfaced badlands. Basal $10 \mathrm{ft}$ is light-gray $(N 7)$ and grayish-purple $\left(\begin{array}{ll}5 P & 4 / 2\end{array}\right)$ silty very fine grained sandstone containing common fineto coarse-grained accessory white mica. This silty sandstone weathers as a slope with the rest of the unit. Unit contains several horizons of limestone nodules

Total of lower part of Petrified Forest Member (lower contact uncertain)
Feet 
Chinle Formation (incomplete)-Continued

Petrified Forest Member (incomplete)-Con. Total of Petrified Forest Member (lower contact uncertain, thickness composite of sections A and $B$ )

Lower red member (upper contact uncertain) :

5. Sandstone (50 percent) and limestone pebble conglomerate (50 percent). Sandstone, very light gray $\left(\begin{array}{ll}N & 8\end{array}\right)$, weathers same color, very fine grained, well sorted; composed of clear quartz; well cemented, calcareous; horizontally laminated to thin bedded, sparse low-angle cross-strata, one occurrence of contorted laminae noted. Limestone pebble conglomerate, brownish gray $(5 Y R 4 / 1)$, weathers same color, composed of granules to pebbles, as large as 2 in. in maximum diameter, of limestone in a limy sand matrix similar to rest of the unit. Limestone pebble conglomerate is well cemented, structureless, and forms most of upper two-thirds of unit. Unit as whole weathers to form ledge. Lateral to line of section, unit is about twice as thick and is mostly horizontally laminated and ripple-laminated sandstone

4. Silty claystone, dark gray $\left(\begin{array}{l}N \\ 3\end{array}\right)$ to light gray $(N 7)$, minor grayish purple $(5 P 4 / 2)$, weathers same colors, swelling clay; firmly indurated, noncalcareous clay binding; structureless; weathers to form frothysurfaced badlands

Total of lower red member (upper contact uncertain)

Mottled strata:

3. Sandstone (90 percent) to conglomerate (10 percent), mottled white ( $N 9)$, grayish purple $(5 P 4 / 2)$, and minor very dusky red purple (5RP 2/2) and dark yellowish orange $(10 Y R$ $6 / 6)$, weathering same colors. Conglomerate confined to basal $2.5 \mathrm{ft}$ and composed of granules to pebbles of yellow and minor gray, black, and red chert, sparse black quartzite, and white quartz. Granules and pebbles average from $1 / 4$ to $1 / 2$ in. in diameter and are as large as $2 \frac{1}{2} \mathrm{in}$. in maximum diameter. A few granules and pebbles are scattered in the rest of unit. Sandstone and matrix of conglomerate is fine grained with minor fine and medium grains and abundant interstitial white silt or clay, poorly to fair sorted; composition largely concealed; about 20 percent of grains are black or red; well cemented, noncalcareous. Stratification is largely concealed by mottled colors, but the

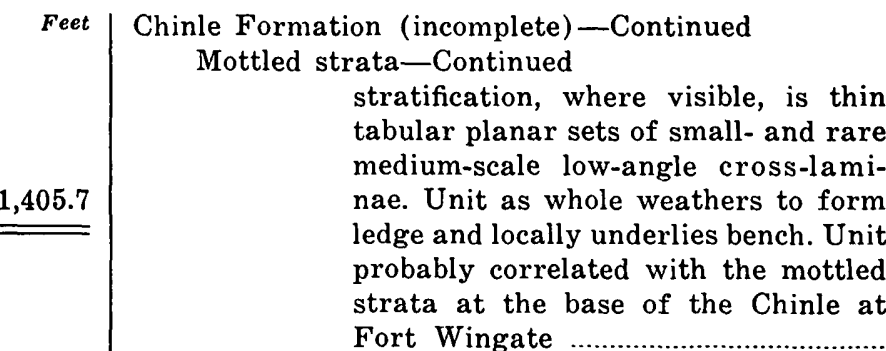

Feet

Total of mottled strata.

Total of mottled strata.................... posite of sections $A$ and $B$ )............

Unconformity. Basal contact of unit is undulatory and sharp. Scours as deep as $0.5 \mathrm{ft}$ are present along the contact.

NoTE. - Section off set so that overlying units measured $1,000 \mathrm{ft}$ west of unit 2 .

Moenkopi (?) Formation:

2. Siltstone ( 60 percent) and sandstone $(40$ percent). Siltstone, grayish red $(10 R$ $4 / 2$ and minor $5 R 4 / 2$ ), weathers same colors, sandy (very fine grained) in parts, common very fine grained white mica; well indurated, noncalcareous; structureless, sparse ripplelaminated and horizontally laminated parts, one thin tabular planar set of medium-scale cross-laminae (may be delta foreset). Sandstone, pale red (5R 6/2 and minor $10 R 6 / 2$ ) weathers same colors and grayish red $(5 R$ $4 / 2$ ), very fine grained, silty in parts, fair to well sorted; composition concealed; well cemented, calcareous in parts; horizontally laminated to thin bedded, sparse thin trough sets of low-angle small-scale cross-laminae. Sandstone is present as thin to very thick sets and cosets interstratified with siltstone. Unit as a whole weathers to form steep slope. Thin bed of grayish red purple (5RP 4/2) limestone granule and pebble conglomerate $4 \mathrm{ft}$ above base of unit. Unit highly variable in lithology along outcrop; locally it appears to be dominantly siltstone. Within 2 miles of section, Moenkopi locally contains conglomerate beds consisting of granules and pebbles of quartz, quartzite, and chert

Total of Moenkopi(?) Formation....

Unconformity; 3- to 5-ft high "folds" at top of San Andres Limestone are truncated by overlying beds.

San Andres Limestone:

Limestone member

1. Limestone, moderate orange pink $(10 R$ $7 / 4)$ and light olive gray (5Y 6/1), weathering light brownish gray ( $5 Y R$ $6 / 1$ ), dense, some parts contain many small pores; well cemented, horizontally thin to thick bedded; weathers 
San Andres Limestone-Continued

Limestone member-Continued

to form vertical cliffs along sides of

wash ......................................nmeasured

Base of section; base of exposure. Base of section in wash bottom.

\section{NM-lb. CHAVEZ-PREWITT SECTION B}

Units 1-10 measured starting at point about 2 miles west of Prewitt and $500 \mathrm{ft}$ south of U.S. Highway 66 in central part of sec. 11, T. 13 N., R. 12 W., NMPM, continuing along a $N .30^{\circ} \mathrm{W}$. line for 2 miles and ending on a prominent point on the cliffs about $11 / 2$ miles north of U.S. Highway 66 in east-central part of sec. $34, T .14 N ., R .12 W . ;$ units 11-20 measured starting at point 2 miles northeast of Chavez in east-central part of sec. $30, T .14 \mathrm{~N} ., \mathrm{R} .12 \mathrm{~W}$., continuing for $11 / 8$ miles northwest, and ending on prominent point about 4 miles east-northeast of Thoreau in southwestern part of sec. 19, T. 14 N., R. 12 W., McKinley County

[Measured by J. H. Stewart and R. F. Wilson, April and May 1956]

Top of section; top of accessible exposure. Top of section is about $500 \mathrm{ft}$ northeast of tip of promontory developed on Entrada Sandstone. Top of section is $\mathrm{N}$. $57^{\circ} \mathrm{W}$. of oil refinery near Chavez and Prewitt and N. $65^{\circ}$ E. of Thoreau.

Entrada Sandstone (incomplete) :

Upper sandy member:

20. Sandstone, light brown $(5 Y R 6 / 4)$ and moderate reddish orange $(10 R 6 / 6)$, weathering same colors, very fine grained, sparse disseminated fine to medium grains; well sorted; composed of subrounded to rounded reddish-stained quartz and sparse black accessory mineral; poorly cemented, calcareous; horizontally laminated in basal $5 \mathrm{ft}$ and composed of thin to very thick planar sets of medium- to large-scale cross-laminae in rest of unit; weathers to form vertical cliff. Basal $2 \mathrm{ft}$ of unit is yellowish gray $(5 Y 8 / 1)$, and this lighter color forms continuous color band on the vertical cliff. Only basal $25 \mathrm{ft}$ of unit examined .............................................. Unmeasured

Medial silty member:

19. Siltstone ( 80 percent) to silty sandstone (20 percent), pale reddish brown $(10 R 5 / 4)$, abundant light greenish gray (5GY 8/1) mottling, weathering same colors and light brown (5YR $6 / 4)$, grades from fine- to mediumgrained siltstone to silty very fine grained sandstone, in places sandstone contains a few fine to medium grains disseminated in the siltstone or silty sandstone; well cemented, calcareous; horizontally laminated to thick bedded, stratification has slight waviness; weathers to form vertical cliff continuous with that of overlying unit. Unit forms horizontally stratified and wavy bedded interval
Entrada Sandstone (incomplete)-Continued Medial silty member-Continued

at base of cliff developed on Entrada Sandstone

Total of medial silty member.

Total of incomplete Entrada Sandstone

Contact of Entrada Sandstone and Wingate Sandstone sharp and placed at change from cross-stratified sandstone below to horizontally stratified siltstone above.

Wingate Sandstone (Lukachukai Member) :

18. Sandstone, light brown $(5 Y R 6 / 4)$ to moderate reddish orange $(10 R 6 / 6)$, weathering same colors, fine grained, minor fine- to medium-grained parts, fair to well sorted; composed of subrounded to rounded reddish-stained quartz, sparse black accessory minerals and white chert(?); poorly cemented calcareous; horizontally laminated in parts and composed of thick, possibly planar sets of low- and highangle medium-scale cross-laminae in other parts; weathers to form steep slope. Sandstone contains common medium to coarse rounded to subrounded reddish-stained quartz grains in a finer grained matrix. Basal 10 $\mathrm{ft}$ of unit contains minor amounts of fine to coarse grains, locally very coarse grains to granules, of white chert(?). Cross-stratified parts of unit are from 3 to $23 \mathrm{ft}, 44$ to $61 \mathrm{ft}$, and 75 to $80 \mathrm{ft}$. Rest of unit is horizontally laminated; possibly very thick bedded in a few places...

Total of Wingate Sandstone (Lukachukai Member)

Contact of Wingate Sandstone and Chinle Formation sharp and marks change from purplish siltstone below to brownish sandstone above. In places, Wingate Sandstone fills clastic dikes extending as much as $5 \mathrm{ft}$ down into the Chinle Formation. These clastic dikes are irregular in shape, and some are several feet wide.

Chinle Formation (incomplete) :

Owl Rock Member:

17. Siltstone and limestone. Siltstone, pale red purple $(5 R P 6 / 2)$ to grayish red purple $(5 R P 4 / 2)$, weathering same colors, fine to medium silt; firmly cemented, calcareous; structureless, a few thin horizontal beds. Limestone, same colors as siltstone, dense; well cemented; present as limestone nodules and thin lenses in basal $9 \mathrm{ft}$ and as thick horizontal bed from 4.1 to $7.1 \mathrm{ft}$. Thick bed of limestone contains abundant small masses of chert. Unit as whole weathers to form steep slope with persistent ledge developed on the limestone bed. Limestone bed 
Chinle Formation (incomplete) - Continued

Owl Rock Member-Continued

forms conspicuous thin purplish band along exposure. Most of unit probably does not contain swelling clays; locally, however, swelling clays may be present

Total of Owl Rock Member.

Petrified Forest Member:

Upper part:

16. Siltstone ( 80 percent) to silty claystone (20 percent), pale reddish brown $(10 R 5 / 4)$, sparse grayish red $(5 R$ $4 / 2$ ), weathering same colors, probably swelling clays; firmly to well cemented, calcareous; dominantly structureless, minor horizontally laminated parts; weathers to form steep slope. Some of unit weathers with a frothy surface

15. Limestone and siltstone. Limestone, light gray $(N 7)$, weathering dark yellowish orange $(10 Y R 6 / 6)$, dense; well cemented; present as two thin horizontal beds separated by 0.3 -in.thick horizontal bed of siltstone. Siltstone, light gray ( $N 7)$, weathering same color, firmly cemented, calcareous. Unit as whole weathers to form small ledge. Unit persistent along exposure and marks change from purplish rocks below to reddish rocks above

14. Silty claystone and minor clayey siltstone and siltstone, very light gray $(N 8)$ in basal $10 \mathrm{ft}$ and grayish red $(5 R 4 / 2)$, pale red $(5 R 6 / 2)$, and minor grayish red purple $(5 R P 4 / 2)$ in rest of unit, weathering same colors, swelling clays, firmly to well cemented, calcareous; structureless; weathers to form steep frothy-surfaced slope. From a distance unit appears as purplish interval between reddish rocks above and below.

13. Siltstone to silty sandstone, and limestone pebble conglomerate. Siltstone to silty sandstone, pale reddish brown $(10 R 5 / 4)$ and pale red $(10 R 6 / 2$ and $5 R 6 / 2$ ), weathering same colors, grades from medium siltstone to silty very fine grained sandstone. Sandstone is fair sorted and composed of subangular grains (composition of grains is masked). Siltstone to silty sandstone contains common mediumgrained accessory white mica and is firmly to well cemented, calcareous. They are horizontally laminated and contain some medium-scale crossstrata on nearby exposures and possibly along line of section. Limestone pebble conglomerate, grayish red pur-
Feet

Chinle Formation (incomplete)-Continued

Petrified Forest Member-Continued

Upper part-Continued

ple $(5 R P 4 / 2)$, weathering same color, composed of coarse grains to cobbles of limestone or limy siltstone in a limy silty or clay matrix; poorly cemented; structureless, possibly some very thin horizontal beds. Limestone pebble conglomerate is present as a 3-ft bed at base of unit and as $2-\mathrm{ft}$ bed at top of unit. Basal bed is mostly composed of coarse grains to granules and minor pebbles. Top bed is composed mainly of granules and pebbles. Top bed contains cobbles as large as 6 in. in maximum diameter. Unit as whole weathers to form steep slope. Locally top limestone pebble conglomerate forms ledge. Position and amount of limestone pebble conglomerate in unit is highly variable along exposure............

12. Siltstone to silty claystone, pale reddish brown $(10 R 5 / 4)$, minor grayish red $(10 R \quad 4 / 2$ and $5 R 4 / 2)$, and sparse pale red $(10 R 6 / 2)$, weathering same colors, silt fraction is fine to medium silt, clay fraction is composed of swelling clay; firmly to well cemented, calcareous; structureless; weathers to form frothy-surfaced badlands. Contains many horizons and thin intervals of limestone nodules.

11. Covered, forms $3 / 4$-mile-wide flat with minor hills and knolls.

Long offset in section so that overlying units measured about $21 / 2$ miles, $N$. $65^{\circ}$ $W$. of underlying units.

10. Sandstone, pale red purple $(5 R P \quad 6 / 2)$ and minor light greenish gray ( $5 G Y$ $8 / 1)$, weathering pale red $(5 R 6 / 2)$ and pale brown $(5 Y R 5 / 2)$, very fine to fine grained, fair sorted; composed of subangular milky quartz(?) and 20 percent dark-gray and sparse orange grains; firmly to well cemented, calcareous; composed of thin to thick tabular planar sets of smallto medium-scale cross-laminae; weathers to form prominent vertical cliff and underlies bench. Unit is most prominent cliff and bench-forming unit in the Chinle Formation above the Sonsela Sandstone Bed. Basal $3.3 \mathrm{ft}$ of unit is limestone pebble conglomerate. Limestone pebble conglomerate, light greenish gray ( $5 G Y$ $8 / 1$ ), composed of rounded coarse grains to pebbles as large as 2 in. in maximum diameter of gray limestone, limy silt matrix, firmly to well cemented; very low angle cross-strata; intertongues with rest of unit. Thick-
Feet

23.0 
Chinle Formation (incomplete)-Continued

Petrified Forest Member-Continued

Upper part-Continued

ness of unit appears to be maximum for local area. Units 6-10 measured up prominent point N. $50^{\circ}$ W. of Prewitt

9. Sandstone, pale red purple (5RP 6/2) subordinate light-greenish-gray ( $5 G Y$ $8 / 1$ ) mottling, weathering same colors, very fine grained, well sorted; composition mostly masked, 10 percent of rock is orange or black grains, common coarse-grained accessory white and dark mica; well indurated, noncalcareous; horizontally laminated and minor thin shallow trough sets of very low angle small- to mediumscale cross-laminae; weathers to form ledgy slope

8. Siltstone (70 percent), silty sandstone (20 percent), and silty claystone (10 percent), all lithologies intergrading, pale reddish brown $(10 R 5 / 4)$ and minor pale red $(10 R 6 / 2)$, weathering same colors, silty sandstone is similar to that in unit 6 , swelling clays in both the siltstone and silty claystone; firmly to well indurated, noncalcareous; mostly structureless, a few thin sets of horizontal laminae, many horizontal stratification planes; weathers to form steep slope, locally slope weathers with a frothy surface. Unit contains a few thin lenses of limestone-grain sandstone similar to that in unit 6 except that some are light greenish gray (5GY 8/1)

7. Silty sandstone to sandy siltstone, pale red $(10 R 6 / 2$ and $5 R 6 / 2)$, weathering same colors, grades from silty, very fine grained sandstone to very fine grained sandy siltstone, sparse coarse-grained accessory white mica; well indurated, noncalcareous; horizontally laminated and minor amounts of thin to very thin shallow trough sets of very low angle small-scale cross-laminae; weathers to form ledge. Locally along exposure ledges similar in lithology to this one are found in the underlying unit and as high as $15 \mathrm{ft}$ up in the overlying unit

6. Siltstone to silty sandstone, pale red $(10 R 6 / 2)$ and pale reddish brown $(10 R 5 / 4)$, weathering same colors, grades from siltstone to silty finegrained sandstone, all gradations of lithology, probably 60 percent of unit is silty sandstone, 30 percent sandy siltstone and 10 percent siltstone, composition masked; firmly to well cemented, noncalcareous to slightly calcareous; structureless (40 percent), horizontally laminated (30
$39.2 \quad \begin{array}{r}\text { Chinle Formation (incomplete)-Continued } \\
\text { Petrified Forest Member-Continued } \\
\text { Upper part-Continued } \\
\text { percent), and medium- to large-scale } \\
\text { very low angle cross-strata (30 per- } \\
\text { cent). Cross-strata are in sets from a } \\
\text { few feet to } 20 \mathrm{ft} \text { thick. Probably both } \\
\text { shallow trough sets and tabular pla- } \\
\text { nar sets are present. Unit as whole } \\
\text { weathers to form steep slope. About } \\
5 \text { percent of unit is pale-red (10R } \\
6 / 2) \text { limestone-grain sandstone. The } \\
\text { limestone-grain sandstone is coarse to } \\
\text { very coarse grained and locally grades } \\
\text { to limestone granule conglomerate. } \\
\text { The limestone-grain sandstone and } \\
\text { limestone granule conglomerate occur } \\
\text { as thin to thick lenses interstratified } \\
\text { with the rest of the unit................... }\end{array}$

5. Covered, weathers to form mile-wide flat. Measured along a N. $30^{\circ} \mathrm{W}$. line

4. Sandstone (70 percent) and siltstone (30 percent). Sandstone, pale red purple (5 RP 6/2), weathering same color, very fine grained, well sorted; composition mostly masked (about 20 percent of grains are either dark gray or orange); well cemented, slightly calcareous; composed of thin trough sets of very low angle smallto medium-scale cross-laminae, subordinate horizontal laminae. Siltstone, grayish red $(10 R 4 / 2)$, weathering same color, about 20 percent of rock is coarse grains to granules of lightgray siltstone; poorly cemented, calcareous; structureless; present as thin to thick lenses interstratified with thin to thick sets or cosets of sandstone. Unit as whole weathers to form small irregular ledge and underlies bench

3. Clayey siltstone to sandy siltstone, grayish red $(5 R 4 / 2)$ and minor grayish purple $(5 P 4 / 2)$, common light-greenish-gray $(5 G Y$ 8/1) mottling, weathering same colors, sandy (very fine grained) in part, probably swelling clays; firmly cemented, calcareous, structureless, exposed in roadcut

2. Covered, weathers to form flat between Sonsela Sandstone Bed and unit $3 \ldots$.

Total of upper part of Petrified Forest Member

308.0

$8.0 \pm$

Sonsela Sandstone Bed:

1. Sandstone, same as that in unit 14 of Chavez-Prewitt section A. Contains a few scattered granules and pebbles of chert, quartzite, and quartz, stratification is not distinct but appears to be mostly low-angle medium-scale cross-laminae. Only $10 \mathrm{ft}$ of unit ex- 
Chinle Formation (incomplete)-Continued

Petrified Forest Member-Continued

Sonsela Sandstone Bed-Continued posed. Weathers to form lowest part of dip slope developed on Sonsela Sandstone Bed. Observation suggests that the incomplete thickness of the Sonsela in Chavez-Prewitt section A is within $50 \mathrm{ft}$ of being the complete thickness Unmeasured

Total of incomplete Chinle Formation

Base of section; base of exposure. Base of section about $500 \mathrm{ft}$ south of U.S. Highway 66 and about 2 miles west of Prewitt.

\section{NM-2. FORT DEFIANCE SECTION}

Measured on cliff about $5 \frac{1}{2}$ miles north-northeast of Fort Defiance, about $\&$ miles north of Clay Springs Wash, and about 1 mile south of Twin Buttes Wash, long $109^{\circ} 01^{\prime} 50^{\prime \prime}$ W., lat $35^{\circ} 49^{\prime} 25^{\prime \prime}$ N., McKinley County

[Mensured by J. H. Stewart and R. F. Wilson, April 1956]

Top section; top of accessible exposure.

Entrada Sandstone (incomplete) :

Upper sandy member (unmeasured) :

10. Sandstone, light brown $(5 Y R 6 / 4)$ and pale reddish brown $(10 R 5 / 4)$, weathering same colors, very fine grained, common medium to coarse wellrounded quartz and minor chert(?) grains, well sorted; composed of subrounded reddish-stained quartz and 2 percent black minerals; poorly to firmly cemented, calcareous; composed dominantly of wedge and some tabular(?) planar sets of high-angle medium- to large-scale cross-laminae, but some trough sets of low-angle medium-scale cross-laminae are present in basal $10 \mathrm{ft}$ of unit; weathers to form vertical cliff. Only basal $10 \mathrm{ft}$ of unit examined. Unit about $300 \mathrm{ft}$ thick. Basal contact distinct and is the only distinct contact in the section between the top of the medial ledge of the Rock Point Member to the top of the Entrada Sandstone.

Unmeasured

Medial silty member:

9. Sandy siltstone to silty sandstone, light brown $(5 Y R$ 6/4) and pale reddish brown $(10 R 5 / 4)$, weathering same colors, composed of particles ranging from coarse silt to very fine sand; well sorted; composed of reddishstained quartz and 2 percent black grains; firmly cemented, slightly calcareous; horizontally laminated, slight waviness to laminae suggests ripple laminae in places, ripple laminae common in top $15 \mathrm{ft}$; sparse thin trough sets of low-angle small-scale crosslaminae; weathers to form vertical cliff. Locally a thin lens of white (N 9) sandstone is present away
Feet Entrada Sandstone (incomplete)-Continued Medial silty member-Continued

from line of section, either at the base or in the basal $5 \mathrm{ft}$ of the unit. This sandstone is composed of wellrounded coarse quartz grains. Basal $10 \mathrm{ft}$ of unit contains a few percent of medium to coarse well-rounded clear quartz and white chert (?) grains. Unit weathers with a knobby or hoodoo appearance. Unit very similar to underlying unit but contains medium to coarse grains in basal $10 \mathrm{ft}$, weathers with a more hoodoo-type cliff, and possibly contains more ripple laminae than underlying unit. From a distance unit can be differentiated from one below by hoodoo weathering

Total of medial silty member..........

Total of incomplete Entrada Sandstone

Feet

Wingate Sandstone:

Rock Point Member:

8. Sandstone, light brown $(5 Y R 6 / 4)$ and minor pale reddish brown (10R 5/4), weathering same colors, very fine grained, well sorted; composed of subrounded amber-stained quartz and about 2 percent black minerals; poorly cemented, calcareous; horizontally laminated, some wavy laminae suggesting ripple laminae in places, sparse thin trough sets of low-angle small-scale cross-laminae; weathers to form steep slope or vertical cliff. Unit very similar to underlying unit but is somewhat coarser grained, contains better developed laminae, and contains some cross-strata....................

7. Sandstone to sandy siltstone, light brown $(5 Y R 6 / 4)$ and a few light greenish gray (5GY 8/1) color bands, weathering same colors, grades from coarse silt to very fine grained sand, well sorted; composed of subrounded clear quartz and abundant black accessory minerals; horizontally laminated to thick bedded; weathers to form slope

6. Sandstone, light brown (5YR 6/4), weathering same color, very fine to fine grained, sparse disseminated coarse grains, fair sorted; composed of subrounded to rounded clear quartz and common black accessory minerals, coarse grains commonly white chert(?) ; poorly cemented, calcareous; composed of thin to very thick wedge planar sets of low- and high-angle medium- and possibly large-scale cross-laminae, abundant horizontally laminated sets in top $\mathbf{1 5}$
54.0 
Wingate Sandstone-Continued

Rock Point Member-Continued

$\mathrm{ft}$; massive splitting; weathers to form vertical cliff that forms most prominent cliff in. Rock Point Member $\therefore$

5. Sandstone, light brown $(5 Y R \quad 6 / 4)$, weathering same color, very fine grained, well sorted; composed of subrounded reddish-stained quartz and abundant black accessory mineral; poorly cemented, calcareous; horizontally laminated, and a few poorly defined low-angle cross-strata; weathers to form ledgy interval at base of vertical cliff developed on overlying unit

4. Siltstone, light brown $(5 Y R 6 / 4)$, weathering pale reddish brown $(10 R 5 / 4)$, coarse silt; firmly cemented, calcareous; horizontally laminated; weathers to form steep slope or vertical cliff....

3 . Siltstone, grayish red $(10 R 4 / 2)$, weathering pale reddish brown (10R 5/4), medium silt; firmly cemented, calcareous; structureless, a few horizontal stratification planes; weathers to form steep slope...

2. Covered. Weathers to form gentle slope between cliffs on Entrada Sandstone and hogback on Owl Rock Member. Unit probably lithologically similar to unit 3

Total of Rock Point Member

Total of Wingate Sandstone

Owl Rock Member:

1. Siltstone (80 percent) and limestone or limy siltstone (20 percent). Siltstone, grayish red purple (5 $R P 4 / 2$ ), weathering pale red purple $(5 R P$ $6 / 2$ ), fine silt; firmly cemented, calcareous; structureless. Limestone, grayish red purple $(5 R P 4 / 2)$, light greenish gray ( $5 G Y 8 / 1)$, and sparse grayish red $(10 R 4 / 2)$, weathering same colors, dense; well cemented; horizontally laminated to thin bedded; present as thin sets interstratified with siltstone. About $30 \mathrm{ft}$ of unit exposed; weathers to form low purplish knobs or hogback about $200 \mathrm{ft}$ west of main cliffs Unmeasured

Base of section; base of exposure.

\section{NM-3a. FORT WINGATE SECTION A}

Measured starting at point about $1 / 2$ mile $N .20^{\circ} \mathrm{W}$. of Navajo Sheep Laboratory and continuing for about $11 / 2$ miles northnortheast to promontory on line of cliffs in northernmost part of Fort Wingate ordinance depot. Section about 11/2 miles west of town of Fort Wingate, long $108^{\circ} 33^{\prime} 35^{\prime \prime}$ to $108^{\circ} 34^{\prime} 15^{\prime \prime} W$., lat $35^{\circ} 27^{\prime} 40^{\prime \prime}$ to $35^{\circ} 28^{\prime} 55^{\prime \prime}$ N., McKinley County

[Measured by J. H. Stewart and R. F. Wilson, April 1956]

42.2
Feet Top of section; top of exposure. Top of section is about 1 mile N. $50^{\circ}$ W. from water tower at Fort Wingate and about 1 mile N. $17^{\circ}$ E. from Navajo Sheep Laboratory.

Chinle Formation (incomplete) : Petrified Forest Member (incomplete) :

Sonsela Sandstone Bed (incomplete):

18. Sandstone, similar to unit 16. Sandstone commonly contains gray and green claystone and siltstone pellets. A few thin sets contain a few (5 percent) gray chert granules and pebbles as large as $1 \mathrm{in.}$ in maximum diameter. Basal $4 \mathrm{ft}$ of unit is composed of greenish-gray fine-grained well-cemented sandstone that is dominantly horizontally laminated but that contains some very low angle cross-laminae. Unit weathers to form vertical cliff and underlies mesa

andy and silty claystone, grayish red $(5 R 4 / 2)$, greenish gray $(5 G Y 6 / 1)$ in top $0.5 \mathrm{ft}$, weathering same colors, sandy (very fine grained) in parts; poorly indurated, clay binding; stratification concealed; weathers to form slope

16. Sandstone, very pale orange $(10 Y R$ $8 / 2)$, pinkish gray $(5 Y R 8 / 1)$, and yellowish gray $(5 Y 8 / 1)$, weathering same colors, fine to medium grained, fair to well sorted; composed of subrounded to subangular clear and milky quartz and common black accessory mineral; firmly cemented, calcareous; composed of thin to thick trough and tabular planar sets of small- to medium-scale cross-laminae; weathers to small ledge. Unit contains abundant purplish claystone and siltstone pellets and films along laminae. No conglomerate noted

15. Silty claystone to sandy siltstone $(80$ percent) and sandstone (20 percent). Silty claystone to sandy siltstone, light greenish gray (5GY 8/1), medium gray ( $N 5)$, and grayish purple (5P $4 / 2$ ), weathering same colors, sand fraction is very fine grained; firmly indurated, clay binding, noncalcareous; stratification concealed. Sandstone, light greenish gray ( $5 G Y 8 / 1)$ to greenish gray ( $5 G Y 6 / 1)$, weathering same colors, fine grained, well sorted; composed of subangular clear quartz and sparse orange accessory minerals; well indurated, noncalcareous; horizontally laminated, some wavy laminae, sparse small- to medium-scale low-angle cross-laminae. Unit as a whole weathers to form slope. Sandstone is present as set from 5.6 to $7.0 \mathrm{ft}$ and forms ledge....
Feet 
Chinle Formation (incomplete)-Continued

Petrified Forest Member (incomplete)-Con.

Sonsela Sandstone Bed (incomplete)-Con.

14. Sandstone, light greenish gray (5GY $8 / 1$ ), weathering same color, medium to coarse grained, some very coarse grains and granules, abundant interstitial clay, poorly sorted; composed of subangular clear and milky quartz, 5 percent orange mineral; poorly indurated, clay binding and calcareous cement; stratification concealed; weathers to form slope. Possibly a few chert granules

Total of incomplete Sonsela Sandstone Bed

Lower part:

13. Silty claystone, grayish purple (5P 4/2) with light-greenish-gray (5GY 8/1) mottling, common very light gray (N 8), weathering same colors, swelling clays; firmly to well indurated, noncalcareous clay binding; structureless; weathers to form steep frothysurfaced slope. Contains several limestone-nodule horizons. Unit is light greenish gray $(5 G Y 8 / 1)$ or yellowish gray $(5 Y 8 / 1)$ in top $5 \mathrm{ft}$.

12. Sandy siltstone (90 percent) to silty sandstone $(10$ percent $)$, pale red purple $(5 R P \quad 6 / 2)$ and light greenish gray (5GY 8/1), colors mottled, grades from silt with minor very fine to fine grains to silty, fine-grained sandstone, poorly to fair sorted; sand fraction composed of subangular milky quartz(?), 10 percent orange grains, and 3 percent coarse-grained darkgreen mica; well indurated, noncalcareous, clay binding; horizontally laminated, minor amounts of very low angle large-scale cross-laminae, much of stratification concealed; weathers to form steep slope. Unit forms conspicuous white band along local and distant exposures. Base of unit marks prominent change from reddish rocks below to purplish rocks above.

11. Silty claystone, moderate red $(5 R 5 / 4)$, pale reddish brown $(10 R 5 / 4)$, and grayish red $(5 R 4 / 2)$, weathering moderate red $(5 R 5 / 4)$, contains some clayey siltstone; firmly to well indurated, noncalcareous, clay binding; structureless; weathers to form frothy-surfaced slope. Probably bentonitic although claystone does not swell noticeably on contact with water. Units 11 to 18 measured about 1 mile N. $50^{\circ} \mathrm{W}$. of water tower at Fort Wingate

10. Siltstone to silty sandstone, pale red $(5 R \quad 6 / 2)$ and light greenish gray \begin{tabular}{l} 
Fee \\
12.0 \\
\hline 88.3 \\
\hline
\end{tabular}

Chinle Formation (incomplete)-Continued

Petrified Forest Member (incomplete)-Con.

Lower part-Continued

$(5 G Y 8 / 1)$ in top $1.5 \mathrm{ft}$, weathering same colors, grades from coarse siltstone to silty very fine grained sandstone, common medium- to fine-grained accessory white mica; well cemented, calcareous; ripple laminated in top $1.5 \mathrm{ft}$, possibly some small-scale lowangle cross-strata; weathers to form small ledge at base of prominent cliff

9. Claystone, grayish red $(5 R 4 / 2)$, grayish red purple $(5 R P 4 / 2)$, some light-greenish-gray ( $5 G Y$ 8/1) mottling, weathering same colors and pale red $(5 R 6 / 2)$, probably swelling clays; firmly indurated, noncalcareous, clay binding; structureless; weathers to form slope.

8. Covered, forms 1,000 -ft-wide flat............

Total of lower part of Petrified Forest Member

Total of incomplete Petrified Forest Member

Total of Petrified Forest Member (composite of Fort Wingate sections $\mathrm{A}$ and $\mathrm{B}$ )

Lower red member:

7. Sandstone (70 percent) and limestone pebble conglomerate (30 percent). Sandstone, very light gray (N 8), white $(N 9)$, and pinkish gray (5YR 8/1), weathering pinkish gray $(5 Y R 8 / 1)$, very fine to fine grained, well sorted; composed of subrounded clear quartz and common black and sparse green accessory minerals, sparse medium-grained accessory white mica; firmly to well cemented, calcareous; composed of thin shallow trough and tabular planar sets of small- to medium-scale low-angle cross-laminae, ripple-laminated in top $3 \mathrm{ft}$ of unit. Limestone pebble conglomerate, very light gray ( $N 8)$, weathering moderate yellowish brown $(10 Y R$ 5/4), composed of subrounded to rounded coarse grains to pebbles of grayish limestone and possibly siltstone in a fine-grained matrix similar to that in the sandstone part of the unit (pebbles are commonly as large as 1 in. in maximum diameter); well cemented, calcareous; present as thin to thick structureless lenses interstratified with and interfingering irregularly with the sandstone part of unit. Limestone pebble conglomerate confined to lower half of unit. Unit as whole weathers to form ledge. Unit highly variable in lithology and thick- 
Chinle Formation (incomplete)-Continued

Lower red member-Continued

ness along exposure. Locally entire unit is limestone pebble conglomerate

Section off set at top of unit 6 , so that overlying units measured about 1,000 ft north of unit 6 .

6. Claystone, grayish purple $(5 P 4 / 2)$, grayish red purple $(5 R P 4 / 2)$, and sparse greenish gray $(5 G Y 6 / 1)$ in basal $50.4 \mathrm{ft}$, dark reddish brown $(10 R 3 / 4)$ in top $40.2 \mathrm{ft}$, weathering same colors, silty in parts, swelling clays; firmly indurated, calcareous in parts; structureless, a few horizontal stratification planes; weathers to form frothy-surfaced slope

5. Covered; forms 1,000 -ft-wide flat ........

Total of lower red member.

Shinarump(?) Member:

4. Sandstone (70 percent) to conglomerate (30 percent), pale yellowish brown $(10 Y R 6 / 2)$ and very light gray $(N$ $8)$, weathering very pale orange $(10 Y R 8 / 2)$. Sandstone is very fine grained, well sorted, and composed of subrounded clear quartz. Conglomerate is composed of white and orange granules and pebbles of quartz averaging about $1 / 4$ to $1 / 2$ in. in maximum diameter and of white or yellowish gray granules and pebbles of siltstone or possibly dolomite; granules and pebbles are in a very fine to fine-grained matrix. Sandstone to conglomerate is well cemented, calcareous; composed of thin trough sets of low-angle medium-scale cross-laminae in lower half and ripple laminae in upper half; weathers to form ledge. Thickness is maximum for local area. Conglomerate is present as thin to thick lenses interstratified with and interfingering irregularly with the sandstone. Basal contact is erosion surface with scours as much as $3 \mathrm{ft}$ deep

Total of Shinarump (?) Member......

Section transferred on top of unit 3 , so that overlying units measured $2,000 \mathrm{ft}$ north, down creek from where unit 3 and underlying units measured.

Mottled strata :

3. Silty sandstone, mottled light greenish gray $(5 G Y 8 / 1)$, grayish purple ( $5 P$ $4 / 2)$, pale red purple $(5 R P 6 / 2)$, and grayish red $(5 R 4 / 2)$, sparse dark yellowish orange $(10 Y R 6 / 6)$, weathering same colors, silty, very fine to fine grained, about 10 to 20 percent of rock is medium grains to pebbles as large as $1 / 2$ in. in maximum diameter, poorly sorted; composition of very fine
Chinle Formation (incomplete)-Continued Mottled strata-Continued

to fine grains concealed, medium to coarse grains are subangular clear quartz and, in lesser amounts, orange quartz; granules and pebbles are subrounded clear and orange quartz; wellindurated, possibly siliceous cement, noncalcareous; structureless; weathers to form hackly surfaced ledge and forms tops of low mesas or hills in local area

Total of mottled strata

Total of Chinle Formation (composite of Fort Wingate sections $A$ and $B$ )
90.6

$\underline{112.0}$

224.6

$\underline{=}$
Moenkopi (?) Formation:

2. Siltstone (40 percent) and sandstone (60 percent). Siltstone, grayish red $(10 R 4 / 2)$, weathering same color, medium to coarse silt, sandy in parts (very fine grained), sparse very fine grained accessory white mica; firmly indurated, noncalcareous clay binding; stratification concealed; platy splitting suggesting that rock is horizontally laminated. Silty sandstone, pale red $(5 R 6 / 2)$, rare dark reddish brown $(10 R 3 / 4)$, weathering pale reddish brown $(10 R 5 / 4)$, silty, very fine to fine grained, fair to well sorted; composition masked, grains are dark gray or red; well indurated, noncalcareous; stratification mostly concealed, some horizontal(?) laminae, possibly a few low-angle crosslaminae. Sandstone is present as thin to thick sets interstratified with the siltstone. Top $5 \mathrm{ft}$ of unit is dominantly dark reddish brown $(10 R 3 / 4)$ and contains mottling of very light gray $(N 8)$ and pale red purple (5RP $6 / 2$ ). Possibly some of the mottled rock belongs in overlying unit. Contact with overlying unit placed at change from dominantly brownish rock below to dominantly mottled purple, white, and brown rock above, and also at change from sandstone below to sandstone above containing a few scattered granules of quartz. In addition, overlying unit forms a fairly well defined ledge

Total of Moenkopi(?) Formation...

San Andres Limestone:

Limestone member:

1. Dolomite and possibly some limestone, yellowish gray $(5 Y 8 / 1)$, weathering same color, dense; well cemented; structureless, some suggestion of horizontal stratification planes; weathers to form ledge. About $12 \mathrm{ft}$ exposed Unmeasured 
Base of section; base of exposure. Base of section about $1 / 2$ mile N. $20^{\circ}$ W. of Navajo Sheep Laboratory on east side of creek that passes directly west of the laboratory.

\section{NM-3b. FORT WINGATE SECTION B}

Measured in westernmost part of Fort Wingate ordinance depot about $31 / 2$ to $41 / 2$ miles west of town of Fort Wingate; units 1-11 measured from long $108^{\circ} 35^{\prime} 50^{\prime \prime}$ to $108^{\circ} 36^{\prime} 40^{\prime \prime} W$. and lat $35^{\circ} 28^{\prime} 05^{\prime \prime} N$., and units 12-22 measured from long $108^{\circ} 36^{\prime} 50^{\prime \prime}$ to $108^{\circ} 37^{\prime} 30^{\prime \prime} \mathrm{W}$. and lat $35^{\circ} 28^{\prime} 50^{\prime \prime} \mathrm{N}$., McKinley County

[Measured by J. H. Stewart and R. F. Wilson, April 1956]

Top of section; not top of exposure.

Entrada Sandstone (incomplete):

Upper sandy member:

22. Sandstone, light brown (5YR 6/4), weathering same color, very fine grained, well sorted; composed of subrounded reddish-stained quartz and abundant black accessory mineral; firmly to poorly cemented, calcareous; composed of thin to very thick wedge planar sets of low-angle medium- to large-scale cross-laminae, common sets from 1 to $30 \mathrm{ft}$ thick of horizontally laminated sandstone interstratified with rest of unit; weathers to form smooth bare rock slope and ledges. Basal foot of unit is white ( $N$ 9) Unmeasured

Medial silty member:

21. Sandstone and minor sandy siltstone, light brown (5YR 6/4) and pale reddish brown $(10 R 5 / 4)$, weathering pale reddish brown $(10 R 5 / 4)$, very fine grained sandstone to coarse siltstone with subordinate very fine grained sand, well sorted; composed of subrounded reddish-stained quartz and 5 percent black mineral; firmly to well cemented, calcareous; structureless, stratification concealed in some places; weathers to form earthy slope. Contains two thin beds of white (N 9) fine-grained sandstone in basal half

Total of medial silty member.

Wingate Sandstone:

Total of incomplete Entrada Sandstone

Lukachukai Member:

20. Sandstone, light brown (5YR 6/4), weathering same color, fine grained, sparse disseminated medium to coarse grains, fair to well sorted; composed of subrounded reddish-stained quartz and abundant black and white accessory minerals; poorly cemented, calcareous; composed of thin to very thick wedge and tabular planar sets of medium- to large-scale high-angle cross-laminae, common (20 percent) horizontally laminated or structure-
Wingate Sandstone-Continued

Feet

Lukachukai Member-Continued

less parts; weathers to form vertical cliff in basal $50 \mathrm{ft}$ and rough gentle slope in rest of unit. One lamina was noted that was 30 percent very coarse grains to small granules of gray and milky quartz and white chert. Basal foot of unit is white (N 9). Unit from 139.4 to $144.4 \mathrm{ft}$ is siltstone. Siltstone, grayish red (10R 4/2), weathering same color fine silt, abundant very fine grained mica; poorly cemented, slightly calcareous; stratification concealed, platy splitting. Parts of unit poorly exposed

Total of Lukachukai Member ........

158.4

$\overline{\mathbf{1 5 8 . 4}}$

Rock Point Member:

19. Siltstone, pale reddish brown $(10 R 5 / 4)$ and light brown (5YR 6/4), weathering same colors, medium silt; poorly to firmly cemented, calcareous; structureless; a few horizontal stratification planes; weathers to form slope...

Total of Rock Point Member ........

Total of Wingate Sandstone

$\frac{30.8}{\frac{30.8}{189.2}}$

Chinle Formation (incomplete) :

Owl Rock Member:

18. Siltstone (50 percent) and silty limestone (50 percent). Siltstone pale reddish brown $(10 R 5 / 4)$, weathering same color, fine silt; firmly cemented, calcareous; stratification concealed. Silty limestone, pale reddish brown $(10 R 5 / 4)$, and minor pale red purple (5RP 6/2), weathering same colors, dense; well cemented; stratification concealed; silty limestone grades to siltstone. Siltstone contains abundant limestone nodules in places. Unit marks top of purplish-appearing rocks

14.4

17. Limestone, grayish red $(5 R P 4 / 2)$ and minor light greenish gray ( $5 G Y 8 / 1$ ), weathering light gray $(N 7)$, dense; well cemented; unit is a thick horizontal bed; weathers to form ledge which is most prominent one in the upper part of Chinle Formation........

16. Siltstone, pale reddish brown $(10 R 5 / 4)$ and pale red purple $(5 R P 6 / 2)$ in top foot, weathering same colors, fine to medium silt; firmly cemented, calcareous; structureless, weathers to form slope

15. Limestone, grayish red purple (5RP $4 / 2$ ), weathering same color, dense; well cemented; unit is horizontal bed; weathers to form knobby ledge. Unit does not appear to extend more than $100 \mathrm{ft}$ away from line of section........

Total of Owl Rock Member 
Chinle Formation (incomplete)-Continued

Petrified Forest Member (incomplete) : Upper part:

14. Clayey siltstone, pale reddish brown $(10 R 5 / 4)$, light brown $(10 Y R 6 / 4)$, sparse brownish gray $(5 Y R 4 / 1)$ and moderate yellowish brown $(10 Y R$ $5 / 4)$, weathering same color:s, fine to medium silt, clayey, some silty claystone, probably nonbentonitic; firmly cemented, noncalcareous; structureless; weathers to form slope covered by thin loose veneer of debris. This unit might contain some bentonitic rocks but base of unit marks change from largely bentonitic rocks below to largely nonbentonitic rocks above. When viewed from a distance, unit weathers with smooth surface instead of frothy surface as does underlying unit. Locally away from line of section about top $40 \mathrm{ft}$ of unit contains a few thin silty limestone beds

13. Claystone (40 percent), siltstone (43 percent), and minor silty and clayey sandstone (17 percent), pale reddish brown $(10 R 5 / 4)$, moderate red $(5 R$ $5 / 4)$, grayish red $(5 R 4 / 2)$, pale red $(10 R 6 / 2)$, and sparse light-greenish-gray ( $5 G Y 8 / 1$ ) bands; swelling clays; firmly indurated, clay binding, noncalcareous; structureless, indistinct horizontal beds in some parts, possibly a few low-angle cross-strata. Silty and clayey sandstone is very fine grained; the composition is concealed. Purplish colors are most conspicuous in basal 30 to $40 \mathrm{ft}$ of unit. Top half of unit probably contains more siltstone than bottom half. These siltstones do not appear to contain swelling clays

12. Sandstone, yellowish gray (5Y 8/1), light greenish gray $(5 G Y 8 / 1)$, and light olive gray $(5 Y 6 / 1)$, weathering same colors, very fine to fine grained, fair sorted; composed of subangular clear quartz, accessory minerals masked; well cemented, calcareous; horizontally laminated and thin trough and tabular planar sets of low-angle small- to medium-scale cross-laminae; weathers to form hogback. Hogback is about as prominent as that developed on the Sonsela Sandstone Bed. Unit contains abundant siltstone pellets in some places. Unit is highly variable in thickness along exposure and locally sandstone is split into two ledges separated by a siltstone or claystone interval. Unit measured at place S. $45^{\circ}$ E. of water tower on Fort Wingate ordinance depot

\author{
Feet Chinle Formation (incomplete)-Continued \\ Petrified Forest Member (incomplete)-Con. \\ Upper part-Continued \\ Offset in section, so that unit 12 and over- \\ lying units are measured about $3 / 4$ mile \\ north of underlying units. Possibly as \\ much as 10 or $20 \mathrm{ft}$ of section lost or \\ gained in offset.
}

11. Clayey siltstone to clayey sandstone, light greenish gray (5GY 8/1), weathering same color, grades from clayey siltstone to very fine grained clayey sandstone, some fine to coarse grains, common accessory white and dark mica; stratification concealed; weathers to form slope

10. Sandstone, light brownish gray (5YR $6 / 1)$ and light olive gray (5Y 6/1), weathering same colors, fine grained, well sorted; composed of subrounded to subangular clear quartz and abundant black and orange accessory minerals; firmly cemented, calcareous; horizontally laminated, some shallow, thin trough sets and tabular planar sets of low-angle small-scale crosslaminae; weathers to form ledge. Unit is a lens extending for about $1,000 \mathrm{ft}$ along the outcrop. Contains some siltstone pellets. One bone fragment noted

9. Claystone to clayey siltstone, pale reddish brown $(10 R 5 / 4)$, moderate red $(5 R 5 / 4)$, and grayish red $(5 R 4 / 2)$, subordinate grayish red purple ( $5 R P$ $4 / 2$ ) in basal $30 \mathrm{ft}$, weathering same colors; swelling clays; firmly indurated, clay binding, calcareous; mostly structureless, a few horizontal bedding planes and very thin to thin beds; weathers to form frothy-surfaced badlands. Contains several thin to very thick lenses of clayey and silty sandstone in basal half. These sandstones range from very fine to medium grained

8. Siltstone to silty sandstone, grayish red $(5 R 4 / 2)$ and grayish red purple (5RP $4 / 2$ ), weathering same colors, nonswelling clays, horizontally very thin to thick bedded in upper part, lowangle inclined laminae in lower part; weathers to form slope.

Total of upper part of Petrified Forest Member

Sonsela Sandstone Bed:

7. Sandstone, light olive gray (5Y 6/1), light gray $(N 7)$, and light greenish gray ( $5 G Y 8 / 1)$, weathering same colors, fine to medium grained, fair to poorly sorted, composed of subrounded to subangular clear and milky quartz, 5 percent black grains and 2 percent orange grains; poorly
Feet 6.8

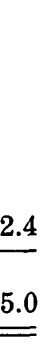


Chinle Formation (incomplete)-Continued

Petrified Forest Member (incomplete)-Con.

Sonsela Sandstone Bed-Continued

cemented, calcareous; composed of thin to thick trough sets of mediumscale low-angle cross-laminae; weathers to form ledge and basal part of dip slope developed in upper part of Sonsela Sandstone Bed. Contains a thin bed of conglomerate at base. Conglomerate contains pebbles of red, black, and gray chert and sparse white quartz. Pebbles are as large as $11 / 2$ in. in maximum diameter. A few scattered granules and pebbles are present in rest of unit.

6. Silty and clayey sandstone (90 percent) and silty claystone (10 percent). Silty and clayey sandstone, light greenish gray $(5 G Y 8 / 1)$ and greenish gray (5GY 6/1), weathering same colors, fine to medium grained, sparse coarse grains, poorly sorted; composed of subangular to angular clear and milky quartz and abundant orange and green accessory minerals, common dark-green accessory mica; poorly indurated, clay binding; horizontally laminated to thin bedded. Silty claystone, similar to claystone in unit 3. Unit as whole weathers to form slope.

5. Mostly covered, probably mostly reddish claystone and siltstone

4. Sandstone to conglomerate, yellowish gray $(5 Y 8 / 1)$, weathering same color, fine to medium grained, fair sorted; composed of subangular clear and milky quartz and 2 to 5 percent black and red accessory minerals; firmly to well cemented, noncalcareous; composed of thin to thick trough sets of low-angle medium-scale crosslaminae; weathers to form a ledge and part of dip slope of hogback developed on Sonsela Sandstone Bed. Conglomerate to conglomeratic sandstone constitutes about 10 to 20 percent of the unit and is composed of gray, red, and black chert and minor white quartz pebbles in a fine- to mediumgrained sand matrix. Pebbles are as large as $2 \mathrm{in.}$ in maximum diameter. Unit is highly variable in thickness and in content of conglomerate.

3. Claystone (80 percent) and clayey sandstone (20 percent). Claystone, grayish red purple ( $5 R P 4 / 2)$, weathering same color; swelling clays; poorly indurated, slightly calcareous; stratification concealed. Clayey sandstone, light brownish gray (5YR 6/1) and light greenish gray (5GY 8/1), weathering same colors, very fine to Feet $\mid \begin{array}{r}\text { Chinle Formation (incomplete)-Continued } \\ \text { Petrified Forest Member (incomplete)-Con. } \\ \text { Sonsela Sandstone Bed-Continued } \\ \text { fine grained, fair sorted; composed } \\ \text { of subangular clear and milky quartz } \\ \text { and } 5 \text { percent black and green acces- } \\ \text { sory mineral; poorly cemented, clay } \\ \text { binding; stratification concealed. Unit } \\ \text { as whole weathers to form slope....... } \\ \text { 2. Sandstone, same as unit 16, Fort Win- } \\ \text { gate section A. In basal 20 ft, unit } \\ \text { contains a few thin lenses containing } \\ \text { a few scattered granules and pebbles. } \\ \text { Granules and pebbles are as large as } \\ 1 \text { in. in maximum diameter and are } \\ \text { composed of gray, and minor red, } \\ \text { chert. Basal contact of unit covered. } \\ \text { Unit poorly exposed in upper part. } \\ \text { Thickness of unit may be slightly in } \\ \text { error because of low dips and long } \\ \text { dip slopes ............................................ }\end{array}$

Feet

Total of Sonsela Sandstone Bed.....

Lower part of Petrified Forest Member:

1. Silty claystone, same as unit 13 , Fort Wingate section A.......................... Unmeasured

Base of section; not base of exposure. Base of section is about 2 miles N. $65^{\circ}$ W. of Navajo Sheep Laboratory, about 2 miles N. $85^{\circ} \mathrm{W}$. of Fort Wingate, and about $1 \frac{1}{2}$ miles $S .71^{\circ} \mathrm{W}$. of top of Fort Wingate section $A$. Units 1-11 measured across a 1-mile-wide area along a S. $75^{\circ} \mathrm{W}$. line.

11.6

16.4

Measured in Todilto Park, 11/4 miles north-northeast of junction of Todilto Wash and Bowl Canyon Wash, long $108^{\circ} 58^{\prime} 05^{\prime \prime} W$., lat $35^{\circ} 57^{\prime} 30^{\prime \prime}$ N., McKinley County

[Measured by J. H. Stewart and R. F. Wilson, April 1956]

Top of section; not top of exposure.

Entrada Sandstone (incomplete) :

Upper sandy member:

14. Sandstone, moderate reddish brown $(10 R 4 / 6)$ to light brown $(5 Y R 6 / 4)$, weathering same colors, very fine grained, well sorted; composed "of subrounded amber-stained quartz and common black accessory mineral; poorly cemented, calcareous; composed of planar sets of small- and medium-scale cross-laminae, some horizontal stratification planes; weathers to form vertical cliff. Only basal $10 \mathrm{ft}$ examined. Basal $3 \mathrm{ft}$ is yellowish gray $(5 Y$ 8/1) and this color forms a prominent band at the base of unit. Unit close to $200 \mathrm{ft}$ thick and forms main part of cliffs in Todilto Park. Base of unit sharp and marks conspicuous lithologic change Unmeasured

Medial silty member:

13. Sandy siltstone to silty sandstone, pale reddish brown $(10 R 5 / 4)$, weathering

83.2

\section{ured}


Entrada Sandstone (incomplete)-Continued

Medial silty member-Continued

same color, grades from sandy siltstone to silty very fine grained sandstone, well sorted; composed of subrounded clear quartz and sparse black accessory minerals; well cemented, slightly calcareous; stratification indistinct, wavy horizontal laminae appear to be dominant, minor thin trough sets of low-angle smallscale cross-laminae; weathers to form vertical cliff with hoodoo or knobby surface. Unit contains about 1 percent medium to coarse quartz and white chert(?) grains. Units 12 and 13 might represent the entire medial silty member. Units 10 and 11 were included in this member because they contain medium to coarse disseminated grains commonly present in the medial silty member and because unit 10 may be a marker horizon of the base of the medial silty member........

12. Sandstone, light brown $(5 Y R 6 / 4)$ and moderate reddish brown $(10 R 4 / 6)$, weathering light brown (5YR 6/4); very fine grained, well sorted; composed of subrounded clear quartz and sparse black accessory minerals; firmly cemented, calcareous. Unit is a tabular planar set of low-angle large-scale cross-laminae. Unit weathers to form steep bare rock slope at base of vertical cliff developed on overlying units. About 1 percent of the grains in the sandstone are medium to coarse clear quartz and white chert (?)

11. Silty sandstone and minor sandy siltstone, light brown $(5 Y R$ 6/4) and pale reddish brown $(10 R 5 / 4)$, weathering same colors, silty, very fine grained sandstone grading to sandy siltstone, fair to well sorted; composed of subrounded reddish-stained quartz and sparse black accessory mineral; firmly cemented, calcareous; structureless; weathers to form slope. A few medium to coarse quartz and white chert(?) grains are present.....

10. Sandstone, pale reddish brown $(10 R$ $5 / 4)$, grayish orange pink (5YR $7 / 2)$ in top foot, weathering same colors, fine to medium grained, common disseminated coarse grains in places, fair to poorly sorted; composed of subrounded to subangular reddishstained quartz and 1 percent black grains, coarse grains are commonly white chert (?) ; firmly cemented, calcareous; composed dominantly of thin trough sets of low-angle small-scale cross-laminae in lower half, and dom-
Feet

Entrada Sandstone (incomplete)-Continued

Medial silty member-Continued

inantly of horizontal laminae in upper half; weathers to form small ledge. Unit apears to be persistent, although it varies in thickness along the outcrop. In places unit forms whitish ledge. This unit may be the same as the thin white sandstone at the base of unit 9 of the Fort Defiance section

Total of medial silty member

Total of incomplete Entrada Sandstone

Feet

$\frac{5.7}{57.2}$

Wingate Sandstone (Rock Point Member) :

9. Siltstone, pale reddish brown $(10 R 5 / 4)$ and light brown $(5 Y R 6 / 4)$, weathering same colors, coarse silt grading, in a few places, to silty very fine grained sandstone; well cemented, calcareous; horizontal wavy laminae, gnarly bedding in part; weathers to form steep slope with vertical cliff at top. No medium to coarse grains noted

8. Sandstone, light brown (5YR 6/4), weathering same color, very fine grained, well sorted; composed of subrounded reddish-stained quartz and $<1$ percent black mineral; poorly cemented, calcareous; composed of thin to very thick wedge planar sets of medium- to large-scale cross-laminae, some concealed stratification; weathers to form ledge. This unit and units 6 and 7 form the prominent ledgy interval in the middle of the Rock Point Member. Top $10 \mathrm{ft}$ poorly exposed

Offiset on top of unit so that overlying units measured 1,000 ft $S .30^{\circ} \mathrm{W}$. of unit 7 .

7. Siltstone, moderate brown (5YR 4/4), weathering same color, fine silt; firmly to well cemented, calcareous, structureless; weathers to form reentrant between ledges.

6. Silty sandstone, light brown ( $5 Y R \quad 6 / 4$ and $5 Y R 5 / 6$ ), weathering same colors, very. fine grained, silty, well sorted; composed of subrounded reddish-stained quartz and 1 or 2 percent black grains; firmly cemented, calcareous; appears to be mostly structureless, some thin to thick possibly planar sets of small- to medium-scale high- and low-angle crosslaminae in lower half of unit, structureless parts may actually contain concealed cross-stratification; weathers to form bare rock ledge......

5. Siltstone to sandy siltstone, light brown (5YR 6/4), minor moderate brown (5YR 4/4), and sparse pale reddish 
Wingate Sandstone (Rock Point Member)-Con. brown $(10 R 5 / 4)$, weathering same colors, medium to coarse silt, sandy (very fine grained) in parts; firmly to well cemented, calcareous. From a distance unit appears to be very thick bedded, but on close examination most of unit appears structureless, some parts appear horizontally laminated, a few places contain poorly defined very low angle cross-laminated sets, and a few other places appear to be composed of thin poorly defined lenses. Unit weathers to form slopes and smooth bare rock ledges. Ledges are not continuous along exposure. A thin to thick lens of intraformational conglomerate is present at $52 \mathrm{ft}$ above base of unit. This conglomerate is composed of rounded reddish granules to pebbles (as large as 2 in. in maximum diameter) set in a silt matrix. A few bone fragments as large as $1 / 2$ in. are present in the conglomerate.

4. Siltstone, pale reddish brown $(10 R 5 / 4)$, sparse pale red $(10 R 6 / 2)$, weathering same colors, fine silt; firmly to well cemented, calcareous; stratification concealed; weathers to form slope. Unit is lighter colored than overlying unit. Top of Owl Rock Member could be placed at top of this unit

3. Limy siltstone, pale red $(10 R 6 / 2)$, weathering same color, coarse silt; well cemented, calcareous; horizontally laminated, minor ripple laminae; weathers to form small ledge. May belong in Owl Rock Member but is not a limestone.

2. Siltstone, moderate reddish brown $(10 R$ $4 / 6)$, weathering pale reddish brown $(10 R 5 / 4)$, medium silt; poorly indurated, . calcareous; structureless; weathers to form slope.

Total of Wingate Sandstone (Rock Point Member)

1. Limestone (50 percent) and siltstone (50 percent). Limestone, pale red purple $(5 R P 6 / 2)$ and light greenish gray $(5 G Y 8 / 1)$ to greenish gray (5GY 6/1), colors mottled, weathering same colors, dense; well cemented; thin to thick horizontal beds interstratified with siltstone. Siltstone, grayish red $(5 R 4 / 2)$, weathering pale red $(5 R 6 / 2)$, fine silt; firmly indurated, clay binding and calcareous cement; stratification concealed. Siltstone is present as very thin to very thick sets interstratified with limestone. Unit as whole weathers to form steep slope with ledges
Feet Wingate Sandstone (Rock Point Member)-Con.

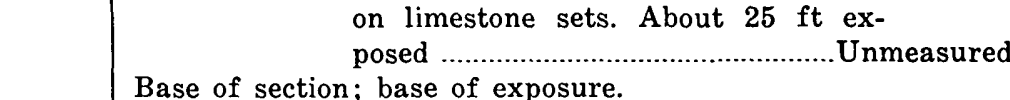

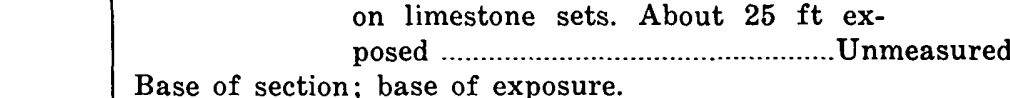
Feet
Base of section; base of exposure.

\section{NM-5a. ZUNI SECTION A}
Measured on southwest side of hill lying about 1 mile north- west of high mesa capped by Dakota Sandstone and about 2 miles east of the town of Zuni, southwest quarter of sec. 26, T. 10 N., R. 19 W., NMPM, McKinley County
[Measured by J. H. Stewart and R. F. Wilson, April 1956]

Top of section; top of exposure.

Wingate Sandstone (Rock Point Member):

6. Siltstone to sandstone (70 percent) and siltstone (30 percent). Siltstone to sandstone, light brown (5YR 6/4) and subordinate very pale orange $(10 Y R 8 / 2)$, weathering same colors, grades from coarse siltstone to very fine grained sandstone, well sorted; composed of subrounded clear and reddish-stained quartz and common black accessory mineral; firmly to well cemented, calcareous; horizontally laminated, abundant cuspate ripple laminae, and common planar and trough sets of low-angle smallscale cross-laminae. Siltstone, grayish red $(10 R 4 / 2)$, weathering pale reddish brown $(10 R 5 / 4)$, fine silt; common very fine grained accessory white mica; firmly indurated, clay binding and calcareous cement; stratification concealed but appears to be dominantly horizontally laminated. Siltstone present as laminae to very thick beds interstratified with thin to very thick sets of siltstone to sandstone. Unit weathers to form a ledgy slope and caps small hill.

5. Sandstone, light greenish gray (5GY $8 / 1$ ), weathering same color, very fine grained, well sorted; composed of subrounded clear and milky quartz and 1 percent orange and black minerals; poorly cemented, calcareous; stratification concealed; weathers to form reentrant along line of section. Contains granules to pebbles as large as $1 \mathrm{in}$. in diameter of chert and subordinate quartz. The granules and pebbles comprise from 1 to 5 percent of the unit and are disseminated in the sandstone. A few of the larger pebbles are faceted and appear to be ventifacts. Base of unit covered........

Total of Wingate Sandstone (Rock Point Member)

Chinle Formation (incomplete):

Petrified Forest Member (incomplete) :

4. Silty claystone, pale reddish brown $(10 R 5 / 4)$, dark reddish brown $(10 R$ $3 / 4)$, and grayish red $(10 R 4 / 2)$,
Feet 
Chinle Formation (incomplete)-Continued

Petrified Forest Member (incomplete)-Con. weathering same colors; swelling clays; firmly indurated, noncalcareous; structureless; weathers to form steep frothy-surfaced slope. Exposure of unit contains many slump blocks of overlying unit. Unit contains a few thick lenses of very fine grained clayey sandstone and a few thin layers near the top containing limestone nodules

3. Sandstone, same as unit 1. This unit probably correlates with the sandstone unit below the water tank on south side of the town of Zuni. This unit and unit 1 are locally quarried for flagstone. Unit weathers to form ledge and marks top of purplish zone at base of hill.

2. Clayey siltstone, pale reddish brown $(10 R 5 / 4)$, weathering same color; poorly cemented, clay binding; structureless; weathers to form frothysurfaced slope. Unit probably contains swelling clays.

1. Sandstone, pale red purple $(5 R P$ 6/2), weathering same color, very fine to fine grained, fair sorted; composed of subangular milky quartz and 10 percent black grains; well cemented, calcareous; horizontally laminated, common thin trough and tabular planar sets of small-scale low-angle crosslaminae; weathers to form ledge. Unit pinches out $50 \mathrm{ft}$ to west of line of section. Base of unit not exposed..

Total of incomplete Petrified Forest Member

Total of incomplete Chinle Formation

Base of section; base of exposure. Base of section is about 2 miles N. $86^{\circ}$ E. of water tank on south side of town of Zuni.

\section{NM-5b. ZUNI SECTION B}

Measured on west side of high mesa capped by Dakota Sandstone about 3 miles east-southeast of the town of Zuni and about 21/2 miles south of town of Black Rock, west-central part of sec $36, T .10$ N., R. 19 W., NMPM, McKinley County

[Measured by J. H. Stewart and R. F. Wilson, April 1956]

Top of section; not top of exposure. Section ends about $400 \mathrm{ft}$ below top of mesa. Top of section about 3 miles $\mathrm{S} .81^{\circ} \mathrm{E}$. of water tower on south side of town of Zuni.

Entrada Sandstone (incomplete) :

Upper sandy member:

10. Sandstone, light brown $(10 Y R 6 / 4)$ and very pale orange $(10 Y R 8 / 2)$, very fine to fine grained, well sorted; composed of subrounded clear quartz and sparse black accessory mineral; poorly to firmly cemented, calcareous;

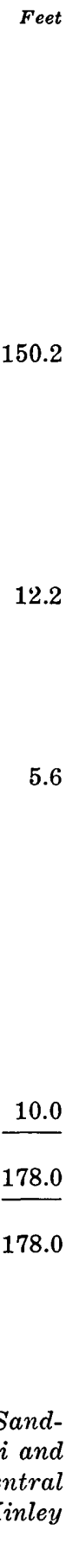

Entrada Sandstone (incomplete)-Continued

Upper sandy member-Continued composed of horizontal laminae, which have irregular waviness with a maximum amplitude of about $1 / 2$ in., and poorly defined thin planar(?) sets of small- to medium-scale low to very low angle cross-laminae; weathers to form vertical cliff. Unit contains about 1 percent medium to very coarse well-rounded clear quartz grains, white chert(?) grains, and grains of a black mineral. Only basal $20 \mathrm{ft}$ of unit examined. Unit is totally about $300 \mathrm{ft}$ thick.

Unmeasured

Medial silty member(?) :

9. Siltstone (70 percent) and sandstone (30 percent). Siltstone, grayish red (10R 4/2), weathering same color, common fine-grained accessory white mica; firmly indurated, clay binding, noncalcareous; statification concealed. Sandstone, light brown (5YR 6/4), weathering same color, very fine grained, well sorted; composed of subrounded reddish-stained quartz and sparse black accessory minerals; horizontally laminated. Sandstone is present as thin sets interstratified with siltstone. Some parts of unit are poorly exposed. Unit might be an upper part of the Rock Point Member and not part of the Entrada Sandstone. Unit pinches out to north along exposure. Unit as whole weathers to form a bench........

Total of medial silty member(?).... Total of incomplete Entrada Sandstone

Wingate Sandstone (Rock Point Member) :

8. Sandstone; same as unit 5 ; weathers to form a vertical cliff.

7. Sandstone (50 percent) and siltstone (50 percent). Sandstone same as that in unit 5, present as laminae to thin sets interstratified with siltstone. Sets are horizontally laminated and rarely contain thin trough sets of smallscale low-angle cross-laminae. Siltstone, same as that in unit 3 . Abundant mud-crack fillings. This unit and underlying unit weather to form a reentrant.

6. Sandstone; same as unit 4 ; poorly exposed. This unit and overlying unit weather to form a reentrant

5. Sandstone, light brown (5YR 6/4), weathering same color, very fine to fine grained, well sorted, composed of subrounded clear quartz and abundant black accessory minerals; poorly cemented, calcareous; composed of sets of horizontal laminae from about 
Wingate Sandstone (Rock Point Member) - Con. a foot to over $10 \mathrm{ft}$ thick alternating with cosets of about same thickness of thin trough sets of low-angle medium-scale cross-laminae; weathers to form a steep ledgy slope or locally a vertical cliff. Contains laminae of grayish-red siltstone interstratified with sandstone. These laminae comprise about 3 percent of unit.

4. Sandstone, very pale orange (10YR $8 / 2)$, sparse light brown (5YR 6/4), weathering same color, very fine grained, sparse disseminated fine to medium grains, fair sorted; composed of subrounded clear quartz and sparse black accessory mineral; poorly to firmly cemented, calcareous; composed of thin wedge-planar sets of small- to medium-scale high-angle cross-laminae; weathers to form ledge which makes conspicuous white band along line of exposure.

3. Siltstone to sandstone (60 percent) and siltstone (40 percent). Siltstone to sandstone, light brown (5YR 6/4), very pale orange $(10 Y R 8 / 2)$, and light greenish gray $(10 Y R \quad 8 / 1)$, grades from coarse silt to very fine grained sand, well sorted; composed of subangular clear, milky and reddish-stained quartz and common black accessory mineral; well cemented, calcareous; horizontally laminated, abundant ripple laminae; flaggy and slabby spitting. Siltstone, grayish red (10R 4/2), weathering same color; well indurated, clay binding; horizontally laminated to very thin bedded. Siltstone present as laminae to thick sets interstratified with laminae to very thick sets of sandstone to siltstone. Unit as whole weathers to form ledges separated by reentrants on siltstone. Unit forms brownish lower part of Rock Point Member. Unit contains common mud-crack fillings. Top $10 \mathrm{ft}$ of unit is about 80 percent light-brown $(5 Y R \quad 6 / 4)$ fine to very fine grained fair-sorted sandstone that is composed of trough sets of medium-scale low-angle cross-laminae and minor horizontal laminae to thin beds. Some of the sandstone contains common medium well-rounded grains

2. Silty pebbly sandstone, light greenish gray (5GY 8/1), weathering same color, composed of granules and pebbles as large as $1 \mathrm{in}$. in maximum diameter, in a silty, very fine grained sand matrix. Granules and pebbles comprise about 5 to 10 percent of unit and are faceted and pitted chert and
Feet Wingate Sandstone (Rock Point Member) - Con.

Feet rarely quartzite. The granules and pebbles are probably ventifacts. Unit is firmly cemented, calcareous; composed of horizontal laminae to very thin beds; weathers to form reentrant

Total of Wingate Sandstone (Rock Point Member)
73.8

4.0

Base of section; not base of exposure.
Measured about 41/4 miles west-northwest of town of Abiquiu, starting at U.S. Highway 85 ; northeastern part of section 10 (unsurveyed), T. 23 N., R. 5 E., NMPM, Rio Arriba County

[Measured by J. H. Stewart and R. F. Wilson, July 1956]

Top of section; top of exposure. Top of section is probably close to, if not at, the top of the Poleo Sandstone Lentil.

Chinle Formation (incomplete) :

Poleo Sandstone Lentil:

4. Three interstratified. rock types: (1) sandstone, (2) conglomerate, and (3) silty claystone to silty sandstone. Sandstone, yellowish gray (5Y 8/1 and $5 Y 7 / 2)$, grayish yellow $(5 Y$ $8 / 4)$, and grayish orange (10YR $7 / 4$ ), weathering same colors, fine to medium grained, fair to well sorted, composed of subangular clear quartz and sparse black accessory minerals; firmly to well cemented, calcareous; composed of thin to thick trough and possibly planar sets of small- to medium-scale low- and high-angle crossstrata. Much of sandstone, possibly 50 percent, is structureless or the stratification is concealed. Conglomerate, dark yellowish orange $(10 Y R \quad 6 / 6)$ to very pale orange $(10 Y R \quad 8 / 2)$, weathering pale yellowish orange (10YR 8/6), composed of granules and pebbles of quartz, quartzite, and chert in a silt or fine- to coarsegrained sand matrix. Orange and red chert pebbles are common. Granules and pebbles average about $1 / 4$ to $1 / 2$ in. in diameter. Largest pebbles are about $2 \frac{1}{2}$ in. in maximum diameter. Conglomerate is poorly cemented. The cement is slightly calcareous and is 
Chinle Formation (incomplete)-Continued

Poleo Sandstone Lentil-Continued probably mostly limonite. Some of the conglomerate occurs in layer 10 or more feet thick which contains lowangle large-scale cross-laminae. Some of the cross-laminae extend for at least $100 \mathrm{ft}$. These long cross-laminae possibly are part of delta forest bedding. Some of conglomerate is structureless. All gradations from conglomerate to sandstone are present. Silty claystone to silty sandstone, grayish red $(10 R 4 / 2)$, and minor moderate red $(5 R 5 / 4)$ and pale yellowish brown $(10 Y R 6 / 4)$, weathering same colors, composed of particles grading from clay to very fine grained sand, some swelling clays; firmly to well cemented, calcareous in places; horizontally laminated to thin bedded. Unit as whole weathers to form vertical cliff. Proportion and position of the three lithologic types vary greatly along outcrop. Along line of section lithologic types are present in following sequence: 0 to $12.7 \mathrm{ft}$ conglomerate, 12.7 to $19.0 \mathrm{ft}$ sandstone, 19.0 to $28.0 \mathrm{ft}$ conglomerate, 28.0 to $32.0 \mathrm{ft}$ sandstone, 32.0 to 45.0 $\mathrm{ft}$ conglomerate, 45.0 to $61.6 \mathrm{ft}$ sandstone, 61.6 to $64.6 \mathrm{ft}$ silty claystone (type 3), 64.6 to $72.8 \mathrm{ft}$ conglomerate, 72.8 to $101.0 \mathrm{ft}$ sandstone, 101.0 to $112.0 \mathrm{ft}$ silty claystone to siltstone (type 3), 112.0 to $123.2 \mathrm{ft}$ sandstone, 123.2 to $125.0 \mathrm{ft}$ siltstone, 125.0 to $129.0 \mathrm{ft}$ sandstone, 129.0 to $137.0 \mathrm{ft}$ siltstone to silty sandstone, and 137.0 to $162.4 \mathrm{ft}$ sandstone. Base of unit is sharp and is surface of erosion. Scours several feet deep are present

Total of Poleo Sandstone Lentil......

Agua Zarca Sandstone Member:

3. Siltstone, light gray ( $N 7)$, greenish gray $(5 G Y 6 / 1)$, and pale red $(10 R$ $6 / 2$ ), weathering same colors, silt with common disseminated very fine to coarse angular quartz grains; firmly indurated, noncalcareous; stratification concealed; weathers to form slope. Unit poorly exposed. Top $3 \mathrm{ft}$, or possibly more, of the unit is sandstone. Sandstone, pale purple $(5 P 6 / 2)$, medium to coarse grained, clay matrix, angular to subangular grains, composition masked; stratification concealed. Away from line of section, the sandstone of top of unit thickens to about $15 \mathrm{ft}$

2. Sandstone to conglomerate, light gray (N 7), yellowish gray (5Y 8/1),
Chinle Formation (incomplete)-Continued Agua Zarca Sandstone Member-Continued grayish yellow ( $5 Y 8 / 4)$, grayish purple $(5 P 4 / 2)$, and grayish red $(5 R$ $4 / 2$ ), weathering same colors, medium to coarse grained, some very coarse grains, fair sorted; composed of subangular to angular clear quartz, possibly some feldspar, no accessory minerals noted; poorly cemented, calcareous in parts; composed of thin to thick trough sets of small- to medium-scale cross-laminae. Cross-strata difficult to see. Some parts of unit appear structureless. Possibly some horizontally stratified parts. Unit weathers to form vertical cliff. Sandstone grades to conglomerate. Probably 10 percent of unit is conglomerate and 20 percent of unit is conglomeratic sandstone. Conglomerate contains granules to cobbles of quartz, quartzite, and chert. Granules and small pebbles are largely quartz and chert. Large pebbles and cobbles are dominantly quartzite. Cobbles are as large as 5 in. in maximum diameter and are commonly 2 to 3 in. in maximum diameter. Base of unit is surface of erosion. Irregularities on erosion surface are as much as $5 \mathrm{ft}$

Total of Agua Zarca Sandstone Member

Total of incomplete Chinle Formation

Cutler Formation:

1. Silty sandstone to sandy siltstone (60 percent) and sandstone (40 percent). Silty sandstone to sandy siltstone, grayish red $(10 R 4 / 2)$, pale reddish brown $(10 R 5 / 4)$, common light greenish gray $(5 G Y 8 / 1)$ spots and streaks, weathering same colors, silt to very fine grained sand, subordinate fine to coarse grains, abundant accessory white and dark-green mica; firmly to well cemented, calcareous; irregular horizontal stratification, thin to thick horizontal lenses common. Sandstone, grayish red $(5 R 4 / 2)$, pale red $(5 R$ $6 / 2)$, pale reddish brown $(10 R 5 / 4)$, and minor light greenish gray ( $5 G Y$ $8 / 1$ ), weathering same colors, fine to very coarse grained, poorly to fair sorted, composed of reddish-stained quartz in reddish parts and clear quartz in greenish parts, 10 percent pink feldspar, and 2 percent darkgreen and white mica; poorly cemented, calcareous; composed of thin trough sets of medium-scale crosslaminae, and of horizontal laminae to
Feet 
Cutler Formation-Continued

thin beds, some contorted strata.

Sandstone is present as thin to very thick cosets or lenses interstratified with the rest of the unit. Unit as whole weathers to form vertical cliff. Sandstone contains a few scattered pebbles of dark-gray quartzite. About $100 \mathrm{ft}$ of unit exposed..

Unmeasured

Base of section; base of exposure. Base of section at U.S. Highway 85.

\section{NM-7. COYOTE}

Measured about $33 / 4$ miles N. $10^{\circ} \mathrm{W}$. of the town of Coyote and within 1,500 ft east of prominent north-trending fault, northwestern part of sec. 21, T. 23 N., R. \& E., NMPM, Rio Arriba County

[Measured by J. H. Stewart and R. F. Wilson, July 1956]

Top of section; not top of exposure. Top of section is Feet N. $59^{\circ} \mathrm{W}$. of Cerro Pedernal.

Entrada Sandstone:

13. Sandstone, light brown $(5 Y R 6 / 4)$ to moderate reddish orange $(10 R 6 / 6)$, subordinate yellowish gray ( $5 Y 8 / 1)$, weathering same colors, fine to medium grained, fair to well sorted; composed of subrounded to round reddish-stained quartz (in places clear quartz), and sparse black accessory minerals; poorly cemented, calcareous; horizontally laminated, possibly some large-scale cross-strata; weathers to form steep slope in lower part and vertical cliff in upper part. Unit about $300 \mathrm{ft}$ thick but only basal 50 ft examined Unmeasured

Chinle Formation:

Petrified Forest Member:

12. Siltstone to clayey siltstone, grayish red $(10 R 4 / 2)$, minor pale reddish brown $(10 R 5 / 4)$, and common light-greenish-gray ( $5 G Y 8 / 1)$, sparse dark-yellowish-orange $(10 Y R \quad 6 / 6)$ spots, weathering same colors, fine to coarse silt, swelling clays in part of unit; firmly cemented, calcareous in places; structureless in places and horizontally laminated in other places; weathers to form steep slope, frothysurfaced in places. Top $4 \mathrm{ft}$ of unit contains several thin beds of pale-red $(10 R 6 / 2)$ to grayish-red $(10 R 4 / 2)$ very fine grained sandstone. This unit is siltier and contains less swelling clay than unit 10

11. Covered; exposures of part of this interval to north of line of section show rocks similar to those of unit $10 \ldots \ldots . .$.

10. Clayey siltstone to silty claystone, pale reddish brown $(10 R 5 / 4)$, moderate red $(5 R 5 / 4)$, dark reddish brown $(10 R 3 / 4)$, grayish red $(5 R 4 / 2)$, and common mottles and spots of light greenish gray (5GY 8/1), weathering
Feet

Chinle Formation-Continued

Petrified Forest Member-Continued

same colors, swelling clays; grades to siltstone in places; firmly cemented, clay binding, calcareous; dominantly structureless, some horizontal stratification planes, some horizontally laminated parts; weathers to form frothy-surfaced slope. Unit contains many layers of limestone nodules. Unit contains a few thin horizontal beds of very fine grained sandstone. Unit from $220 \mathrm{ft}$ to $264 \mathrm{ft}$ is dominantly siltstone. This siltstone is horizontally laminated and contains some ripple laminae and a few low-angle large-scale cross-strata ........................

9. Unit composed of two intergrading lithologic types: type 1 (60 percent), siltstone to sandy siltstone, type 2 (40 percent), sandstone to sandy siltstone. Siltstone to sandy siltstone (type 1) grayish red $(10 R 4 / 2)$ and sparse greenish gray (5GY 6/1), weathering same colors, fine siltstone to very fine grained sandy coarse siltstone, sparse very fine grained accessory white mica; firmly cemented, calcareous; appears dominantly structureless, subordinate horizontally laminated and ripple laminated (cuspate type) parts. Sandstone to sandy siltstone (type 2), light greenish gray $(5 G Y 8 / 1)$, greenish gray (5GY $6 / 1)$, and grayish red (5R 4/2), weathering same colors, very fine grained sandstone to sandy (very fine grained) coarse siltstone, common fine-grained accessory white and dark-green mica; well cemented, calcareous; ripple laminated (cuspate type), minor horizontal laminae and sparse thin trough sets of small- to medium-scale cross-laminae; sandstone to sandy siltstone (type 2) is present as very thin to very thick sets interstratified with the rest of the unit. Sandstone to sandy siltstone (type 2) weathers to form ledges, and siltstone to sandy siltstone (type 1) forms intervening slopes. Both lithologic types contain carbonaceous material. A few thin sets of limestone-grain sandstone are present. Some of siltstone contains swelling clay. Unit may be laterally equivalent to part of Poleo Sandstone Lentil. Unit contains a few largescale low-angle cross-stratified sets that may be deltaic foreset strata.....

Total of Petrified Forest Member.. $\frac{71.5}{710.5}$

Poleo Sandstone Lentil:

8. Sandstone (80 percent) and sandy silt-
Feet 
Chinle Formation-Continued

Poleo Sandstone Lentil-Continued

stone (20 percent). Sandstone, yellowish gray (5Y 8/1 and $5 Y 7 / 2)$, weathering pale yellowish brown $(10 Y R 6 / 2)$, fine to medium grained, subordinate very fine grained parts, fair sorted; composed of subrounded to subangular clear quartz and sparse black accessory mineral; well cemented, calcareous; horizontally laminated, minor ripple laminae (cuspate type) and sparse thin trough sets of small- to medium-scale cross-laminae. Sandy siltstone, greenish gray ( $5 G Y$ $6 / 1$ ) and light olive gray (5Y 6/1), weathering same colors, sandy (very fine grained) coarse siltstone, abundant medium-grained accessory white and dark-green mica; firmly cemented, calcareous; horizontally thinly laminated to laminated, minor ripple-laminated parts, cuspate-type ripples. Unit weathers to form vertical cliff in lower parts and ledges and slopes in upper part. Slopes are mostly developed on sandy siltstone. Sandy siltstone is present in upper half of unit and occurs as thick to very thick sets interstratified with very thick sets of sandstone. Poorly preserved carbonaceous material is common in the sandy siltstone. Molds of fossil wood are common in the sandstone. Basal $20 \mathrm{ft}$ of sandstone contains a few thin lenses of pebbly sandstone. Pebbly sandstone contains granules and pebbles of siltstone and a few granules and pebbles of white quartz

Total of Poleo Sandstone Lentil ....

Offset in section, so that unit 8 and overlying units measured 1,000 ft north of unit 7 and on other side of prominent canyon. Salitral Shale Tongue:

7. Silty claystone to clayey siltstone, grayish red (5R $4 / 2$ and $10 R \quad 4 / 2)$ and subordinate pale purple $(5 P 6 / 2)$ and light greenish gray (5GY 8/1), weathering grayish red $(5 R \quad 4 / 2$ and $10 R 4 / 2$ ), swelling clays; firmly indurated, noncalcareous; structureless; weathers to form frothy-surfaced slope. About $50 \mathrm{ft}$ to southwest of line of section, unit from about 12 to $25 \mathrm{ft}$ above base is composed of yellowish-gray $(5 Y 8 / 1)$ very fine to fine-grained well-sorted horizontally laminated sandstone. This sandstone is a lens that extends for about $500 \mathrm{ft}$ along the exposure. Unit contains a few very thin beds of light-greenish-gray (5GY 8/1) lime- \begin{tabular}{r|r} 
Feet & $\begin{array}{r}\text { Chinle Formation-Continued } \\
\text { Salitral }\end{array}$ \\
Shale Tongue-Continued \\
stone-grain sandstone. Unit contains \\
abundant limestone nodules in places \\
Total of Salitral Shale Tongue...... \\
Agua Zarca Sandstone Member: \\
6. Sandstone, yellowish gray $(5 Y$ 8/1) \\
and very light gray $(N 8)$, weath- \\
ering light olive gray (5Y 6/1), \\
very fine to fine grained, well sorted, \\
composed of subrounded clear quartz \\
and sparse black accessory mineral, \\
abundant coarse grained accessory \\
white and dark-green mica; firmly \\
to well cemented, calcareous, ripple \\
laminated (cuspate type) and sparse \\
thin trough and tabular planar sets \\
of small-scale cross-laminae; weathers \\
to form ledge. Basal foot of unit is \\
composed of medium- to coarse- \\
grained sandstone containing a few \\
very coarse grains and granules of \\
quartz .........................................
\end{tabular}

5. Silty claystone to clayey siltstone, grayish purple (5P 4/2), light greenish gray (5GY 8/1), and sparse dark yellowish orange $(10 Y R 6 / 6)$; colors mottled; weathering same colors; swelling clays; firmly indurated, noncalcareous; stratification concealed; weathers to form vertical cliff

4. Sandstone, bluish white $(5 B 9 / 1)$, weathering same color, medium to coarse grained, common interstitial white clay, fair sorted; composed of subangular clear quartz and sparse black and orange accessory minerals; poorly to firmly indurated, calcareous in part; composed of horizontal laminae to thin beds, sparse small-scale cross-laminae; weathers to form protruding ledge. Contains very coarse grains and granules of quartz in places

3. Siltstone to silty claystone, grayish purple $(5 P 4 / 2)$, medium gray $(N 5)$, light greenish gray ( $5 G Y 8 / 1)$, grayish red $(10 R 4 / 2)$, and subordinate dusky yellow ( $5 Y 6 / 4)$, colors mottled, weathering same colors; swelling clays in parts; firmly to well indurated, noncalcareous; stratification concealed; weathers to form vertical cliff

2. Sandstone, pale red purple (5RP 6/2) and pale purple (5P 6/2), grayish red $(10 R 4 / 2)$, light greenish gray $(5 G Y 8 / 1)$, and minor pale red $(5 R 6 / 2)$ and pale yellowish orange $(10 Y R 8 / 6)$, weathering same colors, fine to coarse grained, silty and clayey in parts, fair sorted; composed of subangular clear quartz and sparse
Feet

$\frac{79.0}{79.0}$ 
Chinle Formation-Continued

Agua Zarca Sandstone Member-Continued black and orange accessory minerals; poorly cemented, noncalcareous; stratification difficult to determine, some small- to medium-scale crossstrata. Unit appears to be composed dominantly of irregular thin horizontal beds or lenses. Unit weathers to form vertical cliff. Unit contains some very coarse grained parts. Basal $5 \mathrm{ft}$ contains a few scattered pebbles and cobbles as large as about 4 in. in maximum diameter; these pebbles and cobbles are mostly composed of a coarse-grained quartzite. A few conglomeratic or pebbly lenses are present higher in unit. The granules and pebbles in these lenses are of quartz and, to a less extent, of chert, and the pebbles are as large as about 1 in. in diameter. Base of unit placed at color change from dominantly reddish rock below to purplish rock above. This color change locally marks change from siltstone below to sandstone above. From a distance unit appears as a whitish and purplish interval

Total of Agua Zarca Sandstone Member .

Total of Chinle Formation

Cutler Formation:

1. Sandstone (70 percent) and siltstone (30 percent). Sandstone, grayish red $(5 R 4 / 2)$, pale reddish brown $(10 R$ $5 / 4)$, and minor light greenish gray (5GY 8/1), weathering same colors, medium to coarse grained, silty in places; poorly to fair sorted; composed of subangular quartz, subordinate pink feldspar in places (quartz is reddish stained in reddish parts and is clear in greenish parts) ; 1 to 2 percent dark-green coarsegrained mica; poorly cemented slightly calcareous; stratification concealed. Siltstone, grayish red $(10 R 4 / 2)$, weathering same color, fine silt, common fine to coarse scattered sand grains in places, all gradations from siltstone to sandstone; firmly cemented, clay binding, noncalcareous, structureless; siltstone is present as thin to very thick sets interstratified with sandstone. Unit weathers to form steep slope with ledges developed on some of the sandstone beds. About $200 \mathrm{ft}$ of unit exposed. Only top $50 \mathrm{ft}$ examined. Top $10 \mathrm{ft}$ of unit along line of section is siltstone. Top $2 \mathrm{ft}$ of unit is mottled pale red purple $(5 R P 6 / 2)$ and light greenish gray (5GY 8/1). Mottling increases
Feet | Cutler Formation-Continued

Feet in amount upward, and top $0.5 \mathrm{ft}$ of unit is all purplish and greenish colors ..............................................Unmeasured

Base of section; base of exposure. Base of section is N. $62^{\circ} \mathrm{W}$. of Cerro Pedernal and about $200 \mathrm{ft}$ south of prominent canyon that heads in good exposure of the Chinle Formation.

\section{NM-8. GALLINA}

Measured about 2 miles northeast of town of Gallina, northeastern part of sec. 3, T. 23 N., R. 1 E., NMPM, Rio Arriba County

[Measured by J. H. Stewart and R. F. Wilson, July 1956]

Top of section; top of exposure.

Chinle Formation (incomplete):

Poleo Sandstone Lentil:

6. Sandstone (75 percent) and conglomerate (25 percent). Sandstone, yellowish gray (5Y 8/1 and $5 Y 7 / 2)$ and sparse grayish yellow $(5 Y \quad 8 / 4)$, weathering same colors, fine to medium grained, sparse coarse grains, fair sorted; composed of subround to subangular clear quartz and common black accessory mineral; poorly to firmly cemented, calcareous; stratification difficult to see, and some parts of unit appear structureless, probably composed dominantly of thin to thick trough and tabular planar sets of medium-scale low-angle crosslaminae, also contains abundant horizontally laminated to thin bedded parts. Conglomerate, pale yellowish orange $(10 Y R 8 / 6)$ to dark yellowish orange $(10 Y R 6 / 6)$, weathering same colors, consists of granules and pebbles in a matrix of sand similar to that in the sandstone part of unit; all gradations from sandstone to conglomerate. Granules and pebbles are of chert and subordinate quartz and quartzite. Chert pebbles are dominantly reddish and yellowish, and quartz is dominantly white or smoky. Conglomerate is firmly to well cemented, calcareous. Conglomerate appears to be structureless and is present as a 10-ft-thick bed at the base of unit and as thin to very thick lenses from 10 to $40 \mathrm{ft}$. A few thin conglomerate lenses occur higher in unit. Basal $5 \mathrm{ft}$ of unit contains pebbles, cobbles, and boulders of siltstone as large as 9 in. in maximum diameter. Locally siltstone pellets occur in the conglomerate and sandstone. Basal contact of unit is sharp and is a surface of erosion. Unit contains a few casts of plant material. Unit weathers to form vertical cliff and underlies bench

Total of Poleo Sandstone Lentil .... $\overline{125.2}$

Feet 
Chinle Formation (incomplete)-Continued Salitral Shale Tongue:

5. Same as unit 3 ; top $4 \mathrm{ft}$ of unit is medium gray $(N 5)$, grayish red $(10 R 4 / 2)$, subordinate light greenish gray $(5 G Y 8 / 1)$. The colors are mottled, and coloration is similar to that in unit 2 .

4. Sandstone, grayish blue $(5 F B 5 / 2)$ in basal 6 in. and yellowish gray (5Y $7 / 2$ ) in rest of unit, weathering same colors; medium to coarse grained; composed of subangular clear quartz and sparse black accessory mineral; firmly cemented, slightly calcareous; stratification poorly developed but appears to be composed mostly of small-scale cross-strata; weathers to form small ledge

3. Siltstone to sandy siltstone, greenish gray $(5 G Y 6 / 1)$, grayish red $(10 R$ $4 / 2)$, and subordinate dusky red (5R 3/4), weathering light gray (N 7), grades from fine siltstone to siltstone containing very fine grains to granules of subangular to subrounded clear, reddish-stained, and gray quartz; poorly to firmly cemented, clay binding, noncalcareous; stratification concealed; weathers to form steep slope. Siltstone in places contains swelling clays

Total of Salitral Shale Tongue........

Agua Zarca (?) Sandstone Member:

2. Silty sandstone ( 80 percent), to sandy siltstone (20 percent), grayish red (5R $4 / 2$ and $10 R 4 / 2$ ), very light gray $(N \quad 8)$, light greenish gray (5GY 8/1), and minor pale yellowish orange $(10 Y R 8 / 6)$ and pale red purple (5RP 6/2), colors mottled, weathering same colors, grades from silty very fine to fine-grained sandstone to siltstone containing minor amounts of very fine to coarse sand; fair sorted; composed of subangular clear and reddish-stained quartz and minor reddish chert(?); firmly to well cemented, possibly siliceous, noncalcareous; stratification concealed by mottled coloration, possibly horizontally stratified, contains some lowangle cross-strata; weathers to form vertical cliff. Base of unit placed at change from dominantly reddish rocks below to lighter colored mottled rocks above. Rocks above contact appear to be slightly coarser than those below. A small lens of sandstone containing. abundant orange and reddish chert is present near top of unit

Total of Agua Zarca(?) Sandstone Member

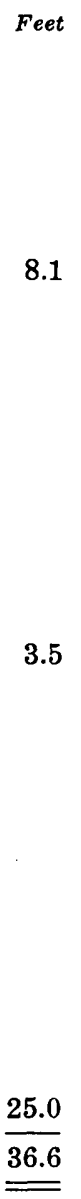

Chinle Formation (incomplete)-Continued

Total of incomplete Chinle Formation

Feet

176.8

Cutler Formation:

1. Silty sandstone, pale red $(10 R 6 / 1)$, weathering light brown (5YR 6/4), silty, very fine grained, in places contains some disseminated fine grains, fair sorted; composition masked; firmly cemented, silt and clay binding, noncalcareous; mostly horizontally stratified, sparse poorly distinguishable medium-scale crossstrata; weathers to form vertical cliff. Top $10 \mathrm{ft}$ of unit contains some grayish-red-purple $(5 R P \quad 4 / 2)$ and light-greenish-gray $(5 G Y$ 8/1) mottling. Amount of mottling increases upward, and about 50 percent of the unit near the top is purplish and greenish .......................................Unmeasured

Base of section; not base of exposure. Base of section is S. $38^{\circ} \mathrm{E}$. of ranch house and N. $67^{\circ} \mathrm{E}$. of prominent point developed on gypsum in $\mathrm{To}$ dilto Limestone.

\section{NM-9. GHOST RANCH}

Measured about 1 mile west and southwest of Ghost Ranch, northern part of sec. 11 and eastern part of section 2, T. 24 N., R. \& E., NMPM, Rio Arriba County

[Measured by J. H. Stewart and R. F. Wilson, July 1956]

Top of section; top of accessible exposures. Top of section N. $5^{\circ}$ E. of Cerro Pedernal.

Entrada Sandstone:

Upper sandy member:

7. Sandstone, pinkish gray (5YR 8/1), yellowish gray $(5 Y 8 / 1)$, and light brown $(5 Y R 6 / 4)$, white $(N 9)$ in basal foot, weathering same colors; fine grained with common scattered medium grains; well sorted; composed of subrounded to rounded frosted and reddish-stained quartz and common dark accessory minerals; firmly cemented; composed of wedge planar sets of medium- to large-scale lowand high-angle cross-laminae; weathers to form vertical cliff. Only basal $20 \mathrm{ft}$ of unit examined. Unit probably about $250 \mathrm{ft}$ thick. Base of unit sharp and flat Unmeasured

Chinle Formation (incomplete): Siltstone member:

6. Siltstone, pale reddish brown $(10 R$ $5 / 4)$, light brown (5YR 6/4 and $5 Y R 5 / 6)$, and sparse pale red $(10 R$ $6 / 2)$ and grayish red $(5 R 4 / 2)$, common light-greenish-gray (5GY 8/1) mottling; weathering same colors; fine to coarse silt; firmly cemented, calcareous; structureless, a few horizontal stratification planes; weathers to form steep loose slope. Unit similar to underlying unit except contains more pale-reddish-brown rocks and 
Chinle Formation (incomplete)-Continued

Siltstone member-Continued

contains thin layers of siltstone containing either limestone nodules or coarse grains of limestone. Basal 10 $\mathrm{ft}$ of unit contains several thin beds of siltstone containing some limestone grains. Some of these thin beds in basal $10 \mathrm{ft}$ are cross-stratified at a low angle and on a medium scale........

5. Siltstone to clayey siltstone, light brown (5YR 6/4 and 5YR 5/6) and uncommon grayish red $(10 R 4 / 2)$, mostly fine to medium silt; firmly cemented, calcareous, structureless, some horizontal stratification planes; weathers to form steep loose slope. Basal $35 \mathrm{ft}$ of unit is silty claystone. This silty claystone has the same colors as the rest of the unit but contains swelling clays whereas rest of unit does not. This basal $35 \mathrm{ft}$ probably is a transition interval between the rocks containing swelling clay below and those above that do not. The base of the unit is placed at the color change from dominantly reddish rocks below to brownish rocks above. Base of unit approximately at base of steep slopes developed on Chinle Formation.

Total of siltstone member

Petrified Forest Member:

4. Clayey siltstone to silty claystone, pale reddish brown $(10 R 5 / 4)$ to dark reddish brown $(10 R 3 / 4)$, moderate red $(5 R 5 / 4)$, grayish red $(5 R 4 / 2$ and $10 R 4 / 2$ ), and sparse greenish gray $(5 G Y 6 / 1)$, weathering same colors, contains swelling clays; firmly cemented, calcareous in parts, mostly structureless, some horizontally laminated and ripple-laminated parts. One 10-ft-thick layer about $20 \mathrm{ft}$ above base of unit is siltstone and is composed of large-scale low-angle crosslaminae. Unit weathers to form frothy-surfaced badlands. Unit measured along a $1 / 2$-mile traverse. Greenish-gray parts of unit occur in lenses about $10 \mathrm{ft}$ thick and possibly 1,000 ft wide. The greenish-gray parts are siltstone, contain abundant carbonized wood, and are mostly horizontally laminated. Unit contains several very thin to thick beds of greenish gray (5GY 6/1) limestone-grain sandstone composed of fine grains to granules of limestone in a limy silt matrix. Locally limestone pebbles are present in these sandstone beds. Several thin layers in unit contain limestone nodules

3. Covered; forms 1,000-ft-wide flat

2. Sandstone to siltstone, yellowish gray
Petrified Forest Member-Continued $(5 Y 7 / 2)$, grayish red $(10 R 4 / 2)$ in top $3 \mathrm{ft}$, weathering same colors, composed of particles ranging in size from coarse silt to very fine grained sand; abundant white and dark-green accessory mica; firmly cemented, calcareous; ripple laminated, cuspatetype ripples; weathers to form steep slope containing small ledges. Unit poorly exposed in part. Unit is probably a transition sequence from Poleo Sandstone Lentil to the Petrified Forest Member

$\frac{11.2}{198.0}$

Total of Petrified Forest Member.

Poleo Sandstone Lentil:

1. Sandstone, pale yellowish brown (10YR $6 / 2)$ and yellowish gray (5Y $7 / 2)$, weathering same colors, fine grained, well sorted; composed of subangular clear quartz and 2 percent darkgreen mica; firmly cemented, calcareous; horizontally laminated to very thin bedded, and thin trough sets of medium-scale low-angle cross-laminae; exposed along creek bottom. About $10 \mathrm{ft}$ of unit exposed...........Unmeasured

Total of incomplete Chinle Formation

Base of section; base of exposure. Base of section about 1 mile west of Ghost Ranch.

\section{NM-11. TOADLENA}

Measured 4.2 miles northwest of Toadlena at northernmost outcrops of Owl Rock and Rock Point Members in the Toadlena area, long $108^{\circ} 56^{\prime} W$., lat $36^{\circ} 17^{\prime}$ N., San Juan County

[Measured by J. H. Stewart and R. F. Wilson, May 1956]

Top of section; not top of exposure.

Todilto Limestone:

15. Limestone, medium light gray $(N$ 6), weathering light gray $(N 7)$, dense or possibly very finely crystalline in places; well cemented; horizontally thinly laminated to very thin bedded, abundant ripple laminae; flaggy to slabby splitting; weathers to form ledge. Unit is conspicuous light-colored ledge. Todilto Limestone is about $10 \mathrm{ft}$ thick Unmeasured

Entrada Sandstone

Upper sandy member:

14. Sandstone to sandy siltstone, same as unit 12. Top $2 \mathrm{ft}$ is light greenish gray $(5 G Y 8 / 1)$ and light brownish gray $(5 Y R 6 / 1)$ and contains a few discontinuous $1 / 4$-in.-wide greenishstained bands. In places, stratification is well exposed and is composed of discontinuous wavy laminae that may be ripple laminae. Unit weathers to form reentrant under Todilto Limestone 
Entrada Sandstone-Continued

Upper sandy member-Continued

13. Sandstone, light brown $(5 Y R 6 / 4)$ and sparse very pale orange $(10 Y R 8 / 2)$, weathering same colors, very fine to fine grained, sparse scattered medium to coarse grains, fair to well sorted; composed of subrounded reddishstained quartz and abundant black accessory mineral; poorly cemented, calcareous; horizontally laminated (laminae commonly are discontinuous and wavy) and thin to thick wedgeplanar (?) sets of low- and high-angle medium- to small-scale cross-laminae; weathers to form vertical cliff..

Total of upper sandy member..

Medial silty member:

12. Sandstone (80 percent) and sandy siltstone (10 percent), light brown (10R $6 / 4)$ and minor pale reddish brown $(10 R 5 / 4)$, weathering same colors, very fine grained sandstone to very fine grained sandy siltstone, fair sorted; composed of subrounded reddish-stained quartz and abundant black accessory mineral; firmly to poorly cemented, calcareous; stratification poorly exposed, horizontally laminated in parts, laminae may be slightly wavy; weathers to form steep slope

Total of medial silty member.

Total of Entrada Sandstone

Wingate Sandstone:

Rock Point Member:

11. Sandy siltstone and sandstone. Sandy siltstone, light brown $(5 Y R 6 / 4)$ and pale reddish brown $(10 R 5 / 4)$, sparse light-greenish-gray $(5 G Y \quad 8 / 1)$ thin bands and mottling, weathering pale reddish brown $(10 R 5 / 4)$, sandy (very fine grained) ; firmly to well cemented, calcareous; horizontally laminated to thin bedded, possibly some ripple laminae. Sandstone, light brown (5YR 6/4), sparse thin bands of light greenish gray ( $5 G Y 8 / 1)$, weathering same colors, very fine grained, well sorted; composed of subrounded reddish-stained quartz and 1 percent black mineral; poorly cemented, calcareous. Sandstone forms basal $13 \mathrm{ft}$ and top $6 \mathrm{ft}$ of unit. Basal $13 \mathrm{ft}$ is composed of thin tabular-planar sets of medium-scale low-angle cross-laminae and of horizontal laminae (possibly some ripple laminae). Top 6 $\mathrm{ft}$ is composed of horizontal laminae and thin beds. Stratification difficult to determine in much of unit. Unit as whole weathers to form vertical cliff

\section{Feet Wingate Sandstone-Continued}

Rock Point Member-Continued

with lighter colored layers in the sandstone at top and bottom of the unit

10. Siltstone to sandy siltstone, sand fraction is very fine grained, horizontally thin to very thick bedded, subordinate horizontal laminae; otherwise same as unit 8, weathers to form steep ledgy slope. Contains several thin light-colored bands

9. Sandy siltstone, light brown (5YR 6/4) and minor pale reddish brown (10R $5 / 4)$, weathering same colors, sandy (very fine grained); firmly to well cemented, calcareous; horizontally laminated in part, structureless in part; weathers to form most prominent vertical cliff in Rock Point Member. Top $12 \mathrm{ft}$ of unit contains about 80 percent light-brown (5YR 6/4) very fine grained sandstone composed of subrounded reddish-stained quartz and about 2 percent black mineral. This sandstone appears structureless but is similar to cross-stratified sandstone in other sections of the Rock Point Member

8. Siltstone, light brown $(5 Y R 6 / 4)$, pale reddish brown $(10 R 5 / 4)$, and sparse grayish red $(10 R 4 / 2)$, weathering same colors, thin to very thick beds or sets of fine to medium siltstone alternating with thin to thick beds or sets of coarse siltstone; firmly to well cemented, calcareous; thin to very thick horizontal beds (totally about $35 \mathrm{ft}$ of unit is horizontally laminated); weathers to form steep slope containing many small ledges. Unit contains silty very fine grained sandstone to sandy siltstone from 173.4 to $183.6 \mathrm{ft}$ and 204.0 to $224.4 \mathrm{ft}$ above base. These two layers weather to form most prominent ledges in unit

Total of Rock Point Member

Total of Wingate Sandstone

Chinle Formation (incomplete) :

Owl Rock Member:

7. Siltstone and limestone. Siltstone, pale reddish brown $(10 R 5 / 4)$, pale red (10R 6/2 and $5 R 6 / 2$ ), light brown (5YR 6/4), common light-greenishgray ( $5 G Y 8 / 1)$ mottling, weathering same colors, otherwise same as unit 3 . Siltstone in places contains abundant limestone nodules. Limestone, pale red $(10 R 6 / 2$ and $5 R 6 / 2)$, light greenish gray $(5 G Y 8 / 1)$, subordinate pale reddish brown (10R 5/4), colors mostly mottled, weathering same 
Chinle Formation (incomplete)-Continued Owl Rock Member-Continued colors; dense; well cemented; horizontally very thin to thick bedded; present as thin to thick sets or beds interstratified with siltstone. Basal $0.8 \mathrm{ft}$ of unit is a limestone which contains abundant fish scales. Unit as whole weathers to form steep slope with ledges on the limestone beds. Some of the limestone beds contain a few small gray chert nodules. Unit composed of limestone from 0.0 to $0.8 \mathrm{ft}, 23.2$ to $24.2 \mathrm{ft}$, 28.2 to $29.2 \mathrm{ft}$, contains several thin limestone beds from 71.0 to $79.4 \mathrm{ft}$, composed of limestone from 104.9 to $106.9 \mathrm{ft}, 108.9$ to $113.9 \mathrm{ft}, 127.1$ to $130.8 \mathrm{ft}$, contains several thin limestone beds from 132.8 to $146.7 \mathrm{ft}$, and composed of limestone from 155.0 to $157.7 \mathrm{ft}$

6. Siltstone, same as unit 3 , weathers to form steep slope

5. Conglomerate ( 80 percent) and silty sandstone $(20$ percent $)$. Conglomerate, pale red $(10 R 6 / 2)$ and light greenish gray ( $5 G Y 8 / 1$ ), weathering same colors, composed of coarse grains to cobbles as large as $3 \mathrm{in}$. in maximum diameter of limestone and siltstone in a limy silt matrix; firmly to well cemented, calcareous; composed of thin to thick shallow trough sets of medium-scale cross-laminae, subordinate horizontal laminae. Silty sandstone, pale red $(10 R 6 / 2)$, weathering same color, silty very fine grained sandstone, well sorted; composed of subangular clear quartz and abundant black accessory minerals; same stratification as conglomerate. Sandstone interfingers irregularly with conglomerate. Unit as whole weathers to form a ledge

4. Siltstone and limestone. Siltstone, same as unit 3 except is partly pale red $(5 R 6 / 2)$. Limestone, pale red $(10 R$ $6 / 2)$ and light greenish gray (5GY $8 / 1$ ), weathering same colors, dense; well cemented; horizontal thick beds. Limestone is present from 17.5 to $20.5 \mathrm{ft}$. Unit contains two thin to thick beds of yellowish-gray ( $5 Y 8 / 1)$ limy siltstone to siltstone in basal $10 \mathrm{ft}$

3. Siltstone, pale reddish brown $(10 R 5 / 4)$ and light brown $(5 Y R 6 / 4)$, weathexing same colors, fine to medium silt; firmly cemented, calcareous; structureless; fractures into angular fragments; weathers to form small hills and knolls at base of exposure.
Feet Chinle Formation (incomplete)-Continued

Feet Petrified Forest Member (incomplete) :

2. Siltstone, pale red $(5 R 6 / 2)$, weathering same color, fine silt; firmly cemented, calcareous; stratification concealed; weathers to form loose slope. Unit poorly exposed. The siltstone absorbs water quickly, suggesting that it contains swelling clays. Top of unit marks change from reddish colors below to brownish colors above. Unit may belong to either the Petrified Forest Member or the Owl Rock Member. Unit placed in Petrified Forest Member because of the possible presence of swelling clays

1. Silty claystone to clayey siltstone, pale reddish brown $(10 R 5 / 4)$ and moderate red $(5 R 4 / 6)$, weathering same colors, swelling clays; firmly cemented, slightly calcareous; stratification concealed; exposed along creek. Surface is slightly frothy. Contains disseminated limestone pellets the size of coarse and very coarse grains. About $20 \mathrm{ft}$ exposed ................................................ Unmeasured

Total of incomplete Petrified Forest Member

Total of incomplete Chinle Formation

Base of section; base of exposure.

NM-12. ARROYO DE LOS PINOS

Measured on the main Arroyo de los Pinos or on a major tributary of this arroyo, measured parallel to arroyo and from 200 to $1,000 \mathrm{ft}$ north of arroyo, 11/3 miles south of San Miguel Canyon and 101/2 miles south-southeast of Cuba, northern part of sec. 13 and northeastern corner of sec. 14, T. 19 N., R. 1 W., NMPM, Sandoval County

[Measured by J. H. Stewart and R. F. Wilson, June 1956]

Top of section; not top of exposure.

Todilto Limestone:

19. Limestone, dusky yellow (5Y 6/4) weathering same color, dense; well cemented; thin horizontally laminated; weathers to form small ledge; gives fetid odor. Limestone is about $5 \mathrm{ft}$ thick. Overlying the limestone is transitional interval of limestone and gypsum, and this in turn is overlain by a gypsum unit at least $100 \mathrm{ft}$ thick Unmeasured

Entrada Sandstone:

Upper sandy member:

18. Sandstone, light brown (5YR 6/4), thin band of yellowish gray $(5 Y 8 / 1)$ at base of unit, yellowish gray $(5 Y$ $8 / 1$ ) and light greenish gray ( $5 G Y$ $8 / 1$ ) from 81.7 to $103.2 \mathrm{ft}$ above base of unit and dusky yellow (5Y 6/4) from $103.2 \mathrm{ft}$ to top of unit, weathering same colors, very fine to fine 
Entrada Sandstone-Continued

Upper sandy member-Continued grained, from 1 to 10 percent medium to coarse grains, fair to well sorted, composed of rounded to subrounded frosted and reddish-stained quartz and sparse black and orange accessory minerals; poorly cemented, calcareous in part; composed of thin to thick wedge-planar sets of mediumscale low-angle (?) cross-laminae, and horizontal laminae and thin beds; weathers to form vertical cliff of "slick rim" type.

Total of upper sandy member .........

Medial silty member(?) :

17. Siltstone $(70$ percent) to sandstone (30 percent), pale reddish brown $(10 R 5 / 4)$, grayish red $(10 R \quad 4 / 2)$, and minor grayish red $(5 R 4 / 2)$ and light brown $(5 Y R \quad 6 / 4)$ and light greenish gray ( $5 G Y 8 / 1)$, weathering same colors. All lithologic types from fine siltstone to very fine grained sandstone. Sandstone is well sorted and composed of subangular clear quartz and abundant black, orange, and green accessory minerals. Siltstone to sandstone is firmly cemented with a calcareous cement, is structureless or, in places, composed of very thick sets of horizontal laminae. Unit weathers to form a slope. A thin set of siltstone about $10 \mathrm{ft}$ above base of unit contains medium to very coarse grains of limestone. Unit contains horizontally laminated siltstone typical of the medial silty member of the Entrada Sandstone. The contact of this unit with the underlying Chinle Formation, however, is difficult to locate and marks the change from rocks containing swelling clays below to rocks containing nonswelling clays above. The basal $40 \mathrm{ft}$ of unit is not conspicuously horizontally laminated and may belong in the Chinle Formation. The siltstone, $10 \mathrm{ft}$ above base of unit, containing limestone grains is also suggestive of Chinle lithology. The light-greenish-gray rocks form thin color bands along exposure. Thin bed about $15 \mathrm{ft}$ below top of unit contains about 50 percent fine to coarse grains of frosted quartz and subordinate gray and orange quartz(?) ........

Total of medial silty member(?)....

Total Entrada Sandstone.

Chinle Formation:

Petrified Forest Member:

16. Siltstone to silty sandstone, grayish red $(5 R 4 / 2)$ and light greenish gray

. (2) y

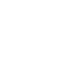


Chinle Formation-Continued

Petrified Forest Member-Continued

11. Clayey siltstone, grayish red $(5 R \quad 4 / 2$ and $10 R 4 / 2$ ), and common lightgreenish-gray (5GY 8/1) mottling, swelling clays; firmly cemented, calcareous; structureless; weathers to form frothy-surfaced badlands.

10. Siltstone to silty claystone, greenish gray $(5 G Y 6 / 1)$ and medium light gray $(N 6)$, weathering light greenish gray ( $5 G Y 8 / 1)$, swelling clays in part of unit, common very fine grained accessory white mica; firmly cemented, calcareous; stratification concealed, weathers to form slope. Unit forms greenish band on exposure. Locally basal 1 or $2 \mathrm{ft}$ of unit is composed of light-greenish-gray (5GY $8 / 1$ ) very fine grained ripple-laminated silty sandstone. In addition, basal few inches of unit in places is composed of sandstone. Sandstone is composed of medium grains to granules of gray and yellowish-gray siltstone and (or) limestone. Some carbonaceous material is present in basal $3 \mathrm{ft}$ of unit

9. Silty claystone to siltstone, grayish red $(5 R 4 / 2)$, pale reddish brown $(10 R$ $5 / 4)$, and grayish red purple (5RP $4 / 2$ ), common light-greenish-gray mottling, weathering same colors, contains swelling clays; firmly cemented, calcareous; structureless; weathers to form frothy-surfaced slope.

8. Sandy siltstone to silty sandstone, pale red $(10 R 6 / 2)$ and subordinate light gray $(N 7)$, weathering brownish gray $(5 Y R 4 / 1)$, all intermixtures of coarse silt and very fine grained sand; abundant very fine grained accessory white mica; well cemented, calcareous; ripple laminated; weathers to form ledge. Unit contains. a thin set of grayish-red $(10 R \quad 4 / 2)$ coarse siltstone about $1 \mathrm{ft}$ above base of unit. Siltstone contains abundant very fine grained accessory white mica. The stratification of the siltstone is concealed

7. Siltstone to clayey siltstone, greenish gray $(5 G Y 6 / 1)$ to light greenish gray $(5 \mathrm{GY} 8 / 1)$, abundant grayish red $(5 R 4 / 2)$ in basal $6 \mathrm{ft}$, weathering same colors, coarse siltstone, clayey and sandy (very fine grained), abundant fine-grained accessory white mica; firmly cemented, calcareous; stratification concealed; weathers to form slope. Basal $4 \mathrm{ft}$ of unit contains several thin sets of sandstone. Sandstone, yellowish gray (5Y 7/2) and minor grayish red $(5 R 4 / 2)$, very
Feet Chinle Formation-Continued

Feet

Petrified Forest Member-Continued . fine grained, composed of clear quartz; horizontally laminated, some ripple marks. These sandstone sets probably mark a transition from the sandstone member to the overlying part of the Chinle

$\frac{58.8}{541.1}$

Total of Petrified Forest Member...

Sandstone member:

6. Sandstone and conglomeratic sandstone, yellowish gray (5Y 8/1), pinkish gray (5YR 8/1), and very pale orange $(10 Y R 8 / 2)$, weathering very pale orange $(10 Y R 8 / 2)$ and medium gray $(N 5)$, very fine to fine grained, fair to well sorted, composed of subangular clear quartz and sparse black accessory minerals; firmly cemented, calcareous; composed of thin to thick tabular-planar sets of small- to medium-scale low-angle cross-laminae and of thin to very thick sets of horizontal laminae (some sets may be composed of very low angle crosslaminae instead of horizontal laminae); weathers to form hogback. Fifty percent of basal $20 \mathrm{ft}$ of unit is composed of conglomeratic sandstone which is present in thin to very thick lenses. Conglomeratic sandstone contains pebbles and granules of greenish-gray and gray limestone and siltstone pebbles as large as $2 \frac{1}{2}$ in. in maximum diameter. Pebbles and granules are in a very fine to medium-grained matrix similar to the rest of the unit. No quartz, quartzite, or chert granules or pebbles were noted

Total of sandstone member

Mottled strata (possibly equivalent to Agua Zarca Sandstone Member) :

5. Sandstone, very light gray $(N 8)$, dark yellowish orange $(10 Y R 6 / 6)$, grayish purple (5P 4/2), and grayish red ( $5 R 4 / 2$ ), colors mottled (grayish red is absent in top half of unit, increases in amount downward and is dominant color in basal third of unit), weathering same colors, very fine grained, well sorted; composed of subangular to subround clear quartz and sparse black accessory mineral; well cemented, noncalcareous, structureless; weathers to form slope..

4. Covered. About $500 \mathrm{ft}$ away from line of section, unit is exposed and is composed of silty sandstone. Silty sandstone, grayish red ( $5 R \quad 4 / 2)$, weathering same color, very fine grained, silty, fair sorted; composi- 
Chinle Formation-Continued

Mottled strata (possibly equivalent to Agua

Zarca Sandstone Member) - Continued

tion masked; firmly indurated, noncalcareous; horizontally laminated. Units 4 and 5 weather to form slope separating cliff-forming sandstones of units 3 and 6 .

Total of mottled strata (possibly equivalent to Agua Zarca Sandstone Member)

Total of Chinle Formation

Note. - Nearby drill holes in the San Juan basin contain about 1,200 ft of Chinle. The surface section described here is along the west flank of the Nacimiento Mountains in an area of steeply dipping and faulted strata, and the thickness (624 ft) of the Chinle here is probably related to structural complications rather than to an original thinness of the strata.

\section{Glorieta Sandstone:}

3. Sandstone, pale reddish brown (10R $5 / 4)$, moderate reddish orange $(10 R$ $6 / 6)$, pale red $(10 R 6 / 2)$, and light brown $(10 Y R 6 / 4)$, weathering same colors, very fine to fine grained, well sorted; composed of subround reddish-stained quartz and sparse black accessory mineral; firmly cemented, calcareous in part; composed of thick to very thick horizontal beds; weathers to form vertical cliff. Unit is fractured, possibly concealing detailed stratification

Total of Glorieta Sandstone..

Yeso Formation (incomplete) :

San Ysidro Member:

2. Sandstone ( 70 percent) to siltstone ( 30 percent), pale reddish brown (10R $5 / 4)$ to grayish red $(10 R 4 / 2)$, weathering same colors, grades from coarse siltstone to very fine to fine-grained sandstone, in places sandstone contains common medium to coarse grains (sandstone is commonly silty). Sandstone is composed of subangular to subround reddish-stained quartz and common black accessory mineral; medium to coarse grains are rounded, frosted quartz. Sandstone to siltstone is firmly cemented with a calcareous cement and is indistinctly horizontally laminated to thin bedded. Unit weathers to form steep slope. Unit contains a thick bed of limestone about $5 \mathrm{ft}$ below top. Limestone is yellowish gray $(5 Y 8 / 1)$ and pinkish gray $(5 Y R 8 / 1)$, finely crystalline, and poorly exposed.

Total of San Ysidro Member.

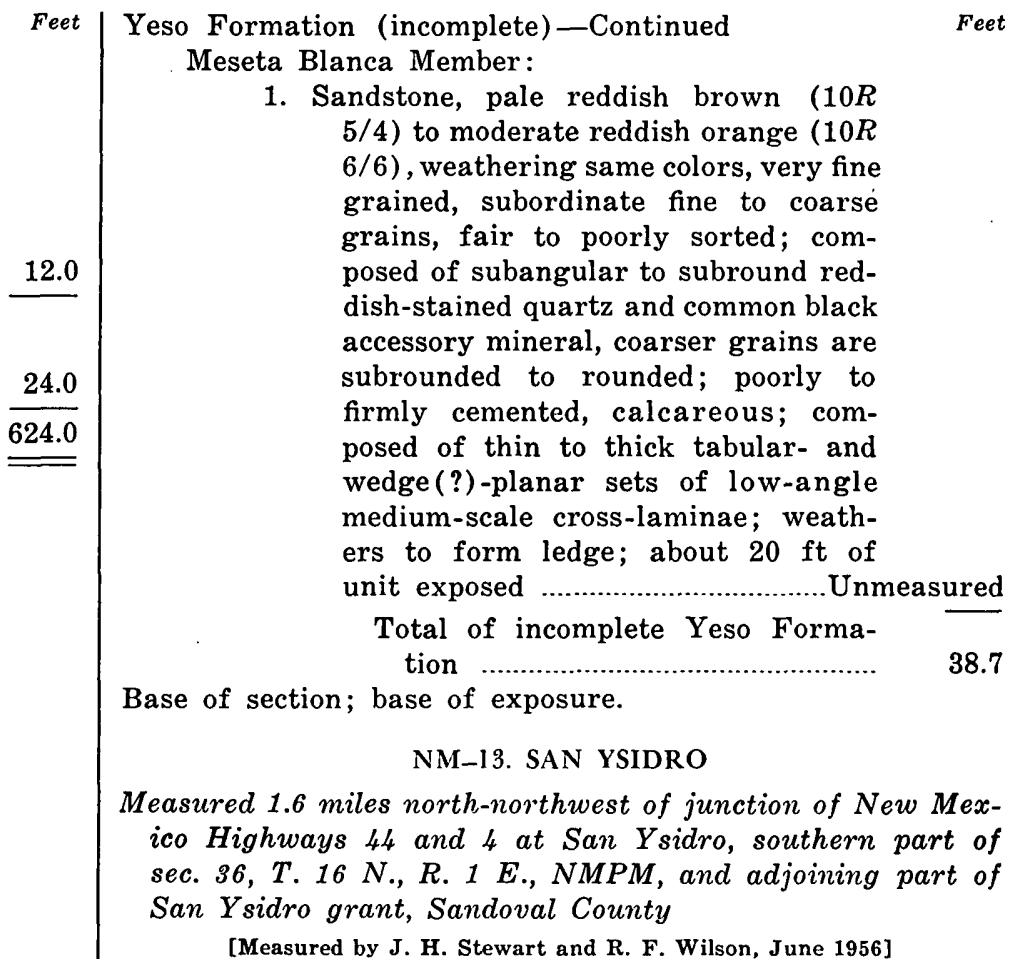

Top of section; top of exposure.

Chinle Formation (incomplete) :

Petrified Forest Member (incomplete) :

6. Possibly $125 \mathrm{ft}$ of strata is exposed above unit 3 about 1 mile south of section. This $125 \mathrm{ft}$ appears to be similar to unit 4 . These exposures south of the section contain two discontinuous sandstone sets from 10 to $20 \mathrm{ft}$ thick: one about the middle and the other at the top of the exposure. These sandstone sets are yellowish gray $(5 Y 8 / 1)$ and pale red purple $(5 R P 6 / 2)$, very fine grained, and composed of ripple laminae, horizontal laminae, and some low-angle crossstrata. The basal parts of the sandstone sets contain some conglomerate containing granules and pebbles of limestone and siltstone. Unmeasured

5. Conglomerate to sandstone, medium gray ( $N 5)$, spots of grayish orange (10YR 7/4), weathering olive gray (5Y 4/1), grades from conglomerate containing coarse grains to pebbles of yellowish and grayish siltstone and limestone in a very fine to fine-grained limy matrix to a very fine to finegrained sandstone; very fine to fine grains are dominantly clear quartz; well cemented, calcareous; horizontally very thin bedded, minor thin sets of small-scale low-angle crossbeds; weathers to form ledge and caps small mesa.

Feet eet 
Chinle Formation (incomplete)-Continued

Petrified Forest Member (incomplete)-Con. grayish red purple $(5 R P 4 / 2)$ and grayish red $(5 R 4 / 2)$ in top $10 \mathrm{ft}$; weathering same colors; probably swelling clays; firmly cemented, calcareous in part; structureless; weathers to form steep frothy-surfaced slope

Total of incomplete Petrified Forest Member

Sandstone member:

3. Sandstone, conglomerate, and siltstone. Sandstone, very pale orange $(10 Y R$ $8 / 2)$, grayish orange $(10 Y R \quad 7 / 4)$, grayish yellow $(5 Y 8 / 4)$, yellowish gray $(5 Y 8 / 1)$, and sparse medium gray $(N 5)$ and pale red $(10 R 6 / 2)$, weathering same colors, fine to medium grained, sparse very fine or coarse-grained parts, fair sorted; composed of subangular to subround clear quartz and sparse black accessory mineral; poorly to firmly cemented, calcareous in parts; composed of thin to thick trough and planar sets of very low to low-angle smallto medium-scale cross-laminae, some horizontal laminae to very thin beds, stratification in much of unit is poorly developed and difficult to see. Conglomerate, same colors as sandstone except about 50 percent is medium gray ( $N 5$ ), weathering same colors; composed of granules to pebbles of quartz, quartzite, and chert in a medium to very coarse grained matrix; firmly to well cemented, calcareous; present as thin to very thick lenses interstratified with sandstone. Lenses are structureless in places and contain low-angle cross-strata in other places. Along line of section pebbles are generally less than 1 in. in maximum diameter, but away from line of section a cobble with a maximum diam. eter of $5 \mathrm{in}$. was noted. A few of the conglomerate lenses contain moderateyellowish-brown $(10 Y R 5 / 4)$ siltstone granules. Siltstone, light gray $(N 7)$ to medium light gray $\left(N_{6}\right)$ and light greenish gray ( $5 G Y 8 / 1)$, weathering same colors, grades from fine silt to very fine grained sandy siltstone; common very fine grained accessory white mica in places; firmly indurated, noncalcareous; stratification concealed. In places siltstone contains thin ripple-laminated sets of grayishorange $(10 Y R 7 / 4)$ very fine grained sandstone. Unit as whole weathers to form vertical cliff in lower part and underlies bench in upper part. Thick-
Feet Chinle Formation (incomplete)-Continued Feet Sandstone member-Continued ness of unit probably somewhat in error because of variable dip and long dip slope on top of unit. Conglomerate occurs from 0 to $2.5 \mathrm{ft}, 23$ to 29 $\mathrm{ft}, 41$ to $43 \mathrm{ft}, 46$ to $51 \mathrm{ft}, 60$ to $64 \mathrm{ft}$, and 73 to $75 \mathrm{ft}$. Siltstone occurs from 70 to $73 \mathrm{ft}, 80$ to $86 \mathrm{ft}$, and 130 to 143 $\mathrm{ft}$. Rest of unit is sandstone................

Total of sandstone member. 165.0

Total of incomplete Chinle Formation

165.0

San Andres Limestone:

Upper clastic member:

2. Sandstone ( 80 percent) to siltstone $(20$ percent), pale reddish brown (10R $5 / 4)$, grayish red $(5 R \quad 4 / 2$ and $10 R$ $4 / 2)$, and sparse yellowish gray ( $5 Y$ $8 / 1$ ), weathering same colors, all gradations in lithologic type from medium-grained sandstone to fine siltstone (sandstone and sandy siltstone commonly contain medium to very coarse rounded grains in a finer matrix), poorly to fair sorted; composed of subangular to rounded clear and reddish-stained quartz; firmly cemented, calcareous; composed of indistinct horizontal beds (bedding is slightly wavy and possibly contorted in places); weathers to form steep rubble-covered slope

Total of upper clastic member of San Andres Limestone

Glorieta Sandstone:

1. Sandstone, yellowish gray $(5 Y$ 8/1) and very pale orange $(10 Y R 8 / 2)$, and subordinate pale reddish brown $(10 R 5 / 4)$, weathering same colors, medium grained, sparse coarse grains, fair sorted; composed of subangular to subround clear quartz and sparse black accessory mineral; poorly to firmly cemented, calcareous; horizontally thin to thick bedded and minor medium-scale low-angle cross-strata; weathers to form steep ledgy slope or in some places a vertical cliff. Unit is over $100 \mathrm{ft}$ thick. Unmeasured

Base of section; not base of exposure. Base of section is S. $65^{\circ}$ W. of Jemez and N. $42^{\circ}$ W. of San Ysidro.

\section{NM-14. SENORITO CANYON}

Measured parallel to New Mexico Highway 126 and from 200 to $500 \mathrm{ft}$ north of the highway, 41/4 miles southeast of Cuba, southwestern part of $\sec 1, T .20$ N., R. 1 W., NMPM, Sandoval County

[Measured by J. H. Stewart and R. F. Wilson, June 1956]

Top of section; top of good exposure. Probably most if not all of the Poleo Sandstone Member is exposed. 
Chinle Formation (incomplete):

Poleo Sandstone Lentil (incomplete) :

10. Sandstone, same as unit 6 , contains several thin lenses of conglomerate. Conglomerate is light gray $(N 7)$ and yellowish gray $(5 Y 8 / 1)$ and is composed of medium grains to small pebbles of greenish-gray and yellowish-gray siltstone and possibly limestone in a very fine grained limy matrix

9. Siltstone to clayey siltstone, pale brown $(5 Y R 5 / 2)$ to brownish gray (5YR $4 / 1$ ), weathering same colors, common very fine grained accessory white mica; firmly cemented, calcareous; weathers to form slope.

8. Sandstone, same as unit 6 , weathers to form ledge

7. Silty claystone to clayey siltstone, grayish red $(10 R 4 / 2)$ in lower half and greenish gray (5GY 6/1) in upper half, weathering same colors; swelling clays in part; firmly cemented, slightly calcareous; stratification concealed; weathers to form slope. Unit thins and possibly pinches out to south, and thickens to north. Unit poorly exposed in places. Unit may be transitional into overlying unit.........

6. Sandstone, pale greenish yellow (10Y $8 / 2)$ and minor yellowish gray $(5 Y$ $8 / 1$ ), weathering same colors, fine grained, sparse medium-grained parts, well sorted; composed of subround clear quartz and sparse black accessory minerals; firmly cemented, calcareous; horizontally laminated, minor thin tabular-planar sets of small-scale very low angle cross-laminae; weathers to form ledge.

Total incomplete Poleo Sandstone Lentil

Salitral Shale Tongue:

5. Silty claystone, grayish red (5R $4 / 2$ and $10 R 4 / 2)$, subordinate pale reddish brown $(10 R 5 / 4), 10 \mathrm{ft}$ layer of greenish gray $(5 G Y 6 / 1)$ in basal third of unit; swelling clays; firmly cemented, slightly calcareous in parts; structureless; weathers to form valley between hogback developed on Agua Zarca and Poleo. Unit poorly exposed in places. Greenish interval contains some flakes of carbonaceous material and a black ( $N$ 1 $)$ coaly layer about $1 / 2$ in. thick. Unit weathers with a frothy surface

Total of Salitral Shale Tongue.

Agua Zarca Sandstone Member and sandstone member:

Note. - Basal $58 \mathrm{ft}$ of unit 2 is probably the Agua Zarca Sandstone Member; rest of unit
Chinle Formation (incomplete)-Continued

Agua Zarca Sandstone Member and sandstone member-Continued

2 and all of units 3 and 4 may correlate with the sandstone member. These correlations, however, are tentative.

4. Sandstone, yellowish gray $(5 Y \quad 8 / 1)$ and very pale orange $(10 Y R 8 / 2)$, very fine to fine grained, well sorted; composed of subround to round clear quartz and common black accessory mineral; firmly to well cemented, noncalcareous, probably siliceous cement; horizontally laminated; weathers to form small ledge and underlies dip slope on back side of hogback formed on the Agua Zarca Sandstone Member
15.9

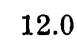

3. Mostly covered. Locally top $2 \frac{1}{2} \mathrm{ft}$ of unit is exposed and consists of chert. Chert, white $(N 9)$ and minor pale yellowish orange $(10 Y R 8 / 6)$, weathering pale yellowish orange $(10 Y R$ $8 / 6)$, consists of chalky-appearing chert and irregular lenses of vitreous chert

2. Sandstone, very pale orange $(10 Y R 8 / 2)$ to light brown $(5 Y R 6 / 4)$, weathering same colors, dominantly coarse to very coarse-grained in basal $58 \mathrm{ft}$, and fine to medium grained in rest of unit (coarser grained part is fair to poorly sorted, finer grained part is fair to well sorted); composed of subangular clear quartz and sparse black accessory mineral; poorly cemented, possibly slightly calcareous. Coarser grained part of unit is indistinctly cross-stratified at a low angle and on a medium scale; finer grained part is composed of thin to thick tabularplanar sets of small- to medium-scale cross-laminae. Unit weathers to form hogback. Coarser grained part of unit in places contains some granules of clear quartz. Locally a few pebbles of quartz, quartzite, and chert are scattered in the sandstone. A few lenses of conglomerate are present in the basal $20 \mathrm{ft}$ of the unit away from the line of section. The conglomerates contain granules, pebbles, and cobbles of quartz, quartzite, and chert, and the cobbles are as large as about 3 in. in maximum diameter.

Total of Agua Zarca Sandstone Member and sandstone member..

Total of incomplete Chinle Formation

Abo Formation:

1. Sandy siltstone, light brown (5YR 6/4) to moderate brown $(5 Y R 4 / 4)$, minor yellowish gray $(5 Y 8 / 1)$, weathering 
Abo Formation-Continued

same colors, sandy (very fine grained) siltstone; firmly cemented, slightly calcareous; stratification indistinct, probably thin to thick horizontal beds; weathers to form ledgy slope. Only about $15 \mathrm{ft}$ exposed................. Unmeasured

Base of section; base of exposure.

\section{NM-15. WHITE MESA}

Measured 4 miles south-southwest of San Ysidro and near western end of line of cliffs on north side of White Mesa, middle of sec. 16, T. 15 N., R. 1 E., NMPM, Sandoval County

[Measured by J. H. Stewart and R. F. Wilson, June 1956]

Top of section; top of exposure.

Todilto Limestone (incomplete) :

7. Gypsum and limestone. Gypsum, white (N 9), weathering same color and light olive gray (5Y 6/1), medium crystalline; well indurated, structureless. Limestone, same as underlying unit; present as thin laminae separating laminae to very thin beds of gypsum. Limestone forms about half of basal few feet of unit, decreases in amount upward, and is absent higher than $20 \mathrm{ft}$ above base of unit. In places, gypsum forms nodular masses disrupting stratification of limestone. About $50 \mathrm{ft}$ of unit exposed along line of section, but locally unit appears to be $100 \mathrm{ft}$ thick.... Unmeasured

6. Limestone, light olive gray (5Y 6/1), weathering same color, dense; well indurated, horizontally thin laminated; paper splitting; weathers to form ledge. Limestone has fetid odor..

Total of incomplete Todilto Limestone

Entrada Sandstone:

Upper sandy member:

5. Sandstone, yellowish gray (5Y 8/1), light greenish gray $(5 G Y 8 / 1)$ and subordinate grayish yellow (5Y 8/4), light gray $(N 7)$, very pale orange $(10 Y R 8 / 2)$ and pale yellowish orange $(10 Y R 8 / 6)$, weathering same colors, very fine to fine grained, minor medium to coarse grains; fair sorted; composed of subround to rounded frosted quartz and common black accessory mineral; poorly cemented, calcareous; composed of thin to thick tabular and wedge-planar sets of very low and low-angle small- to medium-scale cross-laminae and subordinate horizontal laminae to thin beds. Top $35 \mathrm{ft}$ of unit is entirely horizontally laminated to thin bedded. Unit weathers to form vertical cliff. Unit contains thin bed of light-greenish-gray ( $5 G Y 8 / 1)$ sandy (very fine
Feet Entrada Sandstone-Continued

Upper sandy member-Continued

grained) coarse siltstone $65 \mathrm{ft}$ above base of unit. Unit contains round nodules of sandstone from 30 to 35 $\mathrm{ft}$ above base. Nodules contain interstitial pyrite and are generally 2 in. in diameter

Total of upper sandy member.

79.4

$\overline{79.4}$

Medial silty member:

4. Sandy siltstone to silty sandstone, light brown $(5 Y R \quad 6 / 4)$ and minor pale reddish brown $(10 R 5 / 4)$, weathering same colors, all intermixings of coarse silt and very fine grained sand; firmly cemented, calcareous; structureless, some suggestions of discontinuous wavy laminae; weathers to form steep slope. Basal $2 \mathrm{ft}$ contains common fine to very coarse rounded and frosted quartz grains and orange, red, and gray grains........

3. Silty claystone to sandy siltstone, finer grained rocks are grayish red $(10 R$ $4 / 2$ ) and coarser grained rocks are light brown $(5 Y R \quad 6 / 4)$ and light greenish gray $(5 G Y 8 / 1)$, weathering pale reddish brown $(10 R 5 / 4)$ with light-greenish-gray $(5 G Y$ 8/1) color bands; all lithologic types from silty claystone to sandy (very fine grained) coarse siltstone; firmly cemented, calcareous; ripple laminated and very thin to thin horizontally bedded; weathers to form steep slope...

2. Sandstone and silty claystone. Sandstone, light greenish gray (5GY 8/1) and minor light-brown (5YR 6/4) mottling, weathering same colors, very fine to fine grained, minor mediumgrained parts, well sorted; composed of rounded clear quartz, sparse black accessory mineral; poorly cemented, calcareous; horizontally thin to thick bedded and minor thin sets of lowangle small-scale cross-laminae. Silty claystone, grayish red (10R 4/2), weathering same colors; firmly cemented, noncalcareous; present as thin horizontal beds interstratified with sandstone; platy splitting. Silty claystone beds and possibly some of the sandstone beds have a slight waviness. Unit as a whole weathers to form conspicuous whitish ledge lying between reddish rocks. This unit might correlate with the Wingate Sandstone, but the authors consider that it is best placed in the Entrada Sandstone

Total of medial silty member.........

Total of Entrada Sandstone...
52.4 
Chinle Formation (incomplete) :

Petrified Forest Member (incomplete) :

1. Clayey siltstone ( 80 percent) to siltstone (20 percent), pale reddish brown $(10 R 5 / 4)$ to grayish red $(10 R$ $4 / 2$ ), subordinate light brown (5YR $6 / 4)$ and sparse grayish red $(5 R$ $4 / 2$ ), weathering same colors; about $1 / 3$ of unit contains swelling clays, rest of unit probably is too silty to detect swelling clays; fine to medium silt; firmly cemented, calcareous; structureless, unit contains color bands suggestive of horizontal stratification; weathers to form steep frothy-surfaced slope. Unit contains two thick beds of light-greenish-gray $(5 G Y 8 / 1)$ limestone-grain sandstone. One bed of sandstone is $40 \mathrm{ft}$ above base, and the other is $5 \mathrm{ft}$ below top of unit. This sandstone is composed of fine grains to granules of gray limestone in a silt and clay matrix....

Total of incomplete Petrified Forest Member

Total of incomplete Chinle Formation

(1)

Base of section; base of exposure.

\section{NM-18. BLUEWATER CREEK}

Measured on point about one-third mile south of Bluewater Creek, northeastern part of sec. $36, T .6 N ., R .7 W$., NMPM, Valencia County

[Measured by J. H. Stewart and R. F. Wilson, May 1956]

Top of section; top of good exposure. Higher exposures consist of medium-gray ( $N 5)$ siltstone and of a few ledge-forming sandstones. About $150 \mathrm{ft}$ of this siltstone and sandstone unit exposed below basalt which caps mesa. Top of section is S. $70^{\circ} \mathrm{W}$. of Seis-Wilson Ranch, and one-third mile south of Bluewater Creek.

Dakota Sandstone (incomplete) :

10. Sandstone, white $(N 9)$, yellowish gray (5Y 8/1), and grayish orange (10YR $7 / 4)$, weathering grayish orange $(10 Y R$ 7/4), fine to medium grained, well sorted; composed of subrounded to rounded clear and frosted or etched quartz, common limonite spots; well cemented, calcareous in parts, probably siliceous in parts; composed of planar and trough sets of small- to medium-scale high- and low-angle cross-laminae; weathers to form vertical cliff. A thick conglomerate lens is present $2.5 \mathrm{ft}$ above base of unit. Conglomerate is composed of granules and pebbles of white, gray, and black quartz, chert, and minor quartzite in a sand matrix which is the same as the sand in the rest of the unit. Unit also contains several lenticular sets of intraformational siltstone pellet conglomerate. Unit forms top darker colored cap of vertical cliff

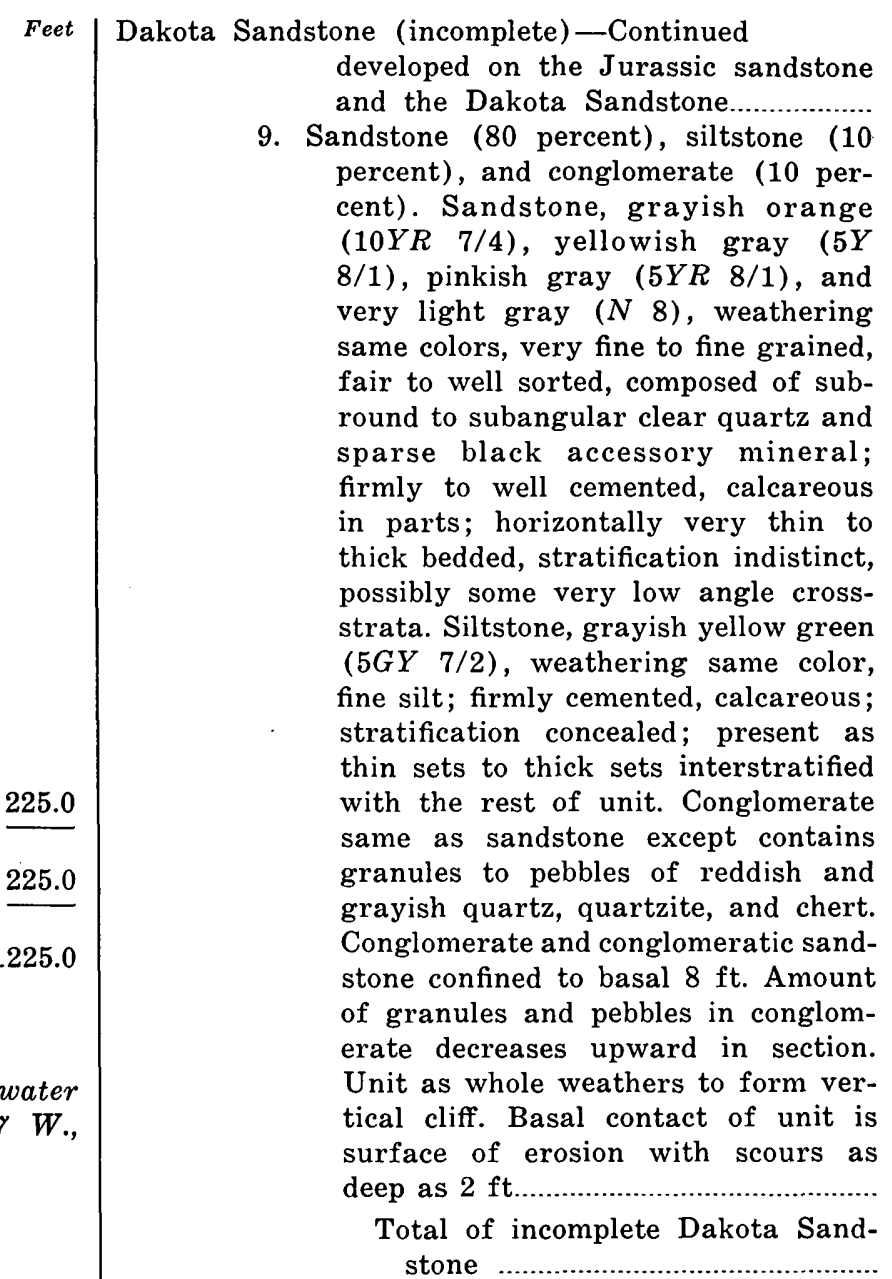

Feet

Unit of Jurassic age (probably equivalent to the Summerville Formation) :

8. Siltstone to silty sandstone, yellowish gray $(5 Y 7 / 2)$ and grayish yellow (5Y 8/4), weathering same color, grades from coarse siltstone to silty very fine grained sandstone; the sandstone is composed of subangular milky and possibly clear quartz, and common black accessory mineral; firmly to well cemented, calcareous; s'tratification indistinct, but appears to be dominantly horizontally laminated to thick bedded, common low- and highangle small- to medium-scale crosslaminae; weathers to form vertical cliff

Chinle Formation (incomplete) :

Reddish sandstone member (this name was applied to these strata by Silver, 1948):

7. Siltstone, pale reddish brown $(10 R$ $5 / 4)$ and light brown (5YR 6/4), weathering same color, medium to coarse silt; firmly to well cemented, calcareous; horizontally laminated, probably in part structureless; weath- 
Chinle Formation (incomplete)-Continued

Reddish sandstone member-Continued ers to form steep slope. Unit is yellowish gray $(5 Y 8 / 1)$ in top $2 \mathrm{ft}$........

6. Siltstone, light brown (5YR 6/4), weathering same color, coarse silt; well cemented, calcareous; horizontally laminated, laminae indistinct in places; weathers to form prominent and persistent ledge. Unit forms most prominent ledge in the reddish sandstone member. Unit contains small interference ripples(?) along a few stratification planes

5. Siltstone, same as unit 3 , contains a few thin to thick horizontal beds similar to those in unit 4 . These beds weather to form ledges; rest of unit forms steep slope.

4. Siltstone, light brown (5YR 6/4), weathering same color, coarse silt; well cemented, calcareous; horizontally thin to thick bedded; weathers to form persistent ledge

3. Siltstone, light brown $(5 Y R 6 / 4)$ and minor grayish red $(10 R 4 / 2)$, weathering light brown $(5 Y R$ 6/4), medium to coarse silt; firmly to well cemented, calcareous; a few horizontal stratification planes, mostly structureless; fractures into angular fragments; weathers to form steep loose slope

Total of reddish sandstone member

Petrified Forest Member (incomplete) :

2. Siltstone, pale red $(5 R 6 / 2)$, minor grayish red $(5 R 4 / 2)$, pale reddish brown $(10 R 5 / 4)$ and light greenish gray (5GY 8/1), weathering same colors, fine silt; firmly cemented, calcareous; structureless; weathers to form steep slope. Contains thin limy siltstone bed about $10 \mathrm{ft}$ below top of unit. This bed contains limy masses within a silty matrix. The unit may be equivalent to the Owl Rock Member of the Chinle Formation or may be a peculiar lithologic unit at the top of the Petrified Forest Member...

1. Clayey siltstone to silty claystone, pale reddish brown $(10 R 5 / 4)$ and subordinate grayish red purple (5RP $4 / 2$ ), weathering same colors; swelling clays; firmly indurated, slightly calcareous to noncalcareous; probably structureless, possibly some horizontal stratification planes; weathers to form frothy-surfaced badlands.......

Total of incomplete Petrified Forest Member

$\frac{56+}{131.8+}$

Base of section; base of exposure.

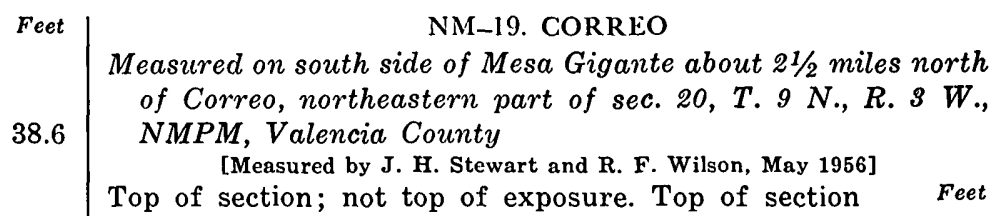
is N. $7^{\circ}$ E. of overpass of U.S. Highway 66 over AT\&SF railroad and N. $22^{\circ} \mathrm{W}$. of middle of Mesa Redondo.

Todilto Limestone:

8. Limestone, light olive gray (5Y 6/1), weathering yellowish gray $(5 Y 8 / 1)$ in basal $4.5 \mathrm{ft}$ and light olive gray $(5 Y 6 / 1)$ in rest of unit, dense to very finely crystalline; horizontally thinly laminated; weathers to form conspicuous darkish ledge. Only basal few feet of unit examined. Unit is about $20 \mathrm{ft}$ thick

Unmeasured

Entrada Sandstone:

Upper sandy member:

7. Sandstone, light greenish gray ( $5 G Y$ $8 / 1$ ), very thin bands of moderate greenish yellow $(10 Y 7 / 4)$ and grayish red purple $(5 R P 4 / 2)$ in basal 0.5 $\mathrm{ft}$, weathering same colors, very fine grained, well sorted; composed of subrounded clear quartz and sparse black accessory mineral; poorly cemented, calcareous; horizontally laminated to very thin bedded; weathers to form vertical cliff

6. Sandstone, light brown $(5 Y R 6 / 4)$ and light greenish gray $(5 G Y 8 / 1)$ in top $25 \mathrm{ft}$, weathering same colors, fine to medium grained, fair sorted; composed of subround to round reddishstained quartz in lower $105 \mathrm{ft}$ of unit and clear quartz in top $25 \mathrm{ft}$, common orange and black accessory minerals, poorly cemented, calcareous; composed of thin to very thick wedgeplanar sets of small- to large-scale high- and low-angle cross-laminae; weathers to form hill and gully topography in lower part of unit and steep slope to vertical cliff in upper part. Basal few feet in places contain medium to very coarse rounded clear quartz and black, white, and orange grains

Total of upper sandy member....... $\overline{\mathbf{1 3 4 . 5}}$

Medial silty member:

5. Siltstone $(80$ percent) to sandstone $(20$ percent), pale reddish brown (10R $5 / 4)$ thin color bands and mottling of light greenish gray ( $5 G Y 8 / 1$ ), weathering same colors, all gradations from fine siltstone to very fine grained sandstone; firmly to well cemented, calcareous; horizontally laminated to thin bedded, sparse thin sets of ripple laminae, many beds contain indistinct wavy laminae which are possibly contorted ripple laminae; 
Entrada Sandstone-Continued

Medial silty member-Continued

weathers to form gentle slope. In places unit contains funnel-shaped masses of rock as much as $3 \mathrm{ft}$ high. These masses are similar to clastic dikes at base of unit. Basal $2 \mathrm{ft}$ of unit is dominantly light greenish gray and contain medium grains to granules of white, gray, and red quartz and chert(?)

Total of medial silty member

Total of Entrada Sandstone.

Contact between Entrada Sandstone and Chinle Formation is sharp and irregular and marks change from siltstone and silty claystone below to sandstone above. Contact marks color change from purples below to reds above, and basal part of Entrada contains abundant medium grains to granules of quartz and chert(?). Entrada fills clastic dikes extending down into Chinle Formation. Dikes are as deep as $3 \mathrm{ft}$ and as wide as $2 \mathrm{ft}$. Chinle Formation (incomplete) :

Petrified Forest Member (incomplete) :

4. Siltstone to silty claystone, grayish red $(5 R 4 / 2)$, moderate red $(5 R 5 / 4)$, subordinate pale red $(5 R 6 / 2)$, common light-greenish-gray $(5 G Y \quad 8 / 1)$ mottling, weathering same colors, fine to medium silt; common very fine grained accessory white mica in places, swelling clays in places; firmly cemented, noncalcareous clay binding; structureless with probably some horizontally laminated parts; weathers to form small hills and knolls. Unit contains a few thin sets of palered $(5 R 6 / 2)$ very fine grained horizontally laminated sandstone and possibly some very low angle crossstratified sandstone

Correo Sandstone Bed:

3. Sandstone (80 percent) and conglomerate (20 percent). Sandstone, pale red $(5 R 6 / 2$ and $10 R 6 / 2)$, weathering grayish orange pink (5YR $7 / 2)$, fine to medium grained, fair sorted, composed of subangular pinkishstained quartz and about 3 percent black mineral; abundant mediumgrained accessory white mica; poorly cemented, calcareous; composed of thin to thick trough sets of low-angle small- to medium-scale cross-laminae, some parts probably horizontally laminated. Conglomerate, yellowish gray $(5 Y 7 / 2)$ to pale olive $(10 Y 6 / 2)$, weathering olive gray ( $5 Y 4 / 1)$, composed of coarse grains to granules (subordinate pebbles) of gray and white siltstone and limestone, set in either sand or limy silt matrix. Con-

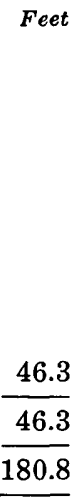

Chinle Formation (incomplete)-Continued

Petrified Forest Member (incomplete)-Con.

Correo Sandstone Bed-Continued

glomerate is firmly to well cemented, calcareous; horizontally very thin bedded, some thin trough sets of very low angle small- to medium-scale cross-strata. Conglomerate is present as thin to very thick sets interstratified and intertonguing irregularly with sandstone. Conglomerate forms blackish parts of unit and sandstone forms brownish parts. Unit weathers to form vertical cliff in lower part and bench in upper part. Pebbles are as large as $2 \frac{1}{2}$ in. in maximum diameter

2. Conglomerate, pale olive $(10 Y 6 / 2)$, weathering yellowish gray $(5 Y 7 / 2)$. Gravel fraction, coarse grains to cobbles of light-greenish-gray (5GY 8/1) limestone, reddish and gray siltstone, and gray sandstone. Granules to cobbles constitute about 70 percent of rock. Matrix, very fine to fine grained sand, fair sorted, composed of subangular to angular milky grains and about 3 percent medium- to coarsegrained dark-green mica. Conglomerate is poorly cemented, calcareous; composed of indistinct low-angle medium- and possibly large-scale crossstrata, some parts of unit are probably structureless; weathers to form steep slope in lower half and vertical cliff in upper half. Unit highly variable in thickness along exposure and probably fills channels cut into underlying unit. Disk-shaped cobbles are common and are as large as $7 \frac{1}{2}$ in. in maximum diameter.......

Total of Correo Sandstone Bed.

Siltstone to clayey siltstone, grayish red ( $5 R 4 / 2$ and $10 R 4 / 2)$, weathering same colors and pale reddish brown $(10 R 5 / 4)$, fine silt; swelling clays; firmly cemented, calcareous, clay binding; stratification mostly concealed, probably mostly structureless; weathers to form frothy-surfaced slope. Unit contains some light-greenish-gray $(5 G Y$ 8/1) mottling and is light greenish gray in top $0.3 \mathrm{ft}$. Locally along exposure about $150 \mathrm{ft}$ of this unit is exposed................

Total of incomplete Petrified Forest Member

Total of incomplete Chinle Formation

Base of section; base of exposure. Base of section is N. $9^{\circ}$ E. of overpass of U.S. Highway 66 over AT\&SF railroad tracks and N. $23^{\circ} \mathrm{W}$. of middle of Mesa Redondo.
Feet 
NM-21. PETOCH BUTTE

Measured on the east side of Petoch Butte, middle of sec. 32, T. 8 N., R. 6 W., NMPM, Valencia County

[Measured by J. H. Stewart and R. F. Wilson, May 1956]

Top of section; not top of exposure.

Entrada Sandstone (incomplete) :

Upper sandy member:

5. Sandstone, light brown (5YR 6/4), weathering same color, fine grained, fine to medium grained in parts, common disseminated medium to very coarse grains in places, fair to well sorted; composed of subround reddish-stained quartz and common black accessory mineral; poorly cemented, slightly calcareous; composed of thin to thick tabular and wedge-planar sets of low- and high-angle small- to medium-scale cross-laminae; weathers to form vertical cliff. Basal contact of unit sharp and persistent. Possibly a few 2-in.-deep scours along basal contact. Only basal $10 \mathrm{ft}$ of unit examined Unmeasured

Medial silty member:

4. Siltstone to sandstone, pale reddish brown $(10 R 5 / 4)$ and subordinate light brown (5YR 6/4), weathering pale reddish brown $(10 R 5 / 4)$, thin to very thick beds and sets of siltstone alternate with thin to thick beds and sets of silty sandstone to sandstone, all lithologic types intergrade. Silty sandstone to sandstone is very fine grained, silty in parts, fair to well sorted; composed of subround reddish-stained quartz and common black accessory mineral. Unit as whole is firmly to well cemented, calcareous; horizontally thinly laminated to thin bedded, ripple laminated in a few places, indistinct wavy laminae (possible ripples) in places. Unit weathers to form slope in lower half and vertical cliff in upper half. Sandstone in basal foot of unit contains about 10 percent coarse grains to granules of black, orange, and clear quartz, quartzite (?), and chert. One or two sets of sandstone in upper part of unit contain common medium to very coarse rounded grains of quartz(?). Base of unit appears gradational with underlying unit........

Total of medial silty member..........

Total of incomplete Entrada Sandstone

Wingate Sandstone:

Lukachukai Member:

3. Sandstone, light brown $(5 Y R 6 / 4)$ to moderate reddish orange $(10 R 6 / 6)$, weathering same color, fine grained,
Wingate Sandstone-Continued

Lukachukai Member-Continued

minor fine- to medium-grained parts, medium grains commonly concentrated along stratification planes, fair to well sorted; composed of subround reddish-stained quartz and 2 to 3 percent black mineral; poorly cemented, calcareous; composed of thin to thick wedge- and tabular-planar sets of low- and high-angle smallto medium-scale cross-laminae; weathers to form ledge.

2. Sandstone, siltstone, and conglomeratic sandstone, light brown (5YR 6/4), pale reddish brown $(10 R 5 / 4)$, and light greenish gray $(5 G Y 8 / 1)$, colors mottled, weathering same colors. Unit is composed of siltstone, silty very fine grained sandstone with common scattered fine to coarse grains, and conglomeratic sandstone. These rock types are poorly sorted, composed of subround to subangular clear and reddish-stained quartz and sparse black accessory minerals. Coarser grains are subrounded to rounded. Granules to pebbles are of quartzite, quartz, and chert, are faceted and pitted, and may be ventifacts. One cobble is $31 / 4$ in. in maximum diameter. Unit as whole is well to firmly cemented, calcareous; structureless and gnarly stratified; and weathers to form basal part of cliff. Unit is highly variable in thickness and may be absent locally..

Total of Lukachukai Member

Contact of Wingate Sandstone and Chinle Formation sharp and marked by change from siltstone below to conglomeratic sandstone to sandstone above. Wingate fills channels cut as deep as $2 \mathrm{ft}$ into the Chinle. Contact also marked by many clastic dikes about 3 to $4 \mathrm{ft}$ deep and from a few inches to a foot wide. The dikes extend down into the Chinle Formation and are filled with sandstone and conglomeratic sandstone of the overlying unit.

Chinle Formation:

Petrified Forest Member:

1. Siltstone, pale reddish brown $(10 R$ $5 / 4)$, pale red $(10 R 6 / 2)$, and grayish red ( $10 R 4 / 2$ and $5 R 4 / 2)$, weathering same colors; firmly cemented, calcareous; structureless, weathers to form steep slope. About $200 \mathrm{ft}$ exposed. Unit contains swelling clays in lower half. Siltstone in about upper half weathers with a frothy surface, suggesting that it contains swelling clays, but siltstone did not swell on 
Chinle Formation-Continued

Petrified Forest Member-Continued contact with water. Possibly some of this upper half of the exposed Chinle is equivalent to unit 2 of the Bluewater Creek section.........................Unmeasured

Base of section; not base of exposure. Base of section on east side of Petoch Butte.

\section{UTAH}

\section{U-1. LAKE FORK RIVER}

Measured on south side of canyon of Lake Fork River in SE1/4 sec. 34, T. 2 N., R. 5 W., UM, Duchesne County

[Measured by F. G. Poole and J. H. Stewart, September 1956]

Top of section; not top of exposure. Line of section trends about S. $25^{\circ}$ E. Top of section about 3,000 ft $\mathrm{N}$. $75^{\circ}$ E. from bridge across small northwarddraining tributary of Lake Fork River.

Glen Canyon Sandstone:

19. Sandstone, yellowish-gray $(5 Y 8 / 1)$ to very pale orange $(10 Y R 8 / 2)$ with minor grayish-orange $(10 Y R \quad 7 / 4)$ mottling, weathering same colors, very fine to fine grained, well sorted; composed of rounded to well-rounded clear and milky quartz, common feldspar and uncommon black (iron oxide?) accessory mineral; firmly to poorly cemented, very calcareous; composed of thin to very thick trough and planar sets of small-, medium-, and large-scale cross-laminae to very thin crossbeds. Weathers to form steep rough slope. Only basal $20 \mathrm{ft}$ of unit examined in detail............Unmeasured

Chinle Formation:

Upper member:

18. Silty claystone, basal $4 \mathrm{ft}$ is pale reddish brown (10R 5/4), grading upward to grayish red $(10 R 4 / 2)$ and pale red $(5 R 6 / 2)$, grayish yellow green $(5 G Y 7 / 2)$ and grayish green $(10 G Y 5 / 2)$ in upper half of unit, weathering same colors; firmly cemented, calcareous; horizontally thinly laminated; papery splitting. Weathers to form smooth gentle slope. Basal $4 \mathrm{ft}$ of unit grades laterally into sandy siltstone 20 yd to east. Upper contact is not exposed....

17. Sandstone, light greenish gray (5GY $8 / 1)$ to pinkish gray $(5 Y R 8 / 1)$, weathering same colors and pale red $(10 R 6 / 2)$, very fine grained, silty, well sorted; composed of rounded and well-rounded clear, milky, and amberstained quartz and sparse feldspar and black accessory mineral; firmly to well cemented, calcareous; horizontally laminated to thin bedded; platy to slabby splitting; weathers to form conspicuous ledge..

16. Siltstone, pale red (5R $6 / 2$ and $10 R$ $6 / 2)$ to grayish red $(10 R 4 / 2)$, weath-
Feet

Chinle Formation-Continued

Upper member-Continued

15. Silty claystone, pale red $(10 R 6 / 2$ and

14. Clayey siltstone, pale reddish brown

13. Silty claystone, grayish red purple

12. Sandstone, light greenish gray $(5 G Y$

11. Silty claystone to clayey siltstone, gray-

10. Sandstone, light greenish gray ( $5 G Y$ calcareous; horizontally laminated to ering same colors; contains common well-rounded very fine grains of amber-stained quartz; firmly cemented, slightly calcareous; horizontally thinly laminated to laminated; slabby splitting; weathers to form smooth slope $5 R 6 / 2)$ to grayish red $(10 R 4 / 2)$, subordinate grayish-yellow-green (5GY 7/2) mottling, weathering pale red $(10 R 6 / 2)$; firmly cemented, noncalcareous to slightly calcareous; horizontally thinly laminated; papery splitting; weathers to form smooth gentle slope $(10 R 5 / 4)$, weathering same color; scattered well-rounded very fine grains of quartz; firmly cemented, calcareous; appears structureless; weathers to form smooth gentle slope. Topmost part of unit covered... $(5 R P 4 / 2)$ to grayish red $(5 R 4 / 2)$ and greenish gray $(5 G 6 / 1)$, weathering same colors and pale red $(10 R$ $6 / 2)$; similar to unit 11 . Topmost part of unit not exposed. $8 / 1)$ and yellowish gray (5Y 8/1), subordinate light-brown (5YR 6/4) mottling, weathering same colors and pinkish gray $(5 Y R 8 / 1)$; similar to unit 10 ; light-brown parts composed largely of amber-stained quartz. Unit weathers to form highest conspicuous ledge in section ish red $(10 R 4 / 2)$, weathering same color; firmly cemented, slightly calcareous; horizontally thinly laminated, papery splitting. Weathers to form smooth slope. $8 / 1$ and $5 G 8 / 1$ ), weathering same colors and white $(N 9)$, very fine grained, silty, well sorted; composed of rounded to well-rounded clear and milky quartz grains, common feldspar and black (iron oxide?) accessory mineral; firmly to well cemented, very thick bedded, common ripple laminae, sparse trough and planar sets of lowangle medium- and small-scale crosslaminae, sparse cuspate ripples and sparse current lineations. Unit weathers to form prominent ledge.

Feet

9. Siltstone, light greenish gray ( $5 G Y 8 / 1$ and $5 G 8 / 1)$, grayish red $(10 R 4 / 2)$, weathering same colors; firmly to well cemented, calcareous, in part 
Chinle Formation-Continued

Upper member-Continued

very argillaceous; horizontally laminated to thin bedded, sparse structureless parts, numerous ripple laminations and mud cracks. Greenish parts of unit are limy, similar to limy siltstone in unit 7, and form thin ledges. These limy parts contain silty claystone pellets. Unit weathers to form steep ribbed slope. Upper contact is transitional with overlying unit

8. Siltstone, light brown $(5 Y R \quad 6 / 4)$ to pale red $(10 R 6 / 2)$, subordinate lightgreenish-gray ( $5 G Y 8 / 1$ and $5 G 8 / 1$ ) mottling; weathering same colors and pale reddish brown (10R 5/4); firmly to well cemented, calcareous; horizontally laminated, ripple laminated and structureless. Unit weathers to form steep slope. Unit is transitional with overlying unit

7. Limy siltstone to silty limestone, light greenish gray ( $5 G Y 8 / 1$ and $5 G 8 / 1)$, greenish gray ( $5 G Y 6 / 1$ and $5 G 6 / 1$ ), subordinate light-brownish-gray $(5 Y R \quad 6 / 1)$ and pale-red $(10 R \quad 6 / 2$ and $5 R 6 / 2$ ) mottling in upper part of unit, weathering same colors and pinkish gray $(5 Y R \quad 8 / 1)$; contains abundant crystalline calcite; firmly to well cemented; horizontally laminated to thin bedded and ripple laminated; platy to slabby splitting. Numerous clayey siltstone pellets in lower part of unit. Upper 2 to $3 \mathrm{ft}$ of unit weathers to form rough ledge

Total of upper member

Ocher siltstone member:

6. Silty claystone to clayey siltstone, blackish red $(5 R 2 / 2)$, grayish red $(5 R$ $4 / 2$ ), moderate brown (5YR $4 / 2$ and $5 Y R 3 / 4)$, dark yellowish orange $(10 Y R 6 / 6)$, and pale reddish brown $(10 R 5 / 4)$, weathering same colors and grayish orange $(10 Y R \quad 7 / 4)$. Lower $65 \mathrm{ft}$ of unit is blackish-red to grayish-red silty claystone with subordinate moderate-yellowish-brown $(10 Y R 5 / 4)$ mottling; upper $82 \mathrm{ft}$ of unit, which is poorly exposed, is dominantly moderate-brown and dark-yellowish-orange silty claystone and clayey siltstone with common scattered oolitic structures which are probably composed of analcite, calcite and (or) dolomite. Goethite probably accounts for ocher color of unit. Silty claystone to clayey siltstone is firmly to well cemented (noncalcareous to calcareous), structureless, and breaks into small angular and rounded fragments. Unit as whole weathers to
Feet | Chinle Formation-Continued

Ocher siltstone member-Continued form smooth rubble-covered slope. Topmost part of unit covered by debris from overlying unit.

5. Covered. Based on nearby partial exposures, this part of section is part of ocher siltstone member

Total of ocher siltstone member.....

Mottled member:

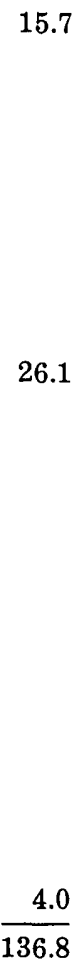

4. Covered. Based on nearby partial exposures, this part of section belongs in the mottled member.

Total of mottled member

Gartra Member:

3. Sandstone to pebble conglomerate, white $(N 9)$ to pinkish gray $(5 Y R 8 / 1)$, with minor grayish orange $(10 Y R$ $7 / 4)$, dark yellowish orange (10YR $6 / 6)$, and light brown (5YR 6/4), weathering same colors, very fine sandstone to pebble conglomerate, well to poorly sorted; composed of subangular to subrounded clear, milky, and amber-stained quartz with sparse pink quartz, uncommon gray feldspar, sparse black accessory mineral, and sparse white mica; firmly to poorly cemented, noncalcareous to slightly calcareous, clay binding; composed of very thin to thick trough and planar sets of low-angle mediumand small-scale cross-laminae to thin crossbeds; flaggy to massive splitting. Granules and pebbles are composed of subround to round clear, milky, and pink quartz (as much as $0.8 \mathrm{in}$. in maximum diameter) and subordinate chert. Estimated 40 percent of unit is sandstone and 60 percent is granule sandstone and small-pebble conglomerate. Matrix of coarse fraction of unit is largely coarse to very coarse grained sand. Unit along line of section appears to be along side of a channel which is centered about $200 \mathrm{ft}$ to east. In the deepest part of the channel, the unit is about $100 \mathrm{ft}$ thick. Unit weathers to form cliff with many rough ledges

Total of Gartra Member.

Total of Chinle Formation.

Unconformity. Mahogany Formation (incomplete) :

2. Sandstone (90 percent) and clayey siltstone (10 percent). Sandstone, pale red $(5 R 6 / 2$ and $10 R 6 / 2)$, pale red purple $(5 R P 6 / 2)$, grayish red purple $(5 R P 4 / 2)$, mottling of very light gray $(N 8)$ to pinkish-gray (5YR $8 / 1$ ), zone in upper $2 \mathrm{ft}$ of unit consisting of greenish-gray (5GY 6/1), $\frac{68.0}{68.0}$

Feet

147.0

$\frac{68.0}{215.0}$ 
Mahogany Formation (incomplete)-Continued light-greenish-gray $(5 G Y 8 / 1)$, and dark-yellowish-gray $(10 Y R \quad 6 / 6)$, weathering same colors; very fine to fine grained, well sorted; composed of rounded to well-rounded clear, milky, and smoky quartz with subordinate iron-stained quartz and common white and dark-green mica ; firmly to poorly cemented, calcareous to noncalcareous, clay binding; horizontally laminated to very thin bedded; platy to flaggy splitting; weathers to form smooth steep slope. Numerous silty clay pellets scattered throughout sandstone. Clayey siltstone, greenish gray $(5 G Y 6 / 1)$, light greenish gray ( $5 G Y 8 / 1$ and $5 G 8 / 1$ ), dark yellowish orange $(10 Y R 6 / 6)$, and moderate yellowish brown $(10 Y R$ 5/4); composed of abundant very fine grained quartz and sparse to common mica; firmly cemented, slightly calcareous to noncalcareous; horizontally thinly laminated to very thin bedded; papery to flaggy splitting; weathers to form steep smooth slope. The clayey siltstone occurs in top $2 \mathrm{ft}$ of unit. Unit as a whole forms a bleached zone at the top of the Mahogany Formation

1. Claystone and siltstone ( 75 percent) and sandstone (25 percent). Claystone and siltstone, dark reddish brown $(10 R 3 / 4)$ and grayish red $(10 R 4 / 2$ and $5 R 4 / 2$ ), weathering same colors with subordinate pale red $(5 R 6 / 2)$, claystone grades through silty claystone and clayey siltstone to siltstone; contains abundant very fine quartz grains and common white mica; firmly cemented, calcareous; thinly laminated and laminated to structureless; papery and shaly splitting; weathers to form steep smooth slope. Sandstone, light greenish gray (5GY 8/1 and $5 G 8 / 1$ ) and minor pale red $(5 R 6 / 2)$ and grayish red (10R $4 / 2$ and $5 R 4 / 2$ ), weathering same colors, very fine to medium grained with common coarse grains, fair to well sorted; composed of rounded and well-rounded milky and smoky quartz with minor clear, pink, and amber-stained quartz, sparse to common white and black mica and chlorite, some black and green accessory minerals; firmly to well cemented, very calcareous; horizontally laminated to thick bedded and ripple laminated; platy to blocky splitting; weathers to form resistant ledges. Sandstone is present as thin to very thick sets interstratified with claystone and siltstone. Numerous clay
Mahogany Formation (incomplete)-Continued pellets are scattered throughout the sandstone; these weather out, leaving a pitted surface. Only top few feet of Mahogany Formation examined....Unimeasured

Total of incomplete Mahogany Formation

Base of section; not base of exposure. Base of section on point about $500 \mathrm{ft}$ south of river.

\section{U-3. BUCKHORN WASH}

Measured along west side of Buckhorn Wash, about 2 miles north of San Rafael River, and up side of canyon to west; southeast corner of secs. 3 and 10 (unsurveyed), T. $20 \mathrm{~S}$., R. 11 E., SLM, Emery County

[Measured by J. H. Stewart and C. H. Scott, July 1953]

Top of section; top of accessible exposure.

Wingate Sandstone:

22. Sandstone, yellowish gray (5Y 8/1) and very pale orange $(10 Y R 8 / 2)$ weathering grayish orange $(10 Y R$ $7 / 4$ ), very fine grained, well sorted; composed of subrounded to rounded clear quartz and rare black accessory minerals; poorly to firmly cemented, calcareous; composed of thin to thick trough sets of small- to medium-scale high-angle cross-laminae; dominantly massive splitting; weathers to form vertical cliff. Only basal $20 \mathrm{ft}$ examined. Basal 7 to $8 \mathrm{ft}$ forms ledge weathering away from main vertical cliff. Strata from 4.3 to about $8.0 \mathrm{ft}$ above base of unit are dominantly horizontally laminated. Basal 1 in. contains rare medium well-rounded quartz grains. Very thin set of horizontal laminae at about $8 \mathrm{ft}$ above base of unit is pale red $(10 R 6 / 2)$ and contains markings similar to worm borings on bedding planes....Unmeasured

Unconformity. Base of Wingate cuts about a foot into top of Chinle in about $20 \mathrm{ft}$ along outcrop.

Chinle Formation:

Church Rock Member:

21. Silty claystone to siltstone, same as unit 17. Unit contains thin set of light-greenish-gray ( $5 G Y 8 / 1)$ wellcemented ripple-laminated siltstone at $1.1 \mathrm{ft}$. Unit from 9.8 to $10.9 \mathrm{ft}$ above base is sandstone. Sandstone, yellowish gray (5Y 8/1) and minor light greenish gray ( $5 G Y 8 / 1)$, weathering same colors, very fine grained, well sorted; composed of subrounded clear quartz and sparse black accessory minerals; firmly cemented, slightly calcareous; horizontally and ripple laminated, slabby splitting. Top $0.1 \mathrm{ft}$ of unit is pale green (5G $7 / 2$ )

20. Sandstone, same as lower half of unit 16. Unit weathers to form steep ledgy slope 
Chinle Formation-Continued

Church Rock Member-Continued

19. Silty claystone to siltstone, same as unit 17 except contains sparse ( 5 percent) very thin horizontal beds of lightgreenish-gray (5GY 8/1) very fine

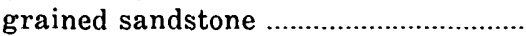

18. Sandstone, pale red $(10 R 6 / 2)$ and pinkish gray (5YR 8/1), weathering grayish orange $(10 Y R 7 / 4)$, very fine grained, well sorted; composed of subangular to subrounded clear quartz and sparse black accessory minerals; well cemented, calcareous; ripple laminated, platy to slabby splitting; weathers to form minor ledge

17. Silty claystone to siltstone, grayish red $(10 R 4 / 2)$, weathering pale reddish brown $(10 R 5 / 4)$; common very fine grained accessory white mica; firmly cemented, noncalcareous; stratification and splitting concealed; weathers to form steep, rubble-covered slope. Unit poorly exposed...

16. Sandstone, pale red $(10 R 6 / 2)$, and sparse light greenish gray ( $5 G Y$ $8 / 1)$, weathering pale red $(10 R 6 / 2)$, very fine grained, well sorted; composed of subrounded clear quartz and common orange and black accessory minerals; poorly cemented, calcareous; tabular unit, composed of poorly developed thin trough to planar sets of low-angle medium-scale crosslaminae in lower half and of horizontal and ripple laminae in upper half, platy to flaggy splitting; weathers to form ledge

15. Silty sandstone, light greenish gray $(5 G Y 8 / 1)$ and minor pale reddish brown $(10 R 5 / 4)$, weathering same colors, very fine grained with minor silt, well sorted; composed of subrounded clear quartz and common black and orange accessory minerals; well cemented, slightly calcareous; tabular unit of horizontal laminae and minor ripple laminae; platy to flaggy splitting; weathers to form vertical cliff. Sparse fine-grained accessory white mica. Unit forms conspicuous ledge and light-colored band about midway between top of Moss Back Member and base of Wingate Sandstone

14. Silty claystone, dark greenish gray (5GY 4/1), grayish purple $(5 P 4 / 2)$, and subordinate grayish red $(5 R$ $4 / 2$ ), weathering reddish purple ( $5 P$ $4 / 2$ ) ; firmly cemented, noncalcareous; tabular unit of horizontal laminae; platy splitting; weathers to form steep slope. Thin set of grayishred $(5 R 4 / 2)$ and light-greenish-gray
Feet $\mid$ Chinle Formation-Continued Feet Church Rock Member-Continued

$(5 G Y 8 / 1)$ well-cemented horizontally laminated limy siltstone occurs $2 \mathrm{ft}$ above base of unit

5.4
10.1
13. Limy siltstone, grayish purple (5P 4/2) and subordinate light greenish gray (5GY 8/1), weathering same colors; well cemented; lenticular unit, stratification concealed, but some suggestion of horizontal bedding planes; slabby splitting; weathers to form minor ledge

12. Silty claystone to siltstone, grayish red $(10 R 4 / 2)$ and pale reddish brown $(10 R 5 / 4)$, weathering pale reddish brown $(10 R 5 / 4)$; abundant very fine grained accessory white mica in parts of unit; firmly to well cemented, calcareous; tabular unit, stratification mostly concealed but contains sparse thin ripple-laminated sets and thin horizontal beds; splitting concealed; weathers to form bench in lower part and steep slope in upper part. Thin beds of limy siltstone and siltstone with abundant limy masses occur at 53.3 and $57.8 \mathrm{ft}$ above base of unit...

Total of Church Rock Member......

Moss Back Member:

11. Sandstone (70 percent) and conglomeratic sandstone (30 percent). Sandstone, yellowish gray (5Y 8/1), white $(N 9)$, very pale orange $(10 Y R$ $8 / 2)$, and light greenish gray ( $5 G Y$ $8 / 1$ ), weathering very pale orange $(10 Y R 8 / 2)$ and pale reddish brown $(10 R 5 / 4)$, fine grained, well sorted; composed of subrounded clear quartz and sparse black and green accessory minerals; poorly to well cemented, calcareous; composed of thin trough to planar sets of medium- to small-scale low-angle cross-laminae; platy to massive splitting. Conglomeratic sandstone, same colors as sandstone, fine to coarse grained with granules to pebbles which generally comprise 20 percent of the rock, poorly to fair sorted; composed of subrounded clear quartz and common black and orange accessory minerals, granules and pebbles composed of subrounded to rounded gray, white, and orange quartzite, quartz, and subordinate brown and light-gray siltstone; poorly to firmly cemented, calcareous; stratification the same as in sandstone although less well developed; flaggy to massive splitting. Granules and pebbles average about $5 / 8$ in. in diameter, and the largest pebbles are about 2 in. in diameter. Unit as a whole is tabular and weath- 
Chinle Formation-Continued

Moss Back Member-Continued ers to form vertical cliff. Stratification in unit as whole gives horizontal appearance. Unit has abundant limonite spots. Unit contains sparse (1 percent) light-greenish-gray ( $5 G Y$ $8 / 1$ ) siltstone to claystone seams

Total of Moss Back Member.

Temple Mountain Member:

10. Clayey siltstone, pale purple $(5 P 6 / 2)$ to grayish purple $(5 P 4 / 2)$, subordinate grayish red $(10 R 4 / 2)$, and sparse light greenish gray (5GY $8 / 1$ ), weathering grayish purple ( $5 P$ $4 / 2)$; firmly cemented, noncalcareous; appears structureless, but some suggestion of horizontal bedding planes; massive splitting; weathers to form vertical cliff under overhang of Moss Back Member. Sparse poorly defined thin layers of silty sandstone. Silty sandstone composed of coarse to very coarse rounded to subrounded clear quartz in siltstone matrix. Grayish-red color appears to be primary color and the purple to be secondary..

9. Silty claystone to siltstone, grayish purple $(5 P 4 / 2)$ and grayish yellow $(5 Y$ $8 / 4)$, weathering pale red purple (5RP 6/2) ; firmly cemented, noncalcareous; stratification mostly concealed, but suggestion of horizontal laminae; weathers to form steep slope

8. Sandstone (50 percent) and silty claystone. Sandstone, light brown (5YR $5 / 6)$, weathering dark yellowish brown $(10 Y R 4 / 2)$, coarse grained, fair sorted; composed of subrounded clear quartz, accessory minerals masked; well cemented, noncalcareous; stratification concealed. Silty claystone, similar to that in overlying unit. Silty claystone is interstratified with sandstone. Unit as whole weathers to form very minor ledge

7. Clayey siltstone similar to that in unit 5 ; weathers to form slope.

6. Clayey sandstone, light greenish gray (5GY 8/1), subordinate white (N 9) and grayish yellow $(5 Y 8 / 4)$, and sparse light brown $(5 Y R 5 / 6)$, weathering light greenish gray (5GY 8/1), medium to very coarse grained with some interstitial clay, poorly sorted; composed of subangular to subrounded clear quartz, common limonite spots; poorly cemented, clayey binding; stratification concealed; weathers to form steep rubbly slope.

5. Clayey siltstone, light greenish gray $(5 G 8 / 1)$, common moderate yellow
Chinle Formation-Continued

Temple Mountain Member-Continued

(5Y 7/6) along fractures, weathering grayish yellow (5Y 8/4); firmly cemented; stratification concealed; weathers to form bench.

4. Sandstone, medium gray $(N 5)$ to light gray $(N 7)$, common light brown (5YR 5/6), weathering light brown (5YR 6/4), medium to very coarse grained, fair sorted; composed of subangular to subrounded clear quartz, accessory minerals masked, sparse subangular granules of clear quartz and a few pebbles of quartz as large as $1 / 4$ in. in diameter; firmly cemented, calcareous; lenticular unit of thin trough sets of medium-scale low-angle cross-laminae; slabby splitting; weathers to form minor ledge. Unit thickens to north within $500 \mathrm{ft}$ to form ledge about $5 \mathrm{ft}$ thick and appears to pinch out to south of line of section. Unit highly petroliferous.

3. Sandstone to sandy siltstone, light gray $(N 7)$, grayish yellow $(5 Y 8 / 4)$, dark yellowish orange $(10 Y R 6 / 6)$, and moderate red $(5 R 5 / 4)$, weathering pale yellowish orange (10YR $8 / 6)$, grades from very fine grained sandstone in lower $8 \mathrm{ft}$ to sandy (very fine grained) siltstone in higher part of unit; firmly cemented, noncalcareous, probable clay binding; appears structureless, massive splitting; fractures into angular fragments; weathers to form steep slope. Unit from 0.2 to $0.6 \mathrm{ft}$ above base contains about 20 to 30 percent medium to very coarse grains of subrounded milky quartz and orange and gray minerals. About $500 \mathrm{ft}$ to north of line of section a coarse-grained sandstone occupies a stratigraphic position equivalent to that of the basal few feet of unit. This sandstone is similar to that in unit 4. It is as much as $3 \mathrm{ft}$ thick and contains sparse quartz pebbles

Total of Temple Mountain Member

Total of Chinle Formation

Moenkopi Formation (incomplete) :

2. Siltstone, light greenish gray $(5 G 8 / 1)$, grayish yellow $(5 Y 8 / 4)$ along fractures and bedding planes, otherwise same as unit 1. Unit appears to be a bleached zone at the top of the Moenkopi Formation

1. Siltstone, grayish orange $(10 Y R 7 / 4)$, weathering same color; sparse finegrained accessory white mica; firmly cemented, calcareous; horizontally and
Feet 
Moenkopi Formation (incomplete)-Continued ripple laminated; platy splitting; weathers to form steep rubble-covered slope. Unit contains sparse (1 percent) black mineral (iron oxide?), the size of fine grains. This black mineral may be cubical or irregularly spherical. About $15 \mathrm{ft}$ of unit exposed above creek level. Unmeasured

Total of incomplete Moenkopi Formation

Base of section; base of exposure.

\section{U-4. CANE WASH}

Measured about 4 miles west of the Wickiup on the western side of the San Rafael Swell, northeast corner sec. 23 and northwest corner sec. 24, T. 22 S., R. 10 E., SLM; long $110^{\circ} 45^{\prime} 30^{\prime \prime}$ W., lat $38^{\circ} 53^{\prime} 35^{\prime \prime}$ N., Emery County

[Mensured by J. H. Stewart and C. H. Scott, July 1953]

Top of section; not top of exposure. Top of section on northwest side of large outlier of Wingate Sandstone.

Wingate Sandstone:

16. Sandstone, grayish yellow $(5 Y 8 / 4)$, weathering same color, fine grained, well sorted; composed of rounded clear quartz and sparse black accessory mineral; poorly cemented, calcareous; composed of thick to very thick trough sets of medium- to largescale cross-laminae; massive splitting; weathers to form vertical cliff. Basal $3 \mathrm{ft}$ contains abundant wellrounded quartz grains. Basal $1.5 \mathrm{ft}$ is horizontally laminated. Common small-scale cross-laminae from 1.5 to $5.0 \mathrm{ft}$ above base of unit. Only basal $10 \mathrm{ft}$ of unit examined.

Unmeasured

Chinle Formation:

Church Rock Member:

15. Sandstone, greenish gray (5GY 6/1) and light greenish gray (5GY 8/1) in basal $5.6 \mathrm{ft}$ of unit, yellowish gray (5Y 7/2) and light greenish gray ( $5 G Y 8 / 1$ ) from 5.6 to $10.4 \mathrm{ft}$ above base of unit, weathering light greenish gray ( $5 G Y 8 / 1)$, very fine grained, well sorted; composed of subrounded clear quartz, basal $5.6 \mathrm{ft}$ contains common interstitial clay; poorly cemented, calcareous; tabular unit of horizontal and ripple laminae; platy splitting; weathers to form steep slope containing ledge from 5.6 to $10.4 \mathrm{ft}$ above base of unit. Common finegrained accessory white mica. Units 13 through 15 form light-colored sequence at top of Chinle.

14. Sandstone, grayish orange $(10 Y R 7 / 4)$ and pale yellowish orange $(10 Y R$ $8 / 6)$, weathering grayish yellow ( $5 Y$ $8 / 4)$, very fine to fine grained, well sorted; composed of subangular clear
Feet Chinle Formation-Continued Church Rock Member-Continued quartz, uncommon coarse-grained accessory white mica; tabular unit of thin trough to planar sets of smallto medium-scale low-angle cross-laminae; platy to slabby splitting; weathers to form conspicuous ledge near top of Chinle Formation.

13. Clayey siltstone, greenish gray (5GY $6 / 1)$, light greenish gray (5GY 8/1), subordinate dusky yellow (5Y 6/4), weathering light greenish gray ( $5 G Y$ $8 / 1)$; poorly cemented, noncalcareous; stratification and splitting concealed; weathers to form steep slope. Basal $1.6 \mathrm{ft}$ of unit is sandstone. Sandstone, grayish orange $(10 Y R$ $7 / 4)$, subordinate pale red $(10 R 6 / 2)$, very fine grained; firmly cemented, calcareous; ripple laminated, platy splitting; weathers to form minor ledge

12. Siltstone (75 percent) and sandstone (25 percent). Siltstone, grayish red $(10 R 4 / 2)$ and dark reddish brown $(10 R 3 / 4)$, weathering pale reddish brown $(10 R 5 / 4)$; firmly cemented, noncalcareous; stratification concealed. Sandstone, pale red $(10 R$ $6 / 2)$, subordinate pale reddish brown $(10 R 5 / 4)$, weathering pale reddish brown $(10 R 5 / 4)$, very fine grained; firmly cemented, calcareous; ripple laminated; platy splitting. Sandstone is present as 5-ft-thick set in middle of unit and as common thin sets in rest of unit. Unit as whole tabular and weathers to form steep slope containing minor ledges. Unit forms smooth earthy red slope on cliffs to southwest of line of section.

11. Sandstone, pale reddish brown (10R $5 / 4)$, subordinate grayish orange $(10 Y R 7 / 4)$ and olive gray $(5 Y 4 / 1)$, weathering pale reddish brown $(10 R$ $5 / 4)$, very fine grained, well sorted; composed of subangular to subrounded clear quartz and sparse black accessory minerals; well cemented, calcareous; tabular unit, stratification poorly developed but probably ripple laminated; massive splitting; weathers to form steep slope. Unit from about 4 to $6 \mathrm{ft}$ from base is entirely grayish orange $(10 Y R 7 / 4)$ and olive gray $(5 Y 4 / 1)$ and contains sparse rounded medium to coarse grains of quartz and common petroliferous material. This part of unit forms persistent light-colored ledge in local area. Basal 3 in. of unit is light greenish gray $(5 G Y 8 / 1)$ and limy...
Feet 
Chinle Formation-Continued

Church Rock Member-Continued

So-called Black Ledge:

10. Sandstone, light gray $(N 7)$, subordinate light greenish gray $(5 G Y 8 / 1)$, light olive gray $(5 Y 6 / 1)$, and olive gray $(5 Y 4 / 1)$, weathering yellowish gray $(5 Y 8 / 1)$, fine grained, well sorted; composed of subrounded milky quartz, sparse coarse-grained accessory white mica and common interstitial green clay in upper half; poorly cemented, calcareous, tabular unit of thin trough sets of small- to medium-scale low-angle cross-laminae (boundaries of sets are nearly horizontal) ; platy splitting; weathers to form steep ledgy slope. Common petroliferous material. Unit forms vertical cliff in places.

9. Sandstone (50 percent) and conglomerate (50 percent). Sandstone, yellowish gray $(5 Y 8 / 1)$, pinkish gray (5YR 8/1), and medium light gray (N 6), weathering medium light gray $(N$ 6), fine to medium grained, well sorted; composed of subrounded clear and milky quartz; sparse flakes of green clay; well cemented, calcareous; not porous, interstices probably filled with calcite; composed of thin trough sets of low-angle mediumscale cross-laminae; slabby splitting. Conglomerate, pale red purple (5PR $6 / 2)$ and greenish gray (5GY 6/1), weathering medium light gray $(N$ $6)$; composed of rounded to wellrounded greenish gray and pale-red limestone granules to cobbles in aphanitic calcite matrix; well cemented; composed of thin trough sets of medium- to large-scale cross-laminae; slabby splitting. Granules to cobbles average about $1 / 8 \mathrm{in}$. in diameter, but rarely cobbles have maximum diameter of $6 \mathrm{in}$. Thin sets of conglomerate interstratified with sandstone throughout unit. Unit as whole tabular and weathers to form most conspicuous ledge in Chinle above Moss Back Member

Total of so-called Black Ledge.

8. Siltstone, grayish purple $(5 P 4 / 2)$, pale red purple (5RP 6/2), subordinate grayish red $(5 R 4 / 2)$, sparse pale green $(5 G 7 / 2)$, weathering pale red purple $(5 R P 6 / 2)$; firmly to well cemented, calcareous; stratification and splitting concealed; weathers to form steep slope. Thin bed of limy siltstone at $34.2 \mathrm{ft}$. Top $1.5 \mathrm{ft}$ is pale green (5G $7 / 2$ ) and contains abundant palegreen $(5 G 7 / 2)$ limestone nodules......
Feet

Chinle Formation-Continued

Church Rock Member-Continued

7. Clayey siltstone, grayish red $(10 R 4 / 2)$, subordinate greenish gray ( $5 G Y 6 / 1)$, weathering pale reddish brown $(10 R$ $5 / 4)$; common fine-grained accessory white mica; firmly cemented, calcareous; stratification concealed; weathers to form steep slope.

Total of Church Rock Member

Moss Back Member:

6. Sandstone (70 percent) and siltstone (30 percent). Sandstone, same as sandstone in unit below except is horizontally laminated and contains subordinate ripple laminae and thin trough sets of medium-scale low-angle cross-laminae. Sandstone commonly contains light-greenish-gray $(5 G Y$ $8 / 1$ ) interstitial clay. Sandstone in upper $20 \mathrm{ft}$ is entirely fine grained. Siltstone, greenish gray (5GY 6/1) and light greenish gray (5GY 8/1), weathering light greenish gray ( $5 G Y$ $8 / 1$ ), commonly clayey; sparse finegrained accessory white mica; firmly cemented, noncalcareous; horizontally thinly laminated to laminated; platy splitting. Unit varies considerably in thickness along outcrop. Unit weathers to form steep slope containing abundant sandstone ledges. Unit poorly exposed. Exact percentage of siltstone and sandstone not determinable. To the north of the line of section, unit forms massive sandstone cliff continuous with unit below. To the southeast of the line of section, the upper $2 / 3$ of the unit grades into reddish-brown siltstone the same as that in the overlying unit. About 30 percent of unit is covered

5. Sandstone (90 percent) and conglomeratic sandstone (10 percent). Sandstone, yellowish gray (5Y 8/1), grayish orange $(10 Y R 7 / 4)$, and light gray $(N 7)$, weathering yellowish gray $(5 Y 8 / 1)$, fine to medium grained, well sorted; composed of subrounded clear quartz and sparse black accessory mineral; poorly cemented, calcareous; composed of thin to thick trough sets of small- to medium-scale low-angle cross-laminae, and subordinate horizontal laminae; platy to massive splitting. Conglomeratic sandstone, yellowish gray (5Y $8 / 1$ ) and light gray (N 7), weathering same colors; composed of granules and pebbles in sand matrix. Sand matrix is same as sand in rest of unit. Granules and pebbles are composed of siltstone, limestone, and sub-
Feet

$\overline{178.0}$ $=$ 
Chinle Formation-Continued

Moss Back Member-Continued

ordinate quartzite, quartz, and chert. Granules and pebbles average about $1 / 4$ in. in diameter. Conglomeratic sandstone grades to conglomerate in a few places. Conglomeratic sandstone is present as thin to thick sets interbedded with sandstone and is dominantly found in lower $10 \mathrm{ft}$ of unit but rarely elsewhere in unit. Unit contains sparse light-greenishgray $(5 G Y 8 / 1)$ clay pellets and very thin to thin beds of claystone. Unit contains common carbonaceous material and sparse silicified wood. Unit as whole gives impression of containing abundant horizontal stratification planes and weathers, in general, to form a vertical cliff.

Total of Moss Back Member.

Temple Mountain Member:

4. Siltstone, pale red purple (5RP 6/2), medium light gray $(N 6)$, subordinate grayish red $(5 R 4 / 2)$ and dusky yellow $(5 Y 6 / 4)$, top $5 \mathrm{ft}$ consist of light gray $(N 7)$ and light greenish gray $(5 G Y 8 / 1)$ with subordinate moderate yellow $(5 Y 7 / 6)$, weathering pale purple $(5 P 6 / 2)$ and greenish gray $(5 G Y 6 / 1)$; lower few feet of unit contains common well-rounded medium to coarse quartz grains; firmly cemented, noncalcareous; stratification and splitting concealed; fractures into pebble-size angular fragments; weathers to form steep slope

3. Siltstone (50 percent) and sandstone (50 percent). Siltstone, grayish red (5R 4/2), subordinate light greenish gray $(5 G Y 8 / 1)$ and dusky yellow (5Y $6 / 4)$; firmly cemented, noncalcareous; stratification concealed. Sandstone, grayish red purple (5RP 4/2) and light greenish gray (5GY 8/1), weathering pale red purple (5RP $6 / 2$ ), very fine grained; well cemented, noncalcareous; stratification concealed. Sandstone confined to about upper half of unit where it occurs along with layers of siltstone. Unit as whole weathers to form steep slope....

2. Sandstone, moderate brown (5YR 4/4), grayish red purple (5RP 4/2), coarsegrain-sized white $(N 9)$ spots, weathering light brown (5YR 6/4), medium-grained, minor interstitial clay and silt, poorly to well sorted; composed of subrounded clear quartz and common black accessory minerals; lenticular unit, stratification con-
Feet Chinle Formation-Continued Feet Temple Mountain Member-Continued cealed; slabby splitting; weathers to form inconspicuous ledge.

Total of Temple Mountain Member

Total of Chinle Formation.

$\begin{array}{r}1.6 \\ 24.2 \\ \hline 367.8 \\ \hline\end{array}$

Moenkopi Formation:

1. Siltstone, grayish red $(10 R 4 / 2)$ and pale reddish brown $(10 R 5 / 4)$, weathering pale reddish brown $(10 R 5 / 4)$; abundant fine- to medium-grained white mica; firmly cemented, noncalcareous; stratification and splitting concealed; weathers to form slope. Only top few feet examined............Unmeasured

Base of section; not base of exposure.

U-5. LUCKY STRIKE MINE

Measured about $3 / 4$ mile south of Lucky Strike mine on the west side of the Sinbad in the San Rafael Swell, sec. 6 (unsurveyed), T. 24 S., R. 9 E., SLM, long $110^{\circ} 57^{\prime} 00^{\prime \prime} W$., lat $38^{\circ} 44^{\prime} 55^{\prime \prime}$ N., Emery County

[Measured by J. H. Stewart and C. H. Scott, July 1953]

Top of section; top of accessible exposure. Top of section about S. $10^{\circ} \mathrm{W}$. of Lucky Strike mine and N. $56^{\circ} \mathrm{W}$. of prominent northern outlier of Chinle Formation.

Wingate Sandstone:

13. Sandstone, light olive gray (5Y 6/1)

Contact of Wingate Sandstone and Chinle Formation placed at lithologic change from siltstone below to fine-grained sandstone above. Wingate forms vertical cliff whereas Chinle forms slope. Bottom 1 in. of Wingate contains abundant well-rounded medium grains.

Chinle Formation:

Church Rock Member: and yellowish gray $(5 Y 7 / 2)$, weathering grayish orange $(10 Y R \quad 7 / 4)$, fine grained, well sorted; composed of rounded clear quartz, poorly cemented, slightly calcareous; composed of thin to very thick trough sets of medium-scale cross-laminae; massive splitting; weathers to form vertical cliff. Contains petroliferous material. Bottom 1 in. contains abundant wellrounded medium quartz grains. Only bottom $10 \mathrm{ft}$ of unit examined........Unmeasured

12. Siltstone, dusky yellow $(5 Y 6 / 4)$ and light greenish gray ( $5 G Y 8 / 1)$, weathering same colors, sparse fine-grained accessory white mica; firmly cemented, noncalcareous; stratification concealed, weathers to form steep lightcolored slope at top of Chinle Formation. Thin set of grayish-yellow ( $5 Y$ $8 / 4$ ) horizontally laminated very fine grained sandstone occurs at $9.4 \mathrm{ft}$ above base of unit.

Feet

11. Siltstone, grayish red $(10 R 4 / 2)$ and sparse grayish red purple (5RP 4/2), 
Chinle Formation-Continued

Church Rock Member-Continued weathering pale reddish brown $(10 R$ $5 / 4$ ), uncommon very fine grained accessory white mica, firmly cemented, noncalcareous; stratification concealed, weathers to form steep slope. Three thin sets of pale-red $(10 R 6 / 2)$ horizontally and ripple laminated very fine grained sandstone occurs at about $22 \mathrm{ft}$ above base of unit, and one thin set of this same sandstone occurs at about $36 \mathrm{ft}$

10. Sandstone (50 percent) and conglomeratic sandstone to conglomerate (50 percent), pale red $(10 R 6 / 2)$ and subordinate light greenish gray ( $5 G Y$ $8 / 1)$, weathering pale brown ( $5 Y R$ $5 / 2$ ), fine to medium grained, sparse very fine grained, fair sorted; composed of subrounded clear quartz and common orange and gray accessory minerals, firmly cemented, calcareous; composed of thin trough sets of medium-scale low-angle cross-laminae, subordinate ripple laminae; platy to slabby splitting. Conglomeratic sandstone to conglomerate, granules and cobbles in fine- to medium-grained sand matrix. Sand matrix same as sand in rest of unit. Granules to cobbles are composed of rounded siltstone and limestone. The maximum cobble diameter is about 4 in. Conglomeratic sandstone to conglomerate is interstratified with and intergrades with the sandstone. Unit as whole is lenticular and forms minor ledge. Unit is not present on exposures to west.

9. Sandy siltstone to silty sandstone, pale red $(10 R 6 / 2)$ and pale reddish brown $(10 R 5 / 4)$, sparse light greenish gray ( $5 G Y 8 / 1$ ), weathering pale reddish brown $(10 R 5 / 4)$, grades from siltstone with minor amounts. of very fine sand grains to very fine grained sandstone with minor silt; uncommon very fine grained accessory white mica; firmly cemented, calcareous; horizontally laminated to thinly laminated and ripple laminated; platy splitting; weathers to form steep slope.

So-called Black Ledge:

8. Sandstone, very light gray $(N 8)$ to light gray $(N 7)$ and yellowish gray (5Y 8/1), weathering yellowish gray (5Y 8/1), fine grained, well sorted, composed of subrounded clear quartz, and common orange accessory minerals, abundant black spots which may possibly be petroliferous material, un-
Church Rock Member-Continued

So-called Black Ledge-Continued common medium-grained accessory white mica; poorly cemented, calcareous; composed of thin trough sets of medium-scale low-angle cross-laminae, possibly horizontally laminated in top few feet; platy splitting; weathers with unit below to form vertical cliff which is most prominent cliff in the Chinle Formation above that in the Moss Back Member..

7. Heterogeneous unit, sandstone type 1 (50 percent) and type 2 (20 percent) and conglomeratic sandstone (30 percent). Sandstone type 1 , light greenish gray $(5 G Y 8 / 1)$, weathering grayish orange $(10 Y R 7 / 4)$, very fine grained, may grade to siltstone at places; well cemented, calcareous ; ripple laminated, uncommon thin trough sets of low-angle medium-scale crosslaminae; platy to slabby splitting. Sandstone type 2, light greenish gray (5GY 8/1) and minor pale red purple $(5 R P 6 / 2)$, weathering grayish orange $(10 Y R \quad 7 / 4)$ with minor amounts of pale red purple (5RP $6 / 2$ ), fine to medium grained, well sorted; composed of subangular clear quartz and abundant orange and gray accessory minerals; abundant interstitial clay; poorly cemented, calcareous horizontally laminated, subordinate thin trough sets of low-angle crosslaminae; platy to slabby splitting. Conglomeratic sandstone, same as sandstone type 2 except contains from a few percent to as much as 40 percent granules and pebbles of limestone and siltstone. Pebbles are as large as 4 in. in diameter. Unit as whole weathers to form vertical cliff..

Total of so-called Black Ledge.

6. Siltstone, grayish red $(10 R 4 / 2)$ and subordinate grayish red purple $(5 R P$ $4 / 2)$ and greenish gray (5GY 6/1) in top $10 \mathrm{ft}$ of unit, weathering pale reddish brown $(10 R 5 / 4)$ and, in top $10 \mathrm{ft}$, pale red purple (5RP 6/2), common very fine grained accessory white mica; firmly cemented, slightly calcareous; tabular unit, stratification mostly concealed but where exposed is horizontally laminaed, platy splitting; weathers to form steep slope between two prominent sandstone layers. Grayish-red ( $10 R 4 / 2)$ very fine grained sandstone occurs from 21.4 to $22.4 \mathrm{ft}$ above base of unit. Unit mostly covered from 23.0 to $33.0 \mathrm{ft}$ above base of unit.
Feet

$\frac{13.0}{31.8}$ 
Chinle Formation-Continued

Church Rock Member-Continued

5. Sandstone, olive gray $\left(\begin{array}{ll}5 Y & 4 / 1\end{array}\right)$ and subordinate greenish gray ( $5 G 6 / 1$ ) weathering pale yellowish brown $(10 Y 6 / 2)$, very fine grained, well sorted; common fine-grained accessory white mica; firmly cemented, calcareous; horizontally and ripple laminated; platy splitting; weathers to form bench. Immediately to the west of line of section, unit appears to grade into greenish-gray ( $5 G Y$ 6/1) siltstone

Total of Church Rock Member..

Moss Back Member:

4. Sandstone and conglomeratic sandstone. Sandstone, light gray $(N 7)$ to medium light gray $(N 6)$, with subordinate light olive gray $(5 Y 6 / 1)$ and olive gray ( $5 Y 4 / 1)$, weathering yellowish gray $(5 Y 8 / 1)$, fine grained with subordinate very fine grained parts well sorted; composed of subrounded clear quartz and sparse finegrained accessory white mica; poorly cemented, calcareous; composed of thin trough sets of medium-scale lowangle cross-laminae; platy splitting. Conglomeratic sandstone, same as sandstone except contains about 30 percent granules and pebbles. Granules and pebbles average about $1 / 4$ in. in diameter, but pebbles may be as large as $1 \frac{1}{2}$ in. in diameter. Granules and pebbles are light-brown-weathering siltstone and limestone and minor amounts of quartz, quartzite, and chert. Conglomeratic sandstone confined to and comprises about 40 percent of lower $13.6 \mathrm{ft}$ of unit. Conglomeratic sandstone is in thick sets interbedded with sandstone. Position and content of conglomeratic sandstone varies considerably along exposure. Unit as whole tabular and weathers to form prominent vertical cliff. In places, unit is stained dark gray, probably because of presence of petroliferous material. Bottom $13.6 \mathrm{ft}$ of unit contains common thin poorly exposed sets of greenish-gray ( $5 G 6 / 1$ ) silty claystone

Total of Moss Back Member..

Monitor Butte Member:

3. Silty claystone, grayish purple (5GP $4 / 2$ ) and common light greenish gray $(5 G Y 8 / 1)$ and grayish yellow (5Y $8 / 4)$, weathering same colors; poorly cemented, calcareous; stratification concealed; weathers to form steep slope. Top $2 \mathrm{ft}$ is light greenish gray $\begin{array}{r}\text { Feet } \\ \\ 3.0 \\ \hline \underline{167.4} \\ \hline\end{array}$

Chinle Formation-Continued

Monitor Butte Member-Continued

(5GY 8/1) with minor amounts of grayish yellow $(5 Y 8 / 4)$. Unit contains swelling clay

Total of Monitor Butte Member......

$\underline{\underline{29.5}}$

Temple Mountain Member:

2. Sandstone, light greenish gray ( $5 G Y$ $8 / 1)$ with subordinate grayish purple (5P 4/2) and common pale yellowish orange $(10 Y R 8 / 6)$, weathering yellowish gray $(5 Y 8 / 1)$ and pale red purple (5RP 6/2), very fine grained; firmly cemented, calcareous; appears structureless; massive splitting; fractures into angular particles; weathers to form small ledge. The basal $3 \mathrm{ft}$ of unit contains as much as 30 percent rounded to wellrounded medium to very coarse frosted quartz and orange and gray minerals. Unit forms persistent ledge at base of Chinle. Colors irregularly distributed in unit.

Total of Temple Mountain Member

Total of Chinle Formation..

Feet

$\begin{array}{r}8.8 \\ \hline 8.8 \\ \hline 264.3 \\ \hline \hline\end{array}$

Moenkopi Formation:

1. Siltstone, grayish red $(10 R 4 / 2)$, weathering pale reddish brown $(10 R 5 / 4)$, abundant very fine grained accessory white mica; firmly cemented, noncalcareous; horizontally laminated, platy splitting; weathers to form steep slope. Upper $1 \mathrm{ft}$ contains common thin light-greenish gray (5GY 8/1) sets Unmeasured

Base of section; not base of exposure.

U-6. MUDDY RIVER

Measured west of the Muddy River and west of the first outcrop of Kaibab Limestone up the river along the east side of the San Rafael Swell, long $110^{\circ} 58^{\prime} 00^{\prime \prime}$ W., lat $38^{\circ} 34^{\prime} 30^{\prime \prime}$ N., Emery County

[Measured by J. H. Stewart, June 1953]

Top of section; top of accessible outcrop.

Feet

Wingate Sandstone:

23. Sandstone, yellowish gray (5Y 8/1), weathering very pale orange $(10 Y R$ $8 / 2$ ), very fine grained, well sorted; composed of subrounded clear quartz and common black accessory minerals; firmly cemented, noncalcareous; composed of thin to thick trough and planar sets of small- to medium-scale cross-laminae; platy and massive splitting; weathers to form vertical cliff. Unit contains abundant well-rounded medium to coarse grains of clear quartz. Amount of these quartz grains decreases upward in lower $10 \mathrm{ft}$ of unit. Lower 6 in. of unit appear ripple laminated Unmeasured 
Contact between Chinle and Wingate placed at conspicuous color change from the green strata of the Chinle to the yellowish-gray strata of the Wingate. The basal Wingate contains abundant medium to coarse grains. No irregularities in the contact noticed.

Chinle Formation:

Church Rock Member:

22. Clayey sandstone to silty claystone, pale green $(5 G 7 / 2)$, weathering same color. Clayey sandstone comprises about 50 percent of unit. Clayey sandstone, very fine grained, minor amounts of interstitial clay, grades to sandy claystone, poorly sorted. Entire unit is firmly cemented (slightly calcareous), has concealed stratification, and weathers to form steep loose slope. Unit and underlying unit form conspicuous green color band in Chinle. Sparse coarse grains of white mica. Abundant gray chert nodules as large as $0.3 \mathrm{ft}$ in diameter occur in top $6 \mathrm{in}$. of unit. Upper $1.1 \mathrm{ft}$ of unit is about 50 percent dusky yellow $(5 Y 6 / 4)$

21. Siltstone, light greenish gray $(5 G 8 / 1)$, light brownish gray $(5 Y R$ 6/1) from 3.0 to $6.0 \mathrm{ft}$ above base of unit, minor amounts of dusky yellow $(5 Y 6 / 4)$ in upper $5 \mathrm{ft}$, weathering same colors; well cemented, slightly calcareous; stratification concealed; weathers to form steep slope containing ledges. Away from line of section, unit in some places forms vertical cliff. Unit appears limy but does not effervesce in acid and may be dolomitic. Unit grades into overlying unit

20. Siltstone, pale red purple $(5 R P 6 / 2)$, weathering same color; firmly cemented, noncalcareous; stratification concealed; fractures into granuleand pebble-sized fragments; weathers to form slope.

19. Siltstone, grayish red $(10 R 4 / 2)$, pale reddish brown $(10 R 5 / 4)$ and sparse light brown $(5 Y R 6 / 4)$, weathering pale reddish brown $(10 R 5 / 4)$; firmly cemented, calcareous; stratification concealed; fractures into granuleand pebble-sized angular fragments; weathers to form steep loose slope containing small ledges. Common light-greenish-gray spots

18. Siltstone, grayish red $(10 R 4 / 2)$, weathering pale red $(5 R 6 / 2)$ and pale reddish brown $(10 R 5 / 4)$; firmly cemented, calcareous; stratification concealed; fractures into granule-sized fragments; weathers to form steep loose slope. A slight difference in fresh and weathering colors distinguishes unit from overlying unit.
Feet | Chinle Formation-Continued

Church Rock Member-Continued

Grades into overlying unit. One thin set of micaceous ripple-laminated siltstone near base.

Total of Church Rock Member.

Moss Back Member:

17. Sandstone and conglomeratic sandstone, light greenish gray (5GY 8/1), yellowish gray (5Y 8/1), light gray $(N$ 7 ), pale olive $(10 Y 6 / 2)$, and minor amounts of grayish red (10R 4/2), weathers light brown $(5 Y R 6 / 4)$ and grayish red $(10 R 4 / 2)$, fine to medium grained (some thick sets contain minor amounts of course sand); fair to well sorted. About 30 percent of unit is conglomeratic. Conglomeratic parts contain granules and pebbles that average $1 / 4 \mathrm{in}$. in diameter and that reach a maximum diameter of 2 in. Granules and pebbles are composed dominantly of light-brownweathering siltstone and limy siltstone and to a lesser extent of gray and white quartz and white chert. Where present, granules and pebbles constitute about 30 to 40 percent of rock and occur in a sand matrix. Sand matrix and sandstone composed of fine- to medium-grained (rarely coarse-grained) clear quartz and uncommon black accessory minerals, sparse fine-grained white mica; firmly to well cemented, calcareous; some possible petroliferous material; some parts contain abundant interstitial clay; composed of thin to thick trough sets of low-angle mediumscale cross-laminae, upper one-third of unit either is horizontally laminated or composed of very low angle cross-laminae; platy splitting; weathers to form prominent vertical cliff..

Total of Moss Back Member.

Monitor Butte Member:

16. Siltstone, grayish red purple (5RP $4 / 2$ ) in lower part and moderate red $(5 R 5 / 4)$ in upper part, weathers moderate red $(5 R 5 / 4)$ and pale red purple (5RP 6/2); firmly cemented, slightly calcareous; stratification concealed; weathers to form steep earthy slope. Unit from 3.0 to $0.7 \mathrm{ft}$ below the top is dusky yellow $(5 Y 6 / 4)$, and from $0.7 \mathrm{ft}$ below top to the top is light greenish gray (5G 8/1). Top $5 \mathrm{ft}$ of unit contains irregular thin beds, seams, and irregular nodules of light-greenish-gray ( $5 G Y$ $8 / 1$ ) and grayish-yellow (5Y 8/4) limestone. One thin set of ripple-

Feet

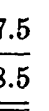

1.2 
Chinle Formation-Continued

Monitor Butte Member-Continued

laminated siltstone noted about $8 \mathrm{ft}$ above base of unit

15. Sandy siltstone, light greenish gray (5GY 8/1) in lower two thirds, grayish red (5R 4/2) with irregular mottling of moderate yellow (5Y 8/1) in top third, weathers light greenish gray $(5 G Y 8 / 1)$ and pale red $(5 R$ $6 / 2$ ), sandy (very fine grained) ; common medium-grained white and dark mica; firmly cemented, slightly calcareous; stratification concealed; weathers to form steep frothy slope....

14. Siltstone, grayish red purple $(5 R P 4 / 2)$, about 20 percent of rock is light greenish gray $(5 G Y 8 / 1)$ irregular spots and mottles; well cemented, noncalcareous; stratification concealed; weathers to form steep frothy slope. Common limestone nodules averaging 4 in. in diameter of lightgreenish-gray $(5 G Y 8 / 1)$ and palered-purple (5RP 6/2) aphanitic to very coarse grained calcite. Unit forms conspicuous band on outcrop..

13. Siltstone, grayish red $(10 R 4 / 2)$, with common yellowish-gray $(5 Y \quad 8 / 1)$ spots and irregular mottles, weathers pale reddish brown $(10 R 5 / 4)$, common medium-grained dark-green mica; stratification concealed; weathers to form steep frothy slope............

12. Sandstone to sandy siltstone and siltstone. Sandstone to sandy siltstone, very pale green $(10 G 8 / 2)$, weathers same color, very fine grained sandstone to very fine grained sandy siltstone; abundant very fine grained dark-green mica; firmly cemented, slightly calcareous; thinly ripple laminated; papery splitting. Siltstone, grayish red $(10 R 4 / 2)$, weathers pale red $(5 R 6 / 2)$, abundant very fine grained white mica; firmly cemented, noncalcareous; splitting concealed. Unit as a whole weathers to ledgy slope at base of Chinle Formation. Basal Chinle in line of section and on distant cliffs is marked by lightgreenish-gray band. Thickness of unit variable along outcrop.

Total of Monitor Butte Member...

Total of Chinle Formation

Moenkopi Formation (incomplete) :

Cliff-forming member:

11. Siltstone, similar to unit 10 except 33 percent of unit is ripple laminated (mostly parallel ripples); weathers to form steep ledgy slope and vertical cliff. Basal $35 \mathrm{ft}$ of unit is mostly structureless siltstone. Unit grades

Feet $\mid$ Moenkopi Formation (incomplete) -Continued Feet Cliff-forming member-Continued

into underlying unit. Abundant gypsum nodules. Top $1.5 \mathrm{ft}$ of unit contains abundant pale-red-purple $(5 R P$ $6 / 2$ ) and light-greenish-gray mottling

Total of cliff-forming member........

114.0

114.0

Upper slope-forming member:

10. Siltstone, grayish red $(10 R 4 / 2)$, weathers pale reddish brown $(10 R 5 / 4)$, abundant very fine grained white mica; firmly to well cemented, noncalcareous; thinly horizontally laminated to structureless, 10 percent ripple laminated (parallel and sparse cuspate ripples); papery to slabby splitting; weathers to form steep slope. About 5 percent of unit consists of very thin to thick beds of light-greenish-gray $(5 G Y 8 / 1)$ siltstone. Unit contains abundant gypsum in seams cutting across bedding and as irregular nodules elongated along bedding planes

Total of upper slope-forming member

161.7

Total of incomplete Moenkopi Formation

275.7

Base of section; not base of exposure.

Units 1-9 described in Stewart, Poole, and Wilson (1972).

37.9

Measured along south side of Straight Wash and up cliff on east side of San Rafael Swell, sec. 29, T. 23 S., R. $13 E$., SLM, Emery County

[Measured by J. H. Stewart and A. C. Gorveatt, July 1953]

Top of section; not top of exposure.

Wingate Sandstone (incomplete) :

43. Silty sandstone, pale reddish brown $(10 R 5 / 4)$, weathering same color, very fine grained with subordinate silt, fair sorted; composed of subrounded clear quartz and uncommon black accessory mineral; firmly cemented, calcareous; horizontally laminated. Laminae are wavy, but apparently not ripple laminated. Weathers to form largest reentrant in Wingate Sandstone

42. Sandstone, very pale orange (10YR $8 / 2)$, pale yellowish orange $(10 Y R$ $8 / 6)$, grayish orange pink $(5 Y R 7 / 2)$, and subordinate grayish orange $(10 Y R 7 / 4)$, moderate orange pink $(5 Y R 8 / 4)$, and pale red $(10 R 6 / 2)$, weathering very pale orange $(10 Y R$ $8 / 2$ ), fine to medium grained, well sorted; composed of subrounded to rounded clear quartz and uncommon black accessory mineral; poorly cemented, slightly calcareous; composed of thin to very thick trough sets of 
Wingate Sandstone (incomplete)-Continued medium- and large-scale (subordinate small-scale) cross-laminae; massive splitting; weathers to form vertical cliff. Basal $49.0 \mathrm{ft}$ of unit contains sparse well-rounded medium to coarse frostèd quartz grains. Medium to coarse grains generally concentrated along set boundaries. Basal $10.5 \mathrm{ft}$ of unit contains some horizontally laminated parts and some small-scale deformed bedding

Total of incomplete Wingate Sandstone

Top unit of Chinle Formation measured at point $S$. $80^{\circ} \mathrm{E}$. of place where Straight Wash crosses Coconino-Kaibab contact.

Chinle Formation:

Church Rock Member:

41. Silty sandstone, similar to unit 33 except is horizontally laminated with possibly some very low angle crosslaminae

40. Sandy siltstone, similar to unit 34 , very poorly exposed, weathers to form slope

39. Silty sandstone, similar to unit 35 except is ripple laminated and contains one thin trough set of large-scale lowangle cross-laminae. Unit weathers to form small ledge.

38. Very poorly exposed, sparse exposures suggest that this unit is sandy siltstone similar to that in unit 34. Unit weathers to form slope...

37. Silty sandstone, similar to unit $35 \mathrm{ex}-$ cept contains subordinate thin trough to planar sets of low-angle crosslaminae. Unit weathers to form conspicuous ledge

36. Sandy siltstone, similar to unit $34 \ldots \ldots .$.

35. Silty sandstone, pale red $(10 R 6 / 2)$ and pale reddish brown $(10 R 5 / 4)$, weathering pale reddish brown (10R 5/4), very fine grained with subordinate silt; firmly cemented, calcareous; composed of horizontal and ripple laminae; weathers to form ledge. Unit contains sparse light-greenishgray $(5 G Y 8 / 1)$ irregular mottles....

34. Sandy siltstone, pale reddish brown $(10 R 5 / 4)$, weathering same color, sandy (very fine grained), uncommon fine-grained accessory white mica, firmly cemented, calcareous; composed of horizontal and ripple laminae; weathers to form slope; unit poorly exposed

So-called Black Ledge:

Note. - Correlation of units 32 and 33 with the so-called Black Ledge elsewhere in the San Rafael Swell is tentative.

33. Sandstone, light gray $(N 7)$ and pale yellowish brown $(10 Y R 7 / 2)$, weath-
Chinle Formation-Continued

Church Rock Member-Continued

So-called Black Ledge-Continued

ering pale yellowish brown (10YR $6 / 2)$, very fine grained, abundant interstitial green clay; abundant coarse-grained accessory white mica and common coarse-grained accessory dark mica, well cemented, highly calcareous; composed of horizontal laminae; possibly some of the horizontal laminae may be large-scale very low angle cross-laminae; platy to flaggy splitting; weathers to form conspicuous dark-colored ledge above thick light-colored sandstone of unit $32 \ldots . .$.

32. Sandstone, light greenish gray ( $5 G Y$ $8 / 1)$ from 0.0 to $47.0 \mathrm{ft}$ and pale red $(5 R 6 / 2)$ from 47.0 to top of unit, weathering yellowish gray (5Y 8/1) in lower $47.0 \mathrm{ft}$ and pale red $(10 R$ $6 / 2$ ) in rest of unit, fine grained, well sorted; composed of subangular clear quartz and milky mineral, subordinate medium grains of green clay and uncommon black accessory mineral; uncommon coarse-grained white and black accessory mica; firmly cemented, calcareous; composed of thin trough and minor planar sets of small- to medium-scale mostly lowangle cross-laminae; platy splitting; weathers to form steep ledgy slope or vertical cliff. Basal $0.4 \mathrm{ft}$ is a conglomerate composed of rounded pebbles of siltstone. Pebbles reach maximum size of about 2 in. Thin set of conglomerate also occurs at $29 \mathrm{ft}$ above base of unit. Cobbles in this conglomerate have a maximum diameter of 5 in., and pebbles and cobbles are composed of siltstone. Top $4.0 \mathrm{ft}$ of unit composed of reddish siltstone along line of section; away from line of section this siltstone is not present

Total of so-called Black Ledge.

31. Limestone, moderate yellowish brown $(10 Y R 5 / 4)$ and medium light gray $(N$ 6), weathering grayish orange (10YR 7/4), aphanitic with common coarse to very coarse calcite crystals, well cemented; possibly some horizontal stratification; weathers to form small ledge

30. Siltstone, grayish red purple (5RP $4 / 2)$, grayish red $(10 R 4 / 2)$, and subordinate greenish gray $(5 G Y$ $6 / 1)$ and dusky yellow (5Y 6/4); firmly cemented, calcareous; some suggestion of horizontal stratification planes; weathers to form steep slope. About 20 percent of unit consists of
Feet 
Chinle Formation-Continued

Church Rock Member-Continued

light-greenish-gray ( $5 G 8 / 1)$, duskyyellow $(5 Y 6 / 4)$, and pale-red $(10 R$ 6/2) limestone nodules. Limestone nodules are irregularly spherical or cylindrical. Nodules average about 2 to $3 \mathrm{in}$. in diameter

29. Siltstone, pale red $(10 R 6 / 2)$ and grayish red $(10 R 4 / 2)$, weathering grayish red (10R 4/2), sandy (very fine grained) in parts; abundant medium-grained accessory white mica; firmly cemented, calcareous; stratification and splitting concealed; weathers to form slope. Unit contains sparse thin sets of very fine grained ripple-laminated sandstone, identical in color with the rest of the unit. Basal $14.2 \mathrm{ft}$ poorly exposed but contains dominant greenish-gray $(5 G 6 / 1)$ siltstone. Basal $4.0 \mathrm{ft}$ of unit to north of line of section composed of light-greenish-gray (5GY 8/1) ripple-laminated siltstone. About $200 \mathrm{ft}$ to north of line of section, these greenish rocks in the lower $\mathbf{1 4 . 2}$ ft of unit appear to have changed to reddish siltstone similar to that in the rest of the unit

28. Sandstone, light gray $(N 7)$ to light greenish gray (5G8/1), weathering yellowish gray $(5 Y 8 / 1)$, fine to coarse grained; well sorted; composed of angular to subangular milky quartz and possibly some other milky mineral, sparse ( 5 percent) grains of green clay and interstitial green clay, sparse accessory black mineral, sparse very coarse grains to pebbles of gray limestone; firmly cemented, calcareous; composed of planar thin sets of small-scale cross-laminae; weathers to form ledge at base of dip slope....

27. Conglomerate to conglomeratic sandstone, medium light gray $\left(\begin{array}{ll}N & 6\end{array}\right)$ with some spots of grayish-orange (10YR 7/4), weathering moderate yellowish gray (10YR 5/4); composed of well-rounded very coarse grains to pebbles of gray limestone in a lime and sand matrix. Limestone grains to pebbles constitute about 60 percent of the rock. Sand matrix constitutes about 30 percent of the rock, and lime about 10 percent. Sand matrix composed of medium to very coarse grains of subangular to rounded clear quartz. Rock is well cemented and is impervious. Unit is composed of very thin horizontal beds and thin planar sets of small-scale cross-laminae, is flaggy splitting, and weathers to form a bench. Units 24

Feet Chinle Formation-Continued Feet Church Rock Member-Continued through 27 form conspicuous bench on top of Moss Back sandstone. This unit grades into overlying unit..

26. Silty claystone to clayey sandstone, similar to unit 24. Poorly exposed......

16.1

25. Sandstone, yellowish gray (5Y 8/1), light greenish gray $(5 G Y 8 / 1)$ and medium light gray $(N 6)$, weathering pale yellowish brown (10YR 7/2), fine to medium grained, well sorted; composed of subangular milky minerals and abundant black accessory minerals, sparse green interstitial clay; poorly to well cemented, calcareous; composed of thin trough sets of small- to medium-scale lowangle cross-laminae; weathers to form benches on a dip slope. Lower $3.7 \mathrm{ft}$ of unit contains sparse conglomeratic sandstone. Conglomeratic sandstone consists of light-brown-weathering limestone granules to cobbles in a fine- to coarse-grained sand matrix. Matrix is well cemented with lime. One cobble has a diameter of $3 \frac{1}{2}$ in.

24. Silty claystone to clayey sandstone, light greenish gray $(5 G 8 / 1)$ and greenish gray ( $5 G Y 6 / 1$ ), weathering same colors, claystone containing subordinate silt to very fine grained sandstone with subordinate clay; uncommon fine-grained accessory white mica, poorly cemented, noncalcareous; stratification concealed; weathers to form slope; unit poorly exposed........

Total of Church Rock Member........

Moss Back Member:

NoTE. - Units 15-20 are provisionally assigned to the Moss Back Member, but they may be Monitor Butte Member.

11.4

23. Sandstone, poorly exposed but where seen it is similar to sandstone of unit 21

22. Sandstone, pale yellowish brown (10YR $6 / 2$ ), weathers same color, medium to coarse grained, well sorted; composed of subangular to subrounded clear quartz and sparse gray accessory mineral; poorly cemented, highly calcareous; composed of thick planar sets of medium-scale cross-laminae; flaggy splitting; weathers to form small ledge back from vertical cliff of underlying unit. Unit contains sparse granules and pebbles as large as $1 / 2$ in. in maximum diameter..........

21. Sandstone, light olive gray (5Y 6/1), yellowish gray $(5 Y 8 / 1)$ and light gray $(N 7)$, weathers yellowish gray (5Y 8/1), fine to medium grained, well sorted; composed of subrounded
5.1

$\begin{array}{r}3.1 \\ \hline 251.9 \\ \hline\end{array}$ 4.7 
Chinle Formation-Continued

Moss Back Member-Continued

to rounded clear quartz, sparse accessory fine-grained white mica, poorly to firmly cemented, calcareous; composed of thick planar and subordinate trough sets of low-angle medium-scale cross-laminae, possibly some horizontal laminae; weathers to form most conspicuous cliff in Chinle Formation. Unit contains a varying proportion (probably from a few percent to as much as 20 percent) of conglomeratic sandstone. Conglomeratic sandstone is generally fine to very coarse grained and contains minor amounts of granules and pebbles. The granules and pebbles are composed of gray quartzite, quartz, and limestone and to a lesser extent of light-brown limestone and white quartz. Granules and pebbles are in a matrix of subangular to subrounded clear quartz grains. Conglomeratic sandstone generally occurs in lower $10 \mathrm{ft}$ of unit, but also occurs rarely as thin sets in rest of unit. Pebbles reach maximum diameter of 2 in.; all gradations are found from conglomeratic sandstone to sandstone

20. Siltstone, greenish gray $(5 G Y 6 / 1)$ and pale olive $(10 Y 6 / 2)$, weathering light greenish gray ( $5 G Y 8 / 1)$, firmly cemented, noncalcareous; possibly some horizontal bedding; one example of deformed bedding seen about 100 $\mathrm{ft}$ southwest of line of section. Deformed bedding consists of siltstone and sandstone dipping at high angle to regional dip. About $10 \mathrm{ft}$ of beds is deformed. Unit contains one thin set of very fine grained ripple-laminated sandstone about $5.0 \mathrm{ft}$ above base of unit. This sandstone is similar to that in the deformed beds........

19. Sandstone, yellowish gray $(5 Y 8 / 1)$, very light gray $(N 8)$, and pale yellowish brown $(10 Y R 6 / 2)$, weathering pale yellowish brown (10YR 6/2), very fine grained, well sorted; composed of subangular to subrounded clear and milky quartz and uncommon black accessory mineral; abundant limonite spots; well cemented, highly calcareous, intergranular spaces are completely filled with calcite (?) ; composed of thin trough sets of small- to medium-scale low-angle cross-laminae; weathers to form small ledge. Abundant limonite spots

18. Very poorly exposed. Partial outcrops indicate that most of unit is siltstone. Siltstone, greenish gray ( $5 G Y 6 / 1)$, weathering light greenish gray ( $5 G Y$
Chinle Formation-Continued

Moss Back Member-Continued

$8 / 1$ ), firmly cemented, calcareous; stratification concealed; paper splitting. Partial exposure in middle of unit reveals a thin set of very fine grained micaceous ripple-laminated sandstone

17. Sandstone, very light gray $\left(\begin{array}{l}N \\ 8)\end{array}\right)$ with abundant light-brown (5YR 5/6) spots, weathers pale yellowish brown (10YR 6/2), fine grained; well sorted, composed of subrounded clear quartz and sparse black accessory mineral; abundant light-brown limonite spots; well cemented, highly calcareous, intergranular spaces completely filled with calcite(?); composed of thin trough sets of small- to medium-scale cross-laminae; weathers as part of prominent ledge contiguous with unit below

16. Sandstone, light greenish gray (5GY $8 / 1)$, yellowish gray $(5 Y 8 / 1)$, and white $(N 9)$, weathers brown gray (5YR 4/1), medium grained, except contains about 10 percent scattered coarse to very coarse grains, and less than 1 percent granules, fair sorted; composed of subangular to subrounded clear quartz; abundant limonite spots; well cemented, highly calcareous, all intergranular spaces filled with calcite (?) ; composed of thin trough sets of low-angle medium-scale cross-laminae; weathers to form conspicuous ledge at base of Chinle

15. Siltstone to sandstone, grayish yellow $(5 Y 8 / 4)$ and dark yellowish orange $(10 Y R 6 / 6)$, weathers same colors; color probably from abundant limonite; siltstone to coarse-grained sandstone with minor silt, medium to coarse sand grains are subangular to subrounded clear quartz and abundant gray accessory mineral; firmly cemented, probably with limonite binding; stratification concealed; weathers to form slight reentrant.

Total of Moss Back Member............

Total of Chinle Formation.

Moenkopi Formation (incomplete)

Upper slope-forming member:

14. Siltstone, yellowish gray $(5 Y 7 / 2)$ and grayish yellow $(5 Y 7 / 4)$, weathers grayish yellow $(5 Y 7 / 4)$, firmly to well cemented, calcareous; horizontally and ripple laminated; weathers to form overhanging ledge below vertical cliff of Moss Back Member. Basal $0.5 \mathrm{ft}$ of unit is composed of dark-yellowishorange $(10 Y R 6 / 6)$ and light-brown $(5 Y R 5 / 6)$ powdery siltstone mixed
Feet
13.3 
Moenkopi Formation (incomplete)-Continued

Upper slope-forming member-Continued

with siltstone similar to that in rest of unit. Unit contains 2 percent cubes and spheres of limonite(?) pseudomorphic after pyrite.

13. Siltstone, pale olive $(10 Y 6 / 2)$, grayish yellow $(5 Y 7 / 4)$, and light olive gray (5Y 6/1), weathers pale yellowish orange $(10 Y R 8 / 6)$, sparse very fine grained accessory white mica; firmly cemented, noncalcareous; stratification mostly concealed; 5 percent thin to thick ripple-laminated sets; weathers to form steep slope. Unit does not contain conspicuous resistant ledges that characterize unit below, and it weathers a more yellowish color than unit below. Unit contains 2 percent brownish cubes and spherical masses of limonite(?) pseudomorphic after pyrite. Top few feet of unit is light greenish gray (5G 8/1) and contains 2 percent small pyrite crystals.

Total of upper slope-forming member

Total of incomplete Moenkopi Formation

Base of section; not base of exposure.

Units 1-12 described in Stewart, Poole, and Wilson (1972).

\section{U-8. TEMPLE MOUNTAIN}

Measured up northeast corner of north Temple Mountain on the east side of the San Rafael Swell, long 110 $40^{\prime} 35^{\prime \prime} W$. lat $38^{\circ} 41^{\prime} 20^{\prime \prime}$ N., Emery County

[Measured by J. H. Stewart and C. H. Scott, July 1953]

Top of section; not top of exposure. Top of section N. $67^{\circ} \mathrm{W}$. of conspicuous group of mines.

Wingate Sandstone:

20. Sandstone, grayish orange $(10 Y R 7 / 4)$ in bottom $5 \mathrm{ft}$ and medium light gray $(N 6)$ above basal $5 \mathrm{ft}$, weathering same colors, fine grained, well sorted; composed of subround clear quartz and sparse black accessory minerals; composed of very thick trough sets of high-angle large- to medium-scale cross-laminae; massive splitting; weathers to form steep slope or cliff. Bottom 1 in. contains abundant wellrounded frosted quartz grains. Medium-light-gray color due to vanadium minerals impregnating the sandstone. Bottom $1 \mathrm{ft}$ of Wingate appears horizontally laminated. Only basal $20 \mathrm{ft}$ of unit examined Unmeasured

Contact between Chinle and Wingate placed at texture change from the very fine grained sandstone of the Chinle to the fine-grained sandstone of the Wingate. Bottom 1 in. of the Wingate contains abundant well-rounded medium to coarse frosted quartz grains.
Chinle Formation:

Church Rock Member:

19. Sandstone, grayish orange $(10 Y R 7 / 4)$, weathering same color, very fine grained, well sorted; well cemented, slightly calcareous; stratification poorly exposed but probably dominantly ripple laminated, sparse thin sets of medium-scale low-angle crosslaminae; massive splitting; weathers to form ledge

18. Siltstone, light greenish gray $(5 G 8 / 1)$ grayish orange $(5 Y R 7 / 4)$, and subordinate dark yellowish orange $(10 Y R$ $6 / 6)$, weathering light greenish gray $(5 G 8 / 1)$; poorly cemented, noncalcareous; some suggestion of horizontal bedding planes; splitting concealed; weathers to form slope. Unit is poorly exposed.

17. Clayey siltstone, grayish red $(10 R 4 / 2)$ weathering same color; firmly cemented, noncalcareous; stratification concealed; weathers to form slope......

16. Sandstone, light greenish gray ( $5 G Y$ $8 / 1$ ) and subordinate light olive gray $(5 Y 6 / 1)$ and medium gray $(N 6)$ weathering light greenish gray ( $5 G Y$ $8 / 1$ ), very fine grained, well sorted; well cemented, highly calcareous; ripple laminated; slabby to massive splitting; weathers to form light-colored ledge. Unit appears to contain vanadium minerals. The color of unit is probably the result of bleaching associated with the vanadium mineralization

15. Sandstone, grayish red purple (5RP $4 / 2)$, pale red purple $(5 R P 6 / 2)$ light greenish gray $(5 G Y 8 / 1)$, and subordinate pale reddish brown $(10 R$ $5 / 4)$, purple and red colors constitute about 70 percent of unit, weathering pale red purple $(5 R P 6 / 2)$ and light greenish gray $(5 G Y 8 / 1)$, very fine grained, well sorted; uncommon medium-grained accessory white mica; firmly to well cemented, calcareous; ripple laminated in lower $15 \mathrm{ft}$ and upper $10 \mathrm{ft}$, rest of unit composed of thin trough sets of low-angle mediumscale cross-laminae; platy splitting; weathers to form vertical cliff or steep ledgy slope. Upper $3 \mathrm{ft}$ of unit is siltstone

14. Silty claystone, grayish red purple (5RP 4/2), weathering same color; firmly cemented, slightly calcareous; stratification and splitting concealed. Top 6 in. is greenish gray ( $5 G Y 6 / 1)$. Unit weathers to form slope

13. Sandy siltstone to sandstone, pale red $(10 R 6 / 2)$, pale reddish brown $(10 R$ $5 / 4)$, and sparse pale yellowish brown 
Chinle Formation-Continued

Church Rock Member-Continued

$(10 Y R 6 / 2)$, weathering pale red $(10 R 6 / 2)$; common medium-grained accessory white mica; well cemented, calcareous; ripple laminated; platy splitting, weathers to form slope........

12. Siltstone to sandstone, pale reddish brown $(10 R 5 / 4)$, weathering same color, very fine grained sandstone in lower half grading to siltstone in upper half; common accessory white mica; well cemented, highly calcareous; ripple laminated, subordinate thin trough sets of medium-scale lowangle cross-laminae in lower half of unit; platy splitting; weathers to form prominent ledge. This unit forms the second most prominent ledge in Church Rock Member on the cliffs to the east of the line of section...

11. Siltstone, grayish red $(10 R 4 / 2)$ and grayish red purple $(5 R P 4 / 2)$, weathering same colors; well cemented, highly calcareous; where exposed, unit is structureless; weathers to form steep slope.

So-called Black Ledge:

10. Sandstone ( 80 percent) and siltstone (20 percent). Sandstone, pale olive $(10 Y 6 / 2)$, yellowish gray (5Y $7 / 2)$, and subordinate light gray $(N 7)$, weathering light olive gray $(5 Y 6 / 1)$ and pale olive $(10 Y 6 / 2)$, fine grained, fair sorted; composed of subangular milky quartz and uncommon (10 percent) gray mineral, sparse coarsegrained accessory white mica; well cemented; highly calcareous, grains tightly cemented together leaving no open spaces, rock commonly breaks across grains; composed of thin trough and minor planar sets of small- to medium-scale cross-laminae and of horizontal and ripple laminae; platy to slabby splitting. About 10 percent of sandstone is conglomeratic and contains granules and pebbles of unidentified gray rock and of gray and brown siltstone and limestone. Conglomeratic parts mostiy in bottom half of unit; common carbonaceous material. Siltstone, grayish green (5GY 6/1), pale olive $(5 Y 6 / 2)$, and minor grayish red $(10 R 4 / 2)$, weathering same colors; some scattered very fine grains in siltstone in places; uncommon medium-grained accessory white mica ; firmly cemented, calcareous; horizontally thinly laminated to very thin bedded; papery to flaggy splitting. Siltstone is present as thin to thick sets interbedded with sandstone. Siltstone contains common car-
Feet

Chinle Formation-Continued

Church Rock Member-Continued

So-called Black Ledge-Continued bonaceous material. Unit forms most prominent sandstone in the Church Rock Member on the cliffs to the east of the line of section. Unit as a whole tabular but varies in thickness; weathers to form vertical cliff. Thickness of unit along line of section extreme for local area

Total of so-called Black Ledge........

9. Limy siltstone, grayish purple (5P 4/2), grayish red purple $(5 R P 4 / 2)$ and pale red purple (5RP 6/2), subordinate greenish gray $(5 G Y 6 / 1)$ and light greenish gray (5GY 8/1), sparse pale reddish brown $(10 R 5 / 4)$, weathering same colors; well cemented, calcareous; stratification poorly developed, common horizontal bedding planes; massive splitting; weathers to form steep slope. About half of upper half of unit contains about 40 percent limestone nodules which are generally about 2 in. in diameter. Base of unit is characterized by common grayish-yellow $(5 G Y 7 / 2)$ bands

8. Siltstone, pale reddish brown $(10 R 5 / 4)$, subordinate grayish red (10R 4/2), sparse medium light gray $(N 6)$, weathering pale reddish brown $(10 R$ $5 / 4)$; common fine-grained accessory white mica; firmly cemented, calcareous; stratification poorly exposed but probably mostly ripple laminated or horizontally laminated; splitting concealed; weathers to form steep loose slope. Thin set of pale olive (10Y $6 / 2$ ) ripple-laminated siltstone is present about $8 \mathrm{ft}$ above base of unit

Total of Church Rock Member.......

Moss Back Member:

7. Sandstone, greenish gray (5GY 6/1) and light greenish gray (5GY 8/1), weathering same colors and pale reddish brown $(10 R 5 / 4)$, very fine to fine grained, well sorted; composed of subangular to subround milky and clear quartz, and abundant mediumgrained accessory white mica; firmly cemented, calcareous; composed of horizontal laminae and subordinate thin trough sets of small-scale lowangle cross-laminae; papery to platy splitting; weathers to form vertical cliff contiguous with unit below. Unit may be discontinuous along exposure and may not properly belong in the Moss Back Member. In local area, the Moss Back Member has apparently been bleached to gray. Possibly the
Feet 
Chinle Formation-Continued

Moss Back Member-Continued

Moss Back Member is petroliferous and the bleaching is related to the presence of petroleum

6. Sandstone and conglomeratic sandstone. Sandstone, light gray $(N 7)$ to medium light gray $(N 6)$, subordinate very light gray $\left(\begin{array}{l}N \\ 8)\end{array}\right)$, weathering very light gray $(N 8)$ and pale reddish brown $(10 R 5 / 4)$, fine to medium grained with sparse coarse grains, well sorted; composed of subround clear quartz and sparse gray accessory minerals; poorly to firmly cemented, calcareous in parts; composed of thin trough and uncommon planar sets of low-angle small- to medium-scale cross-laminae; platy to massive splitting. Conglomeratic sandstone, similar to sandstone except contains about 10 percent granules and pebbles of rounded white and gray quartzite and, to a lesser extent, of quartz. Conglomeratic sandstone confined to lower $10 \mathrm{ft}$. Unit as whole tabular and weathers to form vertical cliff. Ore deposits in Temple Mountain area are in lower part of unit. One mine is about $200 \mathrm{ft}$ to south of line of section and about $15 \mathrm{ft}$ above base of unit. Unit contains sparse $(<1$ percent) carbonaceous material and abundant limonite spots and stains..

Total of Moss Back Member.

Temple Mountain Member:

5. Clay siltstone, greenish gray $(5 G Y 6 / 1)$ and medium light gray $(N 6)$, subordinate dark yellowish orange $(10 Y R$ $6 / 6$ ), weathering same colors; firmly cemented, noncalcareous; structureless; fractures into granule-sized angular fragments; weathers to form steep slope. Unit is poorly exposed. Unit grades into underlying unit. Contact with overlying unit is covered

4. Siltstone, grayish purple $(5 P 4 / 2)$, light greenish gray $(5 G Y 8 / 1)$, subordinate pale red purple (5RP 6/2), weathering same colors; well cemented, noncalcareous; structureless; massive splitting, fractures into angular fragments; weathers to form steep slope or vertical cliff. Unit appears to be highly fractured. Uncommon black metallic coatings, probably of iron mineral......................

3. Sandstone, pale red purple (5RP 6/2), grayish red $(10 R 4 / 2)$, pale red $(10 R$ $6 / 2$ ), and light greenish gray ( $5 G Y$ $8 / 1)$, weathering pale red $(10 R 6 / 2)$,
Feet | Chinle Formation-Continued

Feet

\section{Temple Mountain Member-Continued}

very fine to fine grained, fair sorted; composition undeterminable; firmly cemented, noncalcareous; composed of thin horizontal laminae, of very thin to thin sets of small- to medium-scale cross-laminae and of uncommon sets of contorted stratification; papery to flaggy splitting; weathers to form small ledge. Grades into underlying and overlying units.

2. Clayey sandstone, white $(N 9)$, grayish pink $(5 R 8 / 2)$, and light brown ( $5 Y R$ $5 / 6)$, weathering light brown ( $5 Y R$ $6 / 4)$, coarse to very coarse grained, poorly sorted; composed of subangular to subround milky and clear quartz and 5 percent orange and gray minerals; interstices filled with white clay, clay constitutes about 20 percent of rock; poorly cemented clay binding; composed of thin to thick sets of small- to medium-scale cross-laminae; massive to platy splitting; weathers to form small ledge. Unit contains rare (1 percent) granules and pebbles of quartz and siltstone. Unit grades into overlying unit; contains abundant irregular mottles of limonite

Total of Temple Mountain Member

Total of Chinle Formation.

71.6 Moenkopi Formation (incomplete) :

1. Siltstone, grayish red $(10 R 4 / 2)$; micaceous; firmly cemented, slightly calcareous; horizontally and ripple laminated; weathers to form slope....

Total of incomplete Moenkopi Formation

Base of section; base of exposure. Base of section about $200 \mathrm{ft}$ to northwest of small mine.

\section{U-9. BUCKACRE, POINT}

Measured on side of canyon from $1 / 2$ to 1 mile northeast of junction of Poison Springs Box Canyon with Dirty Devil River, lat $38^{\circ} 6^{\prime}$ N., long $110^{\circ} 24^{\prime} W$., Garfield County

[Measured by J. H. Stewart, June 1953]

Top of section; top of accessible exposure.

Wingate Sandstone:

27. Sandstone, basal $3 \mathrm{ft}$ yellowish gray $(5 Y 8 / 1)$, rest of unit light brown (5YR 6/4), weathering light brown (5YR 6/4), very fine to fine grained, well sorted; composed of subrounded clear and amber quartz and abundant black accessory mineral; firmly cemented, calcareous; horizontally laminated and thinly bedded; lower $9 \mathrm{ft}$ has conspicuous slabby splitting; weathers to form vertical cliff. Basal $1 \mathrm{ft}$ of unit contains abundant wellrounded coarse clear quartz grains. 
Wingate Sandstone-Continued Only basal $12 \mathrm{ft}$ of unit examined ..Unmeasured

Contact of Wingate and Chinle Formations placed at sharp lithologic break between reddish-brown sandstone and siltstone of the Chinle and the brownish sandstone of the Wingate. The basal font of the Wingate is characterized by abundant well-rounded coarse grains. The stratification is more reguiar in the Wingate than in the Chinle.

Chinle Formation:

Church Rock Member:

Hite Bed:

26. Sandstone ( 80 percent) and siltstone (20 percent). Sandstone, pale red $(10 R 6 / 2)$, very light gray $(N 8)$, pale red purple $(5 R P 6 / 2)$, and moderate brown $(5 Y R 4 / 4)$, weathering pale reddish brown $(10 R 5 / 4)$, very fine grained, sparse fine grained, fair sorted; fine-grained parts composed of subangular milky quartz and common orange, green, and black accessory minerals, abundant medium-grained white mica; firmly cemented, calcareous; thinly horizontally laminated and ripple laminated, common thin trough sets of low-angle small-scale crosslaminae and sparse thick trough sets of medium-scale cross-laminae; platy to blocky splitting. Siltstone, pale reddish brown $(10 R 5 / 4)$ and pale red purple $(5 R P 6 / 2)$, weathering same colors; firmly cemented, noncalcareous, abundant very fine grained white mica; structureless. Siltstone occurs as thin to thick lenticular beds interstratified with sandstone and also as laminae along stratification planes. Sandstone contains clay pellets in some places. Unit as a whole is tabular; weathers to form ledges and cliffs at top of Chinle Formation........

Total of Hite Bed..

25. Siltstone, similar to unit 23

24. Siltstone, similar to unit 22

23. Siltstone, light brown $(5 Y R 6 / 4)$ and moderate brown (5YR 4/4), weathering pale reddish brown $(10 R 5 / 4)$; well cemented, noncalcareous; stratification concealed; weathers to form slope containing small ledges. Rock fractures into angular fragments. Common light-greenish-gray (5GY $8 / 1$ ) spots. Light-greenish-gray ( $5 G Y$ $8 / 1$ ) thin band at base.

22. Siltstone, grayish red $(10 R 4 / 2$ and $5 R$ $4 / 2)$, weathering pale red $(10 R 6 / 2)$; firmly cemented, noncalcareous; stratification and splitting concealed; weathers to form slope.

Total of Church Rock Member
Feet Chinle Formation-Continued

Owl Rock Member:

21. Siltstone to limestone, pale red $(10 R$ $6 / 2)$, grayish orange pink (5YR 7/2), spots and layers of light greenish gray (5GY 8/1), weathering same colors. Rock grades from siltstone to limestone and is well cemented. The limestone is aphanitic. Unit varies in thickness and is composed of thin horizontal laminae, thin ripple laminae, and thin trough sets of smallscale cross-laminae; slabby splitting; weathers to form prominent ledge. Unit contains common thin beds of pale-reddish-brown $(10 R 5 / 4)$ siltstone interstratified with rest of unit

20. Limy siltstone, light greenish gray $(5 G Y 8 / 1)$, pale reddish brown $(10 R$ $5 / 4)$, pale red $(10 R 6 / 2)$, and light olive gray ( $5 Y 6 / 1)$, weathering dominantly light greenish gray $(5 G Y$ $8 / 1$ ) ; well cemented, highly calcareous; stratification mostly concealed, some horizontal stratification planes; weathers to form steep slope. Sparse light-greenish-gray $(5 G Y 8 / 1)$ and pale-red $(10 R 6 / 2)$ nodules and thin lenticular beds of limestone throughout unit. Concentration of limestone beds from 66.9 to $71.7 \mathrm{ft}$ above base of unit makes small ledge.

19. Siltstone and limestone. Siltstone, grayish red purple $(5 R P 4 / 2)$ in lower 2.5 ft, pale reddish brown (10R 5/4), pale red $(10 R 6 / 2)$, and grayish red $(10 R 4 / 2)$ in rest of unit, weathering same colors, minor amounts of very fine sand in a few places; firmly cemented, calcareous; stratification concealed. Limestone, light greenish gray (5GY 8/1), weathering same color; well cemented, horizontally and ripple laminated; platy splitting. Unit as a whole is tabular and weathers to form small ledge. In combination with unit below, forms one of prominent ledges in Chinle. Limestone occurs from 4.5 to $5.8 \mathrm{ft}$ above base of unit and in top $1.0 \mathrm{ft}$.

18. Limestone, light gray $(N 7)$, weathering same color, aphanitic; well cemented; structureless; slabby splitting; weathers to form ledge.

17. Siltstone, pale red $(5 R 6 / 2)$, abundant light-greenish-gray $(5 G Y 8 / 1)$ spots, weathering pale red $(10 R 6 / 2)$ and light greenish gray $(5 G Y \cdot 8 / 1)$; well cemented, calcareous; stratification concealed; weathers to form steep slope. Common silty limestone nodules. Unit from 69.9 to $75.4 \mathrm{ft}$ above base weathers to form two small ledges and is commonly light brown
Feet 
Chinle Formation-Continued

Owl Rock Member-Continued

$(5 Y R 6 / 4)$. Top $3.2 \mathrm{ft}$ of unit is limy. Top $1.5 \mathrm{ft}$ of unit is light greenish gray $(5 G Y 8 / 1)$

16. Limestone granule conglomerate, grayish red $(10 R 4 / 2)$ and greenish gray (5GY 6/1), weathering same colors, composed of limestone granules and minor amounts of very coarse grains and pebbles of limestone, pebbles as large as $1 \mathrm{in}$. in diameter, fair sorted; firmly cemented, calcareous; poorly developed thin horizontal beds; slabby splitting; weathers to form ledge. Some parts of unit are highly silty....

15. Siltstone, pale red $(5 R 6 / 2)$, weathering same color and pale red purple (5RP 6/2); no swelling clays present; firmly cemented, calcareous; structureless; weathers to form steep slope. Limestone nodules form crude beds (about 70 percent nodules) from 15.3 to $17.1 \mathrm{ft}$ and 22.7 to $26.2 \mathrm{ft}$ above base of unit and are common in rest of top $16 \mathrm{ft}$ of unit. The nodules are pale red $(5 R 6 / 2)$ and pale red purple (5RP 6/2), aphanitic, and mostly 3 to 5 in. in maximum diameter. Unit forms persistent purplish band in Chinle

Total of Owl Rock Member

Petrified Forest Member:

14. Silty claystone to clayey sandstone, grayish red $(5 R 4 / 2)$, weathering same color, grades from silty claystone to clayey, very fine grained sandstone; contains swelling clays, composition of sandstone is masked; firmly cemented, slightly calcareous; stratification mostly concealed, some ripple-laminated and small-scale cross-laminated parts; weathers to form slope

13. Sandstone, light greenish gray $(5 G Y$ $8 / 1)$, light brownish gray (5YR 6/1), and light gray $(N 7)$, weathering light brownish gray $(5 Y R 6 / 1)$, fine grained, well sorted; composed of subangular to subrounded clear quartz and abundant orange, green, and gray accessory minerals, abundant interstitial white material (probably calcite); firmly cemented, calcareous; composed of thin to thick horizontal cosets of thin trough sets of smallscale cross-laminae; platy splitting; weathers to form prominent brownish ledge. Sparse thin sets of silty claystone, similar to that in unit 11 , occur near base of unit

12. Sandstone (90 percent) and silty claystone (10 percent). Sandstone, light

14.6

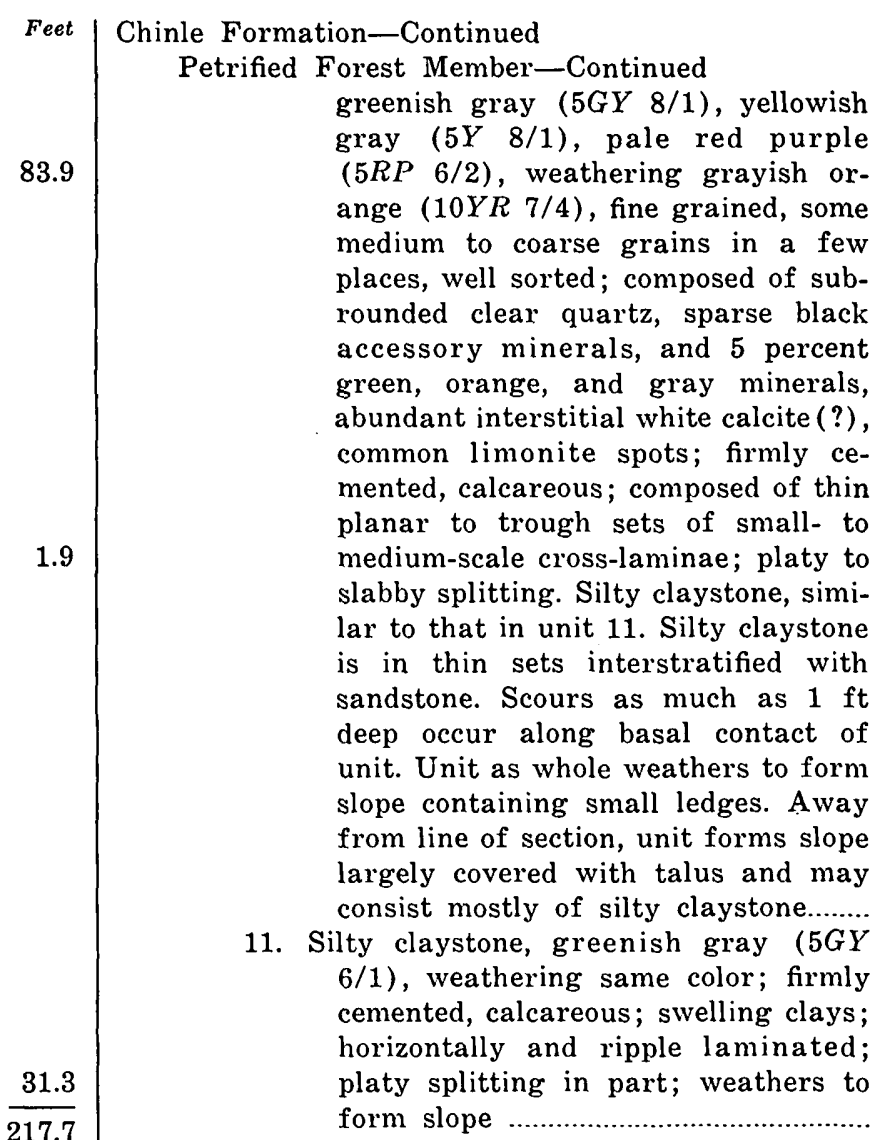

Total of Petrified Forest Member.

Moss Back Member:

10. Sandstone, greenish gray (5GY 6/1) and yellowish gray $(5 Y 8 / 1)$, weathering same colors, medium to coarse grained, fair sorted; composed of subrounded clear quartz and 10 percent orange, gray, and green minerals; well cemented, highly calcareous; calcite fills interstices between grains; composed of thin trough sets of crosslaminae; platy to slabby splitting; weathers to form ledge. Scours occur along lower contact of unit. Common granules and pebbles of limestone and siltstone near base. Upper $4 \mathrm{ft}$ of unit is similar to unit 8

9.9

9. Siltstone (60 percent) and sandstone (40 percent). Siltstone, greenish gray (5GY 6/1), weathering same color; abundant dark-green medium-grained mica; poorly cemented, noncalcareous; thinly laminated; papery splitting. Sandstone, similar to unit 8 . Sandstone occurs as thin sets interbedded with siltstone. Content of sandstone in unit varies along exposure. Unit weathers to form small reentrant in prominent ledge

8. Sandstone, light greenish gray (5GY $8 / 1)$ and yellowish gray $(5 Y 8 / 1)$,
24.6 
Chinle Formation-Continued

Moss Back Member-Continued

weathering very pale orange $(10 Y R$ $8 / 2$ ), medium grained, contains some scattered fine and coarse grains, fair sorted; composed of subrounded to rounded clear quartz and sparse black accessory minerals; firmly to well cemented, calcareous; composed of thin to thick planar to trough sets of small- to medium-scale cross-laminae; platy to massive splitting; weathers together with two overlying units to form most prominent ledge in Chinle. Conglomeratic sandstone as much as $2.5 \mathrm{ft}$ thick occurs locally at base and contains granules and pebbles as large as 1.5 in. in diameter of gray quartz and quartzite.

Total of Moss Back Member

Monitor Butte Member:

7. Siltstone, grayish red purple $(5 R P 4 / 2)$ and grayish purple (5P 4/2), weathering same colors; firmly cemented, noncalcareous; horizontally laminated to thin bedded; slabby splitting; weathers to form reentrant below overlying ledge-forming units. Unit contains 5 percent thin sandstone sets similar to those in upper part of the underlying unit. Upper $0.9 \mathrm{ft}$ of unit altered to light greenish gray (5G $8 / 1)$

6. Sandstone (50 percent) and claystone to siltstone (50 percent). Sandstone, dominantly light greenish gray ( $5 G Y$ $8 / 1$ ) in lower half and grayish purple $(5 P 4 / 2)$ in upper half, weathering same colors, fine to very fine grained, fair sorted ; composed of subangular milky and clear quartz, and 10 percent orange, gray, and black minerals, common medium-grained white mica; firmly cemented, slightly calcareous in parts; composed of thin trough sets of low-angle cross-laminae in lower half, horizontally ripple laminated in upper half; platy splitting. Claystone to siltstone, light greenish gray (5GY 8/1) and light gray $(N 7)$, weathering light greenish gray ( $5 G Y 8 / 1)$; firmly cemented, noncalcareous; thinly laminated in parts; papery splitting in parts. Unit as whole tabular and weathers to form slope. Lower half of unit similar to underlying unit but differentiated on the basis of a higher content of claystone and siltstone. Sandstone occurs as thin sets interstratified with thin sets of claystone to siltstone. Content of sandstone highly variable along exposure
Feet

Chinle Formation-Continued

Monitor Butte Member-Continued

5. Sandstone (80 percent) and silty claystone (20 percent). Sandstone, light greenish gray $(5 G Y 8 / 1)$ and yellowish gray (5Y 8/1), weathering same colors, fine grained, fair sorted; composed of milky mineral (quartz?) and abundant orange and green accessory minerals; composed of thin trough sets of low-angle small- to mediumscale cross-laminae; platy splitting. Common light-greenish-gray (5GY $8 / 1)$ clay pellets. Silty claystone, greenish gray $(5 G Y 6 / 1)$, weathering same color; firmly cemented, noncalcareous; thinly laminated in parts; papery splitting in parts. Unit as a whole can be seen on all local exposures but is indistinct on distant exposures. Unit weathers to form ledge. Silty claystone occurs as thin sets interstratified with sandstone....

Total of Monitor Butte Member.....

Mottled strata:

4. Siltstone, grayish purple (5P 4/2), weathering same color, contains sparse fine to very coarse wellrounded sand grains; firmly cemented, noncalcareous; structureless; weathers to form prominent purple band in cliff below a prominent sandstone. Common masses of brownish quartz, one of which is about $1.5 \mathrm{ft}$ wide and $0.5 \mathrm{ft}$ thick.

3. Siltstone, similar to unit 1 except contains prominent greenish-gray ( $5 G Y$ 6/1) mottling

2. Siltstone, greenish gray (5GY 6/1), common grayish-red $(10 R 4 / 2)$ mottling, weathering same colors; contains a few fine sand grains; firmly to well cemented, noncalcareous; structureless. Copper staining occurs in a few places. Forms fairly prominent green band.

Total of mottled strata

Total of Chinle Formation

Contact of Chinle and Moenkopi placed at lowest green bed. This contact is arbitrary, as siltstone similar to that of the Moenkopi occurs above. However the occurrence of fine sand grains in unit 2 suggests that this unit is part of the Chinle rather than part of the Moenkopi.

Moenkopi Formation:

1. Siltstone, grayish red $(10 R 4 / 2)$, weathering same color, common fine-grained white mica; firmly to well cemented, noncalcareous; appears structureless at top; weathers to steep slope with vertical cliff at top. No sand grains
Feet 
Moenkopi Formation-Continued noted in unit. Only top few feet examined Unmeasured

Base of section; not base of exposure.

\section{U-10. HORSE CANYON}

Measured in northwestern part of Circle Cliffs, on promontory about 4.5 miles $S .79^{\circ} \mathrm{W}$. from Lampstand, long $111^{\circ} 14^{\prime} 10^{\prime \prime}$ W., lat $37^{\circ} 57^{\prime} 45^{\prime \prime}$ N., Garfield County

[Mensured by J. H. Stewart and G. A. Williams, August 1952]

Top of section; not top of outcrop.

Wingate Sandstone:

16. Sandstone, very pale orange $(10 Y R$ $8 / 2)$, weathering pale yellowish orange $(10 Y R 8 / 6)$, very fine grained, well sorted; composed of rounded clear quartz and sparse orange and black accessory minerals; firmly cemented, slightly calcareous. Unit is tabular with large-scale trough sets of crosslaminae. Unit is blocky to massive splitting. Unit weathers to form vertical cliff. Basal contact is slightly irregular. Bottom foot of Wingate is siltstone containing granules and coarse grains of sandstone, clear quartz, and siltstone; lower $3 \mathrm{ft}$ of unit contains medium to coarse rounded sand grains Unmeasured

Chinle Formation:

Owl Rock Member:

15. Siltstone, pale reddish brown $(10 R 5 / 4)$ and minor amounts of pale olive $(10 Y 6 / 2)$, weathering pale reddish brown $(10 R 5 / 4)$; firmly cemented, slightly calcareous; bedding concealed. Unit is tabular and weathers to form steep loose slope. At $9 \mathrm{ft}$ and $14 \mathrm{ft}$ above base of unit are limy siltstone (or limestone?) ledges. These ledges do not persist laterally.

14. Sandstone, pale reddish brown (10R $5 / 4)$ with blotches of light greenish gray $(5 G 8 / 1)$, weathering pale reddish brown (10R 5/4), fine grained, fair sorted; composed of angular clear quartz, abundant orange accessory minerals; firmly cemented, slightly calcareous. Unit is tabular and contains small-scale planar sets of crosslaminae; parts are laminated. Rocks platy splitting. Unit weathers to form inconspicuous ledge.

13. Siltstone, pale reddish brown $(10 R 5 / 4)$ and minor amounts of light greenish gray $(5 G 8 / 1)$, weathering pale reddish brown $(10 R 5 / 4)$; firmly cemented, calcareous and argillaceous; bedding concealed; weathers to form steep loose slope. At $48.4 \mathrm{ft}$ is a 3 - $\mathrm{ft}$ thick limy siltstone bed, and at $\mathbf{5 5 . 8}$ ft a 2-ft-thick limy siltstone bed; a few very thin beds of limy siltstone
Feet

Chinle Formation-Continued

Owl Rock Member-Continued

occur elsewhere in unit away from line of section

Total of Owl Rock Member

Petrified Forest Member :

12. Silty claystone to siltstone, pale red $(10 R 6 / 2$ and $5 R 6 / 2)$, weathering same colors, contains swelling clays; firmly cemented, calcareous; structureless; weathers to form frothysurfaced slope. Unit grades upward into overlying unit. Top of unit is highest occurrence in section of strata containing swelling clay

So-called Capitol Reef bed:

11. Sandstone, grayish purple $(5 P 4 / 2)$, light greenish gray $(5 G Y 8 / 1)$ and grayish red $(10 R 4 / 2)$, weathering pale red purple $(5 R P 6 / 2)$ and very pale orange $(10 Y R 8 / 2)$, mediumgrained, fair sorted; composed of subangular clear quartz with abundant orange and black accessory minerals; poorly cemented, calcareous. Unit is tabular and contains small- to mediumscale trough sets of cross-laminae. Rock is shaly to slabby splitting. Unit weathers to form ledge

Total of so-called Capitol Reef bed

10. Siltstone ( 60 percent) to clayey sandstone (40 percent), pale reddish brown $(10 R 5 / 4)$, subordinate greenish gray $(5 G Y 6 / 1)$ in lower part and rarely elsewhere, weathering moderate red $(5 R 5 / 4)$; grades from siltstone containing sparse to abundant medium to coarse sand grains to clayey fineto medium-grained sandstone; composed of clear quartz and black and orange accessory minerals; firmly cemented, calcareous; stratification concealed; weathers to form steep rubbly slope. Unit contains, near base, a very thin bed of granule conglomerate. The conglomerate also contains sparse pebbles

9. Sandstone, dusky red $(5 R 3 / 4)$, minor amounts of light greenish gray ( $5 G Y$ $8 / 1$ ), weathering moderate yellowish brown $(10 Y R 5 / 4)$, medium grained, fair sorted; composed of subangular clear quartz, abundant orange and black accessory minerals; poorly cemented; calcareous. Unit is tabular and is composed of large-scale planar and trough sets of cross-laminae. Unit contains a few ripple laminae. Unit weathers to form a steep bare rock slope. Unit contains a few very thin light greenish gray (5GY 8/1) beds between sets of cross laminae
Feet

69.0

163.8

17.4

39.2

$\overline{39.2}$

83.4

12.8 
Chinle Formation-Continued

Petrified Forest Member-Continued

8. Silty claystone to clayey siltstone, pale reddish brown $(10 R 5 / 4)$, dusky red $(5 R 3 / 4)$ and grayish red purple (5RP 4/2), weathering same colors; firmly cemented, argillaceous; stratification concealed; weathers to form steep frothy slope. Unit forms red band on exposure

7. Sandy siltstone, light greenish gray $(5 G Y 8 / 1)$ and pale red (10R 6/2), colors mottled in part, weathering same colors, sandy, very fine grained; abundant very fine grained accessory white mica; firmly to well cemented, calcareous cement and clay binding; stratification mostly concealed, a few horizontal laminae and ripple laminae are present; weathers to form very steep slope. To north of line of section unit forms ledge

Total of Petrified Forest Member....

Monitor Butte Member:

6. Claystone, predominantly greenish gray (5GY 6/1), minor amounts of brownish gray $(5 Y R 4 / 1)$ and dark reddish brown $(10 R 3 / 4)$, variegated, greater amount dark reddish brown $(10 R$ $3 / 4)$ near top, weathers light greenish gray $(5 G 8 / 1)$; firmly cemented, calcareous and argillaceous. Unit contains a few beds of siltstone, sandstone, and limestone pebble conglomerate which extend for only short distances along the outcrop. These beds are grayish red $(10 R 4 / 2)$, very dusky red purple (5RP 2/2), and pale green $(5 G 7 / 2)$. Siltstone and sandstone are highly micaceous, current ripple laminated, and shaly to slabby splitting. These beds are distributed irregularly throughout unit and have no consistent strike or dip; the dips ranging from horizontal to vertical. Entire unit weathers to form steep frothy slope containing small ledges

5. Siltstone and sandstone interbedded, pale reddish brown $(10 R 5 / 4)$ and very pale green $(10 G 8 / 2)$, weathering pale reddish brown (10R 5/4). Sandstone, very fine grained; composed of clear quartz and common mica flakes; abundant limonite spots. Unit is firmly cemented, calcareous. Bedding is mostly concealed, but ledges contain current ripple laminae. Rock is shaly to blocky splitting. Unit weathers to form steep rubbly slope

4. Claystone and siltstone, light bluish gray $(5 B \quad 7 / 1)$ and medium bluish gray $(5 B 5 / 1)$, bottom $5 \mathrm{ft}$ is pale
Feet

Chinle Formation-Continued

Monitor Butte Member-Continued

yellowish orange $(10 Y R 8 / 6)$, weathers light bluish gray ( $5 B 7 / 1)$; common mica flakes; firmly cemented, calcareous and argillaceous. Unit is lenticular. Bedding in claystone is concealed. Siltstone forms lenticular beds as much as $4 \mathrm{ft}$ thick scattered throughout the unit. Siltstone is current ripple laminated. Beds of siltstone commonly dip at gentle angles to regional dip. Siltstone is shaly to blocky splitting. Entire unit weathers to a steep frothy and rubbly slope. The sandstone of the Shinarump Member develops laterally within the stratigraphic position of this unit.....

Total of Monitor Butte Member...... Mottled strata:

3. Siltstone, grayish red $(10 R 4 / 2)$, weathering same color; abundant finegrained accessory white mica; firmly to well cemented, slightly calcareous in places; composed of very thin to thin sets of ripple laminated sandy siltstone separating very thin to thin horizontal beds of siltstone; weathers to form small ledge. Unit is very similar to siltstone in Moenkopi Formation

2. Siltstone, pale red purple (5RP 6/2), grayish red purple $(5 R P 4 / 2)$, dark yellowish orange $(10 Y R 6 / 6)$, and light greenish gray ( $5 G Y 8 / 1)$, colors mottled, weathering same colors, contains about 5 percent very fine to coarse sand grains; well indurated, noncalcareous; structureless; weathers to form steep slope or vertical cliff

Total of mottled strata

Total of Chinle Formation

Moenkopi Formation:

1. Siltstone, grayish red $(10 R 4 / 2)$ and pale reddish brown $(10 R 5 / 4)$, weathering pale reddish brown $(10 R 5 / 4)$; firmly cemented, calcareous; horizontally laminated to thin bedded, minor ripple-laminated parts; shaly to flaggy splitting; weathers to form steep slope containing thin ledges ........Unmeasured

Base of section; not base of exposure.

\section{U-11. MULEY TWIST}

Measured on prominent point 1.1 miles south of where Muley Twist road enters Muley Twist Wash, long $111^{\circ} 1^{\prime} 30^{\prime \prime} W$., lat $37^{\circ} 49^{\prime} 11^{\prime \prime} N$., Garfield County

[Measured by J. H. Stewart and G. A. Williams, August 1952]

Top of section; not top of exposure. Vertical cliff of Wingate Sandstone.
Feet

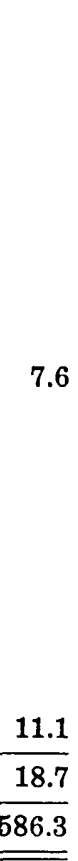


Wingate Sandstone (incomplete) :

12. Sandstone, grayish orange $(10 Y R 7 / 4)$, weathering pale reddish brown $(10 R$ $5 / 4)$, fine grained, well sorted; composed of subrounded clear quartz with sparse black and orange accessory minerals; firmly cemented, calcareous; very thick bedded, with largescale planar and trough sets of crossbedding; massive splitting; forms vertical cliff. Basal contact contains abundant coarse well-rounded sand grains Unmeasured

11. Siltstone. Upper half grayish red ( $5 R$ $4 / 2$ ), weathering same color; contains abundant pebbles of limestone, a few granules of chert, and common scattered fine to medium well-rounded quartz grains; firmly cemented, calcareous; thinly bedded. Lower half predominantly pale greenish yellow $(10 Y 8 / 2)$, minor amounts of grayish red ( $5 R 4 / 2)$, weathering same colors; very thick bedded. Entire unit is massive splitting; forms vertical cliff at base of Wingate. Presence of scattered fine to medium grains, similar to those in overlying unit, indicates that this unit is basal bed of Wingate Sandstone. Unit indicates reworking of underlying units and possibly an unconformable or disconformable contact with the underlying Chinle Formation

Total of incomplete Wingate

Sandstone

Chinle Formation:

Owl Rock Member:

10. Siltstone, pale reddish brown $(10 R 5 / 4)$, weathering same color; firmly cemented, argillaceous, somewhat calcareous; bedding concealed; weathers to frothy and rubbly steep slope. Sandstone occurs from 61.2 to $63.1 \mathrm{ft}$ above base of unit. It is reddish brown and fine grained (common rounded coarse grains of clear quartz) and locally forms a ledge

9. Sandstone, predominantly pale reddish brown $(10 R 5 / 4)$, minor amounts of bluish white $(5 B 9 / 1)$, weathers to moderate red (5R 5/4), medium grained, fair sorted; composed of subrounded clear quartz grains and abundant green and black accessory minerals; firmly cemented, highly calcareous. Unit is tabular and contains small-scale planar sets of cross-laminae. Unit is shaly splitting and weathers to form a steep slope containing small ledges. Green color commonly confined to individual laminae

8. Siltstone, and limestone to limey silt-
Feet Chinle Formation-Continued

Owl Rock Member-Continued

stone. Siltstone, pale reddish brown $(10 R 5 / 4)$ and pale green (5G 7/2), weathering pale reddish brown $(10 R$ $5 / 4)$ and light greenish gray (5GY $8 / 1$ ) ; firmly cemented, calcareous; horizontally bedded. Limestone to limy siltstone, pale red $(10 R 6 / 2)$ and light greenish gray $(5 G Y 8 / 1)$, weathering same colors, dense; well cemented; present as thin to thick horizontal beds interstratified with the siltstone. Limestone beds probably are siliceous in some places. Limestone and limy siltstone locally contain granules and pebbles of limestone. Unit as whole weathers to form steep slope; small ledges form on the limestone and limy siltstone. Limeston 2 and limy siltstone are present from 5.0 to $7.3,31.7$ to $35.7,63.8$ to $66.3,76.9$ to $79.9,87.6$ to $90.6,95.9$ to $96.9 \mathrm{ft}$ above base of unit. Base of unit is sharp and marks color change from brown below to red and green above

113.0

7. Siltstone, light brown $(5 Y R 5 / 6)$ and pale reddish brown $(10 R 5 / 4)$, weathering pale red $(10 R 6 / 2)$ and moderate reddish orange $(10 R 6 / 6)$; firmly cemented, calcareous and argillaceous; horizontally very thick bedded; weathers to steep frothy and rubbly slope. Basal $10 \mathrm{ft}$ of unit contains some swelling clay. No definitely swelling clay could be noticed in rest of unit. Contact between part containing swelling clay and part not containing swelling clay is gradational and obscure. Several beds of yellowish-gray thinly bedded siltstone less than 8 in. thick occur in unit ......

Total of Owl Rock Member

Contact between Owl Rock and Petrified Forest Members placed at change from strata below in which swelling clays are prominent to strata above in which swelling clays are absent or rare. The basal $10 \mathrm{ft}$ of unit 7 may belong in the Petrified Forest Member.

Petrified Forest Member:

6. Sandstone, very pale green $(10 G 8 / 2)$, bluish white $(5 B 9 / 1)$, pale reddish brown $(10 R 5 / 4)$, and moderate yellowish brown $(10 Y R 5 / 4)$, weathering pale yellowish orange $(10 R 8 / 6)$, pale reddish brown $(10 Y R 5 / 4)$, light greenish gray $(5 G Y 8 / 1)$, and moderate brown (5YR 4/4), medium grained to very coarse grained, sparse granules and pebbles of sandstone and limy siltstone, poorly sorted; composed of subangular clear quartz and

Feet

$\begin{array}{r}81.6 \\ \hline 327.2 \\ \hline\end{array}$ 
Chinle Formation-Continued

Petrified Forest Member-Continued common green and orange accessory minerals; poorly cemented, calcareous; medium-scale trough and planar sets of cross-strata, ripple laminated in part; flaggy to slabby splitting; weathers to form the most prominent cliff in the Chinle. Unit may correlate with the so-called Capitol Reef bed....

5. Claystone to siltstone, bottom half dark yellowish orange $(10 Y R 6 / 6)$, top half light brown (5YR 6/4), weathering pale yellowish orange $(10 Y R$ $8 / 6)$ and light brown (5YR 6/4); firmly cemented, calcareous and argillaceous; stratification poorly exposed, but parallel bedded where exposed; weathers to form steep frothy slope. Top half of unit mostly siltstone ......

4. Silty claystone to clayey siltstone, pale red $(5 R 6 / 2)$ and grayish red $(5 R$ $4 / 2$ ), weathering same colors; firmly cemented, argillaceous, slightly calcareous; unit is tabular, bedding generally concealed, but where visible is cross stratified; weathers to steep rubbly slope. Contains a 5-ft-thick pale-red fine-grained clayey sandstone about $40 \mathrm{ft}$ below top. Above this sandstone, unit is mostly siltstone. Four-inch siltstone bed occurs $3 \mathrm{ft}$ above base of unit. Siltstone is pale olive $(10 Y 6 / 2)$, weathers pale reddish brown $(10 R 5 / 4)$, is very thinly laminated, and is shaly splitting. Unit contains some pale greenish yellow $(10 Y 8 / 2)$, very fine grained, highly calcareous sandstone nodules as large as 3 in. in diameter. Unit contains some pale-greenish-yellow $(10 Y 8 / 2)$ bleached spots as large as $1 / 2$ in. in diameter

Total of Petrified Forest Member....

Monitor Butte Member:

3. Silty claystone to siltstone, variegated, predominant pale olive $(10 Y 6 / 2)$, minor grayish red $(5 R 4 / 2)$ and light gray $(N 7)$, moderate yellowish brown $(10 Y R 5 / 4)$ at base of unit, weathering same colors; contains high percentage of swelling clays; parallel bedding; forms hard, crusty slope. Conglomeratic sandstone is present from 85.2 to $86.7 \mathrm{ft}$. Conglomeratic sandstone, dark yellowish orange (10YR 6/6), weathering same color, very coarse grained, poorly sorted; contains subrounded granules, pebbles and cobbles of limestone; forms lens exposed for about $100 \mathrm{ft}$ along outcrop. Entire unit weathers to form rubbly slope containing small ledge.
Feet

Chinle Formation-Continued

Monitor Butte Member-Continued

Lower $20 \mathrm{ft}$ of unit contains calcite

(satin spar) dikes

Total of Monitor Butte Member ....

Mottled strata:

2. Siltstone, pale purple $(5 P 6 / 2)$, yellowish gray $(5 Y 7 / 2)$, and medium dark gray $(N 4)$, weathers medium light gray ( $N 6)$; abundant mica with iron minerals, uncommon orange accessory minerals; firmly cemented, argillaceous, iron cement; bedding obscured; forms steep slope with prominent ledge in middle; ledge pinches out within $100 \mathrm{yd}$ to each side of section. Hematite (?) nodules abundant in upper third of unit

Total of mottled strata.

Total of Chinle Formation

Feet

107.1

107.1

$\underline{\overline{107.1}}$

Moenkopi Formation (incomplete) :

1. Siltstone, predominantly dark reddish brown $(10 R 3 / 4)$ minor amounts of grayish yellow $(5 Y$ 8/4) and pale brown $(5 Y R 5 / 2)$, weathering dark reddish brown (10R $3 / 4)$; abundant mica; firmly cemented, probably siliceous and argillaceous; very thin bedded to laminated; some ripplelaminated parts; some current ripples with wavelength of $1 \mathrm{in}$. and amplitude of $3 / 10$ in.; flaggy and shaly splitting; unit forms steep slope with prominent ledges at 0 to $3.5 \mathrm{ft}$ and at 35.0 to $38.0 \mathrm{ft}$. The Moenkopi is sandier near the top

Total of incomplete Moenkopi

Formation

Base of section; not base of exposure.
132.6

220.3

\section{U-13. RANGE CANYON}

Measured from near head of the north fork of Range Canyon to northernmost extremity of the promontory about $3 / 4$ mile east of where middle trail crosses the Wingate Sandstone, long $110^{\circ} 06^{\prime} 15^{\prime \prime} W$., lat $38^{\circ} 07^{\prime} 35^{\prime \prime}$ N., Garfield County

[Measured by J. H. Stewart and O. B. Raup, October 1953]

Top of section; top of accessible exposure. Top of section on most northern local point. Top of section is S. $4^{\circ} \mathrm{E}$. of Bagpipe Butte and N. $64^{\circ} \mathrm{E}$. of where middle trail crosses Wingate Sandstone. Wingate Sandstone:

24. Sandstone, light brown ( $5 Y R 6 / 4)$, weathering same color, very fine grained, well sorted; composed of subrounded amber-stained quartz and common black accessory mineral, sparse fine-grained accessory white mica; poorly cemented, calcareous; composed of horizontal laminae, ripple laminae, and very thin to thick planar and trough sets of small- to medium-scale cross-laminae; massive 
Wingate Sandstone-Continued splitting, weathers to form vertical cliff. Sandstone contains common subrounded amber medium to coarse sand grains. Only basal $10 \mathrm{ft}$ of unit exChinle Formation: amined ............................................. Unmeasured

Church Rock Member:

Hite Bed:

23. Sandy siltstone, pale reddish brown $(10 R 5 / 4)$, weathering same, sandy (very fine grained), firmly cemented, noncalcareous; ripple laminated, weathers to form reentrant below Wingate Sandstone

22. Sandstone, pale red $(5 R 6 / 2)$, minor amounts of pale reddish brown $(10 R$ $5 / 4)$ and light greenish gray (5GY $8 / 1)$, weathering pale reddish brown $(10 R 5 / 4)$, very fine grained, well sorted; composed of subrounded grains, composition not determinable; firmly cemented, slightly calcareous; horizontally and ripple laminated to thinly laminated; weathers to form vertical cliff. Unit contains abundant medium- to coarse-grained white and dark mica

Total of Hite Bed

21. Sandy siltstone, similar to unit 19 . Weathers to form steep slope with several prominent ledges in upper half

20. Sandy siltstone, pale red (5R 6/2), weathering same color, sandy (very fine grained); well cemented, calcareous; structureless; weathers to form ledge. Unit contains pale-reddishbrown $(10 R 5 / 4)$ tabular structures that might possibly be worm borings. Many vertically columnar or tabular masses that project into underlying unit and that may possibly be mudcrack fillings occur at base of unit....

19. Sandy siltstone, pale reddish brown $(10 R 5 / 4)$, minor amounts of light brown $(5 Y R 6 / 4)$, weathering pale reddish brown $(10 R \quad 5 / 4)$, sandy (very fine grained); firmly cemented, slightly calcareous; mostly structureless but contains sparse horizontal stratification planes; weathers to form steep slope; contains one thin lightgreenish-gray ( $5 G Y 8 / 1)$ color band about $8 \mathrm{ft}$ below top of unit..

18. Siltstone, grayish red $(5 R 4 / 2)$ and minor amounts of pale reddish brown $(10 R 5 / 4)$ and grayish red $(10 R$ $4 / 2)$, weathering pale reddish brown $(10 R 5 / 4)$ and pale red $(5 R 6 / 2)$; firmly cemented, highly calcareous; weathers to form steep slope. This
Feet

Chinle Formation-Continued

Church Rock Member-Continued

unit is differentiated from the overlying unit only by a color difference. Underlying unit contains dominantly grayish-red siltstone that weathers pale red, whereas overlying unit contains dominantly pale-reddish-brown and light-brown siltstone that weathers pale reddish brown

Total of Church Rock Member.

235.0

Owl Rock Member:

17. Siltstone, light gray $(N 7)$ in lower half grading upward to pale red purple $(5 R P 6 / 2)$ in upper half, weathering light greenish gray $(5 G Y 8 / 1)$ and pale red purple $(5 R P 6 / 2)$ in upper half; firmly cemented, calcareous; structureless; weathers to form steep slope. Laterally to line of section, top of unit contains light-greenish-gray-weathering siltstone

16. Limestone-grain sandstone, light greenish gray ( $5 G Y 8 / 1)$ and pale red $(10 R 6 / 2)$, weathering light greenish gray ( $\left.5 G Y^{\prime} 8 / 1\right)$, coarse grained, fair sorted; composed of about 60 percent round limestone grains in dense lime matrix; well cemented; stratification poorly exposed but in some parts thinly bedded; weathers to form small ledge. Unit contains sparse limestone pebbles. Unit poorly exposed

15. Siltstone to silty claystone, pale red $(5 R 6 / 2)$ and minor amounts of light greenish gray $(5 G Y 8 / 1)$ and light gray $(N 7)$, weathering same colors; firmly cemented, highly calcareous; structureless; weathers to form steep slope

14. Conglomeratic sandstone, light greenish gray $(5 G Y 8 / 1)$, weathering same color, medium to coarse grained, fair sorted; composed of rounded limestone clasts in dense lime or green-clay matrix; well cemented; composed of very thin horizontal beds, possibly one small-scale cross-laminated set, common ripple laminae(?). Unit weathers to form ledge. Conglomeratic sandstone contains granules and cobbles as large as 5 in. in diameter of lightgreenish-gray $(5 G Y$ 8/1) limestone and, to a lesser extent, silicified limestone (?). Unit thickens to the east to about $5 \mathrm{ft}$ and appears to lense out to the west along the local exposure. One fossil tree $\log 6$ in. in diameter found in unit

13. Siltstone, pale red purple (5RP 6/2) and grayish red (5R $4 / 2$ and $10 R$ $4 / 2$ ), weathering same colors; firmly
56.9

Feet

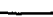


Chinle Formation-Continued

Owl Rock Member-Continued

cemented, highly calcareous; structureless; weathers to form steep slope

12. Limestone, light greenish gray $(5 G$ $8 / 1$ ), weathering same color, dense; well cemented; some possible horizontal laminae; weathers to form small ledge. To east of line of section unit appears to thicken to $3 \mathrm{ft}$

11. Siltstone, grayish red $(10 R 4 / 2)$ in lower $13.7 \mathrm{ft}$ and grayish red $(5 R$ $4 / 2$ ) in rest of unit, weathering pale reddish brown $(10 R 5 / 4)$ in lower half and pale red $(5 R 6 / 2)$ in upper half; firmly cemented, highly calcareous; structureless; weathers to form steep slope. Lower $5 \mathrm{ft}$ of unit is silty claystone; upper $12.3 \mathrm{ft}$ contains abundant poorly defined lenses of pale-red $(5 R 6 / 2)$ limy siltstone ........

10. Sandstone, light greenish gray ( $5 G Y$ $8 / 1)$ and grayish red (5R 4/2), weathering grayish orange pink (5YR 7/2), fine to medium grained, fair sorted; composed of subangular milky mineral and about 10 percent orange and green minerals, abundant very coarse to coarse accessory white mica ; poorly cemented, calcareous; composed of thin planar sets of small-scale crosslaminae; weathers to form ledge. Unit lithologically similar to sandstone units in the Petrified Forest Member

9. Siltstone and limestone. Siltstone, grayish red $(5 R 4 / 2)$ and minor amounts of greenish gray ( $5 G Y 6 / 1)$, weathering grayish red purple (5RP 4/2) with thick light-greenish-gray ( $5 G Y$ $8 / 1$ ) band at base; firmly cemented, highly calcareous; structureless. Limestone, light greenish gray $(5 G 8 / 1)$, weathering same color, dense; well cemented; structureless. Limestone is present as poorly defined tabular bed from 5.6 to $8.2 \mathrm{ft}$ above base of unit. Limestone nodules are common in the siltstone. Unit as whole weathers to form slope

Total of Owl Rock Member

Petrified Forest Member:

8. Sandstone (60 percent) and silty claystone (40 percent). Sandstone, grayish red $(10 R 4 / 2)$ and pale red purple $(5 R P 6 / 2)$, weathering same colors, very fine to medium grained, fair sorted; composed of subangular milky mineral, 15 percent dark-green mineral (probably biotite) and about 5 percent green mineral; firmly cemented, highly calcareous; stratification mostly concealed but contains some medium-scale cross-laminae.

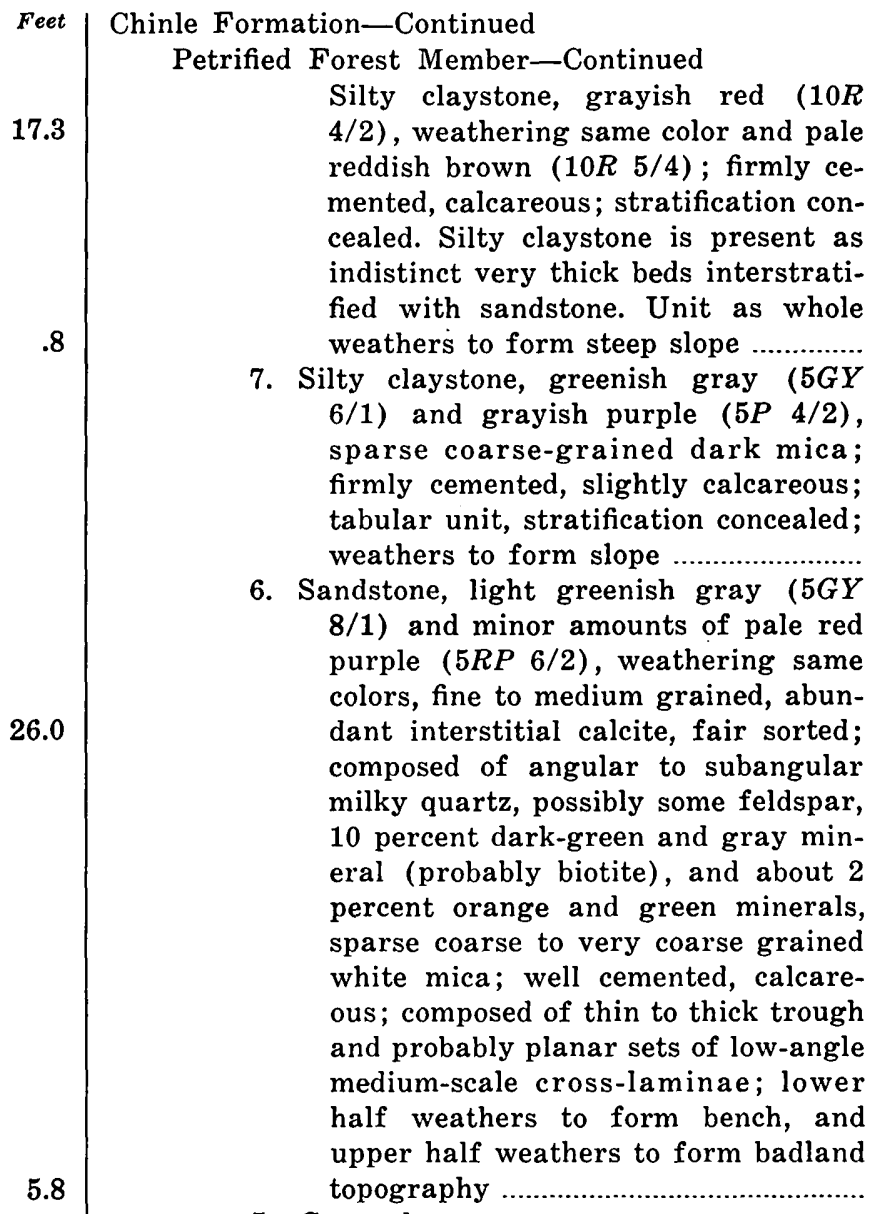

5. Covered

Total of Petrified Forest Member

Moss Back Member:

4. Sandstone (90 percent) and conglomeratic sandstone (10 percent). Sandstone, yellowish gray $(5 Y 8 / 1)$ and very pale orange $(10 Y R 8 / 2)$, weathering same colors, fine to medium grained, well sorted; composed of subangular to subround clear quartz and uncommon gray accessory mineral; poorly cemented, calcareous; composed of thin to thick trough and planar sets of small- to medium-scale and sparse large-scale cross-laminae. Conglomeratic sandstone, same as sandstone except contains rounded granules to pebbles of quartzite and to a lesser extent of chert. Conglomeratic sandstone is commonly medium to coarse grained and contains abundant interstitial silt. All gradations present from sandstone containing a few disseminated granules to conglomeratic sandstone containing from 30 to 40 percent pebbles. Conglomerate is present as thin lenses interstratified with rest of unit and is generally present at base or in basal
Feet

40.4 
Chinle Formation-Continued

Moss Back Member-Continued

$10 \mathrm{ft}$ of unit. Unit as whole weathers to form vertical cliff, contains sparse petrified logs as large as $1 \mathrm{ft}$ in diameter

Total of Moss Back Member

Monitor Butte Member:

3. Claystone to clayey sandstone, greenish gray $(5 G Y 6 / 1)$ and medium light gray $(N 6)$. Sandstone, fine grained, clayey, fair sorted; composition masked, uncommon coarse-grained accessory white mica. Silty claystone to clayey sandstone, poorly cemented, noncalcareous; stratification and splitting concealed; weathers to form slope; unit poorly exposed

Total of Monitor Butte Member ....

Total of Chinle Formation

Moenkopi Formation (incomplete) :

2. Siltstone, grayish red $(10 R 4 / 2)$, grayish purple (5P 4/2), and light greenish gray (5GY 8/1), grayish purple increases upward and is dominant in the upper part of unit, weathering same colors; otherwise same as underlying unit; unit poorly exposed. Possibly some of this unit is part of the Chinle Formation

1. Siltstone, grayish red $(10 R 4 / 2)$, weathering same color, commonly clayey; abundant fine to very fine grained accessory white mica; stratification concealed; weathers to form steep slope; unit is poorly exposed ........Unmeasured

Total of incomplete Moenkopi

Formation

Base of section; not base of exposure.

\section{U-14. SILVER FALLS CREEK}

Measured at southwest side of the farthest outlying mesa between Dry Fork and South Fork of Silver Falls Creek, long $111^{\circ} 08^{\prime} 00^{\prime \prime} W$., lat $37^{\circ} 43^{\prime} 20^{\prime \prime} N$., Garfield County

[Measured by L. C. Craig, G. A. Williams, H. F. Albee, and J. H. Stewart,

Top of section; top of accessible outcrop; N. $85^{\circ} \mathrm{W}$. of the southwest end of airstrip.

Wingate Sandstone (incomplete) :

14. Sandstone, moderate reddish orange $(10 R 6 / 6)$, weathering moderate reddish orange $(10 R 6 / 6)$ to moderate reddish brown $(10 R 4 / 6)$, very fine grained to fine grained; subangular to angular grains, some scattered coarse rounded to well-rounded grains; composed of amber-stained clear quartz with uncommon black and sparse orange accessory grains; firmly cemented, slightly calcareous; composed of large-scale trough to
Feet Wingate Sandstone (incomplete)-Continued Feet planar sets of cross-laminae; blocky weathering; forms vertical cliff....Unmeasured

13. Conglomeratic sandstone, grayish red $(10 R 4 / 2)$ to pale greenish yellow $(10 Y 8 / 2)$, weathering pale reddish brown $(10 R 5 / 2)$, very coarse grained to fine grained, poorly sorted; abundant well-rounded white mineral, black and yellow accessory minerals, sparse clear quartz; well cemented, argillaceous, very weakly calcareous; structureless to faintly parallel bedded with small cross-laminated lenses; slabby weathering. Contains granules to pebbles as large as $1 \mathrm{in}$. in diameter consisting predominantly of gray and angular chert. Basal contact bevels the Owl Rock Member disconformably and cuts out as much as $5 \mathrm{ft}$ of beds in $15 \mathrm{ft}$ along contact

Total of incomplete Wingate Sandstone

Chinle Formation:

Owl Rock Member:

12. Similar to unit below, but weathers locally to vertical slopes with hoodoo shapes. Unit is tabular with mediumscale trough sets of cross-laminae, subparallel laminae, and ripple laminae. Common light-greenish-gray circular spots appear to have black carbonaceous center

11. Siltstone, pale red $(10 R 6 / 2)$; firmly cemented, highly calcareous; hackly weathering, forms steep rubbly slope broken by two ledges; one at base of upper third of unit is $1.5 \mathrm{ft}$ thick, and one at top of unit is $3.5 \mathrm{ft}$ thick. Ledges are conglomeratic sandstone, pale red $(10 R 6 / 2)$ mottled a light greenish gray ( $5 G Y 8 / 1)$, weathering light brown (5YR 6/4); composed of reddish and greenish calcareous siltstone pebbles as large as 1 in. in diameter and minor amounts of clear quartz, pinkish to white chert granules, and sparse interstitial clear quartz. Unit is tabular, parallel to subparallel bedded, slightly calcareous

10. Alternating limestone and siltstone. Limestone, moderate orange pink $(10 R 7 / 4)$, very light gray $(N 8)$, weathers pale red $(5 R 6 / 2)$ with very light gray $(N 8)$ mottling, very finely crystalline; black to red silica-filled stringers; thick bedded to very thick bedded; hackly splitting; weathers to form ledges. Siltstone, pale red (10R $6 / 2)$, light olive gray $(5 Y 6 / 1)$, to very light gray ( $N 8)$, weathering pale red $(10 R 6 / 2)$, well sorted; com- 
Chinle Formation-Continued

Owl Rock Member-Continued

posed of white mineral and sparse clear quartz; firmly cemented, calcareous; parallel laminated; platy to papery and in part hackly splitting; weathers into steep slope. From bottom, unit consists of $12.1 \mathrm{ft}$ siltstone, $2.8 \mathrm{ft}$ limestone, $15.9 \mathrm{ft}$ siltstone, $\mathbf{5 . 0}$ $\mathrm{ft}$ limestone, $12.6 \mathrm{ft}$ siltstone, $6.0 \mathrm{ft}$ limestone, $7.9 \mathrm{ft}$ siltstone, $5.3 \mathrm{ft}$ limestone, $4.5 \mathrm{ft}$ siltstone, and $5.9 \mathrm{ft}$ limestone

9. Siltstone, pale reddish brown $(10 R 5 / 4)$ and minor pale red, weathering same colors; no swelling clays; firmly cemented, calcareous; structureless; weathers to form steep loose slope. Basal contact appears gradational....

Total of Owl Rock Member

Petrified Forest Member:

8. Clayey siltstone, pale reddish brown (10R 5/4), weathering same color; swelling clays; firmly indurated, noncalcareous; structureless; weathers to form frothy-surfaced slope. A thin interval at the top of the unit contains light-greenish-gray limestone (?) nodules

7. Sandstone and siltstone, pale red $(10 R$ $6 / 2)$, pale brown $(5 Y R 5 / 2)$, pale reddish brown $(10 R 5 / 4)$, very dusky red purple $(5 R P 5 / 2)$, and very light gray $(N 8)$ (grays are coarser sandstone), weathering moderate reddish orange $(10 R 6 / 6)$, silt to medium sand, well sorted; composed of rounded clear quartz grains and common pink and black accessory minerals; firmly to poorly cemented, calcareous; sandstone is tabular with lenticular sand lenses of mediumscale trough sets of crossbeds; most of the crossbeds are alternately light gray and very dusky red purple. Unit has hackly fracture. Unit weathers to form a steep slope

6. Claystone, pale reddish brown $(10 R$ $5 / 4)$ to light brown $(5 Y R 5 / 4)$ to pale red $(10 R 6 / 2)$ with a middle unit of mottled light greenish gray (5GY $8 / 1)$ and moderate yellowish brown (10YR 5/4), highly silty to sandy (very fine grained); hackly fracture, weathers with a frothy surface. Entire unit poorly exposed, covered by talus of Wingate Sandstone

5. Claystone, pale red purple (5RP 6/2) to grayish red purple $(5 R P 4 / 2)$ in bottom $1 / 3$, pale reddish brown $(10 R$ $5 / 4)$ in middle $1 / 3$, and pale red $(5 R$ $6 / 2$ ) in top $1 / 3$, slightly silty bottom $1 / 3$ and top $1 / 3$, highly silty middle $1 / 3$;
Feet Chinle Formation-Continued

Petrified Forest Member-Continued

hackly fracture; weathers to a frothysurfaced slope. At top is 6-in. layer of sandstone. Sandstone, white $(N$ 9 ), fine to medium grained, poorly sorted; composed of clear quartz with abundant red, green, and black accessory minerals and uncommon biotite flakes; composed of small-scale trough sets of cross-laminae. Sandstone forms indistinct capping ledge above steep badland slope developed in claystone. Unit forms prominent bright-colored band above gray Monitor Butte Member below. Abundant limestone nodules from granule to boulder sized in lower half of unit

Monitor Butte Member:

4. Alternating sandstone and siltstone. Sandstone, light brown (5YR 6/1) to grayish yellow ( $5 Y 8 / 4)$, weathering light brownish gray (5YR 6/1), fine grained to very fine grained, fair sorted; composed of clear quartz, common black minerals, sparse to common biotite flakes, some interstitial limonite(?); firmly cemented, calcareous. Sandstone layers lenticular and composed of thin to very thin sets of ripple laminae and cross-laminae. Siltstone, light olive gray ( $5 Y$ $6 / 1)$, weathering light gray $(N 7)$; poorly cemented, calcareous; very thin to thinly laminated; irregular splitting; weathers to gentle slope. At base of unit is a thin lenticular conglomerate containing pebbles, as large as $3 / 8$ in. in diameter, predominantly of limestone. Sandstone lenses occur at $7.3 \mathrm{ft}, 21.2 \mathrm{ft}, 27.5 \mathrm{ft}, 31.8 \mathrm{ft}$; between $33.8 \mathrm{ft}$ and $37.1 \mathrm{ft}$ sandstone lenses predominant. Each sandstone lens has a different dip and strike, probably owing to penecontemporaneous slumping

3. Silty claystone, pale green $(10 G 6 / 2)$ to medium light gray $(N 6)$, weathering light gray $(N 7)$, well sorted; composition masked; poorly cemented, calcareous; shaly; weathers to a steep slope. Unit contains swelling clay and rounded limonite concretions as large as 4 in. in diameter. Unit contains several prominent, steeply dipping sandstone beds in lower $20 \mathrm{ft}$

Total of Monitor Butte Member......

Shinarump Member:

2. Sandstone, grayish yellow $(5 Y 8 / 4)$ to moderate yellow $(5 Y 7 / 6)$, weathering brownish black (5YR 2/1), 
Chinle Formation-Continued

Shinarump Member-Continued

predominantly coarse grained with subordinate scattered very coarse grains, poorly sorted; composed of subangular clear quartz and sparse black grains; brown-stained interstitial clay; clay binding, slightly calcareous; composed of medium-scale trough sets of cross-laminae; slabby to platy splitting, forms thin capping ledge that thickens to $40 \mathrm{ft} 1 / 4$ mile to northeast and pinches out $25 \mathrm{ft}$ to southwest

Total of Shinarump Member

Total of Chinle Formation

Contact of Shinarump and Moenkopi is sharp. Shinarump fills small scours cut into Moenkopi Formation.

Moenkopi Formation:

1. Siltstone, reddish brown, ripple laminated and structureless. About $50 \mathrm{ft}$ of cliff-forming member is present at top of Moenkopi. Top $5 \mathrm{ft}$ of Moenkopi is yellowish gray Unmeasured

Base of section; base of outcrop.

\section{U-15. SOUTH BLOCK}

Measured up east side of outcrop that has outlier of Wingate Sandstone on top. Outlier lies just south of most southerly outcrop of Wingate Sandstone on South Block. Top of section about $500 \mathrm{ft}$ south of the northern extremity of the outlier of Wingate Sandstone. Long $110^{\circ} 16^{\prime} 25^{\prime \prime} W$., lat $37^{\circ} 58^{\prime} 21^{\prime \prime}$ N., Garfield County

[Measured by J. H. Stewart and D. A. McManus, June 1954]

Top of section; top of accessible exposure.

Wingate Sandstone:

21. Sandstone, light brown $(5 Y R 6 / 4)$ and very pale orange $(10 Y R 8 / 2)$, weathering light brown $(5 Y R 6 / 4)$, very fine grained, fair sorted; composed of rounded clear quartz and sparse black accessory minerals; poorly cemented, very slightly calcareous; composed of thin to very thick trough sets of lowangle cross-laminae; massive splitting; weathers to form vertical cliff. Unit contains about 5 percent scattered medium to coarse well-rounded, frosted grains. Basal $0.5 \mathrm{ft}$ of unit contains about 50 percent of these medium to coarse grains. This basal $0.5 \mathrm{ft}$ is composed of indistinct lowangle cross-laminae suggestive of fluvial deposition. Top of this basal 0.5 $\mathrm{ft}$ is a consistent stratigraphic horizon whereas bottom is slightly irregular

Unmeasured

Contact of Chinle Formation and Wingate Sandstone placed at lithologic change from the purplish irregularly cross stratified sandstone of the Chinle to the brownish smoothly cross stratified sandstone
Feet of the Wingate. In addition, the Wingate contains common well-rounded frosted grains. The contact is slightly irregular within a 2 -in. zone.

Chinle Formation:

Church Rock Member:

Hite Bed:

20. Sandstone, pale red $(5 R 6 / 2)$, weathering same color, very fine grained, fair sorted; composition masked; firmly cemented, slightly calcareous; composed of thin to thick trough and minor planar sets of small- to mediumscale low-angle cross-laminae, sparse thick structureless lenses; weathers to form vertical cliff, vertical cliff continuous with that of Wingate Sandstone. Unit contains sparse lenses of micaceous ripple-laminated siltstone

19. Siltstone, dark reddish brown $(10 R$ $3 / 4)$, weathering moderate red $(5 R$ $5 / 4)$; abundant very fine grained white mica; poorly cemented, noncalcareous; stratification concealed; weathers to form steep slope. Commonly unit is sandy (very fine grained), and rarely it grades to silty sandstone. Top $5 \mathrm{ft}$ of unit very poorly exposed

18. Sandstone, pale red $(5 R 6 / 2)$ and light greenish gray ( $5 G Y 8 / 1)$, weathering pale red $(5 R 6 / 2)$, very fine grained, fair sorted; composition masked; well cemented, slightly calcareous; composed of thin to thick trough sets of low-angle medium-scale cross-laminae; weathers to form vertical cliff. Unit is highly variable in lithology along exposure. Locally contains thin to thick lenses of grayish-red ( $5 R$ $4 / 2$ ) siltstone. Unit contains many silicified tree logs as large as 2.0 by $1.1 \mathrm{ft}$

Total of Hite Bed

17. Siltstone, pale reddish brown $(10 R 5 / 4)$ and light brown $(5 Y R 6 / 4)$, weathering same colors, sandy (very fine grained) in places; well cemented, slightly calcareous in places; appears structureless; weathers to steep loose slope

16. Siltstone, pale red $(5 R 6 / 2)$ and pale reddish brown $(10 R 5 / 4)$, weathering same colors; well cemented, calcareous; structureless; weathers to form steep loose slope. Unit contains thin light-greenish-gray $(5 G Y 8 / 1)$ band at base and at a position about $5 \mathrm{ft}$ above base of unit. Unit contains resistant horizontal bed of light-brown (5YR 6/4) and light-greenish-gray (5GY 8/1) siltstone from 31.7 to 33.0 $\mathrm{ft}$ above base of unit. Unit appears to 
Chinle Formation-Continued

Church Rock Member-Continued

be a transition from the pale-red siltstone of Owl Rock Member to palereddish-brown siltstone of the Church Rock Member

Total of Church Rock Member

Owl Rock Member:

15. Siltstone and limestone to limy siltstone. Siltstone, pale red (5R 6/2 and $10 R$ $6 / 2), 1$ percent pinkish gray (5YR $8 / 1)$, pale reddish brown $(10 R 5 / 4)$ from 74 to $90.6 \mathrm{ft}$, otherwise similar to siltstone in unit 11. Limestone to limy siltstone, pale red (10R 6/2) and light greenish gray (5GY 8/1), weathering same colors; well cemented; dense. Limestone is preseni as horizontal bed from 17.6 to $19.0 \mathrm{ft}$ and thin horizontal beds comprising about 20 percent of the interval from 90.6 to $110.7 \mathrm{ft}$ above base of unit. Siltstone commonly contains limestone nodules. Unit weathers to form steep loose slope

Offset in section, so that units 15 and higher were measured about $200 \mathrm{ft}$ south of where unit 14 and underlying units were measured.

14. Limestone (80 percent) and siltstone (20 percent). Limestone, light greenish gray $(5 G Y 8 / 1)$, pinkish gray $(5 Y R 8 / 1)$, and pale red $(10 R 6 / 2)$, weathering pale red $(10 R 6 / 2)$, dense; well cemented. Siltstone, similar to siltstone in unit 11 , very thin to thin poorly defined horizontal beds of siltstone interstratified with thin to thick poorly defined horizontal beds of limestone, all gradation between siltstone and limestone. Limestone in many places contains common to abundant limestone grains. Unit as a whole tabular and weathers to form most conspicuous ledge in the upper part of the Chinle

13. Siltstone, pale red $(5 R \quad 6 / 2$ and $10 R$ $6 / 2$ ) and sparse light greenish gray $(5 G Y 8 / 1)$, otherwise similar to siltstone in unit 11 . Unit contains lightgreenish-gray $(5 G Y \quad 8 / 1)$ limestone from 14.5 to $15.6 \mathrm{ft}$ above base of unit. This limestone consists of about 30 percent medium to very coarse limestone grains in an aphanitic matrix. Top $10 \mathrm{ft}$ of unit contains two very thin limestone beds similar to limestone in unit 11

12. Siltstone, pale red $(10 R 6 / 2)$ (35 percent), light brown (5YR 6/4) (35 percent), and pale reddish brown (10R 5/4) (30 percent), color banded, weathering pale red $(5 R 6 / 2)$ and
Feet

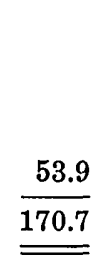

Chinle Formation-Continued

Owl Rock Member-Continued

light brown (5YR 5/6); well cemented, calcareous; stratification concealed; weathers to form steep slope. Unit forms distinctive orange band on cliff

11. Siltstone and limestone. Siltstone, pale red $(10 R 6 / 2)$, weathering same color; well cemented, highly calcareous; stratification concealed. Limestone, pale red $(10 R 6 / 2)$ and light greenish gray ( $5 G Y 8 / 1)$, weathering grayish orange pink (5YR 7/2), dense. Limestone forms thin lenticular bed from 9.3 to $10.1 \mathrm{ft}$ above base of bed. Unit as whole weathers to form slope containing small ledge on the limestone bed. Siltstone commonly contains abundant limestone nodules

Total of Owl Rock Member

Petrified Forest Member:
121.1

8.3

40.8
10. Sandy siltstone, pale reddish brown (10R 5/4), weathering same color; abundant medium-grained accessory dark mica; well cemented, noncalcareous; stratification concealed; weathers to form steep slope ...

9. Sandstone, pale red $(5 R 6 / 2)$, weathering grayish red $(5 R 4 / 2)$, fine grained, fair sorted; composition masked, common coarse-grained accessory dark mica; well cemented, calcareous; stratification concealed; weathers to form ledgy slope....

8. Sandstone, light greenish gray (5GY $8 / 1)$ and pale pink $(5 R P 8 / 2)$, weathering pale pink ( $5 R P 8 / 2)$, fine to medium grained, fair sorted; composed of subangular milky grains and about 5 percent dark-green mica; well cemented, calcareous; stratification poorly exposed but many mediumscale cross-strata noted; weathers to form slope. Forms conspicuous lightcolored band. Basal $0.5 \mathrm{ft}$ forms minor ledge containing about 20 percent light-greenish-gray (5GY 8/1) limestone pebbles and cobbles

Total of Petrified Forest Member..

Stratigraphic equivalent of Moss Back Member:

7. Sandstone (30 percent), conglomerate sandstone (10 percent) and siltstone (60 percent). Sandstone, pale red $(5 R 6 / 2)$, otherwise similar to sandstone in underlying unit. Conglomeratic sandstone, similar to sandstone except contains about 20 percent siltstone pebbles. Siltstone, grayish red $(10 R 4 / 2)$, weathering pale reddish brown $(10 R 5 / 4)$; common fine-
Feet 
Chinle Formation-Continued

Stratigraphic equivalent of Moss Back Member-Continued

grained white mica; poorly cemented, noncalcareous; stratification concealed. Sandstone and conglomeratic sandstone mostly found in basal third of unit and intertonguing with siltstone. Siltstone occupies most of upper two-thirds of unit. Unit as whole is tabular and weathers to form ledge in lower third and slope in upper twothirds. Units 6 and 7 weather to form the most conspicuous cliff in the Chinle Formation. This cliff forms a red band on the exposure

6. Sandstone, pale red $(5 R 6 / 2)$ and common dusky yellow (5Y 6/4) and light gray $(N 7)$ in basal half, weathering same colors, fine grained, fair sorted; composed of subangular milky grains and abundant green accessory minerals, common dark and white accessory mica; well cemented, slightly calcareous; composed of thin trough sets of small- to medium-scale crosslaminae, subordinate horizontal laminae; weathers to form steep slope or vertical cliff

5. Sandstone (50 percent) and conglomeratic sandstone ( 50 percent). Sandstone, pale red purple (5RP 6/2) and light greenish gray (5GY 8/1), weathering light greenish gray ( $5 G Y$ $8 / 1$ ), fine grained, fair sorted; composed of subangular milky grains and about 10 percent orange and green grains, common dark and white mica; well cemented, calcareous; composed of thin planar sets of small-scale cross-laminae. Conglomeratic sandstone, similar to sandstone except contains from 10 to 50 percent granules and pebbles of light-brown siltstone and gray limestone. Unit as a whole tabular and weathers to form persistent light colored ledge

Total of stratigraphic equivalent of Moss Back Member

Monitor Butte Member:

4. Silty claystone, pale reddish brown $(10 R 5 / 4)$ and about 3 percent grayish purple $(5 P 4 / 2)$ and 3 percent light greenish gray $(5 G Y 8 / 1)$, colors banded, weathering same colors; firmly cemented, calcareous; stratification mostly concealed, but unit contains sparse horizontal stratification planes; weathers to form frothy-surfaced slope. Thin layer containing grayish-pink ( $5 R 8 / 2)$ limestone nodules occurs at $68.0 \mathrm{ft}$ above base of unit. Thick layer about $15 \mathrm{ft}$ above
Feet

Chinle Formation-Continued

Monitor Butte Member-Continued

base of unit contains common ripplelaminated siltstone

3. Silty claystone, grayish purple (5P $4 / 2$ ), weathering same color; firmly cemented, noncalcareous; stratification concealed; weathers to form frothy-surfaced slope. Dusky yellow $(5 Y 6 / 4)$ is commonly present in bottom $3 \mathrm{ft}$

Total of Monitor Butte Member.....

Mottled strata:
14.6

17.0
2. Siltstone, grayish red purple (5RP 4/2), abundant light-greenish-gray (5GY $8 / 1$ ) mottling, weathering same colors; well cemented, noncalcareous; structureless (unit as whole forms persistent horizontal bed); fractures into angular fragments; weathers to form small ledge. Unit contains from 0 to 5 percent well-rounded medium grains

Total of mottled strata 8.8

Total of Chinle Formation

Feet

$\underline{105.6}$

Moenkopi Formation:

1. Siltstone, grayish red $(10 R 4 / 2)$, weathering same color; common fine-grained white mica; well cemented, noncalcareous; structureless. Unit is exposed in gully. Top $2 \mathrm{ft}$ contains about 50 percent light-greenish-gray (5GY 8/1) mottles Unmeasured

Base of section; not base of exposure.

\section{U-16. SOUTH DRAW}

Measured about 1/4 mile north of westernmost part of South Draw Point. Line of section S. $25^{\circ} \mathrm{E}$. Near middle of east side of section 7, T. 31 S., R. 7 E., SLM, Garfield County

[Measured by J. H. Stewart and H. F. Albee, October 1952]

Top of section; not top of exposure. Section ends about middle of place where the Wingate Sandstone is eroded away and only a few remnants are left; these forming a break in the line of cliffs. Wingate Sandstone:

22. Sandstone, yellowish gray (5Y 8/1), weathering light brown ( $5 Y R 6 / 4)$, fine grained, well sorted; composed of round clear quartz and common to abundant black accessory minerals; firmly cemented, noncalcareous; composed of thick to very thick medium- to large-scale planar sets of cross-laminae. Lower $5 \mathrm{ft}$ of unit composed of horizontal thin beds and common thin medium-scale trough sets of low-angle cross-laminae. Unit is massive splitting and weathers to rounded surfaces and pinnacles along line of section and vertical cliff away from section. Bottom $5 \mathrm{ft}$ contains common to abundant medium grains 
Wingate Sandstone-Continued scattered in the sandstone and concentrated along bedding planes. Contact Chinle Formation: with Chinle Formation covered....Unmeasured Owl Rock Member:

21. Siltstone and sandstone, grayish red $(10 R 4 / 2$ and $5 R 4 / 2)$ and pale red $(10 R 6 / 2)$, weathering pale red $(5 R$ $6 / 2$ ). Siltstone, sandy (very fine grained); poorly cemented, argillaceous; stratification and splitting concealed. Siltstone occurs in lower $3 \mathrm{ft}$ of unit along line of section but is not present $50 \mathrm{ft}$ to south, where entire unit is sandstone. Sandstone, fine to very fine grained, argillaceous, fair to poorly sorted; composed of subangular clear quartz, accessory minerals masked; poorly to firmly cemented, argillaceous and slightly calcareous; stratification concealed on line of section, but $50 \mathrm{ft}$ to south stratification is thin small- to memedium-scale trough sets of low-angle cross-laminae; platy splitting. Entire unit weathers to form steep rubblecovered slope. Contact with Wingate covered. This unit might be related to the Hite Bed

20. Limestone, pale red $(10 R 6 / 2)$, weathering same color, dense, probably highly siliceous; well indurated; stratification poorly exposed but probably mostly horizontally thinly bedded; slabby to blocky splitting; weathers to form ledge. Red and gray chert nodules at top contact. Grades into unit below

19. Siltstone, pale brown $(5 Y R 5 / 2)$ predominantly in lower half and grayish red $(5 R 4 / 2)$ predominantly in upper half; firmly cemented, noncalcareous; stratification concealed; weathers to form steep loose slope

18. Limestone, similar to unit 16 except consists predominantly of very thin beds. Probably siliceous

17. Siltstone, pale brown $(5 Y R 5 / 2)$ and pale yellowish brown $(10 Y R 6 / 2)$, weathering pale yellowish brown $(10 Y R 6 / 2)$; firmly cemented, noncalcareous; tabular unit, stratification concealed. Thin bed of light-greenishgray $(5 G Y 8 / 1)$ limy siltstone from 1.1 to $1.8 \mathrm{ft}$ above base of unit. Abundant thin sets of light-greenish-gray $(5 G Y 8 / 1)$ horizontally laminated or rarely ripple-laminated siltstone from 2.2 to $5.6 \mathrm{ft}$ above base of unit

16. Limestone, light greenish gray ( $5 G Y$ $8 / 1)$ with pale-red $(10 R 6 / 2)$ mottles and laminae, weathering light greenish gray (5GY 8/1), dense; composed
Feet

Chinle Formation-Continued

Owl Rock Member-Continued

of thin horizontal beds; slabby splitting; weathers to form small ledge. Common laminae of pale-red (10R $6 / 2$ ) probably argillaceous, limy siltstone

15. Sandy siltstone, pale reddish brown $(10 R 5 / 4)$, top $3 \mathrm{ft}$ pale yellowish brown, weathering pale reddish brown $(10 R 5 / 4)$. Similar to type 1 sandy siltstone in unit 14 except for color and absence of mica. Common lightgreenish-gray (5GY 8/1) calcareous nodules as large as $1 \mathrm{in}$. in diameter. Unit is well cemented. Unit not noticeably limy

Total of Owl Rock Member

Petrified Forest Member:

14. Sandy siltstone, types 1 and 2. Type 1, moderate reddish brown $(10 R 4 / 6)$, weathering pale reddish brown $(10 R$ $5 / 4)$, sandy (very fine grained) argillaceous; sparse fine-grained white mica, contains swelling clays; poorly cemented, argillaceous; stratification concealed. Type 2 , predominantly pale red $(10 R 6 / 2)$, some light-greenishgray $(5 G Y 8 / 1)$ sets, laminae, and mottling, sandy (very fine grained); firmly to well cemented, calcareous; equal proportions of horizontal and ripple laminae; platy splitting. Type 2 sandy siltstone from 10.2 to $11.2 \mathrm{ft}$, 16.6 to $18.4 \mathrm{ft}$, and 20.7 to $28.4 \mathrm{ft}$ above base of unit. Entire unit is tabular and weathers to form steep slope with small ledges in type 2 sandy siltstone

So-called Capitol Reef bed:

13. Sandstone, most commonly pale reddish brown $(10 R 5 / 4)$ and grayish red (10R 4/2), abundant light-greenishgray $(5 G Y$ 8/1) laminae, common sets of moderate yellowish brown $(10 Y R 5 / 4)$, pale red purple (5RP $6 / 2$ ) and light greenish gray ( $5 G Y$ $8 / 1)$, weathering pale reddish brown $(10 R 5 / 4)$ and pale red purple $(5 R P$ $6 / 2$ ), fine grained, fair sorted; composed of subangular clear quartz and common orange and dark-green accessory minerals, common to abundant medium- to coarse-grained darkgreen mica; poorly to firmly cemented, calcareous; composed of thin small- to medium-scale trough sets of low-angle cross-laminae and common very thin crossbeds, possibly some horizontal laminae present; platy and rarely slabby splitting; weathers to form steep slope with prominent ledge 
Chinle Formation-Continued

Petrified Forest Member-Continued

So-called Capitol Reef bed-Continued from 23.2 to $31.6 \mathrm{ft}$ above base of unit. One thin set of light-greenishgray $(5 G Y 8 / 1)$ limestone granule conglomerate $2 \mathrm{ft}$ above base

Total of so-called Capitol Reef bed

12. Siltstone, predominantly grayish red $(10 R 4 / 2)$, minor greenish gray (5GY 6/1), weathering grayish red (10R 4/2); sandy (very fine grained) in parts; poorly to firmly cemented, calcareous; stratification concealed; weathers to form steep rubble-covered slope. Unit poorly exposed. Sharp basal contact

11. Sandstone, pale red $(10 R 6 / 2)$ to grayish red $(10 R 4 / 2)$, weathering pale red $(10 R 6 / 2)$, very fine to fine grained, fair sorted; composed of subangular clear and milky quartz and abundant green and common orange accessory minerals; poorly cemented, noncalcareous; stratification concealed; weathers to form steep rubble-covered slope; sharp basal contact; abundant greenish-gray (5GY 6/1) mottling. Argil'aceous in part

10. Siltstone, light brown ( $5 Y R 5 / 6)$, weathering same color; firmly cemented, calcareous; stratification concealed; weathers to form steep frothy slope. Upper $4 \mathrm{ft}$ argillaceous and grades from pale reddish brown $(10 R$ $5 / 4)$ in lower part to moderate red $(5 R 5 / 4)$ in the upper part. Unit forms prominent brown band on outcrop

9. Silty claystone, pale red $(10 R 6 / 2)$ to grayish red $(10 R 4 / 2)$ and greenish gray ( $5 G Y 6 / 1)$, weathering to pale red $(10 R 6 / 2)$ and pinkish gray (5YR 8/1) ; firmly cemented, calcareous; stratification concealed; weathers to form steep frothy slope. Unit forms prominent light-colored band along outcrop. Unit grades into overlying unit

8. Silty claystone, dark reddish brown $(10 R 3 / 4)$, weathering dusky red $(5 R$ $3 / 4)$; firmly cemented, calcareous and argillaceous; stratification concealed; weathers to form steep frothy slope. Unit grades into overlying unit

7. Sandstone, grayish red $(10 R \quad 4 / 2$ and $10 R 5 / 2)$, blackish red $(5 R 2 / 2)$ at base and light-greenish-gray ( $5 G Y$ 8/1) mottling throughout, weathering grayish red, fine grained in lower part grading to very fine grained in upper part, fair sorted; composed of subangular clear quartz and orange,
Feet $\begin{array}{r}\text { Chinle Formation-Continued } \\ \text { Petrified Forest Member-Continued } \\ \text { green, and gray minerals. Orange, } \\ \text { green, and gray grains comprise } \\ \text { about } 30 \text { percent of the sandstone. } \\ \text { Abundant coarse-grained white and } \\ \text { black mica near base. Poorly ce- } \\ \text { mented, slightly calcareous; stratifi- } \\ \text { cation concealed. Weathers to form } \\ \text { steep slope. Grades into overlying unit }\end{array}$

Feet

6. Sandstone, yellowish gray (5Y 8/1) and light greenish gray (5GY 8/1), weathering to light greenish gray (5GY 8/1), medium grained, fair sorted; composed of subangular to angular clear quartz and orange, black, and green minerals. Orange, black, and green grains comprise about 25 percent of rock. Poorly cemented, slightly calcareous. Stratification poorly exposed, but probably horizontally laminated or composed of low-angle cross-laminae. Weathers to form steep rubble-covered slope......

Total of Petrified Forest Member....

Monitor Butte Member:

5. Clayey sandstone to siltstone, greenish gray $(5 G Y 6 / 1), 20-\mathrm{ft}$ grayish-red $(10 R 4 / 2)$ band in middle of unit. Clayey sandstone or sandy siltstone, very fine to fine grained, poorly sorted; composed of subangular clear quartz and abundant orange, green, and black accessory minerals. Entire unit poorly to firmly cemented, slightly calcareous; stratification concealed; weathers to form a steep frothy slope. Unit contains common (5 percent) well-cemented ripplelaminated thin to thick sandstone sets interbedded with rest of unit. The texture and composition of these sets are identical with those of the sandstone in the rest of the unit. The upper $2 \mathrm{ft}$ of the unit grades from medium gray (N 5) in the lower part to light brownish gray $(5 Y R 6 / 1)$ in the upper part

4. Sandstone, light gray $(N 7)$, weathering yellowish gray $(5 Y 8 / 1)$, fine grained, fair sorted; composed of subangular clear quartz and uncommon green and orange accessory minerals, abundant interstitial calcite; firmly to well cemented, calcareous; composed of thin medium-scale trough to planar sets of cross-laminae; platy to slabby splitting; weathers to form prominent ledge. Unit pinches out about $50 \mathrm{ft}$ to north of line of section but reappears $300 \mathrm{ft}$ farther north and forms a continuous ledge for about $1 / 4$ mile along the exposure. Abundant 
Chinle Formation-Continued

Monitor Butte Member-Continued

dark-yellowish-orange $(10 Y R \quad 6 / 6)$

limonite spots as large as $1 \mathrm{~mm}$ in diameter

3. Silty claystone to siltstone, greenish gray $(5 G Y 6 / 1)$, weathering light greenish gray (5GY 8/1); firmly cemented, probably argillaceous; stratification and splitting concealed; weathers to form steep frothy slope. Basal 1 to $5 \mathrm{ft}$ of unit away from line of section contains sandstone lenses less than $20 \mathrm{ft}$ across which appear to be poorly developed lenses of the Shinarump Member. Sandstone, light gray $(N 7)$ and grayish yellow (5Y 8/4), medium grained, fair sorted, composed of subround clear quartz and sparse dark-green accessory minerals, abundant interstitial calcite, some limonite spots; firmly to well cemented, calcareous; composed of lenticular layers of medium-scale cross-laminae; slabby splitting; weathers to form small ledge at base of unit away from line of section. This ledge commonly is grayish yellow and white

Total of Monitor Butte Member ....

Total of Chinle Formation

Moenkopi Formation (incomplete) :

2. Siltstone, grayish red $(10 R 4 / 2)$, grayish-purple (5P 4/2) and greenishgray $(5 G 6 / 1)$ mottling, purple and green mottling increases upward in unit from very slight amount in lower half to a large amount at top of unit, weathering grayish red $(10 R \quad 4 / 2)$ with slight purple cast; firmly cemented, noncalcareous, probably argillaceous; horizontally laminated in places, probably mostly structureless; weathers to form steep slope. Unit is probably an altered interval at top of Moenkopi Formation

1. Sandy siltstone, pale reddish brown $(10 R 5 / 4)$, weathering same color, sandy (very fine grained); abundant fine-grained white mica; firmly cemented, slightly calcareous; composed of parallel laminae and common ripple laminae; platy splitting; weathers to form steep slope containing small ledges. Uncommon thin to very thin sets of light-greenish-gray (5GY 8/1) laminae Unmeasured

Total of incomplete Moenkopi

Formation

14.2
Feet

8.8

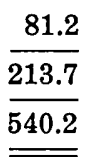

Chinle Formation:

Church Rock Member:

20. Silty claystone to clayey siltstone and sandstone. Silty claystone to clayey siltstone, grayish red $(10 R 4 / 2)$, weathering grayish red (5R 4/2); firmly cemented, noncalcareous; stratification poorly exposed but appears to be mostly horizontally laminated, contains some contorted stratification. Sandstone, light brown (5YR 6/4), minor amounts of very pale orange $(10 Y R 8 / 2)$ and light greenish gray $(5 G Y 8 / 1)$, very fine grained, well

Base of section; not base of exposure. 
Chinle Formation-Continued

Church Rock Member-Continued

sorted; composed of horizontal laminae to thin beds, common ripple marks; massive splitting. Sandstone is present as sets from 0.0 to $1.7 \mathrm{ft}$, 3.9 to $4.4 \mathrm{ft}, 9.0$ to $9.9 \mathrm{ft}, 11.3$ to 11.9 $\mathrm{ft}$, and 12.1 to $18.1 \mathrm{ft}$ above base of unit. This sandstone resembles in many respects that of the Wingate Sandstone. Unit as a whole tabular. The clayey siltstone to silty claystone weathers to form steep slopes, and the sandstone, to form ledges. A few rounded medium grains noted in the sandstone parts of this unit.

19. Siltstone to sandstone, pale red $(10 R$ $6 / 2)$ to grayish red $(10 R 4 / 2)$, weathering grayish red $(5 R 4 / 2)$, siltstone to very fine grained sandstone; common medium-grained accessory white and dark mica; well cemented, slightly calcareous; ripple laminated, some horizontal laminae; weathers to form steep slope

18. Siltstone, pale reddish brown (10R $5 / 4)$, grayish red $(10 R 4 / 2)$, sparse pale red $(10 R 6 / 2)$, mottles of light greenish gray $(5 G Y 8 / 1)$, weathering pale reddish brown $(10 R 5 / 4)$, commonly contains some very fine grained sand; firmly cemented, calcareous; stratification indistinct but in gross aspect is horizontally stratified, contains some ripple laminae, some horizontal laminae to thin beds, and some structureless parts; fractures into angular fragments; weathers to form a steep slope containing some small ledges. Unit from $64.8 \mathrm{ft}$ to top contains several ( 0.5 percent) thin lenses of siltstone containing from a few percent to as much as 50 percent medium grains to granules to limy siltstone and (or) possibly limestone

17. Siltstone (60 percent) and sandstone to conglomerate (40 percent). Siltstone, pale reddish brown $(10 R 5 / 4)$, sparse light brown $(5 Y R 6 / 4)$, and yellowish gray (5Y 8/1), weathering pale reddish brown $(10 R 5 / 4)$; well cemented, calcareous; horizontally and ripple laminated, common structureless parts. Sandstone to conglomerate, pale reddish brown $(10 R 5 / 4)$, common light-greenish-gray (5GY 8/1) mottling, weathering same colors, coarse to very coarse grained sandstone to granule and pebble conglomerate; poorly sorted; composed of rounded pale-reddish-brown (10R $5 / 4)$ coarse grains to pebbles of siltstone to limy siltstone in a matrix of calcite. Calcite forms as much as
Feet

Chinle Formation-Continued

Church Rock Member-Continued

30 percent of rock in places. Sandstone to conglomerate is poorly to well cemented; composed of very thin horizontal beds and very thin planar and trough sets of small- to mediumscale cross-laminae; slabby to massive splitting. Sandstone to conglomerate is present as thin to very thick cosets interstratified with siltstone. Unit as whole weathers to form ledges and steep slopes

16. Siltstone to silty claystone, moderate yellowish brown (10YR 5/4), minor amounts of pale reddish purple (5RP $6 / 2)$, weathering pale red $(10 R 6 / 2)$ in lower $1 / 2$ and grayish orange $(10 Y R \quad 7 / 4)$ in upper $1 / 2$; firmly cemented, calcareous; structureless; weathers to form steep slope. Unit forms fairly conspicuous light-colored band on exposure. Unit contains sparse ( 3 percent) medium to very coarse rounded grains. Basal half of unit contains common (10 percent) pale-red $(10 R 6 / 2)$ limestone nodules averaging about $1.5 \mathrm{in}$. in diameter...

Basal sandstone unit:

15. Sandstone, pale red $(10 R 6 / 2)$ and very light gray ( $N 8)$, weathering light brown $(5 Y R 6 / 4)$, coarse to very coarse grained, fair sorted; composed of rounded gray grains and minor amounts of clear and milky quartz; calcite completely fills the area between the grains and comprises about 30 to 40 percent of the rock; poorly cemented, calcareous; unit is lenticular, structureless; weathers to form inconspicuous ledge at base of lightcolored interval at base of Chinle ......

Total of basal sandstone unit

Total of Church Rock Member ......

Total of Chinle Formation

50.5

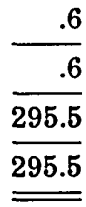

Moenkopi Formation (incomplete) :

Sewemup Member:

14. Siltstone (70 percent) to clayey siltstone (30 percent), pale reddish brown $(10 R 5 / 4)$, grayish red $(10 R$ $4 / 2$ ), minor amounts of light brown (5YR 6/4), weathering pale reddish brown $(10 R 5 / 4)$; abundant fine- to medium-grained accessory white and dark mica; firmly to well cemented, dominantly noncalcareous; horizontally and ripple laminated, stratification commonly concealed; weathers to form steep talus-covered slope containing a few small ledges 
Moenkopi Formation (incomplete)-Continued

Total of incomplete Moenkopi

Formation

Feet

173.0

Base of section; not base of exposure.

Units 1-13 described in Stewart, Poole, and Wilson (1972).

\section{U-19. SPRING CANYON}

Measured on west side of Spring Canyon about 3,200 ft up canyon from the Green River and about $500 \mathrm{ft}$ down canyon from mining camp. Line of section is $N$. $70^{\circ} W$., long $109^{\circ} 59^{\prime} 45^{\prime \prime} W$., lat $38^{\circ} 37^{\prime} 40^{\prime \prime} N$., Grand County

[Measured by J. H. Stewart, November 1953]

Top of section; top of accessible exposure. Feet Wingate Sandstone:

19. Sandstone, grayish orange pink (5YR $7 / 2)$ and very pale orange $(10 Y R$ $8 / 2$ ), weathering same colors, very fine grained, well sorted; composed of subrounded to rounded clear quartz and common black accessory mineral; poorly cemented, slightly calcareous; basal $2.5 \mathrm{ft}$ ripple laminated, rest of unit composed of thin to thick trough sets of low-angle medium-scale crosslaminae; massive splitting; weathers to form vertical cliff. Only basal $6 \mathrm{ft}$ of unit examined. Basal $0.4 \mathrm{ft}$ contains common round frosted medium to coarse grains of brown and gray mineral (probably quartz). Basal $0.4 \mathrm{ft}$ contains sparse granules of white and brown chert. Basal contact sharp..Unmeasured

Chinle Formation:

Church Rock Member:

Hite Bed (?) :

18. Sandstone (97 percent) and conglomerate (3 percent). Sandstone, pale red $(10 R 6 / 2)$, common medium light gray $(N 6)$, sparse rare yellowish gray $(5 \mathrm{Y} 8 / 1)$, weathering pale brown $(5 Y R 5 / 2)$, very fine to fine grained, fair sorted; composition masked, uncommon coarser grained accessory white mica; firmly cemented, calcareous; composed of horizontal laminae and thin to thick trough sets of lowangle medium- to large-scale crosslaminae. Conglomerate, same as sandstone except composed of about 50 percent granules and pebbles of white and pink chert, pale-brown siltstone, and pale brown sandstone in a sand matrix. The largest pebble is chert and has a maximum diameter of $21 / 2$ in. The conglomerate is confined to the basal $5 \mathrm{ft}$ of the unit, where it is present as thin lenses interstratified with sandstone. Unit as whole weathers to form vertical cliff continuous with the overlying Wingate Sandstone. From a distance this unit appears to be part of the Wingate.
Chinle Formation-Continued

Church Rock Formation-Continued

Hite Bed(?) —Continued

Basal strata of unit fill scours cut as deep as $1 \mathrm{ft}$ into the underlying unit

Total of Hite Bed (?)

17. Siltstone to silty sandstone, pale reddish brown $(10 R 5 / 4)$ to grayish red $(10 R$ $4 / 2$ ), weathering same colors, very fine grained; sparse fine-grained accessory white mica; firmly cemented, calcareous; horizontally laminated to thinly bedded; platy splitting in part; weathers to form slope. On outcrops to east, unit is persistently covered with talus.

16. Sandstone $(90$ percent), siltstone (5 percent), and conglomerate ( 5 percent). Sandstone, from 0.0 to $68.2 \mathrm{ft}$ light greenish gray $(5 G Y 8 / 1)$ and yellowish gray $(5 Y 8 / 1)$ with about 5 percent pale greenish yellow $(10 Y$ $8 / 2)$, about 5 percent light brownish gray $(5 Y R 6 / 1)$, about 2 percent pale blue $(5 P B 7 / 2)$, and about 2 percent pale brown $(5 Y R 5 / 2)$, from 68.2 to $122.0 \mathrm{ft}$ light brownish gray $(5 Y R$ $6 / 1)$ and medium light gray $(N 6)$, and from 122.0 to $144.2 \mathrm{ft}$ pale red $(5 R 6 / 2)$ to grayish red $(5 R 4 / 2)$ and about 10 percent medium light gray $(N 6)$, weathering light brown $(5 Y R 6 / 4)$ and pale red $(5 R 6 / 2)$, very fine to fine grained, well sorted; composed of subangular milky minerals and abundant black accessory mineral, common medium- to coarsegrained accessory white mica; firmly cemented, calcareous; composed of horizontal laminae, subordinate thin trough sets of low-angle medium- to large-scale cross-laminae, sparse ripple laminae, and common wavy laminae. Siltstone, greenish gray (5GY $6 / 1$ ), weathering same color, firmly cemented, slightly calcareous; structureless; present as thin to very thick lenses interstratified with rest of unit. Conglomerate, similar to sandstone except contains about 60 percent granules to cobbles of siltstone and sandstone. Conglomerate present as thin to thick sets interstratified with rest of unit. Siltstone and conglomerate more common in lower $1 / 3$ of unit. Position and content of siltstone and conglomerate highly variable along outcrop. Unit contains sparse carbonaceous material in lower half. 'Unit as a whole weathers to form vertical cliff
Feet
15. Sandstone (50 percent) and siltstone 
Chinle Formation-Continued

Church Rock Member-Continued

(50 percent). Sandstone, greenish gray $(5 G Y 6 / 1)$, weathering same color, very fine grained; abundant medium-grained accessory white mica; firmly to poorly cemented, calcareous; ripple laminated, one thin trough set of medium-scale cross-laminae noted. Sandstone is present as thin to thick sets interstratified with siltstone. Siltstone, greenish gray (5GY 6/1), weathering same color; poorly cemented, calcareous; stratification concealed. Unit as whole weathers to form slope containing several small ledges. Some intergrading of siltstone and sandstone. Sparse carbonaceous material. Unit poorly exposed in places

14. Sandstone (90 percent) and conglomerate (10 percent), similar to unit 12 ; weathers to form ledge. Conglomerates contain common granules of limestone. Unit contains common carbonaceous material. Unit might be related to the so-called Black Ledge although it does not appear to be continuous in the local area................

13. Sandstone ( 60 percent) to siltstone $(40$ percent), greenish gray (5GY 6/1) and dark greenish gray (5GY 4/1), weathering greenish gray $(5 G Y 6 / 1)$, very fine grained; uncommon finegrained accessory white mica; firmly to well cemented, calcareous; horizontally laminated, highly contorted basal half, some possible cross-laminae in one thin set of sandstone. Sandstone commonly occurs in very thin horizontal or contorted sets interstratified with the siltstone, but the sandstone and siltstone also intergrade. Unit contains common carbonaceous material. Unit weathers to form slope

12. Sandstone to conglomerate, moderate greenish yellow (10Y 7/4) and greenish gray ( $5 G Y 6 / 1)$, weathering same colors, and light brown (5YR 6/4). Sandstone and matrix of conglomerate is very fine grained, contains common fine-grained accessory white mica, and is fair sorted. Conglomerate composed of about 60 percent granules and pebbles of siltstone to limy siltstone in sand matrix. Sandstone to conglomerate is firmly cemented, calcareous; horizontally and ripple laminated, weathers to form ledge. Unit contains abundant carbonaceous material

Total of Church Rock Member
Feet Chinle Formation-Continued

Feet Owl Rock(?) Member:

11. Limestone, yellowish gray (5Y 7/2) and uncommon light greenish gray $(5 G 8 / 1)$, weathering grayish orange $(10 Y R \quad 7 / 4)$, aphanitic with sparse vugs of coarsely crystalline calcite; well cemented; structureless; weathers to form ledge. About 10 percent of unit is irregular, gray and white chert nodules

10. Siltstone, similar to unit 8 . Top $1.8 \mathrm{ft}$ is pale green $(10 G 6 / 2)$. Unit weathers to form slope

9. Limestone and siltstone. Limestone, greenish gray (5GY 6/1), weathering same color, aphanitic; well cemented; thinly bedded, faint suggestion of horizontal laminae. Siltstone, grayish green $(5 G 5 / 2)$, weathering greenish gray $(5 G Y 6 / 1)$, firmly cemented, calcareous; present as thin horizontal bed from 1.0 to $1.3 \mathrm{ft}$. Unit as whole weathers to form white ledge

8. Siltstone, grayish red $(10 R 4 / 2)$ to pale reddish brown $(10 R 5 / 4)$, weathering same colors; poorly cemented, calcareous; structureless; weathers to form slope. Sparse pale-green (10G 6/2) and grayish-green $(5 G 5 / 2)$ very thin beds in bottom and top $5 \mathrm{ft}$ of unit. Top $1 \mathrm{ft}$ of unit is entirely these green colors. Immediately to north of line of section, unit from 27.0 to 31.4 $\mathrm{ft}$ above base is light-greenish-gray $(5 G Y 8 / 1)$ and pale-red $(10 R 6 / 2)$ horizontally and ripple laminated well cemented limy siltstone. Siltstone does not appear to be bentonitic

Total of Owl Rock(?) Member......

Moss Back(?) Member:

7. Sandstone (65 percent) and clayey siltstone ( 35 percent). Sandstone, light greenish gray $(5 G Y 8 / 1)$ and pale brown $(5 Y R 5 / 2)$, weathering same colors, very fine grained, silty in parts; common medium-grained accessory white and dark mica; well cemented, calcareous; horizontally and ripple laminated; platy splitting. Clayey siltstone, grayish red (10R $4 / 2$ ), weathering same color; poorly cemented, calcareous; present as very thin beds interstratified with very thin to thin sets of sandstone. Basal $3 \mathrm{ft}$ of unit is entirely greenish gray (5GY 6/1) clayey siltstone ...............

6. Sandstone, grayish orange pink (5YR $7 / 2$ ), common light greenish gray (5GY 8/1), weathering moderate brown (5YR 4/4), fine to medium grained, well sorted; composed of sub- 
Chinle Formation-Continued

Moss Back(?) Member-Continued rounded clear quartz and abundant black accessory mineral, uncommon medium- to coarse-grained accessory white mica; firmly cemented, calcareous; composed of thin trough sets. of low-angle medium-scale cross-laminae; weathers to form conspicuous cliff near base of Chinle Formation. Sandstone commonly contains granules and pebbles of reddish-brown siltstone. Base of unit contains a few pebbles of limestone

5. Siltstone (50 percent), sandstone (30 percent), and conglomeratic sandstone (20 percent). Siltstone, grayish red $(10 R 4 / 2)$, weathering same color; common very fine grained white mica; firmly cemented, noncalcareous; horizontally laminated. Sandstone, light greenish gray ( $5 G 8 / 1)$, weathering same color and light olive gray (5Y $6 / 1$ ), very fine, fine, and medium grained, grades to sandy siltstone in a few places, fair sorted; composed of subangular milky mineral, common medium- to coarse-grained accessory white mica; firmly to well cemented, calcareous; horizontally laminated, sparse ripple laminae and thin trough sets of low-angle medium- to smallscale cross-laminae. Conglomeratic sandstone, similar to sandstone except contains about 40 percent granules and pebbles of limestone and to a lesser extent of siltstone, quartz, quartzite, and chert. Conglomerate sandstone grades into sandstone. Sandstone and conglomeratic sandstone are present as very thin to thin sets interstratified with siltstone. Unit as whole weathers to form vertical cliff continuous with that in overlying unit

Total of Moss Back(?) Member ....

Mottled strata (unit 4 may not belong with the mottled strata) :

4. Claystone, grayish red purple (5RP $4 / 2)$, sparse light-greenish-gray ( $5 G Y$ $8 / 1$ ) spots, weathering same colors, firmly cemented, noncalcareous; structureless; weathers to form slope. Contains swelling clays. Unit contains sparse white aphanitic to coarsely crystalline irregular limestone nodules that range from 1 in. to 8 in. in diameter

3. Siltstone, greenish gray (5GY 6/1), common grayish purple ( $5 P 4 / 2)$, weathering same colors; firmly to well cemented, noncalcareous; struc- $\frac{5.7}{25.4}$

Base of section; base of exposure.

\section{U-20. MOAB C.ANYON}

Measured up point on southeast side of prominent reentrant in cliffs lying to west of The Dugway about 6 miles northwest of Moab, northwestern corner of sec. 19, T. 25 S., R. 21 E., SLM, Grand County

[Measured by J. H. Stewart and D. A. McManus, June 1954]

Top of section; top of accessible exposure. Feet Wingate Sandstone:

19. Sandstone, very pale orange $(10 Y R$ $8 / 2)$, weathering pale reddish brown $(10 R 5 / 4)$, very fine grained, well sorted; composed of subangular clear quartz, common black and sparse orange accessory minerals; fair cemented, noncalcareous; parallel bedded; weathers to form vertical cliff. Unit contains sparse ( $<1$ percent) coarse well-rounded grains Unmeasured
Feet Chinle Formation-Continued Mottled strata-Continued tureless; weathers to form small ledge. Unit contains 1 to 10 percent subrounded to subangular milky, clear, and pink quartz grains. Some of the purple parts of unit have a metallic luster. Several very thin horizontal lenses of reddish-orange quartz in top $0.5 \mathrm{ft}$ of unit

2. Claystone, grayish red purple (5RP $4 / 2$ ), sparse ( 5 percent) lightgreenish-gray $(5 G Y 8 / 1)$ spots, weathering pale red purple (5RP $6 / 2$ ), poorly cemented; structureless; weathers to form slope. Unit contains sparse ( 1 to 5 percent) very fine to very coarse sand grains. These grains are rounded to subangular clear, milky, and pinkish quartz. Unit is differentiated from upper $1.8 \mathrm{ft}$ of underlying unit on the basis of the presence of these very fine to coarse grains. Basal contact appears gradational

Total of mottled strata

Total of Chinle Formation

Moenkopi Formation:

1. Siltstone, pale reddish brown $(10 R 5 / 4)$ to dark reddish brown $(10 R 3 / 4)$, sparse ( 3 percent) greenish-gray (5GY 6/1), weathering same colors; sparse fine-grained accessory white mica; poorly cemented, noncalcareous; stratification poorly exposed but probably dominantly structureless to horizontally thinly bedded, sparse horizontal laminae; weathers to form steep slope. Not measured, but about $150 \mathrm{ft}$ of unit exposed. Top $1.8 \mathrm{ft}$ of unit is about 50 percent grayish red purple $(5 R P 4 / 2)$ and about 10 percent pale yellowish green $(10 G Y 7 / 2)$.

Feet 
Chinle Formation (not differentiated into formal members, although most of Chinle is lithologically similar to the Church Rock Member) : Upper unit:

18. Sandstone, grayish red $(10 R 4 / 2)$ and pale reddish brown $(10 R 5 / 4)$, weathering pale reddish brown $(10 R 5 / 4)$, very fine grained, silty in parts, well sorted; well cemented, noncalcareous; composed of ripple laminae and subordinate thin trough sets of low-angle small-scale cross-laminae; weathers to form vertical cliff continuous with that of the overlying Wingate Sandstone

17. Siltstone, grayish red purple $(5 R P 4 / 2)$, weathering same color; firmly cemented, noncalcareous; stratification concealed; weathers to form slope ....

16. Sandstone to conglomeratic sandstone, pale red $(10 R 6 / 2)$ and subordinate light greenish gray ( $5 G Y 8 / 1)$, weathering pale reddish brown $(10 R 5 / 4)$, very fine grained, well sorted; well cemented, highly calcareous; composed of thin trough sets of low-angle medium-scale cross-laminae and horizontal laminae; weathers to form a small ledge. Conglomeratic parts of unit are composed of about 40 percent angular grayish-pink $(5 R 8 / 2)$ chert clasts in the sand matrix. Conglomeratic parts comprise about 40 percent of unit and are irregularly distributed both laterally and vertically in unit....

15. Sandstone to silty sandstone, pale red (5R 6/2), weathering pale reddish brown $(10 R 5 / 4)$, very fine grained, well sorted; composed of subangular clear quartz and sparse green and black and abundant white accessory minerals; well cemented, calcareous; composed of sets as large as $4 \mathrm{ft}$ thick of horizontal beds and ripple laminae; weathers to form ledgy slope. The parts of the unit that form a slope are silty sandstone

Total of upper unit

So-called Black Ledge(?) :

14. Sandstone, pale red $(10 R 6 / 2)$, grayish red $(5 R 4 / 2)$, subordinate yellowish gray $(5 Y 8 / 1)$ and dark yellowish orange (10YR 6/6), weathering pale reddish brown $(10 R 5 / 4)$ and dark yellowish orange $(10 Y R 6 / 6)$, very fine grained, well sorted; poorly to firmly cemented, slightly calcareous; horizontally laminated, subordinate thin trough sets of low-angle mediumscale cross-laminae, sparse contorted stratification; weathers to form the higher of two prominent ledges in the

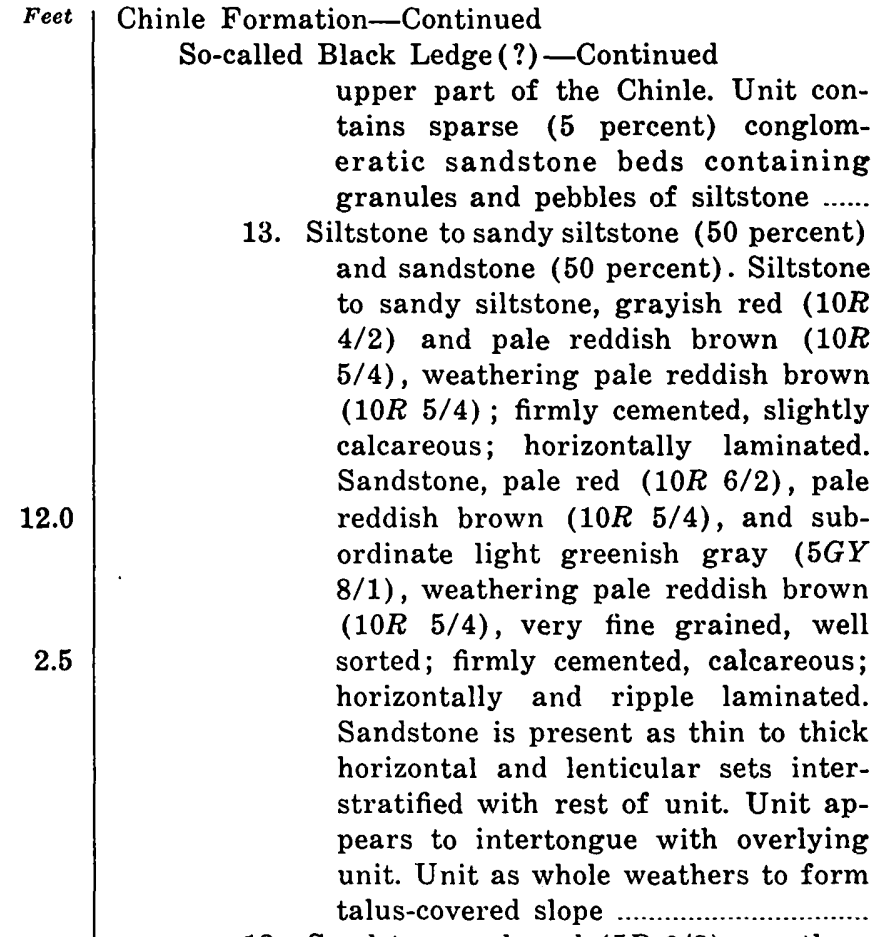

Feet upper part of the Chinle. Unit contains sparse (5 percent) conglomeratic sandstone beds containing granules and pebbles of siltstone ......

12. Sandstone, pale red (5R 6/2), weathering pale reddish brown $(10 R 5 / 4)$, very fine grained, well sorted; well cemented, calcareous; composed of thin to thick trough and planar sets of small- to medium-scale cross-laminae, subordinate horizontal laminae; massive splitting; weathers to form ledge. Basal $0.5 \mathrm{ft}$ contains abundant pebbles and cobbles of siltstone ........

11. Siltstone and sandstone. Siltstone, grayish red $(10 R 4 / 2)$, and sparse light greenish gray (5GY 8/1), weathering pale reddish brown (10R 5/4); well cemented, calcareous; stratification poorly exposed, but appears to be dominantly horizontally laminated. Sandstone, pale red $(5 R 6 / 2)$ and common yellowish gray $(5 Y 7 / 2)$, weathering pale red $(5 R 6 / 2)$, very fine grained; well cemented, calcareous; horizontally and ripple laminated. Sandstone forms about 60 percent of top $10 \mathrm{ft}$. of unit. Unit as a whole weathers to form a slope ....

10. Silty sandstone, light" greenish gray $(5 G Y 8 / 1)$ and grayish yellow ( $5 Y$ $8 / 4)$, weathering moderate yellowish brown $(10 Y R 5 / 4)$, very fine grained; well cemented, calcareous; ripple laminated, sparse thin trough sets of small-scale cross-laminae; weathers to form ledge. Top $0.5 \mathrm{ft}$ of unit is limestone pebble conglomerate which is well cemented by a lime matrix......

9. Conglomeratic sandstone, light greenish gray $(5 G Y 8 / 1)$ and subordinate pale 
Chinle Formation-Continued

So-called Black Ledge(?)-Continued red $(5 R 6 / 2)$, weathering moderate yellowish brown (10YR 5/4), granules and pebbles of siltstone in matrix of medium to very coarse grains of limestone, poorly sorted; well cemented by lime cement that completely fills interstitial spaces; structureless; weathers with unit above to form conspicuous ledge ........

Total of so-called Black Ledge(?)

Siltstone unit (probably represents an intermixing of strata lithologically similar to the Church Rock Member with a lesser amount of strata lithologically similar to the Petrified Forest Member) :

8. Siltstone, grayish red $(10 R 4 / 2)$, pale red $(5 R 6 / 2)$, and about 30 percent light greenish gray ( $5 G Y 8 / 1)$, weathering pale red $(10 R 6 / 2)$ and light greenish gray (5GY 8/1); firmly cemented, calcareous; stratification poorly exposed but appears to be mostly horizontally and ripple laminated; platy splitting in part; weathers to form steep slope. About 5 percent of the siltstone contains interstitial swelling clay. On cliffs to northwest, this unit appears to be almost entirely light greenish gray. A thin lens of greenish-gray ( $5 G Y$ $6 / 1$ ) limestone-grain sandstone is present at $31.3 \mathrm{ft}$. This sandstone has calcite completely filling the interstitial spaces

7. Siltstone to sandstone (50 percent) and siltstone (50 percent). Siltstone to sandstone, light greenish gray ( $5 G Y$ $8 / 1)$ and sparse pale red $(5 R 6 / 2)$, weathers brownish gray $(5 Y R 4 / 1)$, silt to very fine grained sand; common accessory white mica; firmly cemented, highly calcareous; composed of thin sets of ripple laminae interstratified with rest of unit. Siltstone, grayish red purple $(5 R P 4 / 2)$, weathering same color; firmly cemented, slightly calcareous; stratification concealed. Siltstone in basal $1 \mathrm{ft}$ contains interstitial swelling clay. Unit as whole weathers to form ledgy slope. Thin lens of limestone pebble conglomerate occurs at $9.2 \mathrm{ft}$ above base of unit

Total of siltstone unit

Basal sandstone unit:

6. Sandstone, light greenish gray (5GY $8 / 1)$, minor grayish red $(5 R 4 / 2)$, and pale red purple (5RP 6/2), weathers pinkish gray (5YR 8/1), medium to very coarse grained, poorly
Chinle Formation-Continued

Basal sandstone unit-Continued sorted; abundant interstitial white material (probably clay), composed of subangular to angular milky grains, sparse black accessory minerals; poorly cemented, calcareous; stratification poorly exposed but seems to be dominantly thin to very thick trough sets-of small- to medium-scale cross-laminae; weathers to form conspicuous light-colored ledge at base of Chinle Formation. Colors in the unit do not follow stratification but form irregular mottles. Unit becomes silty toward top. Unit contains sparse lenses of gritty and pebbly sandstone near base; granules and pebbles are composed of clear quartz and are as large as $3 / 4$ in. in diameter. A few thin seams containing malachite were seen at base of unit

Total of basal sandstone unit

Total of Chinle Formation

Moenkopi Formation (incomplete) :

5. Siltstone to sandy siltstone, light brown (5YR 6/4) and common pale reddish brown $(10 R 5 / 4)$, sparse light-greenish-gray ( $5 G Y 8 / 1)$ mottles and laminae; sandy (very fine grained); firmly cemented, calcareous; consists of thin to thick interstratified horizontal sets of horizontal laminae and ripple laminae; weathers to form ledgy slope

4. Sandy siltstone, light brown (5YR 6/4), common light-green-gray ( $5 G Y$ $8 / 1$ ) mottles and laminae; weathers same color; sandy (very fine grained) ; common fine-grained accessory white mica; firmly cemented, calcareous; stratification poorly exposed but seems to be horizontally and ripple laminated; massive splitting; weathers to form most conspicuous massive vertical cliff in line of section. Base of unit is sharp and horizontal and marks most noticeable lithologic change in Moenkopi

Total of incomplete Moenkopi Formation

Units 1-3 described in Stewart, Poole, and Wilson (1972).

Measured on west bank of Colorado River approximately 1 mile south of Westwater Creek and 1/4 mile south of prominent fault at north end of Westwater Canyon, northeast corner of sec. 22, T.20 S., R. 25 E., SLM, Grand County [Measured by R. F. Wilson, June 1956]

Top of section; not top of exposure.

Wingate Sandstone: 
Wingate Sandstone-Continued

5. Sandstone, grayish orange pink (5YR $7 / 2$ ), weathering same color, very fine grained with scattered fine to medium grains in places; well sorted; composed of subround to round clear and frosted quartz and common dark accessory mineral; firmly to well cemented, calcareous; composed in part of horizontal laminae, but predominant stratification is wedge and tabular planar sets of medium- to large-scale high- and low-angle cross-laminae; weathers to form vertical cliff. Thickness estimated at 300 $\mathrm{ft}$.

Unmeasured

Chinle Formation:

Church Rock Member:

4. Siltstone, grayish red $(10 R 4 / 2)$, weathering same color, medium silt; firmly cemented, calcareous; structureless; weathers to form loose slope ...............

3. Siltstone, pale reddish brown $(10 R$ 5/4), weathering same color, coarse silt; contains common accessory white mica; firmly to well cemented, calcareous, horizontally to wavy laminated to very thin bedded in lower half, structureless in upper half; weathers to form irregular ledge ......

2. Siltstone, grayish red $(10 R 4 / 2)$ and pale reddish brown $(10 R 5 / 4)$, weathering pale reddish brown $(10 R 5 / 4)$, medium to coarse silt; firmly to well cemented, calcareous in part; structureless; weathers to form partly covered slope. Unit contains several thin layers of siltstone containing lime nodules

Total of Church Rock Member ......

Total of Chinle Formation

Precambrian:

1. Schist and granitic gneiss, dark gray $(N 3)$, medium gray ( $N 5)$, brownish gray $(5 Y R 4 / 1)$, subordinate pale pink (5RP 8/2) and grayish red $(10 R 4 / 2)$, weathering same colors, medium to very coarsely crystalline; composed of foliated black biotite, quartz, and feldspar; hard; weathers to form dark slope; about $40 \mathrm{ft}$ of unit exposed above river. Upper $10 \mathrm{ft}$ of unit is a regolith composed of deeply weathered granitic material. The foliation planes of the underlying gneiss are preserved in the regolith and dip at an angle to the dip of the overlying strata ........................Unmeasured

Base of section; base of exposure. Base of section is on west side of Colorado River, about $1 / 4$ mile west of prominent fault, and is $S .30^{\circ} \mathrm{W}$. of town of Westwater.
Feet

U-22. KANARRAVILLE

Measured 0.7 mile north of Taylor Creek and 4.5 miles south of Kanarraville, east-central part of sec. 21 and westcentral part of sec. 22, T. 38 S., R. 12 W., SLM, Washington County

[Measured by J. H. Stewart and F. G. Poole, October 1955]

Top of section; top of exposure. Top of section is at crest of high hogback in Kayenta Formation. Top of section is about N. $60^{\circ} \mathrm{E}$. of place where U.S. Highway 91 crosses Taylor Creek and N. $85^{\circ}$ E. of base of section.

Kayenta Formation:

19. Siltstone and sandstone. Siltstone, grayish red $(10 R 4 / 2)$ and pale reddish brown $(10 R 5 / 4)$; firmly cemented, noncalcareous; horizontally laminated to very thick bedded; weathers to form slope. Sandstone, pale red (5R 6/2), subordinate moderate orange pink $(10 R 7 / 4)$, weathering pale red $(5 R$ $6 / 2$ ), fine to medium grained, fair sorted, composed of subrounded to subangular clear quartz, common black accessory minerals, firmly cemented, calcareous; horizontally laminated, also thin to thick trough sets of very low angle medium-scale crosslaminae; weathers to form ledge. Sandstone is present as about 10 -ftthick layer approximately $100 \mathrm{ft}$ above base of unit and 60-ft-thick layer about $200 \mathrm{ft}$ above base of unit. Sandstone in many places contains grayish-red siltstone pellets. About $250 \mathrm{ft}$ of Kayenta Formation exposed. Unit not examined in detail Unmeasured Moenave Formation: Springdale Sandstone Member:

18. Sandstone, pale red ( $5 R 6 / 2)$, sparse grayish-yellow (5Y 8/4) mottling, weathering same colors, fine to medium grained, fair sorted; composed of subangular to subrounded clear quartz, common black accessory minerals; poorly cemented, calcareous in places; composed of horizontal laminae and subordinate thin to thick trough sets of very low angle mediumscale cross-laminae, some parts appear structureless; weathers to form vertical cliff. Unit contains a few (5 percent) lenses of sandstone that contain abundant grayish-red $(10 R 4 / 2)$ claystone or siltstone pellets

Total of Springdale Sandstone Member

Whitmore Point(?) Member:

17. Siltstone to sandstone, grayish red $(10 R$ $4 / 2$ and $5 R 4 / 2)$, pale red $(10 R 6 / 2)$, light brownish gray (5YR 6/1), and minor light greenish gray (5GY 8/1) to dark greenish gray (5GY 4/1), weathering same colors, ranges from

Feet

(n) 
Moenave Formation-Continued

Whitmore Point(?) Member-Continued fine siltstone to very fine grained sandstone. Sandstone is well sorted and composed of subangular to subrounded clear quartz and abundant black and green accessory minerals. Siltstone to sandstone is firmly cemented, calcareous; composed of horizontal laminae and minor very thin to thin horizontal beds, sparse thin trough sets of low-angle small-scale cross-laminae; weathers to form steep ledgy slope. Unit is composed of a complexly interstratified sequence of very thin to very thick sets and cosets each of which has a homogeneous lithologic character differing slightly from that of the underlying or overlying set or coset

16. Silty sandstone, light brownish gray (5YR 6/1) and sparse yellowish gray (5Y 8/1), weathering same colors, very fine grained, well sorted; composed of subrounded clear quartz, 1 to 2 percent fine-grained dark-green mica; poorly cemented, calcareous; mostly structureless; some suggestion of horizontal laminae and possibly some low-angle cross-laminae, weathers to form light-colored ledge

15. Siltstone type 1 (60 percent) and siltstone type 2 (40 percent). Type 1 , dark greenish gray $(5 G Y 4 / 1)$ and minor pale olive $(10 Y 6 / 2)$ and grayish red $(10 R 4 / 2)$, weathering same colors; common very fine grained accessory white mica in places; firmly to well cemented, noncalcareous; horizontally laminated to thick bedded. Type 2, light greenish gray (5GY $8 / 1)$, pale olive $(10 Y 6 / 2)$, light brown (5YR 6/4), pale yellowish brown $(10 Y R 6 / 2)$, sparse dusky yellow $(5 Y 6 / 4)$, weathering same colors, coarse silt; well cemented, slightly calcareous in parts; horizontally laminated, ripple laminated, possibly some small-scale cross-strata. Type 2 siltstone is present as thin to thick sets interstratified with type 1 siltstone. Unit as whole weathers to form steep ledgy slope. Base of unit sharp and marks prominent color change, which can be seen at a distance

Total of Whitmore Point(?)

Member

Dinosaur Canyon Member:

14. Silty claystone to siltstone (60 percent) and siltstone (40 percent). Silty claystone to siltstone, grayish red $(10 R$ $4 / 2)$, sparse pale reddish brown $(10 R$ $5 / 4)$, weathering same colors; sparse
Feet $\begin{array}{r}\text { Moenave Formation-Continued } \\ \text { Dinosaur Canyon Member-Continued } \\ \text { very fine grained accessory white } \\ \text { mica; firmly cemented, noncalcareous; } \\ \text { horizontally laminated to thin bed- } \\ \text { ded. Siltstone, light brown (5YR 6/4) } \\ \text { and sparse pale reddish brown }(10 R \\ 5 / 4) \text {, weathering same colors, coarse } \\ \text { silt; firmly cemented, slightly calcar- } \\ \text { eous; horizontally and ripple lami- } \\ \text { nated, common thin trough sets of } \\ \text { small- to medium-scale low-angle } \\ \text { cross-laminae. Unit as whole weath- } \\ \text { ers to form steep slope. Siltstone is } \\ \text { present as very thin to thick sets } \\ \text { interstratified with silty claystone to } \\ \text { siltstone. One } 5 \text {-ft set of grayish-red } \\ \text { (5R } 4 / 2) \text { very fine horizontally lami- } \\ \text { nated silty sandstone is present about } \\ 1 / 3 \text { of the way up in the unit. One } \\ \text { thin siltstone bed contains stringers } \\ \text { of coarse grains composed chiefly of } \\ \text { quartz .......................................... }\end{array}$

13. Sandy siltstone to silty sandstone, light brown $(5 Y R$ 6/4) and pale reddish brown $(10 R 5 / 4)$, common yellowishgray $(5 Y 8 / 1)$ mottling, weathering same colors, grades from siltstone containing minor amounts of very fine sand to sandstone with minor silt, well sorted; composed of subrounded clear and amber-stained quartz and common black accessory mineral; poorly cemented, slightly calcareous; irregularly horizontally laminated or possibly ripple laminated, laminae may be slightly contorted. Unit weathers to form prominent smooth surfaced and rounded cliff near base of Moenave Formation

12. Siltstone to sandstone, light brown $(5 Y R 6 / 4)$, pale reddish brown $(10 R$ $5 / 4)$ to dark reddish brown $(10 R 3 / 4)$ and sparse grayish red $(5 R 4 / 2)$ and very pale orange $(10 Y R 8 / 2)$, weathering same colors. Grades from fine siltstone to very fine grained sandstone. Sandstone is well sorted and composed of subrounded clear, subordinate amber-stained quartz, and common black accessory mineral. Siltstone to sandstone is firmly to well cemented, calcareous in places; horizontally laminated to thin bedded, or rarely ripple laminated; commonly contains irregular bedding that may be contorted ripples. Unit weathers to form steep slope. Some of the sandstone contains from 1 to 10 percent medium to coarse subangular to rounded clear quartz and subordinate red and orange grains

Feet

159.4

40.0

Total of Dinosaur Canyon Member 
Moenave Formation-Continued

Total of Moenave Formation

Feet 525.

Chinle Formation:

Petrified Forest Member:

11. Silty claystone and subordinate siltstone, pale red purple $(5 R P 6 / 2)$ and grayish red purple $(5 R P 4 / 2)$, common light greenish gray (5GY 8/1) mottling, weathering same colors, swelling clays in places; firmly cemented, noncalcareous; structureless; weathers to form frothy-surfaced slope. Unit contains common lightgreenish-gray (5GY 8/1) and palered-purple $(5 R P 6 / 2)$ dense limestone nodules. These limestone nodules average 2 to 3 in. in diameter but are as much as $1 \mathrm{ft}$ in diameter; they generally comprise only a few percent of the rock, but in a 10-ft layer about $20 \mathrm{ft}$ below top of unit, the limestone nodules constitute about 50 percent of the rock

10. Sandstone, pale red purple (5RP 6/2) and subordinate yellowish gray $(5 Y$ $8 / 1$ ), colors mottled, weathering same colors, fine to medium grained, fair sorted; composed of angular to subangular clear and milky quartz and 15 percent orange grains, abundant dark-green accessory mica; well cemented, slightly calcareous in parts; composed of thin trough and planar sets of small- to medium-scale lowangle cross-laminae; weathers to form ledge

9. Clayey siltstone, grayish red $(10 R 4 / 2)$, weathering same color; swelling clays, common very fine grained white mica; firmly to well cemented, noncalcareous; horizontally laminated to thinly bedded; weathers to form reentrant

8. Sandstone to pebbly sandstone, very pale orange $(10 Y R 8 / 2)$ and sparse pale red purple (5RP 6/2), weathering pinkish gray ( $5 Y R 8 / 1)$, medium to very coarse grained, fair sorted; composed of subangular to subrounded clear quartz and 15 percent orange grains, sparse green accessory grains; firmly to well cemented, noncalcareous; composed of thin trough and wedge planar sets of small- and medium-scale low-angle cross-laminae; weathers to form ledge. Unit contains disseminated granules and pebbles of white, green, and red chert and to a lesser extent of quartz and quartzite. Granules and pebbles average about $1 / 2$ in. in medial diameter but are as much as $31 / 2$ in. in maximum diameter. Granules and pebbles comprise about 5 percent of unit
Chinle Formation-Continued

Petrified Forest Member-Continued

7. Siltstone (90 percent) and sandstone (10 percent). Siltstone, grayish red $(10 R 4 / 2)$ and sparse grayish purple (5P 4/2), weathering same colors; common very fine grained accessory white mica, contains some swelling clays ; firmly cemented, noncalcareous, structureless. Sandstone, grayish red purple $(5 R P 4 / 2)$ and yellowish gray (5Y 8/1), colors mottled, weathering same colors; fine grained, well sorted; composed of subangular clear quartz, 10 percent orange grains, 5 percent green grains, and common dark-green accessory mica; well cemented, slightly calcareous; present as thin to very thin horizontal beds interstratified with siltstone. Sandstone is present mostly in lower half of unit. Unit as whole weathers to form steep slope and is covered except in a gully ........

6. Claystone to clayey siltstone, greenish gray ( $5 G Y 6 / 1)$, medium gray (N 5), and grayish red $(5 R 4 / 2)$, common pale-yellowish-orange $(10 Y R \quad 8 / 6)$ mottling, weathering light greenish gray $(5 G Y 8 / 1)$ and pale purple (5P $6 / 2)$; swelling clays; firmly cemented, noncalcareous; stratification concealed; weathers to form frothy-surfaced badlands

5. Sandstone, pale red $(5 R 6 / 2)$, weathering same color, very fine to fine grained, fair sorted; composed of subangular clear and amber-stained quartz, 10 percent orange grains, and abundant coarse-grained accessory dark and white mica; well cemented, slightly calcareous; horizontally laminated to very thin bedded, subordinate thin trough sets of medium-scale cross-laminae; weathers to form dip slope on east side of hogback in middle of Chinle Formation. Top $3 \mathrm{ft}$ of unit locally contains grayish-red $(5 R$ $4 / 2$ ) ripple-laminated silty very fine grained sandstone. Unit intertongues with overlying unit. Thickness of unit estimated and could possibly be as thin as $3 \mathrm{ft}$ or as thick as $10 \mathrm{ft}$

4. Claystone to siltstone, greenish gray $(5 G Y$ 6/1) and grayish red purple (5RP 4/2), weathering light greenish gray $(5 G Y 8 / 1)$; probably mostly swelling clays; poorly cemented, calcareous; stratification concealed; weathers to form frothy-surfaced slope along hogback in middle of Chinle Formation

3. Sandstone, pale red $(10 R 6 / 2)$, weathering same color, fine to medium grained, fair sorted; composed of

. 
Chinle Formation-Continued

Petrified Forest Member-Continued subangular clear and amber-stained quartz and 2 to 3 percent coarsegrained dark mica; firmly cemented, calcareous; composed of thin trough and planar sets of medium-scale lowangle cross-strata and subordinate very thin horizontal beds. Unit weathers to form ledge

2. Silty claystone to siltstone ( 80 percent) and clayey sandstone (20 percent). Silty claystone to siltstone, light greenish gray (5GY 8/1) (70 percent), light gray $(N 7)$, and grayish red $\left(5 R^{4 / 2}\right.$ and $\left.10 R 4 / 2\right)$, weathering same colors; mostly swelling clays; firmly cemented, calcareous in parts; stratification concealed. Clayey sandstone, light greenish gray ( $5 G Y$ $8 / 1$ ), weathering same color, fine to medium grained, poorly sorted; composed of angular to subangular milky quartz, 5 percent orange grains, and 5 percent dark-green mica; poorly cemented, calcareous and clay binding; stratification concealed. Unit weathers to form frothy-surfaced slope. Parts of unit poorly exposed. Middle of unit contains a 10-ft set of horizontally laminated, micaceous, platy splitting siltstone which contains sparse fairly well preserved carbonized plant remains

Total of Petrified Forest Member

Shinarump Member:

1. Sandstone (95 percent) to conglomerate (5 percent), very pale orange $(10 Y R$ $8 / 2)$ and grayish orange $(10 Y R 7 / 4)$, weathering same colors. Sandstone, fine to very coarse grained, fair to poorly sorted; composed of angular to subrounded clear and milky quartz and sparse black accessory minerals, common interstitial clays; firmly to poorly cemented, calcareous, some limonite(?) cement; composed of thin trough and planar sets of small- and medium-scale cross-strata and thin to thick horizontal beds. Conglomerate, grades to conglomeratic sandstone; composed of granules, pebbles, and "sparse cobbles of reddish, white and gray quartz, quartzite, and chert in a matrix of sand similar to that in sandstone part of unit. Granules and pebbles are in thin to thick lenses of conglomerate and are also scattered irregularly in the sandstone. Largest cobble noted was 3 in. in maximum diameter. Unit weathers to form vertical cliff in lower part and long dip slope in upper part. Base of
Chinle Formation-Continued Shinarump Member-Continued unit not exposed. Thickness of unit difficult to measure because of high dip and long dip slope. Thickness might be in error by 10 percent. Unit contains common silicified logs

Total of Shinarump Member

13.9

Total of Chinle Formation

Moenkopi Formation, top part covered.

Base of section; not base of exposure. Base of section is $\mathrm{N} .55^{\circ}$ E. of place where U.S. Highway 91 crosses Taylor Creek and S. $49^{\circ} \mathrm{E}$. of junction of U.S. Highway 91 and New Harmony road. Section measured along an east-trending line.

\section{U-23. FOSSIL WOOD WASH}

Measured 17 miles southwest of Paria, Utah, at Petrified Forest, secs. 34 and 35, T. 42 S., R. 4 W., and sec. 2, T. 43 S., R. \& W., SLM, Kane County ।

[Measured by L. C. Craig and T. E. Mullens, May 1952]

Top of section; top of accessible exposure.

Moenave Formation (incomplete) :

Springdale Sandstone Member (incomplete) :

34. Sandstone (60 percent) and silty to sandy claystone (40 percent). Sandstone, moderate reddish orange $(10 R$ $6 / 6)$ to pale reddish brown (10R $5 / 4)$, very fine to fine grained, well sorted; composed of subangular clear quartz with common mica flakes, other accessory minerals masked; subhorizontally bedded with fine- to mediumscale cross-laminae and horizontal to ripple laminae. Claystone similar to claystone in unit 30 . Claystone predominates in lower half, sandstone in upper half. Lower part of unit forms steep ledgy slope, upper part a ledgy cliff. Fish plates occur in middle of unit

33. Sandstone, similar to that in unit 30 except clay partings are missing. Units 31,32 , and 33 form prominent cliff

32. Sandstone, pale-red $(5 R 6 / 2)$, mediumgrained; composed of clear quartz, accessory minerals masked; abundant interstitial clay and grayish red clay pellets; poorly cemented, noncalcareous

Total of incomplete Springdale Sandstone Member

Dinosaur Canyon Member:

NoTE. - Contact of Dinosaur Canyon and Springdale Sandstone Members not certain. Unit 31 may be part of Springdale.

31. Sandstone (80 percent) and siltstone (20 percent). Sandstone, moderate reddish brown $(10 R 4 / 6)$ to moderate reddish orange $(10 R 6 / 6)$, similar
Feet

Feet

$\frac{82 \pm}{\frac{82 \pm}{484.5}}$

97.5 
Moenave Formation (incomplete)-Continued

Dinosaur Canyon Member-Continued

texture and composition to sandstone in unit 30 ; parallel to ripple laminated. Siltstone, pale reddish brown $(10 R 4 / 4)$, minor dusky red $(5 R 3 / 4)$. Siltstone forms partings 2 to 6 in. thick separating horizontal to gently lensing beds of sandstone 1 to $4 \mathrm{ft}$ thick. Abundant and prominent mud cracks occur in siltstone and are filled with sand. Mud cracks about 6 in. deep

30. Sandstone (60 percent) and claystone (40 percent). Sandstone, moderate reddish orange $(10 R 6 / 6)$, moderate reddish brown $(10 R 4 / 6)$, streaks and mottles of pale greenish yellow ( $10 Y$ $8 / 2$ ), very fine grained, well sorted; composed of angular to subangular clear quartz, common black accessory minerals; horizontally bedded (6-in. to 3-ft beds) with abundant cuspate ripple marks. Claystone, variably silty to sandy, grayish red ( $5 R$ $4 / 2$ ) and moderate reddish brown $(10 R 4 / 6)$, fissile to earthy weathering. Lithologies gradational. Sandstone forms ledges in earthy slope. Banded Butte due south of base of unit

Section offset so that overlying units measured about $1 / 2$ mile west of underlying units.

29. Sandstone, similar to unit 27. Capped by a $11 / 2-f t$ white sandstone. Unit forms cliff with two ledges and is exposed at head of gully

28. Claystone, silty to sandy (fine-grained), moderate reddish brown (10R 4/6), light-green mottles, contains abundant biotite flakes, hackly to earthy weathering, forms steep slope ............

27. Sandstone, moderate-reddish-orange $(10 R 6 / 6)$ to moderate-reddish-brown $(10 R 4 / 6)$, very fine grained; composed of clear and amber-stained quartz with common black accessory minerals, moderate cement. Unit is sequence of parallel beds 6 in. to $6 \mathrm{ft}$ thick containing ripple laminae and small-scale cross-laminae. Unit forms steep cliff locally. Top $15 \mathrm{ft}$ of unit forms double ledge capping talus slope. Unit capped by a 6 in. white sandstone bed

26. Claystone, moderate-reddish-brown $(10 R 4 / 6)$, slightly silty; hackly weathering; forms moderate-reddishbrown earthy slope

25. Sandstone, very pale orange (10YR $8 / 2)$, mottled with pale-reddish-brown $(10 R 5 / 4)$ streaks, very fine grained;
Moenave Formation (incomplete)-Continued Dinosaur Canyon Member-Continued composition same as unit 24. Forms blocky capping ledge over unit $24 \ldots$

24. Sandstone, yellowish gray $(5 Y$ 8/1) and very pale orange $(10 Y R 8 / 2)$, very fine grained with disseminated medium and coarse grains, poorly sorted; composed of clear quartz with abundant red, orange, and black accessory minerals; poorly cemented, noncalcareous; structures masked; forms prominent white band at base of orange cliff

23. Sandstone, moderate-reddish-brown $(10 R 4 / 6)$, very fine grained to silty, poorly sorted; composed of clear and amber-stained quartz, accessory minerals masked; horizontally to ripple laminated; shaly to earthy weathering; forms earthy slope

22. Sandstone, conglomeratic at base, very pale orange $(10 Y R 8 / 2)$, weathers grayish orange pink $(5 Y R 7 / 2)$, very fine and coarse grained, poorly sorted; composed of clear quartz (some coarse well-rounded and frosted grains) and red, green, and black accessory minerals; thinly bedded and laminated, some ripple marks; forms small lenticular ledge

Total of Dinosaur Canyon Member Total of incomplete Moenave

Formation

Chinle Formation:

Petrified Forest Member:

21. Sandstone (80 percent) and claystone (20 percent). Sandstone, pale red to grayish red, streaks of light greenish gray, fine to medium grained, fair sorted; composed of clear quartz with abundant biotite flakes and red, green, and black accessory minerals. Claystone, silty to sandy (fine-grained), moderate reddish brown (10R 4/6). Claystone forms indistinct cap of unit. Unit weathers to a grayish-pink $(5 R$ 8/2) steep slope

20. Claystone, slightly silty to moderately sandy, pale reddish brown $(10 R 5 / 4)$, weathers same color; sand grains of clear quartz, abundant black, green, and orange accessory minerals, black mineral probably biotite; earthy to frothy weathering; forms steep slope

19. Gypsum, white, coarsely crystalline, fibrous in places, fairly persistent bed

18. Sandstone, grading upward to sandy claystone and silty claystone. Sandstone, pale red $(10 R 6 / 2)$, very fine to medium grained, poorly sorted; composed of clear quartz, abundant

\section{4}

$=$ 
Chinle Formation-Continued

Petrified Forest Member-Continued

green, orange, and black accessory minerals; contains granules and pebbles of red claystone as large as $1 / 2$ in. at base; locally calcareous and well cemented, but mostly poorly cemented. Claystone, moderate reddish brown. $(10 R 4 / 6)$, earthy weathering

17. Claystone, grayish red $(10 R 4 / 2)$, pale reddish brown $(10 R 5 / 4)$, light greenish gray $(5 G 8 / 1)$, and greenish gray $(5 G Y 6 / 1)$ in roughly parallel bands with gray and purple the dominant color; variably silty and sandy, sand grains up to medium grained; hackly to frothy weathering; forms very steep frothy. slope. Color bands gently lenticular. Basal $160 \mathrm{ft}$ contains more purple colors; common limestone nodules and local carnelian in the upper part of the $160 \mathrm{ft}$. The upper part of the unit has a more reddish-brown tint than the basal part

16. Silty claystone, grayish-red $(10 R 4 / 2)$; frothy weathering; forms a persistent distinctive band

15. Silty claystone, greenish gray ( $5 G Y$ $6 / 1)$, mottled grayish red $(10 R 4 / 2)$ along fractures; frothy weathering....

14. Sandstone, similar to unit 12 except contains more interstitial clay, is a very lenticular bed, and does not form a prominent ledge

13. Claystone, silty and sandy (finegrained), grayish red purple $(5 P R$ $4 / 2)$, weathers grayish red $(5 R 4 / 2)$; hackly to frothy weathering; forms lenticular parting between units 12 and 14

12. Sandstone, yellowish gray $(5 Y 8 / 1)$ to grayish orange pink $(10 R 8 / 2)$, weathers pinkish, fine to very fine grained, poorly sorted; composed of subangular clear quartz, abundant orange and sparse red and green accessory minerals, slightly calcareous, abundant interstitial clay; bedding indistinct, lenticular cross-laminated sets; weathers to smooth rounded cliff with lower part steeper and more resistant than upper part

11. Claystone, variegated, silty and slightly sandy (very fine grained). Colors range from light gray $(N 7)$ to medium dark gray $(N \quad 4)$ with thin bands of grayish red $(10 R 4 / 2)$ and grayish red purple (5RP 4/2). Slightly hackly to deep frothy weathering. Unit forms steep slope under sandstone ledge of overlying unit ....

Section offset, so that overlying units were measured starting 200 yd west of where unit 10 was measured.
Feet Chinle Formation-Continued

Petrified Forest Member-Continued

10. Claystone, slightly silty in lower half, very silty and sandy in upper half, grayish red purple $(5 R P 4 / 2)$ and grayish red $(10 R 5 / 2)$ interbanded, minor greenish-gray mottling; hackly to frothy weathering in lower half, earthy weathering in upper half ......

9. Claystone, slightly silty, very light gray $(N 8)$ to medium light gray $(N 6)$; hackly to frothy weathering, much reddish iron staining along fractures in lower two-thirds of unit and a concentration of red color about $10 \mathrm{ft}$ above base. Unit forms a prominent white band

8. Claystone, silty, grayish red $(10 R 4 / 2$ and $5 R 4 / 2$ ), weathering pale reddish brown $(10 R 5 / 4)$; hackly weathering; conchoidal fracture; forms prominent band near foot of slope ....
204.4
7. Claystone, silty and slightly sandy (up to coarse grained), grayish purple (5P 4/2) ; frothy weathering. Lateral to section unit contains clayey sandstone at top, but on line of section sand occurs only as disseminated grains. Sparse light-greenish-gray mottles. Unit forms base of variegated slope on east side of the wash

6. Covered. Forms flat surface

5. Sandstone and minor amounts of claystone. Sandstone, very clayey, pale red purple (5RP 5/2) to grayish orange pink $(5 Y R 7 / 2)$, weathering grayish orange pink $(5 Y R 7 / 2)$, very fine to coarse grained with sparse granules, poorly sorted; composed of subangular quartz with uncommon pink and gray accessory minerals. Sand grains in matrix of grayishorange-pink $(5 Y R 7 / 2)$ to grayishred clay. Sandstone poorly cemented, noncalcareous; weathers to earthy frothy slope. Claystone, grayish purple $(5 P 4 / 2)$, silty; hackly weathering. Unit forms small knob at road....

4. Claystone, silty to slightly sandy (as coarse as fine grained), greenish gray (5GY 6/1) to dusky yellow green $(5 G Y 5 / 2)$, weathers very light gray $(N 8)$ to grayish yellow green $(5 G Y$ $7 / 2$ ) ; frothy weathering; forms low badlands on flat surface. At top of unit is horizon of silicified trees. Trees are mainly light gray, weather tan, and contain well preserved structures. Largest tree observed is $33 \mathrm{ft}$ long and 13 in. in diameter. This fossil-wood horizon is persistent in line of section

3. Claystone, silty to sandy (fine-grained), light greenish gray (5GY 8/1) 
Chinle Formation-Continued

Petrified Forest Member-Continued (weathering very light gray $(N 8)$ ) in lower half, grayish red $(10 R 4 / 2)$ (weathering dark reddish brown $(10 R$ $3 / 4)$ ) in upper half. Clay is slightly fissile; earthy to frothy weathering. The upper red part is covered with a rubble of grayish-brown $(5 Y R 3 / 2)$ very fine grained calcareous concretions of irregular shapes and as large as $1 \frac{1}{2}$ in. in diameter

Total of Petrified Forest Member

Shinarump Member:

2. Sandstone, slightly conglomeratic, yellowish-gray (5Y 8/1), very fine to coarser-grained, mainly coarsegrained, poorly sorted; composed of angular to well-rounded quartz, common black and pink accessory minerals. Basal $2 \mathrm{ft}$ and top $1 \mathrm{ft}$ moderately calcareous and form ledges. Middle part is poorly exposed but contains pebbles as large as 2 in. in diameter of gray to tan quartzite, of black, tan, and light-red chert, and to a lesser extent of white quartz. Thin ledges suggest scour-type bedding. Small-scale cross-laminations present in ledges. Base of Shinarump exposed in wash. Top ledge caps a small hill on bank of wash. Unit poorly exposed

Total of Shinarump Member..........

Total of Chinle Formation

Moenkopi Formation (incomplete) :

Upper red member (incomplete) :

1. Claystone, silty and slightly sandy, very dusky red $(10 R 2 / 2)$, grading upward to grayish yellow green ( $5 G Y 7 / 2$ ), slightly fissile, earthy weathering. Section measured in wash and through place called Petrified Forest on central Kane County map of Gregory (1948)

Total of incomplete upper red member

Base of local exposure.

$$
\text { U-24. PARIA }
$$

Measured generally $N .42^{\circ} W$. up promontory about 2 miles N. $80^{\circ} \mathrm{W}$. of abandoned town of Paria, sec. $14, T .41 \mathrm{~S}$. $R$. 2 W., SLM, Kane County

[Measured by J. H. Stewart, October 1954]

Top of section; top of exposure. Section ends at flat at top of cliffs.

Kayenta Formation (incomplete) :

27. Sandstone, very pale orange (10YR $8 / 2$ ), weathering same color, fine grained, well sorted; composed of rounded clear quartz and sparse black accessory minerals; poorly cemented,
Feet | Kayenta Formation (incomplete)-Continued slightly calcareous; composed of thin to very thick (as much as $10 \mathrm{ft}$ ) trough and planar sets of small- to large-scale cross-laminae; weathers to form slope with many conspicuous ledges. About 15 percent of unit is composed of strata similar to those in the underlying two units. These strata are present as thick to very thick (probably as much as $15 \mathrm{ft}$ ) cosets interstratified with the rest of the unit. Many of these strata contain abundant (as much as 30 percent) reddish siltstone granules to pebbles. Unit is transitional between the Kayenta Formation and the Navajo Sandstone. Cross-stratified sandstone strata may be tongues of the Navajo Sandstone. Unit approximately $200 \mathrm{ft}$ thick, and 1 mile southwest of line of section is overlain by large-scale cross-stratified sandstone typical of the Navajo Sandstone.... Unmeasured

26. Sandstone, pale red (10R $6 / 2$ and $5 R$ $6 / 2$ ) and minor amounts of grayish orange $(10 Y R 7 / 4)$, weathering pale red $(5 R 6 / 2)$, grayish orange $(10 R$ $7 / 4)$, and very pale orange $(10 Y R$ $8 / 2$ ), dominantly fine grained; weathers to form ledgy slope; otherwise similar to underlying unit. Sets containing abundant reddish granules to cobbles of siltstone occur commonly in unit

Total of incomplete Kayenta Formation

Moenave Formation:

Springdale Sandstone Member:

25. Sandstone, pale reddish brown $(10 R$ $5 / 4)$, moderate reddish orange ( $10 R$ $6 / 6)$, and minor amounts of pale red (5R $6 / 2$ and $10 R 6 / 2$ ), weathering light brown $(5 Y R \quad 6 / 4)$ and pale reddish brown $(10 R 5 / 4)$, very fine grained, well sorted; composed of subangular amber quartz and sparse black accessory minerals; poorly to firmly cemented, calcareous; dominantly horizontally laminated, about 10 percent is composed of thin to thick trough sets of small- to mediumscale cross-laminae, sparse thin planar sets of very low angle cross-laminae; massive splitting; weathers to form cliff containing many smooth and round ledges, forms most conspicuous cliff below that of unit 27. The sandstone in many places contains diskshaped coarse grains to pebbles of reddish siltstone. One thin set of dark-reddish-brown $(10 R \quad 3 / 4)$ siltstone seen at $131 \mathrm{ft}$ above base of 
Moenave Formation-Continued

Springdale Sandstone Member-Continued unit. Basal $2 \mathrm{ft}$ of unit contains common medium to very coarse rounded and frosted grains

Total of Springdale Sandstone

Member

Dinosaur Canyon Member:

24. Sandstone to siltstone ( 80 percent) and siltstone (20 percent). Sandstone to siltstone, pale reddish brown (10R $5 / 4)$ and light brown (5YR 6/4), weathering pale reddish brown (10R $5 / 4)$, mostly very fine grained sandstone, silty in places, but commonly grades to sandy siltstone and siltstone, fair sorted; sand is subangular and composed of amber quartz grains; poorly to firmly cemented, slightly calcareous; horizontally laminated and cuspate ripple laminated; flaggy to massive splitting. Sandstone to siltstone is present as very thin to very thick sets interstratified with very thin to thick sets of siltstone. Siltstone, pale reddish brown $(10 R 5 / 4)$, weathering same; sandy (very fine grained) in parts; common very fine grained white mica; firmly cemented, calcareous; horizontally laminated. Sandstone to siltstone weathers to form flaggy to massive ledges separated by reentrants formed in siltstone. To north of line of section entire unit weathers to form a vertical cliff. Medium to coarse grains occur in the sandstone to siltstone in a few places

23. Silty sandstone, pale reddish brown $(10 R 5 / 4)$ to grayish red $(10 R 4 / 2)$, weathering same colors, very fine grained, silty, fair sorted; firmly cemented, calcareous; seems to be mostly structureless but horizontal laminae visible in places; weathers to form slope or reentrant in cliff. Unit has sharp basal contact. Grades to sandy siltstone in places and contains abundant fine-grained accessory white mica in places

Total of Dinosaur Canyon Member

Total of Moenave Formation

Wingate (?) Sandstone (this unit is lithologically similar to, if not identical with, the Wingate Sandstone and is tentatively correlated with that formation) :

22. Sandstone, light brown (5YR 6/4), weathering same color, very fine grained, well sorted; composed of subrounded clear quartz and sparse black accessory minerals; poorly cemented, slightly calcareous; composed

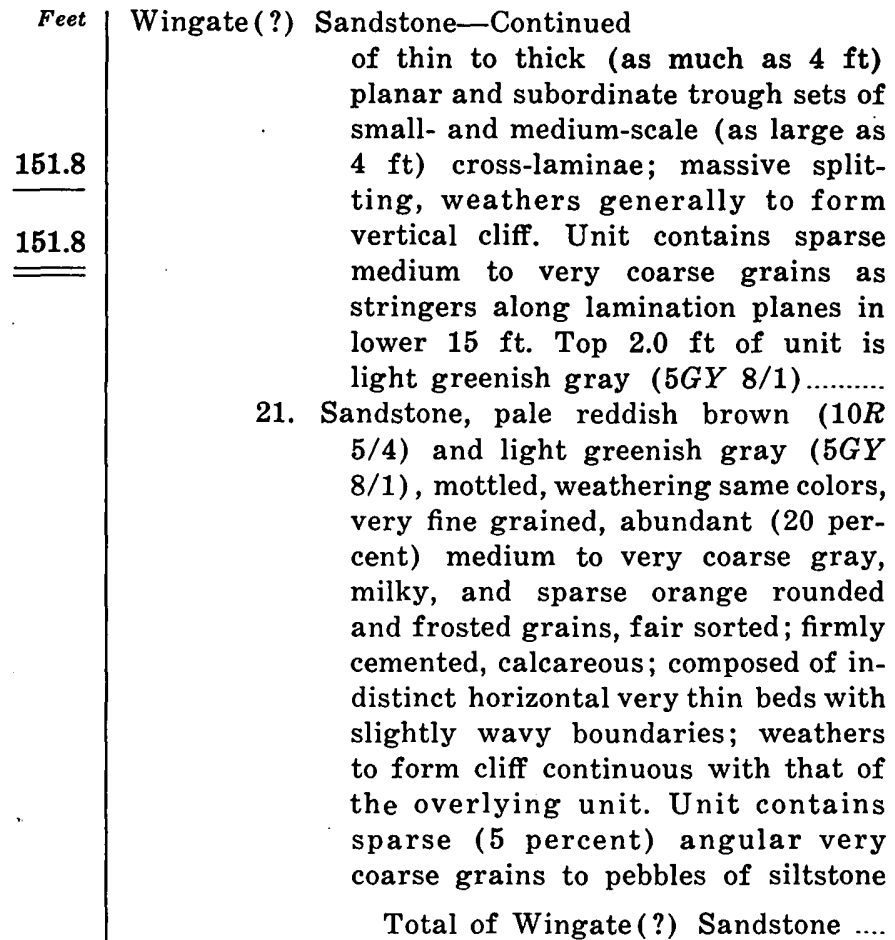

Feet

Contact of Chinle Formation and Wingate(?) Sandstone sharp and even. Contact placed at lithologic and topographic break from reddish and purplish slope-forming siltstone and sandstone below to brownish cliff-forming sandstone above. Basal 1.0 $\mathrm{ft}$ of Wingate(?) contains light-colored streaks and abundant medium to very coarse grains.

Chinle Formation:

Petrified Forest Member:

20. Siltstone, moderate reddish brown $(10 R$ $4 / 6)$, pale reddish brown $(10 R 5 / 4)$, and grayish red $(5 R 4 / 2)$, weathering pale reddish brown $(10 R 5 / 4)$ and moderate pink $(5 R 7 / 4)$, otherwise similar to unit 18 . Thin lenticular unit of sandy siltstone occurs at $30.5 \mathrm{ft}$ above base of unit. This sandy siltstone contains about 30 percent very coarse grains of siltstone. Top $7.3 \mathrm{ft}$ of unit is grayish red $(5 R 4 / 2)$ and is sandy (very fine grained). This top $7.3 \mathrm{ft}$ appears to be ripple laminated

19. Sandstone, pale red $(10 R 6 / 2)$, grayish orange $(10 Y R \quad 7 / 4)$, and subordinate light greenish gray (5GY $8 / 1)$, weathering pale red $(10 R 6 / 2)$, very fine grained, well sorted; composed of subangular clear and milky grains, common medium-grained accessory dark-green mica; firmly cemented, calcareous; composed of thin trough sets of small-scale cross-laminae; stratification partly concealed; weathers to form small ledge. Common seams of gypsum cutting across unit 
Chinle Furmation-Continued

Petrified Forest Member-Continued

18. Clayey siltstone, moderate reddish brown $(10 R 4 / 6)$, weathering pale reddish brown $(10 R \quad 5 / 4)$; firmly indurated, slightly calcareous; structureless; fractures into angular fragments; weathers to form earthy slope. Unit does not appear to be bentonitic. Unit is somewhat similar to strata of the Church Rock Member of the Chinle Formation

17. Sandstone, pale-red $(10 R 6 / 2)$ and lightgreenish-gray (5GY 8/1) mottled, weathering same colors, fine grained, fair sorted; composed of subangular clear quartz and milky grains, common medium-grained accessory white mica; poorly cemented, calcareous; composed of thin to thick trough and planar sets of small- and mediumscale cross-laminae; weathers to form steep bare slope

16. Silty claystone, grayish red $(5 R \quad 4 / 2)$ and subordinate pale red purple $(5 R P$ $6 / 2)$, weathering pale red $(5 R 6 / 2)$; swelling clays; firmly indurated; structureless; weathers to form frothy-surfaced slope

15. Sandstone, pale greenish yellow (10Y $8 / 2)$, grayish red (5R $4 / 2$ and $10 R$ $4 / 2)$, weathering pale red $(10 R 6 / 2)$, fine to medium grained, poorly sorted; composed of angular clear quartz, milky grains, and sparse orange and green grains, common accessory dark mica; poorly indurated, noncalcareous; no stratification seen; weathers to form steep slope. Unit contains several ( 5 percent) thin intervals of grayish-red ( $5 R \quad 4 / 2)$ claystone to silty claystone interstratified with the rest of the unit

14. Claystone, silty in places, variegated, grayish red $(5 R 4 / 2)$, dark reddish brown.(10R 3/4), pale reddish brown $(10 R 5 / 4)$, grayish red $(10 R 4 / 2)$, minor dusky yellow $(5 Y$ 6/4) and grayish yellow green (5GY $7 / 2)$, one conspicuous thick interval of dusky yellow (5Y 6/4), weathering pale red $(10 R 6 / 2)$ and grayish yellow (5Y 8/4); swelling clays; firmly cemented; structureless; weathers to form frothy-surfaced slope. Unit forms conspicuous light-colored interval in Chinle, easily seen on distant exposures

13. Sandstone, pale reddish brown $(10 R$ $5 / 4)$ and pale red $(10 R 6 / 2)$, weathering pale reddish brown (10R 5/4), very fine to fine grained, fair sorted; composed of subangular milky, amber, and black grains, common medium- to
Feet

Chinle Formation-Continued

Petrified Forest Member-Continued coarse-grained dark mica; firmly cemented, slightly calcareous; horizontally thinly laminated to laminated; weathers to form steep slope. Unit in top $10 \mathrm{ft}$ grades to siltstone. One medium-scale cross-stratified set seen at about $8 \mathrm{ft}$ above base

12. Limestone-grain sandstone to limestone pebble conglomerate, grayish purple $(5 P 4 / 2)$ and brownish gray $(5 Y R$ $4 / 1$ ), weathering pale brown (5YR $5 / 2)$, composed of medium grains to pebbles of limestone, very fine to medium milky quartz(?) grains, and interstitial clay (40 percent), poorly sorted; poorly cemented; crudely horizontally laminated; weathers to form slope. Lens-shaped pebbles and cobbles of pale-reddish-brown (10R 5/4) silty claystone are common in unit ....

11. Sandstone, grayish orange pink (5YR $7 / 2$ ), weathering same color, very fine to fine grained, fair sorted; composed of subangular clear, milky, and amber grains, abundant fine- to mediumgrained dark mica; poorly cemented, slightly calcareous; horizontally thinly laminated to laminated; weathers to form slope. Light-greenish-gray ( $5 G Y$ $8 / 1)$ spots are abundant in unit ........

10. Claystone, moderate red $(5 R 4 / 6)$, dusky red $(5 R 3 / 4)$, pale reddish brown $(10 R 5 / 4)$, grayish red $(5 R$ $4 / 2)$, and grayish red purple (5RP $4 / 2$ ), weathering same colors; firmly indurated; structureless; horizontal color bands suggest horizontal stratification; weathers to form frothysurfaced slope. Limestone nodules are present rarely. Thin layers of limestone nodules occur at $42 \mathrm{ft}$ above base of unit and at top of unit ........

9. Claystone, pale red purple (5RP 6/2), abundant light-greenish-gray ( $5 G Y$ $8 / 1$ ) mottling, light greenish gray increases in content. upward and forms 50 percent of the upper third of the unit, weathering pinkish gray $(5 Y R .8 / 1)$, limy throughout, top 0.5 $\mathrm{ft}$ of unit contains abundant limestone nodules and lenses several feet long; firmly to well cemented, calcareous; structureless; weathers to form slope. Unit forms persistent white band easily seen on cliffs about 2 miles east and 1.5 miles south of line of section. Two pelecypods about $3 / 8$ in. across seen in cross section in limestone nodule at top of unit

8. Claystone, dominantly greenish gray $(5 G Y 6 / 1)$ and light greenish gray $(5 G Y 8 / 1)$ in lower half and pale
Feet

63.8 
Chinle Formation-Continued

Petrified Forest Member-Continued reddish brown $(10 R 5 / 4)$ and moderate red $(5 R 4 / 6)$ in upper half, but colors are variegated throughout, and unit contains sparse (5 percent) pale red purple (5RP 6/2) throughout, weathering same color; but in lighter values; swelling clays; well cemented; color bands probably reflect bedding, color bands generally from 5 to $20 \mathrm{ft}$ thick; weathers to form frothy-surfaced slopes and badlands. Limestone nodules are common in a few thin layers

7. Sandstone, yellowish gray $(5 Y 8 / 1)$ and very light gray $(N 8)$, weathering same colors, medium to coarse grained, fair sorted; composed of subangular to subrounded clear quartz; poorly cemented, calcareous; composed of thin to thick trough and planar sets of small- to medium-scale cross-laminae; weathers to form most prominent ledge and bench in the Chinle Formation. Bottom $1 \mathrm{ft}$ of unit contains many seams of carbonaceous material. Unit is discontinuous and may be present as lenses on distant exposures to east

6. Conglomeratic sandstone, yellowish gray $(5 Y \quad 8 / 1)$ and grayish yellow (5Y $8 / 4)$. Matrix, very fine to very coarse grains of subangular to subrounded clear quartz; clasts, rounded granules to pebbles as large as $1.5 \mathrm{in}$. in diameter of white to black chert; one quartz pebble seen; chert pebbles commonly contain some fossil material.. Unit is poorly cemented, slightly calcareous; structureless; and weathers with the overlying unit to form a cliff

5. Claystone to clayey sandstone, greenish gray $(5 G Y 6 / 1)$, light greenish gray $(5 G Y 8 / 1)$, grayish red purple (5RP $4 / 2)$, grayish red $(5 R 4 / 2)$, and yellowish gray $(5 Y .8 / 1)$, variegated, weathering same colors, grades from claystone to clayey very fine grained sandstone. Sandstone composed of subangular milky and subordinate orange and green grains and common coarse-grained accessory darkgreen mica. Sandstone is poorly cemented and has a slightly calcareous clay binding. Unit appears structureless; exposures to north appear to have large-scale cross-strata. Unit as whole weathers to form slope ........

4. Sandstone, light greenish gray (5GY $8 / 1$ ), weathering same color, fine to medium grained, fair sorted; com-
Feet

Chinle Formation-Continued

Petrified Forest Member-Continued

posed of subangular milky grains and 10 percent orange and green minerals, abundant accessory mediumto coarse-grained dark-green mica; poorly cemented, slightly calcareous; structureless; weathers to form whitish-appearing slope

3. Claystone, greenish gray $(5 G Y 6 / 1)$ medium light gray $(N 6)$, and subordinate grayish red $(10 R 4 / 2) \quad(10$ percent) and grayish red purple (5RP 4/2) (5 percent), variegated, weathering mostly light greenish gray (5GY 8/1), claystone grading commonly to siltstone and very fine grained sandstone; swelling clays; firmly indurated; structureless, some horizontal bedding planes; weathers to form frothy-surfaced slope. A conspicuous sandstone about $1,500 \mathrm{ft}$ to the northeast of line of section develops out of the lower half of this unit

2. Claystone to clayey sandstone, grayish purple $(5 R 4 / 2)$ in lower $6 \mathrm{ft}$, and grayish red $(5 R 4 / 2)$ in rest of unit, weathering pale red purple (5RP $6 / 2$ ), claystone in basal $6 \mathrm{ft}$ of unit grades upward into clayey very fine grained sandstone in upper part of unit. Sandstone composed of subangular grains of unknown composition and of sparse accessory mediumto coarse-grained mica. Stratification is concealed. Unit weathers to form frothy-surfaced slope. Unit forms purplish and reddish band at base of Chinle. Contains swelling clays ........

Total of Petrified Forest Member

Total of Chinle Formation

Contact of Chinle and Moenkopi sharp and placed at color and texture change.

Moenkopi Formation:

1. Siltstone, grayish red $(10 R 4 / 2)$, weathering pale reddish brown $(10 R 5 / 4)$; common very fine grained white mica; well indurated, noncalcareous; structureless to thinly horizontally bedded; weathers to form earthy slope. Unit contains common thin light-colored bands. Abundant light-greenish-gray (5GY 8/1) mottling in top $0.4 \mathrm{ft}$..Unmeasured

Base of section; not base of exposure.

\section{U-25. BEARS EARS}

Measured up gully to the southwest of the Bears Ears and up southwest side of eastern peak of the Bears Ears, sec. 30 (unsurveyed), T. 36 S., R. 19 E., SLM, San Juan County

[Measured by J. H. Stewart and G. A. Williams, May 1953]

Top of section; not top of exposure. 
Wingate Sandstone:

31. Sandstone, light brown (5YR 6/4), weathering same color, very fine grained, well sorted; composed of subrounded clear quartz and sparse black accessory minerals; firmly cemented, calcareous; stratification poorly exposed, but apparently mostly horizontally laminated; massive splitting; weathers to form vertical cliff. Sandstone contains abundant well-rounded coarse grains. Only basal $10 \mathrm{ft}$ of unit examined. Basal $0.3 \mathrm{ft}$ is pale reddish brown $(10 R 5 / 4)$ and appears silty. Unit is very light gray $(N 8)$ from $0.3 \mathrm{ft}$ to $0.7 \mathrm{ft}$ above base. No scouring along basal contact noted.. Unmeasured

Contact of Wingate and Chinle placed at lowest occurrence of coarse well-rounded grains, a feature which is typical of the basal Wingate. Aside from the basal $0.7 \mathrm{ft}$ of the Wingate, which has anomalous colors, the Wingate is a distinctly different color from the Chinle. The Wingate is a light brown, whereas the Chinle is reddish or purplish.

Chinle Formation:

Church Rock Member:

Hite Bed:

30. Sandstone, pale reddish brown $(10 R$ $5 / 4)$, pale red $(10 R 6 / 2)$, and pale red purple $(5 R P 6 / 2)$; abundant yellowish-gray $(5 Y 8 / 1)$ laminae and mottles; weathers same colors; very fine grained; well sorted; firmly cemented, slightly calcareous; composed of thin to thick trough sets of low-angle medium- to large-scale cross-laminae; platy splitting; weathers to form vertical cliff. Sparse thin sets of sandstone that contain up to 30 percent siltstone granules and pebbles

Total of Hite Bed

29. Siltstone, similar to dominant siltstone in unit 28. Weathers to form steep slope and prominent small ledges......

Total of Church Rock Member

Owl Rock Member:

28. Heterogeneous unit of siltstone and limestone. Siltstone, grayish red (10R 4/2), abundant light-greenishgray $(5 G Y$ 8/1) spots, weathering pale red $(10 R 6 / 2)$; firmly cemented, calcareous, stratification concealed. Interstratified with this main siltstone type, which makes up about 85 percent of unit, are another type of siltstone, silty claystone, limestone, and silty conglomerate to silty sandstone. The other type of siltstone is pale red $(10 R 6 / 2)$, with abundant light-greenish-gray (5GY
Feet

Chinle Formation-Continued

Owl Rock Member-Continued

8/1) spots, weathering same colors; firmly to well cemented, calcareous; horizontally laminated; platy splitting. This type of siltstone comprises about 10 percent of the unit and is mostly in lower third of unit. The silty claystone is the same as the dominant type of siltstone except for the grain size and platy splitting. The silty claystone occurs rarely in the lower third of the unit. The limestone is light greenish gray (5G $8 / 1$ ), aphanitic; well cemented; very thin to thick bedded; flaggy to slabby splitting. Limestone from 1.7 $\mathrm{ft}$ to $3.7 \mathrm{ft}$ contains as much as 30 percent granules to cobbles of siltstone as large as $3 \mathrm{in}$. in diameter (many flat pebbles and cobbles). Limestone occurs from $1.7 \mathrm{ft}$ to 3.7 $\mathrm{ft}$ and constitutes about 20 percent of unit from $27.5 \mathrm{ft}$ to $39.8 \mathrm{ft}$. Silty conglomerate to silty sandstone occurs in lower $1.7 \mathrm{ft}$ of unit and is composed of about 40 percent wellrounded grayish-red $(10 R \quad 4 / 2)$ siltstone granules or very coarse grains in silt matrix. Unit as whole weathers to form steep pale-red (10R 6/2) slope

27. Siltstone, light brown (5YR 6/4), sparse pale reddish brown $(10 R 5 / 4)$, and grayish red $(10 R 4 / 2)$, weathering light brown (5YR 6/4); firmly to well cemented, calcareous; stratification poorly exposed and developed, mostly thick to very thick horizontal beds, sparse parallel and ripple laminae; fractures into angular pebble-sized fragments; weathers to form steep loose slope with common thin to thick ledges

26. Siltstone, light brown (5YR 6/4) weathering same color; well cemented, calcareous; ripple laminated, sparse thin trough sets of mediumscale cross-laminae; platy to slabby splitting; weathers to form prominent ledge on ridge in saddle between Bears Ears. Unit grades into overlying unit. Section transferred on base of unit. Underlying units measured up to ridge in saddle between Bears Ears. Overlying units measured at south ear of Bears Ears

25. Siltstone, light brown $(5 Y R 6 / 4)$ and pale reddish brown $(10 R 5 / 4)$, abundant light-greenish-gray ( $5 G Y$ $8 / 1)$ spots, weathering pale red $(10 R$ $6 / 2)$; firmly to well cemented, calcareous; stratification poorly devel-
Feet 
Chinle Formation-Continued

Owl Rock Member-Continued

oped but some possible ripple laminae; platy to flaggy splitting; weathers to form slope with a few hard ribs. Top 3 ft poorly exposed but probably mostly siltstone similar to that in unit 24. Basal $0.4 \mathrm{ft}$ composed of pale-red $(10 R 6 / 2)$ silty aphanitic limestone about $10 \mathrm{ft}$ to west of line of section

24. Siltstone, pale reddish brown $(10 R$ $5 / 4)$, abundant light-greenish-gray $(5 G Y \cdot 8 / 1)$ spots, weathering pale red $(10 R 6 / 2)$; firmly cemented, calcareous; stratification and splitting concealed; weathers to form loose slope

23. Siltstone to silty sandstone, pale red $(10 R 6 / 2)$ and pale reddish brown $(10 R 5 / 4)$, weathering pale red $(10 R 6 / 2)$. Silty sandstone, fine grained with minor amounts of silt, poor sorting; composed of indistinct white and pale-red grains of unknown composition. Siltstone to silty sandstone, firmly cemented, calcareous; ripple laminated; platy splitting; weathers to form slope. Unit poorly exposed. Abundant lightgreenish-gray $(5 G Y \quad 8 / 1)$ spots ....

22. Poorly exposed or covered along line of section. Exposures along line of section and away from line of section indicate that unit is similar to the underlying unit except that it contains at least one 5 -ft-thick set of clayey sandstone. Clayey sandstone, pale red purple (5RP 6/2) with abundant light greenish gray (5GY 8/1), weathering same colors, very fine grained, minor amounts of clay, grades to siltstone, poorly sorted; firmly cemented, calcareous; horizontally and ripple laminated; papery to flaggy splitting

21. Clayey siltstone, about $2 / 3$ pale reddish brown $(10 R 5 / 4)$ and $1 / 3$ pale red purple (5RP 6/2), weathering dominantly pale red purple $(5 R P 6 / 2)$ with subordinate pale reddish brown (10R 5/4), abundant light greenish gray $(5 G Y 8 / 1)$, otherwise same as unit 19. Five-foot interval in middle of unit contains swelling clay. Limestone-grain sandstone, from 29.0 to $30.0 \mathrm{ft}$ above base of unit, light greenish gray ( $5 G Y 8 / 1)$, weathering same color, poorly sorted; composed of well-rounded very coarse grains of limestone in an aphanitic calcite matrix; well cemented; horizontally thinly bedded; flaggy to slabby split-
Feet

Chinle Formation-Continued

Owl Rock Member-Continued

ting. Limestone-grain sandstone only present locally on outcrop. Unit measured up head of amphitheater at head of gully

20. Limestone, greenish gray (5GY 6/1) and pale red purple (5RP 6/2), weathering grayish orange $(10 Y R$ $7 / 4)$ and pale red purple (5RP 6/2), aphanitic; well cemented; stratification poorly exposed, but contains thin, horizontal beds and possible horizontal laminae; flaggy to slabby splitting; weathers to form small ledge in amphitheater at head of main gully. Section transferred at the base of this unit from hill to west of main gully to amphitheater at head of main gully. Away from the line of section, in the amphitheater area, several thin limestone sets occur a few feet above or below unit

19. Clayey siltstone, pale reddish brown $(10 R 5 / 4)$, pale red $(10 R 6 / 2)$, sparse pale red purple $(5 R P 6 / 2)$, abundant light-greenish-gray $(5 G Y \quad 8 / 1)$ and grayish-yellow-green (5GY $7 / 2)$ spots, weathering same colors; firmly cemented, calcareous; stratification concealed; weathers to form slope. Sparse light-greenish-gray limestone nodules. Basal $40 \mathrm{ft}$ of unit poorly exposed. Measured on hill to west of main gully

Total of Owl Rock Member..

Petrified Forest Member:

18. Covered. Measured from exposures in main gully to exposures on side of hill to west of main gully

17. Silty claystone to clayey siltstone, pale red purple $(5 R P 6 / 2)$, grayish red purple (5RP 4/2), sparse grayish red $(10 R 4 / 2)$, weathering pale red purple $(5 R P$ 6/2) and grayish red purple $(5 R P 4 / 2)$; poorly to firmly cemented, calcareous; stratification concealed; weathers to form broad bench. Abundant greenish-gray ( $5 G Y$ $6 / 1$ ) spots. Limestone, light gray ( $N$ 7) weathering same color, aphanitic with subordinate blebs of mediumgrain-sized calcite crystals, well cemented, structureless; slabby splitting. Limestone is present as thin beds interbedded with the rest of the unit at $12.8 \mathrm{ft}$ and at $16.8 \mathrm{ft}$. Unit is exposed in the bottom of a creek where the exposures are complete or nearly complete. Possibly unit has been displaced in part by recent landslides, as the limestone beds dip at a
Feet

60.9 
Chinle Formation-Continued

Petrified Forest Member-Continued high angle to the regional dip. Most of unit contains swelling clay

Total of Petrified Forest Member....

Moss Back Member:

16. Sandstone, similar to unit 4 except composed of trough sets of medium-scale cross-laminae; weathers to form ledge

15. Covered

14. Sandstone similar to unit 4 except dominantly fine grained and contains thin trough sets of medium-scale crosslaminae

13. Covered

12. Sandstone, yellowish gray $(5 Y 7 / 2)$ and pale yellowish orange $(10 Y R 8 / 6)$, weathering same colors, very fine grained, well sorted; composed of subrounded clear quartz and sparse black accessory minerals; firmly cemented, calcareous; stratification poorly developed, but probably composed of medium-scale low-angle crosslaminae; flaggy splitting. Weathers to form small ledges in creek bottom. Abundant limonite spots

11. Covered

10. Sandstone, similar to unit 4 except composed dominantly of thin to thick trough sets of medium-scale crosslaminae

9. Covered

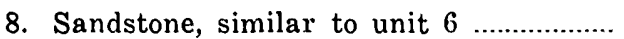

7. Covered

6. Sandstone, similar to unit 4 except fine grained and possibly may be horizontally laminated

5. Covered

4. Sandstone, yellowish gray (5Y 8/1) and grayish yellow (5Y 8/4), weathering yellowish gray $(5 Y 7 / 2)$, medium grained, well sorted; composed of subangular clear quartz and sparse black accessory minerals; firmly cemented, calcareous, common limonite stains and spots; composed of thick trough sets of large-scale low-angle cross-laminae; massive splitting, weathers to form vertical cliff. Chert pebbles as large as $1 / 2$ in. in diameter occur at $24 \mathrm{ft}$ above base of unit .......

3. Conglomeratic sandstone to sandy limestone, light olive gray (5Y 6/1), weathering same color and light brown (5YR 6/4), coarse grained with common to abundant granules and pebbles, poorly sorted; composed of subangular to subrounded clear quartz grains and granules and pebbles of green siltstone, gray limestone, and to a lesser extent of red

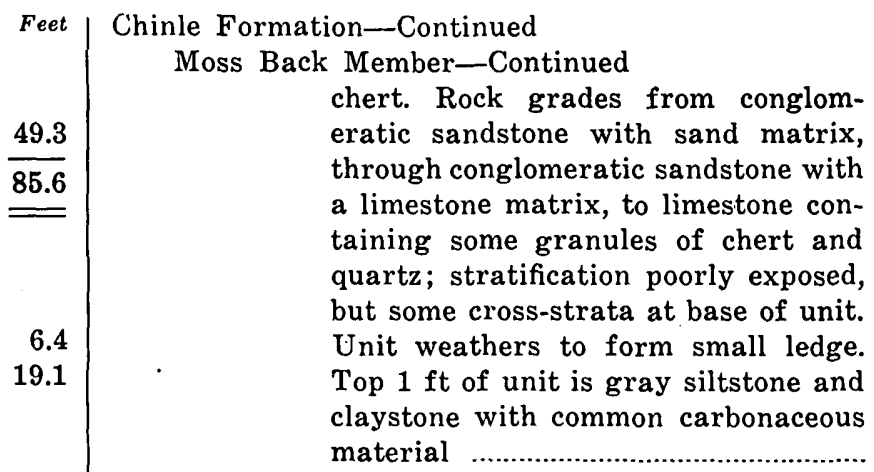

Monitor Butte Member:

$$
\text { Total of Moss Back Member ......... } \overline{135.2}
$$

2. Covered. Interval from 22 to $27 \mathrm{ft}$ forms small bench. This bench is formed by a sandstone layer

Total of Monitor Butte Member....

Feet

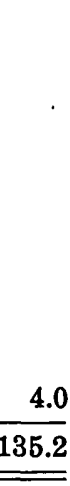

\section{$\frac{104.0}{104.0}$}

Shinarump Member:

1. Sandstone, yellowish gray $(5 Y 8 / 1)$ and pale yellowish orange $(10 Y R 8 / 6)$, weathering grayish orange $(10 Y R$ $7 / 4)$, medium to coarse grained with subordinate scattered very coarse grains, fair sorting; composed of subrounded clear quartz, no accessory minerals noted; poorly to well cemented, calcareous; stratification poorly developed, common trough sets of medium-scale cross-laminae, possibly some thin to thick horizontal beds; slabby to massive splitting; weathers to form minor ledge along creek bottom. Bottom $1 \mathrm{ft}$ of exposure contains a very thin layer of green claystone. Abundant carbonaceous material in bottom $1 \mathrm{ft}$. Unit exposed only along wash. Base of unit not exposed. Because the Shinarump Member is generally thin in this area, the exposure of member is probably nearly complete. Top $3 \mathrm{ft}$ of unit is well cemented. Abundant limonite stains

Total of Shinarump Member.

Total of Chinle Formation

Base of section; base of exposure.

\section{U-26. BRIDGER JACK MESA}

Measured in head of tributary of Lavender Creek and up southwesternmost point of Bridger Jack Mesa, sec. 25 (unsurveyed), T. 32 S., R. 20 E., SLM, San Juan County [Measured by J. H. Stewart, O. B Raup, and A. C. Gorveatt, September

Top of section; top of accessible exposure. Top of section at most southwesterly point of Bridger Jack Mesa.

Wingate Sardstone:

46. Sandstone, yellowish-gray $(5 Y 8 / 1)$ and subordinate pale-reddish-brown $(10 R$ 
Wingate Sandstone-Continued

$5 / 4)$, very fine to fine-grained; composed of subrounded to rounded clear quartz and sparse black accessory mineral; poorly cemented, slightly calcareous; composed of thin trough sets of low-angle medium-scale crosslaminae; massive splitting; weathers to form vertical cliff. Sandstone contains sparse to common rounded medium to coarse grains. Only basal 8.0

Chinle Formation:

$\mathrm{ft}$ examined

Unmeasured

Church Rock Member:

Hite Bed:

45. Sandstone, pale red $(10 R 6 / 2)$ and common light greenish gray $(5 G Y$ $8 / 1)$, weathering pale red ( $5 R 6 / 2)$, very fine to fine grained, fair sorted; composed of subangular grains, composition masked; firmly cemented, slightly calcareous; ripple laminated; massive splitting; weathers to form vertical cliff continuous with that of overlying Wingate Sandstone ...........

44. Siltstone, pale reddish brown $(10 R 5 / 4)$, weathering same color; common to abundant fine-grained muscovite; well cemented, noncalcareous; horizontally and ripple laminated; weathers to form slope. Lower half very poorly exposed

43. Sandy siltstone, light brown (5YR 6/4), weathering pale reddish brown $(10 R$ 5/4), sandy (very fine grained); firmly cemented, noncalcareous; horizontally and ripple laminated; weathers to form ledge

42. Siltstone, pale reddish brown $(10 R 5 / 4)$, weathering same color; firmly cemented, noncalcareous; structureless; weathers to form steep slope. Basal $8 \mathrm{ft}$ of unit is silty sandstone. This silty sandstone is very fine grained, contains abundant coarsegrained, muscovite and biotite, is horizontally laminated, and grades upward into siltstone which comprises the rest of the unit. Parts of unit are poorly exposed

41. Sandstone, pale red $(5 R 6 / 2)$ and subordinate light greenish gray $(5 G Y$ $8 / 1)$, weathering pale red ( $5 R 6 / 2)$, very fine grained, well sorted; firmly cemented, calcareous; composed of thin to thick trough sets of mediumscale cross-laminae and subordinate thin to thick sets of ripple laminae and very thin horizontal laminae; weathers to form vertical cliff. Commonly contains red siltstone pebbles and granules. Base of unit contains thin lenticular bed of limestone grain
Chinle Formation-Continued

Church Rock Member-Continued

Hite Bed-Continued

sandstone which is composed of rounded limestone grains in sand matrix

Total of Hite Bed

Total of Church Rock Member ....

Owl Rock Member:

40. Siltstone (50 percent) and limy siltstone (50 percent). Siltstone, pale reddish brown $(10 R 5 / 4)$; firmly cemented, slightly calcareous; structureless. Limy siltstone, pale red $(10 R 6 / 2)$ and light greenish gray (5GY 8/1); well cemented; thinly horizontally laminated with subordinate laminae to thin beds. Limy siltstone is present as very thin to thick beds interstratified with siltstone. Unit as a whole weathers pale reddish brown $(10 R 5 / 4)$, and forms a vertical and overhanging cliff together with overlying unit

39. Siltstone to clayey siltstone, pale reddish brown $(10 R 5 / 4)$ and sparse pale green $(10 G 6 / 2)$, weathering pale reddish brown $(10 R 5 / 4)$; poorly cemented, calcareous; appears structureless; platy splitting; weathers to form slope

38. Limestone, light greenish gray ( $5 G Y$ $8 / 1$ ), weathering very pale orange $(10 Y R$ 8/2); dense, well cemented; structureless; weathers to form ledge

37. Siltstone to clayey siltstone, pale reddish brown $(10 R 5 / 4)$ in lower half and light olive gray $(5 Y \quad 5 / 2)$ in upper half, weathering pale reddish brown $(10 R 5 / 4)$, siltstone in lower half grading to clayey siltstone in upper half; firmly cemented, calcareous; structureless; fractures into angular fragments in lower half, platy splitting in upper half; weathers to form slope. The upper half of unit resembles unit 39

36. Silty limestone, light greenish gray $(5 G Y 8 / 1)$ and subordinate pale red $(5 R 6 / 2)$, weathering light brown (5YR 6/4), aphanitic to finely crystalline; well cemented; horizontally laminated to thinly bedded, some ripple laminae; platy to slabby splitting; weathers to form ledge

35. Siltstone to sandy siltstone, light brown $(5 Y R 6 / 4)$, common pale reddish brown (10R 5/4), sandy (very fine grained) ; firmly cemented, calcareous; structureless, sparse thin horizontal beds; fractures into angular fragments; weathers to form 
Chinle Formation-Continued

Owl Rock Member-Continued steep slope. Common light-greenishgray ( $5 G Y 8 / 1)$ spots

34. Limestone, light greenish gray ( $5 G Y$ $8 / 1)$ and subordinate pale red $(10 R$ $6 / 2$ ), weathering same colors; dense; well cemented; composed of horizontal thin beds; slabby splitting; weathers to form ledge. Directly to north of line of section, limestone thins to $2.5 \mathrm{ft}$ by intergrading with overlying unit. Directly to south of line of section, limestone thickens by channeling $3 \mathrm{ft}$ into underlying unit. Along line of section and directly to south, limestone contains possible medium-scale cross-laminae.

33. Siltstone, grayish red $(5 R \quad 4 / 2)$ and pale reddish brown $(10 R 5 / 4)$, common light greenish gray $(5 G Y 8 / 1)$, weathering pale red $(5 R 6 / 2)$; firmly cemented, calcareous; structureless; weathers to form steep slope. Thin horizontal beds of dense lightgreenish-gray $(5 G \quad 8 / 1)$ limestone are present at 22.4 and $50.8 \mathrm{ft}$. Thin horizontal bed of limestone pebble conglomerate is present at $36.8 \mathrm{ft} . . .$.

32. Limy siltstone, pale red $(5 R 6 / 2)$, common light-greenish-gray (5G 8/1) mottles, weathering same colors; well cemented; composed of indistinct thin horizontal beds. Horizontal beds weather with nodular surface suggesting internal concretionary structure. Unit weathers to form ledge

31. Siltstone, grayish red $(5 R 4 / 2)$, light brown $(5 Y R \quad 6 / 4)$ in middle onethird of unit, weathering pale red $(10 R 6 / 2)$, weathering pale reddish brown $(10 R 5 / 4)$ in middle third; firmly cemented, calcareous; structureless; weathers to form steep slope

30. Limy siltstone, pale reddish brown $(10 R 5 / 4)$ in lower half and pale red $(10 R 6 / 2)$ in upper half, weathering pale red $(10 R 6 / 2)$; well cemented, highly calcareous; structureless; weathers to form steep slope with small ledge at top. Top of unit marked by thin light-greenishgray $(5 G Y 8 / 1)$ band. Unit contains abundant light-greenish-gray (5G 8/1) spots

29. Limestone-grain sandstone, light greenish gray $(5 G 8 / 1)$ and common pale red $(10 R 6 / 2)$, coarse to very coarse grains of limestone ( 60 percent) in dense calcite matrix ( 40 percent), poorly sorted; composed of rounded
Feet Chinle Formation-Continued

Feet

Owl Rock Member-Continued

sand grains; well cemented, horizontally laminated to thinly bedded; slabby splitting; weathers together with underlying unit to form most conspicuous ledge in lower part of Chinle. Unit contains an irregular mass less than 1 in. in diameter of reddish-brown chert

28. Limestone, pale red $(10 R 6 / 2)$, abundant light-greenish-gray $(5 G \quad 8 / 1)$ mottles, weathering same colors; dense, well cemented; composed of thin horizontal beds; weathers together with overlying unit to form ledge. Laterally to line of section, unit grades into underlying unit ....
5.4

68.9

.0

55.9

9.6
27. Siltstone, moderate brown (5YR 4/4), common pale reddish brown $(10 R$ $5 / 4)$, weathering light brown (5YR 6/4); firmly cemented, calcareous; structureless; weathers to form steep slope. Unit as whole contains sparse to common limestone nodules. From 17.8 to $20.0 \mathrm{ft}$, unit contains abundant limestone nodules and weathers pale red $(10 R 6 / 2) \quad \ldots \ldots \ldots . . .$.

26. Siltstone (70 percent) and limestone (30 percent). Siltstone, pale red (5R 6/2), pale purple (5P 6/2), common pale reddish brown $(10 R$ 5/4); firmly cemented, highly calcareous; structureless. Limestone, pale red $(10 R 6 / 2)$ and light greenish gray (5GY 8/1); dense, well cemented. Limestone is present as irregular thin to thick lenses. Unit contains limestone nodules scattered in the siltstone and concentrated in thin to thick layers. Unit as whole is tabular and weathers to form a conspicuous pale-red (10R 6/2) slope

25. Siltstone, pale reddish brown (10R $5 / 4)$, weathering same color; firmly cemented, calcareous, structureless; weathers to form steep slope with locally a small ledge at top. Near top of unit is thin set of sandy siltstone. This sandy siltstone is light brown $(5 Y R 6 / 4)$, sandy (very fine grained); firmly cemented, calcareous. Lateral to line of section, the sandy siltstone thickens to a thick set and is ripple laminated. On distant outcrops, this sandy siltstone crops out as a discontinuous ledge

24. Siltstone, pale reddish brown (10R $5 / 4)$ in lower half and grayish red $(5 R 4 / 2)$ in upper half, weathering pale reddish brown $(10 R 5 / 4)$ in lower half and pale red $(10 R 6 / 2)$ in 
Chinle Formation-Continued

Owl Rock Member - Continued

upper half; firmly cemented, highly calcareous; structureless; weathers to form steep slope, covered with veneer of angular fragments, fractures to angular fragments. Top 1.0 ft contains an irregular horizontal bed composed of about 80 percent light-greenish-gray dense limestone nodules in a siltstone matrix. Lateral to the line of section, this limy interval thickens to at least $4.0 \mathrm{ft}$. Unit is differentiated from one below by absence of sandy siltstone beds and by its characteristic of fracturing into angular fragments

23. Siltstone and sandy siltstone, pale reddish brown. (10R 5/4), weathering same color, sandy (very fine grained) parts; firmly cemented, calcareous; stratification poorly exposed, but horizontally laminated in part; weathers to form steep slope above bench developed on underlying unit. Sandy siltstone present as common thin horizontal beds interstratified with rest of unit

Total of Owl Rock Member

Moss Back Member:

22. Sandstone, pale red $(5 R 6 / 2)$, weathering same color, very fine grained, well sorted; common fine-grained accessory white mica; firmly cemented, calcareous; ripple laminated, platy splitting; weathers to form bench. Unit in part poorly exposed. In some places, unit contains pale red $(5 R$ $6 / 2$ ) siltstone interbedded with thin sets of sandstone. The thickness of the unit varies considerably along the exposure owing to intertonguing with underlying unit. Unit is included in the Moss Back Member because of its intertonguing relation with the underlying unit and because elsewhere similar sandstone layers occur in the Moss Back Member ....

21. Sandstone, yellowish gray $(5 Y 7 / 2)$, grayish yellow $(5 Y 8 / 4)$, and subordinate very light gray $(N 8)$, weathering light brown (5YR 6/4) to moderate brown $(5 Y R 4 / 4)$, fine to medium grained with sparse (1 percent) coarse grains, well sorted; composed of subrounded clear quartz and sparse black accessory mineral, abundant interstitial limonite, common interstitial white material, possibly clay; poorly to firmly cemented, calcareous; composed of thin to very thin trough and planar sets of cross-

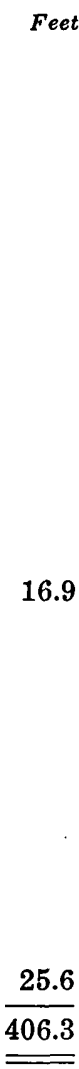

Chinle Formation - Continued

Moss Back Member-Continued

laminae; weathers to form conspicuous vertical cliff. Unit and basal part of overlying unit underlie widespread benches in area. Unit contains about 1 percent clayey siltstone the same as that in underlying unit. This clayey siltstone forms several very thin to thin sets separating thin to very thick cosets of sandstone. The unit contains about 1 percent conglomeratic sandstone. The conglomeratic sandstone is composed of granules to cobbles of gray quartzite, chert, and to a lesser extent of quartz in a fine- to coarse-grained matrix. The conglomeratic sandstone is generally in the basal $5 \mathrm{ft}$, but its position varies along the exposure. The maximum diameter of the cobbles noted in the conglomeratic sandstone is 3 in. The average diameter of the granules to cobbles is about $1 / 2$ in. The upper 10 to $20 \mathrm{ft}$ of the unit is dominantly grayish red $(5 R 4 / 2)$, is very fine grained, and appears to grade and intertongue with the overlying unit

20. Clayey siltstone, medium light gray $(N 6)$ to greenish gray (5GY 6/1), weathering light brown $(5 Y R 6 / 4)$, sparse fine-grained accessory white mica; firmly cemented, noncalcareous; horizontally thinly laminated, some possible ripple laminae; weathers to form reentrant. Unit contains sparse discontinuous thin sets of light-greenish-gray ( $5 G Y$ $8 / 1$ ) very fine grained ripple-laminated quartzitic sandstone. Unit intertongues with overlying unit in places, but in other places the upper contact of the unit is an erosion surface. Units 18-20 measured at good exposure at head of canyon ....

19. Sandstone, yellowish gray (5Y 8/1), very light gray $(N 8)$, grayish yellow $(5 Y 8 / 4)$, weathering grayish orange pink $(5 Y R 7 / 2)$, fine to medium grained, well sorted; composed of subrounded clear quartz and sparse black accessory mineral, abundant interstitial limonite; firmly to well cemented, calcareous; horizontally laminated with subordinate thin trough sets of low-angle medium-scale cross-laminae; weathers to form small ledge below main ledge of the Moss Back Member. In a few places, unit contains conglomeratic sandstone near base. Conglomeratic sandstone is composed of subround-
Feet 
Chinle Formation - Continued

Moss Back Member - Continued

ed to well rounded granules to pebbles of gray chert, quartzite, and to a lesser extent of white quartz. Lower half of unit is quartzitic

Total of Moss Back Member

Monitor Butte(?) Member:

18. Silty claystone, greenish-gray ( $5 G Y$ $6 / 1$ ), dark-greenish-gray ( $5 G Y 4 / 1$ ), and medium-gray $(N \quad 5)$; firmly cemented, noncalcareous; structureless; weathers to form reentrant. Unit is placed in Chinle Formation because it contains a basal very thin lenticular sandstone that is medium to very coarse grained, clayey, and poorly sorted and is composed of subangular clear quartz and common orange accessory mineral. This sandstone has common copper stains and commonly includes pebbles of silty claystone similar to that in rest of unit

Total of Monitor Butte(?) Member

Total of Chinle Formation

Moenkopi Formation (incomplete) :

Upper slope-forming member:

17. Silty claystone to clayey siltstone, grayish-red $(10 R 4 / 2)$, medium-dark-gray $\left(\begin{array}{l}N \\ 4\end{array}\right)$, pale-yellowish-green (10GY $7 / 2)$, and minor grayish-yellow (5Y $8 / 4)$; grayish red is dominant color in lower few feet of unit, other colors gradually replace grayish red vertically so that in top few feet of unit the colors are entirely greens, grays, and yellows; weathers same colors; sparse fine-grained accessory white mica; firmly cemented, noncalcareous; no medium to coarse grains were seen; seems to be horizontally very thinly to thinly bedded, although stratification is poorly exposed; weathers to form slope. Unit is placed in the Moenkopi Formation because it seems to grade downward into the Moenkopi Formation and because it contains horizontal bedding planes. Except for color, this unit is similar to underlying unit.

16. Silty claystone to siltstone, grayish red $(10 R 4 / 2)$ and minor pale reddish brown $(10 R 5 / 4)$ and sparse greenish gray $(5 G Y 6 / 1)$, weathers pale reddish brown $(10 R 5 / 4)$; common to abundant fine-grained accessory white mica; firmly cemented, mostly noncalcareous but some parts slightly calcareous; stratification poorly exposed but seems to be dominantly horizontally laminated; weathers to

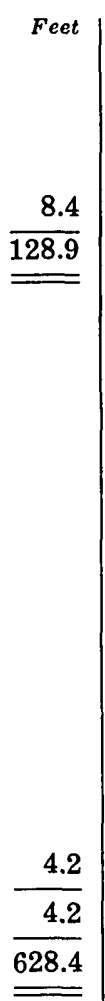

Moenkopi Formation (incomplete) - Continued

Feet Upper slope-forming member-Continued form steep rubble-covered slope. Sparse thin resistant siltstone and sandy siltstone sets

Total of upper slope-forming member

Total of incomplete Moenkopi Formation

Base of section; not base of exposure.

Units 1-15 described in Stewart, Poole, and Wilson (1972).

U-27. COMB WASH

Measured on Comb Ridge about 2.5 miles north of Snake Canyon, long $109^{\circ} 39^{\prime}$ W., lat $37^{\circ} 19^{\prime}$ N., San Juan County [Measured by L. C. Craig and T. E. Mullens, June 1951; slightly modified

Top of measured section; not top of exposure.

Feet

Wingate Sandstone:

35. Sandstone, moderate - reddish - orange $(10 R 6 / 6)$ to light-brown $(5 Y R 6 / 4)$, very fine grained; disseminations and laminar concentrations of medium to coarse clear to white quartz and black and white chert grains; common black accessory minerals; wedging sets 3 to $15 \mathrm{ft}$ in thickness, compound cross-lamination. Unit forms vertical cliff Unmeasured

Chinle Formation:

Church Rock Member:

Hite Bed:

34. Sandstone, pale-reddish-brown $(10 R$ $5 / 4)$ to yellowish-gray $(5 Y 8 / 1)$ to light-greenish-gray $(5 G Y 8 / 1)$, fineto medium-grained; composed of clear subangular quartz, abundant green accessory minerals, uncommon black and orange accessory minerals; moderately calcareous, firmly cemented; lenticular bedding 2 to $8 \mathrm{ft}$ in thickness, well-developed fine $(1 / 32$ in.) festooned cross-lamination. Laminae are gently dipping. Local layers contain grayish-red claystone pebbles. Forms ledgy cliff. Basal contact is scour surface; top contact is even

Total of Hite Bed

33. Sandstone, moderate-reddish-orange $(10 R 5 / 6)$, very fine to fine-grained; angular to subangular; well sorted; composed of amber-stained quartz grains, uncommon black and orange accessory minerals; firmly cemented, moderately calcareous. Unit is mostly horizontally laminated. In places, the laminae are faintly wavy and suggest ripple laminae. A few poorly defined, very low angle, medium-scale crosslaminae are present. Unit weathers to form massive vertical cliff. 
Chinle Formation-Continued

Church Rock Member-Continued

32. Sandstone, moderate reddish orange $(10 R$ 6/6) with light-greenish-gray mottling, very fine grained, subangular, well sorted; composed of clear amber-stained quartz, common orange and black accessory minerals; calcareous; hackly weathering. Unit forms steep slope containing several lenticular ledges 1 to $3 \mathrm{ft}$ thick

Total of Church Rock Member........

Owl Rock Member:

31. Sandstone, very calcareous, pale-red $(10 R 6 / 2)$, very fine grained, wellsorted; composed of subangular to subrounded clear quartz, uncommon black accessory minerals; firm calcareous cement. Along strike grades to pale-red very sandy parallel-bedded ( 2 to 6 in. beds) limestone. Unit makes prominent ledge with abundant pale-green mottling. Recorded as top of Owl Rock Member on basis of color and lithology change...

30. Siltstone, pale red ( $5 R 6 / 2$ to $10 R 6 / 2)$ with abundant pale-green mottling; highly calcareous; hackly weathering; forms hard ledgy rubble-covered slope; ledges composed of slightly sandier parts of unit.

29. Sandstone, pale reddish brown $(10 R$ $5 / 4)$, bleached grayish orange pink $(10 R 8 / 2)$; very fine grained, angular to subangular, well sorted; composed of clear amber-stained quartz with uncommon orange and black accessory minerals; forms massive ledge. Many worm borings noted........

28. Siltstone, pale red ( $5 R 6 / 2$ to $10 R 6 / 2$ ), pale-green mottling; grades to very fine grained sandy siltstone. Contains rounded limestone pellets as long as $1 / 8$ in.; pellets give unit pisolitic texture in places. Highly calcareous; hackly weathering. Forms hard ledgy rubble-covered slope; ledges composed of slightly sandier parts of unit

27. Sandstone, moderate - reddish - or ange $(10 R 5 / 6)$, very fine grained, well sorted; subangular; composed of clear amber-stained quartz grains, accessory minerals masked; highly calcareous; parallel to subparallel bedding, very fine ( $1 / 64$ to $1 / 16$ in.) parallel to ripple lamination and gentle cross-laminae. Forms massive prominent ledge; worm tracks and fine mud cracks on bedding surfaces

26. Siltstone, pale red $(10 R 6 / 2)$, much light-green mottling in streaks, bands, and spots as much as 2 in. in diam-
Feet Chinle Formation-Continued

Owl Rock Member-Continued eter; grades to very fine grained sandy siltstone; hackly weathering. Forms rubble-covered slope.

25. Sandstone, moderate reddish orange $(10 R 5 / 6)$, very fine grained, well sorted; subangular; composed of clear amber-stained quartz, accessory minerals masked; highly calcareous; parallel to subparallel bedding; very fine $(1 / 64$ to $1 / 16$ in.) parallel and ripple laminae, possible gentle crosslaminae. Forms conspicuous massive ledge. Possible reptile tooth noted......

24. Siltstone, mudstone, and subordinate conglomerate. Siltstone, pale red $(10 R 6 / 2)$; grades to very fine grained sandy siltstone, hackly weathering. Mudstone, moderate reddish orange $(10 R 6 / 6)$, silty and sandy (very fine grained). Conglomerate, pale greenish gray $(5 G Y 8 / 1)$ to pale red $(10 R 6 / 2)$; contains pellets of siltstone as large as $3 / 4$ in. in diameter. Siltstone and mudstone form bulk of unit and are intergradational; conglomerate forms 3- to 6-in.thick beds, one at base and one at $8 \mathrm{ft}$ above base of unit. Unit forms steep rubble-covered slope

23. Sandstone, moderate - reddish - or ange $(10 R 6 / 6)$, very fine grained, wellsorted; subangular; composed of clear amber-stained quartz, accessory minerals masked; highly calcareous; parallel to subparallel bedded, very fine $(1 / 64$ to $1 / 16$ in.) parallel to ripple laminae, some gentle cross-laminae, forms prominent massive ledge; worm tracks and fine mud cracks on bedding surfaces

22. Siltstone to sandstone, pale-reddishbrown $(10 R 6 / 4)$ to moderate-reddish-orange $(10 R 6 / 6)$, sandy (very fine grained), highly calcareous, hackly weathering. Forms steep finerubble-covered hard slope. Shows two prominent red bands in upper half of unit separated by faint pinkish-purple bands

21. Siltstone to sandstone, moderateorange-pink $(10 R 7 / 4)$ to pale-reddish-brown $(10 R 5 / 4)$; as coarse as very fine grained sand size, sparse medium-sized quartz grains in some layers; uncommon black accessory minerals; highly calcareous, firmly cemented; a few thin partings of sandy clay; parallel bedded, irregular subparallel lamination. Top locally forms vertical ledge

20. Interval covered along line of section.
Feet 
Chinle Formation-Continued

Owl Rock Member-Continued

Scattered exposures in upper onehalf of unit along strike reveal that rocks are similar to those in unit below

19. Claystone, pale reddish brown $(10 R$ $5 / 4)$ in lower half, pale red purple (5RP 6/2) in third quarter, pale reddish brown $(10 R 5 / 4)$ in top onequarter, light-greenish-gray ( $5 G Y$ 8/1) mottling and streaks; pure clay to very fine grained sand; calcareous. Lower one-half of unit includes lenses of limestone containing pebbles as large as one-half an inch in diameter arranged along lamination planes; lower one-half of unit seems to contain channels and cross-laminae. Entire unit weathers to steep earthy to frothy slope; claystone is hackly weathering

18. Limestone and claystone. Limestone, moderate reddish orange $(10 R 6 / 6)$ to pale red $(10 R 6 / 2)$, pale-green mottling, silt to very fine grained sand; forms three lensing beds, one fairly persistent at base, one $1 \mathrm{ft}$ thick at $40 \mathrm{ft}$ above base, and one at top of unit. Claystone, moderate reddish orange $(10 R 6 / 6)$ to pale red (10R 6/2), mottled light greenish gray $(5 G Y 8 / 1)$, silt to very fine grained sand. Unit forms hard earthy slope; hackly to rubbly weathering

Total of Owl Rock Member

Petrified Forest and Monitor Butte Members undivided:

NoTe.-Units 10-16 might be the Monitor Butte Member, and unit 17 might be the Petrified Forest Member. In addition units 15 and 16 could be a lateral equivalent of the Moss Back Member. These members, however, are not typically developed or easily separated and are not labelled in the section.

17. Claystone, grayish red $(10 R 4 / 2)$ with abundant light-greenish-gray spots in basal $17 \mathrm{ft}$, banded grayish red purple $(5 R P 4 / 2)$ and pale red purple $(5 R P \quad 6 / 2)$ with greenish-gray (5GY 6/1) mottling in rest of lower $2 / 3$ of unit, pale reddish brown $(10 R 5 / 4)$ to pale red $(10 R 6 / 2)$ in upper $1 / 3$ of unit, variably silty; earthy to frothy weathering; variably calcareous. Light-greenish-gray to light-gray calcareous nodules cover slope in lower $1 / 2$ of unit. Basal $42 \mathrm{ft}$ contains clays that swell prominent-
Petrified Forest and Monitor Butte Members undivided-Continued

ly on contact with water. Clays in basal half of upper third of unit swell slightly on contact with water. Rest of unit does not contain swelling clays. Unit forms rounded hard slope

16. Sandstone, pinkish-gray $(5 Y R 8 / 1)$ to light-greenish-gray (5GY 8/1); fine to medium grained, subangular to subrounded, well sorted; composed of clear to amber-stained quartz grains and common to abundant black accessory minerals; slightly to moderately calcareous cement; fine scale cross-lamination, $1 / 2$ in. thick. Except for capping $1 \mathrm{ft}$, unit weathers to earthy slope; top $1 \mathrm{ft}$ well-cemented and forms minor hogback

15. Sandstone, clayey, grayish-orange $(10 Y R 7 / 4)$, very fine to very coarse grained, poorly sorted; subangular to well rounded; composed of clear quartz and uncommon gray accessory minerals; moderately calcareous, poorly cemented; forms earthy slope. Slightly conglomeratic at top; conglomeratic strata composed of clay and limestone pebbles in matrix of quartz grains and lime cement. Conglomeratic strata occur as lenses $1 / 2$ to $1 \mathrm{ft}$ in thickness

14. Claystone, very sandy, very dusky red $(10 R 2 / 2)$, grayish-mottled; weathers grayish red, scattered sand grains as coarse as medium size of clear subangular quartz and abundant orange accessory minerals, sand concentrated along $1 / 10$-in. laminations

13. Claystone, silty to fine sandy, lightgreenish-gray $(5 G Y 8 / 1)$ to lightgray (N 7). Contains common fossilized logs replaced by calcite and minor silica. Unit weathers to form rounded badland hills with hard frothy surface

12. Claystone, medium-light-gray $(N 6)$, silty. Weathers to distinct grayishred band with soft frothy slope .......

11. Claystone, sandy and silty; very light gray $(N 8)$ to medium light gray $(N 6)$; sand as coarse as fine-grain size, hackly fracture. Weathers to form rounded badland hills with steep hard frothy surface that is white at base and light gray at top

10. Interval poorly exposed. Claystone, silty and sandy (fine-grained), grayish-red $(5 R 4 / 2)$; weathers to form
138.4

15.0 
Chinle Formation-Continued

Petrified Forest and Monitor Butte Members undivided-Continued

high hard frothy surface covered with nodules of gray sandy limestone as large as $3 \mathrm{in}$. in diameter. Top contact of unit poorly exposed but marks sharp color break

Total of Petrified Forest and Monitor Butte Members undivided....

Mottled strata :

9. Sandstone, white to light greenish gray (5GY 8/1) with blackish-red $(5 R$ $2 / 2)$, pale-reddish-brown (10R 5/4), grayish-purple $(5 P 4 / 2)$, and darkyellowish-orange $(10 Y R \quad 6 / 6)$ mottling in upper two-thirds, fine to very fine grained, subangular to subrounded, well sorted except for interstitial clay; composed of subangular to subrounded clear quartz, uncommon orange, black, and green accessory minerals; common white interstitial clay; slightly calcareous, firmly cemented unit forms two subparallel lenticular beds as much as $10 \mathrm{ft}$ thick. Lower bed contains gently dipping festooned laminations of fluvial origin, whereas upper bed is structureless. Lower bed forms local ledge and upper bed forms a massive rounded ledge. Unit is lenticular and extends 300-500 ft along Chinle-Moenkopi contact

Total of mottled strata

Total of Chinle Formation

Moenkopi Formation (incomplete) :

Upper slope-forming member:

8. Sandstone ( 80 percent), siltstone (15 percent), and claystone (5 percent). Sandstone and siltstone, light brown (5YR 6/4 to $5 Y R 6 / 5$ ), light-gray mottling seen near contact with Chinle Formation. Unit is similar to underlying unit but differs in percentage of sandstone, siltstone, and claystone. Unit weathers to form minor hogbacks with flaky clay surfaces in places. Upper surface of unit beveled by Chinle Formation

7. Sandstone (40 percent), siltstone $(30$ percent) and claystone (30 percent). Sandstone and siltstone, light brown $(5 Y R 6 / 4)$, silty to very fine grained sand; composed of subangular clear quartz and common white, green, and orange accessory minerals, finely micaceous; moderately calcareous, poorly cemented; possible ripple lamination seen. Claystone, grayish red (5R $4 / 2$ to $10 R 4 / 2)$;

\author{
Feet Moenkopi Formation (incomplete)-Continued \\ Upper slope-forming member-Continued \\ finely micaceous; very fissile, paral- \\ lel bedded in beds 3-10 ft thick. Unit \\ poorly exposed; weathers to earthy \\ and shaly slope with discontinuous \\ green-mottled sandstone giving unit \\ a horizontal banding \\ Total of upper slope-forming mem- \\ ber \\ Total of incomplete Moenkopi \\ Formation \\ Base of section; not base of exposure. \\ Units 1-6 described in Stewart, Poole, and Wilson \\ (1972).

\section{U-28. COTTONWOOD CREEK} \\ Measured on east side of Cottonwood Creek about $3 / 4$ mile \\ north of where Notch Canyon joins Cottonwood Creek, \\ sec. 35 (unsurveyed), T. 34 S., R. 20 E., SLM, San Juan \\ County \\ [Measured by J. H. Stewart and O. B. Raup, September 1953] \\ Feet

Top of section; top of accessible exposure. Top of section is N. $64^{\circ}$ E. of The Notch on Elk Ridge and $100 \mathrm{ft}$ north of fault which forms minor gully or crack in Wingate Sandstone. This fault has about $20 \mathrm{ft}$ displacement.

Wingate Sandstone:

27. Sandstone, light brown $(5 Y R 6 / 4)$ and minor yellowish gray $(5 Y 8 / 1)$, weathering light brown (5YR 6/4), very fine to fine grained, well sorted; composed of subrounded to rounded clear quartz and uncommon black and orange accessory minerals; poorly cemented, noncalcareous; composed of thin to thick trough sets of low-angle medium-scale cross-laminae; massive splitting; weathers to form vertical cliff. Unit contains common rounded medium to coarse grains. Basal $1 \mathrm{ft}$ has poorly developed stratification but appears to be horizontally laminated. Only basal $10 \mathrm{ft}$ of unit examined ............... Unmeasured

Contact of.Wingate Sandstone and Chinle Formation placed at color change from browns of Wingate to reds of Chinle. The contact also marks the lithologic change from poorly cemented sandstones composed of subrounded to rounded sand grains in the Wingate to a well-cemented sandstone composed of subangular sand grains in the Chinle. In addition the sandstone of the Chinle contains common interstitial clay, whereas the sandstone of the Wingate does not. The sandstone of the Chinle contains interstratified siltstone layers and disseminated siltstone pellets. The Wingate Sandstone contains common rounded medium to coarse grains, whereas the Chinle does not.

Chinle Formation (incomplete) :

Church Rock Member:

Hite Bed: Feet 
Chinle Formation (incomplete)-Continued

Church Rock Member-Continued

Hite Bed-Continued

26. Sandstone, pale red $(10 R 6 / 2)$ and light greenish gray ( $5 G Y 8 / 1)$, weathering light brown $(5 Y R 6 / 4)$, very fine to fine grained, well sorted; composed of subangular milky mineral and sparse black accessory mineral; well cemented, slightly calcareous; composed of thin to very thick trough sets of small- to medium-scale crosslaminae, platy and massive splitting; weathers to vertical cliff continuous with vertical cliff of overlying Wingate Sandstone. Unit contains sparse thin lenses of siltstone. Sandstone commonly has claystone and siltstone pellets as large as $3 \mathrm{in.}$ in diameter. Sparse thin lenses of ripple-laminated sandstone

25. Sandstone to siltstone, grayish red ( $10 R$ $4 / 2$ ) and pale red $(10 R 6 / 2)$, weathering grayish red $(10 R 4 / 2)$. Sandstone is very fine grained. Unit as whole is firmly cemented, slightly calcareous; a lenticular unit of horizontal laminae and structureless material; weathers to form slope. Sandstone is ripple laminated and dominantly confined to lower half ...

Total of Hite Bed

24. Siltstone and sandy siltstone. Siltstone, grayish red $(10 R 4 / 2)$, weathering pale reddish brown $(10 R 5 / 4)$; firmly cemented, noncalcareous; structureless. Sandy siltstone, light brown (5YR 6/4), weathering pale reddish brown $(10 R 5 / 4)$, sandy (very fine grained) ; firmly cemented, noncalcareous; structureless. Sandy siltstone is present as two conspicuous horizontal beds about $5 \mathrm{ft}$ thick, one near base of unit and the other slightly above the middle of the unit. These beds form conspicuous ledges near the top of the Chinle. The rest of the unit forms steep slopes. Unit contains sparse light-greenish-gray ( $5 G Y 8 / 1)$ spots; these spots are abundant in underlying units

Total of Church Rock Member ......

Owl Rock Member:

23. Limestone, pale red (5R 6/2), light greenish gray $(5 G 8 / 1)$ in top $0.1 \mathrm{ft}$, weathering light brown (5YR 6/4), dense, well cemented; horizontal tabular structureless bed; conspicuous thin green band at top of unit and at base of overlying unit

22. Siltstone, light brown $(5 Y R$ 6/4) and
Feet Chinle Formation (incomplete)-Continued Feet Owl Rock Member-Continued subordinate grayish red $(5 R \quad 4 / 2)$ in upper half, weathering same colors. Otherwise similar to unit 10

21. Siltstone (70 percent) and limy sandstone (30 percent). Siltstone, grayish red (5R $4 / 2$ and subordinate $10 R$ $4 / 2$ ), weathering same colors, commonly sandy (very fine grained); firmly cemented, noncalcareous; structureless. Limy sandstone, pale red $(5 R 6 / 2)$ and grayish red $(5 R$ $4 / 2$ ), weathering same colors, very fine grained, sparse coarse-grained accessory muscovite; well cemented, calcareous; ripple laminated, subordinate thin trough sets of smallscale cross-laminae. Limy sandstone present as thin to thick sets interbedded with siltstone. The number of these sets decreases progressively upward. One of these sets appears to change laterally into a limy siltstone. About $200 \mathrm{ft}$ south of the line of section, these sets near the bottom of the unit are dipping at an angle of about $20^{\circ}$ to the regional dip. Unit as whole weathers to form steep slope containing small ledges in limy sandstone sets

20. Siltstone, grayish red $(5 R \quad 4 / 2$ and $10 R 4 / 2$ ) with abundant light-greenish-gray $(5 G Y 8 / 1)$ spots, weathering pale reddish brown $(10 R 5 / 4)$, firmly cemented, calcareous; thinly ripple laminated in lower half and structureless in upper half; weathers to form steep rubble-covered slope. Locally at base is thin lens of light-greenish-gray (5GY 8/1) limestone pellet conglomerate. Pellets are generally the size of coarse grains

53.1

19. Siltstone and limestone to limy siltstone. Siltstone, pale reddish brown $(10 R 5 / 4)$ and grayish red $(5 R 4 / 2)$, abundant light-greenish-gray (5GY $8 / 1$ ) spots, weathering same colors. Otherwise similar to siltstone in unit 10. Limestone to limy siltstone, pale red $(10 R 6 / 2)$ and light greenish gray $(5 G Y 8 / 1)$, weathering same colors; dense, well cemented; structureless. Thin tabular bed of limestone occurs from 7.6 to $8.3 \mathrm{ft}$ above base of unit. Sparse thin lenses of limy siltstone occur throughout rest of unit. Limestone bed forms small ledge ......................

18. Siltstone, light brown (5YR 6/4), weathering same color, contains several horizontal stratification planes; otherwise similar to unit 10
16.9 
Chinle Formation (incomplete) - Continued

Owl Rock Member-Continued

17. Siltstone to limy siltstone, light brown $(5 Y R 6 / 4)$ and pale red $(10 R 6 / 2)$, abundant greenish-gray (5GY 8/1) spots, weathering light brown $(5 Y R$ 6/4); firmly cemented, calcareous; structureless; weathers to form ledge. Units 13, 15, and 17 form three conspicuous ledges in an interval that contains common grayish-red (5R 4/2) siltstone

16. Siltstone, grayish red $(5 R 4 / 2)$ in lower $5 \mathrm{ft}$ and pale reddish brown $(10 R 5 / 4)$ to light brown (5YR 6/4) in rest of unit, abundant light-greenish-gray (5GY 8/1) spots, weathering same colors, otherwise similar to unit 10

15. Silty limestone, pale red $(10 R \quad 6 / 2)$ with abundant light-greenish-gray (5GY 8/1) spots, dense; well cemented; composed of horizontal laminae to thin beds; weathers to form small ledge. Silty limestone contains thin films of siltstone and thin discontinuous layers of silty limestone containing about 40 percent coarse grains to granules of siltstone and limestone

14. Siltstone, grayish red $(5 R 4 / 2)$ in lower $6 \mathrm{ft}$, light brown $(5 Y R 6 / 4)$ to moderate brown $(5 Y R \quad 4 / 4)$ with sparse pale reddish brown $(10 R 5 / 4)$ in rest of unit, weathering light brown $(5 Y R 6 / 4)$, otherwise similar to unit 10

13. Limestone, pale red $(10 R 6 / 2)$ and light greenish gray $(5 G Y 8 / 1)$, weathering light brown (5YR 6/4), dense; well cemented; composed of horizontal very thin beds; weathers to form thin ledge

12. Siltstone, grayish red $(5 R 4 / 2)$, abundant light-greenish-gray (5GY 8/1) spots, weathering pale reddish brown $(10 R 5 / 4)$; otherwise similar to unit 10

11. Silty limestone, pale red $(10 R 6 / 2)$, abundant light-greenish-gray (5GY $8 / 1$ ) spots, weathering light brown (5YR 6/4); dense; well cemented; structureless; weathers to form small ledge

10. Siltstone, light brown (5YR 6/4), moderate yellowish brown (10YR $5 / 4), 10$ percent of pale reddish brown $(10 R 5 / 4)$ and pale red $(10 R$ $6 / 2)$, all colors have common lightgreenish-gray $(5 G Y \quad 8 / 1)$ spots, weathering light brown (5YR 6/4), firmly cemented, calcareous; structureless; fractures into angular frag-
Feet Chinle Formation (incomplete)-Continued $\quad F e$ Owl Rock Member-Continued

ments; weathers to form steep slope covered by veneer of angular fragments. Thin lense of dense grayishorange-pink $(5 Y R 7 / 2)$ limestone at $58.6 \mathrm{ft}$ above base of unit

9. Silty sandstone to sandy siltstone, pale reddish brown $(10 R 5 / 4)$, weathering same color, very fine to fine subangular sand grains; composition masked; poorly cemented, calcareous, stratification concealed; weathers to form loose earthy slope. Sparse medium-grained accessory muscovite and biotite

8. Sandstone, pale red ( $5 R 6 / 2)$, weathering pale reddish brown $(10 R 5 / 4)$, fine grained, common interstitial clay, poorly sorted, composed of subangular grains, composition masked; firmly cemented, calcareous; composed of thin planar sets of lowangle small-scale cross-laminae; weathers to form fairly prominent ledge in Chinle

7. Siltstone and limestone. Siltstone, pale red $(5 R 6 / 2)$ and pale reddish brown (10R 5/4), abundant light-greenishgray $(5 G Y 8 / 1)$ spots, weathering same colors; well cemented, highly calcareous; structureless; fractures into angular fragments. Siltstone contains common pale-red $(5 R 6 / 2)$ and light-greenish-gray ( $5 G Y \quad 8 / 1)$ limestone nodules averaging about 1 in. in diameter. Limestone, one bed from 47.6 to $48.2 \mathrm{ft}$ and the other from 63.8 to $66.4 \mathrm{ft}$ above base of unit. Lower bed is light greenish gray $(5 G Y 8 / 1)$, and upper bed is pale red purple $(5 R P 6 / 2)$. Limestone, dense, well cemented; present as thin horizontal beds interstratified with rest of unit. Limestone beds do not have definite upper and lower boundaries and appear to grade into overlying and underlying siltstone. Unit as whole weathers to form steep loose slope with small ledges in the limestone beds. Along line of section, top $1 \mathrm{ft}$ of unit is a conglomerate composed of limestone granules and pebbles in a matrix of lime and finegrained sand. This conglomerate is not persistent along the exposure and possibly may be a basal conglomerate of the overlying unit.

6. Siltstone, pale red purple $(5 R P 6 / 2)$, abundant light greenish gray ( $5 G Y$ $8 / 1$ ), weathering same colors; well cemented, highly calcareous; structureless; fractures into angular 
Chinle Formation (incomplete)-Continued Owl Rock Member-Continued

fragments; weathers to form steep loose slope. Thin irregular lens of pale-red-purple $(5 R P \quad 6 / 2)$ dense limestone at $10.2 \mathrm{ft}$ above unit base. Units 6 through 27 measured starting in prominent gully and continuing up hillside to north

Total of Owl Rock Member.

Petrified Forest Member (upper and lower contacts covered) :

5. Covered. Units 2 through 5 measured in prominent gully. This gully may be related to a fracture continuous with the one seen near the top of the section. Because this fault may be present beneath the cover, the thicknesses of units 2 through 5 might be slightly in error. The maximum displacement seen on this fault is $20 \mathrm{ft}$

4. Clayey sandstone, pale purple (5P $6 / 2$ ), weathering same color, fine grained with subordinate interstitial clay, fair sorted, composed of subangular grains; composition masked; firmly cemented, slightly calcareous; composed of very thin to thin planar sets of small- to medium-scale lowangle cross-laminae; flaggy splitting; exposed in gully bottom. This unit is similar to sandstone associated with the Petrified Forest Member in the type area

3. Covered

Total of Petrified Forest Member ....

Moss Back Member:

2. Sandstone, very pale orange (10YR $8 / 2)$, grayish orange $(10 Y R 7 / 4)$, and pale yellowish orange $(10 Y R 8 / 6)$, weathering very pale orange $(10 Y R$ $8 / 2$ ), fine to medium grained, well sorted, composed of subangular to subrounded clear quartz and sparse black accessory mineral; poorly to firmly cemented, calcareous; abundant limonite spots; composed of thin to thick trough and planar sets of medium-scale cross-laminae, of thick sets of parallel laminae or possible extremely low angle large-scale crosslaminae, and of thin to thick structureless lenses; dominantly massive splitting; weathers to form conspicuous ledge and bench. No conglomerate is present along the line of section, although slump blocks of conglomerate covering part of underlying unit, suggest that conglomerate may occur locally in lowest part of Moss Back Member
Chinle Formation (incomplete)-Continued

Moss Back Member-Continued

Total of Moss Back Member

(upper and lower contacts covered)

50.9

Monitor Butte Member:

1. Covered. Unit is interval from highest exposure of Shinarump Member to lowest exposure of Moss Back Member

Total of Monitor Butte Member....

$\overline{50.9}$

Shinarump Member:

Not measured or described. Shinarump is poorly and only partially exposed. In Notch Canyon, sec. 33 and 34, T. 34 S., R. $20 \mathrm{E}$., the Shinarump Member is 11.0 ft thick.

Total of Chinle Formation (using 11.0 $\mathrm{ft}$ as thickness of Shinarump Member)

Base of section; base of local exposure. Section starts about $200 \mathrm{ft}$ east of Cottonwood Wash and about $100 \mathrm{ft}$ north of prominent side gully of Cottonwood Creek.

\section{U-29. HITE}

Measured beginning near the Colorado River at The Horn and continuing up promontory to the north. Promontory $13 / 4$ miles south-southeast of Hite, Utah, long $110^{\circ} 25^{\prime} 40^{\prime \prime} W$., lat $37^{\circ} 47^{\prime} 05^{\prime \prime}$ N., San Juan County

[Measured by J. H. Stewart, November 1952]

Top of section; not top of outcrop.

Wingate Sandstone:

36. Sandstone, light brown (5YR 6/4), weathering same color, fine to very fine grained, well sorted; composed of subrounded clear quartz and sparse black accessory minerals; poorly cemented, highly calcareous; composed of thin small- to medium-scale trough sets of cross-laminae; massive splitting; weathers to form vertical cliff. Only lower $30 \mathrm{ft}$ of unit examined. Bottom $14 \mathrm{ft}$ contains common to abundant rounded to well-rounded coarse grains of clear and amber quartz. From 3.3 to $5.9 \mathrm{ft}$ above base of unit sandstone does not contain coarse grains and is horizontally laminated and ripple laminated. Basal contact sharp Unmeasured

Chinle Formation:

Church Rock Member:

Hite Bed:

35. Sandstone and conglomeratic sandstone to cobble conglomerate. Sandstone, pale red $(5 R 6 / 2)$, common pale reddish brown $(10 R 5 / 4)$ and pale yellowish orange $(10 Y R 8 / 6)$ to dark yellowish orange $(10 Y R 6 / 6)$, weathering pale red $(5 R 6 / 2)$ and light brown $(5 Y R 6 / 4)$, fine to medium grained, uncommon interstitial green
Feet

678.1 
Chinle Formation-Continued

Church Rock Member-Continued

Hite Bed-Continued

silt, well sorted; composed of subangular clear quartz and uncommon green and orange accessory minerals, common fine-grained white mica; firmly cemented, noncalcareous to moderately calcareous; composed of horizontal laminae and thin small- to medium-scale trough sets of lowangle cross-laminae; platy and blocky to massive splitting. Contains uncommon pale-reddish-brown (10R 5/4) granules and pebbles of siltstone. Conglomeratic sandstone to cobble conglomerate, pale red $(5 R 6 / 2)$ to pale reddish brown $(10 R 5 / 4)$, weathering light brown $(5 Y R 6 / 4)$, fine to medium grained, abundant granules to cobbles, poorly sorted; composed of sand grains like sandstone part of unit and round very coarse grains to cobbles of siltstone and sandy siltstone; firmly to well cemented, noncalcareous; structureless, slabby to massive splitting. Cobbles disk shaped and have a maximum long dimension of $1.2 \mathrm{ft}$. Unit as whole is tabular. Weathers to form vertical cliff. Basal $0.6 \mathrm{ft}$ of unit is cobble conglomerate; 0.6 to $1.6 \mathrm{ft}$ pebble conglomerate; 1.6 to $4.1 \mathrm{ft}$ sandstone; 4.1 to $7.9 \mathrm{ft}$ pebble conglomerate; 7.9 to $8.9 \mathrm{ft}$ cobble conglomerate; 8.9 to $27.8 \mathrm{ft}$ sandstone; 27.8 to $28.8 \mathrm{ft}$ granule conglomerate; 28.8 to $34.0 \mathrm{ft}$ sandstone

Total of Hite Bed

34. Siltstone, similar to unit 31. Contains common thin sets of sandy siltstone in top $5 \mathrm{ft}$ of unit similar to that in unit 33 and grayish-orange part of unit 32. These thin sets dip at an angle of $30^{\circ}$ to the regional dip and are truncated by the overlying unit. Unit does not contain swelling clays

33. Sandy siltstone (70 percent) and siltstone (30 percent). Sandy siltstone, light brown (5YR 6/4) and pale red $(10 R 6 / 2)$, weathering same colors, abundant very fine sand grains; uncommon fine-grained mica, common limonite stains; well cemented, noncalcareous; composed of thin sets of ripple laminae and horizontal laminae interbedded with siltstone; platy splitting. Siltstone, similar to unit 31 . Entire unit is tabular. Unit weathers to form minor ledge. Poorly exposed granule conglomerate occurs from 0.0 to $0.9 \mathrm{ft}$ and 1.4 to $2.0 \mathrm{ft}$ above base
Feet

Chinle Formation-Continued

Church Rock Member-Continued

of unit. Granule conglomerate, pale yellowish brown (10YR 6/2), weathering same color, composed of granules, abundant medium to very coarse sand grains, and sparse pebbles of siltstone, poorly sorted; firmly cemented, noncalcareous; stratification and splitting concealed. Unit does not contain swelling clays.

32. Sandy siltstone, similar to unit 30 . Abundant grayish orange (10YR 7/4) from 7.7 to $14.4 \mathrm{ft}$ above base of unit. Unit weathers to form lighter colored blocky splitting cliff from 7.7 to $\mathbf{1 4 . 4}$ $\mathrm{ft}$ above base of unit; rest of unit is steep slope. Unit does not contain swelling clays

31. Siltstone, pale reddish brown $(10 R 5 / 4)$, weathering same color and pale red $(10 R 6 / 2)$; firmly cemented, noncalcareous; stratification concealed; weathers to form steep rubble-covered slope. Common light-greenish-gray (5GY 8/1) spots. Unit does not contain swelling clays

30. Sandy siltstone, pale reddish brown $(10 R 5 / 4)$ and abundant light-greenish-gray $(5 G Y 8 / 1)$ spots as much as $11 / 2$ in. in diameter, abundant very fine sand grains; firmly cemented, moderately calcareous; composed of horizontal laminae; platy, blocky, and massive splitting; weathers to form vertical cliff in lower $20 \mathrm{ft}$ and steep loose slope in rest of unit. Bottom $3.2 \mathrm{ft}$ of unit contains sandy siltstone that contains abundant light-greenish-gray ( $5 G Y$ 8/1) mottles and is well cemented with a calcareous cement. Abundant light-greenish-gray (5GY 8/1) mottles about $26 \mathrm{ft}$ above base of unit produces a light-colored band $0.5 \mathrm{ft}$ thick. Unit does not contain swelling clays

Total of Church Rock Member ......

Owl Rock Member:

29. Siltstone, pale red $(5 R 6 / 2)$ in basal $4 \mathrm{ft}$ and pale reddish brown (10R $5 / 4)$ in rest of unit, weathering pale red $(10 R 6 / 2)$, similar to unit 27 . Basal $4 \mathrm{ft}$ contains swelling clays ....

28. Sandstone and granule to pebble conglomerate. Sandstone, pale red $(10 R$ $6 / 2$ ) and common light greenish gray (5GY 8/1), weathering same colors, medium grained, well sorted; composed of subangular clear quartz and abundant (10 percent) orange, green, and black accessory minerals; firmly cemented, calcareous; composed of
Feet 
Chinle Formation-Continued

Owl Rock Member-Continued

thin small-scale trough sets, of lowangle cross-laminae, festoons well developed; platy splitting. Granule to pebble conglomerate, light greenish gray $(5 G 8 / 1)$, weathering same color, composed of well-rounded to subrounded coarse grains to cobbles of limestone in a calcite matrix; poorly sorted; poorly cemented, calcareous; composed of thin to thick horizontal beds; slabby blocky weathering. Entire unit is tabular. Unit weathers to form ledge. Granule to pebble conglomerate from 0.0 to 3.1 $\mathrm{ft}, 4.1$ to $5.2 \mathrm{ft}$, and 12.5 to $13.0 \mathrm{ft}$ above base of unit. Granule and pebble conglomerate at top of unit thickens to about $3 \mathrm{ft} 30 \mathrm{ft}$ to east of line of section

27. Silty claystone to siltstone, grayish red purple (5RP 4/2), (weathering pale red purple $(5 R P 6 / 2))$ from 0.0 to $5.0 \mathrm{ft}$ above base of unit; pale reddish brown $(10 R 5 / 4)$ and uncommon grayish red purple (5RP 4/2) (weathering pale red $(10 R 6 / 2)$ and pale red purple (5RP 6/2)) from 5.0 to $47.4 \mathrm{ft}$; light brown (5YR 6/4) (weathering grayish orange (10YR $7 / 4)$ ) from 47.4 to $65.8 \mathrm{ft}$; pale reddish brown $(10 R$ 5/4) (weathering pale red $(10 R 6 / 2))$ from 65.8 to $80.6 \mathrm{ft}$; well cemented, highly calcareous in places, noncalcareous in places; stratification concealed; weathers to form steep rubble-covered slope. Common to abundant light-greenish-gray (5GY 8/1) spots. Sparse (1 percent) light-greenish-gray $(5 G Y \quad 8 / 1)$ thin horizontal beds of granule conglomerate. Granules are composed of limestone. Strata in basal $65.8 \mathrm{ft}$ of unit contain mostly swelling clays; rest of unit does not contain swelling clays

26. Sandstone, pale red $(10 R 6 / 2)$ and common light greenish gray ( $5 G Y$ $8 / 1$ ), weathering same colors, fine to medium grained, fair sorted; composed of subangular clear quartz and uncommon to common orange and black accessory minerals; firmly cemented, moderately calcareous; composed of thin small- to medium-scale trough and planar sets of crosslaminae; platy splitting; weathers to form ledge. Bottom $1 \mathrm{ft}$ of unit is sandstone, light greenish gray (5GY $8 / 1$ ), very coarse grained, poorly sorted; composed of rounded to wellrounded limestone grains; poorly cemented, highly calcareous; thin parallel beds; slabby splitting
Feet Chinle Formation-Continued Owl Rock Member-Continued

25. Siltstone and limestone interbedded. Siltstone, pale red $(10 R 6 / 2)$, common pale red purple (5RP 6/2); firmly to well cemented, highly calcareous; stratification concealed; fractures into angular fragments. Common light-greenish-gray ( $5 G 8 / 1$ ) spots. Limestone, light greenish gray $(5 G Y 8 / 1)$ and sparse grayish red purple (5RP 4/2), weathering same colors and light brown (5YR 6/4), dense, sparse medium-grain-size calcite crystals; well cemented; composed of very thin to thin horizontal beds; slabby to blocky splitting. Limestone occurs in thin to very thin sets interbedded with siltstone. Unit weathers to form steep slope in lower part and vertical cliff in upper part; in places entire unit weathers to form vertical cliff. Unit forms prominent light-colored band. Limestone units weather to form small ledges. Limestone sets occur from 16.7 to $18.6 \mathrm{ft}$, 19.6 to $22.1 \mathrm{ft}, 31.2$ to $36.0 \mathrm{ft}$, and 43.6 to $46.8 \mathrm{ft}$ above base of unit. Abundant thin discontinuous limestone beds occur in basal $16.7 \mathrm{ft}$ of unit

- Total of Owl Rock Member

Contact of Owl Rock and Petrified Forest Members placed at base of unit contains limestone beds typical of Owl Rock Member.

Petrified Forest Member:

24. Siltstone, pale reddish brown $(10 R 5 / 4)$ in lower half grading to light brown (5YR 6/4) in upper half, weathering same colors; firmly to well cemented, calcareous; stratification concealed; fractures into angular fragments; weathers to form steep slope. Unit forms prominent color band in Chinle formation. Common to abundant lightgreenish-gray spots ( $5 G Y 8 / 1)$. Grades into overlying unit. Contains swelling clays in places

23. Silty sandstone of types 1 and 2. Type 1 , light greenish gray (5G 8/1), weathering greenish gray ( $5 G Y 6 / 1)$, coarse grained, abundant interstitial silt, poorly sorted; composed predominantly of round limestone grains; poorly cemented, highly calcareous; stratification poorly exposed but probably consists of horizontal laminae and common thin small trough sets of cross-laminae; platy splitting. Rare fossil teeth(?). Type 2, pale reddish brown $(10 R 5 / 4)$, light-greenish-gray (5GY 8/1) spots, weathering same colors, very fine grained, abundant 
Chinle Formation-Continued

Petrified Forest Member-Continued

silt, poorly sorted; composition not determinable; firmly cemented, highly calcareous; ripple laminated; platy splitting. Type 1 silty sandstone is from 0.0 to $1.2 \mathrm{ft}$ and 2.2 to $4.2 \mathrm{ft}$ above base of unit; rest of unit is type 2 silty sandstone. Unit weathers to form steep slope. Unit contains some swelling clays. Offset in section so that overlying units measured $500 \mathrm{ft}$ east of where underlying units were measured

22. Clayey siltstone, dark reddish brown $(10 R 3 / 4)$ from 0.0 to $1.8 \mathrm{ft}$ above base of unit, grayish red purple (5RP $4 / 2$ ) from 1.8 to $11.1 \mathrm{ft}$, and pale reddish brown $(10 R 5 / 4)$ from 11.1 to $42.0 \mathrm{ft}$, weathering same colors. Laterally a large part of the reddishbrown interval becomes dark reddish brown $(10 R 4 / 4)$ and weathers light brown $(5 Y R 5 / 6)$. Unit is firmly cemented, calcareous; stratification concealed; fractures into angular fragments; weathers to form steep frothy slope. Light-greenish-gray $(5 G Y 8 / 1)$ limy spots throughout unit. Unit contains some swelling clays ....

Total of Petrified Forest Member

Moss Back Member:

21. Sandstone, predominantly pale-red ( $10 R$ $6 / 2)$ and minor pinkish-gray (5YR $8 / 1)$ and yellowish-gray (5Y 8/1); weathers moderate brown ( $5 Y R 4 / 4)$ and brownish black (5YR 2/1); fine to medium grained, well sorted; composed of subrounded clear quartz and sparse white, orange, and black accessory minerals; locally sparse thin conglomeratic beds contain quartz, claystone, and siltstone granules and pebbles; firmly cemented, calcareous, limonite stains as spots $0.25-0.5 \mathrm{~mm}$ in size; composed of thin trough sets of small- and medium-scale crosslaminae, uncommon parallel laminae; platy to blocky and massive splitting; weathers to form most prominent cliff and bench in Chinle Formation. Top $8.8 \mathrm{ft}$ weathers back to form a bench and is very poorly exposed ......

20. Sandstone, pale-red-purple (5RP 6/2) and light-brownish-gray (5YR 6/1); weathers same colors; very fine grained, common clay minerals, fair sorting; angularity and composition mostly concealed; bottom $4 \mathrm{ft}$ well cemented and highly calcareous, and contains abundant reddish-brown, greenish-gray, and yellow-brown siltstone granules and pebbles; firmly
Feet $\begin{array}{r}\text { Chinle Formation-Continued } \\ \text { Moss Back Member-Continued } \\ \text { cemented, noncalcareous; unit is tabu- } \\ \text { lar, but varies in thickness; thin to } \\ \text { thick trough sets of medium-scale } \\ \text { low-angle cross-laminae; platy split- } \\ \text { ting; weathers to form cliff. Base of } \\ \text { Moss Back channels as much as } 3 \mathrm{ft} \\ \text { into underlying Monitor Butte Mem- }\end{array}$

Total of Moss Back Member

Monitor Butte Member:

19. Silty claystone to clayey sandstone, light-greenish-gray $(5 G Y \quad 8 / 1)$ to greenish-gray ( $5 G Y 6 / 1)$, and minor grayish-red (10R 5/2); composed of silty clay to very fine grained sand with abundant clay; common finegrained white mica; firmly to well cemented, argillaceous; stratification mostly concealed; weathers to form steep frothy slope. Sparse interbedded thin sets of ripple-laminated sandstone that is light greenish gray $(5 G Y \quad 8 / 1)$ and grayish red $(10 R$ $4 / 2$ ) ; weathers same colors; very fine grained, well sorted; well cemented, highly calcareous; ripple laminated platy splitting

18. Sandstone and conglomeratic sandstone, light-greenish-gray $(5 G Y \quad 8 / 1)$ and yellowish-gray (5Y 8/1); weathers same colors and pale yellowish brown $(10 Y R 6 / 2)$; fine to very fine grained; top $5 \mathrm{ft}$ well sorted; bottom $4 \mathrm{ft}$ fair to poorly sorted and contains medium grains and abundant coarse to very coarse grains, granules, and pebbles; composed of subrounded clear quartz and common orange and black accessory minerals (granules and pebbles are composed of limestone and limy siltstone); firmly cemented, highly calcareous; unit is tabular, consists of thin trough sets of small- to medium-scale cross-laminae, sparse parallel laminae to thin beds; platy to slabby splitting; weathers to form minor ledge that is fairly persistent along outcrop

17. Silty claystone to clayey sandstone and sandstone. Silty claystone to clayey sandstone is light greenish gray ( $5 G Y$ $8 / 1)$ to greenish gray ( $5 G Y 6 / 1)$, red purple $(5 R P 4 / 2)$ from 82.0 to $86.0 \mathrm{ft}$ above base of unit; weathers predominantly light greenish gray (5GY 8/1); ranges from silt with abundant clay to very fine grained sand with abundant silt and clay, fair sorting; sand grains are composed of subangular clear quartz and common orange and black accessory min-
Feet

$\underline{\underline{13.0}}$

91.1 
Chinle Formation-Continued

Monitor Butte Member-Continued

erals, common fine-grained white mica; poorly to well cemented, moderately to highly calcareous; stratification mostly concealed, but sparse laminae seen; splitting mostly concealed, but where seen is highly fractured with common slickensided surfaces. Silty claystone is confined to bottom 30-40 ft of unit. Along outcrop, bottom $3-20 \mathrm{ft}$ is variegated with grayish purple (5P 4/2), grayish yellow (5Y 8/1), and grayish red $(10 R 4 / 2)$ with common dark-yellowish-orange $(10 Y R 6 / 6)$ stain along fracture surfaces; and contains sparse limestone nodules as much as 5 in. in diameter. Sandstone, light greenish gray $(5 G Y 8 / 1)$ and pale yellowish brown $(10 Y R 6 / 2)$; weathers predominantly light greenish gray ( $5 G Y$ $8 / 1)$ and dark yellowish brown (10YR $4 / 2$ ) ; very fine grained, fair to well sorted; composed of subangular clear quartz and sparse black accessory minerals; well cemented, calcareous; ripple laminated, common parallel laminae, and probably some thin trough and planar sets of mediumscale low-angle cross-laminae; platy to slabby splitting. Sandstone is characteristically contorted and slumped as the result of penecontemporaneous (?) deformation. Unit as a whole weathers to form steep rubble-covered slope containing small irregular ledges...

Total of Monitor Butte Member ....

Total of Chinle Formation

Contact between Moenkopi and Chinle is sharp and marks a change from red rocks below to green rocks above. Strata above the contact contain swelling clays, whereas those below do not.

Moenkopi Formation (incomplete) :

Upper slope-forming member:

16. Siltstone, grayish-red $(10 R 4 / 2)$; weathers same color; common fine-grained mica; firmly cemented, slightly calcareous; unit is tabular, consists of parallel laminae; platy splitting; weathers to form steep slope. Sparse laminae and very thin sets of laminae of grayish-yellow (5Y 8/4) calcareous sandy siltstone are interstratified with the siltstone

15. Siltstone ( 80 percent) and sandy siltstone (20 percent). Siltstone, pale reddish brown $(10 R 5 / 4)$ and grayish red $(10 R 4 / 2)$; weathers same colors; common fine-grained white mica; firmly cemented, noncalcareous; predominantly parallel laminated with
Moenkopi Formation (incomplete)-Continued Upper siope-forming member-Continued minor ripple laminae; platy splitting. Sandy siltstone, grayish orange $(10 Y R 7 / 4)$ and minor pale red $(10 R$ $6 / 2)$; weathers grayish orange $(10 Y R$ $7 / 4)$ and pale reddish brown $(10 R$ $5 / 4)$; composed of silt with abundant very fine sand grains; well cemented, calcareous; predominantly ripple laminated, sparse thin trough sets of medium-scale cross-laminae; platy to blocky splitting. Cross-laminated sets confined to pale-red very thick cosets from 8.8 to $10.8 \mathrm{ft}, 18.5$ to $21.5 \mathrm{ft}$, 35.8 to $37.8 \mathrm{ft}$, and 60.1 to $65.8 \mathrm{ft}$ above base of unit. These cross-laminated cosets grade laterally into ripple-laminated sets. Entire unit is tabular and weathers to form a gentle to steep slope with small ledges in the cross-laminated cosets

14. Sandy siltstone, similar to that in unit 9

Total of upper slope-forming member

Total of incomplete Moenkopi Formation

161.4

Base of section; not base of exposure.

Units 1-13 described in Stewart, Poole, and Wilson (1972).

\section{U-30. JACOBS CHAIR}

Measured from Jacobs Chair road, at a point S. $49^{\circ} \mathrm{W}$. of Jacobs Chair, to the western point of Jacobs Chair, line of section is $N .26^{\circ} \mathrm{E}$., long $110^{\circ} 12^{\prime} 00^{\prime \prime} W$., lat $37^{\circ} 43^{\prime} 40^{\prime \prime} N$., San Juan County

[Measured by J. H. Stewart and G. A. Williams, October 1952]

Top of accessible exposure.

Feet

Wingate Sandstone:

47. Sandstone, pale reddish brown $(10 R$ $5 / 4)$ and yellowish gray $(5 Y 8 / 1)$, weathering pale reddish brown $(10 R$ $5 / 4)$, very fine grained, well sorted; composed of subround to round clear quartz and uncommon orange, green, and black accessory minerals; firmly cemented, noncalcareous; composed of thin to thick medium-scale trough to planar sets of low-angle cross-laminae; massive splitting; weathers to form vertical cliff. Bottom $6 \mathrm{ft}$ contains abundant subround to round coarse grains. Basal contact sharp and smooth Unmeasured

Chinle Formation:

Church Rock Member:

46. Siltstone, similar to unit 35 , weathers to form steep slope which is covered with blocks from the Wingate Sandstone

45. Siltstone, similar to unit 35 except is structureless. Blocky to massive splitting, weathers to form prominent ledge 
Chinle Formation-Continued

Church Rock Member-Continued

44. Siltstone, similar to unit 35 , weathers to form steep rubbly slope

43. Limy siltstone, similar to 32 except for predominance of thin small-scale trough sets of thin cross-laminae ......

42. Siltstone, similar to unit 35 , weathers to a steep rubble-covered slope

41. Limy siltstone, similar to unit 32 , weathers to form small ledge

40. Siltstone, similar to unit 35 except for presence of common light-greenishgray $(5 G Y 8 / 1)$ mottling; weathers to form steep rubble-covered slope....

39. Limy siltstone, similar to unit 32 , weathers to form ledge

38. Sandstone and siltstone, pale reddish brown $(10 R 5 / 4)$ and minor light greenish gray ( $5 G Y 8 / 1)$, weathering pale reddish brown (10R 5/4), grades from very fine grained sandstone in lower $6 \mathrm{ft}$ to siltstone in rest of unit. Sandstone, well sorted; composed of subangular clear quartz and sparse black accessory minerals; firmly to well cemented, slightly calcareous. Unit as a whole is tabular, very thin horizontally bedded, platy to flaggy splitting and weathers to form steep loose slope with ledge at base

37. Siltstone, pale reddish brown $(10 R 5 / 4)$, common light greenish gray (5GY $8 / 1)$, weathering pale reddish brown (10R 5/4); firmly to well cemented, noncalcareous; composed of horizontal laminae and thin beds, sparse thick beds; platy to blocky splitting, fractures into pebble-sized angular fragments; weathers to form steep loose slope with small ledges. Massive splitting ledge occurs from $20.5 \mathrm{ft}$ to $27.0 \mathrm{ft}$ above base of unit

36. Limy siltstone, similar to unit $32 \mathrm{ex}-$ cept for presence of uncommon horizontal laminae and very thin beds. One poorly developed very thin smallscale trough set of low-angle crosslaminae occurs in unit

35. Siltstone, pale reddish brown $(10 R 5 / 4)$, weathering same color; firmly cemented, noncalcareous; stratification concealed; fractures into angular pebble-sized fragments; weathers to form steep rubble-covered slope. Uncommon light-greenish-gray ( $5 G Y$ 8/1) spots

Total of Church Rock Member ......

Owl Rock Member:

34. Limy siltstone, similar to unit 32 ; weathers to form prominent ledge ....
Feet
Chinle Formation-Continued

Owl Rock Member-Continued

33. Siltstone, similar to unit 31 except for lack of ripple laminae and of thin horizontally laminated sets; weathers to form steep smooth slope ........

32. Limy siltstone, light greenish gray $(5 G Y 8 / 1)$ and minor pale red (10R $6 / 2)$, weathering light greenish gray $(5 G Y 8 / 1)$ and pale reddish brown $(10 R 5 / 4)$; well cemented, calcareous; composed of thin horizontal beds; slabby to blocky splitting; weathers to form small ledge

31. Siltstone, pale red $(10 R 6 / 2)$ and light brown (5YR 6/4), weathers pale red $(10 R 6 / 2)$, with light-greenish-gray spots $(5 G Y 8 / 1)$; firmly cemented, calcareous; stratification concealed; weathers to form steep loose slope. Basal $2.3 \mathrm{ft}$ of unit and from $5.1 \mathrm{ft}$ to $8.9 \mathrm{ft}$ above base contains ripplelaminated and horizontally laminated sandy siltstone sets which are commonly altered to light greenish gray (5GY 8/1). Unit contains sparse light-greenish-gray $(5 G Y$ 8/1) limy siltstone beds. Unit distinguished from one below by presence at base of ripple-laminated and horizontally laminated sets. These sets crop out as small ledges and form a lighter colored band

30. Siltstone, pale red $(10 R 6 / 2)$ and pale red purple $(5 R P 6 / 2)$ in basal 54.5 $\mathrm{ft}$ of unit and predominantly pale reddish brown $(10 R 5 / 4)$ and minor light brown $(5 Y R \quad 6 / 4)$ in rest of unit, light-greenish-gray ( $5 G Y 8 / 1)$ spots throughout, weathers pale red purple $(5 R P 6 / 2)$ in basal $54.5 \mathrm{ft}$ of unit and pale reddish brown $(10 R$ $5 / 4$ ) in rest of unit; sandy (very fine grained) in places; firmly cemented, calcareous; stratification concealed; weathers to form steep slope. Sparse light-greenish-gray $(5 G Y$ 8/1) thin horizontal sets of limestone throughout unit. Limestone bed from 89.7 to $91.2 \mathrm{ft}$ above base of unit similar to that in unit 20. This bed pinches out within 20 yds along outcrop. Top 1.7 $\mathrm{ft}$ of unit similar to unit 21

29. Sandstone, similar to unit 22 except for presence of very thin horizontal beds of well cemented sandstone; weathers to form steep rubble-covered slope with well-cemented sandstone forming 2 to 4 in. ledges

28. Sandstone similar to unit 26 except for presence of fragments as large as pebble size; weathers to form small ledge
92.9

Feet 
Chinle Formation-Continued

Owl Rock Member-Continued

27. Sandy siltstone, grayish red ( $5 R 4 / 2)$, weathering same.color, similar to unit 23 except for presence of sandy parts and thin light-greenish-gray (5GY $8 / 1$ ) horizontally laminated sets of fine-grained sandstone (10 percent); weathers to form steep rubble-covered slope. May contain swelling clay in the sandy siltstone

26. Sandstone, light greenish gray $(5 G$ $8 / 1)$, weathering light olive gray ( $5 Y$ $6 / 1$ ), coarser to very coarse grained, common granules, poorly sorted; composed of rounded limestone grains and granules and sparse red accessory grains; firmly cemented, calcareous; composed of thin horizontal beds and thin small-scale trough to planar sets of low-angle cross-laminae; slabby splitting; weathers to form minor ledge

25. Sandy siltstone, pale reddish brown $(10 R 5 / 4)$ and pale red $(5 R 6 / 2)$; weathering same colors, otherwise similar to unit 23. Locally contains swelling clay

24. Sandstone, pale red $(10 R 6 / 2)$, lightgreenish-gray (5GY 8/1) mottling, weathering same colors, very fine grained, clayey, fair sorted; composed of subangular clear quartz and common orange, green, and black accessory minerals; firmly cemented, calcareous; composed of thin trough sets of medium-scale low-angle crosslamination, some horizontal laminae; platy splitting; weathers to form steep ledgy slope

23. Sandy siltstone, grayish red $(5 R 4 / 2)$, weathering pale red $(10 R 6 / 2)$, common very fine grained sand, common fine to very fine grained white mica; stratification concealed; weathers to form steep rubble-covered slope. Locally contains swelling clay ....

22. Sandstone, pale red $(10 R 6 / 2)$, very fine grained, clayey, fair sorted; composed of subangular clear quartz and common orange and green accessory minerals; poorly cemented, calcareous; bedding concealed; weathers to form rubble-covered slope. Unit poorly exposed. May contain swelling clay....

21. Sandstone and conglomerate, greenish gray (5G 6/1), weathering same color, poorly sorted; composed of rounded coarse grains to pebbles of limestone and abundant interstitial calcite; poorly cemented, calcareous; stratification concealed; massive splitting; weathers to form steep loose slope
Feet Chinle Formation-Continued

Owl Rock Member-Continued

20. Limestone, light greenish gray (5G $8 / 1)$ and minor pale red $(10 R 6 / 2)$, weathering light greenish gray, lithographic; well cemented, calcareous; composed of thin horizontal beds; slabby splitting; weathers to form prominent ledge. Upper 6 in. of unit contains pebble-sized irregular masses of medium-light-gray ( $N$ 6) chert as stringers and nodules

19. Siltstone, pale red purple (5RP 6/2) to pale red $(5 R 6 / 2)$, weathering same colors, no swelling clays; firmly to well cemented; structureless; fractures into angular fragments; weathers to form steep slope. Contains a few thin lenticular light-greenishgray $(5 G Y 8 / 1)$ silty limestone beds. Thick silty limestone bed is present near base of unit about $200 \mathrm{ft}$ west of line of section

Total of Owl Rock Member

Petrified Forest Member:

18. Clayey siltstone to siltstone, grayish red purple (5RP 4/2) and grayish red $(5 R 4 / 2)$, weathering same colors, swelling clays in some parts of unit; firmly cemented, calcareous; structureless; weathers to form steep slope. Unit contains common light-greenishgray $(5 G Y 8 / 1)$ limestone nodules. Unit grades into overlying unit. In places, unit weathers with a slightly frothy surface

17. Sandstone, pale red $(10 R 6 / 2)$, weathering same color, very fine grained, fair sorted; contains swelling clays as interstitial material in some parts, composed of subangular clear quartz and abundant orange, red, and green accessory minerals, accessory minerals constitute about 20 percent of rock, abundant fine grained white and dark-green mica; poorly to firmly cemented, noncalcareous; stratification concealed; massive splitting; weathers to form steep rubble-covered slope. One thin trough set of medium-scale cross-laminae noted near base of unit. Limy nodules common on bedding planes

16. Sandstone to conglomerate, light gray $(N 7)$, medium light gray $(N 6)$ and light greenish gray ( $5 G Y 8 / 1)$, weathering brownish gray ( $5 Y R 4 / 1)$, predominantly coarse to very coarse grained, some fine grained parts and some conglomerate, poorly sorted; composed of subangular clear quartz grains and of granules to pebbles (as large as 1 in.) of limestone and 
Chinle Formation-Continued

Petrified Forest Member-Continued siltstone, common green and orange accessory minerals, common mediumgrained white and dark mica; firmly to well cemented, calcareous; composed predominantly of alternating sets of fine-grained sandstone, coarsegrained sandstone, and granule conglomerate; composed of thin trough sets of small-scale cross-laminae, some thin beds; slabby splitting; weathers to form prominent ledge....

15. Siltstone (70 percent) and sandstone (30 percent), grayish red $(10 R 4 / 2$, $5 R 4 / 2)$ and greenish gray (5GY $6 / 1)$, colors mottled, weathering same colors. Siltstone, sparse fine-grained mica; firmly cemented, calcareous; stratification concealed. Sandstone, fine grained, clayey, poorly sorted; composed of subangular clear quartz and common green and gray accessory minerals, common dark-green coarse-grained mica flakes; firmly cemented, calcareous; intergrades with siltstone; thin small-scale sets of cross-laminae; platy splitting in part. Unit as a whole is tabular. Weathers to form steep rubble-covered slope

14. Sandstone, light greenish gray (5GY $8 / 1)$, light brownish gray (5YR 6/1), grayish yellow green $(5 G Y 7 / 2)$ and pale greenish yellow $(10 Y 8 / 2)$, weathering yellowish gray $(5 Y 8 / 1)$ and light greenish gray (5GY 8/1), fine grained, fair sorted; composed of subangular clear quartz, and common orange, green, and gray accessory minerals; firmly and poorly cemented, calcareous; stratification concealed except for trough sets of small- to medium-scale low-angle cross-laminae in firmly cemented parts (10 percent); firmly cemented parts slabby splitting, splitting concealed in rest of unit; weathers to form steep rubble-covered slope with small ledges in firmly cemented parts. Unit poorly exposed

Total of Petrified Forest Member

Moss Back Member:

13. Conglomerate and sandstone. Sandstone, very pale orange $(10 Y R 8 / 2)$, weathering pale red $(10 R 6 / 2)$, fine grained, fair sorted; composed of subangular clear quartz and uncommon green accessory minerals, some limonite(?) spots, common white interstitial mineral, probably calcite; firmly cemented, calcareous; composed of thin to thick trough sets of

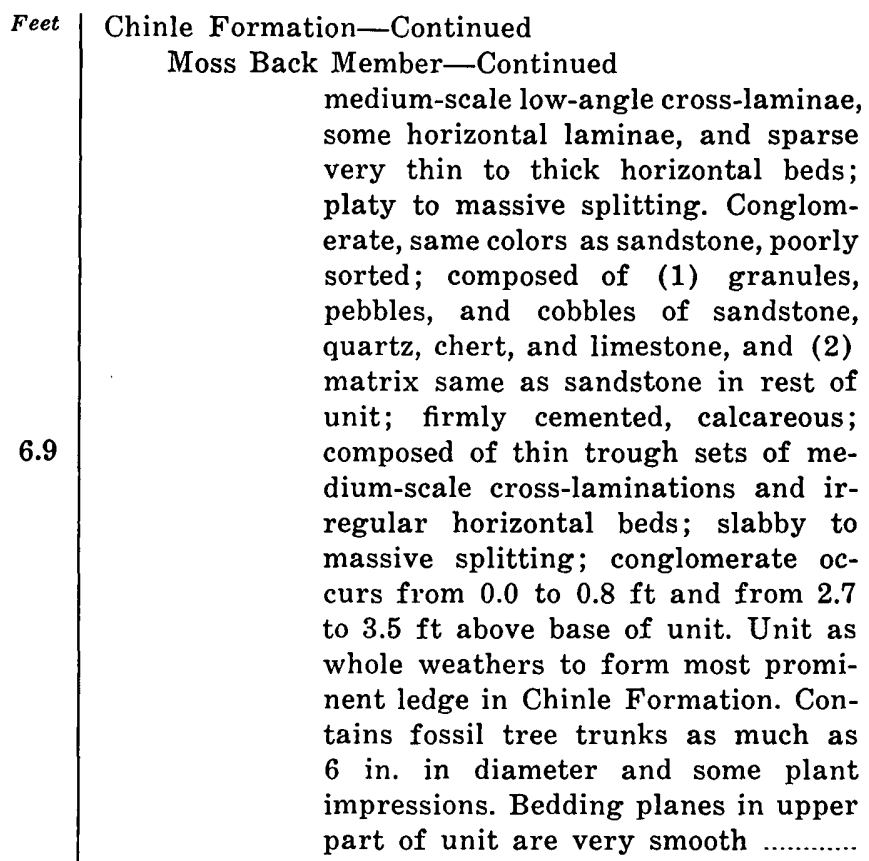

Total of Moss Back Member

Monitor Butte Member:

12. Siltstone, predominantly greenish gray (5GY 6/1, 5G 6/1) and subordinate grayish-red-purple (5RP 4/2) intervals in middle and upper parts; sandy (very fine grained) in places; firmly cemented, calcareous and argillaceous; stratification concealed; massive splitting; fractures into angular pebble-sized fragments; weathers to form steep rubble-covered slope. Unit contains sparse clayey sandstone that intergrades with siltstone. Sandstone is very fine grained and clay-rich and contains abundant orange, green, and red accessory minerals. Upper $6 \mathrm{ft}$ of unit contains abundant irregular limestone concretions

11. Sandstone, light greenish gray (5GY $8 / 1,5 G 8 / 1$ ), weathering same colors, fine to medium grained, common interstitial green clay, fair sorted; composed of subangular clear. and milky quartz and abundant orange and green accessory minerals; sparse medium-grained white mica; firmly to poorly cemented, noncalcareous; stratification poorly exposed, but probably predominantly thin trough sets of small-scale cross-strata; platy and massive splitting; weathers back to form bench on top of underlying unit. Base of unit contains several fossil trees as large as $2 \mathrm{ft}$ in diameter and $70 \mathrm{ft}$ long. Firmly cemented parts of unit weather to form ribs standing out from poorly cemented parts
Feet (1) 
Chinle Formation-Continued

Monitor Butte Member-Continued

10. Sandstone, predominantly yellowish gray $(5 Y 8 / 1)$ in lower half and greenish gray in upper half, fine to medium grained, argillaceous, poorly sorted; composed of subrounded clear and milky quartz and abundant orange, green, and black accessory minerals, abundant interstitial white mineral which is in part calcite; firmly cemented, calcareous; composed of thin trough sets of smallscale low-angle cross-laminae and horizontal laminae; platy splitting; weathers to form steep rubble-covered slope or, in places, a vertical cliff. Unit forms prominent ledge in middle of gray unit in basal third of Chinle

9. Sandy siltstone, greenish gray (5G $6 / 1$ ), weathering same color, abundant very fine grains; firmly cemented, argillaceous; stratification concealed; weathers to form steep rubble-covered slope. Very poorly exposed. Units 5 through 9 contain many penecontemporaneous (?) slump features

8. Sandstone, yellowish gray (5Y 8/1), weathering same color; similar to unit 7 except for less extensive penecontemporaneous slumping. Lower surface bevels top of underlying unit with angular discordance of $25^{\circ}$. Unit is ripple laminated

7. Sandstone, light olive gray (5Y 6/1) and yellowish gray (5Y 8/1), weathering same colors, fine grained; common interstitial green clay; fair sorting; composed of subangular clear quartz and abundant orange, green, and black accessory minerals, sparse medium-grained white mica; firmly cemented, calcareous; composed of thin trough sets of smallscale cross-laminae and of horizontal and ripple laminae; platy and massive splitting, weathers to form steep rubble-covered slope. In places, strata dip at $25^{\circ}$ as the result of penecontemporaneous slumping. Unit contains thin layer of greenish-gray $(5 G Y 6 / 1)$ siltstone at $26 \mathrm{ft}$ above base. $T_{0}$ the west the position of the unit is probably occupied entirely by greenish-gray (5GY 6/1) siltstone ..

6. Siltstone, grayish red $(10 R \quad 4 / 2)$ in lower part and grayish red $(5 R 4 / 2)$ and olive gray $(5 Y$ 6/1) in upper half, weathering same colors; firmly cemented, argillaceous; stratification concealed; fractures into pebble-sized

Feet | Chinle Formation-Continued Monitor Butte Member-Continued

fragments; weathers to form steep rubble-covered slope. Unit pinches or grades out within $50 \mathrm{ft}$ on either side of section

10.8

5. Sandstone, grayish orange $(10 Y R 7 / 4)$, weathering same color, coarse grained, common very coarse grains and granules, poorly sorted; composed of subrounded clear quartz and sparse black accessory minerals; firmly cemented, calcareous; composed of thin trough sets of small- to medium-scale cross-laminae; slabby to blocky splitting; weathers to form small ledge. Abundant limonite spots and stains. Abundant plant impressions. Bottom contact is surface of erosion

43.2

10.4

4. Siltstone, light greenish gray (5GY $8 / 1)$, abundant grayish-red $(10 R$ $4 / 2)$ and very dusky red purple (5RP 2/2) mottling, weathering same colors, abundant very fine grained sand in places; common fine to very coarse grained sand in other places; firmly cemented, noncalcareous; stratification concealed; massive splitting; fractures into angular pebble-sized fragments; weathers to form steep loose slope

Total of Monitor Butte Member Shinarump Member:

3. Sandstone (70 percent) and siltstone (30 percent). Sandstone, light gray $(N 7)$ and grayish yellow (5Y 8/4), weathering grayish orange $(10 Y R$ $7 / 4$ ), fine to medium grained, abundant coarse to very coarse grained sand in places; fair sorting; composed of subrounded clear quartz and uncommon orange and black accessory minerals; firmly cemented, noncalcareous; stratification concealed; massive splitting; fractures into angular fragments. Siltstone, medium gray ( $N 5)$, weathering same color; common coarse grains of clear quartz; firmly cemented, argillaceous; stratification concealed; fractures into pebble-sized angular fragments; siltstone present entirely in lower part of unit. Unit as a whole weathers to form steep slope

2. Sandstone, yellowish gray $(5 Y 7 / 2)$, weathering same color, grayish-yellow $(5 Y 8 / 4)$ staining on weathering surface; medium to coarse grained, common scattered very coarse grains, granules, and pebbles, poorly sorted; composed of subangular 
Chinle Formation-Continued

Shinarump Member-Continued

clear and milky quartz and abundant orange, black, and red accessory minerals; firmly cemented, argillaceous; stratification not well exposed but predominantly thin trough sets of small- to medium-scale cross-laminae; slabby to blocky splitting; weathers to form slope. Common thin beds of light-gray $\left(\begin{array}{ll}N & 7\end{array}\right)$ siltstone interbedded with sandstone. Abundant carbonaceous material, particularly along lamination planes. Bottom contact is surface of erosion

Total Shinarump Member

Total of Chinle Formation

\section{Feet}

Chinle Formation (incomplete)-Continued Church Rock Member-Continued red $(5 R 6 / 2)$ and sparse light greenish gray $(5 G Y 8 / 1)$, weathering grayish red $(5 R 4 / 2)$, very fine grained; well cemented, noncalcareous; ripple laminated, stratification concealed in places. Siltstone, grayish red (5R $4 / 2$ and $10 R \quad 4 / 2)$, weathering same colors; firmly cemented, noncalcareous; stratification concealed. Unit as whole weathers to form ledgy slope. Top $1.1 \mathrm{ft}$ of unit is a fine to very fine grained sandstone containing flakes of grayish-red siltstone. The basal part of this top $1.1 \mathrm{ft}$ appears to belong to the Chinle but grades upward into material resembling the overlying Wingate. Contact of Wingate Sandstone and Chinle Formation placed at lowest layer containing medium to coarse grains, but this contact is not sharp. Top $1.1 \mathrm{ft}$ of Chinle as described in this section may be actually reworked Chinle in the basal part of the Wingate Sandstone

13. Siltstone and sandy siltstone. Siltstone, grayish red $(10 R 4 / 2)$, weathering same color; well cemented, slightly calcareous in places; stratification concealed. Sandy siltstone, light brown $(5 Y R 6 / 4)$, weathering moderate reddish orange $(10 R 6 / 6)$, sandy (very fine grained); well cemented, slightly calcareous; structureless except for a few ripplemarked stratification planes. Sandy siltstone is present as horizontal sets from 16.4 to $22.3 \mathrm{ft}, 29.2$ to $32.2 \mathrm{ft}$, and 44.1 to $55.8 \mathrm{ft}$ above base of unit. Unit as a whole weathers to form steep slope with conspicuous ledges on sandy siltstone sets

12. Sandstone to silty sandstone, pale red $(5 R 6 / 2)$ and sparse light greenish gray $(5 G Y 8 / 1)$, weathering same colors, very fine grained, sparse coarse-grained accessory dark and white mica; firmly cemented, calcareous; composed of thin ripplelaminated sets. These sets dip at an angle to the regional dip (at least $20^{\circ}$ ), probably as the result of penecontemporaneous slumping. These sets contain many recemented faults with a displacement of a few inches. Unit as a whole weathers to form steep ledgy slope. Silty sandstone sets weather to form reentrants between sandstone sets ....
Feet 
Chinle Formation (incomplete)-Continued Church Rock Member-Continued

Total of Church Rock Member ......

Owl Rock Member:

11. Siltstone and limestone. Siltstone, pale reddish brown $(10 R 5 / 4)$, minor moderate red $(5 R \quad 5 / 4)$ and pale red $(5 R 6 / 2)$, weathering same colors; well cemented, calcareous; structureless. Limestone, pale red $(5 R 6 / 2)$, light greenish gray (5GY $8 / 1)$, and minor greenish gray (5GY $6 / 1)$ and grayish red (5R 4/2), weathering moderate red $(5 R 5 / 4)$, dense; well cemented; horizontally laminated to thinly bedded. Limestone is present as sets from 0.0 to $1.5 \mathrm{ft}, 2.3$ to $3.5 \mathrm{ft}, 5.9$ to 7.3 $\mathrm{ft}, 11.4$ to $14.0 \mathrm{ft}, 41.3$ to 41.8 $\mathrm{ft}$, and 42.2 to $43.4 \mathrm{ft}$ above base of unit. In addition to these limestone beds, the unit contains a few limy siltstone layers. Unit seems to have all gradations from pure limestone to siltstone. Unit as whole weathers to form a vertical cliff in basal $15 \mathrm{ft}$ and a steep slope above that

10. Siltstone, pale reddish brown (10R $5 / 4)$ and sparse grayish red $(10 R$ $4 / 2)$, weathering pale reddish brown $(10 R \mathrm{5} / 4)$; well cemented, calcareous; structureless; fractures into angular fragments; weathers to form steep loose slope. Unit contains abundant light-greenish-gray $(5 G Y$ 8/1) spots. Basal $4 \mathrm{ft}$ contains several pale-red (5R 6/2) layers

9. Siltstone, pale red $(5 R 6 / 2)$, weathering grayish red $(5 R 4 / 2)$; well cemented, calcareous; structureless; weathers to form ledgy slope. Unit from 0.0 to $1.4 \mathrm{ft}$ above base is very fine grained sandstone with abundant interstitial grayish clay. Unit from 11.6 to $15.7 \mathrm{ft}$ and from 19.1 to $21.8 \mathrm{ft}$ above base is palered $(5 R 6 / 2)$ limestone and siltstone pebble conglomerate with a silt matrix. Entire unit contains light-gray $(N$ 7) spots

8. Siltstone, grayish red $(5 R 4 / 2)$, pale reddish brown $(10 R 5 / 4)$, and pale red $(5 R 6 / 2)$, weathering grayish red $(10 R 4 / 2)$; abundant calcite masses and stringers throughout; poorly to well cemented, calcareous; stratification mostly concealed, structureless in places; weathers to form steep ledgy slope. Unit contains abundant light-greenish-gray (5GY $8 / 1$ ) spots. Unit from 26.5 to 29.5
Chinle Formation (incomplete)-Continued

Owl Rock Member-Continued $\underline{130.7}$

44.1

68.5

30.9 $\mathrm{ft}$ and 55.7 to $58.3 \mathrm{ft}$ above base is a limestone and siltstone granule conglomerate with a silt matrix grading to a limestone and siltstone grain sandstone with a silt matrix. Unit from 72.7 to $74.2 \mathrm{ft}$ above base is moderate-reddish-brown (10R 4/6) siltstone with abundant limestone stringers and abundant very light gray $(N 8)$ spots. This siltstone appears to be similar to the siltstone in unit 10

7. Sandy siltstone and sandstone. Sandy siltstone, grayish red $(5 R \quad 4 / 2)$, weathering pale red $(5 R 6 / 2)$, sandy (very fine grained); well cemented, calcareous; structureless; weathers to form gentle slope. Sandy siltstone is present only from 0.0 to $7.4 \mathrm{ft}$ above base of unit. Sandstone, grayish red $(10 R 4 / 2)$, weathering same color, very fine grained, fair sorted; abundant interstitial light gray material (possibly clay); well cemented, calcareous; ripple laminated with subordinate thin sets of horizontal thin beds; weathers to form rough vertical cliff. Unit from 7.4 to $9.4 \mathrm{ft}$ above base is a pebble conglomerate. Pebbles are composed of very hard siltstone and matrix of siltstone granules

6. Limestone and silty limestone, palered $(5 R \quad 6 / 2$ and $10 R \quad 6 / 2)$ and light-greenish-gray ( $5 G Y 8 / 1)$; firmly cemented; composed of very thin to thick horizontal beds; weathers to form steep ledgy slope. Unit forms lowest conspicuous purplish ledge in section. Unit contains abundant light-greenish-gray (5G 8/1) spots. Section transferred on top of unit 6 so that overlying units measured $500 \mathrm{ft}$ northwest of underlying units

5. Siltstone and limy siltstone. Siltstone, dark reddish brown $(10 R 3 / 4)$ and grayish red $(10 R 4 / 2)$, weathering dark reddish brown (10R 3/4) ; poorly to firmly cemented; stratification concealed; weathers to form steep rubble-covered slope. Unit contains abundant calcite stringers. Limy siltstone, pale reddish brown (10R $5 / 4)$ and greenish gray (5G 6/1); firmly cemented, highly calcareous; structureless; weathers to form small ledge. Limy siltstone is present as thin horizontal beds from 127.5 to $128.5 \mathrm{ft}$ and 131.0 to $132.0 \mathrm{ft}$ above base of unit. Unit contains abundant light-greenish-gray (5G 8/1) spots. 
Chinle Formation (incomplete)-Continued

Owl Rock Member-Continued

Limy siltstone from 127.5 to 128.5 $\mathrm{ft}$ contains a very thin bed of limestone pebble conglomerate

4. Silty sandstone (60 percent) and sandstone (40 percent). Silty sandstone, grayish red $(10 R 4 / 2)$, weathering same color. Sandstone, pale red $(10 R$ $6 / 2)$, weathering grayish red $(10 R$ 4/2). Silty sandstone and sandstone, very fine to fine grained, fair sorted; composed of subangular reddishbrown quartz grains; well cemented, calcareous. Basal $3.0 \mathrm{ft}$ of unit are ripple-laminated. Upper $2.2 \mathrm{ft}$ of unit is flaggy splitting. The base of the unit is mottled with light gray (N 7)

3. Silty claystone (70 percent) and siltstone (30 percent). Silty claystone, grayish red $(10 R 4 / 2)$, weathering same color; poorly cemented, noncalcareous; structureless; fractures into angular fragments. Siltstone, pale red (5R 6/2), weathering grayish red (10R 4/2); poorly cemented, noncalcareous; structureless; platy splitting in places; fractures into angular fragments. Unit as a whole weathers to form slope. Basal $2.0 \mathrm{ft}$ of unit is sandy (very fine grained). Upper $1.5 \mathrm{ft}$ of unit is platy splitting siltstone

Total of Owl Rock Member

Moss Back Member (incomplete) :

2. Sandstone, light greenish gray ( $5 G Y$ $8 / 1)$, yellowish gray $(5 Y 7 / 2)$, pale yellowish orange $(10 Y R 8 / 6)$, pale yellowish brown $(10 Y R 6 / 2)$, weathering pale yellowish brown (10YR $6 / 2$ ), fine to medium grained, fair sorted; composed of subrounded clear quartz with common black and sparse orange accessory minerals, common limonite specks; firmly cemented, slightly calcareous; composed of thick trough sets of medium-scale crossstrata; weathers to form a rough ledge. Thin basal layer of unit is a conglomerate composed mainly of limestone, siltstone, quartzite, and chert pebbles. At $86.7 \mathrm{ft}$ above base of unit is a 2.4-ft-thick ledge of sandstone along which the section was transferred. Overlying units measured $300 \mathrm{ft} \mathrm{N}$. $12^{\circ} \mathrm{W}$. of place where underlying units were measured

Total of incomplete Moss Back Member

Total of incomplete Chinle Formation
Feet

Chinle Formation (incomplete)-Continued

Moss Back Member (incomplete)-Continued

1. Intrusive igneous rock in contact with Moss Back Member.

153.7 Base of section; base of exposure.

\section{U-32. LOCKHART CANYON}

Measured starting at place 3 miles up Lockhart Canyon from the Colorado River and up the westernmost projection of a conspicuous point, middle of west side of sec. 24, T. 28 S., R. 20 E., SLM, San Juan County

[Measured by J. H. Stewart and G. A. Williams, September 1953]

Top of section; top of accessible outcrop. Top of section is $\mathrm{S} .81^{\circ} \mathrm{E}$. of intersection of Lockhart Canyon and Colorado River.

Wingate Sandstone:

50. Sandstone, light brown (5YR 6/4), weathering same color, fine grained, well sorted; composed of subrounded clear and amber quartz, and common black accessory mineral; firmly cemented, slightly calcareous; composed of thin trough to planar sets of low-angle medium-scale crossstrata; massive splitting; weathers to form vertical cliff. Unit contains about 1 percent medium to coarse grains of subrounded amber quartz and subordinate gray mineral. Only bottom $10 \mathrm{ft}$ of unit examined ..Unmeasured

Chinle Formation:

Church Rock Member:

Hite (?) Bed :

49. Covered. Thickness is from top exposure in Chinle Formation to lowest unslumped exposure of Wingate Sandstone

48. Silty claystone, grayish red ( $5 R 4 / 2)$, weathering same color; firmly cemented, noncalcareous; stratification concealed; fractures into granule-size fragments; weathers to form slope. A very thin set of sandy siltstone occurs at base of unit. This sandy siltstone is yellowish gray $(5 Y 8 / 1)$ and sandy (very fine grained) and contains granule-size flakes of greenish-gray (5G 6/1) claystone

Total of Hite(?) Bed

47. Sandy siltstone, light brown (5YR 6/4) and common light greenish gray (5GY 8/1), weathering pale reddish brown $(10 R 5 / 4)$, sandy (very fine grained); sparse very fine grained accessory white mica; well cemented, noncalcareous to slightly calcareous; composed of thin to very thick beds; fractures into angular fragments, weathers to form steep slope. Unit contains three conspicuous ledges from 22.6 to $26.0 \mathrm{ft}, 73.3$ to $84.3 \mathrm{ft}$, and 88.4 to $92.2 \mathrm{ft}$ above base. These ledges are composed of silty very fine grained sandstone 
Chinle Formation-Continued

Church Rock Member-Continued and sandy siltstone similar to that in the rest of the unit except that tiney are dominantly horizontally laminated and contain some possible ripple laminae. This unit has the typical lithology of the Church Rock Member

46. Siltstone, pale reddish brown (10R $5 / 4)$, weathering same color and common pale red $(5 R 6 / 2)$; poorly cemented; calcareous; structureless; weathers into angular fragments; weathers to form steep slope with thin crusty veneer over fresh rock. Silty limestone is present as thin horizontal beds at 17.6 to $18.2 \mathrm{ft}$ and at 30.2 to $30.7 \mathrm{ft}$. Silty limestone, pale red $(10 R 6 / 2)$, weathering same color; dense; well cemented, structureless; weathers to form lighter colored bands in slope

45. Siltstone (95 percent) and sandy siltstone (5 percent), same as unit 44 except that sandy siltstone is horizontally laminated and to a lesser extent ripple laminated and occurs as very thin sets interstratified with rest of unit. Some recent landslide slumping occurs in unit. Contact with overlying unit appears to be gradational. Unit weathers to form gentle slope

44. Siltstone (50 percent) and sandy siltstone (50 percent). Siltstone, pale reddish brown $(10 R 5 / 4)$ to dark reddish brown $(10 R 3 / 4)$, weathering pale reddish brown (10R 5/4); abundant very fine grained accessory white mica; firmly cemented, calcareous; horizontally laminated, platy splitting. Sandy siltstone, pale red $(5 R 6 / 2)$ and minor light greenish gray $(5 G Y 8 / 1)$, weathering pale reddish brown $(10 R 5 / 4)$; sandy (very fine grained) ; uncommon fineto medium-grained accessory white mica; well cemented, calcareous; ripple laminated, both cuspate and parallel types. Unit weathers to form ledgy slope

43. Silty claystone to siltstone (95 percent) and sandy siltstone (5 percent). Silty claystone to siltstone, greenish gray $(5 G Y 6 / 1)$ dominantly in lower half of unit, grayish red $(10 R 4 / 2)$ in top $5 \mathrm{ft}$; rest of unit is grayish red purple (5RP 4/2) and grayish red $(5 R 4 / 2)$, weathering light greenish gray $(5 G Y 8 / 1)$ and pale red purple $(5 R P 6 / 2)$; firmly cemented, calcareous; stratification concealed. Clays swell in water. Sandy siltstone,
Feet $\begin{array}{r}\text { Chinle Formation-Continued } \\ \text { Church Rock Member-Continued } \\ \text { pale red (5R 6/2) and minor light } \\ \text { greenish gray }(5 G Y \text { 8/1), weather- } \\ \text { ing same colors, very fine grained, } \\ \text { sandy; well cemented, highly calcar- } \\ \text { eous; ripple laminated; present as } \\ \text { thin sets interstratified with rest of } \\ \text { unit. Unit weathers to form slope } \\ \text { and is in part equivalent to ripple- } \\ \text { laminated siltstone forming vertical } \\ \text { cliff to east of section .................... }\end{array}$ So-called Black Ledge:

42. Sandstone, light brownish gray (5YR $6 / 1$ ) and uncommon pale reddish brown $(10 R 5 / 4)$, weathering light brownish gray $(5 Y R 6 / 1)$, very fine grained, well sorted; composed of subangular milky mineral, and about 10 percent orange and green minerals, uncommon fine-grained accessory dark and white mica; poorly cemented, calcareous; composed of thin trough sets of medium- to largescale low-angle cross-laminae and subordinate ripple laminae; weathers to form ledge

41. Sandstone (80 percent) and siltstone (20 percent). Sandstone, greenish gray $(5 G Y 6 / 1)$, weathering light olive gray $(5 Y 6 / 1)$, very fine grained; common medium-grained accessory white and dark mica; well cemented, calcareous; composed of cuspate ripple laminae, common horizontal laminae, and sparse thin trough sets of low-angle medium-scale crosslaminae. Siltstone, greenish gray (5GY 6/1), weathering light greenish gray ( $5 G Y$ 8/1); common finegrained accessory white mica, firmly cemented, calcareous; in part horizontally laminated. Siltstone is present as thin to thick lenses interstratified with the sandstone. The amount of siltstone in unit is highly variable along the outcrop. Unit weathers to form vertical cliff

40. Conglomeratic sandstone, greenish gray (5GY 6/1), weathering same color, coarse grains to pebbles ( 60 percent) in silty limy matrix, poorly sorted. Coarse grains to pebbles are rounded limy siltstone to limestone. Unit is poorly cemented, calcareous; composed of very thin wavy beds or lenses and possibly some crossbeds; weathers to form vertical cliff continuous with that of overlying unit. Abundant carbonaceous material ......

Total of so-called Black Ledge ......

Total of Church Rock Member ......
Feet

19.7 
Chinle Formation-Continued

Owl Rock(?) Member:

39. Siltstone (90 percent), and limy siltstone (10 percent). Siltstone, grayish red (5R 4/2 and 10R 4/2) and grayish red purple $(5 R P 4 / 2)$, weathers pale reddish purple (5RP 6/2); poorly cemented, calcareous; stratification concealed. Limy siltstone, light greenish gray $(5 G Y 8 / 1)$ and minor pale red $(10 R 6 / 2)$, weathering same colors; dense, well cemented; occurs as poorly defined possibly discontinuous thin beds and as sparse nodules averaging $1 \mathrm{in.}$ in diameter. Limy siltstone locally contains coarse to very coarse grains of limestone. The siltstone in the top $2 \mathrm{ft}$ of the unit is pale green (10G 6/2)

38. Siltstone, moderate brown (5YR 4/4) to light brown (5YR 6/4), weathering same colors; firmly cemented, calcareous; stratification concealed; weathers to form steep crusty slope. Unit contains common light-greenishgray $(5 G Y 8 / 1)$ spots and thin irregular mottled patches near base....

37. Siltstone, pale reddish brown $(10 R 5 / 4)$ and grayish red $(5 R 4 / 2)$, weathering grayish red $(5 R 4 / 2)$; poorly cemented, calcareous; stratification concealed; fractures into angular fragments; weathers to form steep crusty slope

36. Siltstone, grayish red purple $(5 R P 4 / 2)$, sparse pale reddish brown $(10 R 5 / 4)$, weathering same colors, fine silt; firmly cemented, calcareous; structureless; weathers to form slope. Basal $5 \mathrm{ft}$ contain a small amount of swelling clay. Base of unit marks change from strata below that contain swelling clays to strata above that contain dominantly nonswelling clays

Total of Owl Rock(?) Member ......

Petrified Forest Member:

35. Claystone to sandy claystone, light greenish gray (5GY 8/1), grayish purple $(5 P 4 / 2)$, and grayish red purple (5RP 4/2), weathering light greenish gray $(5 G Y 8 / 1)$ and pale red purple (5RP 6/2), sandy (very fine grained) in places, locally grades to sandstone; contains swelling clays; firmly cemented, calcareous; appears structureless; weathers to form frothy-surfaced slope. Contains some carbonaceous material

34. Clayey sandstone, light greenish gray $(5 G Y 8 / 1)$ and greenish gray (5GY $6 / 1)$, weathering light greenish gray $(5 G Y 8 / 1)$, fine to medium grained,
Feet

Chinle Formation-Continued

Petrified Forest Member-Continued

fair sorted; composed of subangular milky mineral and about 5 percent orange and green mineral, abundant medium to very coarse grained accessory dark mica; poorly cemented, highly calcareous; composed of thin trough sets of low-angle mediumscale cross-laminae; weathers to form steep frothy-surfaced ledgy slope. Bottom $5 \mathrm{ft}$ of unit contains common greenish-gray ( $5 G Y \quad 6 / 1$ ) siltstone. Lower part of unit contains abundant (40 percent) dark-greenish-gray (5GY 4/1) claystone and siltstone pellets. Carbonaceous material is common along crossbedding planes

Total of Petrified Forest Member

Moss Back Member:

33. Sandstone ( 80 percent), and siltstone (20 percent). Sandstone, light greenish gray (5GY 8/1) and common very light gray $(N 8)$ and yellowish gray. $(5 Y 8 / 1)$, weathering very pale orange $(10 Y R 8 / 2)$, fine grained, fair sorted; composed of subangular to subrounded milky quartz and common orange and black grains, uncommon fine- to medium-grained white and dark mica; firmly to poorly cemented, slightly calcareous to highly calcareous; composed of thin trough sets of medium-scale cross-laminae and sparse thin to thick structureless lenses. Siltstone, greenish gray ( $5 G Y$ $6 / 1$ ), weathering same color; abundant accessory white and dark mica; firmly cemented, calcareous; horizontally laminated. Some of siltstone is ripple-laminated, light-greenish-gray (5GY 8/1), and sand (very fine grained). Siltstone is present as thin to very thick lenticular sets interstratified with sandstone. Sandstone locally contains some medium to very coarse grains of siltstone or, in a few places, of clear quartz. Rarely the sandstone grades to very coarse grained sandstone composed of siltstone and quartz grains in a limy matrix. The sandstone commonly contains pebbles to cobbles composed largely of siltstone. The largest cobble found has a maximum diameter of $0.6 \mathrm{ft}$. A few gray quartz pebbles are present. The sandstone commonly contains carbonaceous material and rarely silicified wood. Unit as a whole weathers to form vertical cliff in lower part and wide bench in upper part
23.5
Feet 
Chinle Formation-Continued

Moss Back Member-Continued

Total of Moss Back Member ..........

Total of Chinle Formation

Moenkopi Formation (incomplete) :

32. Clayey siltstone to sandy siltstone, grayish-red $(10 R 4 / 2)$ and common lightbrown (5YR 6/4); top 2 ft light greenish gray $(5 G Y 8 / 1)$, sparse greenish-gray $(5 G Y 6 / 1)$ very thin bands in rest of unit; weathers pale reddish brown (10R 5/4); sandy (very fine grained), common very fine grained accessory white mica; firmly cemented, calcareous; unit is tabular, stratification poorly exposed, but where seen is horizontally laminated; platy splitting; weathers to form steep earthy slope

31. Siltstone to sandy siltstone, similar to unit 25 except for being dominantly light brown $(5 Y R 6 / 4)$ and at least 50 percent ripple laminated. Unit contains several discontinuous thick resistant sandy siltstone sets and one thin set of contorted strata at $56 \mathrm{ft}$ above base. Unit weathers to form steep slope with common ledges ........

Total of incomplete Moenkopi

Formation

Base of section; not base of exposure.

Units 1-30 described in Stewart, Poole, and Wilson (1972).

\section{U-33. MILK RANCH POINT}

Measured across southward-extending ridge directly west of Comb Ridge at head of Comb Wash and continuing up Comb Ridge. Center of section is 1.5 miles east of the crest of Milk Ranch Point. Sec. 35 (unsurveyed), T. 36 S., R. 20 E., SLM, San Juan County

[Measured by J. H. Stewart and A. C. Gorventt, August 1953]

Top of section; not top of exposure. Top of section is

S. $82^{\circ}$ E. of most southeasterly point of Milk Ranch Point.

Wingate Sandstone:

29. Sandstone, light brown (5YR 6/4), weathering same color, fine to very fine grained, well sorted; composed of subrounded clear quartz and sparse black accessory minerals; poorly cemented, slightly calcareous; stratification poorly exposed, but unit contains some horizontal laminae and cross-laminae; massive splitting; weathers to form vertical cliff. Unit contains sparse to abundant medium to coarse well-rounded grains. These grains are mostly milky quartz but rarely are an orange mineral. Basal foot is yellowish gray $(5 Y 8 / 1)$. Only basal $15 \mathrm{ft}$ of unit examined ........Unmeasured
Chinle Formation:

Feet

Church Rock Member:

Hite Bed:

28. Silty claystone and sandstone. Silty claystone, pale reddish brown $(10 R$ $5 / 4)$, weathering same color; poorly to firmly cemented, calcareous; stratification concealed. Sandstone, similar to that in unit below. Unit very poorly exposed and percent of silty claystone and sandstone cannot be determined. Contact with Wingate Sandstone seems to be in place but might be dislocated by slumping by as much as $3.0 \mathrm{ft}$

27. Sandstone, pale red $(10 R 6 / 2)$ with uncommon light-greenish-gray ( $5 G Y$ $8 / 1$ ) spots and very thin bands, very fine grained, well sorted; firmly cemented, calcareous; composed of horizontal and ripple laminae and subordinate thin trough sets of medium-scale low-angle cross-laminae; massive splitting, weathers to form smooth-surfaced ledge. Unit contains sparse medium-grained accessory white mica

Total of Hite Bed

26. Siltstone, light brown $(5 Y R 6 / 4)$, grayish red $(10 R 4 / 2)$, and sparse pale red $(10 R 6 / 2)$, weathering pale reddish brown $(10 R 5 / 4)$, firmly cemented, slightly calcareous to noncalcareous; seems to be mostly structureless, but massive ledge at base is horizontally laminated; weathers to form steep slope with ledges at base, near middle, and near top of unit. Ledges appear to be composed of slightly coarser material than rest of unit. Unit contains common to abundant light-greenish-gray (5GY 8/1) spots. Fractures into angular fragments

25. Siltstone, similar to that in unit below. Horizontally laminated limy siltstone bed from 0.5 to $1.6 \mathrm{ft}$ above base of unit

Total of Church Rock Member

Owl Rock Member:

24. Siltstone and limestone. Siltstone, pale reddish brown $(10 R 5 / 4)$, grayish red $(5 R 4 / 2)$, common grayish-yellowgreen $(5 G Y 7 / 2)$, weathering same colors, firmly cemented, calcareous; seems to be mostly structureless but contains some horizontal laminae; contains subordinate clayey siltstone to silty claystone layers. Limestone, pale red $(10 R 6 / 2)$ and light greenish gray ( $5 G Y 8 / 1)$, weathering pale red $(10 R 6 / 2)$, dense, well indurated; 
Chinle Formation-Continued

Owl Rock Member-Continued

horizontally laminated to thin bedded. Grayish-red (5R 4/2) siltstone occurs rarely along irregular seams in the limestone. Unit as a whole weathers to form steep slope containing small ledges in limestone; limestone sets occur from 0.0 to $1.7 \mathrm{ft}$, 13.6 to $13.9 \mathrm{ft}, 21.6$ to $22.1 \mathrm{ft}, 25.5$ to $26.0 \mathrm{ft}$, and 27.8 to $29.0 \mathrm{ft}$ above base of unit. Top of Owl Rock Member arbitrarily placed at top of this unit which is top of highest limestone in section

23. Siltstone, pale reddish brown $(10 R 5 / 4)$ and pale red $(10 R 6 / 2)$, weathering pale red $(10 R 6 / 2)$; firmly cemented, calcareous; stratification concealed, fractures into angular fragments; weathers to form steep loose slope. Common greenish-gray (5GY 6/1) spots. Top few feet are grayish red purple $(5 R P 4 / 2)$. This unit appears to vary only in color from underlying unit

22. Siltstone, light brown (5YR 6/4), weathering light brown (5YR 5/6); well cemented, highly calcareous; stratification concealed; fractures into angular fragments; weathers to form steep loose slope with 1-ft-thick ledge at base. Common light-greenish-gray (5GY 8/1) spots. Upper contact of unit is gradational

21. Siltstone, pale reddish brown $(10 R 5 / 4)$ and subordinate pale red $(5 R 6 / 2)$, weathering pale red $(10 R 6 / 2)$; firmly cemented, calcareous; stratification concealed; fractures into angular fragments; weathers to form steep loose slope. Upper $29.4 \mathrm{ft}$ of unit weathers light brown $(5 Y R 6 / 4) \ldots \ldots$.

20. Silty limestone (15 percent) and siltstone (85 percent). Silty limestone, pale red $(10 R 6 / 2)$ and subordinate light greenish gray $(5 G Y 8 / 1)$, weathering pale red $(10 R 6 / 2)$, dense; well indurated; horizontally laminated to thinly bedded. Siltstone, pale red $(10 R 6 / 2)$, pale reddish brown (10R 5/4), common greenish-gray (5GY 6/1) spots; firmly cemented, calcareous; stratification concealed. Silty limestone is present as thin to thick sets interstratified with siltstone. Unit as whole weathers to form steep slope with poorly developed ledges

19. Siltstone, pale reddish brown $(10 R 5 / 4)$ and moderate brown (5YR 4/4), weathering pale reddish brown $(10 R$ $5 / 4)$ and light brown $(5 Y R 6 / 4)$;
Chinle Formation-Continued

Owl Rock Member-Continued

firmly cemented, calcareous; stratifica-

tion concealed; fractures into pebbleand granule-sized angular fragments; weathers to form steep loose slope. Abundant greenish-gray (5GY 6/1) spots. One-inch limestone bed occurs about $15.0 \mathrm{ft}$ above base of unit. Sandstone set occurs from 67.4 to $72.5 \mathrm{ft}$ above base of unit. Sandstone is light brown (5YR 6/4), very fine grained, poorly cemented, calcareous; ripple laminated

\section{Petrified Forest Member:}

16. Silty claystone to clayey siltstone, pale reddish brown $(10 R 5 / 4)$, grayish red $(10 R 4 / 2)$, and subordinate pale red $(5 R 6 / 2)$, uncommon light-greenishgray (5GY 8/1) spots, weathering same colors, poorly cemented, calcareous; stratification concealed; weathers to form knoll along valley bottom. Unit very poorly exposed. Contact with overlying unit covered. Unit
Feet 
Chinle Formation-Continued

Petrified Forest Member-Continued weathers with a frothy surface. Basal $9 \mathrm{ft}$ of unit contains swelling clays. Rest of unit probably does not contain swelling clays, but as exposures are poor, entire unit is arbitrarily assigned to Petrified Forest Member

15. Clayey sandstone, grayish red purple (5RP 4/2), pale red purple (5RP $6 / 2)$, and subordinate light greenish gray $(5 G Y 8 / 1)$ in basal $16.0 \mathrm{ft}$ of unit, rest of unit is grayish red (5R $4 / 2$ ) with subordinate pale reddish brown $(10 R 5 / 4)$, weathering pale red purple $(5 R P 6 / 2)$ and moderate brown $(5 Y R 4 / 4)$, very fine to fine-grained, subordinate clay, fair sorted; composed of subangular milky minerals, common medium- to coarsegrained dark-green and white accessory mica, poorly cemented, calcareous; stratification concealed; weathers to form ridges and slopes along creek bottom. Unit contains clayey siltstone from 29.4 to $34.8 \mathrm{ft}$ above base. Clayey siltstone, grayish red $(5 R 4 / 2)$, weathering same color; firmly cemented, noncalcareous; stratification concealed. Unit contains several thin sets of medium-grained sandstone near base similar to sandstone in rest of unit; this sandstone is composed of thin trough sets of small-scale cross-laminae

14. Covered

13. Claystone to silty claystone, grayish red (10R 4/2), weathering same color; abundant silt-size accessory white mica, poorly to firmly cemented, noncalcareous; stratification concealed, weathers to form steep frothy slope

Total of Petrified Forest Member

Sandstone unit (according to R. Campbell, this sandstone unit is composed partly of the Moss Back Member and partly of a prominent sandstone in the Monitor Butte Member. These sandstone units of the Monitor Butte and Moss Back coalesce along the southern part of Elk Ridge and form an inseparable sequence at this section) :

12. Sandstone (96 percent) and conglomeratic sandstone (4 percent). Sandstone, very pale orange $(10 Y R 8 / 2)$ and grayish orange $(10 Y R \quad 7 / 4)$, weathering grayish orange (10YR $7 / 4)$, fine to medium grained, well sorted; composed of subrounded clear quartz and sparse black accessory minerals, uncommon medium- to coarse-grained accessory white mica; poorly to firmly cemented, calcare-
Feet | Chinle Formation-Continued Feet Sandstone unit-Continued ous; composed of thin trough and planar sets of low-angle mediumscale cross-laminae and subordinate horizontal and ripple laminae. Conglomeratic sandstone, very pale orange $(10 Y R 8 / 2)$ and light gray (N 7), weathering pale yellowish brown $(10 Y R 6 / 2)$, fine to medium grained, abundant scattered coarse grains, very coarse grains, granules, and pebbles, poorly sorted; composed of rounded coarse grains of clear quartz and very coarse grains to pebbles of limestone and to a lesser extent of quartz, quartzite, and chert in a fine- to medium-grained matrix; firmly to well cemented, highly calcareous; generally structureless but contains some thin trough sets of medium-scale cross-laminae. Conglomeratic sandstone is present as thin to thick beds, sets, or cosets interstratified with sandstone and is confined to lower $10 \mathrm{ft}$ of unit. Amount and position of conglomeratic sandstone varies along exposure. Unit as whole is tabular and weathers to form prominent hogback ridge in Chinle Formation. The lower $20 \mathrm{ft}$ of the unit contains about 10 percent very fine grained sandstone that has the same colors as the rest of the unit, contains abundant mediumgrained accessory white mica, is well cemented, is ripple laminated. A few hundred feet to south, similar very fine grained sandstone occurs at the top of the unit or in the overlying unit. The very fine grained sandstone appears identical with the sandstone in the Monitor Butte Member. Top $10 \mathrm{ft}$ of unit measured down long steep dip slope

Total of sandstone unit

Lower part of Monitor Butte Member:

11. Clayey sandstone, pale olive $(10 Y 6 / 2)$ and greenish gray ( $5 G Y 6 / 1)$, weathers light greenish gray (5GY 8/1) and greenish gray $(5 G Y 6 / 1)$, fine to very fine grained with sparse medium grains and about 20 percent clay, poorly sorted; composed of subangular milky mineral and 3-10 percent amber, orange, and green minerals, common medium - to coarse-grained accessory dark-green mica; common to abundant clay pellets and irregular pebble-size masses of clay; slightly swelling clays; poorly cemented, noncalcareous, clay binding; stratifica- 
Chinle Formation-Continued

Lower part of Monitor Butte Member-Con. tion concealed; weathers to form steep rubble-covered slope with frothy surface where exposed. Upper $13 \mathrm{ft}$ of unit contains more clay than rest of unit and grades into sandy claystone

Total of lower part of Monitor

Butte Member

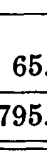

Contact of Chinle and Moenkopi Formations placed at color change from red silty claystone of the Moenkopi to greenish gray swelling claystone of the Chinle.

Moenkopi Formation (incomplete) :

10. Silty claystone to siltstone, grayish red $(10 R 4 / 2)$ and pale reddish brown $(10 R 5 / 4)$, weathering same colors, silty claystone dominant type; micaceous; firmly cemented, siltstone is calcareous, and silty claystone is noncalcareous; stratification poorly exposed but where seen is horizontally laminated with minor ripple laminae; weathers to form steep rubblecovered slope

Total of incomplete Moenkopi

Formation

Base of sections; not base of exposure.

Units 1-9 described in Stewart, Poole, and Wilson (1972).

U-34. MONITOR BUTTE

Measured on northeast side of Monitor Butte, lat $37^{\circ} 14^{\prime} N$., long $110^{\circ} 26^{\prime} \mathrm{W}$., San Juan County

[Measured by L. C. Craig and P. J. Katich, June 1951]

Top of section; not top of exposure.

Wingate Sandstone:

26. Sandstone, moderate reddish orange $(10 R 6 / 6)$ to moderate orange pink $(10 R 7 / 4)$, weathering moderate reddish brown $(10 R 4 / 6)$, very fine grained, abundant concentrations of subangular to subrounded grains on lamination planes; composed of subangular clear quartz with common amber, black, and white accessory minerals; inclined to compound crosslaminations, thin to very thick sets (as much as $6 \mathrm{ft}$ ). Forms vertical desert-varnished cliff. Basal contact not well exposed but is marked by Chinle Formation: color and textural changes ..........Unmeasured

Church Rock Member:

Hite (?) Bed:

25. Sandstone, conglomeratic at base, medium reddish orange $(10 R 5 / 6)$, pale red $(5 R 6 / 2)$, and pale yellowish orange $(10 Y R 7 / 6)$, fine to medium grained, composed of subangular to
Chinle Formation-Continued

Church Rock Member-Continued

Hite (?) Bed-Continued

subrounded clear quartz with common black accessory minerals; moderately calcareous, moderately cemented; festoon cross-lamination, gently dipping lamination (less than $10^{\circ}$ ). At base is prominent but local intraformational conglomerate containing cobbles and pebbles of underlying limestone ........

Total of Hite(?) Bed ......................

Total of Church Rock Member ......

Owl Rock Member:

24. Limestone (90 percent) and subordinate siltstone and claystone. Limestone, light greenish gray ( $5 G Y 8 / 1)$ to very light gray $(N 8)$, dense to very fine grained; in platy slabby, to massive ledges (less than $4 \mathrm{ft}$ ). Siltstone and claystone form interbeds as much as $1 \mathrm{ft}$ thick; siltstone and claystone are pale red $(5 R 6 / 4)$. Unit is horizontally laminated to ripple laminated ltstone to sandstone, moderate reddish orange $(10 R 6 / 6)$, as coarse as very fine grained size; hackly weathering; structureless; unit forms prominent red ledge in lower part and red slope above

22. Claystone (80 percent) and limestone (20 percent). Claystone, grayish red $(10 R 4 / 2)$, mottled and streaked light greenish gray (5GY 8/1), probably silty; hackly weathering; forms very steep slope. Limestone, pale red $(10 R 6 / 2)$ and light greenish gray $(5 G Y 8 / 1)$, forms sequence of prominent hackly to slabby ledges 6 in. to $3 \mathrm{ft}$ thick. Not accessible along line of section

21. Claystone (99 percent) and limestone (1 percent), unit not inspected because of steep slope. Claystone, grayish red $(10 R 4 / 2)$, mottled and streaked light greenish gray (5GY $8 / 1$ ), probably sandy. Limestone occurs as thin discontinuous ledge forming layers less than 6 in. thick. Unit forms steep slope

20. Sandstone, pale red $(10 R 6 / 2)$, weathering with a purplish cast, medium to fine grained; composed of subangular to subrounded clear quartz, common to abundant orange, black, and uncommon green, accessory minerals; abundant interstitial clay; festoon cross-lamination in broad sets; weathers to form ledge

19. Claystone, grayish red $(10 R 4 / 2)$ and pale red $(10 R 6 / 2)$, slightly sandy,
Feet 
Chinle Formation-Continued

Owl Rock Member-Continued as coarse as fine-grain size; highly calcareous; hackly weathering; forms small cliff

18. Limestone, pale red $(5 R 6 / 2)$, mottled light greenish gray $(5 G Y 8 / 1)$, dense to very fine grained; brecciated appearance; no fossils observed

17. Claystone and clayey sandstone, dark reddish brown $(10 R 3 / 4)$ below to pale reddish brown $(10 R 4 / 4)$ and moderate reddish orange $(10 R 6 / 6)$ above, sand as coarse as fine-grain size; moderately calcareous; forms steep slope; hackly to earthy weathering

16. Sandstone and claystone, pale red (5R $6 / 2$ ) and light greenish gray ( $5 G Y$ $8 / 1$ ), variable composition; sand as coarse as medium-grain size; composed of subangular clear quartz, common orange, black, and green accessory minerals; sandstone shows fine cross-laminations (less than $1 / 8$ in.) in indistinct sets. Unit locally forms small ledge

15. Limestone, pale red $(5 R 6 / 2)$, very fine grained to dense; forms local small ledge; contains scattered pelecypods

Total of Owl Rock Member

Petrified Forest Member:

14. Sandstone, very clayey, grades to claystone, pale red $(5 R 6 / 2)$, medium grained; composed of clear subangular to subrounded quartz with common to abundant orange, black, and green accessory minerals; structureless; very friable; forms hard-surfaced steep slopes. Upper $100 \mathrm{ft}$ of unit is predominantly claystone with variable amounts of silt and sand and is hackly weathering. Thin moderatereddish-orange $(10 R 6 / 6)$ clay bed 8 $\mathrm{ft}$ thick at top of unit

Note. - Possibly some of units 8-13 are slumped.

13. Claystone, grayish red $(5 R 4 / 2)$, with light-greenish-gray $(5 G Y$ 8/1) mottles, sandy, as coarse as medium grain size; hard, frothy weathering; forms gentle to steep slopes; contains concretionary rubble of light- to medium-gray dense to fine-grained limestone

12. Covered. Slump blocks of Wingate Sandstone on bench

11. Heterogeneous unit. Sandstone, siltstone, and subordinate claystone and limestone. Sandstone, pale red $(5 R$ $6 / 2)$, pale reddish brown $(10 R 4 / 4)$, moderate red $(5 R 4 / 4)$, pale red

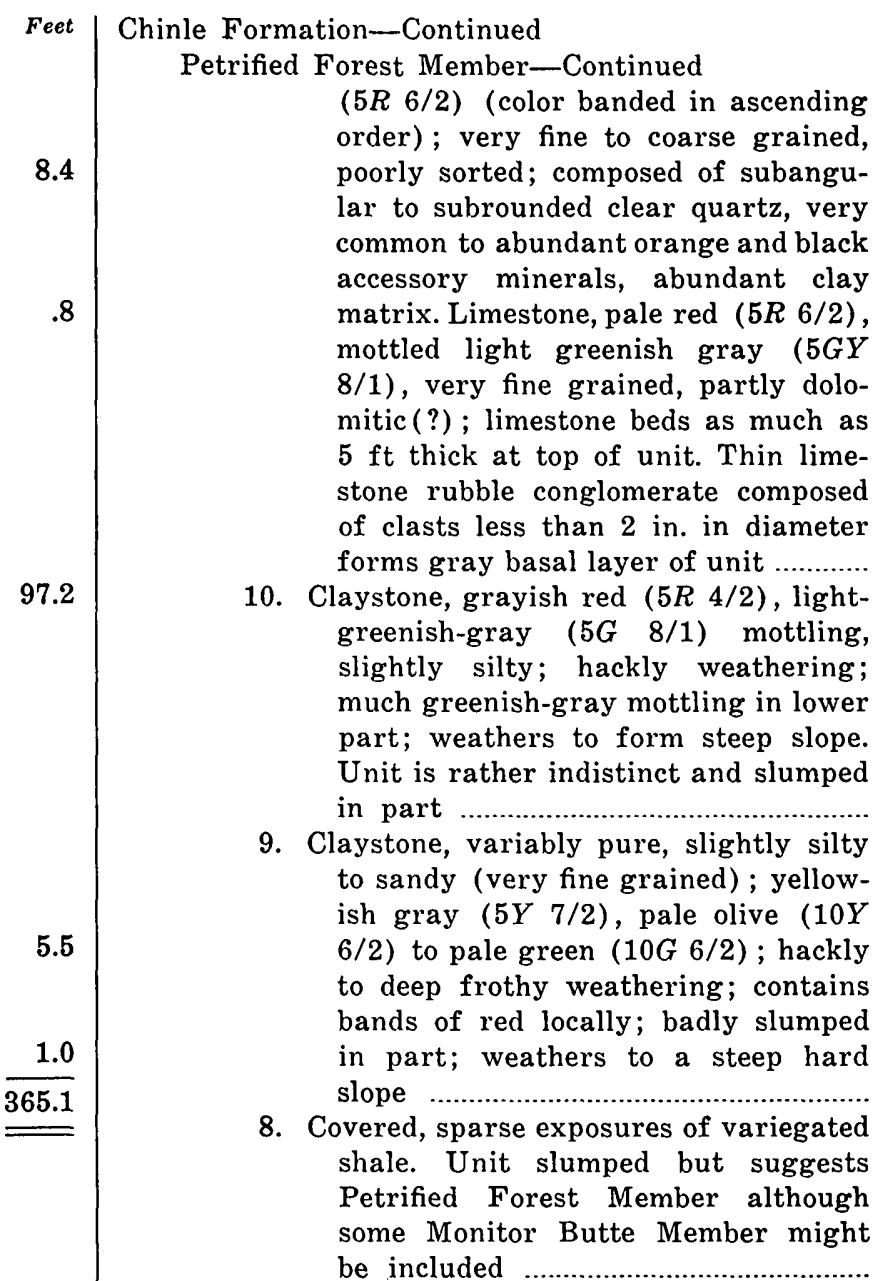

Total of Petrified Forest Member.

Monitor Butte Member:

7. Claystone (80 percent) and sandstone (20 percent), interbedded. Claystone, pale olive $(10 Y 6 / 2)$, silty to sandy (fine grained); earthy weathering; forms poorly exposed slope. Sandstone, brownish gray (5YR 4/1),
Feet fine grained, weathering dark brown; highly calcareous; slabby (2 to $3 \mathrm{ft}$ thick) ripple-laminated ledges showing great distortion. Laterally along strike near section sandstone of Shinarump type builds up as high as top of Monitor Butte Member

Total of Monitor Butte Member....

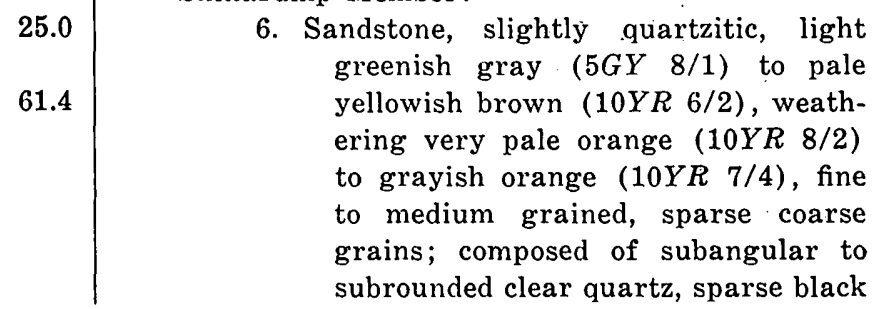
subrounded clear quartz, sparse black
128.2 
Chinle Formation-Continued

Shinarump Member-Continued and orange accessory minerals; festoon type cross-lamination; contains plant,fragments. Layers with pebbles as much as 1 in. in diameter occur in middle of unit

5. Claystone, dusky yellow $(E Y$ 6/4) to yellowish gray $(5 Y 7 / 2)$, flaky to platy weathering, poorly exposed....

4. Sandstone, conglomeratic, pale yellowish orange $(10 Y R 8 / 6)$ to yellowish gray (5Y 8/1), medium grained and coarser, subangular to subrounded; composed of clear quartz, sparse black accessory minerals; pebbles mostly white quartz, rose to pink quartz, white chert, and dark chert, pebbles less than 1 in., mostly $1 / 2$ to $1 / 4$ in. in diameter, pebbles disseminated in sand matrix as well as concentrated in lenses; festoon cross-lamination, sets 1 to $10 \mathrm{ft}$ thick, channels common. Unit weathers to form massive ledge. Common plant fragments and intraformational clay pebbles at base. Channeling contact cuts out $40 \mathrm{ft}$ of Moenkopi in $300 \mathrm{ft}$ along outcrop......

Total of Shinarump Member

Total of Chinle Formation

$\begin{array}{r}76.9 \\ \hline 176.6 \\ \hline 1,194.9 \\ \hline\end{array}$

Moenkopi Formation (incomplete)

3. Claystone and siltstone, interbedded, grayish red $(10 R \cdot 4 / 2)$, mottled light greenish gray $(5 G Y 8 / 1)$. Claystone is silty and micaceous. Unit composed of parallel sets less than 6 in. thick of parallel laminations. Top 4 in. of unit are altered light greenish gray $(5 G Y 8 / 1)$

2. Siltstone, moderate reddish brown $(10 R$ $4 / 6)$, as coarse as very fine grained sand sizes; noncalcareous, firm cement; composed of horizontal sets less than 2 in. thick and of ripple laminae. Unit weathers to form ledges above cliff. Unit is transitional into overlying unit

1. Sandstone, grayish orange pink $(10 R$ $8 / 2$ ), fine grained; well cemented; composed of subangular clear quartz, common black and orange accessory minerals; festoon-type cross-lamination to ripple lamination, sets $6 \mathrm{in}$. to $5 \mathrm{ft}$ thick. Unit weathers to form prominent upper vertical cliff in Moenkopi …................................... Unmeasured Total of incomplete Moenkopi

Formation

25.6

Feet U-35. NORTH SIXSHOOTER PEAK

Measured on north side of North Sixshooter Peak in sec. 31, T. 30 S., R. 21 E., SLM, San Juan County

[Measured by J. H. Stewart and G. W. Weir, May 1953]

Wingate Sandstone:

94.8

4.9

Chinle Formation:

Church Rock Member:

Note. - Along Indian Creek near Dugout Ranch, the Church Rock Member appears to be thicker at the expense of other members of the Chinle. Several internal disconformities were noted in the Church Rock Member of the Chinle along Indian Creek near Dugout Ranch.

Hite Bed:

36. Sandstone, pale reddish brown $(10 R$ $5 / 4)$, pale red $(10 R 6 / 2)$ with subordinate yellowish gray (5Y 8/1), weathering pale reddish brown $(10 R$ $5 / 4$ ), very fine to fine grained; firmly to well cemented, noncalcareous; composed predominantly of ripple laminae, sparse thin small-scale to medium-scale low-angle trough sets; massive splitting; weathers to form cliff containing small ledges. Unit from 6.6 to $8.8 \mathrm{ft}$ contains abundant granules and pebbles of pale-reddishbrown $(10 R 5 / 4)$ siltstone and claystone

35. Silty claystone to clayey siltstone, grayish red $(10 R 4 / 2)$ and pale reddish brown $(10 R 5 / 4)$, weathering same colors; firmly cemented, noncalcareous; stratification concealed; weathers to form steep loose and rubble-covered slope. Sparse lightgreenish-gray $(5 G Y 8 / 1)$ spots ........

34. Sandstone (40 percent) and siltstone (60 percent). Sandstone, pale reddish brown $(10 R 5 / 4)$, pale red $(10 R$ $6 / 2)$, and sparse light greenish gray ( $5 G Y$ 8/1) mottles and in thin bands, weathering same colors, very fine to fine grained, well sorted; firmly to well cemented, noncalcareous; predominantly ripple laminated, sparse thin trough sets of medium-scale low-
Feet

Base of section; not base of exposure. 
Chinle Formation-Continued

Church Rock Member-Continued

Hite Bed-Continued

angle cross-laminae; platy to slabby splitting. Siltstone, pale reddish brown $(10 R 5 / 4)$, weathering same color; firmly cemented, noncalcareous; horizontally and ripple laminated; platy splitting. Thin sets of sandstone interbedded with siltstone. Basal contact of unit sharp. Basal few inches to half foot contains granules to cobbles of pale-reddish-brown (10R 5/4) siltstone. Unit as a whole is tabular but varies in thickness and grades into overlying unit; weathers to form steep slope containing small ledges....

Total of Hite Bed

33. Siltstone, pale reddish brown $(10 R 5 / 4)$ and light brown $(5 Y R 5 / 6)$, weathering light brown $(5 Y R 5 / 6)$ and pale red $(10 R 6 / 2)$ in lower $16.5 \mathrm{ft}$; firmly cemented, calcareous; predominantly structureless but with some possible horizontal and ripple laminae, fractures into pebble-sized fragments; weathers to steep loose slope. Lightgreenish-gray ( $5 G Y 8 / 1)$ spots averaging about $3 / 8$ in. in diameter constitute about 5 percent of unit. Locally a thin set of limestone is present at $16.5 \mathrm{ft}$ above base of unit; limestone is similar to that in unit 27

Total of Church Rock Member........

Contact of Church Rock and Owl Rock Members placed at top of highest persistent set of dense limestone.

Owl Rock Member:

32. Limestone and siltstone. Limestone, pale red $(10 R 6 / 2)$ and light greenish gray ( $5 G Y 8 / 1)$, weathers same colors, aphanitic, horizontally laminated, flaggy to slabby splitting; occurs as discontinuous beds in basal $2.2 \mathrm{ft}$ of unit and from 5.5 to $7.5 \mathrm{ft}$ above base; weathers to form ledges. Siltstone, similar to unit 31 except weathers pale red $(10 R 6 / 2)$; weathers to form steep slope ........................

31. Siltstone, light brown (5YR $5 / 6)$, weathers light brown (5YR 5/6); firmly to well cemented, calcareous; composed of thin sets of poorly developed horizontal laminae; slabby splitting; weathers to form prominent ledges and brown band. Gradational into unit below

30. Siltstone, light brown $(5 Y R 6 / 4)$, pale reddish brown $(10 R 5 / 4)$, and pale
Feet Chinle Formation-Continued Feet Owl Rock Member-Continued red $(10 R 6 / 2$ and $5 R 6 / 2)$, weathers pale red $(10 R 6 / 2)$; firmly cemented, calcareous; stratification concealed, some possible horizontal stratification; weathers to form steep slope. Unit contains swelling clays in $10-\mathrm{ft}$ interval near top of basal third of unit. Clay forms interstitial part of siltstone. Calcarenite and limestonegranule conglomerate occur at $\mathbf{1 6 . 5}$ to $18.5 \mathrm{ft}$ and rarely in rest of unit, are light greenish gray $(5 G Y 8 / 1)$, and are composed of rounded coarse grains to granules of limestone in lime matrix. Some horizontally laminated and ripple-laminated sets of siltstone occur in lower half of unit. Unit probably occupies position of socalled Black Ledge seen to north on cliffs south of Hatch Point and to west near junction of Green and Colorado Rivers

66.5

29. Siltstone, variegated predominantly light brown (5YR 6/4) and pale reddish brown $(10 R 5 / 4)$, subordinate pale red purple $(5 R P 6 / 2)$ in lower half and rarely in upper half, weathering grayish orange (10YR 7/4) and pale reddish brown $(10 R 5 / 4)$, bands of pale red purple (5RP 6/2), firmly cemented, calcareous; stratification concealed; weathers to form steep loose slope; abundant lightgreenish-gray ( $5 G Y$ 8/1) spots from $1 / 2$ to $1 \mathrm{in}$. in diameter; most of unit contains common pale-red $(10 R 6 / 2)$ limy nodules generally about 1 in. in diameter. Top part of unit forms prominent brown band

28. Dolomitic limestone (70 percent) and clayey siltstone (30 percent). Dolomitic limestone, pale purple $(5 P 6 / 2)$, weathering same color, aphanitic, mostly contorted stratification; splitting irregular; common pale reddish brown $(10 R 5 / 4)$ chert masses generally between $1 / 4$ and $1 / 2$ in. in diameter, common light-greenish-gray ( $5 G$ $8 / 1$ ) spots; weathers to form discontinuous knobby-surfaced ledge. Clayey siltstone, grayish red $(10 R \quad 4 / 2)$, weathers pale purple $(5 P 6 / 2)$; firmly cemented, noncalcareous; stratification concealed. Very thick beds of clayey siltstone occur interstratified with very thick beds of dolomitic limestone, but position and amount of claystone vary greatly along outcrop. Unit as a whole tabular and weath- 
Chinle Formation-Continued

Owl Rock Member-Continued ers to form purplish band; weathers to form steep rubble-covered slope with discontinuous ledges

27. Limestone, very light gray ( $N$ 8) weathering grayish orange $(10 Y R$ $7 / 4)$, aphanitic; common coarse calcite crystals; structureless, slabby splitting; weathers to form prominent thin ledge

Total of Owl Rock Member

Petrified Forest Member:

26. Siltstone similar to unit 25 except about 30 percent of unit composed of very light gray $(N 8)$ aphanitic limestone nodules averaging about $1 / 2$ in. in diameter

25. Clayey siltstone, pale reddish brown (10R 5/4), weathering pinkish gray (5YR 8/1); firmly cemented, calcareous; stratification concealed; weathers to form steep loose rubble-covered and locally "crusty" slope. Contains swelling clays. Light-greenish-gray $(5 G Y 8 / 1)$ silty claystone occurs in lower $2 \mathrm{ft}$ of unit. Sandstone occurs from 22.1 to $24.1 \mathrm{ft}$ above base of unit. Sandstone, pale red $(10 R 6 / 2)$ with light-greenish-gray ( $5 G Y 8 / 1)$ spots averaging $1 / 4$ in. in diameter, weathers pale red $(10 R 6 / 2)$ with light-greenish-gray spots, fine grained well sorted; composed of subangular milky mineral, 20 percent orange mineral, 10 percent black mineral and common green mineral; firmly cemented, calcareous; stratification concealed. Unit poorly exposed

24. Sandstone, light greenish gray ( $5 G Y$ $8 / 1)$, very light gray $(N 8)$ and light gray $(N 7)$, weathering very light gray $(N 8)$, fine grained, well sorted; composed of subangular clear quartz and feldspar and 20 percent green, orange, and gray minerals, common brown mica; poorly cemented, highly calcareous; stratification poorly developed, some possible medium-scale low-angle cross-stratification; weathers to form steep slope. Unit forms prominent light colored band slightly above Moss Back Member

23. Sandstone, greenish gray $(5 G Y 6 / 1)$, weathering greenish gray $(5 G Y 6 / 1)$, coarse grained with about 15 percent granules and very coarse grained sand; fair sorted; composed of subangular to subrounded clear quartz, milky quartz, and probably feldspar and of round greenish-gray and gray limestone grains and granules, abun-

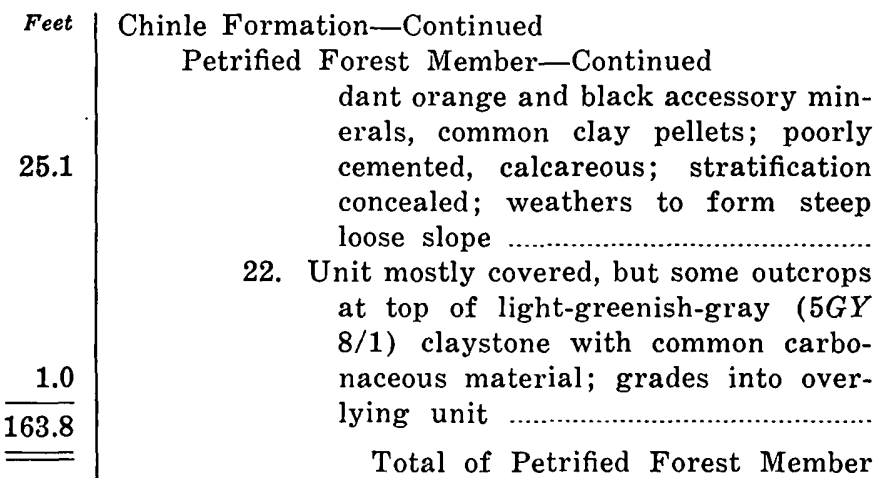

Moss Back Member:

21. Sandstone, similar to unit 20 except for abundant cross-stratification at top that consists of trough sets of medium-scale low-angle cross-laminae; green claystone parting at base ........

20. Sandstone, yellowish-gray ( $5 Y \quad 8 / 1)$; weathers light brown $(5 Y R \quad 5 / 6)$; fine to medium grained, fair sorted; composed of clear quartz and feldspar(?), fine white mica, white to yellowish-gray clay grains (perhaps representing decomposed feldspar), and abundant black and orange accessory minerals; well cemented; stratification poorly exposed, but probably mostly horizontally stratified; massive splitting; weathers to form cliff

19. Silty claystone (50 percent) and sandstone (50 percent). Claystone, pale olive $(10 Y 6 / 2)$; weathers same color; thinly laminated; papery splitting that forms small chips. Sandstone, yellowish gray $(5 Y 7 / 2)$; weathers light brown (5YR 6/4); fine grained, silty, fair sorted; well cemented; ripple marked; occurs as lenticular layers in claystone; platy splitting. Unit as a whole forms prominent notch in cliff. Unit defines prominent local diastem ......................

18. Conglomeratic sandstone, pale-greenishyellow (10Y 8/2); weathers light brown (5YR 6/4); fine to coarse grained with granules and pebbles, poorly sorted; composed of subangular to subrounded grains of milky, bluish-gray, and clear quartz, clear plagioclase (?), greenish-gray and yellowish-orange clay (perhaps representing, in part, decomposed feldspar), and subangular to well-rounded granules and pebbles as large as $11 / 2$ in. in diameter (avg. $3 / 8$ in. diameter) of milky quartz, orange, gray, and black chert, greenish-brown limy siltstone, and light-gray thinly laminated siltstone; firmly cemented, calcareous(?), with some clay binding;
Feet 
Chinle Formation-Continued

Moss Back Member-Continued

trough sets of medium- and smallscale low- to high-angle cross-lamination throughout unit; platy to massive splitting. Unit weathers to form rough steep ledge and breaks up into large blocks $10 \mathrm{ft}$ or more in diameter that are mainly concentrated within $75 \mathrm{ft}$ of the Moss BackMoenkopi contact. Some siltstone and sandstone pebbles and cobbles, as large as $5 \mathrm{in}$. in diameter, were probably derived from the Moenkopi. Carbonaceous material is not conspicuous on the outcrop, but its presence is indicated by some scattered dark spots partly replaced by calcite and by impressions on talus blocks....

Total of Moss Back Member.

Total of Chinle Formation.

Note. - Contact between the Moenkopi and Moss Back is placed at the base of a conglomeratic sandstone that rests on poorly exposed pale-reddishbrown and light-brown siltstone of the Moenkopi. The contact commonly is concealed by slump blocks of Moss Back and slope wash from higher units. If the reddish-brown silty material identified as Moenkopi directly below the conglomeratic sandstone is slope wash from higher formations (Chinle and Wingate), the actual Moss BackMoenkopi contact may be as much as $10 \mathrm{ft}$ below the contact selected here.

Section offset, so that underlying units were measured about 1,000 ft east of unit 18.

Moenkopi Formation (incomplete) :

17. Siltstone to clayey siltstone, pale-reddish-brown $(10 R \quad 5 / 4)$ and lightbrown (5YR 6/4); abundant thin bands of light greenish gray ( $5 G Y$ $8 / 1$ ) from 55.5 to $104.5 \mathrm{ft}$ and locally elsewhere in unit; weathers same colors; contains abundant finegrained white mica; horizontally and ripple laminated; platy splitting with minor flaggy and slabby splitting; weathers to form rubble-covered steep slope with few thin ledges. Unit differentiated from one below by its light-greenish-gray bands and fewer resistant ledges

Total of incomplete Moenkopi Formation

Feet $\mid$ Top of section; not top of exposure.

Feet Kayenta Formation:

102. Sandstone, pink to light gray, medium grained; festoon-type cross-lamination; ledgy channel-filling sandstone with nonresistant shaly material.. Unmeasured

Wingate Sandstone:

101. Sandstone, moderate reddish orange $(10 R \quad 6 / 6)$ and light brown (5YR $6 / 4)$, fine to medium grained, composed of clear subangular quartz grains with common black and pink accessory minerals; predominantly compound cross-laminations on large scale. Upper part of unit contains two 30 - to $50-\mathrm{ft}$ layers of massive structureless darker colored sandstone. The structureless layers probably represent shallow quiet water deposition, in contrast to units of predominant eolian character that make up the remainder. Eolian parts of unit commonly contain coarse wellrounded grains concentrated along cross-lamination planes and disseminated within layers. Thickness of unit approximate because of marked change in strike and dip within unit

100. Sandstone, similar to above - entirely eolian-type cross-lamination - separated from overlying unit because of somewhat less resistance to weathering. Unit composed of clear and, in part, amber-stained subangular to well-rounded quartz grains with common black and orange and sparse green accessory minerals. Thickness approximate because of marked change in strike and dip within unit

Total of Wingate Sandstone

(approximate)

Section offset at top of unit 99 so that overlying units were measured 500 ft north of unit 99 and underlying units.

Chinle Formation:

Church Rock Member:

Hite Bed:

99. Sandstone, moderate orange pink $(10 R$ $6 / 4)$ to moderate reddish orange ( $10 R$ $5 / 6)$, very fine to fine grained, composed of clear subangular quartz with accessory minerals masked; festoon and incline cross-lamination; a few channels occur within units; claystone pebbles occur in strata filling channels. Unit appears fluviatile; forms steep ledgy slope. Contact with Wingate exposed in line of section...

Total of Hite Bed

98. Sandstone, moderate reddish orange $(10 R 6 / 6)$, very fine grained, subangular, composed of clear and 
Chinle Formation-Continued

Church Rock Member-Continued amber-stained quartz with accessory minerals masked, faintly laminated, subparallel laminations throughout most of unit with ripple lamination and very fine scale inclined laminations near top. Two shaly partings less than $2 \mathrm{ft}$ thick occur near top of unit and are separated by bleached and mottled 2-ft sandstone bed. Unit forms reddish cliff

97. Siltstone to very fine grained sandstone, minor claystone; siltstone to sandstone, moderate reddish orange $(10 R 5 / 6)$, as coarse as fine grained; hackly weathering; faint subparallel(?) laminations, some wavy laminae and local brecciation. Claystone, dark reddish brown $(10 R 3 / 4)$, very silty, hackly weathering; forms 5 -ft bed about $10 \mathrm{ft}$ above base of unit. Unit forms irregular ledgy slope.....

Total of Church Rock Member.......

Owl Rock Member:

96. Siltstone and limestone. Siltstone, moderate reddish brown $(10 R 4 / 6)$, forms gentle slope. Limestone, mottled, very light gray $(N 8)$ to grayish pink, weathers light gray $(N 7)$ and pale red $(5 R 5 / 2)$, very fine grained with secondary streaks of medium crystalline limestone. Limestone is highly brecciated and occurs in various sized fragments less than 2 in. in diameter. Limestone forms two distinct beds less than $2 \mathrm{ft}$ thick, one in middle of unit and one at top of unit. At base of top limestone is a 6-in. bed of granule conglomerate consisting predominantly of limestone pebbles but containing some quartz and chert pebbles

95. Siltstone to sandstone, pale reddish brown $(10 R 4 / 4)$, as coarse as very fine grained; hackly weathering; highly calcareous. Unit forms steep slope with four ledges; lower two ledges in lower $10 \mathrm{ft}$, upper two ledges in upper $10 \mathrm{ft}$. Unit is structureless to faintly wavy laminated. Upper ledge is lighter colored and contains fine white fossil fragments

94. Siltstone and minor claystone. Siltstone, pale red $(5 R 6 / 2)$; claystone, moderate reddish brown $(10 R 4 / 6)$. Unit is calcareous; hackly weathering; faintly banded; locally contains channels with festoon cross-lamination. Channels as deep as $15 \mathrm{ft}$. Claystone is very silty, forms 3 -ft unit at top of basal third of unit. Entire unit
Feet

Chinle Formation-Continued

Owl Rock Member-Continued

forms steep slope containing small discontinuous ledges

93. Conglomerate, mottled predominantly pale red $(5 R 6 / 2)$ and light greenish gray, poorly sorted, composed predominantly of pebbles of claystone, siltstone, and to a lesser extent of sandstone; festoon-type cross-lamination on medium scale. Unit contains common pelecypods

iltstone, lower $1 / 2$ predominantly pale red $(5 R 6 / 2)$, upper $1 / 2$ pale reddish brown $(10 R 5 / 4)$; highly calcareous; lower $1 / 2$ rubbly to hackly weathering and forms local steep slope or cliff; upper $1 / 2$ forms steep slope or cliff and contains large-scale crosslamination

91. Siltstone, mottled moderate orange pink $(10 R 7 / 4)$ and light greenish gray $(5 G 8 / 1)$, very calcareous; composed of fine subparallel laminae and of ripple laminae; forms resistant ledge stone, pale reddish brown (10R 4/4), silty, calcareous; hackly to earthy weathering. Thin sandstone bed in middle of unit. Unit shows faint color bandings; forms steep slope

89. Sandstone, mottled moderate red $(5 R$ $5 / 4$ ) with light-greenish-gray spots, fine to medium grained; composed of clear subangular quartz with common to abundant dark mica (chlorite or biotite) ; festoon-type cross-laminations; locally contains claystone and limestone pebbles as large as $1 / 4 \mathrm{in}$. in diameter; local lens extending 500 ft along exposure aystone, slightly silty, pale red $(5 R$ $6 / 2$ ), lighter colored in the upper $1 / 2$; lower $1 / 2$ is hackly weathering and contains limestone-nodule rubble on surface; upper $1 / 2$ weathers to form a frothy surface and does not contain limestone nodules; entire claystone interval highly calcareous

87. Limestone, very light gray to light gray to pale red, dense to very finely crystalline, forms prominent nodular weathered ledge with thin purple band at base

Total of Owl Rock Member

Petrified Forest Member

86. Claystone, slightly silty, grayish red $(5 R 4 / 2)$ in lower $10 \mathrm{ft}$, pale reddish brown $(10 R 4 / 4)$ in second $10 \mathrm{ft}$ and moderate reddish brown $(10 R 4 / 6)$ in upper part; weathers to form a hackly to frothy surface
Feet

111.1 
Chinle Formation-Continued

Petrified Forest Member-Continued

85. Sandstone, white to very light gray, variably clayey, grading to sandy claystone at top, very fine to coarse grained; composed of clear subangular quartz, common black accessory minerals; contains limestone pebble conglomerate (pebbles less than 3 in. in diameter) locally at base

84. Claystone, grayish red, with moderatereddish-brown band 1 to $5 \mathrm{ft}$ thick at top, silty; slightly calcareous; weathers to form a hard frothy surface covered with irregular nodules and rubble of limestone. Limestone nodules are medium gray, dense, and $1 \frac{1}{2}$ in. to 3 in. in diameter. Unit weathers to form minor cuesta ..........

83. Siltstone, clayey, light greenish gray $(5 G Y 8 / 1)$; weathers to form a frothy surface. Limestone pellet conglomerate occurs at base and forms minor bench

82. Claystone, light greenish gray (5GY $8 / 1)$ to pale red $(5 R 6 / 2)$, mottled appearance, weathers pale red $(5 R$ $6 / 2)$; many small inclusions as large as 5 in. in diameter. Unit caps cuesta to east of that developed on underlying unit; weathers with frothy surface

Total of Petrified Forest Member

Monitor Butte Member:

81. Silty claystone, light-greenish-gray (5GY 8/1); contains numerous gypsum flakes in lower part and numerous irregularly oriented logs that are replaced by sand, calcite, and iron oxide; weathers to hackly and highly frothy surface that forms steep cuesta and dip slope

80. Silty claystone, medium-light-gray ( $N$ 6) with faint red and purple bands; weathers to hackly and frothy surface. About $300 \mathrm{ft}$ south of section line a sandstone occurs near top of unit. It is medium gray, lenticular, and much contorted and fills channels and contains plant impressions and some ripple lamination. Laterally member is contorted and thicker than along line of section

Total of Monitor Butte Member...

Total of Chinle Formation

NoTE. - From $1 / 4$ to $3 / 4$ mile south of line of section, a prominent sandstone lens of the Shinarump Member occurs at the base of the Chinle. The lens has a maximum thickness of $40 \mathrm{ft}$, a remarkably flat basal surface, and an irregular top surface. This sandstone is light greenish gray (5GY 8/1) to yellowish gray $(5 Y 8 / 1)$ and very pale orange
Feet $(10 Y R$ 7/4); fine to medium grained, coarser at base; composed of subangular grains of clear quartz with common to abundant black, orange, and white accessory minerals; consists of numerous festoon sets, less than $1 \mathrm{ft}$ thick, of smallscale cross-laminations.

Moenkopi Formation (incomplete) :

Upper part:

79. Claystone and sandstone, similar to unit 77 except. for less sandstone and fine banding. Lithology not examined in detail because unit forms inaccessible cliff along line of section. Entire unit is cut out by channel at base of Chinle $300 \mathrm{ft}$ south of section line. Channel fill consists of strata of the Monitor Butte Member of Chinle

78. Sandstone, pale-red $(10 R 6 / 2)$ and light-greenish-gray $(5 G Y$ 8/1) with white mottling and banding; very fine to fine grained; composed of subangular clear quartz and common gray to black accessory minerals; locally contains small-scale cross-laminated sets; weathers with rounded hoodoo shapes

77. Claystone (50 percent) and sandstone (50 percent). Claystone, pale to dark reddish brown (10R $5 / 4$ to $10 R 3 / 4)$; silty; highly micaceous; seems to be finely ripple laminated. Sandstone, light greenish gray $(5 G Y 8 / 1)$ to white $(N$ 9) and moderate reddish orange $(10 R 6 / 6)$; fine to medium grained; composed of subangular clear quartz; thin bedded ( 2 in. to 2 ft thick), ripple marked and structureless; platy to massive splitting

Total of incomplete Moenkopi

Formation

Base of section; not base of exposure.

Units 1-76 described in Stewart, Poole, and Wilson (1972).

\section{U-37a. RINCON SECTION A}

Measured at the Rincon, from the south side of the Colorado River near the crest of the Waterpocket fold to the prominent point on the east side of the Rincon, long $110^{\circ} 47^{\prime} W$., lat $37^{\circ} 19.5^{\prime}$ N., San Juan County

[Measured by J. H. Stewart, G. A. Williams, and H. F. Albee, March 1953]

Top of section; top of exposure.

Chinle Formation (incomplete) :

Church Rock(?) Member (incomplete) :

31. Mostly covered. Thickness is to highest exposure of Chinle Formation in local area. All Chinle material in unit is slumped. Contact of Chinle and Wingate covered. Visual comparison of thickness of Wingate at point where section measured with complete thickness of Wingate on outcrops to east indicates that base of Wingate is not more than $50 \mathrm{ft}$ above top of unit......
Feet 
Chinle Formation (incomplete) -Continued Church Rock(?) Member (incomplete)-Con.

30. Siltstone, pale reddish brown (10R $5 / 4)$, weathering same color; firmly cemented, calcareous; stratification concealed; weathers to form steep rubble-covered slope; poorly exposed

Total of incomplete Church Rock (?) Member

Owl Rock Member:

29. Limestone, pale red $(10 R 6 / 2)$ and light greenish gray $(5 G Y 8 / 1)$, weathering pale red $(10 R 6 / 2)$, dense; well cemented, calcareous, possibly siliceous; poorly developed thin beds; slabby splitting; weathers to form small ledge

28. Siltstone, moderate red $(5 R 5 / 4)$, dusky red $(5 R .3 / 4)$, pale reddish brown $(10 R 5 / 4)$, weathering moderate red $(5 R 5 / 4)$; firmly cemented, calcareous in parts; stratification concealed; weathers to form steep slope. Some light-greenish-gray ( $5 G Y 8 / 1)$ limestone nodules occur in lower half of unit

27. Siltstone, grayish red purple $(5 R P 4 / 2)$, weathering pale red purple $(5 R P$ $6 / 2)$; firmly cemented, calcareous; stratification concealed; weathers to form steep slope. Contact with overlying unit not well exposed but placed at color change. Abundant lightgreenish-gray (5GY 8/1) limestone nodules. Abundant light-greenishgray (5GY 8/1) spots.

26. Sandstone, light greenish gray (5GY $8 / 1)$ and pale red $(10 R 6 / 2)$, weathering same colors, coarse grained, well sorted; composed of subangular clear quartz and orange and green minerals ( 30 percent); poorly cemented, calcareous; stratification concealed; weathers to form steep slope. Top $0.8 \mathrm{ft}$ of unit is composed of grayish-orange-pink (5YR 7/2) finegrained ripple-laminated sandstone....

25. Limestone pebble conglomerate, light greenish gray ( $5 G Y 8 / 1)$, weathering light brown $(5 Y R 6 / 4)$; massive splitting; weathers to form most prominent ledge in upper part of Chinle; otherwise similar to unit 23

24. Siltstone, type 1 and type 2. Type 1, pale reddish brown $(10 R 5 / 4)$, weathering same color; firmly cemented, calcareous; stratification concealed. Type 2, light greenish gray ( $5 G Y$ $8 / 1$ ), weathering same color, sandy; well cemented, calcareous; ripple laminated; platy splitting. Very thin to thin sets of type 2 siltstone occur interbedded with type 1 siltstone. Unit

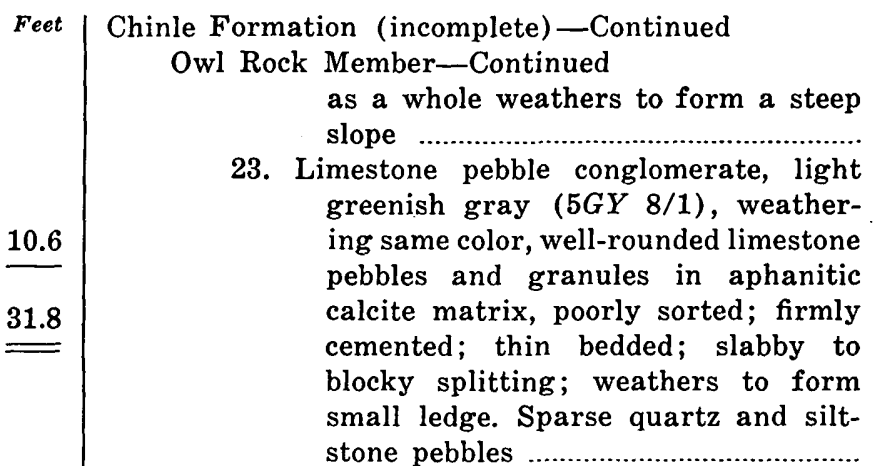

Feet

22. Siltstone and limestone. Siltstone, pale red $(10 R 6 / 2)$, pale reddish brown $(10 R 5 / 4)$, and light brown (5YR $6 / 4)$, weathering same colors; firmly cemented, calcareous; stratification concealed. Contains abundant lightgreenish-gray ( $5 G Y 8 / 1)$ spots. Limestone, pale red $(10 R 6 / 2)$, light greenish gray ( $5 G Y 8 / 1)$, weathering same colors, dense; well cemented; stratification poorly exposed, probably thin bedded; slabby splitting. Limestone occurs in thin sets interstratified with siltstone. Limestone sets abundant from 56.7 to $70.1 \mathrm{ft}$ above base of unit and occur rarely throughout rest of unit. Position and content of limestone changes along outcrop. Light-greenish-gray (5GY 8/1) limestone granule conglomerate from 9.7 to $10.9 \mathrm{ft}$ above base of unit

21. Sandstone, light greenish gray (5GY $8 / 1)$ and minor pale red $(10 R 6 / 4)$, weathering same colors, medium grained, fair sorted; composed of subrounded clear quartz and orange and black minerals (10 percent), possibly 20 percent of rock consists of intergranular calcite and of limestone grains; firmly cemented, calcareous; stratification poorly exposed but probably mostly thin trough sets of lowangle medium-scale cross-laminae, some sets are thicker and locally constitute entire unit; splitting concealed; weathers to form light-colored band and steep slope. Abundant very coarse grains and granules of limestone occur in a few thin sets

20. Siltstone and limestone. Siltstone, pale red $(10 R 6 / 2)$, minor pale reddish brown $(10 R 5 / 4)$, and pale red purple $(5 R P 6 / 2)$, weathering same colors; firmly cemented, calcareous; stratification concealed. Abundant light-greenish-gray (5GY 8/1) spots. Unit contains sparse thin beds of light-greenish-gray $(5 G Y \quad 8 / 1)$ siltstone containing abundant wellrounded limestone granules. Siltstone 
Chinle Formation (incomplete)-Continued

Owl Rock Member-Continued

contains abundant pale-red $(10 R 6 / 2)$ and light-greenish-gray ( $5 G Y \quad 8 / 1)$ limestone nodules which average about $1 / 2$ in. in diameter. Limestone, pale red $(10 R 6 / 2)$ and light greenish gray ( $5 G Y 8 / 1$ ), weathering same colors, dense; well cemented; stratification poorly exposed but probably mostly thin bedded; slabby splitting. Limestone confined to tabular sets from 49.8 to $51.4 \mathrm{ft}, 53.4$ to $56.0 \mathrm{ft}$, 59.9 to $61.6 \mathrm{ft}$ above base of unit. Unit as a whole weathers to form steep slope with small ledges on limestone

Total of Owl Rock Member

Petrified Forest Member:

Reddish-orange unit (possibly the reddishorange unit and the underlying limestone unit, unit 14, belong in the Owl Rock Member) :

19. Clayey siltstone, pale-reddish-brown $(10 R 5 / 4)$ and moderate-brown (5YR $4 / 4)$ in about equal proportions. Otherwise, unit is similar to unit 15. Units 15 to 19 form light-brown (5YR $6 / 4)$ and pale-reddish-brown (10R $5 / 4)$ color band on outcrop

18. Siltstone, pale reddish brown $(10 R 5 / 4)$ and grayish red $(10 R 4 / 2)$; poorly cemented, calcareous; ripple laminated; platy splitting; weathers to form slope. Abundant very fine sand grains along planes of ripple-laminae and disseminated elsewhere in unit. Abundant light-greenish-gray (5GY 8/1) spots. Sparse light-greenish-gray $(5 G Y 8 / 1)$ ripple-laminated very thin sets interbedded with rest of unit. At base of unit is a $0.4-\mathrm{ft}$ thick light-greenish-gray ( $5 G Y 8 / 1)$ siltstone layer that contains abundant limestone granules

17. Similar to unit 15

16. Clayey sandstone, pale reddish brown $(10 R 5 / 4)$, weathering pale red $(10 R$ $6 / 2$ ), very fine grained, probably contains 25 percent silt and clay, fair sorted; composed of subangular grains, composition not determinable, common fine-grained dark-green mica; firmly cemented, calcareous; stratification concealed; weathers to form steep rubble-covered slope. Sandstone grades to siltstone in parts of unit. A coarse-grained sandstone about $0.4 \mathrm{ft}$ thick locally occurs at base of unit

15. Clayey siltstone, pale reddish brown $(10 R 5 / 4)$, pale red $(10 R 6 / 2)$ in
Chinle Formation (incomplete)-Continued

Petrified Forest Member-Continued

Reddish-orange unit-Continued

lower $5 \mathrm{ft}$, weathering same colors; firmly cemented, highly calcareous; stratification concealed; weathers to form steep slope above bench on underlying unit. Abundant light-greenish-gray $(5 G Y 8 / 1)$ spots

Total of reddish-orange unit

36.8

$\overline{128.6}$

14. Limestone, light greenish gray ( $5 G Y$ $8 / 1)$, minor pale red $(10 R 6 / 2)$, weath ers light brown (5YR 6/4), dense; stratification mostly concealed, but contains some horizontal laminae; massive splitting; weathers to form prominent ledge. Grades into unit below

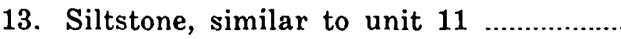

12. Sandstone, pale reddish brown (10R $5 / 4)$, grayish red $(10 R 4 / 2)$, and minor light greenish gray $(5 G Y 8 / 1)$, very fine to fine grained, well sorted; composed of subangular milky mineral and red and green minerals (20 percent); firmly cemented, slightly calcareous; stratification poorly exposed but unit contains some smallscale cross-strata; splitting concealed; weathers to form small ledge. Sandstone contains abundant flakes of pale-reddish-brown siltstone. Along outcrop unit locally forms prominent ledge. Along outcrop, unit appears to grade into prominent limestone ledge

11. Siltstone, pale reddish brown $(10 R 5 / 4)$, weathering pale red $(10 R 6 / 2)$; firmly cemented, calcareous; stratification concealed; weathers to form very steep loose slope. About 10 percent of unit is composed of pale-red $(10 R 6 / 2)$, greenish-gray (5GY 6/1), and white $(N 9)$ limestone nodules which average $1 \mathrm{in.}$ in diameter...

10. Sandstone, pale red purple $(5 R P 6 / 2)$, weathering grayish red purple ( $5 R P$ $4 / 2)$; fine grained, well sorted; composed of subangular undeterminable minerals and green and red minerals; firmly cemented, calcareous; composed of thin trough sets of lowangle small-scale cross-strata; platy splitting; weathers to form prominent dark ledge

9. Sandy granule conglomerate, light greenish gray ( $5 G Y 8 / 1)$, weathering moderate yellowish brown (10YR $5 / 4)$, poorly sorted; composed of wellrounded limestone granules in matrix of subangular fine-grained clear quartz and orange and black minerals; poorly cemented, calcareous;
14.5

30.7

8.2

32.6 
Chinle Formation (incomplete)-Continued Petrified Forest Member-Continued thin bedded; slabby splitting. Sparse pale-reddish-brown $(10 R \quad 5 / 4)$ siltstone pebbles and granules

Total of Petrified Forest Member Monitor Butte Member:

8. Claystone and silty claystone, greenishgray $(5 G Y 6 / 1)$ and grayish-red $(10 R 4 / 2)$; greenish gray generally dominant but colors change laterally on exposure; poorly cemented, calcareous; stratification concealed; weathers to form steep slope ............

7. Sandstone, light greenish gray (5GY $8 / 1)$, weathering pale red $(10 R 6 / 2)$, fine to medium grained, fair sorted; composed of subangular milky mineral and common milky quartz and 20 percent light-brown and green minerals; firmly to well cemented, calcareous; composed of thin trough sets of low-angle small-scale crosslaminae; platy splitting; weathers to form prominent ledge

6. Silty claystone (95 percent) and sandstone (5 percent). Silty claystone, greenish gray $(5 G Y 6 / 1)$ and light olive gray (5Y 6/1); contains common flakes of carbonaceous material and cylindrical bodies that are probably fossilized tree trunks; noncalcareous; stratification and splitting concealed. Sandstone, grayish orange $(10 Y R 7 / 4)$ and pale yellowish orange $(10 Y R 8 / 6)$; weathers brownish black (5YR 2/1); fine grained, well sorted; composed of subangular clear quartz and sparse black accessory minerals; well cemented, slightly calcareous; horizontally and ripple laminated; platy splitting. Sandstone constitutes 20 percent of lower $54 \mathrm{ft}$ of unit, where it occurs as thin to thick sets interbedded with siltstone; sandstone seems contorted and blocks of sandstone lie with strikes and dips at all angles to the regional attitude. A limestone bed $54 \mathrm{ft}$ above base of unit is light olive gray (5Y 6/1); weathers same color and brownish gray (5YR 4/1); dense; well cemented; consists of horizontal laminae and possible ripple laminae; massive splitting; weathers to form bench. Lower half of unit is poorly exposed, and the limestone bed may have slumped to its present position; however, the Monitor Butte Member contains a prominent limestone bed in about the same stratigraphic position east of section line

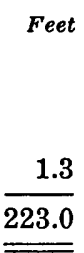

Chinle Formation (incomplete)-Continued

Monitor Butte Member-Continued

Total of Monitor Butte Member ....

Shinarump Member:

5. Sandstone, very pale orange (10YR $8 / 2)$, grayish-orange $(10 Y R 7 / 4)$, yellowish-gray $(5 Y 8 / 1)$, and very light gray $(N \quad 8)$; weathers dominantly grayish orange $(10 Y R 7 / 4)$; abundant grayish-yellow (5Y 8/4) stain; medium to coarse grained, fair sorted; common granules and pebbles as large as $1.5 \mathrm{in}$. in diameter occur locally in unit; composed of subangular to subrounded clear quartz and common black and red accessory minerals; poorly to firmly cemented, slightly calcareous; common carbonaceous and petroliferous material (a $\log$ about $1.5 \mathrm{ft}$ in diameter composed of coal occurs $69 \mathrm{ft}$ above base of unit) ; consists of thin to thick trough sets of medium-scale low-angle crosslaminae, some very low angle crosslaminae or horizontal laminae; platy and massive splitting; weathers to form steep ledgy slope and cliff, top $40 \mathrm{ft}$ forms a prominent cliff

Total of Shinarump Member ........

Total of Chinle Formation (composite of sections A and B. See note under description of unit 1 , Rincon section B)

Moenkopi Formation:

Upper slope-forming(?) member:

4. Siltstone, pale-reddish-brown $(10 R$ $5 / 4)$; weathers same color; top $2 \frac{1}{2}$ ft of unit is dark yellowish orange $(10 Y R 6 / 6)$; firmly to well cemented, calcareous; horizontally and ripple laminated, sparse very thin beds; platy splitting; weathers to form steep ledgy slope. The Moenkopi on north side of river is light brown and grayish orange along crest of Waterpocket fold

Total of upper slope-forming(?) member

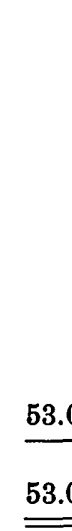

Conglomerate unit:

3. Cobble and pebble conglomerate, grayish-orange $(10 Y R \quad 7 / 4)$; weathers same color and olive gray (5Y 4/1); granules to cobbles as much as 6 in. long are composed of white and lightbrown chert and are set in a matrix of well-rounded fine to medium grains of clear quartz; well cemented, calcareous; very thinly bedded to thin bedded; platy to massive splitting; weathers to form prominent darkcolored ledge

Feet

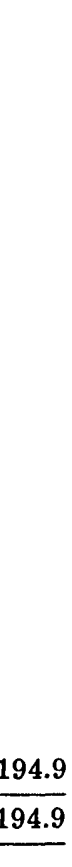


Moenkopi Formation-Continued

Conglomerate unit-Continued

Total of conglomerate unit ............

Total of Moenkopi Formation ......

Unconformity (erosional) marked by scours as much as $1 \frac{1}{2} \mathrm{ft}$ deep cut into underlying unit.

Kaibab (?) Limestone:

2. Sandstone, very pale orange $(10 Y R$ $8 / 2)$; weathers grayish orange $(10 Y R$ $7 / 4$ ); fine to medium grained with abundant coarse grains, fair sorted; composed of subrounded to rounded clear quartz with possibly 25 percent interstitial and intergranular calcite locally; firmly cemented, calcareous; abundant limonite spots; consists of horizontal laminae and very thin beds and possibly some ripple laminae; platy to flaggy splitting; weathers to form ledgy slope above cliff of unit 1

Total of Kaibab(?) Limestone ......

Cutler Formation (incomplete) :

De Chelly Sandstone Member (incomplete) :

1. Sandstone, light-olive-gray (5Y 4/1): weathers pale yellowish brown $(5 Y R$ $6 / 2)$ and grayish orange $(10 Y R$ $7 / 4$ ) ; fine to medium grained, well sorted; composed of rounded clear quartz, no accessory minerals seen; firmly cemented, slightly calcareous; highly petroliferous; common limonite spots; very thick sets of largescale cross-laminae and thin beds; platy and massive splitting; weathers to form cliff. Entire unit not examined in detail: 50-75 $\mathrm{ft}$ more of unit is exposed on north side of river

Total of incomplete De Chelly Sandstone Member

Total of incomplete Cittler Formation

Base of section; base of exposure at Colorado River.

U-37b. RINCON SECTION B

Measured on the farthest east exposure of the Chinle Formation in the Rincon, long $110^{\circ} 46^{\prime} W$, lat $87^{\circ} 19.5^{\prime} \mathrm{N}$., San Juan County

[Measured by J. H. Stewart, March 1953]

Top of section, not top of exposure.

Wingate Sandstone:

13. Sandstone, light brown (5YR 6/4), weathering same color, very fine grained, well sorted; composed of subrounded clear quartz and common black accessories; firmly cemented, calcareous; composed of thin trough sets of small- and medium-scale cross-laminae; massive splitting. Weathers to form vertical cliff. About

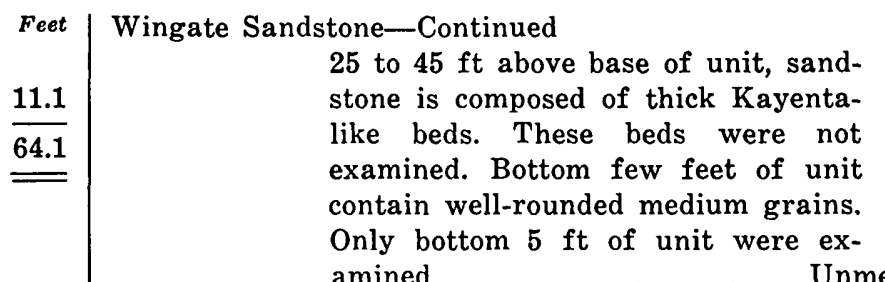

Feet Chinle Formation (incomplete) : Church Rock(?) Member:

12. Siltstone, grayish red $(10 R 4 / 2)$, weathering grayish red purple ( $5 R P$ $4 / 2$ ), well cemented, noncalcareous; in well-exposed parts appears ripple laminated, stratification in rest of unit concealed; siltstone fractures into angular fragments

11. Limestone pebble to granule conglomerate, pale red $(10 R 6 / 2)$, weathering same color; composed of granules and pebbles of limestone in calcite matrix; firmly cemented; stratification and splitting concealed; weathers to form slope containing small ledges. Unit contains $1-\mathrm{ft}$ bed of grayish-red $(10 R \quad 4 / 2)$ siltstone in middle

10. Siltstone, pale reddish brown (10R 5/4), weathering same color; sandy (very fine grained), well cemented, noncalcareous; structureless; fractures into angular fragments; weathers to form slope in lower part and small ledge in upper part. Common light-greenish-gray $(5 G Y 8 / 1)$ spots

9. Siltstone, pale red $(10 R 6 / 2)$ and light greenish gray (5GY 8/1), weathering grayish orange $(10 Y R$ $7 / 4)$; well cemented, very slightly calcareous, possibly siliceous; horizontally laminated, possibly some ripple laminae; platy to slabby splitting; weathers to form small ledge

8. Siltstone, pale reddish brown (10R $5 / 4)$, weathering same color; well cemented, noncalcareous; stratification concealed; weathers to form slope. Pale-yellowish-brown (10YR $6 / 2$ ) siltstone (otherwise similar to rest of unit) forms small ledge 1 $\mathrm{ft}$ above base of unit

7. Siltstone, pale red $(5 R 6 / 2)$ and minor light greenish gray (5GY 8/1), weathering same colors; well cemented, slightly calcareous, possibly siliceous; probably thin horizontally bedded; slabby splitting; weathers to form small ledge

6. Siltstone, similar to unit 4. Unit contains $0.6-\mathrm{ft}$ bed of light-greenishgray $(5 G Y 8 / 1)$ and pale-red $(10 R$ $6 / 2$ ) well-cemented, possibly siliceous, siltstone at $2.6 \mathrm{ft}$ above base.... 
Chinle Formation (incomplete) -Continued Church Rock (?) Member-Continued

5. Siltstone, pale red $(5 R 6 / 2)$, weathering same color; well cemented, slightly calcareous and possibly siliceous; structureless; massive splitting; weathers to form small ledge. Abundant light-greenish-gray (5GY 8/1) spots

4. Siltstone, pale reddish brown $(10 R$ 5/4) weathering same color; firmly cemented, noncalcareous; stratification concealed; weathers to form steep loose slope

3. Limestone-granule conglomerate, light greenish gray ( $5 G Y 8 / 1)$, weathering light brownish gray (5YR 6/1), composed of round limestone granules and sparse pebbles in calcite matrix; stratification concealed; weathers to small ledge ........................

2. Siltstone, pale reddish brown $(10 R$ $5 / 4)$, weathering moderate red $(5 R$ $5 / 4)$ in lower $8.5 \mathrm{ft}$ of unit, rest of unit weathers grayish red $(10 R 4 / 2)$, weathering color masked by debris; firmly cemented, calcareous; stratification and splitting concealed; weathers to form steep loose slope. Uncommon light-greenish-gray ( $5 G Y$ $8 / 1$ ) limestone nodules. Upper threefourths of unit poorly exposed

Total of Church Rock(?) Member

Owl Rock Member:

1. Siltstone, grayish red purple (5RP $4 / 2$ ), weathering pale red purple $(5 R P 6 / 2)$; firmly cemented, calcareous; stratification concealed; weathers to form loose slope. Abundant light-greenish-gray $(5 G Y \quad 8 / 1)$ spots .......................................... Unmeasured

Note. - Unit 1 is probably the same as unit 27 of Rincon section $A$. If this unit is the same as unit 27 of Rincon section $A$, the $29.9 \mathrm{ft}$ of rocks in units 28 and 29 assigned to the Owl Rock Member in Rincon section A must correspond to part of unit 2, Church Rock Member, Rincon section $B$. The color break at the top of unit 1 (Rincon section B), however, appears to be the best tie between the two sections and is used to determine the thickness of the Chinle Formation in the area.

Base of section; not base of exposure.

\section{U-39. TAYLOR CANYON}

Measured on southwest-facing spur at prominent tributary on north side of Taylor Canyon; 1.8 miles upstream from mouth of Taylor Canyon wash; line of section about $N$. $10^{\circ} E$., long $109^{\circ} 58^{\prime} 20^{\prime \prime} W$., lat $38^{\circ} 28^{\prime} 55^{\prime \prime} N$., San Juan County

[Measured by J. H. Stewart, November 1953]
Feet. Top of section; top of accessible exposure. Top of section is about N. $63^{\circ}$ E. of junction of Taylor Canyon wash and the Green River.

Wingate Sandstone:

25. Sandstone, light brown (5YR 6/4), weathering same color, very fine grained, well sorted; composed of subrounded amber quartz and sparse black accessory mineral; poorly cemented, slightly calcareous; composed of thin trough sets of lowangle medium-scale cross-laminae; massive splitting; weathers to form vertical cliff. Only basal $6 \mathrm{ft}$ of unit examined. Basal $0.3 \mathrm{ft}$ is yellowish gray $(5 Y 8 / 1)$. Basal $0.1 \mathrm{ft}$ contains sparse rounded frosted clean quartz and sparse medium to coarse amber quartz grains Unmeasured

Contact between Wingate Sandstone and Chinle Formation placed at color change from reds and purples of the Chinle to light brown of the Wingate. Contact is at change from sandstone below containing pebbles and composed of stream type cross-strata to sandstone above containing no pebbles and composed of eolian type cross-strata. Chinle Formation:

Church Rock Member:

Hite Bed:

24. Sandstone, grayish red $(5 R 4 / 2)$, pale reddish brown $(10 R 5 / 4)$, pale red purple $(5 R P 6 / 2)$ and light greenish gray $(5 G Y 8 / 1)$, weathering grayish red $(5 R 4 / 2)$, very fine grained, fair sorted; composed of subangular clear quartz and milky mineral and sparse orange accessory mineral, uncommon coarse-grained accessory white and dark mica; horizontally laminated, and common thin trough sets of low-angle medium-scale crosslaminae; weathers to form vertical cliff continuous with that of overlying Wingate Sandstone. Lower 2 $\mathrm{ft}$ of unit contains common conglomeratic sandstone with granules to pebbles of light-brown-weathering siltstone. A thin set in the middle of the unit contains common to abundant flakes and pebbles of grayishred-purple (5RP 4/2) siltstone ..........

23. Sandy siltstone to sandstone, pale red $(10 R 6 / 2)$ to pale reddish brown $(10 R 5 / 4)$, weathering same colors, very fine grained, firmly cemented, noncalcareous; ripple laminated, sparse pseudo cross-laminae, common horizontal laminae to thin beds; weathers to form slope containing several small ledges. Bottom $8 \mathrm{ft}$ of unit is very poorly exposed but contains sparse outcrops of siltstone to sandy siltstone similar to the rest of the unit 
Chinle Formation-Continued

Church Rock Member-Continued

Hite Bed-Continued

22. Sandstone and siltstone to claystone. Sandstone, pale red $(10 R 6 / 2)$ and yellowish gray $(5 Y 8 / 1)$, weathering pale reddish brown $(10 R 5 / 4)$, very fine grained; firmly cemented, calcareous; composed of thin trough sets of low-angle medium-scale cross-laminae, horizontal laminae, and ripple laminae; about 50 percent of the sandstone contains common to abundant rounded medium to coarse frosted grains of quartz. Siltstone to claystone, grayish red $(10 R 4 / 2)$, weathering same color; firmly cemented, noncalcareous; stratification concealed. Siltstone to claystone is present from 6.9 to $8.5 \mathrm{ft}$, and rest of unit is sandstone. Unit weathers to form ledge. Basal strata of unit fill scours cut into underlying unit ........

Total of Hite Bed

21. Siltstone, light brown $(5 Y R 6 / 4)$ and pale reddish brown $(10 R 5 / 4)$, sparse light-greenish-gray ( $5 G Y 8 / 1)$ spots, weathering same colors; well cemented, noncalcareous; structureless and thick to very thick horizontally bedded; common horizontal laminae; weathers to form vertical cliff near top of Chinle Formation. Unit contains common irregular tubular structures about $1 / 4 \mathrm{in}$. in diameter that may be worm borings. From about 47 to $50 \mathrm{ft}$, unit contains sparse (2 percent) subangular medium to coarse grains of gray quartz (?) .........

20. Siltstone, light brown ( $5 Y R 6 / 4)$, common pale reddish brown (10R 5/4), sparse light greenish gray (5GY 8/1), weathering pale reddish brown $(10 R$ $5 / 4$ ), sandy (very fine grained); firmly cemented, calcareous; horizontally and ripple laminated; weathers to form small ledge. Unit contains sparse rounded coarse grains of gray and minor orange and green material, possibly siltstone or limestone. Unit contains sparse flakes of grayish-red (10R 4/2) siltstone

19. Siltstone, light brown $(5 Y R 6 / 4)$ to moderate brown $(5 Y R 4 / 4)$, weathering pale reddish brown $(10 R 5 / 4)$, sandy (very fine grained); poorly cemented, calcareous; structureless, sparse horizontal laminae; fractures into angular fragments; weathers to form slope

18. Siltstone, grayish red $(10 R 4 / 2)$ and pale reddish brown $(10 R 5 / 4)$, weathering grayish red $(5 R 4 / 2)$; firmly
Feet Chinle Formation-Continued Feet Church Rock Member-Continued cemented, calcareous; structureless; weathers to form slope. Differentiated from underlying unit by lack of silty sandstone to sandy siltstone sets and from overlying unit by color change

17. Siltstone to clayey siltstone (90 percent) and sandy siltstone to silty sandstone (10 percent). Siltstone to clayey siltstone, pale reddish brown $(10 R 5 / 4)$ to dark reddish brown $(10 R 3 / 4)$, weathering same colors; firmly cemented, slightly calcareous; structureless. Sandy siltstone to silty sandstone, pale red $(10 R 6 / 2)$ and pale reddish brown $(10 R 5 / 4)$, weathering pale brown $(5 Y R 5 / 2)$, very fine grained; uncommon very fine grained accessory white mica; well cemented, calcareous; ripple laminated, sparse small-scale cross-laminae. Sandy siltstone to silty sandstone is present as thin to very thin sets interstratified with the rest of the unit

16. Silty sandstone (70 percent) and siltstone (30 percent). Silty sandstone, pale red $(10 R 6 / 2)$, weathering pale red $(5 R 6 / 2)$, very fine grained; uncommon fine-grained accessory white mica; well cemented, calcareous; ripple laminated, sparse trough sets of small-scale cross-laminae, and sparse horizontal laminae. Silty sandstone is present as thin to very thick sets interstratified with siltstone. Siltstone, grayish red $(10 R 4 / 2)$, weathering pale reddish brown $(10 R 5 / 4)$, uncommon very fine grained accessory white mica; firmly cemented, calcareous; horizontally laminated, ripple laminated, and structureless. Unit as whole weathers to form slope containing ledges developed on silty sandstone sets

So-called Black Ledge:

15. Sandstone, pale red $(10 R 6 / 2)$, weathering grayish red $(5 R 4 / 2)$, very fine grained, well sorted; composed of subangular milky minerals and common black accessory mineral, uncommon medium-grained white mica; firmly cemented, calcareous; composed of thick trough sets of mediumscale cross-laminae and minor very thin horizontal beds; top $8 \mathrm{ft}$ dominantly ripple laminated; weathers to form vertical cliff that is most prominent ledge in middle of Chinle. Top of unit arbitrarily placed at base of a siltstone set of overlying unit

14. Sandstone to conglomerate, medium light gray $(N 6)$ and greenish gray 
Chinle Formation-Continued

Church Rock Member-Continued

So-called Black Ledge-Continued

(5GY 6/1), weathering olive gray (5Y 4/1), composed of rounded medium grains to pebbles in a dense lime matrix; well cemented; structureless and common thin trough sets of small-scale low-angle cross-laminae; weathers to form vertical cliff continuous with that of overlying unit. Unit intertongues and intergrades with overlying unit

Total of so-called Black Ledge ......

Total of Church Rock Member ......

Owl Rock Member:

13. Sandstone to sandy siltstone (50 percent) and siltstone ( 50 percent). Sandstone to sandy siltstone, grayish yellow green $(5 G Y 7 / 2)$ and greenish gray $(5 G Y 6 / 1)$, weathering same colors, very fine to fine grained, fair sorted; composed of subangular milky and green mineral, green mineral possibly clay, uncommon medium- to coarse-grained accessory white mica; poorly cemented, calcareous; horizontally and ripple laminated. Contains common carbonaceous material. Siltstone, same colors as rest of unit; firmly cemented, slightly calcareous; structureless. Sandstone to sandy siltstone is present as very thin to thick sets interstratified with rest of unit. Top $4 \mathrm{ft}$ of unit poorly exposed ........

12. Limestone, grayish yellow $(5 Y 8 / 4)$ and light gray $(N 7)$, weathering yellowish gray (5Y 8/1), aphanitic; well indurated; composed of indistinct thin to very thin horizontal beds; weathers to form ledge. Top $1 \mathrm{ft}$ contains dark-gray ( $N \quad 3$ ) chert masses as large as 3 in. in diameter. Middle of unit contains thin lens of greenish siltstone away from line of section....

Total of Owl Rock Member

Petrified Forest Member:

11. Silty sandstone to clayey siltstone, grayish red (10R 4/2 and sparse $5 R 4 / 2)$, minor greenish gray ( $5 G Y 6 / 1)$ from 0.0 to $11.0 \mathrm{ft}$ and from 34.0 to 37.3 $\mathrm{ft}$ above base of unit, weathering grayish red $(5 R 4 / 2)$, and minor light greenish gray ( $5 G Y 8 / 1)$, very fine grained; firmly cemented, calcareous; stratification mostly concealed, where exposed is ripple laminated; weathers to form slope. Some parts of unit are very clayey and may grade to silty claystone. These clayey parts contain swelling clay. Unit con-

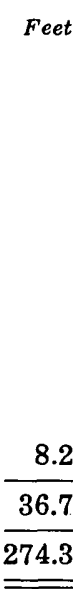

Chinle Formation-Continued

Petrified Forest Member-Continued

tains a limy siltstone lens at $36.0 \mathrm{ft}$.

Top $2 \mathrm{ft}$ of unit contains limestone nodules

10. Mostly covered. A few exposures suggest that most of unit is sandstone. Sandstone, pale olive $(5 Y 6 / 2)$, fine to medium grained, fair sorted; composed of subangular milky mineral and abundant orange, green, and gray accessory mineral; stratification concealed. Unit as whole weathers to form rubble-covered slope

9. Sandstone (90 percent) and conglomeratic sandstone (10 percent). Sandstone, yellowish gray $(5 Y 8 / 1)$ and minor dusky yellow $(5 Y 6 / 4)$ and pale olive $(10 Y 6 / 2)$, weathering yellowish gray (5Y 8/1) and to a lesser extent light greenish gray ( $5 G Y 8 / 1)$, very fine to medium grained, fair sorted; composed of subangular milky mineral and minor clear quartz, common orange and green accessory mineral, sparse coarse-grained accessory white and dark mica; firmly cemented, calcareous; stratification poorly exposed but probably mostly thin to thick trough sets of low-angle smallto medium-scale cross-laminae. Conglomeratic sandstone, similar to sandstone except contains pebbles, some granules, and sparse cobbles as large as $3 \mathrm{in}$. in diameter of dusky-yellow (5Y 6/4) siltstone and limestone. Rarely the conglomeratic sandstone grades to conglomerate containing about 60 percent granules and pebbles. Unit weathers to form ledgy slope. Unit contains common carbonaceous material

8. Conglomerate, grayish yellow ( $5 Y 8 / 4)$, weathering same color and yellowish gray $(5 Y 7 / 2)$; composed of subangular to rounded siltstone and limestone granules, pebbles, and coarse to very coarse grains in an aphanitic to coarsely crystalline lime matrix; poorly cemented; generally structureless with subordinate horizontal laminae and low-angle cross-laminae; weathers to form ledge. Bottom $1.5 \mathrm{ft}$ is poorly exposed but appears to be mostly grayish-yellow (5Y 8/4) finegrained sandstone with sparse granules of limestone and siltstone. This sandstone contains thin sets of smallscale low-angle cross-laminae and common carbonaceous material ..........

7. Sandy siltstone, greenish gray ( $5 G Y$ $6 / 1$ ), weathering same color, sandy (very fine grained), poorly cemented,
Feet

42.2

18.8 
Chinle Formation-Continued

Petrified Forest Member-Continued calcareous; stratification concealed; weathers to form slope. Basal $3 \mathrm{ft}$ poorly exposed

6. Limy sandstone, light greenish gray (5GY 8/1), weathering dark yellowish brown $(10 Y R 4 / 2)$, grades from a very fine grained sandstone composed of subrounded quartz grains and interstitial calcite(?) to a medium- to coarse-grained sandstone composed of rounded limestone grains and interstitial calcite(?); well cemented; composed of thin planar sets of small-scale cross-laminae; weathers to form a ledge or, in some places, a slope. Limestone granule and pebbles are common to abundant in a few parts of unit

5. Sandstone, light greenish gray ( $5 G Y$ $8 / 1)$ and yellowish gray $(5 Y 8 / 1)$, weathering same colors, fine to medium grained, fair sorted; composed of angular to subangular clear quartz and milky mineral, common orange accessory mineral; poorly to firmly cemented, calcareous; composed of thin (sparse thick) planar and probably trough sets of small-scale (minor medium-scale) cross-laminae; weathers to form bench containing several discontinuous ledges

4. Conglomeratic sandstones to conglomerate, greenish gray $(5 G Y 6 / 1)$ and light greenish gray ( $5 G Y 8 / 1)$, weathering dark yellowish brown (10YR $4 / 2)$; composed of granules and subordinate pebbles in medium- to coarsegrained sand matrix, interstices filled with calcite. Granules and pebbles constitute about 20 percent to 70 percent of the rock and consist mostly (95 percent) of siltstone; a few are sandstone, quartzite, or quartz. Sand matrix composed of subrounded milky quartz. Conglomeratic sandstone to conglomerate is well cemented, calcareous; stratification poorly developed but mostly composed of horizontal laminae to very thin beds and probably thin planar sets of small-scale cross-laminae; weathers to form small ledge. Fifty feet to west of line of section, unit is separated from underlying unit by a thick set of green siltstone

Total of Petrified Forest Member..

Moss Back Member:

3. Sandstone (95 percent) and siltstone (5 percent). Sandstone, very pale orange $(10 Y R 8 / 2)$ and subordinate
Feet

Chinle Formation-Continued

Moss Back Member-Continued

yellowish gray $(5 Y$ 8/1) and light greenish gray (5GY 8/1), weathering light brown $(5 Y R 6 / 4)$. Sandstone in bottom $14.7 \mathrm{ft}$ is fine to medium grained (sparse coarse grains) well sorted; composed of subangular clear quartz and sparse black accessory mineral; poorly cemented, calcareous; composed of very thick trough sets of medium-scale cross-laminae. Sandstone in top $12.0 \mathrm{ft}$ is very fine to fine grained, fair sorted; composition not determinable, common coarsegrained accessory white mica, interstitial spaces filled by white material, probably clay; firmly to well cemented, calcareous; composed of thin trough sets of small-scale and minor mediumscale cross-laminae. Siltstone, greenish gray $(5 G Y 6 / 1)$, weathering same color, firmly cemented, noncalcareous; structureless and horizontally laminated. Siltstone is present as thin to thick lenses interstratified with sandstone in top $12.0 \mathrm{ft}$ of unit. Percent of siltstone varies considerably along outcrop. About $500 \mathrm{ft}$ to east of line of section, unit forms massive cliff containing little or no siltstone. Sandstone contains a few scattered pebbles of chert and quartzite. Siltstone contains carbonaceous material. Unit as whole tabular and weathers to form vertical cliff

2. Sandstone (50 percent) and siltstone (50 percent). Sandstone, yellowish gray $(5 Y 8 / 1)$ and subordinate greenish gray $(5 G Y 6 / 1)$, weathering very pale orange $(10 Y R 8 / 2)$, very fine to fine grained, fair sorted; composed of clear quartz and common orange and black accessory mineral, common finegrained accessory white mica; well cemented, calcareous; horizontally and ripple laminated. Sandstone is present as a thick set in the middle of the unit and as very thin to thin sets interstratified with siltstone in the rest of the unit. Siltstone, greenish gray ( $5 G Y 6 / 1)$, weathering light greenish gray $(5 G Y 8 / 1)$, common fine-grained accessory white mica; firmly cemented, slightly calcareous; horizontally laminated. Unit as whole weathers to form vertical cliff. Both the sandstone and the siltstone contain common carbonaceous material. Unit is placed in the Chinle Formation because the sandstone is similar to other sandstone layers in the Chinle, because the unit contains car-
Feet 
Chinle Formation-Continued

Moss Back Member-Continued bonaceous material, and because lateral to the line of section the unit contains siliceous pebbles at its base

Total of Moss Back Member.........

Total of Chinle Formation.

Moenkopi Formation:

1. Siltstone, grayish red $(10 R 4 / 2)$, grayish yellow $(5 Y 8 / 4)$ and subordinate greenish gray $(5 G Y 6 / 1)$, weathering same colors; common to abundant very fine grained accessory white mica; well cemented, calcareous; horizontally laminated to thinly bedded, weathers to form rubble-covered slope with vertical cliff in top part. Common cubes probably of limonite pseudomorphic after pyrite. Cubes are the size of coarse grains and are found only in yellowish and gray part of rock. Unmeasured

Base of section; base of exposure.

\section{U-40. CLIFF CREEK}

Measured in first major reentrant northeast of Cliff Creek water gap. Line of section trends $N .42^{\circ} \mathrm{W}$. through secs. 15 and 16, T. 5 S., R. 24 E., SLM, Uintah County

[Measured by F. G. Poole and C. Koteff, August 1956]

Top of section; not top of exposure. Section ends in lower part of Glen Canyon Sandstone.

Glen Canyon Sandstone:

22. Sandstone, very pale orange $(10 Y R$ $8 / 2)$, grayish yellow $(5 Y 8 / 4)$, and yellowish gray $(5 Y 8 / 1)$, pale-reddish-brown (10R 5/4) mottling and streaks, weathering same colors and lighter shades; very fine grained, silty, well sorted; composed of subrounded to well-rounded clear quartz grains and common to sparse feldspar and black accessory mineral; firmly to poorly cemented, calcareous. Lower $25 \mathrm{ft}$ of Glen Canyon Sandstone is horizontally thinly laminated to very thick bedded; laminae are wavy and may grade into ripples. Unit weathers to form vertical cliff. Most of Glen Canyon Sandstone is cross stratified and contains medium- and largescale planar and subordinate trough sets of high-angle cross-laminae to thin crossbeds Unmeasured

Chinle Formation:

Upper member:

21. Silty claystone, grayish red $(10 R \quad 4 / 2)$ and minor greenish gray (5GY 6/1), weathers grayish red $(5 R 4 / 2)$, pale red $(5 R 6 / 2)$ and minor light greenish gray (5GY 8/1); firmly cemented, noncalcareous to slightly calcareous; structureless and poorly bedded. A siltstone bed about 2 in. thick was

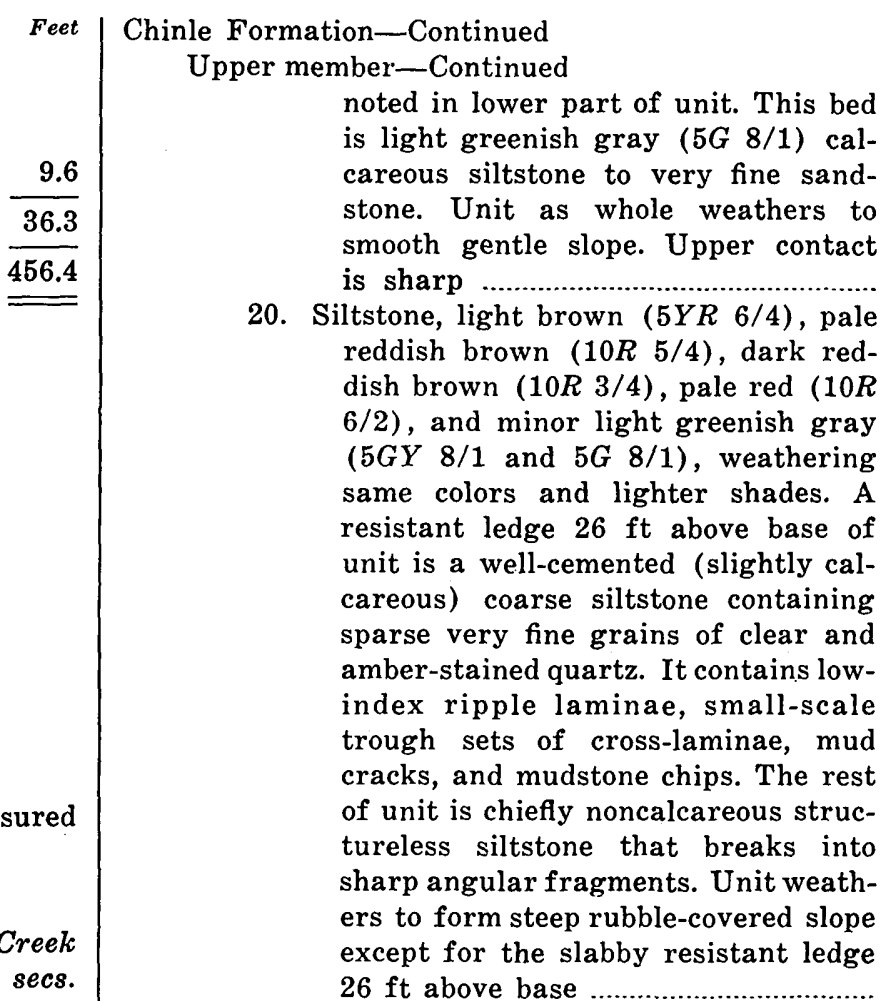

19. Sandstone, light brown $(5 Y R 6 / 4)$, moderate orange pink (5YR 8/4) and pinkish gray $(5 Y R 8 / 1)$, weathering same colors and grayish orange pink $(5 Y R 7 / 2)$ and yellowish gray (5Y $7 / 2$ ), very fine to fine grained, silty, well sorted; composed of rounded to well-rounded clear and amber-stained quartz grains and common feldspar and black accessory mineral; firmly to poorly cemented, very calcareous; very thin bedded to thin bedded. Upper part of unit consists of trough and planar sets of medium- and smallscale cross-laminae. Unit weathers to form slabby ledge and prominent dip slope. Unit is lenticular and pinches out a short distance laterally; similar sandstone ledges occur at various horizons above unit

Total of upper member

Red siltstone member:

18. Sandstone to siltstone (90 percent) and limy siltstone-pebble conglomerate (10 percent). Sandstone to siltstone, moderate reddish brown $(10 R 4 / 6)$, pale reddish brown (10R 5/4), moderate brown (5YR 4/4), light brown (5YR 6/4), and subordinate light greenish gray (5G8/1 and $5 G Y 8 / 1)$, weathering moderate brown $(5 Y R$ $4 / 4)$, moderate reddish brown (10R $4 / 6)$, and minor pale yellowish brown $(10 Y R 6 / 2)$. Sandstone is very fine
Feet 
Chinle Formation-Continued

Red siltstone member-Continued

to coarse grained, fair to well sorted; composed of rounded to well-rounded clear, milky, smoky, and amberstained quartz grains, and uncommon to sparse red and black accessory minerals; firmly to well cemented, very calcareous; very silty; contains mudstone chips. The sandstone in some places grades laterally and vertically into siltstone and in other places into limy siltstone pebble conglomerate. The siltstone in unit is for the most part coarse textured. Abundant rounded and well-rounded clear, milky, smoky, and amber-stained quartz grains of medium sand occur in the siltstone and in very fine grained sandstone in the unit. Conglomerate, light greenish gray ( $5 G Y \quad 8 / 1$ and $5 G 8 / 1$ ), weathering same colors and light brown (5YR 6/4); composed of rounded to well-rounded limy siltstone granules and pebbles as much as $7 \mathrm{~mm}$ in diameter, fair sorted; siltstone matrix with abundant clear, milky, smoky, and amber-stained quartz grains and uncommon to sparse red, black, and white accessory minerals; firmly to well cemented, very calcareous. Conglomerate occurs in basal few feet of unit. Quartz and accessory mineral grains in conglomerate are as large as very coarse in size. Unit is laminated to thin bedded and contains minor ripple laminations and small-scale sets of crossstrata; it is platy to slabby splitting. Unit as a whole weathers to form resistant ledges

17. Siltstone ( 80 percent) and siltstone pebble conglomerate (20 percent). Siltstone, pale red $(10 R 6 / 2$ and $5 R$ $6 / 2$ ) and pale red purple (5RP 6/2), minor mottling and stringers of light greenish gray (5G $8 / 1$ and $5 G Y$ $8 / 1)$ and dark reddish brown (10R $3 / 4)$, weathering same colors and lighter shades; contains scattered subrounded to rounded grains and granules of material from underlying units and common crystalline calcite; well cemented, calcareous; (unit appears to be lenticular) structureless and very thick bedded. Upper part of unit contains numerous vertical cylindrical structures as much as 4 in. in diameter and as much as 8 $\mathrm{ft}$ in length; some of these structures are slightly sinuous. The upper part of the unit weathers to form a vertical cliff with a smooth knobby

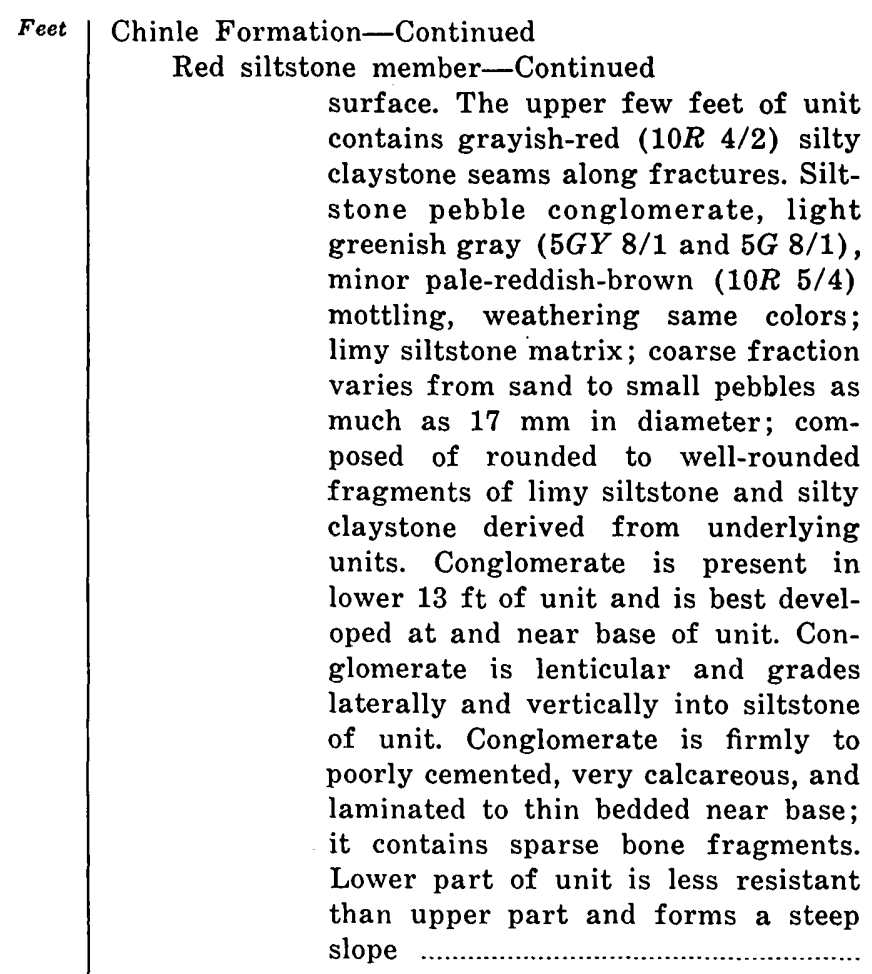

Total of red siltstone member

$\frac{25.4}{35.6}$

Ocher siltstone member:

16. Siltstone to silty claystone, dark yellowish orange $(10 Y R 6 / 6)$, moderate yellowish brown (10YR 5/4), minor light-greenish-gray $(5 G Y \quad 8 / 1)$ and yellowish-gray $(5 Y \quad 8 / 1)$ mottling, minor moderate brown $(5 Y R 4 / 4)$ at top of unit, weathering same colors; abundant secondary oolites on surface and along fractures, goethite; firmly to well cemented, very calcareous; structureless; numerous limy concretions in a zone at top of lower third of unit; breaks into small angular and rounded fragments; weathers to form a smooth deeply weathered slope

15. Silty claystone, dark reddish brown $(10 R 3 / 4)$, grayish red purple (5RP $4 / 2$ ), minor light-greenish-gray ( $5 G Y$ $8 / 1$ ) mottling, weathers same colors and lighter shades; poorly cemented, slightly calcareous to noncalcareous; weathers to form smooth gentle slope. Unit as a whole appears as a purple and red band below ocher of unit above

Total of ocher siltstone member....

Mottled member:

14. Sandstone to siltstone (50 percent) and silty claystone (50 percent). Sand-

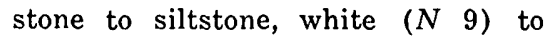
light gray $(N 7)$, dusky blue (5PB
Feet

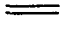

47.9 
Chinle Formation-Continued

Mottled member-Continued

$3 / 2)$, and blackish red ( $5 R 2 / 2)$, iron stained, weathering same colors and lighter shades. Sandstone is very fine to very coarse grained and contains a few granules and small pebbles. It is fair to poorly sorted; composed of subrounded to rounded clear, milky, and smoky quartz, and uncommon to sparse feldspar and rose quartz, some white mica; well to poorly cemented, calcareous. Sandstone layers are lenticular and form resistant ledges when well cemented and smooth, sandy and frothy surface when poorly cemented. Very thin bedded chert layers were noted just above base of unit. The chert beds contain thin wavy laminae of various colors

13. Sandstone to conglomeratic sandstone, white $(N 9)$, with pale-red-purple $(5 R P \quad 6 / 2)$ and grayish-red-purple (5RP 4/2) mottling; medium to very coarse grained sandstone containing granules and pebbles in lenses and as scattered clasts fair to poorly sorted; composed of subangular to rounded clear and milky quartz grains and uncommon feldspar and white mica, sparse pink and dark-gray accessory minerals; firmly to poorly cemented, calcareous. Granules and pebbles are subrounded to rounded and composed of milky, smoky, or rose quartz or varicolored chert. Unit is lenticular and appears to pinch out along strike. Unit weathers to a smooth sandy and pebbly slope

12. Siltstone, mottled dusky blue (5PB $3 / 2)$, grayish red purple (5RP 4/2), grayish purple (5P 4/2), dark yellowish orange $(10 Y R 6 / 6)$, moderate yellowish brown $(10 Y R 5 / 4)$, and yellowish gray $(5 Y 8 / 1)$, weathers same colors and lighter shades; sandy; firmly cemented, noncalcareous to slightly calcareous; structureless, breaks into angular fragments. Unit weathers to form a smooth gentle slope. A 3-in. bed of mediumgrained sandstone is present $2 \mathrm{ft}$ above base of unit. Sandstone is white and composed of subangular to rounded clear and smoky quartz grains and sparse red and black accessory minerals. Pebbles are as much as $2 \frac{1}{2}$ in. in diameter.

11. Sandstone, very fine grained, to coarse siltstone, white $(N 9)$, very light gray $(N 8)$, pinkish gray $(5 Y R 8 / 1)$, light brownish gray (5YR 6/1), pale

Feet Chinle Formation-Continued Mottled member-Continued red purple (5RP 6/2), grayish orange $(10 Y R$ 7/4), grayish red $(10 R 4 / 2)$, and pale reddish brown $(10 R 5 / 4)$, mottled and color banded, weathering same colors and lighter shades; fair to well sorted; composed of subrounded and rounded clear and milky quartz, common to sparse medium- and coarse-grained white mica, and sparse feldspar; firmly to well cemented, calcareous. Lower half of unit is composed of trough and planar sets of mediumand small-scale cross-laminae to very thin crossbeds. Upper half of unit appears to be structureless. Unit as whole weathers to form resistant ledge and dip slope and is the most prominent ridge in section

16.4

\section{Section offset \\ Formation.}

Unconformity.

Moenkopi Formation (incomplete) :

9. Siltstone (50 percent) and claystone (50 percent), grayish red $(10 R 4 / 2)$, dark reddish brown $(10 R 3 / 4)$, and minor greenish gray $(5 G Y 6 / 1)$; firmly cemented, calcareous; thinly laminated to very thin bedded; papery and shaly splitting. Unit as a whole weathers to form steep smooth slope that is darker red than underlying unit

Total of incomplete Moenkopi

Formation

Base of section; not base of exposure.

Units 1-8 described in Stewart, Poole, and Wilson (1972).

7.7

$$
\text { U-41. VERNAL (BRUSH CREEK) }
$$

Units 11-17 measured about 1 mile west of old Vernal-Manila highway (Utah 44); units 18-28 measured from 200 to 500 ft east of Vernal-Manila highway where the old highway
Feet

10.2

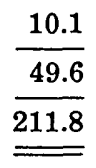


crosses the upper part of the Chinle Formation. Sec. $5, T$. s S., R. 22 E., SLM, Uintah County

[Measured by J. H. Stewart and R. F. Wilson, October 1955 ; revised by F. G. Poole, 1956]

Top of section; not top of exposure. Top of section is about $1,000 \mathrm{ft} \mathrm{S} .47^{\circ} \mathrm{W}$. of bridge across Brush Creek on old Vernal-Manila highway and is about $500 \mathrm{ft}$ east of Vernal-Manila road.

Glen Canyon Sandstone (incomplete) :

28. Sandstone, very pale orange (10YR $8 / 2$ ), weathering same color, fine to medium grained, well sorted; composed of rounded clear and milky quartz and sparse feldspar and black and orange accessory minerals; poorly cemented, noncalcareous; composed of thick to very thick planar sets from 5 to $30 \mathrm{ft}$ thick of highangle large-scale cross-laminae; weathers to form vertical cliff ..Unmeasured

27. Sandstone, light brown (5YR 6/4), minor yellowish gray $(5 Y 8 / 1)$, and sparse pale reddish brown $(10 R$ $5 / 4)$, weathering same colors, very fine to fine grained, sparse medium grains, well sorted; composed of subrounded clear quartz and sparse feldspar; poorly cemented, calcareous; horizontally laminated with minor wavy laminae having amplitude of $1 / 4$ in.; weathers to form reentrant in cliff and locally forms rubble-covered slope

Feet andstone, light brown $(5 Y R 6 / 4)$ and minor very pale orange $(10 Y R 8 / 2)$, weathering same colors, very fine to fine grained, well sorted; composed of subrounded to rounded clear (minor reddish-stained) quartz, minor feldspar, and accessory black ilmenite (?) ; firmly cemented, slightly calcareous in part; composed of thin to minor thick wedge-shaped planar sets of small- to medium-scale lowangle (sparse high-angle) crosslaminae; minor horizontal laminae to very thin beds. Unit contains common calcareous sand concretions up to 1 in. in diameter. Unit weathers to form vertical cliff

Total of incomplete Glen Canyon Sandstone

Chinle Formation:

Upper member :

25. Mostly covered, one thin ledge of horizontally laminated sandstone similar to that in underlying unit is present in middle of unit. Exposure in top foot of unit is siltstone similar to that in unit 23. Top of Chinle Formation placed at top of highest siltstone. Some units in top part of
Chinle Formation-Continued

Upper member-Continued

Chinle are lithologically similar to rocks in the basal part of the Glen Canyon Sandstone

24. Sandstone, grayish orange $(10 Y R 7 / 4)$, weathering same color, very fine to fine grained, well sorted; composed of subrounded clear (minor reddishstained) quartz, sparse feldspar, and black accessory ilmenite(?); poorly cemented, slightly calcareous; horizontally laminated and thin wedge-shaped planar sets of smallto medium-scale cross-laminae. Weathers to form a ledge

23. Silty claystone to siltstone, grayish red (10R $4 / 2$ and $5 R 4 / 2$ ), weathering same colors; firmly cemented, noncalcareous, clay binding; stratification concealed. Top $5 \mathrm{ft}$ of unit mostly covered. Unit contains sparse grayish-red (5R 4/2) silty sandstone in top half. This sandstone is poorly sorted with particles ranging in size from silt to medium sand and composed of clear quartz and sparse orange accessory mineral. Unit weathers to form rubble-covered slope

22. Sandstone, yellowish gray ( $5 Y 8 / 1)$, weathering same color, very fine grained, well sorted; composed of subrounded clear and milky quartz, sparse feldspar, and black and orange accessory minerals; firmly cemented, calcareous; horizontally thinly laminated and minor ripple laminae; weathers to form ledge ....

21. Siltstone, grayish red $(5 R \quad 4 / 2$ and $10 R 4 / 2$ ), weathering same colors; firmly to well cemented, noncalcareous; structureless; weathers to form slope. Poorly exposed in part

20. Sandstone, very pale orange (10YR $8 / 2$ ) and sparse light greenish gray (5GY 8/1), weathering grayish orange $(10 Y R 7 / 4)$, very fine grained, well sorted; composed of subrounded clear quartz, sparse feldspar and black accessory minerals; firmly cemented, calcareous; horizontally laminated to very thin bedded; weathers to form ledge

19. Mostly covered, poor exposures indicate unit to be mostly pale-reddishbrown $(10 R 5 / 4)$ and light-brown (5YR 6/4) very fine grained sandstone composed of subrounded clear quartz and rare black accessory mineral. Sandstone appears to be horizontaliy laminated. Unit weathers to form rubble-covered slope ....
16.2

Feet

11.4

17.8

20.6 
Chinle Formation-Continued

Upper member-Continued

18. Sandstone, grayish orange $(10 Y R$ $7 / 4$ ), weathering same color, fine to medium grained, fair sorted; composed of subrounded to rounded frosted quartz grains, common black accessory mineral, and sparse feldspar; poorly cemented, calcareous; horizontally laminated in lower $4 \mathrm{ft}$ and composed of thin to thick wedge-shaped planar sets of small- to medium-scale cross-laminae in upper part. Sparse "berries" of medium to coarse grains. Unit weathers to form ledge and, locally, a dip slope. This unit is lithologically similar to the Glen Canyon Sandstone

Section offset on top of unit 1\%. Overlying units measured at point about 1,500 ft $S .55^{\circ} \mathrm{E}$. of place where underlying units were measured. Unit 18 measured to northwest-facing promontory about 2,000 ft $N .85^{\circ} \mathrm{W}$. of bridge across Brush Creek on old Vernal-Manila road.

17. Sandstone, light brown $(5 Y R 6 / 4)$ and minor light greenish gray (5GY $8 / 1$ ), weathering same colors, very fine grained, well sorted; composed of subangular to subrounded clear quartz, sparse feldspar, and orange and black accessory minerals; firmly cemented, slightly calcareous; horizontally laminated, minor ripple laminae, horizontal laminae are slightly wavy with amplitude of about $1 / 8$ in.; weathers to form vertical cliff. Unit from 7.9 to $15.7 \mathrm{ft}$ above base contains about 80 percent grayish-red $(10 R$ 4/2) siltstone which occurs in very thin to thick horizontal beds interstratified with sandstone. All gradations from siltstone to sandstone are present in this part of unit. The siltstone weathers to form recess in cliff face

Total upper member

Ocher siltstone member :

16. Siltstone, grayish red $(5 R \quad 4 / 2)$ and sparse moderate yellowish brown (10YR 5/4), weathering same colors; firmly cemented, noncalcareous; structureless; weathers to form steep slope

15. Siltstone to clayey siltstone, dark yellowish orange $(10 Y R 6 / 6)$ to moderate yellowish brown $(10 Y R 5 / 4)$, weathering same colors; firmly cemented, slightly calcareous, clay binding; structureless. Lower $3 / 4$ of unit contains abundant limestone nodules as large as 5 in. in diameter, and upper $1 / 2$ of unit contains com-
Feet $\mid$ Chinle Formation-Continued

Ocher siltstone member-Continued

mon secondary gypsum veinlets. Unit weathers to form steep slope. Unit forms conspicuous yellowish unit in middle of lower part of the Chinle

14. Clayey siltstone to silty claystone, grayish red purple $(5 R P 4 / 2)$, pale red $(5 R 6 / 2)$ in upper $1 / 3$, common moderate yellowish brown (10YR $5 / 4)$ in top $1 / 4$ of unit and as mottling in rest of unit, contains minor amounts of rounded very fine grains in some parts (a few of these grains are reddish orange); poorly cemented, calcareous in parts, clay binding; structureless; weathers to form steep slope. Unit contains common limestone nodules averaging 1 in. in diameter. Unit contains one 2 -in. bed of very fine grained sandstone ..........

Total of ocher siltstone member..

Mottled member :

13. Sandstone, yellowish gray (5Y 8/1) and minor grayish purple (5P 4/2), weathering same colors, fine to medium grained with minor medium- to coarse-grained parts and sparse scattered very coarse grains, granules, and pebbles, poorly to fair sorted; composed of subangular quartz and feldspar grains; poorly cemented, slightly calcareous in places and clay binding in other places; stratification concealed; weathers to form gentle slope. Unit contains a 4 -ft bed of grayish-purple (5P 4/2) and moderate-yellowishbrown $(10 Y R \quad 5 / 4) \quad$ structureless argillaceous sandy siltstone to clayey sandstone in top half of unit

Total of mottled member

Gartra Member :

12. Sandstone (95 percent) to conglomerate (5 percent), very pale orange $(10 Y R 8 / 2)$, weathering same color. Sandstone, medium to very coarse grained, fair to poorly sorted; composed of subangular to angular milky quartz and feldspar and sparse accessory pink feldspar and black grains; sandstone grades to conglomerate and, in most places, is a continuous gradation from medium sand grains to pebble size. Conglomerate, granules to pebbles are composed of white and pink quartz with minor chert and possibly quartzite; poorly cemented, slightly calcareous in parts. Unit consists of thin to thick lenticular trough and
Feet 
Chinle Formation-Continued

Gartra Member-Continued

wedge-shaped planar sets of smallto medium-scale cross-laminae; weathers to form ledge. Base of unit is sharp and rests on pre-Chinle erosional surface; about 2,000 ft east of section line Gartra fills a channel cut $15 \mathrm{ft}$ into the Moenkopi Formation

Total of Gartra Member

Total of Chinle Formation

Unconformity.

Moenkopi Formation (incomplete) :

11. Siltstone, moderate brown (5YR $4 / 4$ and $5 Y R 3 / 4$ ) and minor light brown (5YR 6/4), weathering same colors; contains sparse very fine grained accessory white mica; firmly to well cemented, noncalcareous. Unit is bipartite: the lower part is horizontally laminated to very thick bedded, contains sparse cuspate ripple marks and a few trough sets of small-scale low-angle cross-laminae, and weathers to form a ledgy slope; whereas the upper part consists of structureless finer grained siltstone and weathers to form steep slope. Unit as a whole weathers to form ledgy interval at top of Moenkopi and is darker brown than the rest of the Moenkopi

Total of incomplete Moenkopi Formation

Base of section; not base of exposure.

Units 1-10 described in Stewart, Poole, and Wilson (1972).

\section{U-43. CHIMNEY ROCK}

Measured on west side of minor promontory within large reentrant in cliff face north of The Motorman, SE. cor. sec. 30, T. 28 S., R. 6 E., and NE. cor. sec. 6, T. 29 S., R. 6 E., SLM, Wayne County

[Measured by J. H. Stewart, September 1952]

Top of section; top of accessible exposure.

Wingate Sandstone:

11. Sandstone, pale reddish brown $(10 R$ $5 / 4)$, weathering same color, very fine grained, fair sorted; sparse black accessory minerals; poorly to firmly cemented, calcareous; thin to thick medium-scale planar and trough sets of low-angle cross-laminae; massive splitting; weathers to form vertical cliff. Bottom $3 \mathrm{ft}$ contains common well-rounded medium sand grains Unmeasured

Chinle Formation:

Owl Rock Member:

10. Siltstone and limestone. Siltstone, from
Feet | Chinle Formation-Continued

Feet

Owl Rock Member-Continued

base to $75.1 \mathrm{ft}$ above base is predominantly light olive gray $(5 Y 6 / 1)$ and greenish gray ( $5 G Y 6 / 1)$, minor pale red $(10 R 6 / 2)$, from $75.1 \mathrm{ft}$ to upper contact is predominantly pale reddish brown $(10 R 5 / 4)$, minor greenish gray (5GY 6/1), sparse grayish red purple (5RP 4/2) throughout unit, weathering greenish gray in lower part and pale reddish brown (10R $5 / 4$ ) in upper part, in places siltstone contains very fine to fine sand, in some places siltstone grades to argillaceous sandstone; firmly cemented, argillaceous and calcareous; stratification concealed; massive splitting; fractures into granule-sized angular fragments. Limestone, greenish gray ( $5 G$ $6 / 1$ ), weathering light greenish gray (5GY 8/1), lithographic, probably grades to limy siltstone; well cemented, calcareous; thin to thick horizontally bedded; slabby to blocky splitting. The unit forms a steep loose slope containing small ledges of limestone and siltstone. Siltstone from 0 to $18.4 \mathrm{ft}$ above base of unit, limestone with sparse interbeds of siltstone from 18.4 to $23.8 \mathrm{ft}$, siltstone from 23.8 to $27.4 \mathrm{ft}$, limestone from 27.4 to $28.6 \mathrm{ft}$, siltstone from 28.6 to $55.4 \mathrm{ft}$, limestone from 55.4 to $57.0 \mathrm{ft}$, siltstone from 57.0 to $114.6 \mathrm{ft}$, limestone from 114.6 to $121.2 \mathrm{ft}$, siltstone from 121.2 to $147.9 \mathrm{ft}$

Total of Owl Rock Member

Petrified Forest Member:

9. Silty claystone to silty sandstone, pale red $(10 R 6 / 2$ and $5 R 6 / 2)$, weathering same color, contains swelling clays in lower half, sand is very fine grained; composition masked; firmly cemented, calcareous; stratification concealed; weathers to form rubble-covered slope. Unit is poorly exposed, and parts are covered. Unit forms pinkish band above so-called Capitol Reef bed. Top of unit is approximate upper boundary of strata containing swelling clays. The exact upper contact of the Petrified Forest Member, however, is obscured by talus debris

8. Sandstone, predominantly light greenish gray $(5 G Y 8 / 1)$, pale yellowish orange $(10 Y R 8 / 6)$, and grayish orange pink $(10 R 8 / 2)$, weathering to grayish orange $(10 Y R 7 / 4)$, me- 
Chinle Formation-Continued

Petrified Forest Member-Continued

So-called Capitol Reef bed-Continued dium grained, fair sorted; composed of subangular clear quartz and uncommon orange and green accessory minerals; well cemented, calcareous; composed of thin to thick mediumscale trough sets of high-angle crosslaminae; platy to blocky splitting. A few thin sets of grayish-red-purple (5RP 4/2) fine-grained sandstone containing abundant claystone pellets occur in unit. A pale-red-purple (5RP $6 / 2$ ) and light-greenish-gray (5GY 8/1) sandstone occurs locally at base of unit. This sandstone is fine grained, poorly cemented with a calcareous cement, and consists of thin mediumscale trough sets of low-angle crosslaminae. The overlying well-cemented sandstone fills channels cut into this basal sandstone. Unit as whole is tabular and weathers to form prominent ledge

Total of so-called Capitol Reef bed

7. Limy siltstone, pale red purple (5RP $6 / 2)$ and minor greenish gray ( $5 G Y$ $6 / 1)$, weathering pale red purple (5RP 6/2) ; firmly cemented, calcareous; probably mostly very thick bedded but stratification poorly exposed; massive splitting; weathers to form vertical cliff below overlying unit. Unit contains thin beds of greenish-gray $(5 G Y 6 / 1)$ and light-brownish-gray $(5 Y R 6 / 1)$ lithographic well-cemented limestone. Abundant interbeds of limestone occur from base to $13 \mathrm{ft}$ above base of unit. Limestone beds are sparse elsewhere in unit ..............

6. Claystone in lower half, siltstone in upper half, grayish red (10R 4/2) from base to $18.0 \mathrm{ft}$ above base of unit, rest of unit pale reddish brown $(10 R 5 / 4)$, weathering to pale reddish brown $(10 R 5 / 4)$ in lower part and moderate reddish orange $(10 R$ 6/6) in upper part, firmly cemented, argillaceous and calcareous; stratification concealed; massive splitting; weathers to form steep frothy slope. Contains common white granulesized spherical spots. Lower $1 \mathrm{ft}$ is a micaceous siltstone. Lower half of unit contains swelling clays; upper half does not

5. Sandstone, predominantly grayish red purple (5RP 4/2), minor light. greenish gray ( $5 G Y 8 / 1)$, weathering pale red purple $(5 R P 6 / 2)$, fine to medium grained, fine grained in top $5 \mathrm{ft}$, fair

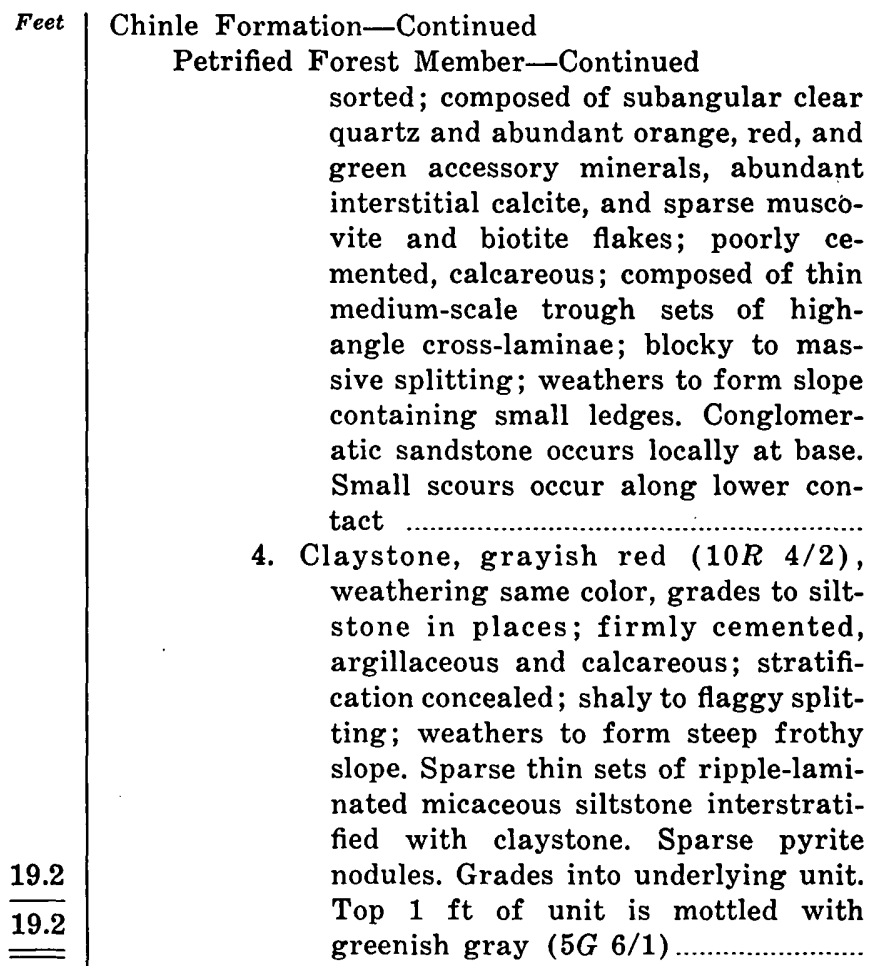

Total of Petrified Forest Member

Monitor Butte Member:

3. Claystone to clayey sandstone and sandstone. Claystone to clayey sandstone, predominantly greenish gray $(5 G Y$ $6 / 1)$, minor olive black (5Y 2/1), weathering to light greenish gray $(5 G Y 8 / 1)$, grades from claystone to clayey very fine to medium-grained sandstone; composed of subangular greenish-stained quartz and 2 to 3 percent orange and green minerals; firmly cemented; stratification concealed; shaly splitting. Sandstone, grayish orange $(10 Y R \quad 7 / 4)$, light olive gray (5Y 6/1), and brownish gray $(5 Y R 4 / 1)$, weathering to dark yellowish brown $(10 Y R 4 / 2)$, fine to very fine grained, fair sorted; composed of subangular clear quartz and common black accessory minerals; well cemented, calcareous and probably partly siliceous; composed of very thin to very thick sets of horizontal and current-ripple laminae and minor high-angle trough sets of crosslaminae; platy to blocky splitting. The sandstone occurs interbedded with the claystone and constitutes about 5 percent of the unit, and it is distributed irregularly throughout the unit. The sandstone commonly occurs in highly contorted sets which strike and dip in almost any conceivable attitude. The claystone is very
35.2
Feet 
Chinle Formation-Continued

Monitor Butte Member-Continued

sandy and commonly grades to a very fine to fine-grained sandstone. Fossil trees as much as $3 \mathrm{ft}$ in diameter are found rarely in unit. A prominent sandstone which is persistent locally and not contorted is found from 61.7 to $70.7 \mathrm{ft}$ above the base of the unit. This prominent sandstone is in part coarse grained and contains welldeveloped small- to medium-scale trough sets of cross-laminae. Carbonaceous material is common in the claystone intervals

Total of Monitor Butte Member....

Shinarump Member:

2. Sandstone, grayish orange $(10 Y R 7 / 4)$ and very pale orange $(10 Y R 8 / 2)$, weathering same colors, medium to coarse grained, fair to well sorted; composed of subangular clear quartz and sparse black accessory minerals; poorly cemented, calcareous; composed of very thin to thin trough sets of high-angle crossbeds and crosslaminae; platy to blocky splitting; weathers to form vertical cliff. Directly west of section a higher lens of the Shinarump is present. This lens increases the total thickness of the Shinarump by $23.2 \mathrm{ft}$. Locally green claystone partings are present in the sandstone of the unit

Total of Shinarump Member.

Total of Chinle Formation.

Moenkopi Formation:

1. Siltstone, pale reddish brown $(10 R 5 / 4)$ and grayish red $(10 R 4 / 2)$, weathering same colors; firmly cemented, argillaceous; composed of horizontal and current ripple laminae; shaly splitting; weathers to form hummocky surface. Limy siltstone bed is present from 9.1 to $10.2 \mathrm{ft}$ below Shinarump Member. Top few feet of unit altered to pale yellowish orange $(10 Y R$ 8/6)

Unmeasured

Base of section; not base of exposure.

\section{U-44. MILLARD CANYON}

Measured on west side of Millard Canyon, starting at westernmost exposure of Moss Back Member in major reentrant and continuing up cliffs to north. Major reentrant is 2.8 miles S. $84^{\circ} \mathrm{W}$. of Cleopatras Chair and 2.2 miles northeast of last exposure of Moss Back sandstone up Millard Canyon, long $110^{\circ} 07^{\prime} 45^{\prime \prime} W$., lat $38^{\circ} 18^{\prime} 00^{\prime \prime} N$., Wayne County

[Measured by J. H. Stewart and O. B. Raup, October 1953]

Top of section; top of accessible exposure.

Wingate Sandstone:

19. Sandstone, light brown (5YR 6/4), weathering same color, very fine

Feet
$\frac{145.4}{145.4}$
Chinle Formation:

Wingate Sandstone-Continued
grained, well sorted; composed of subrounded amber quartz and common black accessory mineral; poorly cemented, calcareous; composed of very thin to thick planar sets of small- to medium-scale cross-laminae; massive splitting; weathers to form vertical cliff. Sandstone contains about 5 percent medium to coarse grains of rounded milky and amber quartz. Basal few inches of unit is yellowish gray $(5 Y 8 / 1)$ Unmeasured

Church Rock Member:

Hite Bed:

18. Sandstone, pale red $(5 R 6 / 2)$, weathering pale reddish brown $(10 R 5 / 4)$; very fine grained, well sorted; composition masked; firmly cemented, calcareous; composed of thin trough sets of medium-scale low-angle crosslaminae; weathers to form vertical cliff continuous with that of Wingate Sandstone. Along line of section, middle $1 / 3$ of unit is composed of sandstone containing about 20 percent very coarse grains to pebbles of siltstone. This conglomeratic sandstone pinches out about $50 \mathrm{ft}$ west of line of section and is covered east of line of section

17. Siltstone, grayish red $(10 R 4 / 2)$ and pale reddish brown $(10 R 5 / 4)$, weathering same color; sparse very fine grains of accessory white mica ; firmly cemented, noncalcareous; stratification concealed; weathers to form steep slope. Basal $5 \mathrm{ft}$ of unit contains about 50 percent sandstone similar to that in underlying unit. This sandstone occurs in thin sets interstratified with the siltstone. The upper $1 / 2$ of the unit contains about 10 percent ripple-laminated well-cemented sandy siltstone sets interstratified with the siltstone. These sandy siltstone sets form small ledges. The upper $1 / 2$ of the unit is very poorly exposed

16. Sandstone, light greenish gray (5GY $8 / 1)$ and pale reddish brown $(10 R$ $5 / 4$ ), weathering pale reddish brown $(10 R 5 / 4)$, very fine grained, well sorted; firmly cemented, slightly calcareous; composed of thin trough sets of medium-scale low-angle cross-laminae; weathers to form ledge which is most conspicuous ledge near the top of the Chinle Formation. Basal contact sharp

Total of Hite Bed
11.4

Feet

29.2 
Chinle Formation-Continued

Church Rock Member-Continued

15. Siltstone to sandy siltstone, grayish red $(10 R 4 / 2)$, pale reddish brown ( $10 R$ $5 / 4)$, and light brown (5YR 6/4), weathering same color, sandy (very fine grained); firmly cemented noncalcareous to slightly calcareous; dominantly structureless but contains sparse very thin to thick parallel beds; fractures into angular fragments; weathers to form steep slope. Units 12 to 14, although reddish brown in color, weather with a slight pale-red tint

14. Silty limestone to limy siltstone, pale red $(5 R 6 / 2$ and $10 R 6 / 2)$, sparse pale reddish brown $(10 R 5 / 4)$, weathering same colors; firmly to well cemented, structureless except for faint suggestion of a few horizontal bedding planes; weathers to form conspicuous ledge. This unit is not present in exposures to east and west of line of section

13. Siltstone, grayish red $(10 R 4 / 2)$ to pale reddish brown $(10 R 5 / 4)$, weathering pale reddish brown $(10 R 5 / 4)$; firmly cemented, calcareous; structureless; weathers to form steep slope. Unit contains common very thin to thin sets of pale-red $(10 R 6 / 2)$ ripplelaminated sandy siltstone in middle $10 \mathrm{ft}$ of unit. A thin horizontal bed of light-greenish-gray $(5 G Y \quad 8 / 1)$ siltstone containing about 40 percent indistinct medium to very coarse grains of limestone occurs from 9.8 to $10.1 \mathrm{ft}$ above base of unit

12. Siltstone (70 percent) and silty sandstone (30 percent). Siltstone, pale reddish brown (10R 5/4), weathering same color; firmly cemented, noncalcareous; stratification concealed. Silty sandstone, pale red $(5 R 6 / 2$ and $10 R$ $6 / 2$ ), weathering pale reddish brown $(10 R 5 / 4)$, very fine grained; abundant medium-grained accessory white and dark mica; firmly cemented, calcareous; ripple laminated. Silty sandstone is present as thin to thick sets interstratified with siltstone. To west of line of section silty sandstone sets disappear. The silty sandstone sets are more numerous near the base of the unit. Unit as whole weathers to form slope. Top $0.5 \mathrm{ft}$ of unit is lightgreenish-gray (5GY 8/1) sandy siltstone

So-called Black Ledge:

11. Sandstone, pale red $(10 R 6 / 2)$, weathering same color, very fine grained, well sorted; composed of subangular
Church Rock Member-Continued

So-called Black Ledge-Continued milky mineral, accessory minerals masked; poorly cemented, calcareous; composed of thin planar to trough sets of medium-scale low-angle cross-laminae. Unit weathers with underlying unit to form the most conspicuous ledge in upper part of Chinle Formation. Unit contains uncommon medium-grained white mica

10. Limy sandstone (types 1 and 2). Type 1 , light greenish gray (5GY 8/1), weathering light brownish gray ( $5 Y R$ $6 / 1$ ), very fine to fine grained, sand grains tightly cemented by interstitial calcite; composition masked; composed of thin trough to planar sets of low-angle medium-scale crosslaminae. Type 2, light greenish gray $(5 G Y 8 / 1)$, weathering moderate olive brown ( $5 Y 4 / 4)$, composed of round medium to very coarse limestone grains well cemented by calcite matrix; composed of thin trough sets of medium-scale very thin crossbeds. Type 2 sandstone grades to conglomeratic sandstone containing rounded limestone granules to pebbles. Amounts of types 1 and 2 sandstone are highly variable along the outcrop. Unit intertongues with overlying unit. Unit as whole weathers to form vertical cliff

Total of so-called Black Ledge......

Total of Church Rock Member......

Owl Rock Member:

9. Limestone (70 percent) and siltstone (30 percent). Limestone, medium light gray $(N 6)$ and pale purple $(5 P 6 / 2)$ with common light greenish gray ( $5 G Y 8 / 1)$, weathering same colors; dense; well cemented. Limestone is present as thin to thick horizontal beds interstatified with siltstone. Siltstone, same colors as limestone, firmly cemented, calcareous; appears structureless. Unit as whole weathers to form steep slope in lower part and vertical cliff in upper part.

8. Silty claystone to claystone, grayish purple $(5 P 4 / 2)$ and light greenish gray $(5 G Y 8 / 1)$, pale reddish brown $(10 R 5 / 4)$ from 5.6 to $21.6 \mathrm{ft}$, weathing same colors; firmly cemented, slightly calcareous; structureless; weathers to form steep slope. Unit contains limestone, similar to that in unit 6, from 4.7 to $5.6 \mathrm{ft}$ above base. Lower $5 \mathrm{ft}$ of unit contains clays
Feet 
Chinle Formation-Continued

Owl Rock Member-Continued

that swell in water. Purplish parts of unit contain nodules of limestone..

7. Limestone, light greenish gray (5GY $8 / 1$ ), weathering same color; dense, well cemented; tabular horizontal bed with faint suggestion of horizontal laminae in basal $0.5 \mathrm{ft}$; weathers to form ledge. Basal $0.5 \mathrm{ft}$ of unit contains about 10 percent amber and gray chert masses from $1 / 8$ in. to several inches in diameter

6. Siltstone to clayey siltstone and limestone. Siltstone to clayey siltstone, pale reddish brown $(10 R 5 / 4)$ in basal $8.4 \mathrm{ft}$, pale red purple (5RP $6 / 2$ ) in rest of unit, weathering same colors; firmly cemented, slightly calcareous; structureless, some horizontal stratification planes. Limestone, light greenish gray ( $5 G Y 8 / 1)$, weathering same color; dense; well indurated. Limestone occurs as thin horizontal beds from 0.0 to $0.5 \mathrm{ft}$ and 8.4 to $9.9 \mathrm{ft}$ above base of unit and as limestone nodules in rest of unit. Unit as whole weathers to form slope

Total of Owl Rock Member

Petrified Forest Member:

5. Clayey siltstone, pale red (5R 6/2) and grayish red $(5 R \quad 4 / 2)$, weathering same colors; contains swelling clays; firmly cemented, slightly calcareous; structureless; weathers to form slope. Contains some limestone nodules

4. Clayey sandstone, pale purple $(5 P 6 / 2)$ and light greenish gray (5GY 8/1), weathering same color, fine grained; composed of subangular milky mineral and abundant orange and green accessory minerals, about 2 percent medium to very coarse grained dark mica; firmly cemented, slightly calcareous; stratification poorly exposed, at least in part composed of thin sets of small-scale cross-laminae; weathers to form slope

3. Siltstone (70 percent) and sandstone (30 percent). Siltstone, greenish gray (5GY 6/1), weathering light greenish gray ( $5 G Y 8 / 1)$; uncommon mediumgrained accessory white mica; firmly cemented, calcareous; stratification concealed. Sandstone, light greenish gray $(5 G Y 8 / 1)$ and yellowish gray (5Y 8/1), weathering dark yellowish brown $(10 Y R 4 / 2)$, fine to medium grained, fair sorted; composed of subangular milky mineral and sparse orange accessory mineral; firmly ceFeet \begin{tabular}{r|} 
Chinle Formation-Continued \\
Petrified Forest Member-Continued \\
mented, calcareous; composed of very \\
thin to thin trough sets of cross- \\
laminae. Sandstone commonly grades \\
to conglomeratic sandstone which \\
contains rounded coarse grains to peb- \\
bles of limestone. Sandstone is pres- \\
ent as thick cosets interstratified with \\
rest of unit. Unit appears to be highly \\
variable in thickness. Sandstone lay- \\
ers may be tongues of the underlying \\
Moss Back Member. Unit weathers to \\
form bench containing small ledges. \\
Unit contains common petrified tree \\
logs. Siltstone commonly grades to \\
fine-grained silty sandstone ..............
\end{tabular}

Moss Back Member:

2. Sandstone (85 percent) and conglomeratic sandstone (15 percent). Sandstone, yellowish gray $(5 Y 8 / 1)$ and uncommon light greenish gray ( $5 G Y$ $8 / 1)$, weathering very pale orange $(10 Y R 8 / 2)$, fine to medium grained, fair sorted; composed of subangular to subrounded clear quartz and common gray accessory mineral, sparse coarse-grained accessory white mica; poorly cemented, calcareous; composed of thin to thick trough to planar sets of medium- and sparse large-scale cross-laminae; dominantly massive splitting. Conglomeratic sandstone, light greenish gray (5GY 8/1) and minor yellowish gray (5Y 8/1), weathering dominantly moderate yellowish brown (10YR 5/4); composed of granules and pebbles in fine- to medium-grained sand or limy silt matrix, grades to fine- to mediumgrained sandstone with abundant lime matrix, common scattered coarse to very coarse grains. Granules to pebbles composed of subrounded to rounded quartzite, and to a lesser extent of chert and quartz. Conglomeratic sandstone is poorly to firmly cemented and calcareous and occurs as thin to very thick lenses. Conglomeratic sandstone is interstratified with sandstone and is dominantly in lower $15 \mathrm{ft}$ of unit. About 5 percent of unit consists of thin lenses of greenish-gray (5GY 6/1) clayey siltstone. Unit as whole tabular and weathers to form vertical cliff. Unit contains common petrified tree logs in basal $10 \mathrm{ft}$.

Total of Moss Back Member 
Moenkopi Formation:

1. Siltstone, grayish red $(10 R 4 / 2)$ to pale reddish brown $(10 R 5 / 4)$, weathering same colors; uncommon to abundant very fine grained accessory white mica; firmly cemented, slightly calcareous; stratification poorly developed but partly structureless and partly horizontally laminated; weathers to form steep rubble-covered slope. Top $2 \mathrm{ft}$ of unit is altered to light greenish gray $(5 G 8 / 1)$ and grayish yellow $(5 Y 8 / 4)$................Unmeasured

Base of section; base of exposure.

\section{U-45. LEEDS}

Measured about half a mile northeast of Virgin River $21 / 2$ miles south-southeast of Leeds, Utah, and $31 / 2$ miles westnorthwest of Hurricane, Utah, in southeast flank of the Harrisburg dome of Virgin anticline, long $113^{\circ} 21^{\prime} \mathrm{W}$., lat $37^{\circ} 12^{\prime}$ N., Washington County

[Measured by J. H. Stewart and R. F. Wilson, October 1955]

Top of section; not top of exposure. Top of section is $\mathrm{N} .16^{\circ} \mathrm{W}$. about 3 miles from extinct volcano, S. $70^{\circ} \mathrm{E}$. of base of section, and about $1,500 \mathrm{ft}$ northeast of the Virgin River.

Navajo Sandstone:

33. Sandstone, moderate orange pink (5YR $8 / 4)$, minor white $(N 9)$, weathering same colors and very pale orange $(10 Y R 8 / 2)$, fine grained, scattered medium grains, well sorted; composed of well-rounded to rounded reddishstained and frosted clear quartz, sparse dark and orange accessory minerals, poorly cemented, slightly calcareous; composed of thick wedgeshaped planar sets of predominantly high-angle medium- to large-scale cross-laminae; weathers to form highest 10 to $20 \mathrm{ft}$ of hogback and back slope of hogback. Base of unit is sharp and slightly irregular. Only basal $40 \mathrm{ft}$ of unit examined. Top of Kayenta Formation placed at base of unit because underlying unit contains highest silty fluvial red beds in section and because unit contains lowest occurrence of large-scale high-angle planar cross-stratification. The overlying many hundreds of feet of the Navajo Sandstone do not contain any Kayenta Formation: reddish units like unit 32 Unmeasured

32. Silty sandstone to sandy siltstone, pale reddish brown $(10 R 5 / 4)$, weathering same color, grades from sandy coarse siltstone to silty very fine sandstone, well sorted, composed of reddish-stained and clear quartz with common dark accessory minerals; firmly cemented, calcareous; horizontally laminated to thin bedded; weathers to form irregular rounded cliff....
31. Sandstone, moderate reddish orange $(10 R 6 / 6)$, minor white (N9), weathering same colors, very fine to fine grained, contains as much as 5 percent medium grains in places, well sorted; composed of well-rounded to subrounded clear, frosted, and reddish-stained quartz and abundant to common dark accessory minerals; poorly cemented, calcareous in parts; composed of thin to thick wedgeplanar sets of medium-scale predominantly high-angle cross-laminae; weathers to form vertical cliff. Medium sand grains occur as in sandstone of unit 28 . Unit contains abundant limy sand concretions..........

30. Sandy siltstone and sandstone. Sardy siltstone, like siltstone in unit 28 except contains minor amounts of very fine grained sand and grades to very fine grained sandstone. Sandstone, light brown (5YR 6/4) and moderate reddish orange $(10 R 6 / 6)$, weathering light brown $(5 Y R 6 / 4)$, very fine grained, contains as much as 15 to 20 percent fine to coarse grains; fair to well sorted; composed of wellrounded to subrounded reddishstained, frosted, milky, and clear quartz and abundant accessory dark and light minerals; poorly to firmly cemented, slightly calcareous; horizontally laminated to very thick bedded, common planar sets of small- to medium-scale low-angle cross-laminae. Unit as whole weathers to form irregular to vertical cliff. Sandstone is present from 0 to $14.7 \mathrm{ft}$ and from 23.5 to $29.4 \mathrm{ft}$ above base of unit. Medium to coarse sand grains occur in a manner similar to that in the sandstone of unit 28 .

29. Siltstone (60 percent) and sandstone (40 percent). Siltstone, similar to that in unit 28. Sandstone, light brown $(10 Y R 6 / 4)$ to pale reddish brown $(10 R 3 / 4)$, weathering light brown $(10 Y R 6 / 4)$, very fine grained, well sorted; composed of rounded to subrounded clear and milky quartz and common dark accessory mineral; poorly to firmly cemented, calcareous; horizontally laminated to very thin bedded. Unit as whole weathers to form ledgy slope.

28. Siltstone and sandstone. Siltstone, pale reddish brown $(10 R 5 / 4)$, mottled to light greenish gray $(5 G Y 8 / 1)$, weathering same colors, coarse silt, sandy (very fine grained) in part; firmly cemented, calcareous; prob-
Feet

18.1

75.2 
Kayenta Formation-Continued ably wavy laminated to thin bedded. Sandstone, light brown (5YR 6/4) to moderate reddish orange $(10 R 6 / 6)$, minor white $(N 9)$, weathering moderate reddish orange $(10 R 6 / 6)$, fine to very fine grained, contains 5 percent medium to coarse grains, well sorted; composed of rounded to subrounded clear, frosted, and reddishstained quartz and minor dark accessory mineral; poorly to firmly cemented, calcareous in part. Unit as whole weathers to form vertical cliff. Sandstone occurs from 19.0 to $29.4 \mathrm{ft}$ and 36.3 to $63.8 \mathrm{ft}$ above base of unit. Lower sandstone unit is horizontally laminated to very thin bedded for the most part. Upper sandstone unit is composed of thin to thick planar sets of small- to mediumscale high- and low-angle cross-laminae which in places are separated by thin sets of horizontal laminae. Medium to coarse sand grains occur disseminated throughout the sandstone and are concentrated along the stratification planes and near the bases of the sandstone units.

27. Siltstone, pale reddish brown $(10 R 5 / 4)$ and light brown (5YR 6/4), weathering pale reddish brown (10R 5/4), medium to coarse silt, sandy (very fine grained) in parts, grades to very fine grained sandstone in places; firmly to well cemented, calcareous; horizontally thinly laminated to thin bedded, minor ripple laminations; weathers to form slope

26. Sandstone, pale reddish brown (10R $5 / 4)$ and moderate orange pink (10R $7 / 4)$, mottled to pinkish gray (5YR $8 / 1$ ) in places, weathering moderate reddish orange $(10 R 6 / 6)$, very fine to fine grained, silty in part, well sorted; composed of round to subrounded reddish-stained and frosted quartz and common dark-colored and orange accessory minerals; firmly to well cemented, calcareous; apparently horizontally laminated to thick bedded; weathers to form ledge at base of cliff topped by the Navajo Sandstone

25. Sandstone (65 percent) and siltstone (35 percent). Sandstone, pale reddish brown $(10 R 5 / 4)$ and light brown $(5 Y R 6 / 4)$ to moderate reddish orange $(10 R 6 / 6)$, weathering pale reddish brown $(10 R 5 / 4)$, very fine grained, silty, well sorted; composed of subangular to subrounded reddish-stained quartz with common black accessory minerals; poorly to firmly cemented,
Feet

Kayenta Formation-Continued

calcareous; horizontally thin to thick bedded in part, in part composed of thin to thick planar and trough sets of small- to medium-scale cross-laminae. Siltstone, light brown (5YR 6/4), mottled to light greenish gray ( $5 G Y$ $8 / 1$ ), medium to coarse silt, sandy (very fine grained) in part; firmly to well cemented, calcareous; horizontally stratified. Unit as a whole weathers to form slope. A lens of ledge-forming cross-stratified sandstone occurs from 43.3 to $53.9 \mathrm{ft}$ above base of unit. Lateral to line of section, this sandstone unit apparently pinches out.

24. Sandstone, moderate reddish orange $(10 R 6 / 6)$ and light brown (5YR $6 / 4$ ), weathering light brown (5YR $6 / 4)$, fine grained, with 2 to 5 percent medium to coarse grains, well sorted; composed of subrounded to rounded clear and frosted(?) quartz and minor accessory dark minerals; poorly to firmly cemented, calcareous; top 2 $\mathrm{ft}$ of unit horizontally is very thin to thin bedded, rest of unit is composed of thin to thick wedge-planar sets of low-angle small- to medium-scale cross-laminae; weathers to form ledge

23. Siltstone to sandy siltstone (60 percent), sandstone (25 percent) and silty claystone (15 percent), similar to unit 21. Sandstone is predominantly in upper third of unit and consists of several very thick sets of horizontal laminae and to a lesser extent of small-scale trough cross-laminae. Two thick beds of light-brown (5YR 6/4) to moderate-reddishorange $(10 R 6 / 6)$ fine to very fine grained sandstone, unlike sandstone in unit 21 , occurs in upper third of unit. Unit measured between two lava-capped mesas..........................

22. Sandstone, pale red $(10 R 6 / 2)$ and $(5 R$ $6 / 2)$, minor light-greenish-gray ( $5 G Y$ 8/1) mottling, weathering pale red $(5 R 6 / 2)$, fine to very fine grained, well sorted; composed of subrounded clear to reddish-stained quartz, common accessory dark and white mica and dark minerals; poorly cemented, calcareous; composed of thin to thick trough and planar sets of small- to medium-scale low-angle cross-laminae, minor cuspate ripple laminations in upper part of unit; weathers to form irregular cliff. Unit contains a few lenses of clay pellet conglomerate near base. Lithologically unit resembles the Springdale Sandstone Member of the Moenave Formation.
72.4

Feet

14.7

269.5 
Kayenta Formation-Continued

21. Siltstone to sandy siltstone (80 percent), sandstone (10 percent), and silty claystone (10 percent). Siltstone to sandy siltstone, pale reddish brown $(10 R 5 / 4)$, grayish red $(10 R 4 / 2)$, and light brown (5YR 6/4), minor mottling to light greenish gray ( $5 G Y$ $8 / 1$ ), weathering same colors, fine to coarse silt, grades to very fine grained silty sandstone in places; common accessory dark and white mica; firmly cemented, calcareous; horizontally thinly laminated to very thick bedded, commonly ripple laminated, sparse cross-stratified parts. Sandstone, pale red $(10 R 6 / 2)$ and light brown $(5 Y R 6 / 4)$, weathering light brown $(5 Y R 6 / 4)$, very fine grained, silty in part, well sorted; composed of subangular to subrounded clear, pinkish, and milky quartz and common accessory white mica and dark minerals; poorly to firmly cemented, calcareous; horizontally laminated to thin trough and planar sets of small- to medium-scale low-angle cross-laminae. Silty claystone, grayish red $(10 R \quad 4 / 2)$ and light greenish gray $(5 G 8 / 1)$, weathering pale red $(5 R 6 / 2)$; firmly cemented, calcareous; stratification concealed. Unit as whole weathers to form partially covered slope. Sandstone occurs predominantly as very thin to thick sets interstratified with sandy siltstone to siltstone in basal third of unit. One prominent sandstone occurs from 7.3 to $17.8 \mathrm{ft}$ above base of unit. Much of sequence is coarse siltstone containing varying percentages of very fine sand. One thin set of siltstone, containing limy nodules, is present in middle part of unit

Total of Kayenta Formation.

Moenave Formation:

Springdale Sandstone Member:

20. Sandstone, pale red (5R 6/2 and $10 R$ $6 / 2$ ) and pale reddish brown, weathering light brown (5YR 6/4), very fine to fine grained, fair sorted; composed of subangular clear and milky quartz and 2 percent black mineral; poorly cemented, calcareous; composed of thin to thick trough sets of medium- to large-scale low-angle cross-laminae; weathers to form ledge on dip slope of hogback developed on Springdale Sandstone Member..

19. Sandstone (40 percent) and silty claystone to siltstone (60 percent). Silty
Moenave Formation-Continued

Springdale Sandstone Member-Continued claystone to siltstone, light greenish gray $(5 G Y 6 / 1)$ and dark greenish gray $(5 G Y 4 / 1)$, sparse pale red (10R 6/2), weathering mostly pale reddish brown $(10 R 5 / 4)$; firmly cemented, noncalcareous; stratification concealed. Sandstone, light greenish gray $(5 G Y 8 / 1)$ and pale red $(10 R$ $6 / 2)$, weathering light brown (5R $6 / 4)$ and yellowish gray $(5 Y 8 / 1)$, very fine grained, fair sorted; composed of subangular clear and milky quartz and abundant black accessory minerals; poorly cemented, calcareous; horizontally laminated to thin bedded. Unit as whole weathers to form slope between cliff-forming parts of the Springdale Sandstone Member. Sandstone present as thin to thick sets interstratified with rest of unit

18. Sandstone, pale red $(5 R 6 / 2)$ and sparse pale red $(10 R 6 / 2)$, weathering same colors and light brown (5YR 6/4), fine grained, well sorted; composed of subangular to subrounded clear, pinkish, and milky quartz with common accessory white and dark mica and 3 to 5 percent black minerals; poorly cemented, calcareous; horizontally laminated to thin bedded with about 30 percent thin to thick planar and trough sets of small- to medium-scale low-angle cross-laminae (some horizontal laminae are probably trough sets of largescale very low angle cross-laminae); weathers to form vertical cliff and main part of hogback developed on the Moenave Formation. Unit contains common plant impressions. Unit contains a few lenses of mudstone pellet conglomerate. Unit from 1 to $4 \mathrm{ft}$ above base is light-greenish-gray $(5 G 8 / 1)$ claystone. Base of unit is marked by $1 \mathrm{ft}$ of clay pellet conglomerate

Total of Springdale Sandstone Member

Whitmore Point Member:

17. Siltstone to clayey siltstone (90 percent) and sandy siltstone $(10$ percent). Siltstone to clayey siltstone, dark greenish gray (5G 4/1), greenish gray ( $5 G 6 / 1$ ), and grayish red $(10 R 4 / 2$ and $5 R 4 / 2)$, weathering light greenish gray (5GY 8/1) and minor pale red $(10 R 6 / 2)$, fine silt, common clay in part; firmly cemented, calcareous; stratification concealed. Sandy siltstone, light greenish
Feet

14.1 
Moenave Formation-Continued

Whitmore Point Member-Continued

gray $(5 G Y 8 / 1)$ and sparse pale red $(10 R 6 / 2)$, weathering same colors, composed of coarse silt with minor very fine grained sand (may grade to very fine grained sandstone in places); firmly cemented, calcareous; horizontally very thin bedded. Unit as whole weathers to form steep slope. Sandy siltstone is present as thin sets interstratified with fine siltstone; it weathers to form small ledges. About 500 $\mathrm{ft}$ north of section, unit contains 20 -ft-thick lens, $200 \mathrm{ft}$ in length, of sandstone resembling that of the Springdale. Line of section passes through southwest corner of Duffin No. 1 claim

16. Siltstone, pale red $(10 R 6 / 2)$ to grayish red $(10 R 4 / 2)$, weathering same colors, fine to coarse silt; firmly to well cemented, calcareous; stratification mostly concealed, where exposed is horizontally thin to very thin bedded; weathers to form steep earthy slope. Coarse siltstone constitutes about 10 percent of unit.

Total of Whitmore Point Member..

Dinosaur Canyon Member:

15. Siltstone to sandy siltstone, light brown (5YR 6/4) and pale reddish brown $(10 R 5 / 4)$, weathering light brown $(5 Y R 6 / 4)$, fine to coarse silt, may grade to silty very fine grained sandstone in a few places; common very fine grained accessory white mica; firmly cemented, calcareous; horizontally laminated to thin bedded and about 25 percent thin planar and possible trough sets of medium-scale low-angle cross-strata; weathers to form ledgy sequence in middle of escarpment topped by Springdale Sandstone Member. One thick bed of greenish-gray (5GY 6/1) siltstone occurs in middle of unit. Coarse siltstone consitutes about 75 percent of unit. A few horizons of cuspate ripples.

14. Siltstone, grayish red $(10 R 4 / 2)$ to pale reddish brown $(10 R 5 / 4)$, minor light brown $(5 Y R 6 / 4)$, and sparse yellowish gray $(5 Y 8 / 1)$, weathering pale reddish brown (10R 5/4), grades from clayey fine siltstone to coarse siltstone; firmly cemented, calcareous; stratification concealed in many places, where exposed siltstone is horizontally thinly laminated to thin bedded, some ripple-laminated parts; weathers to form steep slope. Coarser siltstone layers are mostly light
Feet Moenave Formation-Continued Feet Dinosaur Canyon Member-Continued brown $(5 Y R 6 / 4)$ and weather to form ledges. Ripples are of both the parallel and the cuspate types and occur in about 5 percent of the unit. Coarse siltstone ledges constitute about 12 percent of the unit

139.2

13. Conglomeratic sandstone to sandy conglomerate, and siltstone. Conglomeratic sandstone to sandy conglomerate, light greenish gray (5GY 8/1), and minor pale reddish brown (10R $5 / 4)$, weathering light greenish gray, medium grains to granules (sparse pebbles) of subrounded to rounded gray chert, milky quartz, or limestone; 10 percent interstitial clay; poorly sorted; poorly to well cemented, calcareous; horizontally very thin bedded. Pebbles are entirely chert or limestone. Siltstone, grayish red $(10 R 4 / 2)$, minor light-greenishgray (5Y 8/1) mottling, weathering pale reddish brown $(10 R 5 / 4)$, common very fine grained sand; poorly cemented, calcareous; stratification mostly concealed, but some horizontal laminae. Unit weathers to form slope. Conglomeratic sandstone to sandy conglomerate occurs as thin sets at top and bottom of unit. Siltstone contains scattered granules and pebbles of limestone or chert

Chinle Formation:

Total of Dinosaur Canyon Member

Total of Moenave Formation.

$\overline{356.2}$

Petrified Forest Member:

Upper unit:

12. Claystone, grayish red $(5 R 4 / 2)$, grayish red purple $(5 R P 4 / 2)$, and greenish gray ( $5 G Y 6 / 1)$, weathering pale red purple (5RP 6/2) and light greenish gray ( $5 G Y 8 / 1)$; bentonitic; firmly to well indurated, noncalcareous; stratification concealed, some horizontal stratification planes; weathers to form frothy surfaced hills. Claystone is silty in parts and contains several horizons of limestone nodules. Unit contains several feet of grayish red purple (5RP 4/2) clayey sandstone in basal $10 \mathrm{ft}$

Total of upper unit

Note. - Units 9-11 are closely associated and intertongue. They form the hogback in the middle of the Chinle Formation whereas the rest of the formation forms gentle slopes. The measured thickness of these units is probably close to a maximum for the local area; elsewhere they are from 20 to $30 \mathrm{ft}$ thick. Unit 9 
Chinle Formation-Continued

Petrified Forest Member-Continued may intertongue with the underlying unit and is present only locally along the exposure. Units 9-11 may correlate with a sandstone unit in the middle of the Petrified Forest Member near Kanarraville and with a sandstone unit in the middle of the Petrified Forest Member near Rockville. The Leeds section is similar to that near Kanarraville. In both sections the Petrified Forest Member is about $400 \mathrm{ft}$ thick and consists of bentonitic rocks containing a conspicuous sequence of sandstone in the middle. The claystone below the sandstone sequence in both sections is greenish with minor reddish and purplish colors and does not contain limestone nodules. The claystone above the sandstone sequence in both sections is mostly purplish and contains many limestone nodules. The sandstone sequence is characterized in both sections by abundant conglomerate containing granules and pebbles of chert and, to a lesser extent, of quartzite.

Middle sandstone sequence:

11. Sandstone, grayish red $(10 R 4 / 2)$, pale red purple $(5 R P 6 / 2)$, minor light greenish gray $(5 G Y 8 / 1)$, thin very pale orange $(10 Y R 8 / 2)$ color band at top, weathering same colors, medium grained, poorly sorted; composed of angular clear and milky quartz, 5 percent orange grains and 1 to 2 percent dark-green mica; poorly cemented, noncalcareous; composed of thin planar sets of small- to mediumscale low-angle cross-laminae; weathers to form slope at base of hogback developed on underlying unit. Unit contains common granules and pebbles of yellowish, brown, and gray chert....

10. Sandstone to conglomerate, yellowish gray $(5 Y 8 / 1)$ and light greenish gray ( $5 G Y 8 / 1)$, weathering very pale orange $(10 Y R \quad 8 / 2)$, coarse grained, some interstitial clay, poorly sorted; composed of angular to subangular clear and milky quartz and 5 percent pink or orange grains; poorly cemented, calcareous; composed of thin to thick trough and planar sets of medium-scale lowangle cross-laminae; weathers to form ledge. Granules and pebbles constitute from 5 to 20 percent of the sandstone in most places and constitute from 20 to 50 percent of the sandstone locally. Granules and pebbles are composed of gray, white, and yellowish chert and of gray and pink quartzite. Granules and pebbles average about $3 / 4$ in. in diameter but are as much
Feet

Chinle Formation-Continued

Petrified Forest Member-Continued

Middle sandstone sequence-Continued as 2 in. in diameter. Common impressions of tree logs and stems. Unit forms main part of hogback in middle of Chinle Formation

9. Sandstone, yellowish gray $(5 Y 8 / 1)$ in basal $3 \mathrm{ft}$ and light olive gray (5Y $6 / 1$ ) in rest of unit, weathering same colors, fine to coarse grained, poorly sorted; composed of subangular to angular milky quartz, 5 percent orange mineral, and 1 or 2 percent dark-green mica; poorly to firmly cemented, calcareous in parts; composed of thin to thick trough and planar sets of low-angle small- to mediumscale cross-laminae in basal $3 \mathrm{ft}$, structureless high in unit; weathers to form ledge. Basal $3 \mathrm{ft}$ of unit contains a few scattered granules to pebbles of reddish, gray, and brown chert. Basal contact is sharp and placed at change from claystone below to sandstone above

Total of middle sandstone sequence

Lower unit:

8. Claystone to clayey siltstone, light gray $(N$ 7), light greenish gray (5GY $8 / 1)$, pale reddish brown (10R $5 / 4)$, grayish red $(5 R 4 / 2)$ and pale red purple $(5 R P 6 / 2)$, colors variegated, weathering mostly light greenish gray $(5 G Y 8 / 1)$ and pale red purple (5RP $6 / 2$ ) ; firmly cemented, noncalcareous; stratification concealed, possibly some horizontal stratification planes; weathers to form frothy-surfaced badland topography. Unit exposed in western half of strike valley developed on the Chinle Formation. Locally unit contains sandstone lenses. Along line of section three sandstone lenses occur; the lower two are thin and composed of grayish-orange (10YR $7 / 4$ ) fine-grained well-cemented noncalcareous sandstone whose composition is masked, and the upper one is about $4 \mathrm{ft}$ thick and $158 \mathrm{ft}$ above base of unit. This upper sandstone is pale red purple $(5 R P 6 / 2)$ and fine grained and poorly sorted; it is composed of subangular clear and milky quartz and 2 to 3 percent dark-green mica, and is horizontally laminated. It contains some thin trough sets of medium- to small-scale cross-laminae. All three sandstone lenses pinch out within $1,000 \mathrm{ft}$ along the exposure. Claystone and clayey siltstone in places contain as much as 50 percent very fine grained sand 
Chinle Formation-Continued

Petrified Forest Member-Continued

Lower unit-Continued

Total of lower unit.

.

Lowermost sandstone unit:

7. Sandstone, very pale orange (10YR $8 / 2$ ), abundant dark-yellowish-brown $(10 Y R 4 / 2)$ limonite spots, weathering very pale orange $(10 Y R 8 / 2)$, medium grained, fair to poorly sorted; composed of subangular to subrounded clear and milky quartz and sparse black accessory mineral; firmly cemented, calcareous; horizontally very thin bedded, minor thin planar sets of medium-scale cross-laminae; weathers to form small ledge on upper surface of hogback developed on the Shinarump Member. The sandstone may be a tongue of the Shinarump Member

6. Clayey siltstone to siltstone (80 percent) and siltstone to sandstone (20 percent). Clayey siltstone to siltstone, light gray $(N 7)$, weathering same and light brownish gray (5YR 6/1); bentonitic in part; poorly cemented, noncalcareous, clay binding; stratification concealed. Siltstone to sandstone, grayish orange (10YR 7/4) and pale red $(5 R 6 / 2)$, weathering pale yellowish brown (10YR 6/2), composed of medium silt to very fine grained sand; common accessory white and dark-green mica; well cemented, calcareous in parts; horizontally and ripple laminated. Unit as whole weathers to form slope on upper surface of hogback developed on the Shinarump Member. From distance unit has purplish tint. Siltstone to sandstone present as thin to thick sets interstratified with rest of unit. Parts of unit poorly exposed

Total of lowermost sandstone unit

Total of Petrified Forest Member....

Shinarump Member:

5. Sandstone, similar to that in unit 3 , fine to medium grained, poorly exposed in parts, weathers to form slope. Units 2 to 5 appear to intertongue extensively along the exposure

4. Sandstone (40 percent) to conglomeratic sandstone $(60$ percent $)$, very pale orange $(10 Y R 8 / 2)$ and yellowish gray (5Y 8/1), abundant limonite spots, weathering yellowish gray ( $5 Y$ $8 / 1)$, medium to coarse grained, fair to poorly sorted; composed of subrounded clear and milky quartz; well cemented, calcareous; horizontally
Feet $\mid$ Chinle Formation-Continued Feet
202.8

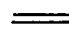

(1)

\section{Shinarump Member-Continued}

very thin to thin bedded; weathers to form ledge on upper surface of hogback developed on Shinarump Member. Conglomeratic sandstone is composed of granules and pebbles averaging from $1 / 4$ to $1 / 2$ in. in diameter. Granules and pebbles are white chert, gray and orange quartzite, or white and pink quartz...

3. Siltstone to sandstone, dark yellowish brown $(10 Y R 4 / 2)$, minor moderate yellowish brown $(10 Y R 5 / 4)$ and greenish gray ( $5 G Y 6 / 1)$, weathering dark yellowish brown (10YR $4 / 2)$; composed of medium silt to very fine grained sand; composition masked, sparse very fine grained accessory white mica; well cemented, calcareous; horizontally laminated, sparse cuspate ripple marks; platy splitting in places; weathers to form part of upper surface of hogback developed on the Shinarump Member....

2. Sandstone (80 percent) and conglomeratic sandstone to conglomerate (20 percent). Sandstone, very pale orange $(10 Y R 8 / 2)$, yellowish gray $(5 Y 8 / 1)$, and sparse grayish orange (10YR $7 / 4)$, weathering grayish orange (10YR 7/4) and dark yellowish brown $(10 Y R 4 / 2)$, fine to coarse grained, fair to poorly sorted; composed of subrounded clear and milky quartz and sparse black accessory mineral; structureless in places, horizontal laminated to thin bedded in other places, and composed of very low angle crosslaminae and common thin planar sets of small- to medium-scale cross-laminae in still other places. Conglomeratic sandstone to conglomerate, similar to sandstone except contains granules and pebbles of whitish quartz, and to a lesser extent of white and gray chert and of black and red quartzite. Conglomeratic parts generally have a coarser sand matrix than the sandstone. Conglomeratic sandstone to conglomerate is present as 0.5 to 5 -ft-thick lenses interstratified with the sandstone. Unit as whole weathers to form vertical cliff. From a distance unit appears to be composed of horizontal lenses or sets from 5 to $10 \mathrm{ft}$ thick. Common limonitic spots and stains.

Total of Shinarump Member..

Total of Chinle Formation.

Moenkopi Formation:

Upper red member:

1. Siltstone, grayish red $(10 R 4 / 2)$ and 
Moenkopi Formation-Continued

Upper red member-Continued moderate brown $(5 Y R 4 / 4)$, weathering grayish red $(10 R 4 / 2)$, fine to coarse silt; common very fine grained accessory white mica; well cemented, noncalcareous; horizontally laminated; weathers to form steep rubble-covered slope ............................Unmeasured

Base of section; not base of exposure. Base of section is on north side of canyon cutting through hogback formed by the Shinarump Member of the Chinle Formation. Base is about 3 miles N. $33^{\circ} \mathrm{W}$. of prominent extinct volcano.

\section{U-46. ROCKVILLE}

Measured $11 / 2$ miles north of Rockville, in Zion National Park. Units 1-3 measured on east side of Huber Wash. Rest of section measured along a northwest to north line up south cliff face of Mount Kinesava. Sec. 36, T. 41 S., R. 11 W., SLM, Washington County

[Measured by J. H. Stewart, September 1953]

Top of section; not top of exposure. Top of section is about $1,500 \mathrm{ft}$ west of fence along boundary of Zion National Park. Top of section is in draw about $75 \mathrm{ft}$ below small saddle between promontory of the Springdale Sandstone Member of the Moenave Formation and talus-covered outlier of Chinle and Moenave.

Moenave Formation (incomplete) :

Dinosaur Canyon Member (incomplete) :

24. Sandstone, light brown (5YR 6/4), pale reddish brown $(10 R 5 / 4)$, and sparse dusky yellow (5Y 6/4), weathering light brown ( $5 Y R 6 / 4)$, very fine grained, well sorted; composed of amber-stained quartz grains, accessory minerals masked; firmly cemented, calcareous; stratification concealed; weathers to form earthy slope. Thin bed of light-greenish-gray ( $5 G Y 8 / 1$ ) sandy silty claystone at base of unit. Only basal $10 \mathrm{ft}$ of unit examined ............................................ Unm

23. Sandstone, light greenish gray (5GY $8 / 1)$, weathering same color and pale brown $(5 Y R 5 / 2)$, very fine grained, well sorted; composed of subrounded clear quartz and sparse black accessory minerals; poorly cemented, highly calcareous; stratification poorly exposed but appears to be thinly to very thinly horizontally bedded; weathers to form fairly conspicuous light-colored ledge. Contains numerous seams of white gypsum.

22. Claystone to clayey sandstone, and gypsum. Claystone to clayey sandstone, pale reddish brown $(10 R 5 / 4)$, abundant light-greenish-gray ( $5 G Y \quad 8 / 1)$ spots, weathering pale reddish brown $(10 R 5 / 4)$; clayey sandstone is very fine grained, fair sorted. Claystone to
Feet

Moenave Formation (incomplete)-Continued

Dinosaur Canyon Member (incomplete)-Con.

clayey sandstone is firmly to poorly cemented, noncalcareous; stratification concealed; composed of clays that do not swell in water. Gypsum, white (N 9), weathering same color and light brown $(5 Y R 6 / 4)$, fine to coarsely crystalline; firmly cemented; beds of gypsum have fibrous appearance. Gypsum in beds from 0.0 to $0.4 \mathrm{ft}$ and 1.7 to $2.8 \mathrm{ft}$ above base of unit and as common nodules about 3 in. in diameter from 2.8 to $8.4 \mathrm{ft}$ above base of unit. Unit as whole weathers to form earthy. slope with small ledges developed on gypsum beds. Unit is put in the Dinosaur Canyon Member because basal contact is abrupt color change and is at change from rock below containing swelling clay to those above that do not. However, the presence of gypsum beds suggest that unit could be part of the Chinle Formation; a gypsum bed is present in the Chinle Formation at about the same stratigraphic horizon in the Fossil Wood Wash section. Unit 21, in the Chinle Formation, contains gypsum beds in the top few feet. Possibly the gypsum beds in unit 21 are veins extending down into the Chinle from the Dinosaur Canyon Member

Total of incomplete Dinosaur Canyon Member

Total of incomplete Moenave Formation

Chinle Formation:

Petrified Forest Member:

21. Claystone, grayish purple ( $5 P$ 4/2) from 0.0 to $9.3 \mathrm{ft}$, greenish gray (5GY 6/1) and medium light gray $(N$ 6) from 9.3 to $13.5 \mathrm{ft}$, grayish red purple $(5 R P 4 / 2)$ with minor grayish red $(5 R 4 / 2)$ from 13.5 to $52.2 \mathrm{ft}$, grayish red $(5 R 4 / 2)$ from 52.2 to $92.8 \mathrm{ft}$, weathering pale red purple (5RP 6/2), commonly silty; firmly cemented, dominantly noncalcareous; some calcareous parts; structureless; weathers to form steep slope, mostly earthy weathering but frothy weathering in lower $22.0 \mathrm{ft}$. Entire unit composed of clays that swell in water. Unit from 17.0 to 92.8 ft contains sparse limestone nodules. These nodules are pale red $(10 R 6 / 2)$ and light greenish gray (5GY 8/1), dense, and average about 1 in. in diameter. Commonly the limestone nodules are poorly cemented crumbly masses. Top $9 \mathrm{ft}$ of unit directly east
3.0
Feet 
Chinle Formation-Continued

Petrified Forest Member-Continued of line of section contains several thin to very thin beds and (or) veins of coarsely crystalline white ( $\left.\begin{array}{ll}N & 9\end{array}\right)$ gypsum. These beds and (or) veins are identical with the two beds in the overlying unit except that some lie at angles as great as $50^{\circ}$ to the regional dip

20. Clayey sandstone, pale brown (5YR $5 / 2)$ and minor grayish red $(10 R$ $4 / 2$ ), weathering moderate brown (5YR 4/4), fine to very fine grained, common interstitial brown clay, fair sorted; composed of subangular clear quartz and milky mineral and abundant orange accessory mineral, sparse accessory dark and white mica; composed of thin trough (possibly in part planar) sets of small-scale crosslaminae; weathers to form earthy slope. Unit becomes more clayey upward and grades to silty claystone in top few feet. Unit contains a thin light-colored band at base

19. Silty claystone, grayish red (5R 4/2) from 0.0 to $2.5 \mathrm{ft}$, grayish red $(5 R 4 / 2)$ and dusky yellow $(5 Y 6 / 4)$ from 2.5 to $5.0 \mathrm{ft}$, greenish gray (5GY 6/1) with minor grayish purple (5P 4/2) and sparse dusky yellow $(5 Y 6 / 4)$ from 5.0 to $31.5 \mathrm{ft}$, and grayish red purple ( $5 R P$ 4/2) from 31.5 to $37.5 \mathrm{ft}$, weathering dominantly greenish gray (5GY 6/1), commonly sandy (very fine grained); firmly cemented, noncalcareous; structureless; weathers to form steep frothy slope. Composed of clays that swell in water

18. Sandstone, yellowish gray $(5 Y 8 / 1)$ and pale red $(5 R 6 / 2)$, weathering same colors, very fine to fine grained, common interstitial white clay, fair sorted; composed of subangular milky and common orange minerals, common fine-grained accessory biotite; firmly cemented, slightly calcareous; lenticular unit, stratification poorly developed but appears ripple laminated, possibly some thin sets of lowangle cross-laminae; weathers to form small white ledge. Line of section is at place where unit is thickest............

17. Sandy claystone, pale red purple ( $5 P R$ $6 / 2$ ) with common light greenish gray $(5 G Y 8 / 1)$ from 0.0 to $13.9 \mathrm{ft}$ and grayish red $(5 R 4 / 2)$ from 13.9 to $25.4 \mathrm{ft}$, weathering pale red purple $(5 P R 6 / 2)$ in lower part and pale reddish brown $(10 R 5 / 4)$ in upper part, sandy (very fine grained); firmly cemented, noncalcareous; struc-
Feet $\begin{array}{r}\text { Chinle Formation-Continued } \\ \text { Petrified Forest Member-Continued } \\ \text { tureless; weathers to form steep slope. } \\ \text { Basal } 3 \mathrm{ft} \text { of unit is very fine grained } \\ \text { clayey sandstone. Tongues of sand- } \\ \text { stone of unit } 16 \text { occur in lower } 2 \text { to } 3 \\ \text { ft of unit. These tongues are probably } \\ \text { ripple laminated }\end{array}$

16. Sandstone, white $(N 9)$ and minor pinkish gray ( $5 Y R 8 / 1$ ), weathering very pale orange $(10 Y R 8 / 2)$, fine to very fine grained, common interstitial white material, possibly clay mineral, fair sorted; composed of subangular milky mineral and about 2 percent orange mineral, sparse medium-grained accessory biotite; firmly cemented, slightly calcareous; composed of very thin to thin trough sets of small-scale cross-laminae; weathers to form small ledge and light-colored band...

15. Claystone, greenish gray $(5 G Y \quad 6 / 1)$ from 0.0 to $11.9 \mathrm{ft}$, greenish gray $(5 G Y 6 / 1)$ with grayish-red-purple (5RP 4/2) mottles from 11.9 to 13.4 $\mathrm{ft}$, grayish red (5R $4 / 2$ and $10 R 4 / 2$ ) from 13.4 to $31.5 \mathrm{ft}$ and grayish red purple (5PR 4/2) from 31.5 to 33.0 $\mathrm{ft}$, weathering dominantly light greenish gray $(5 G 8 / 1)$ in lower half and pale reddish brown $(10 R 5 / 4)$ in upper half, commonly silty and sandy; firmly cemented, noncalcareous; structureless except for horizontal color bands; weathers to form frothy-surfaced slope. Composed of clays that swell in water. Unit from 26.0 to 29.5 $\mathrm{ft}$ is mostly very fine grained clayey sandstone

14. Sandstone, similar to unit 12 except stratification is not exposed. Along line of section, unit weathers to form steep slope and does not contain resistant ribs. Fifty feet to west of line of section unit contains several thin horizontally laminated sets. These sets locally contain malachite stains. About 1,000 ft to the west of the line of section a copper prospect is located in unit..

Feet

$(25.4$

2.4

33.0

13. Sandstone, grayish pink (5R 8/2), weathering light brown ( $5 Y R 6 / 4$ ), medium to coarse grained, common interstitial white material (probably clay), fair sorted; composed of subangular milky minerals and minor light orange mineral, abundant accessory biotite; poorly cemented, calcareous; porous, possibly 5 percent pore spaces; composed of thin trough sets of small- to medium-scale cross-laminae; weathers to form most prominent ledge in Chinle Formation. The basal few feet of unit contains sand- 
Chinle Formation-Continued

Petrified Forest Member-Continued

stone similar to that in unit 12 and may intertongue with the underlying unit. Unit contains many large-scale channels both at the base of the unit and within the unit. Unit together with the underlying and overlying units may correlate with the conspicuous sandstone in the Chinle Formation in the Fossil Wood Wash section

12. Sandstone, pale purple $(5 P 6 / 2)$, minor grayish yellow green $(5 G Y 7 / 2)$, sparse light greenish gray (5GY $8 / 1)$, weathering pale red purple $(5 P R \quad 6 / 2)$ and light greenish gray (5GY 8/1), very fine grained, common interstitial clay, fair sorted; composed of subangular milky and minor orange minerals, biotite constitutes at least 2 percent of rock; poorly to firmly cemented, slightly calcareous; composed of horizontal laminae and minor thin trough and planar sets of small-scale cross-laminae; weathers to form steep ledgy slope. About 30 percent of unit composed of thin lenticular resistant sets that form ribs on outcrop. These resistant sets are generally cross stratified and some may possibly contain ripple laminae

11. Claystone, medium gray ( $N 5)$ to greenish gray ( $5 G Y$ 6/1) from 0.0 to 15.7 $\mathrm{ft}$, grayish red $(5 R 4 / 2)$, very dusky red purple ( $5 R P 2 / 2)$, greenish gray $(5 G Y 6 / 1)$, and medium gray (N 5) with minor grayish yellow (5Y 8/4) from 15.7 to $39.6 \mathrm{ft}$, grayish red purple $(5 R P 4 / 2)$ from 39.6 to $42.7 \mathrm{ft}$, grayish red $(10 R 4 / 2)$ from 42.7 to $48.9 \mathrm{ft}$, medium gray ( $N 5)$ from 48.9 to $54.3 \mathrm{ft}$, moderate yellow ( $5 Y$ $7 / 6)$ to dusky yellow $(5 Y 6 / 4)$ with minor grayish red purple (5RP 4/2) and light greenish gray (5GY 8/1) from 54.3 to $57.3 \mathrm{ft}$, greenish gray (5GY 6/1) with minor grayish red purple (5RP 4/2) from 57.3 to 75.1 $\mathrm{ft}$, grayish red (5R $4 / 2$ and $10 R 4 / 2)$, grayish red purple $(5 R P 4 / 2)$ with minor thin bands of greenish gray (5GY 6/1) from 75.1 to $97.8 \mathrm{ft}$, medium-light-gray $(N 6)$ and common light-greenish-gray (5GY 8/1) mottles from 97.8 to $106.5 \mathrm{ft}$, weathering in lighter shades of these colors; colors are in persistent horizontal bands on outcrop; rarely silty; firmly cemented, consistently noncalcareous; structureless except for horizontal color bands that probably reflect stratification; weathers to form frothy slopes. Clays swell on contact with
Feet

Chinle Formation-Continued

Petrified Forest Member-Continued

water. Color band from $\mathbf{7 5 . 1}$ to $\mathbf{9 7 . 8}$

ft contains one or two thin beds of light-greenish-gray ( $5 G Y 8 / 1)$ clayey sandstone composed of subangular milky minerals and abundant orange accessory minerals; medium- to coarse-grained biotite comprises at least 1 percent of the clayey sandstone

10. Siltstone, light greenish gray ( $5 G Y$ $8 / 1)$, minor dark yellowish orange $(10 Y R 6 / 6)$, and sparse grayish red (5R 4/2), weathering light greenish gray $(5 G Y 8 / 1)$ and grayish yellow (5Y 8/4); firmly to well cemented; noncalcareous; weathers to form yellow color band on steep slope. Away

, from line of section, unit locally contains thin resistant bed near top. At some places unit forms small bench. Siltstone commonly stained black (possible manganese stain)

9. Claystone, grayish red $(10 R 4 / 2)$ and minor grayish red $(5 R 4 / 2)$, weathering pale reddish brown $(10 R 5 / 4)$; firmly cemented, noncalcareous; structureless; weathers to form conspicuous brown color band on steep slope. Unit is commonly sandy and silty. Fifty feet to west of line of section unit contains a 2-ft clayey sandstone set near the top of the unit. This clayey sandstone is grayish red $(5 R 4 / 2)$, with minor light greenish gray $(5 G Y 8 / 1)$ and is fine grained; it is poorly sorted and is composed of subangular milky mineral and abundant orange accessory minerals. Biotite constitutes at least 1 percent of the clayey sandstone. Faint suggestion of cross-laminae in the clayey sandstone.

8. Claystone; greenish-gray $(5 G Y 6 / 1)$ and light-greenish-gray ( $5 G Y 8 / 1$ and $5 G 8 / 1$ ) rocks comprise about 50 percent of the unit and are dominantly in the lower half; grayish-red $(5 R$ $4 / 2)$, grayish-red-purple (5RP 4/2), and grayish-purple (5P 4/2) rocks comprise the other 50 percent and are dominantly in the upper half; weathering light greenish gray (5GY 8/1) and pale red purple (5PR 6/2); firmly cemented; noncalcareous; structureless; weathers to form steep frothy slope. Unit exposed at base of main exposure of Chinle Formation. Unit is locally silty and sandy (very fine grained). Clay swells slightly in water

7. Clayey sandstone to sandy claystone, grayish red $(10 R 4 / 2$ and $5 R 4 / 2)$, weathering same color, very fine sand
Feet

106.5 
Chinle Formation-Continued

Petrified Forest Member-Continued size, sparse fine-grained white mica; firmly cemented, noncalcareous to slightly calcareous; possibly some horizontal laminae; weathers to form slope. Surface commonly covered by platy flakes of sandstone.

6. Silty claystone to clayey siltstone, grayish red $(5 R 4 / 2)$ in lower $1 \mathrm{ft}$ and dark greenish gray $(5 G Y 4 / 1)$ and medium bluish gray $(5 B 5 / 1)$ in rest of unit, weathering grayish red $(5 R$ $4 / 2$ ) in lower $1 \mathrm{ft}$ and light greenish gray $(5 G Y 8 / 1)$ in rest of unit; poorly to firmly cemented, noncalcareous; stratification concealed; weathers to frothy-surfaced slope and to form light-colored band between reddish bands. Thickness of unit varies along outcrop

5. Clayey sandstone, light brownish gray (5YR 6/1), weathering brownish gray (5YR 4/1), very fine grained, minor interstitial brown clay, fair sorted; composed of subangular milky mineral; biotite may make up as much as 2 percent of the rock; poorly cemented, calcareous; stratification concealed; weathers to form lowest brown band below main outcrop of Chinle Formation. Unit commonly contains resistant sandstone. This sandstone is greenish gray (5GY 6/1), weathers brownish gray $(5 Y R 4 / 1)$, and is very fine grained. It contains abundant very fine grained accessory white mica, is well cemented (calcareous), is ripple laminated and occurs as thin sets interstratified with the rest of the unit

Section transferred on top of unit 4, so that unit 5 measured 1,000 ft northwest of unit 4. Unit 5 and overlying units measured up gully starting about $500 \mathrm{ft}$ northwest of fence at boundary of Zion National Park (along boundary of secs. 36 and 31 ).

4. Clayey sandstone, greenish gray ( $5 G Y$ $6 / 1$ ), light greenish gray (5GY 8/1), and sparse yellowish gray $(5 Y 7 / 2)$, weathering grayish yellow $(5 Y 8 / 4)$ in lower few feet and light greenish gray $(5 G Y 8 / 1)$ and greenish gray $(5 G Y 6 / 1)$ in rest of unit; very fine to fine grained, minor interstitial green clay, poorly sorted; composed of subangular milky minerals (probably quartz and feldspar), minor amber minerals; biotite and muscovite make up at least 2 percent of the rock; poorly cemented, slightly calcareous; common to abundant exposures of thin to thick trough sets of small- to large-scale low-angle cross-
Feet Chinle Formation-Continued Feet Petrified Forest Member-Continued

laminae; weathers to form long bench. Unit contains common to abundant carbonaceous material. Concentrations of black minerals are common along laminae boundaries. Limonite stains occur commonly. Unit contains a thin set of resistant sandstone $13 \mathrm{ft}$ above base. This sandstone is similar to that in the rest of the unit except that it is light brownish gray ( $5 Y R$ $6 / 1$ ), weathers dark gray $(N 3)$, and is well cemented; horizontally laminated and platy splitting. About $1 / 4$ mile to the southeast, unit contains several fine to very fine grained wellcemented ripple-laminated sandstone lenses. Unit measured up a conspicuous wash starting at the highest exposure of the Shinarump Member. The thickness of the unit cannot be determined accurately because the unit forms a wide bench

Total of Petrified Forest Member...

Section transferred so that overlying units were measured about $1 / 2$ mile to the east and northeast.

Shinarump Member:

3. Sandstone and conglomeratic sandstone. Sandstone, very pale orange $(10 Y R$ $8 / 2)$ to moderate yellowish orange (10YR 7/6), minor grayish yellow $(5 Y 8 / 4)$, weathering grayish orange $(10 Y R 7 / 4)$, coarse to very coarse grained, fair to poorly sorted; composed of subangular to subrounded clear and milky quartz and uncommon black accessory minerals, sparse (5 percent) yellow interstitial clay (possibly in part limonite); poorly cemented, calcareous; highly porous; composed of thin to thick planar and trough sets of small- to medium-scale cross-laminae; indistinct stratification, locally appears structureless. Sandstone grades to conglomeratic sandstone containing subrounded to rounded granules to cobbles of clear and colored quartz and, to a lesser extent, of chert, silicified limestone, quartzite, and siltstone. Largest diameter of clast noted was 3 in. (a quartz cobble). Conglomeratic sandstone generally constitutes about 30 percent of the unit, but amount is variable along exposure. Unit as a whole is tabular and weathers to form conspicuous cliff and a broad bench. Basal contact sharp; basal strata fill scours cut as deep as $4 \mathrm{ft}$ into the underlying unit. Unit contains sparse ( 2 percent) thin sets of 
Chinle Formation-Continued

Shinarump Member-Continued fine-grained sandstone. Because of off set at top of unit, thickness of unit is not precise, but it is probably within $20 \mathrm{ft}$ of being correct. Unit appears to contain thin to very thick beds of greenish-gray claystone to clayey sandstone on exposures to west. Upper part of unit contains common carbonized and silicified plant remains

Total of Shinarump Member.

Mottled strata:

2. Siltstone, grayish red purple (5RP $4 / 2)$, light gray ( $N 7)$, and greenish gray $(5 G Y 6 / 1)$, uncommon pale yellowish orange $(10 Y R 8 / 6)$, weathering same colors; sparse (less than 1 percent) and locally common fine to very coarse disseminated grains of subangular to rounded clear quartz and orange and black minerals; well cemented, noncalcareous; structureless, some suggestion of thin horizon-
Chinle Formation-Continued Mottled strata-Continued tal beds; weathers to form purple band in vertical cliff continuous with that of overlying unit. Basal strata fill scours cut as deep as $0.5 \mathrm{ft}$ into underlying unit. Unit does not appear to persist laterally

Total of mottled strata

Total of Chinle Formation

Moenkopi Formation:

1. Siltstone, grayish red $(10 R 4 / 2)$, common grayish yellow green $(5 G Y 7 / 2)$ and light greenish gray (5GY 8/1), weathering same colors; firmly to well cemented, noncalcareous to slightly calcareous; horizontally laminated; weathers to form slope. Only top $8 \mathrm{ft}$ of unit examined. A resistant layer occurs from 1 to $4 \mathrm{ft}$ below top of unit.. ..Unmeasured

Base of section; not base of exposure. Base of section on east side of prominent reentrant southwest of West Temple. 


\section{INDEX}

[Italic page numbers indicate major references]

$\mathbf{A}$

\section{Page}

Abajo Mountains, Utah

$35,84,86,195$

Abo Formation............................ 23

Abstract.

Acknowledgments

Acompsosaurus ving

Adamana, Ariz........................................... 82.83

Age, Chinle Formation................................... 86

Agun Zarca Creck, N. Mex........................ 21, 23

Agun Zaren Sandstone Member............... 13, 21

dip direction of cross-strata.................. 76

henvy minerals.........................................

mottled strata.............................................. 16

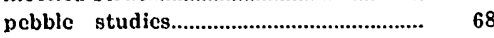

plant remains........................................... 84

source of sediments................................... 94

Algne.................................................... 69, 73, 94

Amnicolidne..................................................... $\quad 78$

Amphibians................................................... 80,87

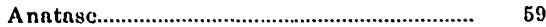

Angistorhinus.............................................. 86, 87

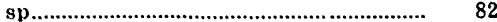

Animal remains, Dolores Formation, lower member..

middle member...

Animas River Canyon, measured section 143

Animas River Valley, measured section.... 142

A patite....................................................... 59

Araucarioxylon arizonicum ................ 79, 84, 89

Araucaritos chiquito...................................... 85

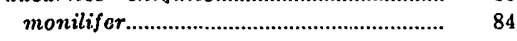

Arkose.......................................................... 56

Aronia................................................... 203

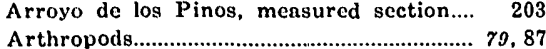

Ash-fall deposits................................................ 93

Aspen, Colo., mensured section.................... 162

Aviculopecten occidentalis.............................. $\quad 76$

$\mathbf{B}$

Baritc................................................ 58, 59, 61 Basal sandstone unit, pebble studies........ 68 Bears Ears, Utah, measured section...... 264

Belodon buceros........................................... 81

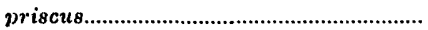
griolomax

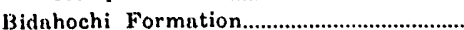

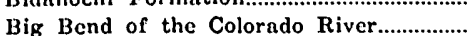

Big Dominques Creck, measured section.

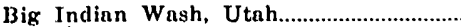

Bishop Conglomerate...

Black Folls, Ariz.............................................. 78

Black Ledge....................................... 43, 98

Black Mountain Wash, measured section 107

Black Rock, N. Mex.................................. 79, 194

Bluewater Canyon, N. Mex., measured

section......................................... 179

Bluewater Creck, N. Mex.................... 41, 47, 210

Bluewater Reservoir, N. Mex., measured section......................................... 179

Bowl Canyon Wash, measured section...... 191

Brachiopods.................................. 68, 69, 71, 74, 94

Brachyphyllum munstori............................. 85

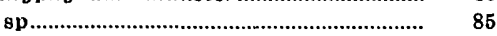

Branchiopods..

Page

Brandyina sp.

Bridgeport, Colo., measured section.......... 144

measured section

Brookite........................................................... 59

Brown, R. W., fossil identifications.......... 85

Bryozoans...................68, 69, 71, 73, 74, 76, 94

Buckacre Point, Utah, measured section.. 231

Buckhorn Wash, Utah, measured section 216

Buettneria major.

Burr Canyon, Utah

\section{C}

Calcarenite

Calcite.

Cane Spring Wash, Utah............................. 31

Cane Wash, Utah, measured section........ 219

Canones Creek, N. Mex................................. $48^{\circ}$

Capitol Reef, Utah.........................................

Capitol Reef bed........................................... 37

Capitol Reef National Monument.............

Carbonaceous material, Monitor Butte Member..

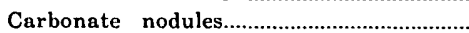

Carbonate rocks, composition

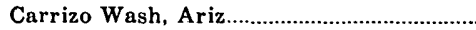

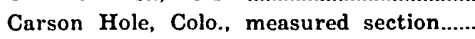

Cedar City, Utah.

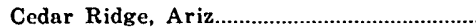

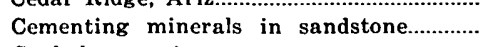

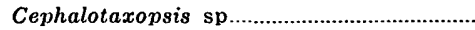

Ceratodus.

Cervella sp..

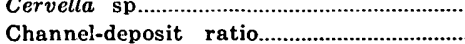

Channels, cross-stratified sandstone and conglomerate deposits.............

filled by Gartra Member........................ filled by Moss Back Member................... filled by Poleo Sandstone Lentil........ in Moenkopi Formation......................... in Shinarump Member..

Chavez, $\mathrm{N}$. Mex measured sec

182

Chee Dodge, Ariz................................. 45, 98, 108

Cheirolepis munsteri.................................... 84

Chert pebbles.

fossiliferous

Moss Back Member........................... 69, 73

Petrified Forest Member................. 74, 76

Shinarump Member....................... 68, 71

Sonsela Sandstone Bed..................... 74

Chimney Rock, Utah, measured section.. 315

Chinle cliffs, Ariz., measured section...... 126

Chinle Formation, naming.......................... 11

Chinle Wash, Utah, measured section...... 299

Chinlea sorenseni.......................................... 80

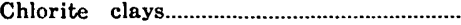

Chugwater Formation, Popo Agie Member....

Church Rock, Ariz..

Church Rock Member feldspar.............................................. 58 source of sediments........................... 100 trough-cross-stratified rocks.................. 54 volcanic detritus...
Cionichthys dunklei

Page

Circle Cliffs, Utah.......... 19, 27, 38, 78, 84, 85, 235

Cladophlebis subfalcata.............................. 85, 86

sp ................................................... 85

Clausotrypa sp............................................. 76

Clay, in fine-textured rocks........................... 61

swelling, Owl Rock Member....................... 40

Clay Hills, Utah............................. 25, 43, 79, 81

Clay minerals............................................... · 59

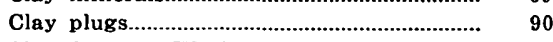

Clay Springs Wash, N. Mex., measured section....................................... 185

Claystone, composition....................................... $\quad 61$

structureless or horizontally stratified, interpretation................... 93

Cleopatras Chair, Utah, measured section 317

Clepsysaurus................................................... 86

Cliff Creek, Utah....................................... 51, 310

Coelophysis........................................... 82, 89, 95

Coelurus ..................................................... 82

Colbert, E. H., and Gregory, J. T., quoted....................................... 87

Collophane....................................................... 59

Colorado National Monument...................... 3, 148

Colorado Plateau region, physiography.. 4

Colorado River, measured sections along 140. $248,254,277,288,301$

Comb Ridge, Ariz.

Utah.............................. 25, 39, 271, 291, 299

Comb Wash, Utah, measured sections.. 271, 291

Composition, petrological classification

basis.............................................

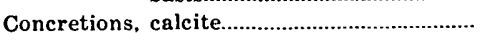

Conglomerate ...................................................

cross-stratified, interpretation.............

limestone pebble..

pebble composition...

trough-cross-stratified, interpretation

volcanic detritus.

Conglomerate. See also Pebble studies.

Conifers.

Contact relations, Agua Zarca Sandstone Member.

between upper and lower parts of Chinle...

Chinle Formation .....................................

Church Rock Member...................................

Dolores Formation, lower member..

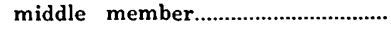
red siltstone member........................ sandstone and conglomerate

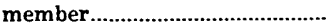

upper member.................................. 49, 51

Gartra Member........................................... 25

lower red member.................................. 28

Mesa Redondo Member......................... 28

Monitor Butte Member........................ 26

Moss Back Member.................................. 33

mottled strata............................................. 18

Owl Rock Member.

Poleo Sandstone Lentil.

red sandstone member.

Rock Point Member, Wingate Sandstone..........................................

Salitral Shale Tongue.............................

sandstone and mudstone member......
56

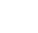




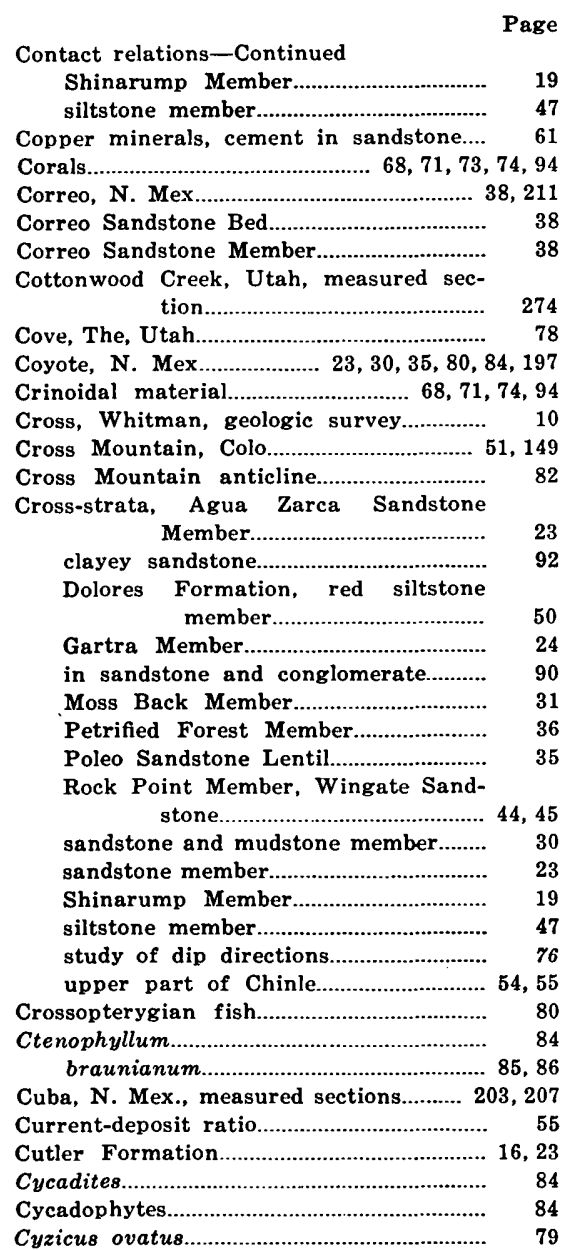

\section{D}

Dakota Sandstone........................................ 14, 47 DeChelly Sandstone, mottling..................... 16 Deer Flat, Utah.......................................... 82, 85 Defiance monocline, measured section.... 115 Defiance uplift.... 14, 27, 44, 45, 49, 53, 55, 74, 98 Depositional environment, Agua Zarca Sandstone Member.................. 23 Black Ledge..............................................

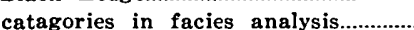
Hite Bed.

limestone, upper part of Chinle........... 54 lower (bentonitic) part of Chinle Formation............................. 87, 95

lower red member.................................. 92 Monitor Butte Member.......................... 92, 93 Moss Back Member............................... 90

Owl Rock Member............................. 95, 97 Petrified Forest Member..................... 92, 93 planar-cross-stratified sandstone........ 55 Rock Point Member, Wingate Sandstone.......................................... 98 Shinarump Member.................... 18, 20, 90, 92 siltstone, upper part of Chinle........ 54 Sonsela Sandstone Bed......................... 90 trough-cross-stratified sandstone......... 54 upper (red-beds) part of Chinle Formation

wavy-stratified siltstone and sandstone, upper part of Chinle

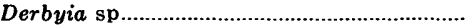

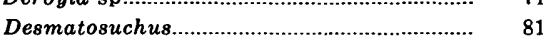
Dictyoclostus................................................ 71 sp................................................. 68, 71 Dinosaur National Monument................... $\quad 3,82$
Dinosaurs..................................................... Pag

Diplodon gregoryi..........................................

Dirty Devil River, Utah, measured section ......................................... 231

Disappointment Creek, Colo............................

Distribution, Agua Zarca Sandstone Member.......................................

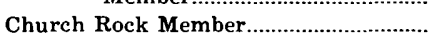

Dolores Formation, lower member.... red siltstone member....................... sandstone and conglomerate member.

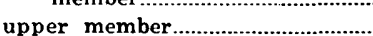

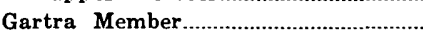

Hite Bed.

lower red member

Mesa Redondo Member

Monitor Butte Member

Moss Back Member..

……......... 90

mottled strata..................................... 16, 17

Owl Rock Member.................................. 38

Petrified Forest Member....................... 35, 36

Poleo Sandstone Lentil............................

red sandstone member.......................... 47

Rock Point Member, Wingate Sandstone.

Salitral Shale Tongue

sandstone member...................................... 24

Shinarump Member.............................. 19, 90

siltstone member...................... 47

Sonsela Sandstone Bed......................... 90

Dockum Group........... 14, 36, 77, 80, 82, 84, 86, 87

Dolores Formation................................. 10, 13, 14

basal sandstone...................................... 49

conglomerate pebble composition........ 62

dinosaurs............................................... 83

feldspar................................................ 58

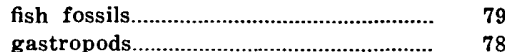

lower member.

lower member, dip direction of cross-strata................................

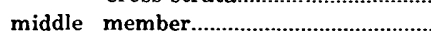

northern San Juan Mountains.............

pebble studies

pelecypods.

77

.

plant rilstone member 50

reptiles........................................... 81

sandstone and conglomerate member

upper member.................. 48, 51

Dolores Formation Member, volcanic detritus.....................................

wavy-stratified siltstone and sandstone........................................ 98

Dolores River, Colo., measured sections............ 155, 156, 158

Dry Fork, Utah, measured section............ 241

Dugway, The, Utah, measured section.. 252 Durango, Colo.......................... 33, 34, 48, 49, 142

\section{E}

East Brush Creek, Colo., measured section 136 Echinoid spines....................................... 71, 73, 94 Echo Cliffs, Ariz.......................................... 17, 78 Egnar, Colo............................................ 31, 35 Elk Ridge, Utah............. 19, 20, 31, 77, 79, 85, 94 Endothyra.............................................. 73

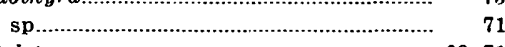

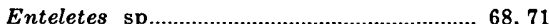
Entrada Sandstone................... 14, 45, 47, 49, 51 medial silty member.

Environment of deposition. See Depositional environment.

Eolian deposits............................................ 98

Eolian sandstone, Wingate Sandstone..... 44, 45

Epidote.....................................................

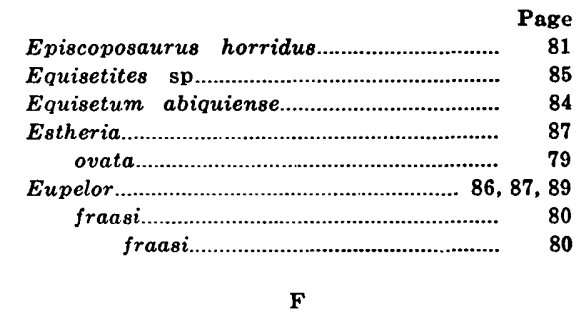

Facies analysis.

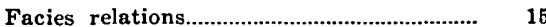

Dolores Formation, red siltstone member.................................... 50, 51

sandstone and conglomerate member..................................... $\mathbf{5 1}$ upper member....................................... 49, 51

lower red member.................................... 28

Mesa Redondo Member......................... 28

Monitor Butte Member........................... 28

Moss Back Member................................. 31

Owl Rock Member

Petrified Forest Member........................ 36

Rock Point Member, Wingate Sandstone

Shinarump Member................................. 20

Feldspar................................................. 58, 61

Fenestella .................................................... 68

sp

Fine-textured rocks, composition................. . 61

Fish remains.................................... 79, 87, 95

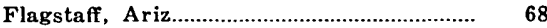

Flaming Gorge Group.................................. 10

Flaxville Formation......................................... 90

Florida River, Colo......................................... 34

Fort Defiance, Ariz _...............44,77 measured section................................... 45, 185

Fort Wingate, N. Mex.................................... 19, $45,77,81,82,84,98,186,189$

Fossil soil zones............................... 89 Fossil Wood Wash, Utah, measured sec-

tion........................................ 258

Fossils ......................... 77 arthropods.................................................. 79 criteria for depositional environment.................................... 87, 95

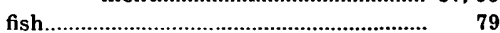

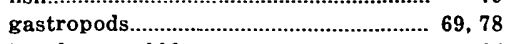
in chert pebbles....................................... 94

in chert pebbles, Moss Back Member 69, 73 Petrified Forest Member................ 74, 76 Shinarump Member....................... 68, 71 Sonsela Sandstone Bed................... 74 pelecypods.................................................. 77 plants..

reptiles....

Front Range highland sediment source................................... 87, 95, 99 Fry Canyon, Utah..................................... 78, 80 Fusulinids.......................................68, 69, 71, 74

\section{G}

Gallina, N. Mex .......... 23, 35, 77, 80, 81, 83, 199 Ganado Mesa, Ariz., measured section.... 119 Garnet.................................................. 59 Gartra Grit Member, Stanaker Formation ......................................... 13, 24 Gartra Member..................................... 13, 17, 24 dip direction of cross-strata............. $\mathbf{7 6}$ pebble studies.............................................. 68

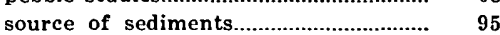
Gastropods............................. 68, 69, 87, 94, 95 Geinitzina sp .............................................. 71 Germany, Keuper rocks............................ 86,87 Ghost Ranch, N. Mex....... 47, 79, 80, 81, 83, 200 Glen Canyon Group............................. 11, 14, 78 Glen Canyon Sandstone............................. 14, 51

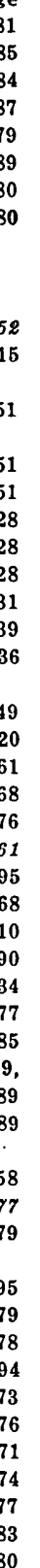

.

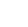




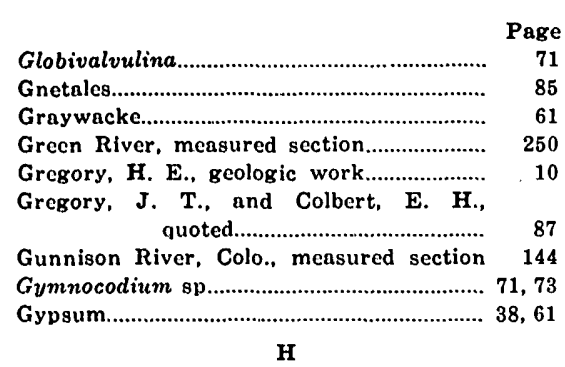

Hayden Survey................................................ 10

Heavy minerals............................................. 58

Hematite............................................... 58, 59, 60

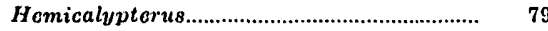

Homitrya....................................................... 71 sp ......................................................... 73

Hesporosuchus agilis.......................................................... 80

Hoterodontosuch.us ganci............................. 81

Hite, Utah............................................... 42, 277

Hite Bed...................................................... 41,43 depositional environment...................... 98 source of sediments................................ 100

Holbrook, Ariz................................................. 27, 28

Horn, The, Utah, measured section.......... 277

Horse Canyon, Utnh, measured section 235

Horse Mesa Creek, Ariz..................... 39, 48, 110

Horse Spring. Nev., measured section...... 168

House Rock Valley, Ariz........................... 29, 78

Huber Wash, Utah, measured section...... 326

Hunt, Ariz.................................................... 28

Hurricanc, Utah, measured section.......... 320

Hustedia sD....................................................

$$
\text { I, J, K }
$$

Igneous rocks, pebbles.................................. 62 Ilmenite........................................................ 59

Insect trails and burrows........................... 79

$\begin{array}{lr}\text { Insects................................................... } & 87 \\ \text { Irish Lake, Colo., measured section........ }\end{array}$

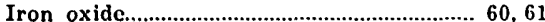

Ives expedition.................................................. 10

Jacobs Chair, Utah..................................... 43, 281

Johnson Creek, Utah, measured section.. 286

Joseph City, A riz................................. 29, 78, 80

Kaibab Limestone..........

Kalamoiketor pinkleyi.

Kanab, Utah..

Kanab, Utah and Ariz...

Utah, measured section.... 255

Kaolinite 60

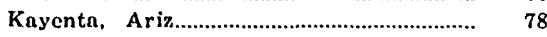

Kayenta Formation..................................... 14

Keuper, of Germany................... 86,87

King Survey................................................... 10

$\mathrm{K} / \mathrm{K}$ Ranch, measured section.................... 164

Laguna, N. Mex.......................................... 80

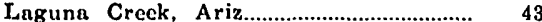

Lake Fork River, Utah.......................... 51,214

Lampstand, Utah, measured section......... 235

Lander, Wyo............................................ 38

Las Vegas, Nev., measured section............ 172

Lasalichthys hillsi....................................... 79

Lavender Creek, Utah, measured section 267

I ceeds, Utah, measured section................. 320

Lees Ferry, Ariz............................ 19, 29, 30, 78

Lopacyclotes circularis................................ 84

Lepidotus..................................................... 80

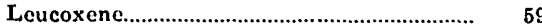

Limestone........................................................ 61 interpretation......................................... 97

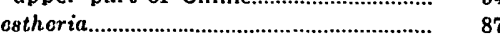

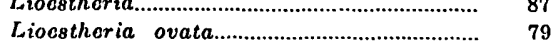

Page Lisbon Valley, Utah............................31, 35, 79, 80 Little Colorado River, Ariz......... 80, 85, 123, 126 Little Snake River, measured section...... 149 Localities, index to location......... 5

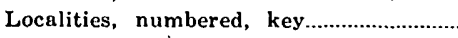
Lockhart Canyon, Utah............................... 43, 288 Lonchopteris virginiensis ................ 85 Lophophyllum sp........................................ Lower (bentonitic) part of Chinle Formation..................................... 15

Lower red member............................... 11, depositional environment...................... 92 plant remains...................................... 83, 84 reptiles................................................... 81, 82

Lucero uplift........................................... 19

Lucky Strike mine, Utah, measured section........................................... 221

Lukachukai, Ariz ........................... 44

Lukachukai Member, Wingate Sandstone.................................. 13, 45, 55

Lukachukai Mountains, Ariz..................... 44, 45

Lukachukai Trading Post, Ariz., measured section........................... 112

Lungfish................................................ 80 Lupton, Ariz............................... 28, 45, 81, 115 $\mathbf{M}$

Machaeroprosopus.......................................... 81, 82 adamanensis........................................ 81

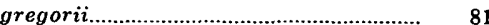

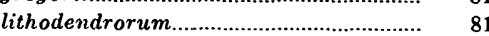
tenuis................................................... 8 validus.

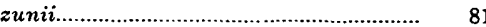
(=Phytosaurus) ...................................... 86 lithodendrorum ................................... 83 zunii 83 Macomb expedition................................................ 10 Macrotaeniopteris....................................... 89 magnifolia................................................ 84, 85 Magnetite.................................................

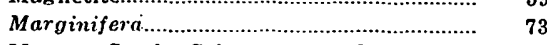
Maroon Creek, Colo., measured section.... 162 Measured sections :

Arizona, Black Mountain Wash......... 107 Black Point....................................... 126 Chee Dodge ........................................ 108 Horse Mesa Creek............................. 110 Lukachukai Trading Post............ 112 Lupton............................................. 115 Nazlini Trading Post............... 117, 119 Owl Rock............................................. 129 St. Johns.............................. 121, 123, 124

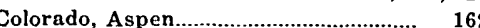
Bridgeport...................................... 144 Carson Hole...................................... 145 Cross Mountain ..................................... 149 Durango............................................ 142 East Brush Creek............................ 136 Meeker (Oak Ridge) ..................... 164 Miller Creek....................................... 151 Ouray.......................................... 160 Palisade, The.................................... 146 Paradox Valley..................................... 158 Piedra River..................................... 134 Sawpit........................................... 165 Serpents Trail, The.......................... 148 Stoner.......................................... 155, 156 South Canyon Creek...................... 140 Vermilion Creek................................ 153

Nevada, Horse Spring Valley.............. 168 Spring Mountains............................. 172 Valley of Fire................................... 175

New Mexico, Abiquiu.............................. 195 Arroyo de los Pinos....................... 203 Bluewater Creek............................... 210 Chavez-Prewitt............................ 179, 182 Correo............................................. 211
Measured sections-Continued

Page

New Mexico-Continued

Coyote............................................. 197

Fort Defiance........ 185

Fort Wingate................................ 186, 189

Gallina............................................. 199

Ghost Ranch..................................... 200

Petoch Butte. 213

San Ysidro........................................ 206

Senorito Canyon.................................... 207

Toadlena........................................... 201

Todilto Park ................................. 191

White Mesa.......................................... 209

Zuni................................................. 193, 194

Utah, Bears Ears

Bridger Jack Mesa........................ 267

Buckacre Point................................... 231

Buckhorn Wash............................... 216

Cane Wash......................................... 219

Chimney Rock .................................... 315

Cliff Creek............................................ 310

Comb Wash....................................... 271

Cotton wood Creek ........................... 274

Fossil Wood Wash.............................. 258

Hite.................................................. 277

Horse Canyon................................... 235

Jacobs Chair................................... 281

Johnson Creek..................................... 286

Kanarraville....................................... 255

Lake Fork River............................. 214

Leeds................................................... 320

Lockhart Canyon............................. 288

Lucky Strike mine............................ 221

Milk Ranch Point.......................... 291

Millard Canyon................................ 317

Moab Canyon........................................... 252

Monitor Butte.................................. 294

Muddy River...................................... 223

Muley Twist......................................... 236

North Sixshooter Peak.................... 296

Paria................................................ 261

Ponch House.................................... 299

Range Canyon...................................... 238

Richardson Amphitheater............ 248

Rincon ...................................... 301, 305

Rockville............................................ 326

Silver Falls Creek.............................. 241

South Block........................................ 243

South Draw...................................... 245

Spring Canyon................................... 250

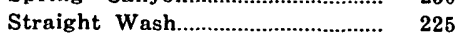

Taylor Canyon................................. 306

Temple Mountain........................... 229

Vernal (Brush Creek) ...................... $\quad 312$

Westwater Canyon.......................... 254

Meeker (Oak Ridge), Colo., measured section....................................... 164

Meekopora sp.............................................. 71

Mesa Gigante, N. Mex............................. 38, 211

Mesa Poleo, N. Mex................................... 80

Mesa Redondo, Ariz........................................ 28

Mesa Redondo Member.................................. 11, 28

pebble studies...................................... 69

Metoposaurs.......................................... $\quad 80$

Metoposaurus.................................................. 86

fraasi............................................... 80

Mica clay.... $\quad 60$

Mica-montmorillonite clays......................... 60

Milk Ranch Point, Utah, measured sec-

tion.................................... 291

Millard Canyon, Utah, measured section $\mathbf{3 1 7}$ Miller Creek, Colo.................................... 51, 151 Mizzia sp ........................................... 71, 73 Moab, Utah.................... 18, 68, 77, 79, 80, 81, 83 Moab Canyon, Utah, measured section.. 252 Moenave Formation................................. 14, 80

Moenkopi Formation................................... 14, 89

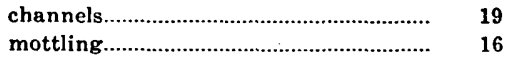


Page

Mogollon highland....................................... 14, 15 sediment source............................ 87, $93,95,99$

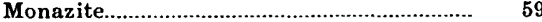

Monitor Butte, Utah........................... 25, 86, 294

Monitor Butte Member................... 11, 13, 15, 25 depositional environment..................... 92, 93 pelecypods............................................... 78 plant remains....................................... 85, 86 reptiles... volcanic detritus.

Montmorillonite clay

Montmorillonite-mica mixed clays............ 60

Monument Valley .............................. 13, 19, 25, $26,29,38,41,43,77,78,82,83,84,90$

Moss Back Member............................ 13, 15, $s 1$ depositional environment..................... 90 dip direction of cross-strata................ 77 fossiliferous chert pebbles................... 69, 73 gastropods.................................................. 79 pebble studies............................................ 69 plant remains.............................................. 85 reptiles... volcanic detritus.

.

Motorman, The, Utah, measured section.. 315

Mottled member mottled strata............................................. 16, 18

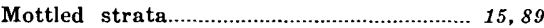

Mount Kinesava, Utah, measured section 326

Mud Well, Nev., measured section........... 168

Muddy River, Utah, measured section.... 223

Mudstone, composition................................. 61

Muley Twist Wash, Utah, measured section......................................... 236

Muscovite.................................................. 59

Myophoria ..................................................... 71

\section{$\mathbf{N}$}

Nacimiento Mountains, N. Mex............... 18, 23 Navajo Indian Reservation.......................... 77 Navajo Sheep Laboratory, N. Mex., measured section...................... 186

Nazlini, Ariz.............................................. 78

Nazlini Trading Post, Ariz., measured sections.............................. 117, 119

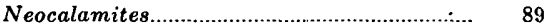
virginiensis................................................ 84

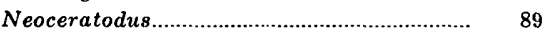

New Red Sandstone..................................... 10

Scotland ................................................. 86

Newark Group ................................... 84, 86, 87

No Thoroughfare Canyon, Colo., measured section........................... 148

Nokai Creek, Utah..................................... 84

Nomenclature, stratigraphic, history........ 11

North Sixshooter Peak, Utah, measured

$$
\text { section.. }
$$

Notch, The, Utah............................................

Notch Canyon, Utah, measured section 274

\section{o}

Ocher siltstone member.. 14,38 source of sediments.

Ojo Caliente, Ariz...

Orange Cliffs, Utah

Ornithosuchus..

Orthoquartit

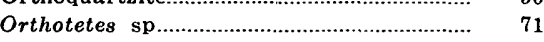

Ostracodes................................ 71, 73, 79, 87, 94

Otozamites macombii.................................... 84 powelli........................................ 84, 85, 86 Ouray, Colo......................................14, 49, 75, 160 Overton, Nev., measured section................ 175

Owl Rock, Ariz......................................... 29, 129 Owl Rock Member......................... 11, 13, 15, 88 calcareous strata.
Owl Rock Member-Continued depositional environment 95,97

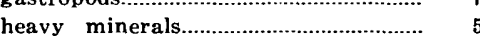
limestone. 54

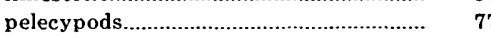
swelling clays. volcanic detritus

\section{$\mathbf{P}$}

Pagiophyllum newberryi.............................. 84 Palaeoctonus........................................... 82

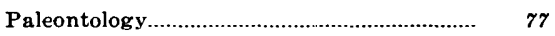
Paleorhinus................................................. 86, 87 sp .................................................... 82

Palisade, The, Colo., measured section.... 146 Palissya...................................................... 84 braunii.................................................. 84

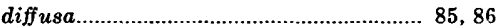

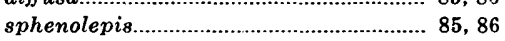
sp ...................................................... 86 Paradox Valley, Colo........................ 50, 79, 80, 158 Parafusulina bakeri............................. 71, 73, 76 maleyi.............................................. 73

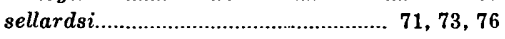

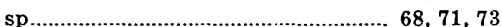

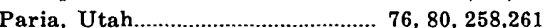

Pebble studies. Agua Zarca Sandstone Member.......................... basal sandstone unit 68 Dolores Formation................................... 75 Gartra Member...

Mesa Redondo Member

Moss Back Member..

Petrified Forest Member.

Poleo Sandstone Lentil..

sandstone member.

Shinarump Member.

Sonsela Sandstone Bed summary of data

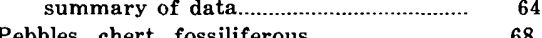
$\begin{array}{r}69,71,73,74,76,94 \\ \hline\end{array}$

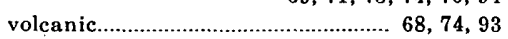

Pelecypods............................. 68, 74, 77, 87, 94, 95

Penninite.................................................... 59

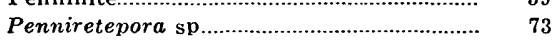

Petoch Butte, N. Mex............................... 47, 213

Petrified Forest, Utah, measured section.. 258 Petrified Forest Member................ 11, 13, 15, 86 age amphibians............................................. 80

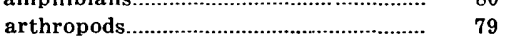
depositional environment...................... 92, 93 feldspar................................................... 58 fish fossils........................................... 79 fossiliferous chert pebbles.................... 74, 76 heavy minerals........................................ 59 pebble studies................................................ 74 pelecypods.......................................... plant remains.......................................... 88 reptiles...................................................... 80,88 source of sediments................................. 93 volcanic detritus..................................... 58 Petrified Forest National Park............... 3 , $36,37,74,76,79,83,84,85$

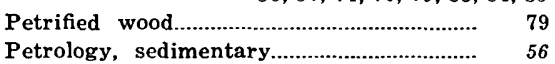
$\begin{array}{lll}\text { Petrology, sedimentary ................................... } & 56 \\ \text { Phlebopteris smithi.................................... } & 85\end{array}$

Phricodothyris sp........................................... 71

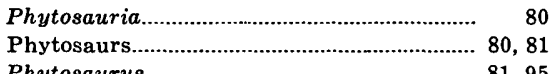

Phytosaurus............................................. 81, 95

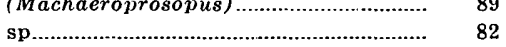
Piedra River, Colo....................... 33, 34, 48, 49, 134 Pityosporites chinleana................................ 85

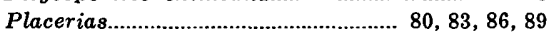
gigas....................................................... 83 hesternus
Page

Placerville, Colo

Plant remains........................................88, 87, 9 interpretation............................................ 90 Monitor Butte Member.......................... 25

Pleurophorus. 76

Podozamites arizonicus..................................... 85 emmonsi............................................... 86 lanceolatus.............................................. 85, 86

Point-bar deposits.................................. 90, 92, 98

Poison Spring Box Canyon, Utah............ 85, 231

Poleo Sandstone Lentil.............. 13, 23, 30, 31, 85 dinosaurs.......................................... 83 dip direction of cross-strata................ 77 heavy minerals........................................ 59 pebble studies................................................ plant remains........................................... 8

Poleo top sandstone.........................................

Polypora .................................................... 71 sp............................................................... 73

Polytaxis sp................................................ 73

Poncho House, Utah, measured section.... 299

Popo Agie Formation...................... 14, 82, 86, 95

Popo Agie Member, Chugwater Formation 38

Poposaurus...................................................... 87

Potosi Mountain, Nev., measured section 172

Powell Survey................................................... 10

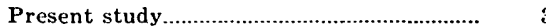

Previous studies............................................. 3.4

Prewitt, N. Mex., measured section............ 182

Productus ivesi.................. 73 (Dictyoclostus) ivesi................................ 76 occidentalis.................................... 71, 76 sp ................................................... 73

Protoretepora sp ............................................

Pseudopalatus pristinus..................................

Pseudosuchia ............................................. 80

Pterophyllum bakeri........................... 84, 85

Puertocito, N. Mex....................................... 74

Pugnoides pingus............................................ 73

Pyramid Creek, Colo., measured section.... 162

Pyrite.................................

\section{Q, R}

Quartz

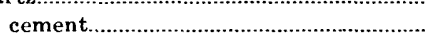
fine-textured rocks.................................... pebbles..

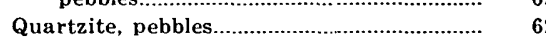

Range Canyon, Utah, measured section...... 238 Red House, Utah........... 79 Red Rock Valley, Ariz....................................... 86 Red sandstone member................................. 47 Red siltstone member................................... 58 Red strata, composition................................... 61 Redondo Member........................................... 11 Reeside, J. B., Jr., fossil identifications.. 78, 79 References cited.......................................... 100 Reptiles......................................... 77, 80, 87, 95

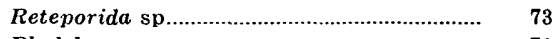
Rhabdomeson .................................................. 71 sp .................................................... 73, 76 Richardson Amphitheater, Utah, measured section............................ 248

Riley, N. Mex Rincon, Utah, measured sections............. 301, 305 Rio Chama area, New Mexico................... 18, Rio Grande, middle, New Mexico................ 92 Rock Point Member, Wingate Sandstone................................. 11, 13, 43

Wingate Sandstone, depositional environment................................ 98 planar-cross-stratified sandstone.. source of sediments......................... 100 wavy-stratified siltstone and sandstone................................... 98 
Round Rock, Ariz....................................... Page Rutile.

St. Johns, Ariz........... 28, 68, 74, 76, 80, 81, 83, 85 mensured sections........................ 121, 123, 124

St. Michnels, Ariz...

Salitral Shale Tongue..................................... 23, 23, 80

Salt-anticline area.............................................. 49, 50

Salt Valley, Utah.

77

San Juan Mountains, northern.................... 49, 75 southern...................................... 33, 35, 48, 75 San Juan Mountains region, Colorado......... 41 San Miguel, Colo ........................................ 84 San Miguel Canyon, Colo., measured sections................................ 165, 203 Snn Nacimiento Mountains, N. Mex.......... 21 San Pedro Mountain, N. Mex.......... 18, 21, 30, 35 San Rafael Group................................ 14 San Rafael River, Utah, measured section 216 San Rafael Swell........................................ 13 $16,18,25,26,31,43,50,54,82,85$ measured sections...... 219, 221, 223, 225, 229 San Ysidro, N. Mex................... 18, 21, 23, 206, 209 Sand dunes..................................................... 55,98 Sandstone...................... 50

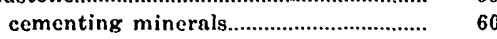
cross-strntified.................................................. 90 cross-stratified clayey.............................. $9 \boldsymbol{g}$ colian, Wingate Sandstone.................... 44, 45 planar-cross-stratified............................ $55,9 s$ ripple-laminated..................................... textural and compositional characteristics, by unit....................... 62 trough-cross-stratified.............................. 54,98 volcanic detritus......................................... 58 wavy-stratified.........................................54, 57

Sandstone and mudstone member................11, 20 mottled stratr.......................................... 16

Sandstone member................................. 13, 22, 29 dip direction of cross-strata................. $\quad 76$ pebble studies........................................... $\quad 68$ Sanmiguelia lewisi.............................................. 85

Santa Rosa Sandstone............................14, 24 Sawpit, Colo........................................ 50, 56, 165 Schilderia adamanica................................. 85, 89

Schizodus sp................................................... 71

Schwagerina sp........................................ 68, 71, 76

Scotland, New Red Sandstone...................... 86

Scours, benenth Rock Point Member, Wingate Sandstone.................... 47

in Cutler Formntion................................. 23

interpretntion............................................ 90

Moenkopi Formation................................ 19, 20

Poleo Sandstone Lentil................... 35

Sediment transport direction, determination..........

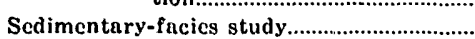

Sedimentary structures, Agua Zarca Sandstone Member................... cross-stratified clayey sandstone........... cross-stratified sandstone and conglomerate...................................

Dolores Formation, northern San Juan Mountains....................... red siltstone member....................... sandstone and conglomerate member...........

upper member.

Gartra Member....

lower red member... Polco Snndstone Lentil

ripple-laminated sandstone.

Rock Point Member, Wingate Sand stone...........

sandstone member.
Sedimentary structures-Continued Shinarump Member............................... 19, wavy-stratified siltstone and sandstone..................................... 97

Semionotus...................................................... 86, 89 sp............................................................ 79

Senorita Canyon, N. Mex............... 23, 30, 35, 207

Septopora sp..

Serpents Trail, The, Colo., measured section.......................................... 148

Shinarump Cliffs, Utah....................................... 18

Shinarump Conglomerate....................... 10, 11, 18

Shinarump Group........................................... 10

Shinarump Member................... 10, 13, 15, 18, 23 arthropods.............................................. 79

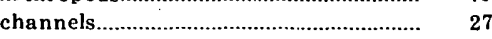
clay plugs................................................. 90

depositional environment..................... 90,92 dip direction of cross-strata.................. 76 mottled strata............................................. 16 pebble studies............................................. 64 plant remains........................................ 84, 85 quartz.................................................. 58 reptiles................................................... 82 source of sediments............................... 93,94

Siltstorie, clayey, structureless or horizontally laminated...................

composition..

structureless and horizontally bedded

trough-cross-stratified............................. 54,98 wavy-stratified.........................................54, 97

Siltstone member................................. 13, 47, 83

Silver Falls Creek, Utah, measured section......................................... 241

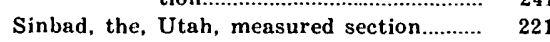

Skull Creek anticline, Colorado, measured section

Slick rim..........................................................

Slumpage features, lower red member......... 28

Monitor Butte Member

Snake Canyon, Utah, measured section.... 271

Solenopora..................................................... 73 sp.................................................. 7

Sonsela Buttes, Ariz., measured section.... 108

Sonsela Sandstone Bed............................11, 15, 37 depositional environment.................... 90 dip direction of cross-strata.................. 77

fossiliferous chert pebbles........................

pebble studies...............................................

source of sediments................................. 93

Source of sediments, determination _........ $\quad 76$

location and terrane.............................. 98,99

lower (bentonitic) part of Chinle

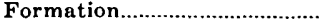

upper (red-beds) part of Chinle Formation...............................

South Block, Utah, measured section........

South Canyon Creek, Colo., measured Poction. Utah, measured sec-

South Draw Point, Utah, measured sec-

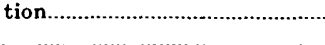

Spandelina

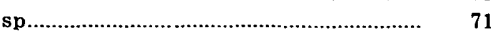

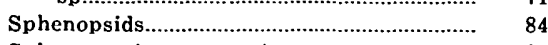
Sphenozamites rogersianus......................... 85, 86 Spherulites.......... 38 Spiriferina hilli.............................................. 76 Sponge..................................69, 73, 74, 76, 94 Spring Canyon, Utah, measured section.... 250 Spring Mountains, Nev................... 14, 20, 76, 172 Springdale Sandstone Member..................... 11 Stagnolepidae................................................ 81 Stanaker Formation, Gartra Grit Member 13, 24 Staurolite.........................................................

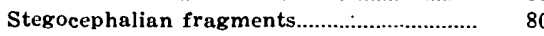
Stoner, Colo........................33, 34, 48, 49, 155, 156 Straight Wash, Utah, measured section.... 225 Structures, sedimentary. See Sedimen-
Summerville Formation.............. Page Synapsida ...................................................... 83 Synorichthys stewarti................................... 79

T

Tabulipera sp .................................................

Tanaocrossus kalliokoskii.............................. $\quad 79$ Tanners Crossing, Ariz................................. 80, 83 Tanystrophaeus........................................... $\quad 82$ Taylor Canyon, Utah, measured section.... 306 Taylor Creek, Utah, measured section........ 255 Telluride, Colo................................77, 78, 79, 81 Temple Mountain, Utah, measured section 229

Temple Mountain Member........................... 13 mottled strata....................................... 16, 18 plant remains................................................ 85

Texture, petrological classification basis... $\quad 56$ The Cove, Utah........................................... 78 The Dugway, Utah, measured section........ 252 The Horn, Utah, measured section............... 277 The Motorman, Utah, measured section.... 315 The Notch, Utah ........................................ 85

The Palisade, Colo., measured section........ 146 The Serpents Trail, Colo., measured section ......................................... 148

Thecodonts................................................. 80 Therapsid reptiles........................................ 83 Thickness, Agua Zarca Sandstone Mem-

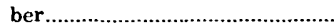

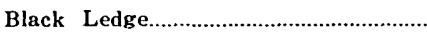

Chinle Formation..

Church Rock Member.............................

Dolores Formation, lower member....

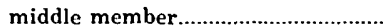
red siltstone member.......................... sandstone and conglomerate

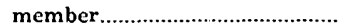
upper member.................................... 49, 51 Gartra Member...................................... 25 Hite Bed............................................ 42, 43 lower red member................................... 28 Mesa Redondo Member............................... 28 Monitor Butte Member.......................... 26

Moss Back Member................................. 32, 90 mottled strata..................................... 17, 18 ocher siltstone member............................ 38

Owl Rock Member................................... 39

Petrified Forest Member........................ 36

Poleo Sandstone Lentil............................. 35

red sandstone member............................

Rock Point Member, Wingate Sandstone...

sandstone and mudstone member........ 30

sandstone member.................................... 24

Shinarump Member.................................. 19, 90

siltstone member..................................... 47

Sonsela Sandstone Bed........................... 90

Thoreau, N. Mex., measured section.......... 182

Toadlena. N. Mex., measured section.......... 201

Todilto Park, N. Mex.............................. 45, 191

Todilto Wash, N. Mex., measured section 191

Torrey, Utah.................................................. 86

Tourmaline

Tramp Range, Nev., measured section...... 168

Transamnicola ..................................... 87, 95

Tres Piedra Ranch, Colo., measured section.......................................... 134

Triasamnicola assiminoides......................... 78, 79 latispira.............................................. 78, 79

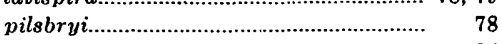

Tucumcari, N. Mex ...................................... 87

Tuff.................................................... 56, 58, 75

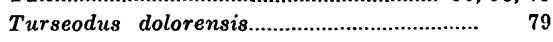

Twin Buttes Wash, N. Mex., measured section........................................ 185

Tyende Mesa, Ariz....................................... 78

Typothorax .............................. 80, 86, 87, 89, 95

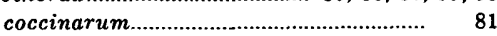


U

Page

Uinta Mountains

$24,38,41,50,51,90,95$

Uncompahgre highland......................... 14, 15, 23 sediment source....................... 87, 94, 95, 99

Uncompahgre Plateau.

Uncompahgre River, Colo., measured section................................... 160

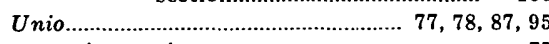
arizonensis............................................. 77 cristonensis.............................................. 77

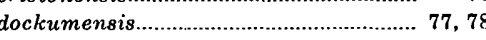
dumblei................................................. 77, 78

gallinensis................ 77

graciliratus........................................... 78

terraerubrae............................................. 77

thomasi.............................................

(Antediplodon) dockumensis................ 78

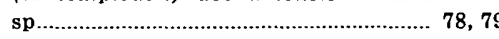

Unionidae.

Upper member

Uranium, relation to kaolinite

Uranium minerals, cement in sandstone.... 61

\section{V}

Vale of Tears, Colo.........................................

Valley of Fire, Nev., measured section...... 175

Valvata gregorii....................................78, 79

Vaughn, P. P., fossil identifications.......... 82

Ventifacts.....................................................

Vermilion Cliff Group................................... 10

Vermilion Creek, Colo., measured section 153

Vernal, Utah....................................... 24, 51, 55

Vernal (Brush Creek), Utah, measured section... \\ INDEX}

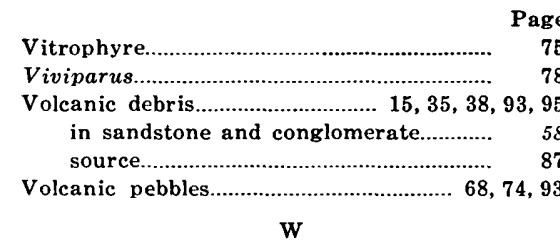

W

Wagon Box Mesa, Utah

Ward bone bed

84

aterpocket fold, Utah, measured section 301

Weathering features, calcite concretions.. 61

Church Rock Member............................. 42

Dolores Formation, middle member.... upper member

Entrada Sandstone

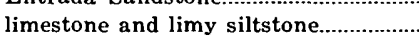

lower red member.

Monitor Butte Member..

Moss Back Member

Owl Rock Member..

Petrified Forest Member

planar-cross-stratified sandston

Poleo Sandstone Lenti

red sandstone member

Rock Point Member, Wingate Sandstone.

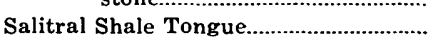
sandstone and mudstone member....... trough-cross-stratified rocks.

wavy-stratified siltstone and sandstone.

West Side Creek

Westwater Canyon, Utah, measured Canyon, Utah, measured section.

78

83 3

White Mesa, N. Mex., measured section.... 209 White River valley, Colorado, measured section

Wickiup, the Utah measured.................. 164

Wingate Sandstone....................................... 14

Lukachukai Member................................ 13, 45 planar-cross-stratified sandstone.. $\quad 55$

Rock Point Member.................... 11, 13, 48 planar-cross-stratified sandstone.. $\quad 55$ source of sediments......................... 100 wavy-stratified siltstone and sandstone..

Winslow, Ariz.......................... 45,8

Wood fragments, Gartra Member................ 24

Mesa Redondo Member............................. 28

Moss Back Member....................................... 31

Shinarump Member............................... 19

Woodworthia arizonica .................................. $\quad 84$

\section{$\mathbf{Y}, \mathbf{Z}$}

Yuccites sp.

Zamites occidentalis

powelli..

Zion National Park .................... 11, 36, 77, 80, 84

measured section

Zircon

Zuni, N. Mex

Zuni uplift........................................... 27, 55, 74 